Nevada

Environmental

Restoration

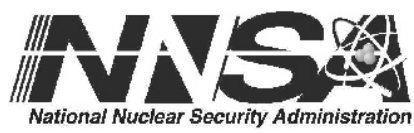

Project

\title{
Addendum to the Closure Report for Corrective Action Unit 113: Area 25 R-MAD Facility, Nevada National Security Site, Nevada
}

Controlled Copy No::

Revision: 0

February 2011

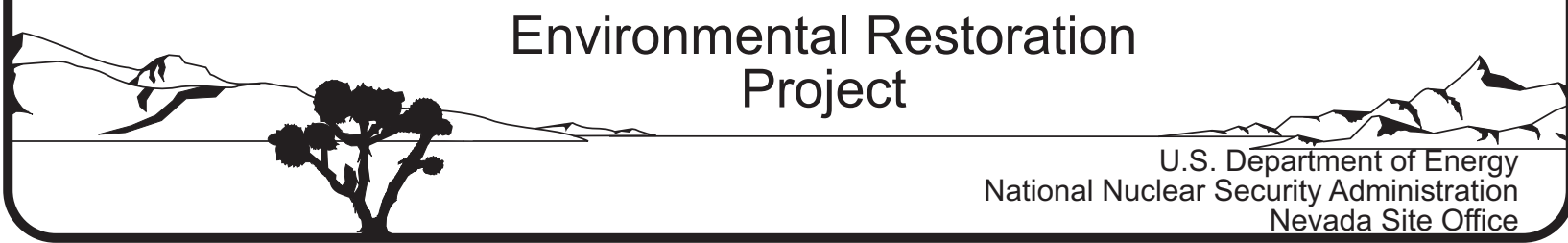




\section{DISCLAIMER}

Reference herein to any specific commercial product, process, or service by trade name, trademark, manufacturer, or otherwise, does not necessarily constitute or imply its endorsement, recommendation, or favoring by the United States Government or any agency thereof.

This report has been reproduced directly from the best available copy.

Available for sale to the public from:

U.S. Department of Commerce

National Technical Information Service

5301 Shawnee Road

Alexandria, VA 22312

Telephone: (800) 553-6847

Fax: (703) 605-6900

E-mail: orders@ntis.gov

Online ordering: http://www.ntis.gov/help/ordermethods.aspx

Available electronically at http://www.osti.gov/bridge.

Available for a processing fee to the U.S. Department of Energy and its contractors, in paper, from:

U.S. Department of Energy

Office of Scientific and Technical Information

P.O. Box 62

Oak Ridge, TN 37831-0062

Telephone: (865) 576-8401

Fax: (865) 576-5728

E-mail: reports@adonis.osti.gov 


\title{
ADDENDUM TO THE CLOSURE REPORT FOR CORRECTIVE ACTION UNIT 113: AREA 25 R-MAD FACILITY, NEVADA NATIONAL SECURITY SITE, NEVADA
}

\author{
U.S. Department of Energy \\ National Nuclear Security Administration \\ Nevada Site Office \\ Las Vegas, Nevada
}

Controlled Copy No.

Revision: 0

February 2011 
THIS PAGE INTENTIONALLY LEFT BLANK 


\section{ADDENDUM TO THE CLOSURE REPORT FOR CORRECTIVE ACTION UNIT 113: AREA 25 R-MAD FACILITY, NEVADA NATIONAL SECURITY SITE, NEVADA}

\footnotetext{
Approved By: /s/: Kevin Cabble

Date:

Kevin J. Cabble

Federal Sub-Project Director

Industrial Sites Sub-Project

Approved By: /s/: Robert Boehlecke

Date: $2 / 14 / 11$

Robert F. Boehlecke

Federal Project Director

Environmental Restoration Project
} 
THIS PAGE INTENTIONALLY LEFT BLANK 


\section{TABLE OF CONTENTS}

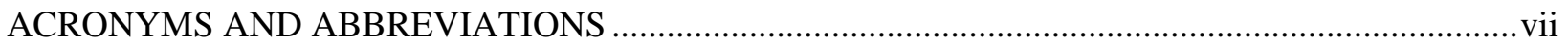

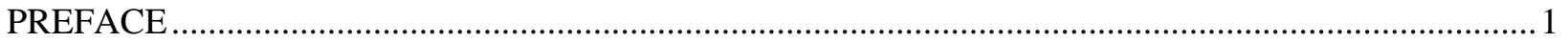

ADDENDUM TO THE CLOSURE REPORT FOR CORRECTIVE ACTION UNIT 113, AREA 25

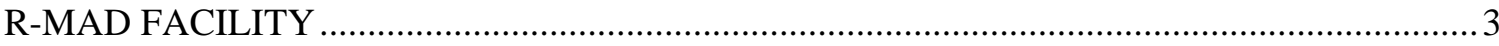

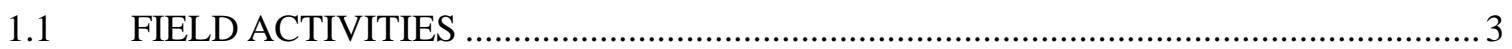

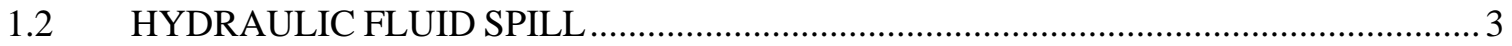

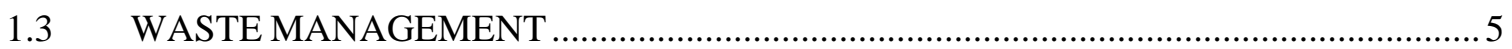

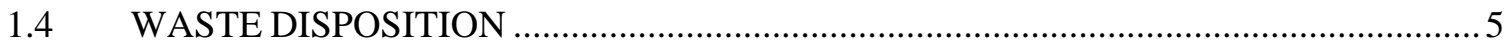

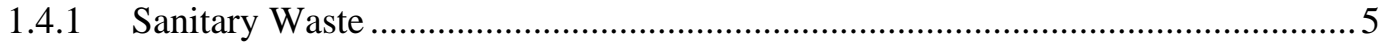

1.4.2 Radioactive Polychlorinated Biphenyl Bulk Product Waste .................................. 5

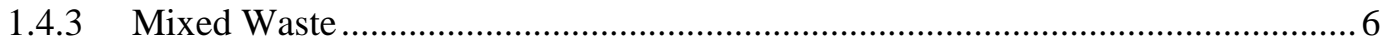

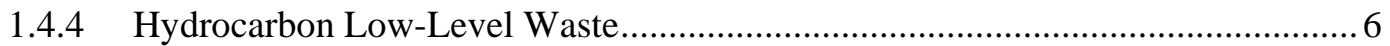

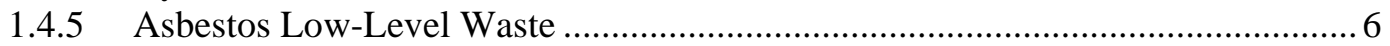

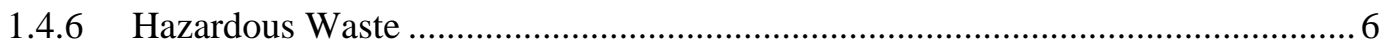

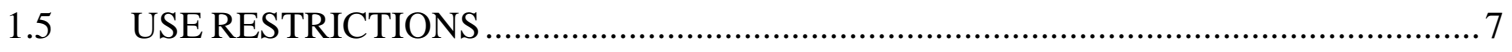

LIBRARY DISTRIBUTION LIST

\section{LIST OF FIGURES}

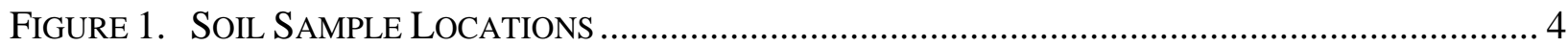

\section{APPENDICES}

ApPEndix A. PhOtOGRAPHS

ApPendix B. Request to Perform Demolition of BuILding 3110 WITHIN The Use

Restriction (UR) FOr CORRECTIVE ACtion Unit (CAU) 113: AREA 25 R-MAD

FACILITY, CORRECTIVE ACTION SiTE 25-41-01 AND NDEP APPROVAL LETTER

Appendix C. Final Hydraulic Fluid Spill Report, Total Petroleum Hydrocarbon

VERIFICATION SAMPLE RESULTS, AND NDEP APPROVAL LETTER

ApPENDIX D. REQUEST FOR VARIANCE FOR WASTE MANAgEMENT ACTIVITIES FOR CORRECTIVE ACTION UNIT (CAU) 113: AREA 25 R-MAD FACILITY AND NDEP APPROVAL LETTER

Appendix E. Polychlorinated Biphenyl Verification SAmple Results

APPENDIX F. WASTE DISPOSITION DOCUMENTATION

ApPENDIX G. WASTE CHARACTERIZATION SAMPLE RESUltS

ApPendix H. Clarification of Final End State For Corrective Action Unit (CAU) 113: AREa 25, ReActor MaintenANCE, ASSEMBly, AND DisASSEMBLy (R-MAD) FACILITY, CORRECTIVE ACTION SITE 25-41-01 AND NDEP APPROVAL LETTER

APPENDIX I. USE RESTRICTION DOCUMENTATION

Appendix J. NeVAda Division of Environmental Protection Comment Response Form 
Addendum to CAU $113 \mathrm{CR}$

Revision: 0

Date: February 2011

THIS PAGE INTENTIONALLY LEFT BLANK 


\section{ACRONYMS AND ABBREVIATIONS}

$\begin{array}{ll}\text { CAU } & \text { Corrective Action Unit } \\ \text { HW } & \text { hazardous waste } \\ \text { LLW } & \text { low-level waste } \\ \text { MW } & \text { mixed waste } \\ \text { NDEP } & \text { Nevada Division of Environmental Protection } \\ \text { NNSA/NSO } & \begin{array}{l}\text { U.S. Department of Energy, National Nuclear Security Administration Nevada } \\ \text { Site Office }\end{array} \\ \text { PCB } & \text { polychlorinated biphenyl } \\ \text { PPE } & \text { personal protective equipment } \\ \text { R-MAD } & \text { Reactor Maintenance, Assembly, and Disassembly } \\ \text { RWMS } & \text { Radioactive Waste Management Site } \\ \text { UR } & \text { use restriction } \\ \text { yd } & \text { cubic yard(s) }\end{array}$


Addendum to CAU 113 CR

Revision: 0

Date: February 2011

THIS PAGE INTENTIONALLY LEFT BLANK 


\section{PREFACE}

This addendum to the Closure Report for Corrective Action Unit 113: Area 25, Reactor Maintenance, Assembly, and Disassembly Facility, Building 3110, Nevada Test Site, Nevada, DOE/NV--891-VOL I-Rev. 1, dated July 2003, provides details of demolition, waste disposal, and use restriction (UR) modification for Corrective Action Unit 113, Area 25 R-MAD Facility. Demolition was completed on July 15, 2010, when the last of the building debris was disposed. Final field activities were concluded on August 30, 2010, after all equipment was demobilized and UR signs were posted. This work was funded by the American Recovery and Reinvestment Act. 
Addendum to CAU $113 \mathrm{CR}$

Revision: 0

Date: February 2011

\section{THIS PAGE INTENTIONALLY LEFT BLANK}




\section{ADDENDUM TO THE CLOSURE REPORT FOR CORRECTIVE ACTION UNIT 113, AREA 25 R-MAD FACILITY}

This addendum to the Closure Report for Corrective Action Unit 113: Area 25, Reactor Maintenance, Assembly, and Disassembly Facility, Building 3110, Nevada Test Site, Nevada, DOE/NV--891-VOL I-Rev. 1, dated July 2003, provides details of demolition, waste disposal, and use restriction (UR) modification for Building 3110, Reactor Maintenance, Assembly, and Disassembly (R-MAD) Facility. Demolition was completed on July 15, 2010, when the last of the building debris was disposed. Final field activities were concluded on August 30, 2010, after all equipment was demobilized and UR signs were posted.

\subsection{FIELD ACTIVITIES}

Field activities began in September 2009 and included the following:

- Mobilization

- Characterization, removal, and disposal of housekeeping waste

- Removal and disposal of asbestos elbows throughout the building and asbestos roofing material on the ground

- Demolition of Building 3110 and water tower (the non-high bay structures were demolished with heavy equipment, and the water tower, large stack, and high bay were lowered with explosives)

- Size reduction and disposal of building debris

- Placement of building debris in basement and 1 foot of grout/concrete over the debris

- Installation of UR signs

- Demobilization

Photographs of field work are included in Appendix A. Prior to conducting demolition work in the use restricted area, a request was submitted by the U.S. Department of Energy, National Nuclear Security Administration Nevada Site Office (NNSA/NSO) to the Nevada Division of Environmental Protection (NDEP) to perform this work. The NNSA/NSO request and NDEP approval letter are included in Appendix B.

\subsection{HYDRAULIC FLUID SPILL}

On January 4, 2010, a hydraulic line broke on an excavator, and approximately 100 gallons of hydraulic oil were released onto a debris ramp and the underlying asphalt and soil. The spill was reported to NDEP on January 4, 2010, and was assigned Spill No. 0100104-05. On January 6, 2010, all visibly impacted material was excavated and packaged in B-25 boxes for disposal.

A preliminary spill report was sent to NDEP on February 23, 2010. Verification samples were collected on August 4, 2010, after the debris ramp was removed because the area was used for demolition and waste disposal activities. Figure 1 shows the sample locations. The samples were submitted for total petroleum hydrocarbon analysis and were below the action level. The final spill report, sample results, and NDEP approval letter are included in Appendix C. 


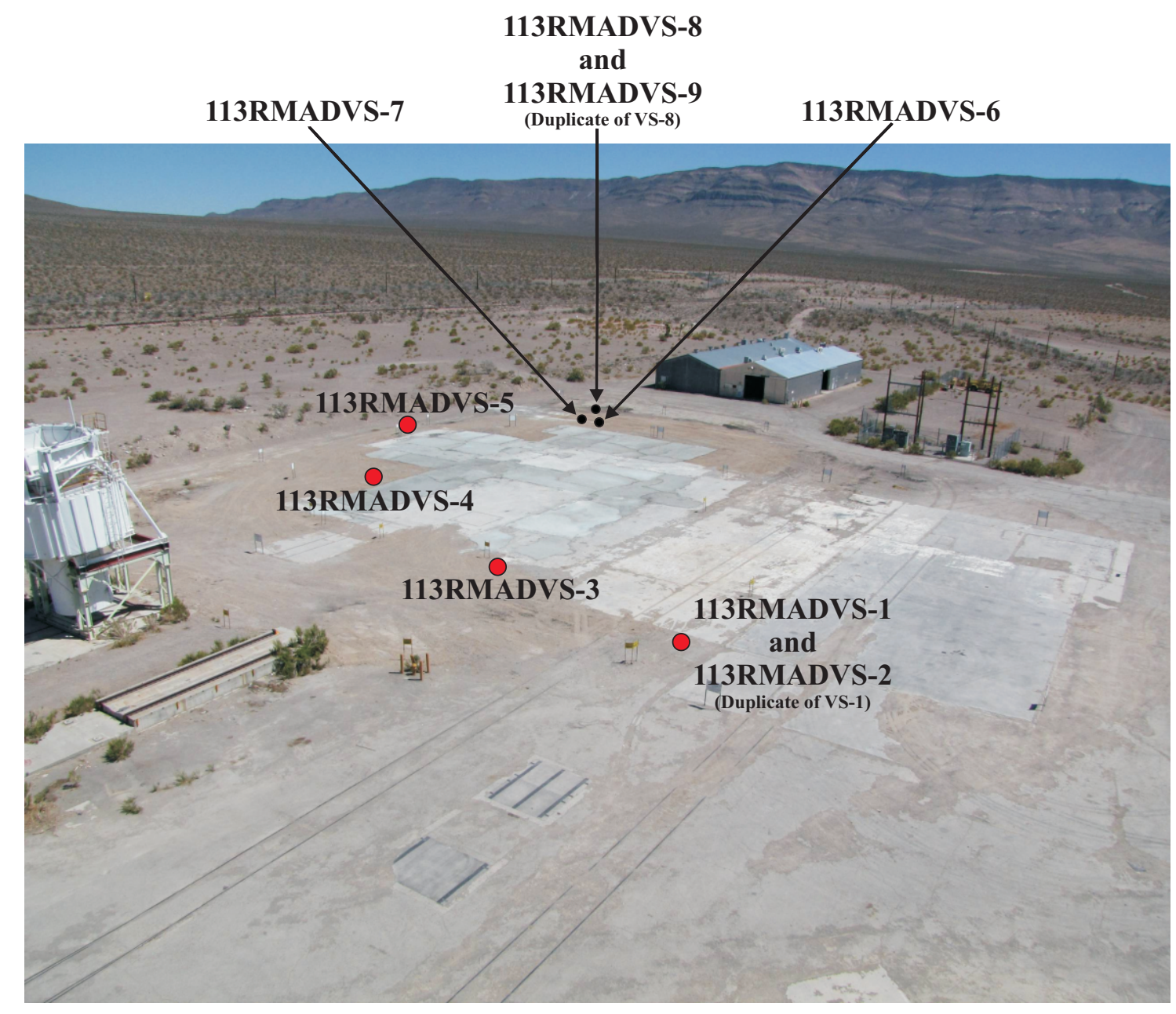

\section{LEGEND}

- Total Petroleum Hydrocarbon Sample Location

- Polychlorinated Biphenyl Sample Location

FIGURE 1 SOIL SAMPLE LOCATIONS 


\subsection{WASTE MANAGEMENT}

Building 3110 demolition debris was considered polychlorinated biphenyl (PCB)-contaminated low-level waste (LLW) as a result of legacy dried paint containing PCBs at concentrations greater than 50 parts per million and residual radiological contamination in the building. The debris met the definition of PCB bulk product waste because the paint applied to the facility was manufactured to contain PCBs and was used for its intended purpose.

NDEP approved a request for variance for waste management activities on December 22, 2009. This included variances for the requirements for a synthetic liner and a cover for the debris pile. The request also stated that samples of surface soil adjacent to the Building 3110 slab would be collected as a best management practice to verify that PCBs from the building debris had not leached into the soil. The request for variance for waste management and approval letter are included in Appendix D.

Soil samples were collected on August 4, 2010. Four soil samples and one duplicate were collected from the pre-demolition ground level after the building debris had been removed (0 to 6 inches) and analyzed for PCBs. PCBs were not detected in any of the samples. The laboratory data is included in Appendix E.

\subsection{WASTE DISPOSITION}

This section describes the waste streams generated during field activities and their final disposition. Waste streams included sanitary waste, radioactive PCB bulk product waste, mixed waste (MW), hydrocarbon LLW, asbestos LLW, and hazardous waste (HW). Waste disposal documentation is included in Appendix F.

\subsubsection{Sanitary Waste}

Sanitary waste included office trash and debris generated during field work that was not impacted above sanitary landfill disposal criteria. Approximately 20 cubic yards $\left(\mathrm{yd}^{3}\right)$ of sanitary waste were transported in a roll-off to the Area 9 U10c Sanitary Landfill for disposal.

\subsubsection{Radioactive Polychlorinated Biphenyl Bulk Product Waste}

Approximately 7,180 $\mathrm{yd}^{3}$ of radioactive PCB bulk product waste were generated during field activities and included housekeeping waste from the yard, building debris, personal protective equipment (PPE), and decontamination waste. Housekeeping debris was packaged into a cargo container and five burrito bags.

Building debris (i.e., concrete and small pieces of metal), decontamination waste, and PPE were packaged into lined intermodal containers. Rebar that was separated from the building debris was rolled into balls, sprayed with fixative, and shipped in end dumps. Larger pieces of metal (e.g., steel doors and crane beams) that could not fit into intermodal containers were sprayed with fixative and shipped on flatbed trucks. Some metal debris was also packaged in burrito wraps for disposal. The waste was transported to the Area 5 Radioactive Waste Management Site (RWMS) for disposal. In total, 834 intermodal liners of concrete and small pieces of metal, 28 burrito wraps of metal debris, and 45 loads of unpackaged metal were disposed. 


\subsubsection{Mixed Waste}

Approximately $45 \mathrm{yd}^{3}$ of MW were generated during field activities. MW included two lead-filled shield doors, lead bricks, and lead plates found under the frames of the previously removed leaded-glass observation windows. The waste was packaged into nine macroencapsulation boxes and transported to the Area 5 RWMS for treatment and disposal.

\subsubsection{Hydrocarbon Low-Level Waste}

Approximately $16 \mathrm{yd}^{3}$ of hydrocarbon LLW were generated during field activities and packaged into four B-25 boxes and one 55-gallon drum. The impacted material from the hydraulic fluid spill was packaged in one B-25 box. Decontamination pad waste and PPE were packaged in the other containers. The waste was shipped to the Area 5 RWMS for disposal.

\subsubsection{Asbestos Low-Level Waste}

Asbestos abatement activities were completed before demolition of the building. Approximately $8 \mathrm{yd}^{3}$ of waste were generated and packaged into two B-25 boxes and transported to the Area 5 RWMS for disposal.

\subsubsection{Hazardous Waste}

Four 55-gallon drums of white powder that were located in the Building 3110 yard were disposed as HW. Samples of the white powder were collected. There were no hazardous constituents detected above minimum detectable concentrations; however, minimum detectable concentrations below regulatory levels could not be achieved for hexachlorobutadiene, hexachlorobenzene, and 2,4-dinitrotoluene due to matrix interference. Therefore, the powder required disposal as HW. The sample results are located in Appendix G. The four 55-gallon drums were sent to U.S. Ecology in Beatty, Nevada, on February 16, 2011, and are listed on line 14 of the HW manifest for this shipment. The HW manifest is included in Appendix F.

PPE and disposable sampling supplies used during sampling of the white powder were packaged in a 20-gallon drum for disposal as HW. The 20-gallon drum was sent to U.S. Ecology in Beatty, Nevada, on August 30, 2010, and is listed on line 15 of the HW manifest for this shipment. The HW manifest is included in Appendix F.

During housekeeping activities, several pieces of equipment located in the Building 3110 yard contained oil that was drained and consolidated. Due to an insufficient total volume of oil, the oil was only analyzed for radioactive constituents, metals, PCBs, volatile organic compounds, and semi-volatile organic compounds. After collecting the samples, no oil remained. However, PPE and disposable sampling supplies used during sampling of the oil were packaged in a 5-gallon drum, and sample results showed that this waste required disposal as HW. The sample results are located in Appendix G. The 5-gallon drum was sent to U.S. Ecology in Beatty, Nevada, on August 30, 2010, and is listed on line 14 of the HW manifest for this shipment. The HW manifest is included in Appendix F.

One mercury-containing item was removed from the facility, placed in a drum, and disposed as HW. The mercury-containing item was sent to U.S. Ecology in Beatty, Nevada, on February 9, 2010. The item was shipped with other mercury waste from other projects and is listed on line 2 of the HW manifest for this shipment included in Appendix F. 


\subsection{USE RESTRICTIONS}

Approximately 1,580 $\mathrm{yd}^{3}$ of radioactive and PCB-impacted building debris were placed into the three basements of Building 3110. Hydraulic rams (classified as PCB articles) that are located in basement Rooms 6 and 7 were left in place. Access to the basements was restricted by capping them with approximately 1 foot of grout/concrete. Prior to demolition activities, a request for clarification of the final end state of R-MAD was submitted to NDEP for approval to fill the basements with building debris, leave the hydraulic rams in the basements, and cap the basements with grout/concrete. The NNSA/NSO request and NDEP approval letter are included in Appendix $\mathrm{H}$.

The UR implemented in the Closure Report for Corrective Action Unit (CAU) 113 was modified. The constituents present and post-closure inspection requirements of the UR are unchanged. However, the original description of the UR stated that contamination was present in Building 3110. The revised UR summary states that all radiological and PCB-impacted material is currently entombed in the basement of the facility. This includes the hydraulic rams and building debris.

The entire footprint of Building 3110 is use restricted as originally implemented in the Closure Report. Additional UR warning signs were installed around the building pad. The boundary of the new UR was surveyed. The size of the UR is essentially the same as the previous UR; however, the shape of the use restricted area more closely reflects the footprint of Building 3110 . These points are listed on the revised UR form. The revised UR form and a figure showing the locations of the surveyed points delineating the UR area are included in Appendix I. Future use of this CAU is restricted from any intrusive activity unless concurrence is obtained in advance and in writing from NDEP. Such intrusive activities would alter and/or modify the established containment controls as approved by the NDEP.

Annual site inspections will continue to be performed to ensure that the signs are intact and legible and that the UR is maintained. 
Addendum to CAU $113 \mathrm{CR}$

Revision: 0

Date: February 2011

\section{THIS PAGE INTENTIONALLY LEFT BLANK}


Addendum to CAU 113 CR

Revision: 0

Date: February 2011

\section{APPENDIX A}

\section{PHOTOGRAPHS}


Addendum to CAU 113 CR

Revision: 0

Date: February 2011

\section{THIS PAGE INTENTIONALLY LEFT BLANK}




\section{Photograph Log}

\begin{tabular}{|c|c|l||}
\hline $\begin{array}{c}\text { PHOTOGRAPH } \\
\text { NuMBER }\end{array}$ & \multicolumn{1}{|c||}{ DATE } & \\
\hline \hline 1 & $07 / 28 / 2009$ & Housekeeping Waste in the Yard \\
\hline 2 & $10 / 22 / 2009$ & Drum of White Powder Disposed as Hazardous Waste \\
\hline 3 & $11 / 18 / 2009$ & Removing Asbestos Elbows \\
\hline 4 & $11 / 19 / 2009$ & Start of Demolition \\
\hline 5 & $11 / 30 / 2009$ & Demolishing the Hot Cells \\
\hline 6 & $12 / 09 / 2009$ & Demolishing the High Bay Shield Door \\
\hline 7 & $01 / 05 / 2010$ & Demolishing the Mezzanine Shield Door \\
\hline 8 & $02 / 08 / 2010$ & Drilling Emplacement Holes in the High Bay for Explosives \\
\hline 9 & $02 / 11 / 2010$ & Explosive Demolition of the Large Stack and Water Tower \\
\hline 10 & $02 / 17 / 2010$ & Arching the High Bay in Preparation for Explosive Demolition \\
\hline 11 & $02 / 17 / 2010$ & Spraying Rebar with Fixative \\
\hline 12 & $03 / 02 / 2010$ & Loading Rebar into an End Dump for Disposal \\
\hline 13 & $03 / 22 / 2010$ & Loading Explosives for the High Bay \\
\hline 14 & $03 / 23 / 2010$ & $\begin{array}{l}\text { Installing Geo-Textile Liner and Chain Link Fencing Material to Control } \\
\text { Debris during Explosive Demolition }\end{array}$ \\
\hline 15 & $03 / 25 / 2010$ & High Bay before Explosive Demolition \\
\hline 16 & $03 / 25 / 2010$ & Lowering the High Bay with Explosives \\
\hline 17 & $03 / 29 / 2010$ & Size Reducing the High Bay \\
\hline 18 & $04 / 01 / 2010$ & Loading Debris into a Lined Intermodal for Disposal \\
\hline 19 & $04 / 07 / 2010$ & Debris Packaged in Intermodals \\
\hline 20 & $05 / 05 / 2010$ & Loading Lead Mixed Waste into a B-25 Box for Disposal \\
\hline 21 & $05 / 20 / 2010$ & Overview of the Debris Pile \\
\hline 23 & $07 / 15 / 2010$ & Capping the Basements with Concrete \\
\hline 24 & $08 / 25 / 2010$ & Use Restriction and Radiological Warning Signs \\
\hline & $08 / 31 / 2010$ & Site after Field Activities \\
\hline & & \\
\hline & & \\
\hline & &
\end{tabular}


Addendum to CAU $113 \mathrm{CR}$

Revision: 0

Date: February 2011

THIS PAGE INTENTIONALLY LEFT BLANK 


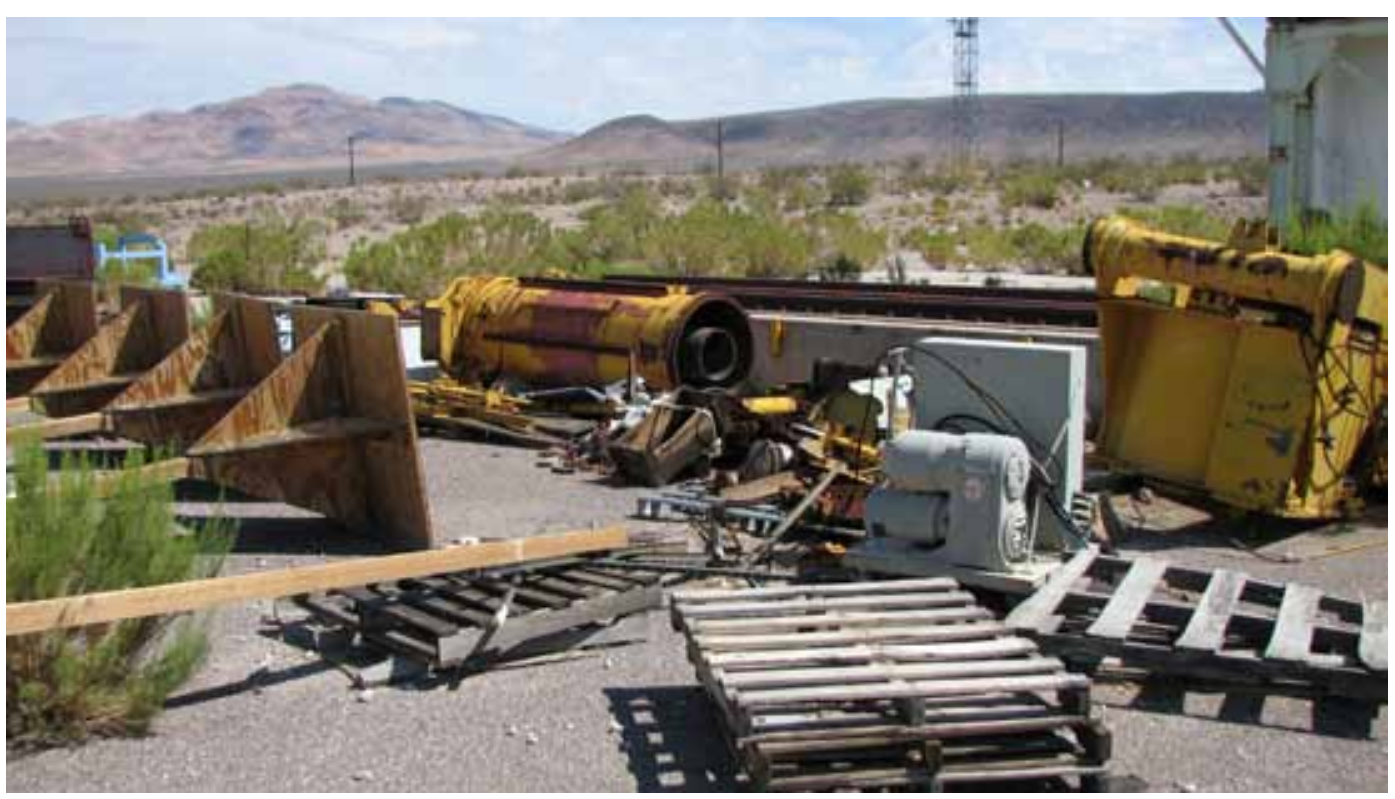

Photograph 1: Housekeeping Waste in the Yard, 07/28/2009

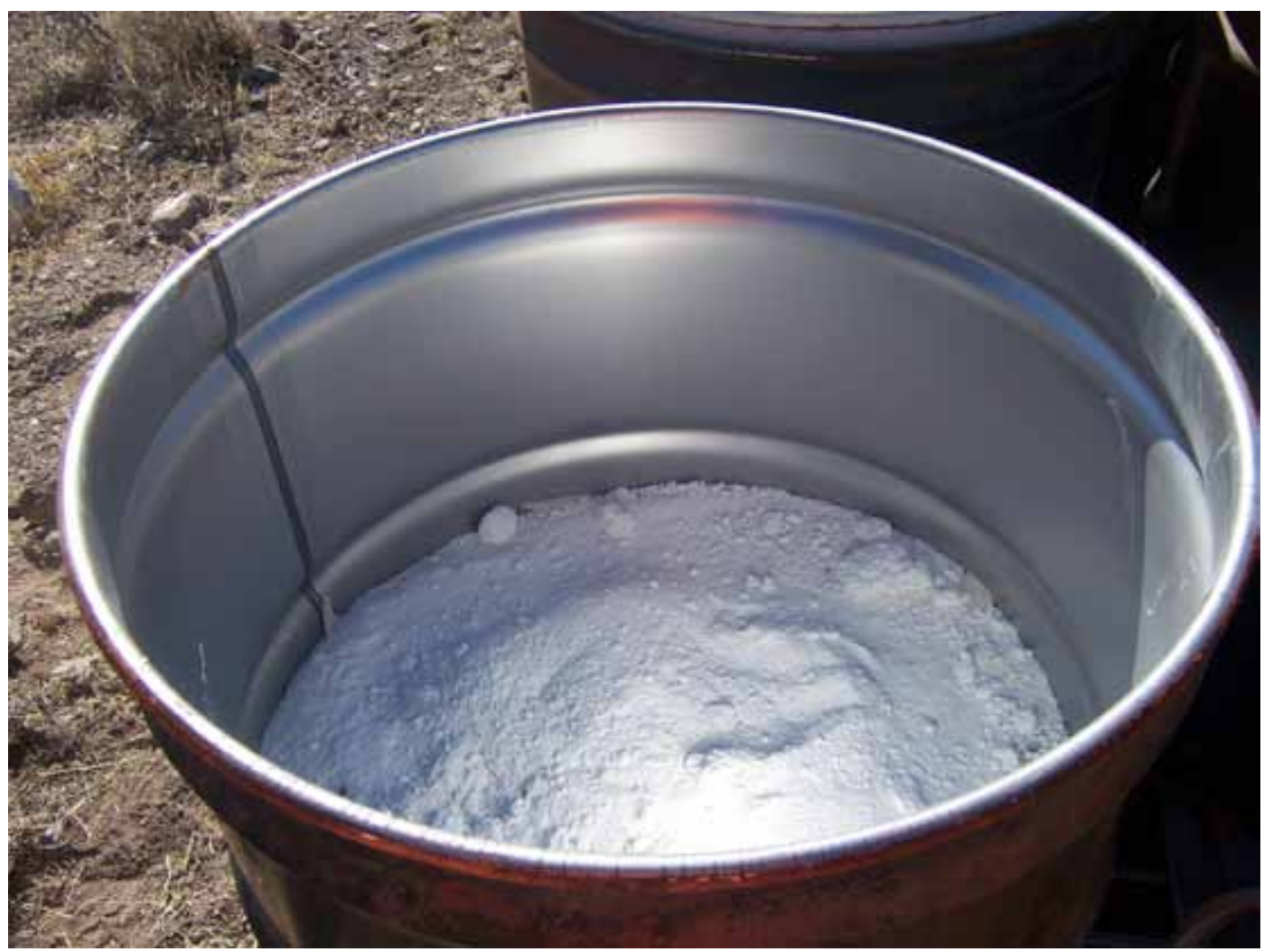

Photograph 2: Drum of White Powder Disposed as Hazardous Waste, 10/22/2009 


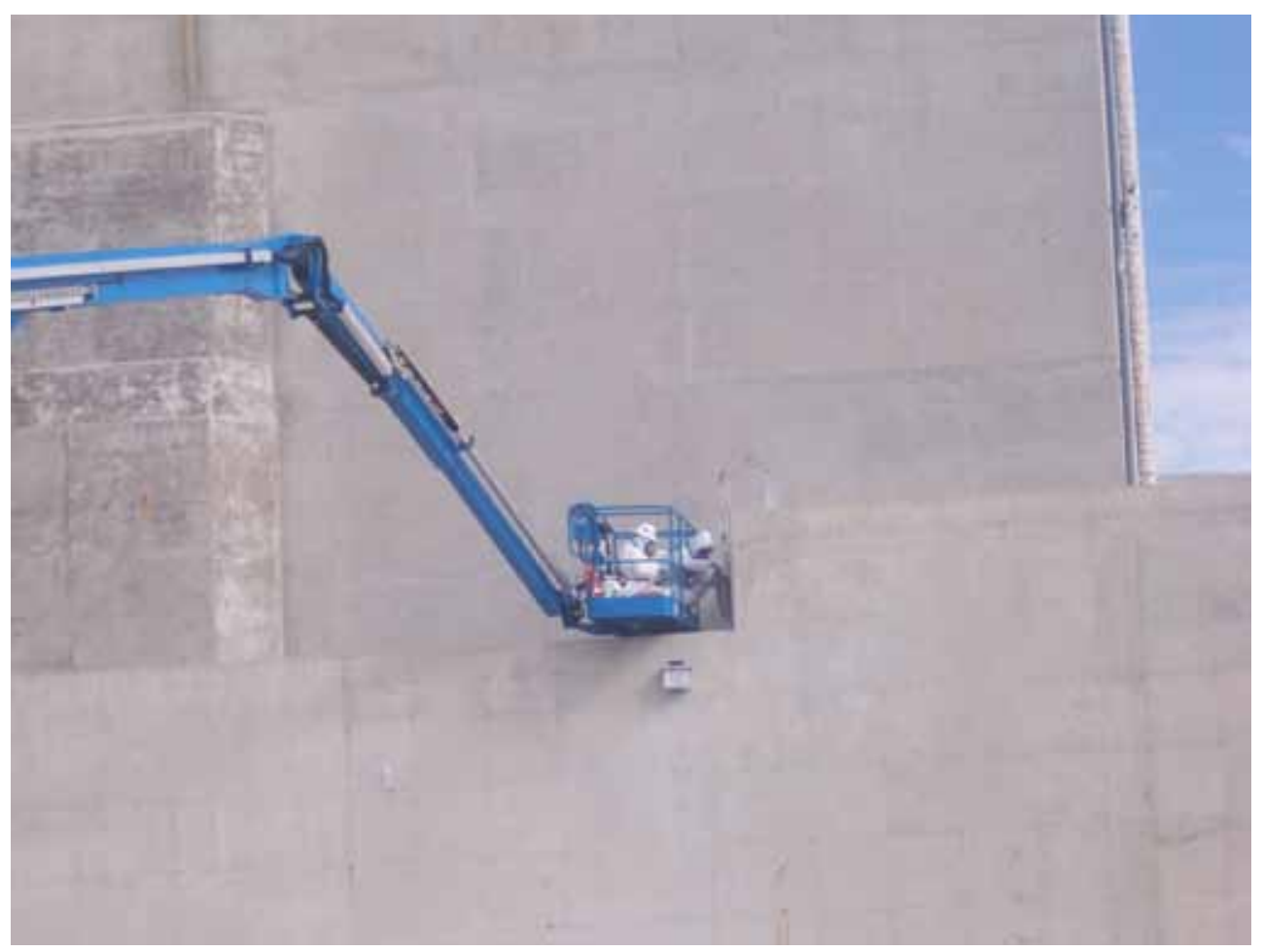

Photograph 3: Removing Asbestos Elbows, 11/18/2009

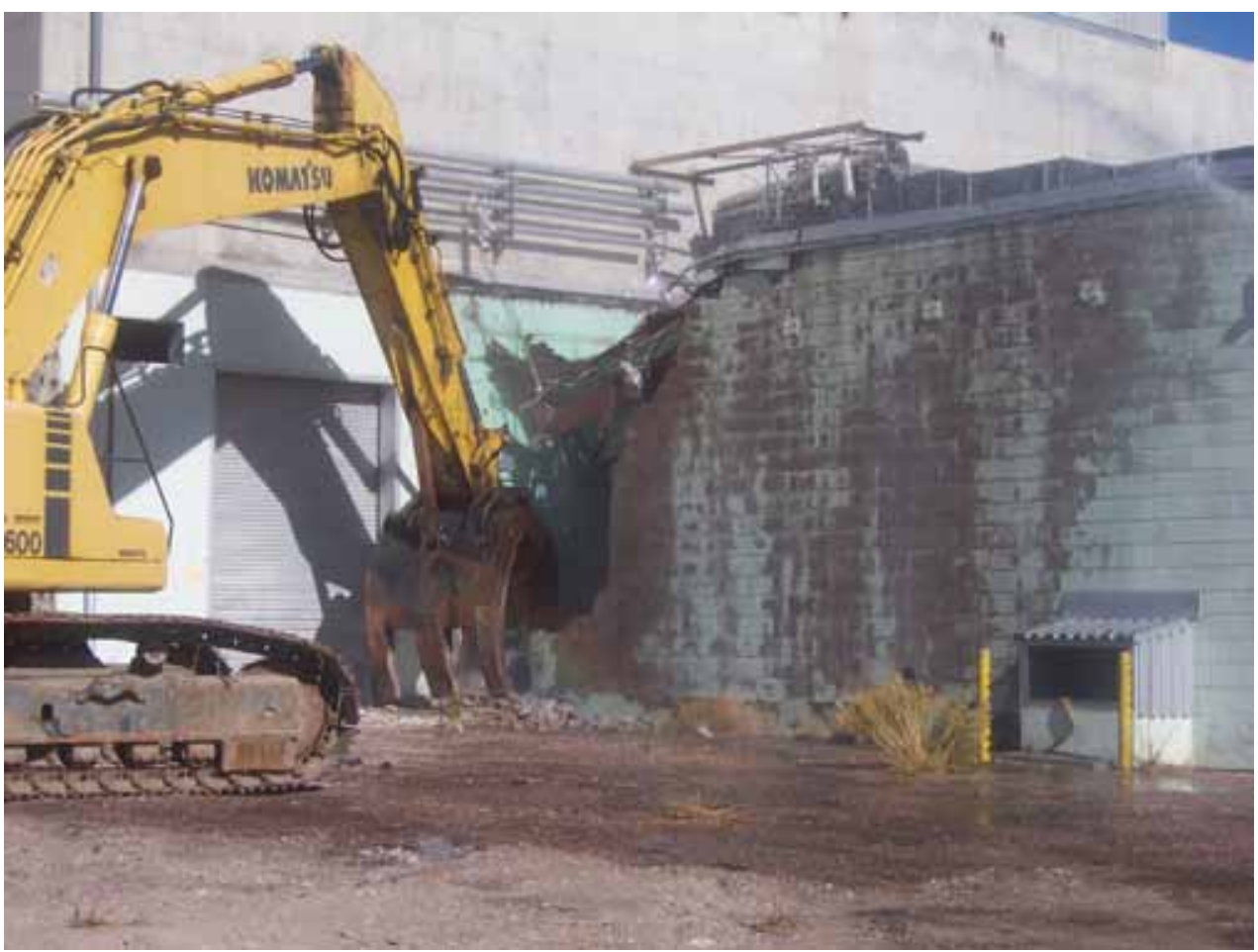

Photograph 4: Start of Demolition, 11/19/2009 


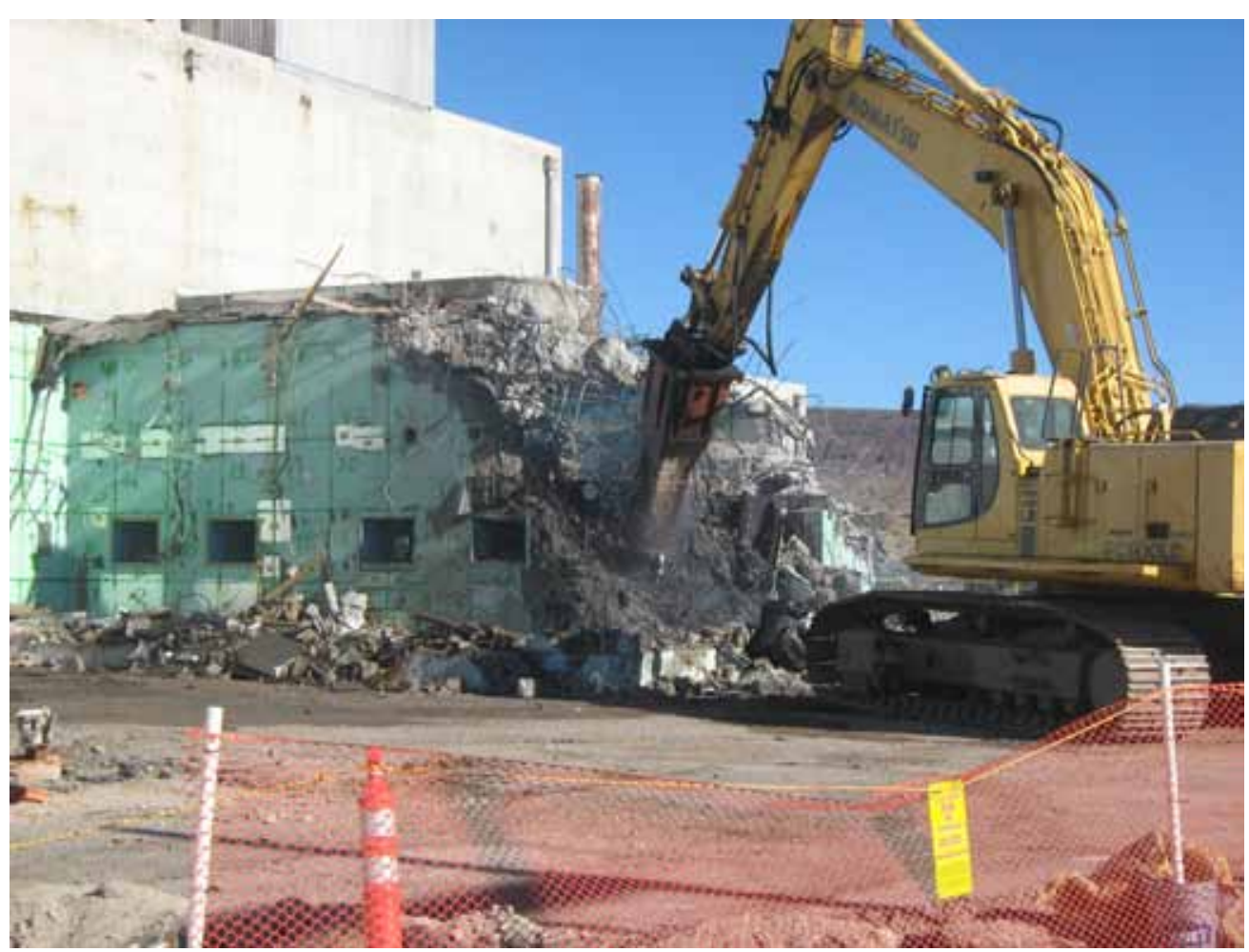

Photograph 5: Demolishing the Hot Cells, 11/30/2009

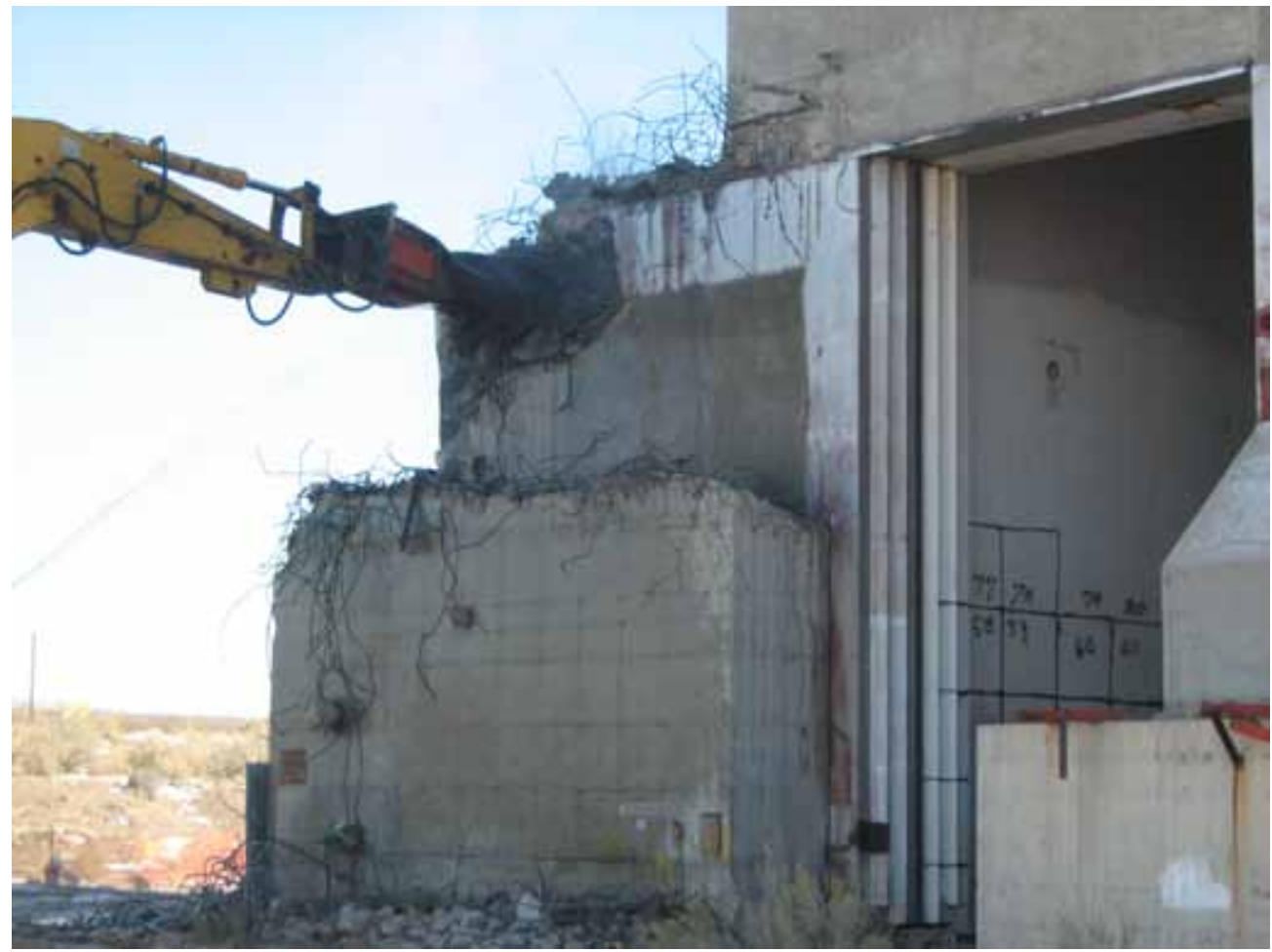

Photograph 6: Demolishing the High Bay Shield Door, 12/09/2009 


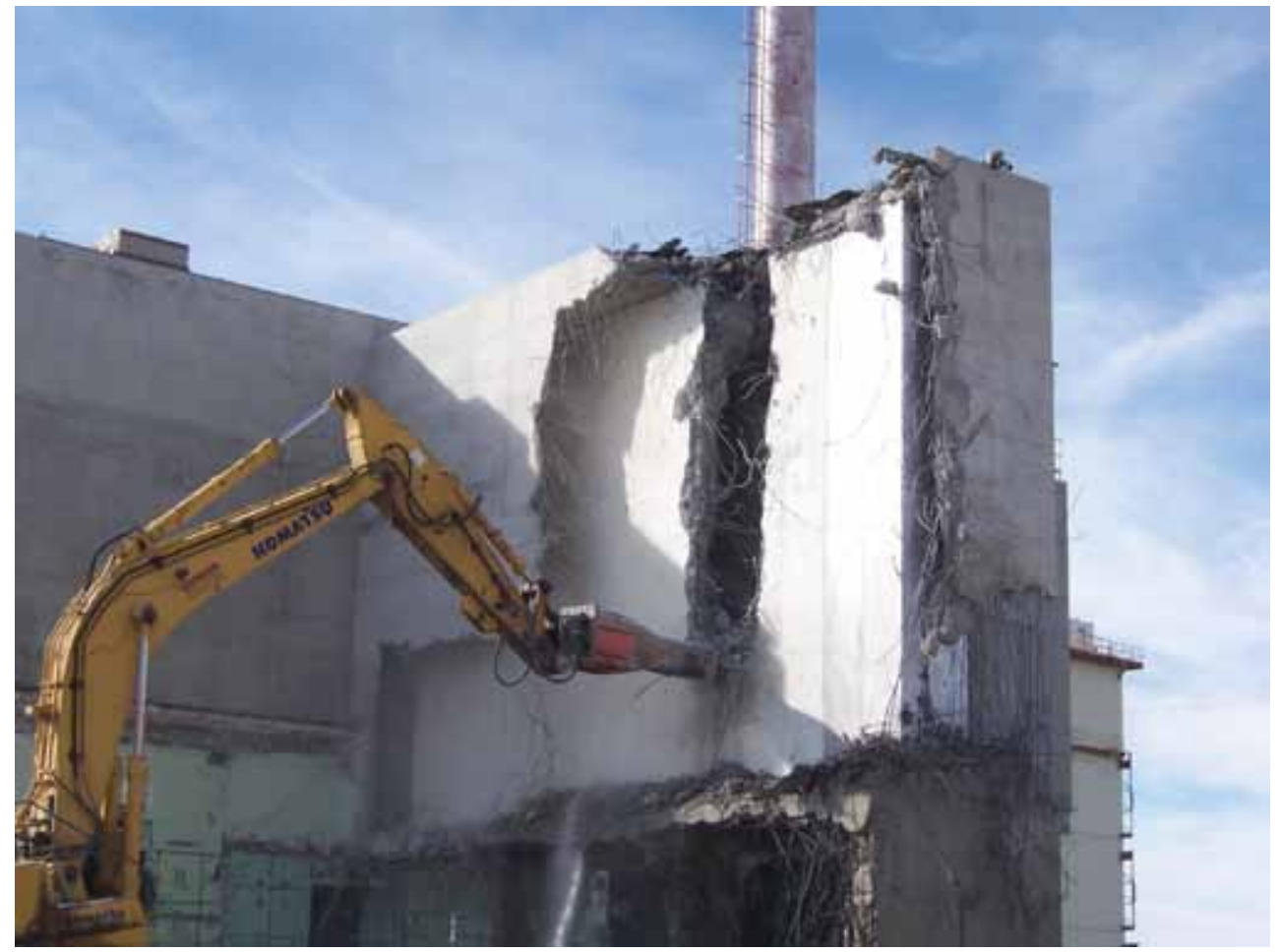

Photograph 7: Demolishing the Mezzanine Shield Door, 01/05/2010

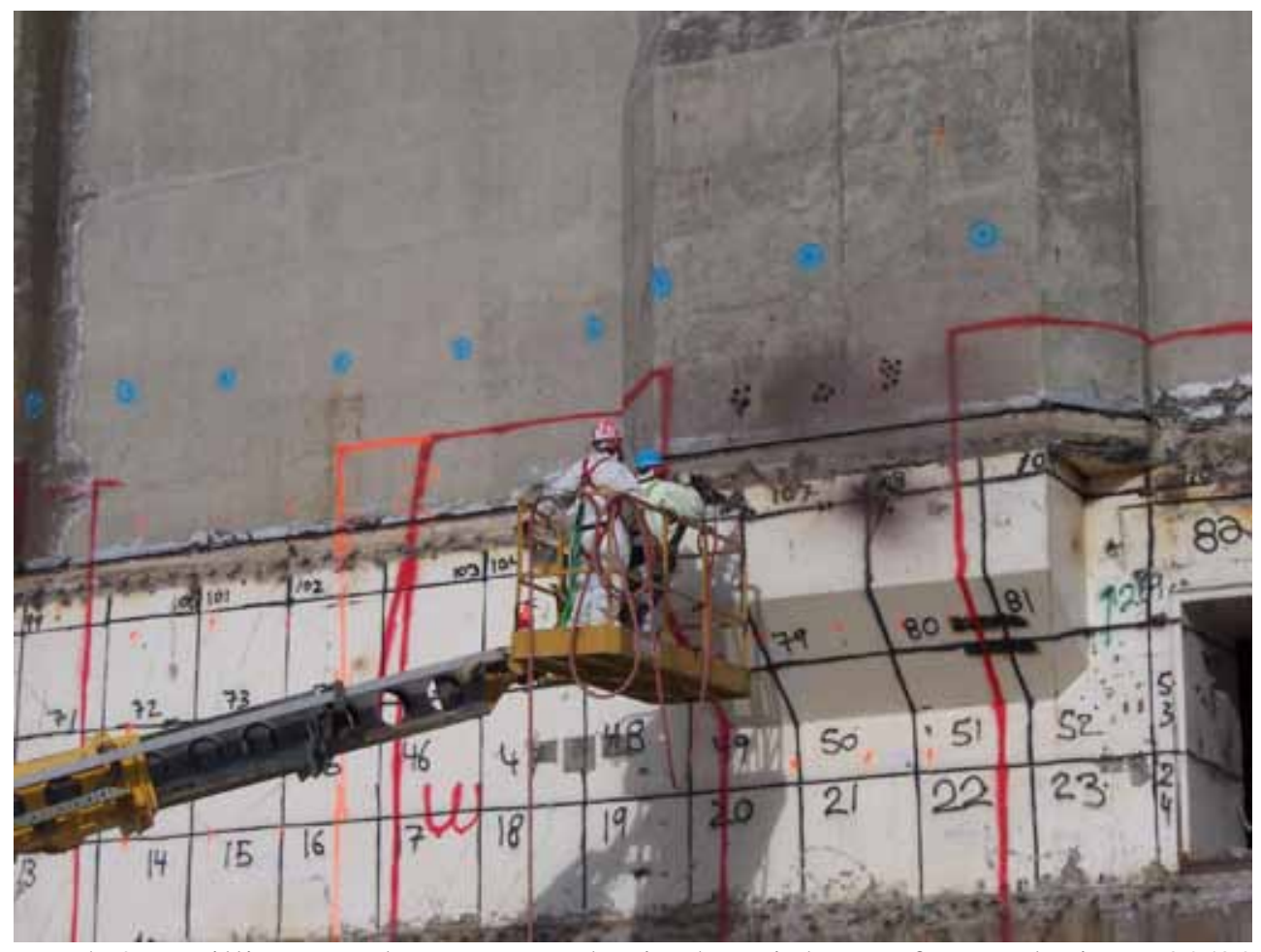

Photograph 8: Drilling Emplacement Holes in the High Bay for Explosives, 02/08/2010 


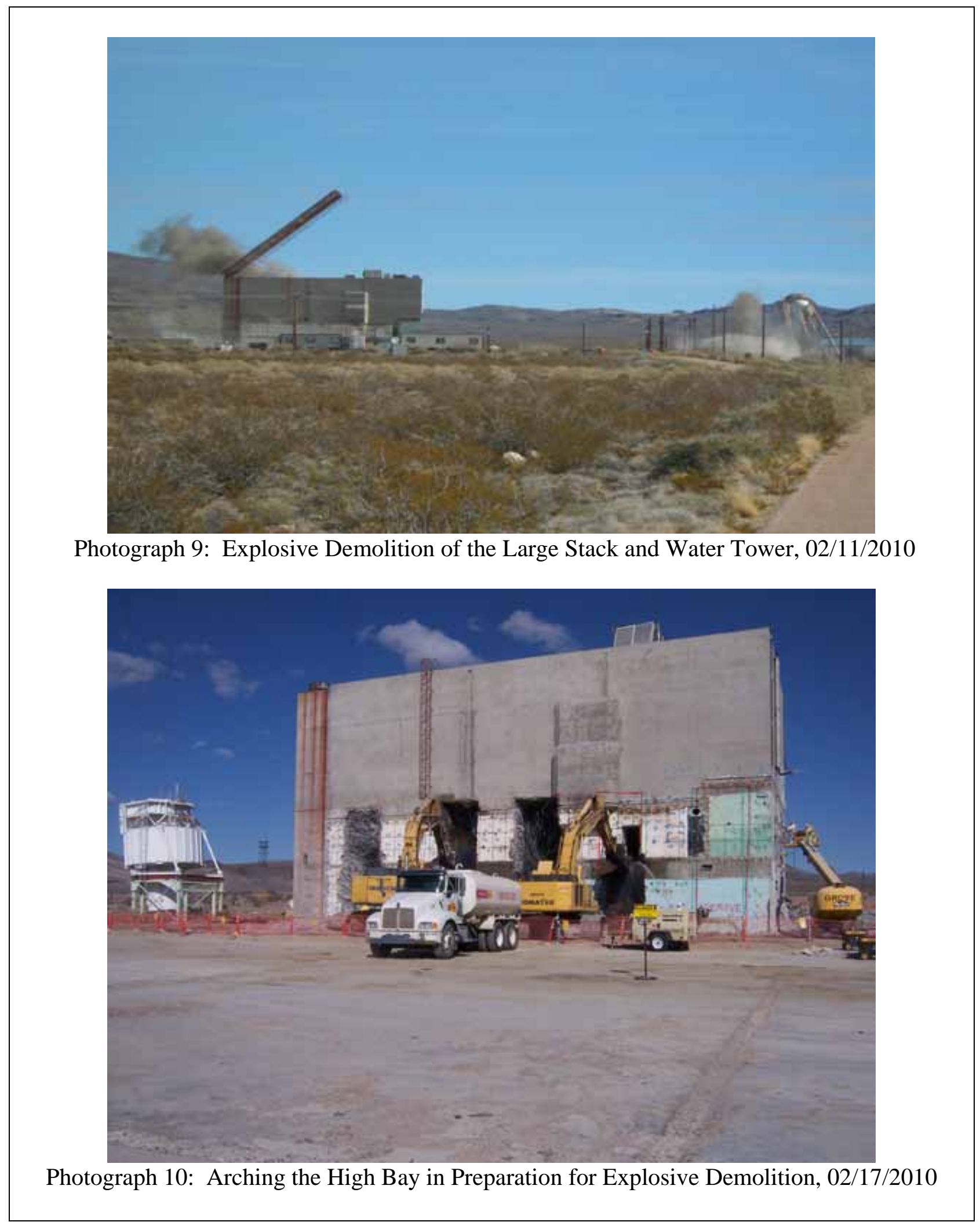




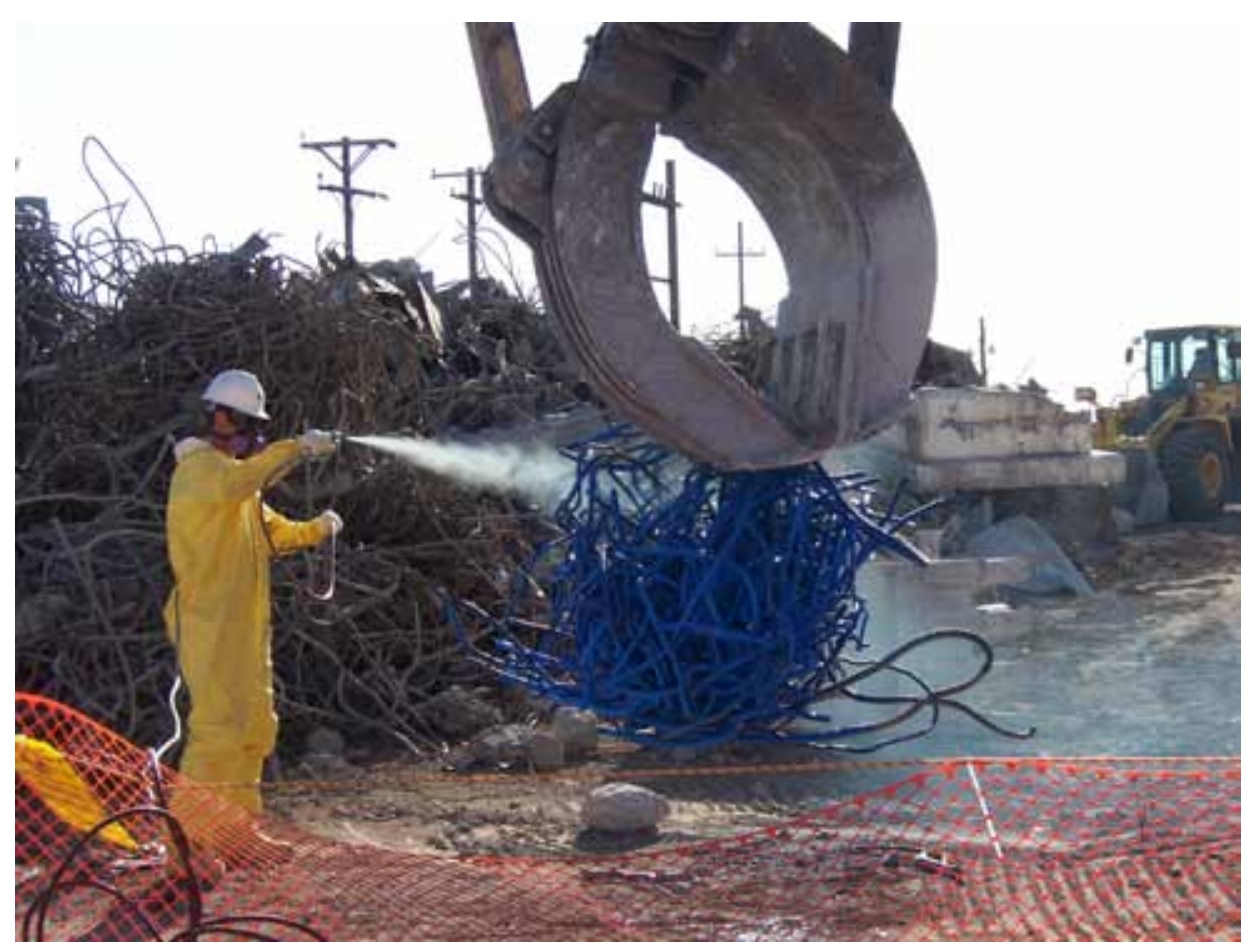

Photograph 11: Spraying Rebar with Fixative, 02/17/2010

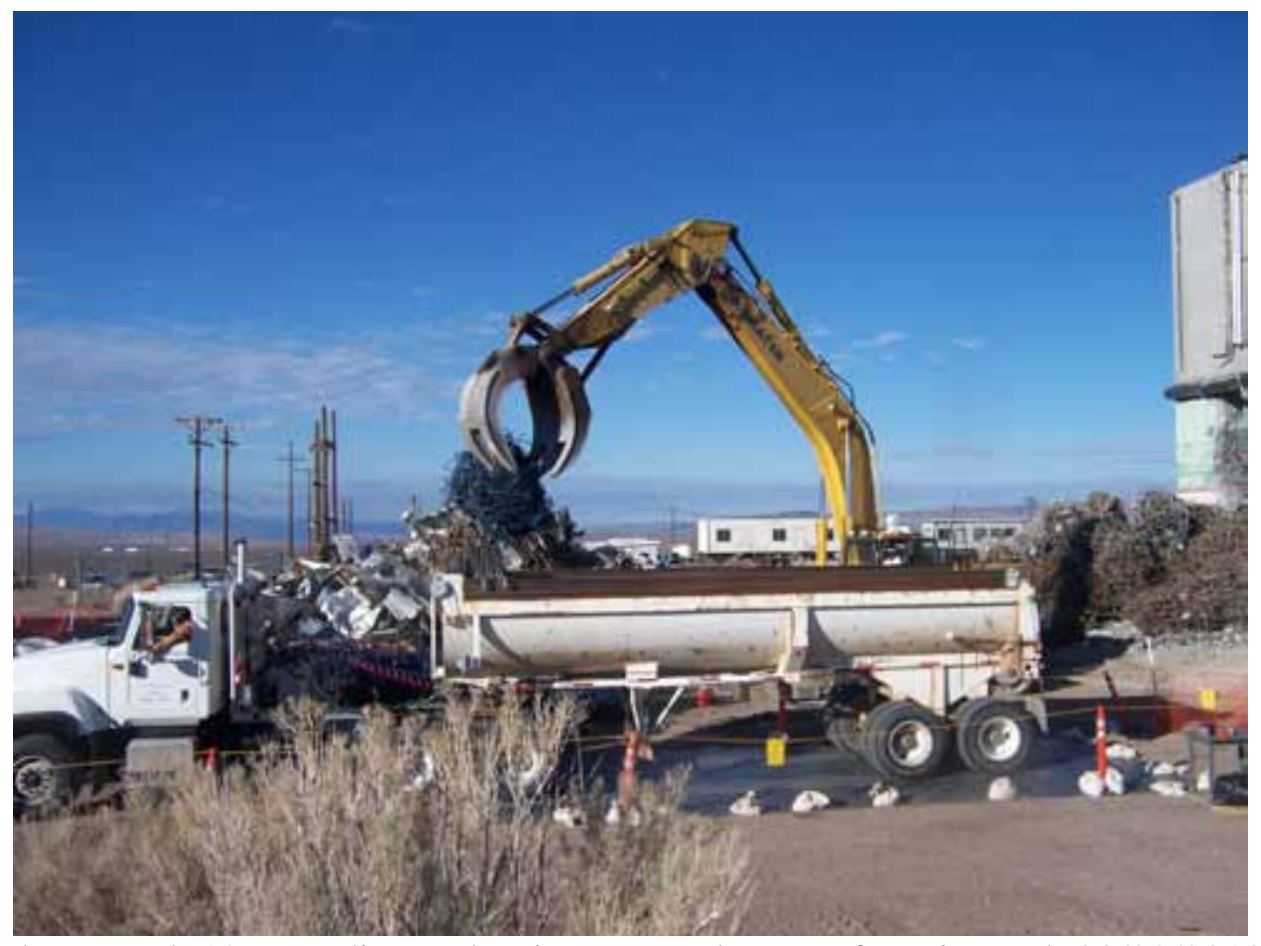

Photograph 12: Loading Rebar into an End Dump for Disposal, 03/02/2010 


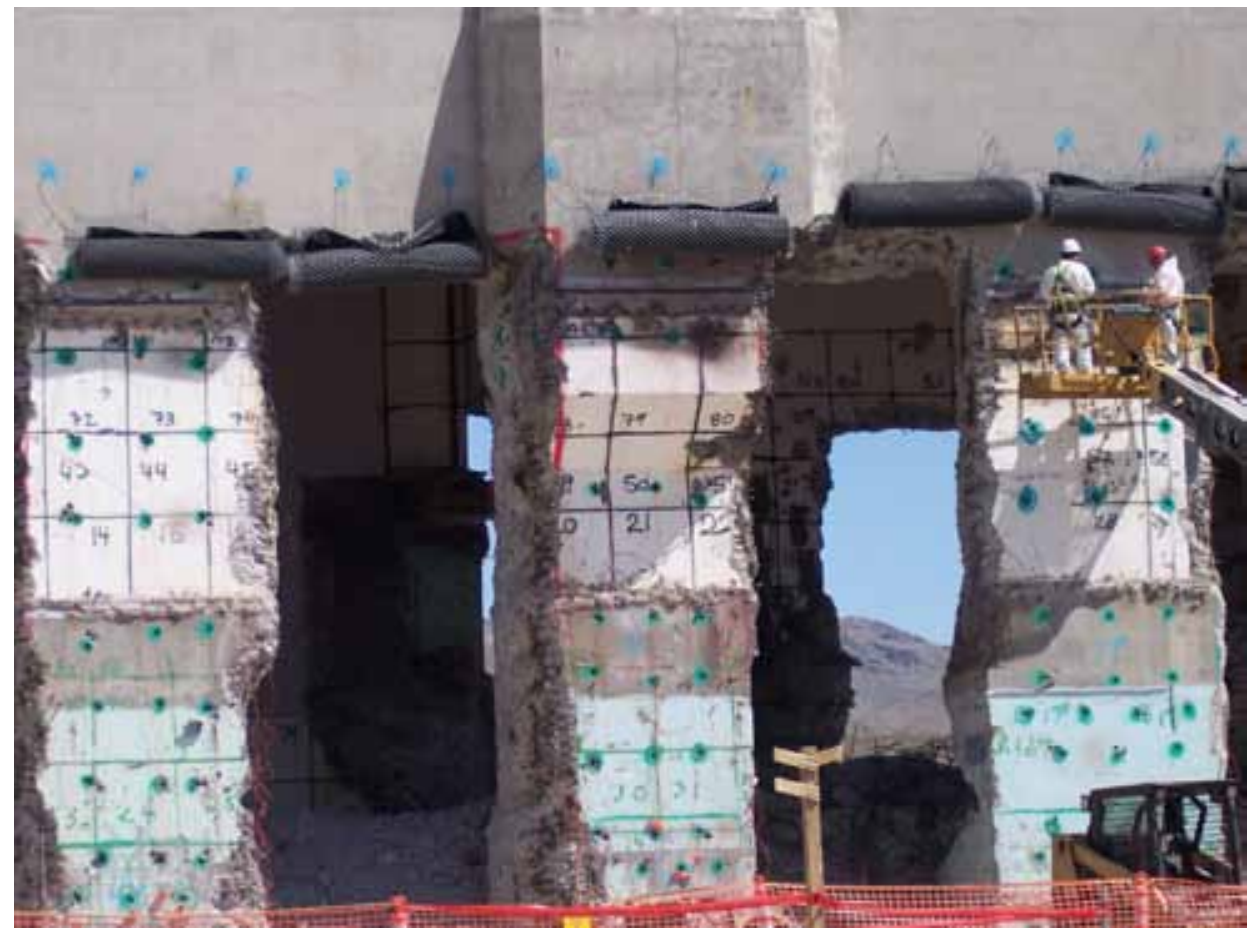

Photograph 13: Loading Explosives for the High Bay, 03/22/2010

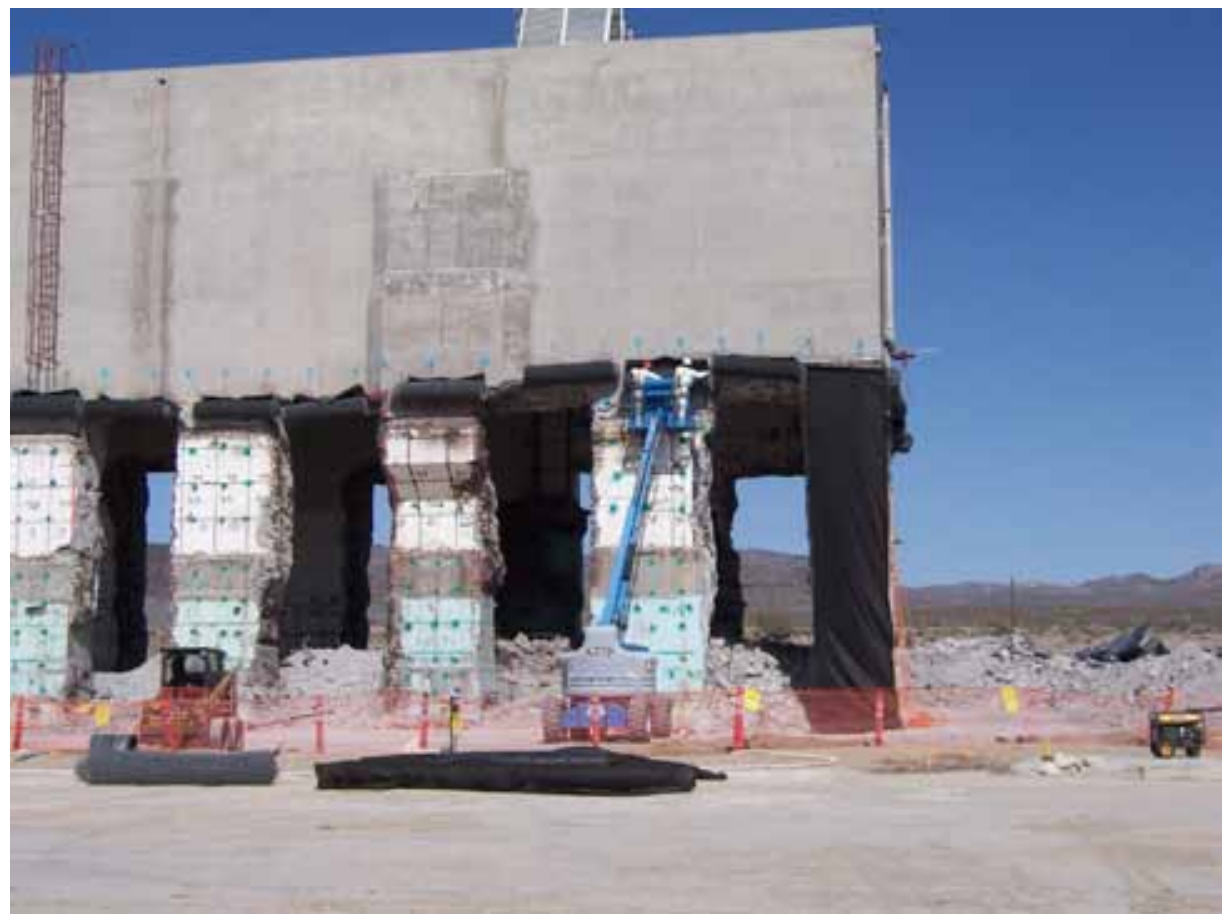

Photograph 14: Installing Geo-Textile Liner and Chain Link Fencing Material to Control Debris during Explosive Demolition, 03/23/2010 


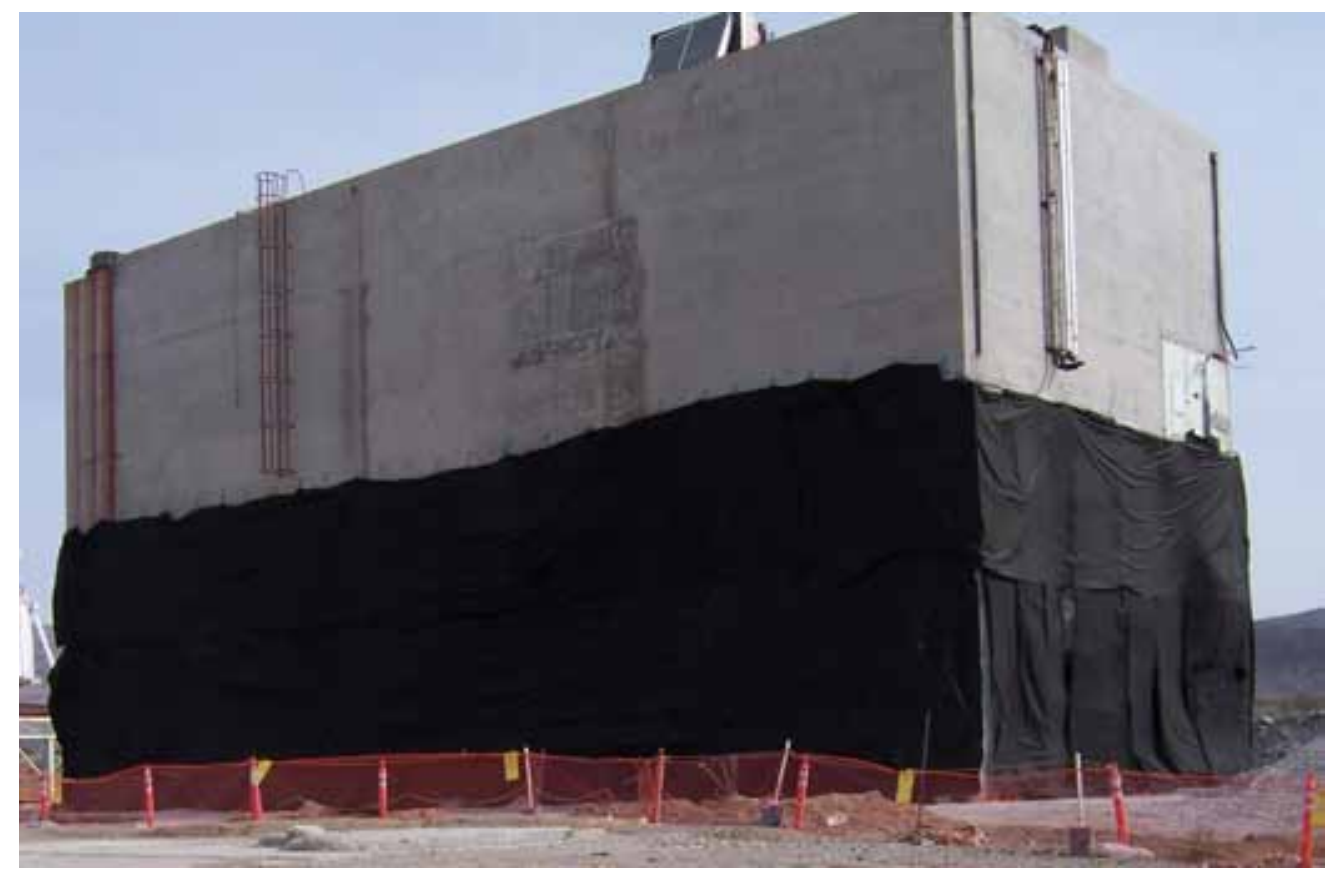

Photograph 15: High Bay before Explosive Demolition, 03/25/2010

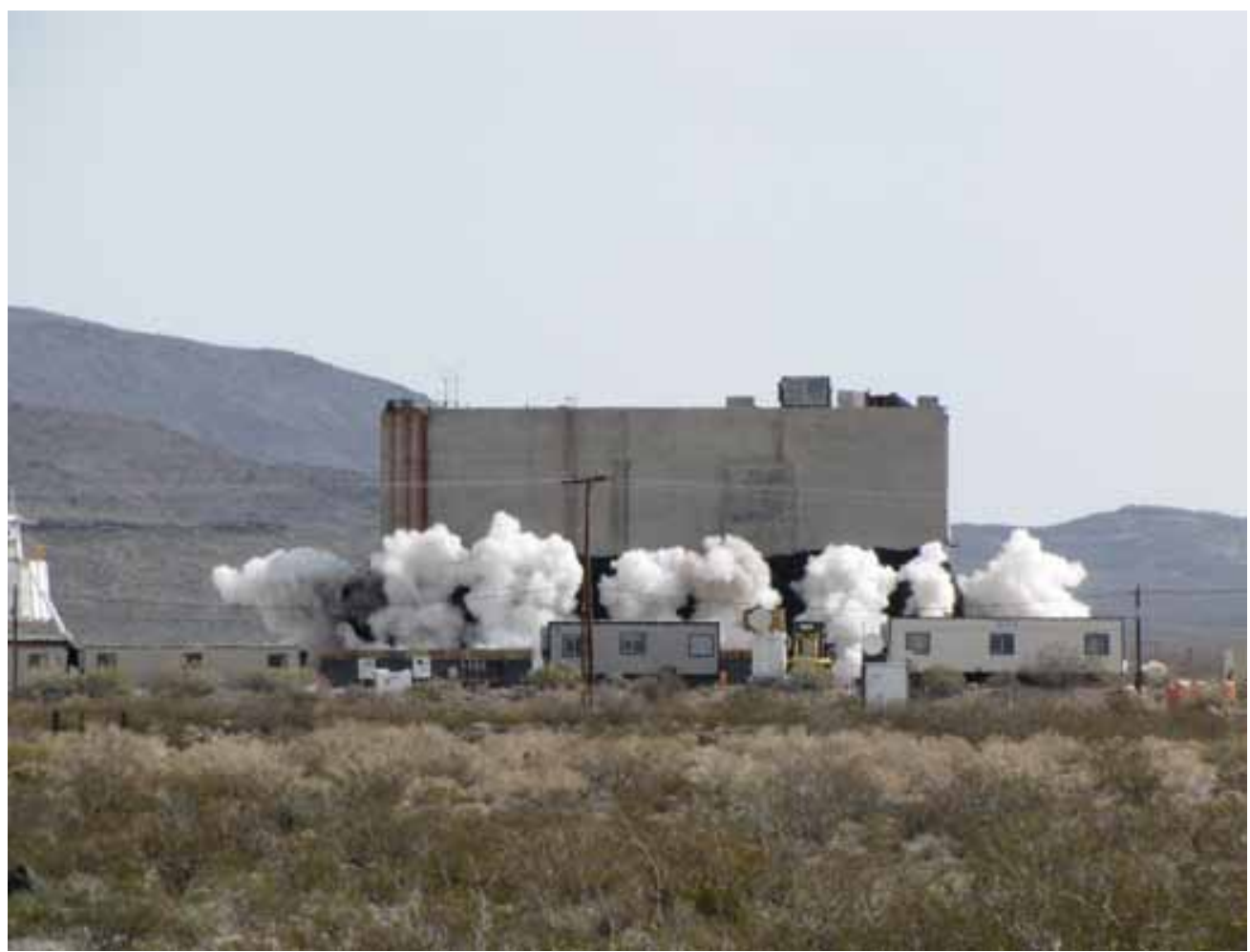

Photograph 16: Lowering the High Bay with Explosives, 03/25/2010 


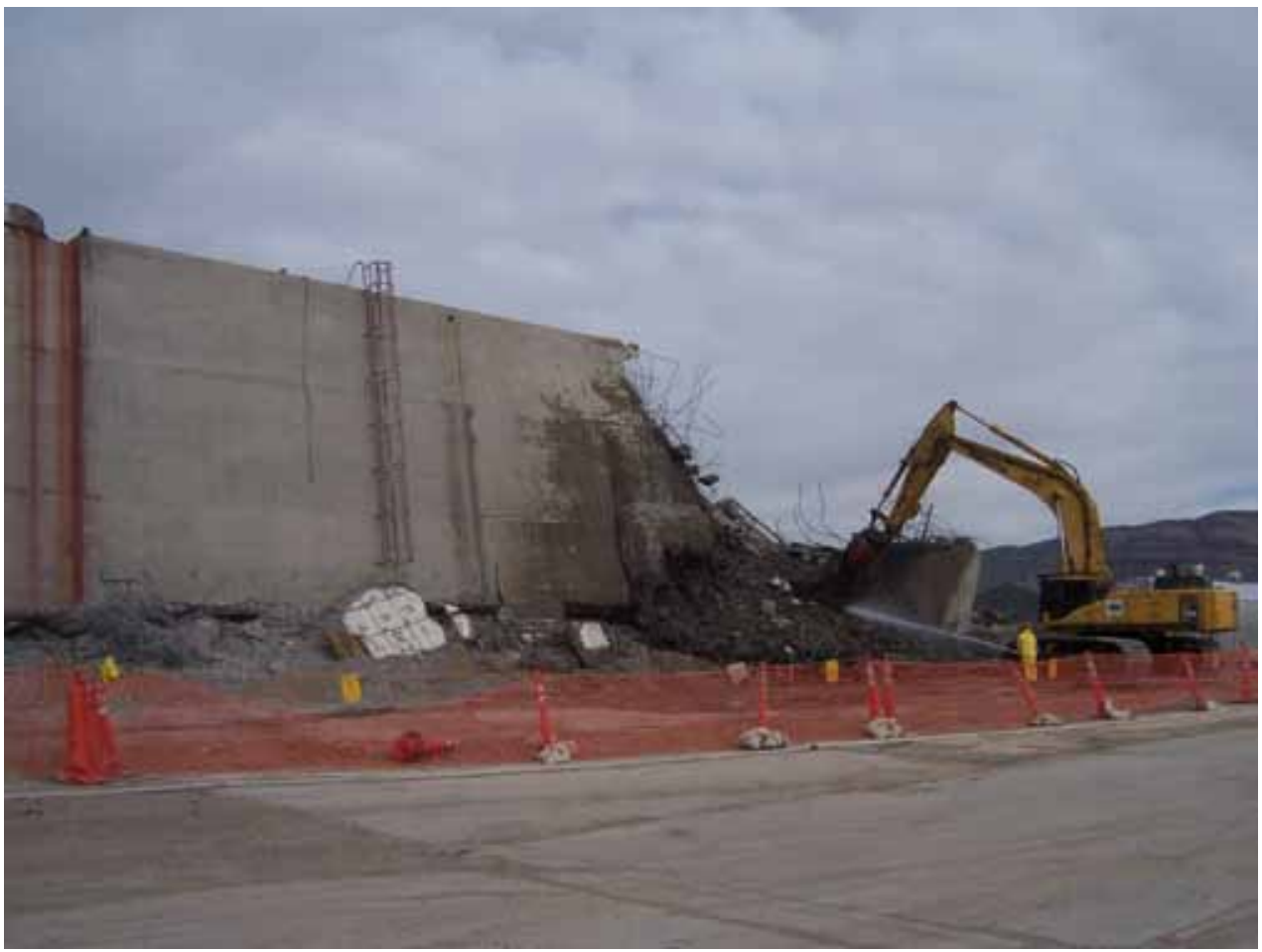

Photograph 17: Size Reducing the High Bay, 03/29/2010

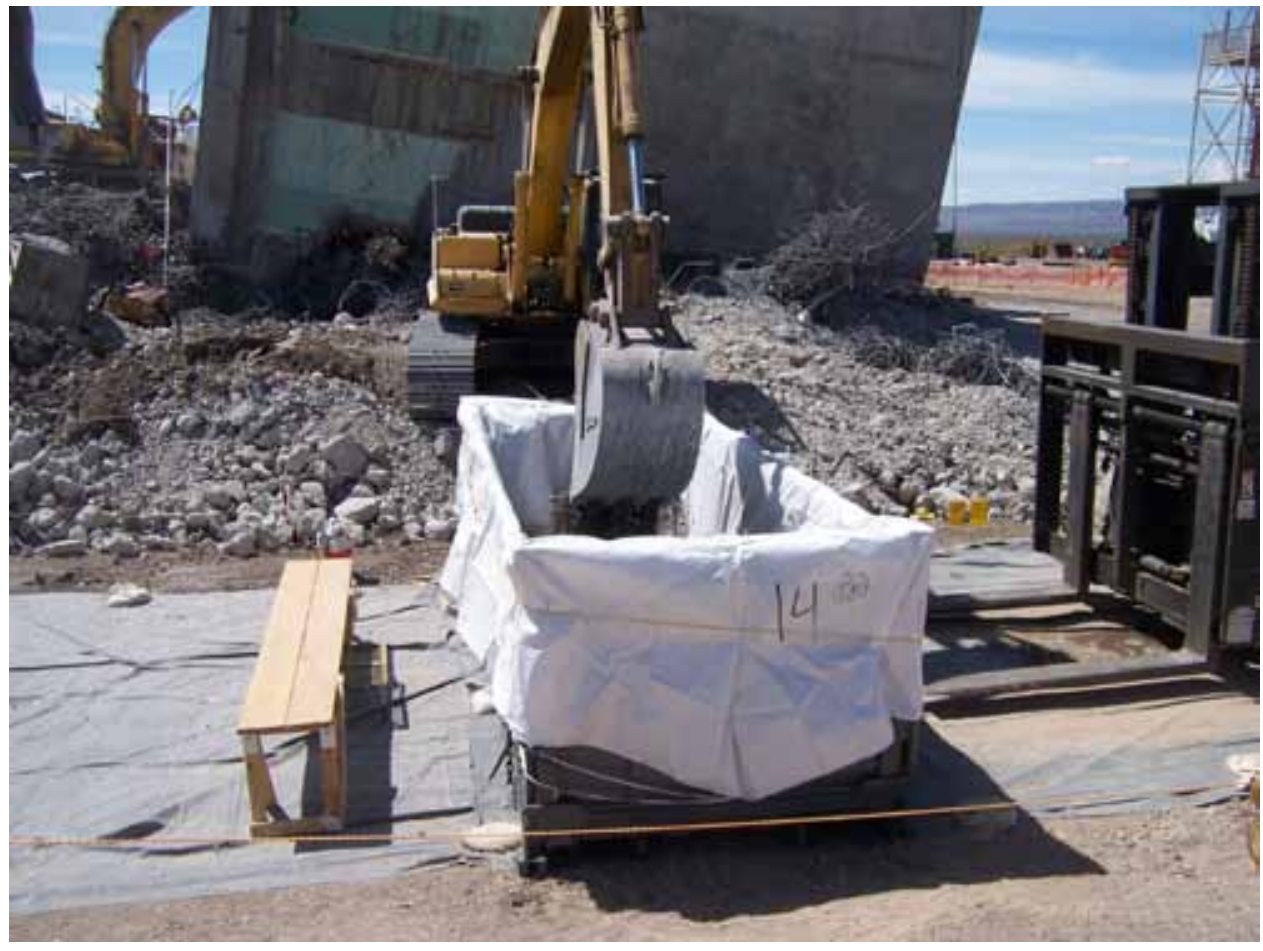

Photograph 18: Loading Debris into a Lined Intermodal for Disposal, 04/01/2010 


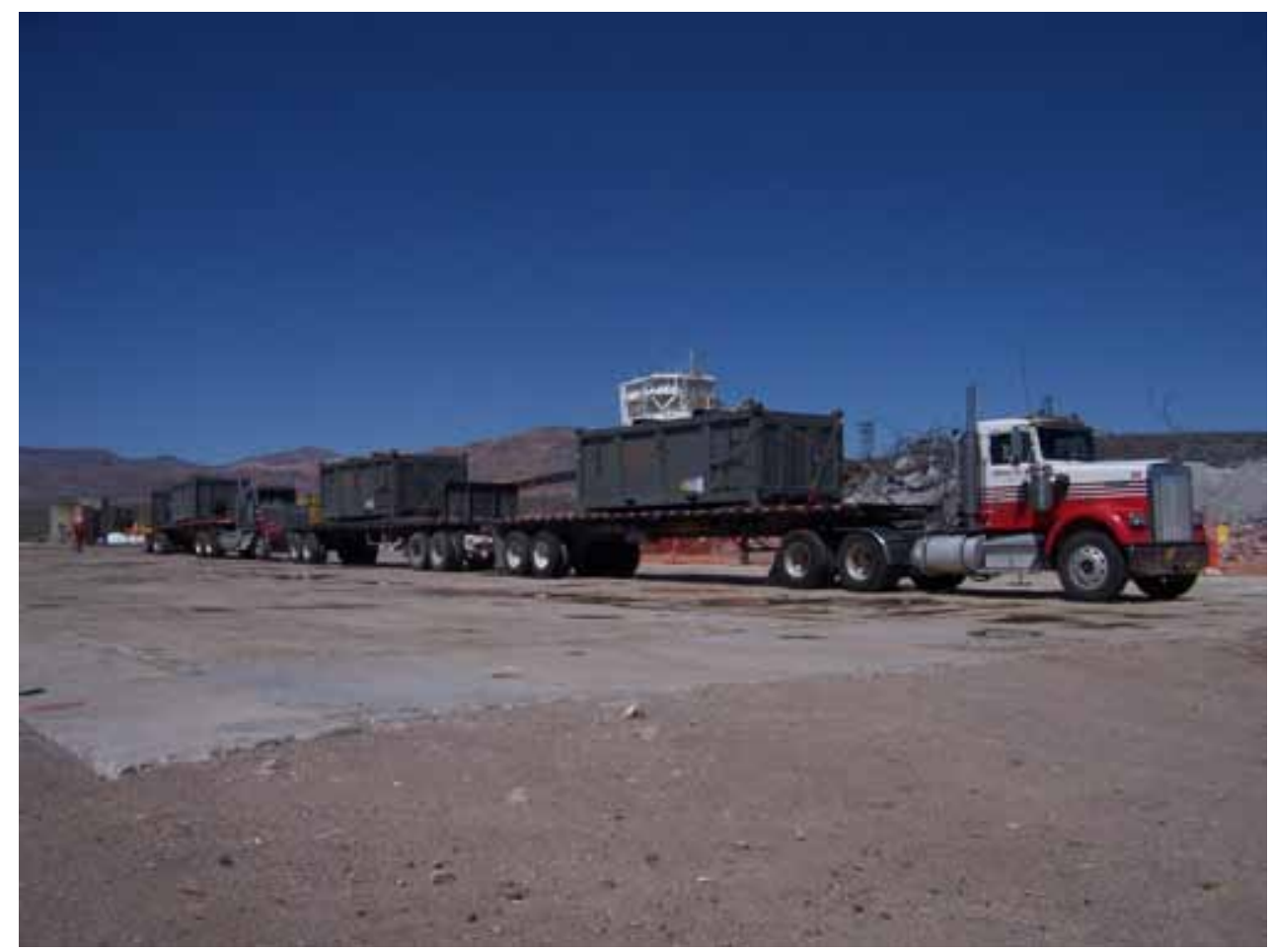

Photograph 19: Debris Packaged in Intermodals, 04/07/2010

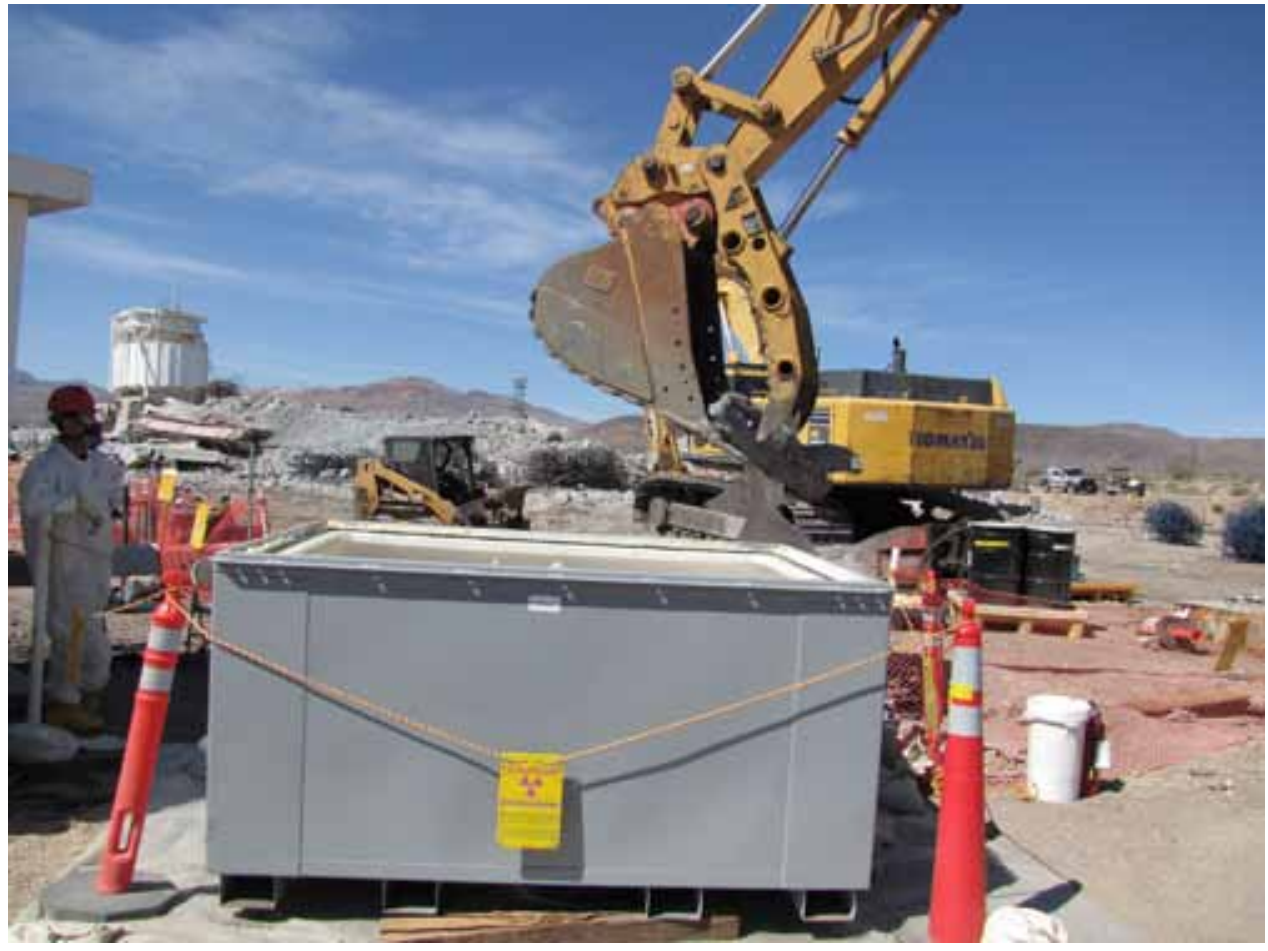

Photograph 20: Loading Lead Mixed Waste into a B-25 Box for Disposal, 05/05/2010 


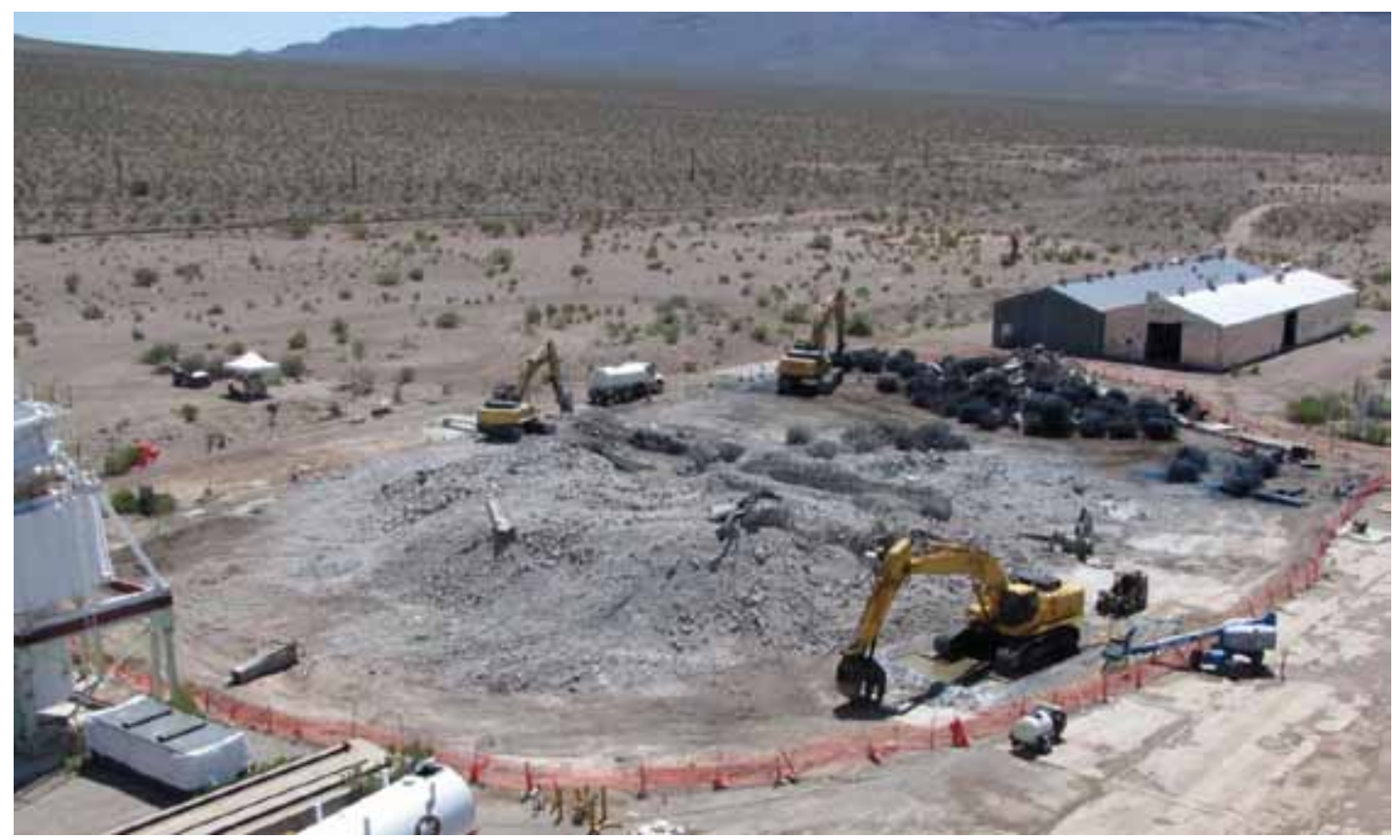

Photograph 21: Overview of the Debris Pile, 05/20/2010

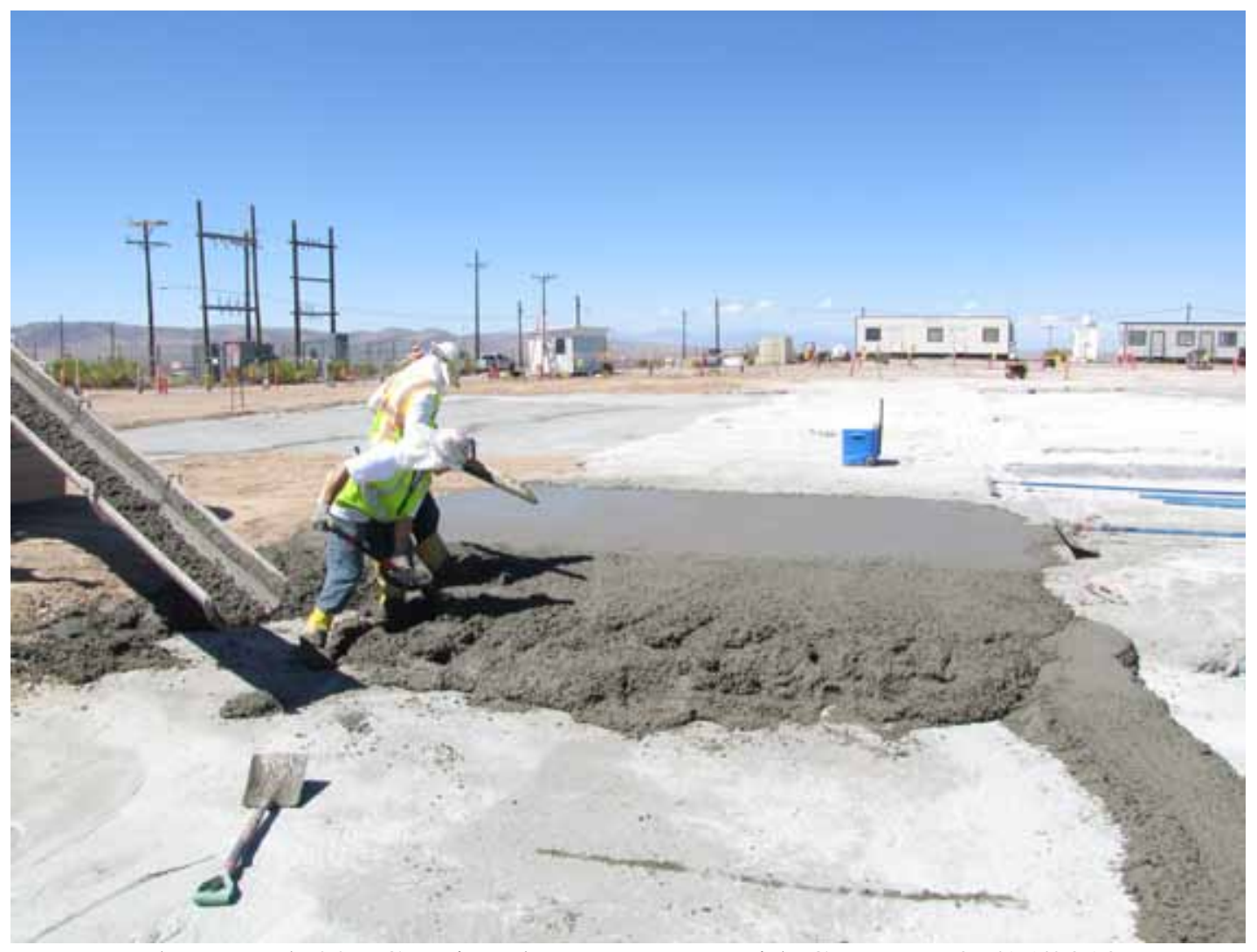

Photograph 22: Capping the Basements with Concrete, 07/15/2010 


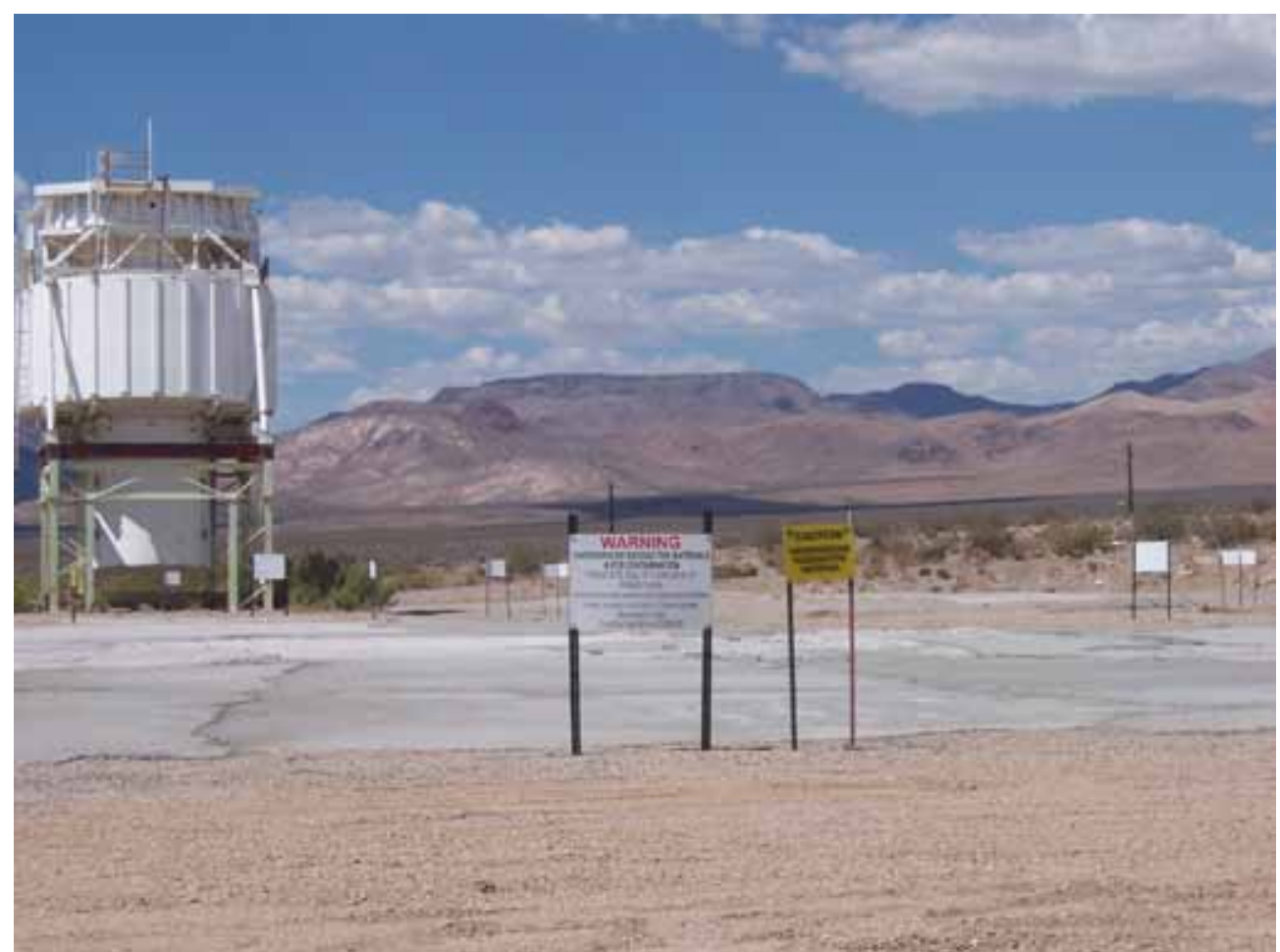

Photograph 23: Use Restriction and Radiological Warning Signs, 08/25/2010

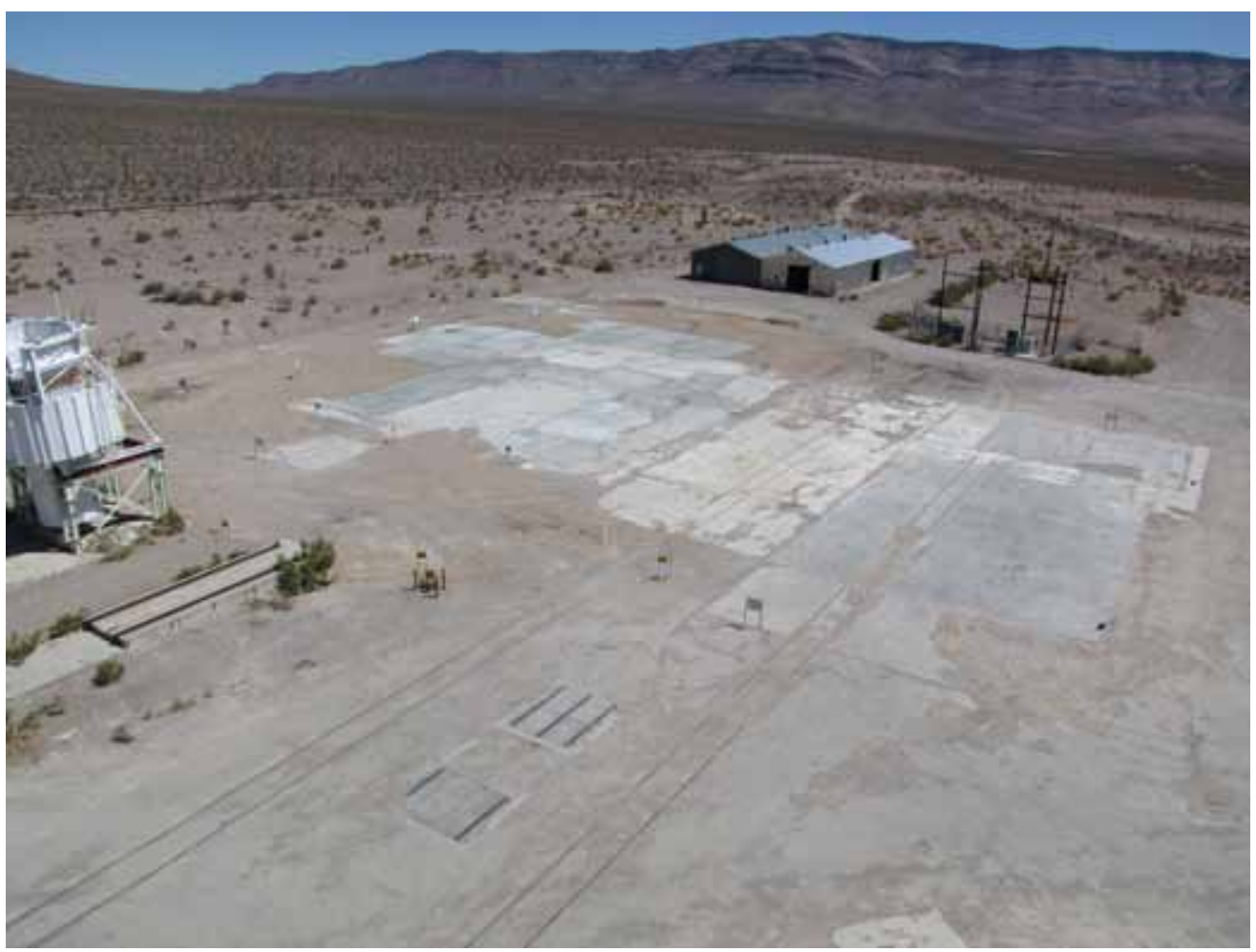

Photograph 24: Site after Field Activities, 08/31/2010 


\title{
APPENDIX B
}

\section{REQUEST TO PERFORM DEMOLITION OF BUILDING 3110 WITHIN THE USE RESTRICTION (UR) FOR CORRECTIVE ACTION UNIT (CAU) 113: AREA 25 R-MAD FACILITY, CORRECTIVE ACTION SITE 25-41-01}

\author{
AND
}

NDEP APPROVAL LETTER 
Addendum to CAU $113 \mathrm{CR}$

Revision: 0

Date: February 2011

THIS PAGE INTENTIONALLY LEFT BLANK 
Department of Energy

National Nuclear Security Administration

Nevada Site Office

P.O. Box 98518

Las Vegas, NV 89193-8518

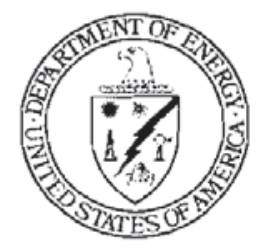

SEP 302009

Tim Murphy, Chief

Bureau of Federal Facilities

Division of Environmental Protection

2030 East Flamingo Road, Suite 230

Las Vegas, NV 89119-0818

REQUEST TO PERFORM DEMOLITION OF BUILDING 3110 WITHIN THE USE RESTRICTION (UR) FOR CORRECTIVE ACTION UNIT (CAU) 113: AREA 25 R-MAD FACILITY, CORRECTIVE ACTION SITE 25-41-01

Previous closure activities performed at CAU 113 addressed removal of hazardous materials and accessible radiological contamination. However, radiological, polychlorinated biphenyl (PCB), and lead contamination remain in various rooms in Building 3110. Several recessed areas and penetrations into the concrete walls and floors throughout Building 3110 contain residual radioactive contamination that could not be removed. Access to these penetrations is restricted. Since the potential exists for intrusive activities to mobilize contamination, a UR was implemented for all of Building 3110 to minimize future potential exposure or mobilization of contaminants, and all intrusive activities throughout Building 3110 are prohibited. Permission is being requested to perform demolition of Building 3110 . The attached summary provides additional detail on the use restricted areas in Building 3110.

Building 3110 and the associated water tower will be demolished. Some of the demolition debris will be placed in the basement, and the basement will be capped with concrete. Demolition debris that does not fit in the basement will be packaged and disposed appropriately. The UR will remain in place, and the area will be reposted per Federal Facility Agreement and Consent Order requirements for radiological, PCB, and lead contamination. Annual inspections will continue to be performed to verify the postings are in good condition and the UR is maintained. Permission is requested to perform this work within the boundary of the CAU 113 UR.

Please direct comments and questions to Kevin J. Cabble at (702) 295-500ฏ.

ERP:5718.TL

/s/: Robert F. Boehlecke

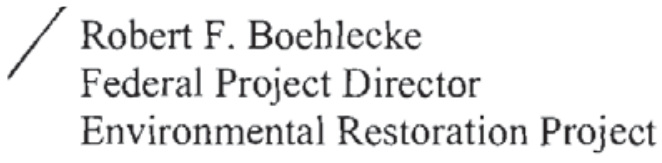

Enclosure:

As stated 
cc w/encl.:

J. J. MacDougall, NDEP, Las Vegas, NV (2 electronic copies)

T. A. Thiele, NSTec, Las Vegas, NV

M. J. Krauss, SNJV, Las Vegas, NV

cc w/o encl.:

J. A. Wong, NDEP, Las Vegas, NV

J. T. Fraher, DTRA/CXTS, Kirtland AFB, NM

NSTec Technical Information Officer, Las Vegas, NV

NSTec Correspondence Control, MS NLV008

T. D. Taylor, SNJV, Las Vegas, NV

K. J. Cabble, ERP, NNSA/NSO, Las Vegas, NV

E. F. Di Sanza, WMP, NNSA/NSO, Las Vegas, NV

FFACO Group, PSG, NNSA/NSO, Las Vegas, NV

NNSA/NSO Read File 


\section{SUMmaRy OF USE RESTRICTED AREAS IN BUILDING 3110}

Radiological, PCB, and lead contamination is present in the concrete foundation and walls in various rooms in Building 3110. Access to these areas has been restricted, and these areas have been posted to communicate applicable hazards. These areas include the following:

- Access to a portion of Basement Room 6, which is located near the southeast corner of the facility and houses the hydraulic rams used to raise and lower the shielding doors, was restricted by capping the floor with concrete and installing a sheet metal wall. Areas inside the enclosure contain fixed and removable contamination within the recessed areas of the shielding doors, on the surface of the hydraulic rams supporting the shielding doors, and within the penetrations into the walls and ceilings. The two hydraulic rams that support the shielding doors are classified as PCB Articles. These items were flushed. The sumps for each hydraulic ram were filled with concrete to a height of approximately 18 inches above the floor. The enclosure was posted for radiological and PCB contamination.

- Basement Room 7, located on the southeast corner of the facility, contains fixed and removable contamination within the recessed areas of the shielding doors, hydraulic rams, and within the penetrations into the floors, walls, and ceilings. The hydraulic rams that support the shielding doors are classified as PCB articles. These items were flushed. The hydraulic rams and shielding doors were encapsulated by sheet metal and posted for radiological and PCB contamination. Penetrations into the floor, walls, and ceiling throughout the room were capped or filled and posted for radiological contamination.

- The contaminated HEPA/HVAC ducts in the concrete walls and recessed areas of the Postmortem Cells were covered with sheet metal and posted to communicate radiological hazards. Additionally, penetrations around the perimeter walls contain contaminated cylindrical steel inserts that were tack-welded in place and in most cases, covered with sheet metal.

- Penetrations in the Lower Disassembly Bay and Mezzanine, located on the northeast corner and center of the building, respectively, contain fixed contamination in the interior portions. These penetrations were covered with sheet metal and posted to communicate radiological hazards.

- Removable contamination is present in the sub grade vault in Room 121, located on the northeast corner of Building 3110 . The vault was covered with a steel grate and posted to communicate radiological hazards. A portion of the track under the door cannot be accessed and may also contain radiological contamination above release criteria.

- Access to the Shielding Door Control Room that houses the shielding door that separates the Lower Disassembly Bay from the Mezzanine was restricted by welding both access doors closed. The area was posted to communicate radiological hazards. Potentially PCBimpacted grease is located on the rollers underneath the door.

- Fixed and removable contamination is present in the sub-grade access tunnel that leads approximately 30 feet into the Lower Disassembly Bay from the Lower Gallery Viewing Area. The door to this access tunnel was welded shut and posted to communicate radiological hazards. 


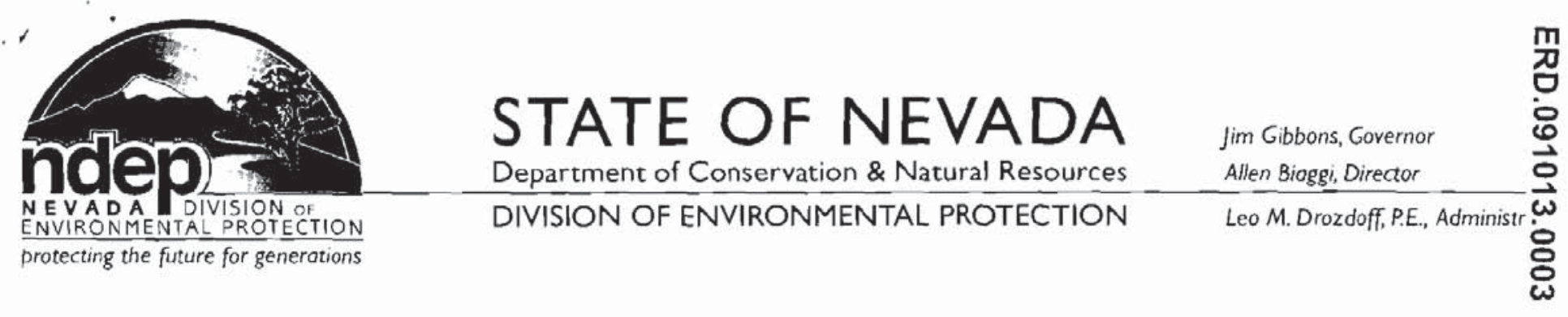

October 8, 2009

Robert F. Boehlecke

Federal Project Director

Environmental Restoration Project

National Nuclear Security Administration

Nevada Site Office

P. O. Box 98518

Las Vegas, NV 89193-8518

RE: Request to Perform Demolition of Building 3110 Within the Use Restriction (UR) For Corrective action Unit (CAU) 113: Area 25 R-MAD Facilty, Corrective Action Site 2541-01

Dear Mr. Boehlecke,

The Nevada Division of Environmental Protection, Bureau of Federal Facilities (NDEP) staff has received and reviewed the subject request to perform demolition of RMAD Building 3110 . The request, which indicates that the use restriction at CAU 113 will be maintained and the area reposted after demolition, is approved as it does not conflict with conditions identified in the approved closure report (NNSA/NSO, April 2003).

NDEP understands that in completing the demolition of Building 3110 , the majority of demolition debris will be placed in the basement of the facilty and capped with concrete. NNSA/NSO will also perform annual inspections to ensure that postings and use restrictions remain in place at CAU 113.

If you have any questions regarding this matter, contact Jeff MacDougall, at 702-486-2850 ext 233 or John Wong at ext 245.

Sincerely,

T. H. Murphy

Chief

Bureau of Federal Facilities
ACTION

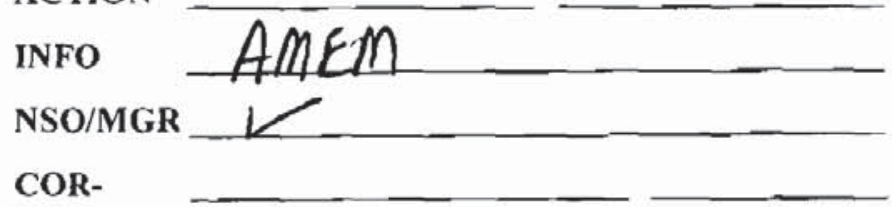

File Code 
Robert F. Boehlecke

Page 2

October 8, 2009

\section{THM/JJM/jaw}

cc: $\quad$ K. J. Cabble, ERP, NNSA/NSO, Las Vegas, NV

E.F. Di Sanza, WMP, NNSA/NSO, Las Vegas, NV

FFACO Group, PSG, NNSA/NSO, Las Vegas, NV

J.T Fraher, DTRA/CXTS, Kirtland AFB, NM 
Addendum to CAU $113 \mathrm{CR}$

Revision: 0

Date: February 2011

THIS PAGE INTENTIONALLY LEFT BLANK 


\section{APPENDIX C}

\section{FINAL HYDRAULIC FLUID SPILL REPORT,}

\section{TOTAL PETROLEUM HYDROCARBON VERIFICATION SAMPLE RESULTS,}

AND

NDEP APPROVAL LETTER 
Addendum to CAU $113 \mathrm{CR}$

Revision: 0

Date: February 2011

\section{THIS PAGE INTENTIONALLY LEFT BLANK}




\section{Hydraulic Fluid Spill, Area 25 \\ NDEP Spill No. 0100104-05 \\ Final Spill Report}

August 31, 2010

Prepared for:

U.S. Department of Energy

National Nuclear Security Administration

Nevada Site Office 


\section{Table of Contents}

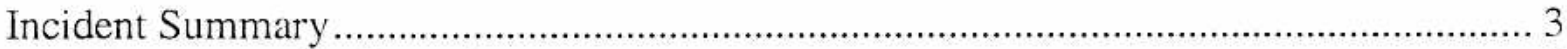

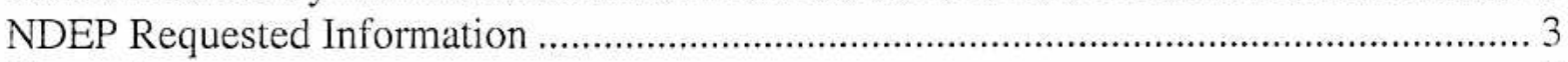

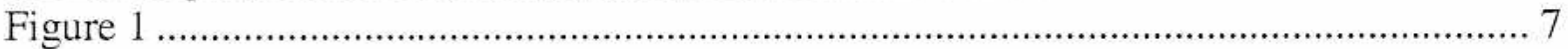

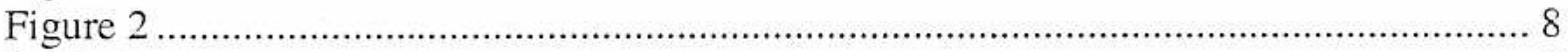

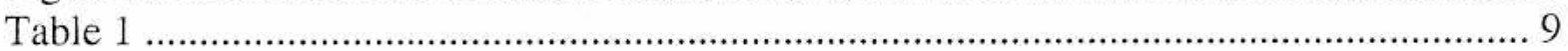

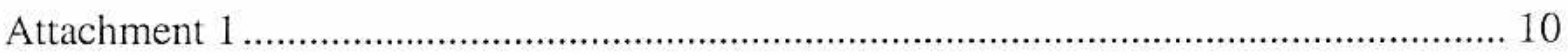




\title{
Hydraulic Fluid Spill, Area 25 RMAD Facility
}

\author{
NDEP Spill No. 0100104-05 \\ FINAL SPILL REPORT
}

Incident Summary

On January 4, 2010, an estimated 100 gallons of hydraulic fluid was released from an excavator. The excavator has a hydraulic reservoir that can hold 100 gallons of fluid, and it was found to be empty after the incident. The excavator was being used for demolition of the RMAD Facility in Area 25. The spill was reported to the Nevada Division of Environmental Protection (NDEP) on January 4, 2010. NDEP assigned Spill No. 0100104-05.

The excavator was on a debris ramp at the demolition site of the Area 25 RMAD Facility. As the excavator began to move off of the debris ramp a large piece of rubble became caught under the machine breaking a main hydraulic line that caused the contents of the reservoir to be released. The hydraulic fluid spilled onto the debris ramp and onto the ground below, which was partially paved with asphalt. Soil was affected to an approximate depth of 6 inches.

On January 6, 2010 there was a window of opportunity to clean up the debris ramp and soil that was affected by the spill. There were approximately $4 \frac{1}{2}$ cubic yards of this material, including demolition debris and soil excavated. All soil observed to be contaminated was removed in the clean-up effort. To avoid delaying the project, demolition continued, and sampling of the affected area was not completed at the time.

The project is now complete, the debris ramp removed, and samples of the affected area were collected on August 4, 2010.

In a letter dated January 27,2010, NDEP requested the following specific information pertaining to the spill.

\section{Description of the Spill/Release of Hazardous or Regulated Substances}

A. Type of material released into the environment;

The released material was hydraulic fluid.

B. Quantity or volume of the material released (metered or estimated);

The estimated quantity of hydraulic fluid released is 100 gallons. This is the amount of fluid the reservoir can hold, according to the manufacturer.

C. Date and time of release;

The release occurred on January 4, 2010, at approximately 1:00 pm. 
D. Cause of the release/spill;

A hydraulic line on the excavator was punctured by a piece of building rubble.

E. Distance to and location of the closest well or reservoir used for drinking water purposes;

The nearest drinking water supply is Well J-12, approximately 15 kilometers ( 9 miles) southeast of the site.

F. Township, Range and Section (Longitude and Latitude if cadastral survey is not available) of contaminated site;

Coordinates for the site are $36^{\circ} 48^{\prime} 54^{\prime \prime} \mathrm{N} 116^{\circ} 14^{\prime} 22^{\prime \prime} \mathrm{W}$.

G. A site map, which depicts the general location of the site;

Figure 1 shows a map of the site.

H. A plot plan that depicts drainage features and structures, underground utilities, roadways and right-of-ways, and spill surface area boundaries and owners(s) of record of any affected properties, include location of nearest electrical distribution transformer (pole or pad mounted);

Figure 1 shows structures, drainage features and spill boundaries. All affected property is owned by NNSA/NSO. The site has no active power lines, and therefore no electrical distribution transformers. The nearest active transformer is approximately 1.9 miles to the southwest.

I. Description/identification and location of any threatened, endangered, or sensitive plant or animal species in the area, that may have been or may be impacted by the release;

A survey of the area was performed prior to the commencement of activities and no threatened, endangered, or sensitive plants or animal species were found.

2. Description of action that will be taken or completed:

A. Soil testing laboratory, test method and results;

a. Results of EPA Method 8015 Modified (or equal), if petroleum products were released to the environment;

After removal of the debris ramp, samples were collected on August 4, 2010. Three samples were collected and analyzed (Figure 2). All samples collected had less than $100 \mathrm{mg} / \mathrm{kg}$ petroleum hydrocarbon contamination.

b. Results of EPA Method 8260 (or equal), if the contamination present is either petroleum hydrocarbons or volatile organic compounds;

The Total Petroleum Hydrocarbons (TPH) chromatogram confirms no volatile organic compounds were present. 
c. Results of EPA Method 624 (or equal), if contamination is encountered at the water table or if waste/used oil is the source of the spill;

Ground water was not affected.

d. Results of "Toxicity Characteristic Leaching Procedure" (TCLP) for the parameters of cadmium, chromium, lead, mercury, arsenic, barium selenium and silver, if waste/used oil is the source of the release or spill; or if preliminary screening indicates that heavy metal may be present;

Not applicable.

e. Results of EPA Method 8080 (or equal), if contaminated area may contain organochlorine pesticides or polychlorinated biphenyls;

Not applicable. The affected area does not contain pesticides or PCBs.

f. Depth to ground water;

Groundwater is approximately $225 \mathrm{~m}(739 \mathrm{ft})$ below ground surface.

g. General lithology of the contaminated area;

The contaminated area consists of native soil with some asphalt pavement.

h. Plot plan which depicts the identification, EPA test method(s), location and depth of any sampling and analysis, including "confirmation" procedures . . confirmation sampling and analysis is required upon completion of any remediation activities;

Figure 2 shows confirmation sample locations. Table 1 contains information on depth of samples and EPA test methods.

B. Description of completed or proposed abatement, containment and other remediation methods;

Soil was initially excavated to a depth of 6 -inches and all of the rubble that was stained was removed.

C. Soil, ground water and air monitoring methods and results, including confirmation sampling and analysis;

A total of three confirmation samples were collected and analyzed for TPH using Methods $3550 \mathrm{~B}$ and M8015D. Analytical results for all sample locations were below the thresholds set forth in NAC 445A. Table 1 shows summary results. Attachment 1 contains the laboratory data report.

D. Measures taken to correct and prevent the recurrence of this incident;

The operator perform a visual inspection of the area to ensure that there are no large pieces of rubble under the equipment or in the path of the equipment that could affect the equipment hydraulic system prior to further movement of equipment on the debris ramp. 


\section{E. Description of proposed remediation plans;}

All contaminated debris and soils have been removed; thus no additional remediation is planned. 
Figure 1

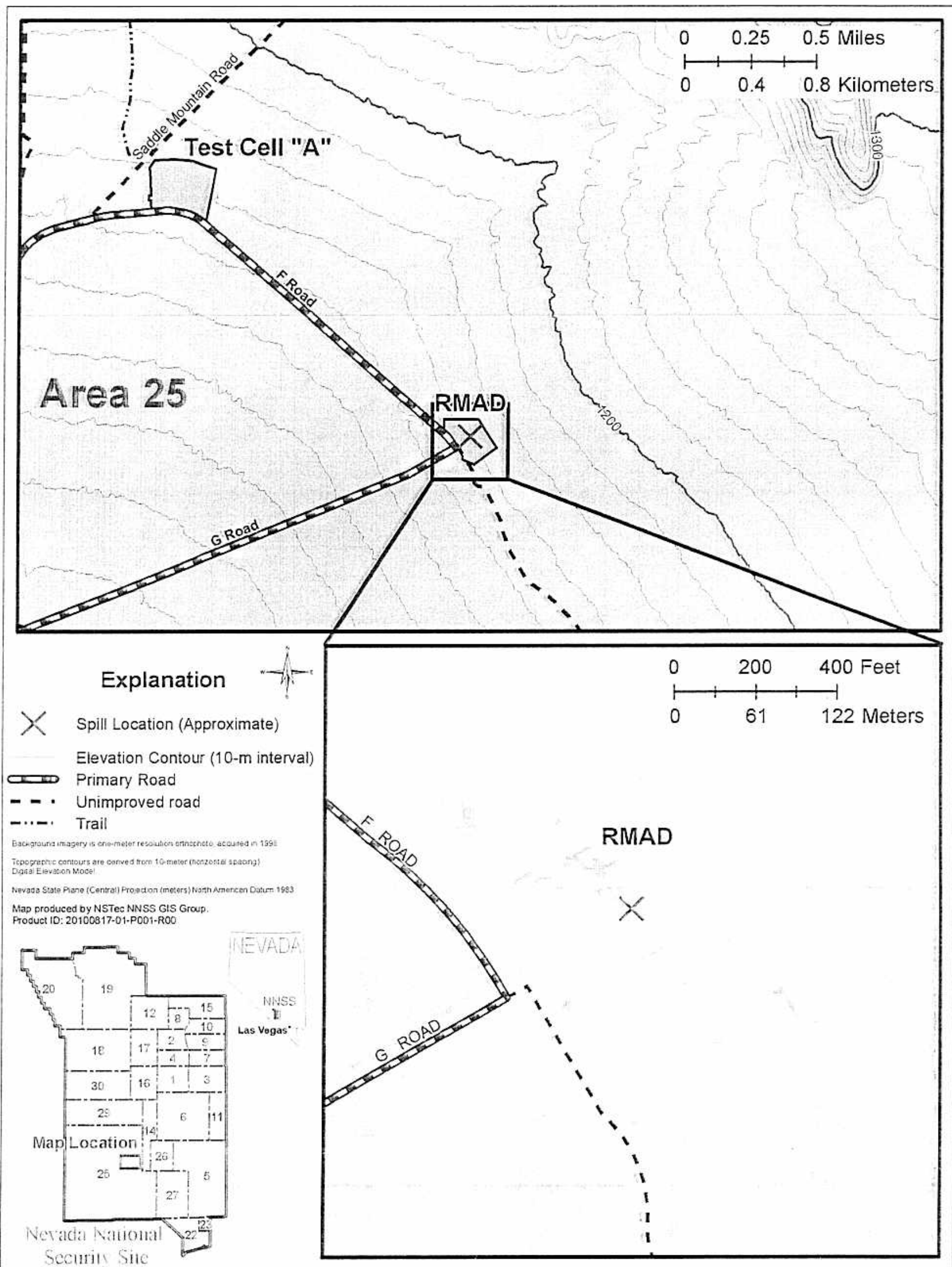

Figure 1. Area 25 Site Map - NDEP Spill No. 100104-05 
Figure 2

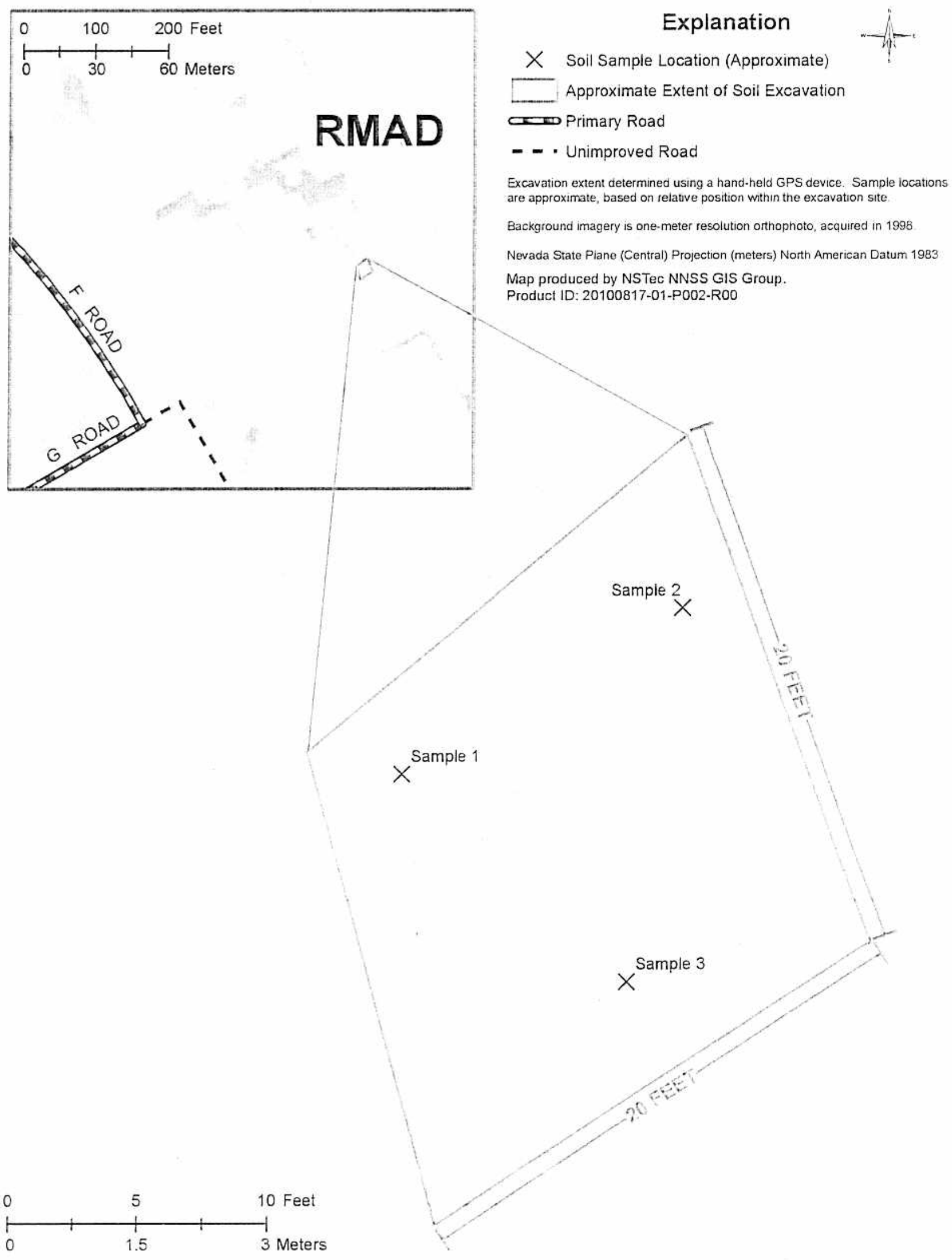

Figure 2. Area 25 Plot Plan - NDEP Spill No. 100104-05 
Table 1

Summary of Sample Results

\begin{tabular}{|c|c|c|c|c|c|}
\hline \multirow[t]{2}{*}{$\begin{array}{l}\text { Sample } \\
\text { Location }\end{array}$} & \multirow[t]{2}{*}{ Sample ID } & \multirow{2}{*}{$\begin{array}{l}\text { Depth } \\
\text { (inches } \\
\text { bgs) }\end{array}$} & \multicolumn{2}{|c|}{$\begin{array}{c}\text { TPH - Method } \\
\text { 3550B/M8015D }\end{array}$} & \multirow{2}{*}{$\begin{array}{c}\text { TPH - NAC } \\
445 \mathrm{~A} \\
\text { Threshold } \\
(\mathrm{mg} / \mathrm{kg}) \\
\end{array}$} \\
\hline & & & Analyte & $\begin{array}{c}\text { Result } \\
(\mathrm{mg} / \mathrm{kg})\end{array}$ & \\
\hline Sample \#1 & 113RMADV5-6 & $0-6$ & $\begin{array}{c}\text { Diesel } \\
\text { Motor Oils }\end{array}$ & $\begin{array}{l}5.8 \mathrm{~J} \\
10 \mathrm{~J}\end{array}$ & $\begin{array}{l}100 \\
100\end{array}$ \\
\hline Sample \#2 & 113RMADV5-7 & $0-6$ & $\begin{array}{c}\text { Diesel } \\
\text { Motor Oils }\end{array}$ & $\begin{array}{l}\mathrm{ND} \\
17 \mathrm{~J}\end{array}$ & $\begin{array}{l}100 \\
100\end{array}$ \\
\hline Sample \#3 & 113RMADV5-8 & $0-6$ & $\begin{array}{c}\text { Diesel } \\
\text { Motor Oils }\end{array}$ & $\begin{array}{l}\text { ND } \\
13 J\end{array}$ & $\begin{array}{l}100 \\
100\end{array}$ \\
\hline $\begin{array}{c}\text { Sample \#4 } \\
\text { Duplicate of \#3 }\end{array}$ & 113RMADV5-9 & $0-6$ & $\begin{array}{c}\text { Diesel } \\
\text { Motor Oils }\end{array}$ & $\begin{array}{l}\text { ND } \\
21 \mathrm{~J}\end{array}$ & $\begin{array}{l}100 \\
100\end{array}$ \\
\hline
\end{tabular}

$\mathrm{J}$ - Estimated concentration between the method detection limit (MDL) and the reporting limit. ND - Not detected at the MDL (see Attachment 1 for MDL values). 


\section{Attachment 1}

Field Logs and Laboratory Data 


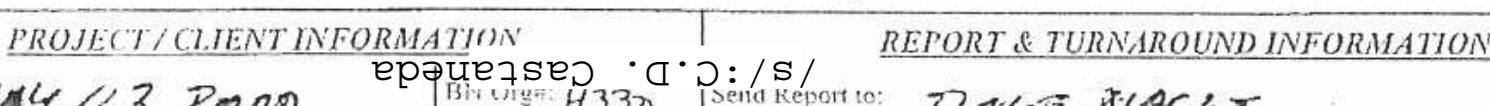

Project:

CAL $/ 3$ RMAD

DALE WACRT

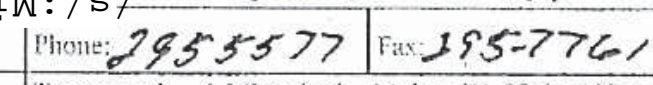

$M / S a n=50 \%$ 5RRA $70 . \omega 6$ PKOTH әУTW:/St

Tumaround: () Standard -14 days $1 \mathrm{H}, 28$ days Non-rat Fiv, 45 dhys Rad Fov Q RUSH Preliminary by: ...._- (IH)


$-1-^{2}-7 \times 14$ (non-Rad Env)

\section{D}

povezsej $\cdot \alpha \cdot 0: / \mathrm{s} /$ Page PKOTн әYTW:/S

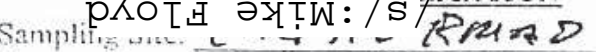
The samples submitled contain (chcck);

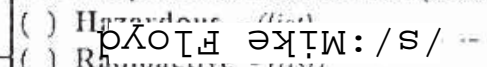

() Unknown contanination. If knuwn, identify

contaminants. This information will ensure compliance with applicable regulations and allow for the safe handling of the sample materials.

Pay Item, Analysis, Method SAMPLE MANA GEMENT INFORMATION

(IH) $\sqrt{34} 48$ (Non-Rad Env) (Rad Eiw) S1) Samples submitted are associated with a signed Project SOW (X) YES ( ) NO (V) YES ( ) NO ( ) N/A thalyses entered here agrce with the SOW. If not, identify the variation: Subcontract Lab(s) used for this work:

EMAX-RELASE \# 104127-8

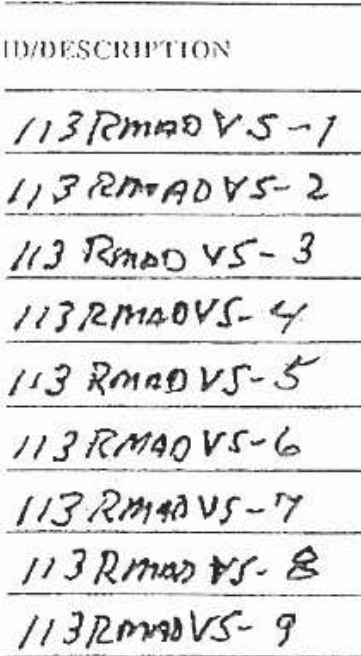
CUSTODY TRANSFER Sumpled/Relinguisliced (primt) Mithe Fiorgn Tefic

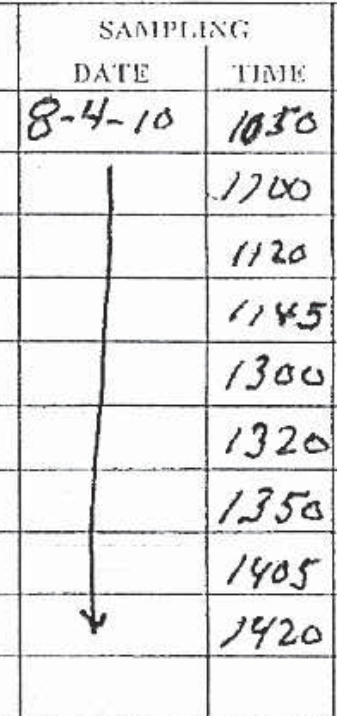
$\frac{5016}{1}$

\begin{tabular}{|c|c|c|c|c|c|}
\hline \multicolumn{2}{|c|}{ CONIAINER } & \multicolumn{3}{|c|}{ QC } & \multirow{2}{*}{$\begin{array}{c}\text { Pres - Analysis } \\
\text { eg IICl - VOCs }\end{array}$} \\
\hline \# & Est. Vol & MD & MS & NISD & \\
\hline 1 & 258 & & & & \\
\hline & & & & & \\
\hline & & & & & \\
\hline & & & & & \\
\hline & X & & & & \\
\hline & 500 & & $X$ & X & \\
\hline & 1 & & & & \\
\hline & & & & & \\
\hline 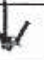 & $\downarrow$ & & & & \\
\hline & & & & & \\
\hline
\end{tabular}

(1)

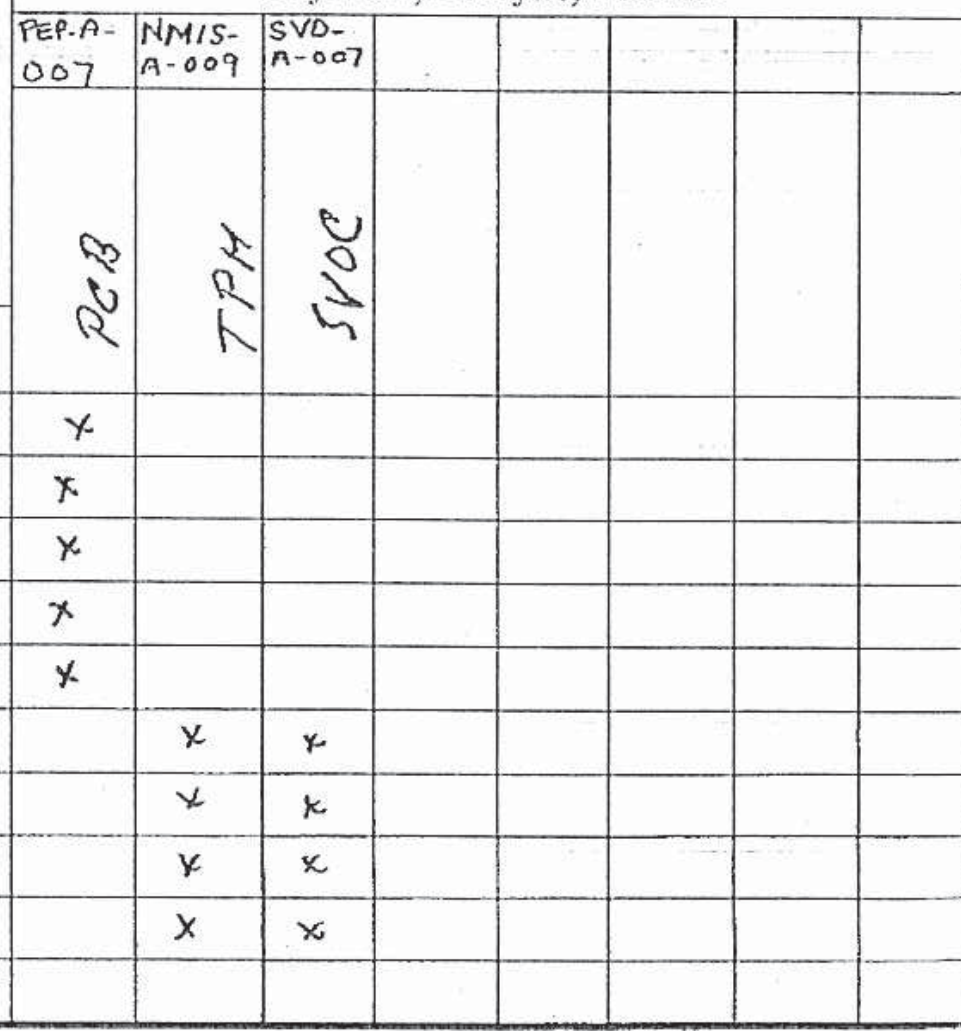

\section{Signature} -/s/:Mike Floyd DATE/TIME Bet/e $/ 630$ Reccived hy (nrint) Signature DATE/TIME VALL FCGD /s/:Mike Floyd f.r/10 0815 s/5t/c 0830 /s/:C.D. Castaneda 8) $5 / 109 / 300$

\begin{tabular}{|c|c|c|}
\hline Reccived hy (nrint) & Siguaturc & DATE/TIME \\
\hline Pehere & & $9 / 4 / 101630$ \\
\hline Muk Elays & $\not \mathrm{s} /$ : Mike Floyd & $\$ 5 / 5 / 2,08 / 5$ \\
\hline C.D. Cantaneala & L/s/:C.D. Castaneda & $8 / 5 / 10 \times 0830$ \\
\hline$F\left(D E X^{y \epsilon}\right.$ & 798918736921 & $8 / 5 / 10 @ 1300$ \\
\hline
\end{tabular}


128 TITLE

Work continued from Page NA

ReAd Soil Sampling
Fut en pțned :/s/

BOOK NO.

$8-4-10$

Personnel

David NaCht-PM Dom Cotronio-RCt

${ }_{5}$ Dudley Ever - ER

Mike Floyd -SS

Cobs Moke - ET

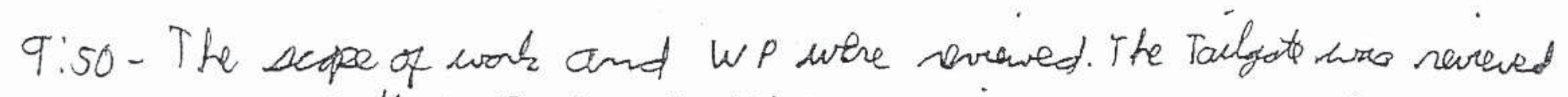
- Collect P(B \& TPHISUOC sis samples per the approved plan.

10:27- The geopabe is sot up

10:30- The site spacitie safety hiefery was held

- Leasing protection

- Stand where the operator can see ser

- do not stan Close a touch the trued dungs the sampling

- heat stress dins pleats of water

- slips, times + fall

${ }^{20} 10: 46$ - find PCB sames locations (250 mL San)

N $36^{\circ} 48.986$ Sample \# I13 RMAD V SA 10.50

$w 116^{\circ} 14.357 \quad 0$ to 6 inches deep in the native sous

- W GS 84. Datum for del sample locations

11:00- sample 113 RMADUS-2 collected at 11:00 duplicate of PCB \#

25 113 RMADUS-1; 250m/ Jar $0-6$ inches deep in the native soil; N $36^{\circ} 48.986 \quad$ PCB analysis $W 116^{\circ} 14.357$

$11: 20$ - Second PCB sample location - 113 RMAD VS -3

ww..scientificbindery88yrs.com

SIGNATURE /s/: David Nacht

DISCLOSED TO AMID UNDERSTOOD BY

DATE

WITNESS

Work continued to Page 129

$$
8-4-10
$$


TITLE

Work continued from Page $28^{--}$
PROJECT NO.

BOOK NO.

$250 \mathrm{~m} / \mathrm{san} ; 0-6$ incles deep in the rative soil; pCBanalysis $N 36^{\circ} 48.983$ in

W $116^{\circ} 14.346^{\circ} 4$

$11: 45$ - Thind PCB sample location, 250mitgan, 0-6 in deap

5

113 RMADUS- 4 in the nateve soil

$N 36 \quad 48.974$

W $116 \quad 14.329$

12:00-lunch

- Founts PCB locatein (last): $250 \mathrm{ml}$ Jar,0-6in de

10

$N 36^{\circ} 48.957$

WII. $6^{\circ} 14.340$

in natio soil

a! 50 Retwow form lwak.

Collet. Lust PCB H. RMADV 5.5

15

20

13: $\frac{100}{30}>2$

TTH/SVoC soockJar

$N 36^{\circ} 48.962^{\circ}$

w $126^{\circ} 14.332^{\prime} \quad 38=182 \%$

13,30 TPH/SVOC SOEC JaV is $36^{\circ} 48.961^{\prime}$

W $116^{\circ} 14.329^{\prime} \quad \xi 358 \mathrm{st}$

25

$113 R M A 2 \cup 5-7$

Colfurt 1358

13:55 TPH/SVOC 500ce Jar 1130MAJV5-8

$N 36^{\circ} 48.960^{\circ}$

c.llected kidio5

wwwscientificbindery88yrs,com

us $1166^{\circ} 14.355^{\circ}$ 3805 t't

Work continued to Page 130 
14:10 TPH/SUOC 500ce Jer IIJRMAD V5-a duplicate zUDen ptraed:/s/ Same loc as US- 8

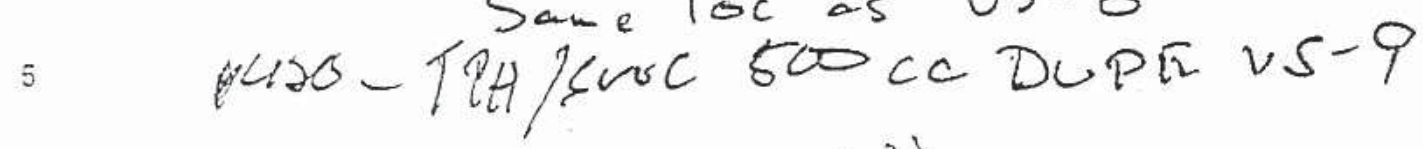

$4^{N}$

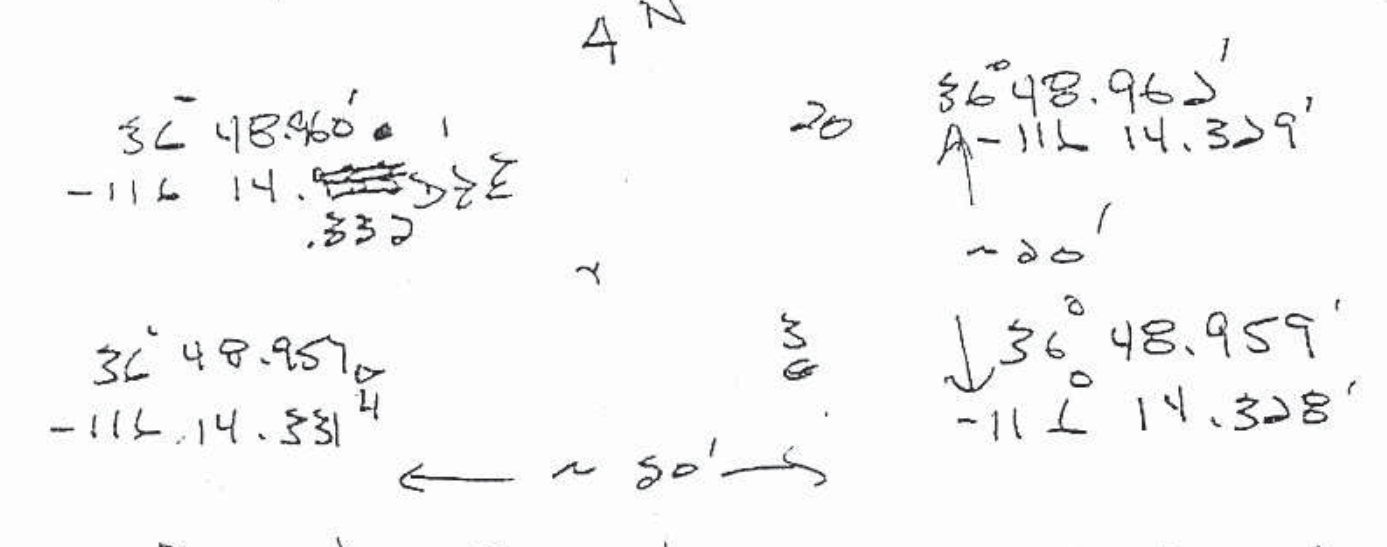

$14: 35$ finisl Sampliwa. all Swipesclean Slat decou of equpant

15

15:45 fisish decow of Geoprober Sampling

15:55 depart RMAD $\rightarrow$ Merk. He secunt Samples.

20

25

W.Wwscientificuinderya8yrs.com

Work continued to Page LA

SIGNATURE

/s/: David Nacht

DATE

DISCLOSED TO ÃND UNDERSTOOD BY

DATE

WITNESS

DATE 
METHOD 3550 B /SW8015C

PETROLEUM HYDROCARBONS BY EXTRACTION

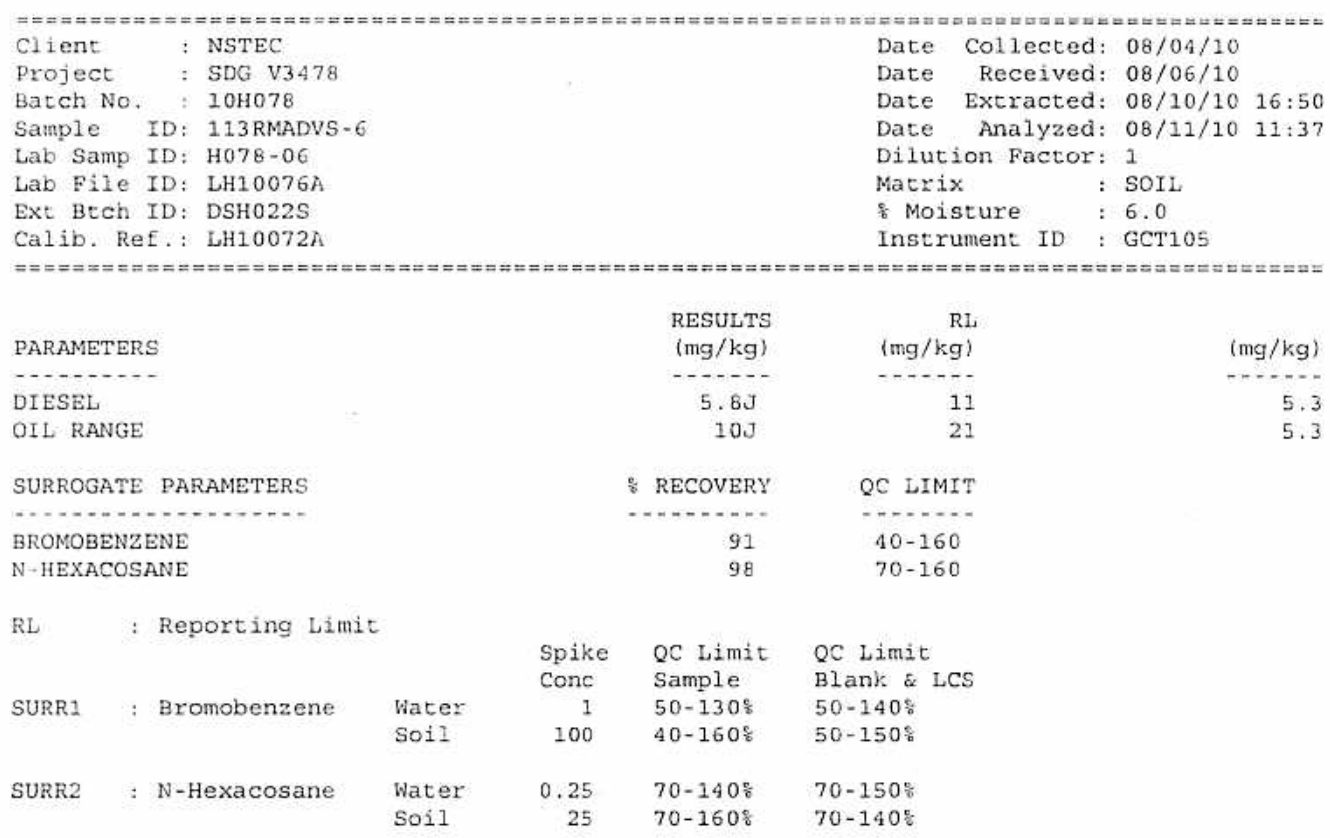


METHOD 3550 B /SW8015C

PETROLEUM HYDROCARBONS BY EXTRACTION

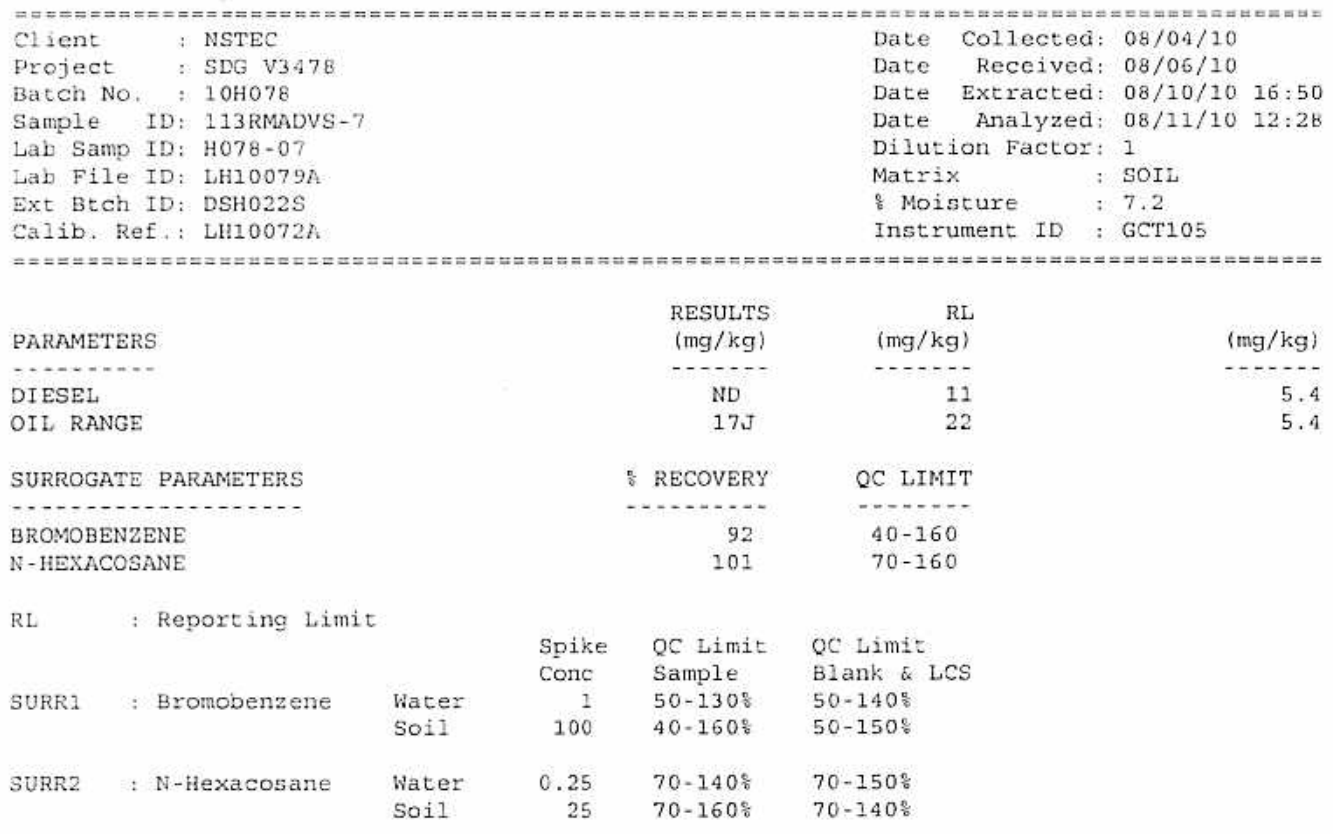


METHOD 3550B/SW8015C

PETROLEUM HYDROCARBONS BY EXTRACTION

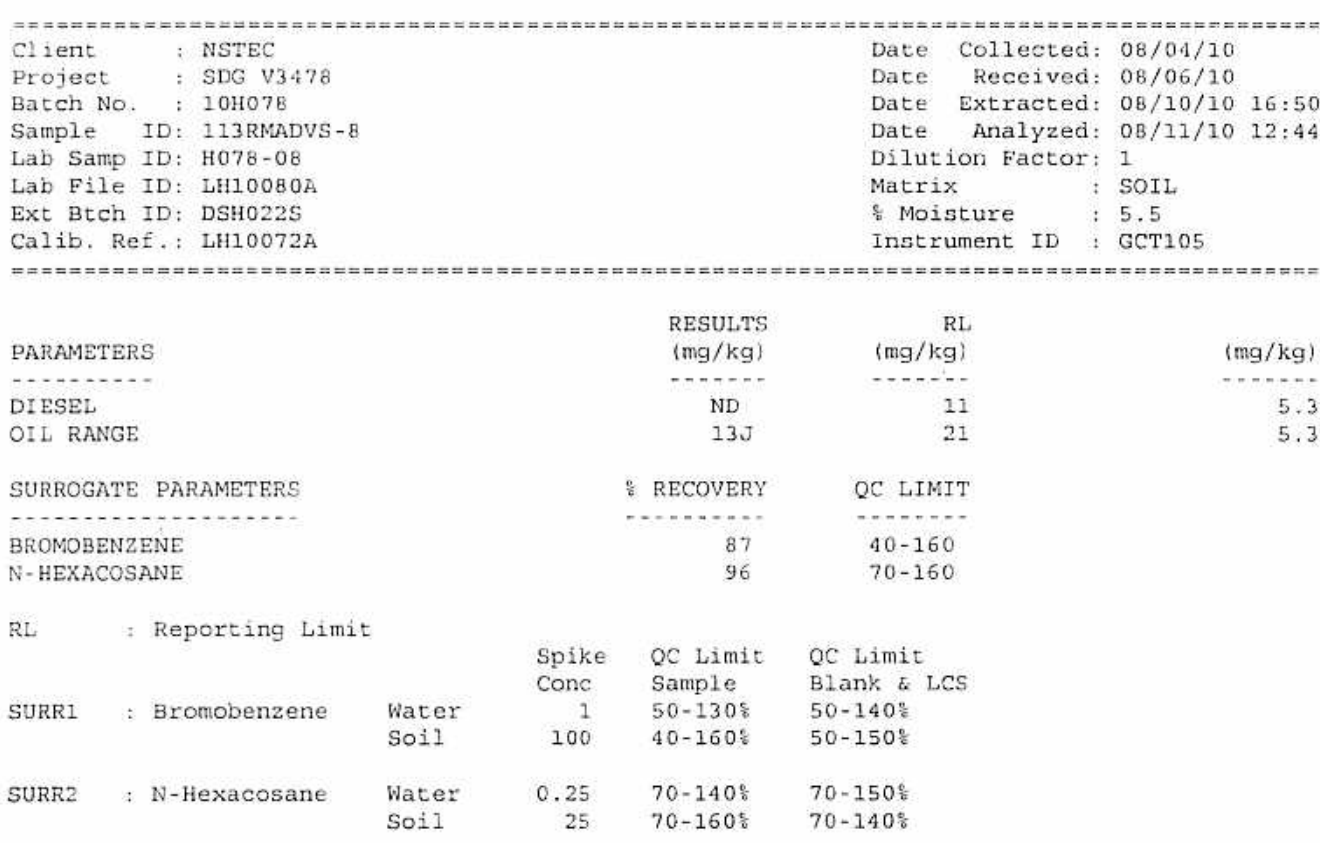


METHOD 3550 OB/SW8015C

PETROLEUM HYDROCARBONS BY EXTRACTION

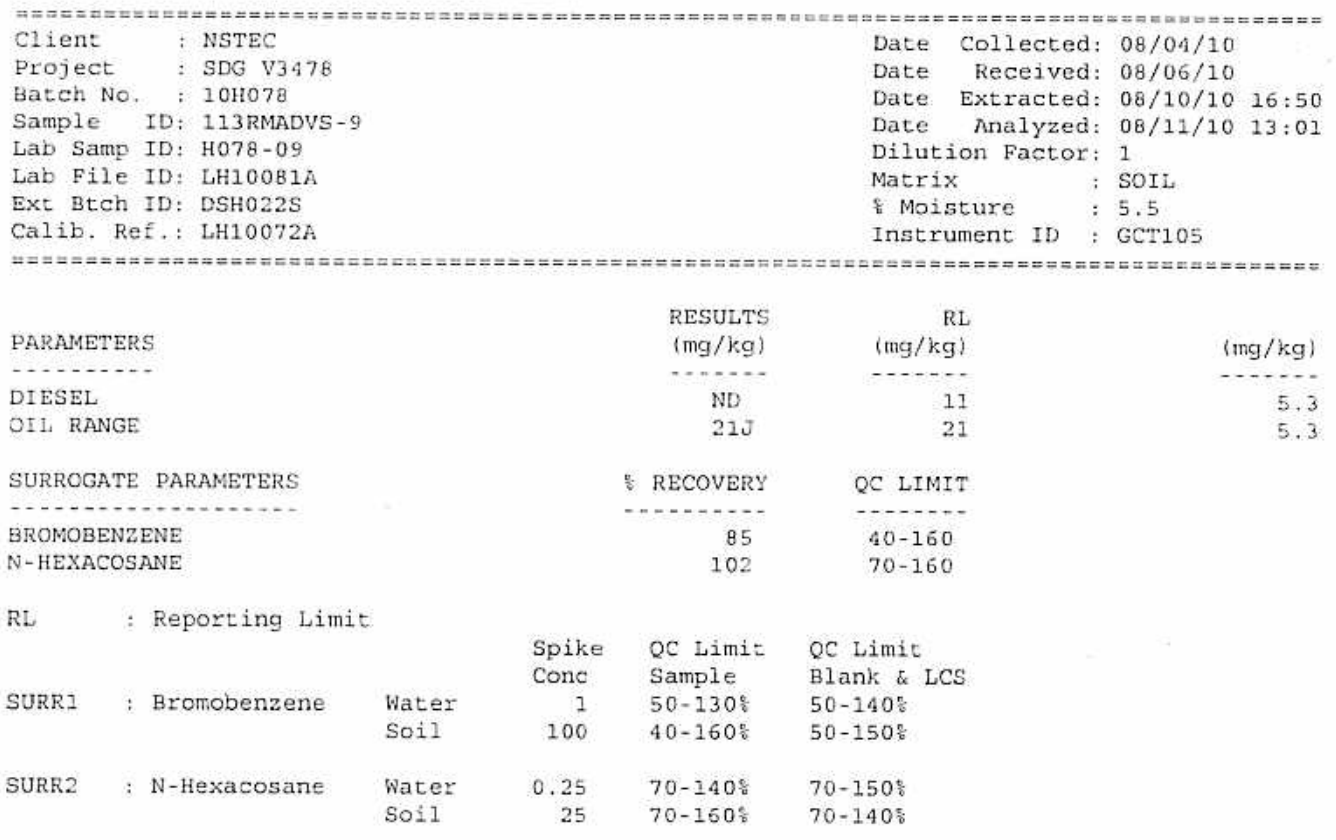


METHOD 3550 B/SW8015C

PETROLEUM HYDROCARBONS BY EXTRACTION

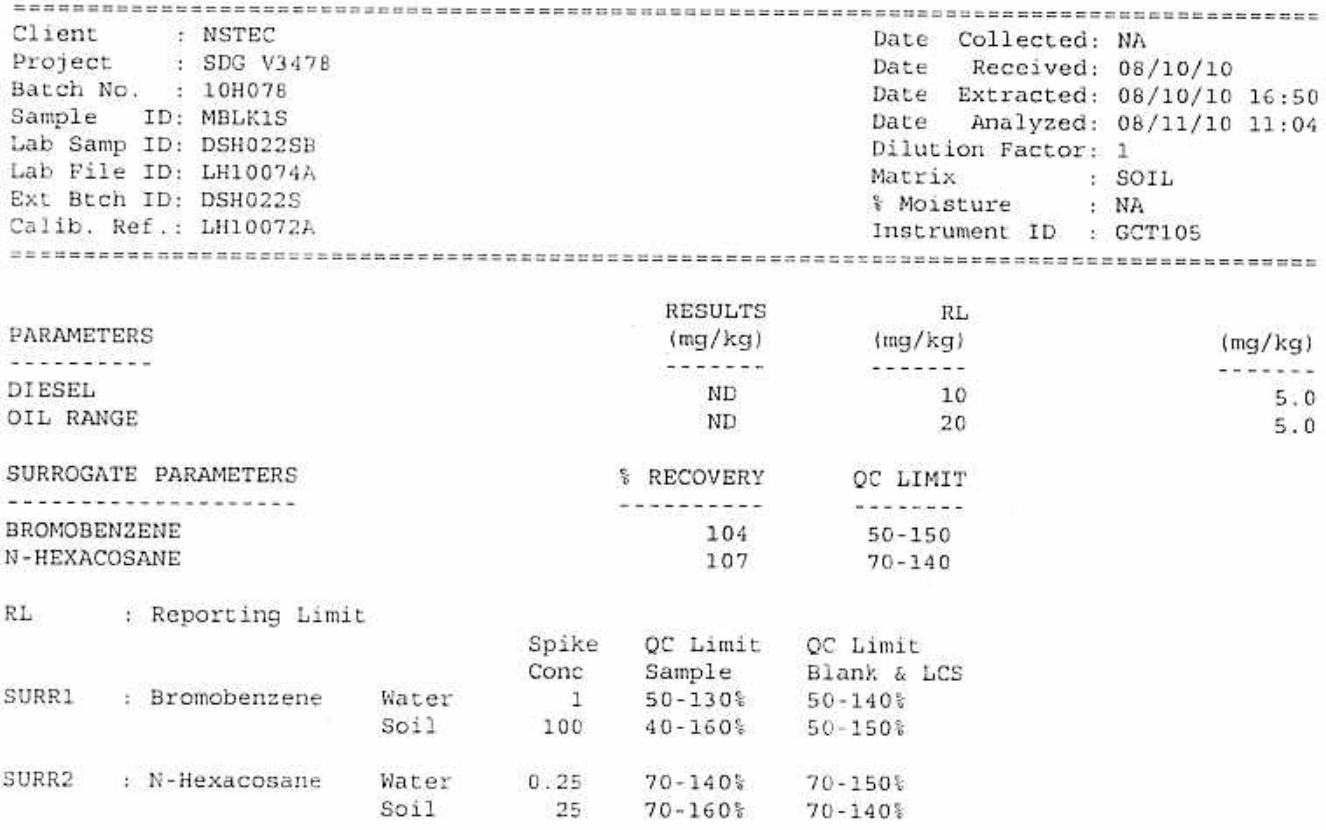


EMAX QUALITY CONTROL DATA

LCS ANALYSIS

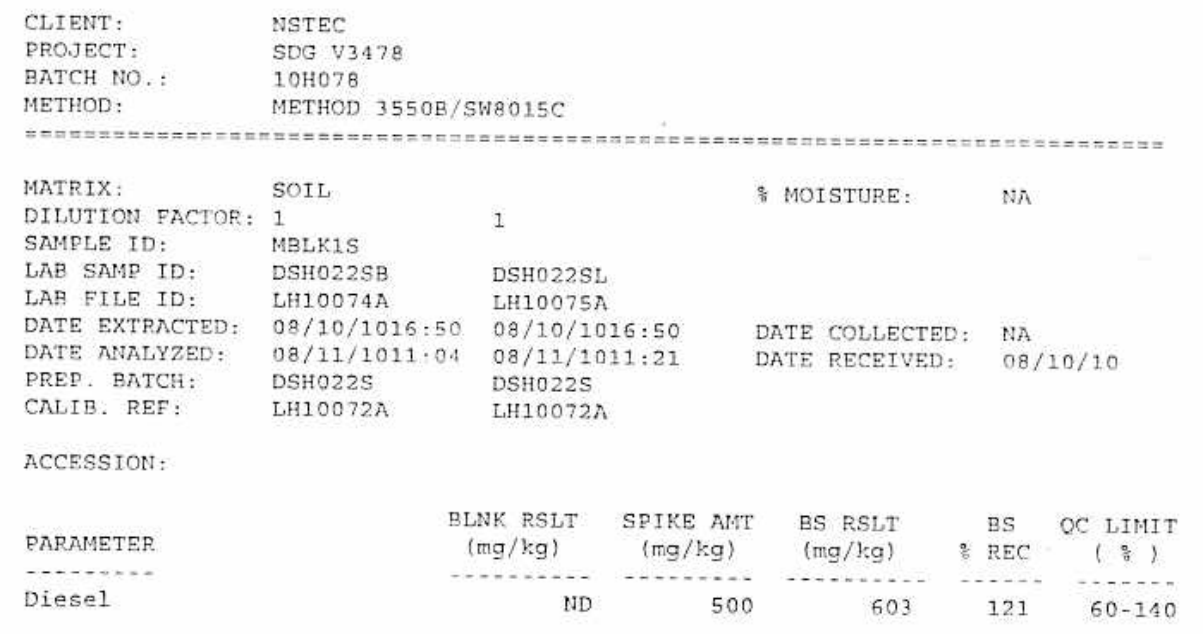

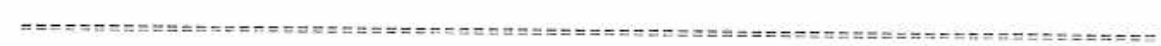

SURROGATE PAPAMETER

$\begin{array}{rrrr}\begin{array}{r}\text { SPIKE AMT } \\ (\mathrm{mg} / \mathrm{kg})\end{array} & \begin{array}{r}\text { BS RSLT } \\ (\mathrm{mg} / \mathrm{kg})\end{array} & \begin{array}{c}\text { BS } \\ \text { REC }\end{array} & \begin{array}{c}\text { OC LIMIT } \\ (\%)\end{array} \\ 100 & 110 & 110 & 50-150 \\ 25.0 & 27.6 & 110 & 70-140\end{array}$

Bromobenzene 
EMAX QUALITY CONTROL DATA

MS/MSD AMNLYSIS

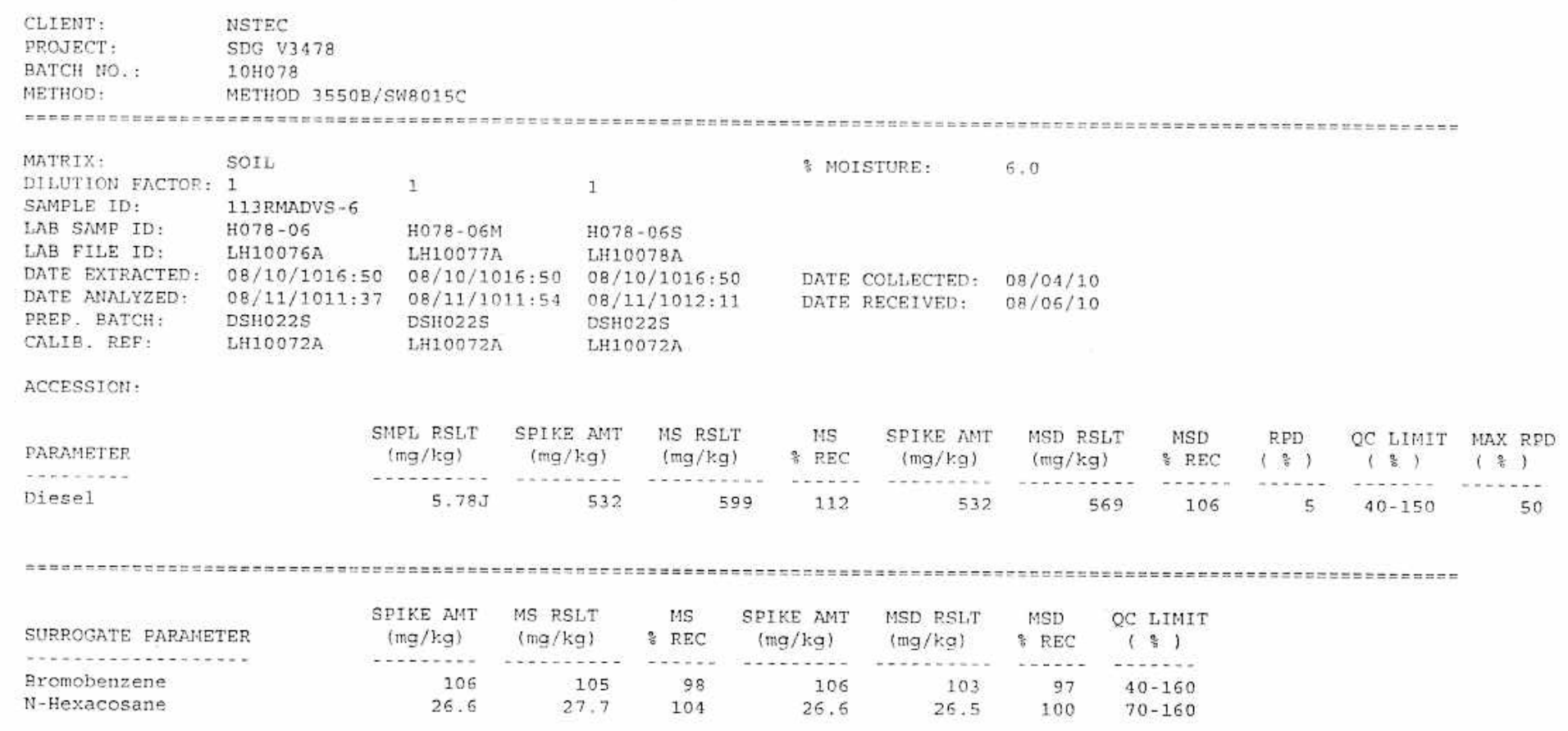




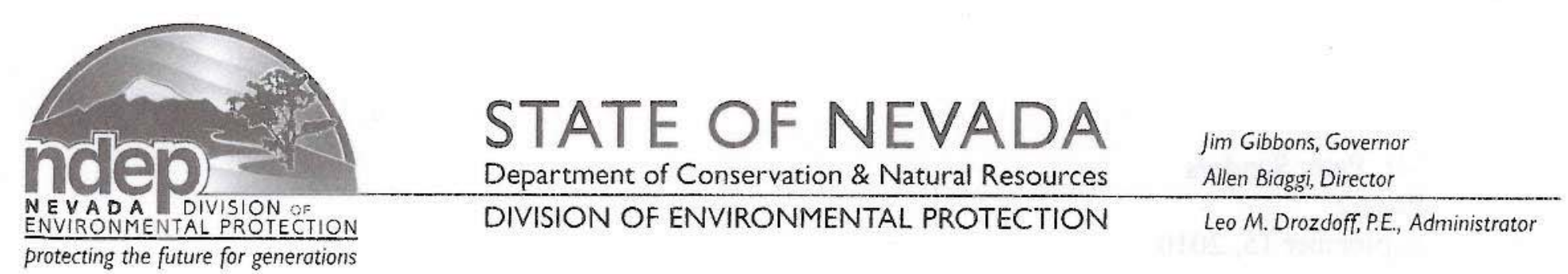

September 15, 2010

Peter A. Sanders

Environmental Protection Team

National Nuclear Security Administration

Nevada Site Office

P.O. Box 98518

Las Vegas, NV 89193-8518

\section{RE: Final Report}

Nevada Division of Environmental Protection Release Spill Report No: 0100104-05, Hydraulic Fluid Spill, R-MAD, Area 25, Nevada Test Site

\section{Dear Mr. Sanders:}

The Nevada Division of Environmental Protection, Bureau of Federal Facilities staff (NDEP) has evaluated the National Nuclear Security Administration/Nevada Site Office's (NNSA/NSO) Final Report on NDEP Spill Case No: 0100104-05. This report documents a release and subsequent remediation of a Hydraulic Fluid Spill, R-MAD, in Area 25, at the Nevada Test Site. NNSA/NSO has requested the closure of this spill site.

NDEP concurs with this request and is not requiring further remedial action at this spill site based upon information and data provided in the Final Report. This action is subject to the qualification of the data and information presented and, if future conditions warrant, NDEP may request further information, data, investigation and/or remediation.

Since the site has no contamination remaining in the subsurface, no land-use restrictions apply.

Questions regarding this matter may be addressed to either me at 702-486-2850, ext. 232, or Greg Raab at 702-486-2850, ext. 242.

Sincerely,

/s/:Christine Andres

Christine D. Andres

Supervisor

Bureau of Federal Facilities 


\section{APPENDIX D}

\section{REQUEST FOR VARIANCE FOR WASTE MANAGEMENT ACTIVITIES FOR CORRECTIVE ACTION UNIT (CAU) 113: AREA 25 R-MAD FACILITY}

AND

NDEP APPROVAL LETTER 
Addendum to CAU $113 \mathrm{CR}$

Revision: 0

Date: February 2011

\section{THIS PAGE INTENTIONALLY LEFT BLANK}




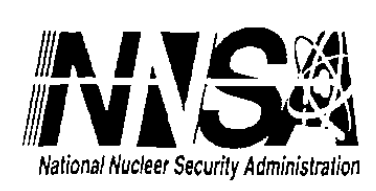

\author{
Department of Energy \\ National Nuclear Security Administration \\ Nevada Site Office \\ P.O. Box 98518 \\ Las Vegas, NV 89193-8518
}

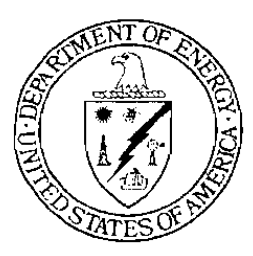

DEC 212009

Tim Murphy, Chief

Bureau of Federal Facilities

Division of Environmental Protection

2030 East Flamingo Road, Suite 230

Las Vegas, NV 89119-0818

\title{
REQUEST FOR VARIANCE FOR WASTE MANAGEMENT ACTIVITIES FOR CORRECTIVE ACTION UNIT (CAU) 113: AREA 25 R-MAD FACILITY
}

The U.S. Department of Energy, National Nuclear Security Administration Nevada Site Office (NNSA/NSO) is requesting that the Nevada Division of Environmental Protection (NDEP) review and concur with the following proposal for storing and disposing of concrete painted with polychlorinated biphenyl (PCB)-containing paint associated with the demolition of Building 3110. Based on the regulations and previous NDEP guidance, this waste will be managed and disposed as radioactive PCB bulk product waste.

Building 3110 demolition debris is considered PCB contaminated low-level radioactive waste (LLW) as a result of legacy dried paint containing PCBs at concentrations greater than 50 parts per million (ppm) that were used throughout the building and residual radiological contamination in the building. Building 3110 demolition debris meets the definition of PCB bulk product waste because the paint applied to the facility was manufactured to contain PCBs and was used for its intended purpose. As defined in Title 40 Code of Federal Regulations (CFR) Part 761.3, PCB bulk product waste is any waste derived from manufactured products containing PCBs in a non-liquid state, at any concentration where the concentration at the time of designation for disposal was $\geq 50$ ppm PCBs. It is further defined as non-liquid bulk wastes or debris from demolition of buildings and other man-made structures manufactured, coated, or serviced with PCBs. The definition also includes "applied dried paints" as a specific example of PCB bulk product waste.

Building 3110 demolition debris is intended for disposal at the Nevada Test Site (NTS) Area 5 Radioactive Waste Management Site (RWMS) as LLW containing PCB bulk product waste. Disposal at the Area 5 RWMS is consistent with 40 CFR 761.62(b)(i), which allows disposal of PCB bulk product waste consisting of "applied dried paints" presumed to leach less than 10 micrograms per liter PCBs and "non-liquid building demolition debris" in a facility permitted, licensed, or registered by a State as a municipal or non-municipal non-hazardous landfill. In addition to 40 CFR 761 regulations, the U.S. Environmental Protection Agency (EPA) has published guidance and interpretation of the PCB regulations contained in 40 CFR 761 in the EPA PCB Q\&A manual January 2009 version 
(http://www.epa.gov/epawaste/hazard/tsd/pcbs/pubs/qacombined.pdf), and contains the following excerpt:

\begin{abstract}
Q: Does this definition include contaminated concrete removed from a building for which the use changes, but there is no demolition?

A: Contaminated concrete that is removed from a building is PCB waste and is regulated for disposal, regardless of whether the building itself is demolished or reused. If the concrete was contaminated by a spill, release, or other unauthorized disposal of $P C B$ liquids, it may be $P C B$ remediation waste depending on the concentration of the PCBs and the date of the spill, release, or disposal. If the concrete contains or is coated with a material that was manufactured to contain PCBs, and at the time of designation for disposal contains PCBs $\geq 50$ ppm, it is PCB bulk product waste.
\end{abstract}

Building 3110 demolition debris does not meet the definition of PCB remediation waste. As defined in Title 40 CFR 761.3, PCB remediation waste is waste that contains PCBs as a result of a spill, release, or other unauthorized disposal, such as soil, gravel, sediments, or structures contaminated from a leaking PCB or PCB-Contaminated Transformer. The waste does not contain soil, construction material, or other material contaminated with PCBs as a result of a spill, release, or other unauthorized disposal. The waste consists of building debris coated with applied dried paint. Because the application of PCB-containing paint was not the result of a spill, release, or other unauthorized disposal, and the paint was manufactured to contain PCBs and was used for its intended purpose, demolition debris from Building 3110 will be considered PCB bulk product waste, and not PCB remediation waste.

Building 3110 will be demolished using conventional and explosive means. The slab at the former cold bay portion of the building will be used to store debris in preparation for packaging and disposal at the NTS Area 5 RWMS under approved waste profile \#LRY5LLFY08002. As Building 3110 is demolished, debris will be size reduced before it is moved to the storage area. If additional size reduction is necessary for packaging, it will be done in the storage area.

The waste pile in the storage area will be managed according to the requirements in 40 CFR 761.65(c)(9), which allows PCB bulk product waste to be stored at the cleanup site for up to 180 days. These are as follows, with a description of the proposed management practices, and where applicable, the requested variance.

- The pile must be designed and operated to control dispersal of the waste by wind. As demolition of the facility proceeds, the debris will be size reduced and transferred to a storage area where it will be continuously packaged and transported to the disposal site. Dispersal control will be attained using a compound commonly used to prevent migration of asbestos fibers that will minimize potential wind dispersal of the debris. The sealant used will be an industry standard compound appropriate for the expected 
climate conditions. The sealant will be sprayed onto the debris from the perimeter of the waste pile, using a man lift if necessary for better coverage.

- The waste must not generate leachate through decomposition or other reactions. The PCB bulk product waste is "applied dried paint" that is not reactive or subject to decomposition from exposure to precipitation, as defined in 40 CFR 761.62(b)(1)(i).

- A liner must be used to prevent migration of waste into the adjacent subsurface soil, ground water, or surface water.

A variance from this requirement is requested to utilize the concrete pad of the former cold bay portion of the building instead of a synthetic liner. An additional synthetic liner on top of the pad is not necessary and would not provide additional protection. The concrete pad will prevent migration of waste to the underlying soil. There is no naturally occurring surface water in this vicinity, and depth to groundwater in this area ranges from 740 feet to 1,040 feet; therefore, there is no likelihood of migration to ground water or surface water. However, as a best management practice, after completion of demolition and associated waste hauling, and prior to closure, the underlying soil adjacent to the remaining slab will be sampled to verify that PCBs have not leached into the substrate (i.e., soil).

- A cover must be installed over the waste to prevent contact with precipitation. A variance from this requirement is being requested. A cover will not be used on the waste pile. As stated above, the PCB bulk product waste is "applied dried paint" that is not reactive or subject to decomposition from exposure to precipitation, as defined in 40 CFR 761.62(b)(1)(i). In addition, significant safety issues are associated with personnel walking over the debris while manipulating a cover. These include uneven surfaces, potential for falling on sharp or pointed objects, and the presence of removable radioactive contamination. This area of the NTS averages approximately 8 inches of precipitation per year, and precipitation events are infrequent.

- A run-on and run-off control system must be designed for a 24-hour, 25-year storm. Control of run-on and run-off from precipitation events will be mitigated using soil berms. Clean soil will be used to construct a berm approximately 1.5 feet high and 2 feet wide on the perimeter of the concrete pad. The berm material will be disposed with the waste stream after completion. As a best management practice, the area will be inspected after every precipitation event, and if a significant amount of standing water is observed in the waste storage area that could potentially affect the berms or release contaminated water outside the boundaries of the waste storage area, then the water will be pumped from the area, characterized, managed, and disposed appropriately. 
To ensure that the debris does not remain in the storage area for longer than 180 calendar days, the waste pile in the storage area will be managed to minimize the quantity of building debris present as much as possible. It is anticipated that the pile will be maintained at a size that can be loaded and disposed in approximately one week. The storage area will be cleared on a regular basis, with only a residual amount of debris left on the pad.

The approach for variance from the cover requirement and the approval of the liner are described in 40 CFR 761.65(c)(9)(iv) which allows modification of these requirements under a risk-based approach that demonstrates the proposed storage method will not pose an unreasonable risk of injury to health or the environment, as stated in 40 CFR 761.61(c) and 40 CFR 761.62(c). The following information supports this risk-based approach.

\section{Nature and quantity of the waste:}

Demolition of Building 3110 will create approximately 225,000 cubic feet of debris that will be packaged and disposed as radioactive PCB bulk product waste under a current approved waste profile at the Area 5 RWMS. The debris contains "applied dried paint" that is not reactive or subject to decomposition from exposure to precipitation, as defined in 40 CFR 761.62(b)(1)(i).

\section{Proposed design of the storage location:}

The waste will be stored on a concrete pad, and soil berms will be maintained on the edge of the concrete pad. A sealant that is commonly used to prevent migration of asbestos fibers will be used to coat the exposed surfaces of the waste pile at the end of each work day.

\section{Hydrogeologic setting of the site:}

Area 25 is located in an intermontane valley bordered by highlands on all sides except for a large drainage outlet to the southwest. The Jackass Flats basin is underlain by alluvium, colluvium, and volcanic rocks of Cenozoic age. The alluvium and colluviums (with thickness of upwards to 1,000 feet) are above the saturated zone throughout most of Jackass Flats. Paleozoic age sedimentary rocks, limestone, and dolomite occur at greater depths. Precipitation measured at the Jackass Flats (4JA) Station from 2003 through 2008 ranged from 3.99 to 11.04 inches per year, with an average annual value of 7.74 inches. The mean annual potential evapotranspiration rate, as estimated for 2003 through 2008 at the Area 3 RWMS, was 61.71 inches. Depths to groundwater for the three water supply wells in Area 25 are approximately 1,039 feet, 927 feet, and 740 feet below ground surface.

4. Any other factor influencing the quality and mobility of the leachate produced and the potential for it to migrate to ground or surface water:

Infiltration of precipitation through subsurface media is not significant due to the low precipitation and high evapotranspiration rates common at the NTS and the depth to groundwater. Therefore, no viable groundwater exposure pathway exists. In addition, the PCB bulk product waste is "applied dried paint" that is not reactive or subject to decomposition from exposure to precipitation, as defined in 40 CFR 761.62(b)(1)(i). 
In summary, NNSA/NSO requests NDEP concurrence on the variances for the requirements for a synthetic liner and a cover for the debris pile. Please advise if this approach is acceptable. Please direct comments and questions to Kevin Cabble, of my staff, at 702-295-5000.

ERP:5963.TL

$$
\text { /s/: Robert F. Boehlecke }
$$

Robert F. Boěhlecke

Federal Project Director Environmental Restoration Project

cc:

J. J. MacDougall, NDEP, Las Vegas, NV

J. A. Wong, NDEP, Las Vegas, NV

J. T. Fraher, DTRA/CXTS, Kirtland AFB, NM

T. A. Thiele, NSTec, Las Vegas, NV

NSTec Technical Information Officer, Las Vegas, NV

NSTec Correspondence Control, MS NL V008

M. J. Krauss, NNES, Las Vegas, NV

T. D. Taylor, NNES, Las Vegas, NV

K. J. Cabble, ERP, NNSA/NSO, Las Vegas, NV

E. F. Di Sanza, WMP, NNSA/NSO, Las Vegas, NV

Ken Small, WMP, NNSA/NSO, Las Vegas, NV

FFACO Group, PSG, NNSA/NSO, Las Vegas, NV

NNSA/NSO Read File 
December 22, 2009

Robert F. Boehlecke

Federal Project Director

Environmental Restoration Project

National Nuclear Security Administration

Nevada Site Office

P.O. Box 98518

Las Vegas, NV 89193-8518

\section{APPROVAL OF VARIANCE FOR THE WASTE MANAGEMENT ACTIVITIES FOR CORRECTIVE ACTION UNIT (CAU) 113: AREA 25 R-MAD FACILITY}

The Nevada Division of Environmental Protection Bureau of Federal Facilities hereby approves the NNSA/NSO variance request for CAU 113 Area 25 R-Mad Facility. NDEP interprets the concrete painted with PCB-containing paint to be PCB bulk product waste per 40 CFR 761 and should be managed as such. Furthermore, the working site conditions are conducive to the proposed storage and handling variances. The use of a concrete pad and sealant are adequate and unlikely to pose an environmental contamination risk.

Please contact Jeff MacDougall at (702) 486-2850 ext. 233 if you have any questions regarding this variance.

\section{T.H. Murphy}

Chief

Bureau of Federal Facilities

THM/JJM/JW/DN/KC

cc: J. T. Fraher, DTRA/CXTS, Kirtland AFB, NM

T. A. Thiele, NSTec, Las Vegas, NV

M. J. Krauss, NNES, Las Vegas, NV

T. D. Taylor, NNES, Las Vegas, NV

K. J. Cabble, ERP, NNSA/NSO, Las Vegas, NV

E. F. Di Sanza, WMP, NNSA/NSO, Las Vegas, NV Ken Small, WMP, NNSA/NSO, Las Vegas, NV

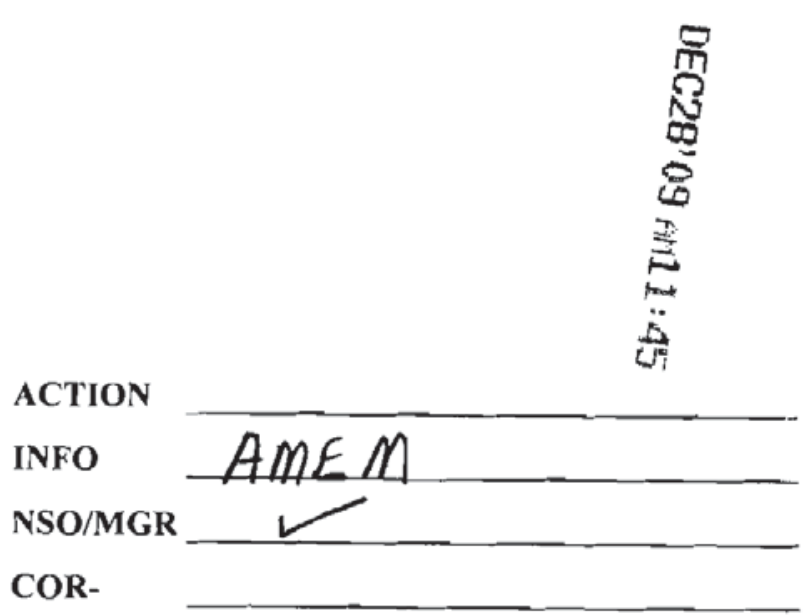

File Code 
Addendum to CAU $113 \mathrm{CR}$

Revision: 0

Date: February 2011

APPENDIX E

\section{POLYCHLORINATED BIPHENYL VERIFICATION SAMPLE RESULTS}


Addendum to CAU $113 \mathrm{CR}$

Revision: 0

Date: February 2011

\section{THIS PAGE INTENTIONALLY LEFT BLANK}


METHOD SW3550B/SW8082

Polychlorinated Biphenyls (PCBS) by Gas Chromatography

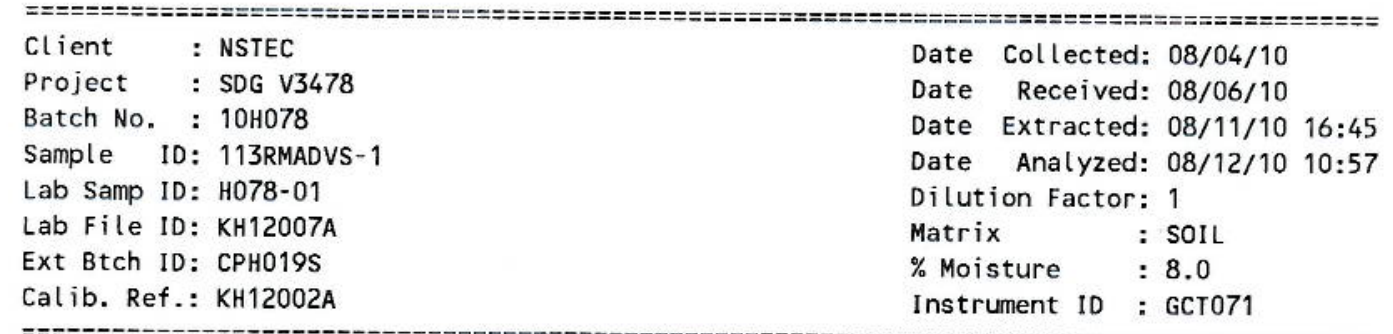

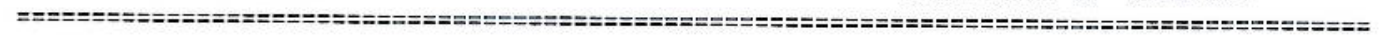

\begin{tabular}{|c|c|c|}
\hline PARAMETERS & $\begin{array}{l}\text { RESULTS } \\
\text { (ug/kg) }\end{array}$ & $\begin{array}{r}R L \\
\text { (ug/ } / \mathrm{kg})\end{array}$ \\
\hline 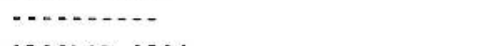 & 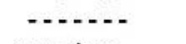 & -....... \\
\hline AROCLOR- 1016 & (ND) $\mid$ ND & 54 \\
\hline AROCLOR-1221 & (ND) $\mid$ ND & 54 \\
\hline AROCLOR-1232 & (ND) $\mid$ ND & 54 \\
\hline AROCLOR-1242 & (ND) $\mid$ ND & 54 \\
\hline AROCLOR-1248 & (ND) $\mid$ ND & 54 \\
\hline AROCLOR-1254 & (ND) $\mid$ ND & 54 \\
\hline AROCLOR-1260 & (ND) $\mid$ ND & 54 \\
\hline SURROGATE PARAMETERS & $\%$ RECOVERY & QC LIMIT \\
\hline (2) & 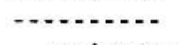 & 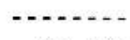 \\
\hline $2,4,5,6$-TETRACHLORO-META-XYLENE & $90 \mid(105)$ & $10-160$ \\
\hline DECACHLOROBIPHENYL & $101 \mid(109)$ & $30-150$ \\
\hline
\end{tabular}

Left of | is related to first column; Right of | related to second column Final result indicated by ( )

* Out side of QC Limit 
METHOD SW3550B/SW8082

Polychlorinated Biphenyls (PCBs) by Gas Chromatography

\begin{tabular}{|c|c|c|c|c|c|}
\hline Client & : NSTEC & Date & Collected: & $08 / 04 / 10$ & \\
\hline Project & : SDG V3478 & Date & Received: & $08 / 06 / 10$ & \\
\hline Batch No. : & $10 \mathrm{H} 078$ & Date & Extracted: & $08 / 11 / 10$ & $16: 45$ \\
\hline Sample ID: & : 113RMADVS-2 & Date & Analyzed: & $08 / 12 / 10$ & $12: 00$ \\
\hline Lab Samp ID: & ; н078-02 & \multicolumn{4}{|c|}{ Dilution Factor: 1} \\
\hline Lab File ID: & : KH12010A & \multicolumn{2}{|c|}{ Matrix } & SOIL & \\
\hline Ext Btch 10 : & : СРH019S & \multicolumn{4}{|c|}{$\%$ Moisture } \\
\hline Calib. Ref.: & : KH12002A & \multicolumn{4}{|c|}{ Instrument ID : GCT071 } \\
\hline
\end{tabular}

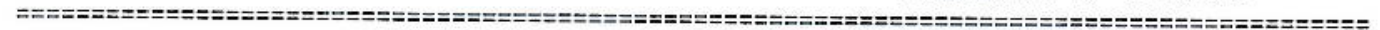

\begin{tabular}{|c|c|c|}
\hline PARAMETERS & $\begin{array}{l}\text { RESULTS } \\
\text { (ug/ } / \mathrm{kg})\end{array}$ & $\begin{array}{r}R L \\
\text { (ug/kg) }\end{array}$ \\
\hline$\ldots+\ldots$ & $\ldots . .$. & $\ldots \ldots$ \\
\hline AROCLOR-1016 & $(N D) \mid N D$ & 54 \\
\hline AROCLOR-1221 & (ND) $\mid$ ND & 54 \\
\hline AROCLOR- 1232 & (ND) $\mid$ ND & 54 \\
\hline AROCLOR-1242 & (ND) $\mid$ ND & 54 \\
\hline AROCLOR- 1248 & (ND) $\mid$ ND & 54 \\
\hline AROCLOR-1254 & (ND) $\mid$ ND & 54 \\
\hline AROCLOR-1260 & (ND) $\mid$ ND & 54 \\
\hline SURROGATE PARAMETERS & $\%$ RECOVERY & QC LIMIT \\
\hline${ }^{2}$ & ............... & $\ldots$ \\
\hline $2,4,5,6$-TETRACHLORO-META-XYLENE & $88 \mid(101)$ & $10-160$ \\
\hline DECACHLOROBIPHENYL & $100 \mid(105)$ & $30-150$ \\
\hline
\end{tabular}

Left of | is related to first column ; Right of | related to second column Final result indicated by ()

* Out side of QC Limit 
METHOD SW3550B/SW8082

Polychlorinated Biphenyls (PCBs) by Gas Chromatography

\begin{tabular}{|c|c|c|c|}
\hline Client : NSTEC & & Date Collectec & d: $08 / 04 / 10$ \\
\hline Project : SDG V3478 & & Receivec & d: $08 / 06 / 10$ \\
\hline Batch No. : $10 \mathrm{H} 078$ & & Date Extractec & d: $08 / 11 / 10$ \\
\hline Sample ID: 113RMADVS -3 & & Analyzec & d: $08 / 12 / 10$ \\
\hline Lab Samp ID: H078-03 & & Dilution Factor & $: 1$ \\
\hline Lab File ID: KH12011A & & Matrix & : SOIL \\
\hline Ext Btch ID: СРH019S & & $\%$ Moisture & $: 5.9$ \\
\hline Calib. Ref.: KH12002A & & Instrument ID & : GCT071 \\
\hline & RESULTS & RL & \\
\hline PARAMETERS & (ug/kg) & (ug/kg) & (ug/kg) \\
\hline 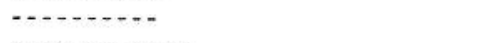 & $\ldots \ldots$ & $\ldots \ldots$ & $\ldots$ \\
\hline AROCLOR-1016 & $(N D) \mid N D$ & 53 & $21 \mid 21$ \\
\hline AROCLOR- 1221 & (ND) ND & 53 & $21 \mid 21$ \\
\hline AROCLOR- 1232 & (ND) $\mid$ ND & 53 & $21 \mid 21$ \\
\hline AROCLOR-1242 & (ND) $\mid$ ND & 53 & $21 \mid 21$ \\
\hline AROCLOR- 1248 & (ND) $\mid$ ND & 53 & $21 \mid 21$ \\
\hline AROCLOR-1254 & (ND) $\mid$ ND & 53 & $21 \mid 21$ \\
\hline AROCLOR- 1260 & (ND) $\mid$ ND & 53 & $21 \mid 21$ \\
\hline SURROGATE PARAMETERS & $\%$ RECOVERY & QC LIMIT & \\
\hline 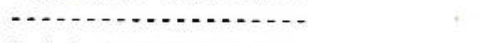 & $\ldots \ldots$ & $\ldots$ & \\
\hline $2,4,5,6$-TETRACHLORO-META-XYLENE & $95 \mid(110)$ & $10-160$ & \\
\hline DECACHLOROBIPHENYL & $103 \mid(108)$ & $30-150$ & \\
\hline
\end{tabular}

Left of | is related to first column; Right of | related to second column Final result indicated by ( )

* Out side of QC Limit 
METHOD SW3550B/SW8082

Polychlorinated Biphenyls (PCBs) by Gas Chromatography

\begin{tabular}{|c|c|c|c|}
\hline $\mathrm{Cl}$ ient & : NSTEC & Date Collected: & : 08/04/10 \\
\hline Project & : SDG V3478 & Date Received: & : $08 / 06 / 10$ \\
\hline Batch No. : & : $10 \mathrm{HO} 078$ & Date Extracted: & : 08/11/10 16:45 \\
\hline Sample ID: & : 113RMADVS- 4 & Date Analyzed: & $: 08 / 12 / 10 \quad 12: 42$ \\
\hline Lab Samp ID: & : $1078-04$ & Dilution Factor: & $: 1$ \\
\hline Lab File ID: & : KH12012A & Matrix : & : SOIL \\
\hline Ext Btch ID: & : СРн019S & $\%$ Moisture & : 6.4 \\
\hline Calib. Ref.: & : KH12002A & Instrument ID : & : GCT071 \\
\hline
\end{tabular}

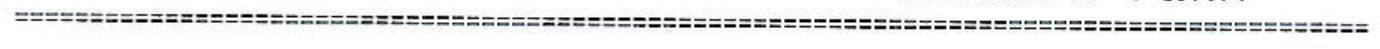

\begin{tabular}{|c|c|c|}
\hline PARAMETERS & $\begin{array}{l}\text { RESULTS } \\
\text { (ug/kg) }\end{array}$ & $\begin{array}{r}R L \\
(u g / k g)\end{array}$ \\
\hline$-1-n$ & $\ldots \ldots$ & -...... \\
\hline AROCLOR-1016 & (ND) $\mid$ ND & 53 \\
\hline AROCLOR-1221 & (ND) $\mid$ ND & 53 \\
\hline AROCLOR-1232 & $(N D) \mid N D$ & 53 \\
\hline AROCLOR - 1242 & (ND) $\mid \mathrm{ND}$ & 53 \\
\hline AROCLOR-1248 & (ND) $\mid$ ND & 53 \\
\hline AROCLOR - 1254 & (ND) $\mid$ ND & 53 \\
\hline AROCLOR-1260 & (ND) $\mid N D$ & 53 \\
\hline SURROGATE PARAMETERS & $\%$ RECOVERY & QC LIMIT \\
\hline$x^{2}$ & 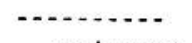 & $\ldots$ \\
\hline $2,4,5,6$-TETRACHLORO-META-XYLENE & $92 \mid(109)$ & $10-160$ \\
\hline DECACHLOROBIPHENYL & $103 \mid(116)$ & $30-150$ \\
\hline
\end{tabular}

Left of | is related to first column; Right of | related to second column Final result indicated by ( )

* Out side of QC Limit 
METHOD SW3550B/SW8082

Polychlorinated Biphenyls (PCBS) by Gas Chromatography

\begin{tabular}{|c|c|c|c|c|c|}
\hline Client & NSTEC & Date & Collected: & $08 / 04 / 10$ & \\
\hline Project & : SDG V3478 & Date & Received: & $08 / 06 / 10$ & \\
\hline Batch No. & : $10 \mathrm{H} 078$ & Date & Extracted: & $08 / 11 / 10$ & $16: 45$ \\
\hline Sample & : 113RMADVS- 5 & Date & Analyzed: & $08 / 12 / 10$ & $13: 03$ \\
\hline Lab Samp ID & : $4078-05$ & Dilut & ion Factor: & 1 & \\
\hline Lab File ID & : KH12013A & Matri & : & SOIL & \\
\hline Ext Btch ID: & : СРH019S & $\%$ Moi & sture & 6.2 & \\
\hline Calib. Ref.: & : KH12002A & Instr & ument ID : & Gст071 & \\
\hline
\end{tabular}

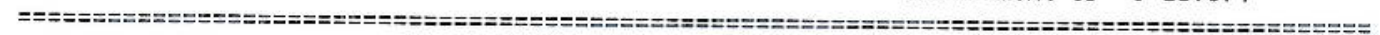

\begin{tabular}{|c|c|c|}
\hline PARAMETERS & $\begin{array}{l}\text { RESULTS } \\
\text { (ug/kg) }\end{array}$ & $\begin{array}{r}R L \\
(u g / k g)\end{array}$ \\
\hline$\cdots$ & $\cdots+\cdots$ & -....... \\
\hline AROCLOR- 1016 & $(N D) \mid N D$ & 53 \\
\hline AROCLOR-1221 & (ND) $\mid$ ND & 53 \\
\hline AROCLOR- 1232 & (ND) $\mid$ ND & 53 \\
\hline AROCLOR-1242 & $(N D) \mid N D$ & 53 \\
\hline AROCLOR- 1248 & (ND) $\mid$ ND & 53 \\
\hline AROCLOR-1254 & (ND) $\mid$ ND & 53 \\
\hline AROCLOR- 1260 & (ND) $\mid$ ND & 53 \\
\hline SURROGATE PARAMETERS & \% RECOVERY & QC LIMIT \\
\hline (n) & 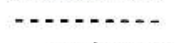 & 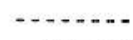 \\
\hline $2,4,5,6$-TETRACHLORO-META-XYLENE & $92 \mid(109)$ & $10-160$ \\
\hline DECACHLOROB IPHENYL & $98 \mid(101)$ & $30-150$ \\
\hline
\end{tabular}

Left of | is related to first column; Right of | related to second column Final result indicated by ( )

* Out side of QC Limit 
Addendum to CAU $113 \mathrm{CR}$

Revision: 0

Date: February 2011

THIS PAGE INTENTIONALLY LEFT BLANK 
Addendum to CAU $113 \mathrm{CR}$

Revision: 0

Date: February 2011

\section{APPENDIX F}

\section{WASTE DISPOSITION DOCUMENTATION}


Addendum to CAU $113 \mathrm{CR}$

Revision: 0

Date: February 2011

\section{THIS PAGE INTENTIONALLY LEFT BLANK}


Addendum to CAU $113 \mathrm{CR}$

Revision: 0

Date: February 2011

\section{CERTIFICATES OF DISPOSAL:}

\section{RAdiOACTIVE POLYCHLORINATED BIPHENYL BULK PRoduct WASTE}


Addendum to CAU $113 \mathrm{CR}$

Revision: 0

Date: February 2011

\section{THIS PAGE INTENTIONALLY LEFT BLANK}


NSTeC

Form

CERTIFICATE OF DISPOSAL

08/06/09

FRM-2217

(LOW LEVEL WASTE)

Rev. 0

Page 1 of 1

\section{Nevada Test Site}

This Certificate acknowledges that the following shipment(s) of waste have been disposed at the Nevada Test Site Radioactive Waste Management Site.

\begin{tabular}{|l|l|l|l|}
\hline Shipment Number & $\begin{array}{c}\text { Waste Stream } \\
\text { Identification \# }\end{array}$ & Package \# & Date of Disposal \\
\hline DPL09051 & LRY5LLFY07002 & 09L070 & 09-23-09 \\
\hline & & & \\
\hline & & & \\
\hline & & & \\
\hline & & & \\
\hline & & & \\
\hline
\end{tabular}

This certification is provided as a courtesy to the waste generator for information purposes only.

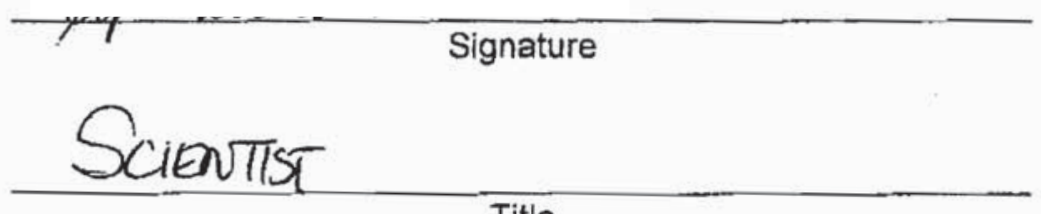

$\frac{23-S E P-2 \phi \phi 9}{\text { Date }}$

Title

\section{Instructions:}

Shipment Number - enter shipment number from LWIS database.

Date of Disposal - enter date waste was placed in disposal cell. 
FRM-2217

\section{(LOW LEVEL WASTE)}

Page 1 of 1

\section{Nevada Test Site}

This Certificate acknowledges that the following shipment(s) of waste have been disposed at the Nevada Test Site Radioactive Waste Management Site.

\begin{tabular}{|l|l|l|l|}
\hline Shipment Number & $\begin{array}{c}\text { Waste Stream } \\
\text { Identification \# }\end{array}$ & Package \# & Date of Disposal \\
\hline & LRY5LLFY07002 & 09L071 & 09-23-09 \\
\hline & & & \\
\hline & & & \\
\hline & & & \\
\hline & & & \\
\hline & & & \\
\hline & & & \\
\hline
\end{tabular}

This certification is provided as a courtesy to the waste generator for information purposes only.

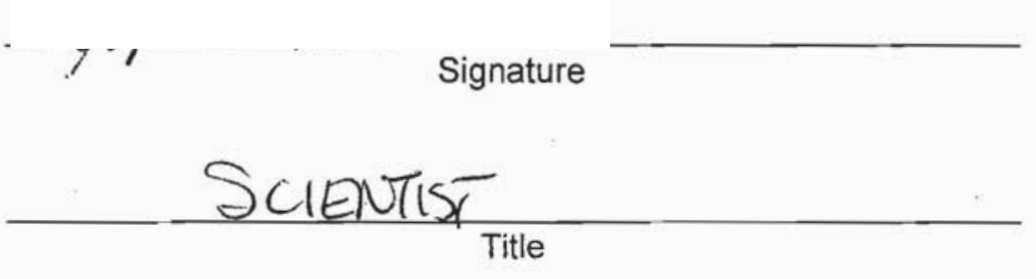

\section{Instructions:}

Shipment Number - enter shipment number from LWIS database.

Date of Disposal - enter date waste was placed in disposal cell. 


\section{Nevada Test Site}

This Certificate acknowledges that the following shipment(s) of waste have been disposed at the Nevada Test Site Radioactive Waste Management Site.

\begin{tabular}{|l|l|l|l|}
\hline Shipment Number & $\begin{array}{c}\text { Waste Stream } \\
\text { Identification \# }\end{array}$ & Package \# & Date of Disposal \\
\hline DPL09054 & LRY5LLFY07002 & 382801 & $09-29-09$ \\
\hline & & & \\
\hline & & & \\
\hline & & & \\
\hline & & & \\
\hline & & & \\
\hline & & & \\
\hline & & & \\
\hline
\end{tabular}

This certification is provided as a courtesy to the waste generator for information purposes only.

Special Set

\section{Instructions:}

Shipment Number - enter shipment number from LWIS database.

Date of Disposal - enter date waste was placed in disposal cell. 
NSTec

Form

CERTIFICATE OF DISPOSAL

08/06/09

FRM-2217

(LOW LEVEL WASTE)

Rev. 0

Page 1 of 1

\section{Nevada Test Site}

This Certificate acknowledges that the following shipment(s) of waste have been disposed at the Nevada Test Site Radioactive Waste Management Site.

\begin{tabular}{|l|l|l|l|}
\hline Shipment Number & $\begin{array}{c}\text { Waste Stream } \\
\text { Identification \# }\end{array}$ & Package \# & Date of Disposal \\
\hline DPL09055 & LRY5LLFY07002 & 09L072 & 09-30-09 \\
\hline & & & \\
\hline & & & \\
\hline & & & \\
\hline & & & \\
\hline & & & \\
\hline
\end{tabular}

This certification is provided as a courtesy to the waste generator for information purposes only.

Speciol isit

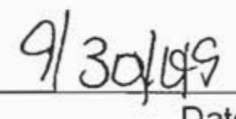

\section{Instructions:}

Shipment Number - enter shipment number from LWIS database.

Date of Disposal - enter date waste was placed in disposal cell. 
NSTec

Form

CERTIFICATE OF DISPOSAL

FRM-2217

\section{Nevada Test Site}

This Certificate acknowledges that the following shipment(s) of waste have been disposed at the Nevada Test Site Radioactive Waste Management Site.

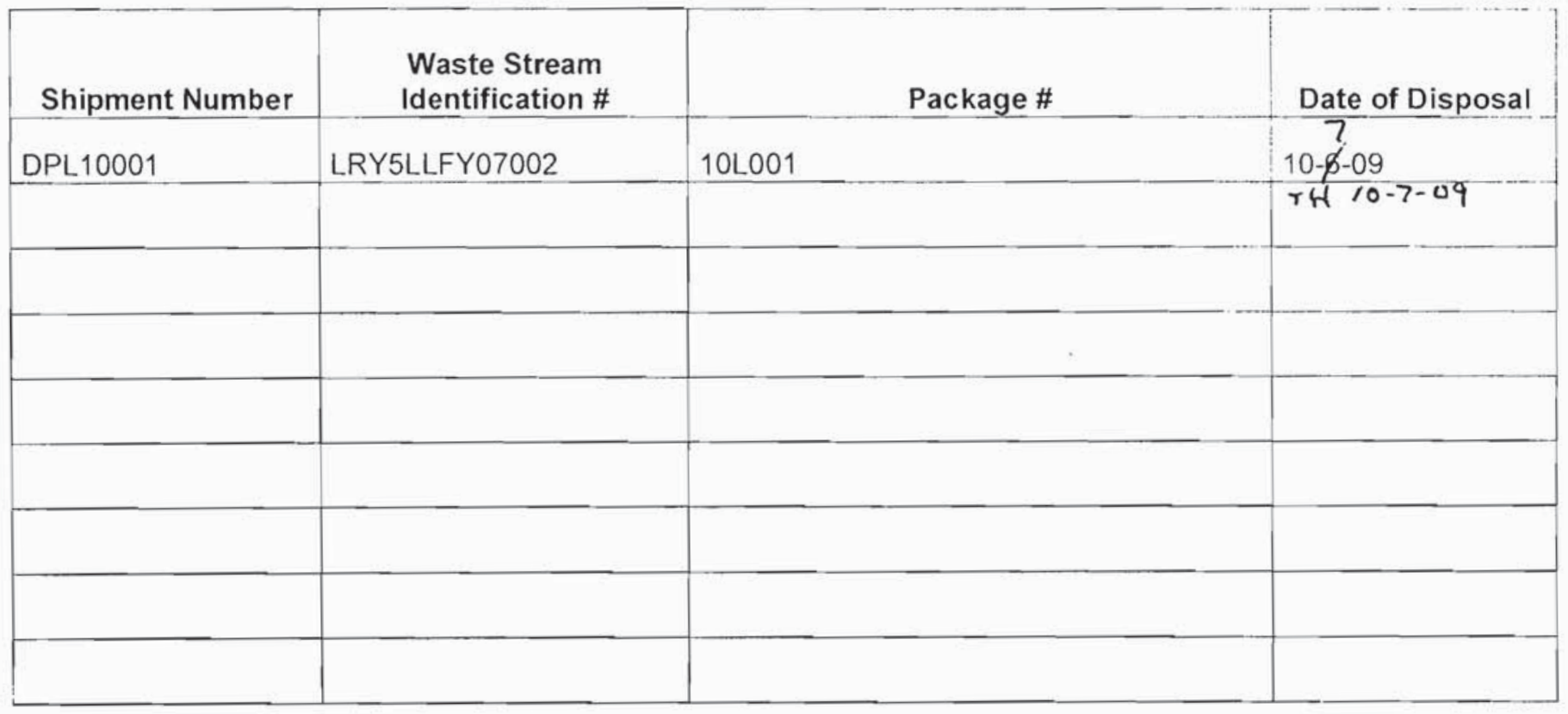

This certification is provided as a courtesy to the waste generator for information purposes only.

\section{Instructions:}

Shipment Number - enter shipment number from LWIS database.

Date of Disposal - cnter date waste was placed in disposal cell. 
NSTec

Form

CERTIFICATE OF DISPOSAL

FRM-2217

(LOW LEVEL WASTE)

Rev. 0

Page 1 of 1

\section{Nevada Test Site}

This Certificate acknowledges that the following shipment(s) of waste have been disposed at the Nevada Test Site Radioactive Waste Management Site.

\begin{tabular}{|l|l|l|l|l|}
\hline Shipment Number & \multicolumn{1}{|c|}{$\begin{array}{c}\text { Waste Stream } \\
\text { Identification \# }\end{array}$} & Package \# & Date of Disposal \\
\hline & LRY5LLFY7002 & 10L002 & & $10-20-09$ \\
\hline & & & & \\
\hline & & & & \\
\hline & & & & \\
\hline & & & & \\
\hline & & & & \\
\hline & & & & \\
\hline
\end{tabular}

This certification is provided as a courtesy to the waste generator for information purposes only.

Signature

i $\frac{1}{2} \times \frac{109}{\text { Date }}$

Instructions:

Shipment Number - enter shipment number from LWIS database.

Date of Disposal - enter date waste was placed in disposal cell. 
NSTec

Form

FRM-2217
CERTIFICATE OF DISPOSAL

(LOW LEVEL WASTE)
08/06/09

Rev. 0

Page 1 of 1

\section{Revada Test Site}

This Certificate acknowledges that the following shipment(s) of waste have been disposed al the Uevada Test Site Radioactive Waste Management Site.

\begin{tabular}{|l|l|l|l|}
\hline Shipment Number & \multicolumn{1}{c|}{$\begin{array}{c}\text { Waste Stream } \\
\text { Identification \# }\end{array}$} & Package \# & Date of Disposai \\
\hline DPL10073 & LRY5LLFY08002 & 10L139 - & 03-01-2010 \\
\hline & & & \\
\hline & & & \\
\hline & & & \\
\hline & & & \\
\hline
\end{tabular}

This certification is provided as a courtesy to the waste generator for information purposes only.

/s/: Theresa Hale.

Shipped By Signature

Waste Inspector

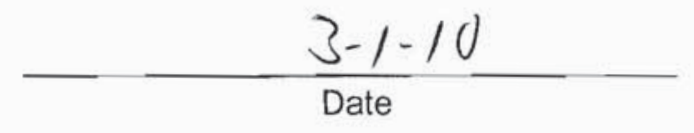

$\phi / M A 2 \phi 1 \phi$

Date

\section{WASTE SPECILET \\ Title}

\section{Instructions:}

Shipment Number - enter shipment number from LWIS database.

Date of Disposal - enter date waste was placed in disposal cell. 
FRI -2217

GLABRATE OF DISPOSAL

(LOW LEVEL WASTE)

Page 1 of 1

Nevada Test Site

This Certificate acknowledges that the following shipments) of waste have been disposed at the Nevada Test Site Radioactive Waste Management Complex.

\begin{tabular}{|l|l|l|l|}
\hline Shipment Number & \multicolumn{1}{|c|}{$\begin{array}{c}\text { Waste Stream } \\
\text { Identification \# }\end{array}$} & Package \# & Date of Disposal \\
\hline & LRY5LLFY08002 & 10 L140 & $03-02-2010$ \\
\hline & & & \\
\hline & & & \\
\hline & & & \\
\hline & & & \\
\hline & & & \\
\hline & & & \\
\hline & & & \\
\hline
\end{tabular}

This certification is provided as a courtesy to the waste generator for information purposes only.

/s/: Theresa Hale

WGS Signature

Waste Inspector

Title

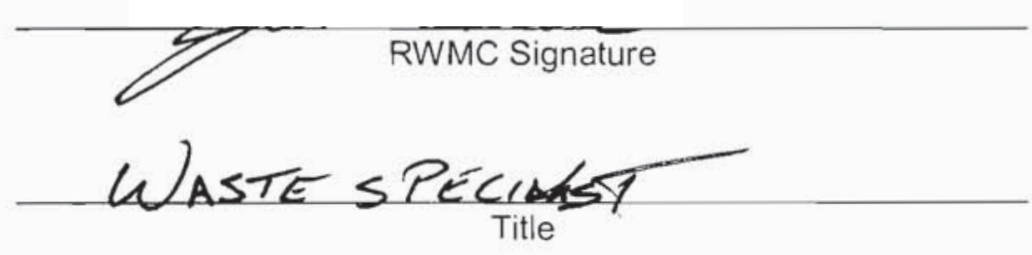

$$
3-2-10
$$

Date

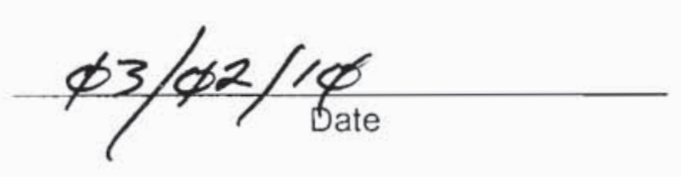

(Reference: OP-2151.304) 


\section{Nevada Test Site}

This Certificate acknowledges that the following shipment(s) of waste have been disposed at the Nevada Test Site Radioactive Waste Management Complex.

\begin{tabular}{|l|l|l|l|}
\hline Shipment Number & $\begin{array}{c}\text { Waste Stream } \\
\text { Identification \# }\end{array}$ & Package \# & Date of Disposal \\
\hline DPL10075 & LRY5LLFY8002 & 10L141 & $03-02-2010$ \\
\hline & & & \\
\hline & & & \\
\hline & & & \\
\hline & & & \\
\hline
\end{tabular}

This certification is provided as a courtesy to the waste generator for information purposes only.

/s/: Theresa Hale

WGS Signature

Waste Inspector
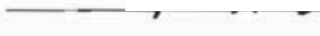

RWMC Signature

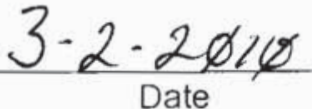

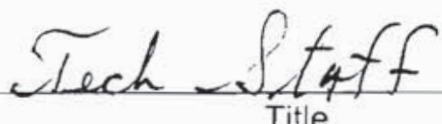


NSTec

Form

FRM-2217
CERTIFICATE OF DISPOSAL

(LOW LEVEL WASTE)
$03 / 01 / 10$

Rev. 01

Page 1 of 1

\section{Nevada Test Site}

This Certificate acknowledges that the following shipment(s) of waste have been disposed at the Nevada Test Site Radioactive Waste Management Complex.

\begin{tabular}{|l|l|l|l|}
\hline Shipment Number & \multicolumn{1}{|c|}{$\begin{array}{c}\text { Waste Stream } \\
\text { Identification \# }\end{array}$} & Package \# & Date of Disposal \\
\hline DPL10076 & LRY5LLFY08002 & 10L142 & $03-03-2010$ \\
\hline & & & \\
\hline & & & \\
\hline & & & \\
\hline & & & \\
\hline & & & \\
\hline
\end{tabular}

This certification is provided as a courtesy to the waste generator for information purposes only.

Ns/: Theresa Hale

WGS Signature

Waste Inspector

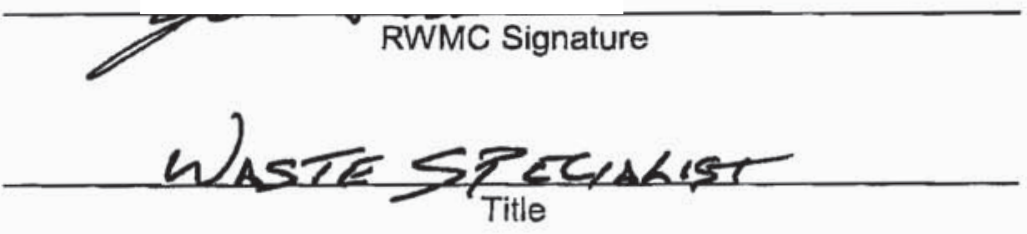

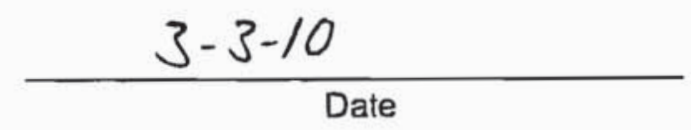

कsMare $20<0$ 
NSTec

Form

FRM-221T
CERTIFICATE OF DISPOSAL

(LOW LEVEL WASTE)
$03 / 01 / 10$

Rev. 01

Page 1 of 1

Nevada Test Site

This Certificate acknowledges that the following shipments) of waste have been dispose of at the Nevada Test Site Radioactive Waste Management Complex.

\begin{tabular}{|l|l|l|l|}
\hline Shipment Number & $\begin{array}{c}\text { Waste Stream } \\
\text { Identification \# }\end{array}$ & Package \# & Date of Disposal \\
\hline DPL10136 & LRY5LLFY08002 & 10L202 & $3-10-10$ \\
\hline & & & \\
\hline & & & \\
\hline & & & \\
\hline & & & \\
\hline
\end{tabular}

This certification is provided as a courtesy to the waste generator for information purposes only.

/s/: Theresa Hale

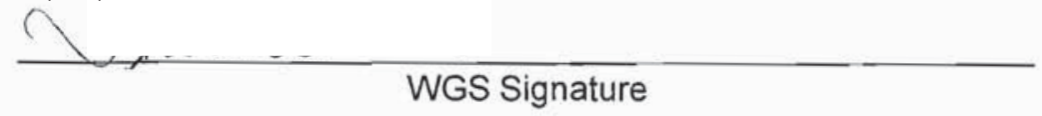

$\frac{3-10-10}{\text { Date }}$

- Waste Inspector
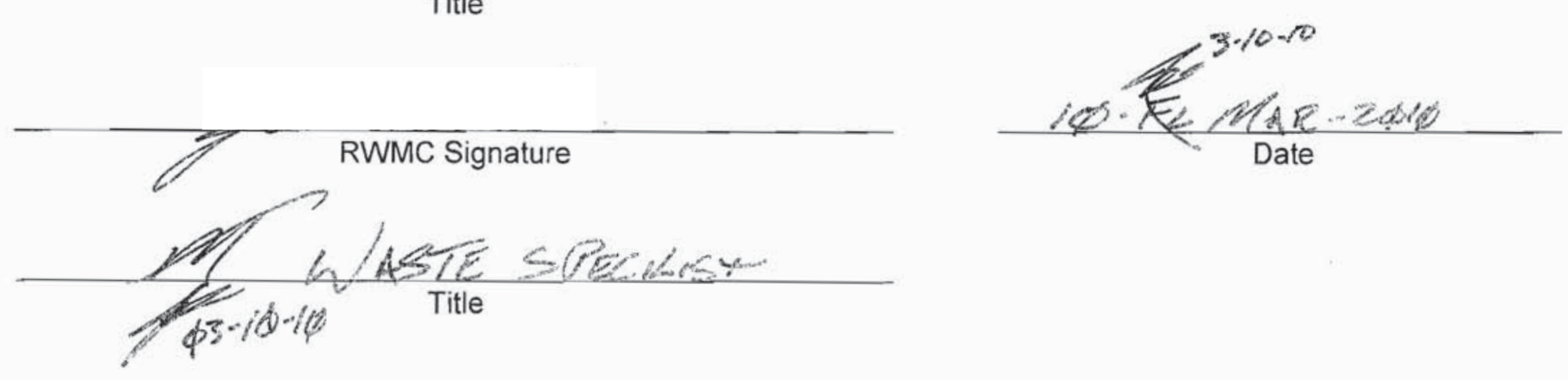

(Reference: OP-2151.304) 
NSTec:

Form

FRM -2217

\section{CERTIFICATE OF DISPOSAL.}

(LOW LEVEL WASTE)
03/01/10

Rev. 01

Page 1 of 1

Fevacia Testisite

This Certificate acknowledges that the following shipment(s) of waste have been disposed at the Neveda Test Site Radioactive Waste Management Complox.

\begin{tabular}{|l|l|l|l|}
\hline Shipment Number & $\begin{array}{c}\text { Waste Stream } \\
\text { Identification \# }\end{array}$ & Package \# & Date of Disposal \\
\hline DPL10137 & LRY5LLFY08002 & 10 L203 & 03-10-2010 \\
\hline & & & \\
\hline & & & \\
\hline & & & \\
\hline & & & \\
\hline
\end{tabular}

This certification is provided as a courtesy to the waste generator for information purposes only.

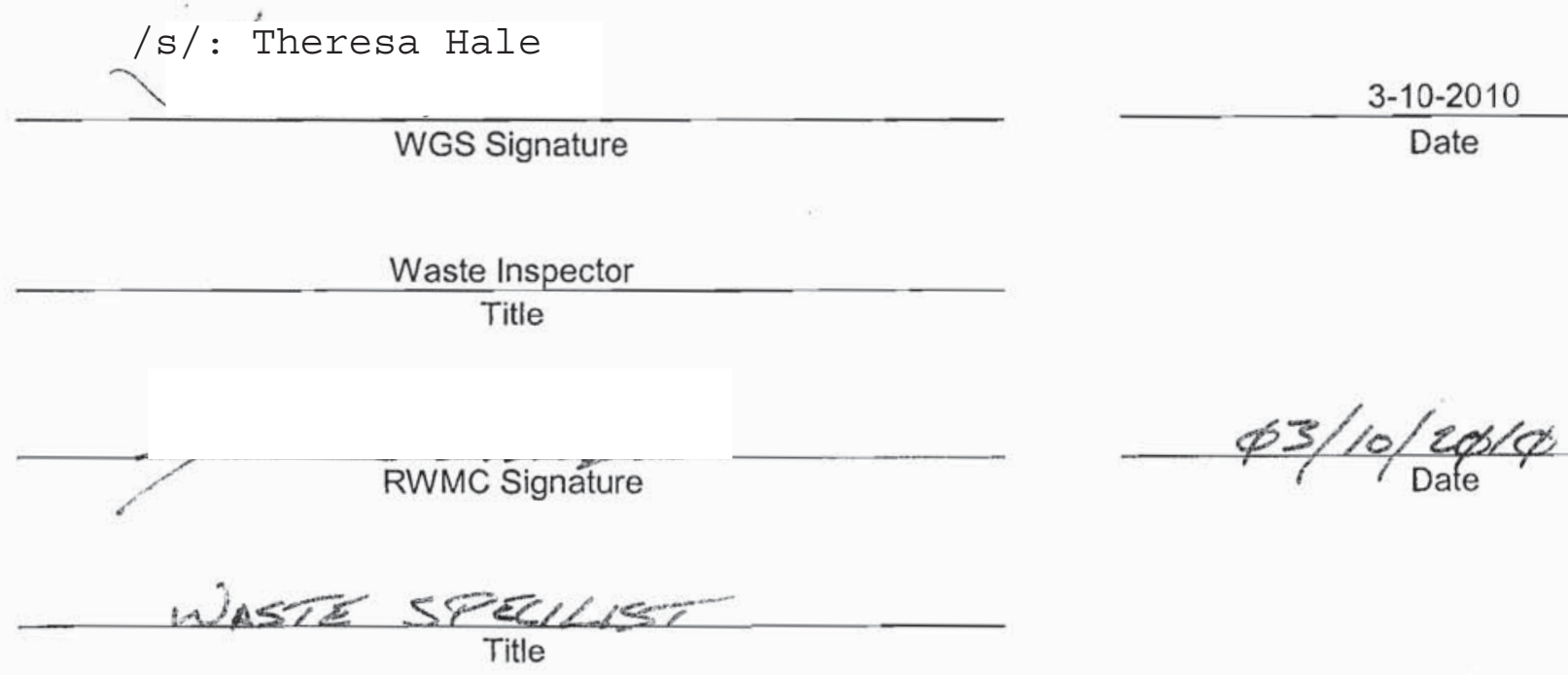


NSTec

Fom

GEDIFICATE OF DISPOSAL

FRML-2217

(LOW LEVEL WASTE)

Rev. 01

Page 1 of 1

Nevada Test site

This Certificate acknowledges that the following shipment(s) of waste have Wec disposec at the Hevada Test Site Radioactive Waske Managemont Complex.

\begin{tabular}{|c|c|c|c|}
\hline Shipment Number & $\begin{array}{l}\text { Waste Stream } \\
\text { Identification } \text { it }\end{array}$ & Package \# & Date of Disposal \\
\hline DPL10138 & LRY5LLFY08002 & 10L.204 & 03-10-2010 \\
\hline & & & \\
\hline & & & \\
\hline & & & \\
\hline & & & \\
\hline & & & \\
\hline & & & \\
\hline & & & \\
\hline
\end{tabular}

This certification is provided as a courtesy to the waste generator for information purposes only.

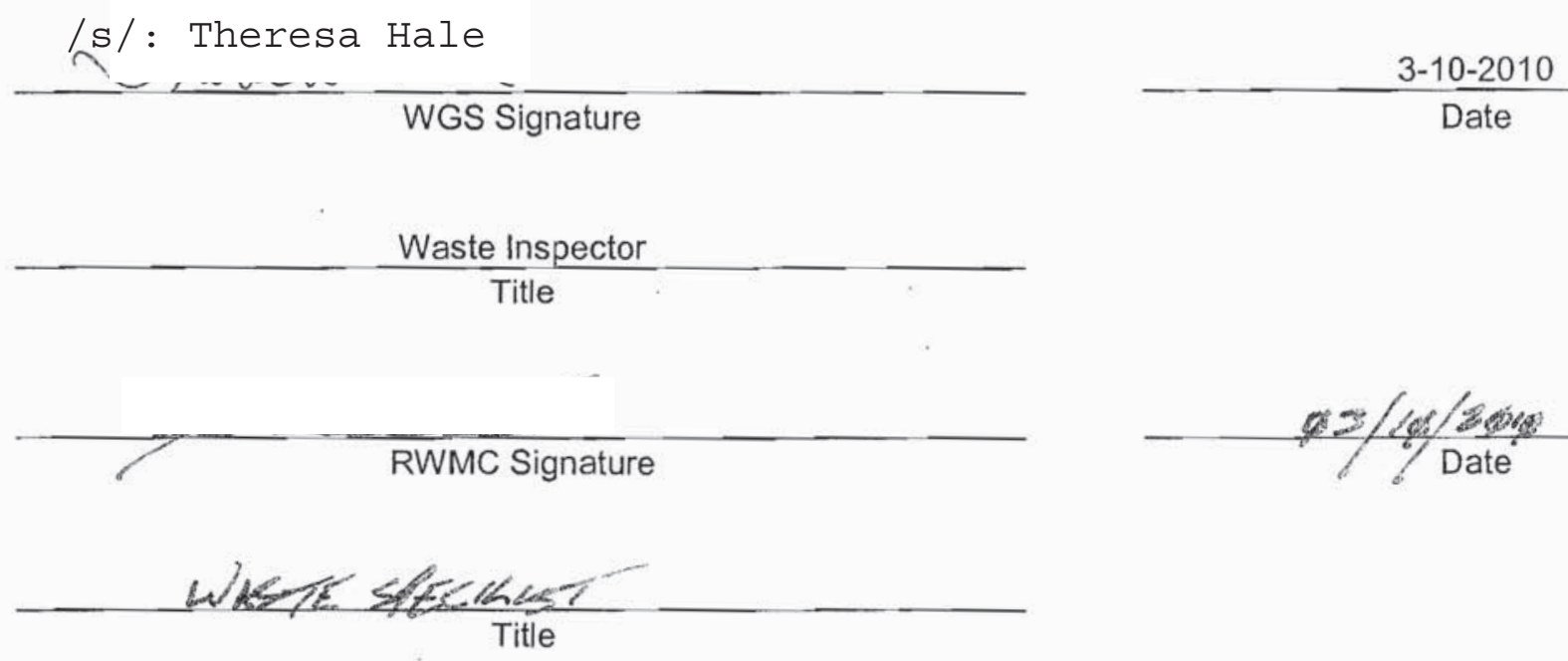



HSTeO
تrom
FM $22 \div 7$
CERTIFICATE OF DISPOSAL
(LOW LEVEL WASTE)

Wade ven the

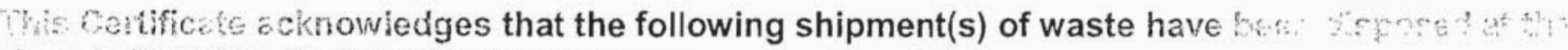
"Grab Test Site Radioactive Waste Management Complex.

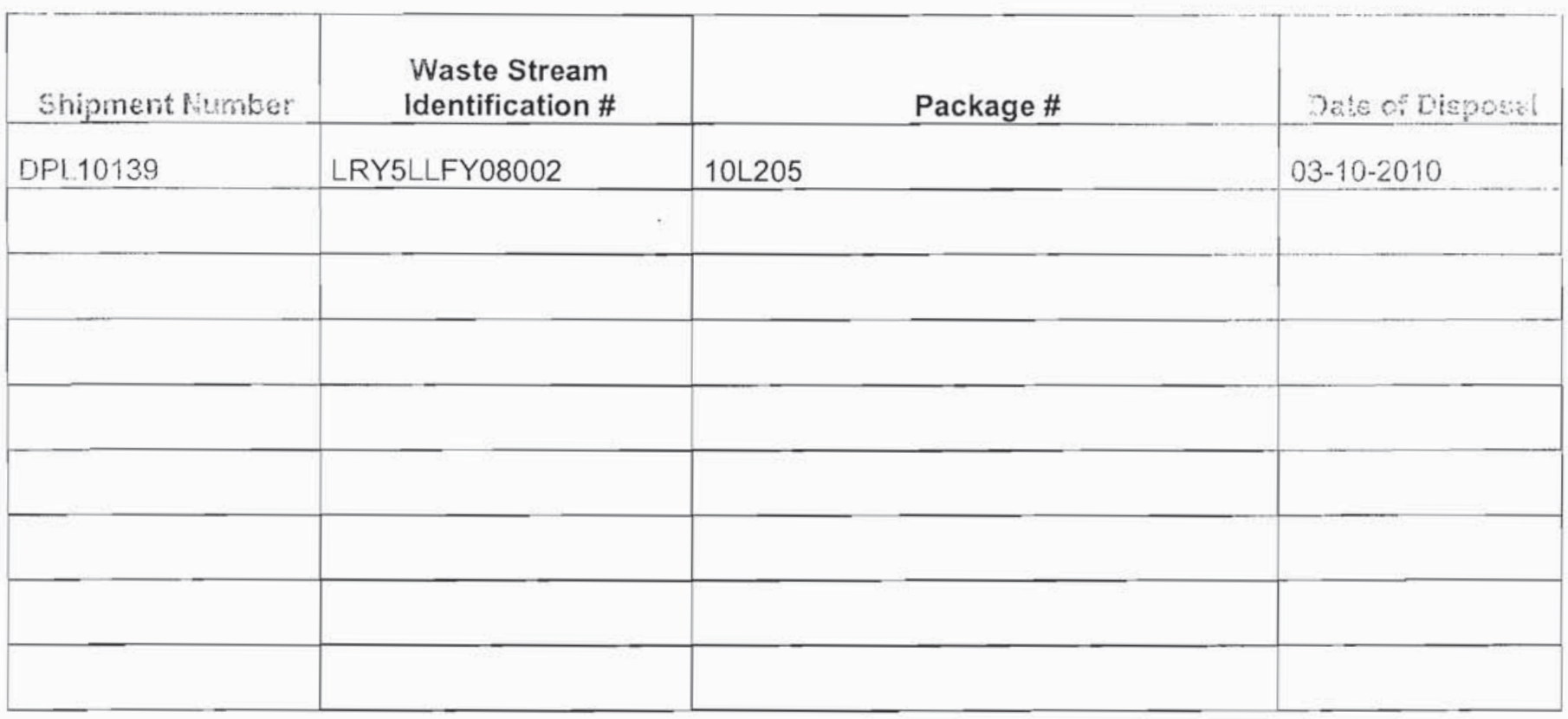

This certification is provided as a courtesy to the waste generator for information purposes only.

$$
\text { /s/: Theresa Hale }
$$

WGS Signature

Waste Inspector

$$
\text { Title }
$$

RWME Signature

$$
\text { WASTE SPECALWS }
$$

3-10-2010

Date

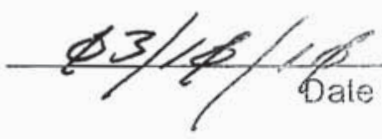




\section{Nevade Test Site}

This Certificate acknowiedges that the following shipments) of waste have been disposed at tht Nevada 'Test Site Radicactive Waste Managenent Complex.

\begin{tabular}{|l|l|l|l|}
\hline Shipment Number & $\begin{array}{c}\text { Waste Stream } \\
\text { Identification \# }\end{array}$ & Package \# & Date of Disposai \\
\hline DPL10140 & LRY5LLFY08002 & 10L206 & $03-10-2010$ \\
\hline & & & \\
\hline & & & \\
\hline & & & \\
\hline & & & \\
\hline & & & \\
\hline
\end{tabular}

This certification is provided as a courtesy to the waste generator for information purposes only.

$$
\text { /s/:Theresa Hale }
$$

WGS Signature

Waste Inspector

Title

/s/:Jon Tanaka

\begin{tabular}{|c|c|}
\hline $\mathrm{RV}$ & MC Ś ignature \\
\hline$U\rangle_{A}=\angle E$ & Spet ahes? \\
\hline
\end{tabular}

3-10-2010

Date

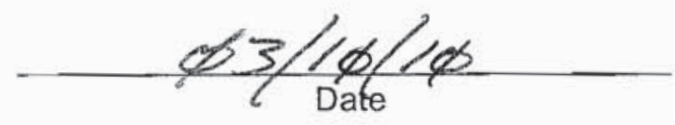




\section{Nevada Test Site}

This Certificate acknowledges that the following shipment(s) of waste have been disposed at the Nevada Test Site Radioactive Waste Management Complex.

\begin{tabular}{|c|c|c|c|}
\hline Shipment Number & $\begin{array}{l}\text { Waste Stream } \\
\text { Identification \# }\end{array}$ & Package \# & Date of Disposal \\
\hline DPL 10077 TH & LRY5LLFY08002 & 10L143 & $03-11-2010$ \\
\hline & & & \\
\hline & & & \\
\hline & & & \\
\hline & & & \\
\hline & & & \\
\hline & & & \\
\hline & & & \\
\hline & & & \\
\hline
\end{tabular}

This certification is provided as a courtesy to the waste generator for information purposes only.

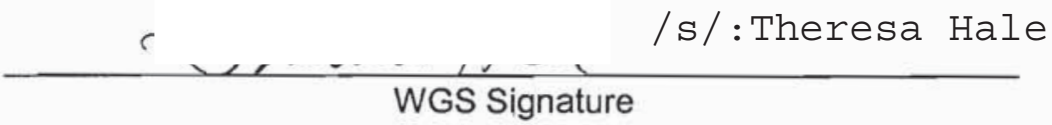

3-11-2010

Date

Waste Inspector

Title

/s/:Jon Tanaka
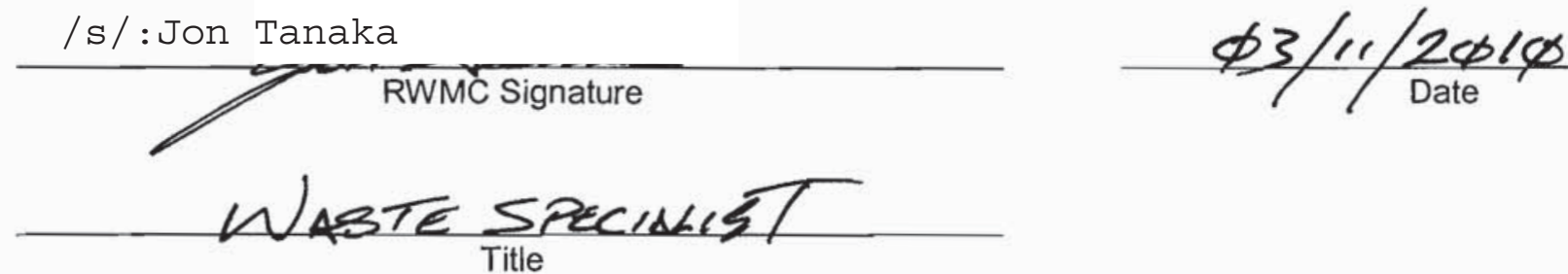
NSTec

Form

FRM-221
CERTIFICATE OF DISPOSAL.

(LOW LEVEL WASTE)

Revada estene

This cerificate cones that the following shipment(s) of waste

Kevada Fet

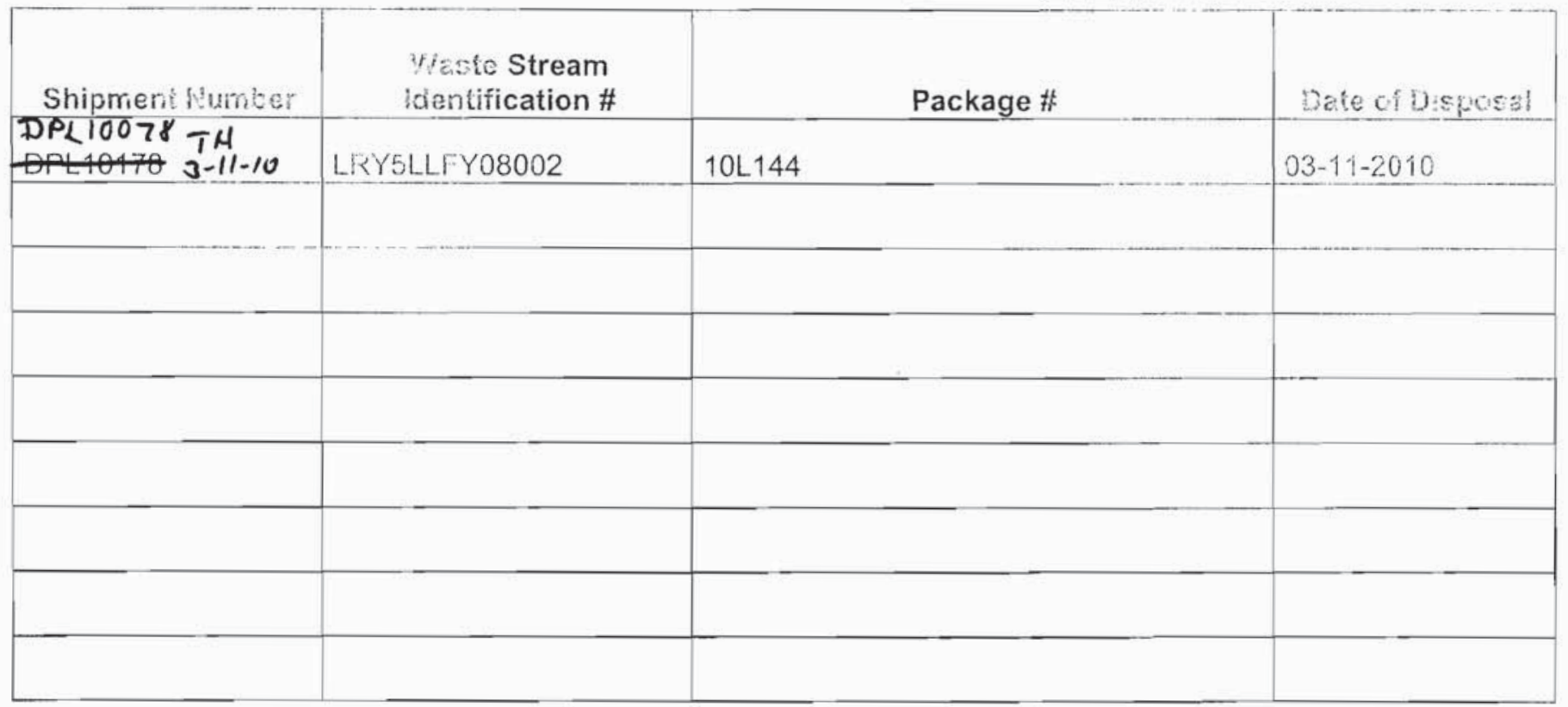

This certification is provided as a courtesy to the waste generator for information purposes only.

WGS Signature
Waste Inspector
Title

/s/:Jon Tanaka
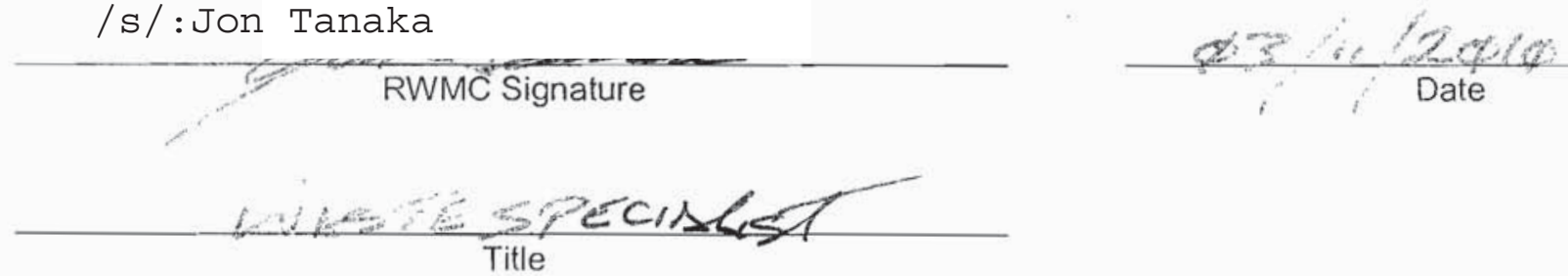
Evada Test Site

This Certificate acknowledges that the following shipment(s) of waste crada Test Site Radioactive Waste Management Complex.

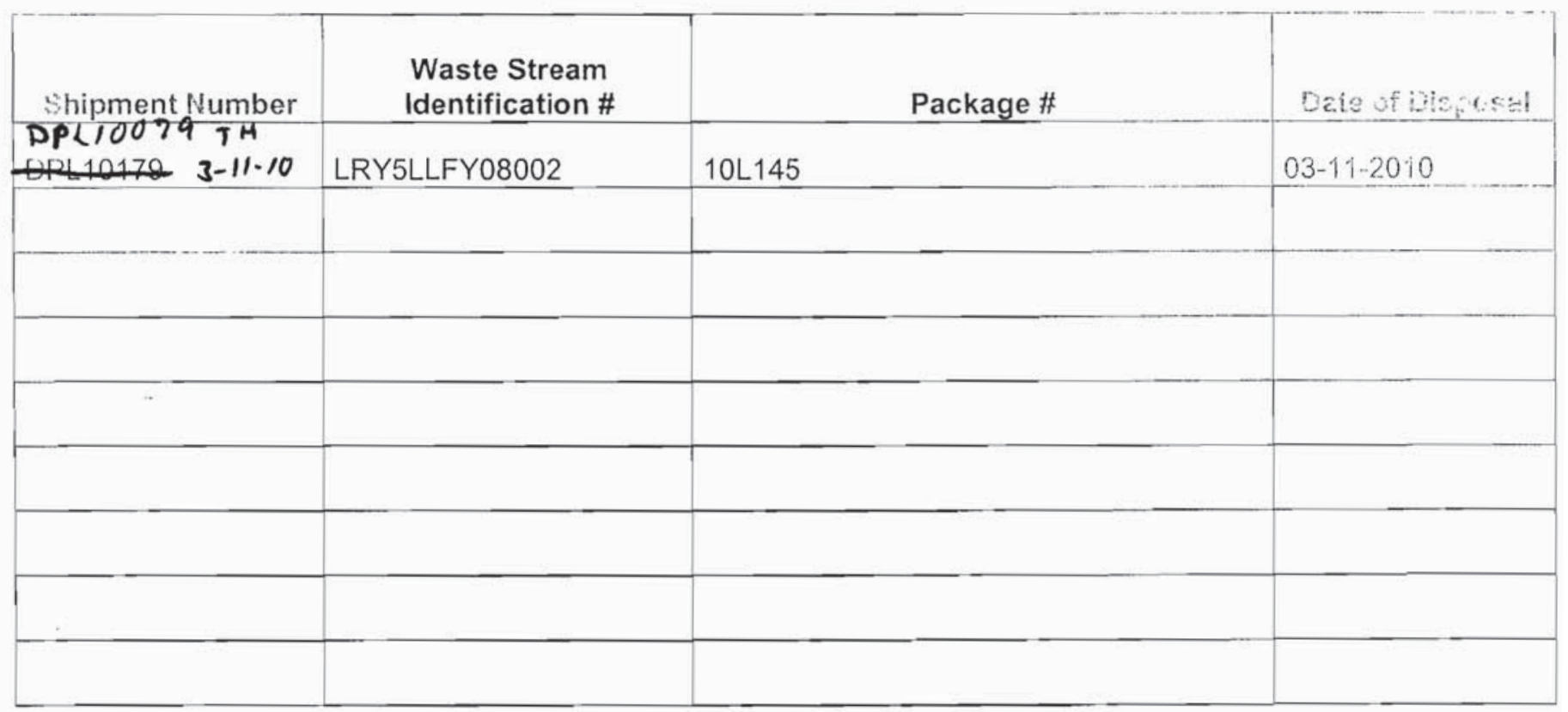

This certification is provided as a courtesy to the waste generator for information purposes only.

/s/:Theresa Hale

WGS Signature

Waste Inspector

Title

/s/:Jon Tanaka

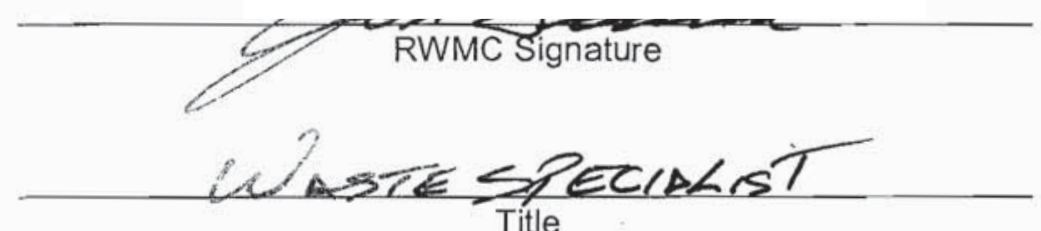

3-11-2010

Date

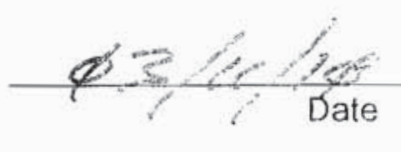


NSTec

Form

FRM-2217
CERTIFICATE OF DISPOSAL

(LOW LEVEL WASTE)
03/01/10

Rev. 01

Page 1 of 1

\section{Nevada Test Site}

This Certificate acknowledges that the following shipment(s) of waste have been disposed at the Nevada Test Site Radioactive Waste Management Complex.

\begin{tabular}{|l|l|l|l|}
\hline Shipment Number & \multicolumn{1}{|c|}{$\begin{array}{c}\text { Waste Stream } \\
\text { Identification \# }\end{array}$} & Package \# & Date of Disposal \\
\hline DPL10080 & LRY5LLFY08002 & 10 146 & $03-11-2010$ \\
\hline & & & \\
\hline & & & \\
\hline & & & \\
\hline & & & \\
\hline & & & \\
\hline & & & \\
\hline
\end{tabular}

This certification is provided as a courtesy to the waste generator for information purposes only.

/s/:Theresa Hale

WGS Signature

Waste Inspector

Title

Y RWMC Signature

Ociembit
3-11-2010

Date 


\begin{tabular}{lcr|} 
NSTEC & CERTIFICATE OF DISPOSAL & $03 / 01 / 10$ \\
Form & (LOWLEVEL WASTE) & ReV. 01 \\
FRM 2217 & Page 1 of 1 \\
\hline
\end{tabular}

\section{Nevada Test Site}

This Certificate acknowledges that the following shipment(s) of waste have been disposed at the Nevada Test Site Radioactive Vaste Mlanagement Complex.

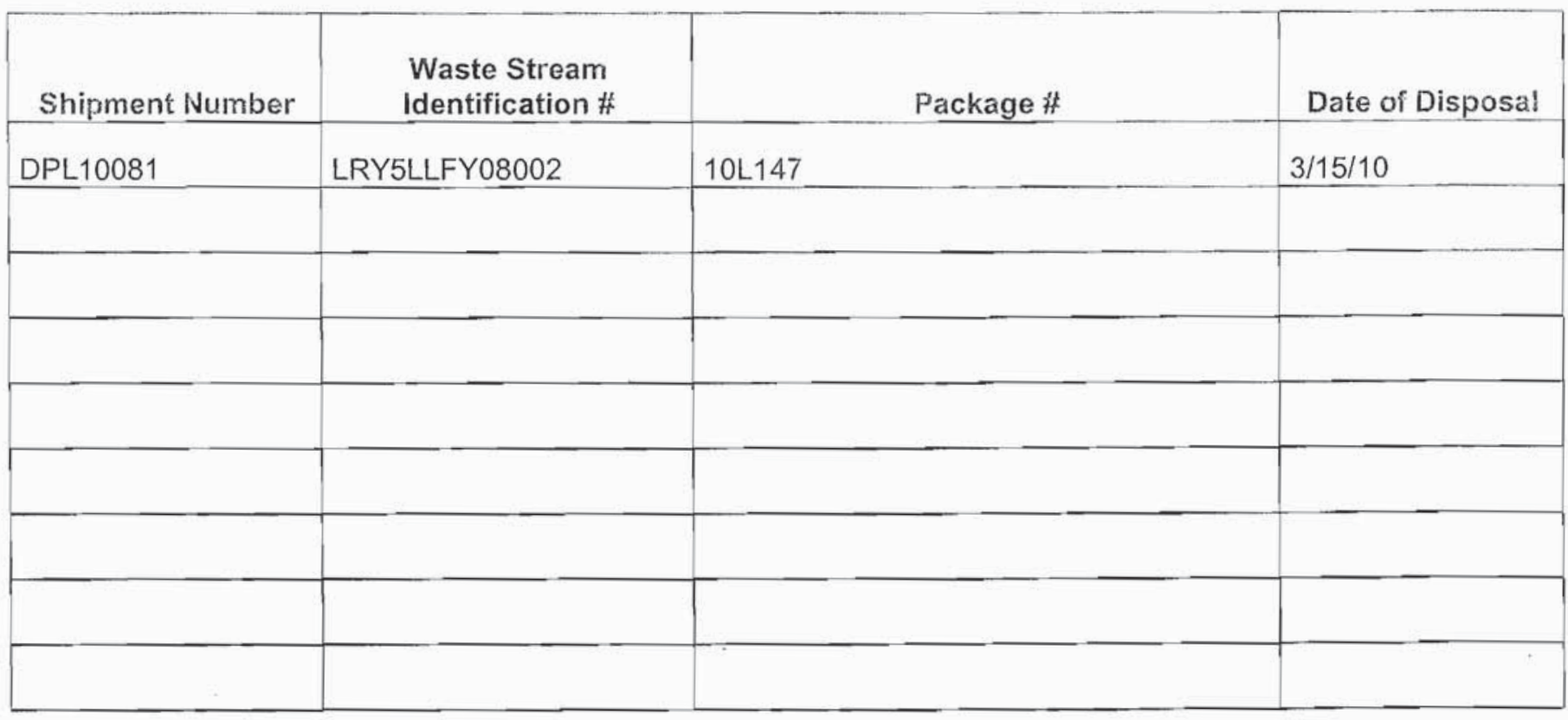

This certification is provided as a courtesy to the waste generator for information purposes only.

$\frac{\text { WGS Signature }}{\frac{\text { Waste Inspector }}{\text { Title }}}$

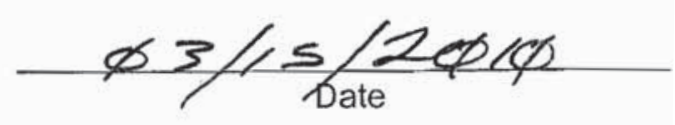




\section{Evada Test Site}

Tis Certificate acknowledges that the following shipment(s) of waste have been dispose - Sovada Test Site Radioactive Waste Management Complex.

\begin{tabular}{|c|c|c|c|}
\hline Shipment Number & $\begin{array}{l}\text { Waste Stream } \\
\text { Identification \# }\end{array}$ & Package \# & Date of 135 \\
\hline DPL10141 & LRY5LLFY08002 & 10L207 & $03-15-2010$ \\
\hline & & & \\
\hline & & & \\
\hline & & & \\
\hline & & & \\
\hline & & & \\
\hline & & & \\
\hline & & & \\
\hline
\end{tabular}

This certification is provided as a courtesy to the waste generator for information purposes only.

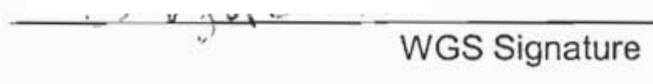

Waste Inspector

$$
\text { Title }
$$

/s/:Jon Tanaka

RWMC Śignature

LSTE

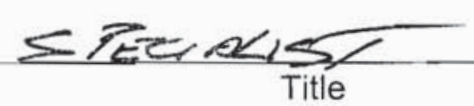

3-15-2010

Date

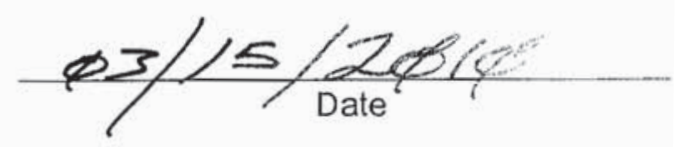




\section{ieverix pest Site}

As sertificate acknowledges that the following shipment(s) of waste have

evade Test Site Racioactive Waste Management Complex.

\begin{tabular}{|c|c|c|c|}
\hline Shiprent Number & $\begin{array}{l}\text { Waste Stream } \\
\text { Identification \# }\end{array}$ & Package \# & 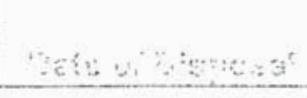 \\
\hline DPL 10142 & LRY5LLFY08002 & 10L208 & $03-15-2010$ \\
\hline & & & \\
\hline & & & \\
\hline & & & \\
\hline & & & \\
\hline & & & \\
\hline & & & \\
\hline & & & \\
\hline
\end{tabular}

This certification is provided as a courtesy to the waste generator for information purposes only.

\section{WGS Signature}

Waste Inspector

Title

/s/:Jon Tanaka

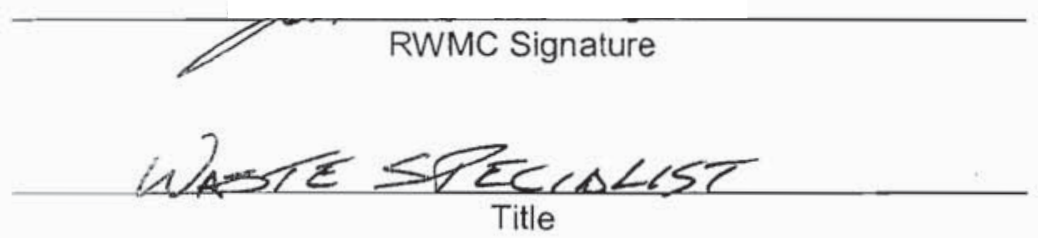

3-15-2010

Date

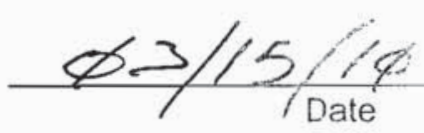


HSTec

Form

FRM-2217

CERTIFICATE OF DISPOSAL

\section{levada Test Site}

This Certificate acknowledges that the following shipment(s) of waste have been disposed $a$ Ifevada Test Site Radioactive Waste Management Complex.

\begin{tabular}{|c|c|c|c|}
\hline Shipment Number & $\begin{array}{l}\text { Waste Stream } \\
\text { Identification \# }\end{array}$ & Package \# & Date of Dis \\
\hline DPL10152 & LRY5LLFY08002 & 10L218 & $03-15-2010$ \\
\hline & & & \\
\hline & & & \\
\hline & & & \\
\hline & & & \\
\hline & & & \\
\hline & & & \\
\hline & & & \\
\hline & & & \\
\hline
\end{tabular}

This certification is provided as a courtesy to the waste generator for information purposes only.

WGS Signature

Waste Inspector

Title

/s/:Jon Tanaka

RWMC Signature

WASTE
03-15-2010

Date

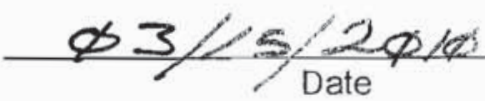




\section{Gevada Test Site}

'this Certificate acknowledges that the following shipment(s) of waste have bee" Hevada Test Site Radioactive Waste Management Complex.

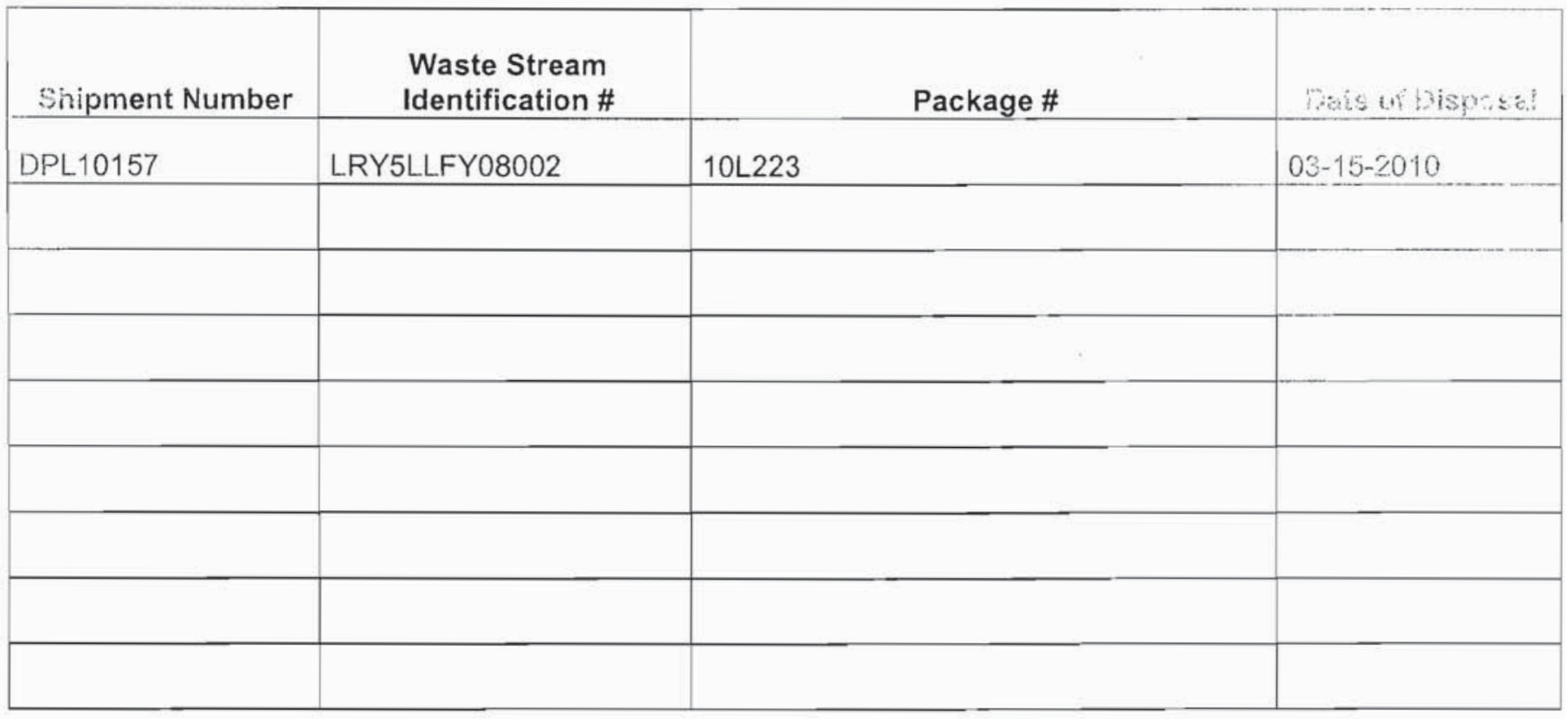

This certification is provided as a courtesy to the waste generator for information purposes only.

$$
\text { - }
$$$$
\text { ¿ }
$$$$
\text { WGS Signature }
$$$$
\text { 03-15-2010 }
$$$$
\text { Date }
$$

Waste Inspector

Title

/s/: Jon Tanaka
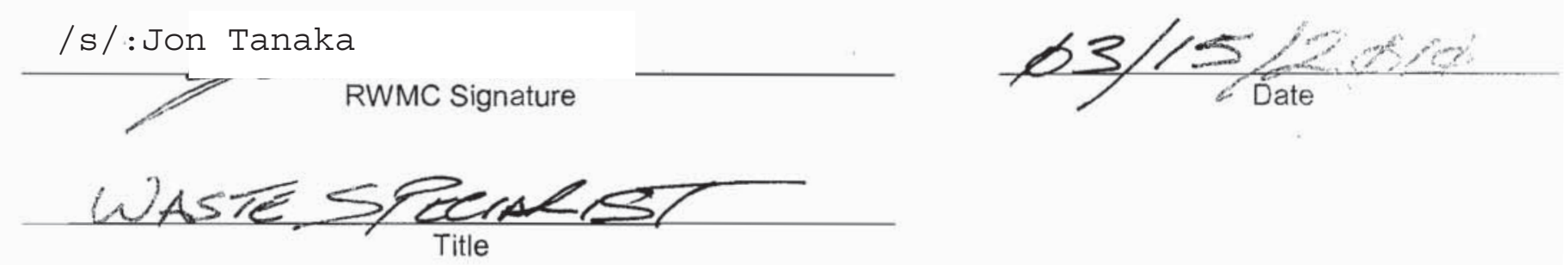
HSTec

Form

CERTIFICATE OF DISPOSAI.

Mevada Test Sife

inis Certificate as on whedges that the following shipment(s) of was Crada Test Site 7 aclieactive Waste Management Complex.

\begin{tabular}{|c|c|c|c|}
\hline Shipment Number & $\begin{array}{l}\text { Waste Stream } \\
\text { identification \# }\end{array}$ & Package \# & Date Molsma \\
\hline DPL10082 & LRY5LLFY08002 & $10 \mathrm{~L} 148$ & \\
\hline & & . & \\
\hline & & & \\
\hline & & & \\
\hline & & & \\
\hline & & & \\
\hline & & & \\
\hline & & & \\
\hline & & & \\
\hline
\end{tabular}

This certification is provided as a courtesy to the waste generator for information purposes only.

WGS Signature

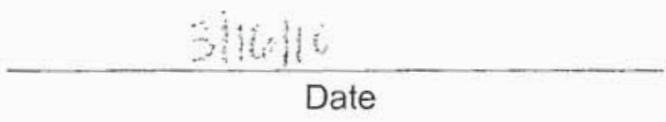

Waste Inspector

$$
\text { Title }
$$

/s/:Jon Tanaka

RWMC Signature

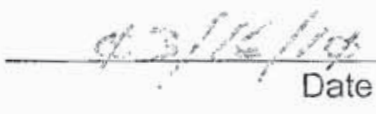

- W L T

Title 
NSTec

Form

FRM-2217

\section{CERTIFICATE OF DISPOSAL}

(LOW LEVEL WASTE)

\section{Revada Test Site}

This Certificate acknowledges that the following shipment(s) of waste have been disposectite Mevada Test Site Radioactive Waste Management Complex.

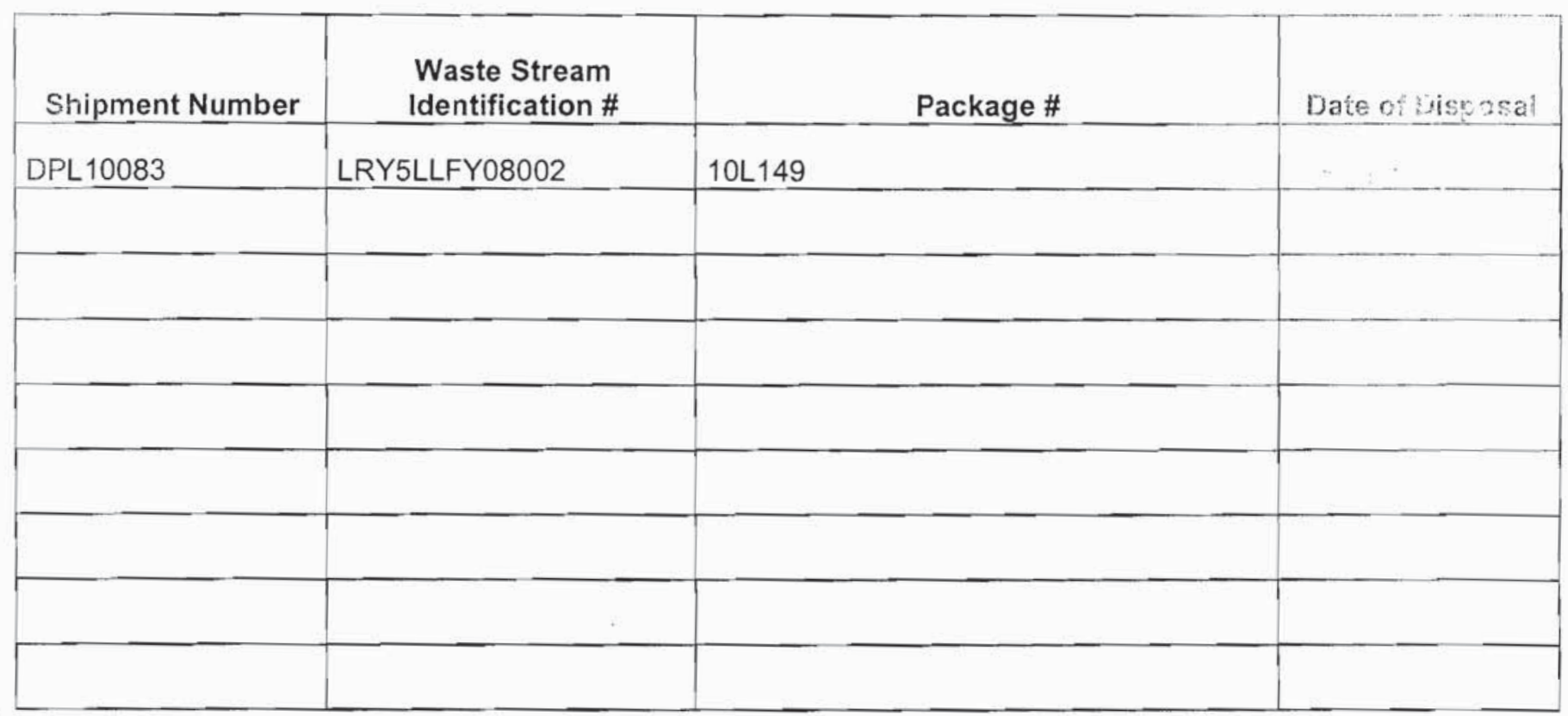

This certification is provided as a courtesy to the waste generator for information purposes only.

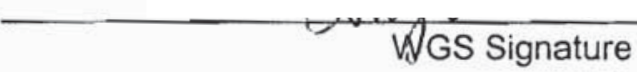

316110

$$
\text { Date }
$$

Waste Inspector

Title

-,$\cdots \cdot-$ RWMC Signàtưre

$3 \cdot 16 \cdot 1 \phi$

Teck SThff 
HSTEC

Form

IRM-2217
CERTIFICATE OF DISPOSAL

(LOW LEVEL WASTE)

Sevade rest site

ihis Certificate acknowledges that the following shipment(s) of waste have Revada Teet Site Radioactive Waste Management Complex.

\begin{tabular}{|c|c|c|c|}
\hline Shipment Humber & $\begin{array}{l}\text { Waste Stream } \\
\text { Identification \# }\end{array}$ & Package \# & Deto of Disposal \\
\hline DPL10143 & LRY5LLFY08002 & 10L209 & $\because$ \\
\hline & & & \\
\hline & & & \\
\hline & & & \\
\hline & & & \\
\hline & & & \\
\hline & & & \\
\hline & & & \\
\hline & & & \\
\hline
\end{tabular}

This certification is provided as a courtesy to the waste generator for information purposes only.

WGS Signature

Waste inspector

Title

/s/: Jon Tanaka

RASMC Signature
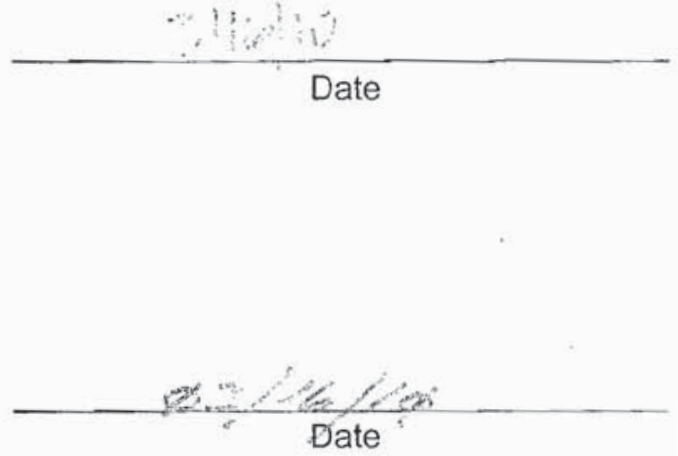
NSTec

Form

FRM-2217
CERTIFICATE OF DISPOSAL

(LOW LEVEL WASTE)
$03 / 01 / 10$

Rev. 01

Page 1 of 1

\section{Nevada Test Site}

This Certificate acknowledges that the following shipment(s) of waste have been disposed at the Nevada Test Site Radioactive Waste Management Complex.

\begin{tabular}{|c|c|c|c|}
\hline Shipment Number & $\begin{array}{l}\text { Waste Stream } \\
\text { Identification \# }\end{array}$ & Package \# & Date of Disposal \\
\hline DPL10144 & LRY5LLFY08002 & $10 \mathrm{~L} 210$ & $3 / 10110$ \\
\hline & & & \\
\hline & & & \\
\hline & & & \\
\hline & & & \\
\hline & & & \\
\hline & & & \\
\hline & & & \\
\hline
\end{tabular}

This certification is provided as a courtesy to the waste generator for information purposes only.

\begin{tabular}{l}
\hline WGS Signature \\
\hline$\frac{\text { Waste Inspector }}{\text { Title }}$ \\
\hline
\end{tabular}

RWMC Signature

316410

Date

hLW woste Spec

$3 / 16 / 0$

Date 
NSTec

Form

CERTIFICATE OF DISPOSAL

$03 / 01 / 10$

FRM-2217

(LOW LEVEL WASTE)

Rev. 01

Page 1 of 1

\section{Nevada Test Site}

This Certificate acknowledges that the following shipment(s) of waste have been disposed at the Nevada Test Site Radioactive Waste Management Complex.

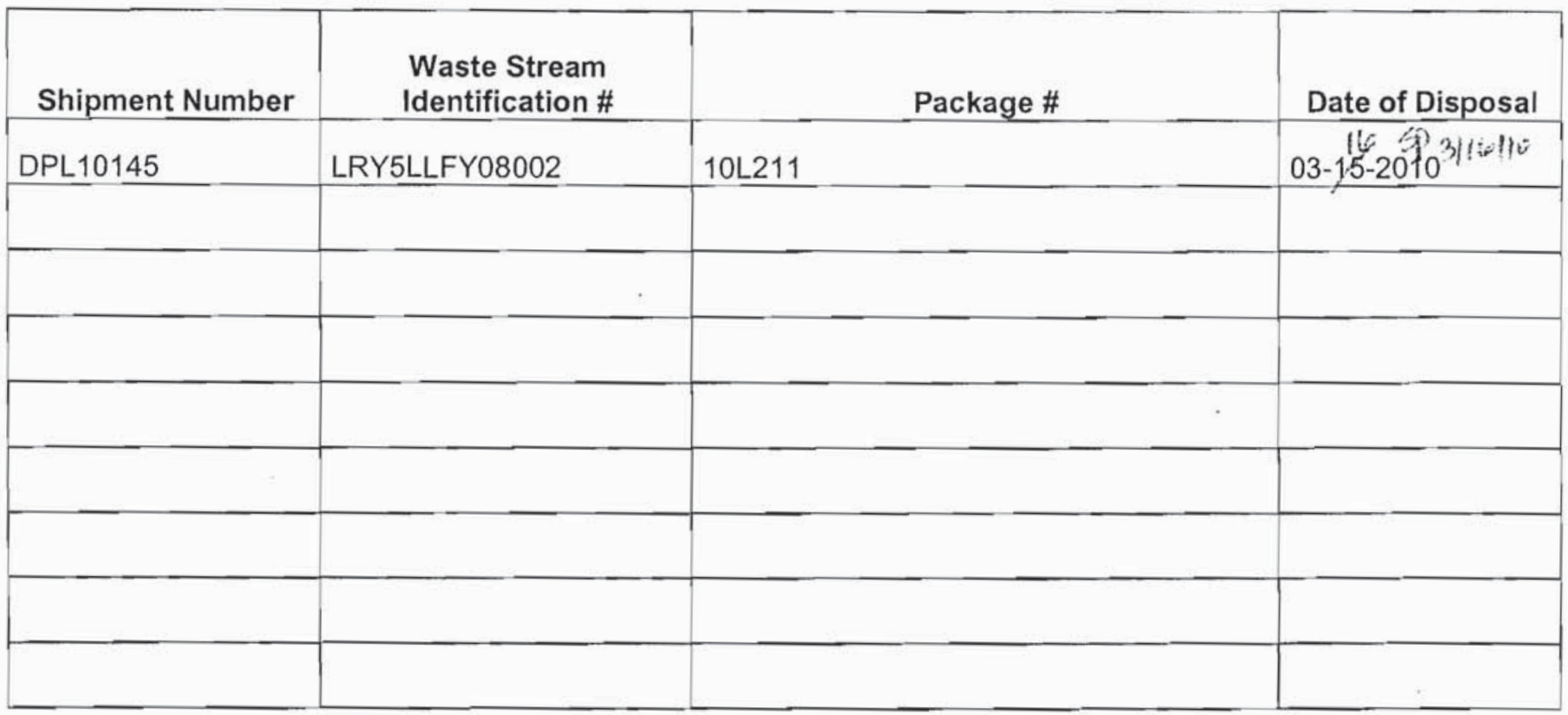

This certification is provided as a courtesy to the waste generator for information purposes only.

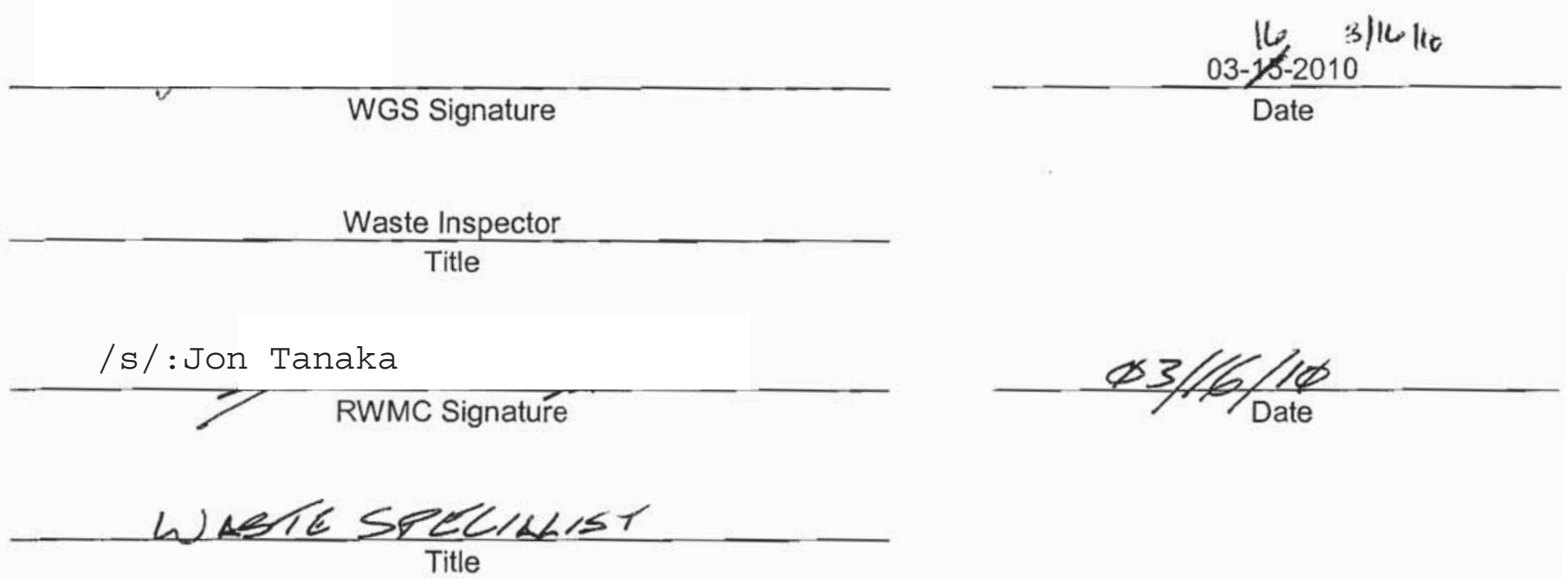


Rstec

Form

CERTIFICATE OF DISPOSAL

FRM -2217

(LOW LEVEL WASTE)

\section{Gevada Test Site}

This Certificate acknowledges that the following shipment(s) of waste have been dispos Mevada Test Site Radioactive Waste Management Complex.

\begin{tabular}{|l|l|l|l|}
\hline Shipment Number & $\begin{array}{c}\text { Waste Stream } \\
\text { Identification \# }\end{array}$ & Package \# & Date of 2isposá: \\
\hline DPL10146 & LRY5LLY08002 & 10L212 & $03-15-2010$ \\
\hline & & & \\
\hline & & & \\
\hline & & & \\
\hline & & & \\
\hline & & & \\
\hline & & & \\
\hline
\end{tabular}

This certification is provided as a courtesy to the waste generator for information purposes only.

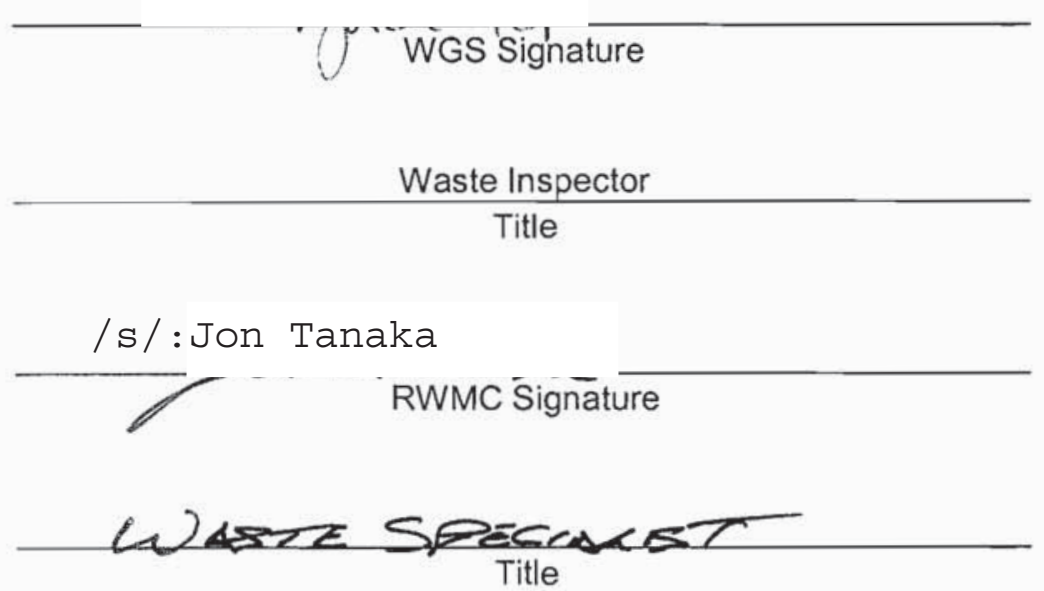

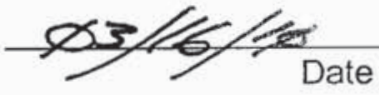




\section{Nevada Test Site}

This Certificate acknowledges that the following shipment(s) of waste have bectit. Hevada Test Site Radioactive Waste Management Complex.

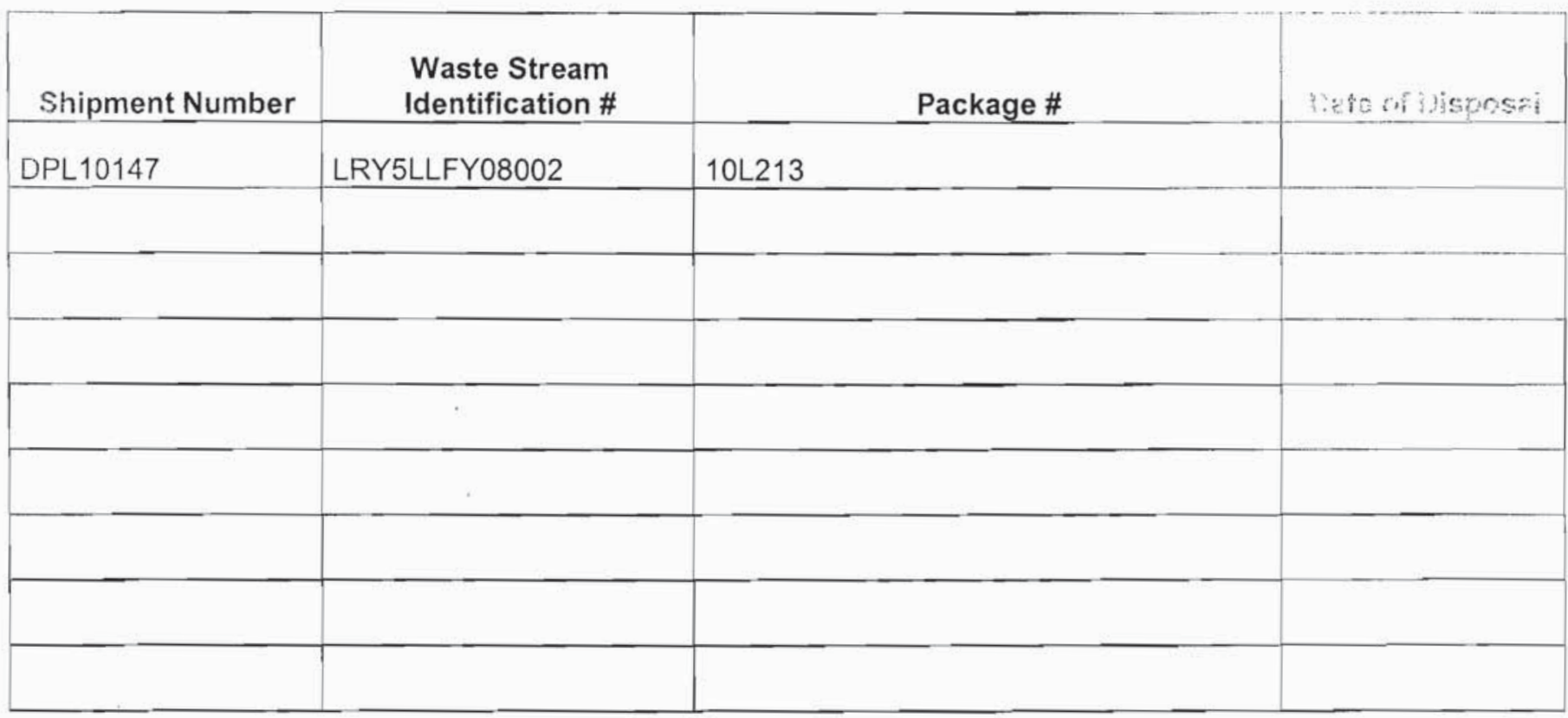

This certification is provided as a courtesy to the waste generator for information purposes only.

WGS Signature
$\frac{\text { Waste Inspector }}{\text { Title }}$
L $/$ : Jon Tanaka
RWMC Signature
Title

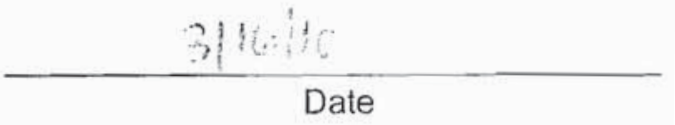

Title 
NSTec

Form

FRM-2217

\section{CERTIFICATE OF DISPOSAL}

Nevada Test Site

This Certificate acknowledges that the following shipment(s) of waste have bees ispesectine Mevada Test Site Radicactive Waste Management Complex.

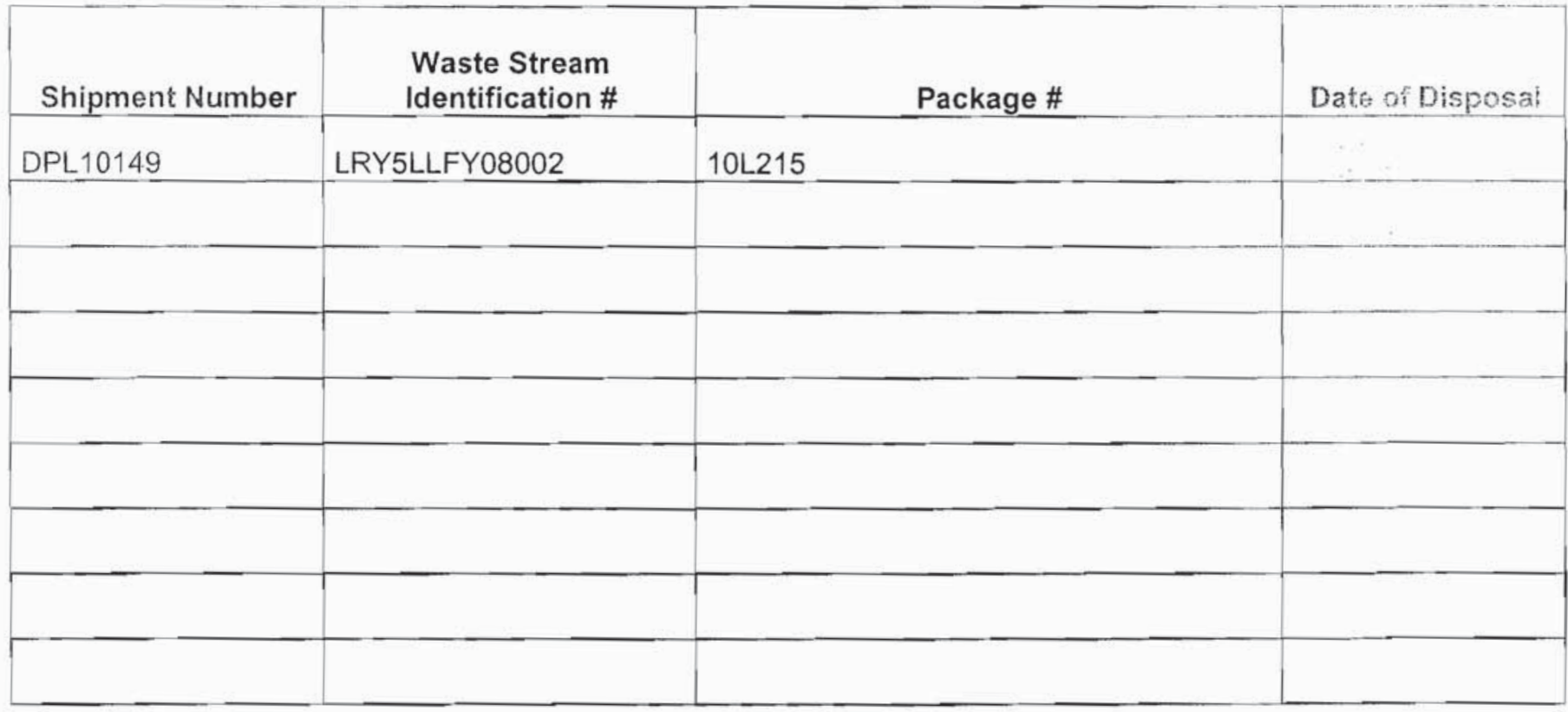

This certification is provided as a courtesy to the waste generator for information purposes only.

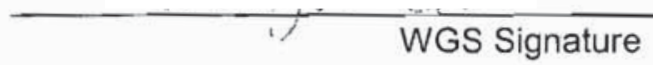

Waste Inspector

Title

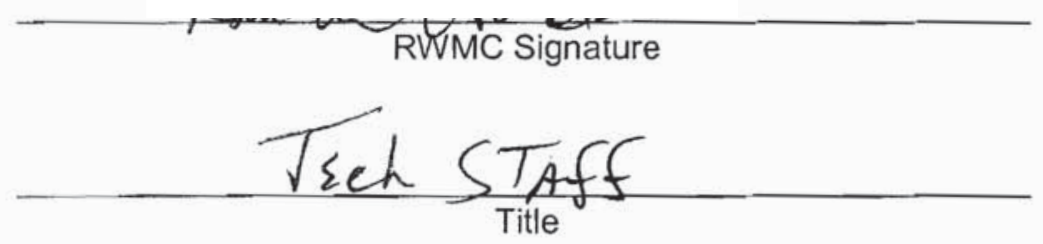

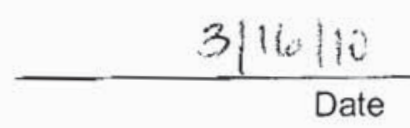

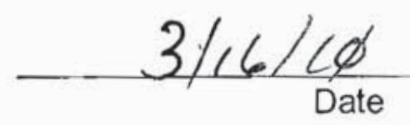


NSTeC

Form

CERTIFICATE OF DISPOSAL

FRM-2217

(LOW LEVEL WASTE)

\section{Nevada Test Site}

This Certificate acknowledges that the following shipment(s) of waste have been dispect Nevada Test Site Radioactive Waste Management Complex.

\begin{tabular}{|l|l|l|l|}
\hline Shipment Number & \multicolumn{1}{|c|}{$\begin{array}{c}\text { Waste Stream } \\
\text { Identification \# }\end{array}$} & Package \# & Date G Disposai \\
\hline DPL10153 & LRY5LLF08002 & 10 L219 & 03-15-2010 \\
\hline & & & \\
\hline & & & \\
\hline & & & \\
\hline & & & \\
\hline
\end{tabular}

This certification is provided as a courtesy to the waste generator for information purposes only.

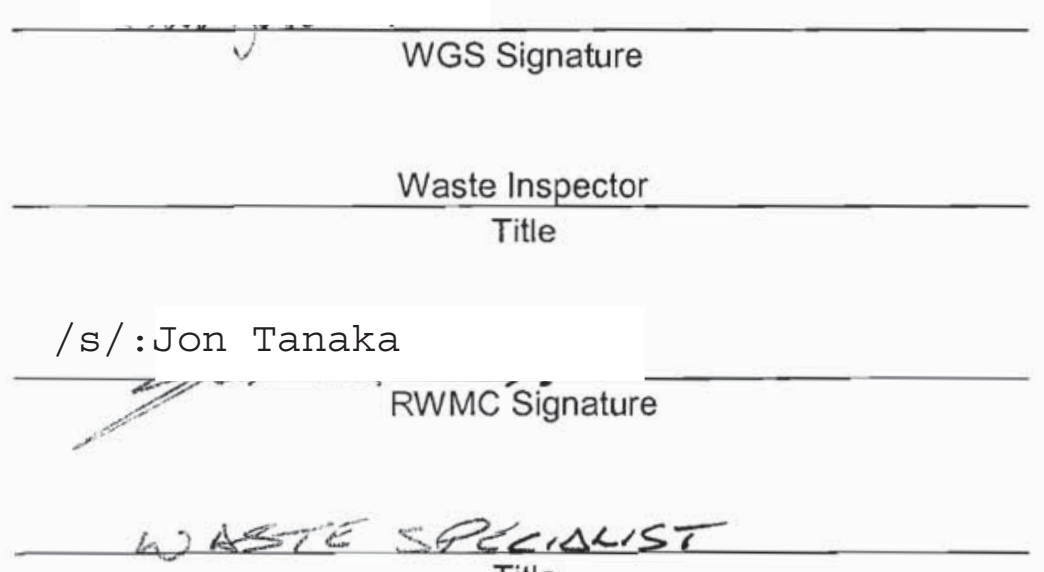




\section{Nevada Test Site}

This Certificate acknowledges that the following shipment(s) of waste have been disposect it ite Nevada Test Site Radioactive Waste Management Complex.

\begin{tabular}{|l|l|l|l|}
\hline Shipment Number & $\begin{array}{c}\text { Waste Stream } \\
\text { Identification \# }\end{array}$ & Package \# & Date of fisposai \\
\hline DPL10154 & LRY5LLFY08002 & 10 L220 & $03-15-2010$ \\
\hline & & & \\
\hline & & & \\
\hline & & & \\
\hline & & & \\
\hline
\end{tabular}

This certification is provided as a courtesy to the waste generator for information purposes only.

$\frac{\text { Waste Inspector }}{\text { Title }}$

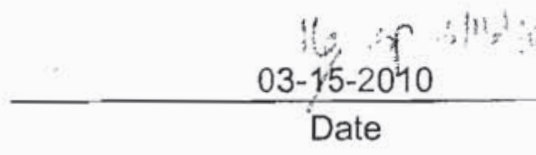


Mevada Test Site

his Certificate acknowledges that the following shipment(s) of waste have bee Nevada Test Site Radioactive Waste Management Complex.

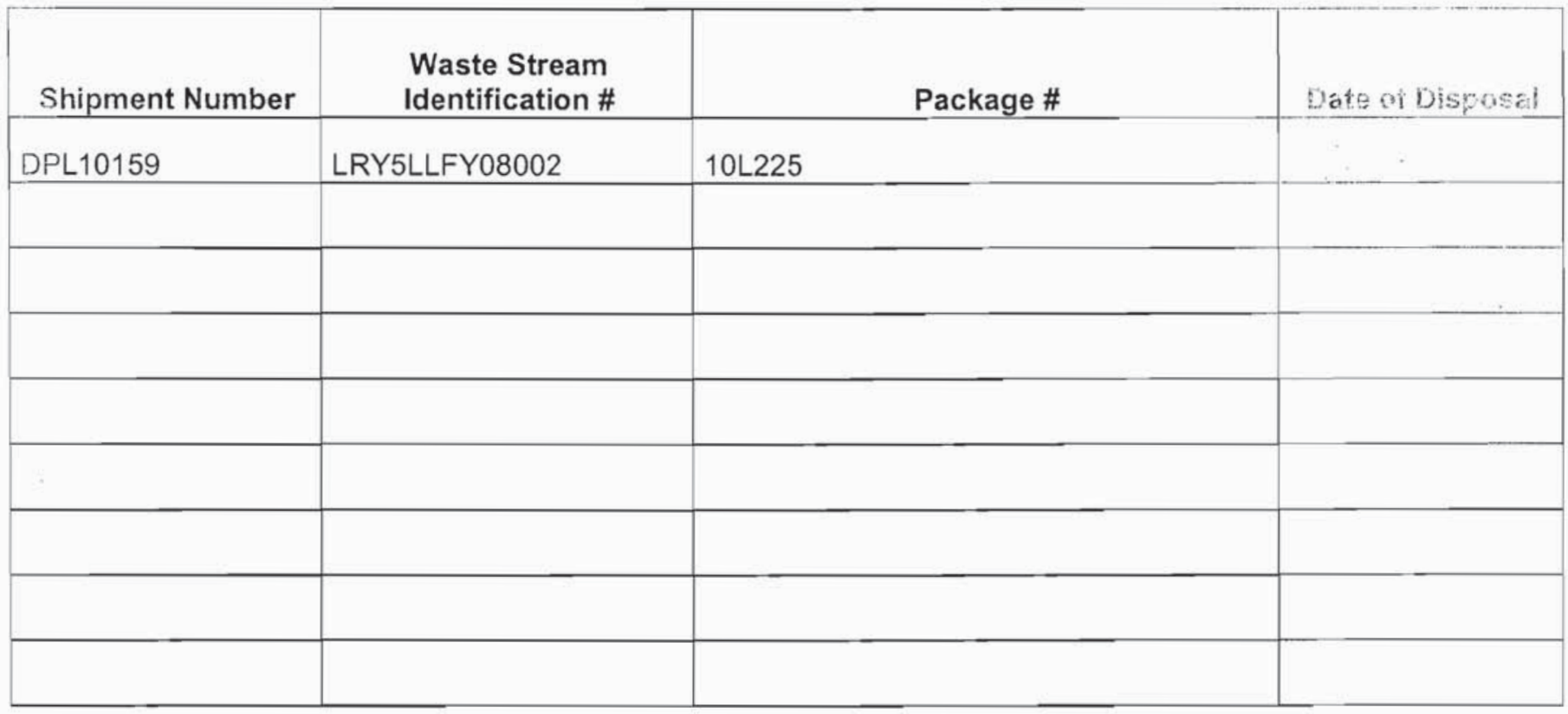

This certification is provided as a courtesy to the waste generator for information purposes only.

\begin{tabular}{c}
\hline WGS Signature \\
Waste Inspector \\
\hline Title
\end{tabular}

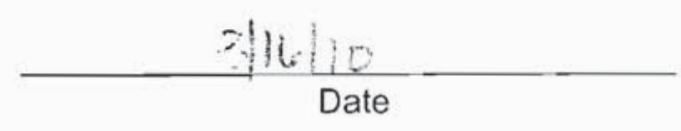

/s/: Jon Tanaka RWMC Signature

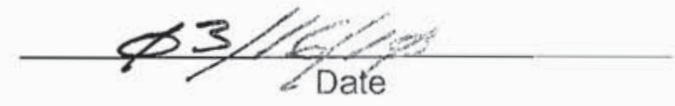

\section{WABTE STERAKSZ}

Title 
is STec

Form

CERTIFICATE OF DISPOSAL

FRIV:-2217

(LOW LEVEL WASTE)

Rev. 01

Page" of '

Hevada Test Site

This Certificate acknowledges that the following shipment(s) of waste have been d sposed at the Tevada Test Site Radioactive Waste Management Complex.

\begin{tabular}{|l|l|l|l|}
\hline Shipment Number & \multicolumn{1}{|c|}{$\begin{array}{c}\text { Waste Stream } \\
\text { Identification \# }\end{array}$} & Package \# & Jate of Dispecaí \\
\hline & LRY5LLFY08002 & 10 L226 & \\
\hline & & & \\
\hline & & & \\
\hline & & & \\
\hline & & & \\
\hline & & & \\
\hline
\end{tabular}

This certification is provided as a courtesy to the waste generator for information purposes only.

WGS Signature

Waste Inspector

Title

/s/:Jon Tanaka

RWMC Sigñature

4 Lste sperars

Title
$3) 64$

Date

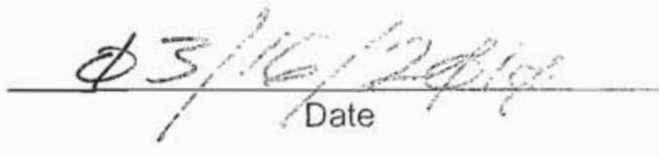


Mevada Tesi Site

This Certificate acknowledges that the following shipment(s) of waste have be: hevada Test Site Radioactive Waste Management Complex.

\begin{tabular}{|l|l|l|l|}
\hline Shipment Mumber & $\begin{array}{c}\text { Waste Stream } \\
\text { Identification \# }\end{array}$ & Package \# & \\
\hline DPL10161 & LRY5LLFY08002 & $10 \mathrm{~L} 227$ & \\
\hline & & & \\
\hline & & & \\
\hline & & & \\
\hline
\end{tabular}

This certification is provided as a courtesy to the waste generator for information purposes only.

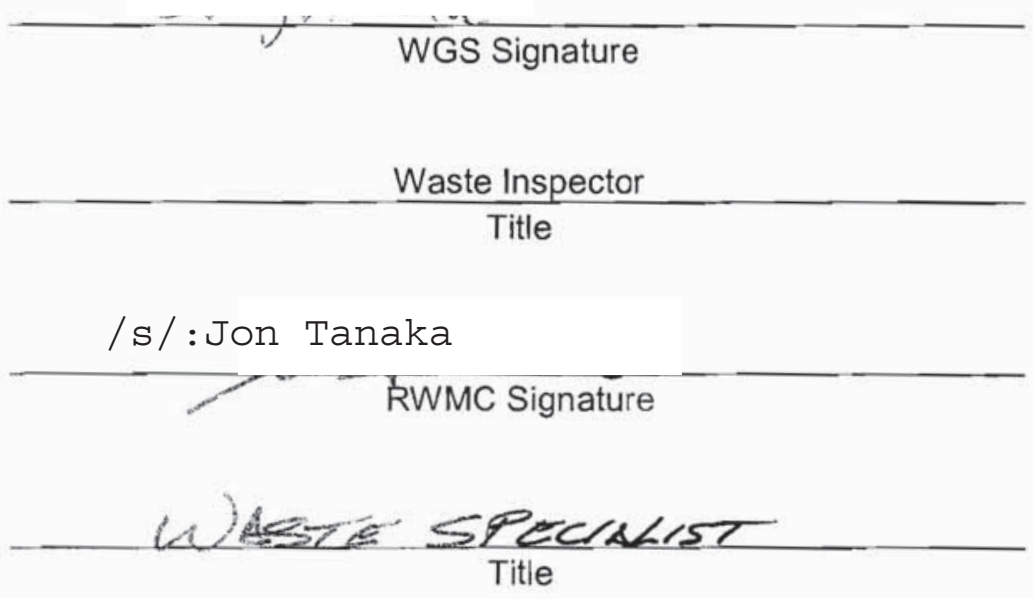
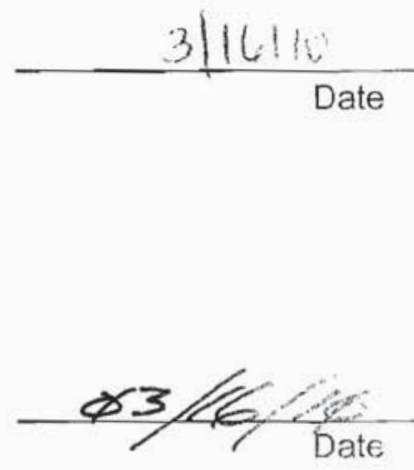
NSTec

Form

FRM-2217
CERTIFICATE OF DISPOSAL

(LOW LEVEL WASTE)
03/01/10

Rev. 01

Page 1 of 1

\section{Nevada Test Site}

This Certificate acknowledges that the following shipment(s) of waste have been disposed at the Nevada Test Site Radioactive Waste Management Complex.

\begin{tabular}{|l|l|l|c|}
\hline \multicolumn{1}{|c|}{$\begin{array}{c}\text { Waste Stream } \\
\text { Identification \# }\end{array}$} & Package \# & Date of Disposal \\
\hline DPL10084 & LRY5LFY08002 & 10L150 & J!I7/ I \\
\hline & & & \\
\hline & & & \\
\hline & & & \\
\hline & & & \\
\hline & & & \\
\hline
\end{tabular}

This certification is provided as a courtesy to the waste generator for information purposes only.

WGS Signature
$\frac{\text { Waste Inspector }}{\text { Title }}$
RWMC Signature
TCITST

311710

Date

\section{1) MAR $A 4$ II Date}




\section{Nevada Test Site}

This Certificate acknowledges that the following shipment(s) of waste have Nevada Test Site Radioactive Waste Management Complex.

\begin{tabular}{|l|l|l|l|}
\hline Shipment Number & $\begin{array}{c}\text { Waste Stream } \\
\text { Identification \# }\end{array}$ & Package \# & Date forsposal \\
\hline DPL10148 & LRY5LLFY08002 & 10 L214 & \\
\hline & & & \\
\hline & & & \\
\hline & & & \\
\hline & & & \\
\hline
\end{tabular}

This certification is provided as a courtesy to the waste generator for information purposes only.

WGS Signature

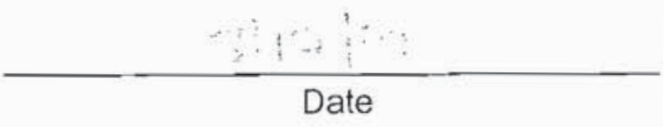

Waste Inspector

\section{Title}

/s/:Jon Tanaka

LASTE SPECIOLIST

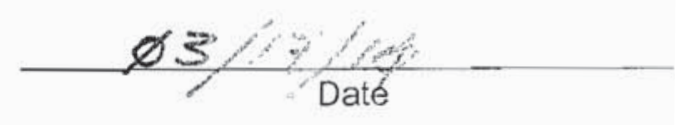


istec

Form

FRM-2217
CERTIFICATE OF DISPOSAL

(LOW LEVEL WASTE)
$03 / 01 / 10$

Rev. 01

Page 1 of $:$

\section{Nevada Test Site}

This Certificate acknowledges that the following shipment(s) of waste have Hevada Test Site Radioactive Waste Management Complex.

\begin{tabular}{|l|l|l|l|}
\hline Shipment Number & $\begin{array}{c}\text { Waste Stream } \\
\text { Identification \# }\end{array}$ & Package \# & Sof́of of Lispesal \\
\hline DPL10150 & LRY5LLFY08002 & 10 L216 & \\
\hline & & & \\
\hline & & & \\
\hline & & & \\
\hline & & & \\
\hline & & & \\
\hline & & & \\
\hline
\end{tabular}

This certification is provided as a courtesy to the waste generator for information purposes only.

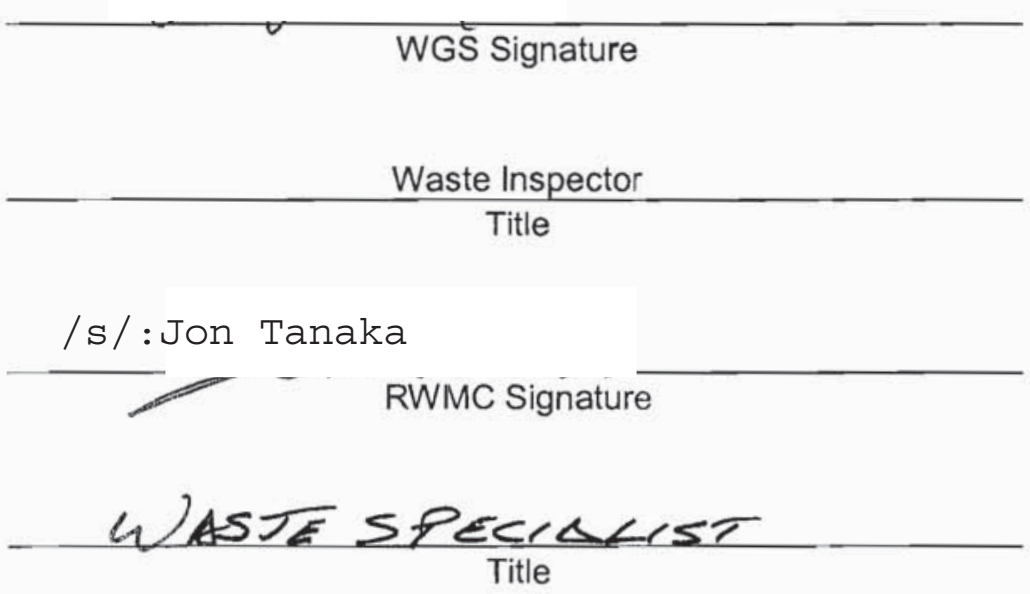$$
317110
$$$$
\text { Date }
$$

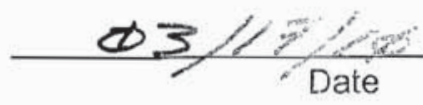


isTec

Form

FRM-2217

CERTIFICATE OF DISPOSAL

\section{Levada Test Site}

This Certificate acknowledges that the following shipment(s) of waste have been disposed: hevada Test Site Radioactive Waste Management Complex.

\begin{tabular}{|c|c|c|c|}
\hline Shipment Number & $\begin{array}{l}\text { Waste Stream } \\
\text { Identification \# }\end{array}$ & Package \# & Date of Dispos 2 ? \\
\hline DPL10155 & LRY5LLFY08002 & 10L221 & : \\
\hline & & & \\
\hline & & & \\
\hline & & & \\
\hline & & & \\
\hline & & & \\
\hline & & & \\
\hline & & & \\
\hline
\end{tabular}

This certification is provided as a courtesy to the waste generator for information purposes only.

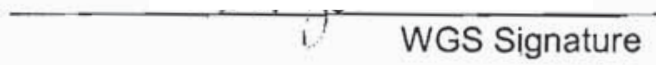

Waste Inspector

$$
\text { Title }
$$

/s/: Jon Tanaka

RiWM Signature

C) ASTE speera HST

Title
317110

Date

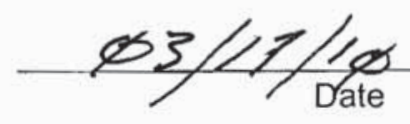


NSTec

Form

CERTIFICATE OF DISPOSAL

\section{Mevada Test Site}

This Certificate acknowledges that the following shipment(s) of waste have bee

Nevada Test Site Radioactive Waste Management Complex.

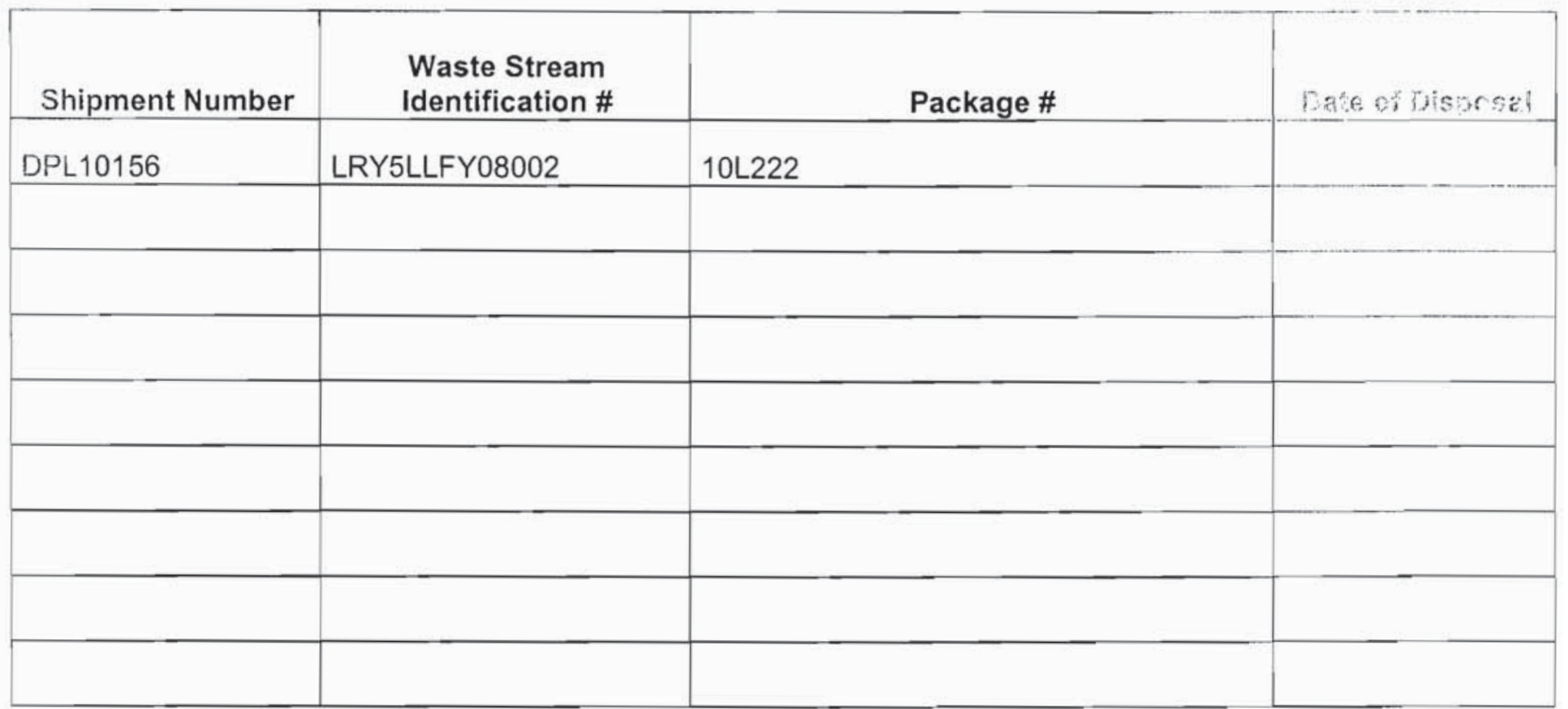

This certification is provided as a courtesy to the waste generator for information purposes only.

$\frac{\text { WGS Signature }}{\text { Waste Inspector }} \frac{\text { Ritle }}{\text { RWMC Signature }}$

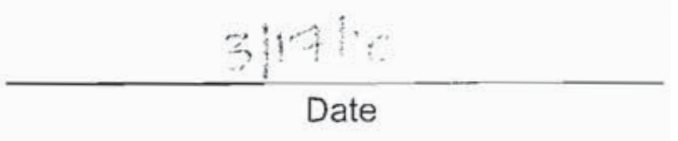

Title 


\section{Nevada Test Site}

This Certificate acknowledges that the following shipment(s) of waste have beer disfos Fevada Test Site Radioactive Waste Management Complex.

\begin{tabular}{|l|l|l|l|}
\hline Shipment Number & $\begin{array}{c}\text { Waste Stream } \\
\text { Identification \# }\end{array}$ & Package \# & Date of Disposal \\
\hline DPL10158 & LRY5LLFY08002 & 10L224 & \\
\hline & & & \\
\hline & & & \\
\hline & & & \\
\hline & & & \\
\hline & & & \\
\hline
\end{tabular}

This certification is provided as a courtesy to the waste generator for information purposes only.

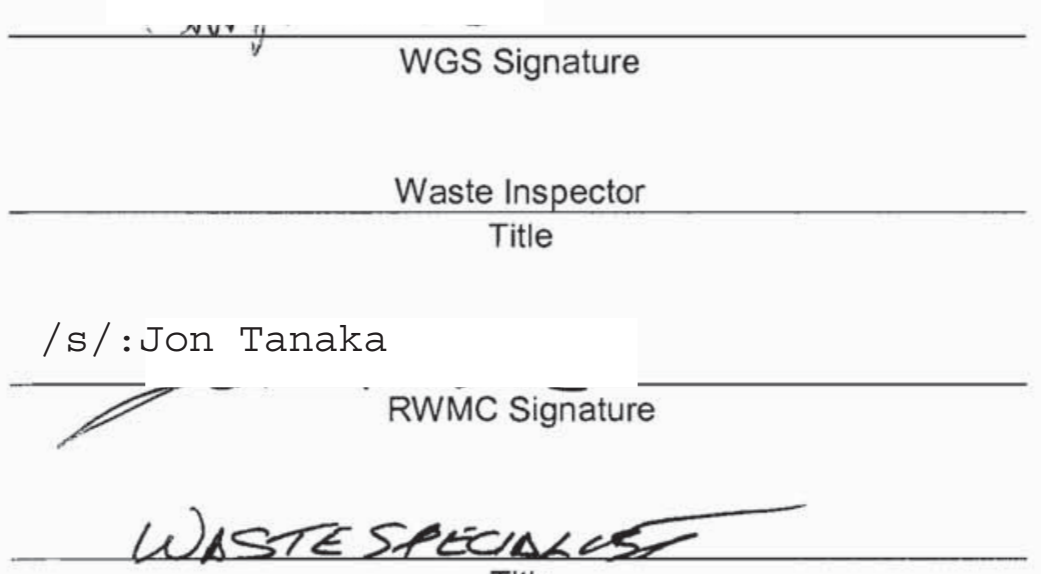

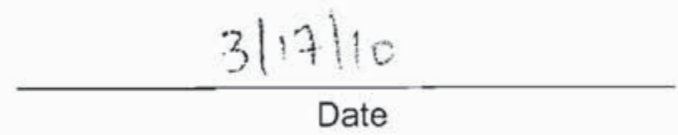

Title

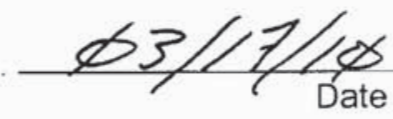


NSTec

Form

FRM-2217

CERTIFICATE OF DISPOSAL

\section{Mevada. Test Site}

This Certificate acknowledges that the following shipment(s) of waste Nevada Test Site Radioactive Waste Management Complex.

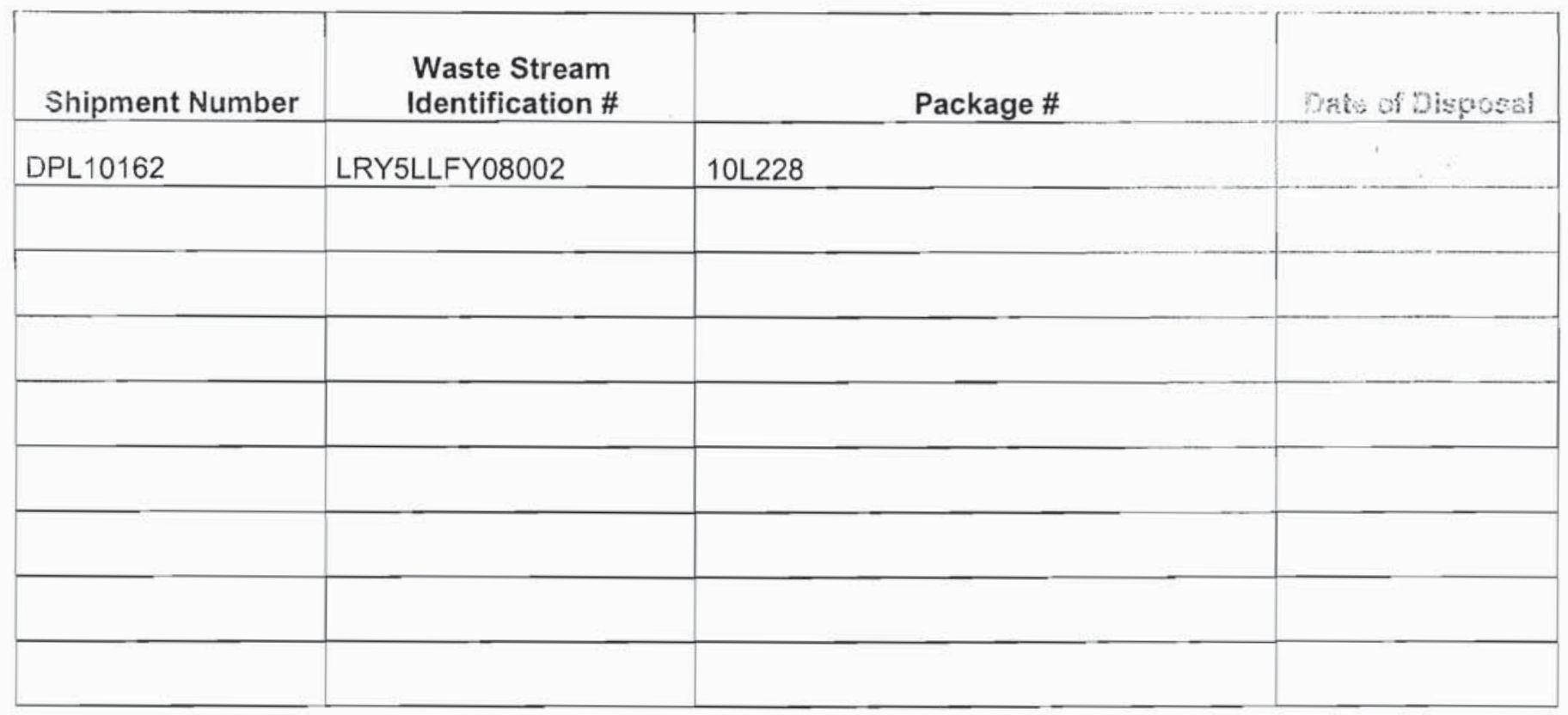

This certification is provided as a courtesy to the waste generator for information purposes only.

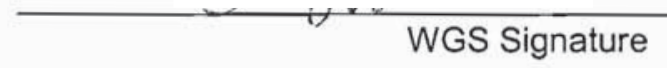

Waste inspector

Title

/s/:Jon Tanaka

RWMC Signature

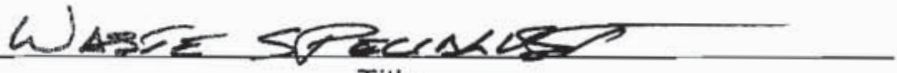

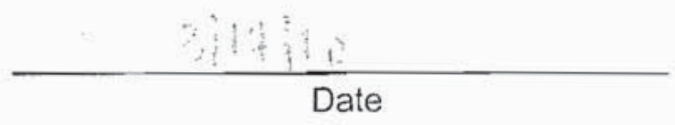

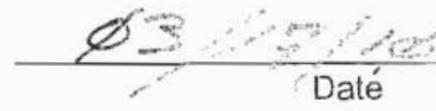




\section{Nevada Test Site}

ithis Certificate acknowledges that the following shipment(s) of waste have been disposect ifevada Test Site Radioactive Waste Management Complex.

\begin{tabular}{|l|l|l|l|}
\hline Shipment Number & $\begin{array}{c}\text { Waste Stream } \\
\text { Identification \# }\end{array}$ & Package \# & Date of Disposal \\
\hline DPL10163 & LRY5LLFY8002 & 10L229 & \\
\hline & & & \\
\hline & & & \\
\hline & & & \\
\hline & & & \\
\hline & & & \\
\hline & & & \\
\hline
\end{tabular}

This certification is provided as a courtesy to the waste generator for information purposes only.

WGS Signature

Waste Inspector

Title

/s/:Jon Tanaka

RWMC Signature

\section{$\frac{3117 / 12}{\text { Date }}$}

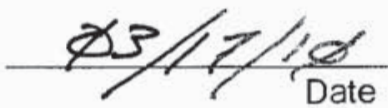




\section{Nevada Test Site}

This Certificate acknowledges that the following shipment(s) of waste have bee Nevada Test Site Radioactive Waste Management Complex.

\begin{tabular}{|c|c|c|c|}
\hline Shipment Number & $\begin{array}{c}\text { Waste Stream } \\
\text { Identification \# }\end{array}$ & Package \# & Date of Disposal \\
\hline DPL10164 & LRY5LLFY08002 & 10 L230 & \\
\hline & & & \\
\hline & & & \\
\hline & & & \\
\hline & & & \\
\hline & & & \\
\hline & & & \\
\hline
\end{tabular}

This certification is provided as a courtesy to the waste generator for information purposes only.

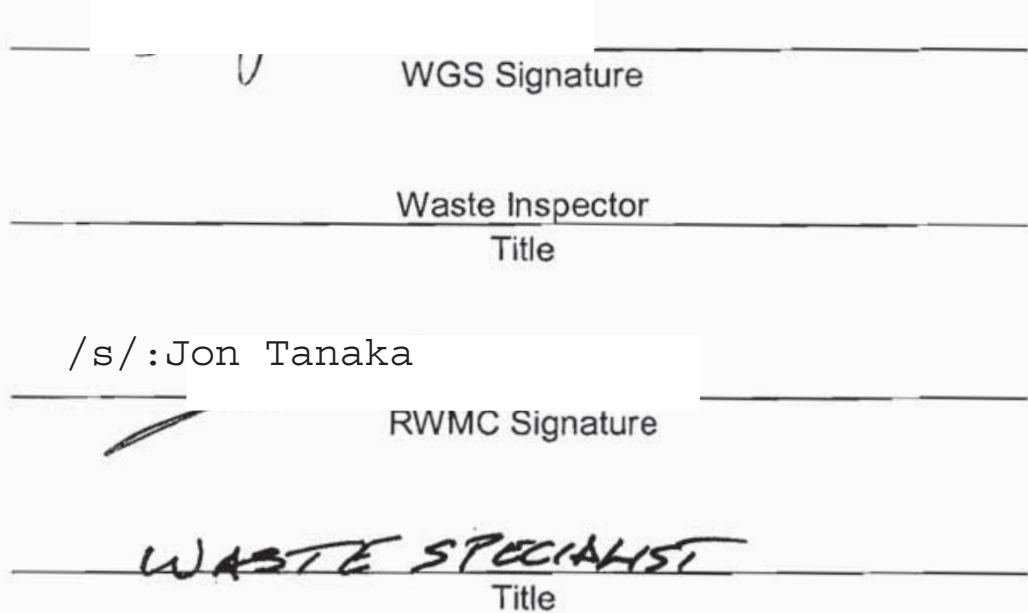

311710

Date 
WSTeC

Form

CERTIFICATE OF DISPOSAL

Wevada Test Site

this Certificate acknowledges that the following shipment(s) of waste have Hevada Test Site Radioactive Waste Management Complex.

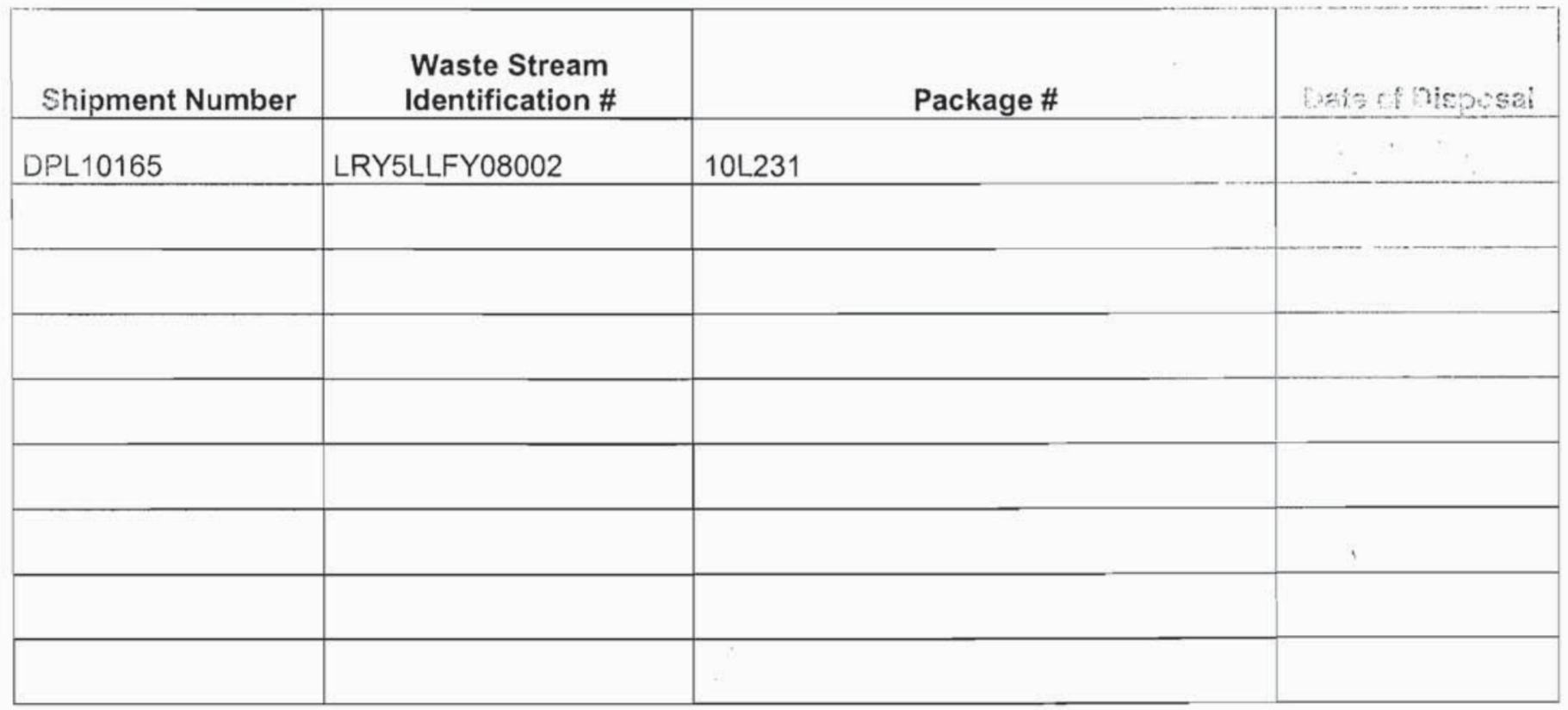

This certification is provided as a courtesy to the waste generator for information purposes only.

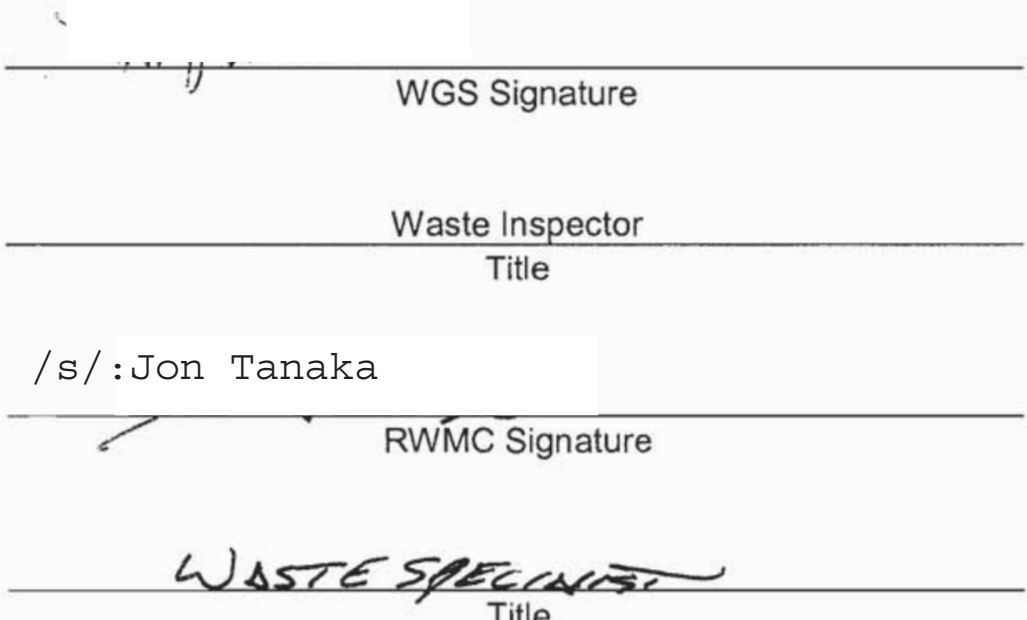

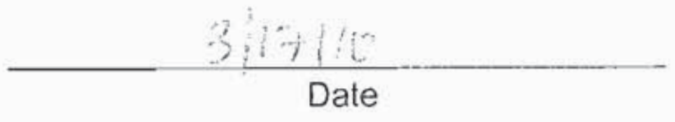

Title

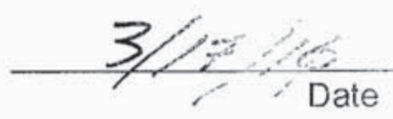


NSTec

Form

FRM-2217
CERTIFICATE OF DISPOSAL.

(LOW LEVEL WASTE)
Page 1 of 1

\section{Nevada Test Site}

This Certificate acknowledges that the following shipment(s) of waste have been disposed at the Nevada Test Site Radioactive Waste Management Complex.

\begin{tabular}{|l|l|l|l|}
\hline Shipment Number & $\begin{array}{c}\text { Waste Stream } \\
\text { Identification \# }\end{array}$ & Package \# & Date of Disposal \\
\hline DPL10166 & LRY5LLFY08002 & 10 L232 & \\
\hline & & & \\
\hline & & & \\
\hline & & & \\
\hline & & & \\
\hline
\end{tabular}

This certification is provided as a courtesy to the waste generator for information purposes only.

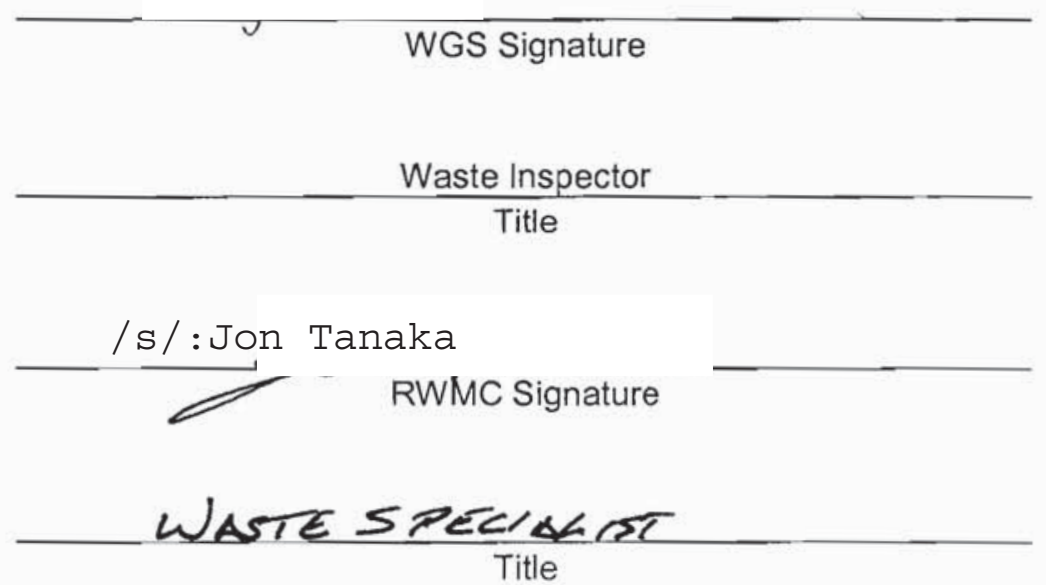

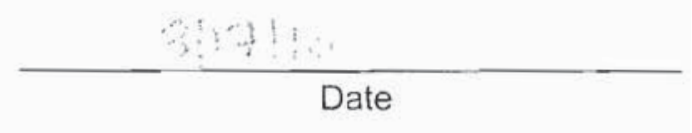


NSTec

Form

FRM-2217
CERTIFICATE OF DISPOSAL

(LOW LEVEL WASTE)
$03 / 01 / 10$

Rev. 01

Page 1 of 1

\section{Nevada Test Site}

This Certificate acknowledges that the following shipment(s) of waste have been disposed at the Nevada Test Site Radioactive Waste Management Complex.

\begin{tabular}{|c|c|c|c|}
\hline Shipment Number & $\begin{array}{c}\text { Waste Stream } \\
\text { Identification \# }\end{array}$ & Package \# & Date of Disposal \\
\hline DPL10167 & LRY5LLFY08002 & 10 L233 & $3 / 1910$ \\
\hline & & & \\
\hline & & & \\
\hline & & & \\
\hline & & & \\
\hline & & & \\
\hline
\end{tabular}

This certification is provided as a courtesy to the waste generator for information purposes only.

$\frac{\text { Waste Inspector }}{\text { Title }}$

317110

Date

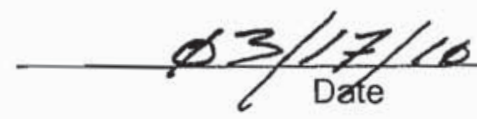


NSTEC

Form

FRM-2217
CERTIFICATE OF DISPOSAL

(LOW LEVEL WASTE)

\section{Mevada Test Site}

This Certificate acknowledges that the following shipment(s) of waste have been Mevada Test Site Radioactive Waste Management Complex.

\begin{tabular}{|l|l|l|l|}
\hline Shipment Number & $\begin{array}{c}\text { Waste Stream } \\
\text { Identification \# }\end{array}$ & Package \# & Date of Disposal \\
\hline DPL10168 & LRY5LLFY08002 & 10L234 & \\
\hline & & & \\
\hline & & & \\
\hline & & & \\
\hline & & & - \\
\hline
\end{tabular}

This certification is provided as a courtesy to the waste generator for information purposes only.

Waste Inspector
Title
Is / : Jon Tanaka
RWMC Signature
Title
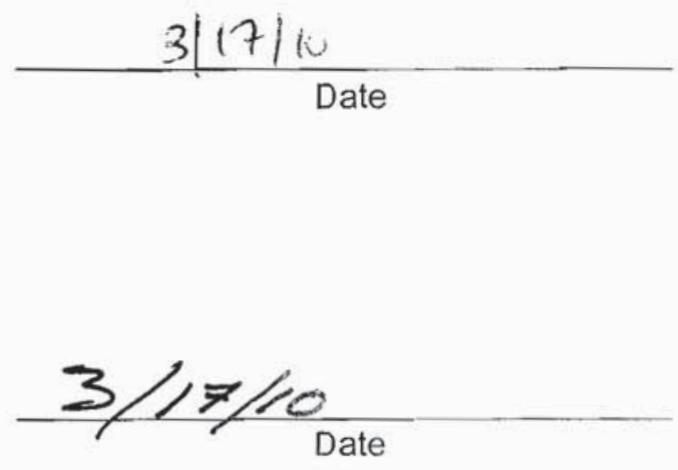
NSTec:

Form

CERTIFICATE OF DISPOSAL.

FRM-2217

(LOW LEVEL. WASTE)

Rev. 01

Page 1 of $i$

\section{Nevada Test Site}

This Cerificate acknowledges that the following shipment(s) of waste have been ofsposed at the Nevada Test Site Radioactive Kiaste Manágement Complex.

\begin{tabular}{|l|l|l|l|}
\hline Shipment Number & \multicolumn{1}{|c|}{$\begin{array}{c}\text { Waste Stream } \\
\text { Identification }\end{array}$} & Package \# & Date of Disposal \\
\hline & LRY5LLFY08002 & 10L_217 & \\
\hline & & & \\
\hline & & & \\
\hline & & & \\
\hline & & & \\
\hline & & & \\
\hline
\end{tabular}

This certification is provided as a courtesy to the waste generator for information purposes only.

$\frac{\text { WGS Signature }}{\text { Waste Inspector }}$

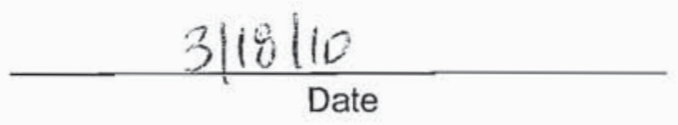

Title 
NSTec

Form

FRM-2217

\section{CERTIFICATE OF DISPOSAL}

(LOW LEVEL WASTE)
$03 / 01 / 10$

Rev. 01

Page 1 of 1

\section{Nevada Test Sifte}

This Certificate acknowicdges that the following shipment(s) of waste have been dieposed at the

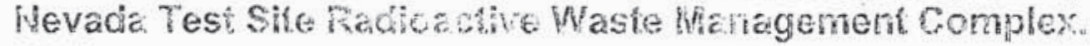

\begin{tabular}{|l|c|c|c|}
\hline Shipment Number & $\begin{array}{c}\text { Waste Stream } \\
\text { identification \# }\end{array}$ & Package \# & Date of Disposal \\
\hline DPL10169 & LRY5LLFY08002 & 10 L235 & \\
\hline & & & \\
\hline & & & \\
\hline & & & \\
\hline & & & \\
\hline & & & \\
\hline
\end{tabular}

This certification is provided as a courtesy to the waste generator for information purposes only.

WGS Signature
Waste inspector
Title
USW : Jon Tanaka
RWMC Signature
Title
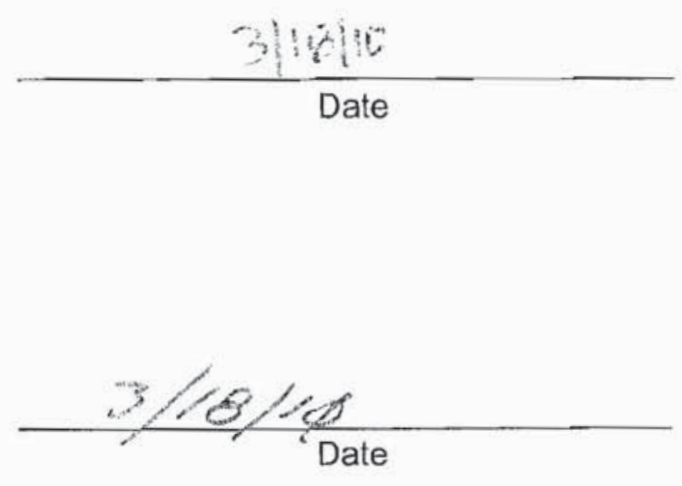
NSTeC

Form

FRM-2217
CERTIFICATE OF DISPOSAL

(L.OW LEVEL. WASTE)
$03 / 01 / 10$

Rev. 01 Page 1 of 1

\section{Nevada Test Site}

This Certificate acknowledges that the following shipment(s) of waste have been disposed at the Hevada Test Site Radioactive Naste Management Complex.

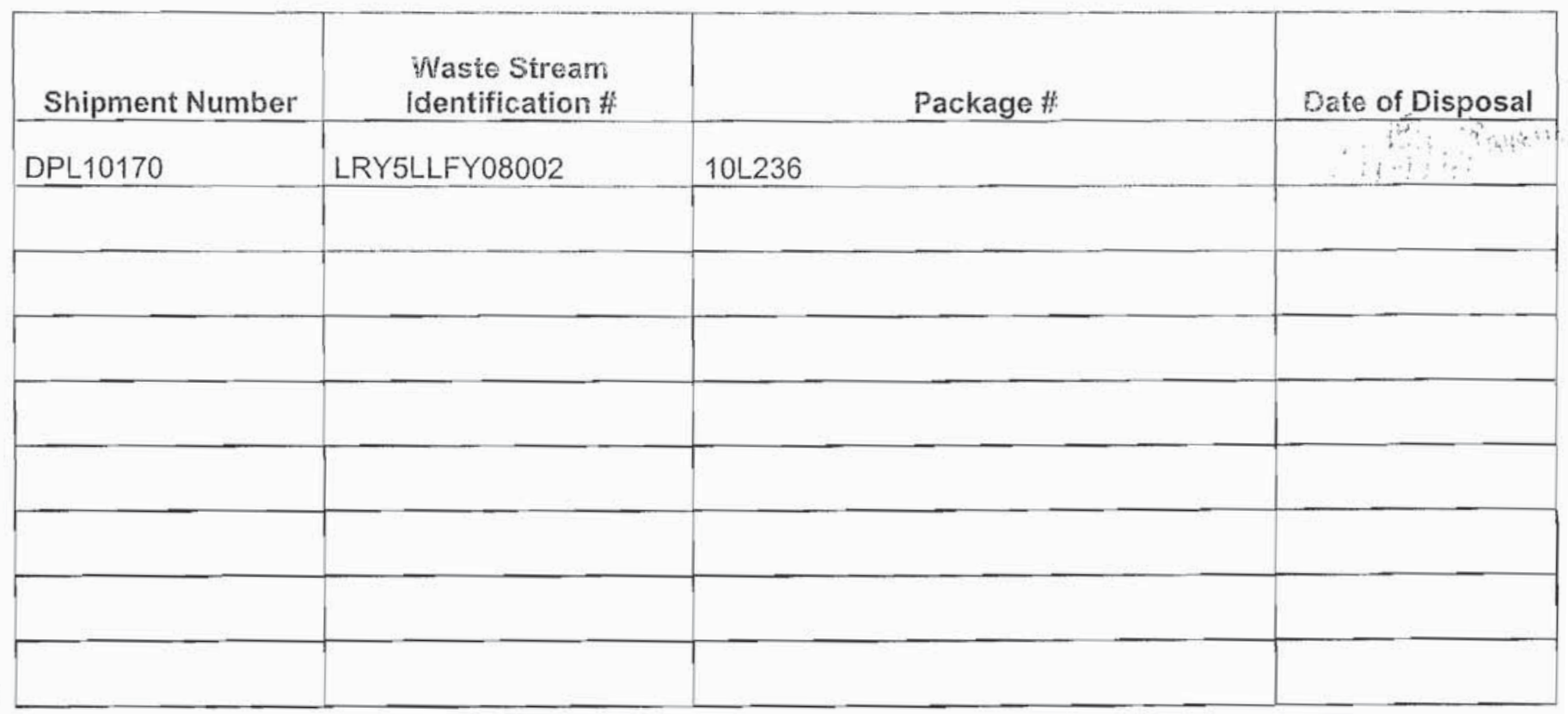

This certification is provided as a courtesy to the waste generator for information purposes only.

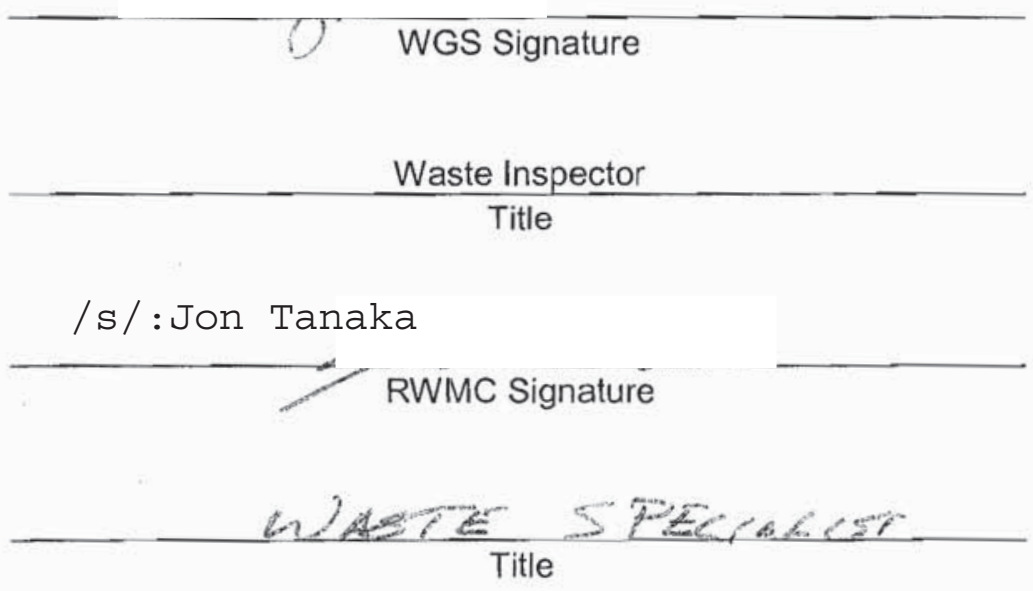

$-\frac{312410}{\text { Date }}$




\section{Nevada Test Site}

This Certificate acknowledges that the following shipment(s) of waste have been disposed at the Nevada Test Site Radioactive Waste Management Compley.

\begin{tabular}{|c|c|c|c|}
\hline Shipment Number & $\begin{array}{l}\text { Waste Stream } \\
\text { Identification }\end{array}$ & Package \# & Date of Disposal \\
\hline DPL10171 & LRY5LLFY08002 & $10\llcorner 237$ & $\therefore$ \\
\hline & & & \\
\hline & & & \\
\hline & & & \\
\hline & & & \\
\hline & & & \\
\hline & & & \\
\hline & & & \\
\hline
\end{tabular}

This certification is provided as a courtesy to the waste generator for information purposes only.

\section{WGS Signature}

Waste Inspector

\section{Title}

/s/: Jon Tanaka

Wh RWTEC Signature
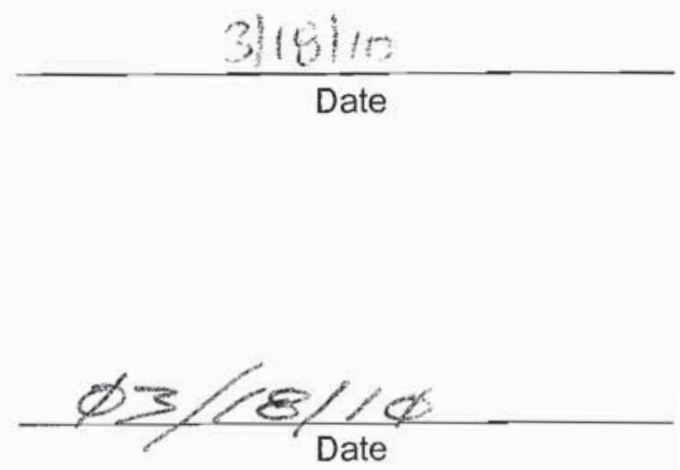
NSTEC

Form

CERTIFICATE OF DISFOSAL

03/01/10

FRM-2217

(LOW LEVEL WASTE)

Rev. 01

Page 1 of 1

\section{Nevade Test Site}

This Cerificate acknowledges that the following shipment(s) pi: wase have been disposed at the Nevada Tust Site Radioactive Waste Management Complex.

\begin{tabular}{|c|c|c|c|}
\hline Shipment Number & $\begin{array}{l}\text { Waste Stream } \\
\text { Identification \# }\end{array}$ & Fackage \# & Date of Disposal \\
\hline DPL10172 & LRY5LLFY08002 & $10 L 238$ & $\because i$ \\
\hline$\because$ & & & \\
\hline & & & \\
\hline & & & \\
\hline & & & \\
\hline & & & \\
\hline & & & \\
\hline & & & \\
\hline
\end{tabular}

This certification is provided as a courtesy to the waste generator for information purposes only.

$\frac{\text { WGS Signature }}{\text { Title }}$

318110

Date

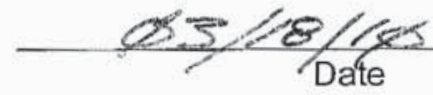


NSTec

Form

CERTIFICATE OF DISPOSAL

03/01/10

FRM-2217

(LOW LEVEL WASTE)

Rev. 01

Page 1 of 1

\section{Nevada Test Site}

This Certificate acknowledges that the following shipment(s) of waste have been cisposed at the Nevada Test Site Radioactive Waste Management Complex.

\begin{tabular}{|l|c|c|c|}
\hline Shipment Number & $\begin{array}{c}\text { Waste Stream } \\
\text { Identification \# }\end{array}$ & Package \# & Date of Disposal \\
\hline DPL10173 & LRY5LLFY08002 & 10 239 & \\
\hline & & & \\
\hline & & & \\
\hline & & & \\
\hline & & & \\
\hline & & & \\
\hline
\end{tabular}

This certification is provided as a courtesy to the waste generator for information purposes only.

W'GS Signature
$\frac{\text { Waste Inspector }}{\text { Title }}$
RWMC Signature
R / : Jon Tanaka

$$
\frac{3 \mid 18110}{\text { Date }}
$$

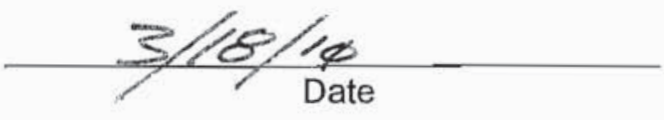


NSTec

Form

FRM-2217
CERTIFICATE OF DISFOSAL

(LOW LEVEL WASTE)
$03 / 01 / 10$

Rev. 01

Page $i$ of 1

\section{Nevada Test Site}

This Certificate acknowledges that the following shipment(s) of waste have been disposed at the Nevada Test Site Radioactive Waste Management Complex.

\begin{tabular}{|c|c|c|c|}
\hline Shipment Number & $\begin{array}{l}\text { Waste Stream } \\
\text { Identification }\end{array}$ & Package \# & Date of Disposal \\
\hline DPL10174 & LRY5LLFY08002 & $10\llcorner 240$ & $\therefore$ \\
\hline & & & \\
\hline & & & \\
\hline & & & \\
\hline & . & & \\
\hline & & & \\
\hline & & & \\
\hline 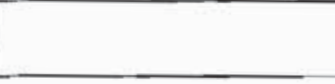 & 年 & 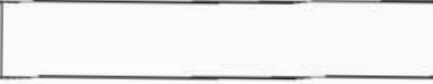 & \\
\hline
\end{tabular}

This certification is provided as a courtesy to the waste generator for information purposes only.

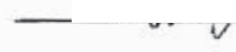

WGS Signature

Waste Inspector

$$
\text { Title }
$$

/s/:Jon Tanaka

RWMC Signature

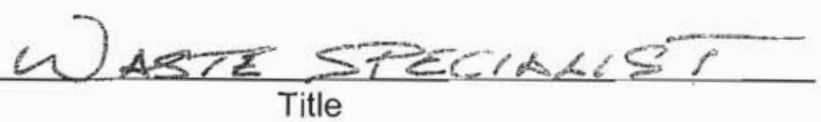

$\frac{318110}{\text { Date }}$

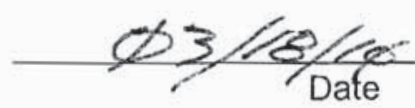


NSTec

Form

FRM-2217
CERTIFICATE OF DISPOSAL

(LOW LEVEL WASTE)
$03 / 01 / 10$

Rev. 01

Page 1 of 1

\section{Nevada Test Site}

This Certificate acknowledges that the following shipment(s) of waste have been disposed at the Nevada Test Site Radicactive Waste Management Complex.

\begin{tabular}{|l|l|l|l|}
\hline \multicolumn{1}{|c|}{ Shipment Number } & \multicolumn{1}{|c|}{$\begin{array}{c}\text { Waste Stream } \\
\text { Identification \# }\end{array}$} & Package \# & Date of Disposal \\
\hline DPL10176 & LRY5LLFY08002 & 10L242 & \\
\hline & & & \\
\hline & & & \\
\hline & & & \\
\hline & & & \\
\hline & & & \\
\hline & & & \\
\hline
\end{tabular}

This certification is provided as a courtesy to the waste generator for information purposes only.

WGS Signature
Waste Inspector
Title
RWMC Signature

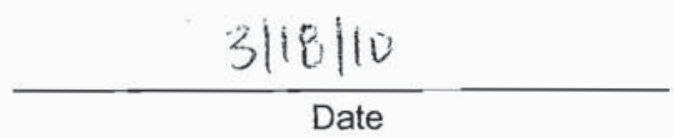

Title

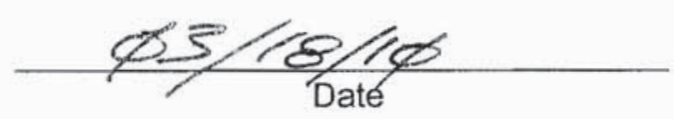


NSTec

Form

FRM-2217
CERTIFICATE OF DISPOSAL

(L.OW LEVEL. WASTE)
03/01/10

Rev. 01

Page 1 of 1

\section{Nevada Test Site}

This Certificate acknowledges that the following shipment(s) of waste have been disposed at the Nevada Test Site Radioactive Waste Management Complex.

\begin{tabular}{|l|l|l|l|}
\hline Shipment Number & \multicolumn{1}{|c|}{$\begin{array}{c}\text { Waste Stream } \\
\text { Identification \# }\end{array}$} & Package \# & Date of Disposal \\
\hline DPL10177 & LRY5LLFY08002 & 10 L243 & \\
\hline & & & \\
\hline & & & \\
\hline & & & \\
\hline & & & \\
\hline & & & \\
\hline & & & \\
\hline
\end{tabular}

This certification is provided as a courtesy to the waste generator for information purposes only.

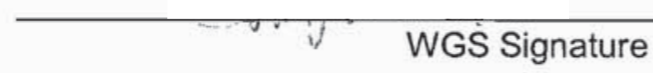

Waste Inspector

Title

/s/:Jon Tanaka

RWMC Signature

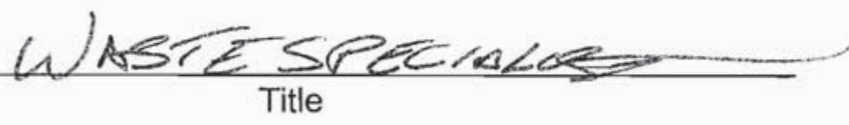

$\frac{3|10| 10}{\text { Date }}$

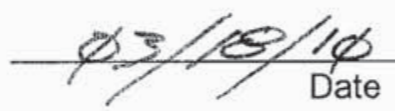


NSTec

Form

FRM-2217
CERTIFICATE OF DISPOSAL.

(LOW LEVEL WASTE)
03/01/10

Rev. 01

Page 1 of 1

\section{Nevada Test Site}

This Certificate acknowledges that the following shipment(s) of waste have been disposed at the Nevada Test Site Radioactive Waste Management Complex.

\begin{tabular}{|l|c|c|c|}
\hline Shipment Number & $\begin{array}{c}\text { Waste Stream } \\
\text { Identification \# }\end{array}$ & Package \# & Date of Disposal \\
\hline DPL10178__ & LRY5LLFY08002 & 10 L244 & \\
\hline & & & \\
\hline & & & \\
\hline & & & \\
\hline & & & \\
\hline & & & \\
\hline
\end{tabular}

This certification is provided as a courtesy to the waste generator for information purposes only.

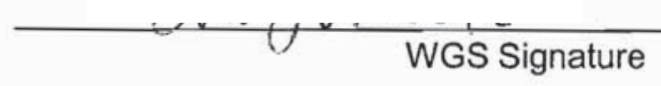

Waste Inspector

$$
\text { Title }
$$

/s/:Jon Tanaka

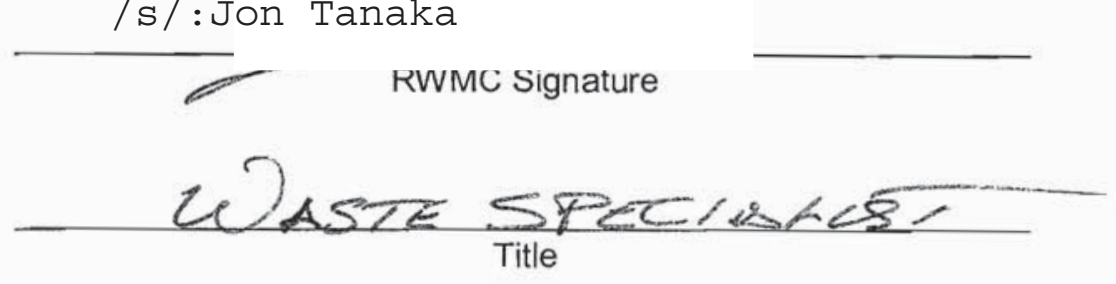

318110

Date

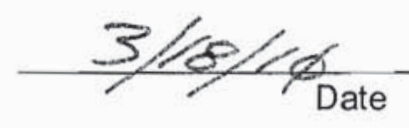


NSTec

Form

FRM-2217
CERTIFICATE OF DISPOSAL.

(LOW LEVEL WASTE)
03/01/10

Rev. 01 Page 1 of 1

\section{Nevada Test Site}

This Certificate acknowledges that the following shipment(s) of waste have been disposed at the Nevada Test Site Radioactive Waste Management Complex.

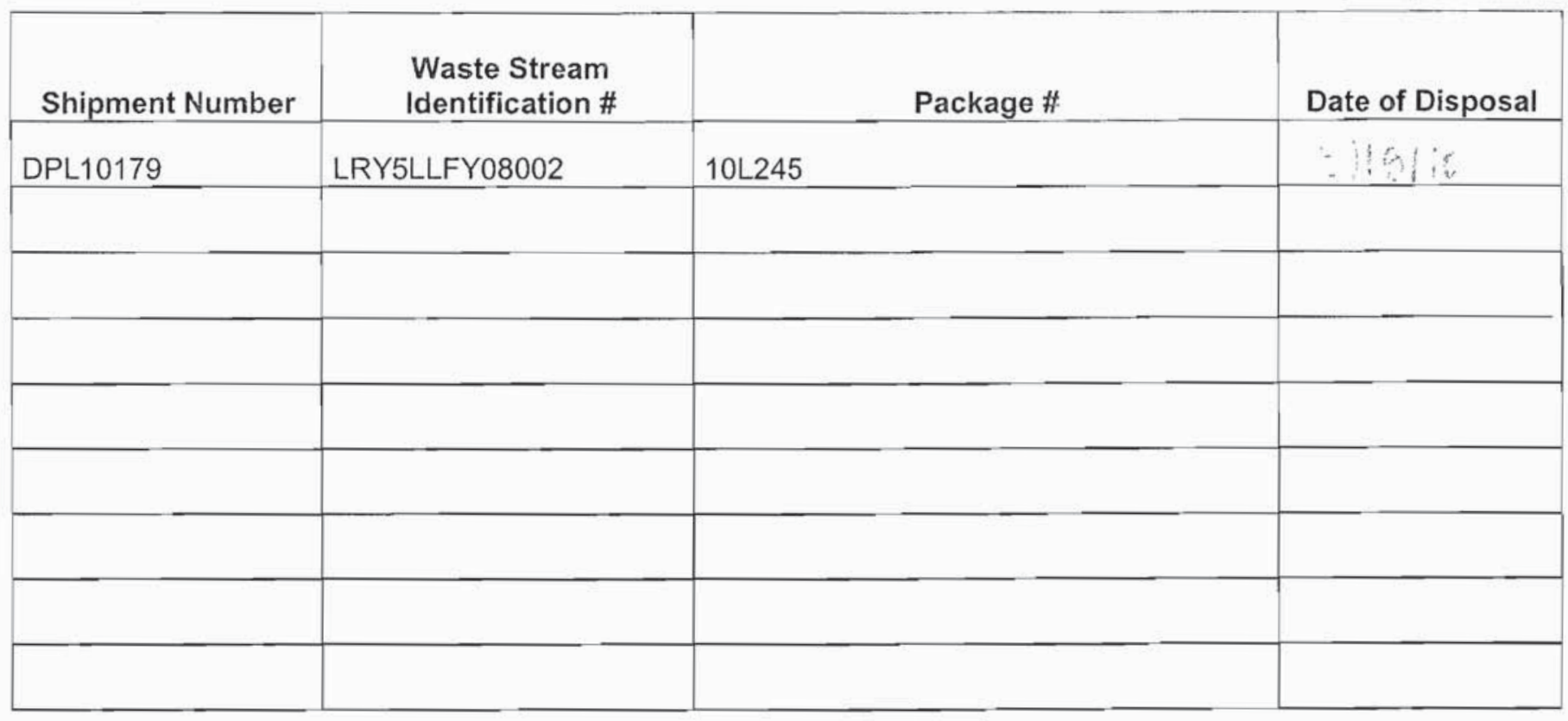

This certification is provided as a courtesy to the waste generator for information purposes only.

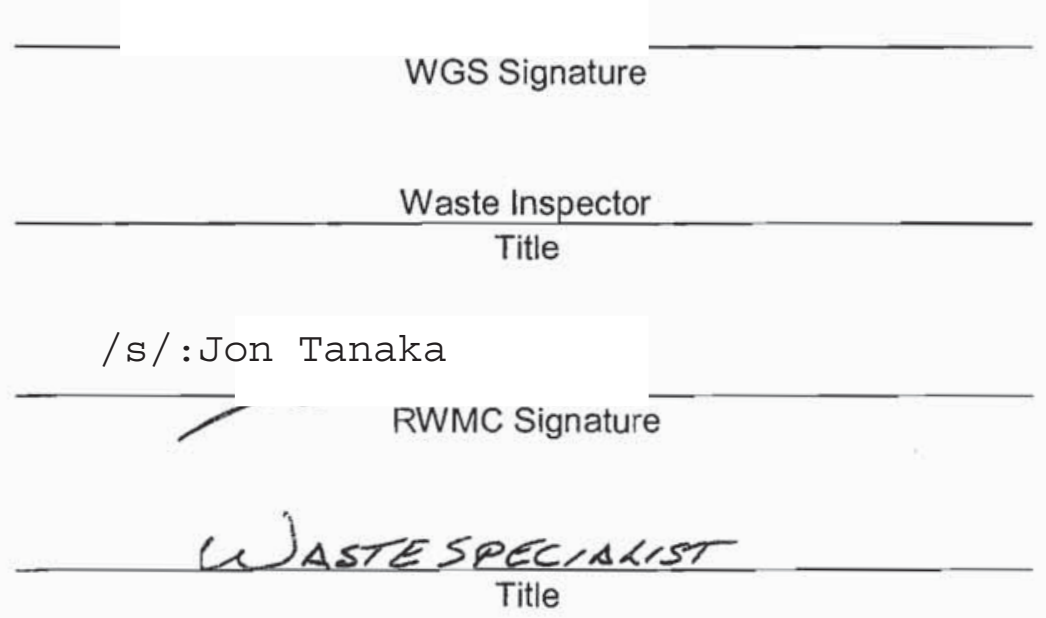

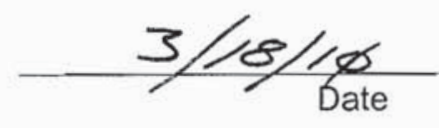


NSTec

Form

FRM-2217
CERTIFICATE OF DISPOSAL

(LOW LEVEL WASTE)
$03 / 01 / 10$

Rev. 01

Page 1 of 1

\section{Nevada Test Site}

This Certificate acknowledges that the following shipment(s) of waste have been disposed at: the Nevada Test Site Radioactive Waste Management Complex.

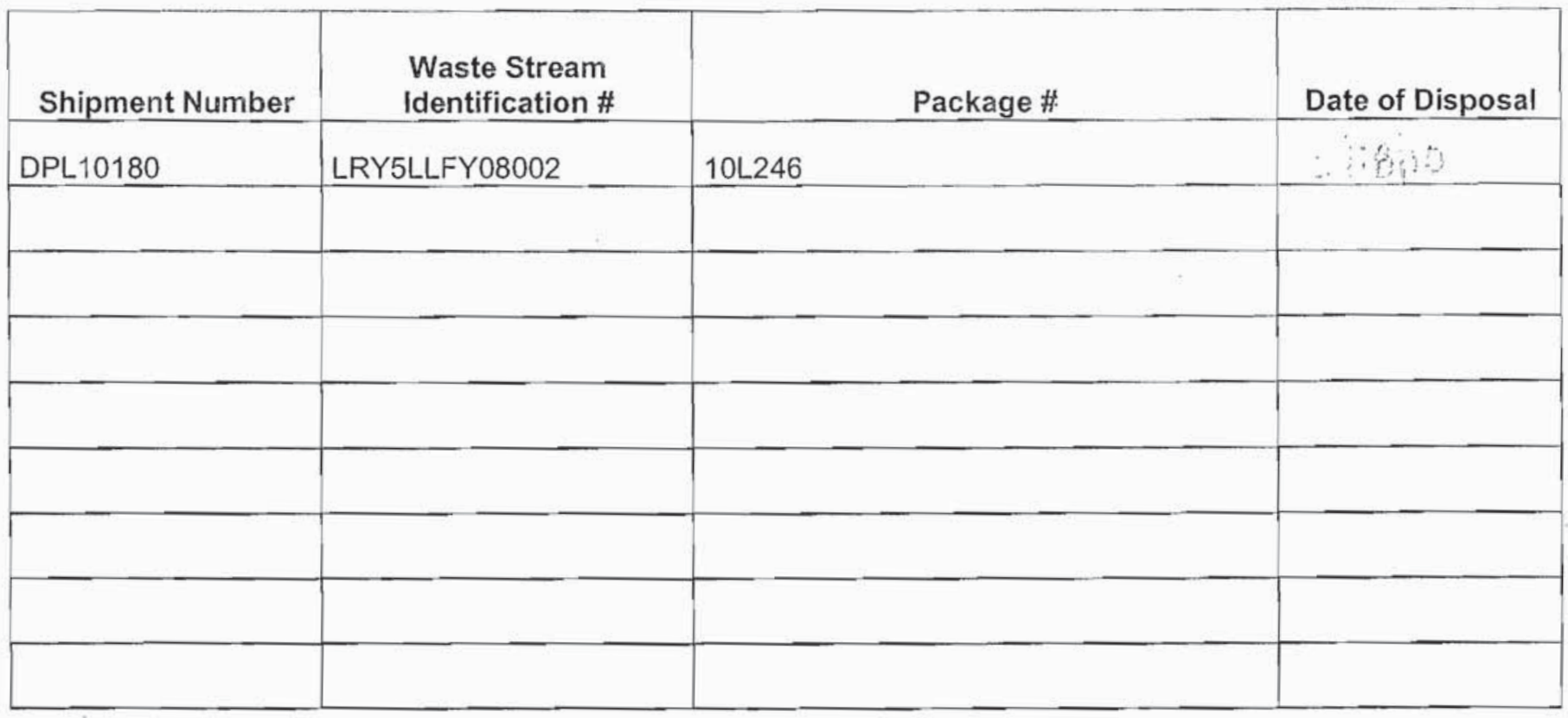

This certification is provided as a courtesy to the waste generator for information purposes only.

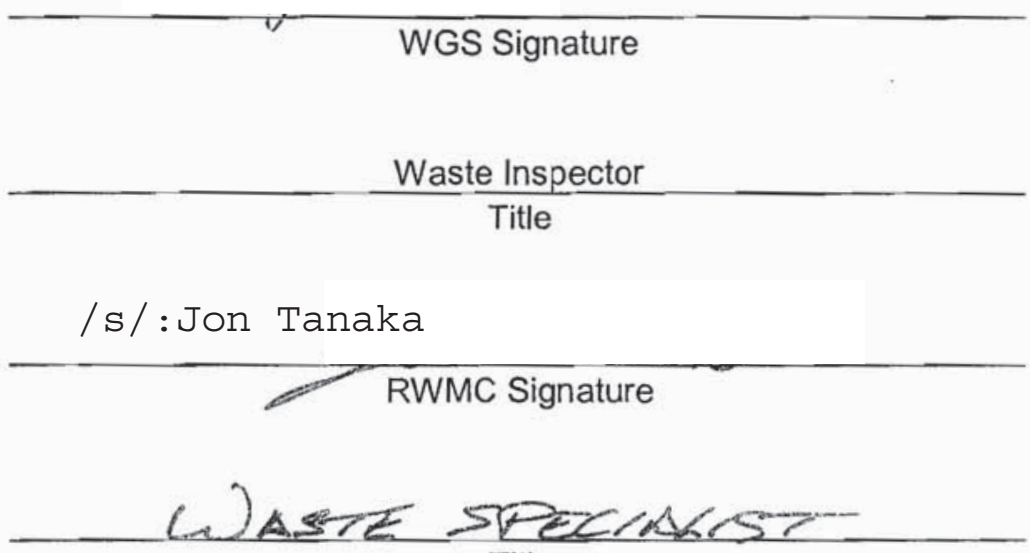

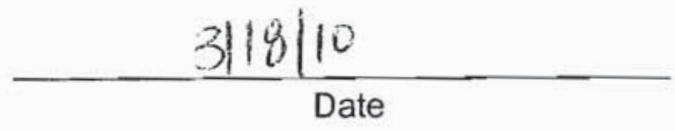

Title

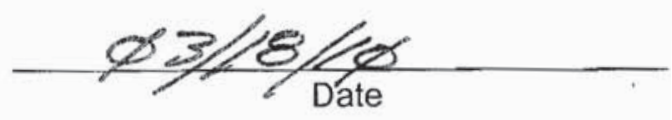


NSTec

Form

FRM-2217
CERTIFICATE OF DISPOSAL

(LOW LEVEL WASTE)
03/01/10

Rev. 01

Page 1 of 1

\section{Nevada Test Site}

This Certificate acknowledges that the following shipment(s) of waste have been dispcsed at the Nevada Test Site Radioactive Waste Management Complex.

\begin{tabular}{|c|c|c|c|}
\hline Shipment Number & $\begin{array}{l}\text { Waste Stream } \\
\text { Identification \# }\end{array}$ & Package \# & Date of Disposal \\
\hline DPL.10181 & LRY5LLFY08002 & 10L247 & 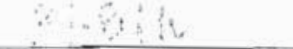 \\
\hline & & . & \\
\hline & & & \\
\hline & & & \\
\hline & & & \\
\hline & & & \\
\hline & . & & \\
\hline & & & \\
\hline
\end{tabular}

This certification is provided as a courtesy to the waste generator for information purposes only.

$\frac{\text { WGS Signature }}{\frac{\text { Waste Inspector }}{\text { Title }}-1 \text { RWMC Signature }}$


NSTec

Form

FRM-2217
CERTIFICATE OF DISPOSAL

(LOW LEVEL WASTE)
$03 / 01 / 10$

Rev. 01

Page 1 of $\hat{\imath}$

\section{Nevada Test Site}

This Certificate acknowledges that the following shipment(s) of waste have been disposed at the Hevada Test Site Radioactive Waste Management Complex.

\begin{tabular}{|l|l|l|l|}
\hline Shipment Number & \multicolumn{1}{|c|}{$\begin{array}{c}\text { Waste Stream } \\
\text { Identification \# }\end{array}$} & Package \# & Date of Disposel \\
\hline DPL10182 & LRY5LLF08002 & 10L248 & \\
\hline & & & \\
\hline & & & \\
\hline & & & \\
\hline & & & \\
\hline & & & \\
\hline
\end{tabular}

This certification is provided as a courtesy to the waste generator for information purposes only.

\begin{tabular}{c}
\hline WGS Signature \\
Waste inspector \\
Title \\
Ls/: Jon Tanaka \\
RWMC Signature
\end{tabular}
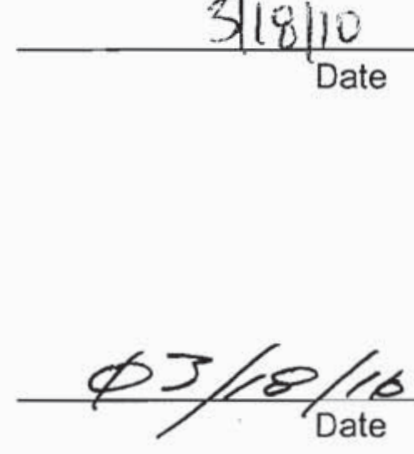
NSTec

Form

FRM-2217
CERTIFICATE OF DISPOSAL

(LOW LEVEL WASTE)
$03 / 01 / 10$

Rev. 01

Page it of $i$

Nevada Test Site

This Certificate acknowledges that the following shipments) of waste have bets Nevada Test Site Radioactive Waste Management Complex.

\begin{tabular}{|l|l|l|l|}
\hline Shipment Number & $\begin{array}{c}\text { Waste Stream } \\
\text { Identification \# }\end{array}$ & Package \# & Date of Disposal! \\
\hline & LRY5LLFY08002 & 10 L249 & \\
\hline & & & \\
\hline & & & \\
\hline & & & \\
\hline & & & \\
\hline & & & \\
\hline
\end{tabular}

This certification is provided as a courtesy to the waste generator for information purposes only.
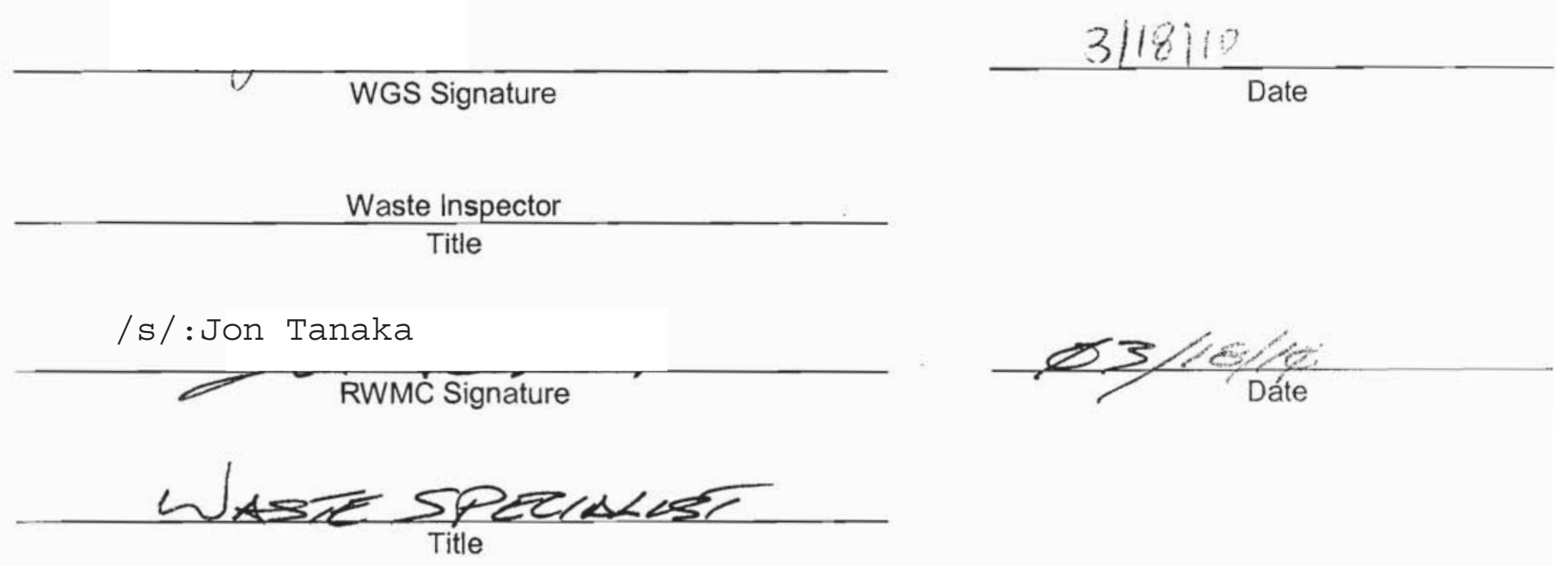

(Reference: OP-2151.304) 


\section{Sevada Test Site}

This Cerificticate acknowledges that the following shipment(s) of waste have been discoses Zevada Test Site Radioactive Waste Management Complex.

\begin{tabular}{|l|l|l|l|}
\hline Shipment Number & $\begin{array}{c}\text { Waste Stream } \\
\text { Identification \# }\end{array}$ & Package \# & Date of Lisposal \\
\hline DPL10184 & LRY5LLFY8002 & 10L250 & \\
\hline & & & \\
\hline & & & \\
\hline & & & \\
\hline & & & \\
\hline & & & \\
\hline
\end{tabular}

This certification is provided as a courtesy to the waste generator for information purposes only.

WGS Signature

Waste Inspector

\section{Title}

/s/: Jon Tanaka

RWMC Signature

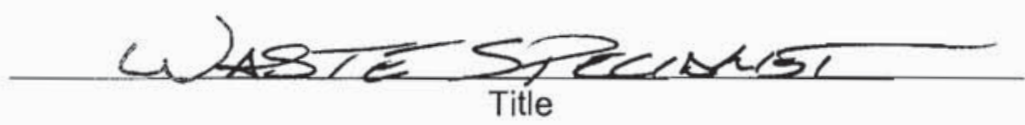

$3 / 18110$

Date

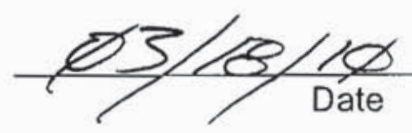


NSTec

Form

FRM-2217
CERTIFICATE OF DISPOSAL

(LOW LEVEL WASTE)
03/01/10

Rev. 01

Page 1 of 1

\section{Nevada Test Site}

This Certificate acknowledges that the following shipment(s) of waste have been disposed at the Nevada Test Site Radioactive Waste Management Complex.

\begin{tabular}{|l|l|l|l|}
\hline Shipment Number & $\begin{array}{c}\text { Waste Stream } \\
\text { Identification \# }\end{array}$ & Package \# & Date of Disposal \\
\hline DPL10085 & LRY5LLFY08002 & 10 L151 & $3 \mid$ J 110 \\
\hline & & & \\
\hline & & & \\
\hline & & & \\
\hline & & & \\
\hline & & & \\
\hline & & & \\
\hline & & & \\
\hline
\end{tabular}

This certification is provided as a courtesy to the waste generator for information purposes only.

WGS Signature

Waste Inspector

Title

\section{/s/:Jon Tanaka}

RWMC Signature

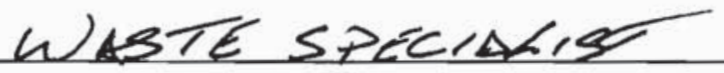

Title $3|\partial \partial| 10$

Date

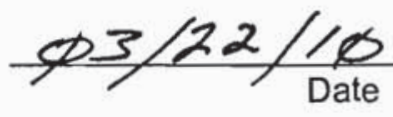


NSTec

Form

FRM-2217
CERTIFICATE OF DISPOSAL

(LOW LEVEL WASTE)
$03 / 01 / 10$

Rev. 01

Page 1 of 1

\section{Nevada Test Site}

This Certificate acknowledges that the following shipment(s) of waste have been disposed at the Nevada Test Site Radioactive Waste Management Complex.

\begin{tabular}{|l|l|l|c|}
\hline Shipment Number & $\begin{array}{c}\text { Waste Stream } \\
\text { Identification \# }\end{array}$ & Package \# & Date of Disposal \\
\hline DPL10086 & LRY5LLF08002 & 10 L152 & 3 ว3/10 \\
\hline & & & \\
\hline & & & \\
\hline & & & \\
\hline & & & \\
\hline & & & \\
\hline & & & \\
\hline & & & \\
\hline
\end{tabular}

This certification is provided as a courtesy to the waste generator for information purposes only.

- WGS Signature
Waste Inspector
Title

/s/:Jon Tanaka
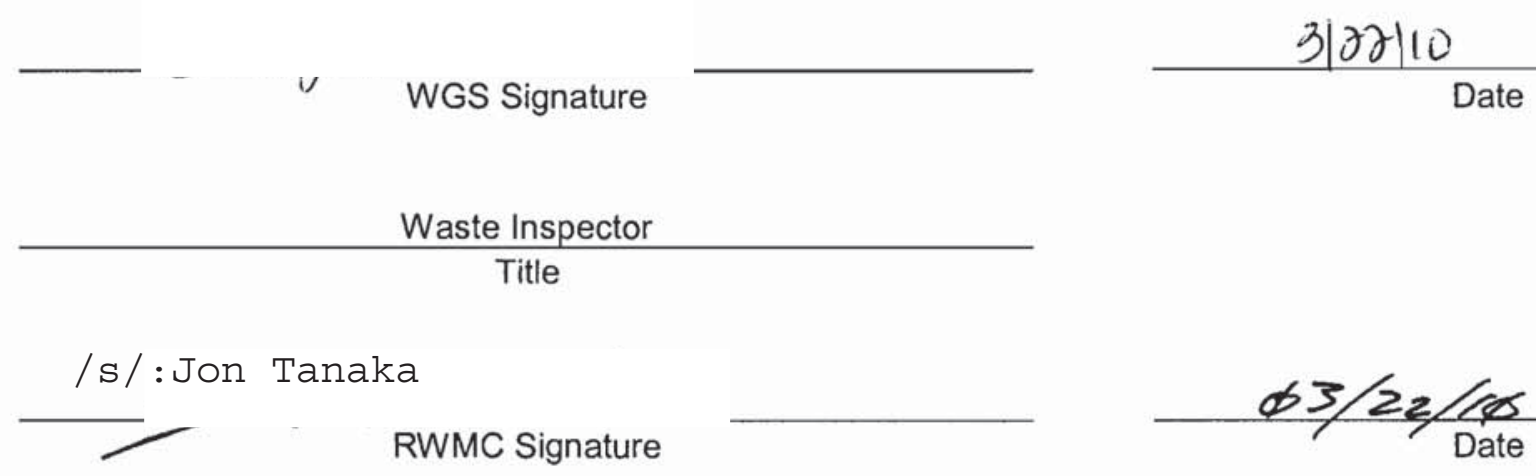

waste spers 
NSTec

Form

CERTIFICATE OF DISPOSAL

$03 / 01 / 10$

FRM-2217

(LOW LEVEL WASTE)

Rev. 01

Page 1 of 1

\section{Nevada Test Site}

This Certificate acknowledges that the following shipment(s) of waste have been disposed at the Nevada Test Site Radioactive Waste Management Complex.

\begin{tabular}{|l|l|l|l|}
\hline Shipment Number & $\begin{array}{c}\text { Waste Stream } \\
\text { Identification \# }\end{array}$ & Package \# & Date of Disposal \\
\hline DPL10087 & LRY5LLFY08002 & 10 153 & $3 / 2 \gamma / 10$ \\
\hline & & & \\
\hline & & & \\
\hline & & & \\
\hline & & & \\
\hline & & & \\
\hline & & & \\
\hline & & & \\
\hline
\end{tabular}

This certification is provided as a courtesy to the waste generator for information purposes only.

W'GS Signature

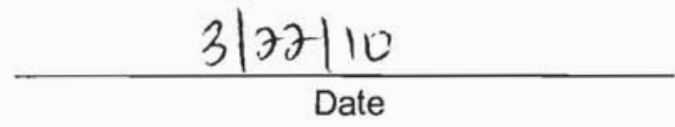

Waste Inspector

Title

/s/: Jon Tanaka

RWMC Signature

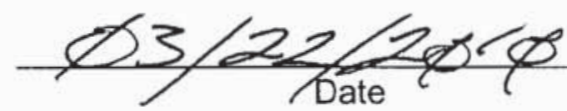

WLBCE SRECALT

Title 
NSTec

Form

FRM-2217
CERTIFICATE OF DISPOSAL

(LOW LEVEL WASTE)
03/01/10

Rev. 01

Page 1 of 1

\section{Nevada Test Site}

This Certificate acknowledges that the following shipment(s) of waste have been disposed at the Nevada Test Site Radioactive Waste Management Complex.

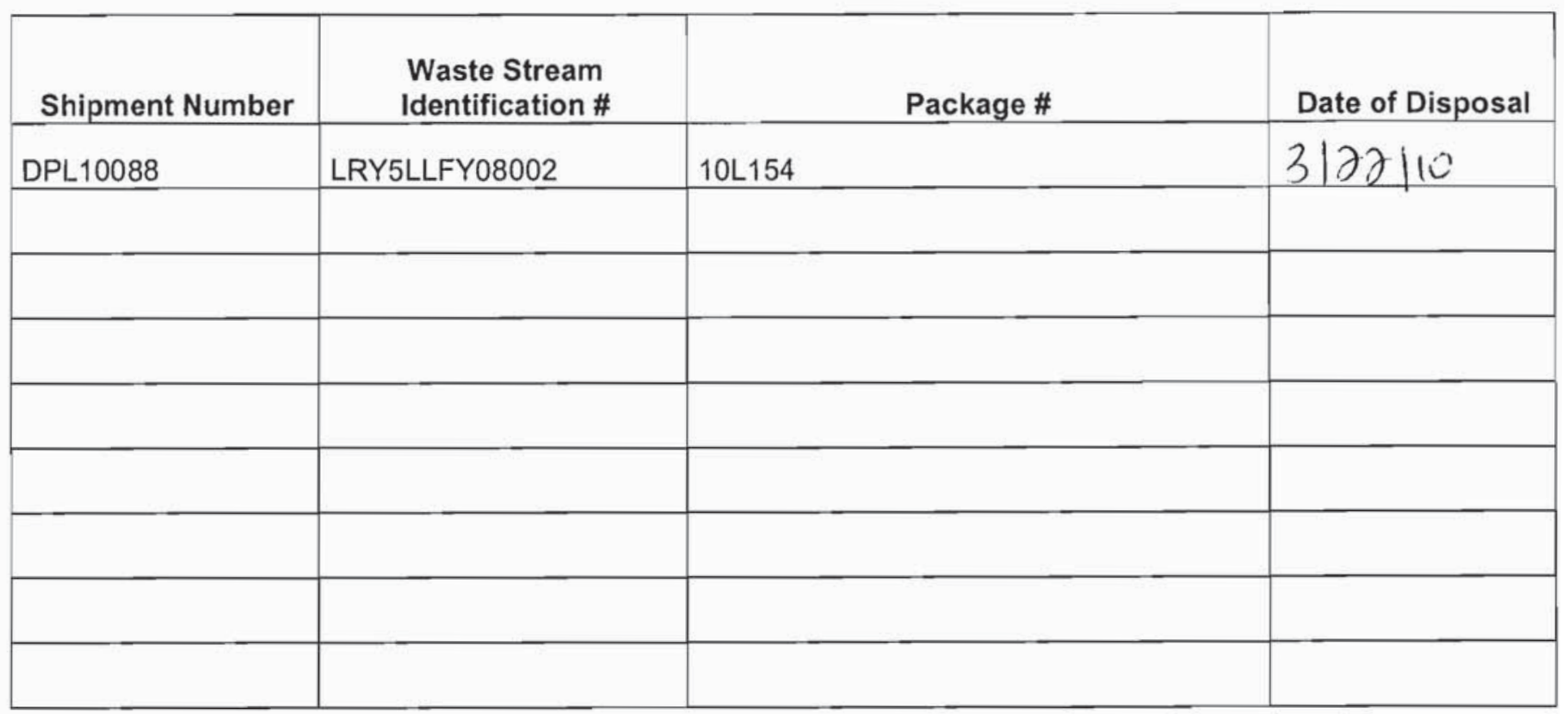

This certification is provided as a courtesy to the waste generator for information purposes only.

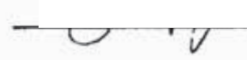

WGS Signature

Waste Inspector

Title

/s/:Jon Tanaka

RWMC Signature

WASTESPECISKS

Title
$3) 27110$

Date

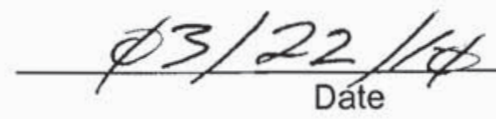


NSTec

Form

FRM-2217
CERTIFICATE OF DISPOSAL

(LOW LEVEL WASTE)
03/01/10

Rev. 01

Page 1 of 1

\section{Nevada Test Site}

This Certificate acknowledges that the following shipment(s) of waste have been disposed at the Nevada Test Site Radioactive Waste Management Complex.

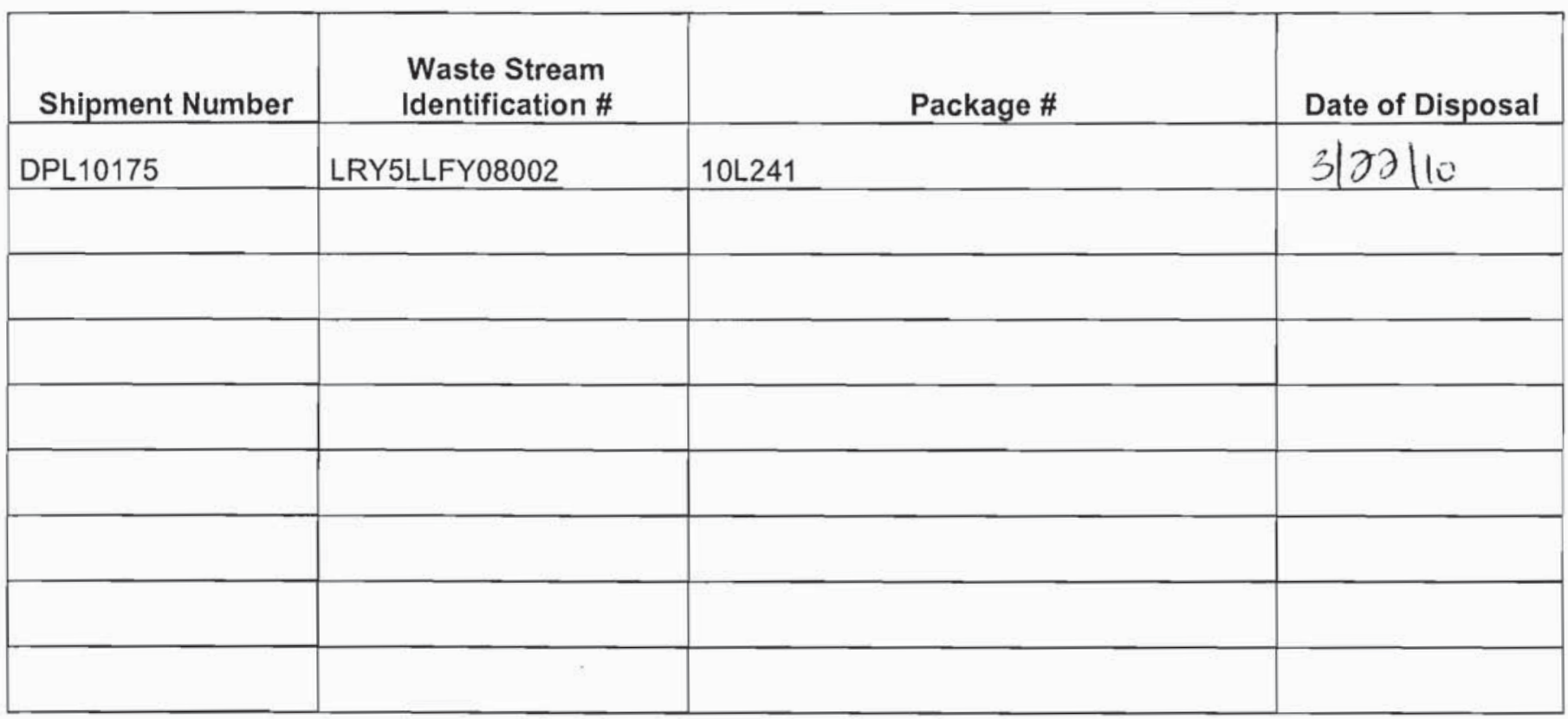

This certification is provided as a courtesy to the waste generator for information purposes only.

WGS Signature

Waste Inspector

Title

/s/:Jon Tanaka

RẂMC Signature

WhSTE SPECWAST
$3 \mid 2 \gamma 110$

Date

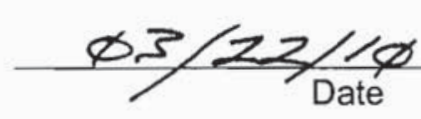


NSTec

Form

FRM-2217
CERTIFICATE OF DISPOSAL

(LOW LEVEL WASTE)
03/01/10

Rev. 01

Page 1 of 1

\section{Nevada Test Site}

This Certificate acknowledges that the following shipment(s) of waste have been disposed at the Nevada Test Site Radioactive Waste Management Complex.

\begin{tabular}{|l|l|l|l|}
\hline Shipment Number & \multicolumn{1}{|c|}{$\begin{array}{c}\text { Waste Stream } \\
\text { Identification \# }\end{array}$} & Package \# & Date of Disposal \\
\hline DPL10185 & LRY5LLFY08002 & 10L251 & $3 / 7 \gamma / 0$ \\
\hline & & & \\
\hline & & & \\
\hline & & & \\
\hline & & & \\
\hline & & & \\
\hline & & & \\
\hline
\end{tabular}

This certification is provided as a courtesy to the waste generator for information purposes only.

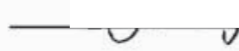

$\checkmark$

WGS Signature

Waste Inspector

Title

/s/:Jon Tanaka

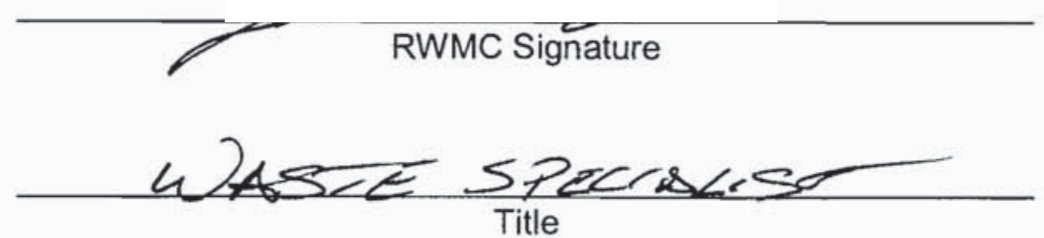

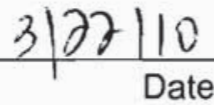

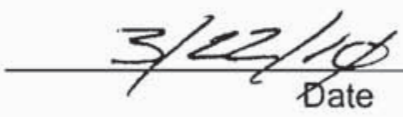


NSTec

Form

FRM-2217
CERTIFICATE OF DISPOSAL

(LOW LEVEL WASTE)
$03 / 01 / 10$

Rev. 01

Page 1 of 1

\section{Nevada Test Site}

This Certificate acknowledges that the following shipment(s) of waste have been disposed at the Nevada Test Site Radioactive Waste Management Complex.

\begin{tabular}{|l|l|l|l|}
\hline Shipment Number & \multicolumn{1}{|c|}{$\begin{array}{c}\text { Waste Stream } \\
\text { Identification \# }\end{array}$} & Package \# & Date of Disposal \\
\hline DPL10186 & LRY5LLFY08002 & 10 252 & 3 PS/ 10 \\
\hline & & & \\
\hline & & & \\
\hline & & & \\
\hline & & & \\
\hline & & & \\
\hline & & & \\
\hline & & & \\
\hline
\end{tabular}

This certification is provided as a courtesy to the waste generator for information purposes only.

WGS Signature

Waste Inspector

Title

/s/:Jon Tanaka

RWMC Signature

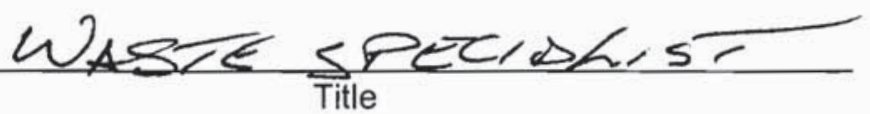

3128110

Date

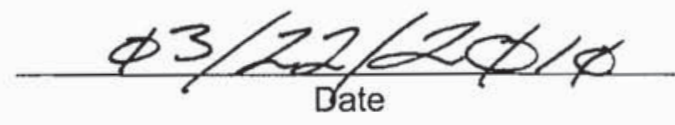


NSTec

Form

FRM-2217
CERTIFICATE OF DISPOSAL

(LOW LEVEL WASTE)
$03 / 01 / 10$

Rev. 01

Page 1 of 1

\section{Nevada Test Site}

This Certificate acknowledges that the following shipment(s) of waste have been disposed at the Nevada Test Site Radioactive Waste Management Complex.

\begin{tabular}{|l|l|l|c|}
\hline Shipment Number & $\begin{array}{c}\text { Waste Stream } \\
\text { Identification \# }\end{array}$ & Package \# & Date of Disposal \\
\hline DPL10187 & LRY5LLFY08002 & 10 L253 & $3 / \partial 3 / 10$ \\
\hline & & & \\
\hline & & & \\
\hline & & & \\
\hline & & & \\
\hline & & & \\
\hline & & & \\
\hline
\end{tabular}

This certification is provided as a courtesy to the waste generator for information purposes only.

\begin{tabular}{c}
\hline WGS Signature \\
Waste Inspector \\
Title \\
/s/: Jon Tanaka \\
RWMC Signature \\
WASEE SPEC/\&LST
\end{tabular}

3132110

Date

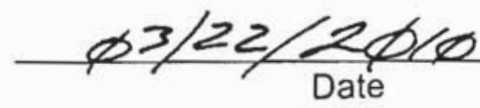




\section{Nevada Test Site}

This Certificate acknowledges that the following shipment(s) of waste have been disposed at the Nevada Test Site Radioactive Waste Management Complex.

\begin{tabular}{|l|l|l|l|}
\hline \multicolumn{1}{|c|}{$\begin{array}{c}\text { Waste Stream } \\
\text { Identification \# }\end{array}$} & Package \# & Date of Disposal \\
\hline DPL10188 & LRY5LLFY08002 & 10 254 & $3 / 7.7110$ \\
\hline & & & \\
\hline & & & \\
\hline & & & \\
\hline & & & \\
\hline & & & \\
\hline & & & \\
\hline
\end{tabular}

This certification is provided as a courtesy to the waste generator for information purposes only.

V

WGS Signature

Waste Inspector

Title
/s/:Jon Tanaka

RWMC Signature

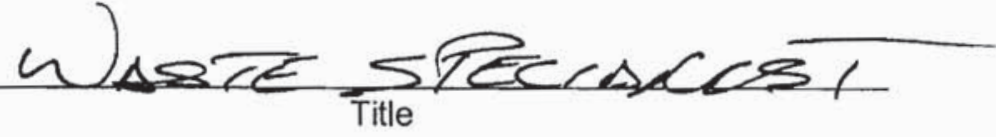

$3|22| 10$

Date

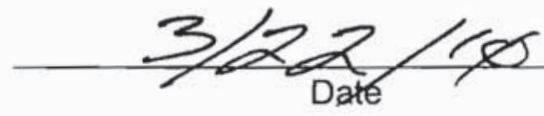


NSTec

Form

FRM-2217
CERTIFICATE OF DISPOSAL

(LOW LEVEL WASTE)
03/01/10

Rev. 01

Page 1 of 1

\section{Nevada Test Site}

This Certificate acknowledges that the following shipment(s) of waste have been disposed at the Nevada Test Site Radioactive Waste Management Complex.

\begin{tabular}{|l|l|l|c|}
\hline Shipment Number & \multicolumn{1}{|c|}{$\begin{array}{c}\text { Waste Stream } \\
\text { Identification \# }\end{array}$} & Package \# & Date of Disposal \\
\hline DPL10189 & LRY5LLFY8002 & 10 L255 & $3|\partial \gamma| 10$ \\
\hline & & & \\
\hline & & & \\
\hline & & & \\
\hline & & & \\
\hline & & & \\
\hline
\end{tabular}

This certification is provided as a courtesy to the waste generator for information purposes only.

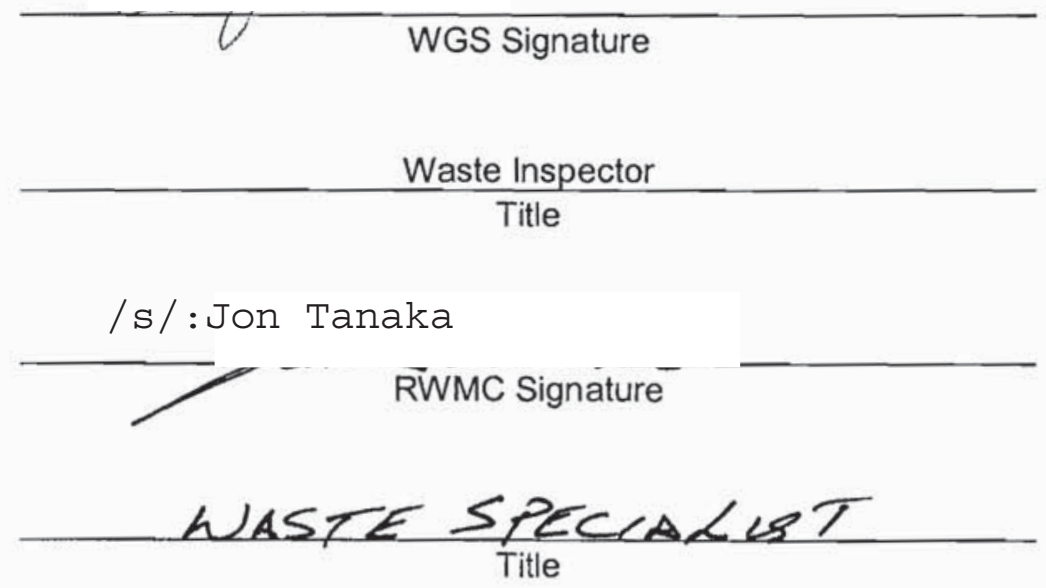
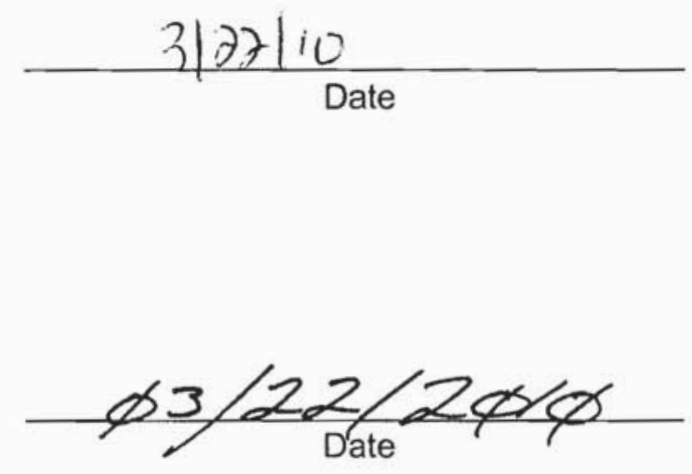


\section{Nevada Test Site}

This Certificate acknowledges that the following shipment(s) of waste have been disposed at the Nevada Test Site Radioactive Waste Management Complex.

\begin{tabular}{|c|c|c|c|}
\hline Shipment Number & $\begin{array}{l}\text { Waste Stream } \\
\text { Identification \# }\end{array}$ & Package \# & Date of Disposal \\
\hline DPL10005 & LRY5LLFY08002 & 10L006 & $33 i 110$ \\
\hline DPL10005 & LRY5LLFY08002 & $10 L 049$ & $3|31| \mathrm{c}$ \\
\hline & & & \\
\hline & & & \\
\hline & & & \\
\hline & & & \\
\hline & & & \\
\hline & & & \\
\hline
\end{tabular}

This certification is provided as a courtesy to the waste generator for information purposes only.

WGS Signature

Waste Inspector

\section{Title}

/s/:Jon Tanaka

RWMC Signature

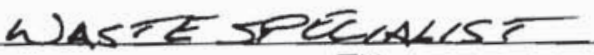

Title

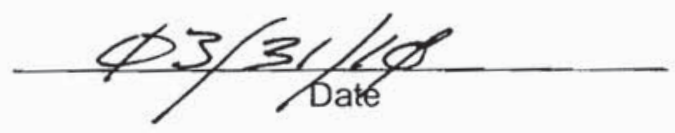


NSTec

Form

FRM-2217
CERTIFICATE OF DISPOSAL

(LOW LEVEL WASTE)
$03 / 01 / 10$

Rev. 01

Page 1 of 1

\section{Nevada Test Site}

This Certificate acknowledges that the following shipment(s) of waste have been disposed at the Nevada Test Site Radioactive Waste Management Complex.

\begin{tabular}{|l|l|l|l|}
\hline \multicolumn{1}{|c|}{ Shipment Number } & \multicolumn{1}{|c|}{$\begin{array}{c}\text { Waste Stream } \\
\text { Identification \# }\end{array}$} & Package \# & Date of Disposal \\
\hline DPL10006 & LRY5LLFY08002 & 10 L007 & $3 / 31110$ \\
\hline DPL10006 & LRY5LLFY08002 & 10 L050 & $3 / 3111 c^{3}$ \\
\hline & & & \\
\hline & & & \\
\hline & & & \\
\hline & & & \\
\hline
\end{tabular}

This certification is provided as a courtesy to the waste generator for information purposes only.

WGS Signature

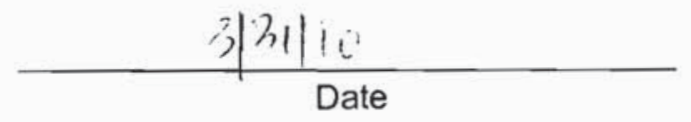

Waste Inspector

Titie

/s/:Jon Tanaka

RWMC Signature

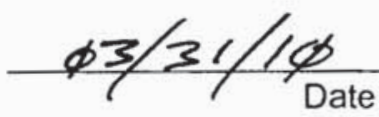

WLABE SPECISKIST

Title 
NSTec

Form

FRM-2217
CERTIFICATE OF DISPOSAL

(LOW LEVEL WASTE)
03/01/10

Rev. 01

Page 1 of 1

\section{Nevada Test Site}

This Certificate acknowledges that the following shipment(s) of waste have been disposed at the Nevada Test Site Radioactive Waste Management Complex.

\begin{tabular}{|l|l|l|l|}
\hline Shipment Number & \multicolumn{1}{|c|}{$\begin{array}{c}\text { Waste Stream } \\
\text { Identification \# }\end{array}$} & Package \# & Date of Disposal \\
\hline DPL10007 & LRY5LLFY08002 & 10 L008 & $3 / 31 / 10$ \\
\hline DPL10007 & LRY5LLFY08002 & 10 L051 & $3 / 31 / 10$ \\
\hline & & & \\
\hline & & & \\
\hline & & & \\
\hline
\end{tabular}

This certification is provided as a courtesy to the waste generator for information purposes only.

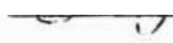

WGS Signature

Waste Inspector

Title

/s/:Jon Tanaka

RWMC Signature

WASTE SPEL $13 \angle I S T$
$3310 \frac{1}{\text { Date }}$

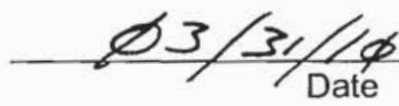


NSTec

Form

FRM-2217
CERTIFICATE OF DISPOSAL

(LOW LEVEL WASTE)
$03 / 01 / 10$

Rev. 01

Page 1 of 1

\section{Nevada Test Site}

This Certificate acknowledges that the following shipment(s) of waste have been disposed at the Nevada Test Site Radioactive Waste Management Complex.

\begin{tabular}{|l|l|l|l|}
\hline Shipment Number & $\begin{array}{c}\text { Waste Stream } \\
\text { Identification \# }\end{array}$ & Package \# & Date of Disposal \\
\hline DPL10192 & LRY5LLF08002 & 10L258 & $3 / 31 !$ i \\
\hline & & & \\
\hline & & & \\
\hline & & & \\
\hline & & & \\
\hline & & & \\
\hline & & & \\
\hline
\end{tabular}

This certification is provided as a courtesy to the waste generator for information purposes only.

WGS Signature

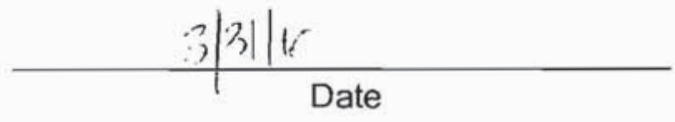

Waste Inspector

Title

/s/:Jon Tanaka

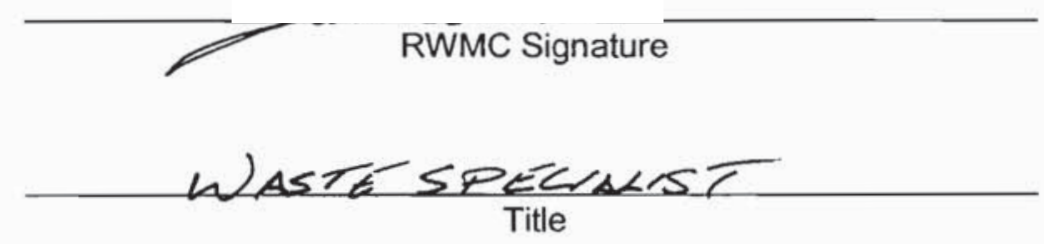

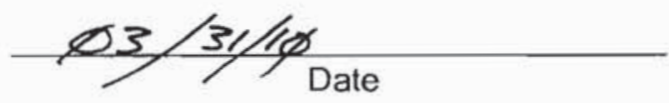


NSTec

Form

FRM-2217
CERTIFICATE OF DISPOSAL

(LOW LEVEL WASTE)
$03 / 01 / 10$

Rev. 01

Page 1 of 1

\section{Nevada Test Site}

This Certificate acknowledges that the following shipment(s) of waste have been disposed at the Nevada Test Site Radioactive Waste Management Complex.

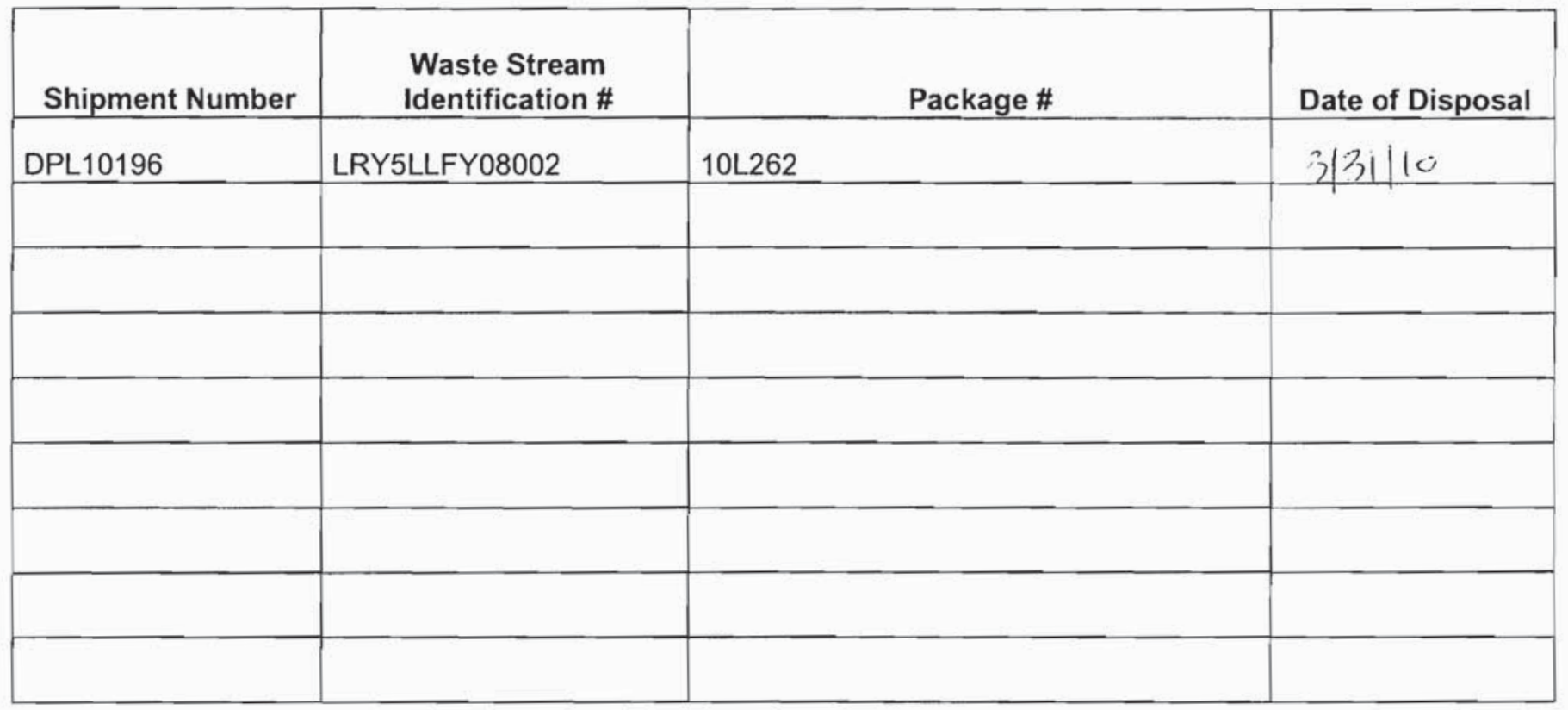

This certification is provided as a courtesy to the waste generator for information purposes only.

W' Waste Inspector
Title
/s/: Jon Tanaka
RWMC Signature

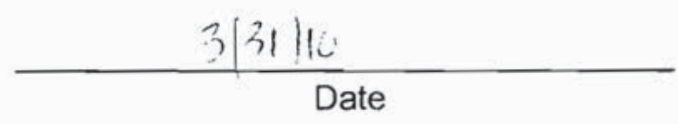

Title 
NSTec

Form

CERTIFICATE OF DISPOSAL

03/01/10

FRM-2217

(LOW LEVEL WASTE)

Rev. 01

Page 1 of 1

\section{Nevada Test Site}

This Certificate acknowledges that the following shipment(s) of waste have been disposed at the Nevada Test Site Radioactive Waste Management Complex.

\begin{tabular}{|l|l|l|l|}
\hline \multicolumn{1}{|c|}{ Shipment Number } & \multicolumn{1}{|c|}{$\begin{array}{c}\text { Waste Stream } \\
\text { Identification \# }\end{array}$} & Package \# & Date of Disposal \\
\hline DPL10008 & LRY5LLFY08002 & 10 L009 & 04-01-2010 \\
\hline DPL10008 & LRY5LLFY08002 & 10 L052 & $04-01-2010$ \\
\hline & & & \\
\hline & & & \\
\hline & & & \\
\hline & & & \\
\hline
\end{tabular}

This certification is provided as a courtesy to the waste generator for information purposes only.

/s/:Theresa Hale

WGS Signature

Waste Inspector

Title

/s/:Jon Tanaka

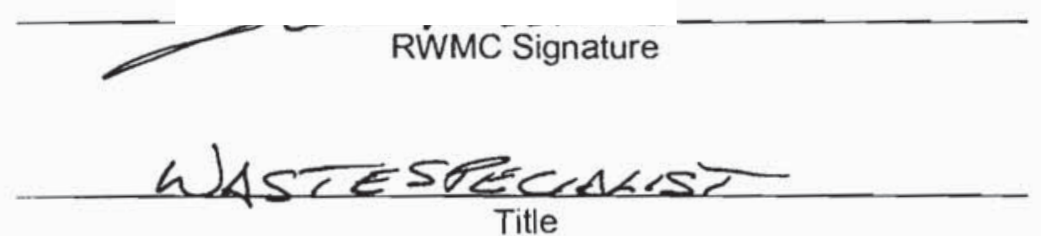

04-01-2010

Date

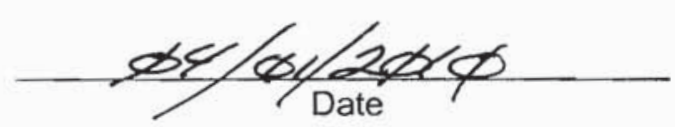




\section{Nevada Test Site}

This Certificate acknowledges that the following shipment(s) of waste have been disposed at the Nevada Test Site Radioactive Waste Management Complex.

\begin{tabular}{|l|l|l|l|}
\hline \multicolumn{1}{|c|}{ Shipment Number } & \multicolumn{1}{|c|}{$\begin{array}{c}\text { Waste Stream } \\
\text { Identification \# }\end{array}$} & \multicolumn{1}{|c|}{ Package \# } & Date of Disposal \\
\hline DPL10009 & LRY5LLFY08002 & 10 010 & $04-01-2010$ \\
\hline DPL10009 & LRY5LLFY08002 & 10 053 & $04-01-2010$ \\
\hline & & & \\
\hline & & & \\
\hline & & & \\
\hline & & & \\
\hline & & & \\
\hline & & & \\
\hline
\end{tabular}

This certification is provided as a courtesy to the waste generator for information purposes only.

/s/:Theresa Hale

WGS Signature

04-01-2010

Date

Waste Inspector

$$
\text { Title }
$$

/s/:Jon Tanaka

RWMC Signature

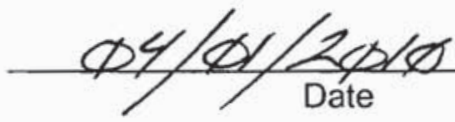

WASTE SPECIANST

Title 
NSTec

Form

CERTIFICATE OF DISPOSAL

03/01/10

FRM-2217

(LOW LEVEL WASTE)

Rev. 01

Page 1 of 1

\section{Nevada Test Site}

This Certificate acknowledges that the following shipment(s) of waste have been disposed at the Nevada Test Site Radioactive Waste Management Complex.

\begin{tabular}{|l|l|l|l|}
\hline \multicolumn{1}{|c|}{ Shipment Number } & \multicolumn{1}{|c|}{$\begin{array}{c}\text { Waste Stream } \\
\text { Identification \# }\end{array}$} & Package \# & Date of Disposal \\
\hline DPL10010 & LRY5LLFY08002 & 10L011 & 04-01-2010 \\
\hline DPL10010 & LRY5LLF08002 & 10L054 & $04-01-2010$ \\
\hline & & & \\
\hline & & & \\
\hline & & & \\
\hline & & & \\
\hline & & & \\
\hline
\end{tabular}

This certification is provided as a courtesy to the waste generator for information purposes only.

$\Lambda$

WGS Signature

Waste Inspector

Title

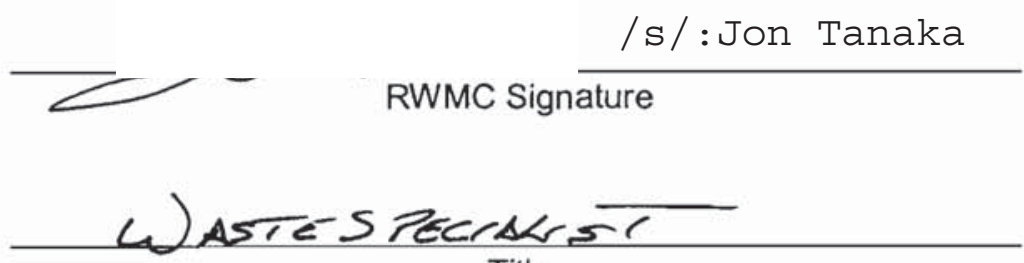

Title
04-01-2010

Date

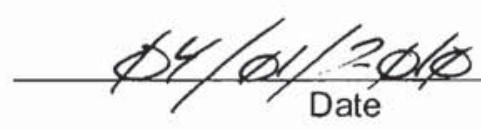


NSTec

Form

FRM-2217
CERTIFICATE OF DISFOSAL

(LOW LEVEL WASTE)
03/01/10

Rev. 01

Page 1 of 1

\section{Nevada Test Site}

This Certificate acknowledges that the following shipment(s) of waste have been disposed at the Nevada Test Site Radioactive Waste Management Complex.

\begin{tabular}{|c|c|c|c|}
\hline Shipment Number & $\begin{array}{l}\text { Waste Stream } \\
\text { Identification \# }\end{array}$ & Package \# & Date of Disposal \\
\hline DPL10012 & LRY5LLFY08002 & $10 L 013$ & $04-01-2010$ \\
\hline DPL10012 & LRY5LLFY08002 & 10L056 & $04-01-2010$ \\
\hline & & & \\
\hline & & & \\
\hline & & & \\
\hline & & & \\
\hline & & & \\
\hline & & & \\
\hline
\end{tabular}

This certification is provided as a courtesy to the waste generator for information purposes only.

/s/:Theresa Hale

WGS Signature

Waste Inspector

Title

/s/:Jon Tanaka

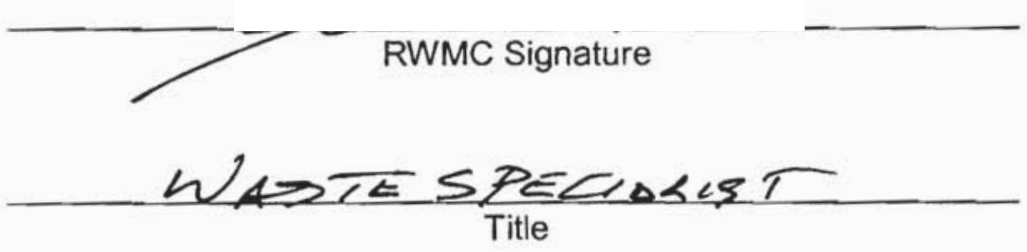

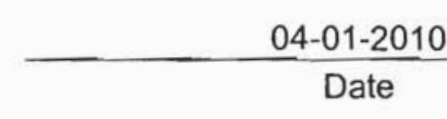

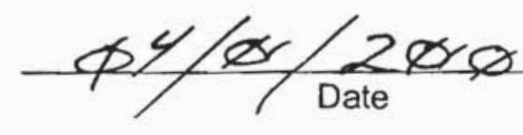


NSTec

Form

FRM-2217
CERTIFICATE OF DISPOSAL

(LOW LEVEL WASTE)
$03 / 01 / 10$

Rev. 01

Page 1 of 1

\section{Nevada Test Site}

This Certificate acknowledges that the following shipment(s) of waste have been disposed at the Nevada Test Site Radioactive Waste Management Complex.

\begin{tabular}{|l|l|l|l|}
\hline Shipment Number & \multicolumn{1}{|c|}{$\begin{array}{c}\text { Waste Stream } \\
\text { Identification \# }\end{array}$} & Package \# & Date of Disposal \\
\hline DPL10011 & LRY5LLFY08002 & 10 L012 & $04-05-2010$ \\
\hline DPL10011 & LRY5LLFY08002 & 10 L055 & $04-05-2010$ \\
\hline & & & \\
\hline & & & \\
\hline & & & \\
\hline & & & \\
\hline & & & \\
\hline
\end{tabular}

This certification is provided as a courtesy to the waste generator for information purposes only.

/s/:Theresa Hale

WGS Signature

Waste Inspector

Title

\section{/s/:Jon Tanaka}

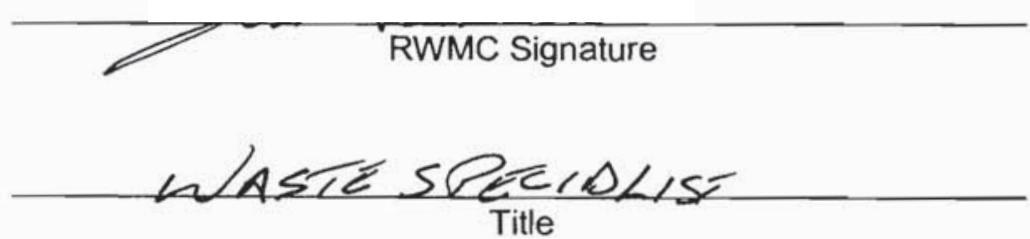

04-05-2010

Date

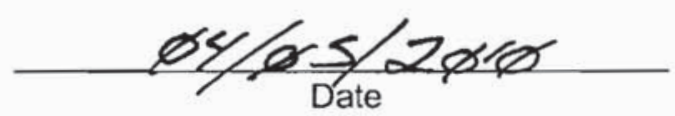


NSTec

Form

FRM-2217
CERTIFICATE OF DISPOSAL

(LOW LEVEL WASTE)
03/01/10

Rev. 01

Page 1 of 1

\section{Nevada Test Site}

This Certificate acknowledges that the following shipment(s) of waste have been disposed at the Nevada Test Site Radioactive Waste Management Complex.

\begin{tabular}{|c|c|c|c|}
\hline Shipment Number & $\begin{array}{l}\text { Waste Stream } \\
\text { Identification \# }\end{array}$ & Package \# & Date of Disposal \\
\hline DPL10013 & LRY5LLFY08002 & 10L014 & $04-05-2010$ 4 $4161 \mathrm{k}$ \\
\hline DPL10013 & LRY5LLFY08002 & 10L057 & $04-05-2010 \hat{2}+1410$ \\
\hline & & & \\
\hline & & & \\
\hline & & & \\
\hline & & & \\
\hline & & & \\
\hline & & & \\
\hline
\end{tabular}

This certification is provided as a courtesy to the waste generator for information purposes only.

WGS Signature

Waste Inspector

Title

RWMC Signature

Surutisi i. fulutic

04-05-2010

Date
QG-AFK

Date 


\section{Nevada Test Site}

This Certificate acknowledges that the following shipment(s) of waste have been disposed at the Nevada Test Site Radioactive Waste Management Complex.

\begin{tabular}{|c|c|c|c|}
\hline Shipment Number & $\begin{array}{l}\text { Waste Stream } \\
\text { Identification \# }\end{array}$ & Package \# & Date of Disposal \\
\hline DPL10014 & LRY5LLFY08002 & 10L058 & $4 l i \mid 16$ \\
\hline DPL10014 & LRY5LLFY08002 & 10L015 & $4 l u l i$ \\
\hline & & & \\
\hline & & & \\
\hline & & & \\
\hline & & & \\
\hline & & & \\
\hline & & & \\
\hline
\end{tabular}

This certification is provided as a courtesy to the waste generator for information purposes only.

WGS Signature

4ltile

Date

Waste Inspector

Title

RWMC Signature

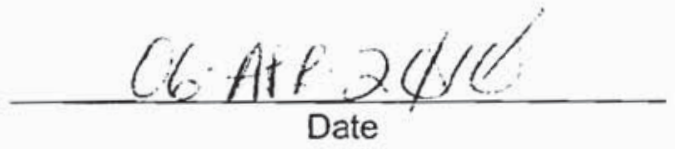

Scientist

Title 
NSTec

Form

FRM-2217
CERTIFICATE OF DISPOSAL

(LOW LEVEL WASTE)
03/01/10

Rev. 01

Page 1 of 1

\section{Nevada Test Site}

This Certificate acknowledges that the following shipment(s) of waste have been disposed at the Nevada Test Site Radioactive Waste Management Complex.

\begin{tabular}{|l|l|l|c|}
\hline Shipment Number & \multicolumn{1}{|c|}{$\begin{array}{c}\text { Waste Stream } \\
\text { Identification \# }\end{array}$} & Package \# & Date of Disposal \\
\hline DPL10018 & LRY5LLFY08002 & 10 L062 & $4 ! 6 / ! 6$ \\
\hline DPL10018 & LRY5LLFY08002 & 10 019 & $4 ! ! \cdot 1 ! i$ \\
\hline & & & \\
\hline & & & \\
\hline & & & \\
\hline & & & \\
\hline
\end{tabular}

This certification is provided as a courtesy to the waste generator for information purposes only.

\begin{tabular}{c} 
WGS Signature \\
$\frac{\text { Waste inspector }}{\text { Title }}$ \\
\hline R.WMC Signature \\
Title
\end{tabular}
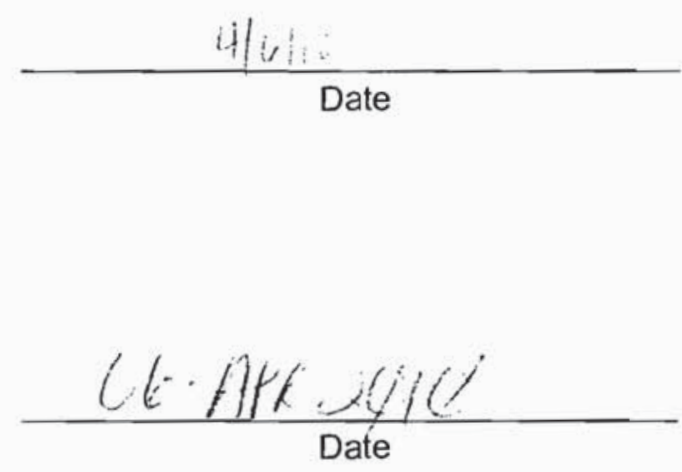
NSTec

Form

CERTIFICATE OF DISPOSAL

03/01/10

FRM-2217

(LOW LEVEL WASTE)

Rev. 01

Page 1 of 1

\section{Nevada Test Site}

This Certificate acknowledges that the following shipment(s) of waste have been disposed at the Nevada Test Site Radioactive Waste Management Complex.

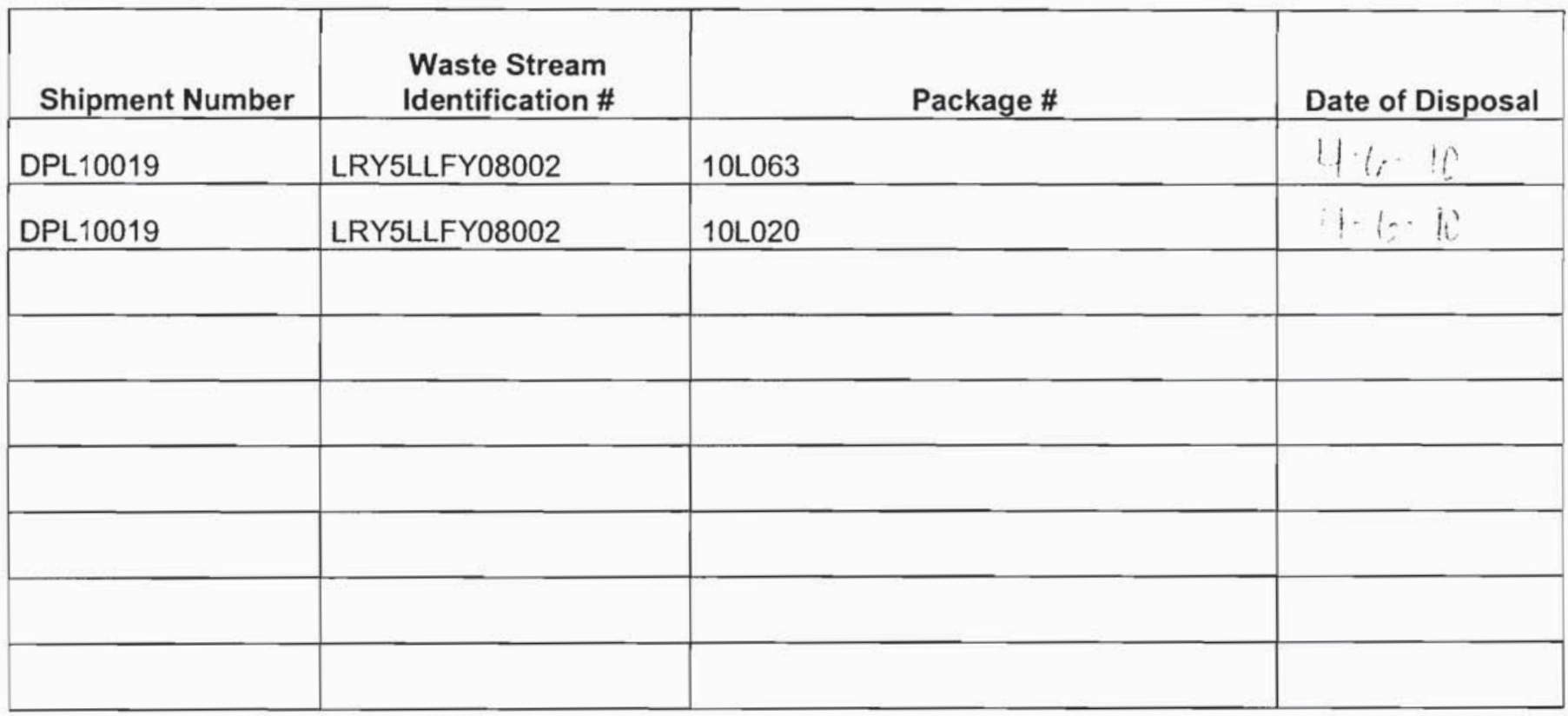

This certification is provided as a courtesy to the waste generator for information purposes only.

WGS Signature

Waste Inspector

Title

- y RWMC Signature

$\frac{C(1 E N T \text { Tis }}{\text { Title }}$
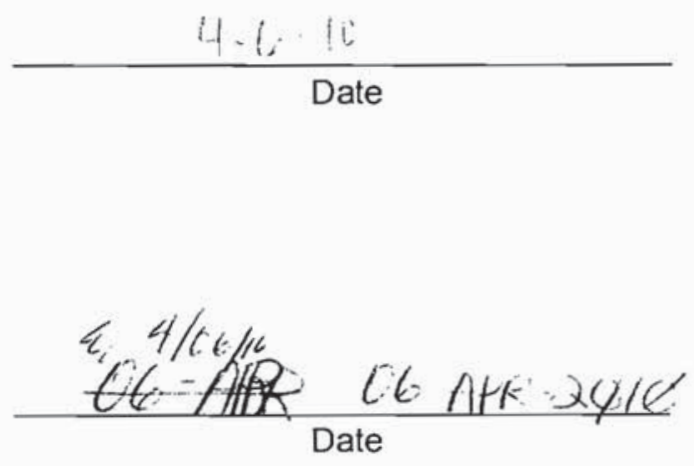
NSTec

Form

FRM-2217
CERTIFICATE OF DISPOSAL

(LOW LEVEL WASTE)
03/01/10

Rev. 01

Page 1 of 1

\section{Nevada Test Site}

This Certificate acknowledges that the following shipment(s) of waste have been disposed at the Nevada Test Site Radioactive Waste Management Complex.

\begin{tabular}{|l|l|l|l|}
\hline \multicolumn{1}{|c|}{ Shipment Number } & \multicolumn{1}{|c|}{$\begin{array}{c}\text { Waste Stream } \\
\text { Identification \# }\end{array}$} & Package \# & Date of Disposal \\
\hline DPL10015 & LRY5LLFY08002 & 10 059 & 4970 \\
\hline DPL10015 & LRY5LLFY08002 & 10 L016 & $4-7-10$ \\
\hline & & & \\
\hline & & & \\
\hline & & & \\
\hline & & & \\
\hline
\end{tabular}

This certification is provided as a courtesy to the waste generator for information purposes only.

WGS Signature
Witle
RWMC Signature
WASTE SPEC PALST

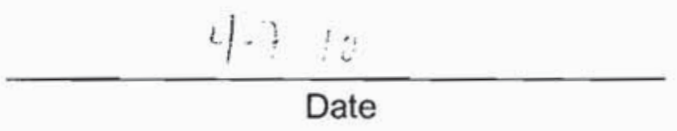

Title 
NSTec

Form

CERTIFICATE OF DISPOSAL

03/01/10

FRM-2217

(LOW LEVEL WASTE)

Rev. 01

Page 1 of 1

\section{Nevada Test Site}

This Certificate acknowledges that the following shipment(s) of waste have been disposed at the Nevada Test Site Radioactive Waste Management Complex.

\begin{tabular}{|l|l|l|l|}
\hline \multicolumn{1}{|c|}{$\begin{array}{c}\text { Whipment Number } \\
\text { Identification \# }\end{array}$} & \multicolumn{1}{|c|}{ Package \# } & Date of Disposal \\
\hline DPL10016 & LRY5LLFY08002 & 10 L060 & $4 \cdot 7-1 \cdot$ \\
\hline DPL10016 & LRY5LLFY08002 & 10 L017 & \\
\hline & & & \\
\hline & & & \\
\hline & & & \\
\hline & & & \\
\hline & & & \\
\hline
\end{tabular}

This certification is provided as a courtesy to the waste generator for information purposes only.

WGS Signature

Waste Inspector

Title

/s/: Jon Tanaka

RWMC Signature

UASTE SPECTAKIST
$4-7 \cdot 11$

Date

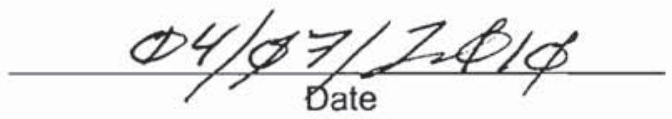


NSTec

Form

CERTIFICATE OF DISPOSAL

FRM-2217

(LOW LEVEL WASTE)

Rev. 01

Page 1 of 1

\section{Nevada Test Site}

This Certificate acknowledges that the following shipment(s) of waste have been disposed at the Nevada Test Site Radioactive Waste Management Complex.

\begin{tabular}{|l|l|l|l|}
\hline Shipment Number & \multicolumn{1}{|c|}{$\begin{array}{c}\text { Waste Stream } \\
\text { Identification \# }\end{array}$} & Package \# & Date of Disposal \\
\hline DPL10017 & LRY5LLFY08002 & 10L061 & $4 / 7 / i:$ \\
\hline DPL10017 & LRY5LLFY08002 & 10L018 & $4 / 7 / 16$ \\
\hline & & & \\
\hline & & & \\
\hline & & & \\
\hline & & & \\
\hline & & & \\
\hline
\end{tabular}

This certification is provided as a courtesy to the waste generator for information purposes only.

WGS Signature
Waste Inspector
Title
RivMC Signature
Ran Tanaka
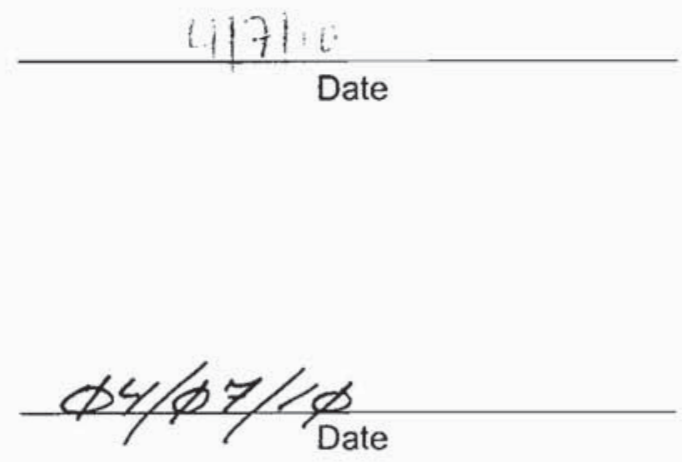


\section{Nevada Test Site}

This Certificate acknowledges that the following shipment(s) of waste have been disposed at the Nevada Test Site Radioactive Waste Management Complex.

\begin{tabular}{|c|c|c|c|}
\hline Shipment Number & $\begin{array}{l}\text { Waste Stream } \\
\text { Identification \# }\end{array}$ & Package \# & Date of Disposal \\
\hline DPL10020 & LRY5LLFY08002 & 10L064 & 417110 \\
\hline DPL10020 & LRY5LLFY08002 & 10L021 & $4171 k$ \\
\hline & & & \\
\hline & & & \\
\hline & & & \\
\hline & & & \\
\hline & & & \\
\hline & & & \\
\hline
\end{tabular}

This certification is provided as a courtesy to the waste generator for information purposes only.

WGS Signature

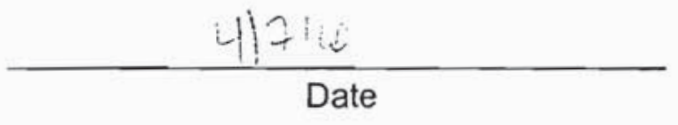

Waste Inspector

Title

/s/:Jon Tanaka

RWMC Signature

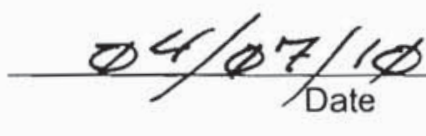

UASTE SPECHALST 
NSTec

Form

FRM-2217
CERTIFICATE OF DISPOSAL

(LOW LEVEL WASTE)
$03 / 01 / 10$

Rev. 01

Page 1 of 1

\section{Nevada Test Site}

This Certificate acknowledges that the following shipment(s) of waste have been disposed at the Nevada Test Site Radioactive Waste Management Complex.

\begin{tabular}{|l|l|l|l|}
\hline Shipment Number & \multicolumn{1}{|c|}{$\begin{array}{c}\text { Waste Stream } \\
\text { Identification \# }\end{array}$} & Package \# & Date of Disposal \\
\hline DPL10021 & LRY5LLFY08002 & 10 0665 & $4 / 7 / / 0$ \\
\hline DPL10021 & LRY5LLFY08002 & 10 L022 & $4 / 7 / 10$ \\
\hline & & & \\
\hline & & & \\
\hline & & & \\
\hline & & & \\
\hline & & & \\
\hline
\end{tabular}

This certification is provided as a courtesy to the waste generator for information purposes only.

WGS Signature

Waste Inspector

Title

/s/:Jon Tanaka

RWMC Signature

n) $A B T E$ SPECLALIST
$4.2,10$

Date

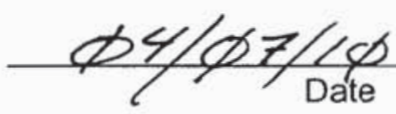




\section{Nevada Test Site}

This Certificate acknowledges that the following shipment(s) of waste have been disposed at the Nevada Test Site Radioactive Waste Management Complex.

\begin{tabular}{|l|l|l|l|}
\hline Shipment Number & \multicolumn{1}{|c|}{$\begin{array}{c}\text { Waste Stream } \\
\text { Identification \# }\end{array}$} & Package \# & Date of Disposal \\
\hline DPL10190 & LRY5LLF08002 & 10 L256 & $417 / 16$ \\
\hline & & & \\
\hline & & & \\
\hline & & & \\
\hline & & & \\
\hline
\end{tabular}

This certification is provided as a courtesy to the waste generator for information purposes only.

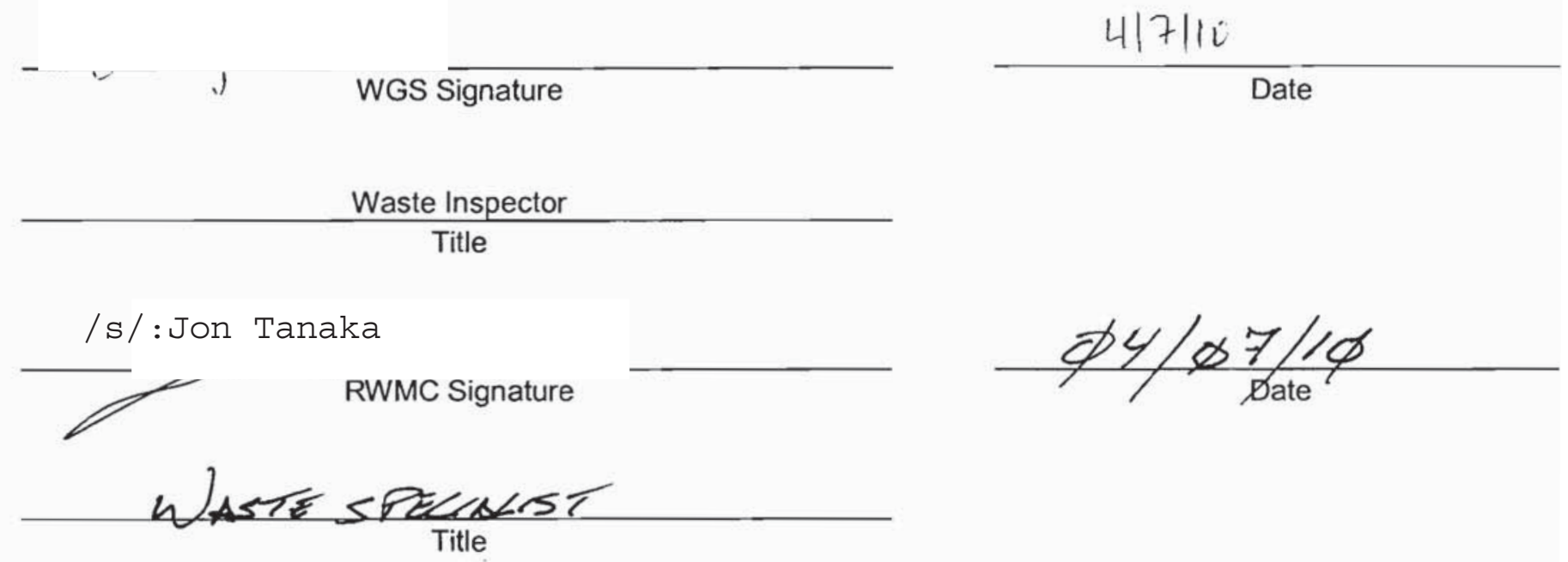


NSTec

Form

CERTIFICATE OF DISPOSAL

FRM-2217

(LOW LEVEL WASTE)

03/01/10

Rev. 01

Page 1 of 1

\section{Nevada Test Site}

This Certificate acknowledges that the following shipment(s) of waste have been disposed at the Nevada Test Site Radioactive Waste Management Complex.

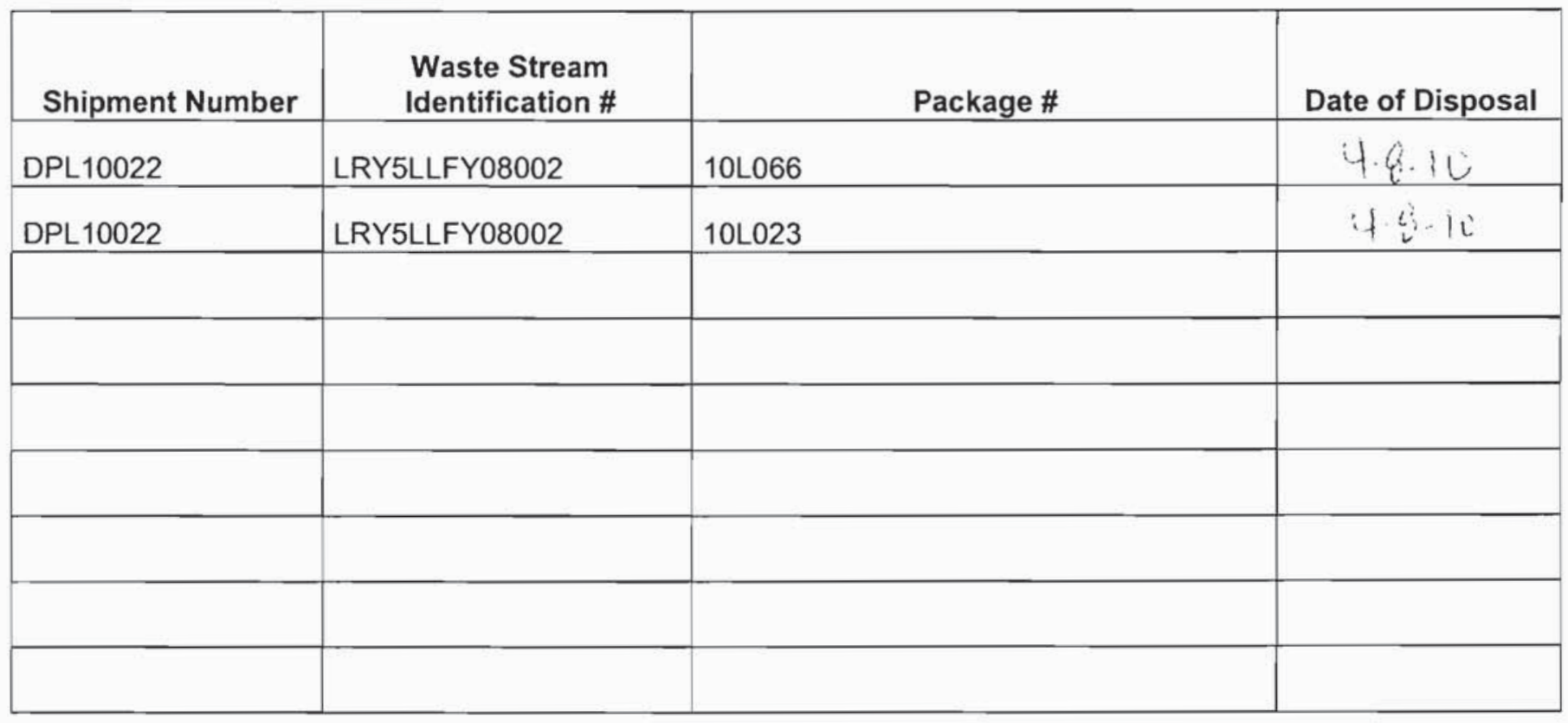

This certification is provided as a courtesy to the waste generator for information purposes only.

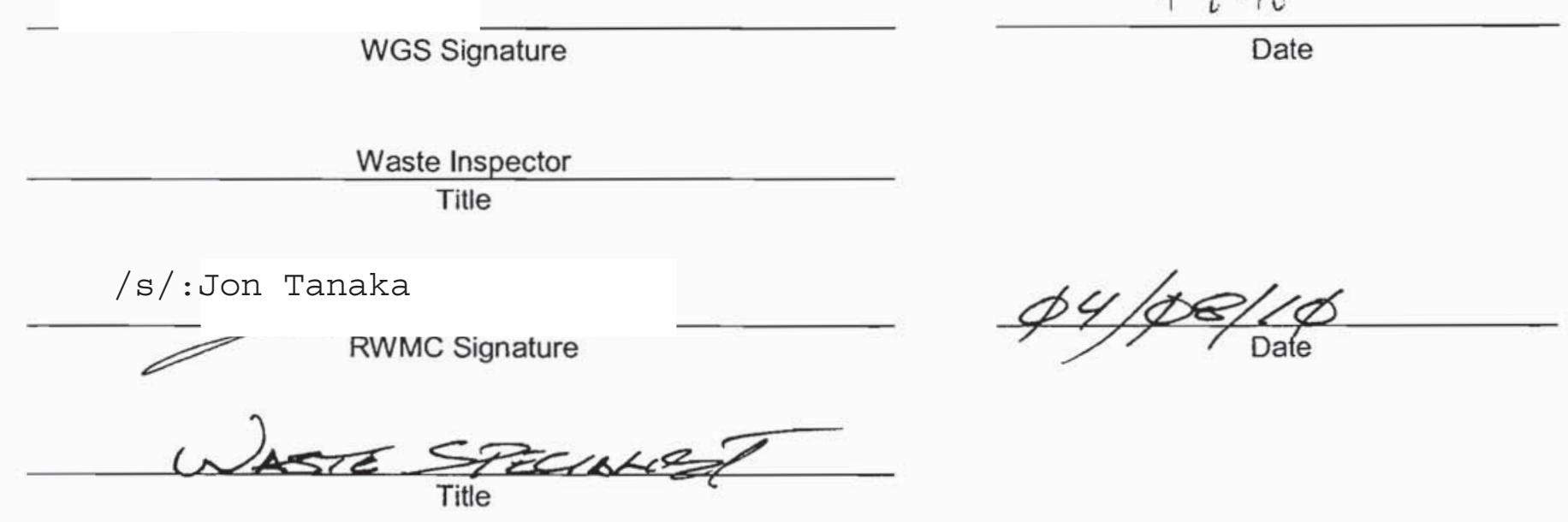


NSTec

Form

FRM-2217
CERTIFICATE OF DISPOSAL

(LOW LEVEL WASTE)
03/01/10

Rev. 01

Page 1 of 1

\section{Nevada Test Site}

This Certificate acknowledges that the following shipment(s) of waste have been disposed at the Nevada Test Site Radioactive Waste Management Complex.

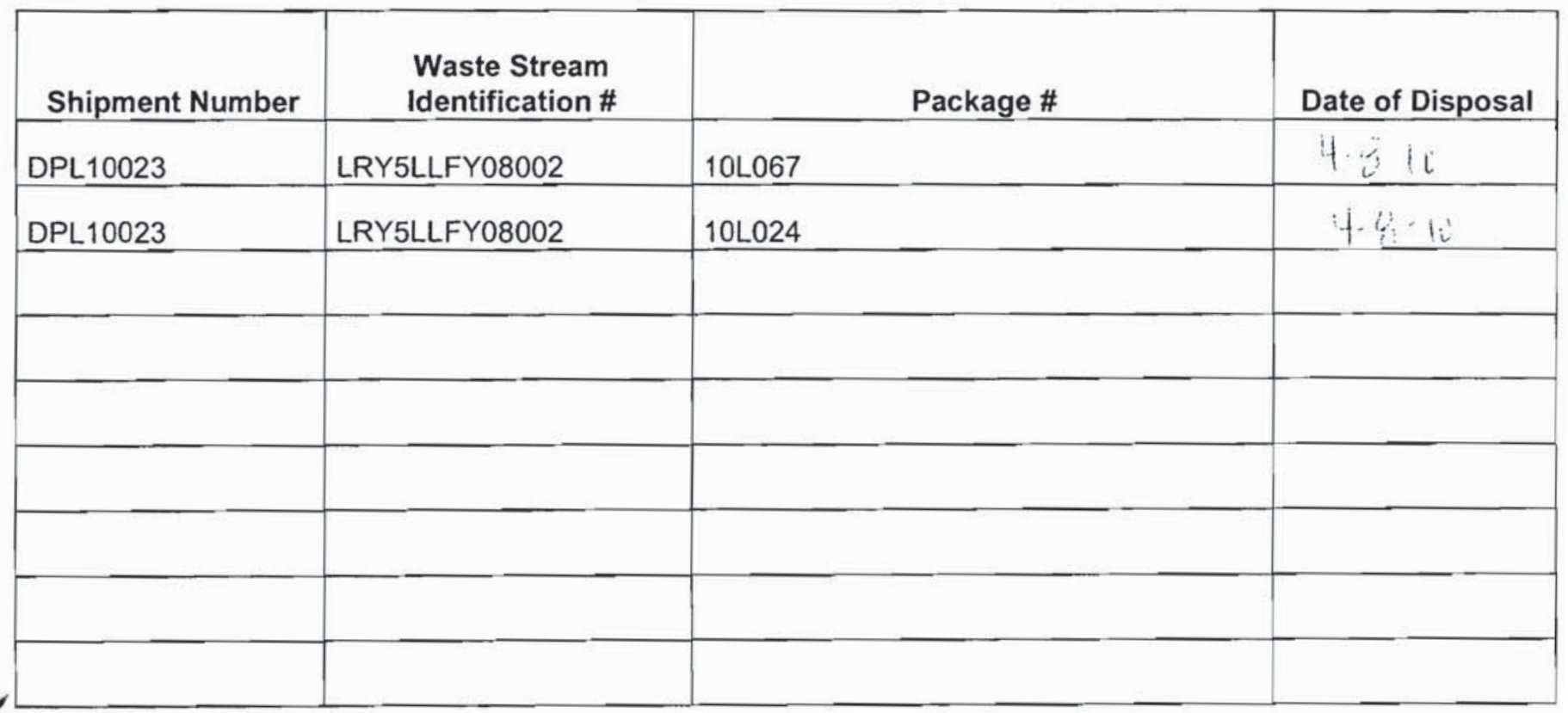

This certification is provided as a courtesy to the waste generator for information purposes only.

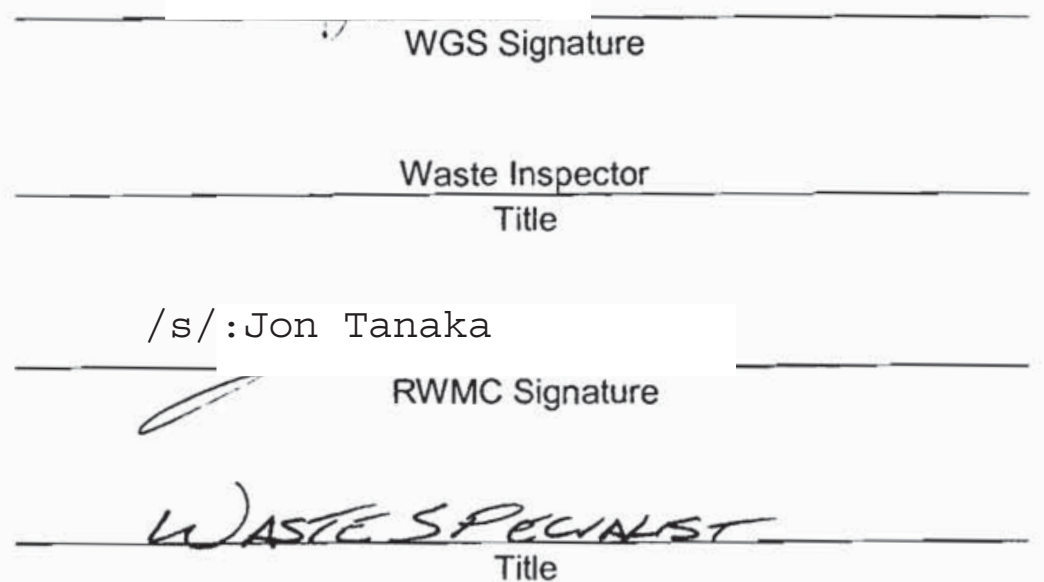

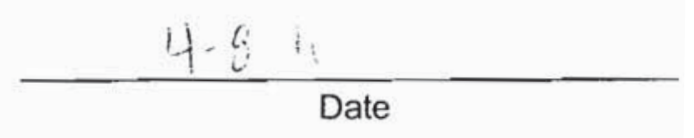

Title

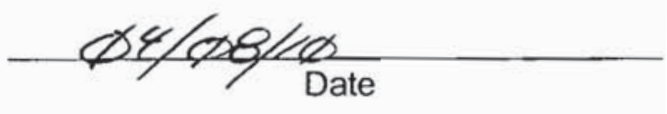


NSTec

Form

CERTIFICATE OF DISPOSAL

$03 / 01 / 10$

FRM-2217

(LOW LEVEL WASTE)

Rev. 01

Page 1 of 1

\section{Nevada Test Site}

This Certificate acknowledges that the following shipment(s) of waste have been disposed at the Nevada Test Site Radioactive Waste Management Complex.

\begin{tabular}{|l|l|l|l|}
\hline Shipment Number & \multicolumn{1}{|c|}{$\begin{array}{c}\text { Waste Stream } \\
\text { Identification \# }\end{array}$} & Package \# & Date of Disposal \\
\hline DPL10024 & LRY5LLFY08002 & 10 068 & 4 \\
\hline DPL10024 & LRY5LLFY08002 & 10 L025 & 14 \\
\hline & & & \\
\hline & & & \\
\hline & & & \\
\hline & & & \\
\hline & & & \\
\hline
\end{tabular}

This certification is provided as a courtesy to the waste generator for information purposes only.

WGS Signature

Waste inspector

Title

/s/:Jon Tanaka

RWMC Signature

W ASTE SPEWALST
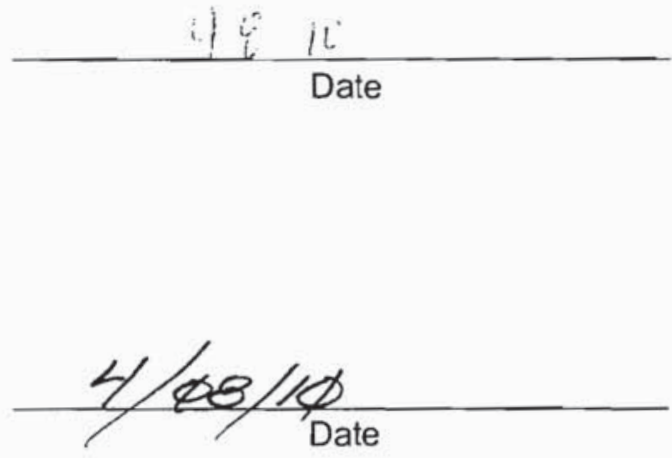
NSTec

Form

CERTIFICATE OF DISPOSAL

$03 / 01 / 10$

FRM-2217

(LOW LEVEL WASTE)

Rev. 01

Page 1 of 1

\section{Nevada Test Site}

This Certificate acknowledges that the following shipment(s) of waste have been disposed at the Nevada Test Site Radioactive Waste Management Complex.

\begin{tabular}{|l|l|l|c|}
\hline \multicolumn{1}{|c|}{ Shipment Number } & \multicolumn{1}{|c|}{$\begin{array}{c}\text { Waste Stream } \\
\text { Identification \# }\end{array}$} & Package \# & Date of Disposal \\
\hline DPL10025 & LRY5LLFY08002 & 10 066 & I \\
\hline DPL10025 & LRY5LLFY08002 & 10 L026 & \\
\hline & & & \\
\hline & & & \\
\hline & & & \\
\hline & & & \\
\hline & & & \\
\hline
\end{tabular}

This certification is provided as a courtesy to the waste generator for information purposes only.

WGS Signature

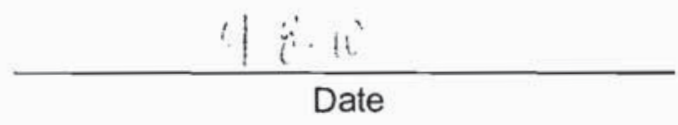

Waste Inspector

Title

/s/: Jon Tanaka

$\Longleftarrow \quad$ RWMC Signature

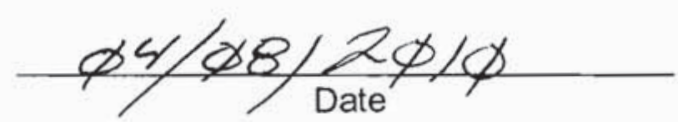


NSTec

Form

CERTIFICATE OF DISPOSAL

03/01/10

FRM-2217

(LOW LEVEL WASTE)

Rev. 01

Page 1 of 1

\section{Nevada Test Site}

This Certificate acknowledges that the following shipment(s) of waste have been disposed at the Nevada Test Site Radioactive Waste Management Complex.

\begin{tabular}{|l|l|l|l|}
\hline Shipment Number & \multicolumn{1}{|c|}{$\begin{array}{c}\text { Waste Stream } \\
\text { Identification \# }\end{array}$} & Package \# & Date of Disposal \\
\hline DPL10026 & LRY5LLFY08002 & 10 L070 & i ill \\
\hline DPL10026 & LRY5LLFY08002 & 10 L027 & \\
\hline & & & \\
\hline & & & \\
\hline & & & \\
\hline & & & \\
\hline
\end{tabular}

This certification is provided as a courtesy to the waste generator for information purposes only.

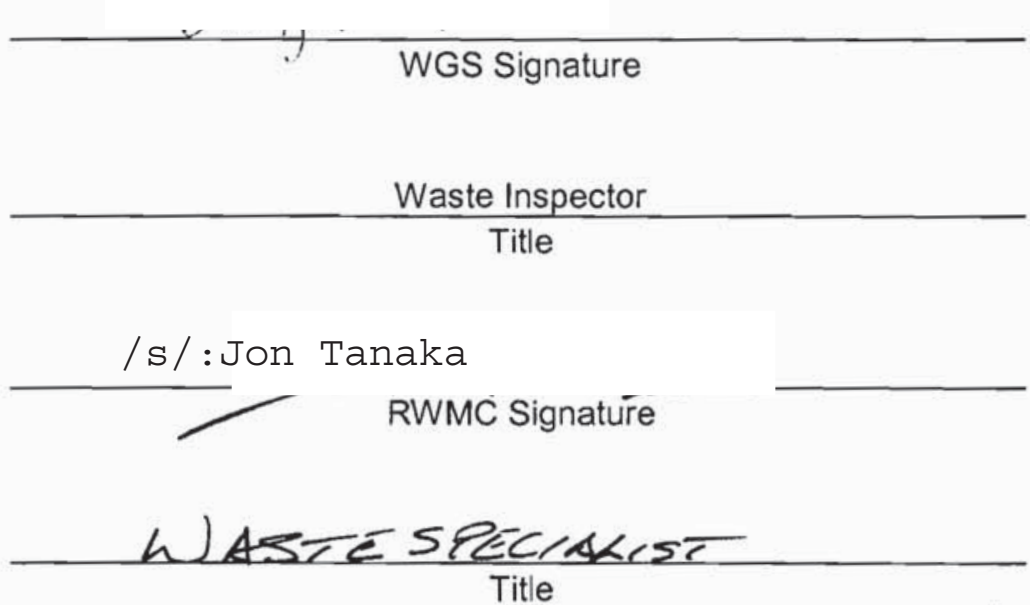

$$
4|8| 10
$$

$$
\text { Date }
$$

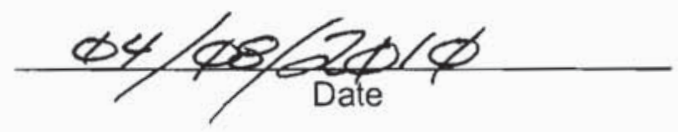

Title 
NSTec

Form

CERTIFICATE OF DISPOSAL

$03 / 01 / 10$

FRM-2217

(LOW LEVEL WASTE)

Rev. 01

Page 1 of 1

\section{Nevada Test Site}

This Certificate acknowledges that the following shipment(s) of waste have been disposed at the Nevada Test Site Radioactive Waste Management Complex.

\begin{tabular}{|l|l|l|c|}
\hline Shipment Number & \multicolumn{1}{|c|}{$\begin{array}{c}\text { Waste Stream } \\
\text { Identification \# }\end{array}$} & Package \# & Date of Disposal \\
\hline DPL10027 & LRY5LLFY08002 & 10L071 & 1 \\
\hline DPL10027 & LRY5LLFY08002 & 10L028 & \\
\hline & & & \\
\hline & & & \\
\hline & & & \\
\hline & & & \\
\hline & & & \\
\hline
\end{tabular}

This certification is provided as a courtesy to the waste generator for information purposes only.

Waste Inspector
Title
$\frac{\text { WGS Signature }}{\text { R / : Jon Tanaka }}$
RWMC Signature
WASLESPECLALST

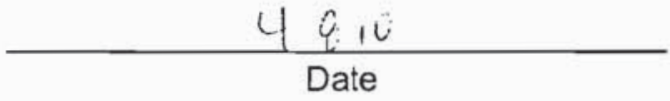

Title 
NSTec

Form

FRM-2217
CERTIFICATE OF DISPOSAL

(LOW LEVEL WASTE)
03/01/10

Rev. 01

Page 1 of 1

\section{Nevada Test Site}

This Certificate acknowledges that the following shipment(s) of waste have been disposed at the Nevada Test Site Radioactive Waste Management Complex.

\begin{tabular}{|c|c|c|c|}
\hline Shipment Number & $\begin{array}{l}\text { Waste Stream } \\
\text { Identification \# }\end{array}$ & Package \# & Date of Disposal \\
\hline DPL10028 & LRY5LLFY08002 & 10L072 & $4 / 8110$ \\
\hline DPL10028 & LRY5LLFY08002 & 10L029 & 10 \\
\hline & & & \\
\hline & & & \\
\hline & & & \\
\hline & & & \\
\hline & & & \\
\hline & & & \\
\hline
\end{tabular}

This certification is provided as a courtesy to the waste generator for information purposes only.

$\frac{\text { WGS Signature }}{\text { Waste Inspector }}$
$\frac{1 \mathrm{~s} / \text { : Jon Tanaka }}{\text { RWMC Signature }}$ RASTE SPECrAkST
Title

4. $4 \cdot 10$

Date

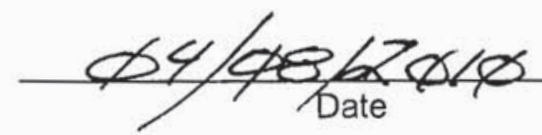


NSTec

Form

FRM-2217
CERTIFICATE OF DISPOSAL

(LOW LEVEL WASTE)
03/01/10

Rev. 01

Page 1 of 1

\section{Nevada Test Site}

This Certificate acknowledges that the following shipment(s) of waste have been disposed at the Nevada Test Site Radioactive Waste Management Complex.

\begin{tabular}{|l|l|l|l|}
\hline \multicolumn{1}{|c|}{$\begin{array}{c}\text { Waste Stream } \\
\text { Identification \# }\end{array}$} & Package \# & Date of Disposal \\
\hline DPL10029 & LRY5LLFY08002 & 10 073 & $4-12-10$ \\
\hline DPL10029 & LRY5LLFY08002 & 10 030 & $4-12-10$ \\
\hline & & & \\
\hline & & & \\
\hline & & & \\
\hline & & & \\
\hline & & & \\
\hline
\end{tabular}

This certification is provided as a courtesy to the waste generator for information purposes only.

/s/:Theresa Hale

WGS Signature

Waste Inspector

$$
\text { Title }
$$
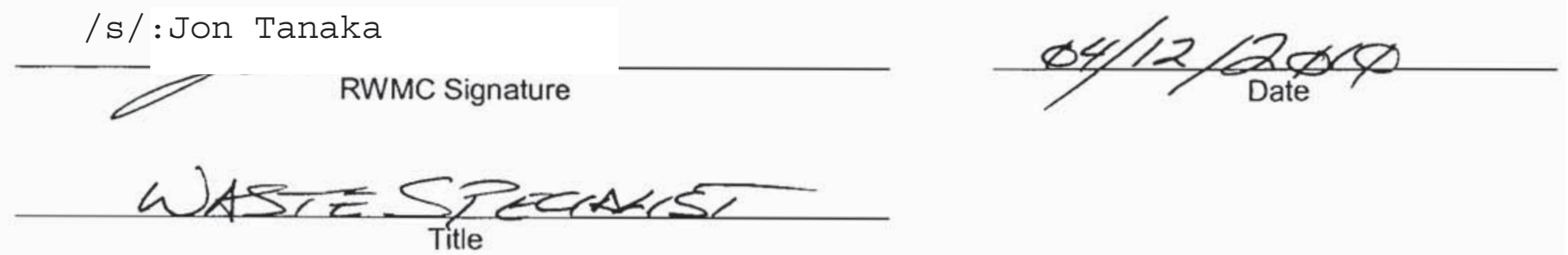
NSTec

Form

CERTIFICATE OF DISPOSAL

$03 / 01 / 10$

FRM-2217

(LOW LEVEL WASTE)

Rev. 01

Page 1 of 1

\section{Nevada Test Site}

This Certificate acknowledges that the following shipment(s) of waste have been disposed at the Nevada Test Site Radioactive Waste Management Complex.

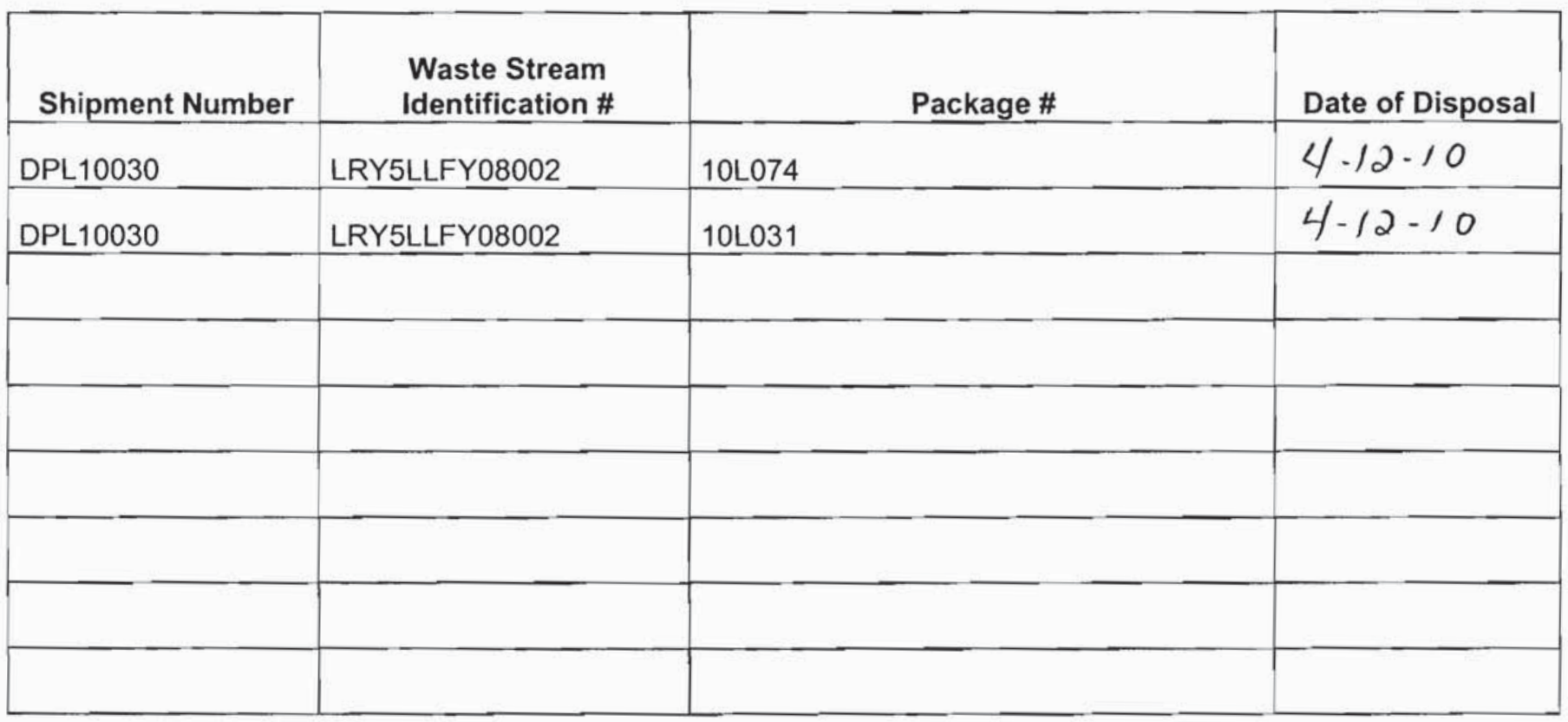

This certification is provided as a courtesy to the waste generator for information purposes only.

/sk: Theresa Hale

WGS Signature

Waste Inspector

Title

/s/:Jon Tanaka

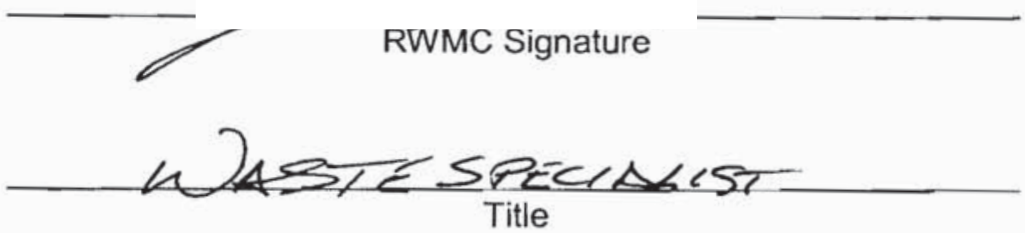

Title
$4-12-10$

Date

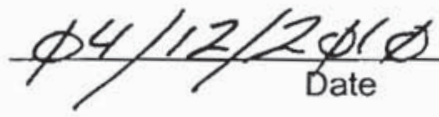


NSTec

Form

FRM-2217
CERTIFICATE OF DISPOSAL

(LOW LEVEL WASTE)
03/01/10

Rev. 01

Page 1 of 1

\section{Nevada Test Site}

This Certificate acknowledges that the following shipment(s) of waste have been disposed at the Nevada Test Site Radioactive Waste Management Complex.

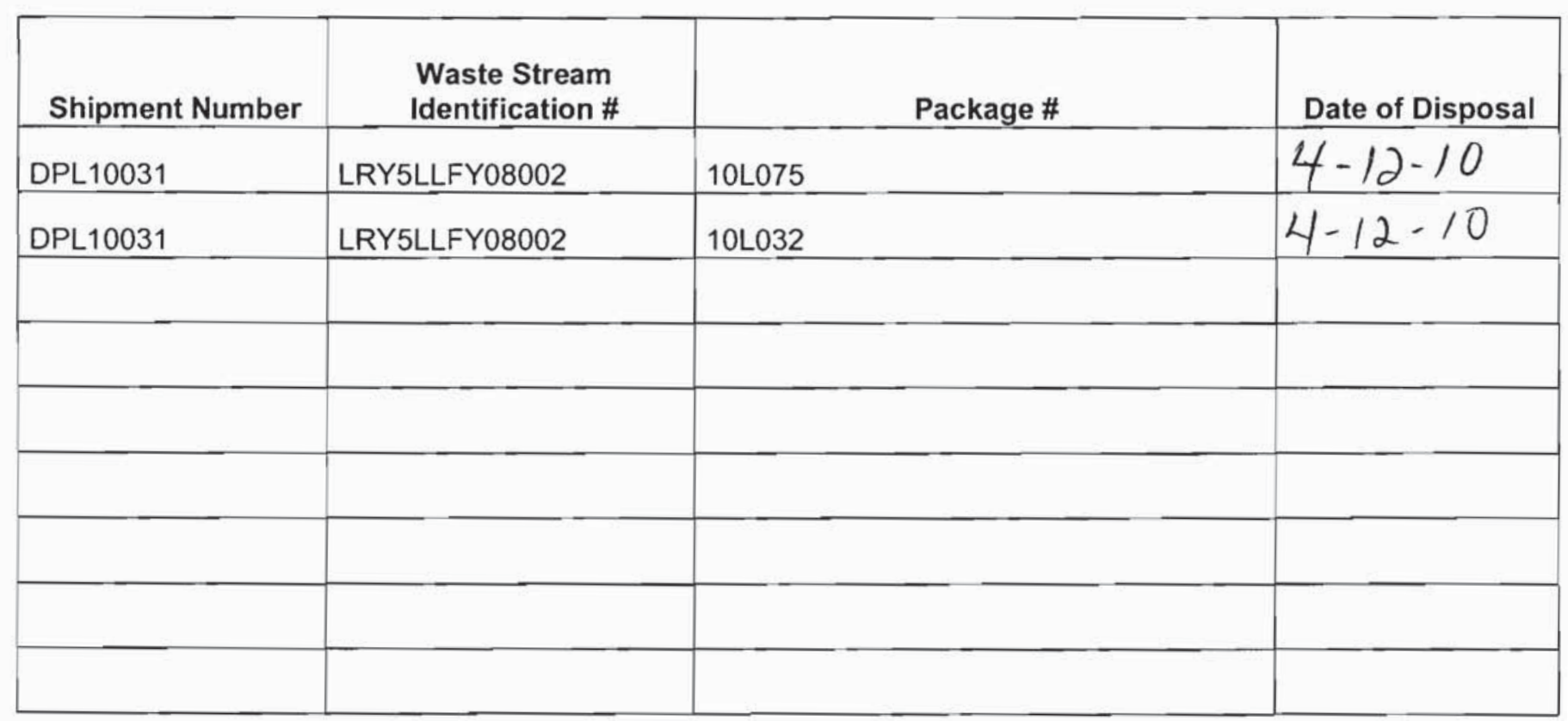

This certification is provided as a courtesy to the waste generator for information purposes only.

/ś/: Theresa Hale

WGS Signature

Waste Inspector

Title
/s/:Jon Tanaka

RWMC Signature

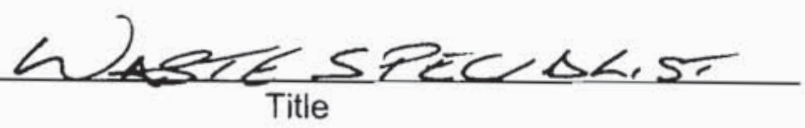

$4-12-10$

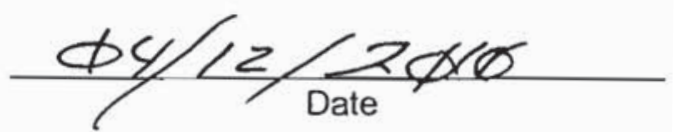


NSTec

Form

FRM-2217
CERTIFICATE OF DISPOSAL

(LOW LEVEL WASTE)
03/01/10

Rev. 01

Page 1 of 1

\section{Nevada Test Site}

This Certificate acknowledges that the following shipment(s) of waste have been disposed at the Nevada Test Site Radioactive Waste Management Complex.

\begin{tabular}{|l|l|l|l|}
\hline \multicolumn{1}{|c|}{$\begin{array}{c}\text { Waste Stream } \\
\text { Identification \# }\end{array}$} & \multicolumn{1}{c|}{ Package \# } & Date of Disposal \\
\hline DPL10032 & LRY5LLFY08002 & 10 L076 & $4-12-10$ \\
\hline DPL10032 & LRY5LLFY08002 & 10 L033 & $4-12-10$ \\
\hline & & & \\
\hline & & & \\
\hline & & & \\
\hline & & & \\
\hline & & & \\
\hline
\end{tabular}

This certification is provided as a courtesy to the waste generator for information purposes only.

/sh: Theresa Hale

WGS Signature

Waste Inspector

Title

/s/:Jon Tanaka

RVVMc Signature

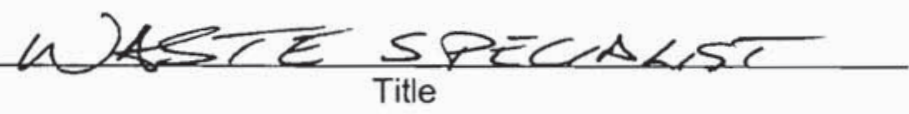

$\frac{4-12-10}{\text { Date }}$

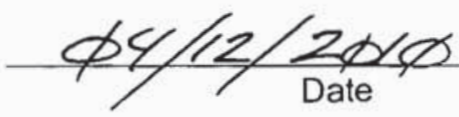




\section{Nevada Test Site}

This Certificate acknowledges that the following shipment(s) of waste have been disposed at the Nevada Test Site Radioactive Waste Management Complex.

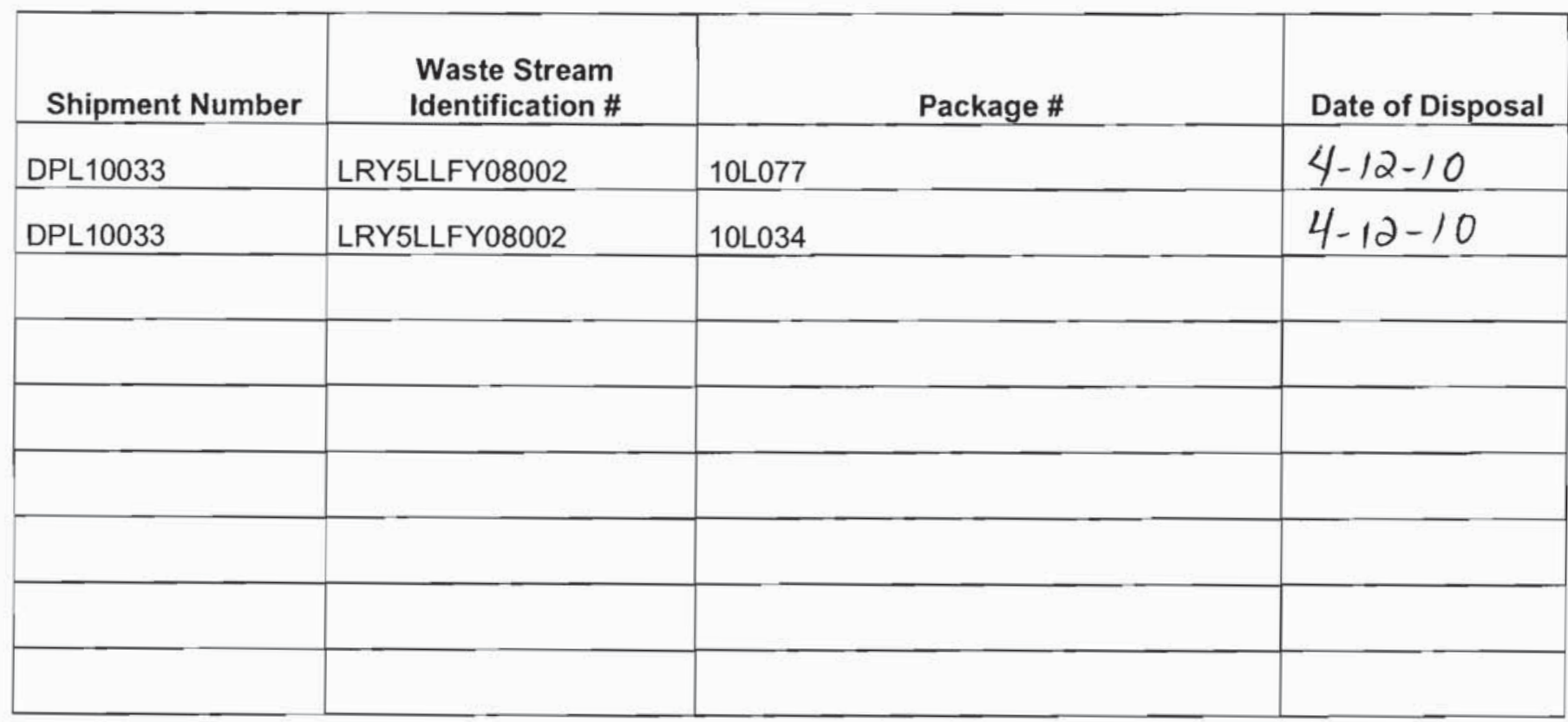

This certification is provided as a courtesy to the waste generator for information purposes only.

/s/:Theresa Hale

$$
\text { WGS Signature }
$$

Waste Inspector

$$
\text { Title }
$$

/s/:Jon Tanaka

RWMC Signature

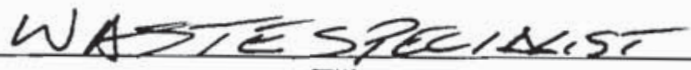

$4.12-10$

Date

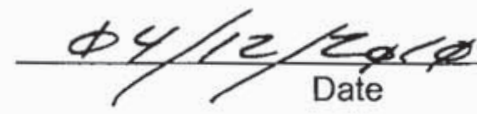


NSTec

Form

FRM-2217
CERTIFICATE OF DISPOSAL

(LOW LEVEL WASTE)
$03 / 01 / 10$

Rev. 01

Page 1 of 1

\section{Nevada Test Site}

This Certificate acknowledges that the following shipment(s) of waste have been disposed at the Nevada Test Site Radioactive Waste Management Complex.

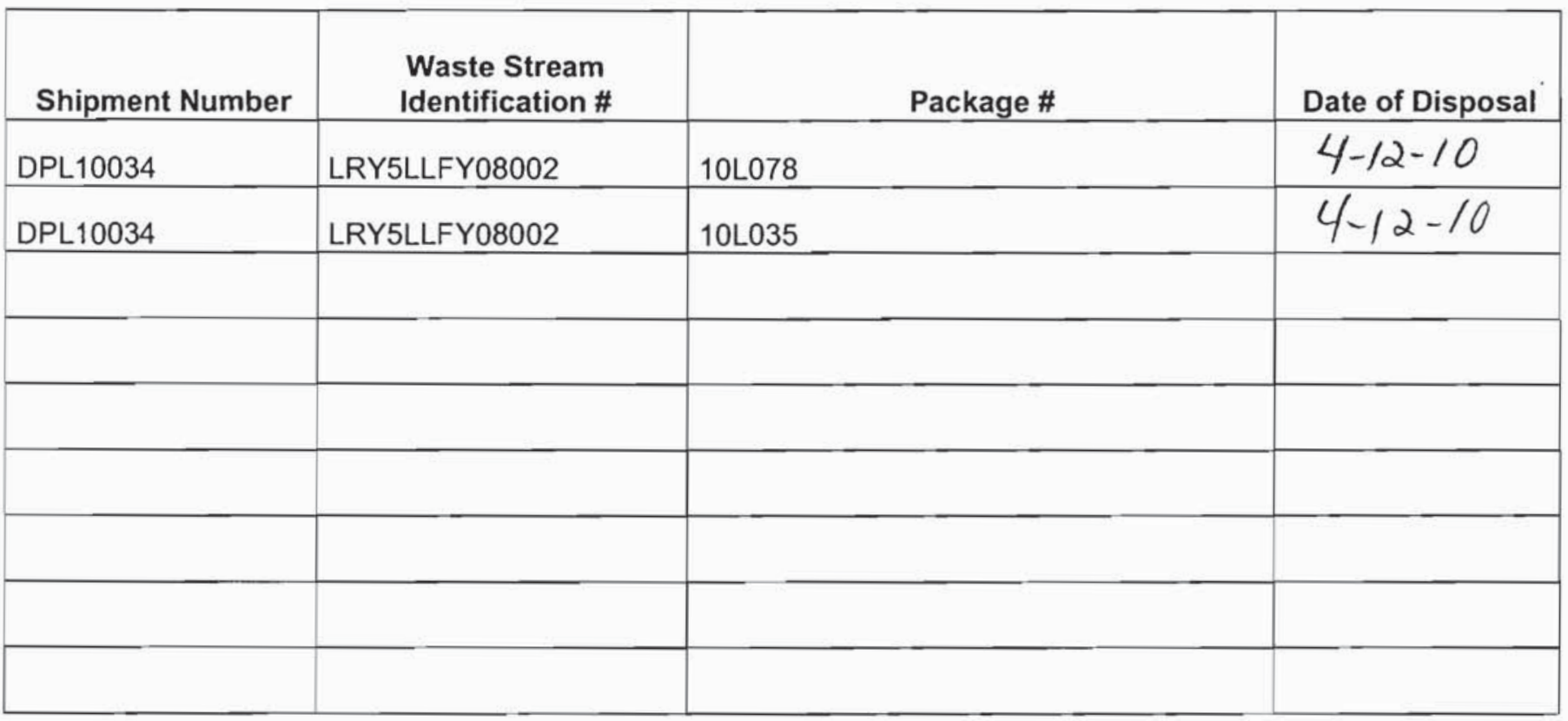

This certification is provided as a courtesy to the waste generator for information purposes only.

/s/: Theresa Hale

WGS Signature

Waste Inspector

Title

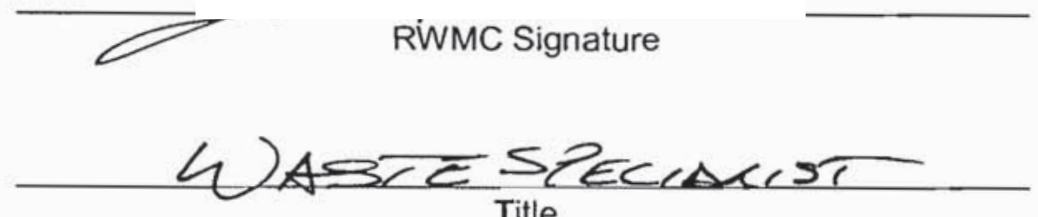

$\frac{4-12-10}{\text { Date }}$

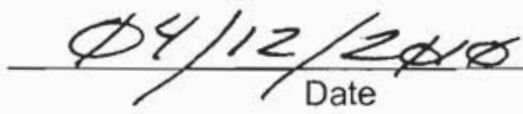




\begin{tabular}{|lcr|}
\hline NSTec & CERTIFICATE OF DISPOSAL & 03/01/10 \\
Form & Rev. 01 \\
FRM-2217 & (LOW LEVEL WASTE) & Page 1 of 1 \\
\hline
\end{tabular}

Nevada Test Site

This Certificate acknowledges that the following shipments) of waste have been disposed at the Nevada Test Site Radioactive Waste Management Complex.

\begin{tabular}{|l|l|l|l|}
\hline \multicolumn{1}{|c|}{ Shipment Number } & \multicolumn{1}{|c|}{$\begin{array}{c}\text { Waste Stream } \\
\text { Identification \# }\end{array}$} & \multicolumn{1}{c|}{ Package \# } & Date of Disposal \\
\hline DPL10035 & LRY5LLFY08002 & 10 L079 & $4-12-10$ \\
\hline DPL10035 & LRY5LLFY08002 & 10 L036 & $4-12-10$ \\
\hline & & & \\
\hline & & & \\
\hline & & & \\
\hline & & & \\
\hline & & & \\
\hline
\end{tabular}

This certification is provided as a courtesy to the waste generator for information purposes only.

/s/ :Theresa Hale

$\frac{4-12 \cdot 10}{\text { Date }}$

Waste Inspector

Title

/s/ :Jon Tanka

RWMC Signature

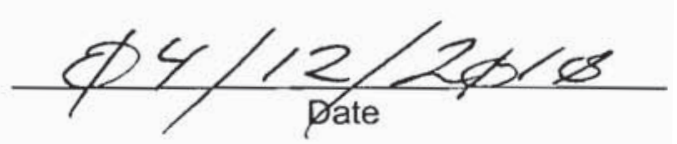

W LATE SPECIALIST

(Reference: OP-2151.304) 


\begin{tabular}{|lcr|}
\hline NSTec & CERTIFICATE OF DISPOSAL & $03 / 01 / 10$ \\
Form & Rev. 01 \\
FRM-2217 & (LOW LEVEL WASTE) & Page 1 of 1 \\
\hline
\end{tabular}

Nevada Test Site

This Certificate acknowledges that the following shipments) of waste have been disposed at the Nevada Test Site Radioactive Waste Management Complex.

\begin{tabular}{|l|l|l|l|}
\hline \multicolumn{1}{|c|}{ Shipment Number } & \multicolumn{1}{c|}{$\begin{array}{c}\text { Waste Stream } \\
\text { Identification \# }\end{array}$} & \multicolumn{1}{c|}{ Package \# } & \multicolumn{1}{c|}{ Date of Disposal } \\
\hline DPL10036 & LRY5LLFY08002 & 10 L080 & $4-12-10$ \\
\hline DPL10036 & LRY5LLFY08002 & 10 L037 & $4-12-10$ \\
\hline & & & \\
\hline & & & \\
\hline & & & \\
\hline & & & \\
\hline & & & \\
\hline
\end{tabular}

This certification is provided as a courtesy to the waste generator for information purposes only.

/s/ :Theresa Hale

WGS Signature

Waste Inspector

Title

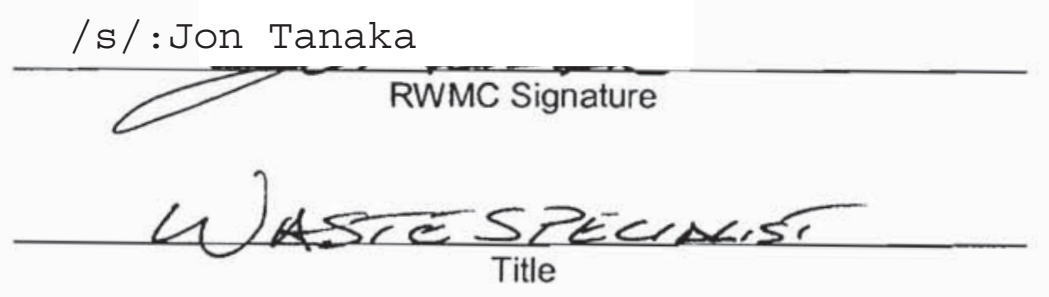

$$
\frac{4-12-10}{\text { Date }}
$$

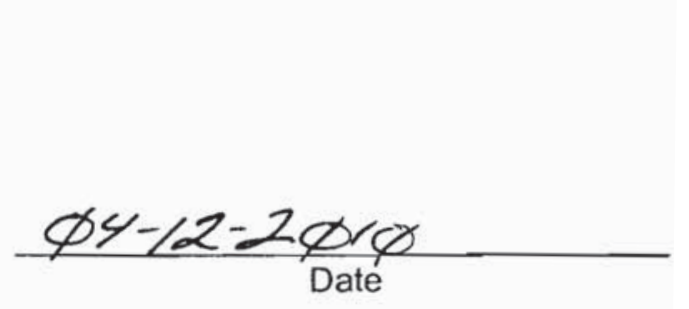

(Reference: OP-2151.304) 


\section{Nevada Test Site}

This Certificate acknowledges that the following shipment(s) of waste have been disposed at the Nevada Test Site Radioactive Waste Management Complex.

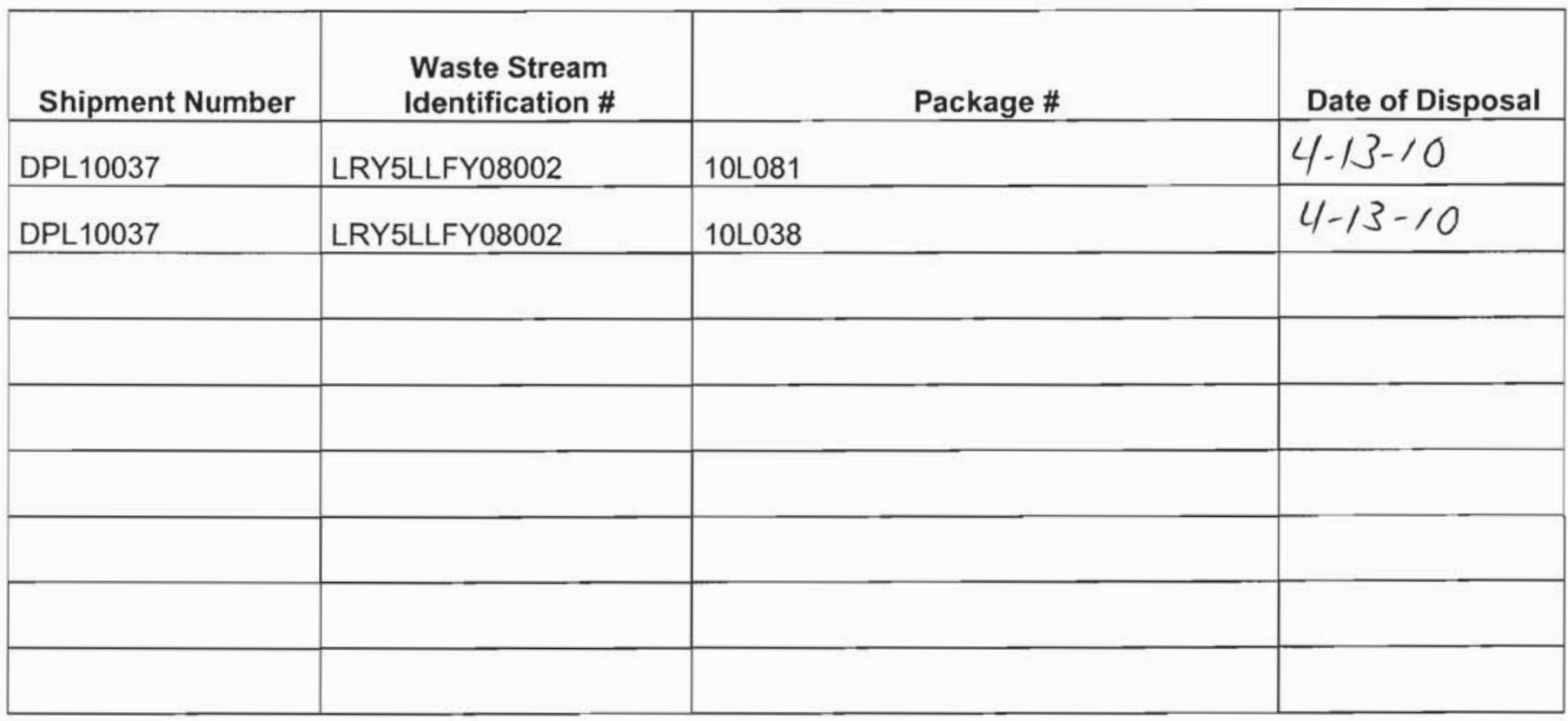

This certification is provided as a courtesy to the waste generator for information purposes only.

/s/:Theresa Hale
WGS Signature
$\frac{\text { Waste Inspector }}{\text { Title }}$
/s/: Jon Tanaka RWMC Signature
RASTE SPECACS$$
4-13-10
$$

Date

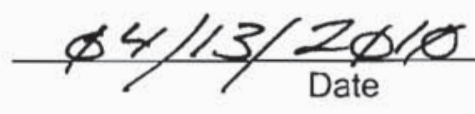




\begin{tabular}{|lcr|}
\hline NSTec & CERTIFICATE OF DISPOSAL & $03 / 01 / 10$ \\
Form & (LOW LEVEL WASTE) & Rev. 01 \\
FRM-2217 & Page 1 of 1 \\
\hline
\end{tabular}

Nevada Test Site

This Certificate acknowledges that the following shipments) of waste have been disposed at the Nevada Test Site Radioactive Waste Management Complex.

\begin{tabular}{|l|l|l|l|}
\hline \multicolumn{1}{|c|}{ Shipment Number } & \multicolumn{1}{|c|}{$\begin{array}{c}\text { Waste Stream } \\
\text { Identification \# }\end{array}$} & Package \# & Date of Disposal \\
\hline DPL10038 & LRY5LLFY08002 & 10 L082 & $4-13-10$ \\
\hline DPL10038 & LRY5LLFY08002 & 10 L039 & $4-13-10$ \\
\hline & & & \\
\hline & & & \\
\hline & & & \\
\hline & & & \\
\hline & & & \\
\hline
\end{tabular}

This certification is provided as a courtesy to the waste generator for information purposes only.

/s/: Theresa Hale

WGS Signature

Waste Inspector

Title

/s/ :Jon Tanka

RWMic Signature

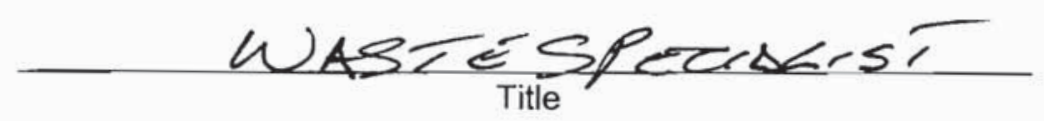

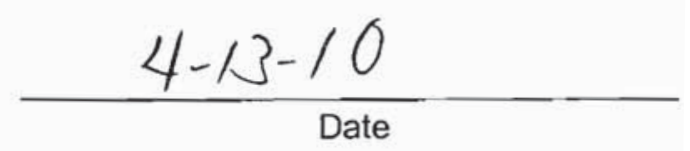

Date

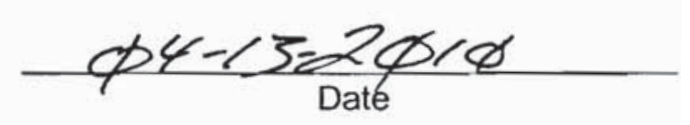

(Reference: OP-2151.304) 


\section{Nevada Test Site}

This Certificate acknowledges that the following shipment(s) of waste have been disposed at the Nevada Test Site Radioactive Waste Management Complex.

\begin{tabular}{|l|l|l|c|}
\hline \multicolumn{1}{|c|}{$\begin{array}{c}\text { Waste Stream } \\
\text { Identification \# }\end{array}$} & Package \# & Date of Disposal \\
\hline DPL10039 & LRY5LLFY08002 & 10 L083 & $4-13-10$ \\
\hline DPL10039 & LRY5LLFY08002 & 10 040 & $4-13-/ 0$ \\
\hline & & & \\
\hline & & & \\
\hline & & & \\
\hline & & & \\
\hline
\end{tabular}

This certification is provided as a courtesy to the waste generator for information purposes only.

\section{/s/:Theresa Hale}

WGS Signature

Waste Inspector

Title

/s/:Jon Tanaka

RWMC Signature

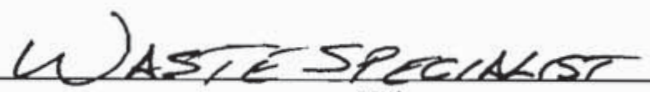

$4-13-10$

Date

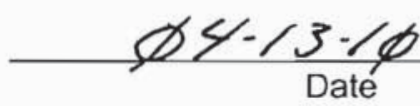




\section{Nevada Test Site}

This Certificate acknowledges that the following shipment(s) of waste have been disposed at the Nevada Test Site Radioactive Waste Management Complex.

\begin{tabular}{|l|l|l|c|}
\hline Shipment Number & \multicolumn{1}{|c|}{$\begin{array}{c}\text { Waste Stream } \\
\text { Identification \# }\end{array}$} & Package \# & Date of Disposal \\
\hline DPL10040 & LRY5LLFY08002 & 10 084 & $4-13-10$ \\
\hline DPL10040 & LRY5LLFY08002 & 10 041 & $4-13-10$ \\
\hline & & & \\
\hline & & & \\
\hline & & & \\
\hline & & & \\
\hline & & & \\
\hline
\end{tabular}

This certification is provided as a courtesy to the waste generator for information purposes only.

/s/eTheresa Hale

WGS Signature

Waste Inspector

Title

/s/:Jon Tanaka

RWḾC Signature

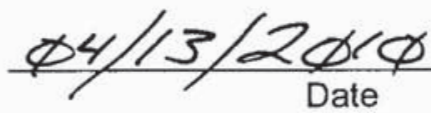

4) ABTE SPECWNST

Title 
NSTec

Form

CERTIFICATE OF DISPOSAL

03/01/10

FRM-2217

(LOW LEVEL. WASTE)

Rev. 01

Page 1 of 1

\section{Nevada Test Site}

This Certificate acknowledges that the following shipment(s) of waste have been disposed at the Nevada Test Site Radioactive Waste Management Complex.

\begin{tabular}{|l|l|l|l|}
\hline \multicolumn{1}{|c|}{$\begin{array}{c}\text { Waste Stream } \\
\text { Identification \# }\end{array}$} & Package \# & Date of Disposal \\
\hline DPL10041 & LRY5LLFY08002 & 10 L085 & $4-13-10$ \\
\hline DPL10041 & LRY5LLFY08002 & 10 L042 & $4-13-10$ \\
\hline & & & \\
\hline & & & \\
\hline & & & \\
\hline & & & \\
\hline & & & \\
\hline
\end{tabular}

This certification is provided as a courtesy to the waste generator for information purposes only.

/s/: Theresa Hale

$$
\text { WGS Signature }
$$

Waste Inspector

Title

/s/:Jon Tanaka

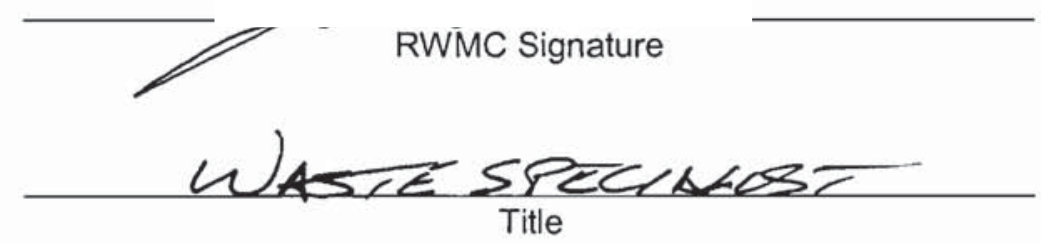

$$
\frac{4-13-10}{\text { Date }}
$$

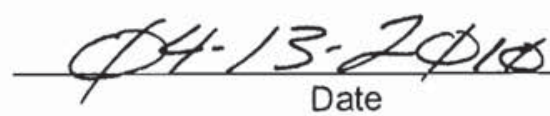


NSTec

Form

FRM-2217
CERTIFICATE OF DISPOSAL

(LOW LEVEL WASTE)
$03 / 01 / 10$

Rev. 01

Page 1 of 1

\section{Nevada Test Site}

This Certificate acknowledges that the following shipment(s) of waste have been disposed at the Nevada Test Site Radioactive Waste Management Complex.

\begin{tabular}{|l|l|l|c|}
\hline \multicolumn{1}{|c|}{ Shipment Number } & \multicolumn{1}{|c|}{$\begin{array}{c}\text { Waste Stream } \\
\text { Identification \# }\end{array}$} & \multicolumn{1}{c|}{ Package \# } & Date of Disposal \\
\hline DPL10042 & LRY5LLFY08002 & 10 0886 & $4-13-10$ \\
\hline DPL10042 & LRY5LLFY08002 & 10 L043 & $4-13-10$ \\
\hline & & & \\
\hline & & & \\
\hline & & & \\
\hline & & & \\
\hline & & & \\
\hline & & & \\
\hline
\end{tabular}

This certification is provided as a courtesy to the waste generator for information purposes only.

/s/: Theresa Hale

$$
\text { WGS Signature }
$$

Waste Inspector

Title

/s/: Jon Tanaka

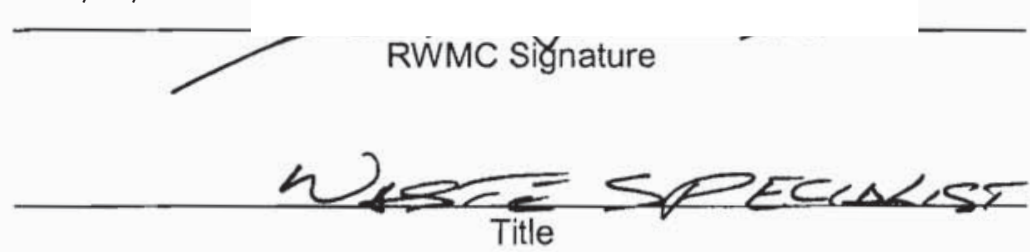

$\frac{4-13-10}{\text { Date }}$

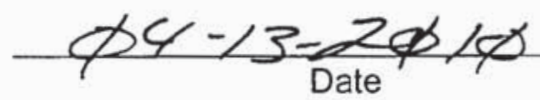


NSTec

Form

FRM-2217
CERTIFICATE OF DISPOSAL

(LOW LEVEL WASTE)
03/01/10

Rev. 01

Page 1 of 1

\section{Nevada Test Site}

This Certificate acknowledges that the following shipment(s) of waste have been disposed at the Nevada Test Site Radioactive Waste Management Complex.

\begin{tabular}{|l|l|l|l|}
\hline \multicolumn{1}{|c|}{$\begin{array}{c}\text { Waste Stream } \\
\text { Identification \# }\end{array}$} & Package \# & Date of Disposal \\
\hline DPL10043 & LRY5LLFY08002 & 10 L087 & $4-13-10$ \\
\hline DPL10043 & LRY5LLFY08002 & 10 L044 & $4-13-10$ \\
\hline & & & \\
\hline & & & \\
\hline & & & \\
\hline & & & \\
\hline
\end{tabular}

This certification is provided as a courtesy to the waste generator for information purposes only.

$\frac{\text { /s': Theresa Hale }}{\text { WGS Signature }}$

Waste Inspector

$$
\text { Title }
$$

/s/:Jon Tanaka

RWMC Signature

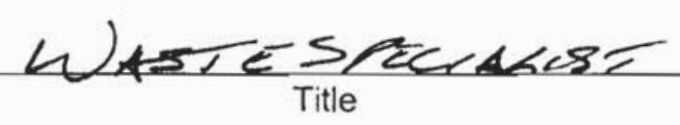

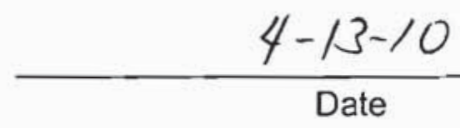

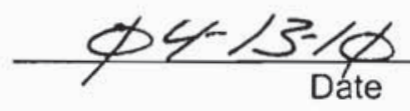


NSTec

Form

FRM-2217
CERTIFICATE OF DISPOSAL

(LOW LEVEL WASTE)
$03 / 01 / 10$

Rev. 01

Page 1 of 1

\section{Nevada Test Site}

This Certificate acknowledges that the following shipment(s) of waste have been disposed at the Nevada Test Site Radioactive Waste Management Complex.

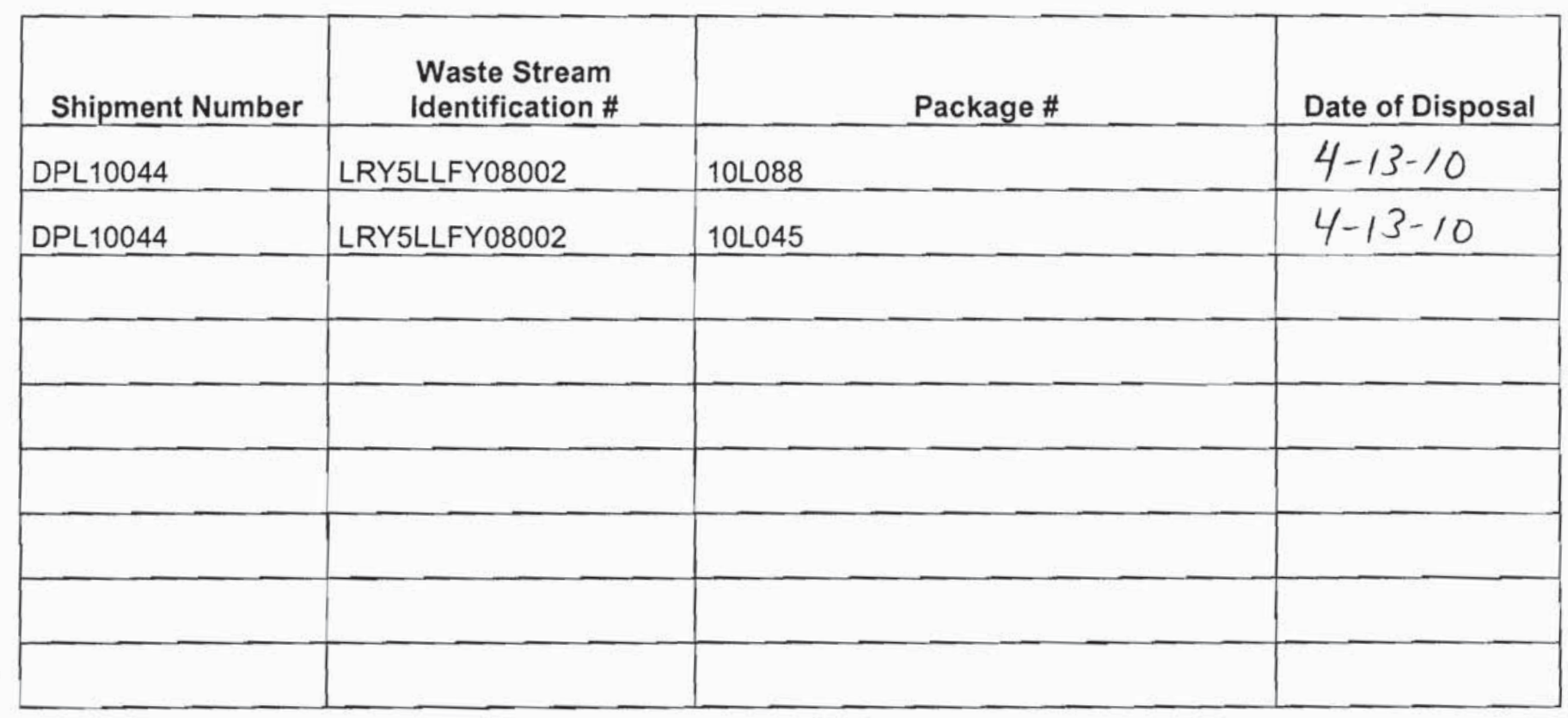

This certification is provided as a courtesy to the waste generator for information purposes only.
/s/: Theresa Hale
WGS Signature
$\frac{4-13-10}{\text { Date }}$
Waste Inspector
/s/:Jon Tanaka
RWMC Signāture

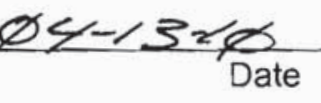


NSTec

Form

FRM-2217
CERTIFICATE OF DISPOSAL

(LOW LEVEL WASTE)
03/01/10

Rev. 01

Page 1 of 1

\section{Nevada Test Site}

This Certificate acknowledges that the following shipment(s) of waste have been disposed at the Nevada Test Site Radioactive Waste Management Complex.

\begin{tabular}{|l|l|l|l|}
\hline Shipment Number & \multicolumn{1}{|c|}{$\begin{array}{c}\text { Waste Stream } \\
\text { Identification \# }\end{array}$} & Package \# & Date of Disposal \\
\hline DPL10045 & LRY5LLFY08002 & 10 L089 & $4-13-10$ \\
\hline DPL10045 & LRY5LLFY08002 & 10 L046 & $4-13-10$ \\
\hline & & & \\
\hline & & & \\
\hline & & & \\
\hline & & & \\
\hline & & & \\
\hline
\end{tabular}

This certification is provided as a courtesy to the waste generator for information purposes only.

$\frac{\text { /s/:Theresa Hale }}{\text { WGS Signature }}$

Waste Inspector

Title

/s/: Jon Tanaka

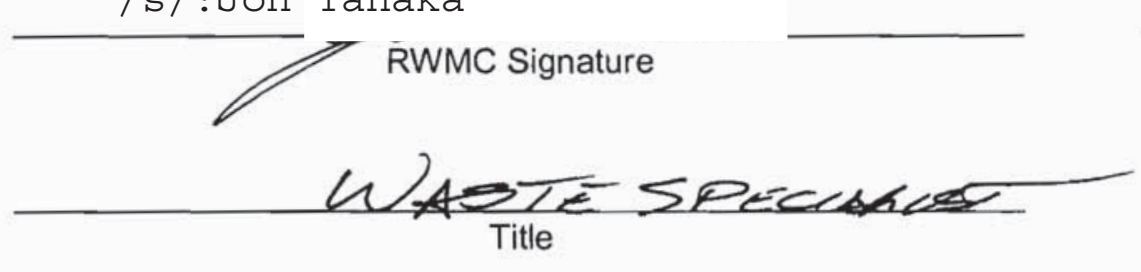

$4-13 \cdot 10$

Date

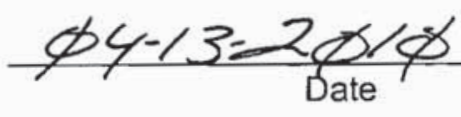


NSTec

Form

CERTIFICATE OF DISPOSAL

03/01/10

FRM-2217

(LOW LEVEL WASTE)

Rev. 01

Page 1 of 1

\section{Nevada Test Site}

This Certificate acknowledges that the following shipment(s) of waste have been disposed at the Nevada Test Site Radioactive Waste Management Complex.

\begin{tabular}{|l|l|l|l|}
\hline \multicolumn{1}{|c|}{ Shipment Number } & \multicolumn{1}{|c|}{$\begin{array}{c}\text { Waste Stream } \\
\text { Identification \# }\end{array}$} & Package \# & Date of Disposal \\
\hline DPL10054 & LRY5LLFY08002 & 10 L101 & $4-/ 4-/ 0$ \\
\hline DPL10054 & LRY5LLFY08002 & 10 L102 & $4-/ 4-/ 0$ \\
\hline & & & \\
\hline & & & \\
\hline & & & \\
\hline & & & \\
\hline & & & \\
\hline
\end{tabular}

This certification is provided as a courtesy to the waste generator for information purposes only.

/s/: Theresa Hale

WGS Signature

Waste Inspector

Title

/s/:Jon Tanaka

RWMC Signature

LASTESFEC $\triangle A K S$

Title
$4-14-10$

Date

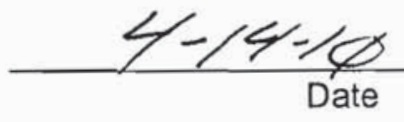


NSTec

Form

CERTIFICATE OF DISPOSAL

$03 / 01 / 10$

FRM-2217

(LOW LEVEL WASTE)

Rev. 01

Page 1 of 1

\section{Nevada Test Site}

This Certificate acknowledges that the following shipment(s) of waste have been disposed at the Nevada Test Site Radioactive Waste Management Complex.

\begin{tabular}{|l|l|l|c|}
\hline \multicolumn{1}{|c|}{$\begin{array}{c}\text { Whipment Number } \\
\text { Identification \# }\end{array}$} & \multicolumn{1}{|c|}{ Package \# } & Date of Disposal \\
\hline DPL10055 & LRY5LLFY08002 & 10 L103 & $4-14-10$ \\
\hline DPL10055 & LRY5LLFY08002 & 10 L104 & $4-14-10$ \\
\hline & & & \\
\hline & & & \\
\hline & & & \\
\hline & & & \\
\hline & & & \\
\hline & & & \\
\hline
\end{tabular}

This certification is provided as a courtesy to the waste generator for information purposes only.

/s/:Theresa Hale

WGS Signature

Waste Inspector

Title

/s/:Jon Tanaka

RWMC Signature

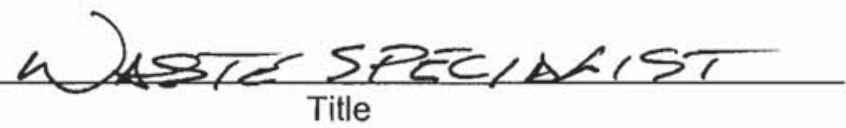

$\frac{4-14-10}{\text { Date }}$

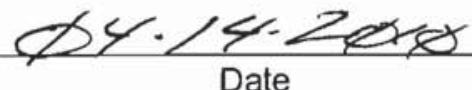




\begin{tabular}{|lcr|}
\hline NSTec & CERTIFICATE OF DISPOSAL & R3/01/10 \\
Form & Rev. 01 \\
FRM-2217 & (LOW LEVEL WASTE) & Page 1 of 1 \\
\hline
\end{tabular}

Nevada Test Site

This Certificate acknowledges that the following shipments) of waste have been disposed at the Nevada Test Site Radioactive Waste Management Complex.

\begin{tabular}{|l|l|l|l|}
\hline \multicolumn{1}{|c|}{ Shipment Number } & \multicolumn{1}{|c|}{$\begin{array}{c}\text { Waste Stream } \\
\text { Identification \# }\end{array}$} & Package \# & Date of Disposal \\
\hline DPL10056 & LRY5LLFY08002 & 10 105 & $4-14-10$ \\
\hline DPL10056 & LRY5LLFY8002 & 10 106 & $4-14-10$ \\
\hline & & & \\
\hline & & & \\
\hline & & & \\
\hline & & & \\
\hline & & & \\
\hline & & & \\
\hline
\end{tabular}

This certification is provided as a courtesy to the waste generator for information purposes only.

/s/ :Theresa Hale

WGS Signature

Waste Inspector

Title
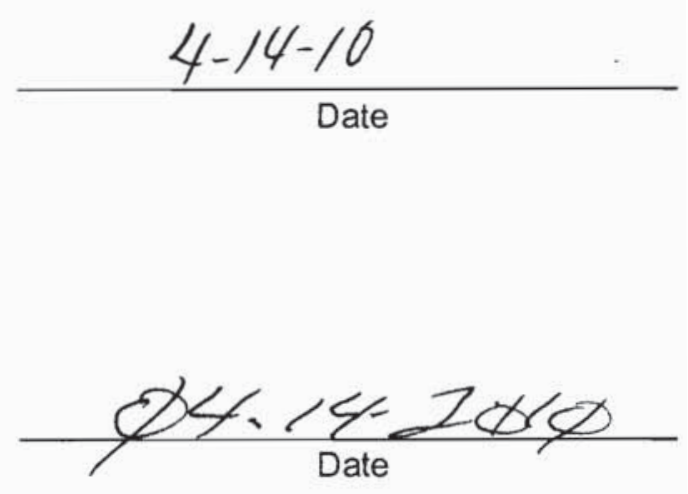

(Reference: OP-2151.304) 


\begin{tabular}{|lcr|}
\hline NSTec & 03/01/10 \\
Form & CERTIFICATE OF DISPOSAL & Rev. 01 \\
FRM-2217 & (LOW LEVEL WASTE) & Page 1 of 1 \\
\hline
\end{tabular}

Nevada Test Site

This Certificate acknowledges that the following shipments) of waste have been disposed at the Nevada Test Site Radioactive Waste Management Complex.

\begin{tabular}{|l|l|l|l|}
\hline \multicolumn{1}{|c|}{$\begin{array}{c}\text { Shipment Number } \\
\text { Identification \# }\end{array}$} & \multicolumn{1}{|c|}{ Package \# } & Date of Disposal \\
\hline DPL10057 & LRY5LLFY08002 & 10 L107 & $4-14-10$ \\
\hline DPL10057 & LRY5LLF08002 & 10 L108 & $4-14-10$ \\
\hline & & & \\
\hline & & & \\
\hline & & & \\
\hline & & & \\
\hline & & & \\
\hline & & & \\
\hline
\end{tabular}

This certification is provided as a courtesy to the waste generator for information purposes only.

/s/: Theresa Hale

WGS Signature

Waste Inspector

Title
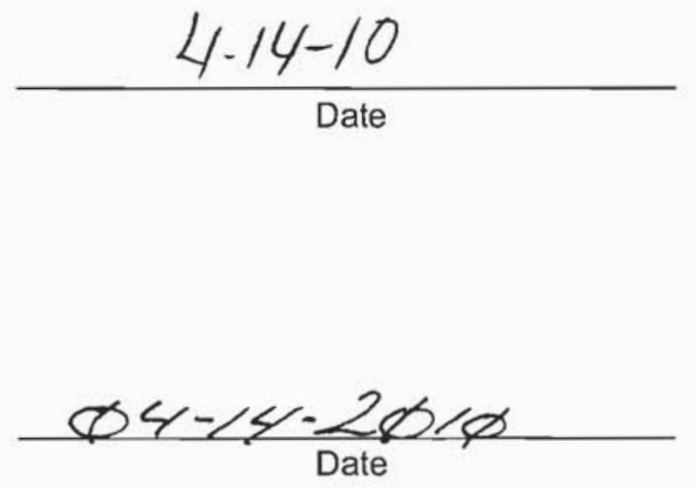

RWMC Signature

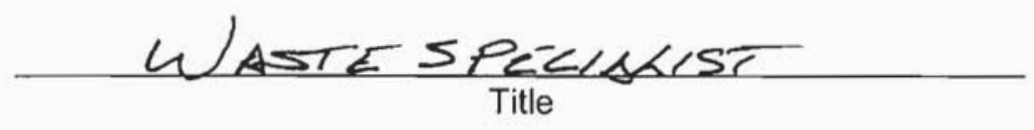

(Reference: OP-2151.304) 
NSTec

Form

CERTIFICATE OF DISPOSAL

$03 / 01 / 10$

FRM-2217

(LOW LEVEL WASTE)

Rev. 01

Page 1 of 1

\section{Nevada Test Site}

This Certificate acknowledges that the following shipment(s) of waste have been disposed at the Nevada Test Site Radioactive Waste Management Complex.

\begin{tabular}{|l|l|l|l|}
\hline Shipment Number & \multicolumn{1}{|c|}{$\begin{array}{c}\text { Waste Stream } \\
\text { Identification \# }\end{array}$} & \multicolumn{1}{|c|}{ Package \# } & Date of Disposal \\
\hline DPL10058 & LRY5LLFY08002 & 10 109 & $4-14-10$ \\
\hline DPL10058 & LRY5LLFY08002 & 10 L110 & $4-14-10$ \\
\hline & & & \\
\hline & & & \\
\hline & & & \\
\hline & & & \\
\hline & & & \\
\hline & & & \\
\hline
\end{tabular}

This certification is provided as a courtesy to the waste generator for information purposes only.

\begin{tabular}{l} 
/s/: Theresa Hale \\
WGS Signature \\
Waste Inspector \\
Title \\
/s/:Jon Tanaka \\
\hline RWMC Signature \\
W ASTE SPEC/SLIS
\end{tabular}

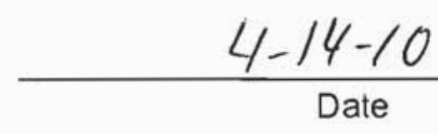


NSTec

Form

FRM-2217
CERTIFICATE OF DISPOSAL

(LOW LEVEL WASTE)
03/01/10

Rev. 01

Page 1 of 1

\section{Nevada Test Site}

This Certificate acknowledges that the following shipment(s) of waste have been disposed at the Nevada Test Site Radioactive Waste Management Complex.

\begin{tabular}{|l|l|l|c|}
\hline Shipment Number & \multicolumn{1}{|c|}{$\begin{array}{c}\text { Waste Stream } \\
\text { Identification \# }\end{array}$} & Package \# & Date of Disposal \\
\hline DPL10059 & LRY5LLFY08002 & 10 L111 & $4-14-10$ \\
\hline DPL10059 & LRY5LLFY08002 & 10 112 & $4-14-10$ \\
\hline & & & \\
\hline & & & \\
\hline & & & \\
\hline & & & \\
\hline & & & \\
\hline
\end{tabular}

This certification is provided as a courtesy to the waste generator for information purposes only.

/s/: Theresa Hale

$$
\text { WGS Signature }
$$

Waste Inspector

Title

/s/:Jon Tanaka

RWMC̄ Signature

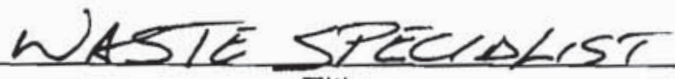

$4-14-10$

Date

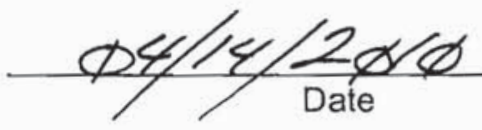


NSTec

Form

FRM-2217
CERTIFICATE OF DISPOSAL

(LOW LEVEL WASTE)
03/01/10

Rev. 01

Page 1 of 1

\section{Nevada Test Site}

This Certificate acknowledges that the following shipment(s) of waste have been disposed at the Nevada Test Site Radioactive Waste Management Complex.

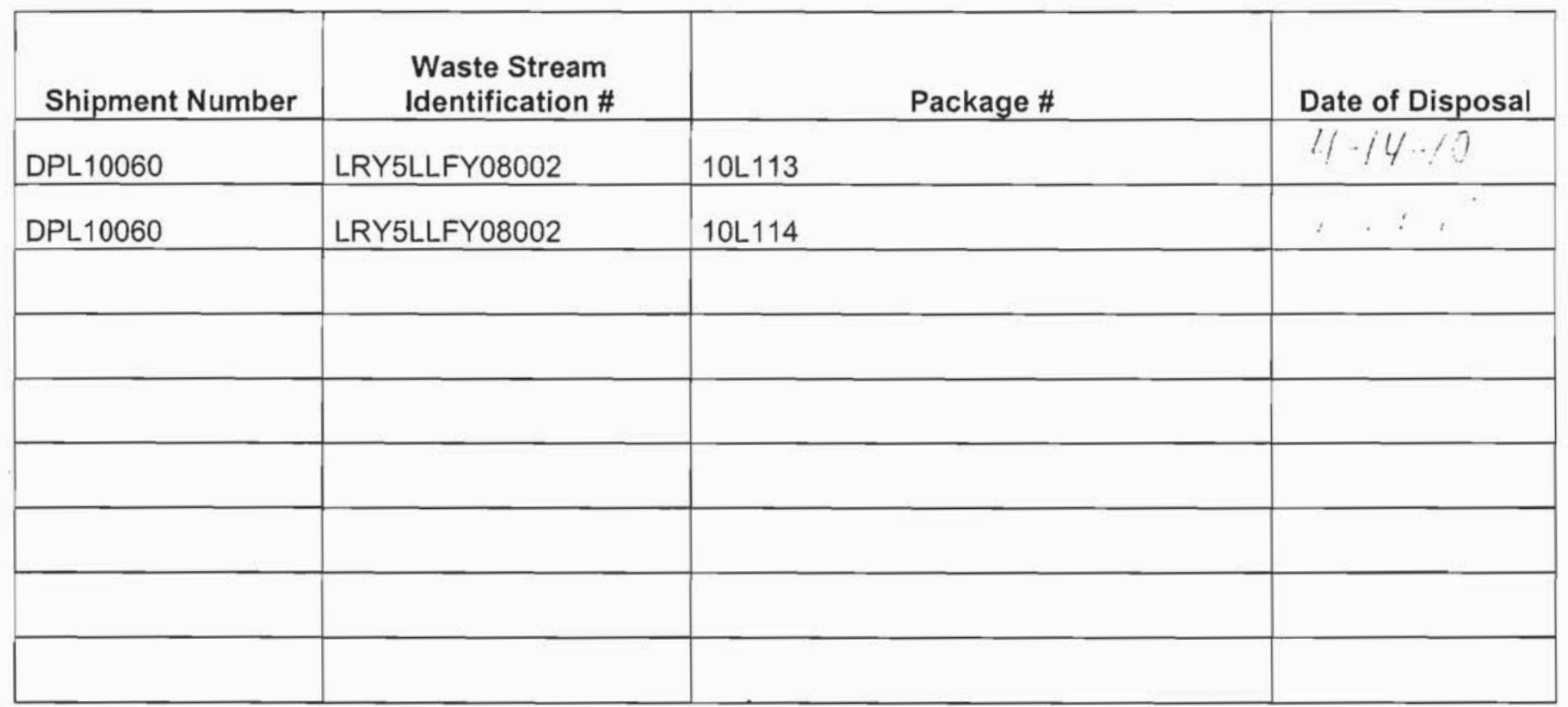

This certification is provided as a courtesy to the waste generator for information purposes only.

/s/: Theresa Hale

WGS Signature

Waste inspector

Title

/s/:Jon Tanaka

RWMC Signature

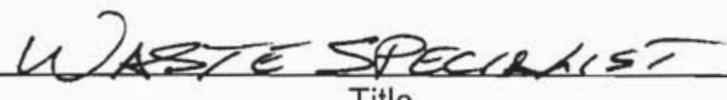

$\frac{4 \cdot 14-10}{\text { Date }}$

$\phi 4-14-2 \phi 1 \phi$

Date 
NSTec

Form

CERTIFICATE OF DISPOSAL

03/01/10

FRM-2217

(LOW LEVEL WASTE)

Rev. 01

Page 1 of 1

\section{Nevada Test Site}

This Certificate acknowledges that the following shipment(s) of waste have been disposed at the Nevada Test Site Radioactive Waste Management Complex.

\begin{tabular}{|l|l|l|l|}
\hline \multicolumn{1}{|c|}{$\begin{array}{c}\text { Waste Stream } \\
\text { Identification \# }\end{array}$} & Package \# & Date of Disposal \\
\hline DPL10061 & LRY5LLFY08002 & 10 L115 & $4 \% / 1 / \%$ \\
\hline DPL10061 & LRY5LLFY08002 & 10 L116 & \\
\hline & & & \\
\hline & & & \\
\hline & & & \\
\hline & & & \\
\hline
\end{tabular}

This certification is provided as a courtesy to the waste generator for information purposes only.

/s/:Theresa Hale

WGS Signature

Waste Inspector

Title

/s/: Jon Tanaka

RWMC Signature

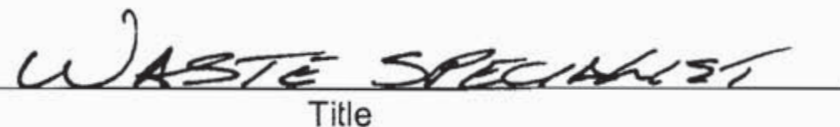

$4-14-10$

Date

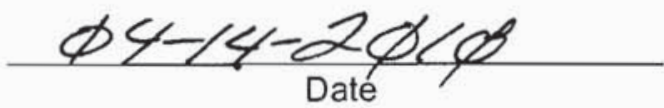


NSTec

Form

CERTIFICATE OF DISPOSAL

FRM-2217

(LOW LEVEL WASTE)

03/01/10

Rev. 01

Page 1 of 1

\section{Nevada Test Site}

This Certificate acknowledges that the following shipment(s) of waste have been disposed at the Nevada Test Site Radioactive Waste Management Complex.

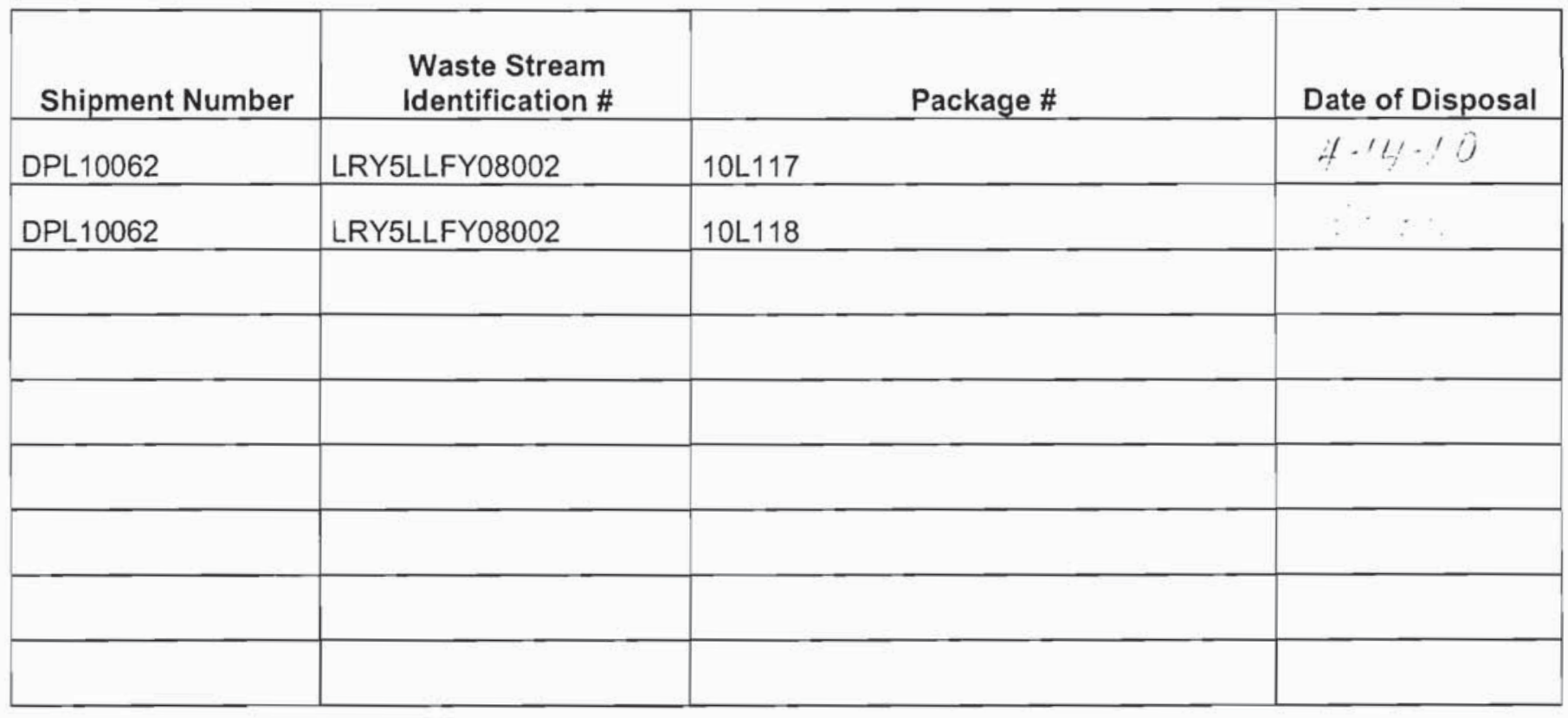

This certification is provided as a courtesy to the waste generator for information purposes only.

/s/:Theresa Hale

WGS Signature

Waste Inspector

Title

/s/: Jon Tanaka

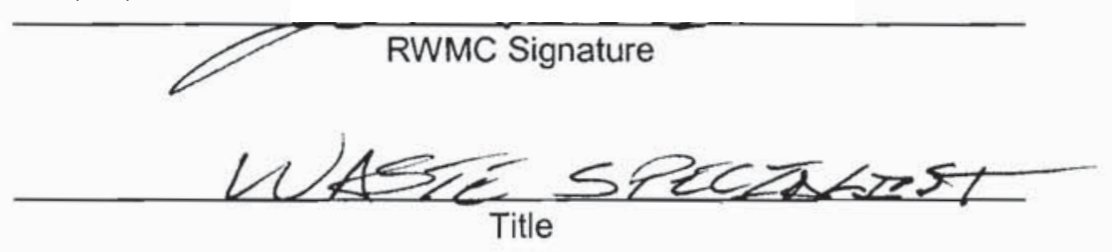

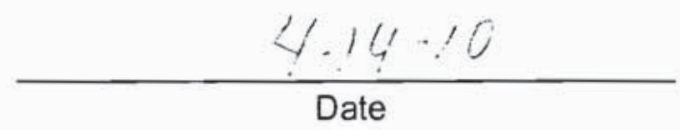

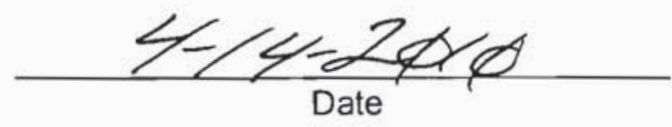


NSTec

Form

FRM-2217
CERTIFICATE OF DISPOSAL

(LOW LEVEL WASTE)
03/01/10

Rev. 01

Page 1 of 1

\section{Nevada Test Site}

This Certificate acknowledges that the following shipment(s) of waste have been disposed at the Nevada Test Site Radioactive Waste Management Complex.

\begin{tabular}{|c|c|c|c|}
\hline Shipment Number & $\begin{array}{l}\text { Waste Stream } \\
\text { Identification \# }\end{array}$ & Package \# & Date of Disposal \\
\hline DPL10063 & LRY5LLFY08002 & 10L119 & $2.14 .1 \%$ \\
\hline DPL10063 & LRY5LLFY08002 & 10L 120 & $\therefore$ \\
\hline & & & \\
\hline & & & \\
\hline & & & \\
\hline & & & \\
\hline & & & \\
\hline & & & \\
\hline
\end{tabular}

This certification is provided as a courtesy to the waste generator for information purposes only.

/s/:Theresa Hale

WGS Signature

Waste Inspector

Title

/s/:Jon Tanaka

RWMC Signature

42 TLESPECALS
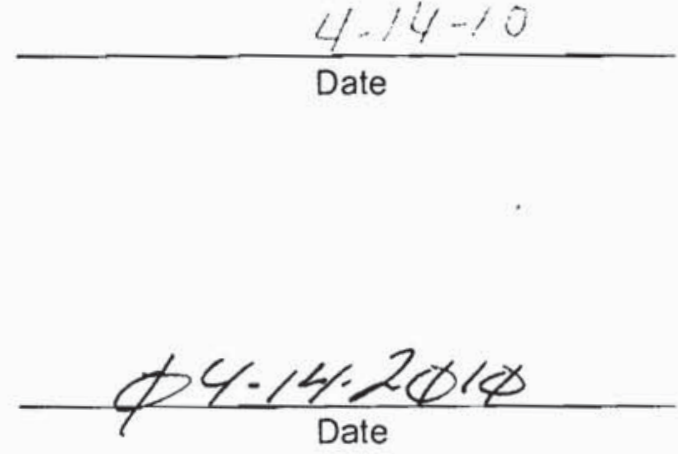


\section{Nevada Test Site}

This Certificate acknowledges that the following shipment(s) of waste have been disposed at the Nevada Test Site Radioactive Waste Management Complex.

\begin{tabular}{|c|c|c|c|}
\hline Shipment Number & $\begin{array}{l}\text { Waste Stream } \\
\text { Identification \# }\end{array}$ & Package \# & Date of Disposal \\
\hline DPL10064 & LRY5LLFY08002 & 10L121 & $4-15 \cdots 0$ \\
\hline DPL10064 & LRY5LLFY08002 & 10L122 & $4-5 \%$ \\
\hline & & & \\
\hline & & & \\
\hline & & & \\
\hline & & & \\
\hline & & & \\
\hline & & & \\
\hline
\end{tabular}

This certification is provided as a courtesy to the waste generator for information purposes only.

/s/: Theresa Hale

WGS Signature

Waste Inspector

$\frac{\text { Waste Inspector }}{\text { Title }}$

/s/:Jon Tanaka

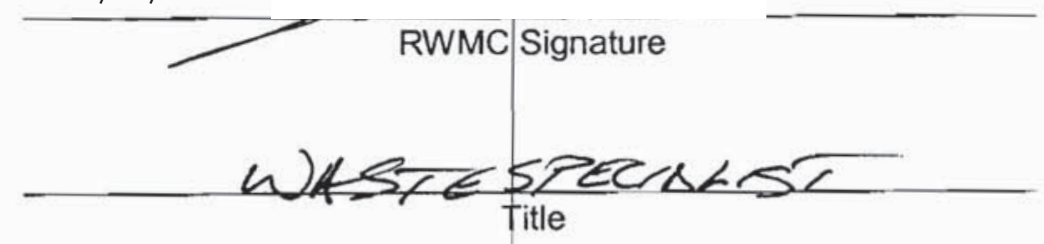

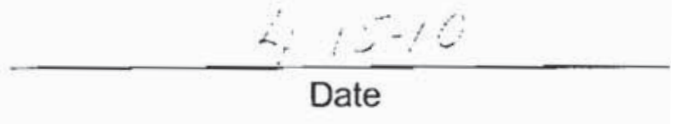

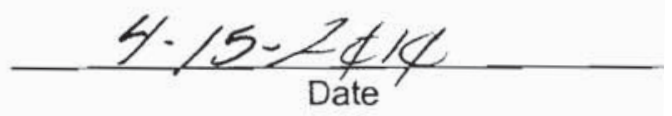




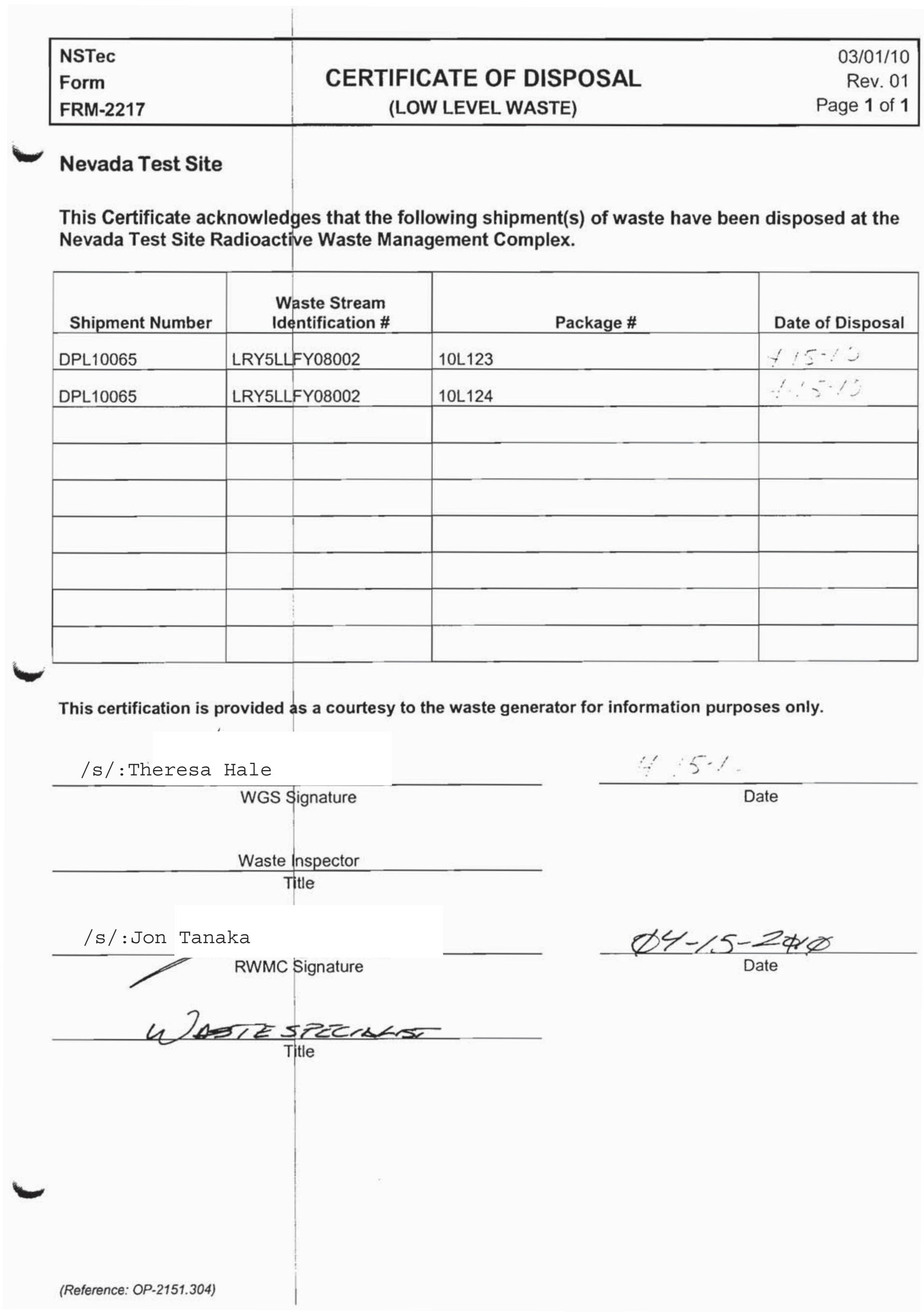


NSTec

Form

CERTIFICATE OF DISPOSAL

03/01/10

FRM-2217

(LOW LEVEL WASTE)

Rev. 01

Page 1 of 1

\section{Nevada Test Site}

This Certificate acknowledges that the following shipment(s) of waste have been disposed at the Nevada Test Site Radioactive Waste Management Complex.

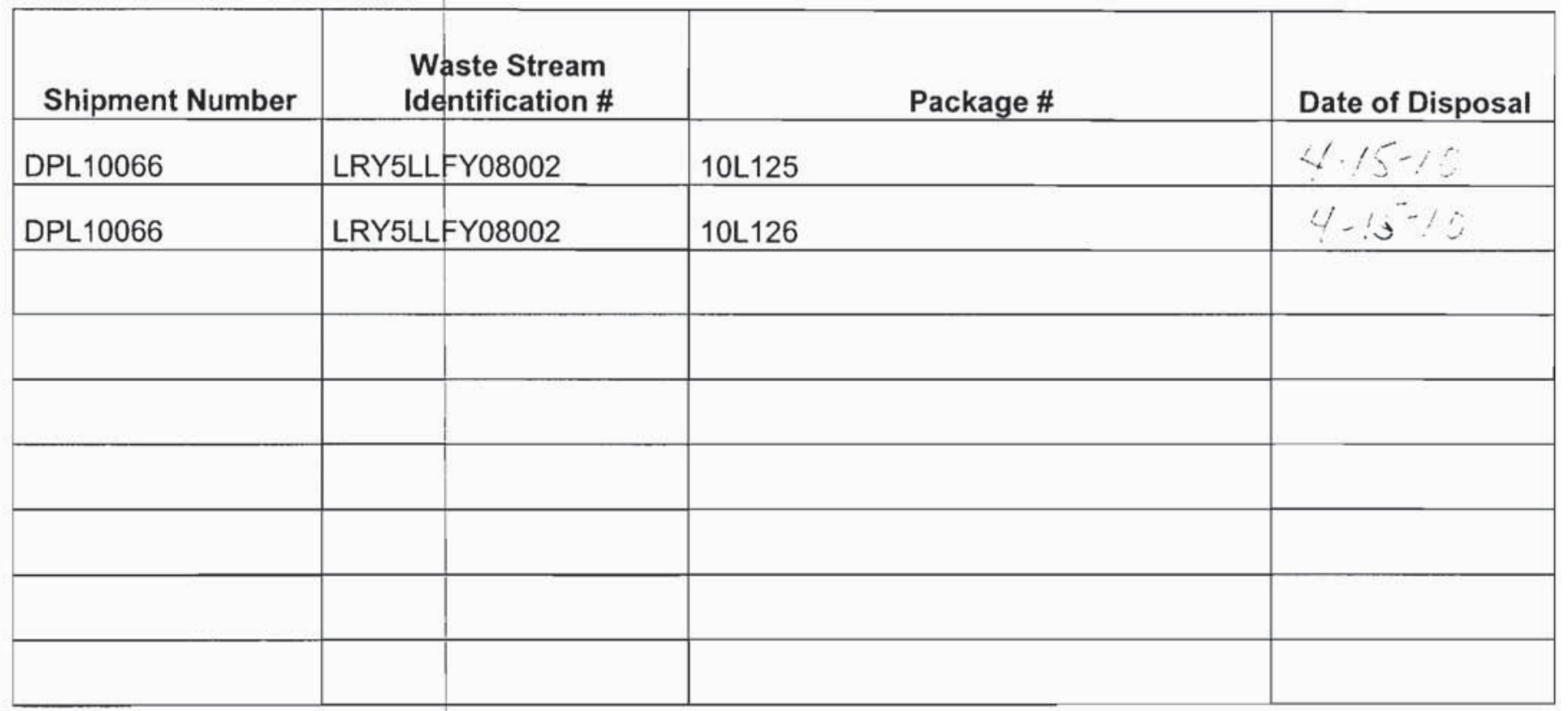

This certification is provided as a courtesy to the waste generator for information purposes only.

/s/:Theresa Hale

WGS Signature

Waste Inspector

\section{Title}

/s/:Jon Tanaka

RWMC Signature

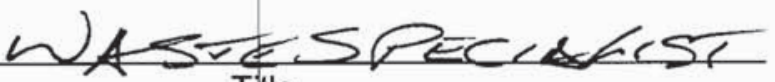

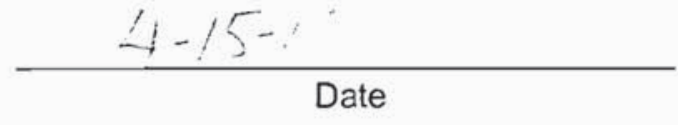

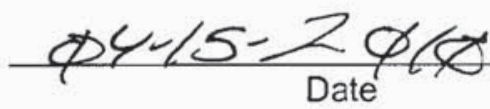


CERTIFICATE OF DISPOSAL

(LOW LEVEL WASTE)
$03 / 01 / 10$

Rev. 01

Page 1 of 1

\section{Nevada Test Site}

This Certificate acknowledges that the following shipment(s) of waste have been disposed at the Nevada Test Site Radioactive Waste Management Complex.

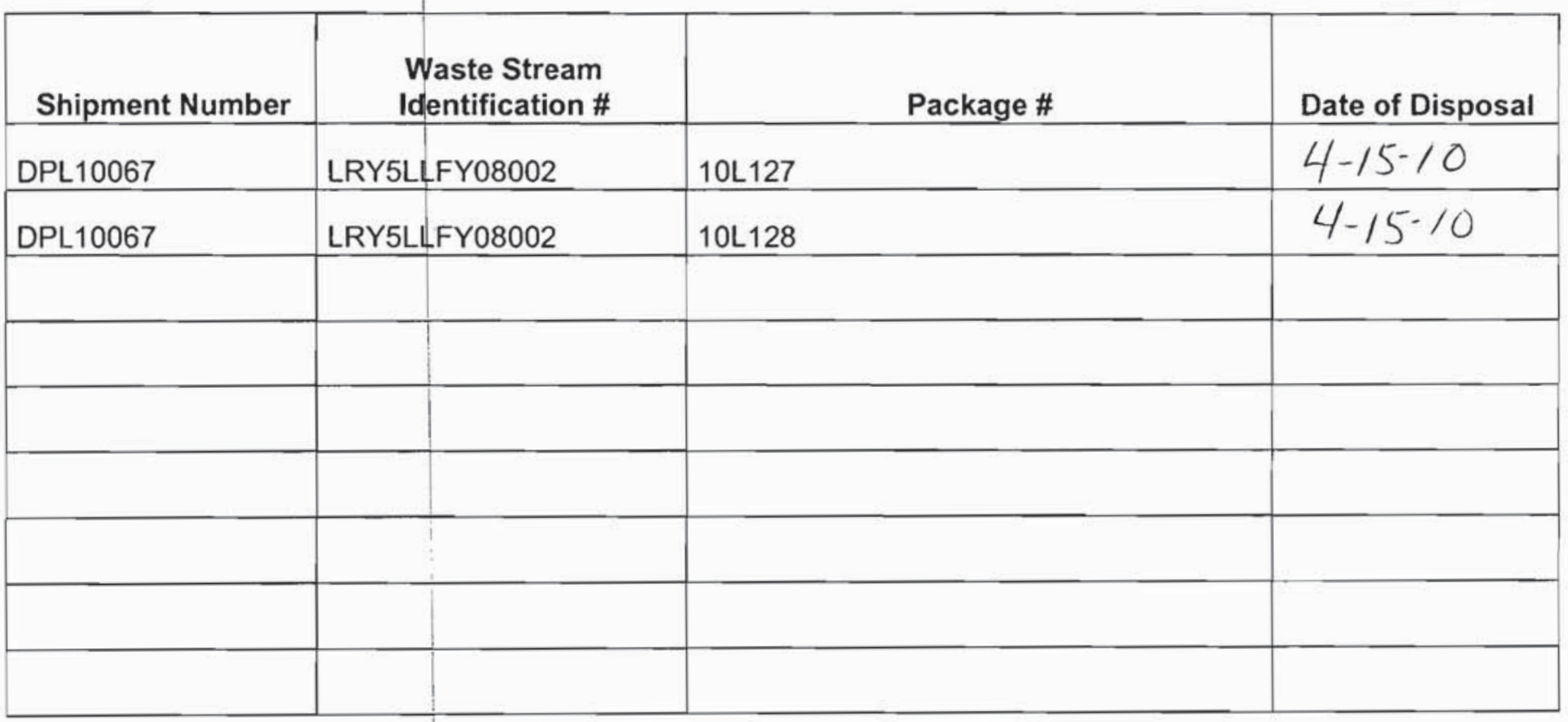

This certification is provided as a courtesy to the waste generator for information purposes only.

/s/: Theresa Hale

WGS Signature

Waste Inspector

Title

/s/:Jon Tanaka
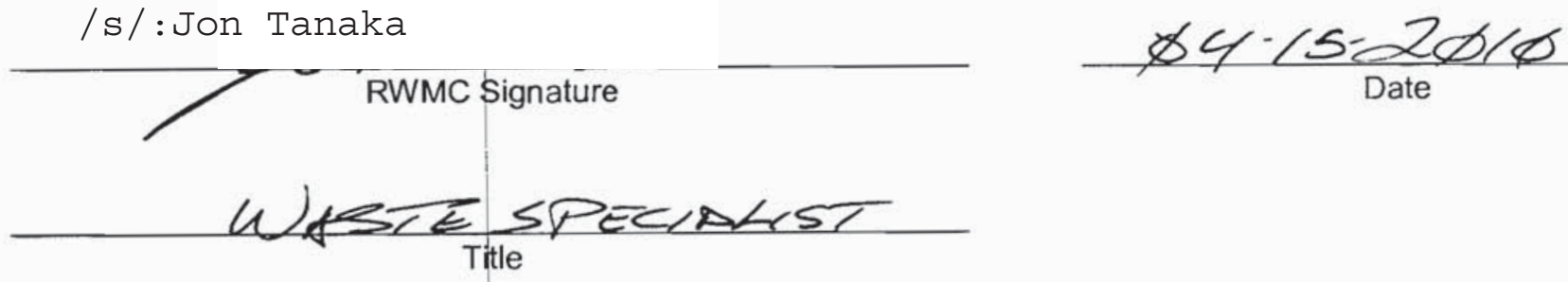
NSTec

Form

CERTIFICATE OF DISPOSAL

03/01/10

FRM-2217

(LOW LEVEL WASTE)

Rev. 01

Page 1 of 1

\section{Nevada Test Site}

This Certificate acknowledges that the following shipment(s) of waste have been disposed at the Nevada Test Site Radioactive Waste Management Complex.

\begin{tabular}{|c|c|c|c|}
\hline Shipment Number & $\begin{array}{l}\text { Waste Stream } \\
\text { Identification \# }\end{array}$ & Package \# & Date of Disposal \\
\hline DPL10068 & LRY5LLFY08002 & 10L129 & $4-15-10$ \\
\hline DPL10068 & LRY5LLFY08002 & 10L130 & $4-15 \cdot 10$ \\
\hline & & & \\
\hline & & & \\
\hline & & & \\
\hline & & & \\
\hline & & & \\
\hline & & 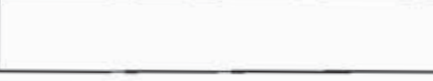 & \\
\hline
\end{tabular}

This certification is provided as a courtesy to the waste generator for information purposes only.

$\frac{\text { Is/: Theresa Hale }}{\text { WGS Signature }}$
$\frac{\text { Waste Inspector }}{\text { Title }}$
$\frac{\text { /s/: Jon Tanaka }}{\text { RWMC Signature }}$


NSTec

Form

FRM-2217
CERTIFICATE OF DISPOSAL

(LOW LEVEL WASTE)
$03 / 01 / 10$

Rev. 01

Page 1 of 1

\section{Nevada Test Site}

This Certificate acknowledges that the following shipment(s) of waste have been disposed at the Nevada Test Site Radioactive Waste Management Complex.

\begin{tabular}{|l|l|l|l|}
\hline Shipment Number & \multicolumn{1}{|c|}{$\begin{array}{c}\text { Waste Stream } \\
\text { Identification \# }\end{array}$} & Package \# & Date of Disposal \\
\hline DPL10069 & LRY5LLFY08002 & 10 L131 & $4-15-10$ \\
\hline DPL10069 & LRY5LLFY08002 & 10 L132 & $4-15-10$ \\
\hline & & & \\
\hline & & & \\
\hline & & & \\
\hline & & & \\
\hline & & & \\
\hline
\end{tabular}

This certification is provided as a courtesy to the waste generator for information purposes only.

/s/:Theresa Hale

WGS Signature

Waste Inspector

Title

/s/:Jon Tanaka

RWMC̄ Signature

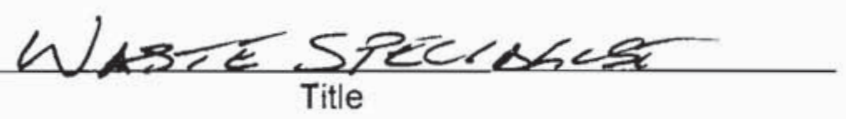

$\frac{4-15-10}{\text { Date }}$

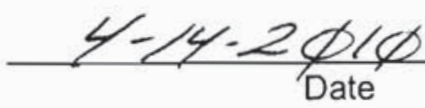


NSTec

Form

CERTIFICATE OF DISPOSAL

03/01/10

FRM-2217

(LOW LEVEL WASTE)

Rev. 01

Page 1 of 1

\section{Nevada Test Site}

This Certificate acknowledges that the following shipment(s) of waste have been disposed at the Nevada Test Site Radioactive Waste Management Complex.

\begin{tabular}{|c|c|c|c|}
\hline Shipment Number & $\begin{array}{l}\text { Waste Stream } \\
\text { Identification \# }\end{array}$ & Package \# & Date of Disposal \\
\hline DPL10070 & LRY5LLFY08002 & 10L133 & $4.15 \cdot 10$ \\
\hline DPL10070 & LRY5LLFY08002 & 10L134 & 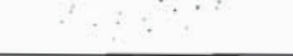 \\
\hline & & & \\
\hline & & & \\
\hline & & & \\
\hline & & & \\
\hline & & & \\
\hline & & & \\
\hline
\end{tabular}

This certification is provided as a courtesy to the waste generator for information purposes only.

/s/: Theresa Hale

WGS Signature $\frac{41.15-10}{\text { Date }}$

\section{Waste Inspector}

$$
\text { Title }
$$

/s/:Jon Tanaka

RWMC Signature
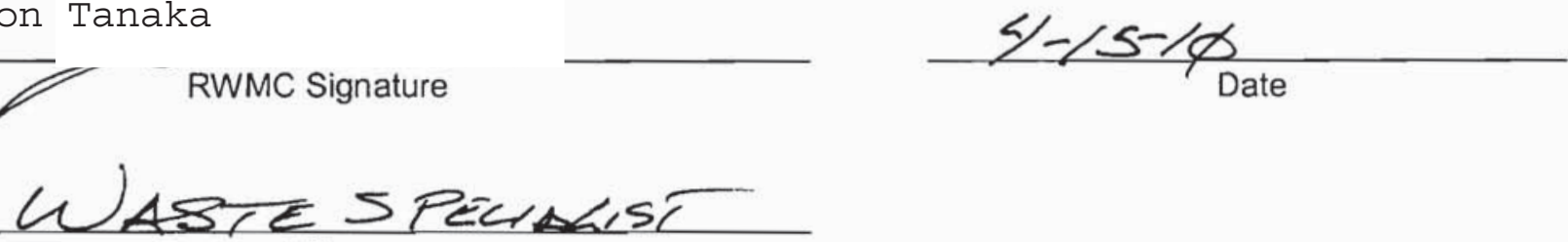

Title 
NSTec

Form

FRM-2217
CERTIFICATE OF DISPOSAL (LOW LEVEL WASTE)
03/01/10

Rev. 01

Page 1 of 1

\section{Nevada Test Site}

This Certificate acknowledges that the following shipment(s) of waste have been disposed at the Nevada Test Site Radioactive Waste Management Complex.

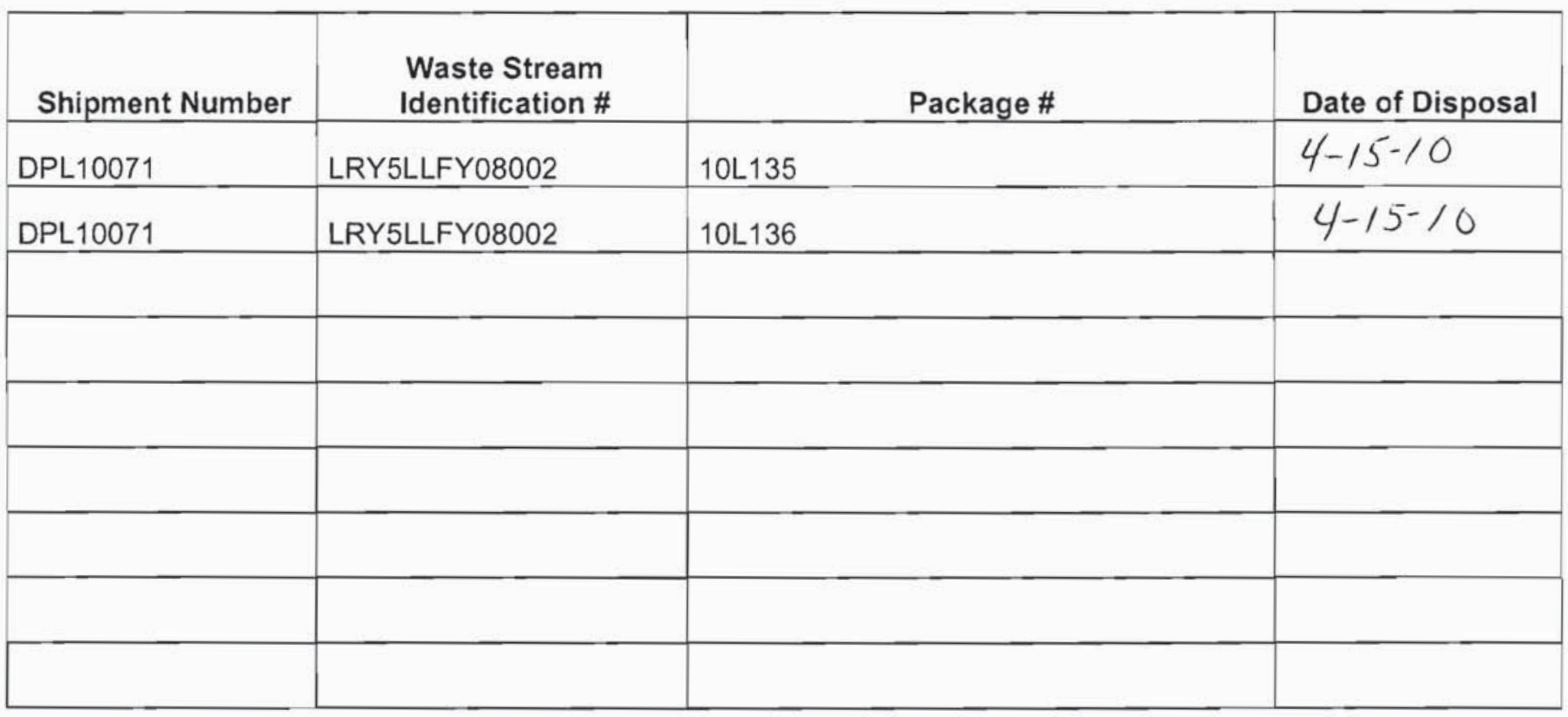

This certification is provided as a courtesy to the waste generator for information purposes only.

/s/: Theresa Hale

WGS Signature

Waste Inspector

Title

/s/: Jon Tanaka

RWḾC Signature

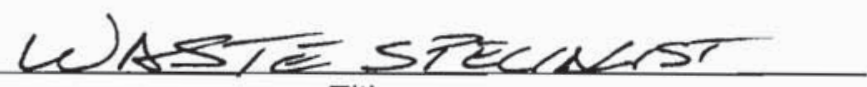

$4-15-10$

Date

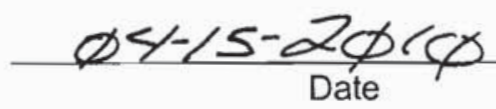


NSTec

Form

FRM-2217
CERTIFICATE OF DISPOSAL

(LOW LEVEL WASTE)
03/01/10

Rev. 01

Page 1 of 1

\section{Nevada Test Site}

This Certificate acknowledges that the following shipment(s) of waste have been disposed at the Nevada Test Site Radioactive Waste Management Complex.

\begin{tabular}{|l|l|l|l|}
\hline \multicolumn{1}{|c|}{ Shipment Number } & \multicolumn{1}{c|}{$\begin{array}{c}\text { Waste Stream } \\
\text { Identification \# }\end{array}$} & Package \# & Date of Disposal \\
\hline DPL10072 & LRY5LLFY08002 & 10 L137 & $4-15-10$ \\
\hline DPL10072 & LRY5LLFY08002 & 10 L138 & $4-15-10$ \\
\hline & & & \\
\hline & & & \\
\hline & & & \\
\hline & & & \\
\hline & & & \\
\hline & & & \\
\hline
\end{tabular}

This certification is provided as a courtesy to the waste generator for information purposes only.

/s/:Theresa Hale

WGS Signature

Waste Inspector

Title

/s/:Jon Tanaka

RWMC Signature

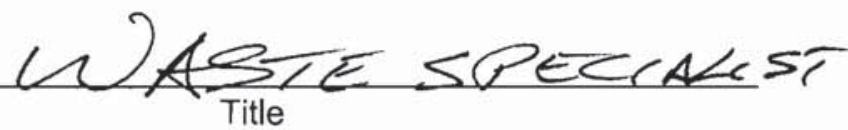

$4-15 \cdot 10$

Date

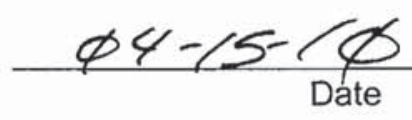


NSTec

Form

FRM-2217
CERTIFICATE OF DISPOSAL

(LOW LEVEL WASTE)
03/01/10

Rev. 01

Page 1 of 1

\section{Nevada Test Site}

This Certificate acknowledges that the following shipment(s) of waste have been disposed at the Nevada Test Site Radioactive Waste Management Complex.

\begin{tabular}{|l|l|l|l|}
\hline \multicolumn{1}{|c|}{ Shipment Number } & \multicolumn{1}{c|}{$\begin{array}{c}\text { Waste Stream } \\
\text { Identification \# }\end{array}$} & \multicolumn{1}{c|}{ Package \# } & Date of Disposal \\
\hline DPL10279 & LRY5LLFY08002 & $\begin{array}{l}102345 \\
104345 \text { TH } 4-29-10\end{array}$ & $4-19-/ 0$ \\
\hline DPL10279 & LRY5LLFY08002 & 10 L346 & $4-19-/ 6$ \\
\hline & & & \\
\hline & & & \\
\hline & & & \\
\hline & & & \\
\hline
\end{tabular}

This certification is provided as a courtesy to the waste generator for information purposes only.

/s/: Theresa Hale

WGS Šignature

Waste Inspector

Title

/s/:Jon Tanaka

RWM̀M Signature

WLSIE SPECINLIST

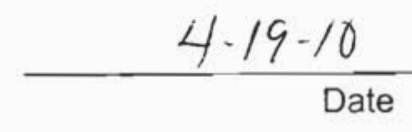

$4-<-\frac{z-2 / \theta}{\text { Date }}$ 
NSTec

Form

FRM-2217
CERTIFICATE OF DISPOSAL

(LOW LEVEL WASTE)
03/01/10

Rev. 01

Page 1 of 1

\section{Nevada Test Site}

This Certificate acknowledges that the following shipment(s) of waste have been disposed at the Nevada Test Site Radioactive Waste Management Complex.

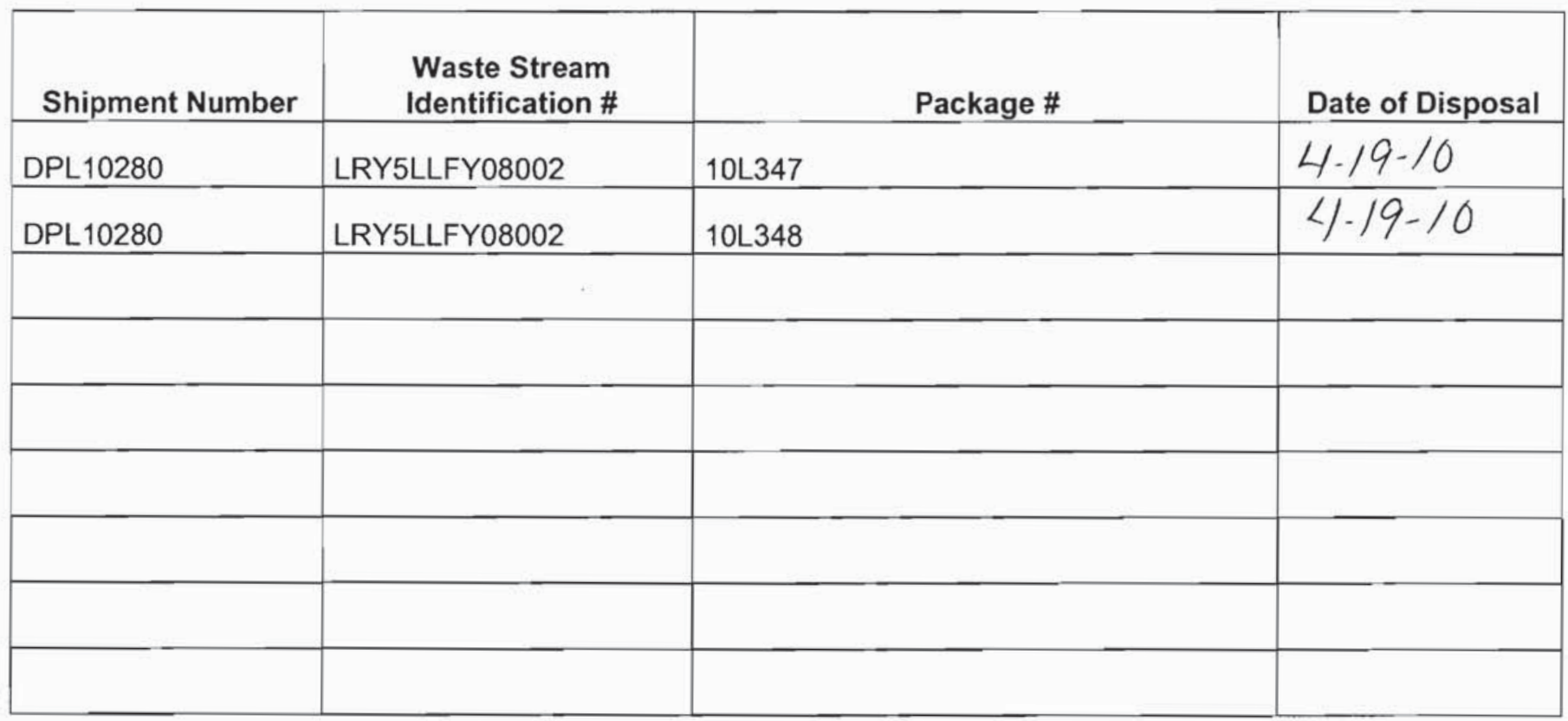

This certification is provided as a courtesy to the waste generator for information purposes only.

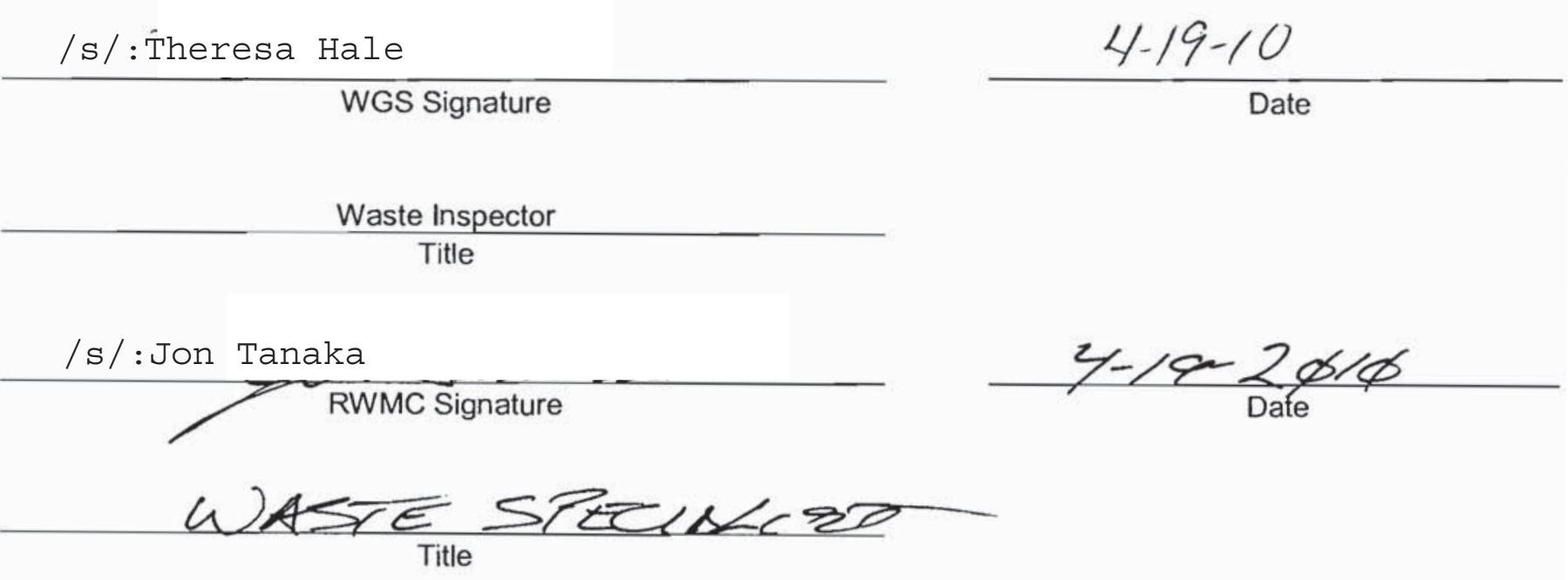




\begin{tabular}{|lcr|}
\hline NSTec & CERTIFICATE OF DISPOSAL & $03 / 01 / 10$ \\
Form & Rev. 01 \\
FRM-2217 & (LOW LEVEL WASTE) & Page 1 of 1 \\
\hline
\end{tabular}

Nevada Test Site

This Certificate acknowledges that the following shipments) of waste have been disposed at the Nevada Test Site Radioactive Waste Management Complex.

\begin{tabular}{|l|l|l|l|}
\hline \multicolumn{1}{|c|}{ Shipment Number } & \multicolumn{1}{c|}{$\begin{array}{c}\text { Waste Stream } \\
\text { Identification \# }\end{array}$} & Package \# & Date of Disposal \\
\hline DPL10281 & LRY5LLFY08002 & 10 349 & $4-19 \cdot 10$ \\
\hline DPL10281 & LRY5LLFY08002 & 10 L350 & $4-19-10$ \\
\hline & & & \\
\hline & & & \\
\hline & & & \\
\hline & & & \\
\hline & & & \\
\hline & & & \\
\hline
\end{tabular}

This certification is provided as a courtesy to the waste generator for information purposes only.

/s/ :Theresa Hale

WGS Signature

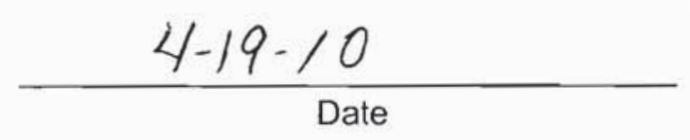

Waste Inspector

Title

/s/ :Jon Kanaka

RWMC Signature

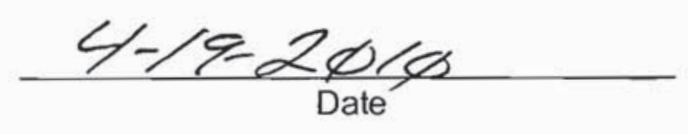

(Reference: OP-2151.304) 


\begin{tabular}{|lcr|}
\hline NSTec & CERTIFICATE OF DISPOSAL & $03 / 01 / 10$ \\
Form & Rev. 01 \\
FRM-2217 & (LOW LEVEL WASTE) & Page 1 of 1 \\
\hline
\end{tabular}

Nevada Test Site

This Certificate acknowledges that the following shipments) of waste have been disposed at the Nevada Test Site Radioactive Waste Management Complex.

\begin{tabular}{|l|l|l|l|}
\hline Shipment Number & \multicolumn{1}{|c|}{$\begin{array}{c}\text { Waste Stream } \\
\text { Identification \# }\end{array}$} & \multicolumn{1}{|c|}{ Package \# } & Date of Disposal \\
\hline DPL10282 & LRY5LLFY08002 & 10 2351 & $4-19-10$ \\
\hline DPL10282 & LRY5LLFY08002 & 10 1552 & $4-19-10$ \\
\hline & & & - \\
\hline & & & \\
\hline & & & \\
\hline & & & \\
\hline & & & \\
\hline & & & \\
\hline
\end{tabular}

This certification is provided as a courtesy to the waste generator for information purposes only.

/s/ :Theresa Hale

WGS Signature

Waste Inspector

Title
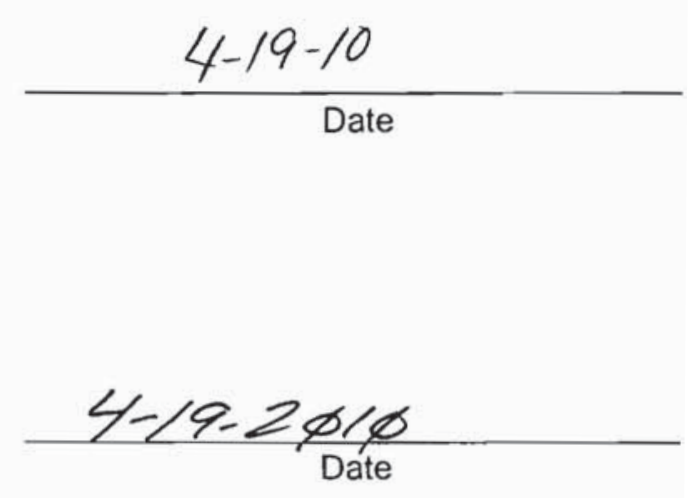

/s/: Jon Kanaka

RWMC Signaüure

WASTE SPECIXKST

(Reference: OP-2151.304) 


\begin{tabular}{|lcr|}
\hline NSTec & CERTIFICATE OF DISPOSAL & $03 / 01 / 10$ \\
Form & Rev. 01 \\
FRM-2217 & (LOW LEVEL WASTE) & Page 1 of 1 \\
\hline
\end{tabular}

Nevada Test Site

This Certificate acknowledges that the following shipments) of waste have been disposed at the Nevada Test Site Radioactive Waste Management Complex.

\begin{tabular}{|l|l|l|l|}
\hline Shipment Number & \multicolumn{1}{|c|}{$\begin{array}{c}\text { Waste Stream } \\
\text { Identification \# }\end{array}$} & \multicolumn{1}{|c|}{ Package \# } & Date of Disposal \\
\hline DPL10283 & LRY5LLFY08002 & 10 2353 & $4-19-10$ \\
\hline DPL10283 & LRY5LLFY08002 & $10 L 354$ & $4-19-10$ \\
\hline & & & \\
\hline & & & \\
\hline & & & \\
\hline & & & \\
\hline & & & \\
\hline & & & \\
\hline
\end{tabular}

This certification is provided as a courtesy to the waste generator for information purposes only.

/s/ :Theresa Hale

WGS Signature

Waste Inspector

Title

RWMC Signature

$\frac{4-19-10}{\text { Date }}$

/s/ :Jon Tanka

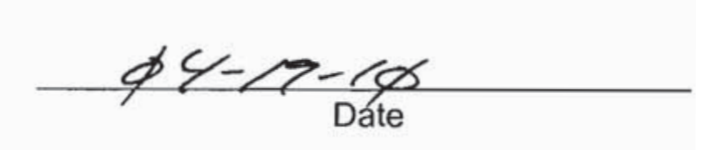

Title

(Reference: OP -21.51 3ก4) 


\section{Nevada Test Site}

This Certificate acknowledges that the following shipment(s) of waste have been disposed at the Nevada Test Site Radioactive Waste Management Complex.

\begin{tabular}{|l|l|l|c|}
\hline \multicolumn{1}{|c|}{$\begin{array}{c}\text { Waste Stream } \\
\text { Identification \# }\end{array}$} & \multicolumn{1}{|c|}{ Package \# } & Date of Disposal \\
\hline DPL10284 & LRY5LLFY08002 & 10 355 & $4-19-10$ \\
\hline DPL10284 & LRY5LLFY08002 & 10 L356 & $4-19-10$ \\
\hline & & & \\
\hline & & & \\
\hline & & & \\
\hline & & & \\
\hline & & & \\
\hline
\end{tabular}

This certification is provided as a courtesy to the waste generator for information purposes only.
/s/: Theresa Hale
WGS Signature
Waste Inspector
Title
/s/: Jon Tanaka
RWMC Signature
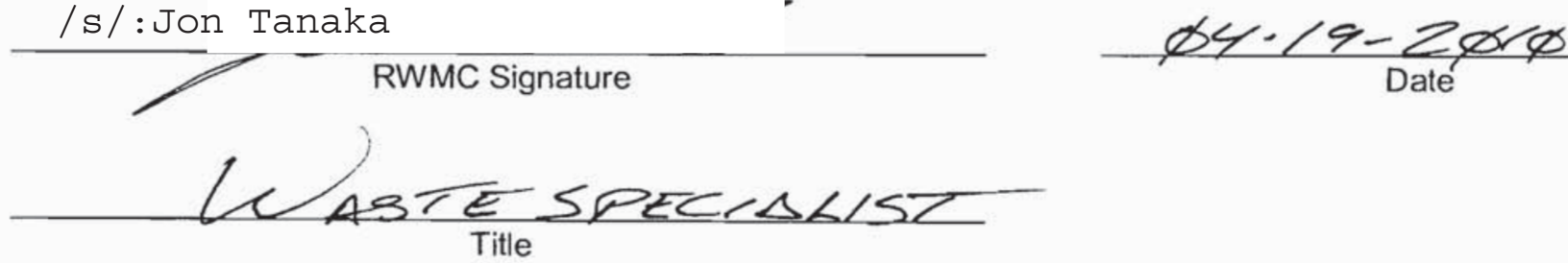

$\frac{4-19 \cdot 10}{\text { Date }}$ 


\section{Nevada Test Site}

This Certificate acknowledges that the following shipment(s) of waste have been disposed at the Nevada Test Site Radioactive Waste Management Complex.

\begin{tabular}{|l|l|l|l|}
\hline \multicolumn{1}{|c|}{ Shipment Number } & \multicolumn{1}{c|}{$\begin{array}{c}\text { Waste Stream } \\
\text { Identification \# }\end{array}$} & Package \# & Date of Disposal \\
\hline DPL10285 & LRY5LLFY08002 & 10 357 & $4-19-10$ \\
\hline DPL10285 & LRY5LLFY08002 & 10 L358 & $4-19-10$ \\
\hline & & & \\
\hline & & & \\
\hline & & & \\
\hline & & & \\
\hline & & & \\
\hline & & & \\
\hline
\end{tabular}

This certification is provided as a courtesy to the waste generator for information purposes only.

/s/:Theresa Hale

WGS Signature

Waste Inspector

Title

/s/:Jon Tanaka

RWMC Signature

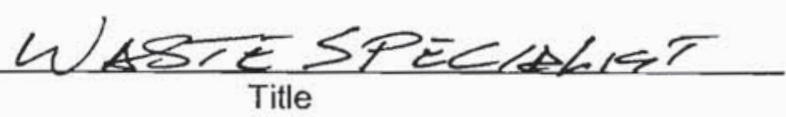

$4-19-10$

Date

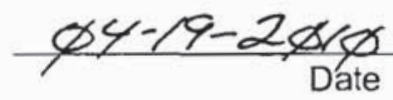


NSTec

Form

FRM-2217
CERTIFICATE OF DISPOSAL

(LOW LEVEL WASTE)
$03 / 01 / 10$

Rev. 01

Page 1 of 1

\section{Nevada Test Site}

This Certificate acknowledges that the following shipment(s) of waste have been disposed at the Nevada Test Site Radioactive Waste Management Complex.

\begin{tabular}{|l|l|l|l|}
\hline Shipment Number & \multicolumn{1}{c|}{$\begin{array}{c}\text { Waste Stream } \\
\text { Identification \# }\end{array}$} & Package \# & Date of Disposal \\
\hline DPL10286 & LRY5LLFY08002 & 10 L359 & $4-/ 9-10$ \\
\hline DPL10286 & LRY5LLFY08002 & 10 L360 & $2 /-/ 9-10$ \\
\hline & & & \\
\hline & & & \\
\hline & & & \\
\hline & & & \\
\hline
\end{tabular}

This certification is provided as a courtesy to the waste generator for information purposes only.

/s/: Theresa Hale

WGS Signature

Waste inspector

Title

/s/:Jon Tanaka

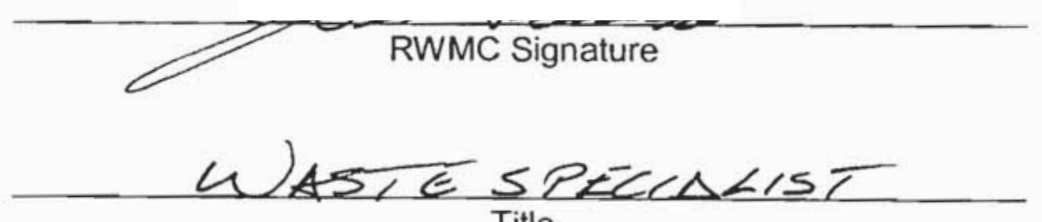

Title

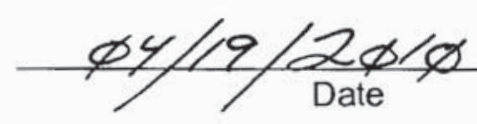

Date 
NSTec

Form

FRM-2217
CERTIFICATE OF DISPOSAL

(LOW LEVEL WASTE)
$03 / 01 / 10$

Rev. 01

Page 1 of 1

\section{Nevada Test Site}

This Certificate acknowledges that the following shipment(s) of waste have been disposed at the Nevada Test Site Radioactive Waste Management Complex.

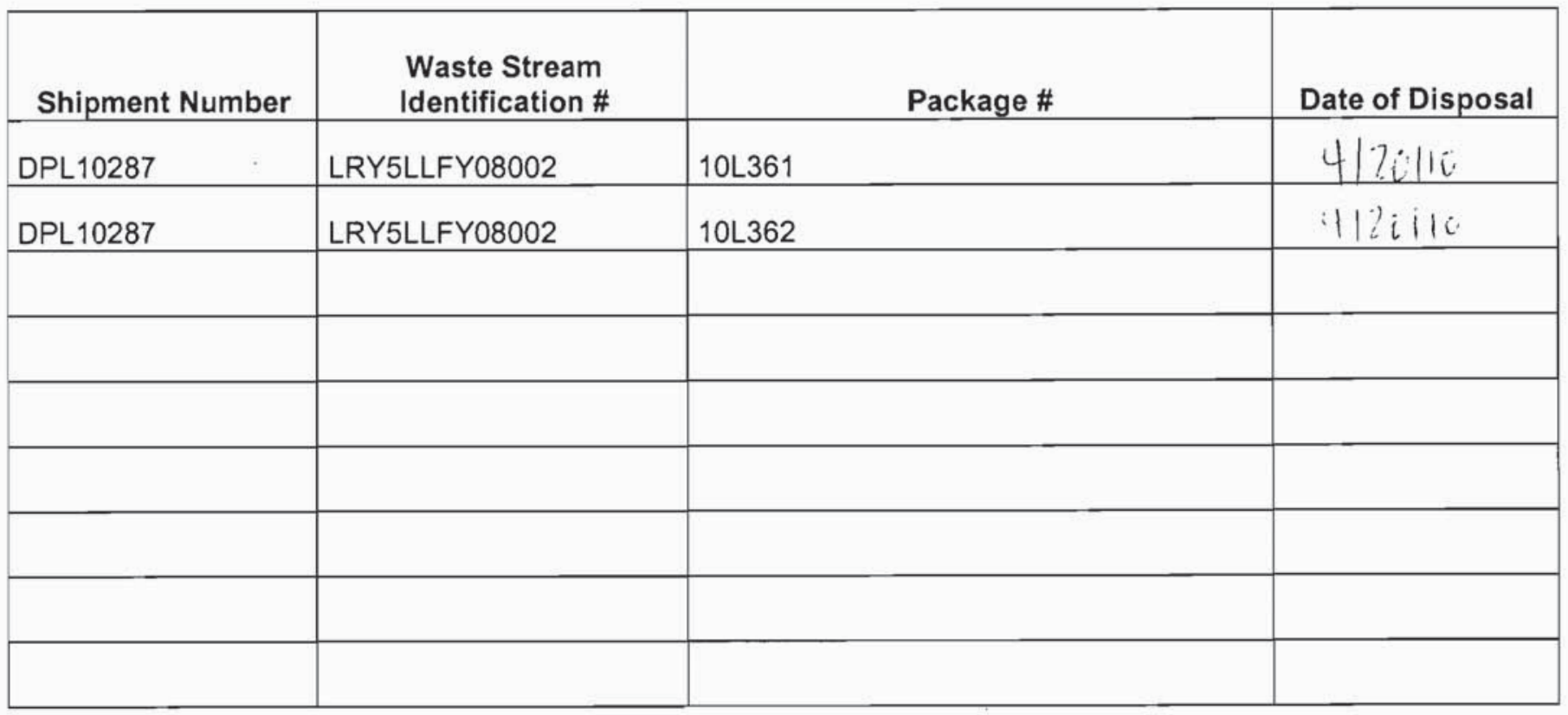

This certification is provided as a courtesy to the waste generator for information purposes only.
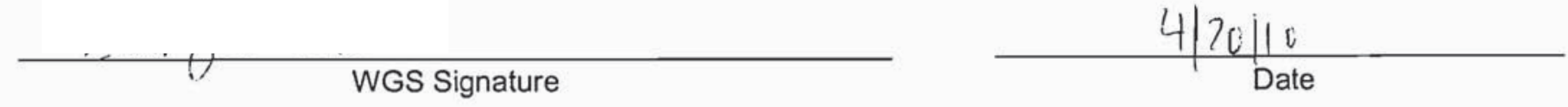

\section{Waste Inspector}

$$
\text { Title }
$$

/s/:Jon Tanaka
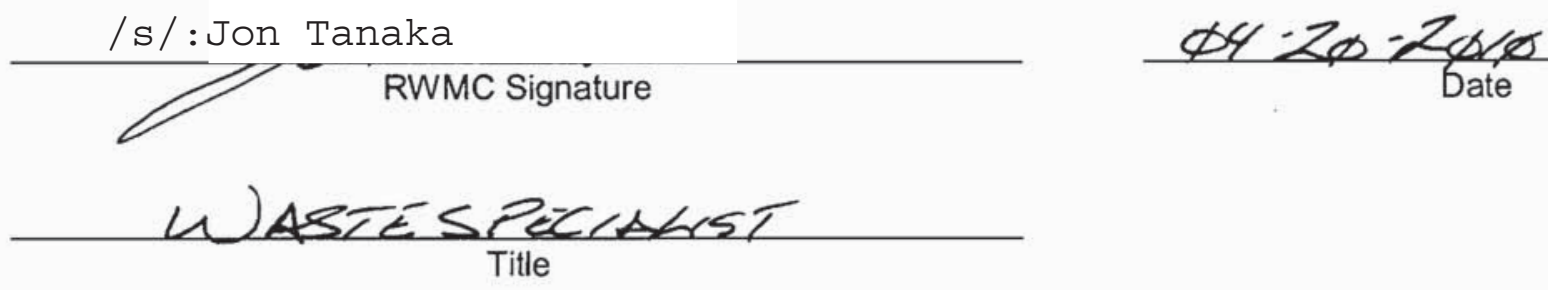
NSTec

Form

CERTIFICATE OF DISPOSAL

FRM-2217

\section{Nevada Test Site}

This Certificate acknowledges that the following shipment(s) of waste have been disposed at the Nevada Test Site Radioactive Waste Management Complex.

\begin{tabular}{|c|c|c|c|}
\hline Shipment Number & $\begin{array}{l}\text { Waste Stream } \\
\text { Identification \# }\end{array}$ & Package \# & Date of Disposal \\
\hline DPL10288 & LRY5LLFY08002 & 10L363 & $47 \% 1 \%$ \\
\hline DPL10288 & LRY5LLFY08002 & $10 \mathrm{~L} 364$ & $11 / 11 \%$ \\
\hline & & & \\
\hline & & & \\
\hline & & & \\
\hline & & & \\
\hline & & & \\
\hline & & & \\
\hline
\end{tabular}

This certification is provided as a courtesy to the waste generator for information purposes only.
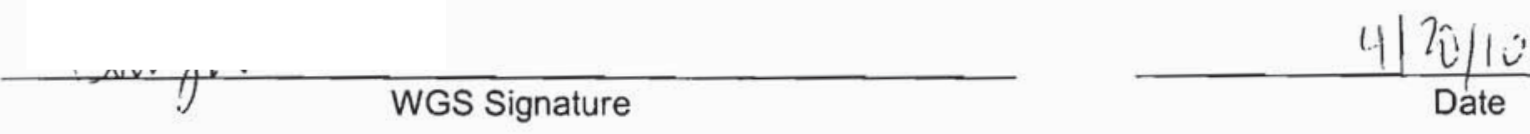
NSTec

Form

FRM-2217

CERTIFICATE OF DISPOSAL

(LOW LEVEL WASTE)
03/01/10

Rev. 01

Page 1 of 1

\section{Nevada Test Site}

This Certificate acknowledges that the following shipment(s) of waste have been disposed at the Nevada Test Site Radioactive Waste Management Complex.

\begin{tabular}{|c|c|c|c|}
\hline Shipment Number & $\begin{array}{l}\text { Waste Stream } \\
\text { Identification \# }\end{array}$ & Package \# & Date of Disposal \\
\hline DPL10289 & LRY5LLFY08002 & $10\llcorner 365$ & thelio \\
\hline DPL10289 & LRY5LLFY08002 & $10 L 366$ & 4120110 \\
\hline & & & \\
\hline & & & \\
\hline & & & \\
\hline & & & \\
\hline & & & \\
\hline & & & \\
\hline
\end{tabular}

This certification is provided as a courtesy to the waste generator for information purposes only.

WGS Signature

Waste Inspector

$$
\text { Title }
$$

/s/:Jon Tanaka

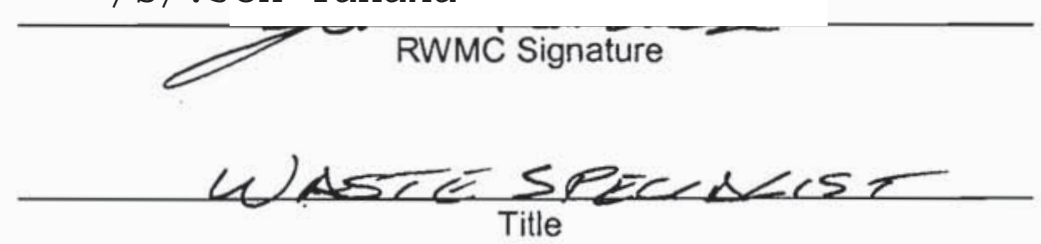

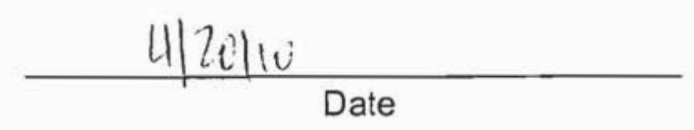

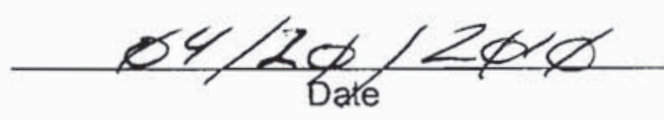




\begin{tabular}{|lcr|}
\hline NSTec & CERTIFICATE OF DISPOSAL & Rev 1/10 \\
Form & (LOW LEVEL WASTE) & 01 \\
FRM-2217 & Page 1 of 1 \\
\hline
\end{tabular}

Nevada Test Site

This Certificate acknowledges that the following shipments) of waste have been disposed at the Nevada Test Site Radioactive Waste Management Complex.

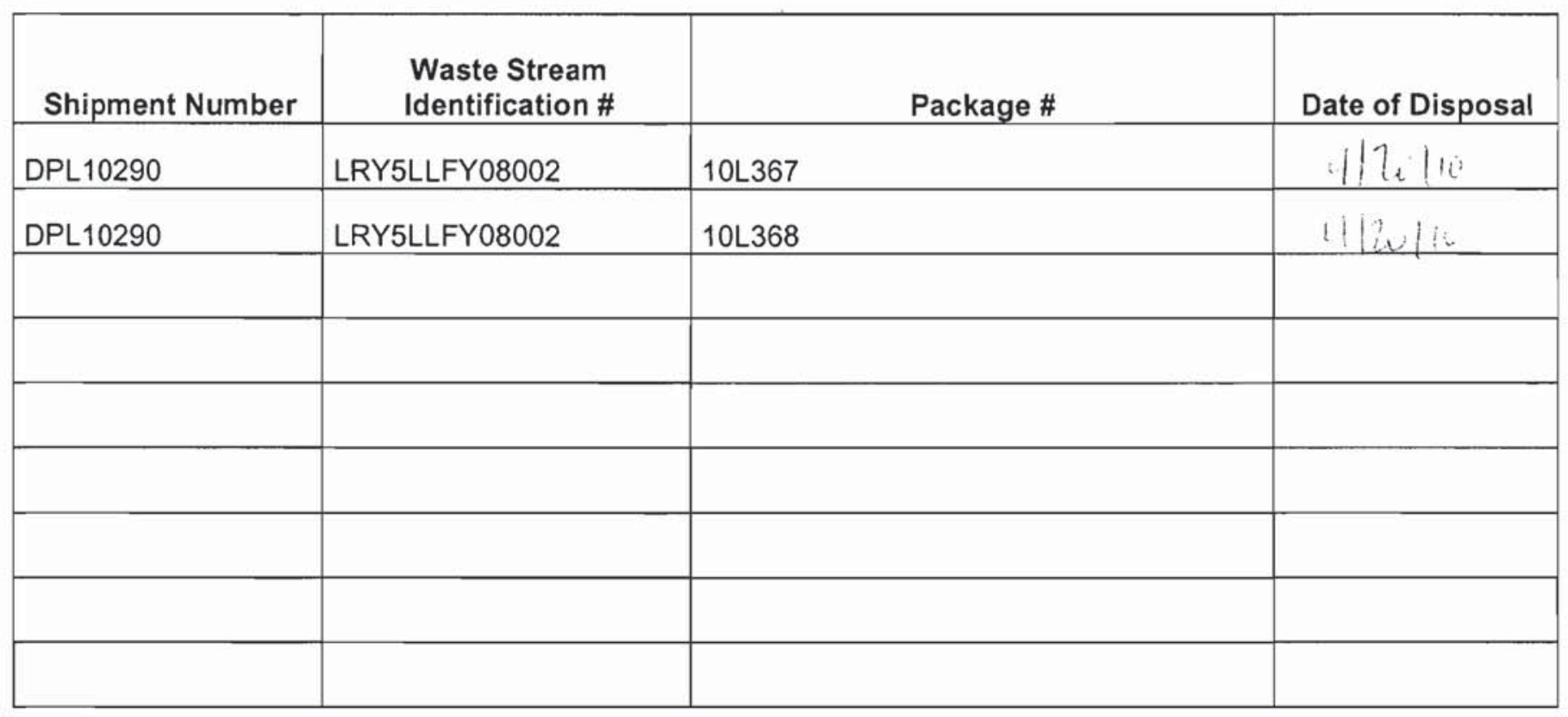

This certification is provided as a courtesy to the waste generator for information purposes only.

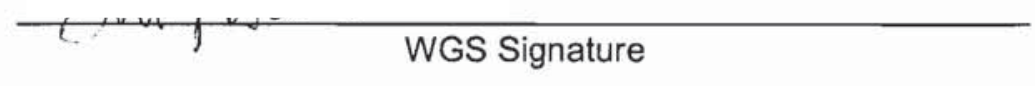

Waste Inspector

Title

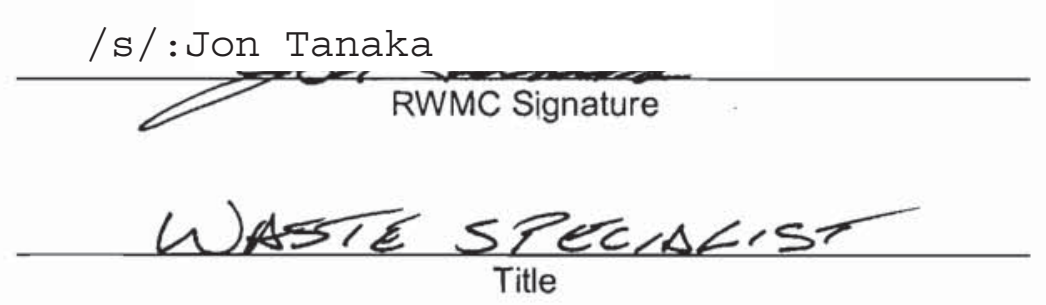

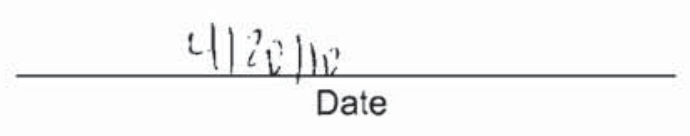

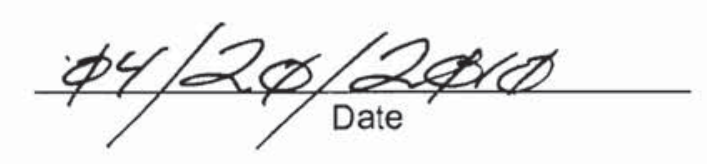

(Reference: OP-2151.304) 
NSTec

Form

FRM-2217
CERTIFICATE OF DISPOSAL

(LOW LEVEL WASTE)
03/01/10

Rev. 01

Page 1 of 1

\section{Nevada Test Site}

This Certificate acknowledges that the following shipment(s) of waste have been disposed at the Nevada Test Site Radioactive Waste Management Complex.

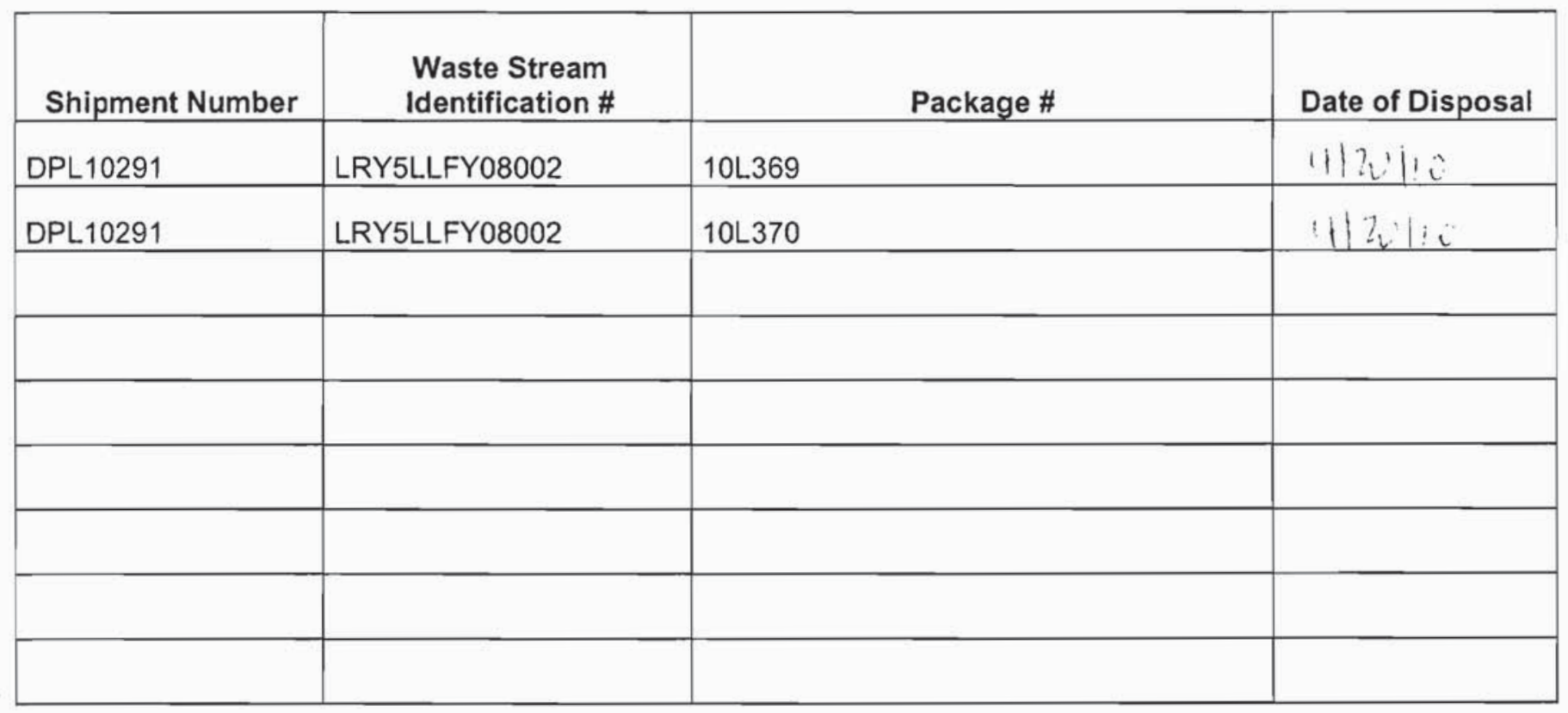

This certification is provided as a courtesy to the waste generator for information purposes only.

$\frac{\text { WGS Signature }}{\text { Waste Inspector }} \frac{\text { Title }}{\text { RWMC Signature }}$
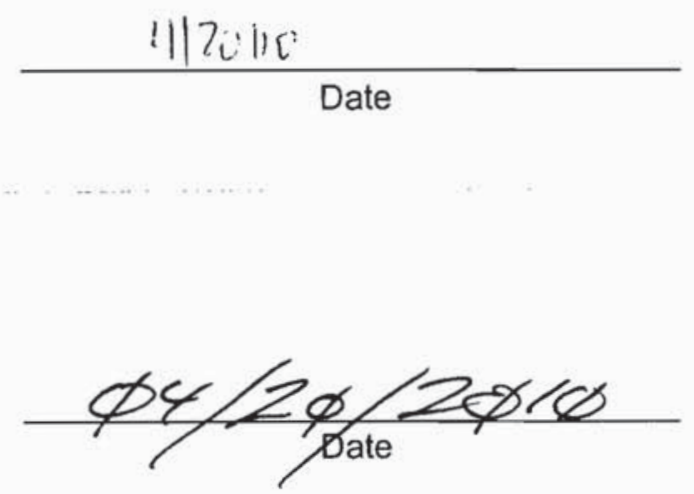
NSTec

Form

CERTIFICATE OF DISPOSAL

03/01/10

FRM-2217

(LOW LEVEL WASTE)

Rev. 01

Page 1 of 1

\section{Nevada Test Site}

This Certificate acknowledges that the following shipment(s) of waste have been disposed at the Nevada Test Site Radioactive Waste Management Complex.

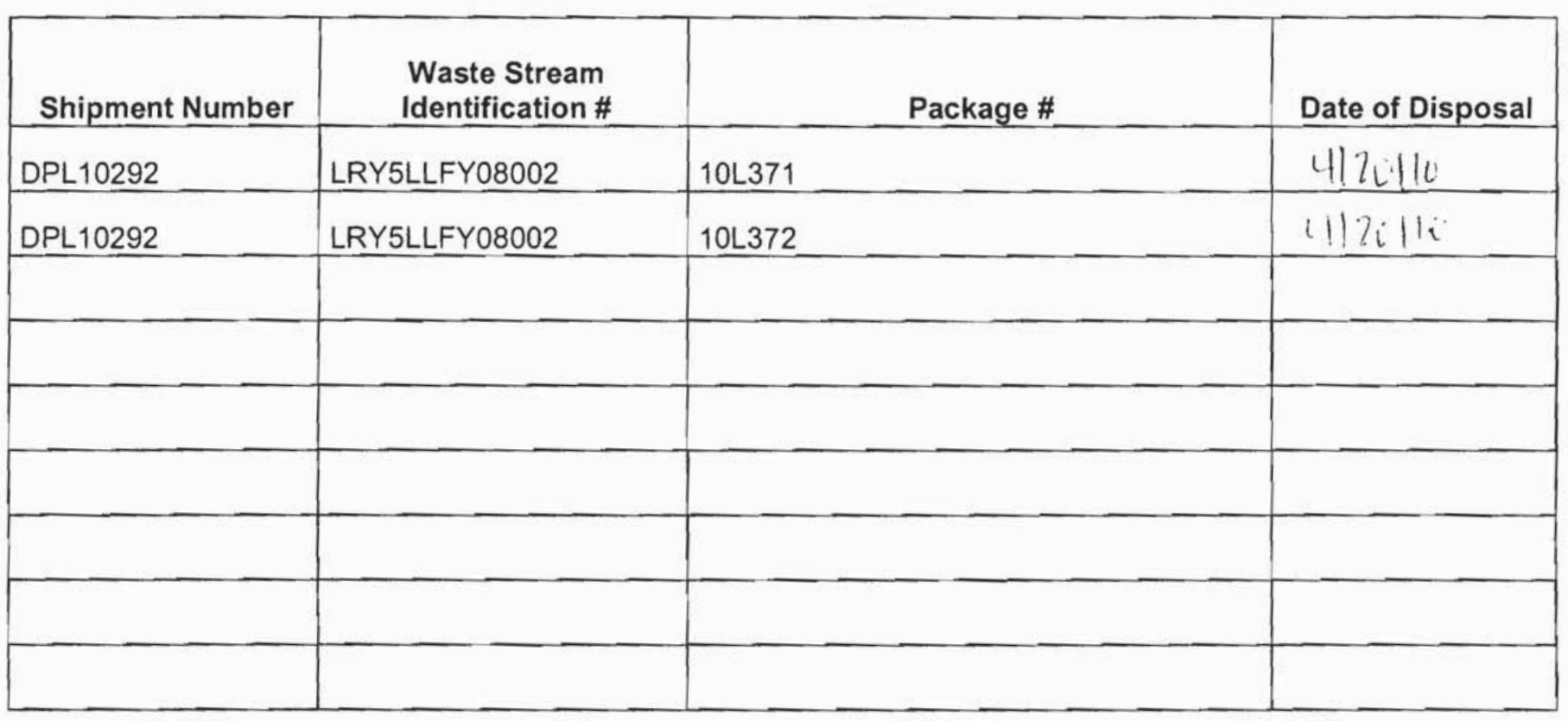

This certification is provided as a courtesy to the waste generator for information purposes only.

$\frac{\text { WGS Signature }}{\frac{\text { Waste Inspector }}{\text { Title }}}$
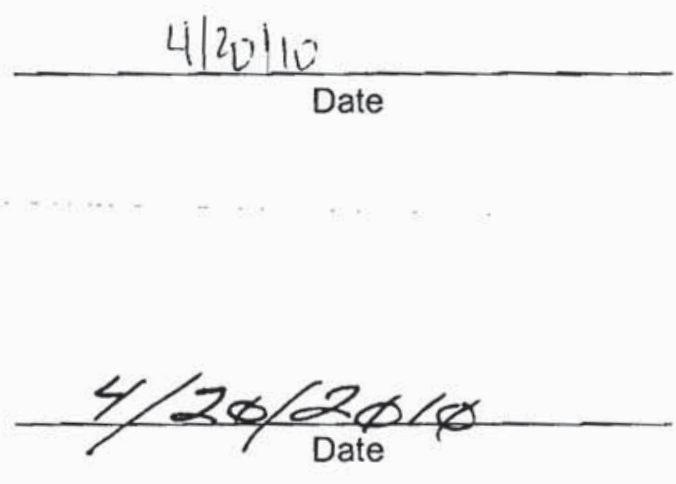
NSTec

Form

FRM-2217
CERTIFICATE OF DISPOSAL

(LOW LEVEL WASTE)
03/01/10

Rev. 01

Page 1 of 1

\section{Nevada Test Site}

This Certificate acknowledges that the following shipment(s) of waste have been disposed at the Nevada Test Site Radioactive Waste Management Complex.

\begin{tabular}{|l|l|l|c|}
\hline Shipment Number & \multicolumn{1}{|c|}{$\begin{array}{c}\text { Waste Stream } \\
\text { Identification \# }\end{array}$} & Package \# & Date of Disposal \\
\hline DPL10293 & LRY5LLFY08002 & $10 \mathrm{~L} 373$ & $! 17: !$ \\
\hline DPL10293 & LRY5LLFY08002 & 10 L374 & \\
\hline & & & \\
\hline & & & \\
\hline & & & \\
\hline & & & \\
\hline & & & \\
\hline
\end{tabular}

This certification is provided as a courtesy to the waste generator for information purposes only.
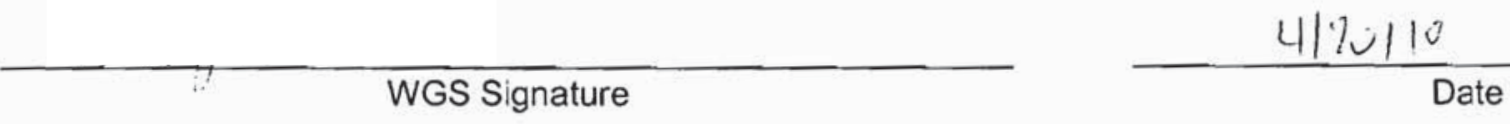

Waste Inspector

Titie

/s/:Jon Tanaka
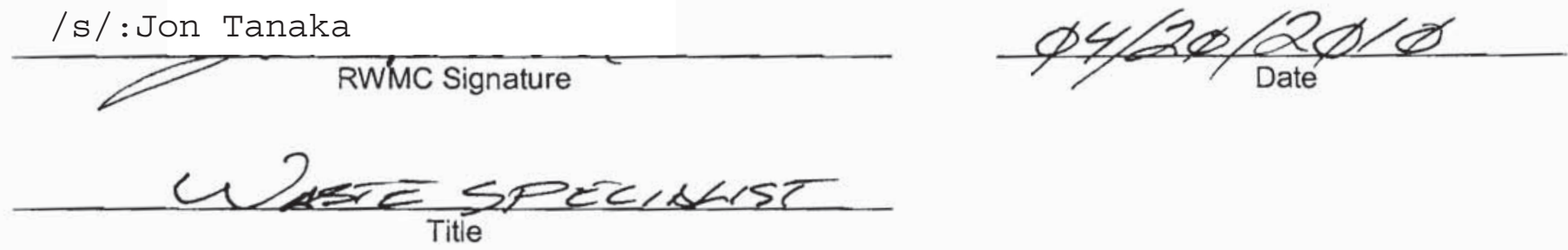
NSTec

Form

FRM-2217
CERTIFICATE OF DISPOSAL

(LOW LEVEL WASTE)
03/01/10

Rev. 01

Page 1 of 1

\section{Nevada Test Site}

This Certificate acknowledges that the following shipment(s) of waste have been disposed at the Nevada Test Site Radioactive Waste Management Complex.

\begin{tabular}{|l|l|l|l|}
\hline Shipment Number & $\begin{array}{c}\text { Waste Stream } \\
\text { Identification \# }\end{array}$ & Package \# & Date of Disposal \\
\hline DPL10294 & LRY5LLFY08002 & 10 375 & $4 / 20 / 10$ \\
\hline DPL10294 & LRY5LLFY08002 & 10 376 & $4 / 20 / 10$ \\
\hline & & & \\
\hline & & & \\
\hline & & & \\
\hline & & & \\
\hline & & & \\
\hline
\end{tabular}

This certification is provided as a courtesy to the waste generator for information purposes only.

WGS Signature

4) 2ilit

Date

Waste Inspector

Title

/s/:Jon Tanaka

RWMC Signature

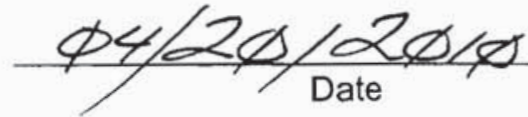

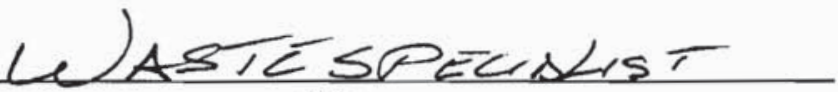


NSTec

Form

CERTIFICATE OF DISPOSAL

03/01/10

FRM-2217

(LOW LEVEL WASTE)

Rev. 01

Page 1 of 1

\section{Nevada Test Site}

This Certificate acknowledges that the following shipment(s) of waste have been disposed at the Nevada Test Site Radioactive Waste Management Complex.

\begin{tabular}{|l|l|l|l|}
\hline Shipment Number & $\begin{array}{c}\text { Waste Stream } \\
\text { Identification \# }\end{array}$ & Package \# & Date of Disposal \\
\hline & LRY5LLFY08002 & 10 L155 & L10089 \\
\hline & & & \\
\hline & & & \\
\hline & & & \\
\hline & & & \\
\hline & & & \\
\hline & & & \\
\hline
\end{tabular}

This certification is provided as a courtesy to the waste generator for information purposes only.

WGS Signature

Waste Inspector

Title

/s / : Jon Tanaka

RWMC Signature

A LASIE SPELIOKIST
4121110

Date

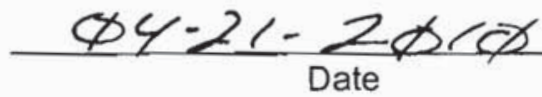


NSTec

Form

FRM-2217
CERTIFICATE OF DISPOSAL

(LOW LEVEL WASTE)
$03 / 01 / 10$

Rev. 01

Page 1 of 1

\section{Nevada Test Site}

This Certificate acknowledges that the following shipment(s) of waste have been disposed at the Nevada Test Site Radioactive Waste Management Complex.

\begin{tabular}{|l|l|l|l|l|}
\hline Shipment Number & $\begin{array}{c}\text { Waste Stream } \\
\text { Identification \# }\end{array}$ & Package \# & Date of Disposal \\
\hline DPL10090 & LRY5LLFY08002 & 10 L156 & $4 / 21 / 10$ \\
\hline & & & & \\
\hline & & & & \\
\hline & & & & \\
\hline
\end{tabular}

This certification is provided as a courtesy to the waste generator for information purposes only.

WGS Signature

Waste Inspector

Title

/s/:Jon Tanaka

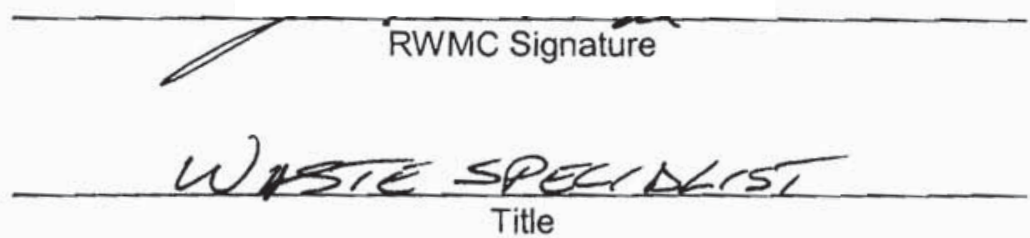

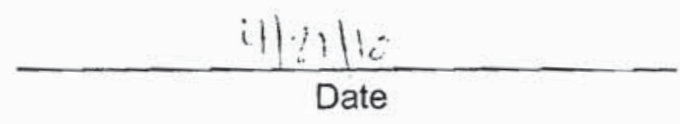

$-\phi z \cdot 2<-\frac{2}{\text { Date }} \phi \phi$ 
NSTec

Form

CERTIFICATE OF DISPOSAL

$03 / 01 / 10$

FRM-2217

(LOW LEVEL WASTE)

Rev. 01

Page 1 of 1

\section{Nevada Test Site}

This Certificate acknowledges that the following shipment(s) of waste have been disposed at the Nevada Test Site Radioactive Waste Management Complex.

\begin{tabular}{|l|l|l|l|}
\hline Shipment Number & \multicolumn{1}{|c|}{$\begin{array}{c}\text { Waste Stream } \\
\text { Identification \# }\end{array}$} & Package \# & Date of Disposal \\
\hline DPL10295 & LRY5LLFY08002 & 10 L377 & 4 \\
\hline DPL10295 & LRY5LLFY08002 & 10 L378 & \\
\hline & & & \\
\hline & & & \\
\hline & & & \\
\hline & & & \\
\hline & & & \\
\hline
\end{tabular}

This certification is provided as a courtesy to the waste generator for information purposes only.

WGS Signature

Waste Inspector

\section{Title}

/s/:Jon Tanaka

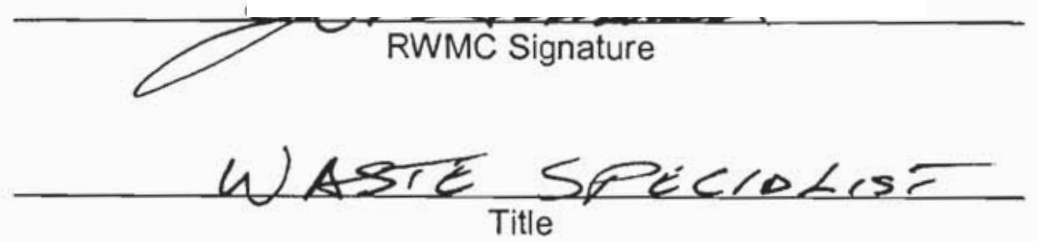

4112110

Date 


\begin{tabular}{|lrr|}
\hline NSTec & CERTIFICATE OF DISPOSAL & 03/01/10 \\
Form & Rev. 01 \\
FRM-2217 & (LOW LEVEL WASTE) & Page 1 of 1 \\
\hline
\end{tabular}

\section{Nevada Test Site}

This Certificate acknowledges that the following shipment(s) of waste have been disposed at the Nevada Test Site Radioactive Waste Management Complex.

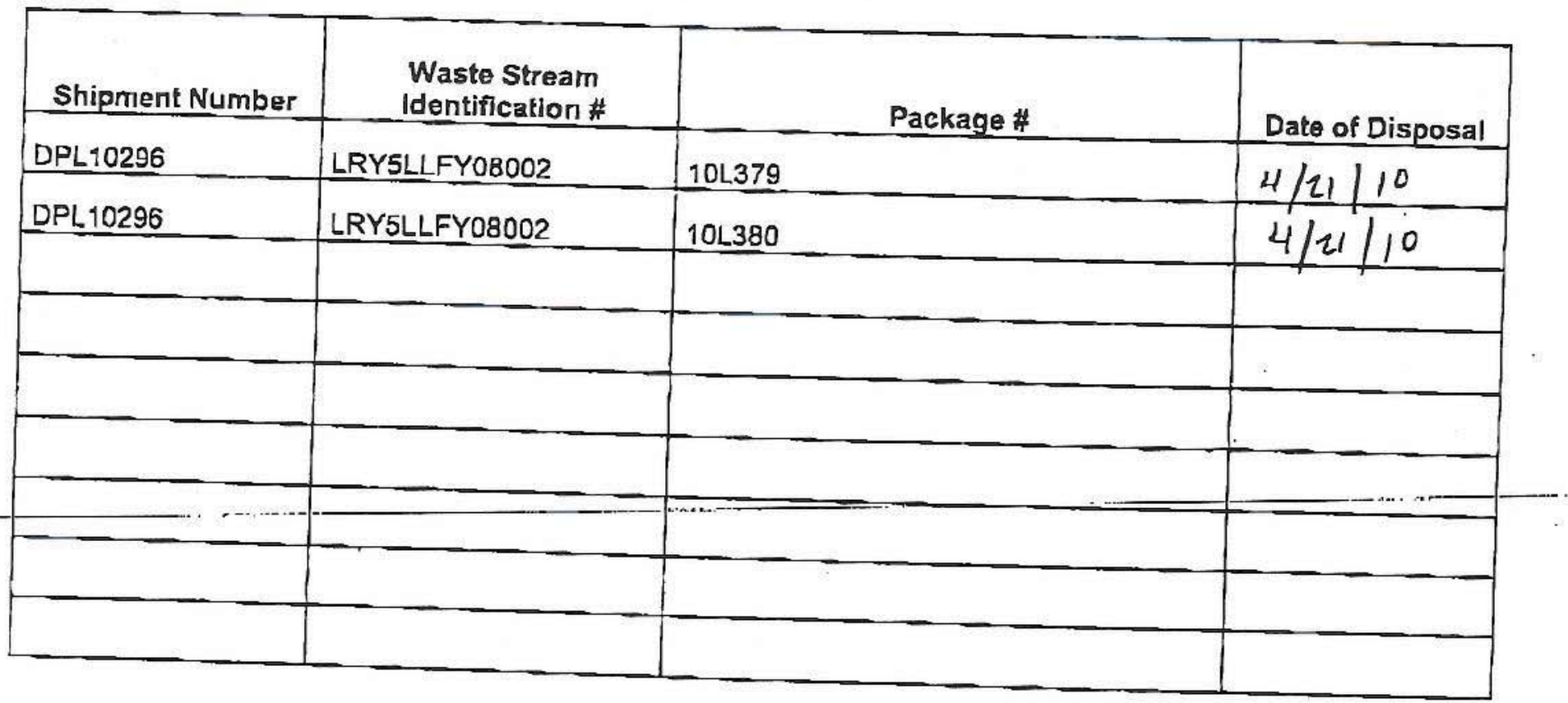

This certification is provided as a courtesy to the waste generator for information purposes only.

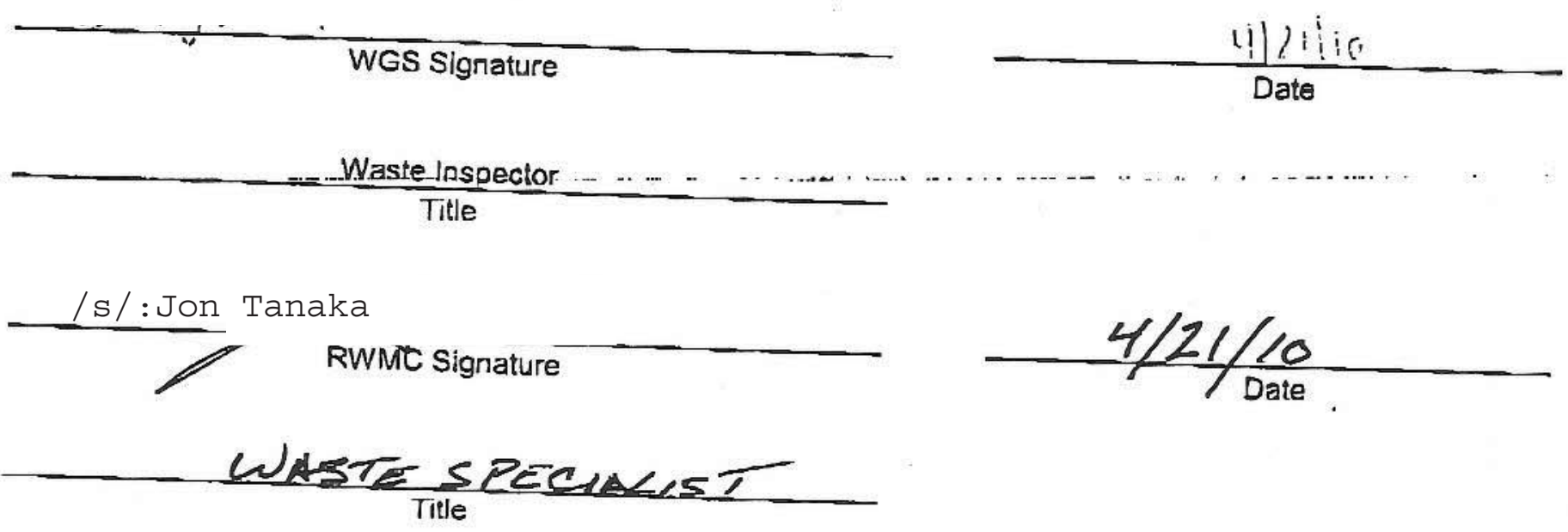


NSTec

Form

FRM-2217
CERTIFICATE OF DISPOSAL

(LOW LEVEL WASTE)
$03 / 01 / 10$

Rev. 01

Page 1 of 1

\section{Nevada Test Site}

This Certificate acknowledges that the following shipment(s) of waste have been disposed at the Nevada Test Site Radioactive Waste Management Complex.

\begin{tabular}{|c|c|c|c|}
\hline Shipment Number & $\begin{array}{l}\text { Waste Stream } \\
\text { Identification \# }\end{array}$ & Package \# & Date of Disposal \\
\hline DPL10297 & LRY5LLFY08002 & $10 \mathrm{~L} 381$ & $4|21| 10$ \\
\hline DPL10297 & LRY5LLFY08002 & 10L382 & $4 / 01 / 10$ \\
\hline & & & \\
\hline & & & \\
\hline & & & \\
\hline & & & \\
\hline & & & \\
\hline & & & \\
\hline
\end{tabular}

This certification is provided as a courtesy to the waste generator for information purposes only.

WGS Signature

Waste Inspector

\section{Title}

\section{/s/: Jon Tanaka}

$\checkmark$ RWMC Signature

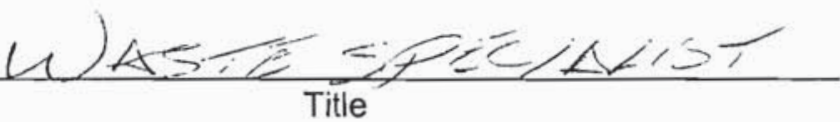

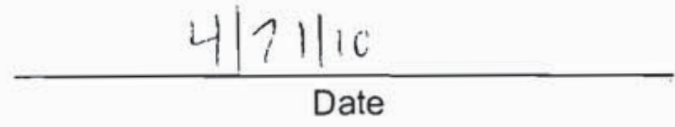

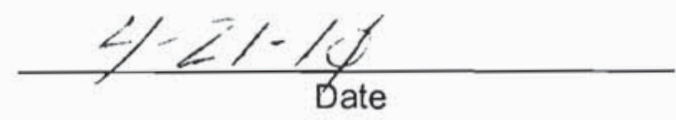




\begin{tabular}{|lcr|}
\hline NSTec & CERTIFICATE OF DISPOSAL & 03/01/10 \\
Form & Rev. 01 \\
FRM-2217 & (LOW LEVEL WASTE) & Page 1 of 1 \\
\hline
\end{tabular}

Nevada Test Site

This Certificate acknowledges that the following shipments) of waste have been disposed at the Nevada Test Site Radioactive Waste Management Complex.

\begin{tabular}{|l|l|l|l|}
\hline Shipment Number & \multicolumn{1}{c|}{$\begin{array}{c}\text { Waste Stream } \\
\text { Identification \# }\end{array}$} & \multicolumn{1}{c|}{ Package \# } & Date of Disposal \\
\hline DPL10298 & LRY5LLFY08002 & 102383 & $4 / 22 / 10$ \\
\hline DPL10298 & LRY5LLFY08002 & $10 L 384$ & $4 / 22 / 10$ \\
\hline & & & 4 \\
\hline & & & \\
\hline & & & \\
\hline & & & \\
\hline & & & \\
\hline
\end{tabular}

This certification is provided as a courtesy to the waste generator for information purposes only.

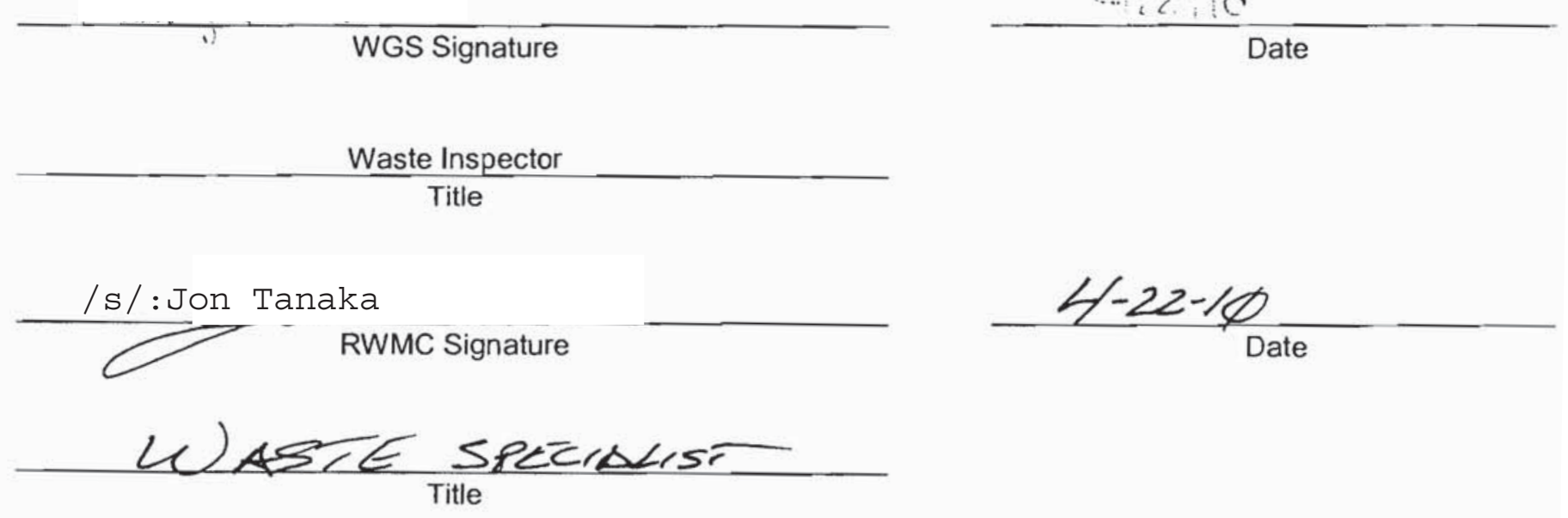

(Reference: OP-2151.304) 
NSTec

Form

FRM-2217
CERTIFICATE OF DISPOSAL

(LOW LEVEL WASTE)
03/01/10

Rev. 01

Page 1 of 1

\section{Nevada Test Site}

This Certificate acknowledges that the following shipment(s) of waste have been disposed at the Nevada Test Site Radioactive Waste Management Complex.

\begin{tabular}{|c|c|c|c|}
\hline Shipment Number & $\begin{array}{l}\text { Waste Stream } \\
\text { Identification \# }\end{array}$ & Package \# & Date of Disposal \\
\hline DPL10299 & LRY5LLFY08002 & $10 L 385$ & $4 \mid 22 / 10$ \\
\hline DPL10299 & LRY5LLFY08002 & $10 L 386$ & 10 \\
\hline & & & \\
\hline & & & \\
\hline & & & \\
\hline & & & \\
\hline & & & \\
\hline & & & \\
\hline
\end{tabular}

This certification is provided as a courtesy to the waste generator for information purposes only.

\section{WGS Signature}

Waste Inspector

Title

/s/: Jon Tanaka

RWMC Signature

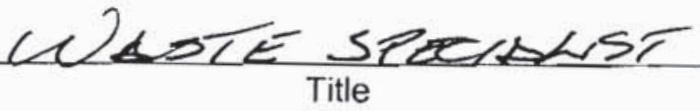

$4(23) 10$

Date

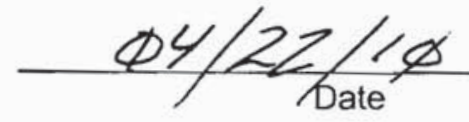




\begin{tabular}{|lcr|}
\hline NSTec & CERTIFICATE OF DISPOSAL & 03/01/10 \\
Form & Rev. 01 \\
FRM-2217 & (LOW LEVEL WASTE) & Page 1 of 1 \\
\hline
\end{tabular}

Nevada Test Site

This Certificate acknowledges that the following shipments) of waste have been disposed at the Nevada Test Site Radioactive Waste Management Complex.

\begin{tabular}{|l|l|l|l|}
\hline \multicolumn{1}{|c|}{ Shipment Number } & \multicolumn{1}{|c|}{$\begin{array}{c}\text { Waste Stream } \\
\text { Identification \# }\end{array}$} & \multicolumn{1}{c|}{ Package \# } & Date of Disposal \\
\hline DPL10300 & LRY5LLFY08002 & 10 387 & $4 / 22 / 10$ \\
\hline DPL10300 & LRY5LLFY08002 & 10 L388 & $4 / 22 / 10$ \\
\hline & & & \\
\hline & & & \\
\hline & & & \\
\hline & & & \\
\hline & & & \\
\hline & & & \\
\hline
\end{tabular}

This certification is provided as a courtesy to the waste generator for information purposes only.

WGS Signature

Waste Inspector

Title

/s/: Jon Tanka

RWMC Signature

$\omega$

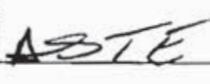

Hollie

Date

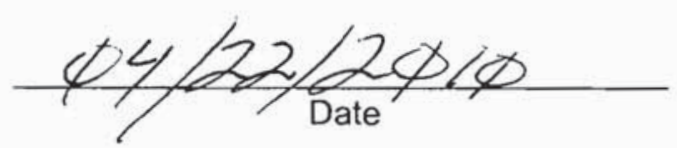

(Reference: OP-2151.304) 
NSTec

CERTIFICATE OF DISPOSAL

03/01/10

Form

(LOW LEVEL WASTE)

Rev. 01

FRM-2217

Page 1 of 1

\section{Nevada Test Site}

This Certificate acknowledges that the following shipment(s) of waste have been disposed at the Nevada Test Site Radioactive Waste Management Complex.

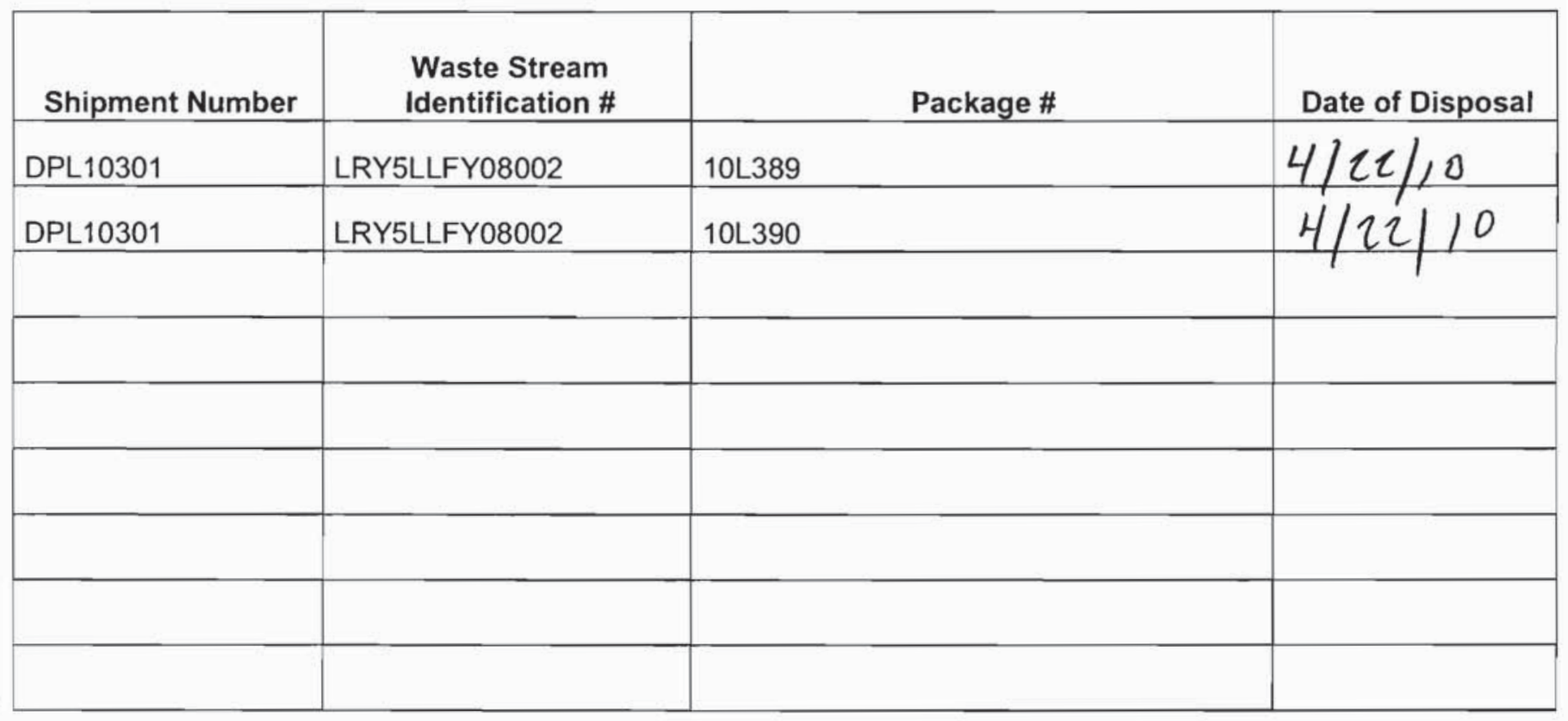

This certification is provided as a courtesy to the waste generator for information purposes only.
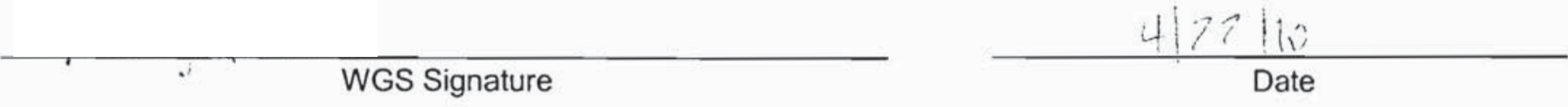

Waste Inspector

Title

/s/:Jon Tanaka

RWMC Signature

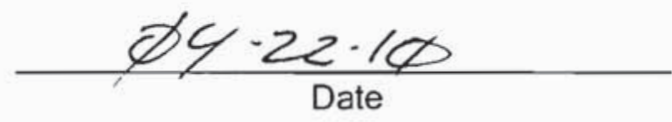

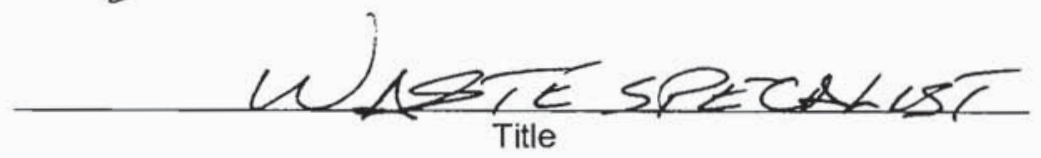


NSTec

Form

FRM-2217
CERTIFICATE OF DISPOSAL

(LOW LEVEL WASTE)
03/01/10

Rev. 01

Page 1 of 1

\section{Nevada Test Site}

This Certificate acknowledges that the following shipment(s) of waste have been disposed at the Nevada Test Site Radioactive Waste Management Complex.

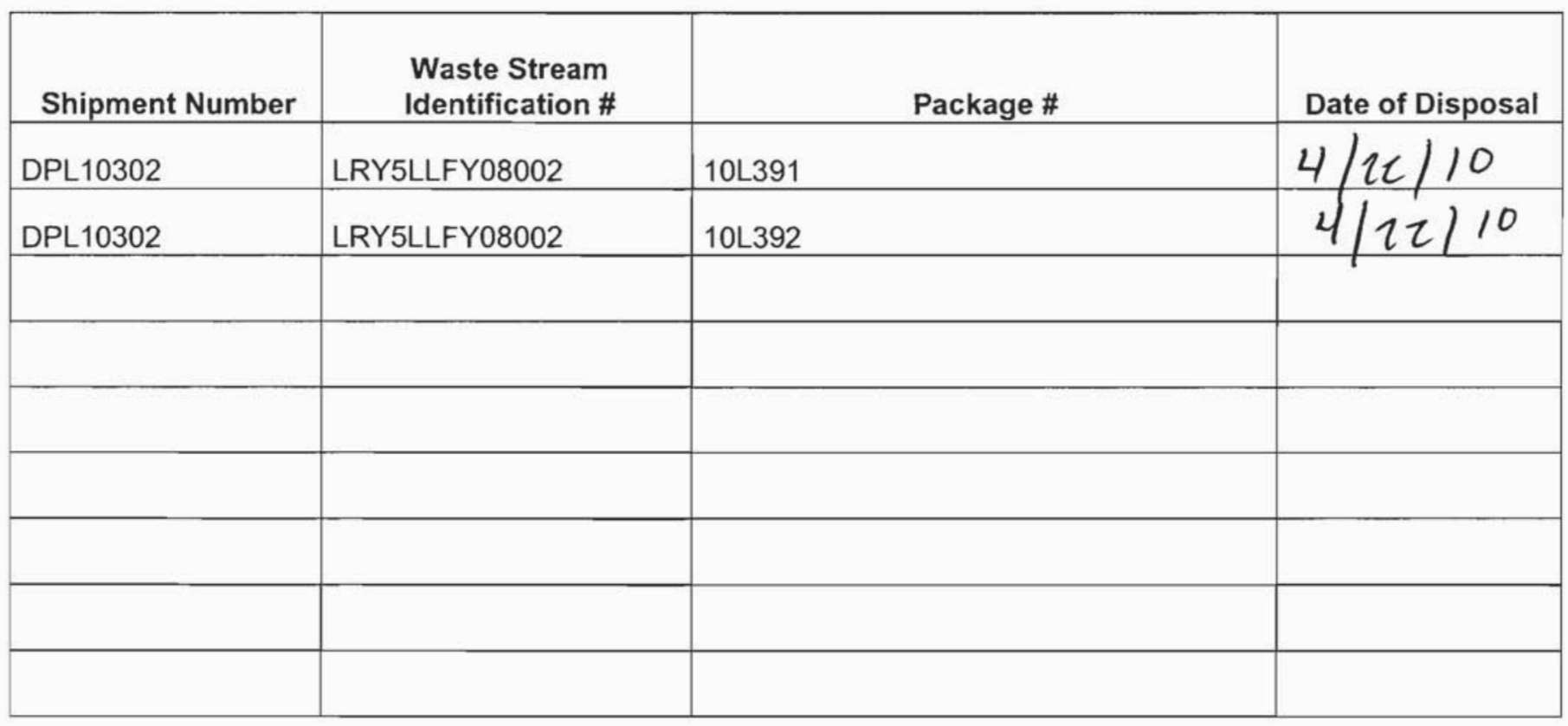

This certification is provided as a courtesy to the waste generator for information purposes only.

\section{WGS Signature}

Waste Inspector

Title

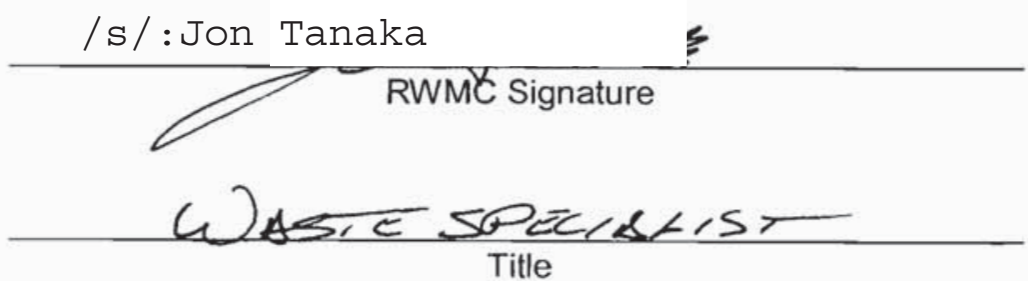

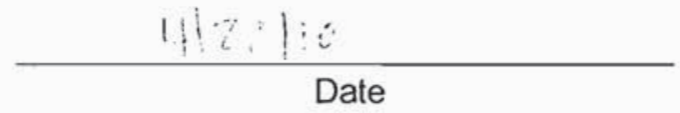

$\phi 4-22-1 \phi$ 
NSTec

CERTIFICATE OF DISPOSAL

$03 / 01 / 10$

Form

(LOW LEVEL WASTE)

Rev. 01

FRM-2217

Page 1 of 1

\section{Nevada Test Site}

This Certificate acknowledges that the following shipment(s) of waste have been disposed at the Nevada Test Site Radioactive Waste Management Complex.

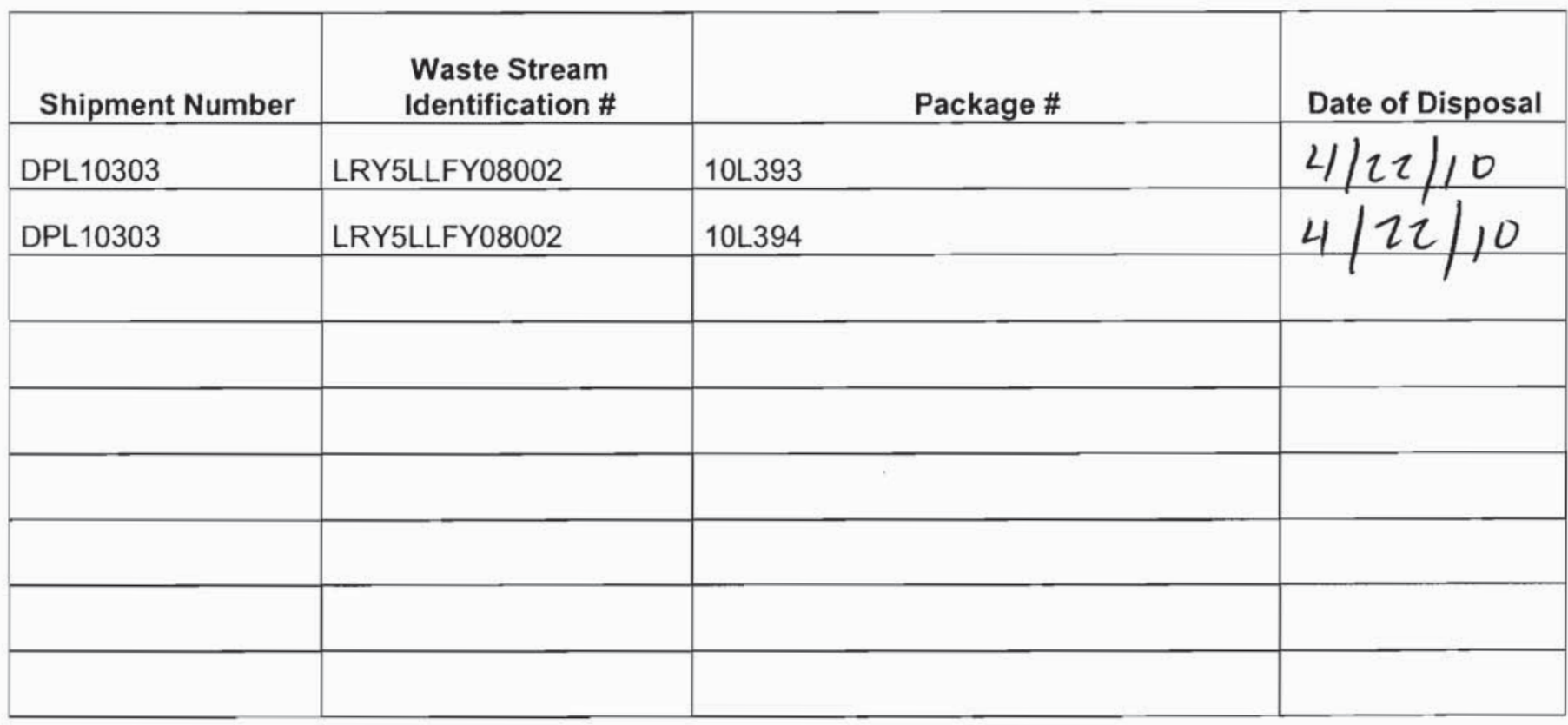

This certification is provided as a courtesy to the waste generator for information purposes only.

WGS Signature

Waste Inspector

Title

/s/:Jon Tanaka

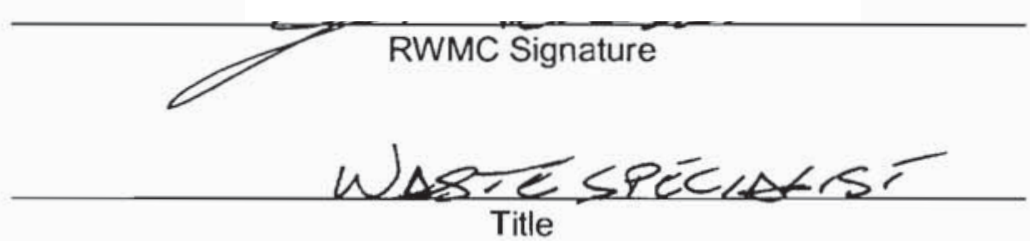

$4.7711 i$

Date

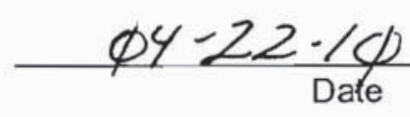




\begin{tabular}{|lcr|}
\hline NSTec & CERTIFICATE OF DISPOSAL & 03/01/10 \\
Form & Rev. 01 \\
FRM-2217 & (LOW LEVEL WASTE) & Page 1 of 1 \\
\hline
\end{tabular}

Nevada Test Site

This Certificate acknowledges that the following shipments) of waste have been disposed at the Nevada Test Site Radioactive Waste Management Complex.

\begin{tabular}{|l|l|l|l|}
\hline Shipment Number & \multicolumn{1}{|c|}{$\begin{array}{c}\text { Waste Stream } \\
\text { Identification \# }\end{array}$} & \multicolumn{1}{|c|}{ Package \# } & Date of Disposal \\
\hline DPL10304 & LRY5LLFY08002 & 10 395 & $4 / 22 / 10$ \\
\hline DPL10304 & LRY5LLFY08002 & 10 L396 & $4 / 22 / 10$ \\
\hline & & & \\
\hline & & & \\
\hline & & & \\
\hline & & & \\
\hline & & & \multicolumn{2}{|l}{} \\
\hline & & & \\
\hline
\end{tabular}

This certification is provided as a courtesy to the waste generator for information purposes only.

WGS Signature

Waste Inspector

Title

/s/ :Jon Tanka

RWMC Signature

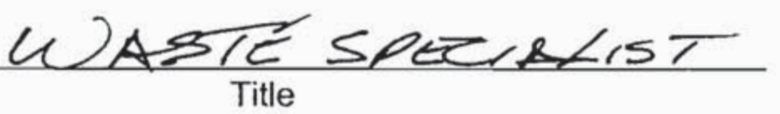

$4 ? ? !$

Date

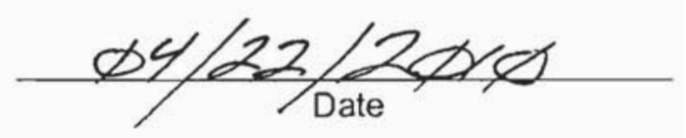

(Reference: OP-2151.304) 


\section{Nevada Test Site}

This Certificate acknowledges that the following shipment(s) of waste have been disposed at the Nevada Test Site Radioactive Waste Management Complex.

\begin{tabular}{|l|l|l|l|}
\hline Shipment Number & \multicolumn{1}{|c|}{$\begin{array}{c}\text { Waste Stream } \\
\text { Identification \# }\end{array}$} & Package \# & Date of Disposal \\
\hline DPL10305 & LRY5LLFY08002 & 10 2397 & $4 / 22 / 10$ \\
\hline DPL10305 & LRY5LLFY08002 & 10 L398 & $4 / 22 / 10$ \\
\hline & & & \\
\hline & & & \\
\hline & & & \\
\hline & & & \\
\hline & & & \\
\hline
\end{tabular}

This certification is provided as a courtesy to the waste generator for information purposes only.

WGS Signature

Waste Inspector

Title

/s/: Jon Tanaka

RWMC Signature

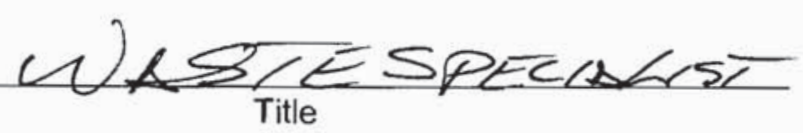

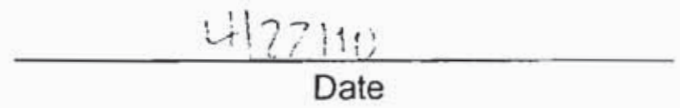

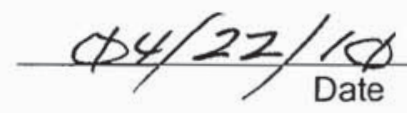


NSTec

Form

FRM-2217
CERTIFICATE OF DISPOSAL

(LOW LEVEL WASTE)
$03 / 01 / 10$

Rev. 01

Page 1 of 1

\section{Nevada Test Site}

This Certificate acknowledges that the following shipment(s) of waste have been disposed at the Nevada Test Site Radioactive Waste Management Complex.

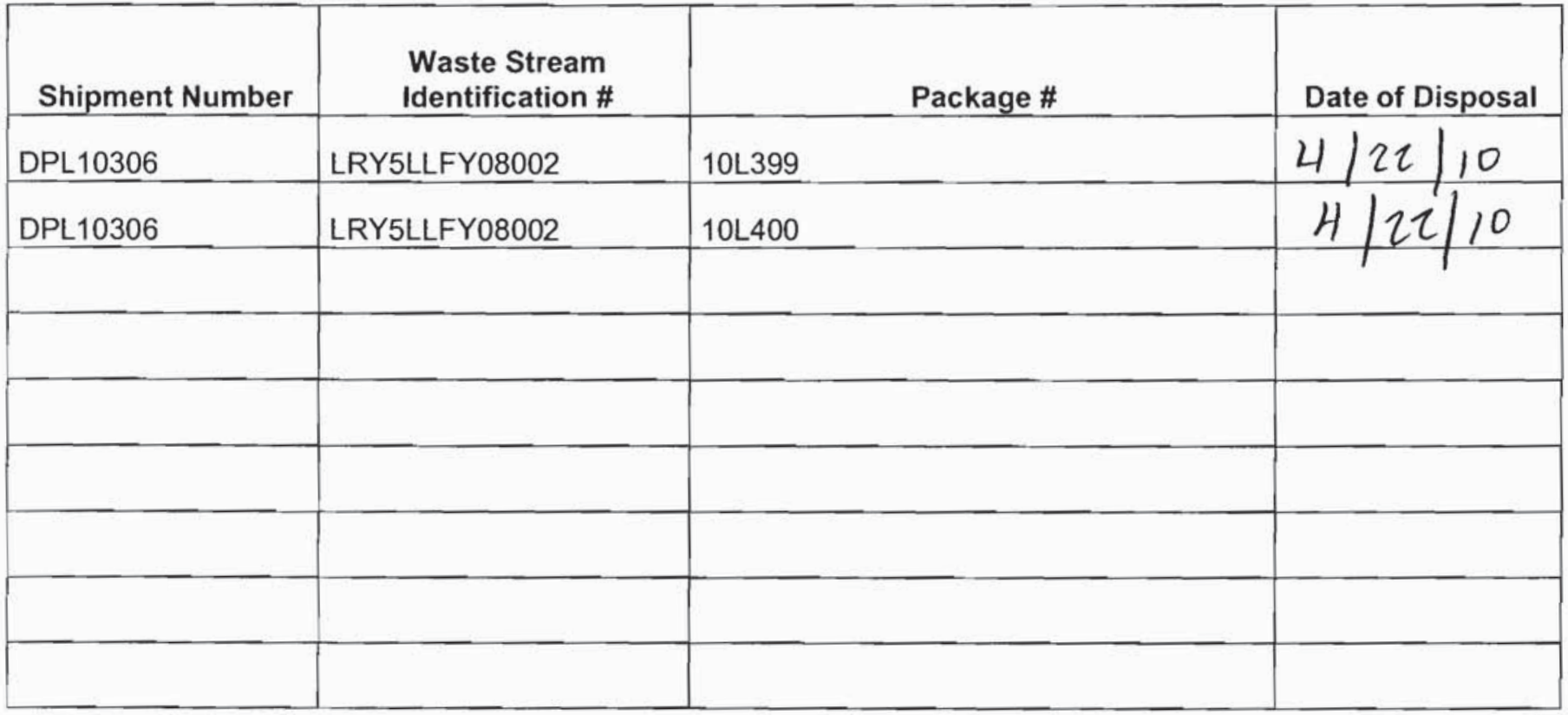

This certification is provided as a courtesy to the waste generator for information purposes only.

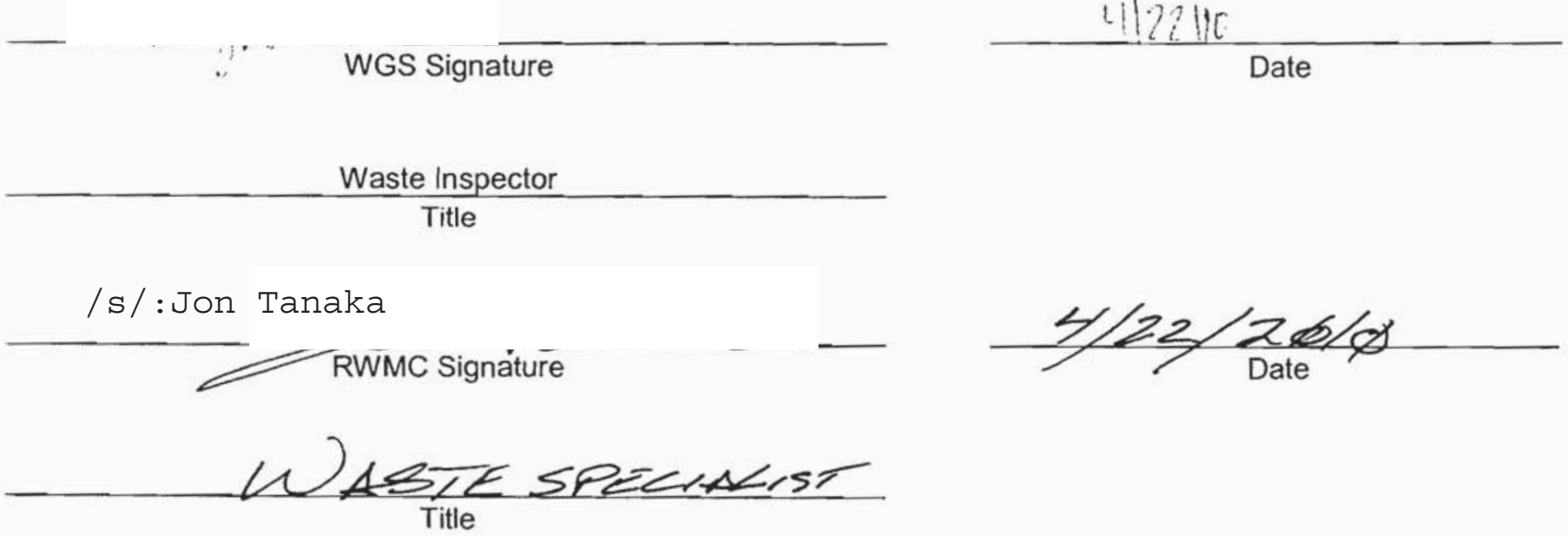


NSTec

Form

CERTIFICATE OF DISPOSAL

03/01/10

FRM-2217

(LOW LEVEL WASTE)

Rev. 01

Page 1 of 1

\section{Nevada Test Site}

This Certificate acknowledges that the following shipment(s) of waste have been disposed at the Nevada Test Site Radioactive Waste Management Complex.

\begin{tabular}{|l|l|l|l|}
\hline \multicolumn{1}{|c|}{ Shipment Number } & \multicolumn{1}{|c|}{$\begin{array}{c}\text { Waste Stream } \\
\text { Identification \# }\end{array}$} & Package \# & Date of Disposal \\
\hline DPL10307 & LRY5LLFY08002 & 10 L401 & 4-26-10 \\
\hline DPL10307 & LRY5LLFY08002 & 10 402 & $4 \cdot 26 / 0$ \\
\hline & & & \\
\hline & & & \\
\hline & & & \\
\hline & & & \\
\hline & & & \\
\hline
\end{tabular}

This certification is provided as a courtesy to the waste generator for information purposes only.

/sy: Theresa Hale

WGS Signature

Waste Inspector

Title

/s/:Jon Tanaka

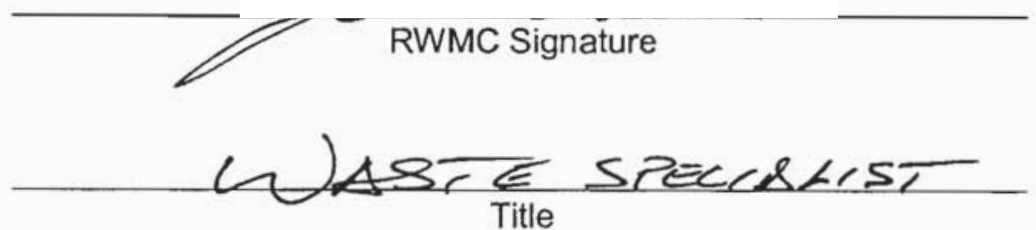

$\frac{4-26-10}{\text { Date }}$

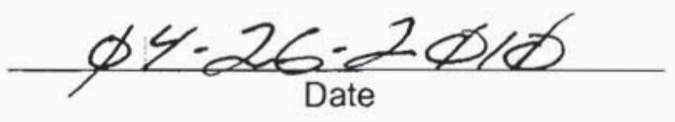




\begin{tabular}{|lcr|}
\hline NSTec & CERTIFICATE OF DISPOSAL & 03/01/10 \\
Form & Rev. 01 \\
FRM-2217 & (LOW LEVEL WASTE) & Page 1 of 1 \\
\hline
\end{tabular}

Nevada Test Site

This Certificate acknowledges that the following shipments) of waste have been disposed at the Nevada Test Site Radioactive Waste Management Complex.

\begin{tabular}{|l|l|l|c|}
\hline Shipment Number & \multicolumn{1}{|c|}{$\begin{array}{c}\text { Waste Stream } \\
\text { Identification \# }\end{array}$} & Package \# & Date of Disposal \\
\hline DPL10308 & LRY5LLFY08002 & $10 L 403$ & $4 \cdot 26-10$ \\
\hline DPL10308 & LRY5LLFY08002 & $10 L 404$ & $4-26-10$ \\
\hline & & & \\
\hline & & & \\
\hline & & & \\
\hline & & & \\
\hline & & & \\
\hline & & & \\
\hline
\end{tabular}

This certification is provided as a courtesy to the waste generator for information purposes only.

/s/ :Theresa Hale

$\frac{4-26-10}{\text { Date }}$

Waste Inspector

Title

/s/: Jon Tanka

RWMC Signature
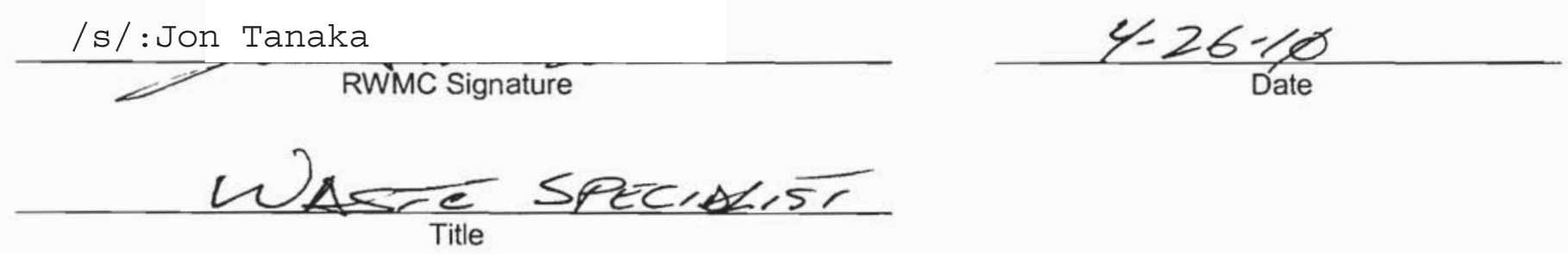

(Reference: OP-2151.304) 


\begin{tabular}{|lcr|}
\hline NSTec & CERTIFICATE OF DISPOSAL & 03/01/10 \\
Form & Rev. 01 \\
FRM-2217 & (LOW LEVEL WASTE) & Page 1 of 1 \\
\hline
\end{tabular}

Nevada Test Site

This Certificate acknowledges that the following shipments) of waste have been disposed at the Nevada Test Site Radioactive Waste Management Complex.

\begin{tabular}{|l|l|l|l|}
\hline \multicolumn{1}{c|}{$\begin{array}{c}\text { Waste Stream } \\
\text { Identification \# }\end{array}$} & \multicolumn{1}{c|}{ Package \# } & Date of Disposal \\
\hline DPL10309 & LRY5LLFY08002 & 10 L405 & $4-26 / \mathrm{C}$ \\
\hline DPL10309 & LRY5LLFY08002 & $10 L 406$ & $4-26 \cdot 1 \mathrm{C}$ \\
\hline & & & \\
\hline & & & \\
\hline & & & \\
\hline & & & \\
\hline & & & \\
\hline
\end{tabular}

This certification is provided as a courtesy to the waste generator for information purposes only.

/s/ :Theresa Hale

WGS Signature

Waste Inspector

Title

/s/: Jon Tanka

RWMC Signature-

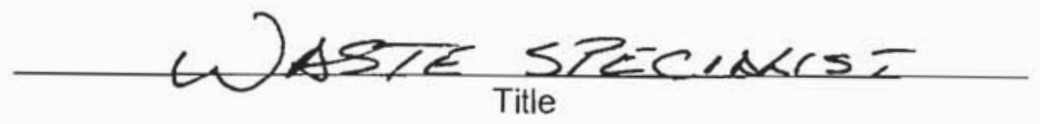

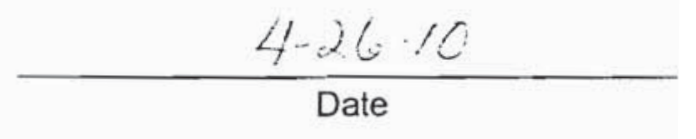

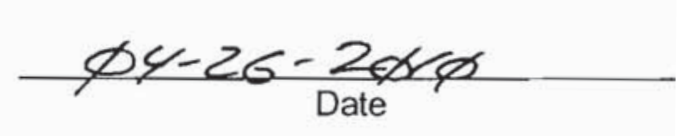

(Reference: OP-2151.304) 
NSTec

Form

FRM-2217
CERTIFICATE OF DISPOSAL

(LOW LEVEL WASTE)
03/01/10

Rev. 01

Page 1 of 1

\section{Nevada Test Site}

This Certificate acknowledges that the following shipment(s) of waste have been disposed at the Nevada Test Site Radioactive Waste Management Complex.

\begin{tabular}{|c|c|c|c|}
\hline Shipment Number & $\begin{array}{l}\text { Waste Stream } \\
\text { Identification \# }\end{array}$ & Package \# & Date of Disposal \\
\hline DPL10310 & LRY5LLFY08002 & $10\llcorner 407$ & $4-26-10$ \\
\hline DPL10310 & LRY5LLFY08002 & $10 \mathrm{~L} 408$ & $426-10$ \\
\hline & & & \\
\hline & & & \\
\hline & & & \\
\hline & & & \\
\hline & & & \\
\hline & & & \\
\hline
\end{tabular}

This certification is provided as a courtesy to the waste generator for information purposes only.

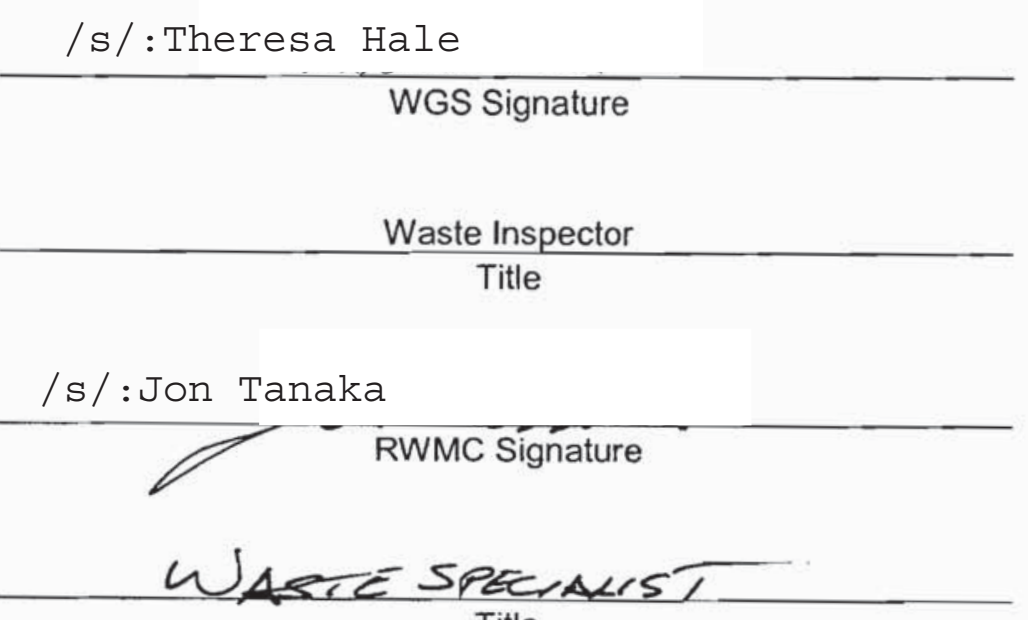

$\frac{426-10}{\text { Date }}$

Title 


\begin{tabular}{|lcr|}
\hline NSTec & CERTIFICATE OF DISPOSAL & $03 / 01 / 10$ \\
Form & Rev. 01 \\
FRM-2217 & (LOW LEVEL WASTE) & Page 1 of 1 \\
\hline
\end{tabular}

Nevada Test Site

This Certificate acknowledges that the following shipments) of waste have been disposed at the Nevada Test Site Radioactive Waste Management Complex.

\begin{tabular}{|l|l|l|l|}
\hline \multicolumn{1}{|c|}{ Shipment Number } & \multicolumn{1}{|c|}{$\begin{array}{c}\text { Waste Stream } \\
\text { Identification \# }\end{array}$} & Package \# & Date of Disposal \\
\hline DPL10311 & LRY5LLFY08002 & 10 L09 & $4 \cdot 26-10$ \\
\hline DPL10311 & LRY5LLFY08002 & 10 410 & $4 \cdot 26-10$ \\
\hline & & & \\
\hline & & & \\
\hline & & & \\
\hline & & & \\
\hline & & & \\
\hline & & & \\
\hline
\end{tabular}

This certification is provided as a courtesy to the waste generator for information purposes only.

/s/: Theresa Hale

WGS Signature

Waste Inspector

Title

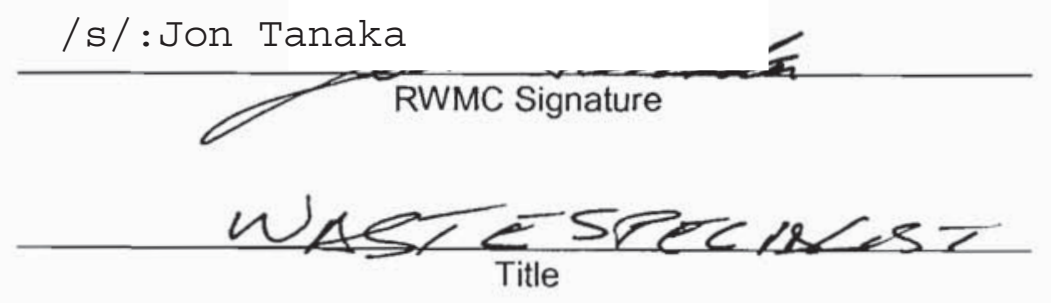

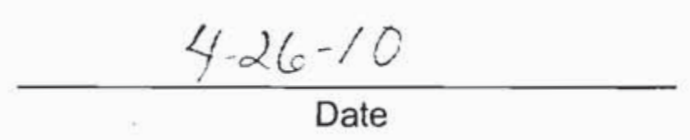

Date

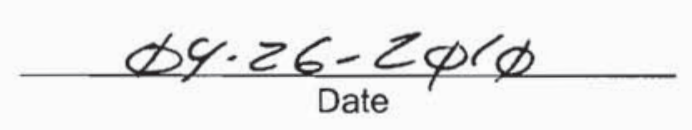




\begin{tabular}{|lcr|}
\hline NSTec & CERTIFICATE OF DISPOSAL & R/01/10 \\
Form & Rev. 01 \\
FRM-2217 & (LOW LEVEL WASTE) & Page 1 of 1 \\
\hline
\end{tabular}

Nevada Test Site

This Certificate acknowledges that the following shipments) of waste have been disposed at the Nevada Test Site Radioactive Waste Management Complex.

\begin{tabular}{|l|l|l|l|}
\hline \multicolumn{1}{|c|}{ Shipment Number } & \multicolumn{1}{|c|}{$\begin{array}{c}\text { Waste Stream } \\
\text { Identification \# }\end{array}$} & \multicolumn{1}{c|}{ Package \# } & Date of Disposal \\
\hline DPL10312 & LRY5LLFY08002 & $10 L 411$ & $4.26-10$ \\
\hline DPL10312 & LRY5LLFY08002 & $10 L 412$ & $4.26-10$ \\
\hline & & & \\
\hline & & & \\
\hline & & & \\
\hline & & & \\
\hline & & & \\
\hline
\end{tabular}

This certification is provided as a courtesy to the waste generator for information purposes only.

/s/: Theresa Hale

WGS Signature

Waste Inspector

Title
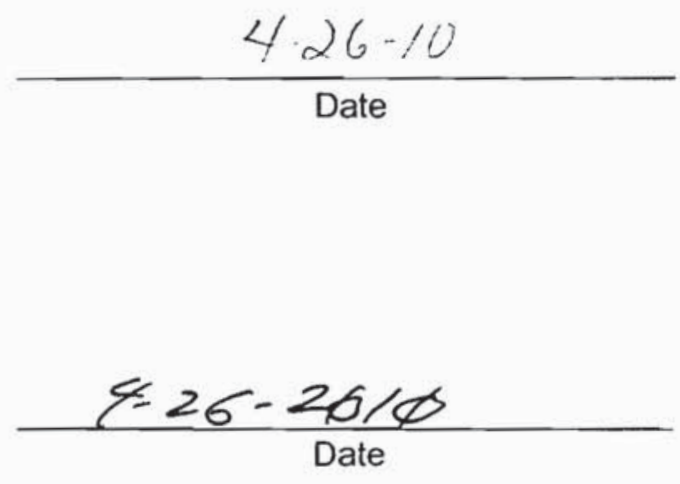

(Reference: OP-2151.304) 
NSTec

Form

FRM-2217
CERTIFICATE OF DISPOSAL

(LOW LEVEL WASTE)
03/01/10

Rev. 01

Page 1 of 1

\section{Nevada Test Site}

This Certificate acknowledges that the following shipment(s) of waste have been disposed at the Nevada Test Site Radioactive Waste Management Complex.

\begin{tabular}{|l|l|l|l|}
\hline \multicolumn{1}{|c|}{$\begin{array}{c}\text { Waste Stream } \\
\text { Identification \# }\end{array}$} & \multicolumn{1}{|c|}{ Package \# } & Date of Disposal \\
\hline DPL10313 & LRY5LLFY08002 & 10 L413 & $4-26-10$ \\
\hline DPL10313 & LRY5LLFY08002 & 10 L414 & $4 / \cdot 26 \cdot 10$ \\
\hline & & & \\
\hline & & & \\
\hline & & & \\
\hline & & & \\
\hline
\end{tabular}

This certification is provided as a courtesy to the waste generator for information purposes only.

/s/:Theresa Hale

WGS Signature

Waste Inspector
/s/:Jon Tanaka

RWMĆ Signature

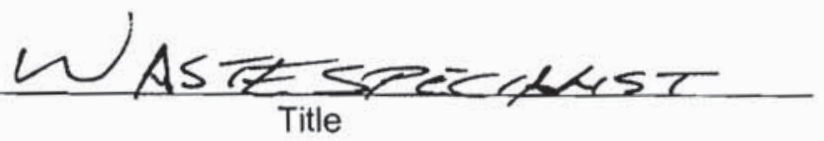

$4.26 \cdot 10$

Date

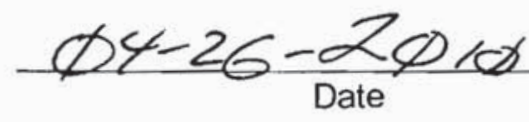




\begin{tabular}{|lcr|}
\hline NSTec & CERTIFICATE OF DISPOSAL & $03 / 01 / 10$ \\
Form & Rev. 01 \\
FRM-2217 & (LOW LEVEL WASTE) & Page 1 of 1 \\
\hline
\end{tabular}

Nevada Test Site

This Certificate acknowledges that the following shipments) of waste have been disposed at the Nevada Test Site Radioactive Waste Management Complex.

\begin{tabular}{|l|l|l|c|}
\hline \multicolumn{1}{|c|}{ Shipment Number } & \multicolumn{1}{|c|}{$\begin{array}{c}\text { Waste Stream } \\
\text { Identification \# }\end{array}$} & Package \# & Date of Disposal \\
\hline DPL10314 & LRY5LLFY08002 & $10 L 415$ & $4 \cdot 26-10$ \\
\hline DPL10314 & LRY5LLFY08002 & $10 L 416$ & $426-10$ \\
\hline & & & \\
\hline & & & \\
\hline & & & \\
\hline & & & \\
\hline & & & \\
\hline
\end{tabular}

This certification is provided as a courtesy to the waste generator for information purposes only.

/s/ :Theresa Hale

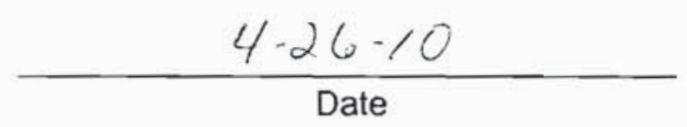

Waste Inspector

Title

/s/: Jon Tanka

RWMC Signature

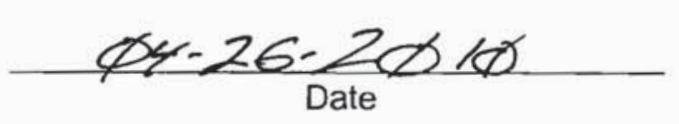

(Reference: OP -2151.304) 
NSTec

Form

FRM-2217
CERTIFICATE OF DISPOSAL

(LOW LEVEL WASTE)
$03 / 01 / 10$

Rev. 01

Page 1 of 1

\section{Nevada Test Site}

This Certificate acknowledges that the following shipment(s) of waste have been disposed at the Nevada Test Site Radioactive Waste Management Complex.

\begin{tabular}{|c|l|l|c|}
\hline \multicolumn{1}{|c|}{ Shipment Number } & $\begin{array}{c}\text { Waste Stream } \\
\text { Identification \# }\end{array}$ & \multicolumn{1}{|c|}{ Package \# } & Date of Disposal \\
\hline DPL10315 & LRY5LLFY08002 & 10 L417 & $4 \cdot 26 / 0$ \\
\hline DPL10315 & LRY5LLFY08002 & $10 L 418$ & $4 \cdot 26-10$ \\
\hline & & & \\
\hline & & & \\
\hline & & & \\
\hline & & & \\
\hline & & & \\
\hline & & & \\
\hline
\end{tabular}

This certification is provided as a courtesy to the waste generator for information purposes only.

/s/:Theresa Hale

WGS Signature

Waste Inspector

Title /s / :Jon Tanaka

$\checkmark$ ŔWMĆ Signature

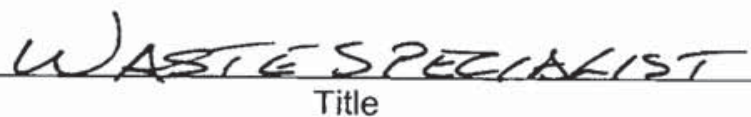

$4-26-10$

Date

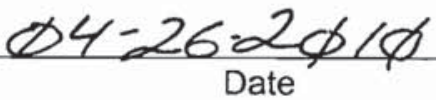


NSTec

Form

FRM-2217
CERTIFICATE OF DISPOSAL

(LOW LEVEL WASTE)
$03 / 01 / 10$

Rev. 01

Page 1 of 1

\section{Nevada Test Site}

This Certificate acknowledges that the following shipment(s) of waste have been disposed at the Nevada Test Site Radioactive Waste Management Complex.

\begin{tabular}{|l|l|l|l|}
\hline \multicolumn{1}{|c|}{ Shipment Number } & \multicolumn{1}{c|}{$\begin{array}{c}\text { Waste Stream } \\
\text { Identification \# }\end{array}$} & Package \# & Date of Disposal \\
\hline DPL10316 & LRY5LLFY08002 & 10 419 & 4-27-10 \\
\hline DPL10316 & LRY5LLFY08002 & 10 L420 & $4-27-10$ \\
\hline & & & \\
\hline & & & \\
\hline & & & \\
\hline & & & \\
\hline & & & \\
\hline
\end{tabular}

This certification is provided as a courtesy to the waste generator for information purposes only.

WGS Signature

Waste Inspector

Title
U.11)

Date

/s/:Jon Tanaka

RWMC Signăture

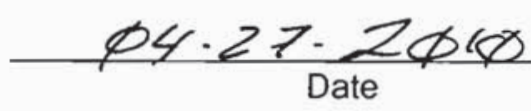


NSTec

Form

FRM-2217
CERTIFICATE OF DISPOSAL

(LOW LEVEL WASTE)
03/01/10

Rev. 01

Page 1 of 1

\section{Nevada Test Site}

This Certificate acknowledges that the following shipment(s) of waste have been disposed at the Nevada Test Site Radioactive Waste Management Complex.

\begin{tabular}{|l|l|l|l|}
\hline \multicolumn{1}{|c|}{$\begin{array}{c}\text { Whipment Number } \\
\text { Identification \# }\end{array}$} & \multicolumn{1}{c|}{ Package \# } & Date of Disposal \\
\hline DPL10317 & LRY5LLFY08002 & $\begin{array}{c}\text { 10L421 } \\
-102421\end{array}$ 7H 4-29-10 & $4-27-10$ \\
\hline DPL10317 & LRY5LLFY08002 & 10 L22 & $4-27-10$ \\
\hline & & & \\
\hline & & & \\
\hline & & & \\
\hline & & & \\
\hline
\end{tabular}

This certification is provided as a courtesy to the waste generator for information purposes only.

WGS Signature

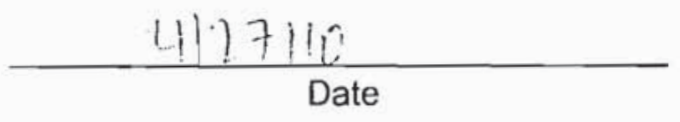

Waste Inspector

Title

/s/:Jon Tanaka

RWMC Signature

$\phi 4-27-2 \phi r \infty$

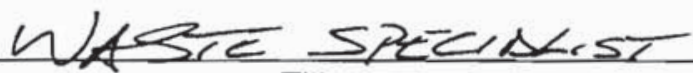

Title 


\begin{tabular}{|lcr|}
\hline NSTec & CERTIFICATE OF DISPOSAL & $03 / 01 / 10$ \\
Form & Rev. 01 \\
FRM-2217 & (LOW LEVEL WASTE) & Page 1 of 1 \\
\hline
\end{tabular}

Nevada Test Site

This Certificate acknowledges that the following shipments) of waste have been disposed at the Nevada Test Site Radioactive Waste Management Complex.

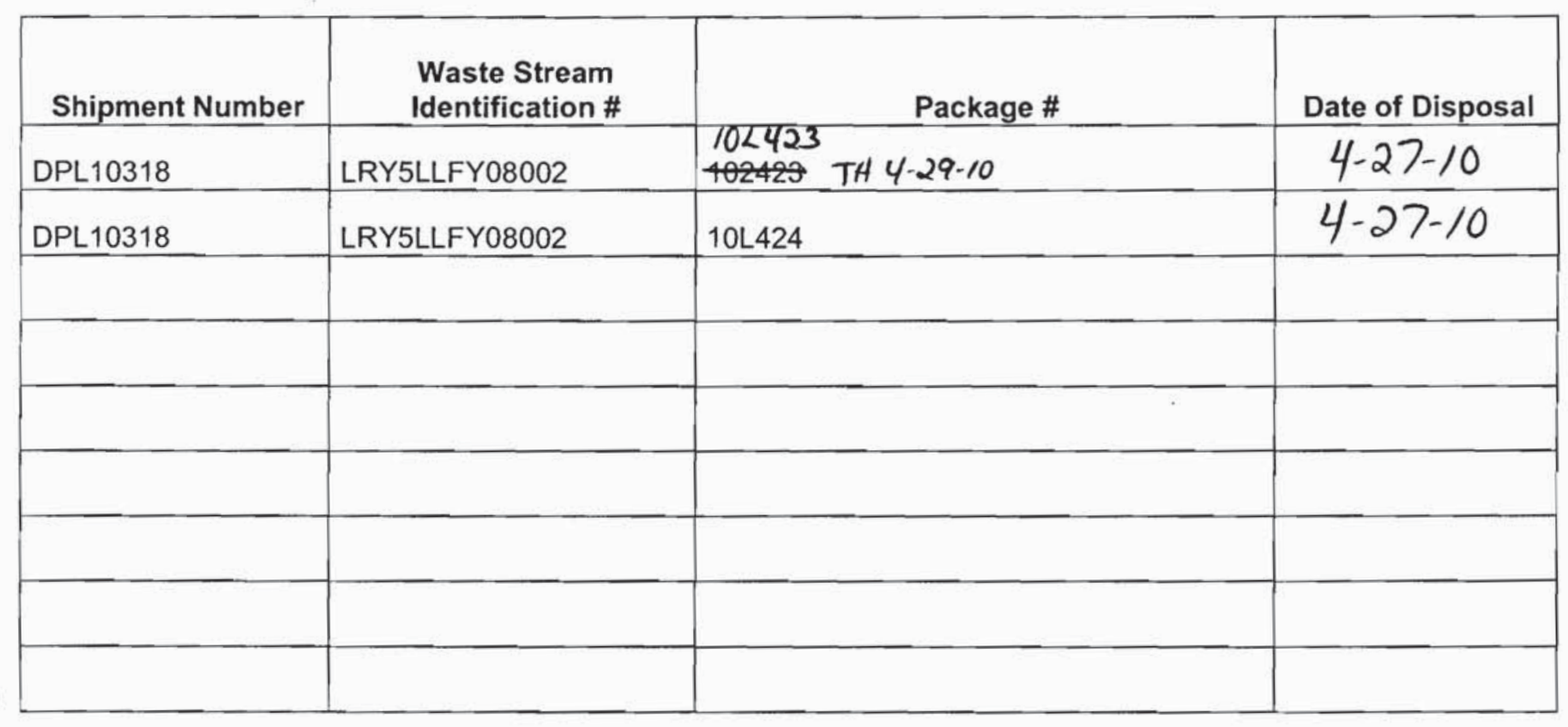

This certification is provided as a courtesy to the waste generator for information purposes only.

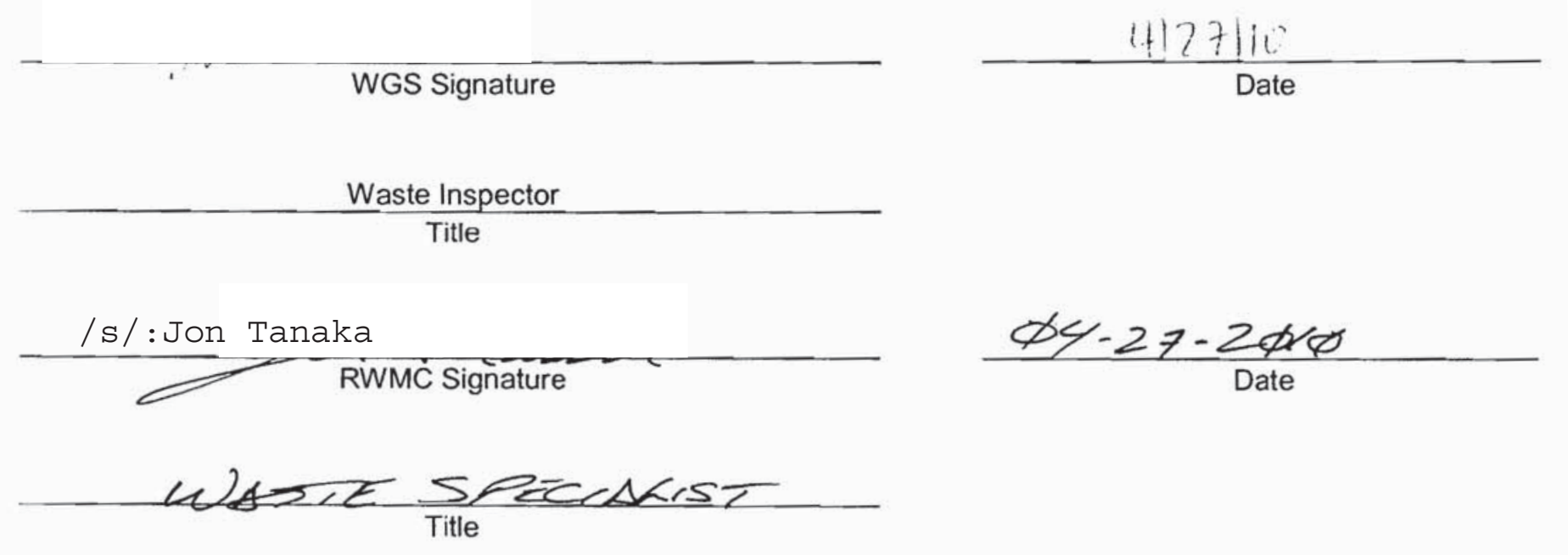


NSTec

Form

FRM-2217
CERTIFICATE OF DISPOSAL

(LOW LEVEL WASTE)
03/01/10

Rev. 01

Page 1 of 1

\section{Nevada Test Site}

This Certificate acknowledges that the following shipment(s) of waste have been disposed at the Nevada Test Site Radioactive Waste Management Complex.

\begin{tabular}{|l|l|l|c|}
\hline Shipment Number & \multicolumn{1}{|c|}{$\begin{array}{c}\text { Waste Stream } \\
\text { Identification \# }\end{array}$} & \multicolumn{1}{|c|}{ Package \# } & Date of Disposal \\
\hline DPL10319 & LRY5LLFY08002 & $\begin{array}{c}102425 \\
-102425\end{array}$ JH $4-29-10$ & $4-27-10$ \\
\hline DPL10319 & LRY5LLFY08002 & 10 L426 & $4-27-10$ \\
\hline & & & \\
\hline & & & \\
\hline & & & \\
\hline & & & \\
\hline
\end{tabular}

This certification is provided as a courtesy to the waste generator for information purposes only.

WGS Signature

Waste Inspector

Title
/s/:Jon Tanaka

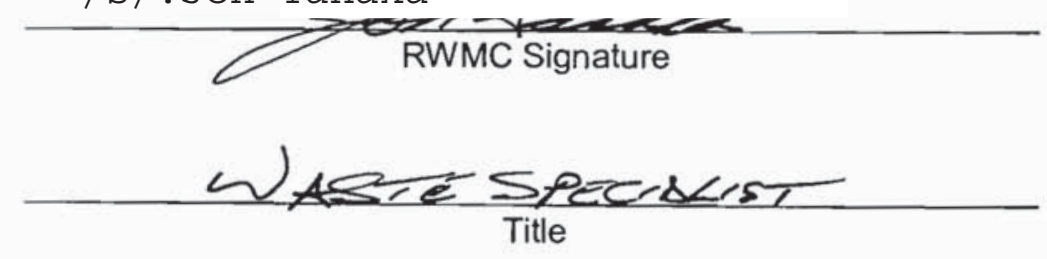

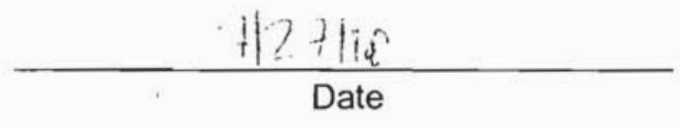

$\frac{\phi<-2 z-2 \phi 1 \phi}{\text { Date }}$ 


\begin{tabular}{|lcr|}
\hline NSTec & CERTIFICATE OF DISPOSAL & $03 / 01 / 10$ \\
Form & (LOW LEVEL WASTE) & Rev. 01 \\
FRM-2217 & Page 1 of 1 \\
\hline
\end{tabular}

Nevada Test Site

This Certificate acknowledges that the following shipments) of waste have been disposed at the Nevada Test Site Radioactive Waste Management Complex.

\begin{tabular}{|l|l|l|l|}
\hline Shipment Number & \multicolumn{1}{|c|}{$\begin{array}{c}\text { Waste Stream } \\
\text { Identification \# }\end{array}$} & \multicolumn{1}{c|}{ Package \# } & Date of Disposal \\
\hline DPL10320 & LRY5LLFY08002 & $\begin{array}{c}102427 \\
102427\end{array}$ TH 4-29-10 & $4-27-10$ \\
\hline DPL10320 & LRY5LLFY08002 & $10 L 428$ & $4-27-10$ \\
\hline & & & \\
\hline & & & \\
\hline & & & \\
\hline & & & \\
\hline & & & \\
\hline & & & \\
\hline
\end{tabular}

This certification is provided as a courtesy to the waste generator for information purposes only.

WGS Signature

Waste Inspector

Title

/s/: Jon Tanka

RWMC Signature

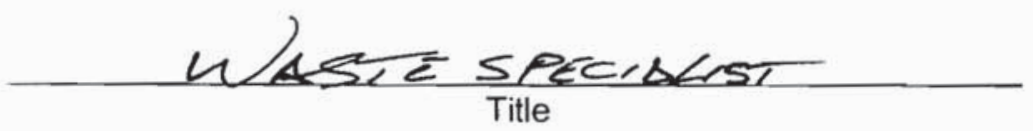

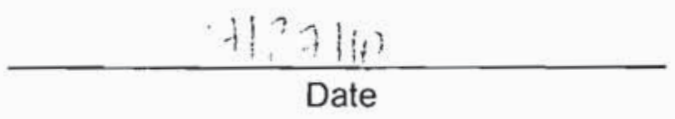

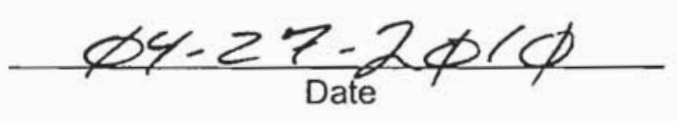

(Reference: OP-2151.304) 


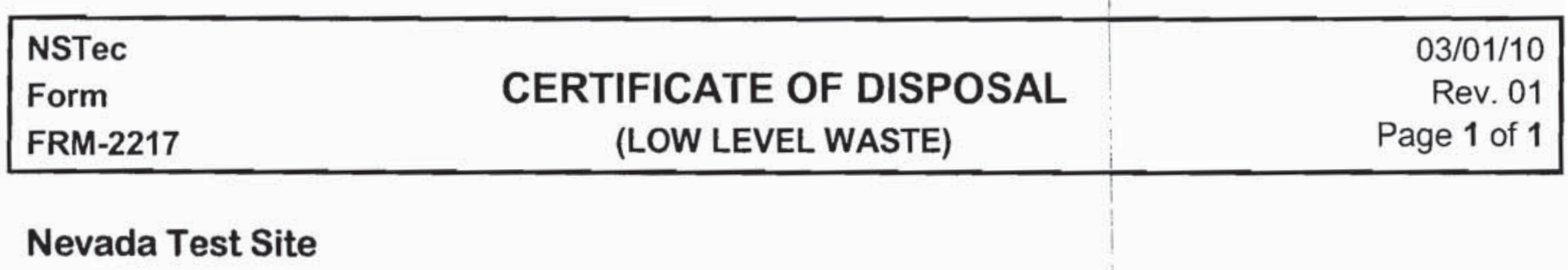

This Certificate acknowledges that the following shipments) of waste have been disposed at the Nevada Test Site Radioactive Waste Management Complex.

\begin{tabular}{|l|l|l|l|l|}
\hline Shipment Number & \multicolumn{1}{|c|}{$\begin{array}{c}\text { Waste Stream } \\
\text { Identification \# }\end{array}$} & \multicolumn{1}{c|}{ Package \# } & Date of Disposal \\
\hline DPL10321 & LRY5LLFY08002 & $\begin{array}{l}\text { ToL429 } \\
\text { T02420 TH 4-29-10 }\end{array}$ & $4-27-10$ \\
\hline DPL10321 & LRY5LLFY08002 & $10 L 430$ & & $4-27-10$ \\
\hline & & & & \\
\hline & & & & \\
\hline & & & & \\
\hline & & & & \\
\hline & & & & \\
\hline & & & & \\
\hline
\end{tabular}

This certification is provided as a courtesy to the waste generator for information purposes only.
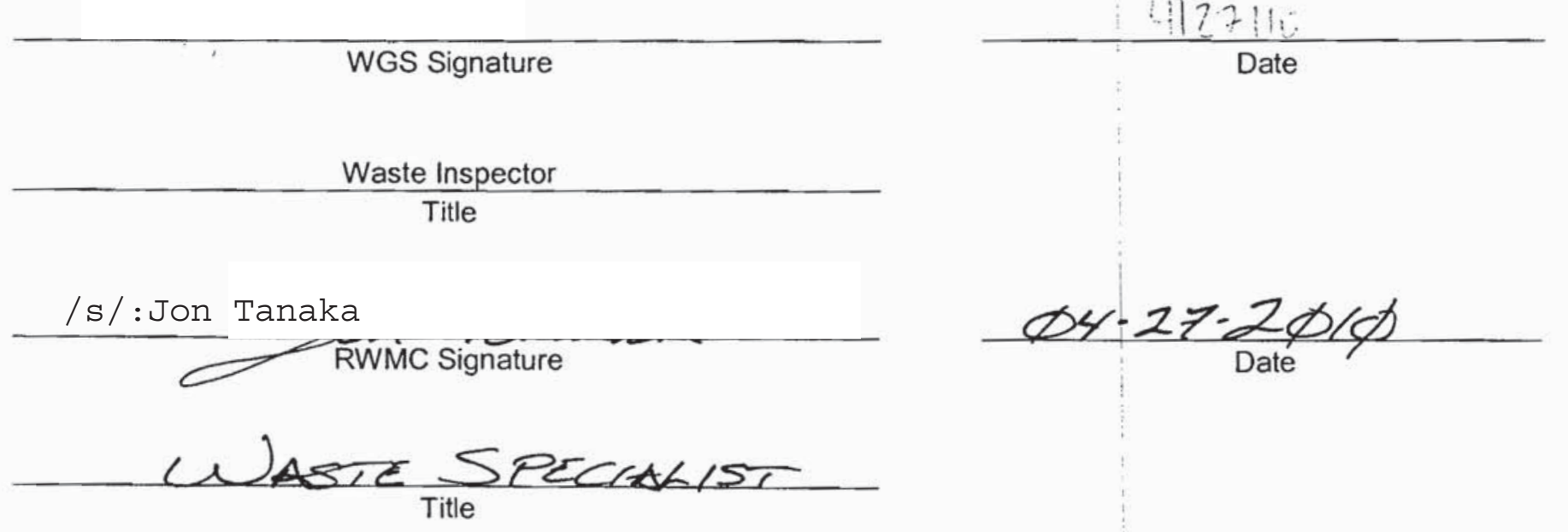

(Reference: OP-2151.304) 
NSTec

Form

FRM-2217
CERTIFICATE OF DISPOSAL

(LOW LEVEL WASTE)
03/01/10

Rev. 01

Page 1 of 1

\section{Nevada Test Site}

This Certificate acknowledges that the following shipment(s) of waste have been disposed at the Nevada Test Site Radioactive Waste Management Complex.

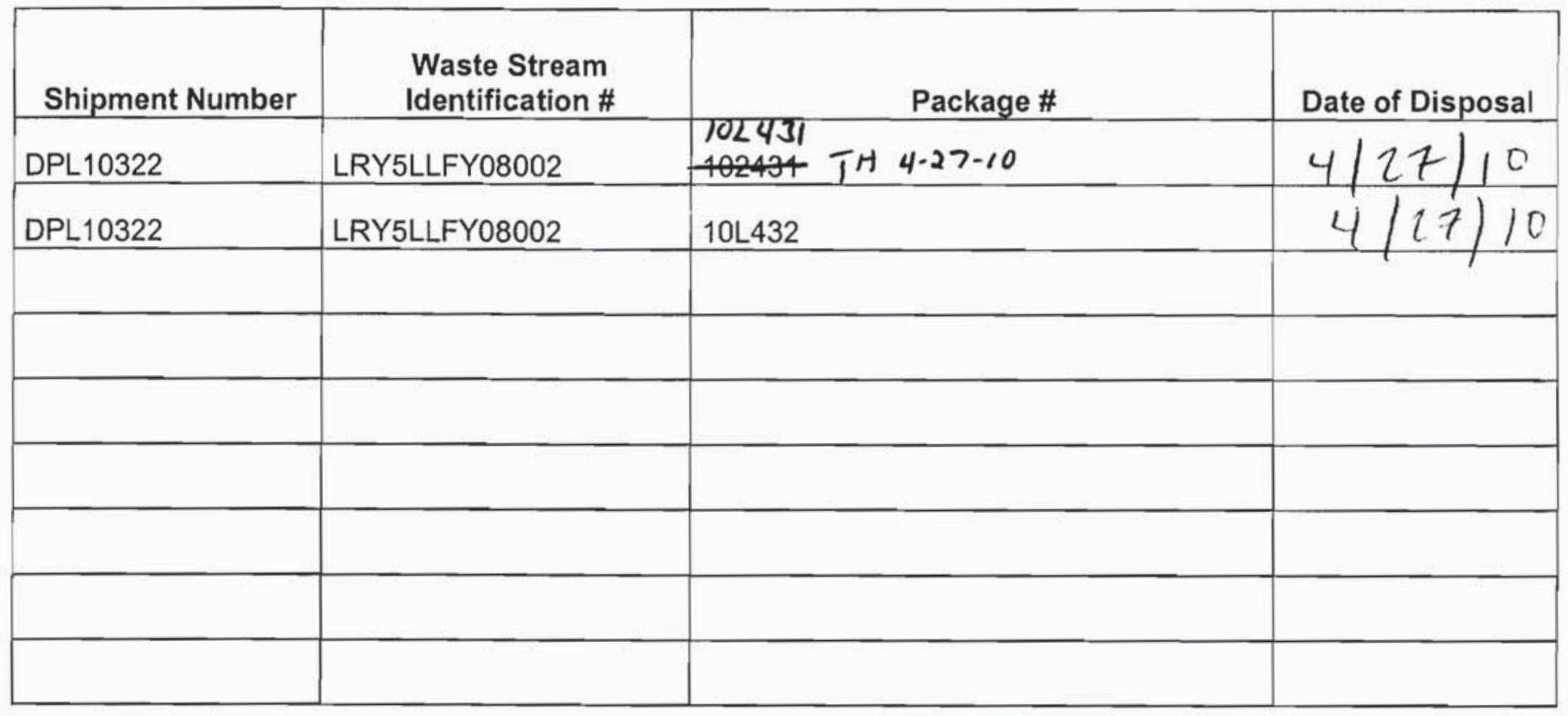

This certification is provided as a courtesy to the waste generator for information purposes only.

\begin{tabular}{c}
\hline WGS Signature \\
Waste Inspector \\
Title
\end{tabular}

$\frac{4127110}{\text { Date }}$

/s/: Jon Tanaka

RWMC Signature

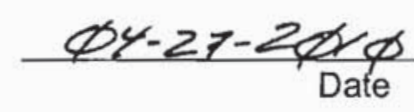

WHSSEE SPECLALIST 
NSTec

Form

FRM-2217
CERTIFICATE OF DISPOSAL (LOW LEVEL WASTE)
03/01/10

Rev. 01

Page 1 of 1

\section{Nevada Test Site}

This Certificate acknowledges that the following shipment(s) of waste have been disposed at the Nevada Test Site Radioactive Waste Management Complex.

\begin{tabular}{|l|l|l|l|c|}
\hline \multicolumn{1}{|c|}{$\begin{array}{c}\text { Whipment Number } \\
\text { Identification \# }\end{array}$} & \multicolumn{1}{|c|}{ Package \# } & & Date of Disposal \\
\hline DPL10323 & LRY5LLFY08002 & $10<433$ TH 4-29-10 & $4-27-10$ \\
\hline DPL10323 & LRY5LLFY08002 & 10 102434 & & $4-27-10$ \\
\hline & & & & \\
\hline & & & & \\
\hline & & & & \\
\hline
\end{tabular}

This certification is provided as a courtesy to the waste generator for information purposes only.

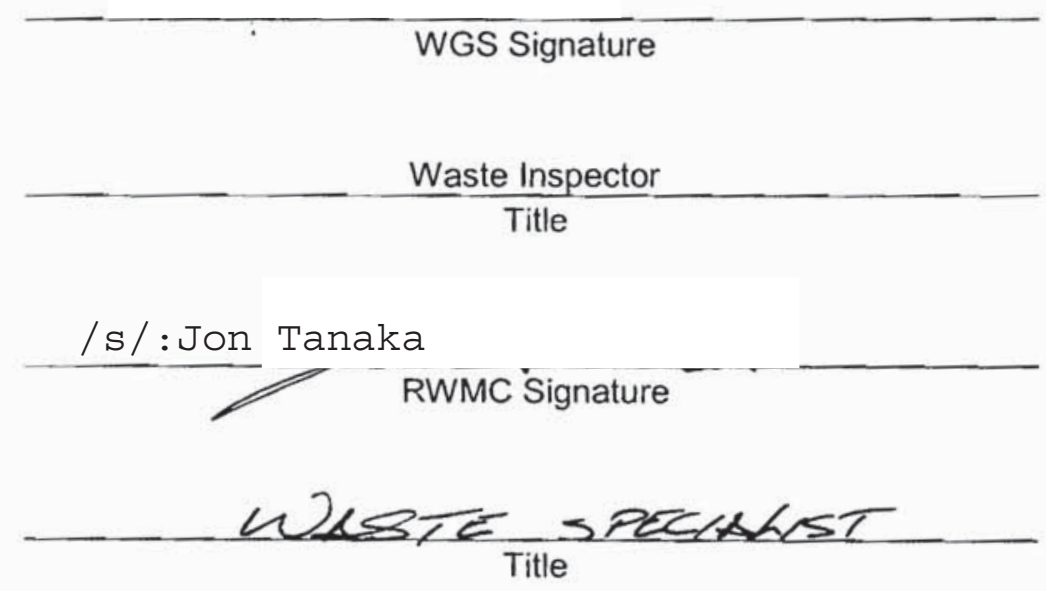
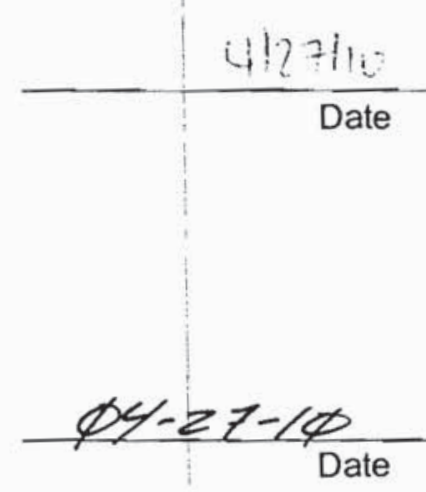
NSTec

Form

FRM-2217
CERTIFICATE OF DISPOSAL

(LOW LEVEL WASTE)
03/01/10

Rev. 01

Page 1 of 1

\section{Nevada Test Site}

This Certificate acknowledges that the following shipment(s) of waste have been disposed at the Nevada Test Site Radioactive Waste Management Complex.

\begin{tabular}{|c|c|c|c|}
\hline Shipment Number & $\begin{array}{l}\text { Waste Stream } \\
\text { Identification \# }\end{array}$ & $\mathrm{T}^{12^{x^{-1}}} \quad$ Package \# & Date of Disposal \\
\hline DPL10324 & LRY5LLFY08002 & 102435 & $4-28-10$ \\
\hline DPL10324 & LRY5LLFY08002 & $10 \mathrm{~L} 436$ & $4-28-10$ \\
\hline & & & \\
\hline & & & \\
\hline & & & \\
\hline & & & \\
\hline & & & \\
\hline & 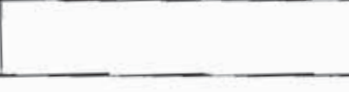 & & \\
\hline
\end{tabular}

This certification is provided as a courtesy to the waste generator for information purposes only.

/s/:Theresa Hale

WGS Signature

Waste Inspector

Title
/s/:Jon Tanaka

R'WMC Signature

WASTE SPECLNIST $\frac{4 \cdot 2 \gamma \cdot 10}{\text { Date }}$

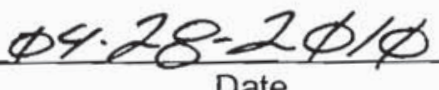




\begin{tabular}{|lcr|}
\hline NSTec & CERTIFICATE OF DISPOSAL & Rev. 01 \\
Form & (LOW LEVEL WASTE) & Page 1 of 1 \\
FRM-2217 & C \\
\hline
\end{tabular}

Nevada Test Site

This Certificate acknowledges that the following shipments) of waste have been disposed at the Nevada Test Site Radioactive Waste Management Complex.

\begin{tabular}{|l|l|l|l|}
\hline Shipment Number & \multicolumn{1}{c|}{$\begin{array}{c}\text { Waste Stream } \\
\text { Identification \# }\end{array}$} & \multicolumn{1}{c|}{ Package \# } & Date of Disposal \\
\hline DPL10325 & LRY5LLFY08002 & $\begin{array}{c}104437 \\
\text { LR 2437 TH 4-28-10 }\end{array}$ & $4-2 \gamma-10$ \\
\hline DPL10325 & LRY5LLFY08002 & $10 L 438$ & $4-2 \gamma-10$ \\
\hline & & & \\
\hline & & & \\
\hline & & & \\
\hline & & & \\
\hline & & & \\
\hline & & & \\
\hline
\end{tabular}

This certification is provided as a courtesy to the waste generator for information purposes only.

/s/ :Theresa Hale

WGS Signature

Waste Inspector

Title

/s/ :Jon Tanaka

RWMC Signature

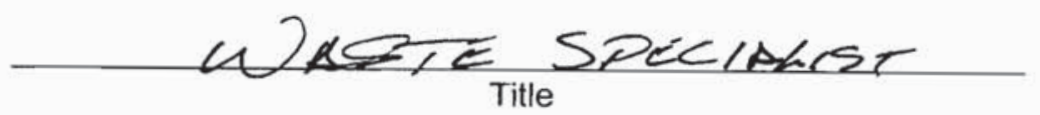

$\frac{4-2 \gamma-10}{\text { Date }}$

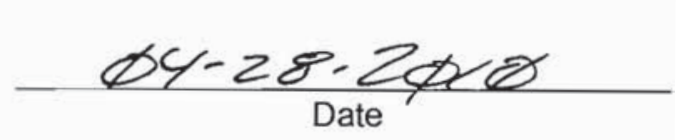

(Reference: OP-2151.304) 
NSTec

Form

FRM-2217
CERTIFICATE OF DISPOSAL

(LOW LEVEL WASTE)
$03 / 01 / 10$

Rev. 01

Page 1 of 1

\section{Nevada Test Site}

This Certificate acknowledges that the following shipment(s) of waste have been disposed at the Nevada Test Site Radioactive Waste Management Complex.

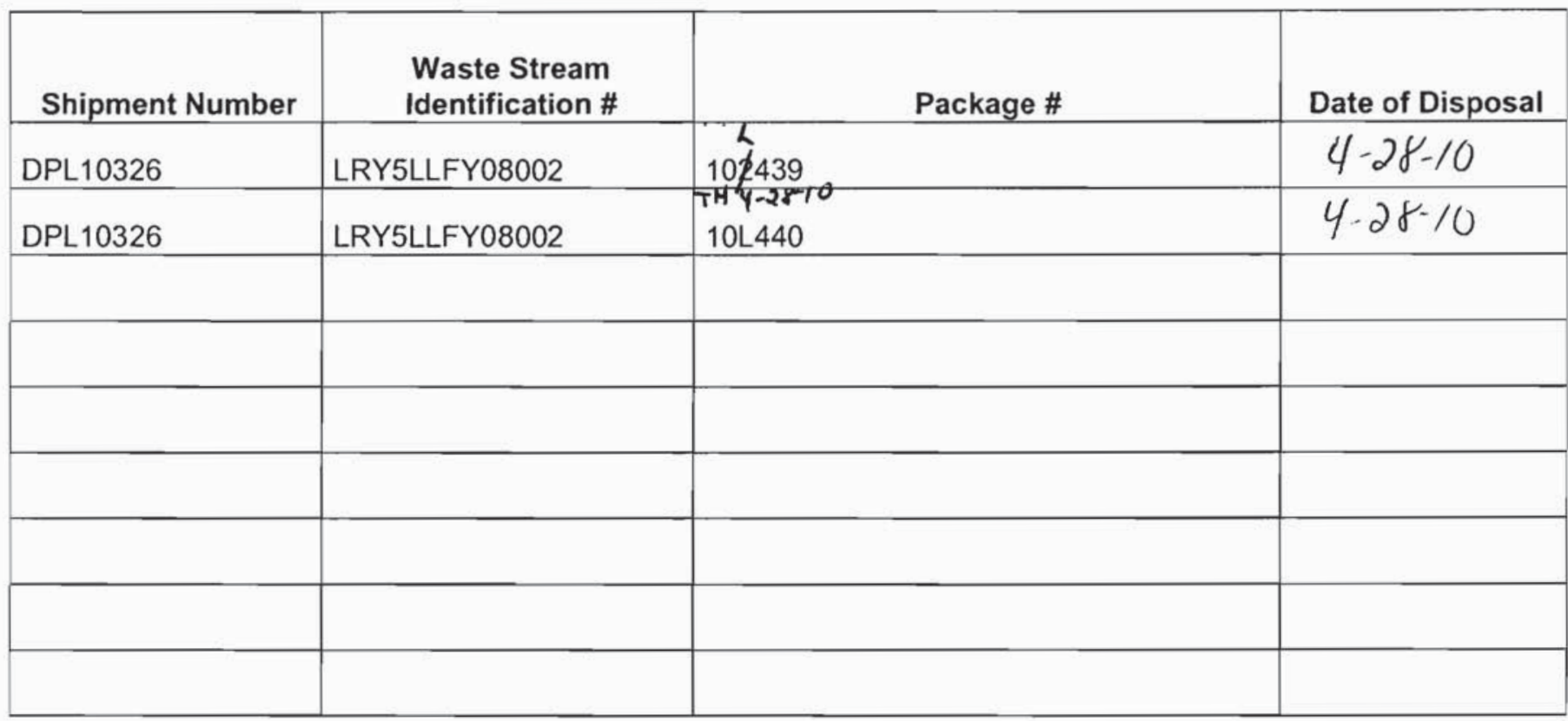

This certification is provided as a courtesy to the waste generator for information purposes only.

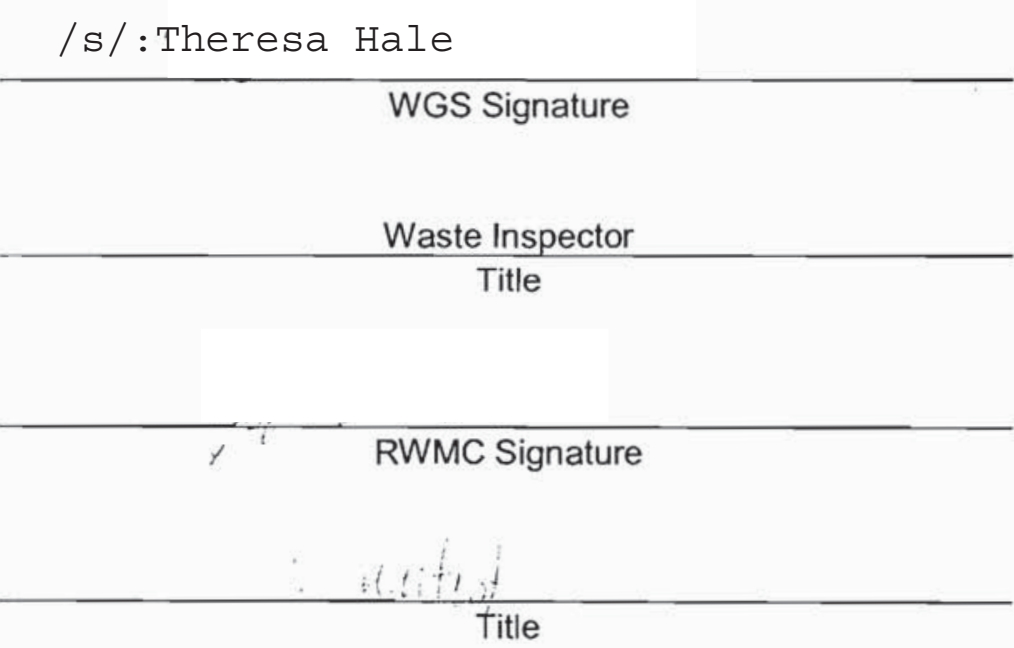

$\frac{4-2 \gamma-10}{\text { Date }}$

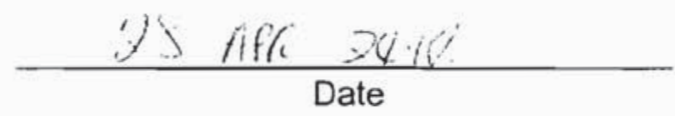


NSTec

Form

CERTIFICATE OF DISPOSAL

FRM-2217

(LOW LEVEL WASTE)

Rev. 01

Page 1 of 1

\section{Nevada Test Site}

This Certificate acknowledges that the following shipment(s) of waste have been disposed at the Nevada Test Site Radioactive Waste Management Complex.

\begin{tabular}{|l|l|l|l|}
\hline Shipment Number & \multicolumn{1}{|c|}{$\begin{array}{c}\text { Waste Stream } \\
\text { Identification \# }\end{array}$} & \multicolumn{1}{c|}{ Package \# } & Date of Disposal \\
\hline DPL10327 & LRY5LLFY08002 & 10 4441 & $4 / 29 / 10$ \\
\hline DPL10327 & LRY5LLFY08002 & 10 L442 & $4 / 29 / 10$ \\
\hline & & & \\
\hline & & & \\
\hline & & & \\
\hline & & & \\
\hline & & & \\
\hline & & & \\
\hline
\end{tabular}

This certification is provided as a courtesy to the waste generator for information purposes only.

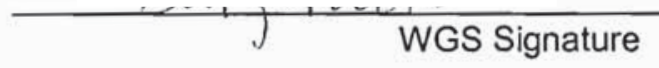

Waste Inspector

Title

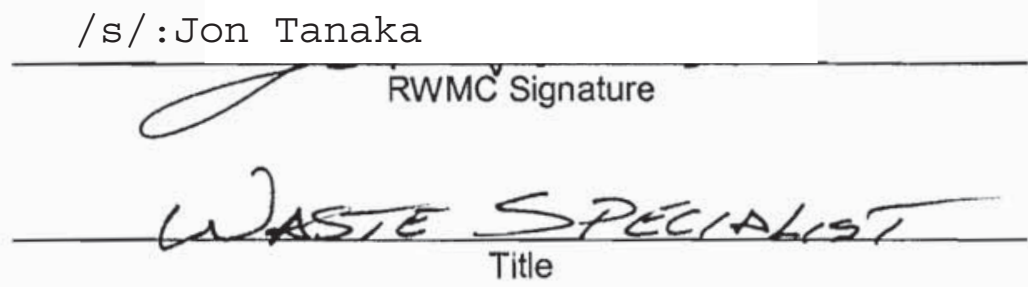

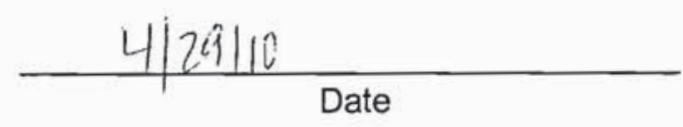

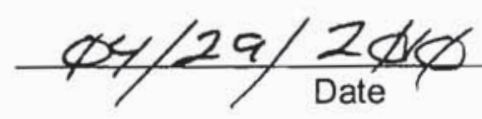


NSTec

Form

CERTIFICATE OF DISPOSAL

03/01/10

FRM-2217

(LOW LEVEL WASTE)

Rev. 01

Page 1 of 1

\section{Nevada Test Site}

This Certificate acknowledges that the following shipment(s) of waste have been disposed at the Nevada Test Site Radioactive Waste Management Complex.

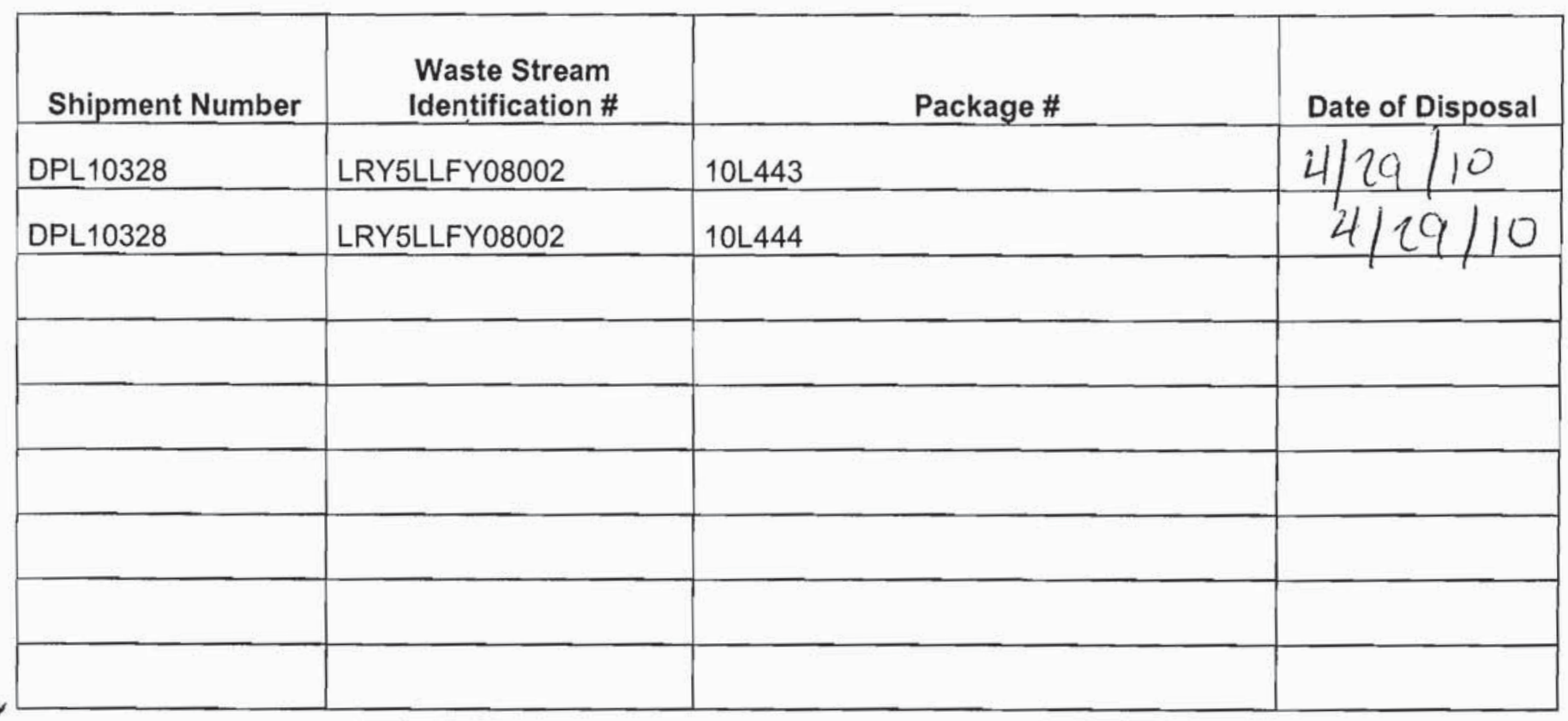

This certification is provided as a courtesy to the waste generator for information purposes only.

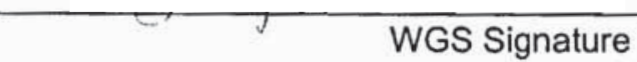

Waste Inspector

$$
\text { Title }
$$

/s/: Jon Tanaka

7 RWMC Signature

$\frac{\text { Q. }}{29-2 \phi \%}$ 
NSTec

Form

CERTIFICATE OF DISPOSAL

$03 / 01 / 10$

FRM-2217

(LOW LEVEL WASTE)

Rev. 01

Page 1 of 1

\section{Nevada Test Site}

This Certificate acknowledges that the following shipment(s) of waste have been disposed at the Nevada Test Site Radioactive Waste Management Complex.

\begin{tabular}{|c|c|c|c|}
\hline Shipment Number & $\begin{array}{l}\text { Waste Stream } \\
\text { Identification \# }\end{array}$ & Package \# & Date of Disposal \\
\hline DPL10329 & LRY5LLFY08002 & 101445 & 4129,0 \\
\hline DPL10329 & LRY5LLFY08002 & $10 \mathrm{~L} 446$ & $4 \cdot 29: 10$ \\
\hline & & & \\
\hline & & & \\
\hline & & & \\
\hline & & & \\
\hline & & & \\
\hline & & & \\
\hline
\end{tabular}

This certification is provided as a courtesy to the waste generator for information purposes only.

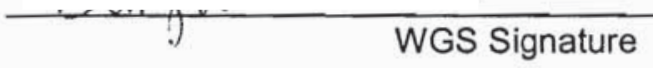

Waste Inspector

Title

/s/:Jon Tanaka

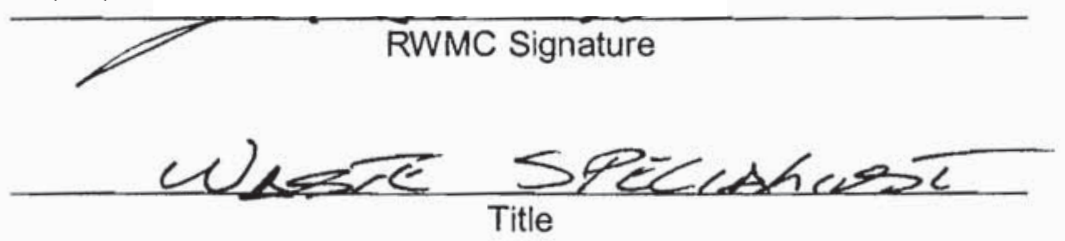

4129110

Date

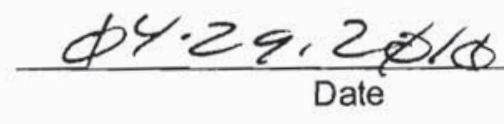




\begin{tabular}{|lcr|}
\hline NSTec & CERTIFICATE OF DISPOSAL & $03 / 01 / 10$ \\
Form & Rev. 01 \\
FRM-2217 & (LOW LEVEL WASTE) & Page 1 of 1 \\
\hline
\end{tabular}

Nevada Test Site

This Certificate acknowledges that the following shipments) of waste have been disposed at the Nevada Test Site Radioactive Waste Management Complex.

\begin{tabular}{|l|l|l|c|}
\hline \multicolumn{1}{|c|}{$\begin{array}{c}\text { Waste Stream } \\
\text { Identification \# }\end{array}$} & \multicolumn{1}{c|}{ Package \# } & Date of Disposal \\
\hline DPL10330 & LRY5LLFY08002 & $10 L 447$ & $4 / 29 / 10$ \\
\hline DPL10330 & LRY5LLFY08002 & $10 L 448$ & $4 / 29 / 10$ \\
\hline & & & \\
\hline & & & \\
\hline & & & \\
\hline & & & \\
\hline & & & \\
\hline & & & \\
\hline
\end{tabular}

This certification is provided as a courtesy to the waste generator for information purposes only.

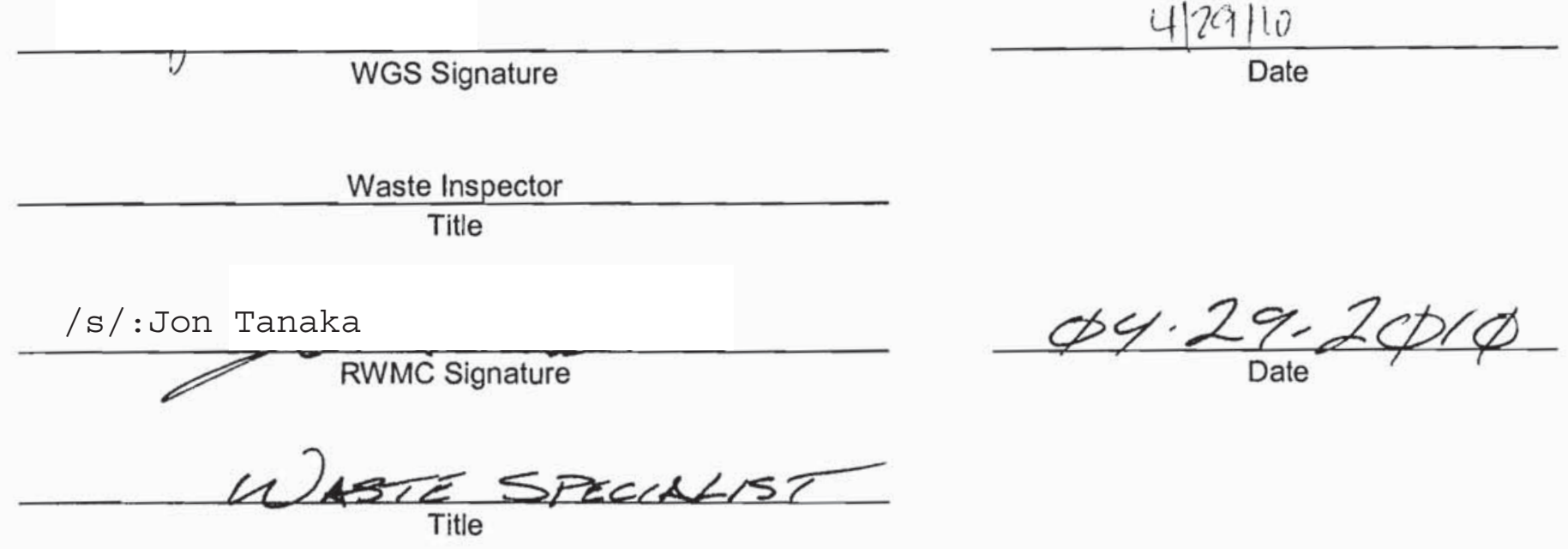

(Reference: OP-2151.304) 
NSTec

Form

FRM-2217
CERTIFICATE OF DISPOSAL

(LOW LEVEL WASTE)
$03 / 01 / 10$

Rev. 01

Page 1 of 1

\section{Nevada Test Site}

This Certificate acknowledges that the following shipment(s) of waste have been disposed at the Nevada Test Site Radioactive Waste Management Complex.

\begin{tabular}{|l|l|l|l|}
\hline Shipment Number & \multicolumn{1}{|c|}{$\begin{array}{c}\text { Waste Stream } \\
\text { Identification \# }\end{array}$} & Package \# & Date of Disposal \\
\hline DPL10331 & LRY5LLFY08002 & 10 449 & $4 / 29 / 10$ \\
\hline DPL10331 & LRY5LLFY08002 & 10 450 & $4 / 29 / 10$ \\
\hline & & & \\
\hline & & & \\
\hline & & & \\
\hline & & & \\
\hline & & & \\
\hline
\end{tabular}

This certification is provided as a courtesy to the waste generator for information purposes only.

WGS Signature

Waste Inspector

Title

/s/:Jon Tanaka

RWMC Signature

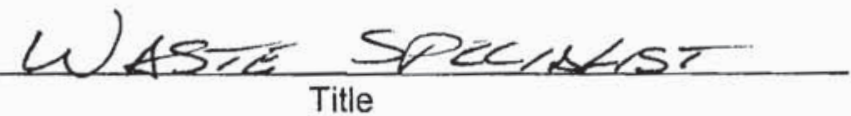

$4 \mid 20110$

Date

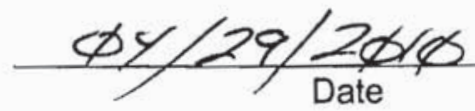


NSTec

Form

FRM-2217
CERTIFICATE OF DISPOSAL

(LOW LEVEL WASTE)
03/01/10

Rev. 01

Page 1 of 1

\section{Nevada Test Site}

This Certificate acknowledges that the following shipment(s) of waste have been disposed at the Nevada Test Site Radioactive Waste Management Complex.

\begin{tabular}{|c|c|c|c|}
\hline Shipment Number & $\begin{array}{l}\text { Waste Stream } \\
\text { Identification \# }\end{array}$ & Package \# & Date of Disposal \\
\hline DPL10332 & LRY5LLFY08002 & $10 L 451$ & 412910 \\
\hline DPL10332 & LRY5LLFY08002 & $10 L 452$ & $\varnothing$ \\
\hline & & & \\
\hline & & & \\
\hline & & & \\
\hline & & & \\
\hline & & & \\
\hline & & & \\
\hline
\end{tabular}

This certification is provided as a courtesy to the waste generator for information purposes only.

WGS Signature

Waste Inspector

$$
\text { Title }
$$

/s/: Jon Tanaka

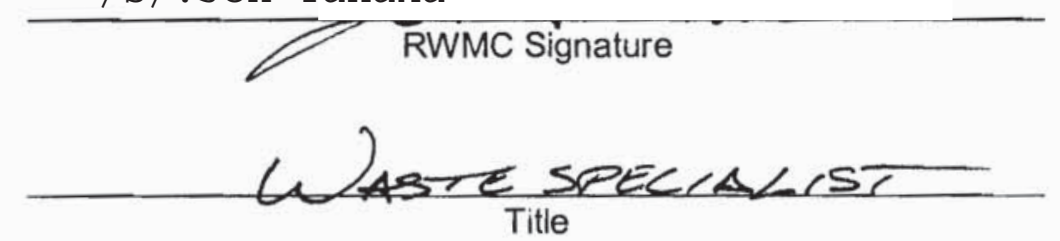

$4 \longdiv { 2 9 1 1 0 }$

Date

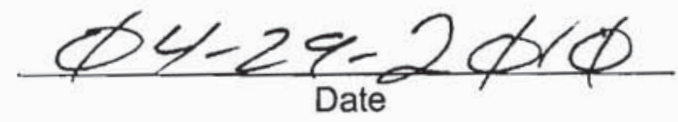




\begin{tabular}{|lcr|}
\hline NSTec & CERTIFICATE OF DISPOSAL & $03 / 01 / 10$ \\
Form & Rev. 01 \\
FRM-2217 & (LOW LEVEL WASTE) & Page 1 of 1 \\
\hline
\end{tabular}

Nevada Test Site

This Certificate acknowledges that the following shipments) of waste have been disposed at the Nevada Test Site Radioactive Waste Management Complex.

\begin{tabular}{|l|l|l|c|}
\hline \multicolumn{1}{|c|}{$\begin{array}{c}\text { Waste Stream } \\
\text { Identification \# }\end{array}$} & \multicolumn{1}{c|}{ Package \# } & Date of Disposal \\
\hline DPL10333 & LRY5LLFY08002 & 10 L453 & $4 / 29 / 10$ \\
\hline DPL10333 & LRY5LLFY08002 & 10 L454 & $4 / 29 / 10$ \\
\hline & & & \\
\hline & & & \\
\hline & & & \\
\hline & & & \\
\hline & & & \\
\hline & & & \\
\hline
\end{tabular}

This certification is provided as a courtesy to the waste generator for information purposes only.

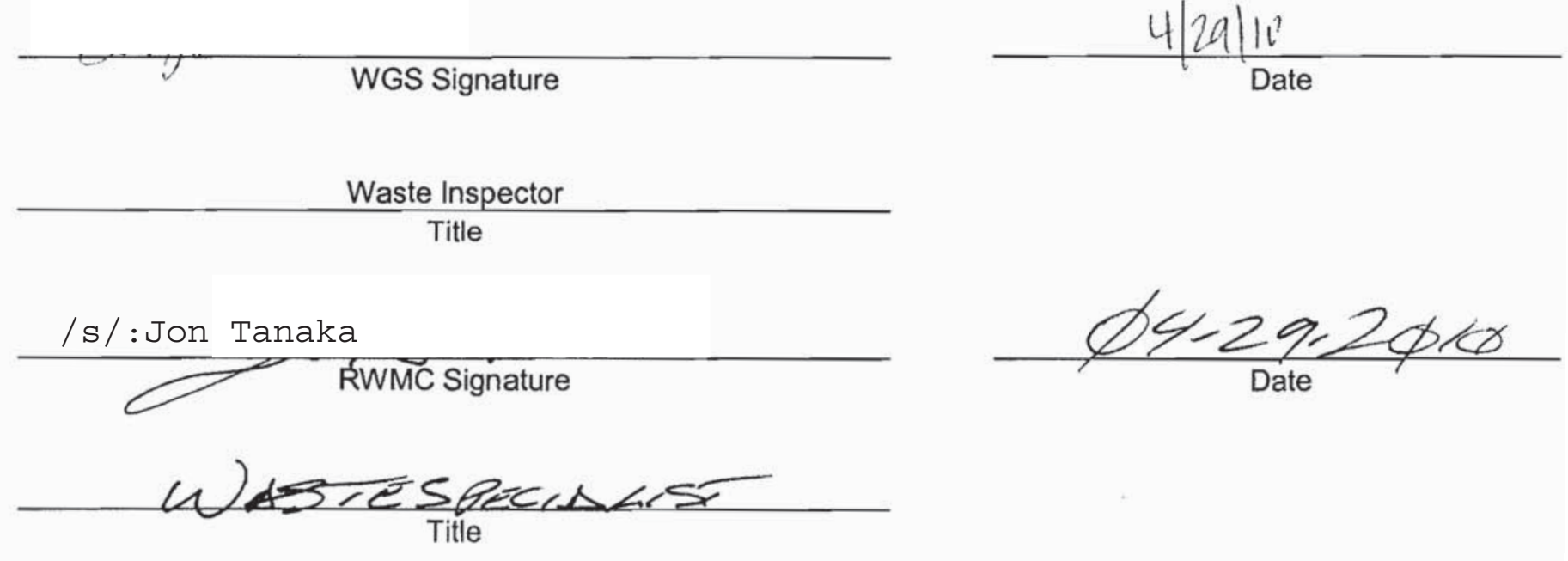


NSTec

Form

FRM-2217
CERTIFICATE OF DISPOSAL

(LOW LEVEL WASTE)
03/01/10

Rev. 01

Page 1 of 1

\section{Nevada Test Site}

This Certificate acknowledges that the following shipment(s) of waste have been disposed at the Nevada Test Site Radioactive Waste Management Complex.

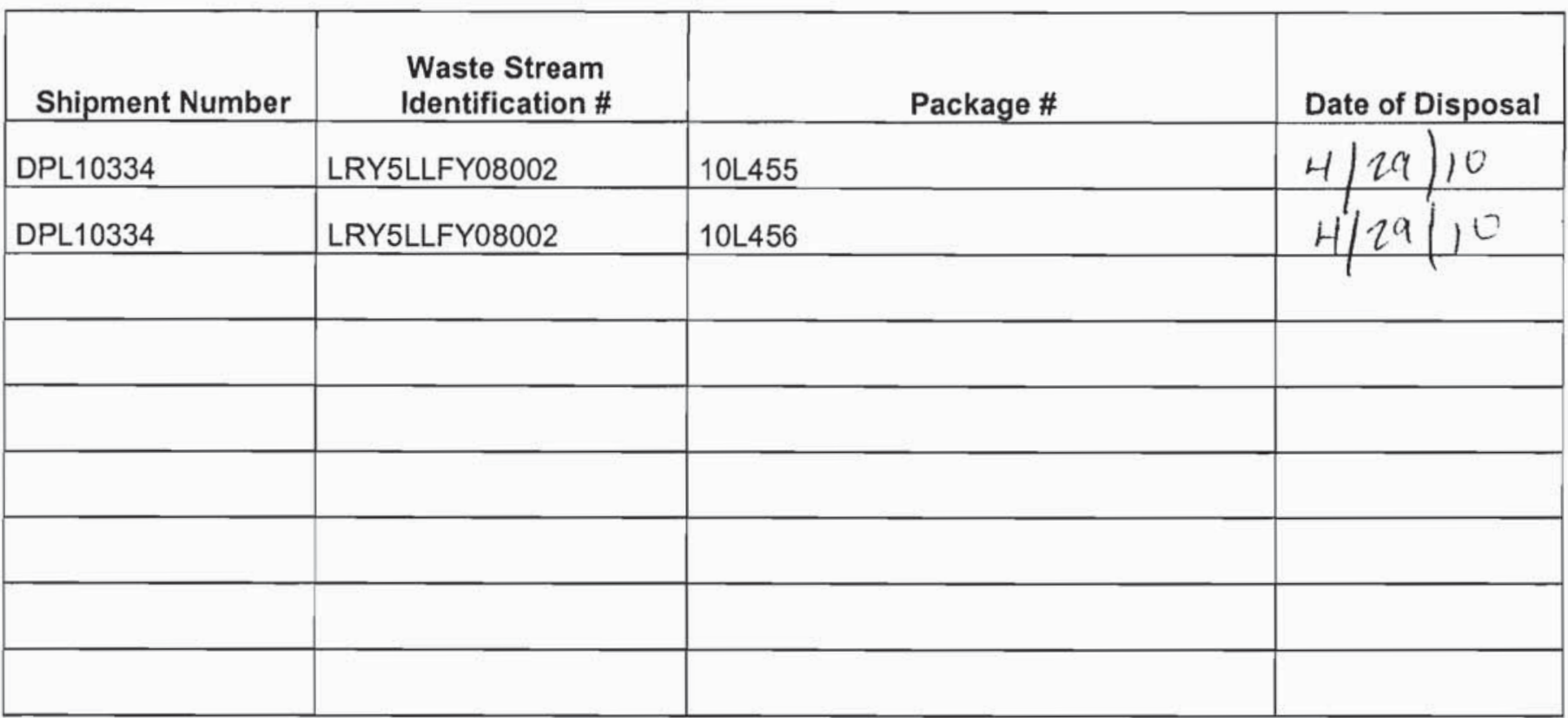

This certification is provided as a courtesy to the waste generator for information purposes only.

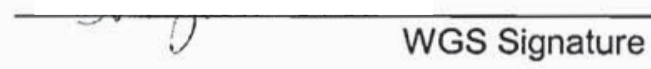

Waste Inspector

$$
\text { Title }
$$

/s/:Jon Tanaka

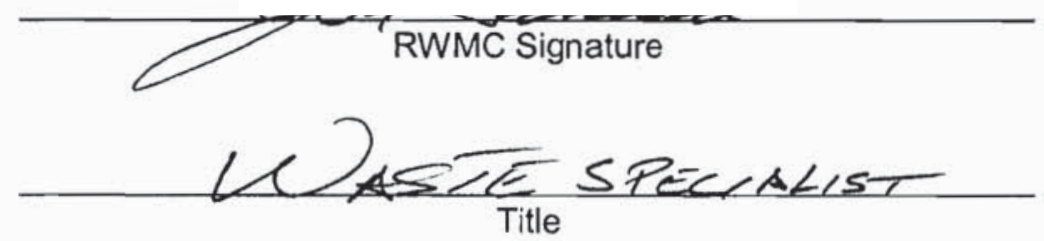

$4 \mid 29110$

Date

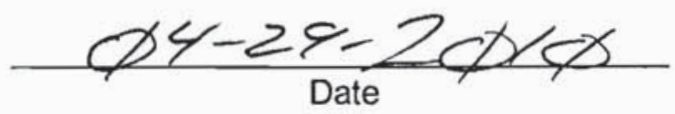


NSTec

Form

FRM-2217
CERTIFICATE OF DISPOSAL

(LOW LEVEL WASTE)
03/01/10

Rev. 01

Page 1 of 1

\section{Nevada Test Site}

This Certificate acknowledges that the following shipment(s) of waste have been disposed at the Nevada Test Site Radioactive Waste Management Complex.

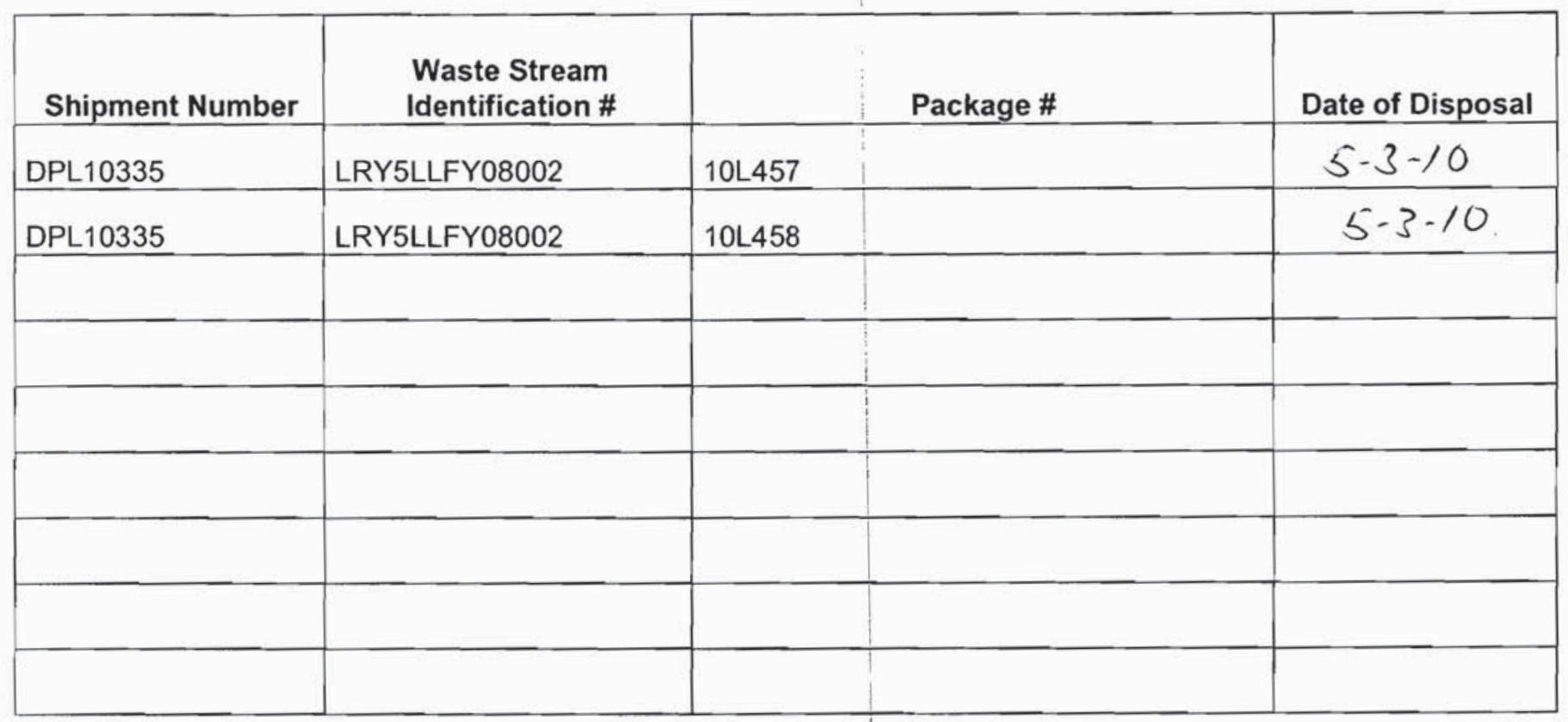

This certification is provided as a courtesy to the waste generator for information purposes only.

\section{/s/:Theresa Hale}

WGS Signature

Waste Inspector

Title

/s/:Jon Tanaka

RWMC Signature

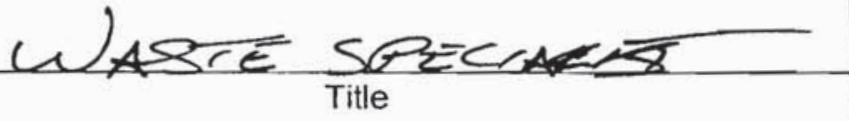

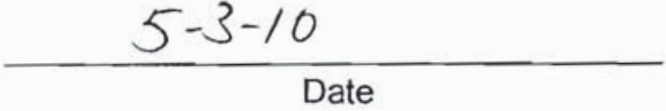

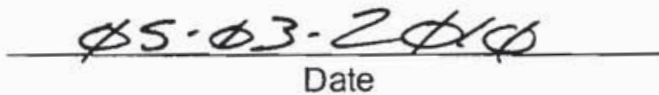


NSTec

Form

CERTIFICATE OF DISPOSAL

03/01/10

FRM-2217

(LOW LEVEL. WASTE)

Rev. 01

Page 1 of 1

\section{Nevada Test Site}

This Certificate acknowledges that the following shipment(s) of waste have been disposed at the Nevada Test Site Radioactive Waste Management Complex.

\begin{tabular}{|l|l|l|l|}
\hline \multicolumn{1}{|c|}{$\begin{array}{c}\text { Waste Stream } \\
\text { Identification \# }\end{array}$} & \multicolumn{1}{|c|}{ Package \# } & Date of Disposal \\
\hline DPL10336 & LRY5LLFY08002 & 10 L459 & $5-3-10$ \\
\hline DPL10336 & LRY5LLFY08002 & 10 L460 & $5-3-10$ \\
\hline & & & \\
\hline & & & \\
\hline & & & \\
\hline & & & \\
\hline & & & \\
\hline
\end{tabular}

This certification is provided as a courtesy to the waste generator for information purposes only.

/s/: Theresa Hale

WGS Signature

Waste Inspector

$$
\text { Title }
$$

/s/:Jon Tanaka

RWMC Šignature

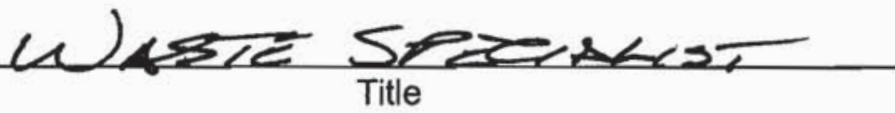

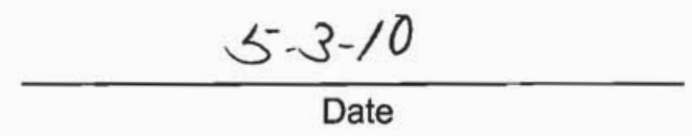

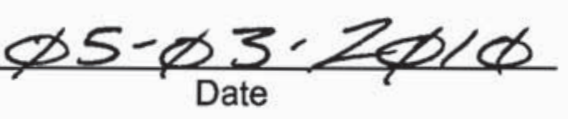




\section{Nevada Test Site}

This Certificate acknowledges that the following shipment(s) of waste have been disposed at the Nevada Test Site Radioactive Waste Management Complex.

\begin{tabular}{|l|l|l|c|c|}
\hline Shipment Number & $\begin{array}{c}\text { Waste Stream } \\
\text { Identification \# }\end{array}$ & Package \# & Date of Disposal \\
\hline DPL10337 & LRY5LLFY08002 & 10 L461 & & $5 \cdot 3-10$ \\
\hline DPL10337 & LRY5LLFY08002 & 10 L462 & & $5 \cdot 3-10$ \\
\hline & & & & \\
\hline & & & & \\
\hline & & & & \\
\hline & & & & \\
\hline & & & & \\
\hline
\end{tabular}

This certification is provided as a courtesy to the waste generator for information purposes only.

/s/:Theresa Hale

$$
\text { WGS Signature }
$$

Waste Inspector

$$
\text { Title }
$$

\section{/s/:Jon Tanaka}

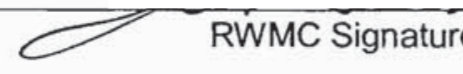

$$
\text { 4) } 45 T E \underbrace{}_{\text {Title }} \text { SPECAKLST }
$$
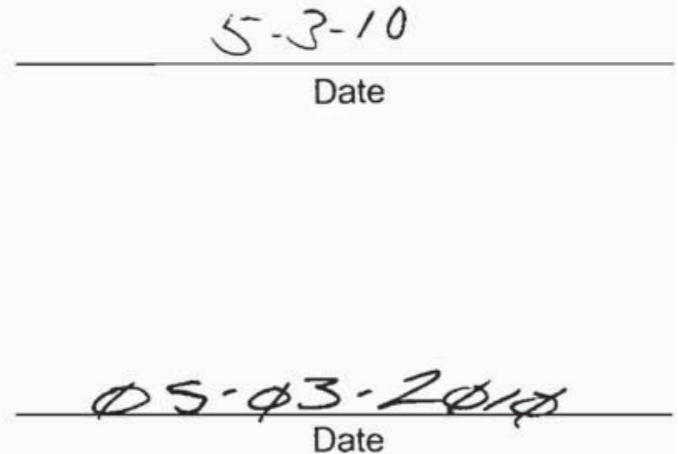
NSTec

Form

FRM-2217
CERTIFICATE OF DISPOSAL

(LOW LEVEL WASTE)
03/01/10

Rev. 01

Page 1 of 1

\section{Nevada Test Site}

This Certificate acknowledges that the following shipment(s) of waste have been disposed at the Nevada Test Site Radioactive Waste Management Complex.

\begin{tabular}{|c|c|c|c|}
\hline Shipment Number & $\begin{array}{l}\text { Waste Stream } \\
\text { Identification \# }\end{array}$ & Package \# & Date of Disposal \\
\hline DPL10338 & LRY5LLFY08002 & $10\llcorner 463$ & $5 \cdot 3-10$ \\
\hline DPL10338 & LRY5LLFY08002 & $10 L 464$ & $5-3-10$ \\
\hline & & & \\
\hline & & & \\
\hline & & & \\
\hline & & 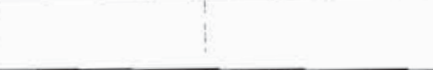 & \\
\hline & & 1 & \\
\hline & & & \\
\hline
\end{tabular}

This certification is provided as a courtesy to the waste generator for information purposes only.

/s/:Theresa Hale

WGS Signature

Waste Inspector

Title

/s/:Jon Tanaka

RWikc Signature
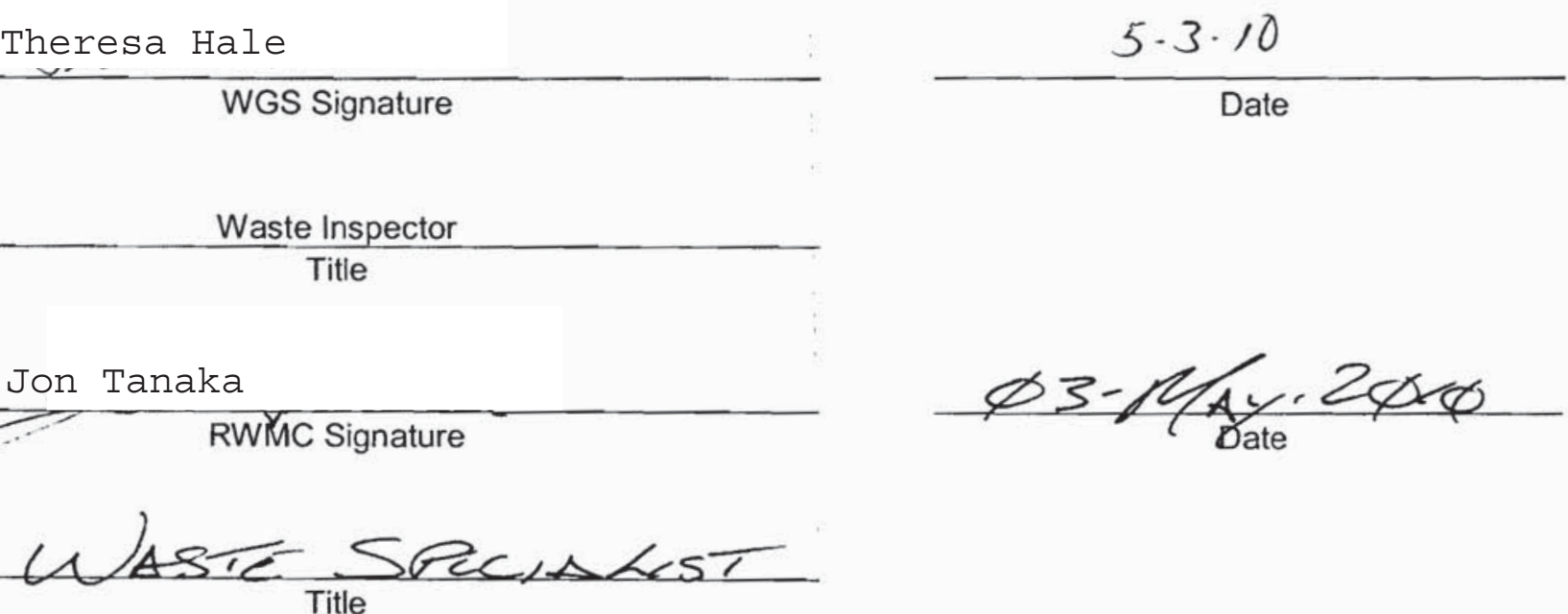
NSTec

Form

FRM-2217
CERTIFICATE OF DISPOSAL

(LOW LEVEL WASTE)
03/01/10

Rev. 01

Page 1 of 1

\section{Nevada Test Site}

This Certificate acknowledges that the following shipment(s) of waste have been disposed at the Nevada Test Site Radioactive Waste Management Complex.

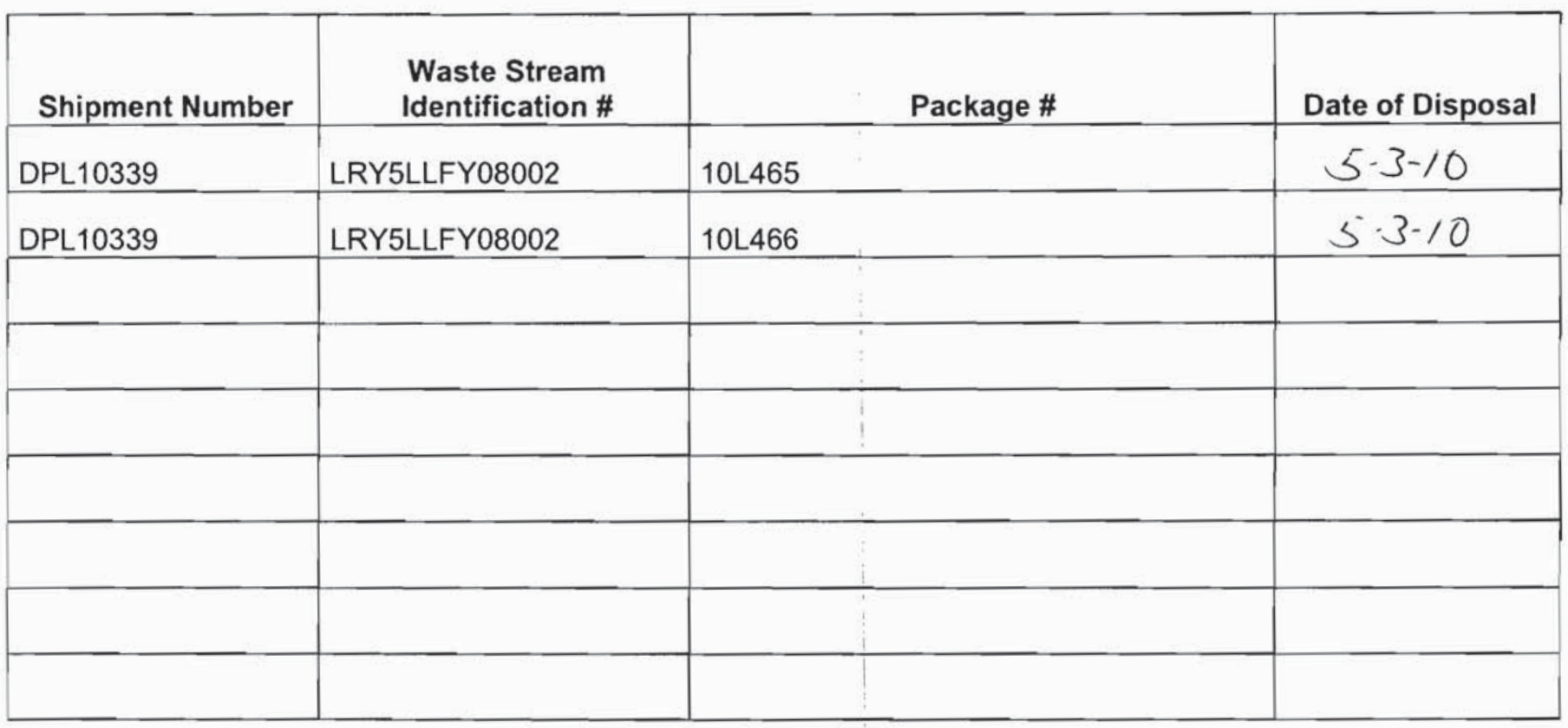

This certification is provided as a courtesy to the waste generator for information purposes only.

$\frac{\text { /s / Theresa Hale }}{\text { WGS Signature }}$
$\frac{\text { Waste Inspector }}{\text { Titie }}$

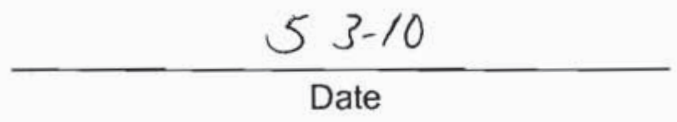

/s/:Jon Tanaka
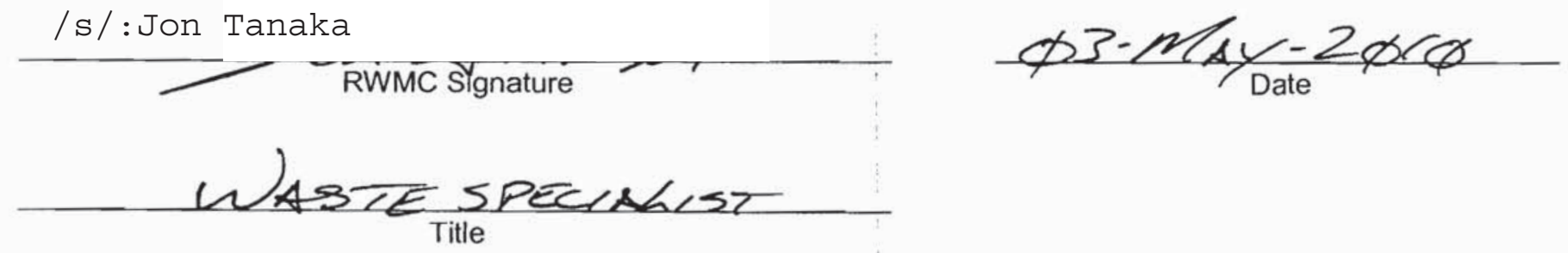
NSTec

Form

FRM-2217
CERTIFICATE OF DISPOSAL

(LOW LEVEL WASTE)
$03 / 01 / 10$

Rev. 01

Page 1 of 1

\section{Nevada Test Site}

This Certificate acknowledges that the following shipment(s) of waste have been disposed at the Nevada Test Site Radioactive Waste Management Complex.

\begin{tabular}{|c|c|c|c|}
\hline Shipment Number & $\begin{array}{l}\text { Waste Stream } \\
\text { Identification \# }\end{array}$ & Package \# & Date of Disposal \\
\hline DPL10340 & LRY5LLFY08002 & $10\llcorner 467$ & $5-3-10$ \\
\hline DPL10340 & LRY5LLFY08002 & $10 L 468$ & $5-3-10$ \\
\hline & & & \\
\hline & & & \\
\hline & & & \\
\hline & . & & \\
\hline & & & \\
\hline & & & \\
\hline
\end{tabular}

This certification is provided as a courtesy to the waste generator for information purposes only.

/s/:Theresa Hale

WGS Signature

Waste inspector

Title

/s/: Jon Tanaka

RWMC Signature

WASTE SPECLAKST

Title

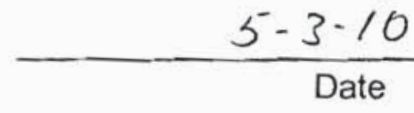

$-\phi s-\phi 3-2 \phi y$ 
NSTec

Form

CERTIFICATE OF DISPOSAL

$03 / 01 / 10$

FRM-2217

(LOW LEVEL WASTE)

Rev. 01

Page 1 of 1

\section{Nevada Test Site}

This Certificate acknowledges that the following shipment(s) of waste have been disposed at the Nevada Test Site Radioactive Waste Management Complex.

\begin{tabular}{|l|l|l|c|}
\hline \multicolumn{1}{|c|}{$\begin{array}{c}\text { Waste Stream } \\
\text { Identification \# }\end{array}$} & Package \# & Date of Disposal \\
\hline DPL10341 & LRY5LLFY08002 & 10 L469 & $5-3-10$ \\
\hline DPL10341 & LRY5LLFY08002 & 10 L70 & $5-3-10$ \\
\hline & & & \\
\hline & & & \\
\hline & & & \\
\hline & & & \\
\hline & & & \\
\hline
\end{tabular}

This certification is provided as a courtesy to the waste generator for information purposes only.

/s/: Theresa Hale

WGS Signature

Waste Inspector

Title

/s/:Jon Tanaka

RWMC Signature

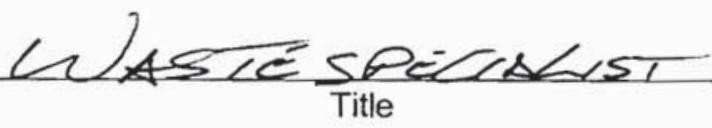

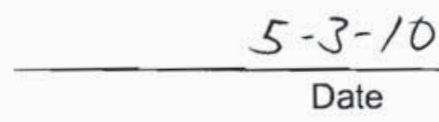

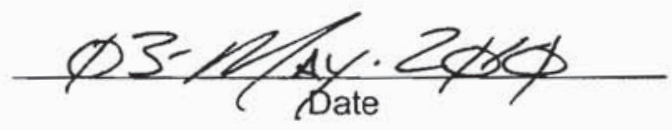


NSTec

Form

CERTIFICATE OF DISPOSAL

03/01/10

FRM-2217

(LOW LEVEL WASTE)

Rev. 01

Page 1 of 1

\section{Nevada Test Site}

This Certificate acknowledges that the following shipment(s) of waste have been disposed at the Nevada Test Site Radioactive Waste Management Complex.

\begin{tabular}{|l|l|l|c|}
\hline \multicolumn{1}{|c|}{$\begin{array}{c}\text { Waste Stream } \\
\text { Identification \# }\end{array}$} & \multicolumn{1}{c|}{ Package \# } & Date of Disposal \\
\hline DPL10342 & LRY5LLFY08002 & 10 L471 & $5 \cdot 3-10$ \\
\hline DPL10342 & LRY5LLFY08002 & 10 L472 & $5-3-10$ \\
\hline & & & \\
\hline & & & \\
\hline & & & \\
\hline & & & \\
\hline
\end{tabular}

This certification is provided as a courtesy to the waste generator for information purposes only.

/s/:Theresa Hale

WGS Signature

Waste Inspector

Title

/s/:Jon Tanaka

7 RWMĆ Signaturē

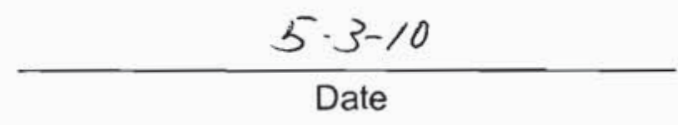

ULSSTE SPECLAKLST

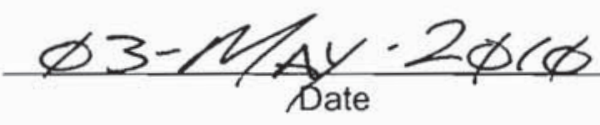


NSTec

Form

FRM-2217
CERTIFICATE OF DISPOSAL

(LOW LEVEL WASTE)
03/01/10

Rev. 01

Page 1 of 1

\section{Nevada Test Site}

This Certificate acknowledges that the following shipment(s) of waste have been disposed at the Nevada Test Site Radioactive Waste Management Complex.

\begin{tabular}{|l|l|l|c|}
\hline \multicolumn{1}{|c|}{ Shipment Number } & \multicolumn{1}{|c|}{$\begin{array}{c}\text { Waste Stream } \\
\text { Identification \# }\end{array}$} & Package \# & Date of Disposal \\
\hline DPL10343 & LRY5LLFY08002 & 10 473 & $5-3-10$ \\
\hline DPL10343 & LRY5LLFY08002 & 10L474 & $5-3-10$ \\
\hline & & & \\
\hline & & & \\
\hline & & & \\
\hline & & & \\
\hline & & & \\
\hline
\end{tabular}

This certification is provided as a courtesy to the waste generator for information purposes only.

/s/:Theresa Hale

WGS Signature

Waste Inspector

Title

/s/:Jon Tanaka

RWMC Signature

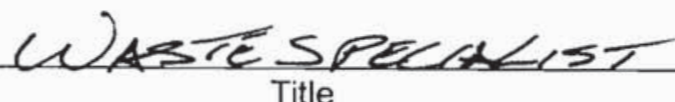

$5-3-10$

Date

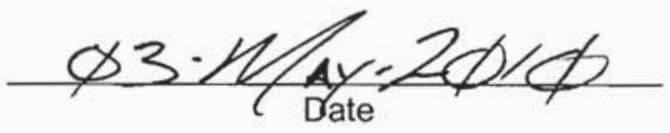


NSTec

Form

FRM-2217
CERTIFICATE OF DISPOSAL

(LOW LEVEL WASTE)
$03 / 01 / 10$

Rev. 01

Page 1 of 1

\section{Nevada Test Site}

This Certificate acknowledges that the following shipment(s) of waste have been disposed at the Nevada Test Site Radioactive Waste Management Complex.

\begin{tabular}{|l|l|l|l|}
\hline \multicolumn{1}{|c|}{$\begin{array}{c}\text { Waste Stream } \\
\text { Identification \# }\end{array}$} & \multicolumn{1}{c|}{ Package \# } & Date of Disposal \\
\hline DPL10344 & LRY5LLFY08002 & 10 L475 & $5-4-10$ \\
\hline DPL10344 & LRY5LLFY08002 & 10 L476 & $5-4-10$ \\
\hline & & & \\
\hline & & & \\
\hline & & & \\
\hline & & & \\
\hline
\end{tabular}

This certification is provided as a courtesy to the waste generator for information purposes only.

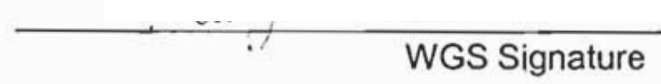

Waste Inspector

Title

/s/: Jon Tanaka

$\Longrightarrow$ RWMC Signature

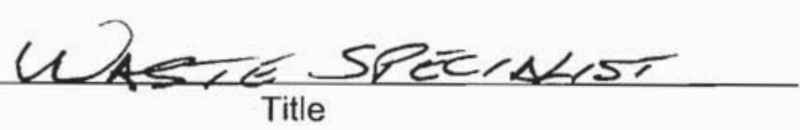

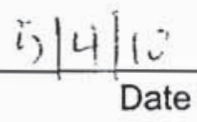

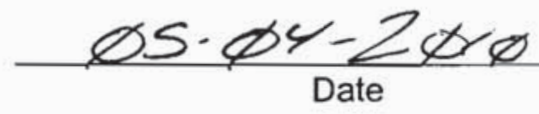


NSTec

Form

FRM-2217
CERTIFICATE OF DISPOSAL

(LOW LEVEL WASTE)
$03 / 01 / 10$

Rev. 01

Page 1 of 1

\section{Nevada Test Site}

This Certificate acknowledges that the following shipment(s) of waste have been disposed at the Nevada Test Site Radioactive Waste Management Complex.

\begin{tabular}{|l|l|l|c|}
\hline \multicolumn{1}{|c|}{$\begin{array}{c}\text { Waste Stream } \\
\text { Identification \# }\end{array}$} & Package \# & Date of Disposal \\
\hline DPL10345 & LRY5LLFY08002 & 10 L477 & $5-4-10$ \\
\hline DPL10345 & LRY5LLFY08002 & 10 L478 & $5-4-10$ \\
\hline & & & \\
\hline & & & \\
\hline & & & \\
\hline & & & \\
\hline & & & \\
\hline
\end{tabular}

This certification is provided as a courtesy to the waste generator for information purposes only.

WGS Signature

Waste Inspector

Title

/s/:Jon Tanaka

RWMC Signature

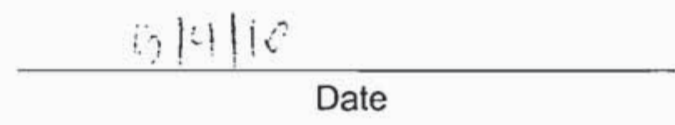

W LABTE SPECLALEST

Title

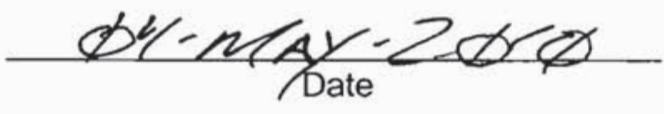




\begin{tabular}{|lcr|}
\hline NSTec & CERTIFICATE OF DISPOSAL & $03 / 01 / 10$ \\
Form & Rev. 01 \\
FRM-2217 & (LOW LEVEL WASTE) & Page 1 of 1 \\
\hline
\end{tabular}

Nevada Test Site

This Certificate acknowledges that the following shipments) of waste have been disposed at the Nevada Test Site Radioactive Waste Management Complex.

\begin{tabular}{|l|l|l|l|}
\hline Shipment Number & \multicolumn{1}{|c|}{$\begin{array}{c}\text { Waste Stream } \\
\text { Identification \# }\end{array}$} & \multicolumn{1}{|c|}{ Package \# } & Date of Disposal \\
\hline DPL10346 & LRY5LLFY08002 & 10 L479 & $5-4-10$ \\
\hline DPL10346 & LRY5LLFY88002 & 10 L880 & $5-4-10$ \\
\hline & & & \\
\hline & & & \\
\hline & & & \\
\hline & & & \\
\hline & & & \\
\hline & & & \\
\hline
\end{tabular}

This certification is provided as a courtesy to the waste generator for information purposes only.

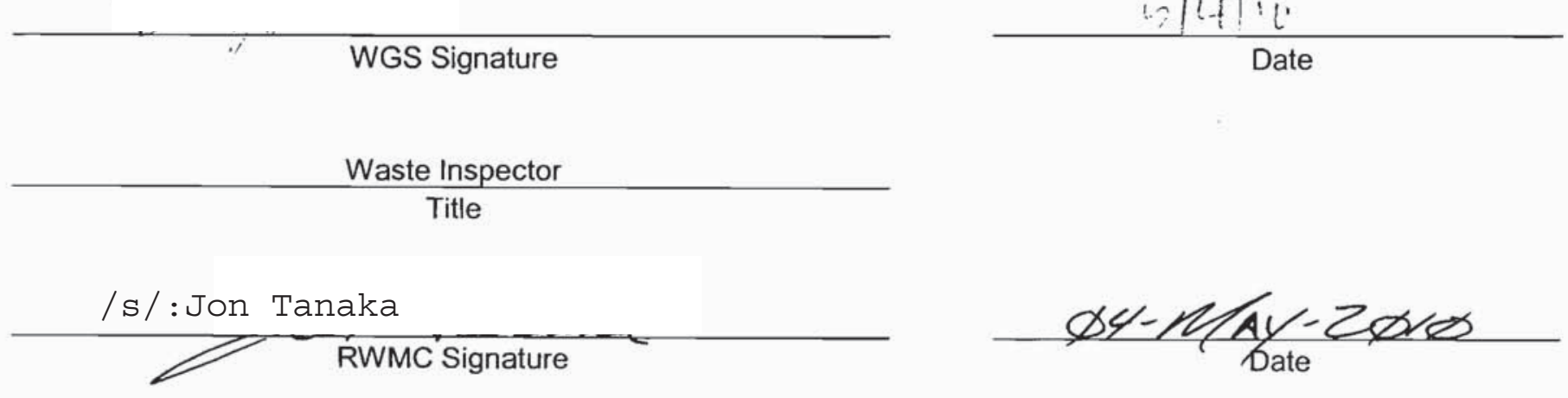




\begin{tabular}{|lcr|}
\hline $\begin{array}{l}\text { NSTec } \\
\text { Form } \\
\text { FRM-2217 }\end{array}$ & CERTIFICATE OF DISPOSAL & $03 / 01 / 10$ \\
Rev. 01 \\
\hline
\end{tabular}

Nevada Test Site

This Certificate acknowledges that the following shipments) of waste have been disposed at the Nevada Test Site Radioactive Waste Management Complex.

\begin{tabular}{|l|l|l|c|}
\hline Shipment Number & $\begin{array}{c}\text { Waste Stream } \\
\text { Identification \# }\end{array}$ & Package \# & Date of Disposal \\
\hline DPL10347 & LRY5LLFY08002 & $10 L 481$ & $5-4-10$ \\
\hline DPL10347 & LRY5LLFY08002 & $10 L 482$ & $5-4-10$ \\
\hline & & & \\
\hline & & & \\
\hline & & & \\
\hline & & & \\
\hline & & & \\
\hline
\end{tabular}

This certification is provided as a courtesy to the waste generator for information purposes only.

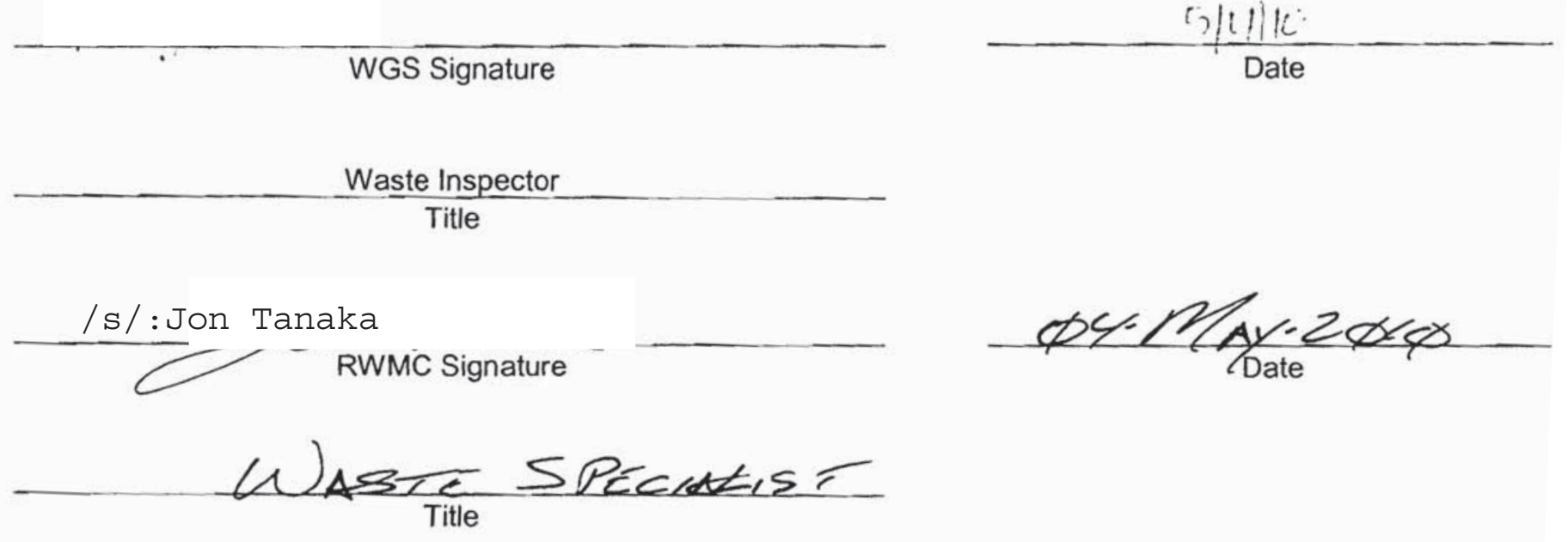


NSTec

Form

FRM-2217
CERTIFICATE OF DISPOSAL

(LOW LEVEL WASTE)
03/01/10

Rev. 01

Page 1 of 1

\section{Nevada Test Site}

This Certificate acknowledges that the following shipment(s) of waste have been disposed at the Nevada Test Site Radioactive Waste Management Complex.

\begin{tabular}{|l|l|l|c|}
\hline Shipment Number & \multicolumn{1}{|c|}{$\begin{array}{c}\text { Waste Stream } \\
\text { Identification \# }\end{array}$} & Package \# & Date of Disposal \\
\hline DPL10348 & LRY5LLFY08002 & 10 L883 & $5-4-10$ \\
\hline DPL10348 & LRY5LLFY08002 & 10 L884 & $5-4-10$ \\
\hline & & & \\
\hline & & & \\
\hline & & & \\
\hline & & & \\
\hline
\end{tabular}

This certification is provided as a courtesy to the waste generator for information purposes only.

WGS Signature

Waste Inspector

Title

/s/:Jon Tanaka

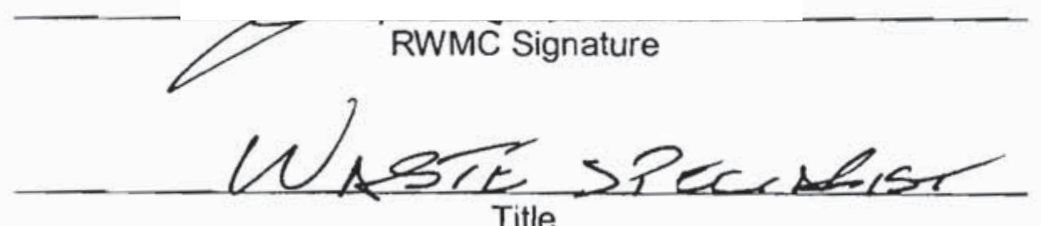

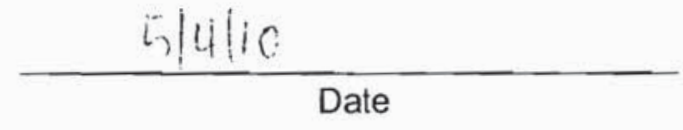

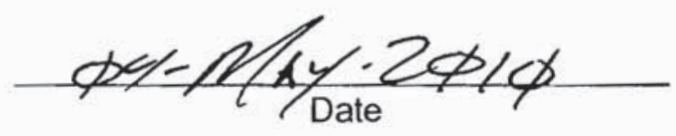


NSTec

CERTIFICATE OF DISPOSAL

$03 / 01 / 10$

Form

(LOW LEVEL WASTE)

Rev. 01

FRM-2217

Page 1 of 1

\section{Nevada Test Site}

This Certificate acknowledges that the following shipment(s) of waste have been disposed at the Nevada Test Site Radioactive Waste Management Complex.

\begin{tabular}{|l|l|l|c|}
\hline Shipment Number & $\begin{array}{c}\text { Waste Stream } \\
\text { Identification \# }\end{array}$ & Package \# & Date of Disposal \\
\hline DPL10349 & LRY5LLFY08002 & 10 L85 & $5-4-10$ \\
\hline DPL10349 & LRY5LLFY08002 & 10 486 & $5-4-10$ \\
\hline & & & \\
\hline & & & \\
\hline & & & \\
\hline & & & \\
\hline & & & \\
\hline
\end{tabular}

This certification is provided as a courtesy to the waste generator for information purposes only.

WGS Signature

Waste Inspector

Title

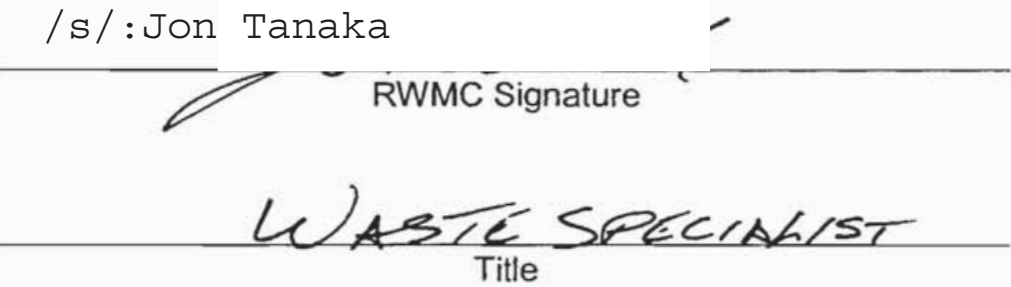

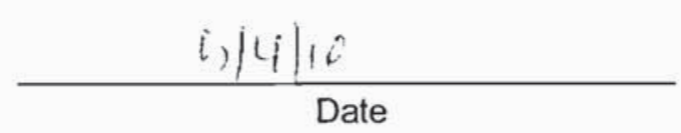

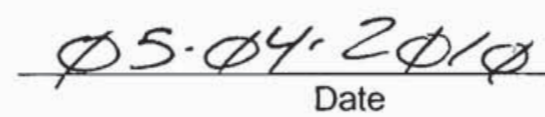




\begin{tabular}{|lcr|}
\hline NSTec & CERTIFICATE OF DISPOSAL & 03/01/10 \\
Form & Rev. 01 \\
FRM-2217 & (LOW LEVEL WASTE) & Page 1 of 1 \\
\hline
\end{tabular}

Nevada Test Site

This Certificate acknowledges that the following shipments) of waste have been disposed at the Nevada Test Site Radioactive Waste Management Complex.

\begin{tabular}{|l|l|l|c|}
\hline Shipment Number & \multicolumn{1}{|c|}{$\begin{array}{c}\text { Waste Stream } \\
\text { Identification \# }\end{array}$} & \multicolumn{1}{|c|}{ Package \# } & Date of Disposal \\
\hline DPL10350 & LRY5LLFY08002 & 10 L487 & $5-4-10$ \\
\hline DPL10350 & LRY5LLFY08002 & $10 L 488$ & $5-4-10$ \\
\hline & & & \\
\hline & & & \\
\hline & & & \\
\hline & & & \\
\hline & & & \\
\hline & & & \\
\hline
\end{tabular}

This certification is provided as a courtesy to the waste generator for information purposes only.
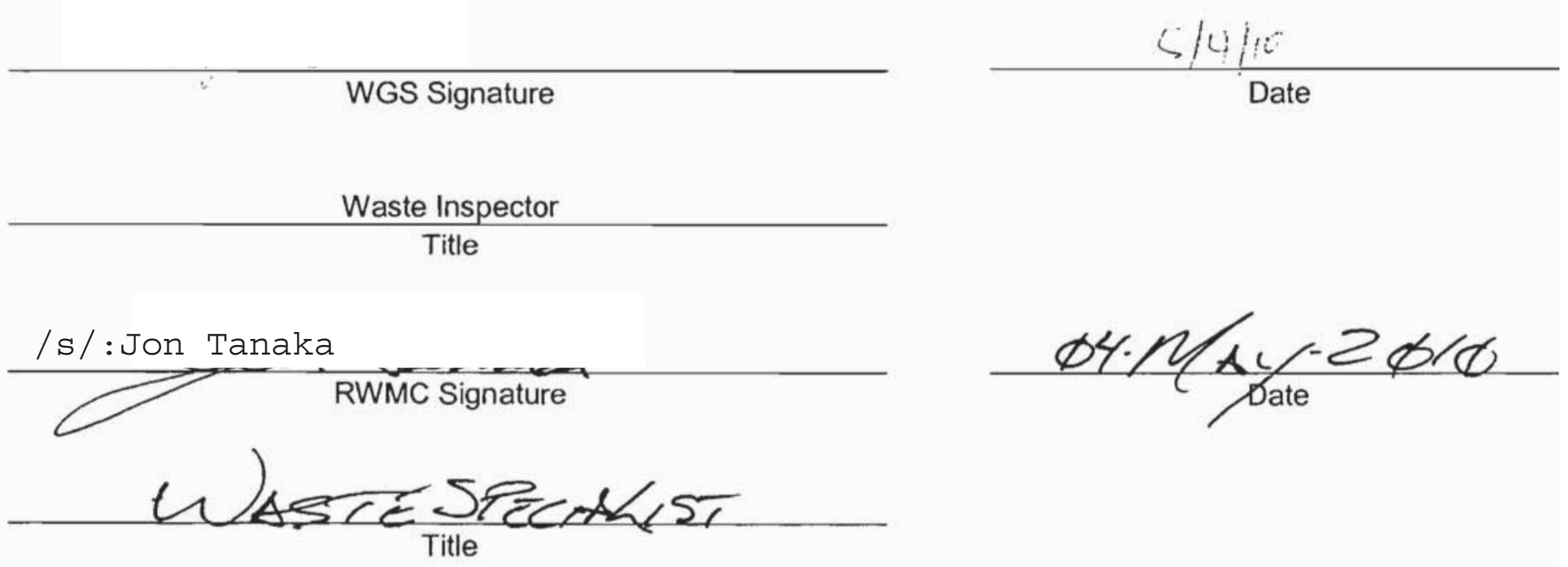
NSTec

Form

FRM-2217
CERTIFICATE OF DISPOSAL

(LOW LEVEL WASTE)
03/01/10

Rev. 01

Page 1 of 1

\section{Nevada Test Site}

This Certificate acknowledges that the following shipment(s) of waste have been disposed at the Nevada Test Site Radioactive Waste Management Complex.

\begin{tabular}{|l|l|l|l|}
\hline \multicolumn{1}{|c|}{$\begin{array}{c}\text { Whipment Number } \\
\text { Identification \# }\end{array}$} & \multicolumn{1}{|c|}{ Package \# } & Date of Disposal \\
\hline DPL10351 & LRY5LLFY08002 & 10 L489 & $5-4-10$ \\
\hline DPL10351 & LRY5LLFY08002 & 10 L490 & $5-4-10$ \\
\hline & & & \\
\hline & & & \\
\hline & & & \\
\hline & & & \\
\hline & & & \\
\hline
\end{tabular}

This certification is provided as a courtesy to the waste generator for information purposes only.

WGS Signature
$\frac{\text { Waste Inspector }}{\text { Title }}$
/s/: Jon Tanaka
RWḾć Signature
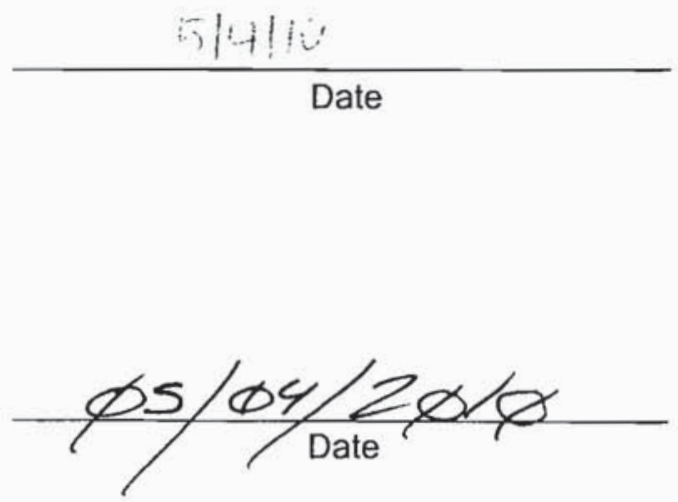


\section{Nevada Test Site}

This Certificate acknowledges that the following shipment(s) of waste have been disposed at the Nevada Test Site Radioactive Waste Management Complex.

\begin{tabular}{|l|l|l|l|}
\hline \multicolumn{1}{c|}{ Shipment Number } & \multicolumn{1}{|c|}{$\begin{array}{c}\text { Waste Stream } \\
\text { Identification \# }\end{array}$} & \multicolumn{1}{c|}{ Package \# } & Date of Disposal \\
\hline DPL10352 & LRY5LLFY08002 & 10 L491 & $5-4-10$ \\
\hline DPL10352 & LRY5LLFY08002 & $10 L 492$ & $5 \cdot 4-10$ \\
\hline & & & \\
\hline & & & \\
\hline & & & \\
\hline & & & \\
\hline & & & \\
\hline
\end{tabular}

This certification is provided as a courtesy to the waste generator for information purposes only.

WGS Signature

Waste Inspector

Title
/s/:Jon Tanaka

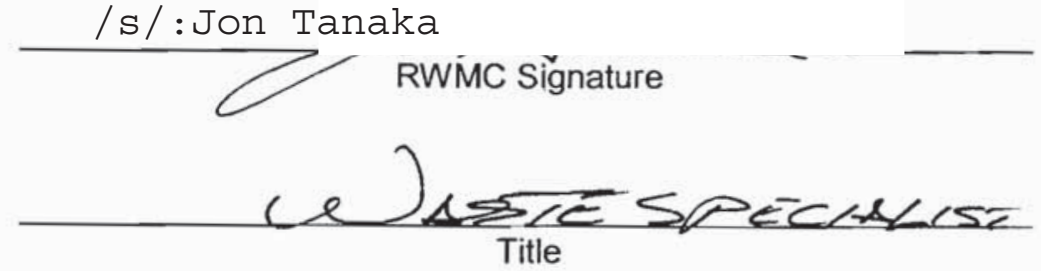

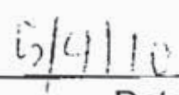

Date

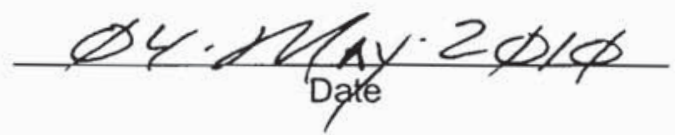


NSTec

Form

FRM-2217
CERTIFICATE OF DISPOSAL

(LOW LEVEL WASTE)
03/01/10

Rev. 01

Page 1 of 1

\section{Nevada Test Site}

This Certificate acknowledges that the following shipment(s) of waste have been disposed at the Nevada Test Site Radioactive Waste Management Complex.

\begin{tabular}{|l|l|l|c|}
\hline \multicolumn{1}{|c|}{$\begin{array}{c}\text { Waste Stream } \\
\text { Identification \# }\end{array}$} & Package \# & Date of Disposal \\
\hline DPL10353 & LRY5LLFY08002 & 10 L493 & $5-5-10$ \\
\hline DPL10353 & LRY5LLFY08002 & 10 4994 & $5-5-10$ \\
\hline & & & \\
\hline & & & \\
\hline & & & \\
\hline & & & \\
\hline & & & \\
\hline
\end{tabular}

This certification is provided as a courtesy to the waste generator for information purposes only.

WGS Signature

$\pi \mid \cdots, 11$

Date

Waste Inspector

Title
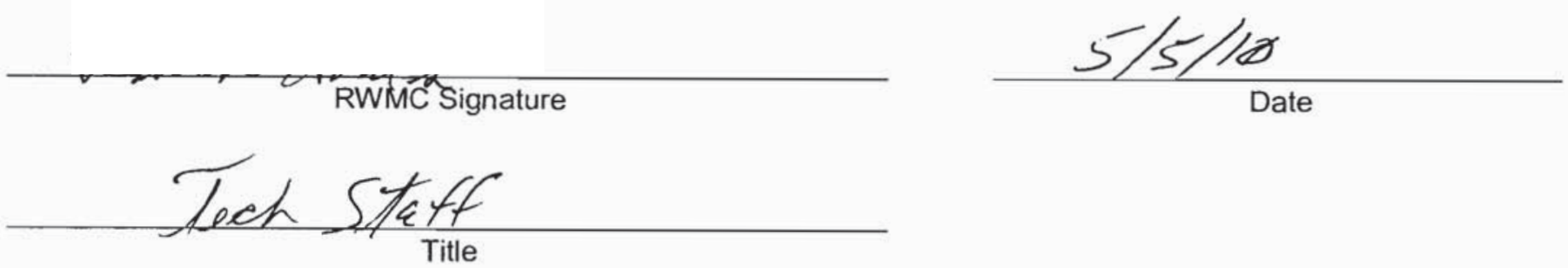
NSTec

Form

FRM-2217
CERTIFICATE OF DISPOSAL

(LOW LEVEL WASTE)
03/01/10

Rev. 01

Page 1 of 1

\section{Nevada Test Site}

This Certificate acknowledges that the following shipment(s) of waste have been disposed at the Nevada Test Site Radioactive Waste Management Complex.

\begin{tabular}{|l|l|l|l|}
\hline \multicolumn{1}{|c|}{$\begin{array}{c}\text { Waste Stream } \\
\text { Identification \# }\end{array}$} & Package \# & Date of Disposal \\
\hline DPL10354 & LRY5LLFY08002 & 10 L95 & $5-5-10$ \\
\hline DPL10354 & LRY5LLFY08002 & 10 L966 & $5-5-10$ \\
\hline & & & \\
\hline & & & \\
\hline & & & \\
\hline & & & \\
\hline
\end{tabular}

This certification is provided as a courtesy to the waste generator for information purposes only.

$\frac{\text { WGS Signature }}{\frac{\text { Waste Inspector }}{\text { Title }}}$
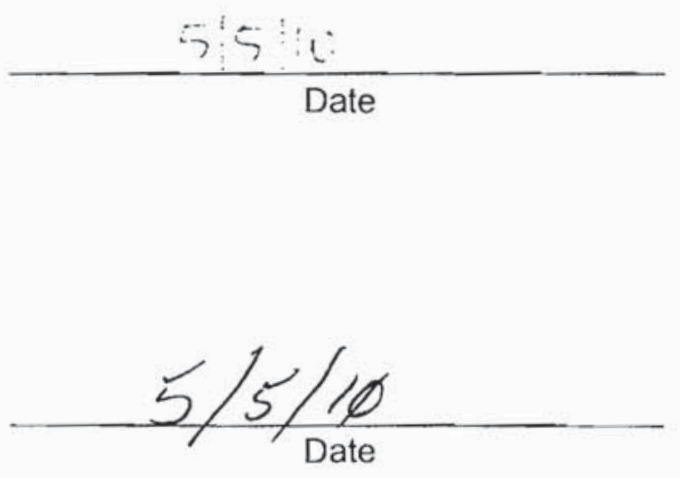


\begin{tabular}{|lcr|}
\hline NSTec & CERTIFICATE OF DISPOSAL & $03 / 01 / 10$ \\
Form & Rev. 01 \\
FRM-2217 & (LOW LEVEL WASTE) & Page 1 of 1 \\
\hline
\end{tabular}

Nevada Test Site

This Certificate acknowledges that the following shipments) of waste have been disposed at the Nevada Test Site Radioactive Waste Management Complex.

\begin{tabular}{|l|l|l|c|}
\hline \multicolumn{1}{|c|}{ Shipment Number } & \multicolumn{1}{|c|}{$\begin{array}{c}\text { Waste Stream } \\
\text { Identification \# }\end{array}$} & \multicolumn{1}{c|}{ Package \# } & Date of Disposal \\
\hline DPL10355 & LRY5LLFY08002 & $10 L 497$ & $5-5-10$ \\
\hline DPL10355 & LRY5LLFY08002 & $10 L 498$ & $5-5-10$ \\
\hline & & & \\
\hline & & & \\
\hline & & & \\
\hline & & & \\
\hline & & & \\
\hline & & & \\
\hline
\end{tabular}

This certification is provided as a courtesy to the waste generator for information purposes only.

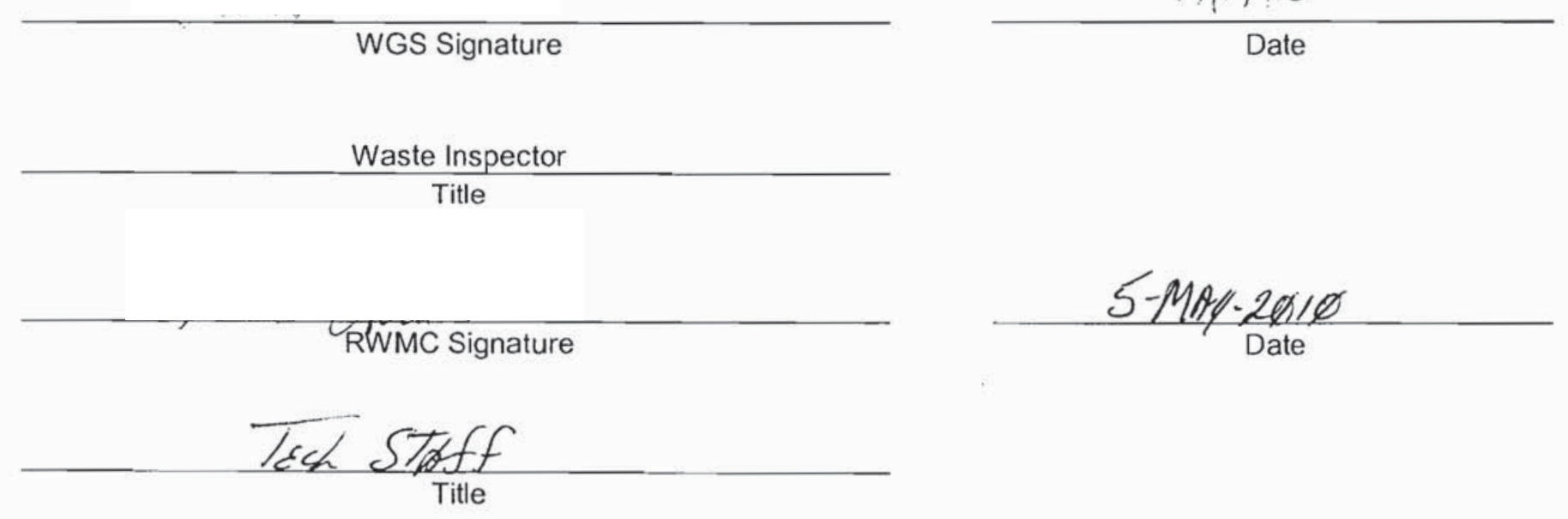

(Reference: OP-2151.304) 
NSTec

Form

FRM-2217
CERTIFICATE OF DISPOSAL

(LOW LEVEL WASTE)
$03 / 01 / 10$

Rev. 01

Page 1 of 1

\section{Nevada Test Site}

This Certificate acknowledges that the following shipment(s) of waste have been disposed at the Nevada Test Site Radioactive Waste Management Complex.

\begin{tabular}{|l|l|l|l|}
\hline Shipment Number & \multicolumn{1}{|c|}{$\begin{array}{c}\text { Waste Stream } \\
\text { Identification \# }\end{array}$} & Package \# & Date of Disposal \\
\hline DPL10356 & LRY5LLFY08002 & 10 L499 & $5-5-10$ \\
\hline DPL10356 & LRY5LLFY08002 & 10 500 & $5-5-10$ \\
\hline & & & \\
\hline & & & \\
\hline & & & \\
\hline
\end{tabular}

This certification is provided as a courtesy to the waste generator for information purposes only.

WGS Signature

Waste Inspector

Title

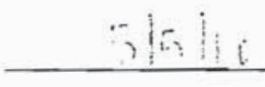

Date

RWMC Signature 


\begin{tabular}{|lcr|}
\hline NSTec & CERTIFICATE OF DISPOSAL & $03 / 01 / 10$ \\
Form & Rev. 01 \\
FRM-2217 & (LOW LEVEL WASTE) & Page 1 of 1 \\
\hline
\end{tabular}

Nevada Test Site

This Certificate acknowledges that the following shipments) of waste have been disposed at the Nevada Test Site Radioactive Waste Management Complex.

\begin{tabular}{|l|l|l|c|}
\hline \multicolumn{1}{|c|}{ Shipment Number } & \multicolumn{1}{|c|}{$\begin{array}{c}\text { Waste Stream } \\
\text { Identification \# }\end{array}$} & Package \# & Date of Disposal \\
\hline DPL10357 & LRY5LLFY08002 & 10 501 & $5-5-10$ \\
\hline DPL10357 & LRY5LLFY08002 & 10 L502 & $5-5-10$ \\
\hline & & & \\
\hline & & & \\
\hline & & & \\
\hline & & & \\
\hline & & & \\
\hline & & & \\
\hline
\end{tabular}

This certification is provided as a courtesy to the waste generator for information purposes only.

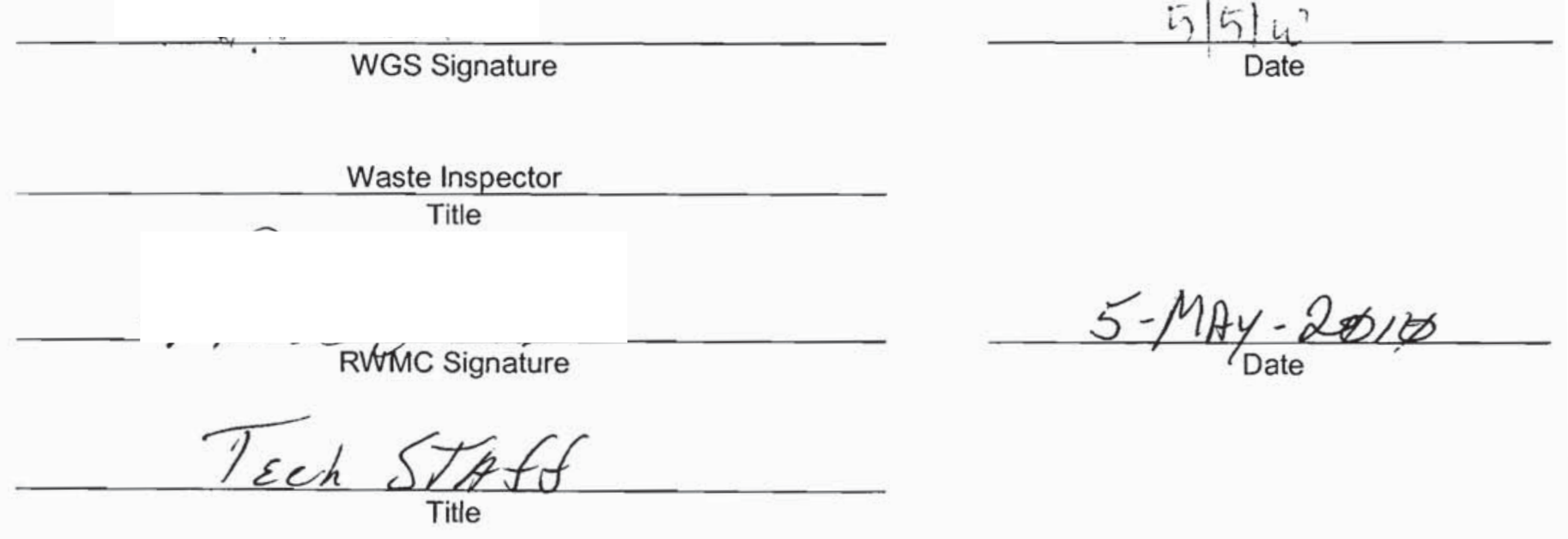


NSTec

Form

FRM-2217
CERTIFICATE OF DISPOSAL

(LOW LEVEL WASTE)
03/01/10

Rev. 01

Page 1 of 1

\section{Nevada Test Site}

This Certificate acknowledges that the following shipment(s) of waste have been disposed at the Nevada Test Site Radioactive Waste Management Complex.

\begin{tabular}{|l|l|l|c|}
\hline Shipment Number & \multicolumn{1}{|c|}{$\begin{array}{c}\text { Waste Stream } \\
\text { Identification \# }\end{array}$} & Package \# & Date of Disposal \\
\hline DPL10358 & LRY5LLFY08002 & 10 L03 & $5-5-10$ \\
\hline DPL10358 & LRY5LLFY08002 & 10 L504 & $5-5-10$ \\
\hline & & & \\
\hline & & & \\
\hline & & & \\
\hline & & & \\
\hline & & & \\
\hline
\end{tabular}

This certification is provided as a courtesy to the waste generator for information purposes only.

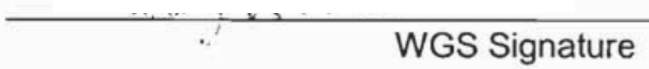

Waste Inspector

$-$
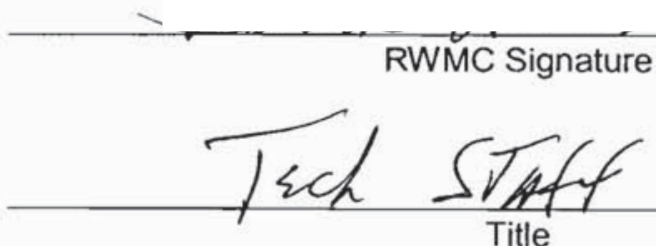
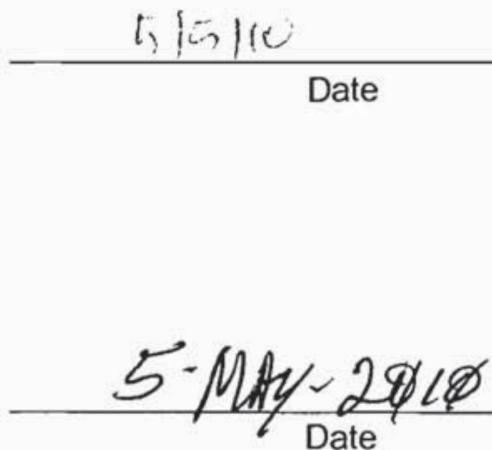
NSTec

Form

FRM-2217
CERTIFICATE OF DISPOSAL

(LOW LEVEL WASTE)
$03 / 01 / 10$

Rev. 01

Page 1 of 1

\section{Nevada Test Site}

This Certificate acknowledges that the following shipment(s) of waste have been disposed at the Nevada Test Site Radioactive Waste Management Complex.

\begin{tabular}{|c|c|c|c|}
\hline Shipment Number & $\begin{array}{l}\text { Waste Stream } \\
\text { Identification \# }\end{array}$ & Package \# & Date of Disposal \\
\hline DPL10359 & LRY5LLFY08002 & 10L505 & $5-5-10$ \\
\hline DPL10359 & LRY5LLFY08002 & 10L506 & $5-5-10$ \\
\hline & & & \\
\hline & & & \\
\hline & & & \\
\hline & & & \\
\hline & & & \\
\hline 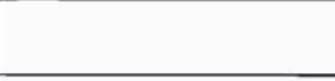 & $x_{0}+2$ & 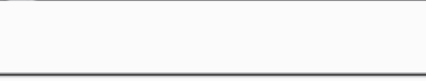 & \\
\hline
\end{tabular}

This certification is provided as a courtesy to the waste generator for information purposes only.

WGS Signature

$\frac{-51510}{\text { Date }}$

Waste Inspector

Title

‘́́víMC Šignature

$5-M B y \cdot 2 \phi i \phi$

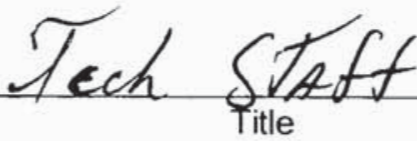


NSTec

Form

FRM-2217
CERTIFICATE OF DISPOSAL

(LOW LEVEL WASTE)
03/01/10

Rev. 01

Page 1 of 1

\section{Nevada Test Site}

This Certificate acknowledges that the following shipment(s) of waste have been disposed at the Nevada Test Site Radioactive Waste Management Complex.

\begin{tabular}{|l|l|l|c|}
\hline \multicolumn{1}{|c|}{$\begin{array}{c}\text { Waste Stream } \\
\text { Identification \# }\end{array}$} & \multicolumn{1}{|c|}{ Package \# } & Date of Disposal \\
\hline DPL10360 & LRY5LLFY08002 & 10 L507 & $5-5-10$ \\
\hline DPL10360 & LRY5LLFY08002 & 10 L508 & $5-5-10$ \\
\hline & & & \\
\hline & & & \\
\hline & & & \\
\hline & & & \\
\hline & & & \\
\hline
\end{tabular}

This certification is provided as a courtesy to the waste generator for information purposes only.

WGS Signature

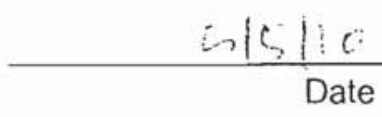

Waste Inspector

Title

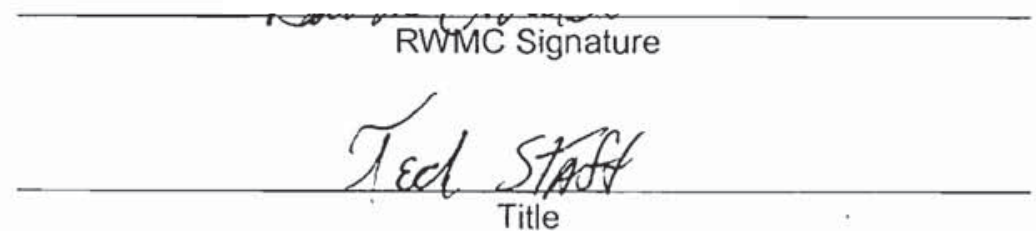

$\frac{5-M A y-2 \phi 1 \varnothing}{\text { Date }}$ 
NSTec

Form

FRM-2217
CERTIFICATE OF DISPOSAL

(LOW LEVEL WASTE)
03/01/10

Rev. 01

Page 1 of 1

\section{Nevada Test Site}

This Certificate acknowledges that the following shipment(s) of waste have been disposed at the Nevada Test Site Radioactive Waste Management Complex.

\begin{tabular}{|l|l|l|c|}
\hline \multicolumn{1}{|c|}{ Shipment Number } & \multicolumn{1}{|c}{$\begin{array}{c}\text { Waste Stream } \\
\text { Identification \# }\end{array}$} & Package \# & Date of Disposal \\
\hline DPL10361 & LRY5LLFY08002 & 10 L509 & $5-5-10$ \\
\hline DPL10361 & LRY5LLFY08002 & 10 L510 & $5-5-10$ \\
\hline & & & \\
\hline & & & \\
\hline & & & \\
\hline & & & \\
\hline
\end{tabular}

This certification is provided as a courtesy to the waste generator for information purposes only.

WGS Signature

Waste Inspector

Title

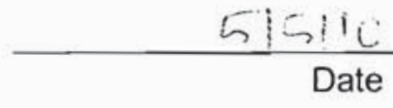

Date
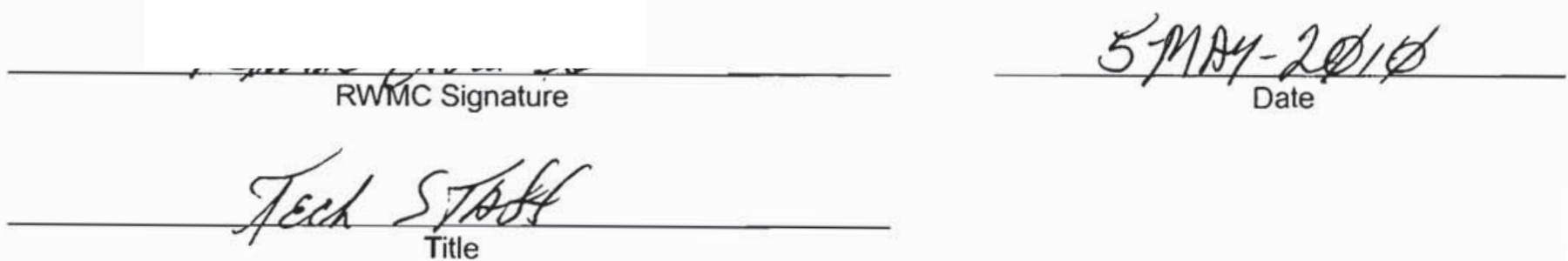
NSTec

CERTIFICATE OF DISPOSAL

03/01/10

Form

(LOW LEVEL WASTE)

Rev. 01

FRM-2217

Page 1 of 1

\section{Nevada Test Site}

This Certificate acknowledges that the following shipment(s) of waste have been disposed at the Nevada Test Site Radioactive Waste Management Complex.

\begin{tabular}{|l|l|l|c|}
\hline \multicolumn{1}{|c|}{ Shipment Number } & \multicolumn{1}{c|}{$\begin{array}{c}\text { Waste Stream } \\
\text { Identification \# }\end{array}$} & Package \# & Date of Disposal \\
\hline DPL10363 & LRY5LLFY08002 & 10 513 & $5-6-10$ \\
\hline DPL10363 & LRY5LLFY08002 & 10 L14 & $5-6-10$ \\
\hline & & & \\
\hline & & & \\
\hline & & & \\
\hline & & & \\
\hline & & & \\
\hline
\end{tabular}

This certification is provided as a courtesy to the waste generator for information purposes only.

/s/: Theresa Hale
WGS Signature
$\frac{\text { Waste Inspector }}{\text { Title }}$
/s/: Jon Tanaka
RWMC Signature

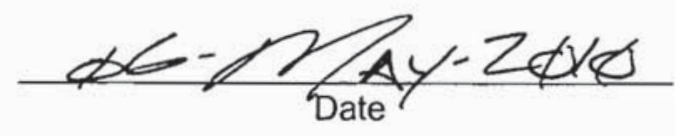


NSTec

Form

FRM-2217
CERTIFICATE OF DISPOSAL

(LOW LEVEL WASTE)
03/01/10

Rev. 01

Page 1 of 1

\section{Nevada Test Site}

This Certificate acknowledges that the following shipment(s) of waste have been disposed at the Nevada Test Site Radioactive Waste Management Complex.

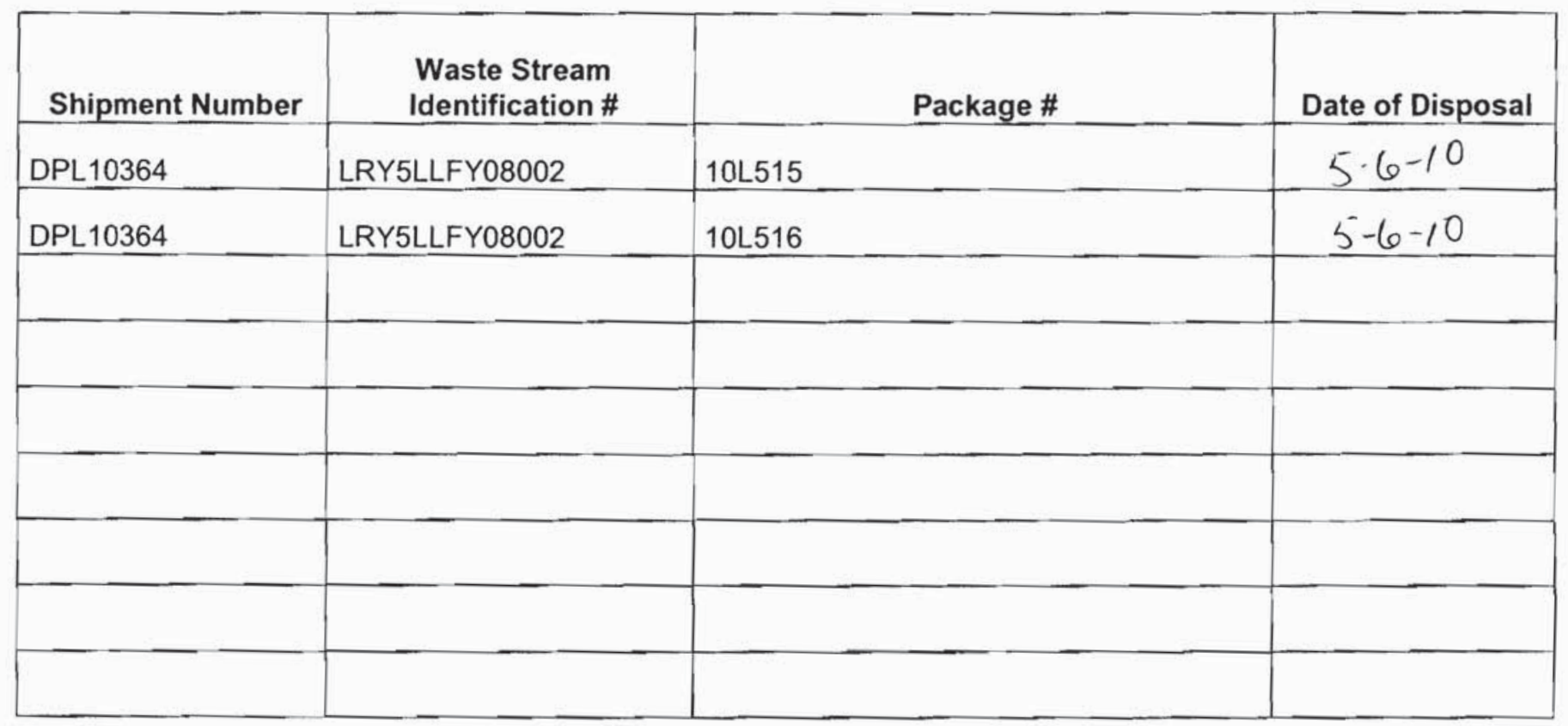

This certification is provided as a courtesy to the waste generator for information purposes only.

/s/: Theresa Hale

WGS Signature

Waste inspector

Title

/s/:Jon Tanaka

RWMC Signature

C) ASTE SFECIAKLST

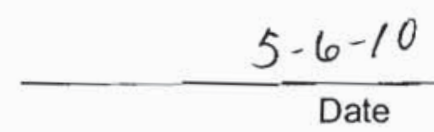

$-\phi 6-2 / A y-2 \phi i \phi$ 
NSTec

Form

CERTIFICATE OF DISPOSAL

03/01/10

FRM-2217

(LOW LEVEL WASTE)

Rev. 01

Page 1 of 1

\section{Nevada Test Site}

This Certificate acknowledges that the following shipment(s) of waste have been disposed at the Nevada Test Site Radioactive Waste Management Complex.

\begin{tabular}{|c|c|c|c|}
\hline Shipment Number & $\begin{array}{l}\text { Waste Stream } \\
\text { Identification \# }\end{array}$ & Package \# & Date of Disposal \\
\hline DPL10365 & LRY5LLFY08002 & $10\llcorner 517$ & $5-6-10$ \\
\hline DPL10365 & LRY5LLFðð08002 & 10 L5 & $5-6-10$ \\
\hline & $\ddot{c}$ & & \\
\hline & & P & \\
\hline & صدم: & $\begin{array}{l}0 \\
0 \\
Q\end{array}$ & \\
\hline & 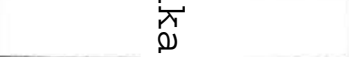 & 焉 & \\
\hline & & (D) & \\
\hline & & & \\
\hline & & & \\
\hline
\end{tabular}

This certification is provided a _.. _urtesy to the waste generator for information purposes only.

/s'/ :Theresa Hale

WGS Signature

Waste Inspector

Title

/s/: Jon Tanaka

RWMC Signature

W ASTE SPECLSLCST
$5-6-10$

Date

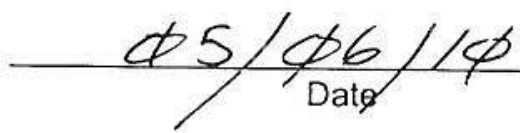


NSTec

Form

FRM-2217
CERTIFICATE OF DISPOSAL

(LOW LEVEL WASTE)
$03 / 01 / 10$

Rev. 01

Page 1 of 1

\section{Nevada Test Site}

This Certificate acknowledges that the following shipment(s) of waste have been disposed at the Nevada Test Site Radioactive Waste Management Complex.

\begin{tabular}{|l|l|l|c|}
\hline \multicolumn{1}{|c|}{ Shipment Number } & $\begin{array}{c}\text { Waste Stream } \\
\text { Identification \# }\end{array}$ & Package \# & Date of Disposal \\
\hline DPL10366 & LRY5LLFY08002 & 10 L519 & $5-6-10$ \\
\hline DPL10366 & LRY5LLFY08002 & 10 L520 & $5-6-10$ \\
\hline & & & \\
\hline & & & \\
\hline & & & \\
\hline & & & \\
\hline
\end{tabular}

This certification is provided as a courtesy to the waste generator for information purposes only.

/s/: Theresa Hale

WGS Signature

Waste Inspector

Title

/s/: Jon Tanaka

RWMC Signature

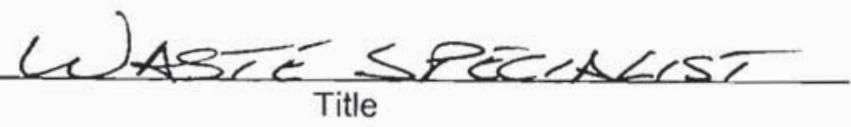

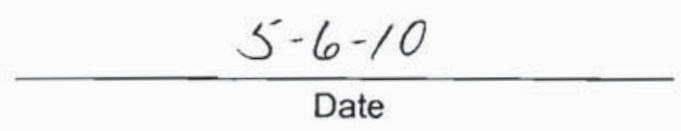

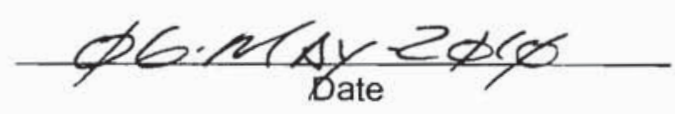




\begin{tabular}{|lcr|}
\hline NSTec & CERTIFICATE OF DISPOSAL & $03 / 01 / 10$ \\
Form & Rev. 01 \\
FRM-2217 & (LOW LEVEL WASTE) & Page 1 of 1 \\
\hline
\end{tabular}

Nevada Test Site

This Certificate acknowledges that the following shipments) of waste have been disposed at the Nevada Test Site Radioactive Waste Management Complex.

\begin{tabular}{|l|l|l|c|}
\hline \multicolumn{1}{|c|}{ Shipment Number } & \multicolumn{1}{|c|}{$\begin{array}{c}\text { Waste Stream } \\
\text { Identification \# }\end{array}$} & Package \# & Date of Disposal \\
\hline DPL10367 & LRY5LLFY08002 & 10 521 & $5-6-10$ \\
\hline DPL10367 & LRY5LLFY08002 & 10 L522 & $5-6-10$ \\
\hline & & & \\
\hline & & & \\
\hline & & & \\
\hline & & & \\
\hline & & & \\
\hline & & & \\
\hline
\end{tabular}

This certification is provided as a courtesy to the waste generator for information purposes only.

/s/ :Theresa Hale

WGS Signature

Waste Inspector

Title

/s/: Jon Tanka

RWMC Signature

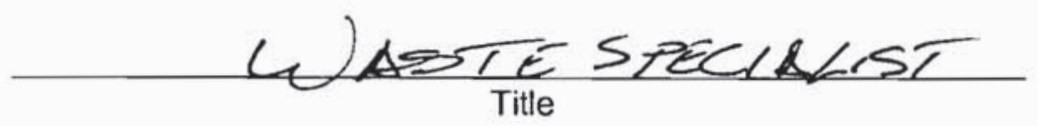

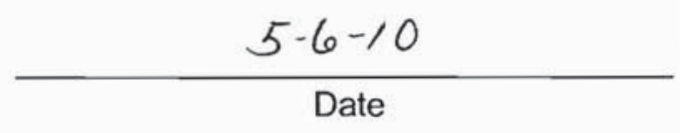

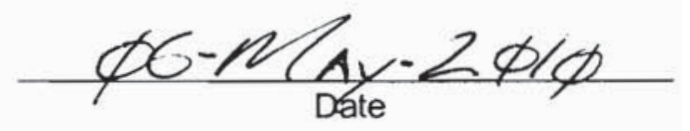

(Reference: OP-2151.304) 


\begin{tabular}{|lcr|}
\hline NSTec & CERTIFICATE OF DISPOSAL & $03 / 01 / 10$ \\
Form & Rev. 01 \\
FRM-2217 & (LOW LEVEL WASTE) & Page 1 of 1 \\
\hline
\end{tabular}

Nevada Test Site

This Certificate acknowledges that the following shipments) of waste have been disposed at the Nevada Test Site Radioactive Waste Management Complex.

\begin{tabular}{|l|l|l|c|}
\hline \multicolumn{1}{|c|}{$\begin{array}{c}\text { Shipment Number } \\
\text { Identification \# }\end{array}$} & \multicolumn{1}{c}{ Package \# } & Date of Disposal \\
\hline DPL10368 & LRY5LLFY08002 & 10 L523 & $5-6-10$ \\
\hline DPL10368 & LRY5LLFY08002 & 10 L524 & $5-6-10$ \\
\hline & & & \\
\hline & & & \\
\hline & & & \\
\hline & & & \\
\hline & & & \\
\hline & & & \\
\hline
\end{tabular}

This certification is provided as a courtesy to the waste generator for information purposes only.

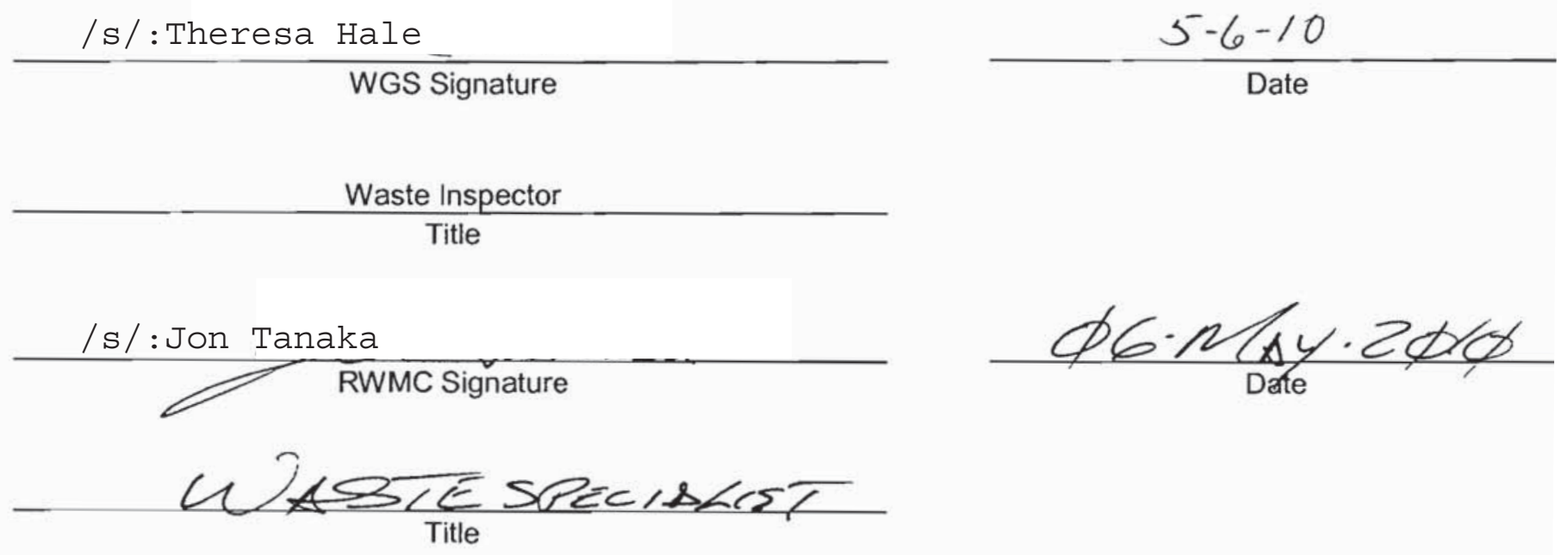

(Reference: OP-2151.304) 
NSTec

Form

FRM-2217
CERTIFICATE OF DISPOSAL

(LOW LEVEL WASTE)
$03 / 01 / 10$

Rev. 01

Page 1 of 1

\section{Nevada Test Site}

This Certificate acknowledges that the following shipment(s) of waste have been disposed at the Nevada Test Site Radioactive Waste Management Complex.

\begin{tabular}{|l|l|l|l|}
\hline Shipment Number & \multicolumn{1}{|c|}{$\begin{array}{c}\text { Waste Stream } \\
\text { Identification \# }\end{array}$} & Package \# & Date of Disposal \\
\hline DPL10369 & LRY5LLFY08002 & 10 L525 & $5-6-10$ \\
\hline DPL10369 & LRY5LLFY08002 & 10 L526 & $5-6-10$ \\
\hline & & & \\
\hline & & & \\
\hline & & & \\
\hline & & & \\
\hline & & & \\
\hline
\end{tabular}

This certification is provided as a courtesy to the waste generator for information purposes only.

/s/: Theresa Hale

WGS Signature

Waste Inspector

Title
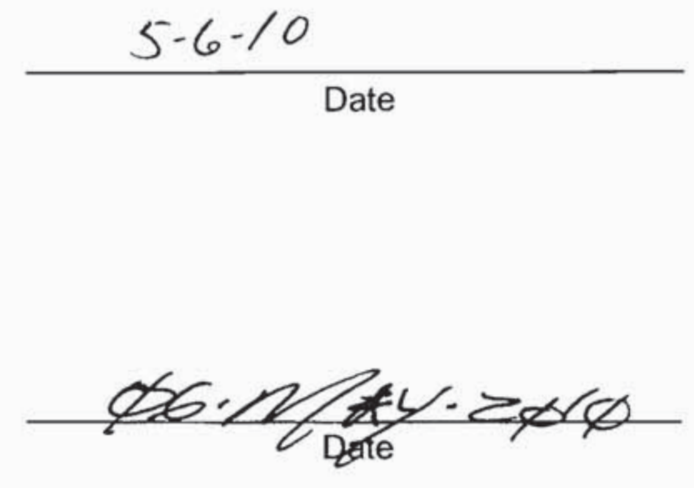


\begin{tabular}{|lcr|}
\hline NSTec & CERTIFICATE OF DISPOSAL & Rev. 01 \\
Form & (LOW LEVEL WASTE) & Page 1 of 1 \\
FRM-2217 & & \\
\hline
\end{tabular}

Nevada Test Site

This Certificate acknowledges that the following shipments) of waste have been disposed at the Nevada Test Site Radioactive Waste Management Complex.

\begin{tabular}{|l|l|l|l|}
\hline Shipment Number & \multicolumn{1}{|c|}{$\begin{array}{c}\text { Waste Stream } \\
\text { Identification \# }\end{array}$} & Package \# & Date of Disposal \\
\hline DPL10362 & LRY5LLFY08002 & 10 511 & $5-6-10$ \\
\hline DPL10362 & LRY5LLFY08002 & 10 L512 & $5-6-10$ \\
\hline & & & \\
\hline & & & \\
\hline & & & \\
\hline & & & \\
\hline & & & \\
\hline & & & \\
\hline
\end{tabular}

This certification is provided as a courtesy to the waste generator for information purposes only.

/s/: Theresa Hale

WGS Signature

Waste Inspector

Title

/s/: Jon Tanka

RWMC Signature

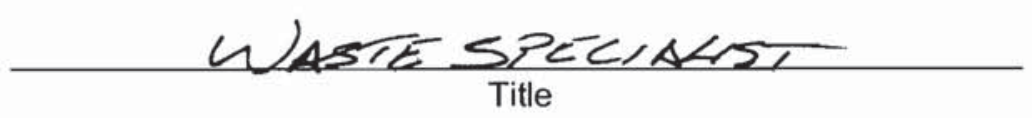

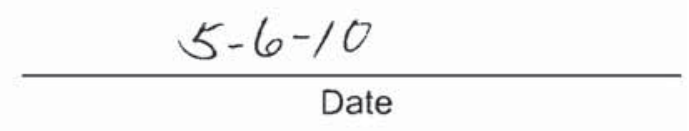

Date

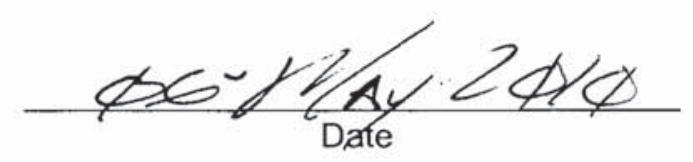

(Reference: OP-2151.304) 
NSTec

Form

FRM-2217
CERTIFICATE OF DISPOSAL

(LOW LEVEL WASTE)
03/01/10

Rev. 01

Page 1 of 1

\section{Nevada Test Site}

This Certificate acknowledges that the following shipment(s) of waste have been disposed at the Nevada Test Site Radioactive Waste Management Complex.

\begin{tabular}{|l|l|l|c|}
\hline Shipment Number & \multicolumn{1}{|c|}{$\begin{array}{c}\text { Waste Stream } \\
\text { Identification \# }\end{array}$} & Package \# & Date of Disposal \\
\hline DPL10370 & LRY5LLFY08002 & 10 L527 & $5-6-10$ \\
\hline DPL10370 & LRY5LLFY08002 & 10 L528 & $5-6-10$ \\
\hline & & & \\
\hline & & & \\
\hline & & & \\
\hline
\end{tabular}

This certification is provided as a courtesy to the waste generator for information purposes only.

/s/:Theresa Hale

WGS Signature

Waste Inspector

Title

/s/:Jon Tanaka

RWMC Signature

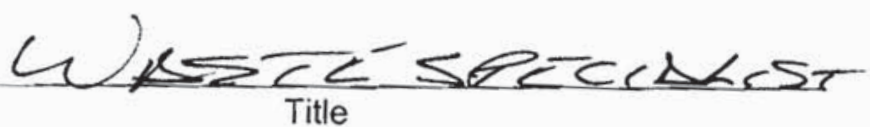

$5-\frac{6-10}{\text { Date }}$

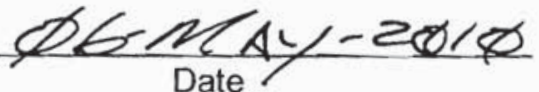


NSTec

Form

CERTIFICATE OF DISPOSAL

03/01/10

FRM-2217

(LOW LEVEL WASTE)

Rev. 01

Page 1 of 1

\section{Nevada Test Site}

This Certificate acknowledges that the following shipment(s) of waste have been disposed at the Nevada Test Site Radioactive Waste Management Complex.

\begin{tabular}{|c|c|c|c|}
\hline Shipment Number & $\begin{array}{l}\text { Waste Stream } \\
\text { Identification \# }\end{array}$ & Package \# & Date of Disposal \\
\hline DPL10371 & LRY5LLFY08002 & 10L529 & $5=10-10$ \\
\hline DPL10371 & LRY5LLFY08002 & 10L530 & $5-10-10$ \\
\hline & & & \\
\hline & & & \\
\hline & & & \\
\hline & & & \\
\hline & & & \\
\hline & & 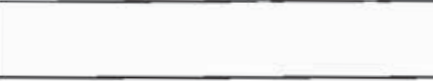 & \\
\hline
\end{tabular}

This certification is provided as a courtesy to the waste generator for information purposes only.

/s/:Theresa Hale

WGS Signature

Waste inspector

Title

/s/: Jon Tanaka

RWMC̄ Signaturē -

ULSTE SPECINKIST
$5-10-10$

Date

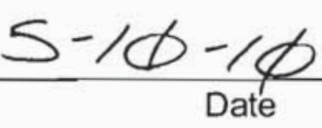




\begin{tabular}{|lcr|}
\hline NSTec & CERTIFICATE OF DISPOSAL & $03 / 01 / 10$ \\
Form & Rev. 01 \\
FRM-2217 & (LOW LEVEL WASTE) & Page 1 of 1 \\
\hline
\end{tabular}

Nevada Test Site

This Certificate acknowledges that the following shipments) of waste have been disposed at the Nevada Test Site Radioactive Waste Management Complex.

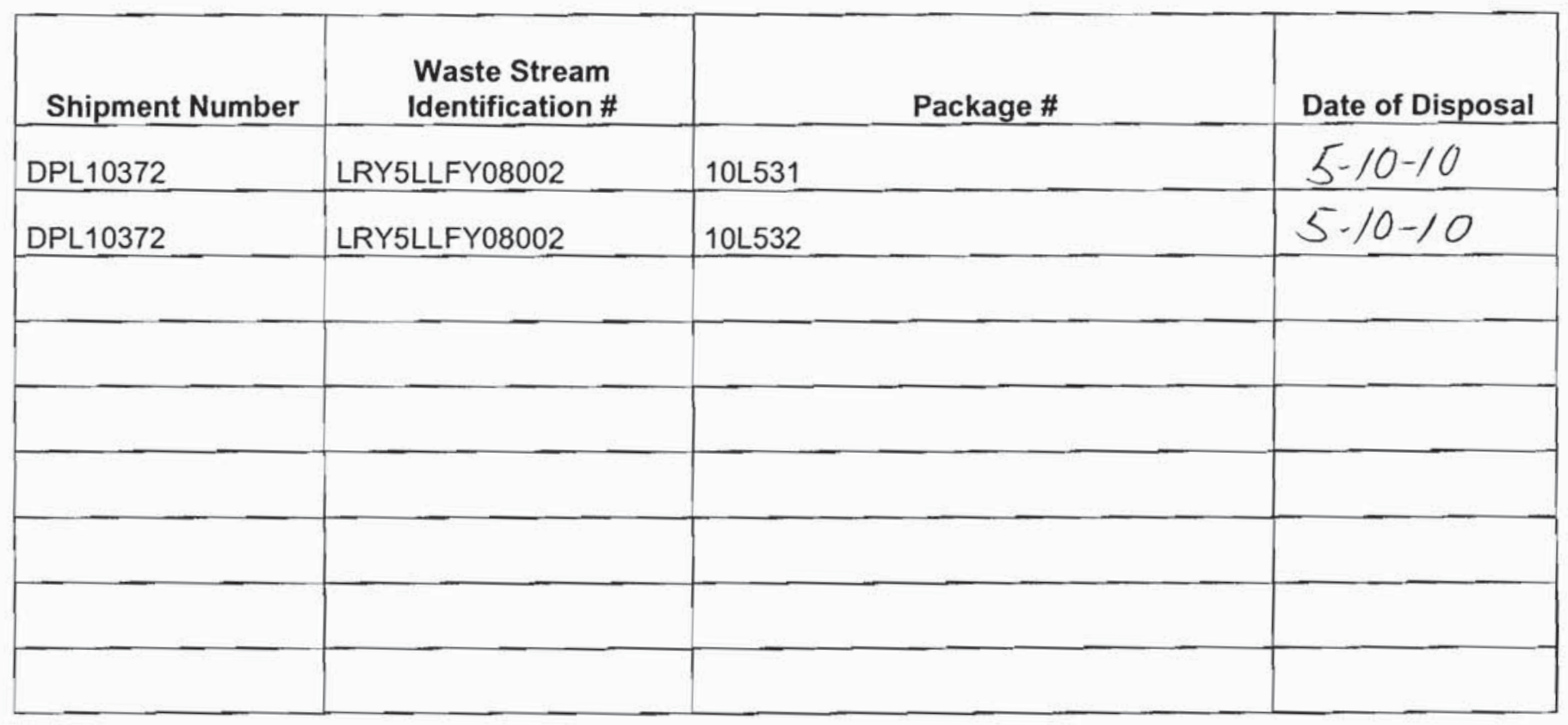

This certification is provided as a courtesy to the waste generator for information purposes only.

/s/ :Theresa Hale.

WGS Signature

Waste Inspector

Title

/s/: Jon Tanka

RWMC Signature

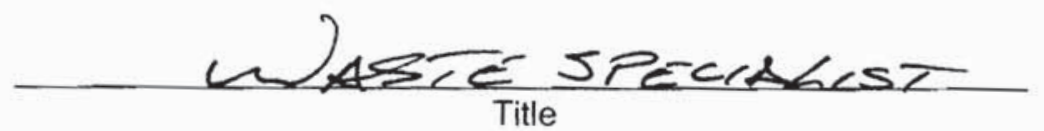

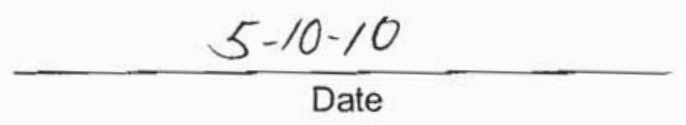

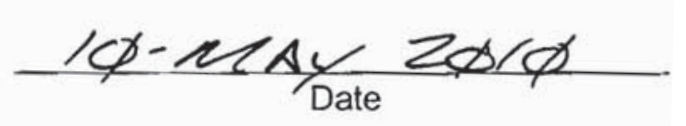

(Dafomnro: nP.2151 Bn) 
NSTec

Form

CERTIFICATE OF DISPOSAL

03/01/10

FRM-2217

(LOW LEVEL WASTE)

Rev. 01

Page 1 of 1

\section{Nevada Test Site}

This Certificate acknowledges that the following shipment(s) of waste have been disposed at the Nevada Test Site Radioactive Waste Management Complex.

\begin{tabular}{|l|l|l|l|}
\hline \multicolumn{1}{|c|}{ Shipment Number } & \multicolumn{1}{|c|}{$\begin{array}{c}\text { Waste Stream } \\
\text { Identification \# }\end{array}$} & Package \# & Date of Disposal \\
\hline DPL10373 & LRY5LLFY08002 & 10 L533 & $5-10-10$ \\
\hline DPL10373 & LRY5LLFY08002 & 10 L534 & $5-10-10$ \\
\hline & & & \\
\hline & & & \\
\hline & & & \\
\hline & & & \\
\hline & & & \\
\hline & & & \\
\hline
\end{tabular}

This certification is provided as a courtesy to the waste generator for information purposes only.

/s/: Theresa Hale

WGS Signature

Waste Inspector

Title

/s/:Jon Tanaka

$\sim$ RWMMC Signäure

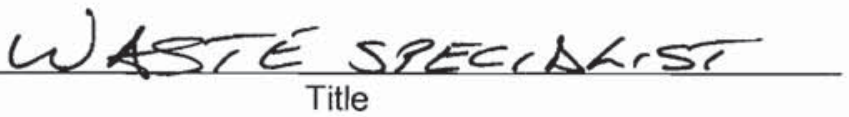

$5 \cdot 10-10$

Date

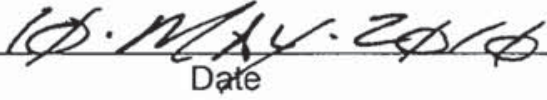


NSTec

Form

FRM-2217
CERTIFICATE OF DISPOSAL

(LOW LEVEL WASTE)
03/01/10

Rev. 01

Page 1 of 1

\section{Nevada Test Site}

This Certificate acknowledges that the following shipment(s) of waste have been disposed at the Nevada Test Site Radioactive Waste Management Complex.

\begin{tabular}{|l|l|l|l|}
\hline \multicolumn{1}{|c|}{ Shipment Number } & \multicolumn{1}{c|}{$\begin{array}{c}\text { Waste Stream } \\
\text { Identification \# }\end{array}$} & Package \# & Date of Disposal \\
\hline DPL10374 & LRY5LLFY08002 & 10 535 & $5-10-/ 0$ \\
\hline DPL10374 & LRY5LLFY08002 & 10 L536 & $5-/ 0-/ 0$ \\
\hline & & & \\
\hline & & & \\
\hline & & & \\
\hline & & & \\
\hline & & & \\
\hline
\end{tabular}

This certification is provided as a courtesy to the waste generator for information purposes only.

/s/:Theresa Hale

WGS Signature

Waste Inspector

Title

/s/:Jon Tanaka

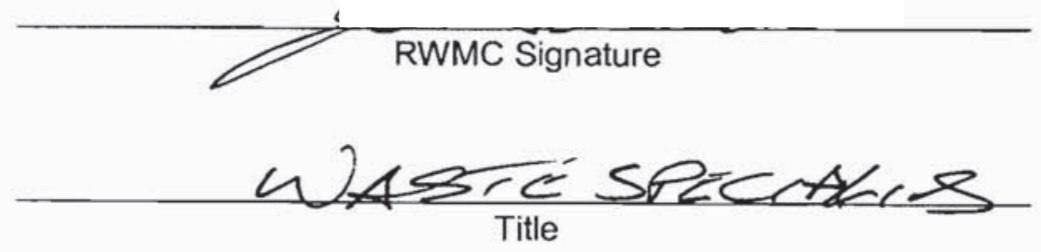

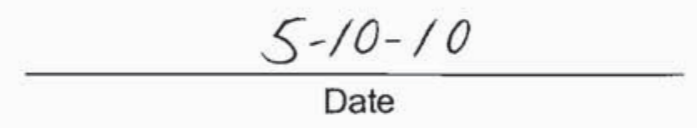

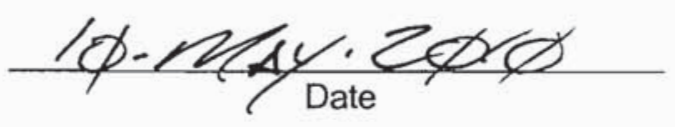


NSTec

Form

FRM-2217
CERTIFICATE OF DISPOSAL

(LOW LEVEL WASTE)
03/01/10

Rev. 01

Page 1 of 1

\section{Nevada Test Site}

This Certificate acknowledges that the following shipment(s) of waste have been disposed at the Nevada Test Site Radioactive Waste Management Complex.

\begin{tabular}{|l|l|l|c|}
\hline Shipment Number & \multicolumn{1}{|c|}{$\begin{array}{c}\text { Waste Stream } \\
\text { Identification \# }\end{array}$} & Package \# & Date of Disposal \\
\hline DPL10375 & LRY5LLFY08002 & 10 L537 & $5-10-10$ \\
\hline DPL10375 & LRY5LLFY08002 & 10 L538 & $5-10-10$ \\
\hline & & & \\
\hline & & & \\
\hline & & & \\
\hline & & & \\
\hline & & & \\
\hline
\end{tabular}

This certification is provided as a courtesy to the waste generator for information purposes only.

$\frac{\text { /s/: Theresa Hale }}{\text { WGS Signature }}$

Waste Inspector

Title

/s/:Jon Tanaka

RWMC Signature

U ASTE SPECCSLRST
$5-10-10$

Date

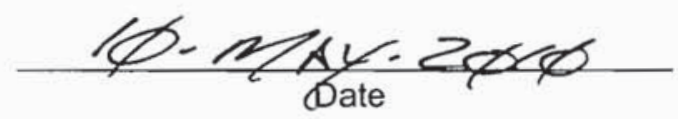


NSTec

Form

CERTIFICATE OF DISPOSAL

$03 / 01 / 10$

FRM-2217

(LOW LEVEL WASTE)

Rev. 01

Page 1 of 1

\section{Nevada Test Site}

This Certificate acknowledges that the following shipment(s) of waste have been disposed at the Nevada Test Site Radioactive Waste Management Complex.

\begin{tabular}{|l|l|l|l|}
\hline \multicolumn{1}{|c|}{$\begin{array}{c}\text { Whipment Number } \\
\text { Identification \# }\end{array}$} & \multicolumn{1}{|c|}{ Package \# } & Date of Disposal \\
\hline DPL10376 & LRY5LLFY08002 & 10 539 & $5-10-10$ \\
\hline DPL10376 & LRY5LLFY08002 & 10 540 & $5-10-10$ \\
\hline & & & \\
\hline & & & \\
\hline & & & \\
\hline & & & \\
\hline & & & \\
\hline
\end{tabular}

This certification is provided as a courtesy to the waste generator for information purposes only.

/s/:Theresa Hale

WGS Signature

Waste Inspector

Title

/s/:Jon Tanaka

RWMC Signature

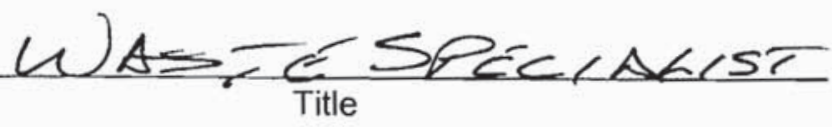

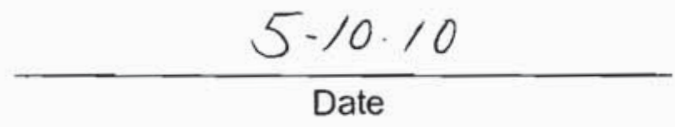

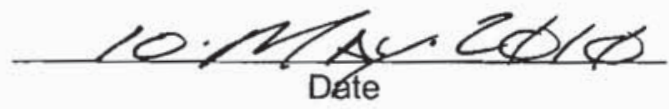


NSTec

Form

CERTIFICATE OF DISPOSAL

03/01/10

FRM-2217

(LOW LEVEL WASTE)

Rev. 01

Page 1 of 1

\section{Nevada Test Site}

This Certificate acknowledges that the following shipment(s) of waste have been disposed at the Nevada Test Site Radioactive Waste Management Complex.

\begin{tabular}{|l|l|l|l|}
\hline \multicolumn{1}{|c|}{ Shipment Number } & \multicolumn{1}{|c|}{$\begin{array}{c}\text { Waste Stream } \\
\text { Identification \# }\end{array}$} & Package \# & Date of Disposal \\
\hline DPL10377 & LRY5LLFY08002 & 10 L541 & $5-10-10$ \\
\hline DPL10377 & LRY5LLFY08002 & 10 L542 & $5-10-10$ \\
\hline & & & \\
\hline & & & \\
\hline & & & \\
\hline & & & \\
\hline & & & \\
\hline
\end{tabular}

This certification is provided as a courtesy to the waste generator for information purposes only.

/s/: Theresa Hale

WGS Signature

Waste Inspector

Title

/s/:Jon Tanaka

RWMC Signature

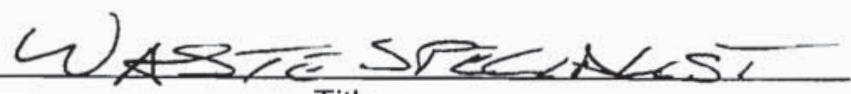

$5-10-10$

Date

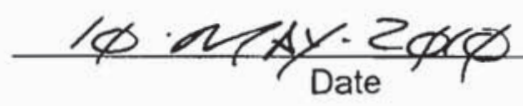


NSTec

Form

FRM-2217
CERTIFICATE OF DISPOSAL

(LOW LEVEL WASTE)
$03 / 01 / 10$

Rev. 01

Page 1 of 1

\section{Nevada Test Site}

This Certificate acknowledges that the following shipment(s) of waste have been disposed at the Nevada Test Site Radioactive Waste Management Complex.

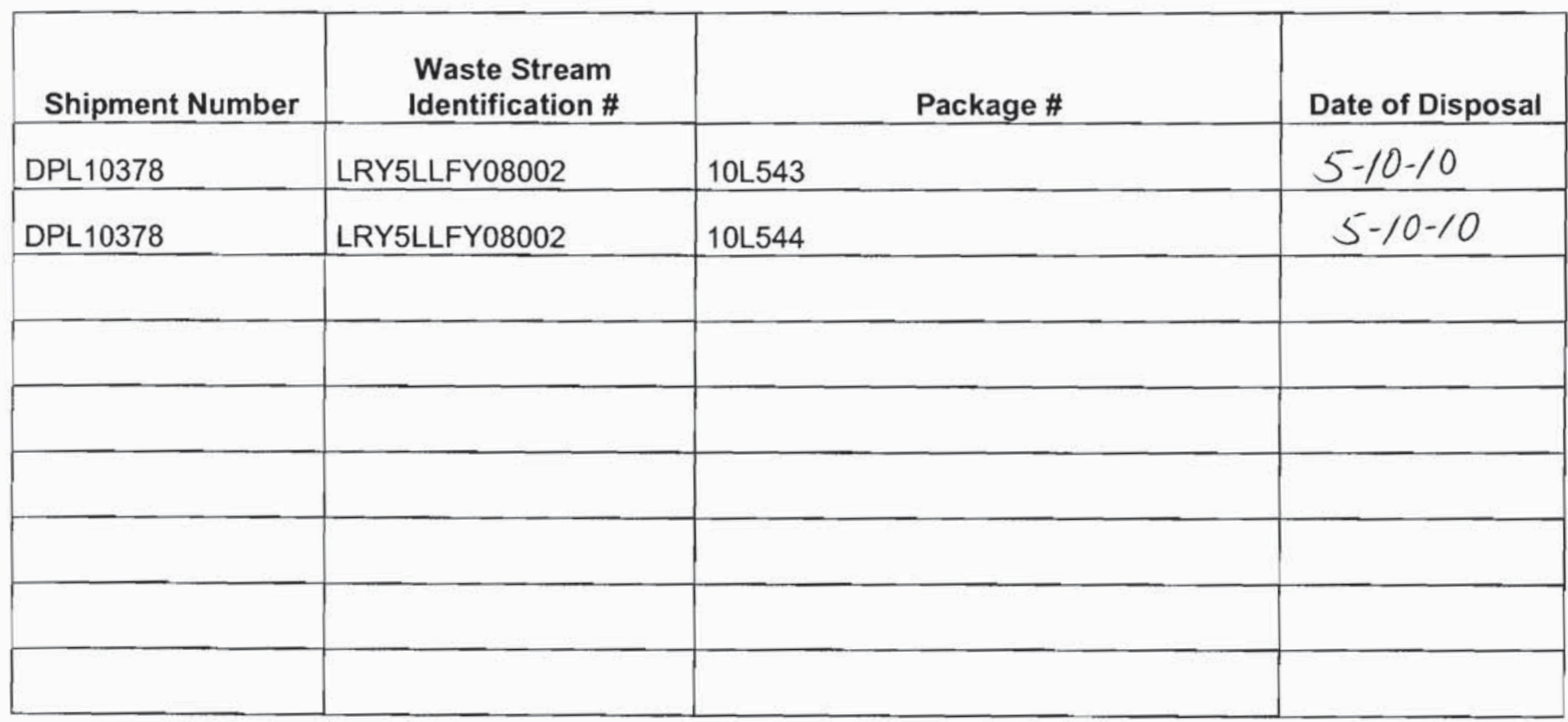

This certification is provided as a courtesy to the waste generator for information purposes only.

/s/:Theresa Hale

WGS Signature

Waste inspector

$$
\text { Title }
$$

/s/:Jon Tanaka

RWMC Signature

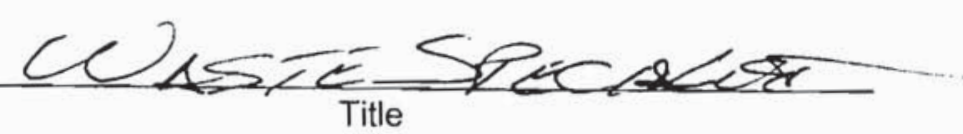

$5-10-10$

Date

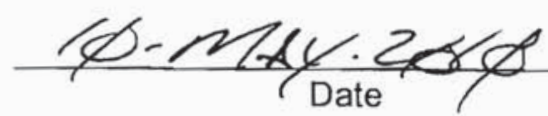




\begin{tabular}{|lcr|}
\hline NSTec & CERTIFICATE OF DISPOSAL & 03/01/10 \\
Form & Rev. 01 \\
FRM-2217 & (LOW LEVEL WASTE) & Page 1 of 1 \\
\hline
\end{tabular}

Nevada Test Site

This Certificate acknowledges that the following shipments) of waste have been disposed at the Nevada Test Site Radioactive Waste Management Complex.

\begin{tabular}{|l|l|l|l|}
\hline Shipment Number & \multicolumn{1}{|c|}{$\begin{array}{c}\text { Waste Stream } \\
\text { Identification\# }\end{array}$} & Package \# & Date of Disposal \\
\hline DPL10379 & LRY5LLFY08002 & 10 L545 & $5-10-10$ \\
\hline DPL10379 & LRY5LLFY08002 & 10 L546 & $5-10-10$ \\
\hline & & & \\
\hline & & & \\
\hline & & & \\
\hline & & & \\
\hline & & & \\
\hline & & & \\
\hline
\end{tabular}

This certification is provided as a courtesy to the waste generator for information purposes only.

/s/ :Theresa Hale

WGS Signature

Waste Inspector

Title

/s/: Jon Kanaka

RWḾC Signature
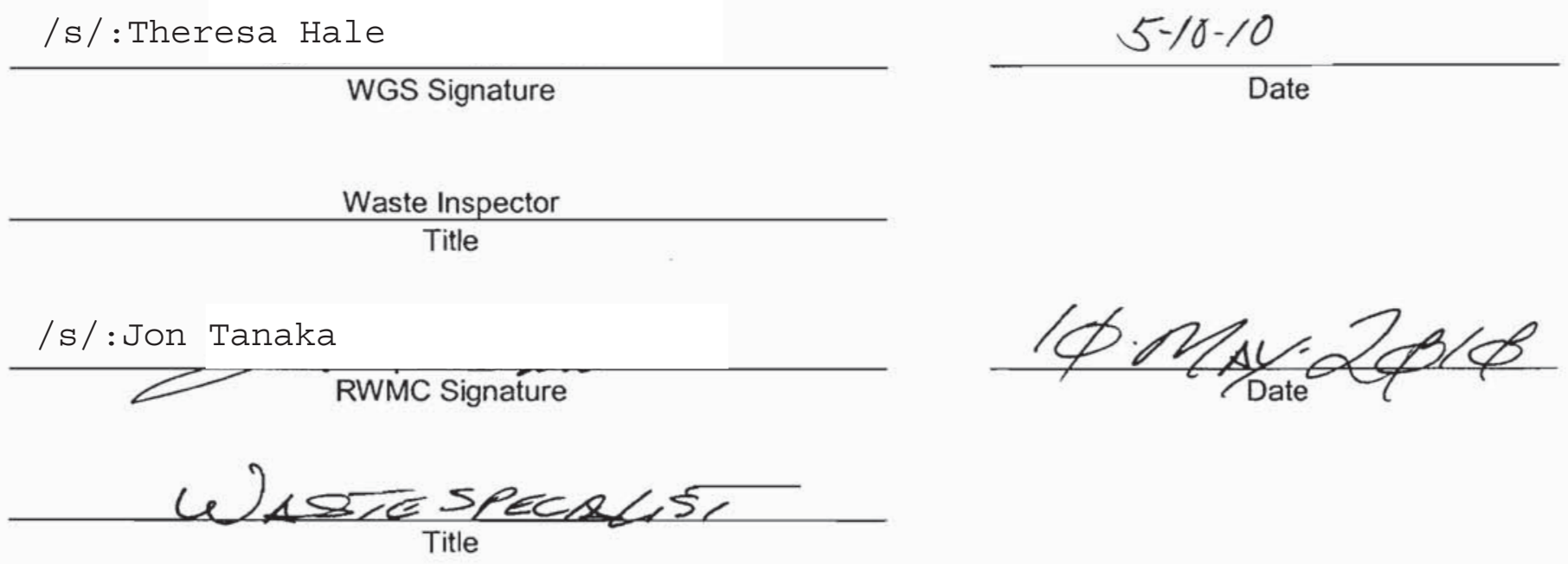

(Reference. OP -2151304) 
NSTec

Form

CERTIFICATE OF DISPOSAL

03/01/10

FRM-2217

(LOW LEVEL WASTE)

Rev. 01

Page 1 of 1

\section{Nevada Test Site}

This Certificate acknowledges that the following shipment(s) of waste have been disposed at the Nevada Test Site Radioactive Waste Management Complex.

\begin{tabular}{|l|l|l|l|}
\hline \multicolumn{1}{|c|}{ Shipment Number } & \multicolumn{1}{c|}{$\begin{array}{c}\text { Waste Stream } \\
\text { Identification \# }\end{array}$} & Package \# & Date of Disposal \\
\hline DPL10380 & LRY5LLFY08002 & 10 L547 & $5-10-10$ \\
\hline DPL10380 & LRY5LLFY08002 & 10 L548 & $5-10-10$ \\
\hline & & & \\
\hline & & & \\
\hline & & & \\
\hline & & & \\
\hline & & & \\
\hline
\end{tabular}

This certification is provided as a courtesy to the waste generator for information purposes only.

/s/: Theresa Hale

WGS Signature

Waste Inspector

$$
\text { Title }
$$

/s/:Jon Tanaka

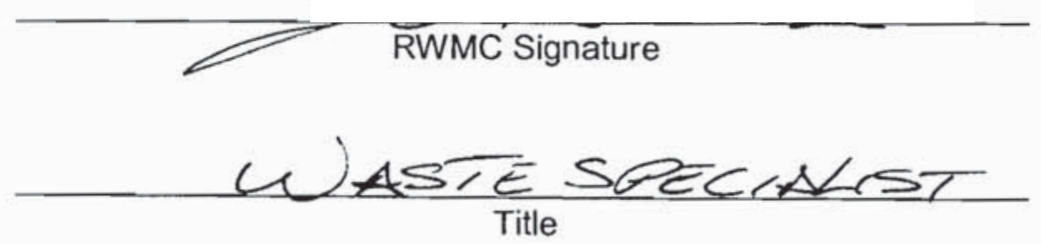

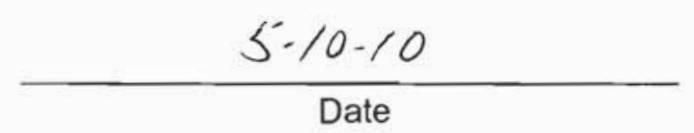

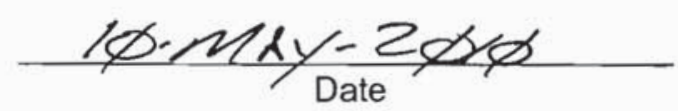




\begin{tabular}{|lcr|}
\hline NSTec & CERTIFICATE OF DISPOSAL & $03 / 01 / 10$ \\
Form & Rev. 01 \\
FRM-2217 & (LOW LEVEL. WASTE) & Page 1 of 1 \\
\hline
\end{tabular}

Nevada Test Site

This Certificate acknowledges that the following shipments) of waste have been disposed at the Nevada Test Site Radioactive Waste Management Complex.

\begin{tabular}{|l|l|l|c|}
\hline \multicolumn{1}{|c|}{ Shipment Number } & $\begin{array}{c}\text { Waste Stream } \\
\text { Identification \# }\end{array}$ & Package \# & Date of Disposal \\
\hline DPL10381 & LRY5LLFY08002 & $10 L 549$ & $5-11-10$ \\
\hline DPL10381 & LRY5LLFY08002 & $10 L 550$ & $5-11-10$ \\
\hline & & & \\
\hline & & & \\
\hline & & & \\
\hline & & & \\
\hline & & & \\
\hline & & & \\
\hline
\end{tabular}

This certification is provided as a courtesy to the waste generator for information purposes only.

/s/ :Theresa Hale

WGS Signature

Waste Inspector

Title

RWMC Signature

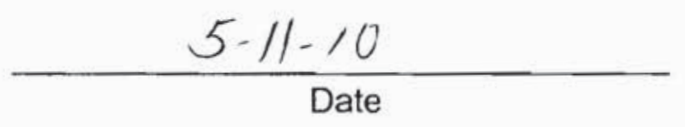

/s/ :Jon Tanka
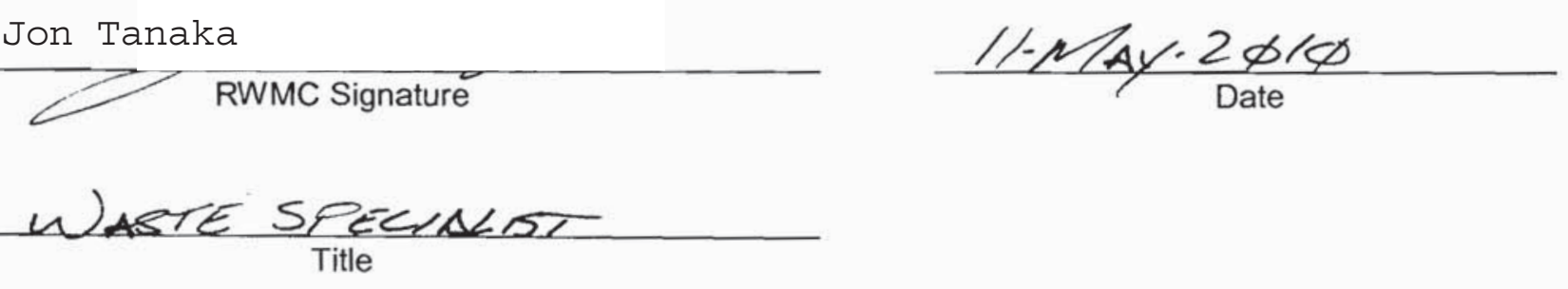

(Reference: OP-2151.304) 
NSTec

Form

CERTIFICATE OF DISPOSAL

03/01/10

FRM-2217

(LOW LEVEL WASTE)

Rev. 01

Page 1 of 1

\section{Nevada Test Site}

This Certificate acknowledges that the following shipment(s) of waste have been disposed at the Nevada Test Site Radioactive Waste Management Complex.

\begin{tabular}{|l|l|l|l|}
\hline \multicolumn{1}{|c|}{ Shipment Number } & \multicolumn{1}{|c|}{$\begin{array}{c}\text { Waste Stream } \\
\text { Identification \# }\end{array}$} & Package \# & Date of Disposal \\
\hline DPL10382 & LRY5LLFY08002 & 10 L551 & $5-1 /-10$ \\
\hline DPL10382 & LRY5LLFY08002 & 10 L552 & $5-1 /-10$ \\
\hline & & & \\
\hline & & & \\
\hline & & & \\
\hline & & & \\
\hline
\end{tabular}

This certification is provided as a courtesy to the waste generator for information purposes only.

/s/: Theresa Hale

WGS Signature

Waste Inspector

Title

/s/:Jon Tanaka

RWMC Signature

WASTE SPECLACST

Title
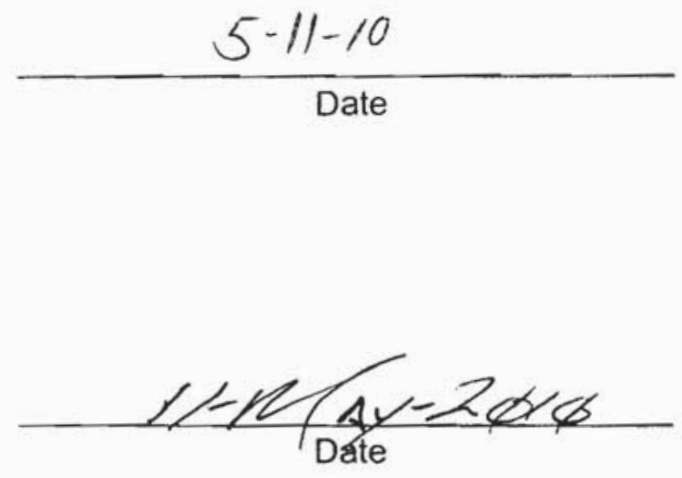
NSTec

CERTIFICATE OF DISPOSAL

03/01/10

Form

(LOW LEVEL WASTE)

Rev. 01

FRM-2217

Page 1 of 1

\section{Nevada Test Site}

This Certificate acknowledges that the following shipment(s) of waste have been disposed at the Nevada Test Site Radioactive Waste Management Complex.

\begin{tabular}{|l|l|l|l|}
\hline \multicolumn{1}{|c|}{ Shipment Number } & \multicolumn{1}{c|}{$\begin{array}{c}\text { Waste Stream } \\
\text { Identification \# }\end{array}$} & Package \# & Date of Disposal \\
\hline DPL10383 & LRY5LLFY08002 & 10L553 & $5-12-10$ \\
\hline DPL10383 & LRY5LLFY08002 & 10 L554 & $5-/ 0-10$ \\
\hline & & & \\
\hline & & & \\
\hline & & & \\
\hline & & & \\
\hline & & & \\
\hline
\end{tabular}

This certification is provided as a courtesy to the waste generator for information purposes only.

/s/: Theresa Hale

WGS Signature

Waste Inspector

Title

/s/:Jon Tanaka

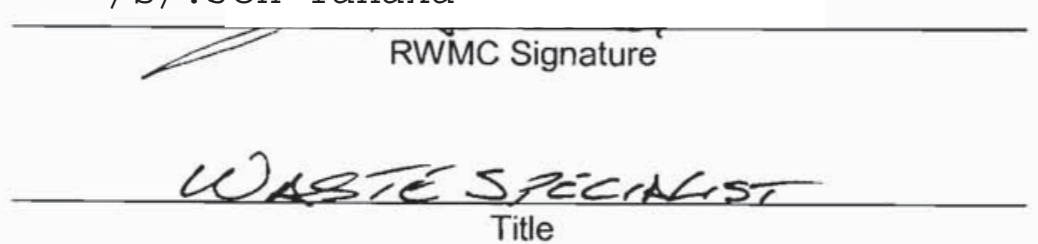

$5-12 \cdot 10$

Date

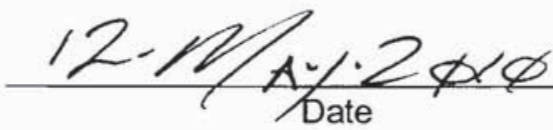


NSTec

Form

FRM-2217
CERTIFICATE OF DISPOSAL

(LOW LEVEL WASTE)
03/01/10

Rev. 01

Page 1 of 1

\section{Nevada Test Site}

This Certificate acknowledges that the following shipment(s) of waste have been disposed at the Nevada Test Site Radioactive Waste Management Complex.

\begin{tabular}{|l|l|l|c|}
\hline Shipment Number & \multicolumn{1}{|c|}{$\begin{array}{c}\text { Waste Stream } \\
\text { Identification \# }\end{array}$} & Package \# & Date of Disposal \\
\hline DPL10384 & LRY5LLFY08002 & 10 L555 & $5-12-10$ \\
\hline DPL10384 & LRY5LLFY08002 & 10 L556 & $5-12-10$ \\
\hline & & & \\
\hline & & & \\
\hline & & & \\
\hline & & & \\
\hline & & & \\
\hline
\end{tabular}

This certification is provided as a courtesy to the waste generator for information purposes only.

\section{/s/:Theresa Hale}

WGS Signature

Waste Inspector

Title

/s/: Jon Tanaka

RWMC Signature

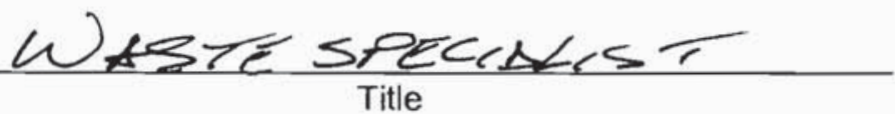

$5-12-10$

Date

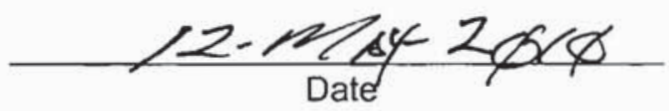




\begin{tabular}{|lcr|}
\hline NSTec & CERTIFICATE OF DISPOSAL & $03 / 01 / 10$ \\
Form & Rev. 01 \\
FRM-2217 & (LOW LEVEL WASTE) & Page 1 of 1 \\
\hline
\end{tabular}

Nevada Test Site

This Certificate acknowledges that the following shipments) of waste have been disposed at the Nevada Test Site Radioactive Waste Management Complex.

\begin{tabular}{|l|l|l|c|}
\hline \multicolumn{1}{|c|}{ Shipment Number } & \multicolumn{1}{|c|}{$\begin{array}{c}\text { Waste Stream } \\
\text { Identification \# }\end{array}$} & Package \# & Date of Disposal \\
\hline DPL10385 & LRY5LLFY08002 & 10 L557 & $5-12-10$ \\
\hline DPL10385 & LRY5LLFY08002 & 10 L558 & $5-12-10$ \\
\hline & & & \\
\hline & & & \\
\hline & & & \\
\hline & & & \\
\hline & & & \\
\hline
\end{tabular}

This certification is provided as a courtesy to the waste generator for information purposes only.

/s/ :Theresa Hale

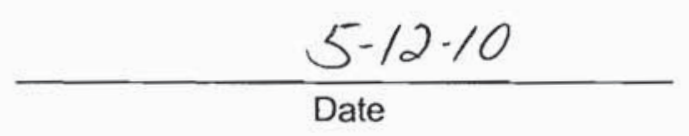

Waste Inspector

Title

/s/ :Jon Kanaka

RWMC Signature

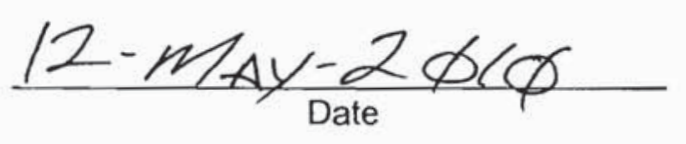


NSTec

Form

FRM-2217
CERTIFICATE OF DISPOSAL

(LOW LEVEL WASTE)
03/01/10

Rev. 01

Page 1 of 1

\section{Nevada Test Site}

This Certificate acknowledges that the following shipment(s) of waste have been disposed at the Nevada Test Site Radioactive Waste Management Complex.

\begin{tabular}{|l|l|l|c|}
\hline \multicolumn{1}{|c|}{$\begin{array}{c}\text { Whipment Number } \\
\text { Identification\# }\end{array}$} & \multicolumn{1}{|c|}{ Package \# } & Date of Disposal \\
\hline DPL10386 & LRY5LLFY08002 & 10 L559 & $5-12-10$ \\
\hline DPL10386 & LRY5LLFY08002 & 10 L560 & $5-12-10$ \\
\hline & & & \\
\hline & & & \\
\hline & & & \\
\hline & & & \\
\hline
\end{tabular}

This certification is provided as a courtesy to the waste generator for information purposes only.

/s/:Theresa Hale

WGS Signature

Waste Inspector

Title

/s/:Jon Tanaka

$\bar{R} W M C$ Signature

U) $4 B$ TE SPECLSLIST
$5-12-10$

Date

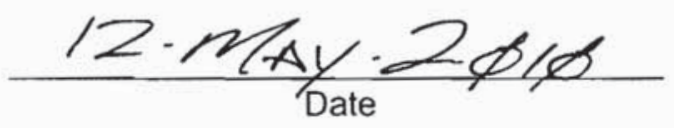


NSTec

Form

FRM-2217
CERTIFICATE OF DISPOSAL

(LOW LEVEL WASTE)
03/01/10

Rev. 01

Page 1 of 1

\section{Nevada Test Site}

This Certificate acknowledges that the following shipment(s) of waste have been disposed at the Nevada Test Site Radioactive Waste Management Complex.

\begin{tabular}{|l|l|l|l|}
\hline \multicolumn{1}{|c|}{$\begin{array}{c}\text { Waste Stream } \\
\text { Identification \# }\end{array}$} & \multicolumn{1}{|c|}{ Package \# } & Date of Disposal \\
\hline DPL10387 & LRY5LLFY08002 & 10 L561 & $5-1 / 2-10$ \\
\hline DPL10387 & LRY5LLFY08002 & 10 L562 & $5-12-10$ \\
\hline & & & \\
\hline & & & \\
\hline & & & \\
\hline & & & \\
\hline
\end{tabular}

This certification is provided as a courtesy to the waste generator for information purposes only.

/s/: Theresa Hale

WGS Signature

Waste Inspector

$$
\text { Title }
$$

/s/:Jon Tanaka

RWMC Signature
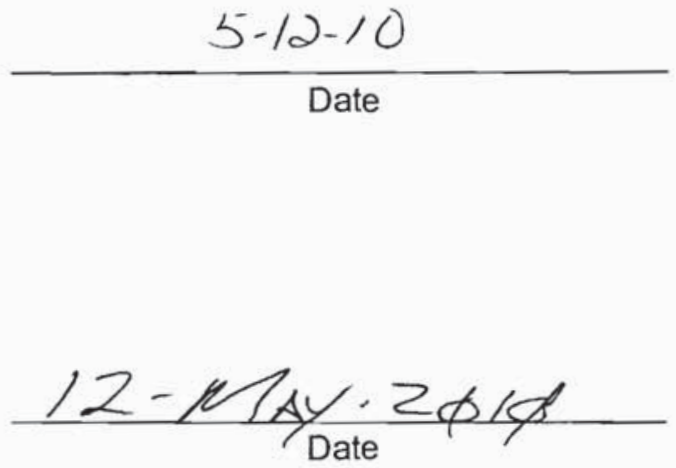

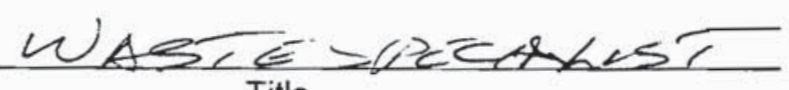


NSTec

Form

FRM-2217
CERTIFICATE OF DISPOSAL

(LOW LEVEL WASTE)
03/01/10

Rev. 01

Page 1 of 1

\section{Nevada Test Site}

This Certificate acknowledges that the following shipment(s) of waste have been disposed at the Nevada Test Site Radioactive Waste Management Complex.

\begin{tabular}{|l|l|l|c|}
\hline \multicolumn{1}{|c|}{ Shipment Number } & \multicolumn{1}{|c|}{$\begin{array}{c}\text { Waste Stream } \\
\text { Identification \# }\end{array}$} & Package \# & Date of Disposal \\
\hline DPL10388 & LRY5LLFY08002 & 10 L563 & $5-12-10$ \\
\hline DPL10388 & LRY5LLFY08002 & 10 L64 & $5-12-10$ \\
\hline & & & \\
\hline & & & \\
\hline & & & \\
\hline & & & \\
\hline & & & \\
\hline
\end{tabular}

This certification is provided as a courtesy to the waste generator for information purposes only.

\section{/ $\mathrm{s}^{\prime} /$ : Theresa Hale}

WGS Signature

Waste Inspector

Title

/s/: Jon Tanaka

RWMC Signature

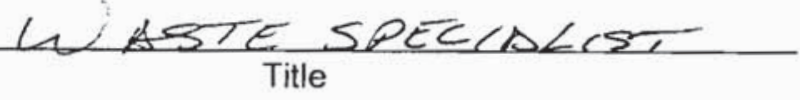

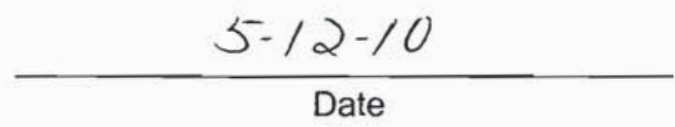

$\frac{12-m A y-2 \phi / \phi}{\text { Date }}$ 
NSTec

Form

FRM-2217
CERTIFICATE OF DISPOSAL

(LOW LEVEL WASTE)
03/01/10

Rev. 01

Page 1 of 1

\section{Nevada Test Site}

This Certificate acknowledges that the following shipment(s) of waste have been disposed at the Nevada Test Site Radioactive Waste Management Complex.

\begin{tabular}{|l|l|l|c|}
\hline \multicolumn{1}{|c|}{ Shipment Number } & \multicolumn{1}{|c|}{$\begin{array}{c}\text { Waste Stream } \\
\text { Identification \# }\end{array}$} & Package \# & Date of Disposal \\
\hline DPL10389 & LRY5LLFY08002 & 10 L565 & $5 \% / 2-10$ \\
\hline DPL10389 & LRY5LLFY08002 & 10 L666 & $5 \% / 2-10$ \\
\hline & & & \\
\hline & & & \\
\hline & & & \\
\hline & & & \\
\hline & & & \\
\hline
\end{tabular}

This certification is provided as a courtesy to the waste generator for information purposes only.

1

/s/:Theresa Hale

WGS Signature

Waste Inspector

Title

/s/:Jon Tanaka

RWMC Signature

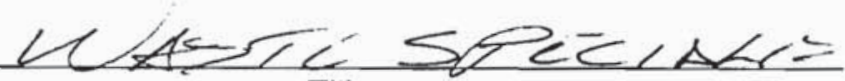

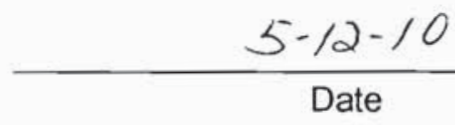

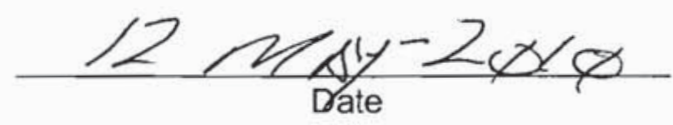


NSTec

Form

CERTIFICATE OF DISPOSAL

03/01/10

FRM-2217

(LOW LEVEL WASTE)

Rev. 01

Page 1 of 1

\section{Nevada Test Site}

This Certificate acknowledges that the following shipment(s) of waste have been disposed at the Nevada Test Site Radioactive Waste Management Complex.

\begin{tabular}{|l|l|l|c|}
\hline Shipment Number & \multicolumn{1}{|c|}{$\begin{array}{c}\text { Waste Stream } \\
\text { Identification \# }\end{array}$} & Package \# & Date of Disposal \\
\hline DPL10390 & LRY5LLFY08002 & 10 567 & $5-13-10$ \\
\hline DPL10390 & LRY5LLFY08002 & 10 L568 & $5-13-10$ \\
\hline & & & \\
\hline & & & \\
\hline & & & \\
\hline & & & \\
\hline & & & \\
\hline
\end{tabular}

This certification is provided as a courtesy to the waste generator for information purposes only.

/s/:Theresa Hale

WGS Signature

Waste Inspector

Title
/s/:Jon Tanaka

RẀMC Šignature

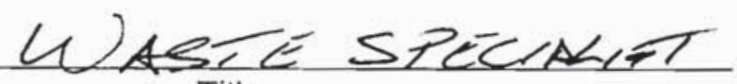

$5-13-10$

Date

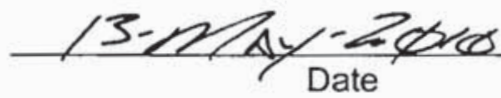


NSTec

Form

FRM-2217
CERTIFICATE OF DISPOSAL

(LOW LEVEL WASTE)
03/01/10

Rev. 01

Page 1 of 1

\section{Nevada Test Site}

This Certificate acknowledges that the following shipment(s) of waste have been disposed at the Nevada Test Site Radioactive Waste Management Complex.

\begin{tabular}{|c|c|c|c|}
\hline Shipment Number & $\begin{array}{l}\text { Waste Stream } \\
\text { Identification \# }\end{array}$ & Package \# & Date of Disposal \\
\hline DPL10391 & LRY5LLFY08002 & 10L569 & $5-13-10$ \\
\hline DPL10391 & LRY5LLFY08002 & $10 \mathrm{~L} 570$ & $5-13-10$ \\
\hline & & & \\
\hline & & & \\
\hline & & & \\
\hline & & & \\
\hline & & & \\
\hline & & & \\
\hline
\end{tabular}

This certification is provided as a courtesy to the waste generator for information purposes only.

/s/:Theresa Hale

WGS Signature

Waste inspector

Title

/s/: Jon Tanaka

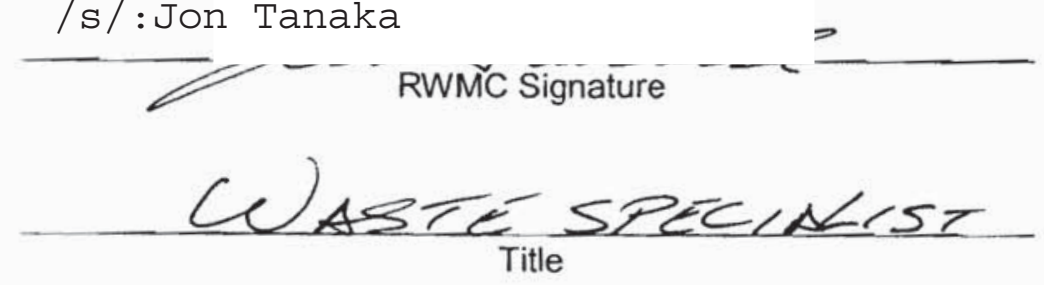

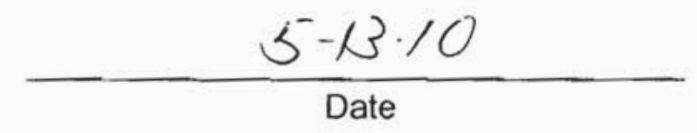

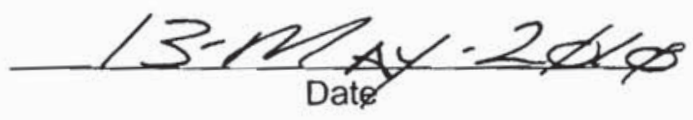


NSTec

Form

FRM-2217
CERTIFICATE OF DISPOSAL

(LOW LEVEL WASTE)
$03 / 01 / 10$

Rev. 01

Page 1 of 1

\section{Nevada Test Site}

This Certificate acknowledges that the following shipment(s) of waste have been disposed at the Nevada Test Site Radioactive Waste Management Complex.

\begin{tabular}{|l|l|l|c|}
\hline \multicolumn{1}{|c|}{$\begin{array}{c}\text { Waste Stream } \\
\text { Identification \# }\end{array}$} & \multicolumn{1}{|c|}{ Package \# } & Date of Disposal \\
\hline DPL10392 & LRY5LLFY08002 & 10 571 & $5-13-10$ \\
\hline DPL10392 & LRY5LLFY08002 & 10 L572 & $5-13-10$ \\
\hline & & & \\
\hline & & & \\
\hline & & & \\
\hline & & & \\
\hline & & & \\
\hline
\end{tabular}

This certification is provided as a courtesy to the waste generator for information purposes only.

/s/:Theresa Hale

WGS Signature

Waste Inspector

Title

/s/:Jon Tanaka

RWMC Signature

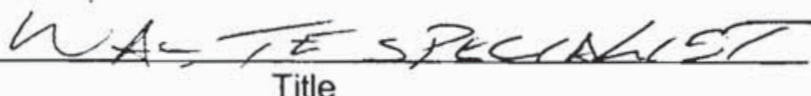

$$
5-13-10
$$

Date

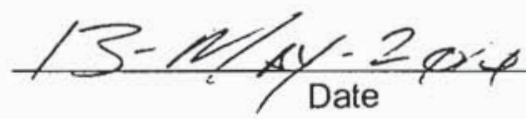


NSTec

Form

FRM-2217
CERTIFICATE OF DISPOSAL

(LOW LEVEL WASTE)
03/01/10

Rev. 01

Page 1 of 1

\section{Nevada Test Site}

This Certificate acknowledges that the following shipment(s) of waste have been disposed at the Nevada Test Site Radioactive Waste Management Complex.

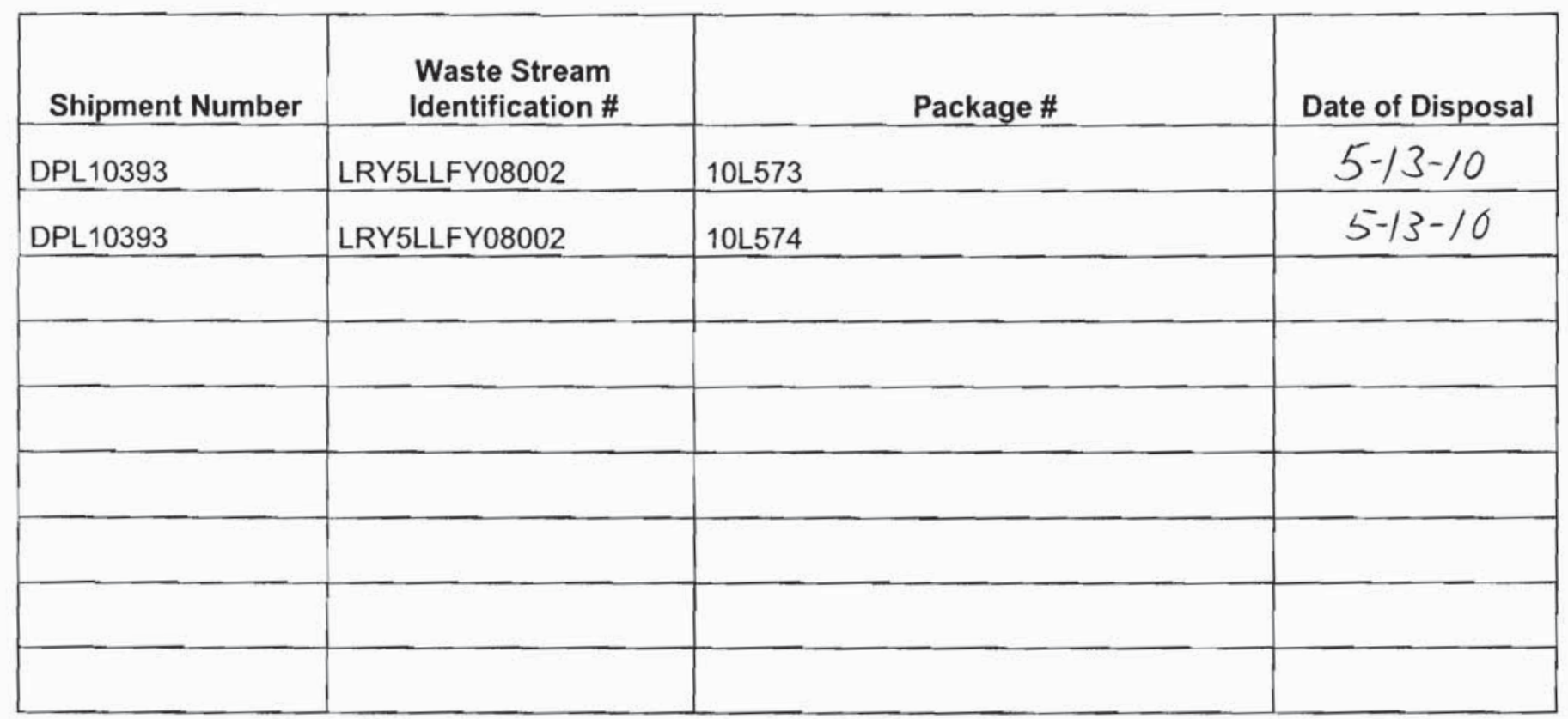

This certification is provided as a courtesy to the waste generator for information purposes only.

/s/:Theresa Hale

WGS Signature

Waste Inspector

$$
\text { Title }
$$

\section{/s/:Jon Tanaka}

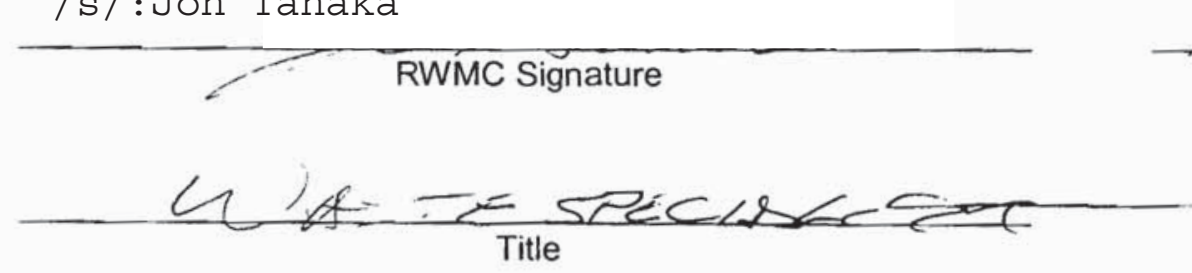

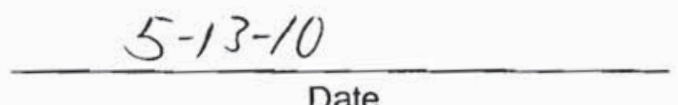

Date

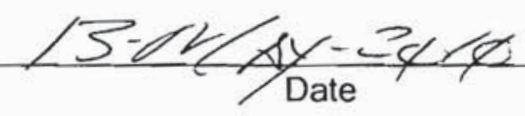




\section{Nevada Test Site}

This Certificate acknowledges that the following shipment(s) of waste have been disposed at the Nevada Test Site Radioactive Waste Management Complex.

\begin{tabular}{|l|l|l|l|}
\hline \multicolumn{1}{|c|}{ Shipment Number } & \multicolumn{1}{c|}{$\begin{array}{c}\text { Waste Stream } \\
\text { Identification \# }\end{array}$} & \multicolumn{1}{c|}{ Package \# } & Date of Disposal \\
\hline DPL10394 & LRY5LLFY08002 & 10 L575 & $5-13-10$ \\
\hline DPL10394 & LRY5LLFY08002 & 10 L576 & $5-13-10$ \\
\hline & & & \\
\hline & & & \\
\hline & & & \\
\hline & & & \\
\hline & & & \\
\hline
\end{tabular}

This certification is provided as a courtesy to the waste generator for information purposes only.

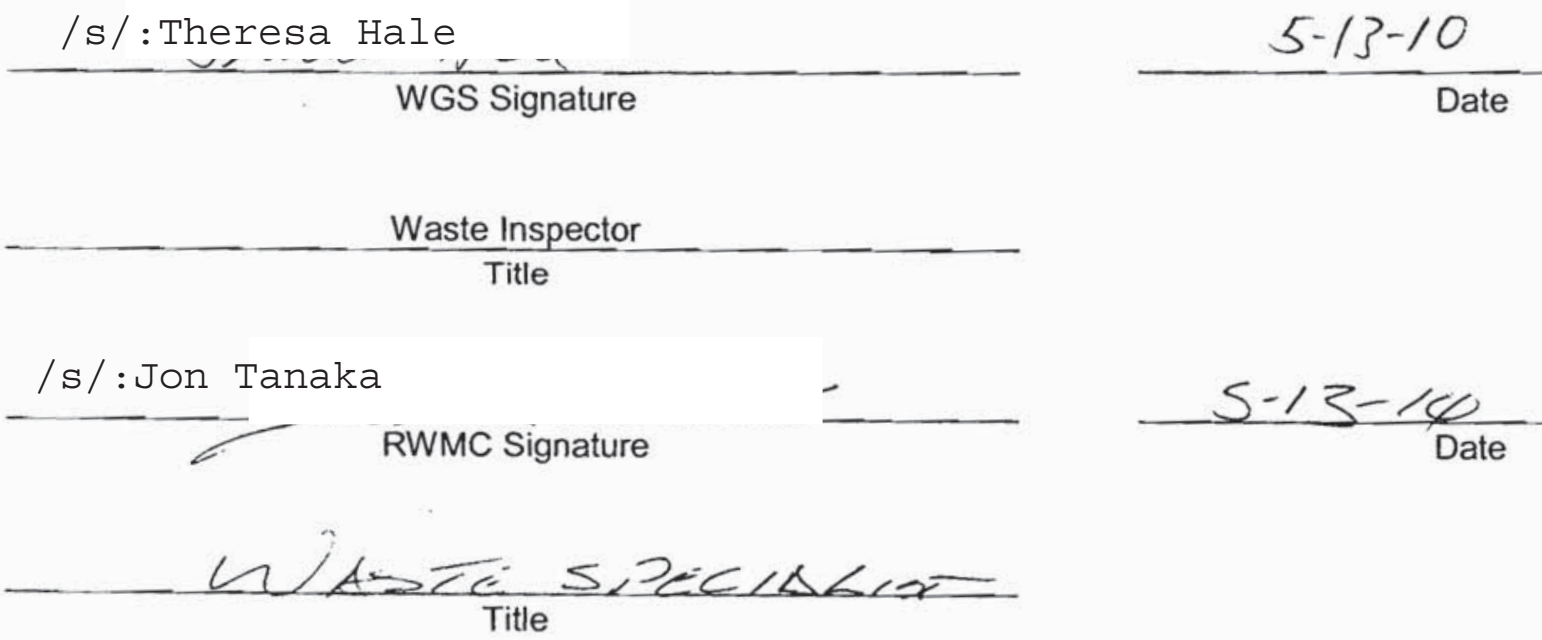


NSTec

Form

CERTIFICATE OF DISPOSAL

$03 / 01 / 10$

FRM-2217

(LOW LEVEL WASTE)

Rev. 01

Page 1 of 1

\section{Nevada Test Site}

This Certificate acknowledges that the following shipment(s) of waste have been disposed at the Nevada Test Site Radioactive Waste Management Complex.

\begin{tabular}{|l|l|l|l|}
\hline Shipment Number & \multicolumn{1}{|c|}{$\begin{array}{c}\text { Waste Stream } \\
\text { Identification \# }\end{array}$} & Package \# & Date of Disposal \\
\hline DPL10395 & LRY5LLFY08002 & 10 L577 & $5-13-10$ \\
\hline DPL10395 & LRY5LLFY08002 & 10 L578 & $5-13-10$ \\
\hline & & & \\
\hline & & & \\
\hline & & & \\
\hline
\end{tabular}

This certification is provided as a courtesy to the waste generator for information purposes only.

/s/: Theresa Hale

WGS Signature

Waste Inspector

Titie

/s/:Jon Tanaka

RWMC Signature

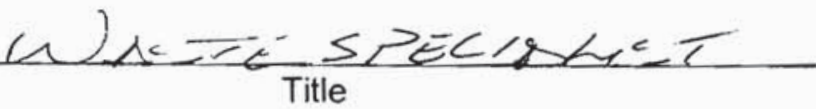

$5-13-10$

Date

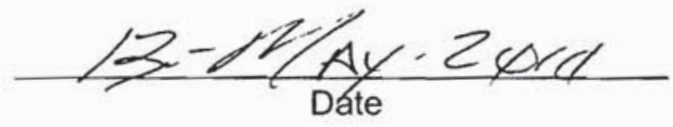


NSTec

Form

FRM-2217
CERTIFICATE OF DISPOSAL

(LOW LEVEL WASTE)
$03 / 01 / 10$

Rev. 01

Page 1 of 1

\section{Nevada Test Site}

This Certificate acknowledges that the following shipment(s) of waste have been disposed at the Nevada Test Site Radioactive Waste Management Complex.

\begin{tabular}{|l|l|l|l|}
\hline Shipment Number & \multicolumn{1}{|c|}{$\begin{array}{c}\text { Waste Stream } \\
\text { Identification \# }\end{array}$} & Package \# & Date of Disposal \\
\hline DPL10396 & LRY5LLFY08002 & 10 L579 & $5-13-10$ \\
\hline DPL10396 & LRY5LLFY08002 & 10 L580 & $5-13-10$ \\
\hline & & & \\
\hline & & & \\
\hline & & & \\
\hline & & & \\
\hline
\end{tabular}

This certification is provided as a courtesy to the waste generator for information purposes only.

/s / : Theresa Hale

WGS Signature

Waste Inspector

Title

/s/: Jon Tanaka

RW̆MC Šignature

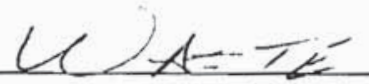

Title $\frac{5-13-10}{\text { Date }}$

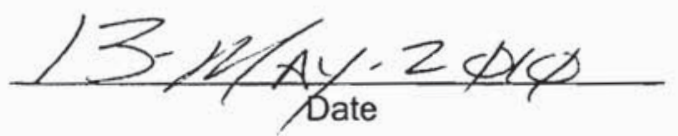




\begin{tabular}{|lcr|}
\hline NSTec & CERTIFICATE OF DISPOSAL & $03 / 01 / 10$ \\
Form & Rev. 01 \\
FRM-2217 & (LOW LEVEL WASTE) & Page 1 of 1 \\
\hline
\end{tabular}

Nevada Test Site

This Certificate acknowledges that the following shipments) of waste have been disposed at the Nevada Test Site Radioactive Waste Management Complex.

\begin{tabular}{|l|l|l|c|}
\hline \multicolumn{1}{|c|}{ Shipment Number } & $\begin{array}{c}\text { Waste Stream } \\
\text { Identification \# }\end{array}$ & Package \# & Date of Disposal \\
\hline DPL10397 & LRY5LLFY08002 & 10 L581 & $5-13-10$ \\
\hline DPL10397 & LRY5LLFY08002 & 10 L582 & $5-13-10$ \\
\hline & & & \\
\hline & & & \\
\hline & & & \\
\hline & & & \\
\hline & & & \\
\hline & & & \\
\hline
\end{tabular}

This certification is provided as a courtesy to the waste generator for information purposes only.

/s/ :Theresa Hale

WGS Signature

$\frac{5-13-10}{\text { Date }}$

Waste Inspector

Title

/s/: Jon Kanaka

RWMC Signature
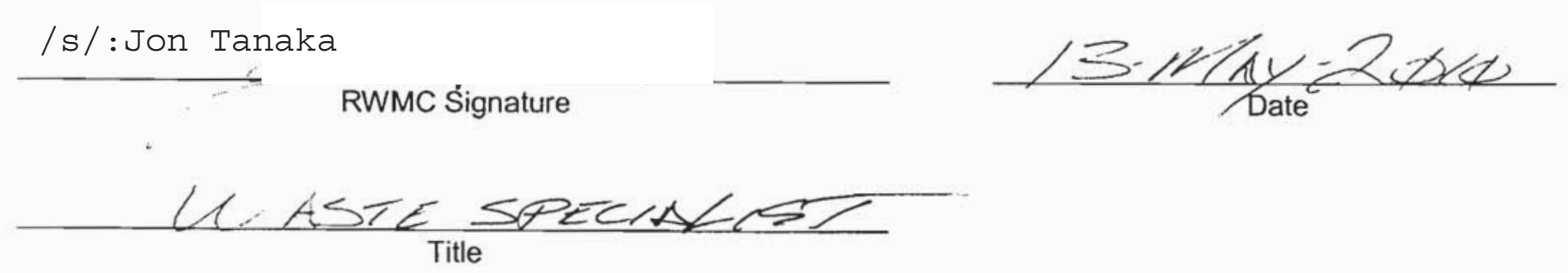

(Reference: OP-2151.304) 
NSTec

Form

FRM-2217
CERTIFICATE OF DISPOSAL

(LOW LEVEL WASTE)
03/01/10

Rev. 01

Page 1 of 1

\section{Nevada Test Site}

This Certificate acknowledges that the following shipment(s) of waste have been disposed at the Nevada Test Site Radioactive Waste Management Complex.

\begin{tabular}{|l|l|l|c|}
\hline Shipment Number & \multicolumn{1}{|c|}{$\begin{array}{c}\text { Waste Stream } \\
\text { Identification \# }\end{array}$} & Package \# & Date of Disposal \\
\hline DPL10398 & LRY5LLFY08002 & 10 583 & $5-17-10$ \\
\hline DPL10398 & LRY5LLFY08002 & 10 L584 & $5-17-10$ \\
\hline & & & \\
\hline & & & \\
\hline & & & \\
\hline & & & \\
\hline
\end{tabular}

This certification is provided as a courtesy to the waste generator for information purposes only.

/s/: Theresa Hale

WGS Signature

Waste Inspector

Title

/s/: Jon Tanaka

$\longrightarrow$ RWMC Signature

CLASTE STZCLNAST
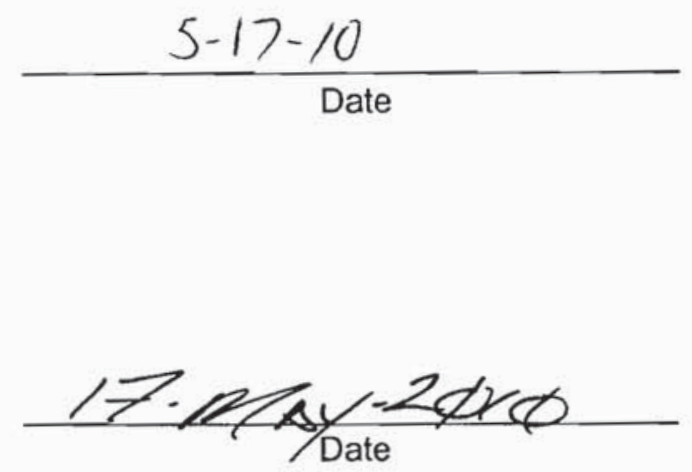
NSTec

Form

FRM-2217
CERTIFICATE OF DISPOSAL

(LOW LEVEL WASTE)
03/01/10

Rev. 01

Page 1 of 1

\section{Nevada Test Site}

This Certificate acknowledges that the following shipment(s) of waste have been disposed at the Nevada Test Site Radioactive Waste Management Complex.

\begin{tabular}{|l|l|l|c|}
\hline \multicolumn{1}{|c|}{ Shipment Number } & \multicolumn{1}{|c|}{$\begin{array}{c}\text { Waste Stream } \\
\text { Identification \# }\end{array}$} & Package \# & Date of Disposal \\
\hline DPL10399 & LRY5LLFY08002 & 10 585 & $5-17-10$ \\
\hline DPL10399 & LRY5LLFY08002 & 10 L586 & $5-17-10$ \\
\hline & & & \\
\hline & & & \\
\hline & & & \\
\hline & & & \\
\hline & & & \\
\hline
\end{tabular}

This certification is provided as a courtesy to the waste generator for information purposes only.

/s/: Theresa Hale

WGS Signature

Waste Inspector

Title

/s/: Jon Tanaka

$\sim$ RWMC Signature

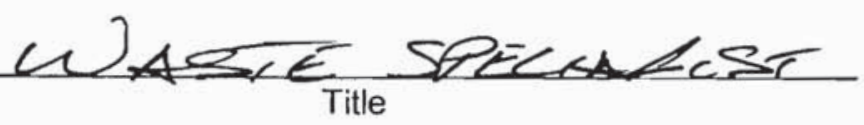

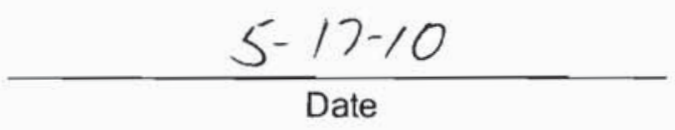

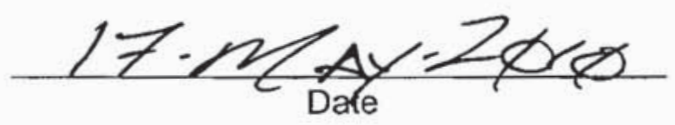




\begin{tabular}{|lcr|}
\hline NSTec & CERTIFICATE OF DISPOSAL & R/01/10 \\
Form & Rev. 01 \\
FRM-2217 & (LOW LEVEL WASTE) & Page 1 of 1 \\
\hline
\end{tabular}

Nevada Test Site

This Certificate acknowledges that the following shipments) of waste have been disposed at the Nevada Test Site Radioactive Waste Management Complex.

\begin{tabular}{|l|l|l|c|}
\hline \multicolumn{1}{|c|}{$\begin{array}{c}\text { Waste Stream } \\
\text { Identification \# }\end{array}$} & \multicolumn{1}{|c|}{ Package \# } & Date of Disposal \\
\hline DPL10400 & LRY5LLFY08002 & 10 L587 & $5-17-10$ \\
\hline DPL10400 & LRY5LLFY08002 & 10 588 & $5-17-10$ \\
\hline & & & \\
\hline & & & \\
\hline & & & \\
\hline & & & \\
\hline & & & \\
\hline & & & \\
\hline
\end{tabular}

This certification is provided as a courtesy to the waste generator for information purposes only.

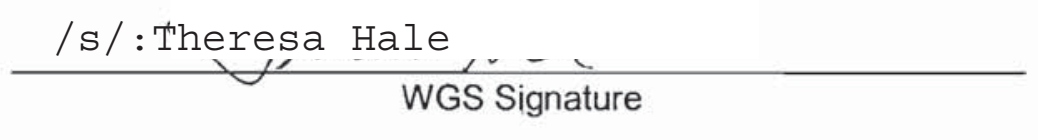

Waste Inspector

Title

/s/: Jon Tanka

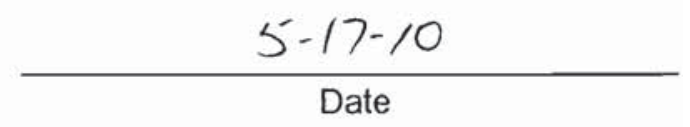

Date

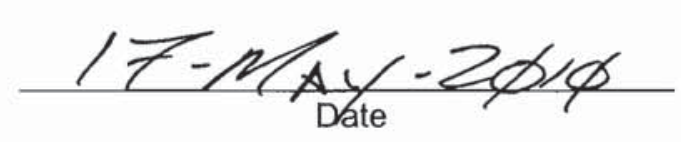


NSTec

Form

FRM-2217
CERTIFICATE OF DISPOSAL

(LOW LEVEL WASTE)
$03 / 01 / 10$

Rev. 01

Page 1 of 1

\section{Nevada Test Site}

This Certificate acknowledges that the following shipment(s) of waste have been disposed at the Nevada Test Site Radioactive Waste Management Complex.

\begin{tabular}{|c|c|c|c|}
\hline Shipment Number & $\begin{array}{l}\text { Waste Stream } \\
\text { Identification \# }\end{array}$ & Package \# & Date of Disposal \\
\hline DPL10401 & LRY5LLFY08002 & 10L589 & $5-17-10$ \\
\hline DPL10401 & LRY5LLFY08002 & $10 L 590$ & $5-17-10$ \\
\hline & & & \\
\hline & & & \\
\hline & & & \\
\hline & & & \\
\hline & & & \\
\hline & & & \\
\hline
\end{tabular}

This certification is provided as a courtesy to the waste generator for information purposes only. I.

/s/: Theresa Hale
WGS Signature
$\frac{\text { Waste Inspector }}{\text { Title }}$
/s/: Jon Tanaka
RWMC Signature

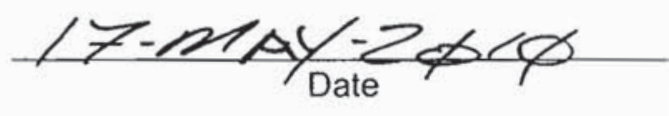


NSTec

Form

FRM-2217
CERTIFICATE OF DISPOSAL

(LOW LEVEL WASTE)
$03 / 01 / 10$

Rev. 01

Page 1 of 1

\section{Nevada Test Site}

This Certificate acknowledges that the following shipment(s) of waste have been disposed at the Nevada Test Site Radioactive Waste Management Complex.

\begin{tabular}{|l|l|l|l|}
\hline \multicolumn{1}{|c|}{ Shipment Number } & \multicolumn{1}{c|}{$\begin{array}{c}\text { Waste Stream } \\
\text { Identification \# }\end{array}$} & Package \# & Date of Disposal \\
\hline DPL10402 & LRY5LLFY08002 & 10 L591 & $5-17-10$ \\
\hline DPL10402 & LRY5LLFY08002 & 10 L592 & $5-17-10$ \\
\hline & & & \\
\hline & & & \\
\hline & & & \\
\hline & & & \\
\hline & & & \\
\hline
\end{tabular}

This certification is provided as a courtesy to the waste generator for information purposes only.

/s/:Theresa Hale

WGS Signature

Waste Inspector

Title

/s/:Jon Tanaka

RWMC Signature

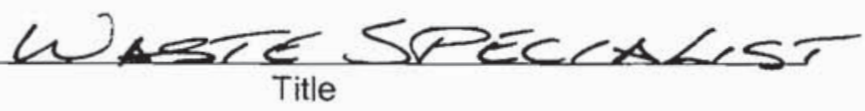

$\frac{5 \cdot 17 \cdot 10}{\text { Date }}$

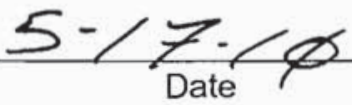


NSTec

Form

FRM-2217
CERTIFICATE OF DISPOSAL

(LOW LEVEL WASTE)
03/01/10

Rev. 01

Page 1 of 1

\section{Nevada Test Site}

This Certificate acknowledges that the following shipment(s) of waste have been disposed at the Nevada Test Site Radioactive Waste Management Complex.

\begin{tabular}{|l|l|l|l|}
\hline \multicolumn{1}{|c|}{ Shipment Number } & \multicolumn{1}{c|}{$\begin{array}{c}\text { Waste Stream } \\
\text { Identification \# }\end{array}$} & Package \# & Date of Disposal \\
\hline DPL10403 & LRY5LLFY08002 & 10 L593 & $5-17-10$ \\
\hline DPL10403 & LRY5LLFY08002 & 10 L594 & $5-17-10$ \\
\hline & & & \\
\hline & & & \\
\hline & & & \\
\hline & & & \\
\hline & & & \\
\hline
\end{tabular}

This certification is provided as a courtesy to the waste generator for information purposes only.

$\frac{\text { /s/:Theresa Hale }}{\text { WGS Signature }}$

Waste Inspector
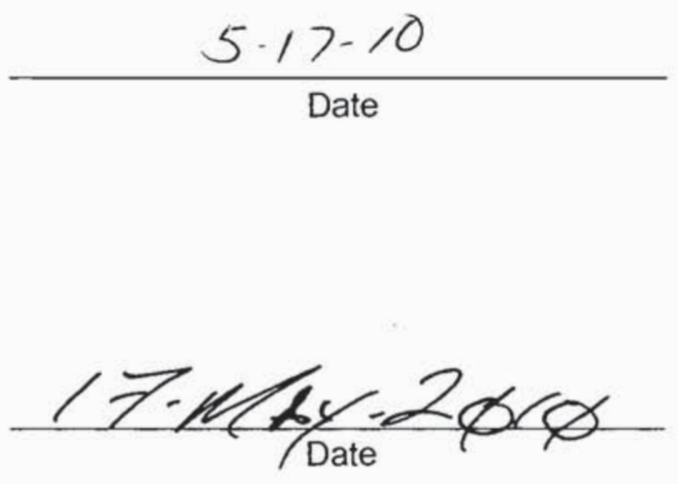

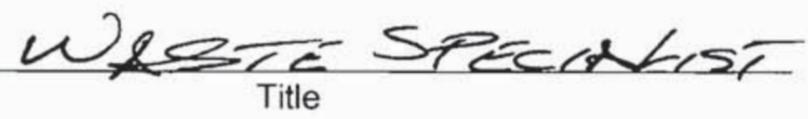


NSTec

Form

FRM-2217
CERTIFICATE OF DISPOSAL

(LOW LEVEL WASTE)
03/01/10

Rev. 01

Page 1 of 1

\section{Nevada Test Site}

This Certificate acknowledges that the following shipment(s) of waste have been disposed at the Nevada Test Site Radioactive Waste Management Complex.

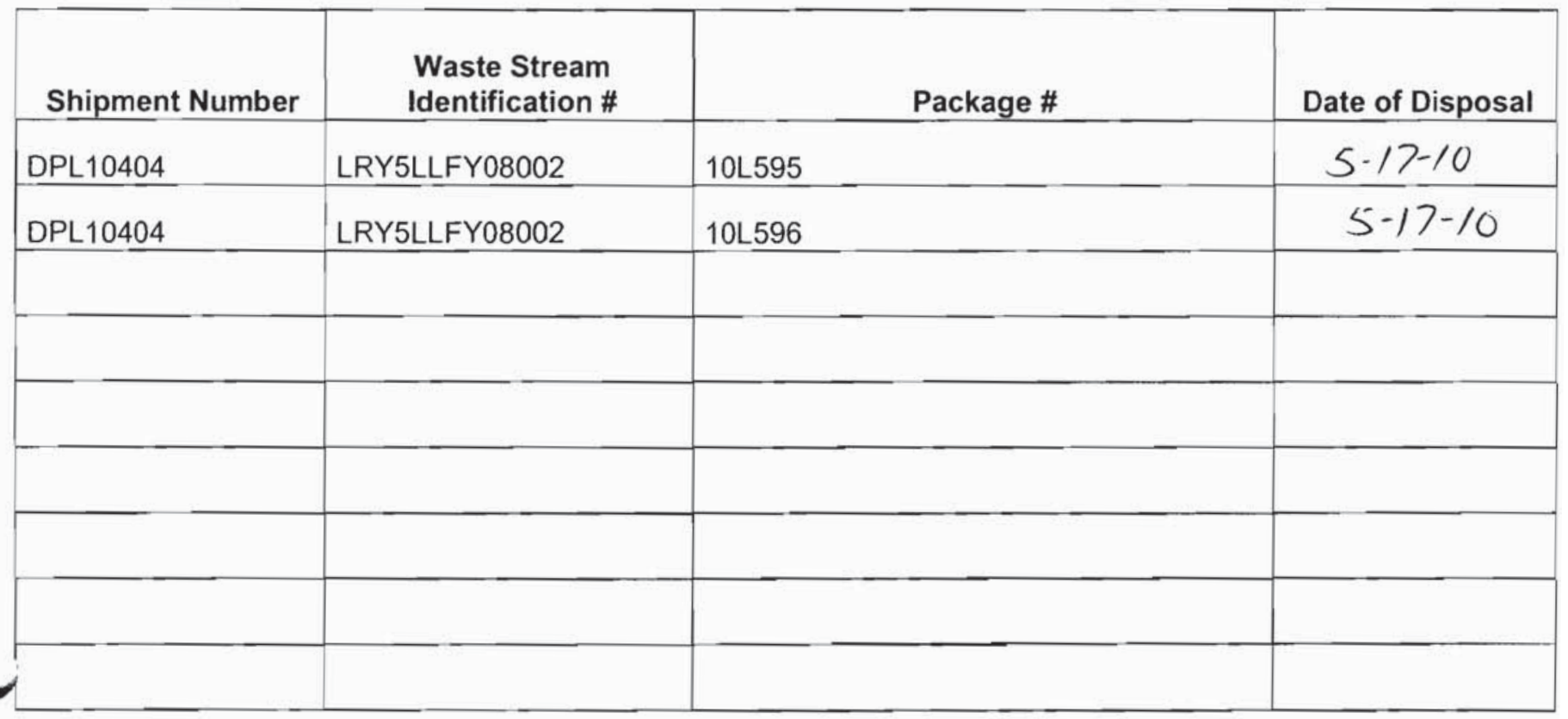

This certification is provided as a courtesy to the waste generator for information purposes only.

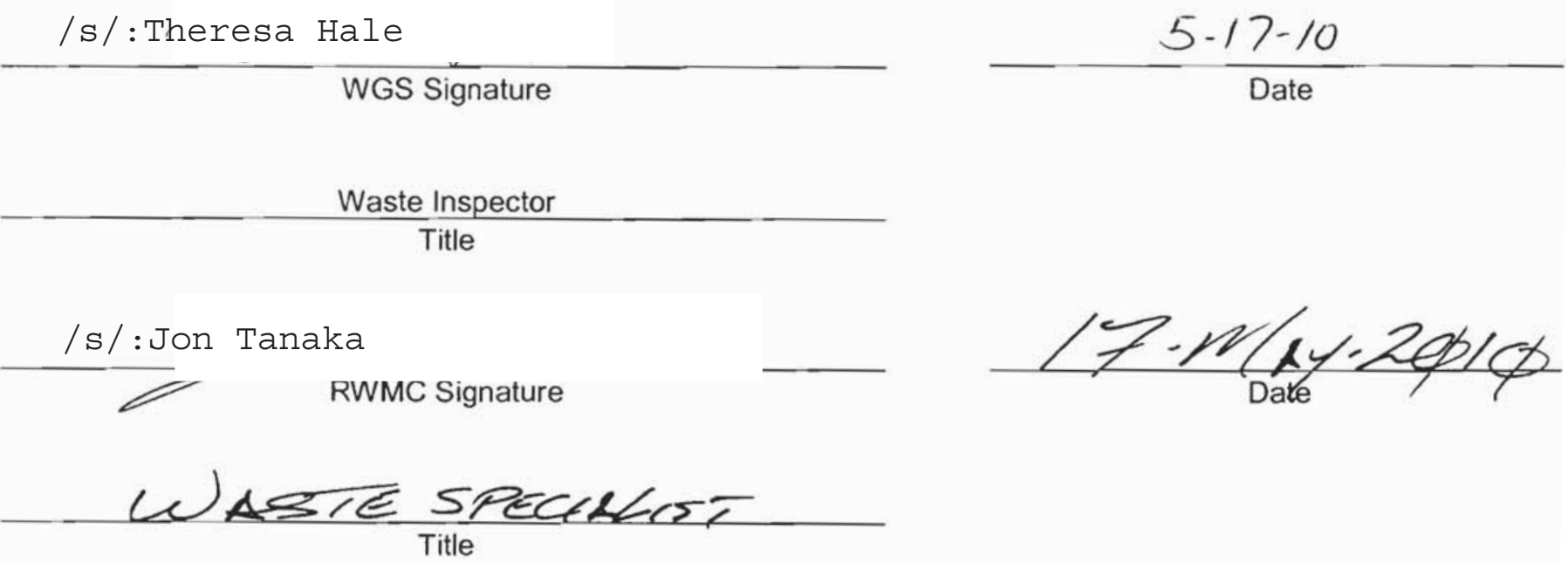


NSTec

Form

FRM-2217
CERTIFICATE OF DISPOSAL

(LOW LEVEL WASTE)
03/01/10

Rev. 01

Page 1 of 1

\section{Nevada Test Site}

This Certificate acknowledges that the following shipment(s) of waste have been disposed at the Nevada Test Site Radioactive Waste Management Complex.

\begin{tabular}{|l|l|l|c|}
\hline Shipment Number & \multicolumn{1}{|c|}{$\begin{array}{c}\text { Waste Stream } \\
\text { Identification \# }\end{array}$} & Package \# & Date of Disposal \\
\hline DPL10405 & LRY5LLFY08002 & 10 L597 & $5-17-10$ \\
\hline DPL10405 & LRY5LLFY08002 & 10 L598 & $5-17-10$ \\
\hline & & & \\
\hline & & & \\
\hline & & & \\
\hline & & & \\
\hline & & & \\
\hline
\end{tabular}

This certification is provided as a courtesy to the waste generator for information purposes only.

/s/:Theresa Hale

WGS Signature

Waste Inspector

Title

/s/:Jon Tanaka

RWM̄C Signature

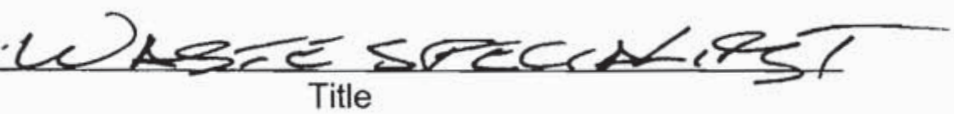

$5-17-10$

Date

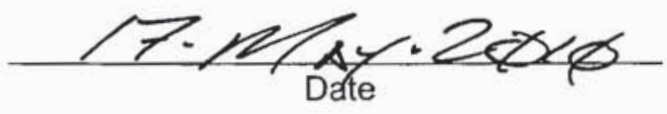


NSTec

Form

FRM-2217
CERTIFICATE OF DISPOSAL

(LOW LEVEL WASTE)
03/01/10

Rev. 01

Page 1 of 1

\section{Nevada Test Site}

This Certificate acknowledges that the following shipment(s) of waste have been disposed at the Nevada Test Site Radioactive Waste Management Complex.

\begin{tabular}{|l|l|l|l|}
\hline \multicolumn{1}{|c|}{$\begin{array}{c}\text { Waste Stream } \\
\text { Identification \# }\end{array}$} & \multicolumn{1}{c|}{ Package \# } & Date of Disposal \\
\hline DPL10406 & LRY5LLFY08002 & 10L599 & $5-17-10$ \\
\hline DPL10406 & LRY5LLFY08002 & 10L600 & $5-17-10$ \\
\hline & & & \\
\hline & & & \\
\hline & & & \\
\hline & & & \\
\hline & & & \\
\hline & & & \\
\hline
\end{tabular}

This certification is provided as a courtesy to the waste generator for information purposes only.

/s/:Theresa Hale

WGS Signature

Waste Inspector

Title

/s/:Jon Tanaka

RWMĆ Signature

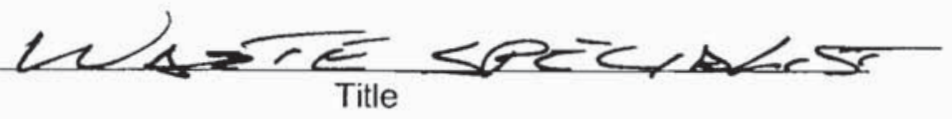

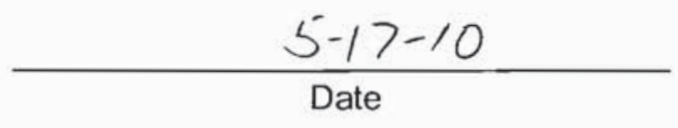

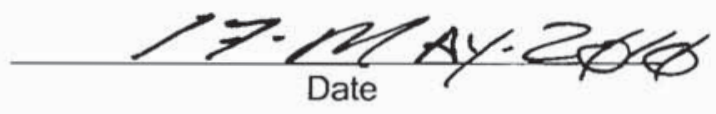


NSTec

Form

FRM-2217
CERTIFICATE OF DISPOSAL

(LOW LEVEL WASTE)
03/01/10

Rev. 01

Page 1 of 1

\section{Nevada Test Site}

This Certificate acknowledges that the following shipment(s) of waste have been disposed at the Nevada Test Site Radioactive Waste Management Complex.

\begin{tabular}{|l|l|l|l|}
\hline \multicolumn{1}{|c|}{ Shipment Number } & \multicolumn{1}{c|}{$\begin{array}{c}\text { Waste Stream } \\
\text { Identification \# }\end{array}$} & Package \# & Date of Disposal \\
\hline DPL10407 & LRY5LLFY08002 & 10 L601 & $5-18-10$ \\
\hline DPL10407 & LRY5LLFY08002 & 10 L602 & $5-/ 8-10$ \\
\hline & & & \\
\hline & & & \\
\hline & & & \\
\hline & & & \\
\hline & & & \\
\hline
\end{tabular}

This certification is provided as a courtesy to the waste generator for information purposes only.

/s/: Theresa Hale

WGS Signature

Waste Inspector

Title

/s/:Jon Tanaka

RWM̄C Signature

U) $T$ TE SPECINIST
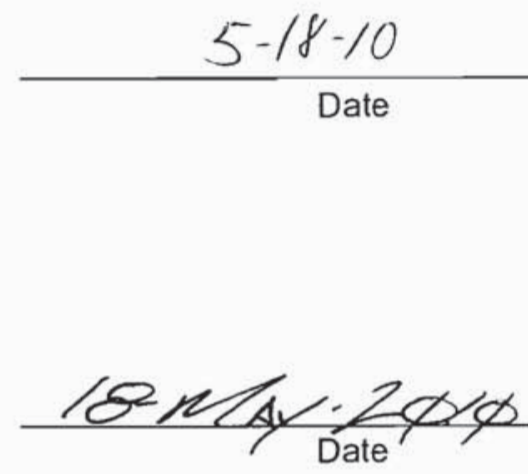


\section{Nevada Test Site}

This Certificate acknowledges that the following shipment(s) of waste have been disposed at the Nevada Test Site Radioactive Waste Management Complex.

\begin{tabular}{|l|l|l|c|}
\hline \multicolumn{1}{|c|}{ Shipment Number } & \multicolumn{1}{c|}{$\begin{array}{c}\text { Waste Stream } \\
\text { Identification \# }\end{array}$} & Package \# & Date of Disposal \\
\hline DPL10408 & LRY5LLFY08002 & 10 L603 & $5-18-10$ \\
\hline DPL10408 & LRY5LLFY08002 & 10 L604 & $5-18-10$ \\
\hline & & & \\
\hline & & & \\
\hline & & & \\
\hline & & & \\
\hline & & & \\
\hline
\end{tabular}

This certification is provided as a courtesy to the waste generator for information purposes only.

/s/:Th́eresa Hale

WGS Signature

Waste Inspector

$$
\text { Title }
$$

/s/:Jon Tanaka

RWMC Signature

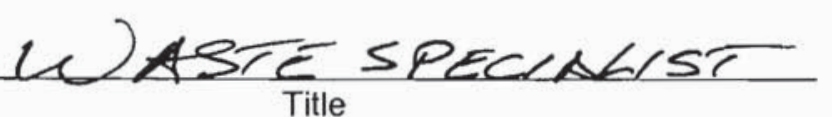

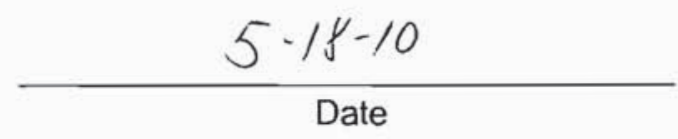

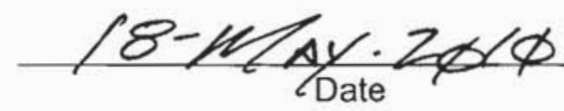


NSTec

Form

FRM-2217
CERTIFICATE OF DISPOSAL

(LOW LEVEL WASTE)
03/01/10

Rev. 01

Page 1 of 1

\section{Nevada Test Site}

This Certificate acknowledges that the following shipment(s) of waste have been disposed at the Nevada Test Site Radioactive Waste Management Complex.

\begin{tabular}{|l|l|l|c|}
\hline Shipment Number & \multicolumn{1}{|c|}{$\begin{array}{c}\text { Waste Stream } \\
\text { Identification \# }\end{array}$} & Package \# & Date of Disposal \\
\hline DPL10409 & LRY5LLFY08002 & 10 L605 & $5-/ 8-10$ \\
\hline DPL10409 & LRY5LLFY08002 & 10 L606 & $5-/ 8-10$ \\
\hline & & & \\
\hline & & & \\
\hline & & & \\
\hline & & & \\
\hline
\end{tabular}

This certification is provided as a courtesy to the waste generator for information purposes only.

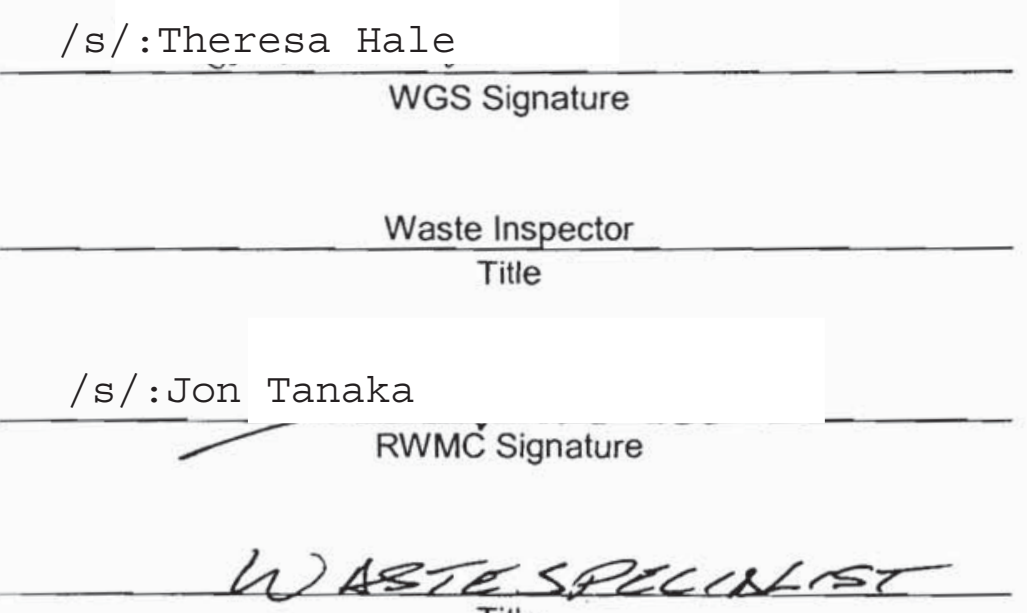

$\frac{5-18-10}{\text { Date }}$

Title

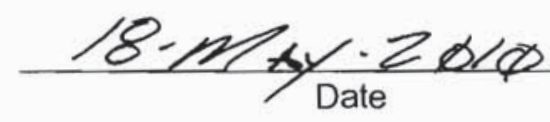




\begin{tabular}{|lcr|}
\hline NSTec & CERTIFICATE OF DISPOSAL & 03/01/10 \\
Form & Rev. 01 \\
FRM-2217 & (LOW LEVEL WASTE) & Page 1 of 1 \\
\hline
\end{tabular}

Nevada Test Site

This Certificate acknowledges that the following shipments) of waste have been disposed at the Nevada Test Site Radioactive Waste Management Complex.

\begin{tabular}{|l|l|l|l|}
\hline \multicolumn{1}{|c|}{ Shipment Number } & \multicolumn{1}{|c|}{$\begin{array}{c}\text { Waste Stream } \\
\text { Identification \# }\end{array}$} & \multicolumn{1}{c|}{ Package \# } & Date of Disposal \\
\hline DPL10410 & LRY5LLFY08002 & 10 L607 & $5-18-10$ \\
\hline DPL10410 & LRY5LLFY08002 & 10 L608 & $5-18-10$ \\
\hline & & & \\
\hline & & & \\
\hline & & & \\
\hline & & & \\
\hline & & & \\
\hline & & & \\
\hline
\end{tabular}

This certification is provided as a courtesy to the waste generator for information purposes only.

/s/ :Theresa Hale

WGS Signature

Waste Inspector

Title

/s/ :Jon Tanka

RWMC Signature

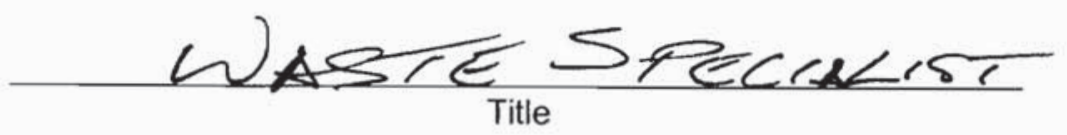

(Reference: OP-2151.304) 


\begin{tabular}{|lcr|}
\hline NSTec & CERTIFICATE OF DISPOSAL & $03 / 01 / 10$ \\
Form & Rev. 01 \\
FRM-2217 & (LOW LEVEL WASTE) & Page 1 of 1 \\
\hline
\end{tabular}

Nevada Test Site

This Certificate acknowledges that the following shipments) of waste have been disposed at the Nevada Test Site Radioactive Waste Management Complex.

\begin{tabular}{|l|l|l|l|}
\hline \multicolumn{1}{|c|}{ Shipment Number } & \multicolumn{1}{c|}{$\begin{array}{c}\text { Waste Stream } \\
\text { Identification \# }\end{array}$} & Package \# & Date of Disposal \\
\hline DPL10411 & LRY5LLFY08002 & 10 L609 & $5-18-10$ \\
\hline DPL10411 & LRY5LLFY08002 & 10 L610 & $5-18-10$ \\
\hline & & & \\
\hline & & & \\
\hline & & & \\
\hline & & & \\
\hline & & & \\
\hline
\end{tabular}

This certification is provided as a courtesy to the waste generator for information purposes only.

/s/ :Theresa Hale

WGS Signature

$\frac{5-18-10}{\text { Date }}$

Waste Inspector

Title

/s/ :Jon Tanka

RWMC Signature

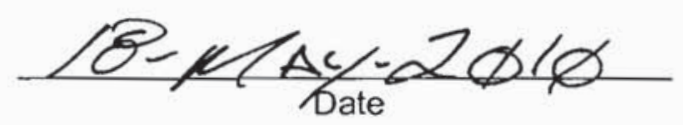

WASTE SPECK

(Reference: OP-2151.304) 
NSTec

Form

FRM-2217
CERTIFICATE OF DISPOSAL

(LOW LEVEL WASTE)
03/01/10

Rev. 01

Page 1 of 1

\section{Nevada Test Site}

This Certificate acknowledges that the following shipment(s) of waste have been disposed at the Nevada Test Site Radioactive Waste Management Complex.

\begin{tabular}{|c|c|c|c|}
\hline Shipment Number & $\begin{array}{l}\text { Waste Stream } \\
\text { Identification \# }\end{array}$ & Package \# & Date of Disposal \\
\hline DPL10412 & LRY5LLFY08002 & 10L611 & $5-18-10$ \\
\hline DPL10412 & LRY5LLFY08002 & 10L612 & $5-18-10$ \\
\hline & & & \\
\hline & & & \\
\hline & & & \\
\hline & & & \\
\hline & & & \\
\hline & & & \\
\hline
\end{tabular}

This certification is provided as a courtesy to the waste generator for information purposes only.

/s/:Theresa Hale

WGS Signature

Waste Inspector

$$
\text { Title }
$$

/s/:Jon Tanaka

RWMC Signatưre

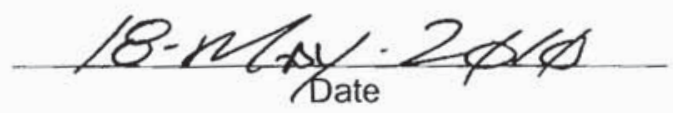




\begin{tabular}{|lcr|}
\hline NSTec & CERTIFICATE OF DISPOSAL & $03 / 01 / 10$ \\
Form & Rev. 01 \\
FRM-2217 & (LOW LEVEL WASTE) & Page 1 of 1 \\
\hline
\end{tabular}

Nevada Test Site

This Certificate acknowledges that the following shipments) of waste have been disposed at the Nevada Test Site Radioactive Waste Management Complex.

\begin{tabular}{|l|l|l|c|}
\hline \multicolumn{1}{|c|}{ Shipment Number } & \multicolumn{1}{|c|}{$\begin{array}{c}\text { Waste Stream } \\
\text { Identification \# }\end{array}$} & Package\# & Date of Disposal \\
\hline DPL10413 & LRY5LLFY08002 & 10 L613 & $5-18-10$ \\
\hline DPL10413 & LRY5LLFY08002 & 10 L614 & $5-18-10$ \\
\hline & & & \\
\hline & & & \\
\hline & & & \\
\hline & & & \\
\hline & & & \\
\hline & & & \\
\hline
\end{tabular}

This certification is provided as a courtesy to the waste generator for information purposes only.

/s/ :Theresa Hale

WGS Signature

Waste Inspector

Title
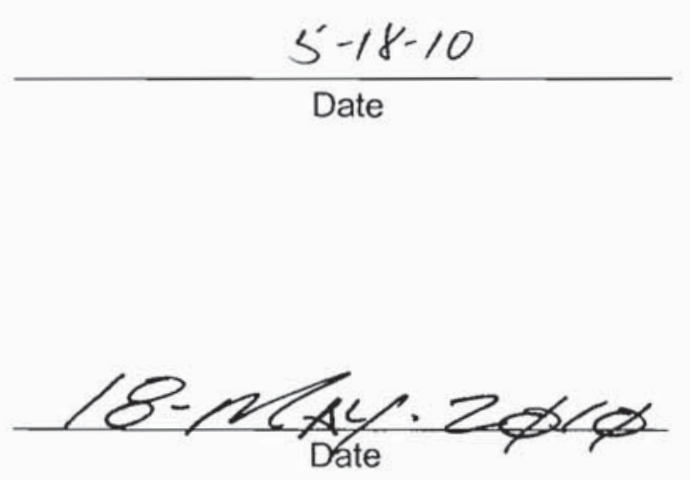

(Reference: OP-2151.304) 
NSTec

Form

FRM-2217
CERTIFICATE OF DISPOSAL

(LOW LEVEL WASTE)
03/01/10

Rev. 01

Page 1 of 1

\section{Nevada Test Site}

This Certificate acknowledges that the following shipment(s) of waste have been disposed at the Nevada Test Site Radioactive Waste Management Complex.

\begin{tabular}{|l|l|l|c|}
\hline \multicolumn{1}{|c|}{ Shipment Number } & \multicolumn{1}{c|}{$\begin{array}{c}\text { Waste Stream } \\
\text { Identification \# }\end{array}$} & Package \# & Date of Disposal \\
\hline DPL10414 & LRY5LLFY08002 & 10 L615 & $5-18-10$ \\
\hline DPL10414 & LRY5LLFY08002 & 10 L616 & $5-18-10$ \\
\hline & & & \\
\hline & & & \\
\hline & & & \\
\hline & & & \\
\hline & & & \\
\hline
\end{tabular}

This certification is provided as a courtesy to the waste generator for information purposes only.

/s/:Theresa Hale

WGS Signature

Waste Inspector

Title

/s/:Jon Tanaka

RWMC Signature

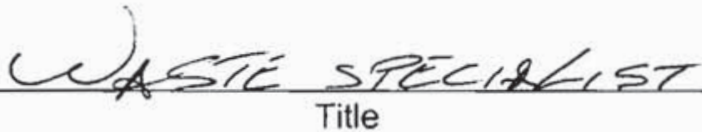

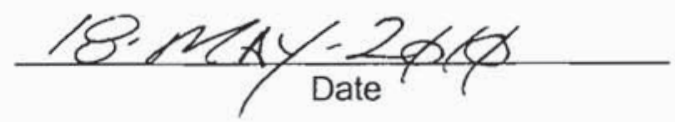




\begin{tabular}{|lcr|}
\hline NSTec & CERTIFICATE OF DISPOSAL & $03 / 01 / 10$ \\
Form & Rev. 01 \\
FRM-2217 & (LOW LEVEL WASTE) & Page 1 of 1 \\
\hline
\end{tabular}

Nevada Test Site

This Certificate acknowledges that the following shipments) of waste have been disposed at the Nevada Test Site Radioactive Waste Management Complex.

\begin{tabular}{|l|l|l|c|}
\hline Shipment Number & \multicolumn{1}{|c|}{$\begin{array}{c}\text { Waste Stream } \\
\text { Identification \# }\end{array}$} & \multicolumn{1}{|c|}{ Package \# } & Date of Disposal \\
\hline DPL10415 & LRY5LLFY08002 & 10 L617 & $5-18-10$ \\
\hline DPL10415 & LRY5LLFY08002 & 10 L618 & $5-18-10$ \\
\hline & & & \\
\hline & & & \\
\hline & & & \\
\hline & & & \\
\hline & & & \\
\hline & & & \\
\hline
\end{tabular}

This certification is provided as a courtesy to the waste generator for information purposes only.

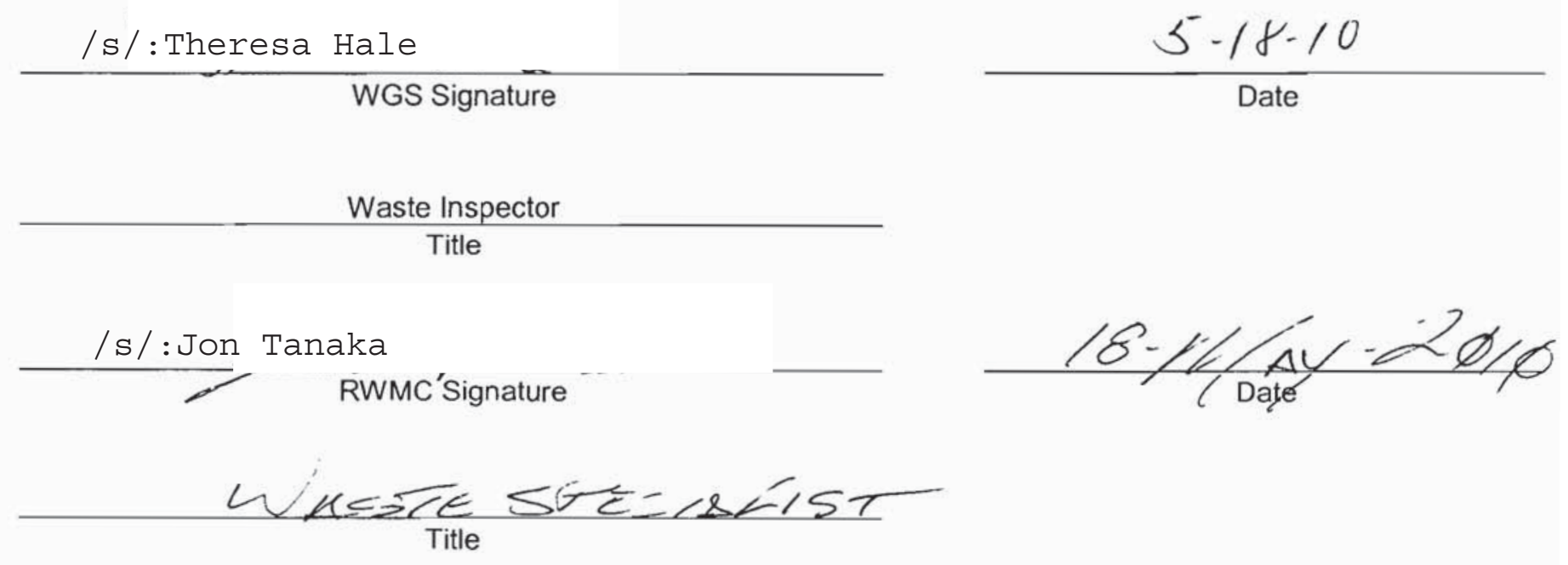

(Reference: OP-2151.304) 
NSTEC

Form

FRM-2217
CERTIFICATE OF DISPOSAL

(LOW LEVEL WASTE)
03/01/10

Rev. 01

Page 1 of 1

\section{Nevada Test Site}

This Certificate acknowledges that the following shipment(s) of waste have been disposed at the Nevada Test Site Radioactive Waste Management Complex.

\begin{tabular}{|c|c|c|c|}
\hline Shipment Number & $\begin{array}{l}\text { Waste Stream } \\
\text { Identification \# }\end{array}$ & Package \# & Date of Disposal \\
\hline DPL10416 & LRY5LLFY08002 & $10 L 619$ & $5-18-10$ \\
\hline DPL10416 & LRY5LLFY08002 & $10 L 620$ & $5-18 \cdot 10$ \\
\hline & & & \\
\hline & & & \\
\hline & & & \\
\hline & & & \\
\hline & & & \\
\hline & & & \\
\hline
\end{tabular}

This certification is provided as a courtesy to the waste generator for information purposes only.

/s/: Theresa Hale

WGS Signature

Waste inspector
5.18 .10

Date

Title

/s/: Jon Tanaka

RWMC Signature

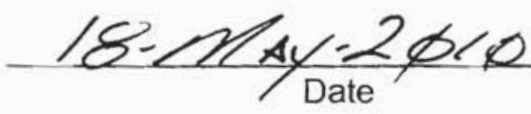

- L DASTE SPEC CHET

Title 
NSTec

Form

FRM-2217
CERTIFICATE OF DISPOSAL

(LOW LEVEL WASTE)
03/01/10

Rev. 01

Page 1 of 1

\section{Nevada Test Site}

This Certificate acknowledges that the following shipment(s) of waste have been disposed at the Nevada Test Site Radioactive Waste Management Complex.

\begin{tabular}{|l|l|l|l|}
\hline Shipment Number & \multicolumn{1}{|c|}{$\begin{array}{c}\text { Waste Stream } \\
\text { Identification \# }\end{array}$} & Package \# & Date of Disposal \\
\hline DPL10417 & LRY5LLFY08002 & 10 L621 & $5-/ 8-10$ \\
\hline DPL10417 & LRY5LLFY08002 & 10 L622 & $5-/ 8-10$ \\
\hline & & & \\
\hline & & & \\
\hline & & & \\
\hline & & & \\
\hline
\end{tabular}

This certification is provided as a courtesy to the waste generator for information purposes only.

/s/:Theresa Hale

WGS Signature

Waste Inspector

Title

/s/:Jon Tanaka

RW̄MC Signature

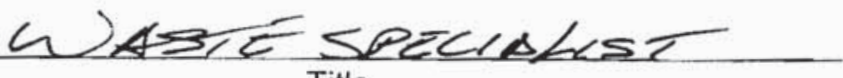

$5-1 \gamma-10$

Date

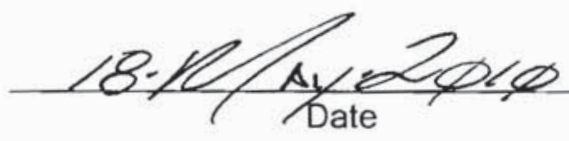


NSTec

Form

CERTIFICATE OF DISPOSAL

03/01/10

FRM-2217

(LOW LEVEL WASTE)

Rev. 01

Page 1 of 1

\section{Nevada Test Site}

This Certificate acknowledges that the following shipment(s) of waste have been disposed at the Nevada Test Site Radioactive Waste Management Complex.

\begin{tabular}{|l|l|l|c|}
\hline \multicolumn{1}{|c|}{ Shipment Number } & \multicolumn{1}{|c|}{$\begin{array}{c}\text { Waste Stream } \\
\text { Identification \# }\end{array}$} & Package \# & Date of Disposal \\
\hline DPL10418 & LRY5LLFY08002 & 10 623 & $5-19-10$ \\
\hline DPL10418 & LRY5LLFY08002 & 10 L624 & $5-19-10$ \\
\hline & & & \\
\hline & & & \\
\hline & & & \\
\hline & & & \\
\hline
\end{tabular}

This certification is provided as a courtesy to the waste generator for information purposes only.

/s/: Theresa Hale

WGS Signature

Waste Inspector

Title

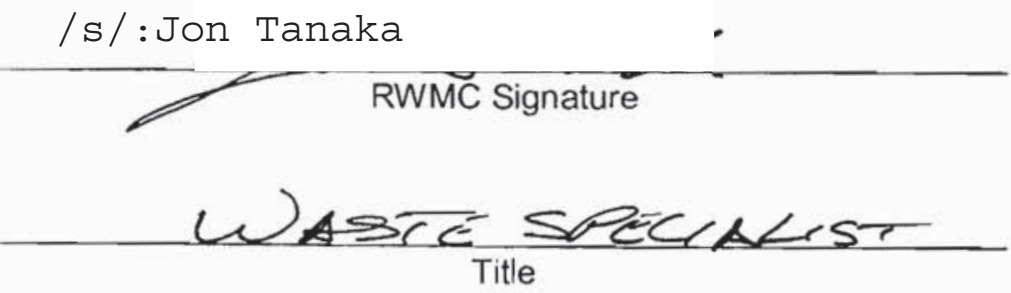

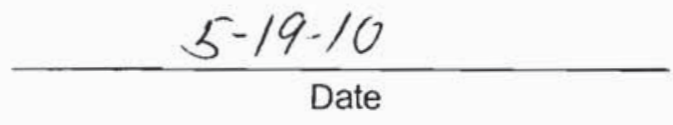

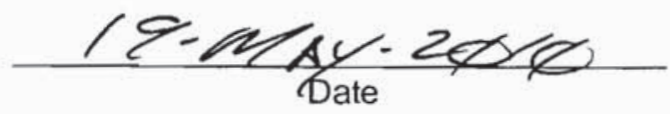


NSTec

Form

CERTIFICATE OF DISPOSAL

$03 / 01 / 10$

FRM-2217

(LOW LEVEL WASTE)

Rev. 01

Page 1 of 1

\section{Nevada Test Site}

This Certificate acknowledges that the following shipment(s) of waste have been disposed at the Nevada Test Site Radioactive Waste Management Complex.

\begin{tabular}{|l|l|l|l|}
\hline \multicolumn{1}{|c|}{ Shipment Number } & \multicolumn{1}{|c|}{$\begin{array}{c}\text { Waste Stream } \\
\text { Identification \# }\end{array}$} & Package \# & Date of Disposal \\
\hline DPL10419 & LRY5LLFY08002 & 10 L625 & $5-19-10$ \\
\hline DPL10419 & LRY5LLFY08002 & 10 L626 & $5-19-10$ \\
\hline & & & \\
\hline & & & \\
\hline & & & \\
\hline & & & \\
\hline & & & \\
\hline & & & \\
\hline
\end{tabular}

This certification is provided as a courtesy to the waste generator for information purposes only.

/s/: Theresa Hale

WGS Signature

Waste Inspector

Title

/s/:Jon Tanaka

RWMC Signature

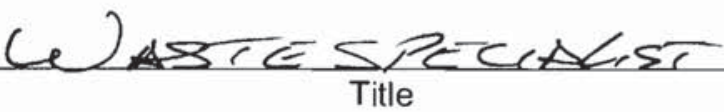

$5-19-10$

Date

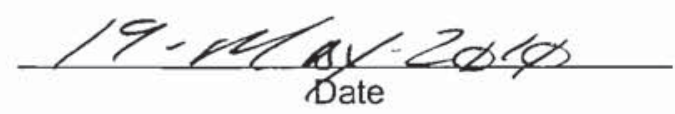




\begin{tabular}{|lcr|}
\hline NSTec & CERTIFICATE OF DISPOSAL & $03 / 01 / 10$ \\
Form & Rev. 01 \\
FRM-2217 & (LOW LEVEL WASTE) & Page 1 of 1 \\
\hline
\end{tabular}

Nevada Test Site

This Certificate acknowledges that the following shipments) of waste have been disposed at the Nevada Test Site Radioactive Waste Management Complex.

\begin{tabular}{|l|l|l|c|}
\hline \multicolumn{1}{|c|}{$\begin{array}{c}\text { Waste Stream } \\
\text { Identification \# }\end{array}$} & \multicolumn{1}{|c|}{ Package \# } & Date of Disposal \\
\hline DPL10420 & LRY5LLFY08002 & 10 L627 & $5-19-10$ \\
\hline DPL10420 & LRY5LLFY08002 & 10 L628 & $5-19-10$ \\
\hline & & & \\
\hline & & & \\
\hline & & & \\
\hline & & & \\
\hline & & & \\
\hline & & & \\
\hline
\end{tabular}

This certification is provided as a courtesy to the waste generator for information purposes only.

/s/ :Theresa Hale

WGS Signature

Waste Inspector

Title

/s/: Jon Tanka

RWMC Signature

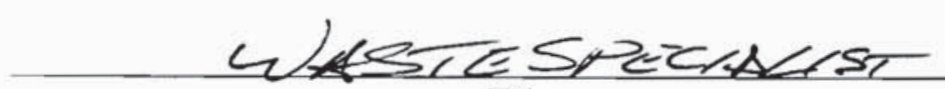

Title
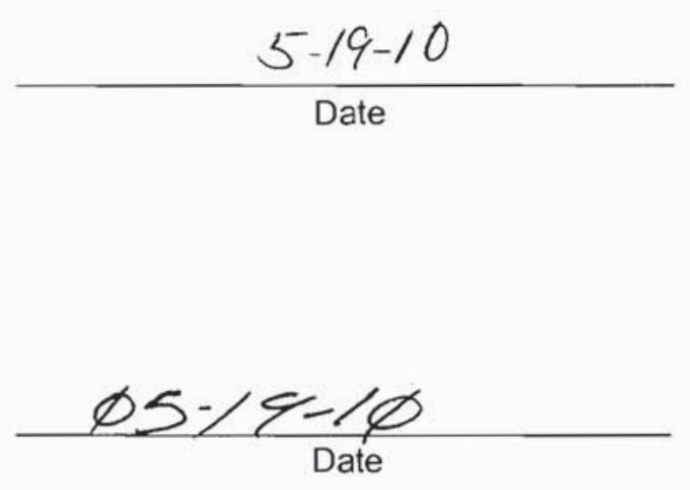

(Reference: OP-2151.304) 
NSTec

Form

FRM-2217
CERTIFICATE OF DISPOSAL

(LOW LEVEL WASTE)
03/01/10

Rev. 01

Page 1 of 1

\section{Nevada Test Site}

This Certificate acknowledges that the following shipment(s) of waste have been disposed at the Nevada Test Site Radioactive Waste Management Complex.

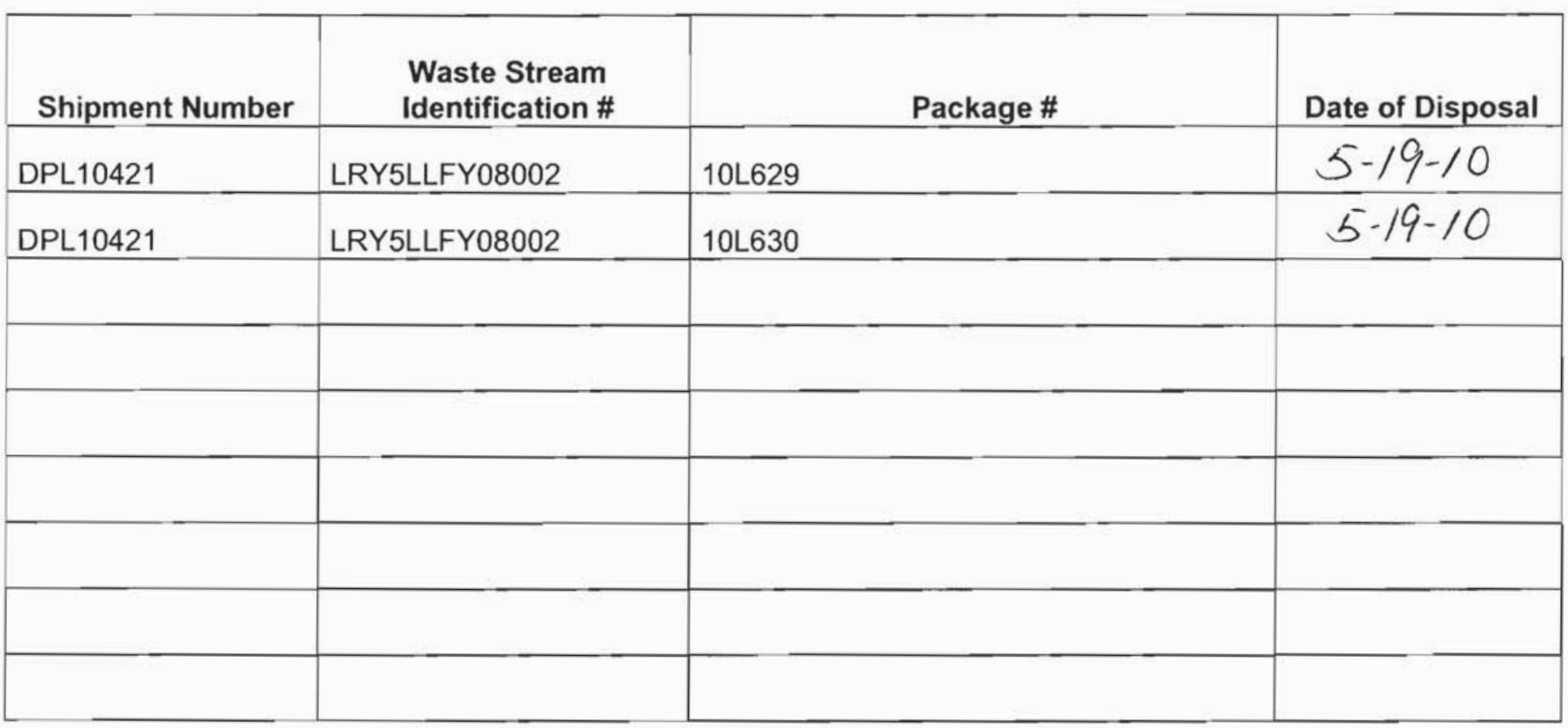

This certification is provided as a courtesy to the waste generator for information purposes only.

/s/:Theresa Hale

WGS Signature

Waste Inspector

Title
/s/:Jon Tanaka

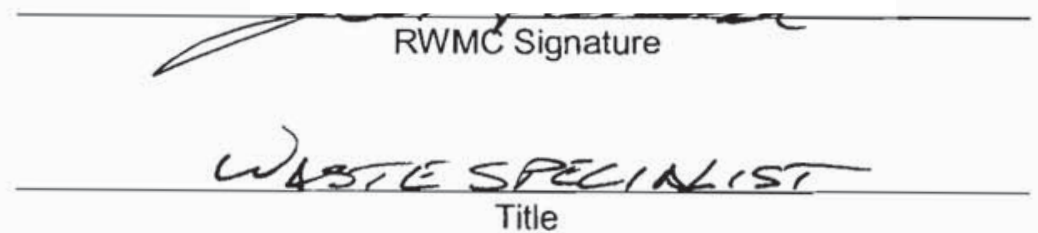

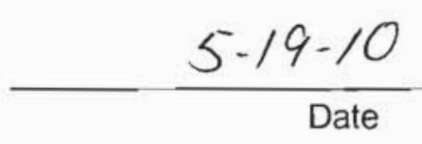

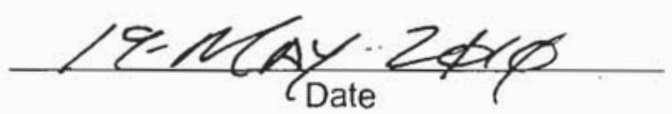


NSTec

Form

CERTIFICATE OF DISPOSAL

$03 / 01 / 10$

FRM-2217

(LOW LEVEL WASTE)

Rev. 01

Page 1 of 1

\section{Nevada Test Site}

This Certificate acknowledges that the following shipment(s) of waste have been disposed at the Nevada Test Site Radioactive Waste Management Complex.

\begin{tabular}{|c|c|c|c|}
\hline Shipment Number & $\begin{array}{l}\text { Waste Stream } \\
\text { Identification \# }\end{array}$ & Package \# & Date of Disposal \\
\hline DPL10422 & LRY5LLFY08002 & 10L631 & $5-19-10$ \\
\hline DPL10422 & LRY5LLFY08002 & 10L632 & $5-19-10$ \\
\hline & & & \\
\hline & & & \\
\hline & & & \\
\hline & & & \\
\hline & & & \\
\hline & & & \\
\hline
\end{tabular}

This certification is provided as a courtesy to the waste generator for information purposes only.

/s/:Theresa Hale

WGS Signature

Waste Inspector

Title

/s/:Jon Tanaka

RWMC Signature

UASTE SPEC LSLCSC $_{\text {Title }}$
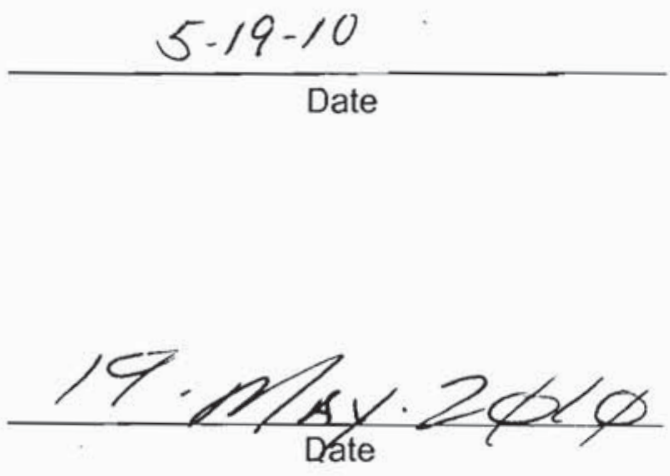
NSTec

Form

FRM-2217
CERTIFICATE OF DISPOSAL

(LOW LEVEL WASTE)
$03 / 01 / 10$

Rev. 01

Page 1 of 1

\section{Nevada Test Site}

This Certificate acknowledges that the following shipment(s) of waste have been disposed at the Nevada Test Site Radioactive Waste Management Complex.

\begin{tabular}{|l|l|l|c|}
\hline Shipment Number & $\begin{array}{c}\text { Waste Stream } \\
\text { Identification \# }\end{array}$ & Package \# & Date of Disposal \\
\hline DPL10423 & LRY5LLFY08002 & 10 L633 & $5-19-10$ \\
\hline DPL10423 & LRY5LLFY08002 & 10 L634 & $5-19-10$ \\
\hline & & & \\
\hline & & & \\
\hline & & & \\
\hline & & & \\
\hline & & & \\
\hline
\end{tabular}

This certification is provided as a courtesy to the waste generator for information purposes only.

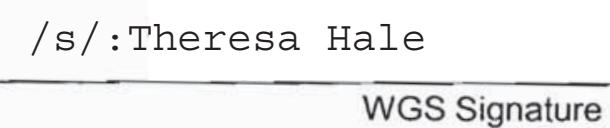

Waste Inspector

$$
\text { Title }
$$

/s/:Jon Tanaka

RWMC Signature

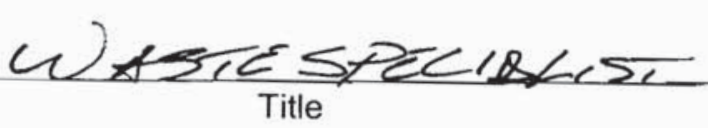

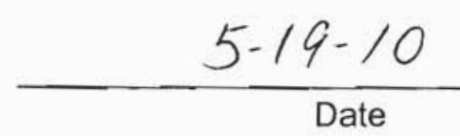

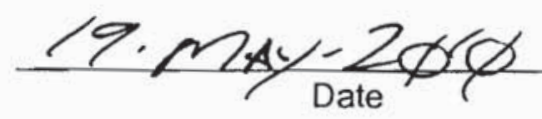


NSTec

Form

CERTIFICATE OF DISPOSAL

03/01/10

FRM-2217

(LOW LEVEL WASTE)

Rev. 01

Page 1 of 1

\section{Nevada Test Site}

This Certificate acknowledges that the following shipment(s) of waste have been disposed at the Nevada Test Site Radioactive Waste Management Complex.

\begin{tabular}{|l|l|l|c|}
\hline Shipment Number & \multicolumn{1}{|c|}{$\begin{array}{c}\text { Waste Stream } \\
\text { Identification \# }\end{array}$} & Package \# & Date of Disposal \\
\hline DPL10424 & LRY5LLFY08002 & 10 6635 & $5-19-10$ \\
\hline DPL10424 & LRY5LLFY08002 & 10 L636 & $5-19-10$ \\
\hline & & & \\
\hline & & & \\
\hline & & & \\
\hline & & & \\
\hline & & & \\
\hline
\end{tabular}

This certification is provided as a courtesy to the waste generator for information purposes only.

/s/: Theresa Hale

WGS Signature

Waste Inspector

Title

/s/:Jon Tanaka

RWMC Signature

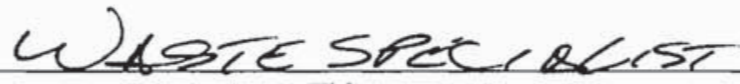

$$
5-19 \cdot 10
$$

Date

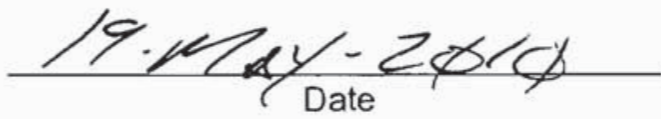


NSTec

Form

FRM-2217
CERTIFICATE OF DISPOSAL

(LOW LEVEL WASTE)
03/01/10

Rev. 01

Page 1 of 1

\section{Nevada Test Site}

This Certificate acknowledges that the following shipment(s) of waste have been disposed at the Nevada Test Site Radioactive Waste Management Complex.

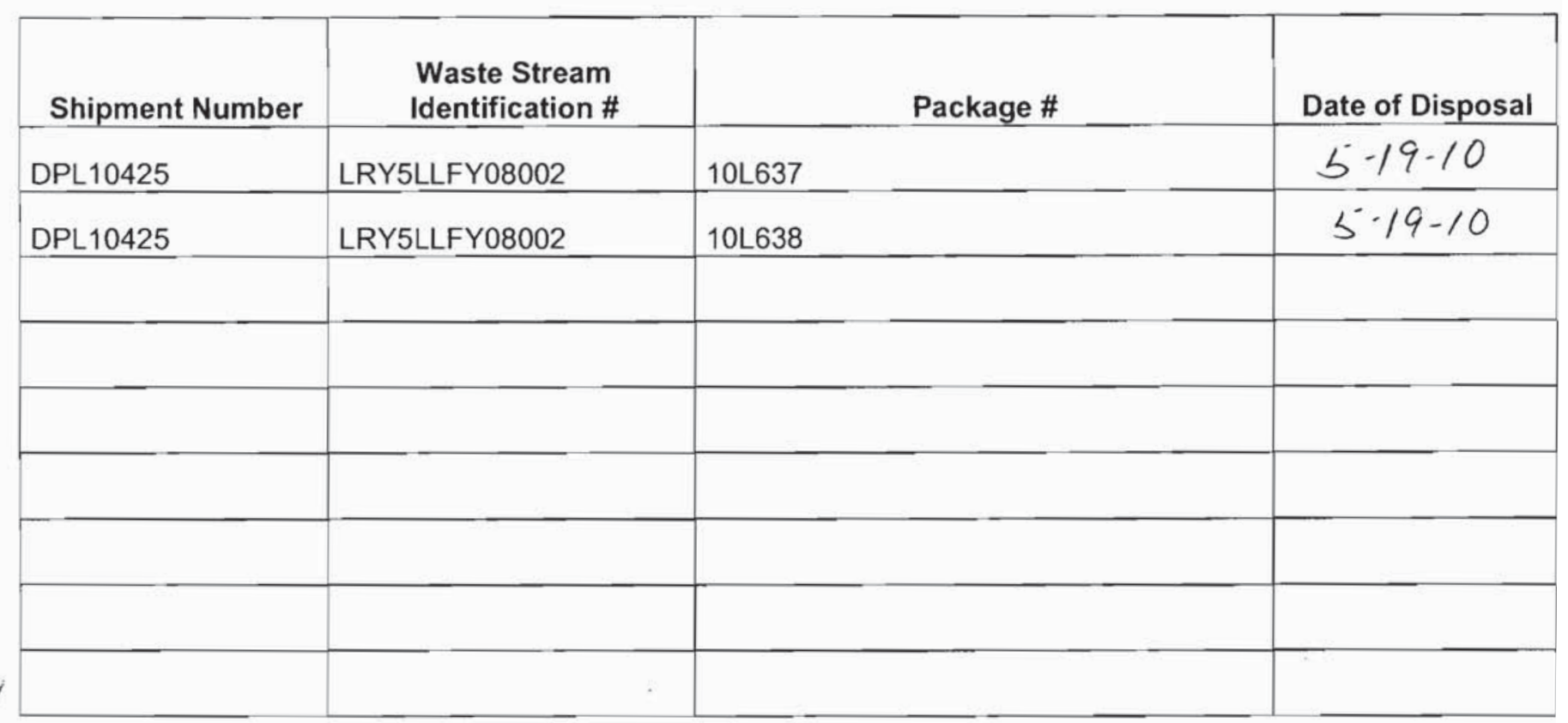

This certification is provided as a courtesy to the waste generator for information purposes only.

/s/: Theresa Hale

WGS Signature

Waste Inspector

Title /s / : Jon Tanaka

RWMC Signature

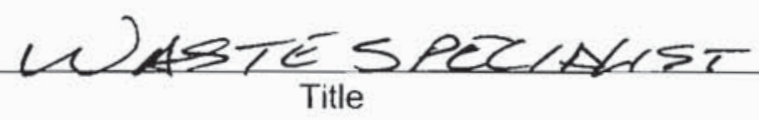

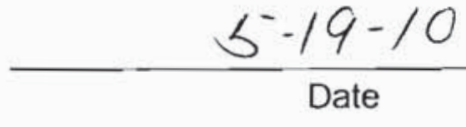

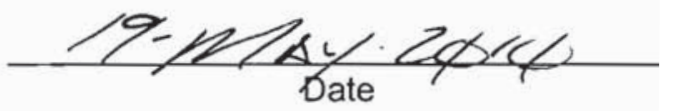




\begin{tabular}{|lcr|}
\hline NSTec & CERTIFICATE OF DISPOSAL & Rev. 01 \\
Form & CERTICATM \\
FRM-2217 & (LOW LEVEL WASTE) & Page 1 of 1 \\
\hline
\end{tabular}

Nevada Test Site

This Certificate acknowledges that the following shipments) of waste have been disposed at the Nevada Test Site Radioactive Waste Management Complex.

\begin{tabular}{|l|l|l|c|}
\hline Shipment Number & \multicolumn{1}{|c|}{$\begin{array}{c}\text { Waste Stream } \\
\text { Identification \# }\end{array}$} & Package \# & Date of Disposal \\
\hline DPL10426 & LRY5LLFY08002 & 10 L639 & $5-19-10$ \\
\hline DPL10426 & LRY5LLFY08002 & 10 L640 & $5-19-10$ \\
\hline & & & \\
\hline & & & \\
\hline & & & \\
\hline & & & \\
\hline & & & \\
\hline & & & \\
\hline
\end{tabular}

This certification is provided as a courtesy to the waste generator for information purposes only.

/s/ :Theresa Hale

WGS Signature

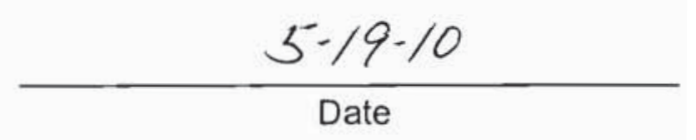

Waste Inspector

Title

/s/ :Jon Tanka

RWMC Signature

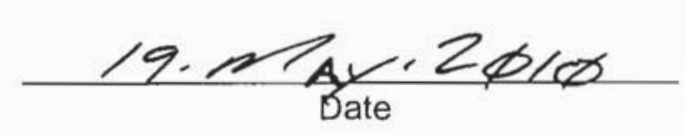

(Roforenre: คP_2151 3ก4) 
NSTec

Form

FRM-2217
CERTIFICATE OF DISPOSAL

(LOW LEVEL WASTE)
03/01/10

Rev. 01

Page 1 of 1

\section{Nevada Test Site}

This Certificate acknowledges that the following shipment(s) of waste have been disposed at the Nevada Test Site Radioactive Waste Management Complex.

\begin{tabular}{|l|l|l|l|}
\hline Shipment Number & $\begin{array}{c}\text { Waste Stream } \\
\text { Identification \# }\end{array}$ & Package \# & Date of Disposal \\
\hline DPL10091 & LRY5LLFY08002 & 10 L157 & $5-20-10$ \\
\hline & & & \\
\hline & & & \\
\hline & & & \\
\hline & & & \\
\hline & & & \\
\hline & & & \\
\hline
\end{tabular}

This certification is provided as a courtesy to the waste generator for information purposes only.

$\frac{\text { /s/:Theresa Hale }}{\text { WGS Signature }}$

Waste Inspector

\section{Title}

/s/:Jon Tanaka

RWMC Signature

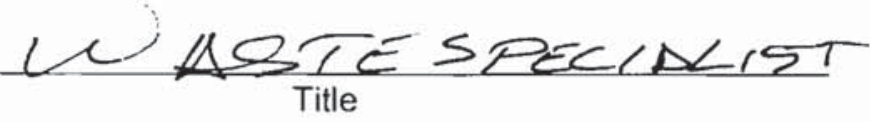

$5-20-10$

Date

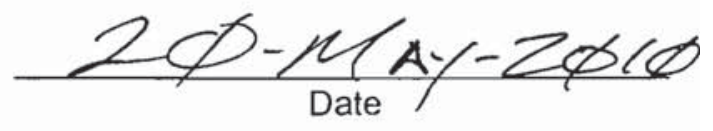




\section{Nevada Test Site}

This Certificate acknowledges that the following shipment(s) of waste have been disposed at the Nevada Test Site Radioactive Waste Management Complex.

\begin{tabular}{|l|l|l|c|}
\hline \multicolumn{1}{|c|}{$\begin{array}{c}\text { Whipte Stream } \\
\text { Identification \# }\end{array}$} & Package \# & Date of Disposal \\
\hline DPL10427 & LRY5LLFY08002 & 10 L641 & $5-20-10$ \\
\hline DPL10427 & LRY5LLFY08002 & 10 L642 & $5-20-10$ \\
\hline & & & \\
\hline & & & \\
\hline & & & \\
\hline & & & \\
\hline & & & \\
\hline
\end{tabular}

This certification is provided as a courtesy to the waste generator for information purposes only.

/s/:Theresa Hale

WGS Signature

Waste Inspector

Title

\section{/s/:Jon Tanaka}

RWMC Signature

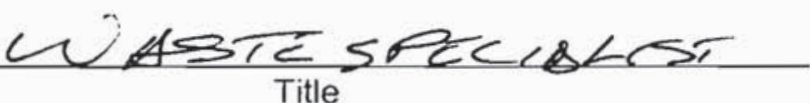

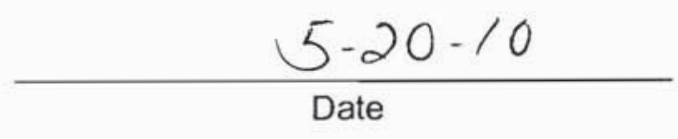

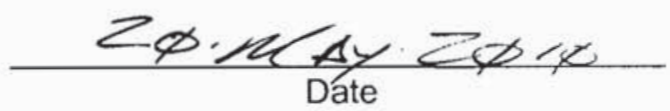


NSTec

Form

FRM-2217
CERTIFICATE OF DISPOSAL

(LOW LEVEL WASTE)
$03 / 01 / 10$

Rev. 01

Page 1 of 1

\section{Nevada Test Site}

This Certificate acknowledges that the following shipment(s) of waste have been disposed at the Nevada Test Site Radioactive Waste Management Complex.

\begin{tabular}{|l|l|l|l|}
\hline \multicolumn{1}{|c|}{$\begin{array}{c}\text { Waste Stream } \\
\text { Identification \# }\end{array}$} & Package \# & Date of Disposal \\
\hline DPL10428 & LRY5LLFY08002 & 10 L643 & $5 \cdot 20-10$ \\
\hline DPL10428 & LRY5LLFY08002 & 10 L644 & $5 \cdot 20 \cdot 10$ \\
\hline & & & \\
\hline & & & \\
\hline & & & \\
\hline & & & \\
\hline & & & \\
\hline
\end{tabular}

This certification is provided as a courtesy to the waste generator for information purposes only.

/s/:Theresa Hale

WGS Signature

Waste Inspector

Title /s/: Jon Tanaka

RWḾc Signature

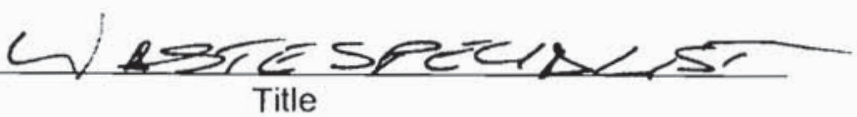

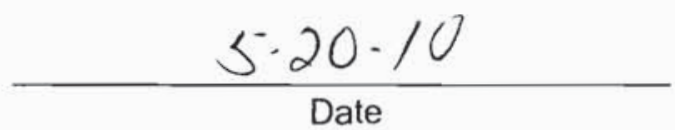

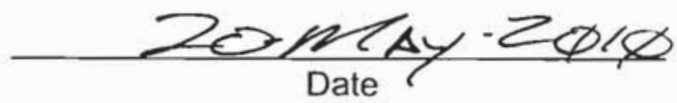




\begin{tabular}{|lcr|}
\hline NSTec & CERTIFICATE OF DISPOSAL & $03 / 01 / 10$ \\
Form & Rev. 01 \\
FRM-2217 & (LOW LEVEL WASTE) & Page 1 of 1 \\
\hline
\end{tabular}

Nevada Test Site

This Certificate acknowledges that the following shipments) of waste have been disposed at the Nevada Test Site Radioactive Waste Management Complex.

\begin{tabular}{|l|l|l|l|}
\hline Shipment Number & \multicolumn{1}{|c|}{$\begin{array}{c}\text { Waste Stream } \\
\text { Identification \# }\end{array}$} & Package \# & Date of Disposal \\
\hline DPL10429 & LRY5LLFY08002 & 10 L645 & $5 \cdot 20 \cdot 10$ \\
\hline DPL10429 & LRY5LLFY08002 & 10 L646 & $5-20 \cdot 10$ \\
\hline & & & \\
\hline & & & \\
\hline & & & \\
\hline & & & \\
\hline & & & \\
\hline & & & \\
\hline
\end{tabular}

This certification is provided as a courtesy to the waste generator for information purposes only.

/s/ :Theresa Hale

WGS Signature

Waste Inspector

Title

/s/ :Jon Tanka

RWMC Signature

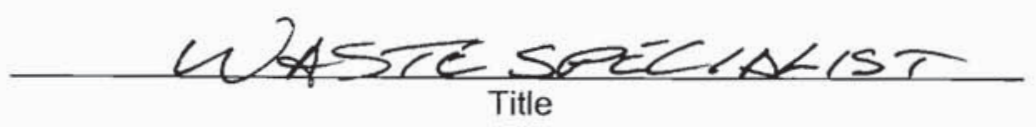

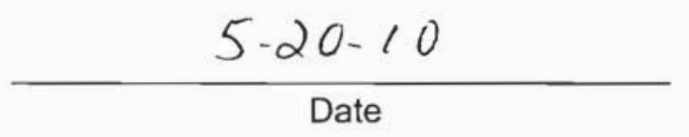

Date

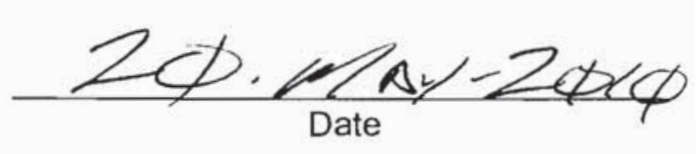


NSTec

Form

FRM-2217
CERTIFICATE OF DISPOSAL

(LOW LEVEL WASTE)
03/01/10

Rev. 01

Page 1 of 1

\section{Nevada Test Site}

This Certificate acknowledges that the following shipment(s) of waste have been disposed at the Nevada Test Site Radioactive Waste Management Complex.

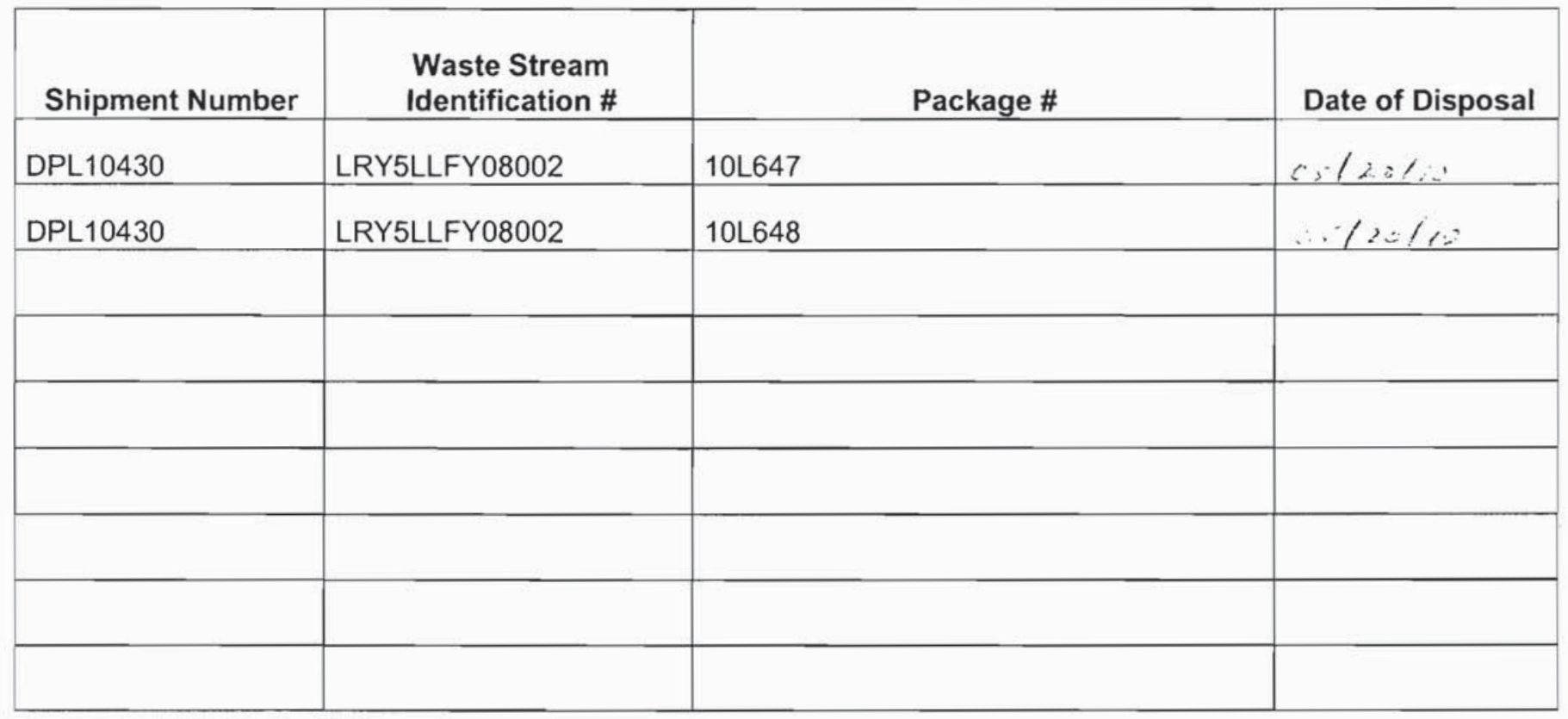

This certification is provided as a courtesy to the waste generator for information purposes only.

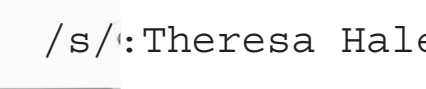

WGS Signature

Waste Inspector

Title
/s/:Jon Tanaka

RWMC Signature

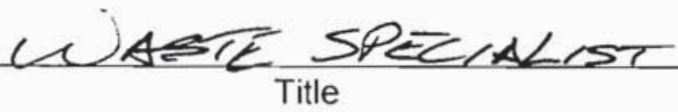

$5 / 20 / 10$

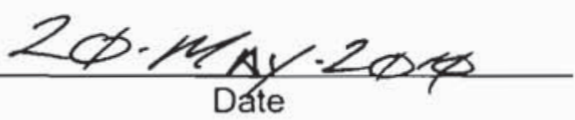


NSTec

Form

FRM-2217
CERTIFICATE OF DISPOSAL

(LOW LEVEL WASTE)
$03 / 01 / 10$

Rev. 01

Page 1 of 1

\section{Nevada Test Site}

This Certificate acknowledges that the following shipment(s) of waste have been disposed at the Nevada Test Site Radioactive Waste Management Complex.

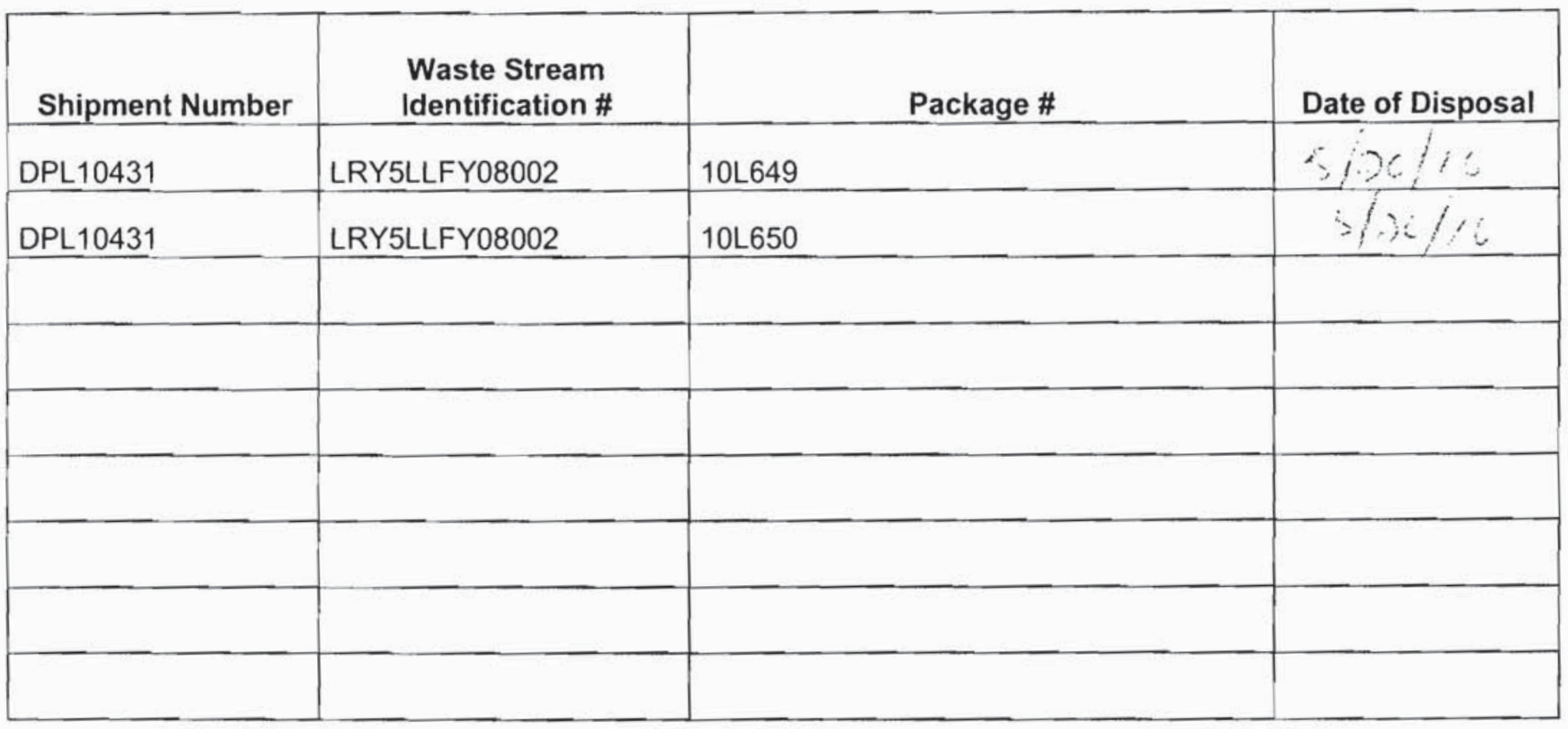

This certification is provided as a courtesy to the waste generator for information purposes only.

/s/:Theresa Hale

WGS Signature

Waste Inspector

Title

/s/:Jon Tanaka

RWMC Signature

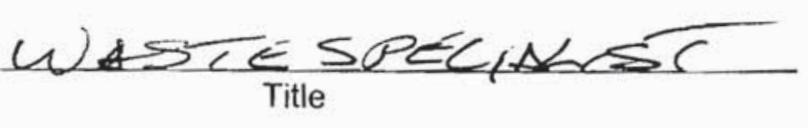

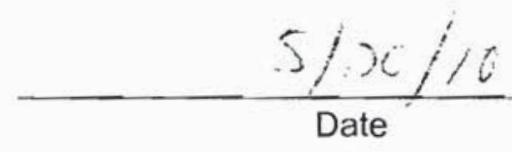

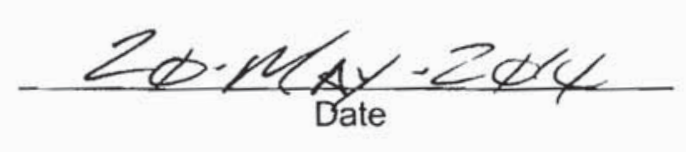


NSTec

Form

CERTIFICATE OF DISPOSAL

$03 / 01 / 10$

FRM-2217

(LOW LEVEL WASTE)

Rev. 01

Page 1 of 1

\section{Nevada Test Site}

This Certificate acknowledges that the following shipment(s) of waste have been disposed at the Nevada Test Site Radioactive Waste Management Complex.

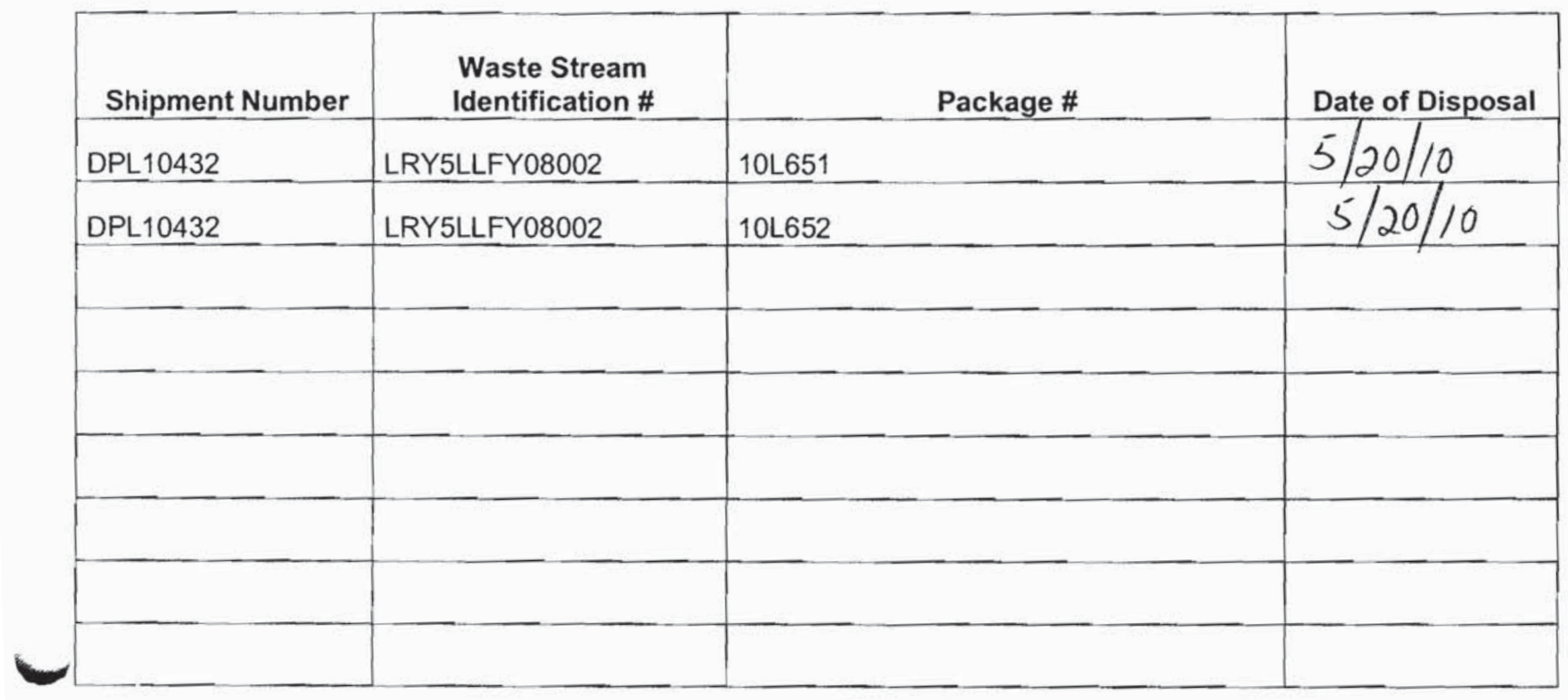

This certification is provided as a courtesy to the waste generator for information purposes only.

/s/:Theresa Hale

WGS Signature

Waste Inspector

$$
\text { Titie }
$$

/s/:Jon Tanaka

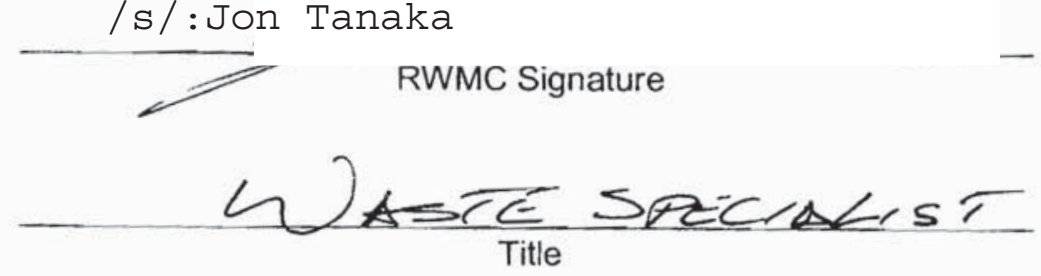

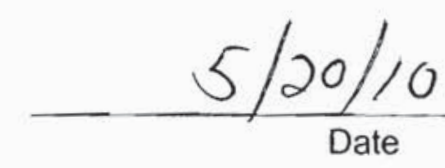

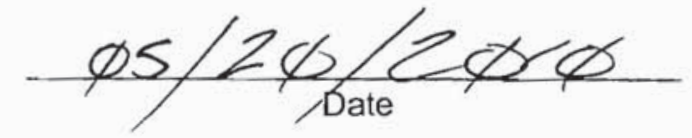




\begin{tabular}{|lcr|}
\hline NSTec & CERTIFICATE OF DISPOSAL & 03/01/10 \\
Form & Rev. 01 \\
FRM-2217 & (LOW LEVEL WASTE) & Page 1 of 1 \\
\hline
\end{tabular}

Nevada Test Site

This Certificate acknowledges that the following shipments) of waste have been disposed at the Nevada Test Site Radioactive Waste Management Complex.

\begin{tabular}{|l|l|l|c|}
\hline \multicolumn{1}{|c|}{ Shipment Number } & $\begin{array}{c}\text { Waste Stream } \\
\text { Identification \# }\end{array}$ & \multicolumn{1}{|c|}{ Package \# } & Date of Disposal \\
\hline DPL10433 & LRY5LLFY08002 & 10 653 & $5 / 20 / 10$ \\
\hline DPL10433 & LRY5LLFY08002 & 10 654 & $5 / 20 / 10$ \\
\hline & & & \\
\hline & & & \\
\hline & & & \\
\hline & & & \\
\hline & & & \\
\hline
\end{tabular}

This certification is provided as a courtesy to the waste generator for information purposes only.

/s/: Theresa Hale

WGS Signature

$5 / 20 / 10$

Waste Inspector

Title

/s/: Jon Tanka

RWMC Signature

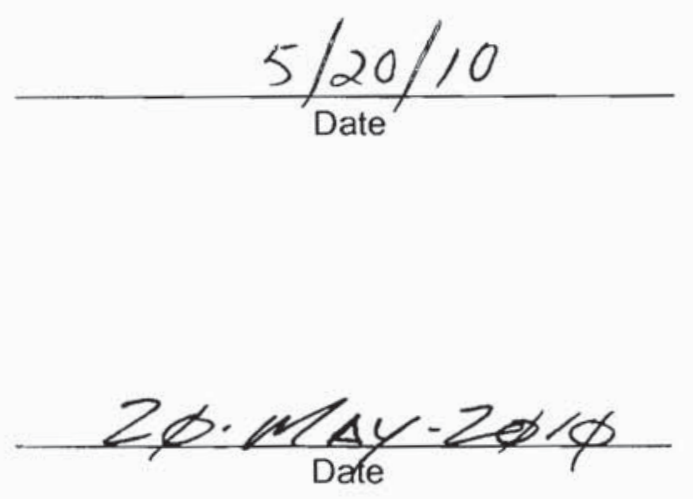




\begin{tabular}{|lcr|}
\hline NSTec & CERTIFICATE OF DISPOSAL & 03/01/10 \\
Form & Rev. 01 \\
FRM-2217 & (LOW LEVEL WASTE) & Page 1 of 1 \\
\hline
\end{tabular}

Nevada Test Site

This Certificate acknowledges that the following shipments) of waste have been disposed at the Nevada Test Site Radioactive Waste Management Complex.

\begin{tabular}{|l|l|l|l|}
\hline \multicolumn{1}{|c|}{ Shipment Number } & $\begin{array}{c}\text { Waste Stream } \\
\text { Identification \# }\end{array}$ & Package \# & Date of Disposal \\
\hline DPL10434 & LRY5LLFY08002 & 10 L655 & $5 / 20 / 10$ \\
\hline DPL10434 & LRY5LLFY08002 & 10 L656 & $5 / 20 / 10$ \\
\hline & & & \\
\hline & & & \\
\hline & & & \\
\hline & & & \\
\hline & & & \\
\hline
\end{tabular}

This certification is provided as a courtesy to the waste generator for information purposes only.

/s/ :Theresa Hale

WGS Signature

Waste Inspector

Title

/s/ :Jon Tanka

RWMC Signature
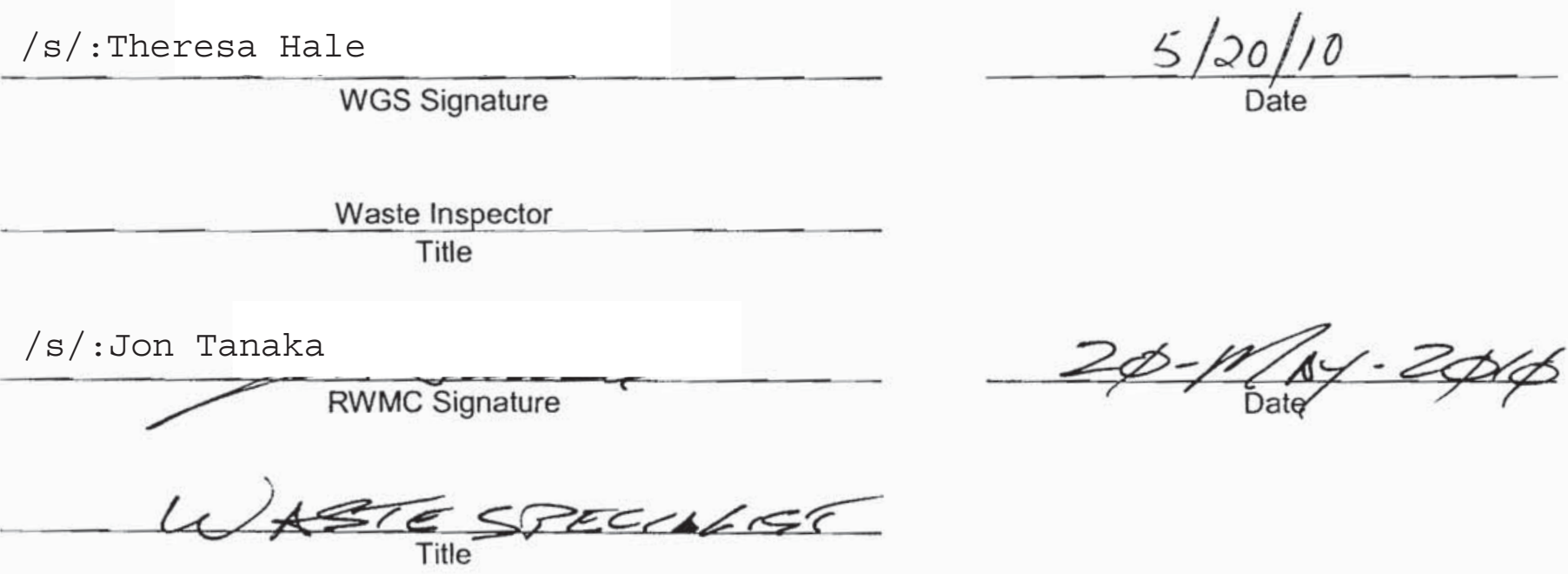


\begin{tabular}{|lcr|}
\hline NSTec & CERTIFICATE OF DISPOSAL & 03/01/10 \\
Form & Rev. 01 \\
FRM-2217 & (LOW LEVEL WASTE) & Page 1 of 1 \\
\hline
\end{tabular}

Nevada Test Site

This Certificate acknowledges that the following shipments) of waste have been disposed at the Nevada Test Site Radioactive Waste Management Complex.

\begin{tabular}{|l|l|l|c|}
\hline \multicolumn{1}{|c|}{$\begin{array}{c}\text { Waste Stream } \\
\text { Identification \# }\end{array}$} & \multicolumn{1}{|c|}{ Package \# } & Date of Disposal \\
\hline DPL10435 & LRY5LLFY08002 & 10 L657 & $5 / 20 / 10$ \\
\hline DPL10435 & LRY5LLFY08002 & 10 L658 & $5 / 20 / / 0$ \\
\hline & & & \\
\hline & & & \\
\hline & & & \\
\hline & & & \\
\hline & & & \\
\hline & & & \\
\hline
\end{tabular}

This certification is provided as a courtesy to the waste generator for information purposes only.
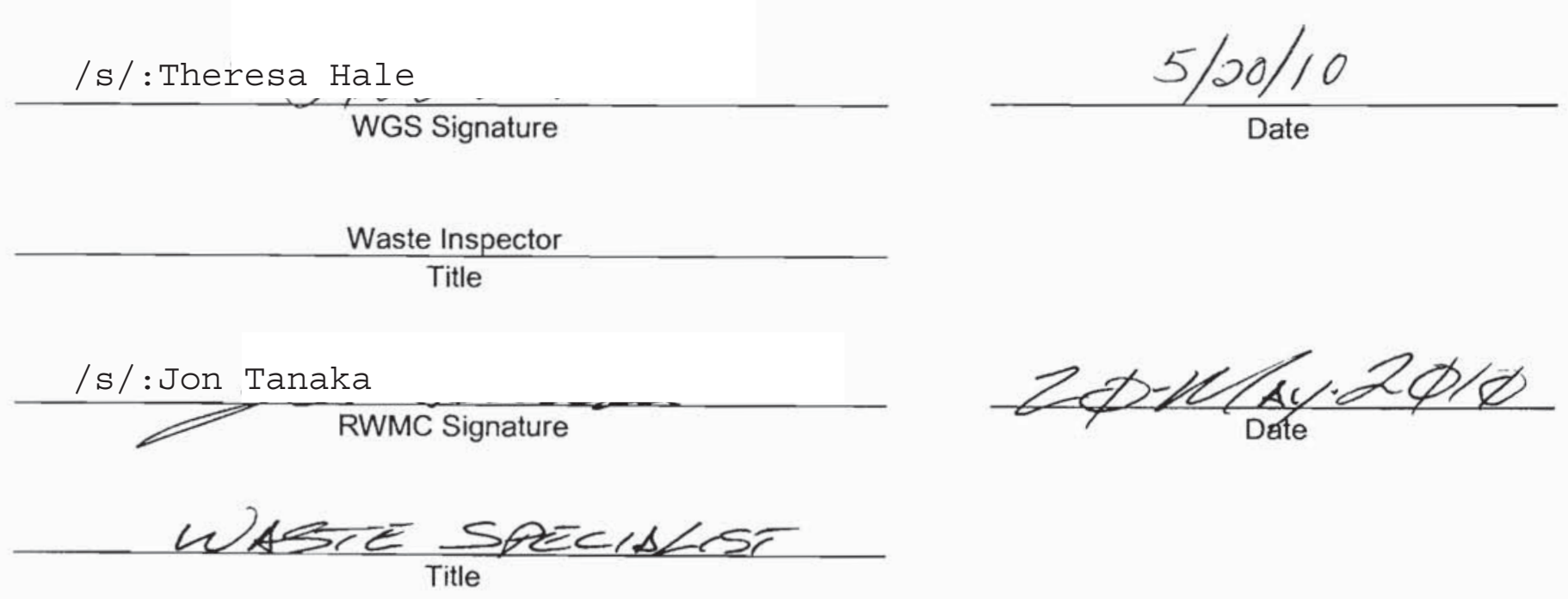
NSTec

Form

FRM-2217

CERTIFICATE OF DISPOSAL

$03 / 01 / 10$

Rev. 01

(LOW LEVEL WASTE)

Page 1 of 1

\section{Nevada Test Site}

This Certificate acknowledges that the following shipment(s) of waste have been disposed at the Nevada Test Site Radioactive Waste Management Complex.

\begin{tabular}{|l|l|l|l|}
\hline Shipment Number & $\begin{array}{c}\text { Waste Stream } \\
\text { Identification \# }\end{array}$ & Package \# & Date of Disposal \\
\hline DPL10092 & LRY5LLY08002 & 10 L158 & $5 / 24 / / j$ \\
\hline & & & \\
\hline & & & \\
\hline & & & \\
\hline & & & \\
\hline & & & \\
\hline
\end{tabular}

This certification is provided as a courtesy to the waste generator for information purposes only.

/s/: Theresa Hale

WGS Signature

Waste Inspector

Title

/s/:Jon Tanaka

RWMC Signature

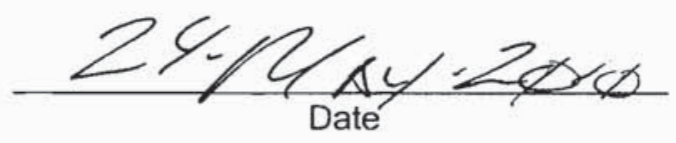




\begin{tabular}{|lcr|}
\hline NSTec & CERTIFICATE OF DISPOSAL & $03 / 01 / 10$ \\
Form & Rev. 01 \\
FRM-2217 & (LOW LEVEL WASTE) & Page 1 of 1 \\
\hline
\end{tabular}

Nevada Test Site

This Certificate acknowledges that the following shipments) of waste have been disposed at the Nevada Test Site Radioactive Waste Management Complex.

\begin{tabular}{|l|c|c|c|}
\hline Shipment Number & $\begin{array}{c}\text { Waste Stream } \\
\text { Identification \# }\end{array}$ & Package \# & Date of Disposal \\
\hline DPL10093 & LRY5LLFY08002 & 10 159 & $5 / 2 \mathrm{Y} / \mathrm{C}$ \\
\hline & & & \\
\hline & & & \\
\hline & & & \\
\hline & & & \\
\hline & & & \\
\hline
\end{tabular}

This certification is provided as a courtesy to the waste generator for information purposes only.

/s/:Théresa Hale

WGS Signature

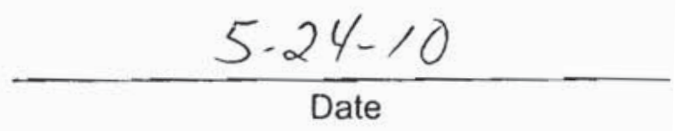

Waste Inspector

Title

/s/ :Jon Tanka

RWMC Signature

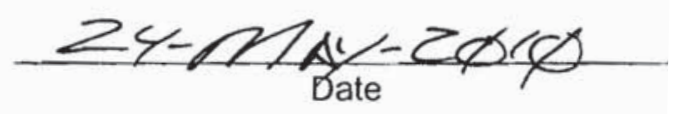

Title

IDofarnnro: OP .21.51 3ก4) 
NSTec

Form

FRM-2217
CERTIFICATE OF DISPOSAL

(LOW LEVEL WASTE)
03/01/10

Rev. 01

Page 1 of 1

\section{Nevada Test Site}

This Certificate acknowledges that the following shipment(s) of waste have been disposed at the Nevada Test Site Radioactive Waste Management Complex.

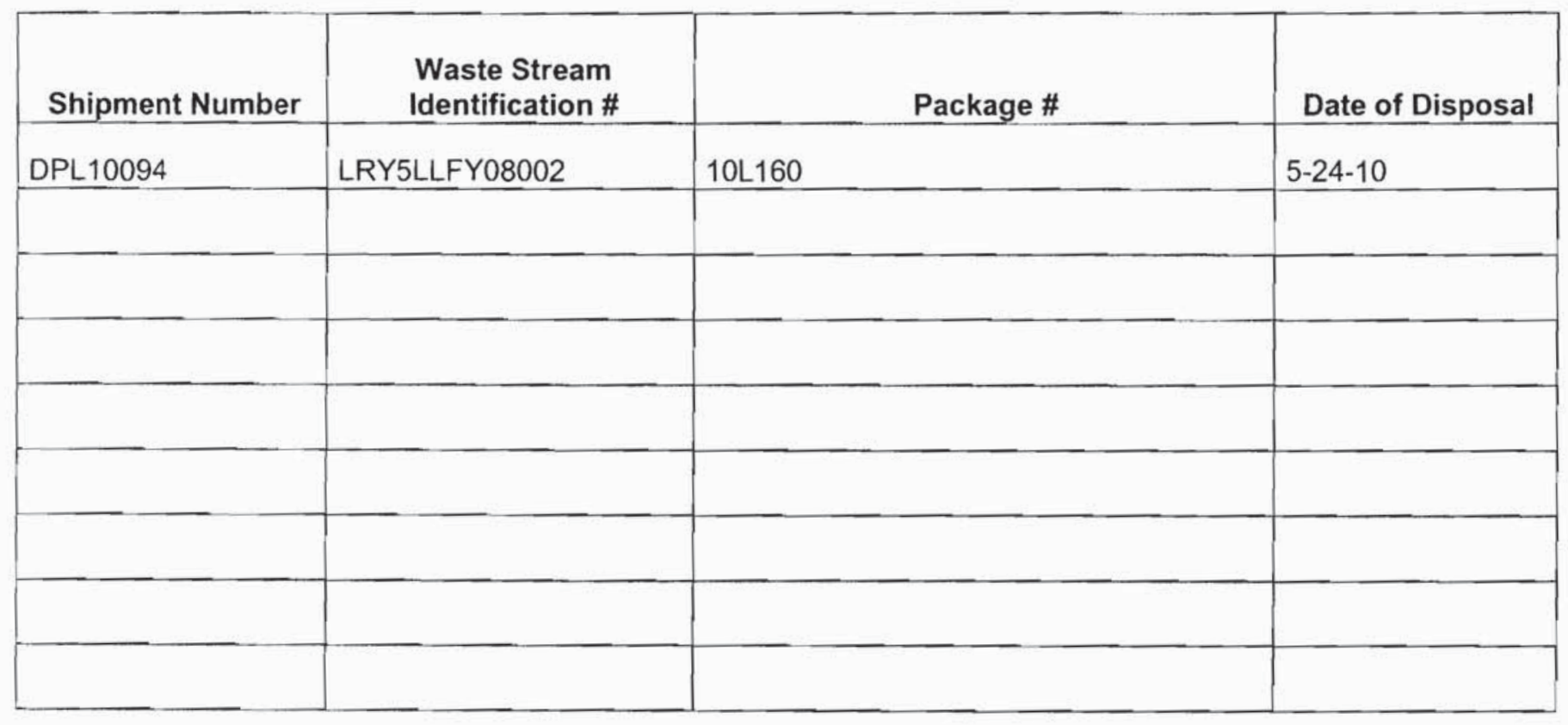

This certification is provided as a courtesy to the waste generator for information purposes only.

/s/:Theresa Hale

WGS Signature

Waste Inspector

Title

/s/:Jon Tanaka

kWMC Signature

(e) 1 TESOZCHALST

Title
5-24-10

Date

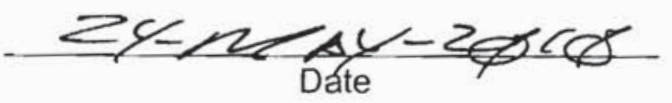




\section{Nevada Test Site}

This Certificate acknowledges that the following shipment(s) of waste have been disposed at the Nevada Test Site Radioactive Waste Management Complex.

\begin{tabular}{|l|l|l|l|}
\hline \multicolumn{1}{|c|}{$\begin{array}{c}\text { Waste Stream } \\
\text { Identification \# }\end{array}$} & \multicolumn{1}{c|}{ Package \# } & Date of Disposal \\
\hline DPL10436 & LRY5LLFY08002 & 10 L659 & $5 / 24 / 10$ \\
\hline DPL10436 & LRY5LLFY08002 & 10 L660 & $5 / 24 / 10$ \\
\hline & & & \\
\hline & & & \\
\hline & & & \\
\hline & & & \\
\hline
\end{tabular}

This certification is provided as a courtesy to the waste generator for information purposes only.

/s/:Theresa Hale

WGS Signature

Waste Inspector

Title

/s/:Jon Tanaka

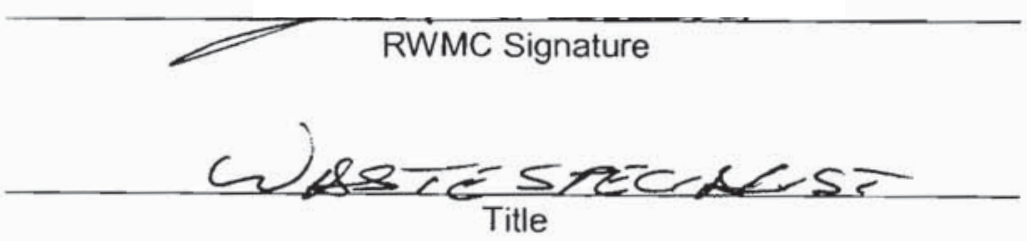

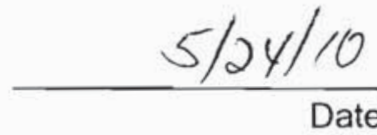

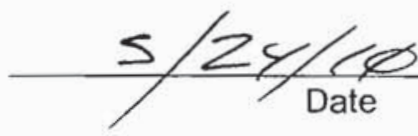


NSTec

Form

FRM-2217
CERTIFICATE OF DISPOSAL

(LOW LEVEL WASTE)
03/01/10

Rev. 01

Page 1 of 1

\section{Nevada Test Site}

This Certificate acknowledges that the following shipment(s) of waste have been disposed at the Nevada Test Site Radioactive Waste Management Complex.

\begin{tabular}{|l|l|l|l|}
\hline \multicolumn{1}{|c|}{$\begin{array}{c}\text { Waste Stream } \\
\text { Identification \# }\end{array}$} & Package \# & Date of Disposal \\
\hline DPL10437 & LRY5LLFY08002 & 10 L661 & $5 / 24 / 10$ \\
\hline DPL10437 & LRY5LLFY08002 & 10 L662 & $5 / 24 / 10$ \\
\hline & & & \\
\hline & & & \\
\hline & & & \\
\hline & & & \\
\hline & & & \\
\hline
\end{tabular}

This certification is provided as a courtesy to the waste generator for information purposes only.

/s/: Theresa Hale

WGS Signature

Waste Inspector

Title

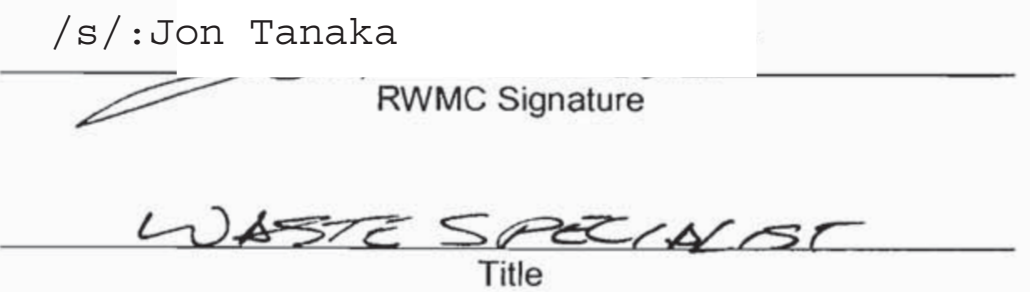

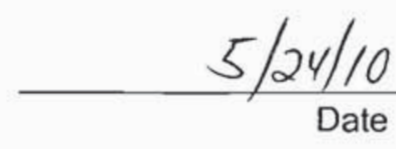

Date

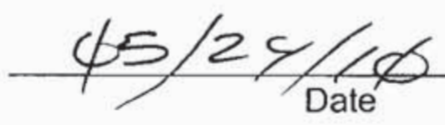


NSTec

Form

FRM-2217
CERTIFICATE OF DISPOSAL

(LOW LEVEL WASTE)
03/01/10

Rev. 01

Page 1 of 1

\section{Nevada Test Site}

This Certificate acknowledges that the following shipment(s) of waste have been disposed at the Nevada Test Site Radioactive Waste Management Complex.

\begin{tabular}{|l|l|l|l|}
\hline \multicolumn{1}{|c|}{ Shipment Number } & \multicolumn{1}{c|}{$\begin{array}{c}\text { Waste Stream } \\
\text { Identification \# }\end{array}$} & Package \# & Date of Disposal \\
\hline DPL10438 & LRY5LLFY08002 & 10 L663 & $5 / 24 / 10$ \\
\hline DPL10438 & LRY5LLFY08002 & 10 L664 & $5 / 24 / 10$ \\
\hline & & & \\
\hline & & & \\
\hline & & & \\
\hline & & & \\
\hline & & & \\
\hline
\end{tabular}

This certification is provided as a courtesy to the waste generator for information purposes only.

/s/:Theresa Hale

WGS Signature

Waste Inspector

Title

/s/:Jon Tanaka

RWMC Signature
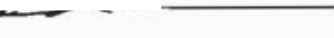

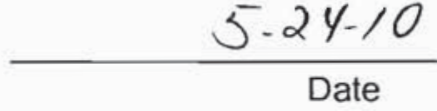

Date

\section{WASTE SPECINCST}


NSTec

Form

CERTIFICATE OF DISPOSAL

$03 / 01 / 10$

FRM-2217

(LOW LEVEL WASTE)

Rev. 01

Page 1 of 1

\section{Nevada Test Site}

This Certificate acknowledges that the following shipment(s) of waste have been disposed at the Nevada Test Site Radioactive Waste Management Complex.

\begin{tabular}{|l|l|l|c|}
\hline Shipment Number & $\begin{array}{c}\text { Waste Stream } \\
\text { Identification \# }\end{array}$ & Package \# & Date of Disposal \\
\hline DPL10439 & LRY5LLFY08002 & 10 L665 & $5 / 24 / 10$ \\
\hline DPL10439 & LRY5LLFY08002 & 10 L666 & $5 / 24 / / 0$ \\
\hline & & & \\
\hline & & & \\
\hline & & & \\
\hline & & & \\
\hline
\end{tabular}

This certification is provided as a courtesy to the waste generator for information purposes only.

/s/: Theresa Hale

WGS Signature

Waste inspector

Title

/s/:Jon Tanaka

RWMC Signature

UABTE STECANST
$5 / 24 / 10$

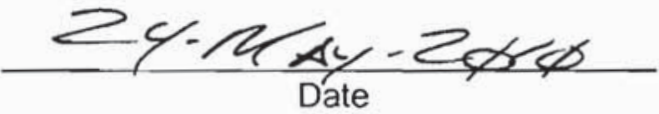


NSTec

Form

FRM-2217
CERTIFICATE OF DISPOSAL (LOW LEVEL WASTE)
03/01/10

Rev. 01

Page 1 of 1

\section{Nevada Test Site}

This Certificate acknowledges that the following shipment(s) of waste have been disposed at the Nevada Test Site Radioactive Waste Management Complex.

\begin{tabular}{|l|l|l|l|}
\hline Shipment Number & \multicolumn{1}{|c|}{$\begin{array}{c}\text { Waste Stream } \\
\text { Identification \# }\end{array}$} & Package \# & Date of Disposal \\
\hline DPL10440 & LRY5LLFY08002 & 10 L667 & $5 / 24 / 10$ \\
\hline DPL10440 & LRY5LLFY08002 & 10 L668 & $5 / 24 / 10$ \\
\hline & & & \\
\hline & & & \\
\hline & & & \\
\hline & & & \\
\hline & & & \\
\hline
\end{tabular}

This certification is provided as a courtesy to the waste generator for information purposes only.

/s/:Theresa Hale

WGS Signature

Waste Inspector

Title

\section{/s/:Jon Tanaka}

RWMC Signature

U STCESTECLRLISE $\frac{5-24-10}{\text { Date }}$

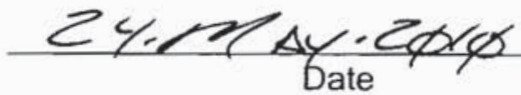




\begin{tabular}{|lcr|}
\hline NSTec & CERTIFICATE OF DISPOSAL & $03 / 01 / 10$ \\
Form & Rev. 01 \\
FRM-2217 & (LOW LEVEL WASTE) & Page 1 of 1 \\
\hline
\end{tabular}

Nevada Test Site

This Certificate acknowledges that the following shipments) of waste have been disposed at the Nevada Test Site Radioactive Waste Management Complex.

\begin{tabular}{|l|l|l|l|}
\hline \multicolumn{1}{|c|}{ Shipment Number } & $\begin{array}{c}\text { Waste Stream } \\
\text { Identification \# }\end{array}$ & \multicolumn{1}{c|}{ Package \# } & Date of Disposal \\
\hline DPL10441 & LRY5LLFY08002 & 10 L669 & $5-24-10$ \\
\hline DPL10441 & LRY5LLFY08002 & 10 L670 & $5-24-10$ \\
\hline & & & \\
\hline & & & \\
\hline & & & \\
\hline & & & \\
\hline & & & \\
\hline
\end{tabular}

This certification is provided as a courtesy to the waste generator for information purposes only.

/s/ :Theresa Hale

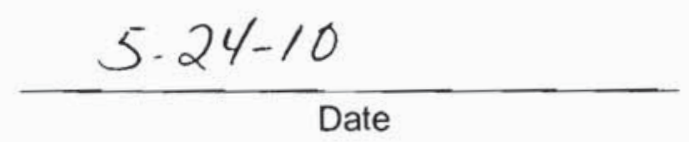

Waste Inspector

Title

/s/ :Jon Tanka

RWMC Signature

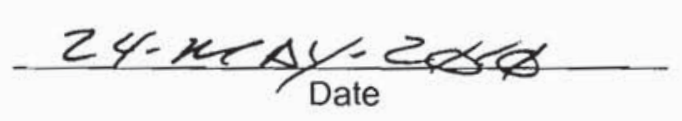


NSTec

Form

FRM-2217
CERTIFICATE OF DISPOSAL

(LOW LEVEL WASTE)
03/01/10

Rev. 01

Page 1 of 1

\section{Nevada Test Site}

This Certificate acknowledges that the following shipment(s) of waste have been disposed at the Nevada Test Site Radioactive Waste Management Complex.

\begin{tabular}{|c|c|c|c|}
\hline Shipment Number & $\begin{array}{l}\text { Waste Stream } \\
\text { Identification \# }\end{array}$ & Package \# & Date of Disposal \\
\hline DPL10442 & LRY5LLFY08002 & 10L671 & $5 / 24 / 10$ \\
\hline DPL10442 & LRY5LLFY08002 & 10L672 & $5 / 24 / 10$ \\
\hline & & & \\
\hline & & & \\
\hline & & & \\
\hline & & & \\
\hline & & & \\
\hline & & & \\
\hline
\end{tabular}

This certification is provided as a courtesy to the waste generator for information purposes only.

/s/:Theresa Hale

WGS Signature

Waste Inspector

Title
/s/:Jon Tanaka

RWMC Signature

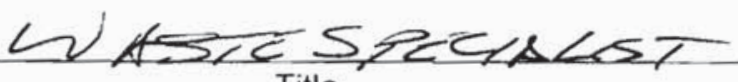

$5 / 24 / 10$

Date

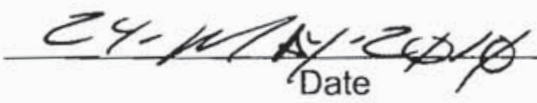


NSTec

Form

FRM-2217
CERTIFICATE OF DISPOSAL

(LOW LEVEL WASTE)
03/01/10

Rev. 01

Page 1 of 1

\section{Nevada Test Site}

This Certificate acknowledges that the following shipment(s) of waste have been disposed at the Nevada Test Site Radioactive Waste Management Complex.

\begin{tabular}{|l|l|l|c|}
\hline Shipment Number & \multicolumn{1}{|c|}{$\begin{array}{c}\text { Waste Stream } \\
\text { Identification \# }\end{array}$} & Package \# & Date of Disposal \\
\hline DPL10443 & LRY5LLFY08002 & 10 L673 & $5 / 24 / 10$ \\
\hline DPL10443 & LRY5LLFY08002 & 10 L674 & $5 / 24 / 10$ \\
\hline & & & \\
\hline & & & \\
\hline & & & \\
\hline & & & \\
\hline
\end{tabular}

This certification is provided as a courtesy to the waste generator for information purposes only.

/s/: Theresa Hale

WGS Signature

Waste Inspector

Title
/s/:Jon Tanaka

RWMC Signature

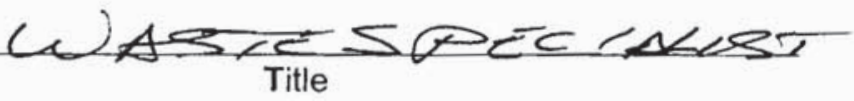

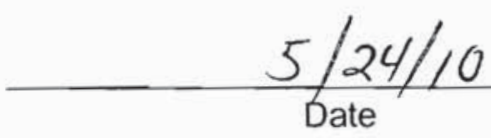

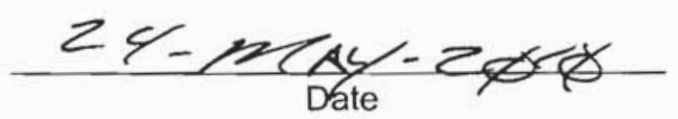




\begin{tabular}{|lcr|}
\hline NSTec & CERTIFICATE OF DISPOSAL & $03 / 01 / 10$ \\
Form & Rev. 01 \\
FRM-2217 & (LOW LEVEL WASTE) & Page 1 of 1 \\
\hline
\end{tabular}

Nevada Test Site

This Certificate acknowledges that the following shipments) of waste have been disposed at the Nevada Test Site Radioactive Waste Management Complex.

\begin{tabular}{|l|l|l|c|}
\hline \multicolumn{1}{|c|}{$\begin{array}{c}\text { Shipment Number } \\
\text { Identification \# }\end{array}$} & \multicolumn{1}{|c|}{ Package \# } & Date of Disposal \\
\hline DPL10444 & LRY5LLFY08002 & 10 6675 & $5 / 24 / 10$ \\
\hline DPL10444 & LRY5LLFY08002 & 10 L676 & $5 / 24 / 10$ \\
\hline & & & \\
\hline & & & \\
\hline & & & \\
\hline & & & \\
\hline & & & \\
\hline & & & \\
\hline
\end{tabular}

This certification is provided as a courtesy to the waste generator for information purposes only.

/s/: Theresa Hale

WGS Signature

Waste Inspector

Title

/s/: Jon Tanka

RWMC Signature

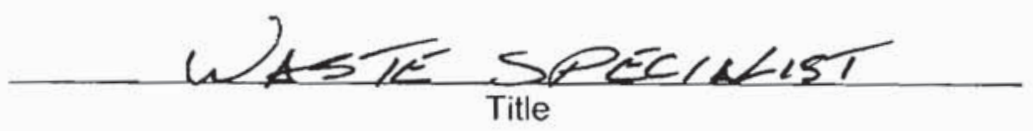

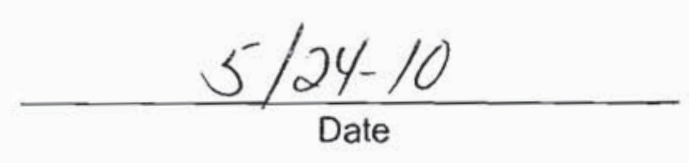

Date

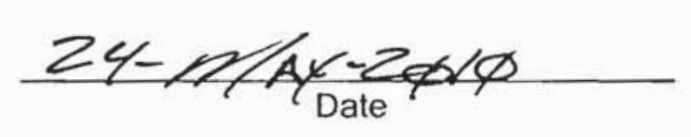




\section{Nevada Test Site}

This Certificate acknowledges that the following shipment(s) of waste have been disposed at the Nevada Test Site Radioactive Waste Management Complex.

\begin{tabular}{|l|l|l|l|}
\hline \multicolumn{1}{|c|}{ Shipment Number } & \multicolumn{1}{|c|}{$\begin{array}{c}\text { Waste Stream } \\
\text { Identification \# }\end{array}$} & Package \# & Date of Disposal \\
\hline DPL10445 & LRY5LLFY08002 & 10 6677 & $5-24-10$ \\
\hline DPL10445 & LRY5LLFY08002 & 10 L678 & $5-24-10$ \\
\hline & & & \\
\hline & & & \\
\hline & & & \\
\hline & & & \\
\hline & & & \\
\hline & & & \\
\hline
\end{tabular}

This certification is provided as a courtesy to the waste generator for information purposes only.

/s/:Theresa Hale

WGS Signature

Waste Inspector

Title

/s/:Jon Tanaka

RWMC Signature

U) 14 TE SPECrets
$5 \cdot 24-10$

Date

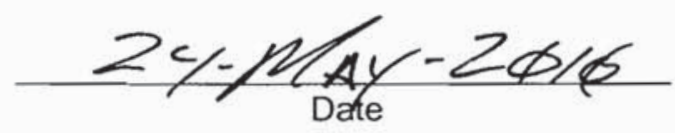


NSTec

Form

FRM-2217
CERTIFICATE OF DISPOSAL

(LOW LEVEL WASTE)
03/01/10

Rev. 01

Page 1 of 1

\section{Nevada Test Site}

This Certificate acknowledges that the following shipment(s) of waste have been disposed at the Nevada Test Site Radioactive Waste Management Complex.

\begin{tabular}{|l|l|l|l|}
\hline Shipment Number & \multicolumn{1}{|c|}{$\begin{array}{c}\text { Waste Stream } \\
\text { Identification \# }\end{array}$} & Package \# & Date of Disposal \\
\hline DPL10446 & LRY5LLFY08002 & 10 L679 & $5 / 24 / 10$ \\
\hline DPL10446 & LRY5LLFY08002 & 10 L680 & $5 / 24 / 10$ \\
\hline & & & \\
\hline & & & \\
\hline & & & \\
\hline
\end{tabular}

This certification is provided as a courtesy to the waste generator for information purposes only.

/s/:Theresa Hale

WGS Signature

Waste Inspector

$$
\text { Title }
$$

/s/:Jon Tanaka

RWMC Signature

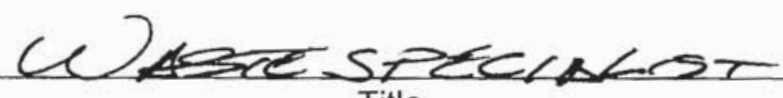

$$
5-24-10
$$

$$
\text { Date }
$$

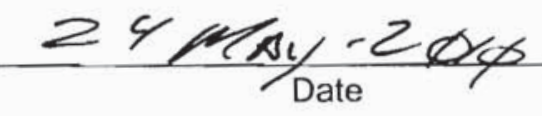


NSTec

Form

FRM-2217
CERTIFICATE OF DISPOSAL

(LOW LEVEL WASTE)
03/01/10

Rev. 01

Page 1 of 1

\section{Nevada Test Site}

This Certificate acknowledges that the following shipment(s) of waste have been disposed at the Nevada Test Site Radioactive Waste Management Complex.

\begin{tabular}{|l|l|l|c|}
\hline \multicolumn{1}{|c|}{$\begin{array}{c}\text { Whaste Stream } \\
\text { Identification \# }\end{array}$} & \multicolumn{1}{c|}{ Package \# } & Date of Disposal \\
\hline DPL10447 & LRY5LLFY08002 & 10 L681 & $5-25-10$ \\
\hline DPL10447 & LRY5LLFY08002 & 10 L682 & $5-25-10$ \\
\hline & & & \\
\hline & & & \\
\hline & & & \\
\hline & & & \\
\hline & & & \\
\hline
\end{tabular}

This certification is provided as a courtesy to the waste generator for information purposes only.

/s/: Theresa Hale

WGS Signature

Waste Inspector

Title

/s/:Jon Tanaka

14
RWMC`̄ignature
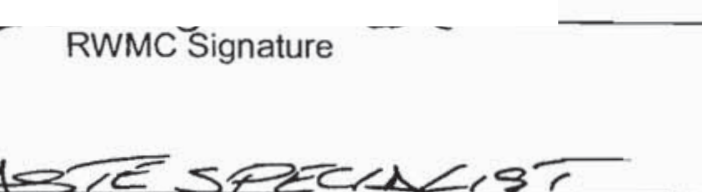

$\frac{5 \cdot 25-10}{\text { Date }}$

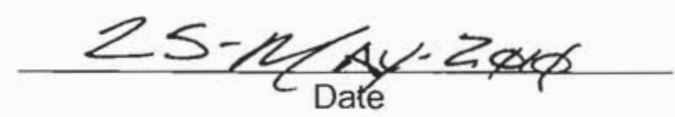




\section{Nevada Test Site}

This Certificate acknowledges that the following shipment(s) of waste have been disposed at the Nevada Test Site Radioactive Waste Management Complex.

\begin{tabular}{|l|l|l|l|}
\hline \multicolumn{1}{|c|}{ Shipment Number } & \multicolumn{1}{|c|}{$\begin{array}{c}\text { Waste Stream } \\
\text { Identification \# }\end{array}$} & \multicolumn{1}{c|}{ Package \# } & Date of Disposal \\
\hline DPL10448 & LRY5LLFY08002 & 10 6883 & $5-25-10$ \\
\hline DPL10448 & LRY5LLFY08002 & 10 L684 & $5 \cdot 25-10$ \\
\hline & & & \\
\hline & & & \\
\hline & & & \\
\hline & & & \\
\hline & & & \\
\hline & & & \\
\hline
\end{tabular}

This certification is provided as a courtesy to the waste generator for information purposes only.

/s/: Theresa Hale
WGS Signature
Waste Inspector
Title

/s/: Jon Tanaka

RWMC Signature

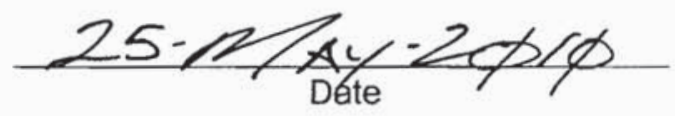

UASTE $\frac{\text { SOECLACST }}{\text { Title }}$ 


\begin{tabular}{|lcr|}
\hline NSTec & CERTIFICATE OF DISPOSAL & $03 / 01 / 10$ \\
Form & Rev. 01 \\
FRM-2217 & (LOW LEVEL WASTE) & Page 1 of 1 \\
\hline
\end{tabular}

Nevada Test Site

This Certificate acknowledges that the following shipments) of waste have been disposed at the Nevada Test Site Radioactive Waste Management Complex.

\begin{tabular}{|l|l|l|c|}
\hline \multicolumn{1}{|c|}{$\begin{array}{c}\text { Waste Stream } \\
\text { Identification \# }\end{array}$} & \multicolumn{1}{|c|}{ Package \# } & Date of Disposal \\
\hline DPL10449 & LRY5LLFY08002 & 10 L685 & $5-25-10$ \\
\hline DPL10449 & LRY5LLFY08002 & 10 L686 & $5-25-10$ \\
\hline & & & \\
\hline & & & \\
\hline & & & \\
\hline & & & \\
\hline & & & \\
\hline & & & \\
\hline
\end{tabular}

This certification is provided as a courtesy to the waste generator for information purposes only.

/s/ :Theresa Hale

WGS Signature

Waste Inspector

Title

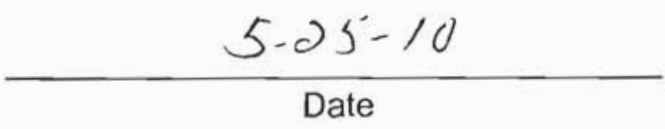

Date

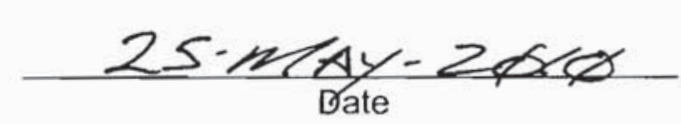

(Reference OP.2151 304) 
NSTec

Form

FRM-2217
CERTIFICATE OF DISPOSAL

(LOW LEVEL WASTE)
03/01/10

Rev. 01

Page 1 of 1

\section{Nevada Test Site}

This Certificate acknowledges that the following shipment(s) of waste have been disposed at the Nevada Test Site Radioactive Waste Management Complex.

\begin{tabular}{|l|l|l|l|}
\hline \multicolumn{1}{|c|}{$\begin{array}{c}\text { Whaste Stream } \\
\text { Identification \# }\end{array}$} & Package \# & Date of Disposal \\
\hline DPL10450 & LRY5LLFY08002 & 10L687 & $5-25-10$ \\
\hline DPL10450 & LRY5LLFY08002 & 10 L688 & $5-25-10$ \\
\hline & & & \\
\hline & & & \\
\hline & & & \\
\hline & & & \\
\hline & & & \\
\hline
\end{tabular}

This certification is provided as a courtesy to the waste generator for information purposes only.

$\frac{\text { /s/:Theresa Hale }}{\text { WGS Signature }}$

Waste inspector

\section{Title}

/s/:Jon Tanaka

RWMC Signature

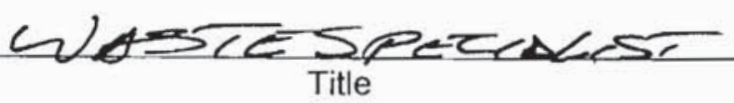

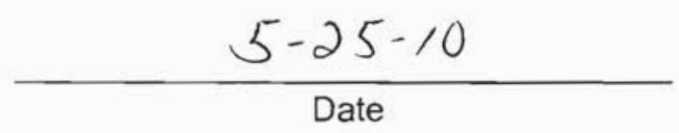

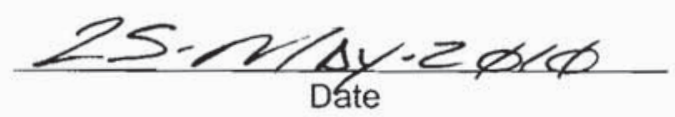


NSTec

Form

CERTIFICATE OF DISPOSAL

03/01/10

FRM-2217

(LOW LEVEL WASTE)

Rev. 01

Page 1 of 1

\section{Nevada Test Site}

This Certificate acknowledges that the following shipment(s) of waste have been disposed at the Nevada Test Site Radioactive Waste Management Complex.

\begin{tabular}{|c|c|c|c|}
\hline Shipment Number & $\begin{array}{l}\text { Waste Stream } \\
\text { Identification \# }\end{array}$ & Package \# & Date of Disposal \\
\hline DPL10451 & LRY5LLFY08002 & 10L689 & $5-25-10$ \\
\hline DPL10451 & LRY5LLFY08002 & $10 L 690$ & 5.25 .10 \\
\hline & & & \\
\hline & & & \\
\hline & & & \\
\hline & & & \\
\hline & & & \\
\hline & & & \\
\hline
\end{tabular}

This certification is provided as a courtesy to the waste generator for information purposes only.

/s/: Theresa Hale

$$
\text { WGS Signature }
$$

Waste inspector

$$
\text { Title }
$$

/s/:Jon Tanaka

Rvvmc signature

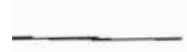

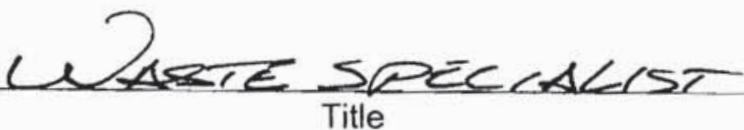

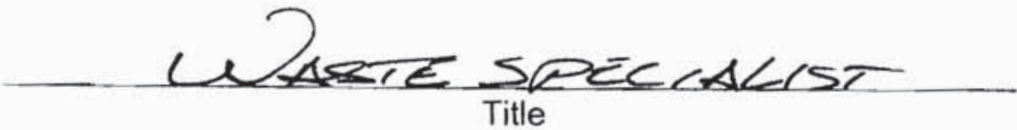

$5 \cdot 25 \cdot 10$

Date

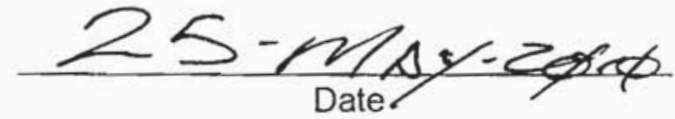




\begin{tabular}{|lcr|}
\hline NSTec & CERTIFICATE OF DISPOSAL & $03 / 01 / 10$ \\
Form & (LOW LEVEL WASTE) & Rev. 01 \\
FRM-2217 & Page 1 of 1 \\
\hline
\end{tabular}

Nevada Test Site

This Certificate acknowledges that the following shipments) of waste have been disposed at the Nevada Test Site Radioactive Waste Management Complex.

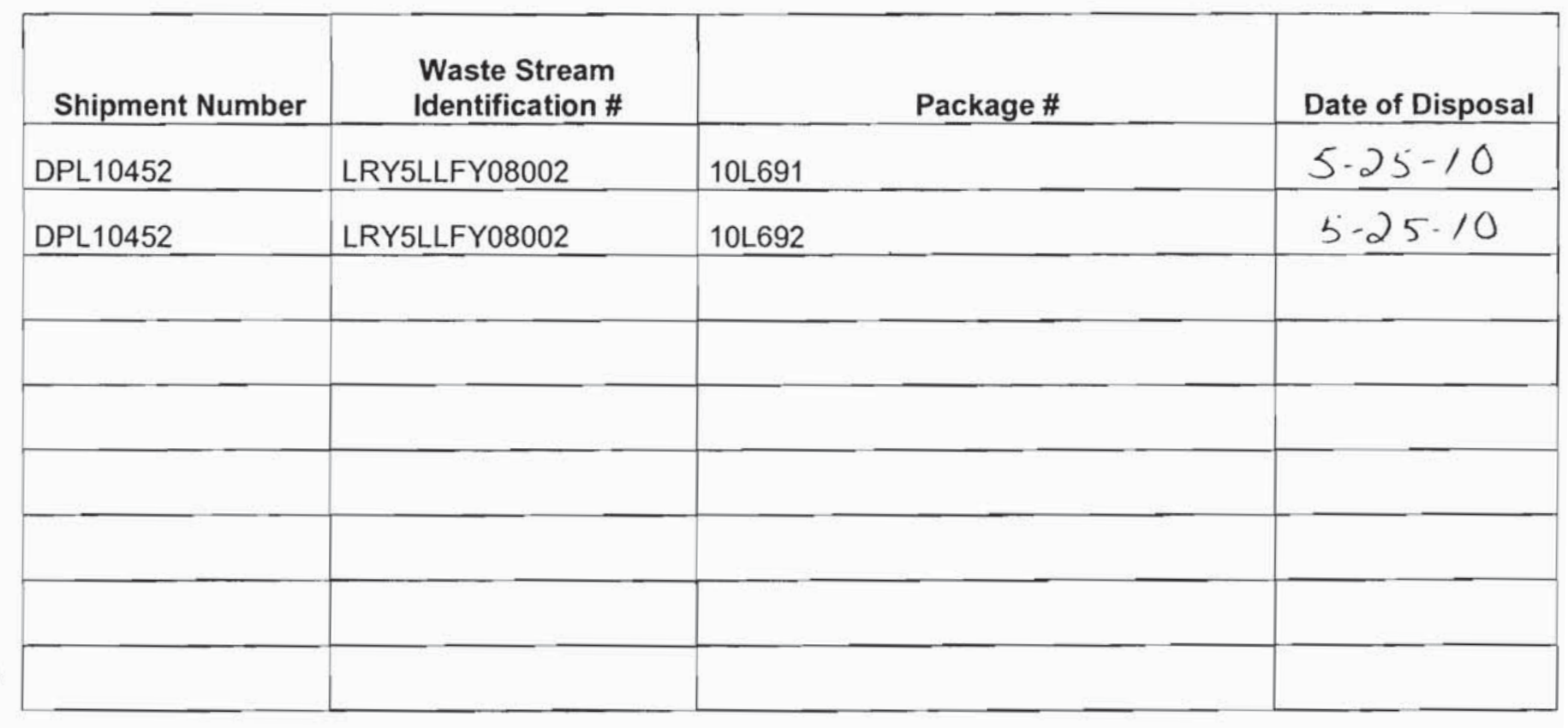

This certification is provided as a courtesy to the waste generator for information purposes only.

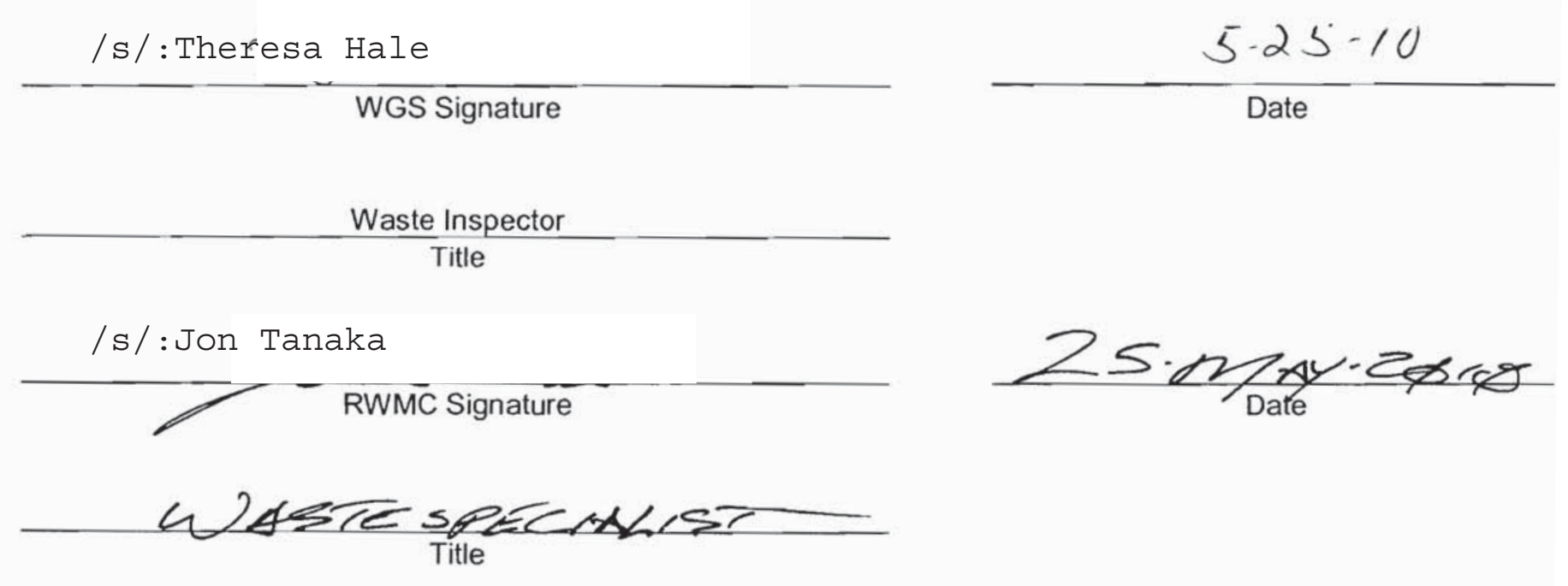


NSTec

Form

FRM-2217
CERTIFICATE OF DISPOSAL

(LOW LEVEL WASTE)
03/01/10

Rev. 01

Page 1 of 1

\section{Nevada Test Site}

This Certificate acknowledges that the following shipment(s) of waste have been disposed at the Nevada Test Site Radioactive Waste Management Complex.

\begin{tabular}{|l|l|l|c|}
\hline \multicolumn{1}{|c|}{$\begin{array}{c}\text { Shipment Number } \\
\text { DPL10453 }\end{array}$} & $\begin{array}{c}\text { Wentification \# } \\
\text { Identream }\end{array}$ & Package \# & Date of Disposal \\
\hline DPL10453 & LRYLLFY08002 & 10 L693 & $5-25-10$ \\
\hline & & 10 L694 & $5-25-10$ \\
\hline & & & \\
\hline & & & \\
\hline & & & \\
\hline
\end{tabular}

This certification is provided as a courtesy to the waste generator for information purposes only.

/s/:Theresa Hale

WGS Signature

Waste Inspector

Title

/s/: Jon Tanaka

RWMC Signafure

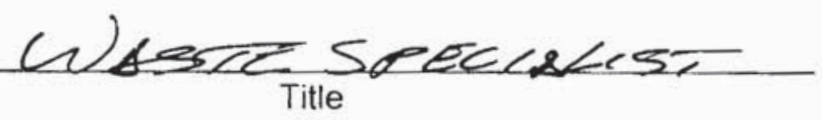

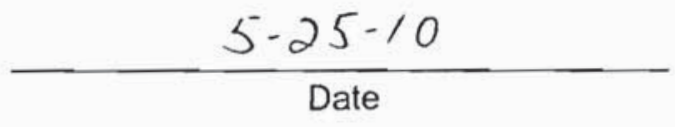

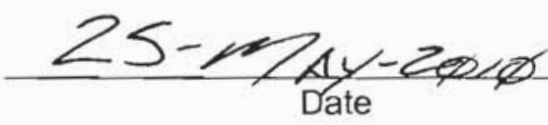


NSTec

Form

FRM-2217
CERTIFICATE OF DISPOSAL

(LOW LEVEL WASTE)
03/01/10

Rev. 01

Page 1 of 1

\section{Nevada Test Site}

This Certificate acknowledges that the following shipment(s) of waste have been disposed at the Nevada Test Site Radioactive Waste Management Complex.

\begin{tabular}{|l|l|l|l|}
\hline \multicolumn{1}{|c|}{$\begin{array}{c}\text { Whipment Number } \\
\text { Identification \# }\end{array}$} & \multicolumn{1}{c|}{ Package \# } & Date of Disposal \\
\hline DPL10454 & LRY5LLFY08002 & 10 L695 & $5 / 25 / 10$ \\
\hline DPL10454 & LRY5LLFY08002 & 10 6966 & $5 / 25 / 10$ \\
\hline & & & \\
\hline & & & \\
\hline & & & \\
\hline & & & \\
\hline
\end{tabular}

This certification is provided as a courtesy to the waste generator for information purposes only.

.1

/s/:Theresa Hale

WGS Signature

Waste Inspector

Title

/s/:Jon Tanaka

RWMC Signature

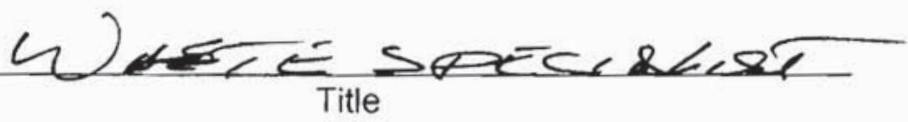

$5 / 25 / 10$

Date

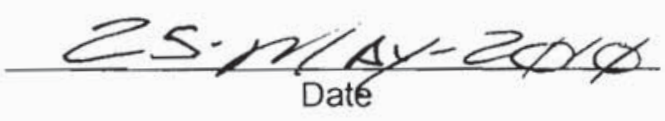


NSTec

Form

FRM-2217
CERTIFICATE OF DISPOSAL

(LOW LEVEL WASTE)
03/01/10

Rev. 01

Page 1 of 1

\section{Nevada Test Site}

This Certificate acknowledges that the following shipment(s) of waste have been disposed at the Nevada Test Site Radioactive Waste Management Complex.

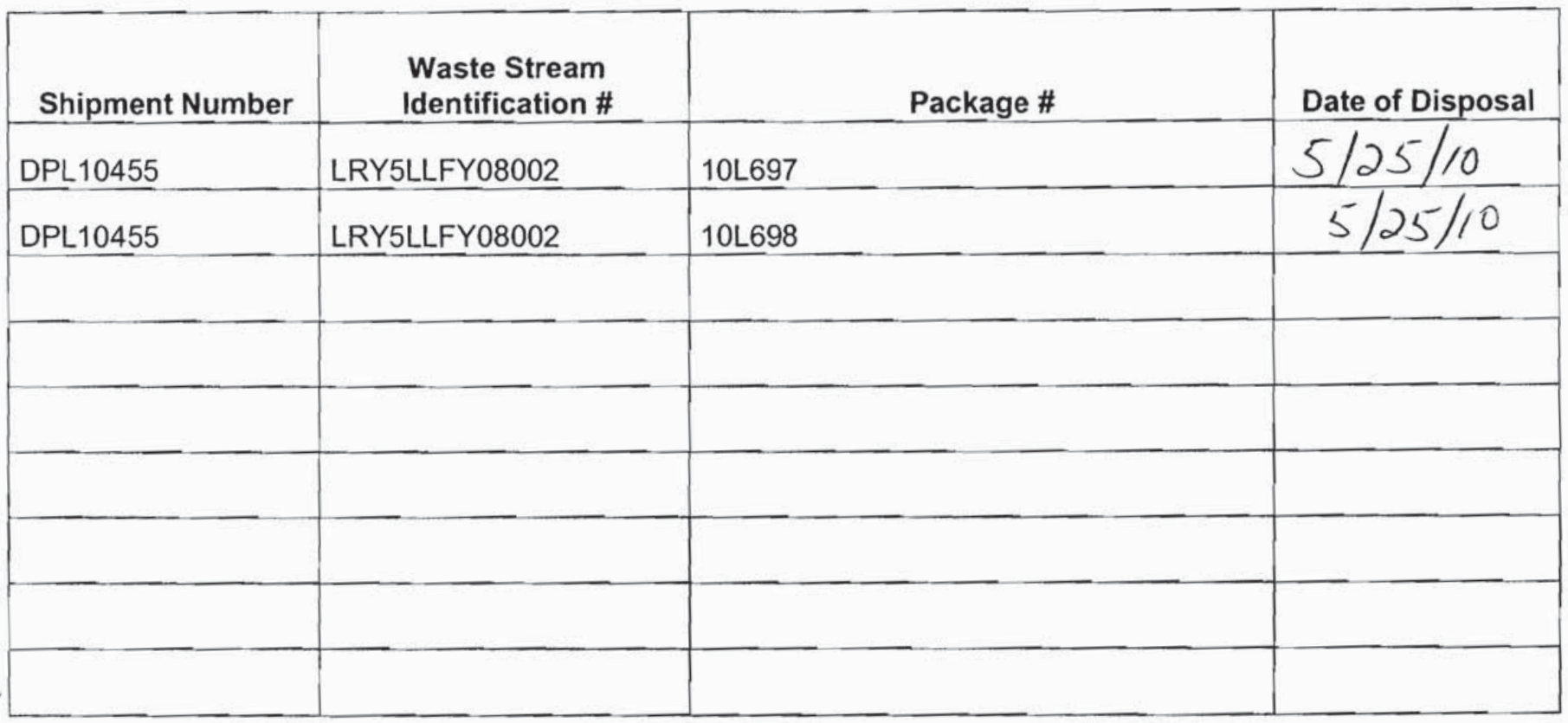

This certification is provided as a courtesy to the waste generator for information purposes only.

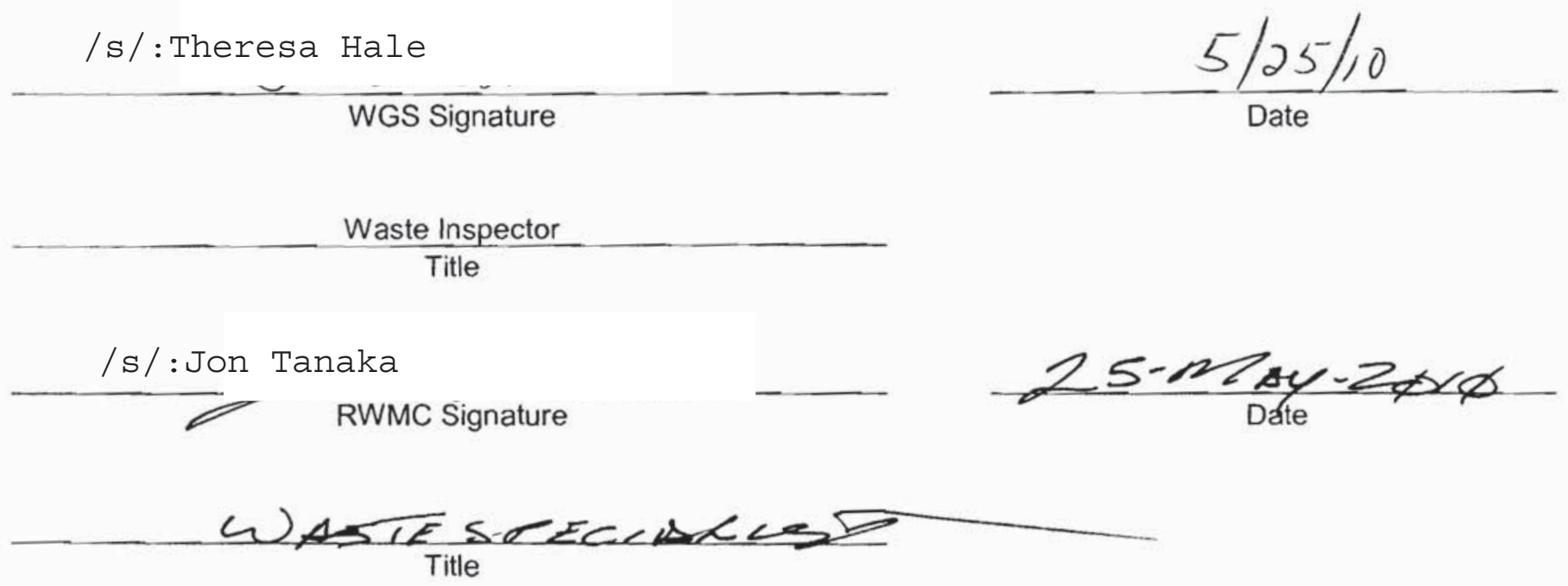




\begin{tabular}{|lcr|}
\hline NSTec & CERTIFICATE OF DISPOSAL & $03 / 01 / 10$ \\
Form & Rev. 01 \\
FRM-2217 & (LOW LEVEL WASTE) & Page 1 of 1 \\
\hline
\end{tabular}

Nevada Test Site

This Certificate acknowledges that the following shipments) of waste have been disposed at the Nevada Test Site Radioactive Waste Management Complex.

\begin{tabular}{|l|c|c|c|}
\hline Shipment Number & $\begin{array}{c}\text { Waste Stream } \\
\text { Identification \# } \\
\text { LRY5LLFY08002 }\end{array}$ & Package\# & Date of Disposal \\
\hline DPL10456 & LRY5LLFY08002 & 10 - 2009 & $5 \cdot 25-10$ \\
\hline DPL10456 & & & $5-25-10$ \\
\hline & & & \\
\hline & & & \\
\hline & & & \\
\hline & & & \\
\hline & & & \\
\hline
\end{tabular}

This certification is provided as a courtesy to the waste generator for information purposes only.

/s/ :Theresa Hale

WGS Signature

$\frac{5-25-10}{\text { Date }}$

Waste inspector

Title

/s/: Jon Tanka

RWMC Signature
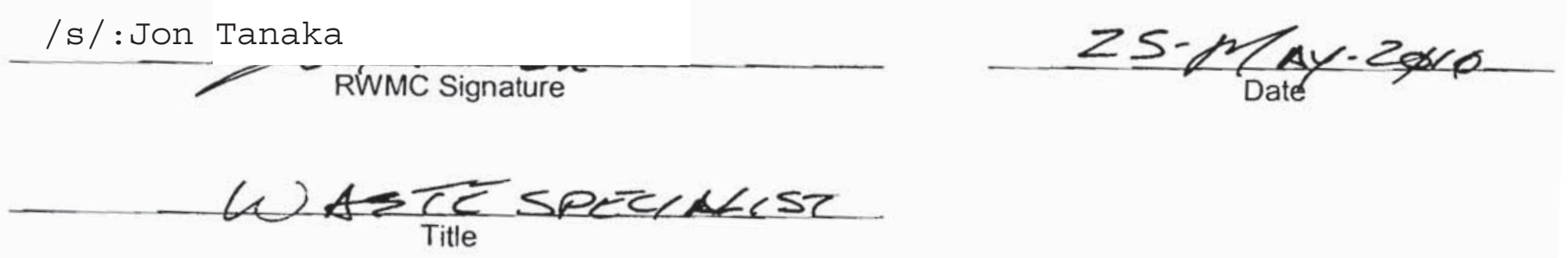
NSTec

Form

FRM-2217
CERTIFICATE OF DISPOSAL

(LOW LEVEL WASTE)
03/01/10

Rev. 01

Page 1 of 1

\section{Nevada Test Site}

This Certificate acknowledges that the following shipment(s) of waste have been disposed at the Nevada Test Site Radioactive Waste Management Complex.

\begin{tabular}{|l|l|l|l|}
\hline \multicolumn{1}{|c|}{ Shipment Number } & \multicolumn{1}{|c|}{$\begin{array}{c}\text { Waste Stream } \\
\text { Identification \# }\end{array}$} & Package \# & Date of Disposal \\
\hline DPL10457 & LRY5LLFY08002 & 10 L701 & $5 / 25 / 10$ \\
\hline DPL10457 & LRY5LLFY08002 & 10 L702 & $5 / 25 / 10$ \\
\hline & & & \\
\hline & & & \\
\hline & & & \\
\hline & & & \\
\hline & & & \\
\hline & & & \\
\hline
\end{tabular}

This certification is provided as a courtesy to the waste generator for information purposes only.

/s/:Theresa Hale

WGS Signature

Waste Inspector

Title

/s/:Jon Tanaka

RWMC Signature

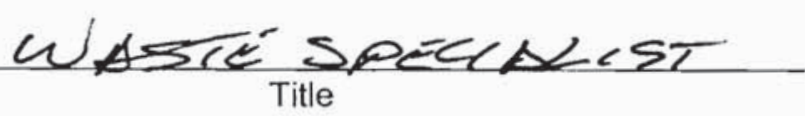

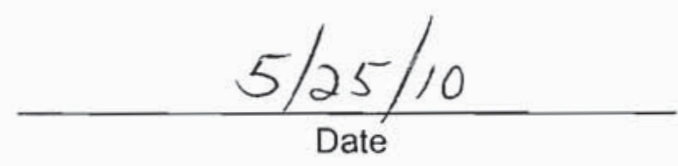

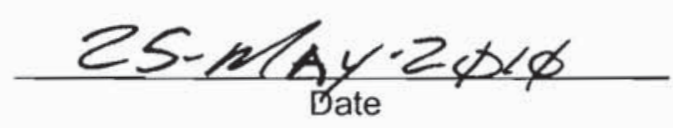




\section{Nevada Test Site}

This Certificate acknowledges that the following shipment(s) of waste have been disposed at the Nevada Test Site Radioactive Waste Management Complex.

\begin{tabular}{|c|c|c|c|}
\hline Shipment Number & $\begin{array}{l}\text { Waste Stream } \\
\text { Identification \# }\end{array}$ & Package \# & Date of Disposal \\
\hline DPL10458 & LRY5LLFY08002 & $10 L 703$ & \\
\hline DPL10458 & LRY5LLFY08002 & 10L704 & $5 / 25 / 10$ \\
\hline & & & \\
\hline & & & \\
\hline & & & \\
\hline & & & \\
\hline & & & \\
\hline & & & \\
\hline
\end{tabular}

This certification is provided as a courtesy to the waste generator for information purposes only.

/s/:Theresa Hale

WGS Signature

Waste Inspector

Title

/s/:Jon Tanaka

RWMC Signature -

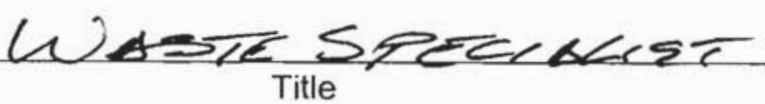

$5 / 25 / 10$

Date

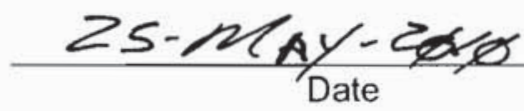




\section{Nevada Test Site}

This Certificate acknowledges that the following shipment(s) of waste have been disposed at the Nevada Test Site Radioactive Waste Management Complex.

\begin{tabular}{|l|l|l|l|}
\hline Shipment Number & $\begin{array}{c}\text { Waste Stream } \\
\text { Identification \# }\end{array}$ & \multicolumn{1}{|c|}{ Package \# } & Date of Disposal \\
\hline DPL10095 & LRY5LLFY08002 & 10 161 & $5-26-10$ \\
\hline & & & \\
\hline & & & \\
\hline & & & \\
\hline & & & \\
\hline & & & \\
\hline & & & \\
\hline & & & \\
\hline
\end{tabular}

This certification is provided as a courtesy to the waste generator for information purposes only.

/s/:Theresa Hale

WGS Signature

Waste Inspector

Title

/s/:Jon Tanaka

RWMC Signature

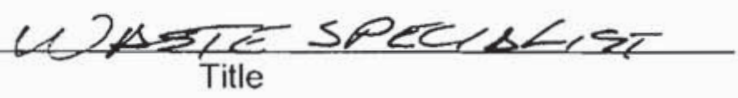

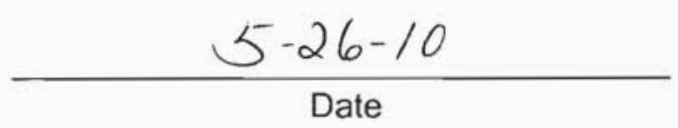

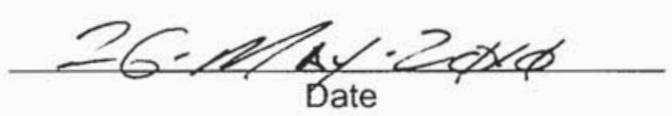


NSTec

Form

CERTIFICATE OF DISPOSAL

03/01/10

FRM-2217

(LOW LEVEL WASTE)

Rev. 01

Page 1 of 1

\section{Nevada Test Site}

This Certificate acknowledges that the following shipment(s) of waste have been disposed at the Nevada Test Site Radioactive Waste Management Complex.

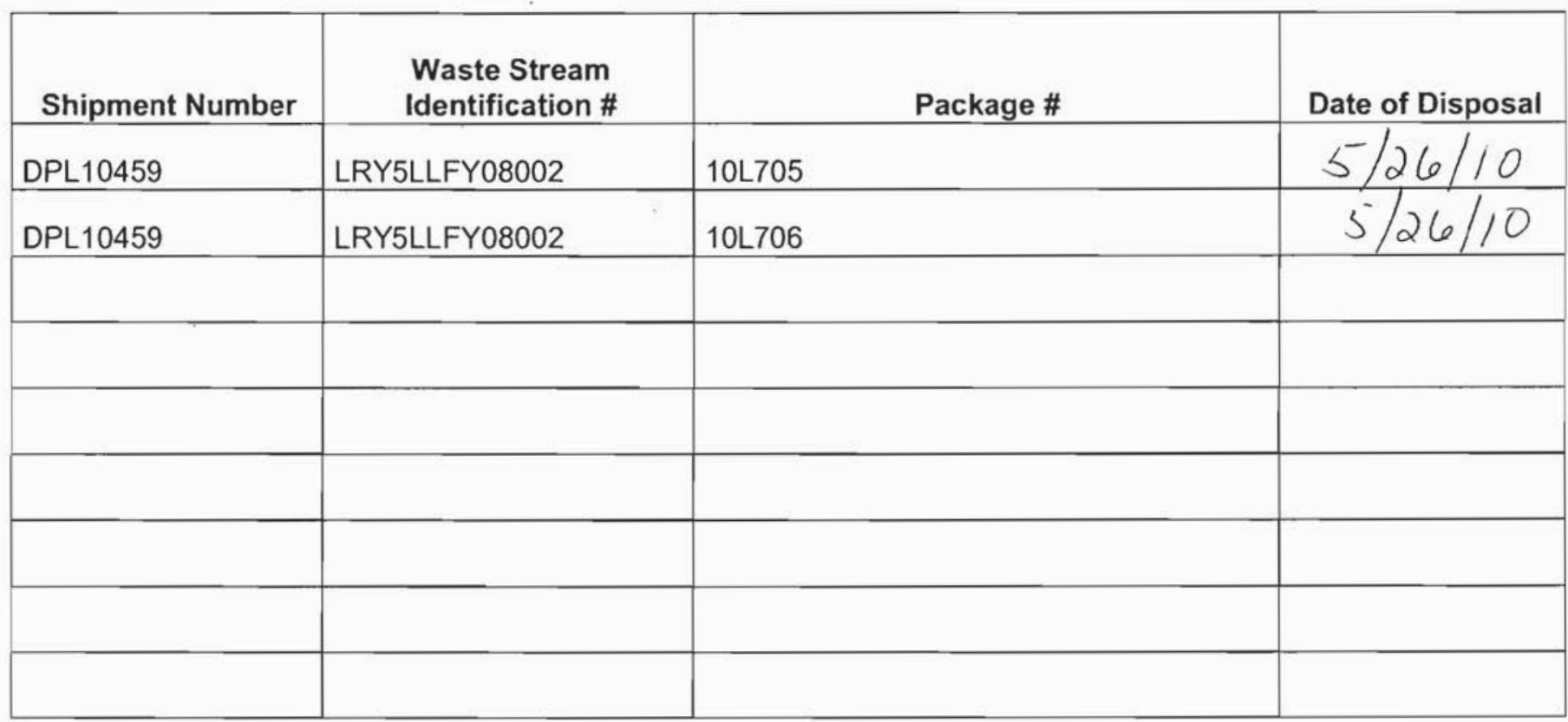

This certification is provided as a courtesy to the waste generator for information purposes only.

/s/:Theresa Hale

WGS Signature

Waste Inspector

Title

/s/:Jon Tanaka

RWMC Signature

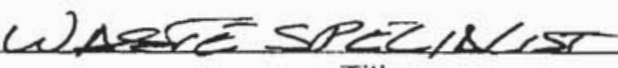

$$
\frac{5-26-10}{\text { Date }}
$$

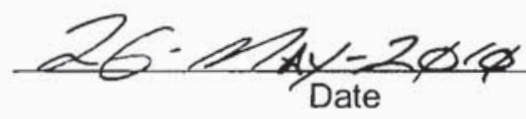


NSTec

Form

FRM-2217
CERTIFICATE OF DISPOSAL

(LOW LEVEL WASTE)
$03 / 01 / 10$

Rev. 01

Page 1 of 1

\section{Nevada Test Site}

This Certificate acknowledges that the following shipment(s) of waste have been disposed at the Nevada Test Site Radioactive Waste Management Complex.

\begin{tabular}{|l|l|l|c|}
\hline Shipment Number & \multicolumn{1}{|c|}{$\begin{array}{c}\text { Waste Stream } \\
\text { Identification \# }\end{array}$} & Package \# & Date of Disposal \\
\hline DPL10460 & LRY5LLFY08002 & 10 L707 & $5 / 26 / / 0$ \\
\hline DPL10460 & LRY5LLFY08002 & 10 L708 & $5 / 26 / 10$ \\
\hline & & & \\
\hline & & & \\
\hline & & & \\
\hline & & & \\
\hline & & & \\
\hline
\end{tabular}

This certification is provided as a courtesy to the waste generator for information purposes only.

/s/:Theresa Hale

WGS Signature

Waste Inspector

Title

/s/:Jon Tanaka

RWMC Signature

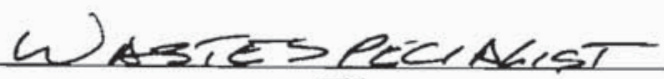

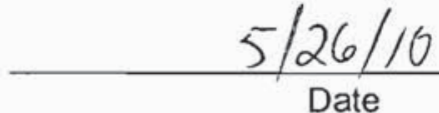

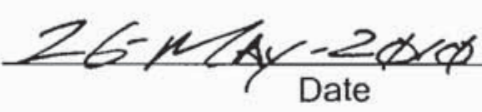




\begin{tabular}{|lcr|}
\hline NSTec & CERTIFICATE OF DISPOSAL & 03/01/10 \\
Form & Rev. 01 \\
FRM-2217 & (LOW LEVEL WASTE) & Page 1 of 1 \\
\hline
\end{tabular}

Nevada Test Site

This Certificate acknowledges that the following shipments) of waste have been disposed at the Nevada Test Site Radioactive Waste Management Complex.

\begin{tabular}{|l|l|l|c|}
\hline Shipment Number & \multicolumn{1}{|c|}{$\begin{array}{c}\text { Waste Stream } \\
\text { Identification \# }\end{array}$} & Package \# & Date of Disposal \\
\hline DPL10461 & LRY5LLFY08002 & 10 L709 & $5 / 26 / 10$ \\
\hline DPL10461 & LRY5LLFY08002 & 10 L710 & $5 / 26 / 10$ \\
\hline & & & \\
\hline & & & \\
\hline & & & \\
\hline & & & \\
\hline & & & \\
\hline & & & \\
\hline
\end{tabular}

This certification is provided as a courtesy to the waste generator for information purposes only.
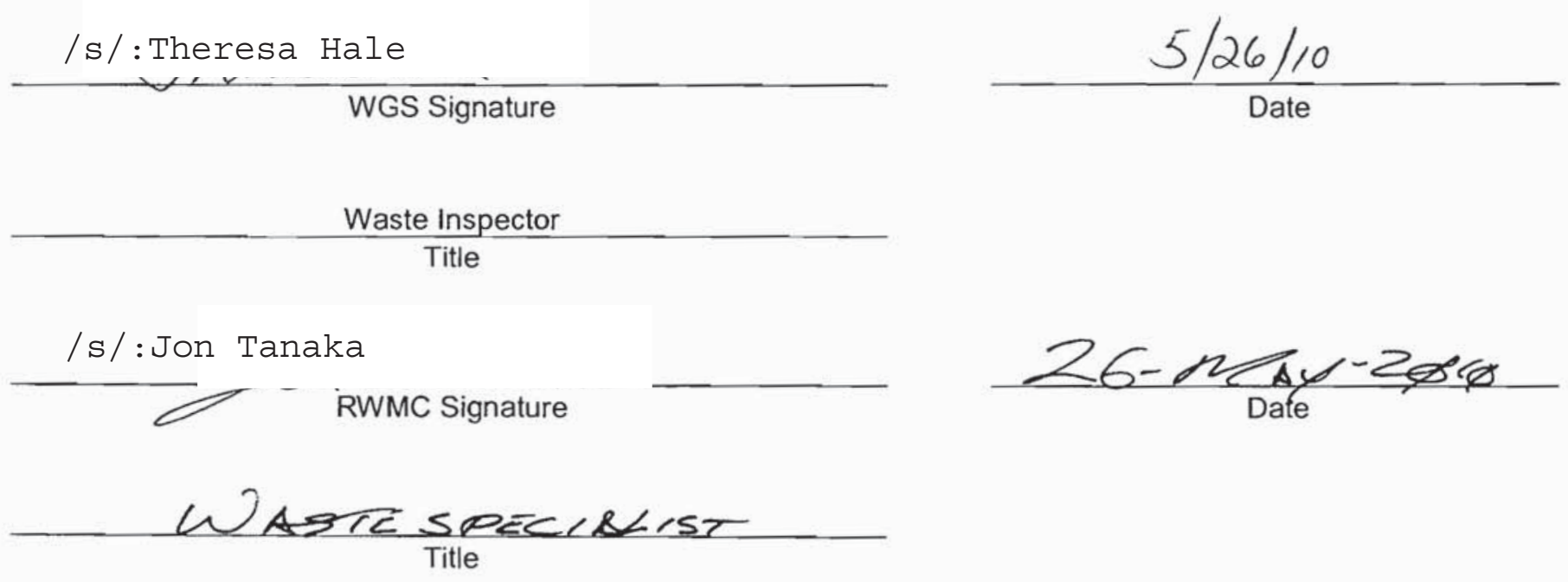
NSTec

Form

FRM-2217
CERTIFICATE OF DISPOSAL

(LOW LEVEL WASTE)
$03 / 01 / 10$

Rev. 01

Page 1 of 1

\section{Nevada Test Site}

This Certificate acknowledges that the following shipment(s) of waste have been disposed at the Nevada Test Site Radioactive Waste Management Complex.

\begin{tabular}{|l|l|l|l|}
\hline \multicolumn{1}{|c|}{$\begin{array}{c}\text { Waste Stream } \\
\text { Identification \# }\end{array}$} & \multicolumn{1}{c|}{ Package \# } & Date of Disposal \\
\hline DPL10462 & LRY5LLFY08002 & 10 L711 & $5 / 26 / / 0$ \\
\hline DPL10462 & LRY5LLFY08002 & 10 L712 & $5 / 26 / / 0$ \\
\hline & & & \\
\hline & & & \\
\hline & & & \\
\hline & & & \\
\hline & & & \\
\hline
\end{tabular}

This certification is provided as a courtesy to the waste generator for information purposes only.

$$
\text { /s/:Theresa Hale }
$$

$$
\text { WGS Signature }
$$

Waste inspector

$$
\text { Title }
$$

\section{/s/:Jon Tanaka}

RWMC Signature

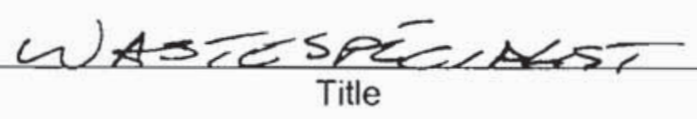

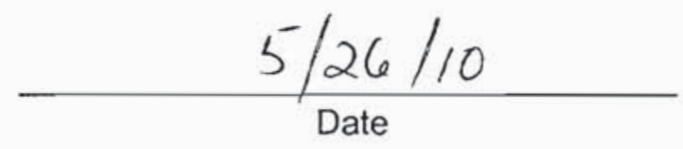

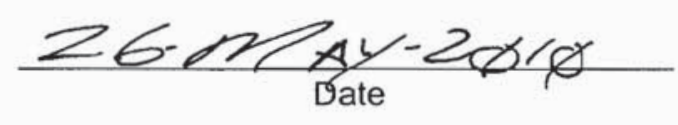




\begin{tabular}{|lcr|}
\hline NSTec & CERTIFICATE OF DISPOSAL & 03/01/10 \\
Form & Rev. 01 \\
FRM-2217 & (LOW LEVEL WASTE) & Page 1 of 1 \\
\hline
\end{tabular}

Nevada Test Site

This Certificate acknowledges that the following shipments) of waste have been disposed at the Nevada Test Site Radioactive Waste Management Complex.

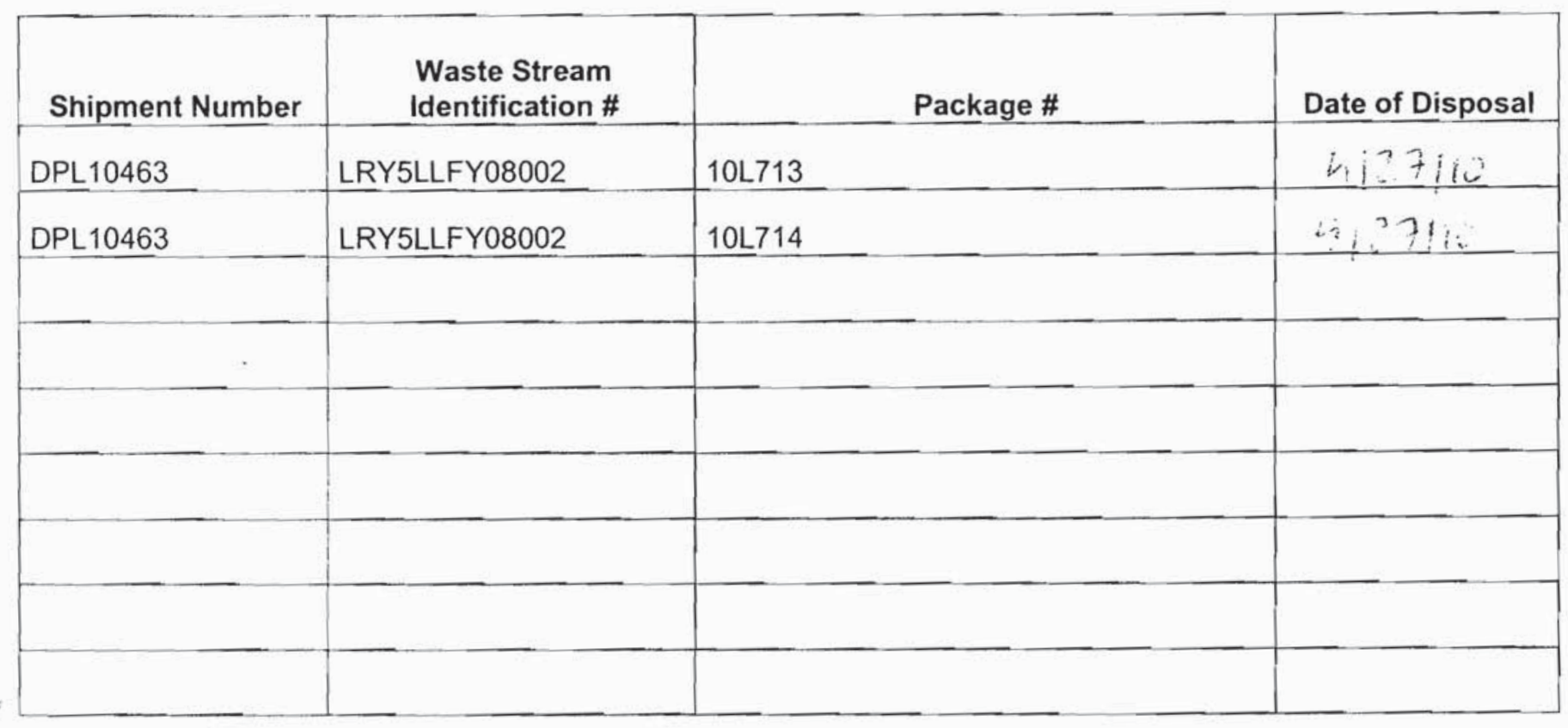

This certification is provided as a courtesy to the waste generator for information purposes only.

WGS Signature

Waste Inspector

Title
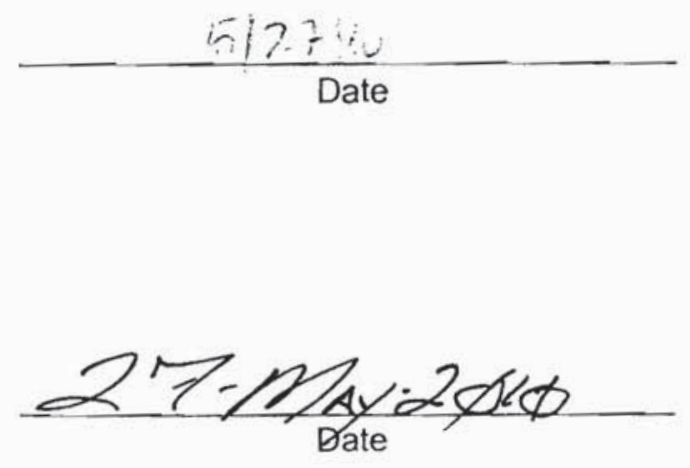

WUSTESPECIANIS 
NSTec

Form

CERTIFICATE OF DISPOSAL

$03 / 01 / 10$

FRM-2217

(LOW LEVEL WASTE)

Rev. 01

Page 1 of 1

\section{Nevada Test Site}

This Certificate acknowledges that the following shipment(s) of waste have been disposed at the Nevada Test Site Radioactive Waste Management Complex.

\begin{tabular}{|l|l|l|l|}
\hline \multicolumn{1}{|c|}{$\begin{array}{c}\text { Whipment Number } \\
\text { Identification \# }\end{array}$} & \multicolumn{1}{|c|}{ Package \# } & Date of Disposal \\
\hline DPL10464 & LRY5LLFY08002 & 10 L715 & $5 / 27 / 10$ \\
\hline DPL10464 & LRY5LLFY08002 & 10 L716 & $5 / 27 / 10$ \\
\hline & & & \\
\hline & & & \\
\hline & & & \\
\hline & & & \\
\hline & & & \\
\hline
\end{tabular}

This certification is provided as a courtesy to the waste generator for information purposes only.

WGS Signature

$5 \mid 2,71 i_{2}$

WGS Signature
Waste Inspector
Title

/s/:Jon Tanaka
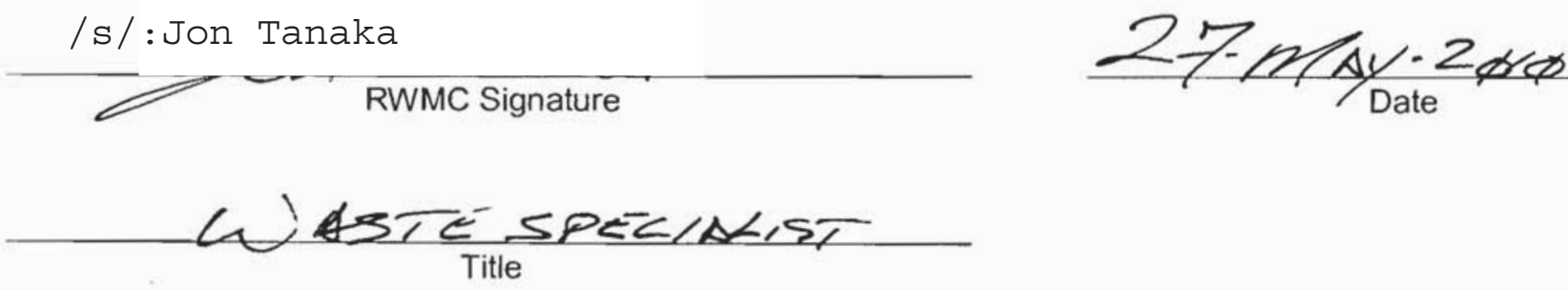
NSTec

Form

CERTIFICATE OF DISPOSAL

$03 / 01 / 10$

FRM-2217

(LOW LEVEL WASTE)

Rev. 01

Page 1 of 1

\section{Nevada Test Site}

This Certificate acknowledges that the following shipment(s) of waste have been disposed at the Nevada Test Site Radioactive Waste Management Complex.

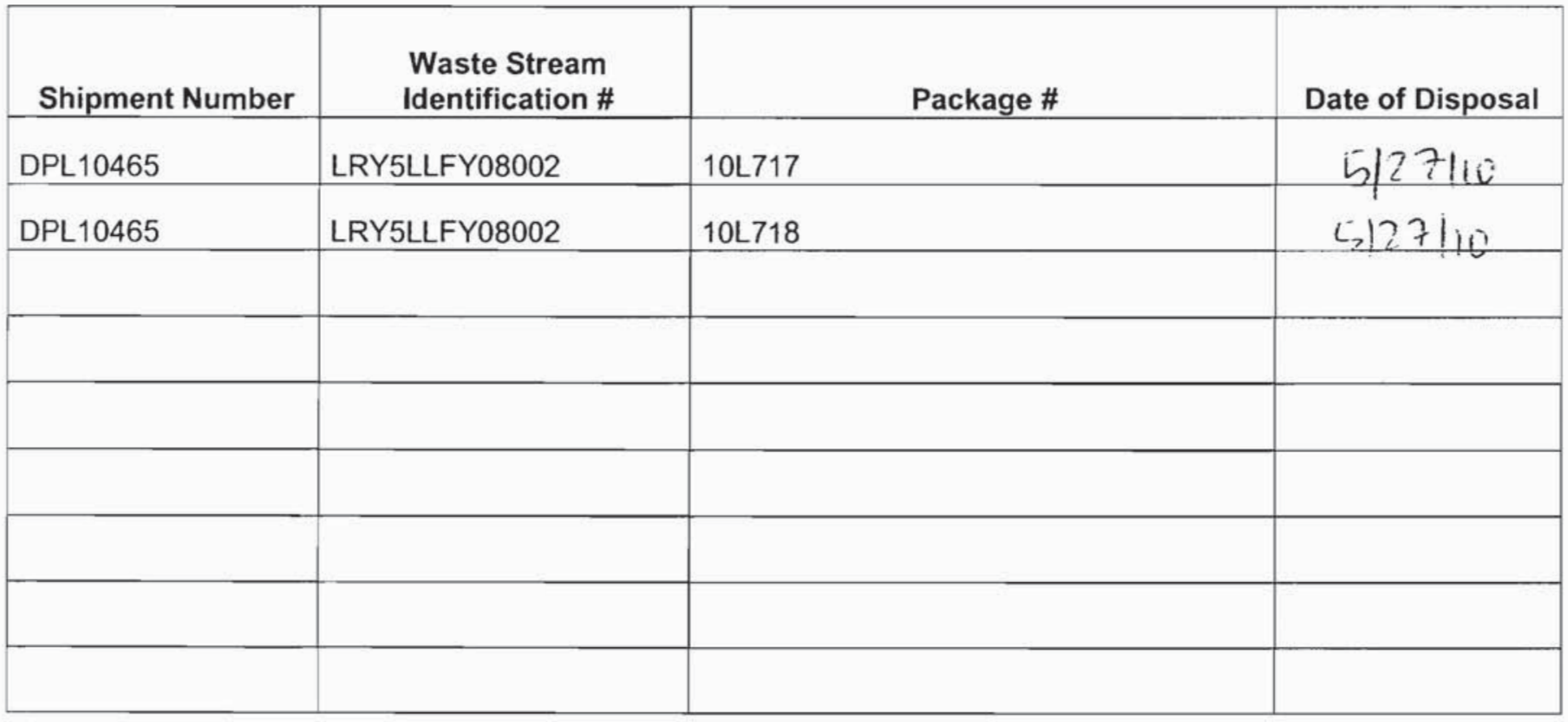

This certification is provided as a courtesy to the waste generator for information purposes only.

\section{WGS Signature}

\section{5,127110}

Date

\section{Waste Inspector}

\section{Title}

/s/:Jon Tanaka

RWMC Signature
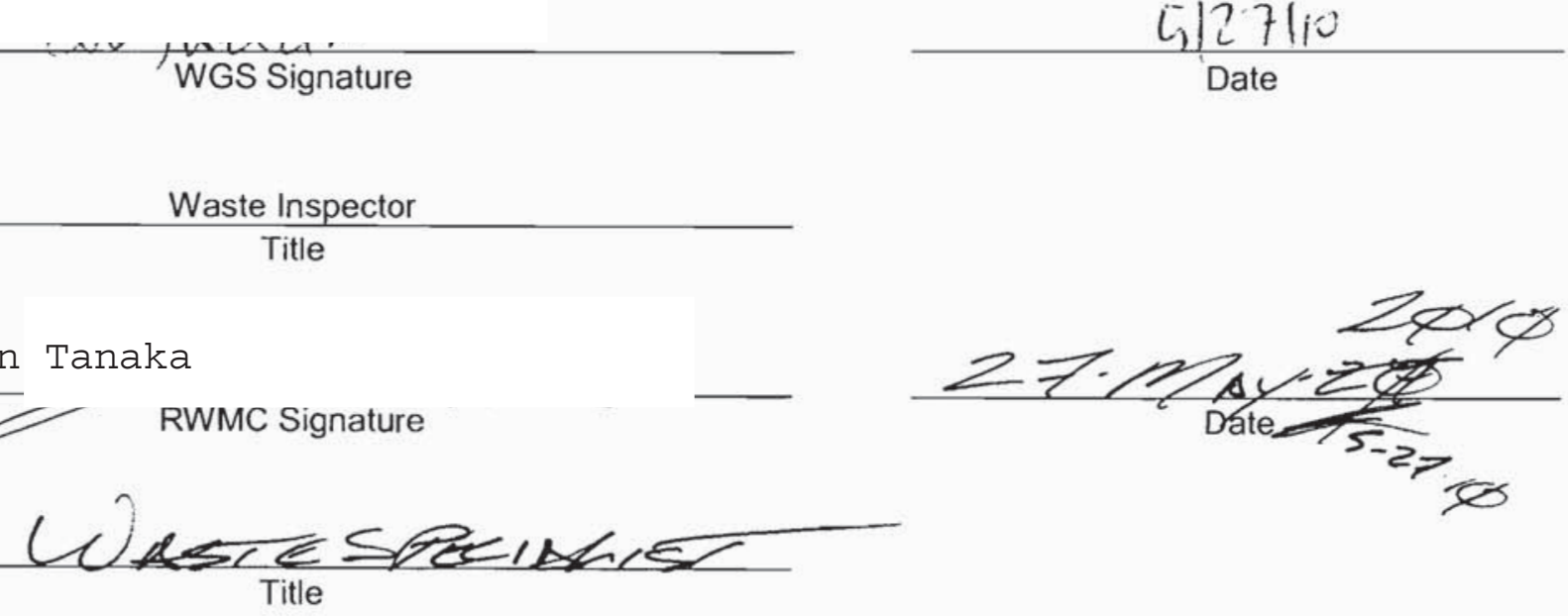


\begin{tabular}{|lcr|}
\hline NSTec & CERTIFICATE OF DISPOSAL & $03 / 01 / 10$ \\
Form & Rev. 01 \\
FRM-2217 & (LOW LEVEL WASTE) & Page 1 of 1 \\
\hline
\end{tabular}

Nevada Test Site

This Certificate acknowledges that the following shipments) of waste have been disposed at the Nevada Test Site Radioactive Waste Management Complex.

\begin{tabular}{|l|l|l|c|}
\hline \multicolumn{1}{|c|}{ Shipment Number } & \multicolumn{1}{c|}{$\begin{array}{c}\text { Waste Stream } \\
\text { Identification \# }\end{array}$} & Package \# & Date of Disposal \\
\hline DPL10466 & LRY5LLFY08002 & $10 \mathrm{~L} 719$ & $5-27.10$ \\
\hline DPL10466 & LRY5LLFY08002 & 10 L 720 & $5-27 \cdot 10$ \\
\hline & & & \\
\hline & & & \\
\hline & & & \\
\hline & & & \\
\hline & & & \\
\hline
\end{tabular}

This certification is provided as a courtesy to the waste generator for information purposes only.

/s/ :Theresa Hale

WGS Signature

Waste Inspector

Title

/s/: Jon Kanaka

RWMC Signature
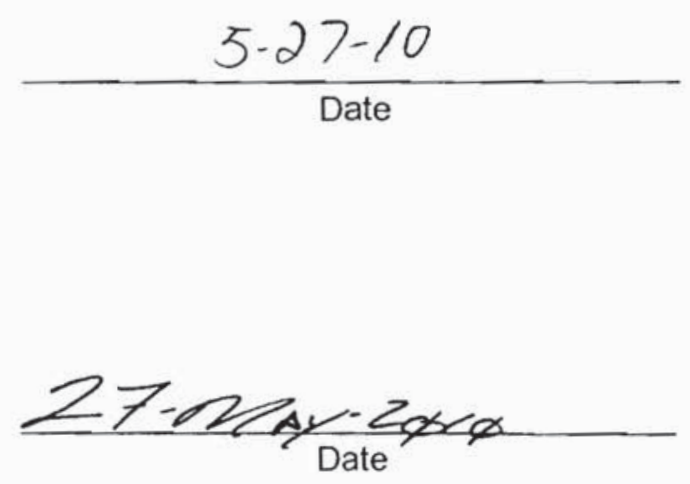

(Reference: OP-2151.304) 
NSTec

Form

FRM-2217
CERTIFICATE OF DISPOSAL

(LOW LEVEL WASTE)
03/01/10

Rev. 01

Page 1 of 1

\section{Nevada Test Site}

This Certificate acknowledges that the following shipment(s) of waste have been disposed at the Nevada Test Site Radioactive Waste Management Complex.

\begin{tabular}{|l|l|l|l|}
\hline Shipment Number & $\begin{array}{c}\text { Waste Stream } \\
\text { Identification \# }\end{array}$ & Package \# & Date of Disposal \\
\hline DPL10096 & LRY5LLF08002 & 10L162 & 6 - / / \\
\hline & & & \\
\hline & & & \\
\hline & & & \\
\hline & & & \\
\hline & & & \\
\hline
\end{tabular}

This certification is provided as a courtesy to the waste generator for information purposes only.

/s/:Theresa Hale

WGS Signature

Waste Inspector

Title

/s/: Jon Tanaka

RWMC Signature

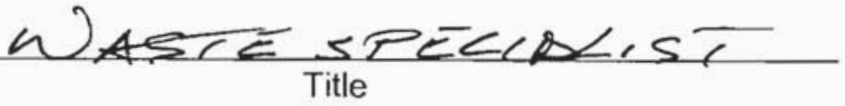

$\frac{6-1-10}{\text { Date }}$

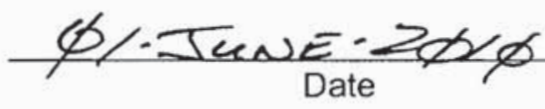


NSTec

CERTIFICATE OF DISPOSAL

03/01/10

Form

(LOW LEVEL WASTE)

Rev. 01

FRM-2217

Page 1 of 1

\section{Nevada Test Site}

This Certificate acknowledges that the following shipment(s) of waste have been disposed at the Nevada Test Site Radioactive Waste Management Complex.

\begin{tabular}{|l|l|l|l|}
\hline Shipment Number & \multicolumn{1}{|c|}{$\begin{array}{c}\text { Waste Stream } \\
\text { Identification \# }\end{array}$} & Package \# & Date of Disposal \\
\hline DPL10467 & LRY5LLFY08002 & 10 L721 & $6-1-10$ \\
\hline DPL10467 & LRY5LLFY08002 & 10 L722 & $6-1-10$ \\
\hline & & & \\
\hline & & & \\
\hline & & & \\
\hline & & & \\
\hline
\end{tabular}

This certification is provided as a courtesy to the waste generator for information purposes only.

/s/:Theresa Hale

WGS Signature

Waste Inspector

Title

\section{/s/:Jon Tanaka}

RWMC Signature

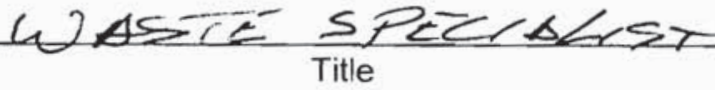

$$
\frac{6-1-10}{\text { Date }}
$$

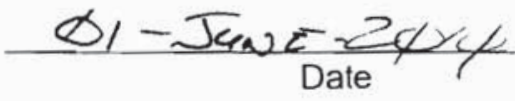


NSTec

Form

CERTIFICATE OF DISPOSAL

03/01/10

FRM-2217

(LOW LEVEL WASTE)

Rev. 01

Page 1 of 1

\section{Nevada Test Site}

This Certificate acknowledges that the following shipment(s) of waste have been disposed at the Nevada Test Site Radioactive Waste Management Complex.

\begin{tabular}{|c|c|c|c|}
\hline Shipment Number & $\begin{array}{l}\text { Waste Stream } \\
\text { Identification \# }\end{array}$ & Package \# & Date of Disposal \\
\hline DPL10468 & LRY5LLFY08002 & $10 L 723$ & $6-1-10$ \\
\hline DPL10468 & LRY5LLFY08002 & $10 \mathrm{~L} 724$ & $6-1-10$ \\
\hline & & & \\
\hline & & & \\
\hline & & & \\
\hline & & & \\
\hline & & & \\
\hline & & 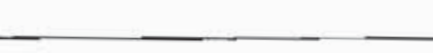 & 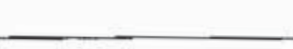 \\
\hline
\end{tabular}

This certification is provided as a courtesy to the waste generator for information purposes only.

/s/:Theresa Hale

WGS Signature

Waste Inspector

Title

/s/:Jon Tanaka

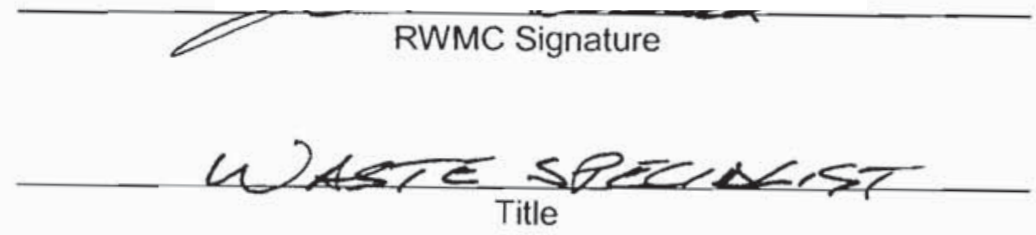

$\frac{6-1-10}{\text { Date }}$

Dritrane Drpos $_{\text {Date }}$ 


\begin{tabular}{|lcr|}
\hline NSTec & CERTIFICATE OF DISPOSAL & $03 / 01 / 10$ \\
Form & Rev. 01 \\
FRM-2217 & (LOW LEVEL. WASTE) & Page 1 of 1 \\
\hline
\end{tabular}

Nevada Test Site

This Certificate acknowledges that the following shipments) of waste have been disposed at the Nevada Test Site Radioactive Waste Management Complex.

\begin{tabular}{|l|l|l|l|}
\hline Shipment Number & \multicolumn{1}{|c|}{$\begin{array}{c}\text { Waste Stream } \\
\text { Identification \# }\end{array}$} & Package \# & Date of Disposal \\
\hline DPL10469 & LRY5LLFY08002 & $10 L 725$ & $6-1-10$ \\
\hline DPL10469 & LRY5LLFY08002 & 10 L 726 & $6-1-10$ \\
\hline & & & \\
\hline & & & \\
\hline & & & \\
\hline & & & \\
\hline & & & \\
\hline
\end{tabular}

This certification is provided as a courtesy to the waste generator for information purposes only.

/s/ :Theresa Hale

WGS Signature

Waste Inspector

Title
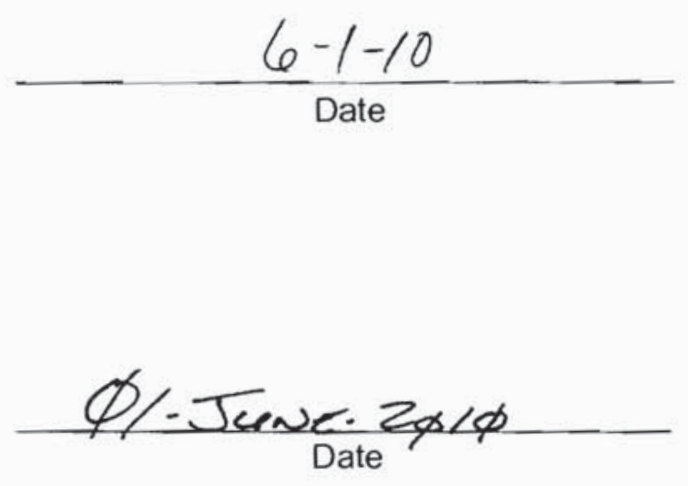
NSTec

Form

CERTIFICATE OF DISPOSAL

03/01/10

FRM-2217

(LOW LEVEL WASTE)

Rev. 01

Page 1 of 1

\section{Nevada Test Site}

This Certificate acknowledges that the following shipment(s) of waste have been disposed at the Nevada Test Site Radioactive Waste Management Complex.

\begin{tabular}{|l|l|l|l|l|}
\hline Shipment Number & $\begin{array}{c}\text { Waste Stream } \\
\text { Identification \# }\end{array}$ & Package \# & Date of Disposal \\
\hline DPL10470 & LRY5LLFY08002 & $10 L 727$ & $6-1-10$ \\
\hline DPL10470 & LRY5LLFY08002 & $10 L 728$ & $6-1-10$ \\
\hline & & & & \\
\hline
\end{tabular}

This certification is provided as a courtesy to the waste generator for information purposes only.

/s/:Theresa Hale

WGS Signature

Waste inspector

Title

/s/:Jon Tanaka

RWMC Signature

WASTESREC $\triangle 15 T$

Title $-\frac{6-1-10}{\text { Date }}$

$\phi /-J_{\cos }=\sum_{\text {Date }}$ 


\begin{tabular}{|lcr|}
\hline NSTec & CERTIFICATE OF DISPOSAL & $03 / 01 / 10$ \\
Form & (LOW LEVEL WASTE) & 01 \\
FRM-2217 & R eve 1 of 1 \\
\hline
\end{tabular}

Nevada Test Site

This Certificate acknowledges that the following shipments) of waste have been disposed at the Nevada Test Site Radioactive Waste Management Complex.

\begin{tabular}{|l|l|l|l|}
\hline Shipment Number & \multicolumn{1}{|c|}{$\begin{array}{c}\text { Waste Stream } \\
\text { Identification \# }\end{array}$} & Package \# & Date of Disposal \\
\hline DPL10471 & LRY5LLFY08002 & 10 L729 & $6-1-10$ \\
\hline DPL10471 & LRY5LLFY08002 & 10 L730 & $6-1-10$ \\
\hline & & & \\
\hline & & & \\
\hline & & & \\
\hline & & & \\
\hline & & & \\
\hline & & & \\
\hline
\end{tabular}

This certification is provided as a courtesy to the waste generator for information purposes only.

/s/ :Theresa Hale

WGS Signature

Waste Inspector

Title

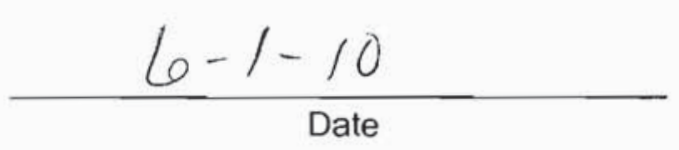

/s/: Jon Tanka

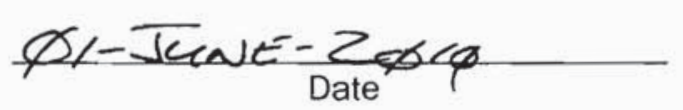

(Reference: OP -2151.304) 
NSTec

Form

CERTIFICATE OF DISPOSAL

03/01/10

FRM-2217

(LOW LEVEL WASTE)

Rev. 01

Page 1 of 1

\section{Nevada Test Site}

This Certificate acknowledges that the following shipment(s) of waste have been disposed at the Nevada Test Site Radioactive Waste Management Complex.

\begin{tabular}{|l|l|l|l|}
\hline \multicolumn{1}{|c|}{ Shipment Number } & \multicolumn{1}{|c|}{$\begin{array}{c}\text { Waste Stream } \\
\text { Identification \# }\end{array}$} & Package \# & Date of Disposal \\
\hline DPL10472 & LRY5LLFY08002 & 10 L731 & $6-1-10$ \\
\hline DPL10472 & LRY5LLFY08002 & 10 L732 & $6-1-10$ \\
\hline & & & \\
\hline & & & \\
\hline & & & \\
\hline & & & \\
\hline & & & \\
\hline
\end{tabular}

This certification is provided as a courtesy to the waste generator for information purposes only.

/s/: Theresa Hale

WGS Signature

Waste Inspector

Title

/s/:Jon Tanaka

UWMC Signature $\frac{6-1-10}{\text { Date }}$

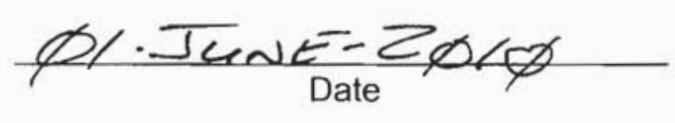


NSTec

Form

FRM-2217
CERTIFICATE OF DISPOSAL

(LOW LEVEL WASTE)
03/01/10

Rev. 01

Page 1 of 1

\section{Nevada Test Site}

This Certificate acknowledges that the following shipment(s) of waste have been disposed at the Nevada Test Site Radioactive Waste Management Complex.

\begin{tabular}{|l|l|l|l|}
\hline \multicolumn{1}{|c|}{ Shipment Number } & \multicolumn{1}{c|}{$\begin{array}{c}\text { Waste Stream } \\
\text { Identification \# }\end{array}$} & Package \# & Date of Disposal \\
\hline DPL10473 & LRY5LLFY08002 & 10 L733 & $6-/-/ 0$ \\
\hline DPL10473 & LRY5LLFY08002 & 10 L734 & $6-/-/ 0$ \\
\hline & & & \\
\hline & & & \\
\hline & & & \\
\hline & & & \\
\hline & & & \\
\hline
\end{tabular}

This certification is provided as a courtesy to the waste generator for information purposes only.

/s/: Theresa Hale

WGS Signature

Waste Inspector

Title

/s/:Jon Tanaka

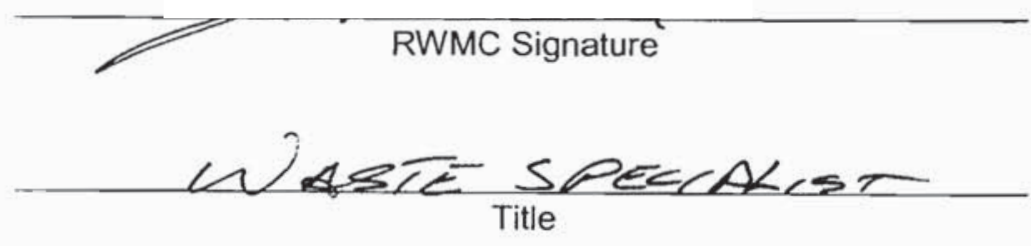

$\frac{6-1-10}{\text { Date }}$

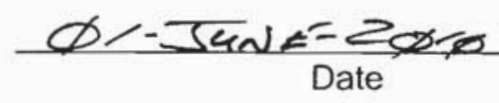


NSTec

Form

FRM-2217
CERTIFICATE OF DISPOSAL

(LOW LEVEL WASTE)
03/01/10

Rev. 01

Page 1 of 1

\section{Nevada Test Site}

This Certificate acknowledges that the following shipment(s) of waste have been disposed at the Nevada Test Site Radioactive Waste Management Complex.

\begin{tabular}{|l|l|l|l|}
\hline \multicolumn{1}{|c|}{$\begin{array}{c}\text { Whaste Stream } \\
\text { Identification \# }\end{array}$} & Package \# & Date of Disposal \\
\hline DPL10474 & LRY5LLFY08002 & 10 L735 & $6-1-10$ \\
\hline DPL10474 & LRY5LLFY08002 & 10 L736 & $6-1-/ 0$ \\
\hline & & & \\
\hline & & & \\
\hline & & & \\
\hline & & & \\
\hline & & & \\
\hline
\end{tabular}

This certification is provided as a courtesy to the waste generator for information purposes only.

\section{/s/:Theresa Hale}

WGS Signature

Waste Inspector

\section{Title}

/s/:Jon Tanaka

4/ASTE STEECAKIST

$$
\frac{6-1-10}{\text { Date }}
$$

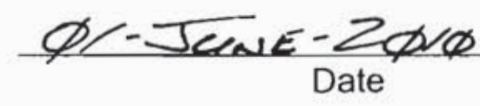


NSTec

Form

FRM-2217
CERTIFICATE OF DISPOSAL

(LOW LEVEL WASTE)
03/01/10

Rev. 01

Page 1 of 1

\section{Nevada Test Site}

This Certificate acknowledges that the following shipment(s) of waste have been disposed at the Nevada Test Site Radioactive Waste Management Complex.

\begin{tabular}{|c|c|c|c|}
\hline Shipment Number & $\begin{array}{l}\text { Waste Stream } \\
\text { Identification \# }\end{array}$ & Package \# & Date of Disposal \\
\hline DPL10475 & LRY5LLFY08002 & 10L737 & $6-1-10$ \\
\hline DPL10475 & LRY5LLFY08002 & $10 L 738$ & $6-1-10$ \\
\hline & & & \\
\hline & & & \\
\hline & & & \\
\hline & & & \\
\hline & & & \\
\hline & & & \\
\hline
\end{tabular}

This certification is provided as a courtesy to the waste generator for information purposes only.

$$
\begin{aligned}
& \text { /s/:Theresa Hale } \\
& \text { WGS Signature }
\end{aligned}
$$

Waste Inspector

$$
\text { Title }
$$

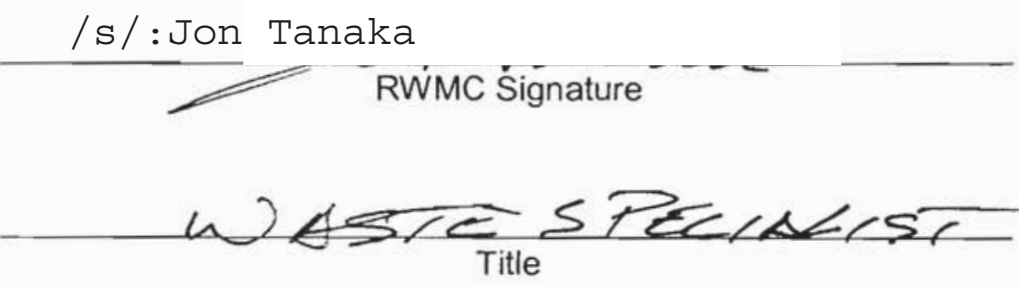

$$
\frac{6-1-10}{\text { Date }}
$$

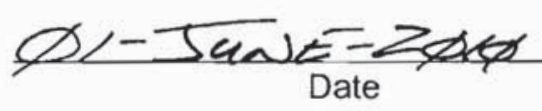




\section{Nevada Test Site}

This Certificate acknowledges that the following shipment(s) of waste have been disposed at the Nevada Test Site Radioactive Waste Management Complex.

\begin{tabular}{|l|l|l|l|}
\hline Shipment Number & $\begin{array}{c}\text { Waste Stream } \\
\text { Identification \# }\end{array}$ & \multicolumn{1}{c|}{ Package \# } & Date of Disposal \\
\hline & LRY5LLFY08002 & 10 L163 & $6-2-10$ \\
\hline & & & \\
\hline & & & \\
\hline & & & \\
\hline & & & \\
\hline & & & \\
\hline & & & \\
\hline
\end{tabular}

This certification is provided as a courtesy to the waste generator for information purposes only.

$$
\text { /s/:Theresa Hale }
$$

WGS Signature

Waste Inspector

$$
\text { Title }
$$

/s/:Jon Tanaka

RWMC Signature

WASTE SRECHALST

$$
\frac{6-2 \cdot 10}{\text { Date }}
$$

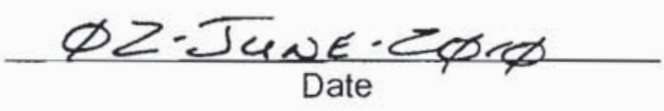




\begin{tabular}{|lcr|}
\hline NSTec & CERTIFICATE OF DISPOSAL & 03/01/10 \\
Form & Rev. 01 \\
FRM-2217 & (LOW LEVEL WASTE) & Page 1 of 1 \\
\hline
\end{tabular}

Nevada Test Site

This Certificate acknowledges that the following shipments) of waste have been disposed at the Nevada Test Site Radioactive Waste Management Complex.

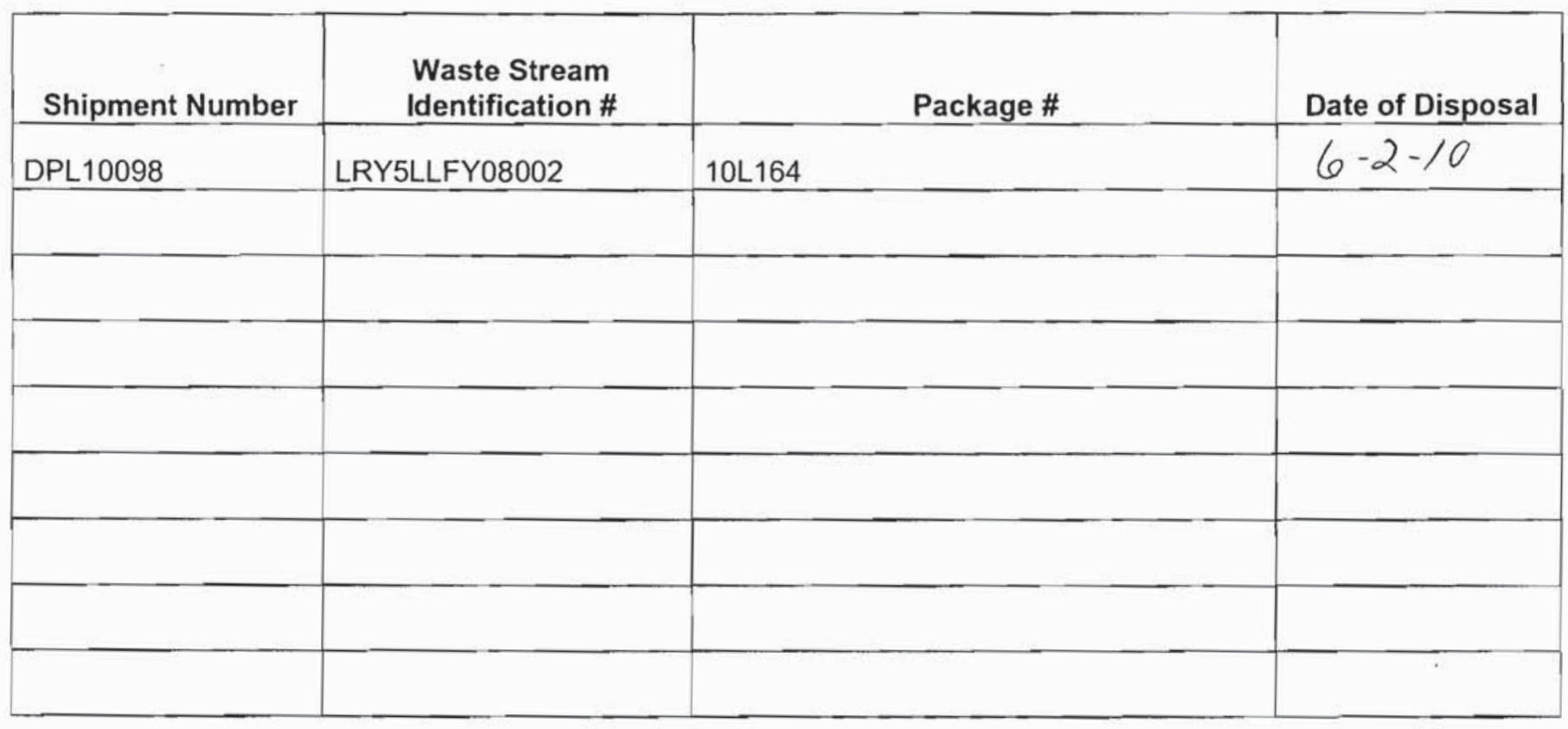

This certification is provided as a courtesy to the waste generator for information purposes only.

/s/: Theresa Hale

WGS Signature

Waste Inspector

Title

/s/ :Jon Tanka

RWMC Signature

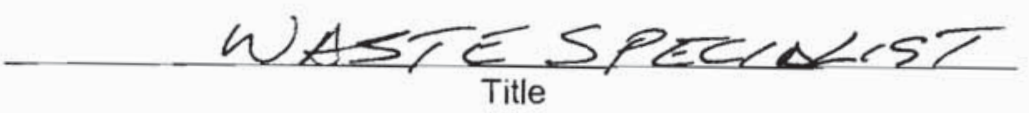

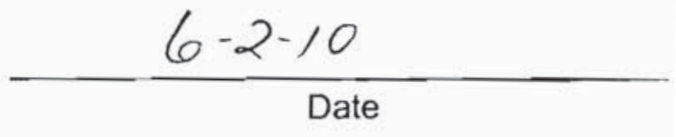

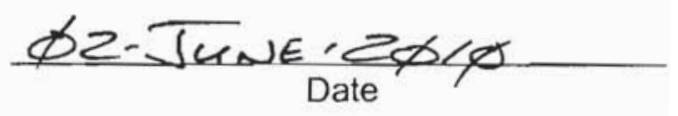




\begin{tabular}{|lcr|}
\hline NSTec & CERTIFICATE OF DISPOSAL & 03/01/10 \\
Form & Rev. 01 \\
FRM-2217 & (LOW LEVEL WASTE) & Page 1 of 1 \\
\hline
\end{tabular}

Nevada Test Site

This Certificate acknowledges that the following shipments) of waste have been disposed at the Nevada Test Site Radioactive Waste Management Complex.

\begin{tabular}{|l|l|l|l|}
\hline Shipment Number & \multicolumn{1}{|c|}{$\begin{array}{c}\text { Waste Stream } \\
\text { Identification \# }\end{array}$} & Package \# & Date of Disposal \\
\hline & LRY5LLFY08002 & 10 L165 & $6-2-/ 0$ \\
\hline & & & \\
\hline & & & \\
\hline & & & \\
\hline & & & \\
\hline & & & \\
\hline & & & \\
\hline & & & \\
\hline
\end{tabular}

This certification is provided as a courtesy to the waste generator for information purposes only.

$$
\text { /s/: Theresa Hale }
$$

WGS Signature

Waste Inspector

Title

/s/ :Jon Tanka

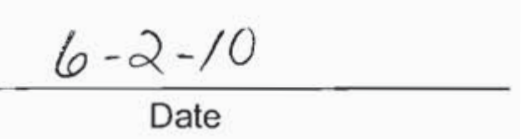

KVVMC signature

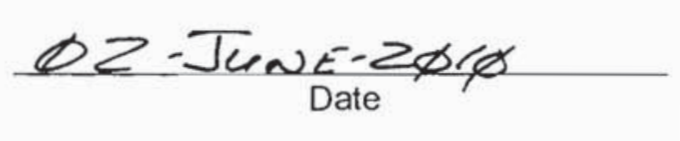


NSTec

Form

FRM-2217
CERTIFICATE OF DISPOSAL

(LOW LEVEL WASTE)
03/01/10

Rev. 01

Page 1 of 1

\section{Nevada Test Site}

This Certificate acknowledges that the following shipment(s) of waste have been disposed at the Nevada Test Site Radioactive Waste Management Complex.

\begin{tabular}{|l|l|l|l|}
\hline \multicolumn{1}{|c|}{ Shipment Number } & \multicolumn{1}{c|}{$\begin{array}{c}\text { Waste Stream } \\
\text { Identification \# }\end{array}$} & Package \# & Date of Disposal \\
\hline DPL10476 & LRY5LLFY08002 & 10 L739 & $6-2-10$ \\
\hline DPL10476 & LRY5LLFY08002 & 10 L740 & $6-2-10$ \\
\hline & & & \\
\hline & & & \\
\hline & & & \\
\hline & & & \\
\hline
\end{tabular}

This certification is provided as a courtesy to the waste generator for information purposes only.

/s/:Theresa Hale

WGS Signature

Waste Inspector

Title

/s/: Jon Tanaka

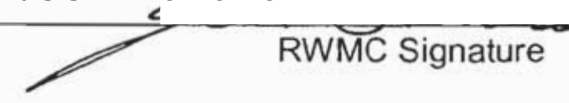

W ASTE SPEC A KIST
$6-2-10$

Date 
NSTec

Form

FRM-2217
CERTIFICATE OF DISPOSAL

(LOW LEVEL WASTE)
03/01/10

Rev. 01

Page 1 of 1

\section{Nevada Test Site}

This Certificate acknowledges that the following shipment(s) of waste have been disposed at the Nevada Test Site Radioactive Waste Management Complex.

\begin{tabular}{|l|l|l|l|}
\hline \multicolumn{1}{|c|}{ Shipment Number } & \multicolumn{1}{c|}{$\begin{array}{c}\text { Waste Stream } \\
\text { Identification \# }\end{array}$} & Package \# & Date of Disposal \\
\hline DPL10477 & LRY5LLFY08002 & 10 L741 & $6-2-10$ \\
\hline DPL10477 & LRY5LLFY08002 & 10 L742 & $6-2-10$ \\
\hline & & & \\
\hline & & & \\
\hline & & & \\
\hline & & & \\
\hline & & & \\
\hline & & & \\
\hline
\end{tabular}

This certification is provided as a courtesy to the waste generator for information purposes only.

/s/:Theresa Hale

WGS Signature

Waste Inspector

Title

/s/:Jon Tanaka

RWMC Signature

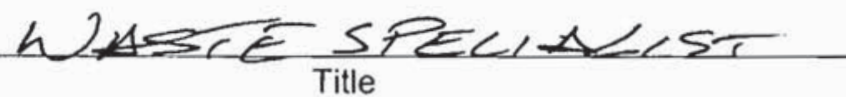

$$
\frac{6-2-10}{\text { Date }}
$$

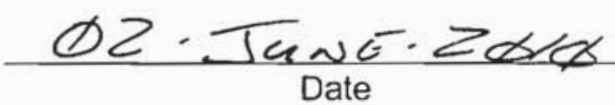




\begin{tabular}{|lcr|}
\hline NSTec & CERTIFICATE OF DISPOSAL & $03 / 01 / 10$ \\
Form & Rev. 01 \\
FRM-2217 & (LOW LEVEL WASTE) & Page 1 of 1 \\
\hline
\end{tabular}

Nevada Test Site

This Certificate acknowledges that the following shipments) of waste have been disposed at the Nevada Test Site Radioactive Waste Management Complex.

\begin{tabular}{|l|l|l|l|}
\hline \multicolumn{1}{|c|}{$\begin{array}{c}\text { Waste Stream } \\
\text { Identification \# }\end{array}$} & \multicolumn{1}{|c|}{ Package \# } & Date of Disposal \\
\hline DPL10478 & LRY5LLFY08002 & 10 L743 & $6-2 \cdot 10$ \\
\hline DPL10478 & LRY5LLFY08002 & $10 L 744$ & $6-2-10$ \\
\hline & & & \\
\hline & & & \\
\hline & & & \\
\hline & & & \\
\hline & & & \\
\hline & & & \\
\hline
\end{tabular}

This certification is provided as a courtesy to the waste generator for information purposes only.

/s/ :Theresa Hale

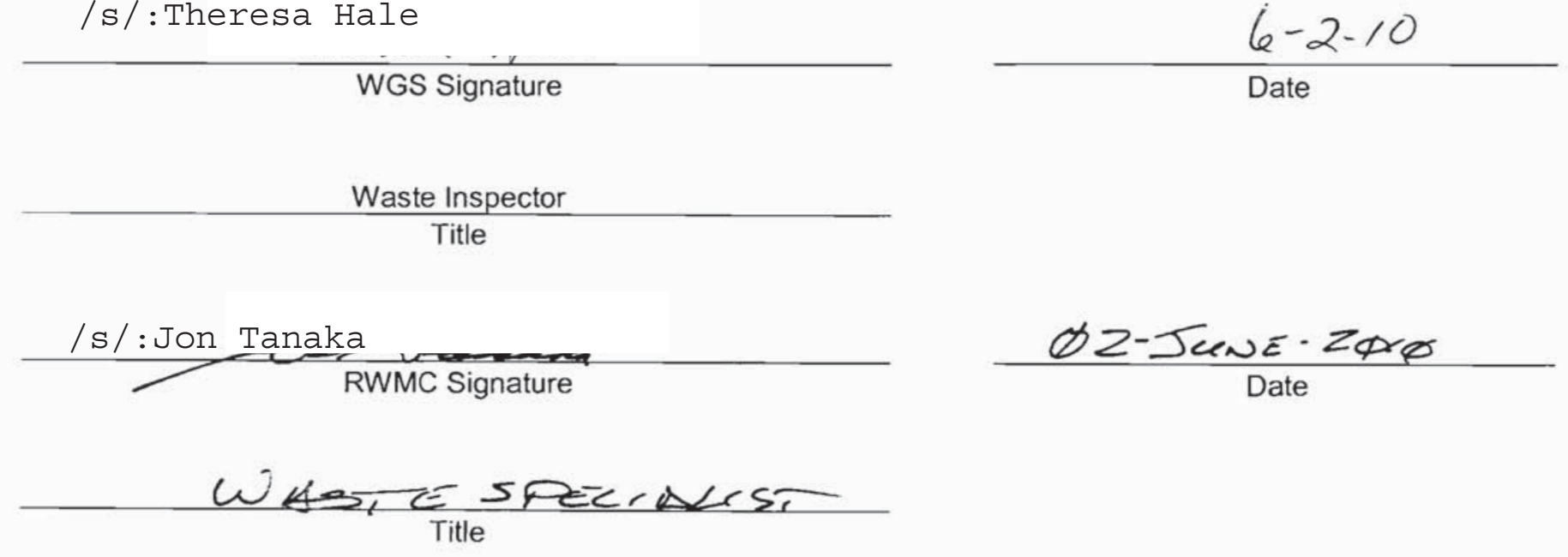


NSTec

Form

FRM-2217
CERTIFICATE OF DISPOSAL

(LOW LEVEL WASTE)
$03 / 01 / 10$

Rev. 01

Page 1 of 1

\section{Nevada Test Site}

This Certificate acknowledges that the following shipment(s) of waste have been disposed at the Nevada Test Site Radioactive Waste Management Complex.

\begin{tabular}{|l|l|l|l|}
\hline \multicolumn{1}{|c|}{$\begin{array}{c}\text { Whipment Number } \\
\text { Identification \# }\end{array}$} & \multicolumn{1}{|c|}{ Package \# } & \multicolumn{1}{c|}{ Date of Disposal } \\
\hline DPL10479 & LRY5LLFY08002 & 10 7745 & $6-2-10$ \\
\hline DPL10479 & LRY5LLFY08002 & 10 L 746 & $6-2-10$ \\
\hline & & & \\
\hline & & & \\
\hline & & & \\
\hline & & & \\
\hline & & & \\
\hline
\end{tabular}

This certification is provided as a courtesy to the waste generator for information purposes only.

$\frac{\text { /s/:Theresa Hale }}{\text { WGS Signature }}$

Waste Inspector

Title

/s/:Jon Tanaka

RiWMC Signature

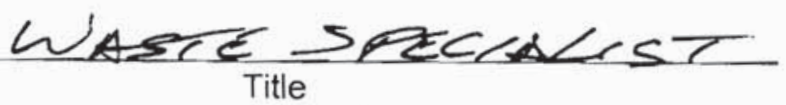

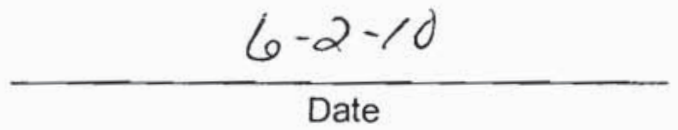

$\frac{\phi 2-I_{a n}-2 \phi 1 \phi}{\text { Date }}$ 


\begin{tabular}{|lcr|}
\hline NSTec & CERTIFICATE OF DISPOSAL & 03/01/10 \\
Form & Rev. 01 \\
FRM-2217 & (LOW LEVEL WASTE) & Page 1 of 1 \\
\hline
\end{tabular}

Nevada Test Site

This Certificate acknowledges that the following shipments) of waste have been disposed at the Nevada Test Site Radioactive Waste Management Complex.

\begin{tabular}{|l|l|l|l|}
\hline \multicolumn{1}{|c|}{$\begin{array}{c}\text { Waste Stream } \\
\text { Identification \# }\end{array}$} & \multicolumn{1}{|c|}{ Package \# } & Date of Disposal \\
\hline DPL10480 & LRY5LLFY08002 & $10 L 747$ & $6-2-10$ \\
\hline DPL10480 & LRY5LLFY08002 & $10 L 748$ & $6-2-10$ \\
\hline & & & \\
\hline & & & \\
\hline & & & \\
\hline & & & \\
\hline & & & \\
\hline & & & \\
\hline
\end{tabular}

This certification is provided as a courtesy to the waste generator for information purposes only.

/s/: Theresa Hale

WGS Signature

Waste Inspector

Title

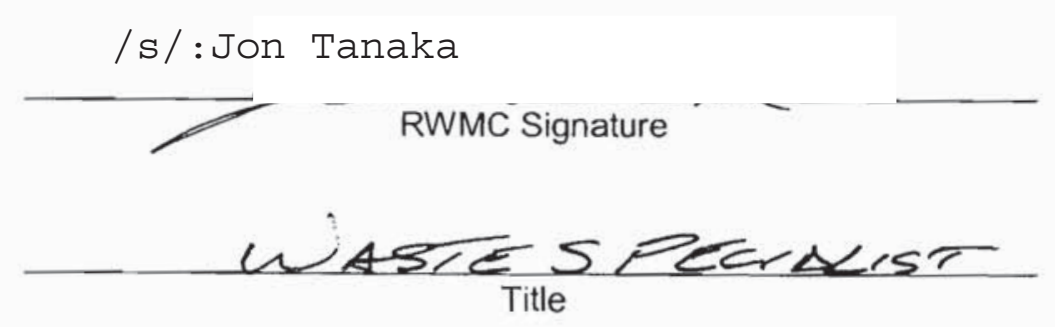

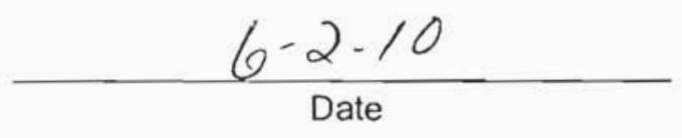

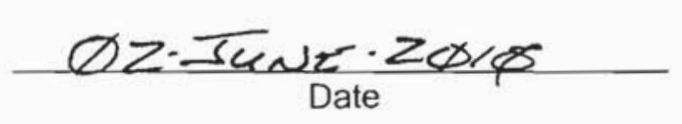

(Reference: OP-2151.304) 


\begin{tabular}{|lcr|}
\hline $\begin{array}{l}\text { NSTec } \\
\text { Form } \\
\text { FRM-2217 }\end{array}$ & CERTIFICATE OF DISPOSAL & $03 / 01 / 10$ \\
(LOW LEVEL WASTE) & Rev. 01 \\
\hline
\end{tabular}

Nevada Test Site

This Certificate acknowledges that the following shipments) of waste have been disposed the Nevada Test Site Radioactive Waste Management Complex.

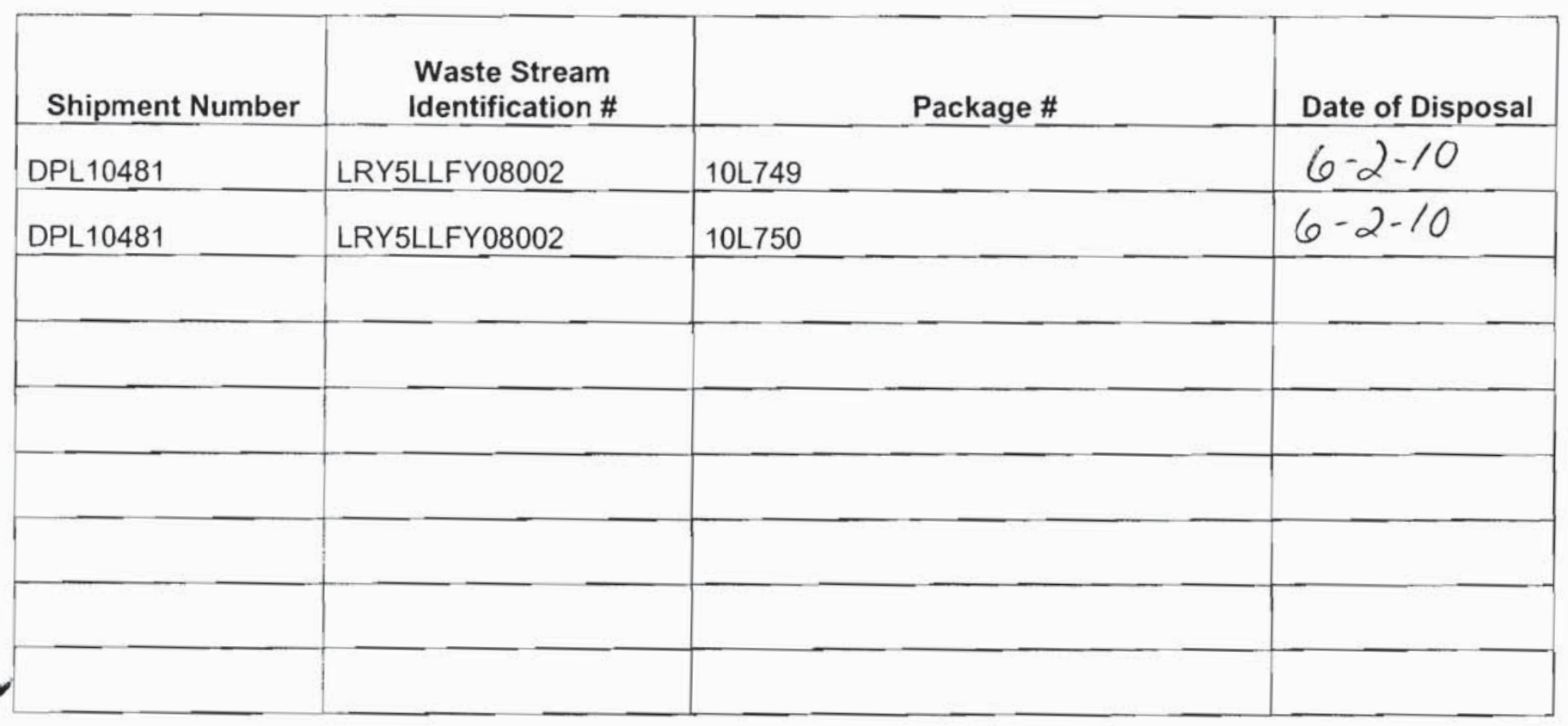

This certification is provided as a courtesy to the waste generator for information purposes only.

/s/ :Theresa Hale

$$
-\frac{6-2-10}{\text { Date }}-
$$

Waste Inspector

Title

/s / : Jon Kanaka

RWM Signature

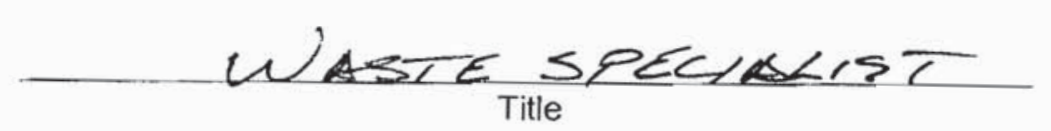

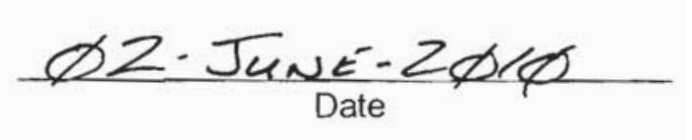

(Reference: OP-2151.304) 
NSTec

Form

CERTIFICATE OF DISPOSAL

03/01/10

FRM-2217

(LOW LEVEL WASTE)

Rev. 01

Page 1 of 1

\section{Nevada Test Site}

This Certificate acknowledges that the following shipment(s) of waste have been disposed at the Nevada Test Site Radioactive Waste Management Complex.

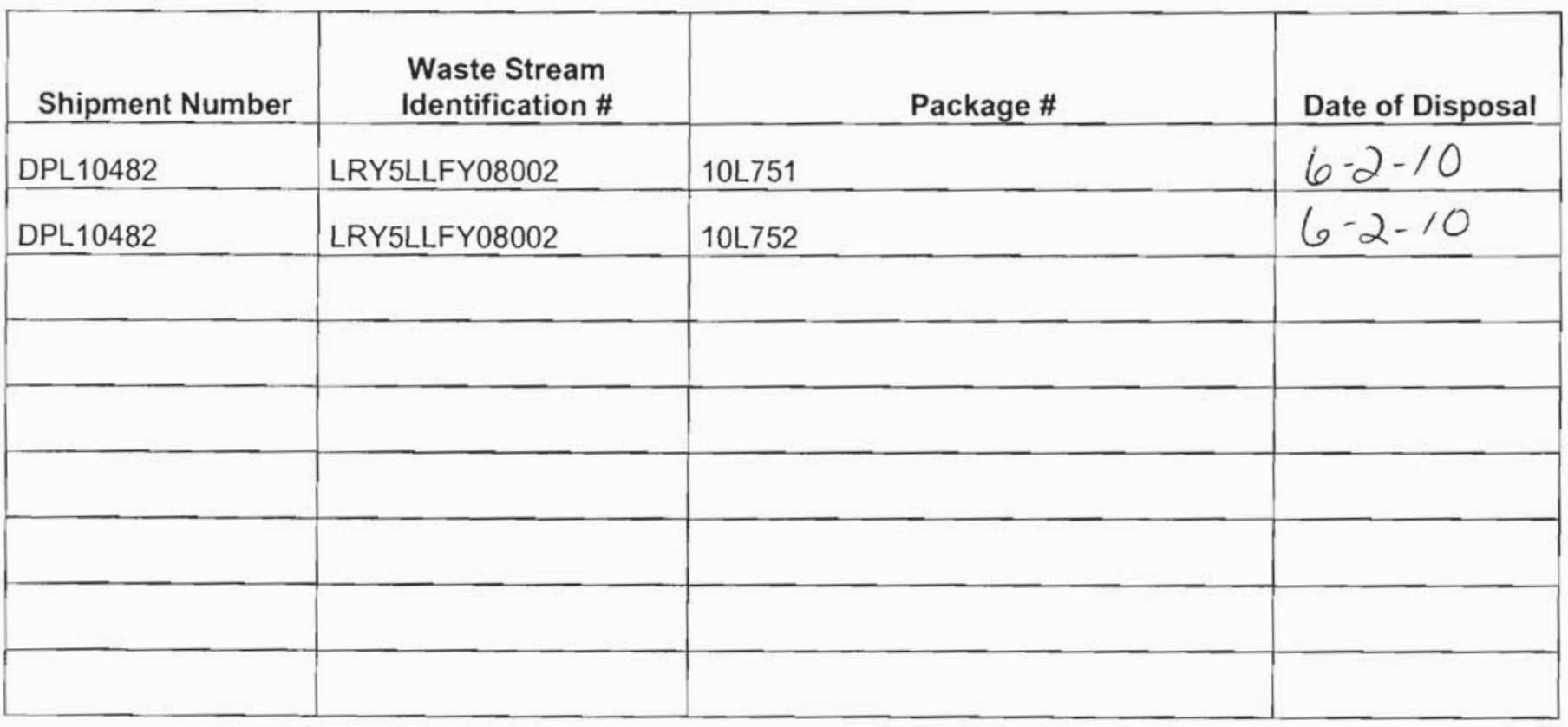

This certification is provided as a courtesy to the waste generator for information purposes only.

/s/:Theresa Hale
WGS Signature
Waste Inspector

$-\frac{6-2-10}{\text { Date }}$

/s/: Jon Tanaka
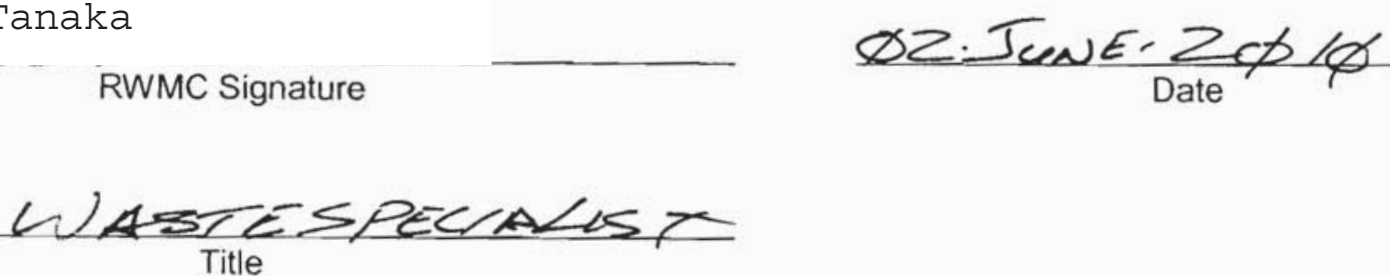


\begin{tabular}{|lcr|}
\hline NSTec & CERTIFICATE OF DISPOSAL & 03/01/10 \\
Form & Rev. 01 \\
FRM-2217 & (LOW LEVEL WASTE) & Page 1 of 1 \\
\hline
\end{tabular}

Nevada Test Site

This Certificate acknowledges that the following shipments) of waste have been disposed at the Nevada Test Site Radioactive Waste Management Complex.

\begin{tabular}{|l|l|l|l|}
\hline \multicolumn{1}{|c|}{ Shipment Number } & $\begin{array}{c}\text { Waste Stream } \\
\text { Identification \# }\end{array}$ & Package \# & Date of Disposal \\
\hline DPL10483 & LRY5LLFY08002 & $10 L 753$ & $6-2-10$ \\
\hline DPL10483 & LRY5LLFY08002 & $10 L 754$ & $6-2-10$ \\
\hline & & & \\
\hline & & & \\
\hline & & & \\
\hline & & & \\
\hline & & & \\
\hline
\end{tabular}

This certification is provided as a courtesy to the waste generator for information purposes only.

/s/ :Theresa Hale

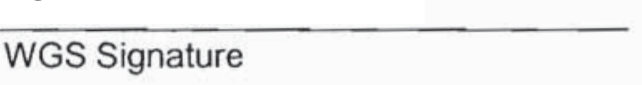

Waste Inspector

Title

/e/: Jon Tanka

RWMMC Signature

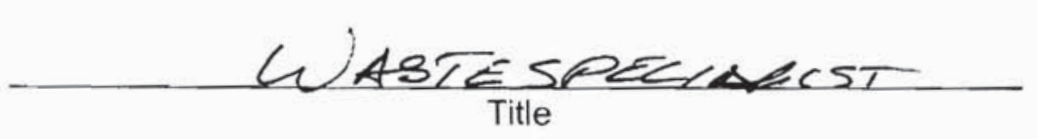

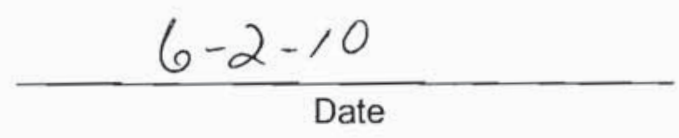

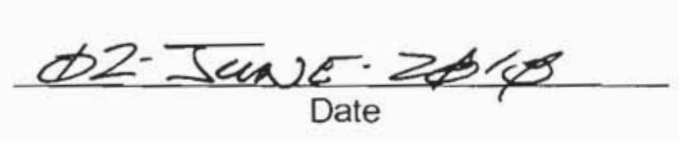

(Reference: OP -2151 304) 
NSTec

Form

FRM-2217
CERTIFICATE OF DISPOSAL

(LOW LEVEL WASTE)
03/01/10

Rev. 01

Page 1 of 1

\section{Nevada Test Site}

This Certificate acknowledges that the following shipment(s) of waste have been disposed at the Nevada Test Site Radioactive Waste Management Complex.

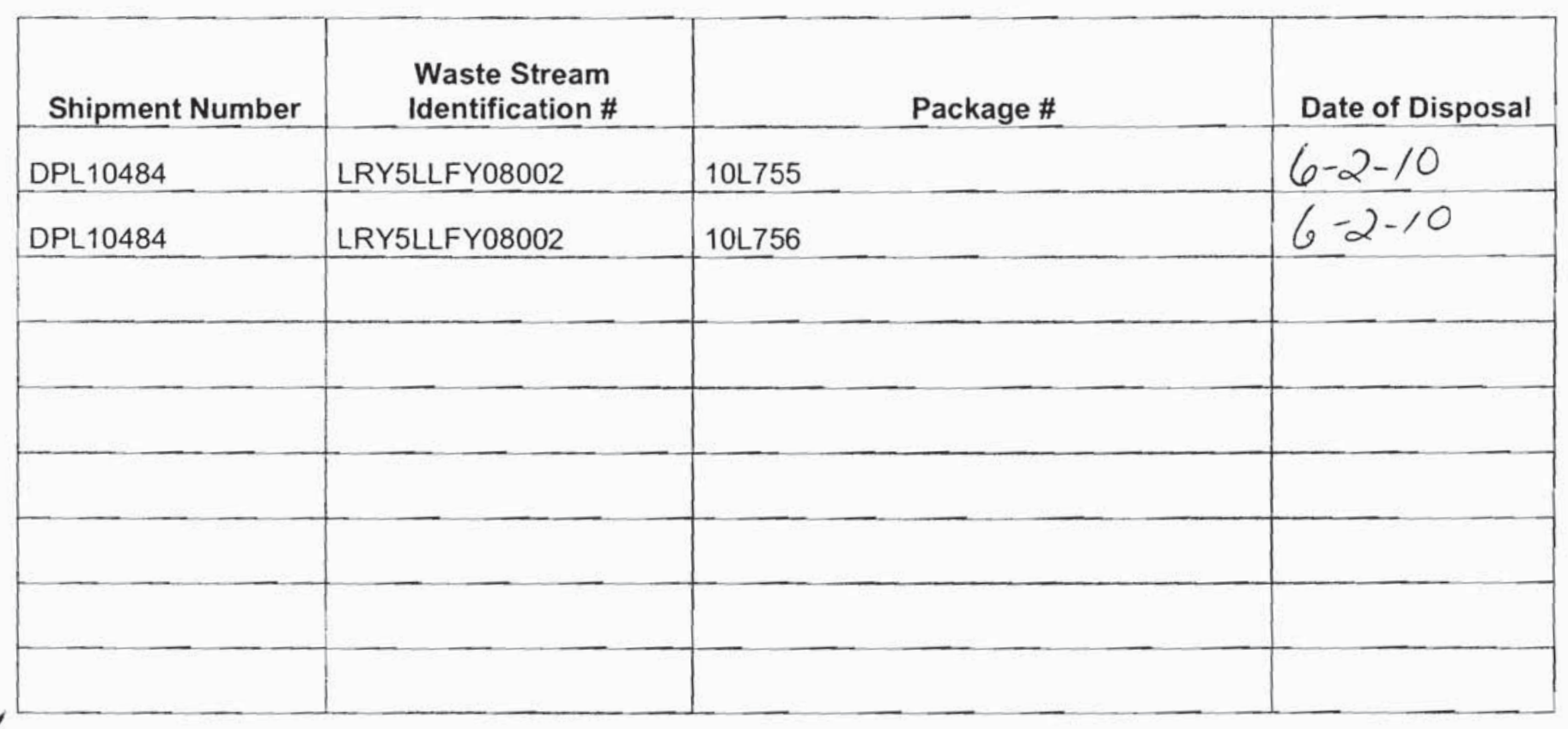

This certification is provided as a courtesy to the waste generator for information purposes only.

/s/: Theresa Hale

WGS Signature

Waste Inspector

Titie

/s/: Jon Tanaka

RWMC Signature

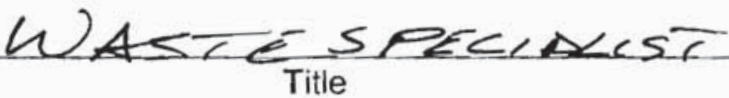

$$
\frac{6-2-10}{\text { Date }}
$$

$\phi \geq-I_{\text {Lan }}=-2 \phi<\phi$ 
NSTec

Form

FRM-2217
CERTIFICATE OF DISPOSAL

(LOW LEVEL WASTE)
03/01/10

Rev. 01

Page 1 of 1

\section{Nevada Test Site}

This Certificate acknowledges that the following shipment(s) of waste have been disposed at the Nevada Test Site Radioactive Waste Management Complex.

\begin{tabular}{|l|l|l|l|}
\hline \multicolumn{1}{|c|}{ Shipment Number } & \multicolumn{1}{c|}{$\begin{array}{c}\text { Waste Stream } \\
\text { Identification \# }\end{array}$} & Package \# & Date of Disposal \\
\hline DPL10485 & LRY5LLFY08002 & 10 .757 & $6-2-10$ \\
\hline DPL10485 & LRY5LLFY08002 & 10 L758 & $6-2-10$ \\
\hline & & & \\
\hline & & & \\
\hline & & & \\
\hline & & & \\
\hline
\end{tabular}

This certification is provided as a courtesy to the waste generator for information purposes only.

/s/: Theresa, Hale

WGS Signature

Waste Inspector

Title

/s/:Jon Tanaka

RWMC Signature

W $63 \pi E^{-}$SPECLALCST

Title $\frac{6-2-10}{\text { Date }}$

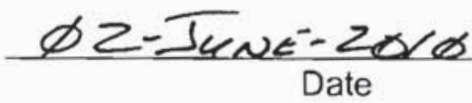


NSTec

Form

FRM-2217
CERTIFICATE OF DISPOSAL

(LOW LEVEL WASTE)
03/01/10

Rev. 01

Page 1 of 1

\section{Nevada Test Site}

This Certificate acknowledges that the following shipment(s) of waste have been disposed at the Nevada Test Site Radioactive Waste Management Complex.

\begin{tabular}{|l|l|l|l|l|}
\hline Shipment Number & $\begin{array}{c}\text { Waste Stream } \\
\text { Identification \# }\end{array}$ & Package \# & Date of Disposal \\
\hline DPL10486 & LRY5LLFY08002 & $10 L 759$ & $6-2-10$ \\
\hline DPL10486 & LRY5LLFY08002 & $10 L 760$ & $6-2-10$ \\
\hline & & & & \\
\hline
\end{tabular}

This certification is provided as a courtesy to the waste generator for information purposes only.

/s/:Theresa Hale

WGS Signature

Waste Inspector

Title

/s/: Jon Tanaka

RWMC Signature

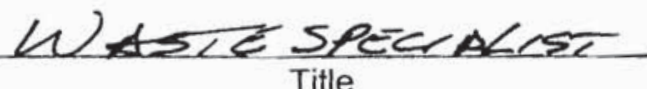

$$
6-2-10
$$

Date

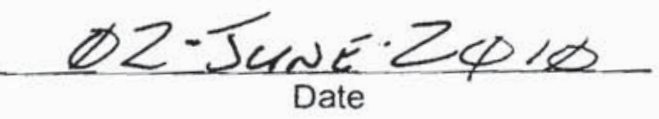




\begin{tabular}{|lcr|}
\hline NSTec & CERTIFICATE OF DISPOSAL & $03 / 01 / 10$ \\
Form & Rev. 01 \\
FRM-2217 & (LOW LEVEL WASTE) & Page 1 of 1 \\
\hline
\end{tabular}

Nevada Test Site

This Certificate acknowledges that the following shipments) of waste have been disposed at the Nevada Test Site Radioactive Waste Management Complex.

\begin{tabular}{|l|l|l|l|}
\hline Shipment Number & \multicolumn{1}{|c|}{$\begin{array}{c}\text { Waste Stream } \\
\text { Identification \# }\end{array}$} & \multicolumn{1}{c|}{ Package \# } & Date of Disposal \\
\hline DPL10487 & LRY5LLFY08002 & $10 L 761$ & $6-2-10$ \\
\hline DPL10487 & LRY5LLFY08002 & $10 L 762$ & $6-2-10$ \\
\hline & & & \\
\hline & & & \\
\hline & & & \\
\hline & & & \\
\hline
\end{tabular}

This certification is provided as a courtesy to the waste generator for information purposes only.

/s/: Theresa Hale

WGS Signature

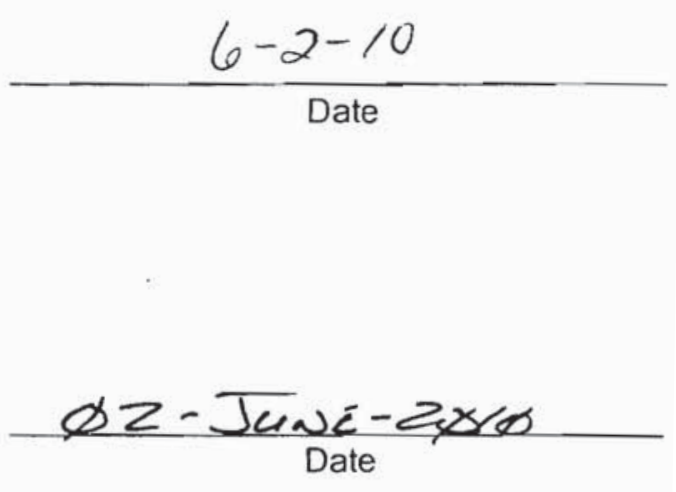

Waste Inspector

Title

/s/: Jon Tanaka

WASTE SPECIALIST

(Reference: OP-2151.304) 


\begin{tabular}{|lcr|}
\hline NSTec & CERTIFICATE OF DISPOSAL & 03/01/10 \\
Form & Rev. 01 \\
FRM-2217 & (LOW LEVEL WASTE) & Page 1 of 1 \\
\hline
\end{tabular}

Nevada Test Site

This Certificate acknowledges that the following shipments) of waste have been disposed at the Nevada Test Site Radioactive Waste Management Complex.

\begin{tabular}{|l|c|c|c|}
\hline Shipment Number & $\begin{array}{c}\text { Waste Stream } \\
\text { Identification \# } \\
\text { LRY5LLFY08002 }\end{array}$ & PaL 166 & Package \# \\
\hline & & & $6 / 3 / 10$ \\
\hline & & & \\
\hline & & & \\
\hline & & & \\
\hline & & & \\
\hline & & & \\
\hline
\end{tabular}

This certification is provided as a courtesy to the waste generator for information purposes only.

/s/: Theresa Hale

WGS Signature

Waste Inspector

Title

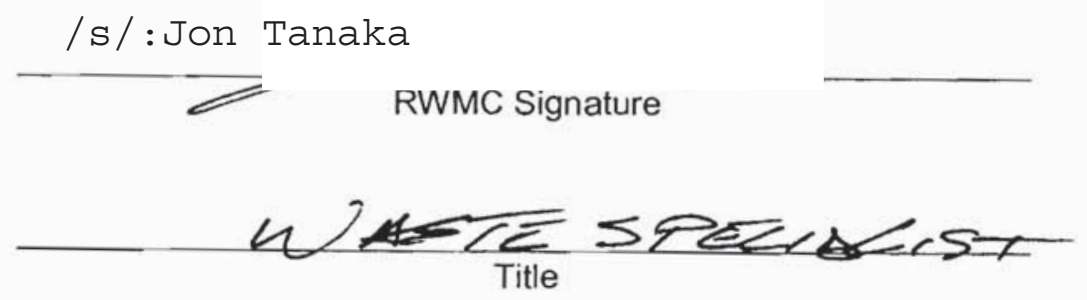

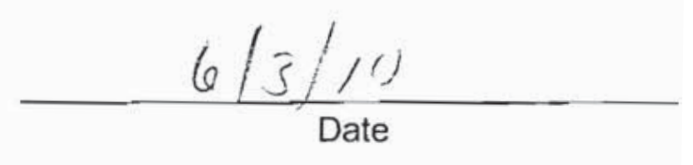

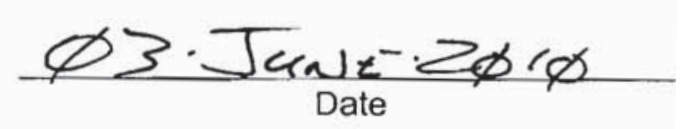

(Reference: OP-2151.304) 
NSTec

Form

FRM-2217
CERTIFICATE OF DISPOSAL

(LOW LEVEL WASTE)
03/01/10

Rev. 01

Page 1 of 1

\section{Nevada Test Site}

This Certificate acknowledges that the following shipment(s) of waste have been disposed at the Nevada Test Site Radioactive Waste Management Complex.

\begin{tabular}{|c|c|c|c|}
\hline Shipment Number & $\begin{array}{l}\text { Waste Stream } \\
\text { Identification \# }\end{array}$ & Package \# & Date of Disposal \\
\hline DPL10488 & LRY5LLFY08002 & $10\llcorner 763$ & $6 \cdot 3-10$ \\
\hline DPL10488 & LRY5LLFY08002 & 10L764 & $6-3-10$ \\
\hline & & & \\
\hline & & & \\
\hline & & & \\
\hline & & & \\
\hline & & & \\
\hline & & & \\
\hline
\end{tabular}

This certification is provided as a courtesy to the waste generator for information purposes only.

/s/: Theresa Hale

WGS Signature

Waste Inspector

Title /s/: Jon Tanaka

RWM̆C Signature

U DASTE $\frac{\text { SRECHAST }}{\text { Title }}$
$6-3-10$

Date

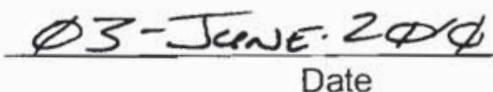




\section{Nevada Test Site}

This Certificate acknowledges that the following shipment(s) of waste have been disposed at the Nevada Test Site Radioactive Waste Management Complex.

\begin{tabular}{|l|l|l|c|}
\hline \multicolumn{1}{|c|}{$\begin{array}{c}\text { Whipment Number } \\
\text { Identification \# }\end{array}$} & \multicolumn{1}{|c|}{ Package \# } & Date of Disposal \\
\hline DPL10489 & LRY5LLFY08002 & 10 L765 & $6-3-10$ \\
\hline DPL10489 & LRY5LLFY08002 & 10 L766 & $6-3 \cdot / 0$ \\
\hline & & & \\
\hline & & & \\
\hline & & & \\
\hline & & & \\
\hline
\end{tabular}

This certification is provided as a courtesy to the waste generator for information purposes only.

/s/: Theresa Hale

WGS Signature

Waste Inspector

Title

/s/:Jon Tanaka

RWMC Signature

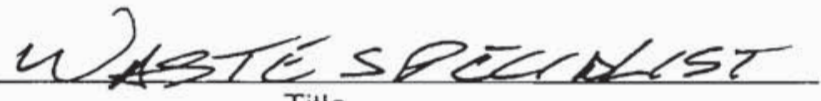

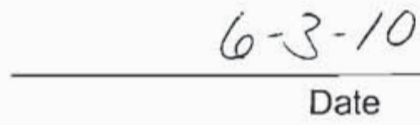

$\phi 3-J_{\text {Date }} \sum \phi / \phi$ 


\begin{tabular}{|lcr|}
\hline NSTec & CERTIFICATE OF DISPOSAL & $03 / 01 / 10$ \\
Form & (LOW LEVEL WASTE) & Rev. 01 \\
FRM-2217 & Page 1 of 1 \\
\hline
\end{tabular}

Nevada Test Site

This Certificate acknowledges that the following shipments) of waste have been disposed at the Nevada Test Site Radioactive Waste Management Complex.

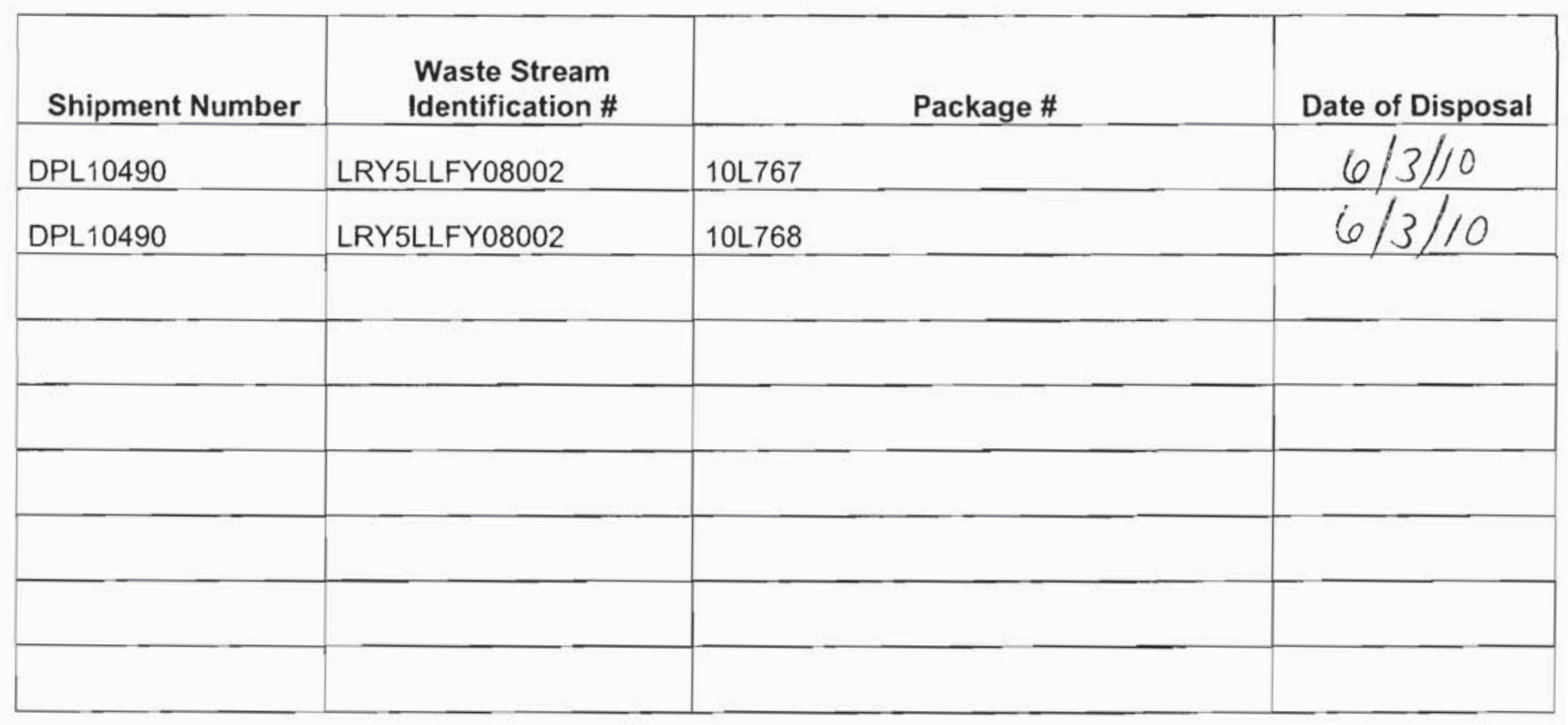

This certification is provided as a courtesy to the waste generator for information purposes only.

/s/ :Theresa Hale

WGS Signature

Waste Inspector

Title

/s/: Jon Tanka

RWM̄C Signature

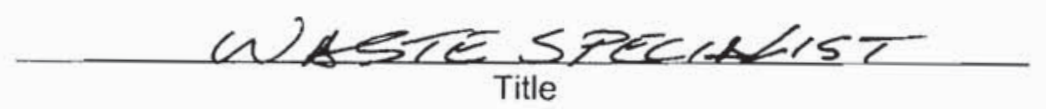

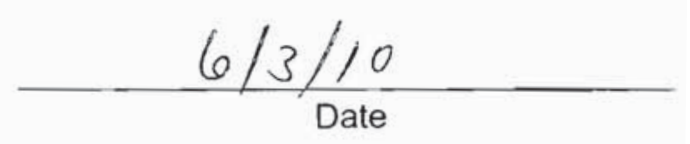

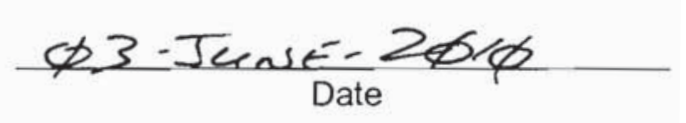

(Reference: OP-2151.304) 


\begin{tabular}{|lcr|}
\hline NSTec & CERTIFICATE OF DISPOSAL & $03 / 01 / 10$ \\
Form & Rev. 01 \\
FRM-2217 & (LOW LEVEL WASTE) & Page 1 of 1 \\
\hline
\end{tabular}

Nevada Test Site

This Certificate acknowledges that the following shipments) of waste have been disposed at the Nevada Test Site Radioactive Waste Management Complex.

\begin{tabular}{|l|l|l|l|}
\hline \multicolumn{1}{|c|}{$\begin{array}{c}\text { Waste Stream } \\
\text { Identification \# }\end{array}$} & Package \# & Date of Disposal \\
\hline DPL10491 & LRY5LLFY08002 & 10 L769 & $6 / 3 / 10$ \\
\hline DPL10491 & LRY5LLFY08002 & 10 L770 & $6 / 3 / 10$ \\
\hline & & & \\
\hline & & & \\
\hline & & & \\
\hline & & & \\
\hline
\end{tabular}

This certification is provided as a courtesy to the waste generator for information purposes only.

/s/ :Theresa Hale

WGS Signature

Waste Inspector

Title

/s/: Jon Kanaka

RẄMC̄ Signature

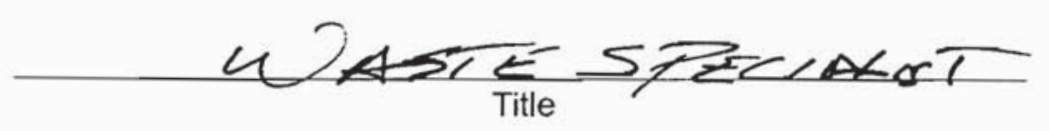

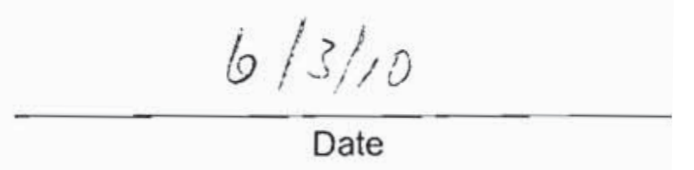

Date

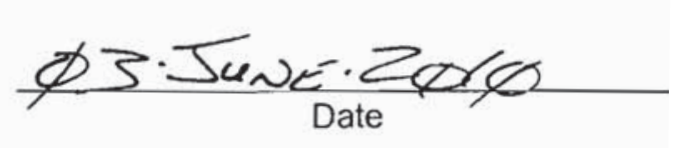

IDAfnennen: กD_2151 3n4i 


\begin{tabular}{|lcr|}
\hline NSTec & CERTIFICATE OF DISPOSAL & 03/01/10 \\
Form & Rev. 01 \\
FRM-2217 & (LOW LEVEL WASTE) & Page 1 of 1 \\
\hline
\end{tabular}

Nevada Test Site

This Certificate acknowledges that the following shipments) of waste have been disposed at the Nevada Test Site Radioactive Waste Management Complex.

\begin{tabular}{|l|l|l|c|}
\hline \multicolumn{1}{|c|}{$\begin{array}{c}\text { Waste Stream } \\
\text { Shipment Number }\end{array}$} & \multicolumn{1}{c|}{ Package \# } & Date of Disposal \\
\hline DPL10492 & LRY5LLFY08002 & 10 L771 & $6 / 3 / 1)$ \\
\hline DPL10492 & LRY5LLFY08002 & 10 L772 & \\
\hline & & & \\
\hline & & & \\
\hline & & & \\
\hline & & & \\
\hline & & & \\
\hline
\end{tabular}

This certification is provided as a courtesy to the waste generator for information purposes only.

/s/: Theresa Hale

WGS Signature

Waste Inspector

Title

/s/: Jon Tanka

RWMC Signature

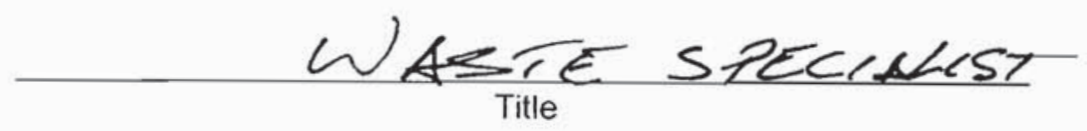

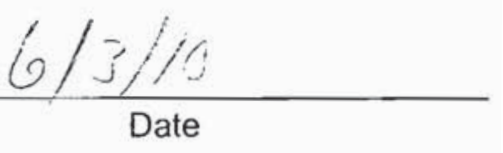

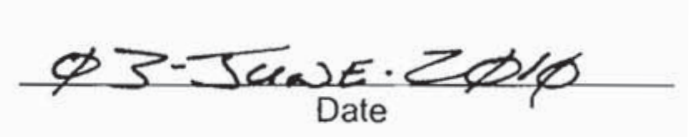

(Reference. กP-2151 3n4) 


\begin{tabular}{|lcr|}
\hline NSTec & CERTIFICATE OF DISPOSAL & 03/01/10 \\
Form & Rev. 01 \\
FRM-2217 & (LOW LEVEL WASTE) & Page 1 of 1 \\
\hline
\end{tabular}

Nevada Test Site

This Certificate acknowledges that the following shipments) of waste have been disposed at the Nevada Test Site Radioactive Waste Management Complex.

\begin{tabular}{|l|l|l|l|}
\hline \multicolumn{1}{|c|}{ Shipment Number } & \multicolumn{1}{|c|}{$\begin{array}{c}\text { Waste Stream } \\
\text { Identification \# }\end{array}$} & Package \# & Date of Disposal \\
\hline DPL10493 & LRY5LLFY08002 & 10 L773 & 0 \\
\hline DPL10493 & LRY5LLFY08002 & 10 L774 & \\
\hline & & & \\
\hline & & & \\
\hline & & & \\
\hline & & & \\
\hline & & & \\
\hline & & & \\
\hline
\end{tabular}

This certification is provided as a courtesy to the waste generator for information purposes only.

/s/ :Theresa Hale

WGS Signature

Waste Inspector

Title

$$
\text { /s/: Jon Tanka }
$$

RWMC Signature

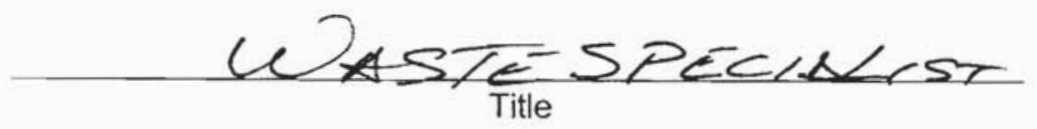

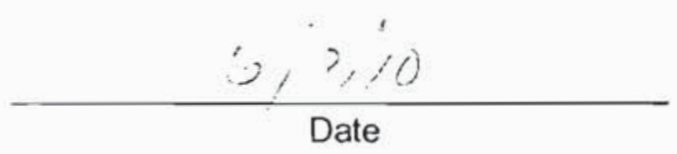

Date

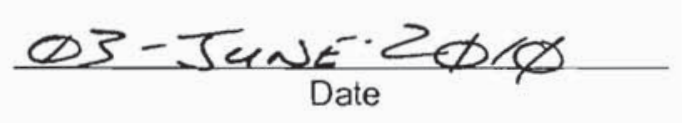

(Reference: OP -2151 304) 
NSTec

Form

FRM-2217
CERTIFICATE OF DISPOSAL

(LOW LEVEL WASTE)
03/01/10

Rev. 01

Page 1 of 1

\section{Nevada Test Site}

This Certificate acknowledges that the following shipment(s) of waste have been disposed at the Nevada Test Site Radioactive Waste Management Complex.

\begin{tabular}{|l|l|l|l|}
\hline Shipment Number & \multicolumn{1}{|c|}{$\begin{array}{c}\text { Waste Stream } \\
\text { Identification \# }\end{array}$} & Package \# & Date of Disposal \\
\hline DPL10494 & LRY5LLFY08002 & 10 7775 & 10L776 \\
\hline DPL10494 & LRY5LLFY08002 & & \\
\hline & & & \\
\hline & & & \\
\hline & & & \\
\hline & & & \\
\hline
\end{tabular}

This certification is provided as a courtesy to the waste generator for information purposes only.

/s/:Theresa Hale

WGS Signature

Waste Inspector

Title

/s/:Jon Tanaka

RWMC Signature

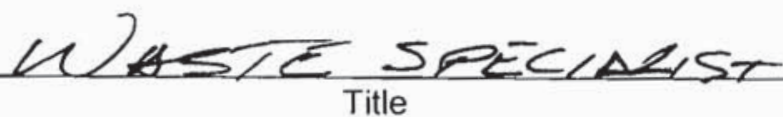
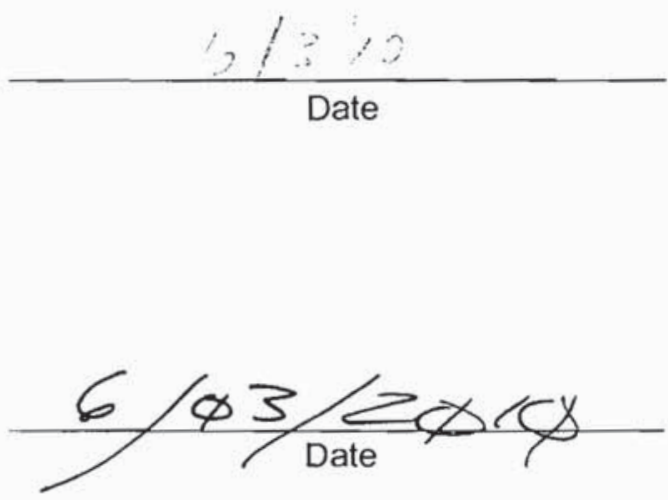


\begin{tabular}{|lcr|}
\hline NSTec & CERTIFICATE OF DISPOSAL & $03 / 01 / 10$ \\
Form & Rev. 01 \\
FRM-2217 & (LOW LEVEL WASTE) & Page 1 of 1 \\
\hline
\end{tabular}

Nevada Test Site

This Certificate acknowledges that the following shipments) of waste have been disposed at the Nevada Test Site Radioactive Waste Management Complex.

\begin{tabular}{|l|l|l|l|}
\hline \multicolumn{1}{|c|}{$\begin{array}{c}\text { Waste Stream } \\
\text { Identification \# }\end{array}$} & \multicolumn{1}{|c|}{ Package \# } & Date of Disposal \\
\hline DPL10495 & LRY5LLFY08002 & 10 L777 & $6 / 3 / 10$ \\
\hline DPL10495 & LRY5LLFY08002 & 10 L778 & $6 / 3 / 10$ \\
\hline & & & \\
\hline & & & \\
\hline & & & \\
\hline & & & \\
\hline & & & \\
\hline & & & \\
\hline
\end{tabular}

This certification is provided as a courtesy to the waste generator for information purposes only.

/s/ :Theresa Hale

WGS Signature

Waste Inspector

Title /s/ :Jon Tanka

RWMČs Signature

Title
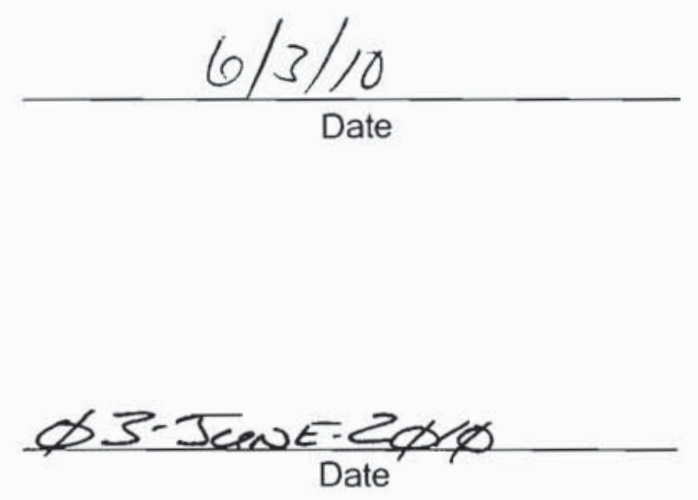

(Reference: OP -2151.304) 


\begin{tabular}{|lcr|}
\hline NSTec & CERTIFICATE OF DISPOSAL & 03/01/10 \\
Form & Rev. 01 \\
FRM-2217 & (LOW LEVEL WASTE) & Page 1 of 1 \\
\hline
\end{tabular}

Nevada Test Site

This Certificate acknowledges that the following shipments) of waste have been disposed at the Nevada Test Site Radioactive Waste Management Complex.

\begin{tabular}{|l|l|l|l|}
\hline Shipment Number & \multicolumn{1}{|c|}{$\begin{array}{c}\text { Waste Stream } \\
\text { Identification \# }\end{array}$} & Package \# & Date of Disposal \\
\hline DPL10496 & LRY5LLFY08002 & 10 L779 & $6 / 3 / 10$ \\
\hline DPL10496 & LRY5LLFY08002 & 10 L780 & $6 / 3 / 10$ \\
\hline & & & \\
\hline & & & \\
\hline & & & \\
\hline & & & \\
\hline & & & \\
\hline & & & \\
\hline
\end{tabular}

This certification is provided as a courtesy to the waste generator for information purposes only.

/s/ :Theresa Hale

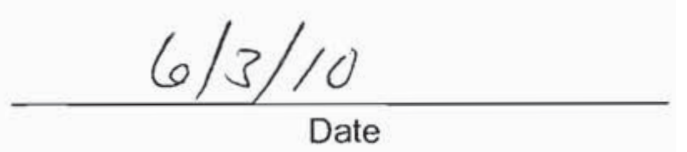

Waste Inspector

Title

/s/: Jon Tanka

RWMC Signature

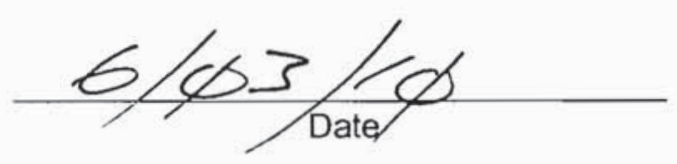

(Reference: OP-2151.304) 


\begin{tabular}{|lcr|}
\hline NSTec & CERTIFICATE OF DISPOSAL & 03/01/10 \\
Form & Rev. 01 \\
FRM-2217 & (LOW LEVEL WASTE) & Page 1 of 1 \\
\hline
\end{tabular}

Nevada Test Site

This Certificate acknowledges that the following shipments) of waste have been disposed at the Nevada Test Site Radioactive Waste Management Complex.

\begin{tabular}{|l|l|l|l|}
\hline \multicolumn{1}{|c|}{$\begin{array}{c}\text { Waste Stream } \\
\text { Identification \# }\end{array}$} & \multicolumn{1}{c|}{ Package \# } & \multicolumn{1}{c|}{ Date of Disposal } \\
\hline DPL10497 & LRY5LLFY08002 & 10 L781 & $6 / 3 / 10$ \\
\hline DPL10497 & LRY5LLFY08002 & 10 L782 & $6 / 3 / 10$ \\
\hline & & & \\
\hline & & & \\
\hline & & & \\
\hline & & & \\
\hline & & & \\
\hline
\end{tabular}

This certification is provided as a courtesy to the waste generator for information purposes only.

/s/ :Theresa Hale

WGS Signature

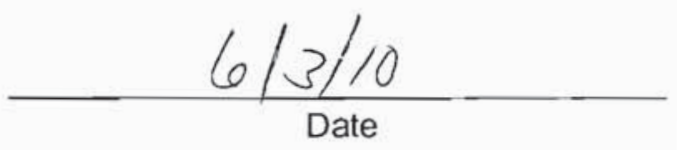

Waste Inspector

Title

/s/ :Jon Tanka

RẂMC Signature

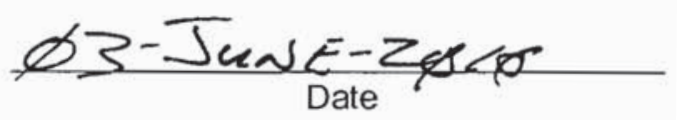

(Reference: OP-2151.304) 
NSTec

Form

FRM-2217
CERTIFICATE OF DISPOSAL

(LOW LEVEL WASTE)
03/01/10

Rev. 01

Page 1 of 1

\section{Nevada Test Site}

This Certificate acknowledges that the following shipment(s) of waste have been disposed at the Nevada Test Site Radioactive Waste Management Complex.

\begin{tabular}{|l|l|l|l|}
\hline Shipment Number & $\begin{array}{c}\text { Waste Stream } \\
\text { Identification \# }\end{array}$ & Package \# & Date of Disposal \\
\hline DPL10101 & LRY5LLFY08002 & 10 L167 & $6 / 7 / / 0$ \\
\hline & & & \\
\hline & & & \\
\hline & & & \\
\hline
\end{tabular}

This certification is provided as a courtesy to the waste generator for information purposes only.

/s/:Theresa Hale

$$
\text { WGS Signature }
$$

Waste Inspector

$$
\text { Title }
$$

/s/:Jon Tanaka
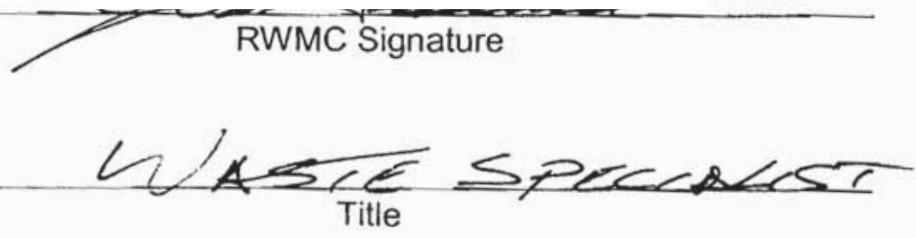

$$
6 / \frac{71 / 0}{\text { Date }}
$$

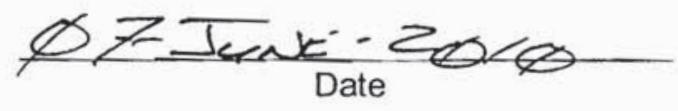




\begin{tabular}{|lcr|}
\hline NSTec & CERTIFICATE OF DISPOSAL & R/01/10 \\
Form & Rev. 01 \\
FRM-2217 & (LOW LEVEL WASTE) & Page 1 of 1 \\
\hline
\end{tabular}

Nevada Test Site

This Certificate acknowledges that the following shipments) of waste have been disposed at the Nevada Test Site Radioactive Waste Management Complex.

\begin{tabular}{|l|l|l|l|}
\hline Shipment Number & $\begin{array}{c}\text { Waste Stream } \\
\text { Identification \# }\end{array}$ & \multicolumn{1}{c|}{ Package \# } & Date of Disposal \\
\hline DPL10102 & LRY5LLFY8002 & 10 L168 & $6-7-10$ \\
\hline & & & \\
\hline & & & \\
\hline & & & \\
\hline & & & \\
\hline & & & \\
\hline & & & \\
\hline & & & \\
\hline
\end{tabular}

This certification is provided as a courtesy to the waste generator for information purposes only.

/s/ :Theresa Hale

WGS Signature

Waste Inspector

Title

/s/ :Jon Tanaka

RWMC Signature

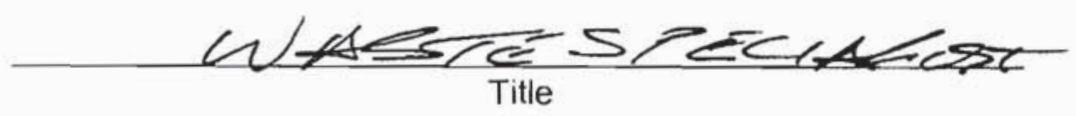

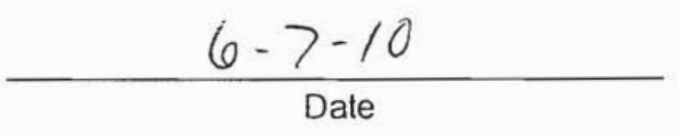

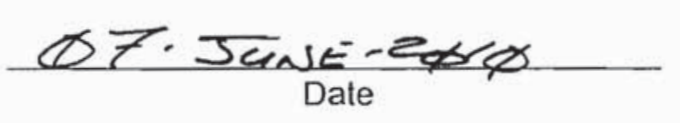

(Reference: OP-2151.304) 


\begin{tabular}{|lcr|}
\hline NSTec & CERTIFICATE OF DISPOSAL & $03 / 01 / 10$ \\
Form & Rev. 01 \\
FRM-2217 & (LOW LEVEL WASTE) & Page 1 of 1 \\
\hline
\end{tabular}

Nevada Test Site

This Certificate acknowledges that the following shipments) of waste have been disposed at the Nevada Test Site Radioactive Waste Management Complex.

\begin{tabular}{|l|l|l|l|}
\hline \multicolumn{1}{|c|}{$\begin{array}{c}\text { Waste Stream } \\
\text { Identification \# }\end{array}$} & \multicolumn{1}{|c|}{ Package \# } & \multicolumn{1}{c|}{ Date of Disposal } \\
\hline DPL10498 & LRY5LLFY08002 & $10 L 783$ & $6 / 7 / 10$ \\
\hline DPL10498 & LRY5LLFY08002 & 10 L 784 & $6 / 7 / 10$ \\
\hline & & & \\
\hline & & & \\
\hline & & & \\
\hline & & & \\
\hline & & & \\
\hline & & & \\
\hline
\end{tabular}

This certification is provided as a courtesy to the waste generator for information purposes only.

/s/ :Theresa Hale

WGS Signature

Waste Inspector

Title

/s/ :Jon Kanaka
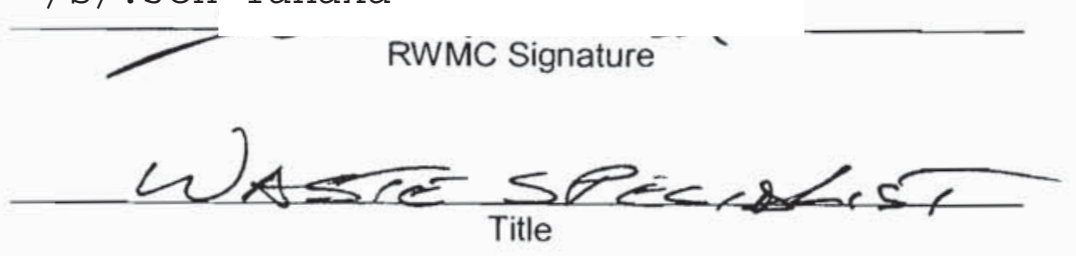
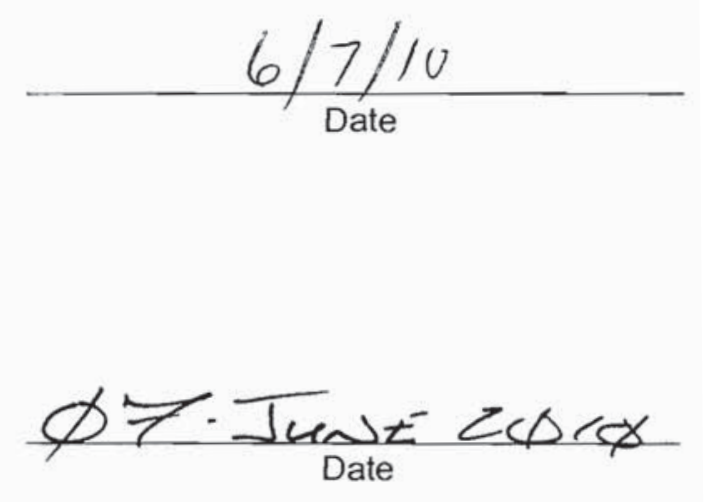

(Reference: OP-2151.304) 


\begin{tabular}{|lcr|}
\hline NSTec & CERTIFICATE OF DISPOSAL & $03 / 01 / 10$ \\
Form & Rev. 01 \\
FRM-2217 & (LOW LEVEL WASTE) & Page 1 of 1 \\
\hline
\end{tabular}

Nevada Test Site

This Certificate acknowledges that the following shipments) of waste have been disposed at the Nevada Test Site Radioactive Waste Management Complex.

\begin{tabular}{|l|l|l|l|}
\hline Shipment Number & \multicolumn{1}{|c|}{$\begin{array}{c}\text { Waste Stream } \\
\text { Identification \# }\end{array}$} & \multicolumn{1}{|c|}{ Package \# } & Date of Disposal \\
\hline DPL10499 & LRY5LLFY08002 & 10 L785 & $6 / 7 / 10$ \\
\hline DPL10499 & LRY5LLFY08002 & 10 L786 & $6 / 7 / 10$ \\
\hline & & & \\
\hline & & & \\
\hline & & & \\
\hline & & & \\
\hline & & & \\
\hline & & & \\
\hline
\end{tabular}

This certification is provided as a courtesy to the waste generator for information purposes only.

$$
\text { /s/ :Theresa Hale }
$$

WGS Signature

Waste Inspector

Title

/s/ :Jon Tanaka

RWMC Signature

$6 / 7 / 10$

(Reference: OP-2151.304) 
NSTec

Form

FRM-2217
CERTIFICATE OF DISPOSAL

(LOW LEVEL WASTE)
03/01/10

Rev. 01

Page 1 of 1

\section{Nevada Test Site}

This Certificate acknowledges that the following shipment(s) of waste have been disposed at the Nevada Test Site Radioactive Waste Management Complex.

\begin{tabular}{|c|c|c|c|}
\hline Shipment Number & $\begin{array}{l}\text { Waste Stream } \\
\text { Identification \# }\end{array}$ & Package \# & Date of Disposal \\
\hline DPL10500 & LRY5LLFY08002 & $10 L 787$ & $6-7-10$ \\
\hline DPL10500 & LRY5LLFY08002 & 10L788 & $6 \cdot 7-10$ \\
\hline & & & \\
\hline & & & \\
\hline & & & \\
\hline & & & \\
\hline & & & \\
\hline & & & \\
\hline
\end{tabular}

This certification is provided as a courtesy to the waste generator for information purposes only.

/s/: Theresa Hale

$$
\text { WGS Signature }
$$

Waste Inspector

Title

/s/:Jon Tanaka

RWMC Signature

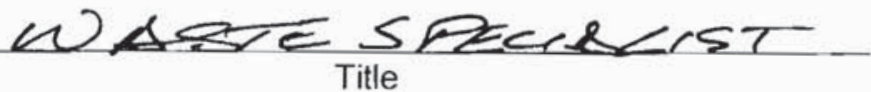

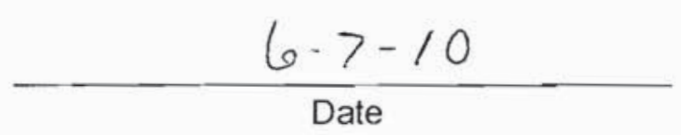

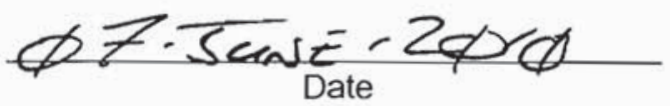




\begin{tabular}{|lcr|}
\hline NSTec & CERTIFICATE OF DISPOSAL & R/01/10 \\
Form & Rev. 01 \\
FRM-2217 & (LOW LEVEL WASTE) & Page 1 of 1 \\
\hline
\end{tabular}

Nevada Test Site

This Certificate acknowledges that the following shipments) of waste have been disposed at the Nevada Test Site Radioactive Waste Management Complex.

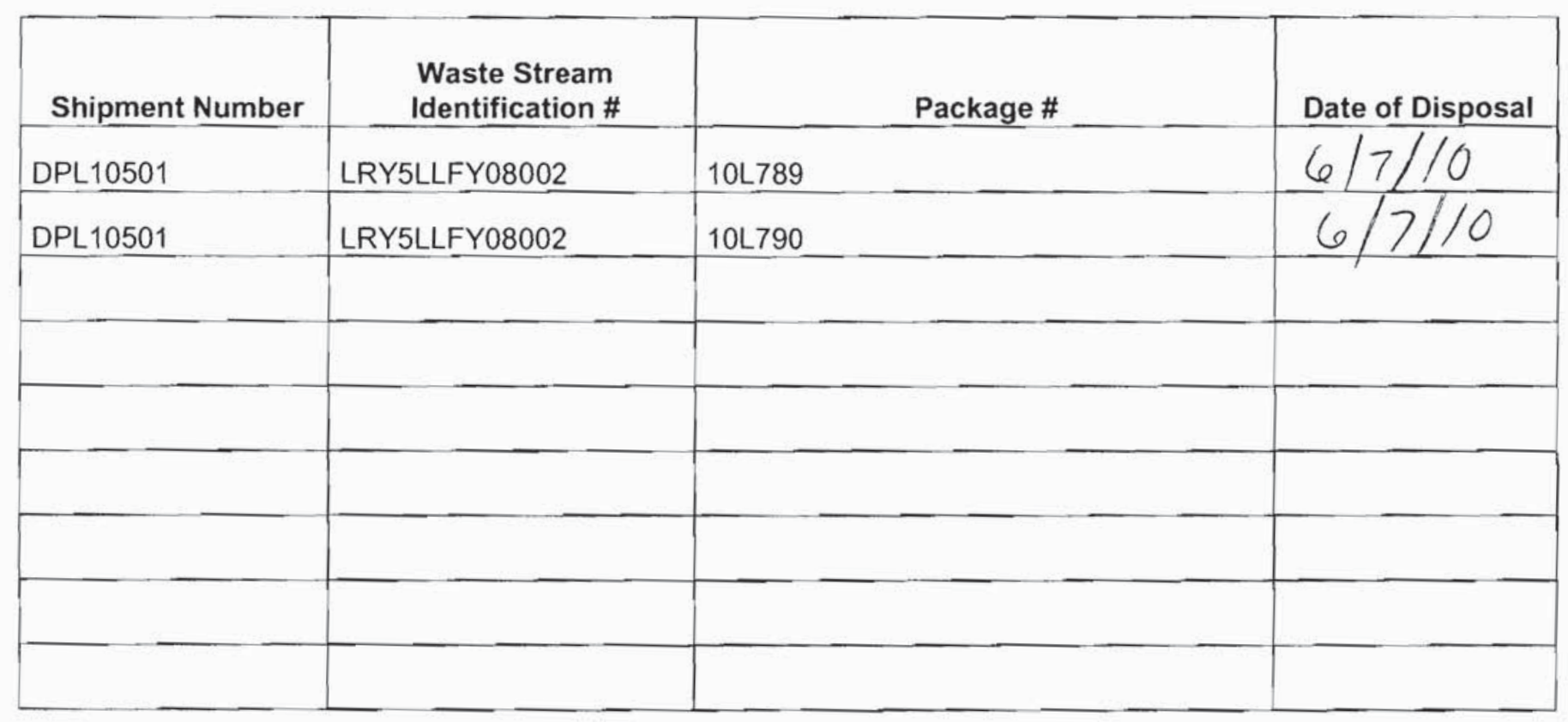

This certification is provided as a courtesy to the waste generator for information purposes only.

/s/ :Theresa Hale

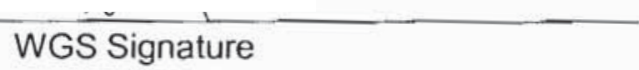

Waste Inspector

Title

/s/: Jon Kanaka
RẄMC Signature $\ldots$

Title
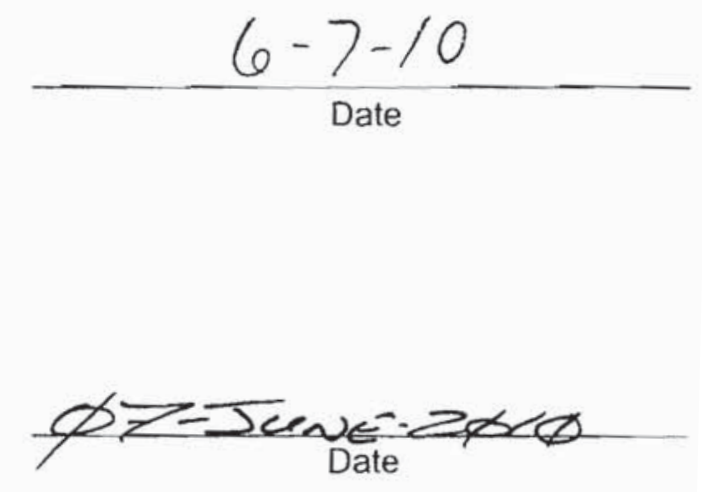

IDafomman ND_2151 3กA1 
NSTec

Form

FRM-2217
CERTIFICATE OF DISPOSAL

(LOW LEVEL WASTE)
03/01/10

Rev. 01

Page 1 of 1

\section{Nevada Test Site}

This Certificate acknowledges that the following shipment(s) of waste have been disposed at the Nevada Test Site Radioactive Waste Management Complex.

\begin{tabular}{|l|l|l|l|}
\hline Shipment Number & $\begin{array}{c}\text { Waste Stream } \\
\text { Identification \# }\end{array}$ & Package \# & Date of Disposal \\
\hline DPL10502 & LRY5LLFY08002 & $10 L 791$ & $6 / 7 / 10$ \\
\hline DPL10502 & LRY5LLFY08002 & 10 L792 & $6 / 7 / 10$ \\
\hline & & & \\
\hline & & & \\
\hline
\end{tabular}

This certification is provided as a courtesy to the waste generator for information purposes only.

/s/:Theresa Hale

WGS Signature

Waste Inspector

Title

/s/:Jon Tanaka

RWMC Signature

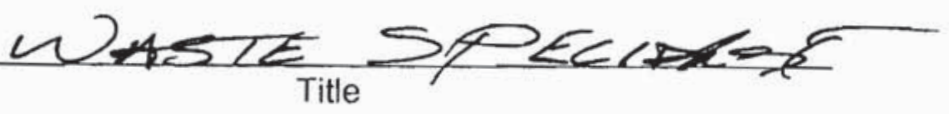

$-\frac{6-7-10}{\text { Date }}$

$\frac{\phi 7 \cdot J_{N}=Z_{\text {Date }}}{\phi \phi}$ 
NSTec

Form

CERTIFICATE OF DISPOSAL

$03 / 01 / 10$

FRM-2217

(LOW LEVEL WASTE)

Rev. 01

Page 1 of 1

\section{Nevada Test Site}

This Certificate acknowledges that the following shipment(s) of waste have been disposed at the Nevada Test Site Radioactive Waste Management Complex.

\begin{tabular}{|c|c|c|c|c|}
\hline Shipment Number & $\begin{array}{c}\text { Waste Stream } \\
\text { Identification \# }\end{array}$ & Package \# & Date of Disposal \\
\hline DPL10503 & LRY5LLFY08002 & 10 L793 & 10L794 & $6-7-10$ \\
\hline DPL10503 & LRY5LLFY08002 & & & $6-7-10$ \\
\hline & & & & \\
\hline & & & & \\
\hline
\end{tabular}

This certification is provided as a courtesy to the waste generator for information purposes only.

/s/:Theresa Hale

WGS Signature

Waste Inspector

Title

/s/:Jon Tanaka

RWMKC Signature

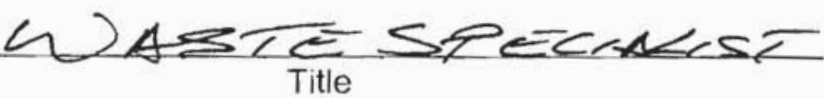

$-\frac{6-7-10}{\text { Date }}$

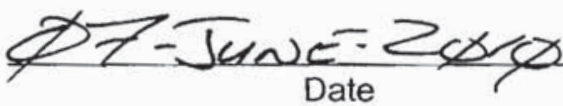


NSTec

Form

FRM-2217
CERTIFICATE OF DISPOSAL

(LOW LEVEL WASTE)
$03 / 01 / 10$

Rev. 01

Page 1 of 1

\section{Nevada Test Site}

This Certificate acknowledges that the following shipment(s) of waste have been disposed at the Nevada Test Site Radioactive Waste Management Complex.

\begin{tabular}{|c|c|c|c|}
\hline Shipment Number & $\begin{array}{l}\text { Waste Stream } \\
\text { Identification \# }\end{array}$ & Package \# & Date of Disposal \\
\hline DPL10504 & LRY5LLFY08002 & $10 L 795$ & $6-7-10$ \\
\hline DPL10504 & LRY5LLFY08002 & $10 L 796$ & $6-7-10$ \\
\hline & & & \\
\hline & & & \\
\hline & & & \\
\hline & & & \\
\hline & & & \\
\hline & & & \\
\hline
\end{tabular}

This certification is provided as a courtesy to the waste generator for information purposes only.

/s/:Theresa Hale

WGS Signature

Waste Inspector

Title
/s/:Jon Tanaka

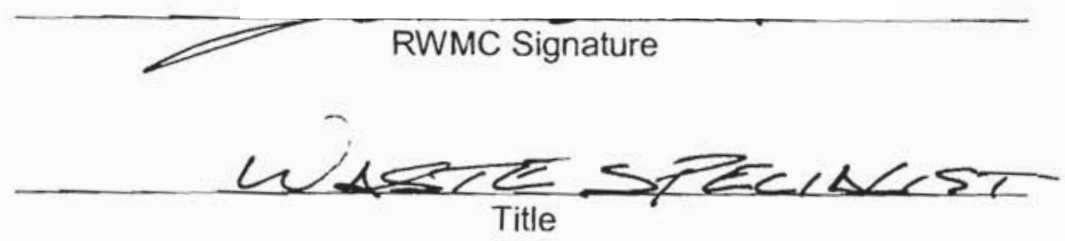

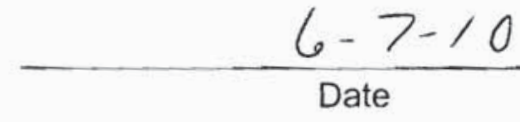

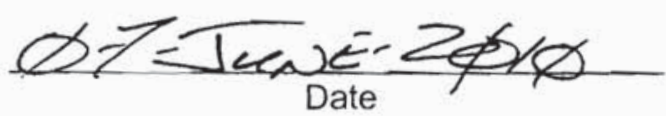


NSTec

Form

CERTIFICATE OF DISPOSAL

03/01/10

FRM-2217

(LOW LEVEL WASTE)

Rev. 01

Page 1 of 1

\section{Nevada Test Site}

This Certificate acknowledges that the following shipment(s) of waste have been disposed at the Nevada Test Site Radioactive Waste Management Complex.

\begin{tabular}{|c|c|c|c|}
\hline Shipment Number & $\begin{array}{l}\text { Waste Stream } \\
\text { Identification \# }\end{array}$ & Package \# & Date of Disposal \\
\hline DPL10103 & LRY5LLFY08002 & 10L169 & $6-\gamma-10$ \\
\hline & & & \\
\hline & & & \\
\hline & & & \\
\hline & & & \\
\hline & & & \\
\hline & & & \\
\hline & & & \\
\hline
\end{tabular}

This certification is provided as a courtesy to the waste generator for information purposes only.

/s/:Theresa Hale

WGS Signature

Waste Inspector

Title

/s/:Jon Tanaka

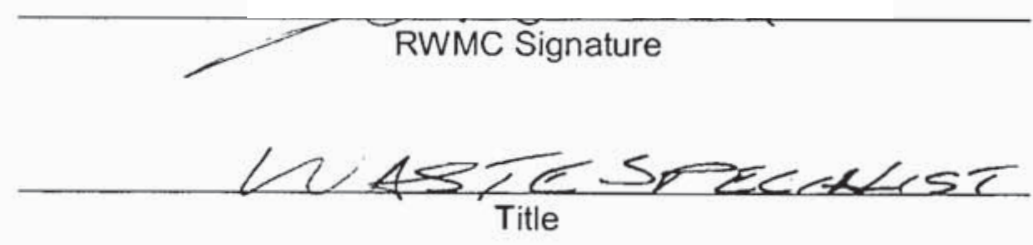

$$
\frac{6-\gamma-10}{\text { Date }}
$$

$\frac{\phi E-I c r a v e-2 \phi r \phi}{\text { Date }}$ 
NSTec
Form

FRM-2217
CERTIFICATE OF DISPOSAL

(LOW LEVEL WASTE)
$03 / 01 / 10$

Rev. 01

Page 1 of 1

\section{Nevada Test Site}

This Certificate acknowledges that the following shipment(s) of waste have been disposed at the Nevada Test Site Radioactive Waste Management Complex.

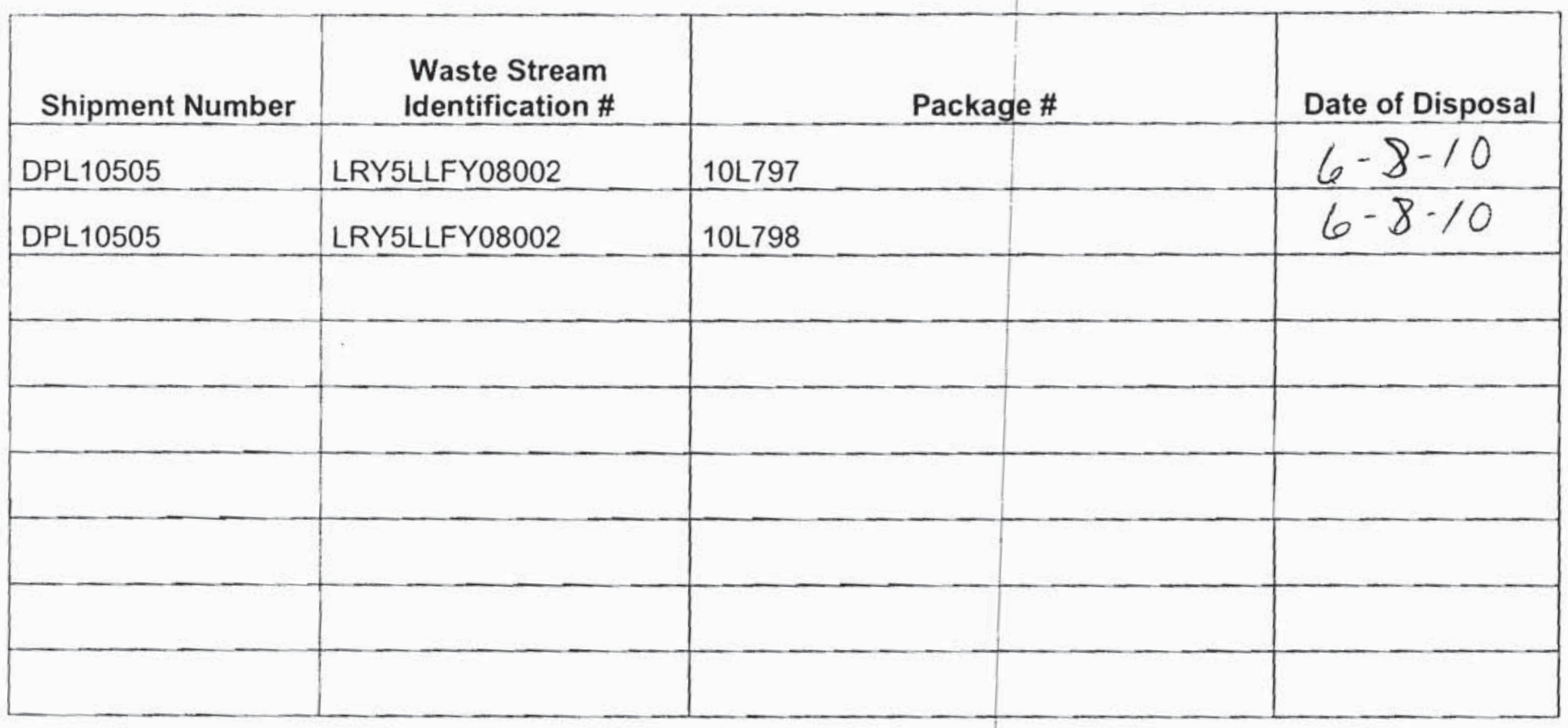

This certification is provided as a courtesy to the waste generator for information purposes only.

/s/: Theresa Hale

$$
\text { WGS Signature }
$$

Waste Inspector

$$
\text { Titie }
$$

/s/:Jon Tanaka

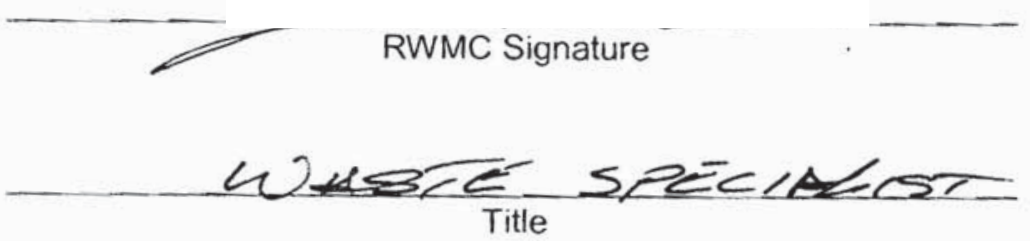

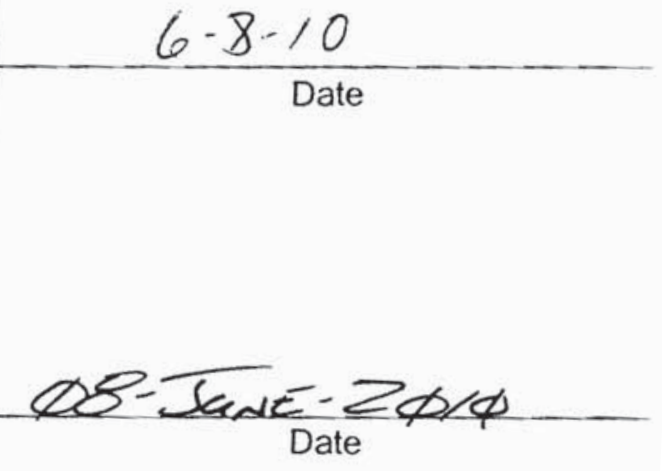




\section{Nevada Test Site}

This Certificate acknowledges that the following shipment(s) of waste have been disposed at the Nevada Test Site Radioactive Waste Management Complex.

\begin{tabular}{|c|c|c|c|}
\hline Shipment Number & $\begin{array}{l}\text { Waste Stream } \\
\text { Identification \# }\end{array}$ & Package \# & Date of Disposal \\
\hline DPL10506 & LRY5LLFY08002 & $10 \mathrm{~L} 799$ & $6-\gamma-10$ \\
\hline DPL10506 & LRY5LLFY08002 & $10 \mathrm{~L} 800$ & $6-8-10$ \\
\hline & & & \\
\hline & & & \\
\hline & & & \\
\hline & & & \\
\hline & & & \\
\hline & & & \\
\hline
\end{tabular}

This certification is provided as a courtesy to the waste generator for information purposes only.

/s/:Theresa Hale

\section{WGS Signature}

Waste Inspector

Title

\section{/s/:Jon Tanaka}

RWMC Signature

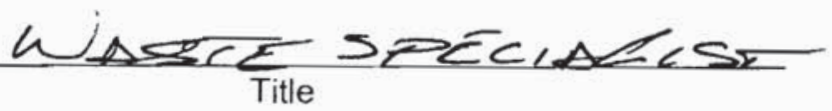

$$
6-8-10
$$

Date

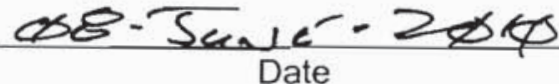




\begin{tabular}{|lrr|}
\hline NSTec & & $03 / 01 / 10$ \\
Form & CERTIFICATE OF DISPOSAL & Rev. 01 \\
FRM-2217 & (LOW LEVEL WASTE) & Page 1 of 1 \\
\hline
\end{tabular}

Nevada Test Site

This Certificate acknowledges that the following shipments) of waste have been disposed at the Nevada Test Site Radioactive Waste Management Complex.

\begin{tabular}{|l|l|l|l|l|}
\hline Shipment Number & $\begin{array}{c}\text { Waste Stream } \\
\text { Identification \# }\end{array}$ & \multicolumn{2}{|c|}{ Package \# } & Date of Disposal \\
\hline DPL10507 & LRY5LLFY08002 & 10 L801 & $6 / 8 / 10$ \\
\hline DPL10507 & LRY5LLFY08002 & 10 L802 & & $6 / 8 / 10$ \\
\hline & & & & \\
\hline & & & & \\
\hline & & & & \\
\hline & & & & \\
\hline & & & & \\
\hline & & & & \\
\hline
\end{tabular}

This certification is provided as a courtesy to the waste generator for information purposes only.

/s/ :Theresa Hale

WGS Signature

Waste Inspector

Title

/s/: Jon Kanaka

RWMic Signature

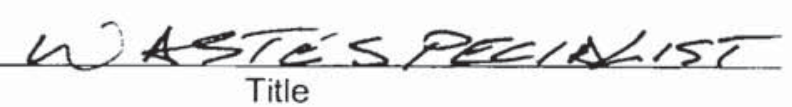

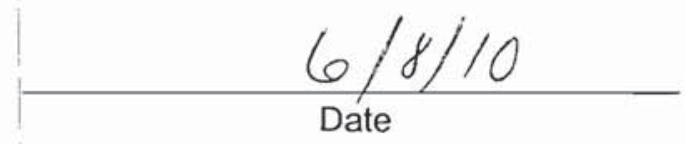

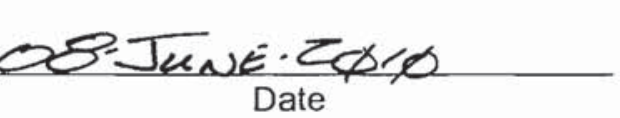




\begin{tabular}{|lcr|}
\hline NSTec & CERTIFICATE OF DISPOSAL & 03/01/10 \\
Form & Rev. 01 \\
FRM-2217 & (LOW LEVEL WASTE) & Page 1 of 1 \\
\hline
\end{tabular}

Nevada Test Site

This Certificate acknowledges that the following shipments) of waste have been disposed at the Nevada Test Site Radioactive Waste Management Complex.

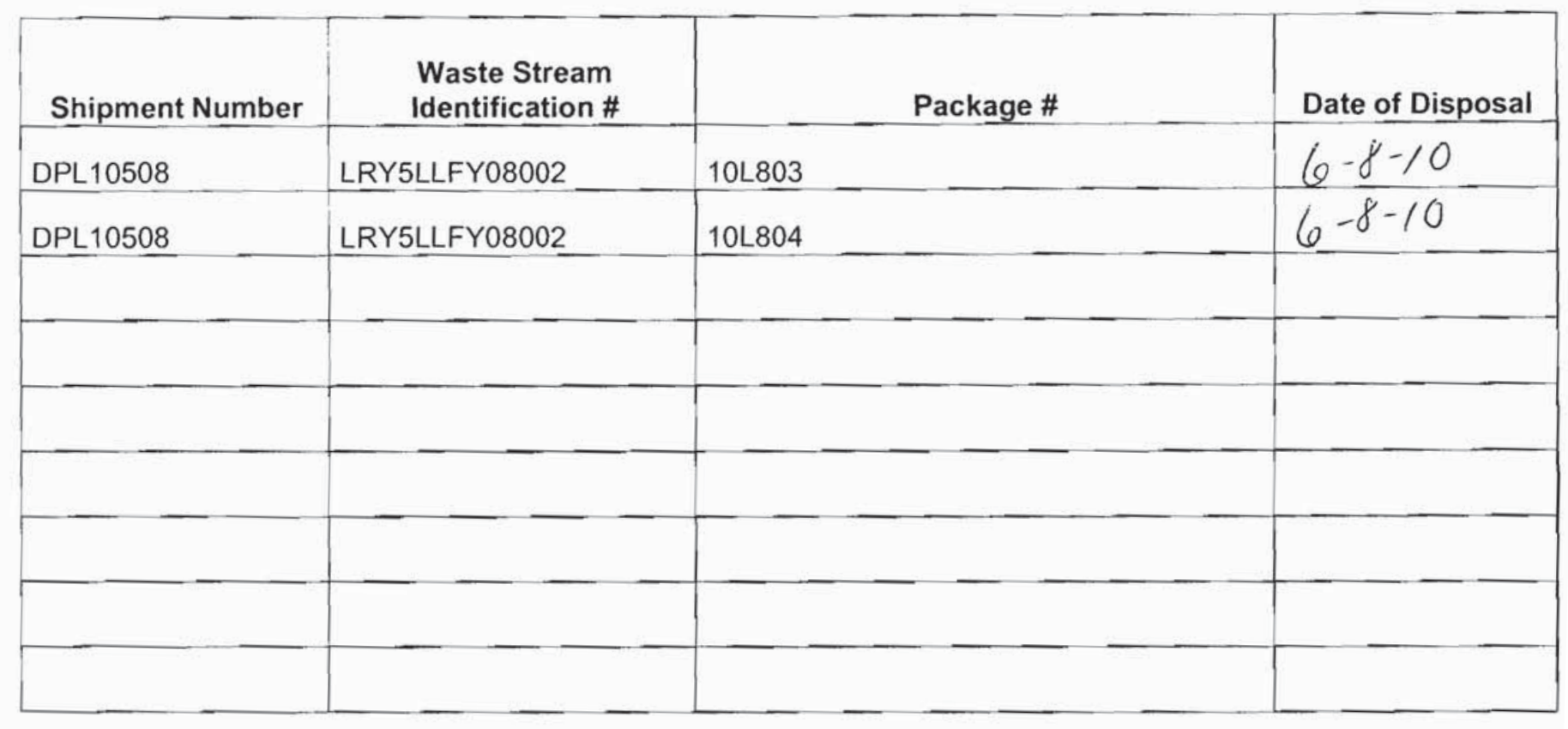

This certification is provided as a courtesy to the waste generator for information purposes only.

/s/ :Theresa Hale

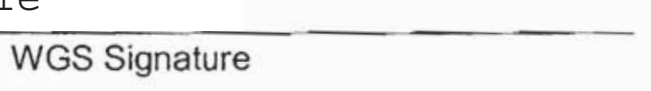

Waste Inspector

Title

RWḾ Signature

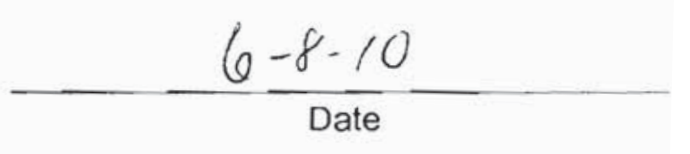

/s/: Jon Tanka

Title 
NSTec

Form

FRM-2217
CERTIFICATE OF DISPOSAL

(LOW LEVEL WASTE)
03/01/10

Rev. 01

Page 1 of 1

\section{Nevada Test Site}

This Certificate acknowledges that the following shipment(s) of waste have been disposed at the Nevada Test Site Radioactive Waste Management Complex.

\begin{tabular}{|l|l|l|l|}
\hline \multicolumn{1}{|c|}{$\begin{array}{c}\text { Waste Stream } \\
\text { Identification \# }\end{array}$} & Package \# & Date of Disposal \\
\hline DPL10509 & LRY5LLFY08002 & 10 L805 & $6-8-10$ \\
\hline DPL10509 & LRY5LLFY08002 & 10 L806 & $6-8-10$ \\
\hline & & & \\
\hline & & & \\
\hline & & & \\
\hline & & & \\
\hline
\end{tabular}

This certification is provided as a courtesy to the waste generator for information purposes only.

/s/: Theresa Hale

WGS Signature

Waste Inspector

Title

/s/:Jon Tanaka

RWMC Signature

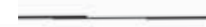

WASTE SPECHACST

Title

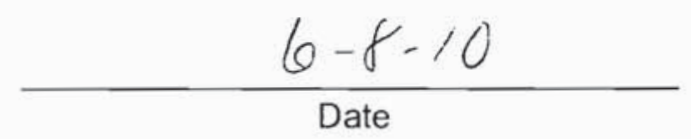

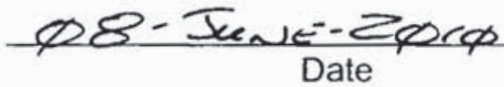


NSTec

Form

FRM-2217
CERTIFICATE OF DISPOSAL

(LOW LEVEL WASTE)
03/01/10

Rev. 01

Page 1 of 1

\section{Nevada Test Site}

This Certificate acknowledges that the following shipment(s) of waste have been disposed at the Nevada Test Site Radioactive Waste Management Complex.

\begin{tabular}{|l|l|l|l|}
\hline \multicolumn{1}{|c|}{$\begin{array}{c}\text { Waste Stream } \\
\text { Identification \# }\end{array}$} & Package \# & Date of Disposal \\
\hline DPL10510 & LRY5LLFY08002 & 10 L807 & $6-8-10$ \\
\hline DPL10510 & LRY5LLFY08002 & 10 L808 & $6-8-10$ \\
\hline & & & \\
\hline & & & \\
\hline & & & \\
\hline & & & \\
\hline
\end{tabular}

This certification is provided as a courtesy to the waste generator for information purposes only.

/s/: Theresa Hale

WGS Signature

Waste Inspector

Title

/s/: Jon Tanaka

RWMC Signature

थ $A=\frac{C E}{\text { Title }} \leq P=C A<\omega T$ $\frac{6-8-10}{\text { Date }}$

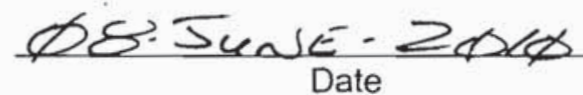


NSTec

Form

FRM-2217
CERTIFICATE OF DISPOSAL

(LOW LEVEL WASTE)
03/01/10

Rev. 01

Page 1 of 1

\section{Nevada Test Site}

This Certificate acknowledges that the following shipment(s) of waste have been disposed at the Nevada Test Site Radioactive Waste Management Complex.

\begin{tabular}{|l|l|l|l|}
\hline \multicolumn{1}{|c|}{$\begin{array}{c}\text { Waste Stream } \\
\text { Identification \# }\end{array}$} & Package \# & Date of Disposal \\
\hline DPL10511 & LRY5LLF08002 & 10 L809 & $6 / 8 / 10$ \\
\hline DPL10511 & LRY5LLFY08002 & 10 L810 & $6 / 8 / / 0$ \\
\hline & & & \\
\hline & & & \\
\hline & & & \\
\hline & & & \\
\hline & & & \\
\hline
\end{tabular}

This certification is provided as a courtesy to the waste generator for information purposes only.

/s/: Theresa Hale

Waste Inspector

$$
\text { Title }
$$

/s/:Jon Tanaka

- RWMC Signature

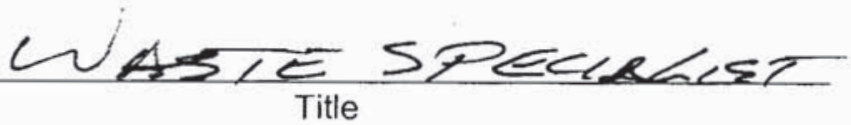

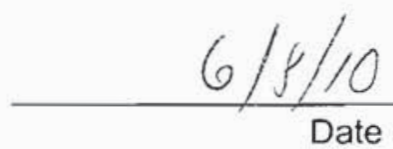

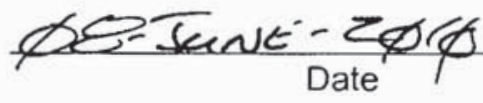


NSTec

Form

FRM-2217
CERTIFICATE OF DISPOSAL

(LOW LEVEL WASTE)
$03 / 01 / 10$

Rev. 01

Page 1 of 1

\section{Nevada Test Site}

This Certificate acknowledges that the following shipment(s) of waste have been disposed at the Nevada Test Site Radioactive Waste Management Complex.

\begin{tabular}{|l|l|l|l|}
\hline \multicolumn{1}{|c|}{ Shipment Number } & \multicolumn{1}{|c|}{$\begin{array}{c}\text { Waste Stream } \\
\text { Identification \# }\end{array}$} & \multicolumn{1}{|c|}{ Package \# } & Date of Disposal \\
\hline DPL10512 & LRY5LLFY08002 & 10 2811 & $6 / 8 / 10$ \\
\hline DPL10512 & LRY5LLFY08002 & 10 L812 & $6 / 8 / 10$ \\
\hline & & & \\
\hline & & & \\
\hline & & & \\
\hline & & & \\
\hline & & & \\
\hline & & & \\
\hline
\end{tabular}

This certification is provided as a courtesy to the waste generator for information purposes only.

/s/:Theresa Hale

$$
\text { WGS Signature }
$$

Waste Inspector

$$
\text { Title }
$$

/s/:Jon Tanaka

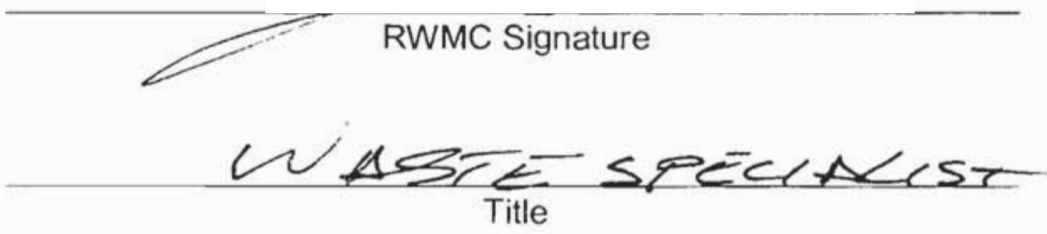

\section{$\frac{6 / 8110}{\text { Date }}$}

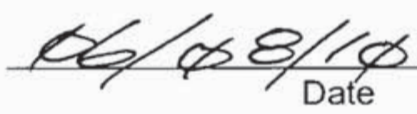




\begin{tabular}{|lcr|}
\hline NSTec & CERTIFICATE OF DISPOSAL & 03/01/10 \\
Form & Rev. 01 \\
FRM-2217 & (LOW LEVEL WASTE) & Page 1 of 1 \\
\hline
\end{tabular}

Nevada Test Site

This Certificate acknowledges that the following shipments) of waste have been disposed at the Nevada Test Site Radioactive Waste Management Complex.

\begin{tabular}{|l|l|l|l|}
\hline Shipment Number & \multicolumn{1}{|c|}{$\begin{array}{c}\text { Waste Stream } \\
\text { Identification \# }\end{array}$} & \multicolumn{1}{|c|}{ Package \# } & Date of Disposal \\
\hline DPL10513 & LRY5LLFY08002 & 10 L813 & $6 / \gamma / 10$ \\
\hline DPL10513 & LRY5LLFY08002 & 10 L814 & $6 / \gamma / 10$ \\
\hline & & & \\
\hline & & & \\
\hline & & & \\
\hline & & & \\
\hline & & & \\
\hline & & & \\
\hline
\end{tabular}

This certification is provided as a courtesy to the waste generator for information purposes only.

/s/: Theresa Hale

WGS Signature

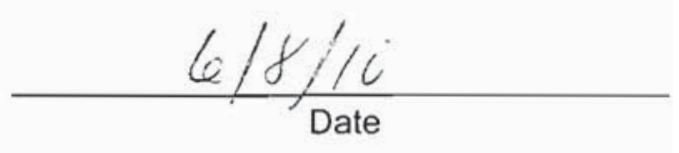

Waste Inspector

Title

/s/: Jon Tanka

RWMC Signature

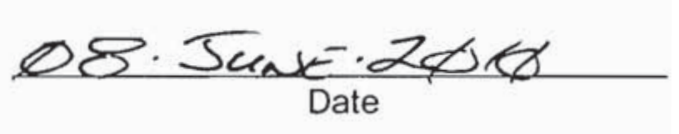




\begin{tabular}{|lcr|}
\hline NSTec & CERTIFICATE OF DISPOSAL & R/o1/10 \\
Form & Rev. 01 \\
FRM-2217 & (LOW LEVEL WASTE) & Page 1 of 1 \\
\hline
\end{tabular}

Nevada Test Site

This Certificate acknowledges that the following shipments) of waste have been disposed at the Nevada Test Site Radioactive Waste Management Complex.

\begin{tabular}{|l|l|l|l|}
\hline \multicolumn{1}{|c|}{ Shipment Number } & \multicolumn{1}{|c|}{$\begin{array}{c}\text { Waste Stream } \\
\text { Identification \# }\end{array}$} & Package \# & Date of Disposal \\
\hline DPL10514 & LRY5LLFY08002 & $10 L 815$ & $6 / 8 / 10$ \\
\hline DPL10514 & LRY5LLFY08002 & 10 L816 & $6 / 8 / 10$ \\
\hline & & & \\
\hline & & & \\
\hline & & & \\
\hline & & & \\
\hline & & & \\
\hline & & & \\
\hline
\end{tabular}

This certification is provided as a courtesy to the waste generator for information purposes only.

/s/ :Theresa Hale

WGS Signature

Waste Inspector

Title

/s/: Jon Kanaka

RWMC Signature

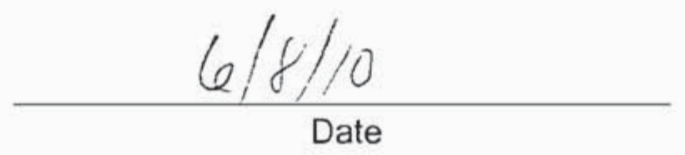

Date

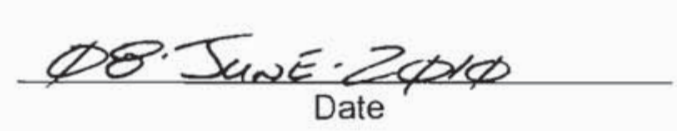

(Reference: OP-2151.304) 
NSTec

Form

FRM-2217
CERTIFICATE OF DISPOSAL

(LOW LEVEL WASTE)
03/01/10

Rev. 01

Page 1 of 1

\section{Nevada Test Site}

This Certificate acknowledges that the following shipment(s) of waste have been disposed at the Nevada Test Site Radioactive Waste Management Complex.

\begin{tabular}{|l|l|l|l|}
\hline \multicolumn{1}{|c|}{$\begin{array}{c}\text { Waste Stream } \\
\text { Identification \# }\end{array}$} & Package \# & Date of Disposal \\
\hline DPL10515 & LRY5LLFY08002 & 10 L817 & $6 / 8 / / 0$ \\
\hline DPL10515 & LRY5LLFY08002 & 10 L818 & $6 / 8 / 0$ \\
\hline & & & \\
\hline & & & \\
\hline & & & \\
\hline & & & \\
\hline
\end{tabular}

This certification is provided as a courtesy to the waste generator for information purposes only.

/s/: Theresa Hale

WGS Signature

Waste Inspector

Title

/s/:Jon Tanaka

RẂMC Signature

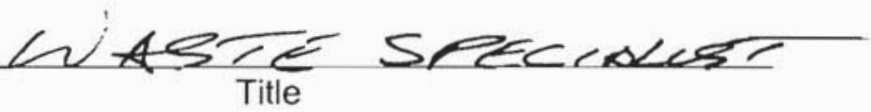

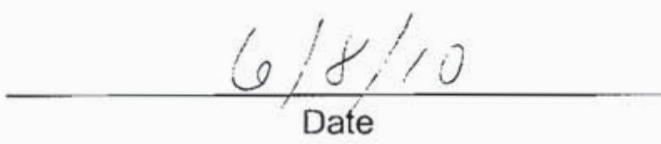

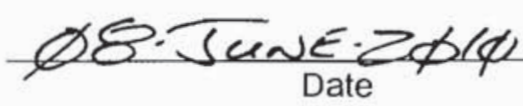




\begin{tabular}{|lcr|}
\hline NSTec & CERTIFICATE OF DISPOSAL & $03 / 01 / 10$ \\
Form & Rev. 01 \\
FRM-2217 & (LOW LEVEL WASTE) & Page 1 of 1 \\
\hline
\end{tabular}

Nevada Test Site

This Certificate acknowledges that the following shipments) of waste have been disposed at the Nevada Test Site Radioactive Waste Management Complex.

\begin{tabular}{|l|l|l|l|}
\hline \multicolumn{1}{|c|}{ Shipment Number } & \multicolumn{1}{|c|}{$\begin{array}{c}\text { Waste Stream } \\
\text { Identification \# }\end{array}$} & Package \# & Date of Disposal \\
\hline DPL10516 & LRY5LLFY08002 & 10 L819 & $6 / 1 / 10$ \\
\hline DPL10516 & LRY5LLFY08002 & 10 L820 & $6 / 1 / 0$ \\
\hline & & & \\
\hline & & & \\
\hline & & & \\
\hline & & & \\
\hline & & & \\
\hline
\end{tabular}

This certification is provided as a courtesy to the waste generator for information purposes only.

/s/: Theresa Hale

WGS Signature

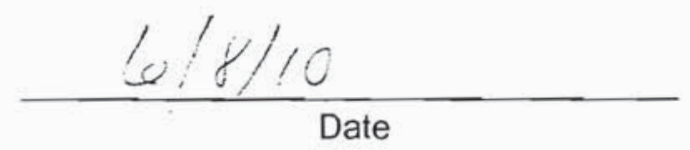

Waste Inspector

Title

/s/: Jon Tanka

RWMC Signature

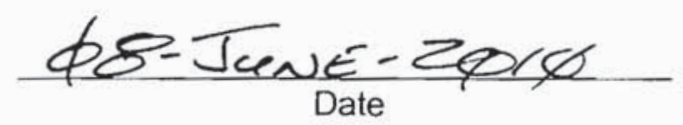

(Reference: OP-2151.304) 
NSTec

Form

FRM-2217
CERTIFICATE OF DISPOSAL

(LOW LEVEL WASTE)
03/01/10

Rev. 01

Page 1 of 1

\section{Nevada Test Site}

This Certificate acknowledges that the following shipment(s) of waste have been disposed at the Nevada Test Site Radioactive Waste Management Complex.

\begin{tabular}{|c|c|c|c|c|}
\hline Shipment Number & $\begin{array}{c}\text { Waste Stream } \\
\text { Identification \# }\end{array}$ & Package \# & Date of Disposal \\
\hline DPL10104 & LRY5LLFY08002 & 10 L170 & & \\
\hline & & & & \\
\hline & & & & \\
\hline & & & & \\
\hline
\end{tabular}

This certification is provided as a courtesy to the waste generator for information purposes only.

$$
\text { /s/:Theresa Hale }
$$

Waste Inspector

$$
\text { Title }
$$

\section{/s/: Jon Tanaka}

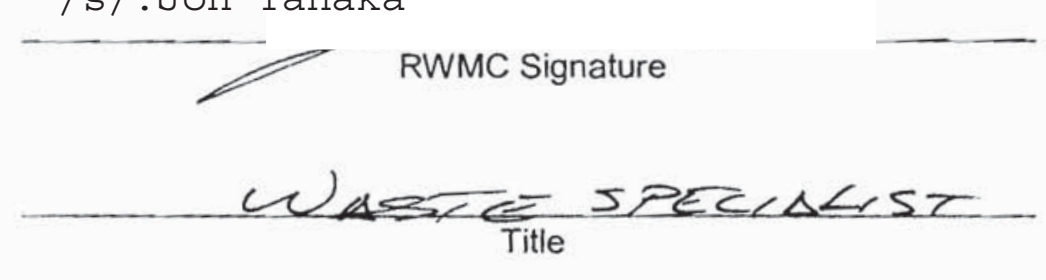

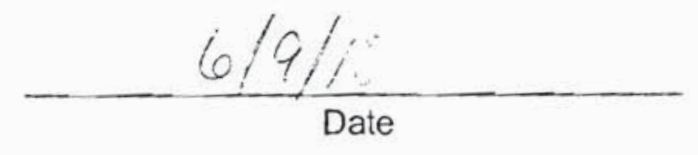

$\frac{\phi 28-3 \times n)-2 \phi / \phi}{\text { Date }}$ 


\begin{tabular}{|lcr|}
\hline NSTec & CERTIFICATE OF DISPOSAL & $03 / 01 / 10$ \\
Form & (LOW LEVEL WASTE) & Rev. 01 \\
FRM-2217 & Page 1 of 1 \\
\hline
\end{tabular}

Nevada Test Site

This Certificate acknowledges that the following shipments) of waste have been disposed at the Nevada Test Site Radioactive Waste Management Complex.

\begin{tabular}{|l|l|l|l|}
\hline Shipment Number & $\begin{array}{c}\text { Waste Stream } \\
\text { Identification \# }\end{array}$ & \multicolumn{1}{|c|}{ Package \# } & Date of Disposal \\
\hline DPL10105 & LRY5LLFY08002 & 10 171 & $6 / 9 / 10$ \\
\hline & & & \\
\hline & & & \\
\hline & & & \\
\hline & & & \\
\hline & & & \\
\hline & & & \\
\hline & & & \\
\hline
\end{tabular}

This certification is provided as a courtesy to the waste generator for information purposes only.

/s/ :Theresa Hale

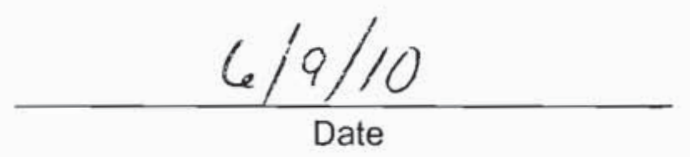

Waste Inspector

Title

/s/ :Jon Kanaka

RWMC Signature

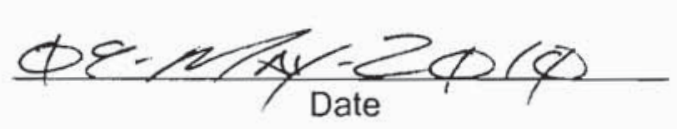




\begin{tabular}{|lcr|}
\hline NSTec & CERTIFICATE OF DISPOSAL & $03 / 01 / 10$ \\
Form & Rev. 01 \\
FRM-2217 & (LOW LEVEL WASTE) & Page 1 of 1 \\
\hline
\end{tabular}

Nevada Test Site

This Certificate acknowledges that the following shipments) of waste have been disposed at the Nevada Test Site Radioactive Waste Management Complex.

\begin{tabular}{|l|l|l|l|}
\hline \multicolumn{1}{|c|}{$\begin{array}{c}\text { Waste Stream } \\
\text { Identification \# }\end{array}$} & Package \# & Date of Disposal \\
\hline DPL10517 & LRY5LLFY08002 & 10 L821 & $6 / 9 / / 0$ \\
\hline DPL10517 & LRY5LLFY08002 & 10 L822 & $6 / 9 / / 0$ \\
\hline & & & \\
\hline & & & \\
\hline & & & \\
\hline & & & \\
\hline & & & \\
\hline
\end{tabular}

This certification is provided as a courtesy to the waste generator for information purposes only.

$$
\text { /s/: Theresa Hale }
$$

WGS Signature

Waste Inspector

Title

/s/ :Jon Kanaka

RWMC Signature

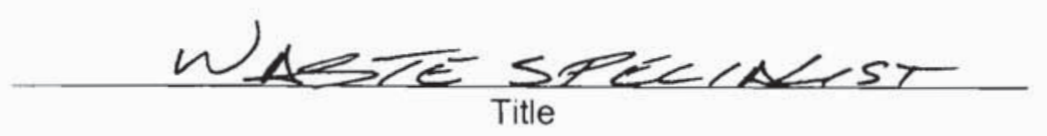

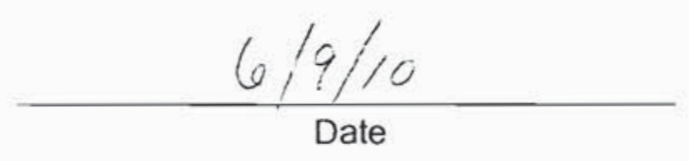

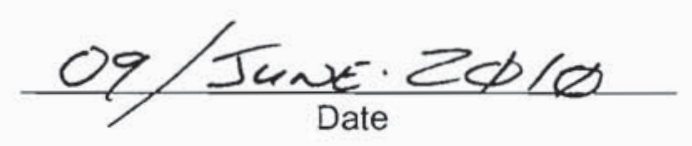

(Reference: OP-2151.304) 


\begin{tabular}{|lcr|}
\hline NSTec & CERTIFICATE OF DISPOSAL & 03/01/10 \\
Form & Rev. 01 \\
FRM-2217 & (LOW LEVEL WASTE) & Page 1 of 1 \\
\hline
\end{tabular}

Nevada Test Site

This Certificate acknowledges that the following shipments) of waste have been disposed at the Nevada Test Site Radioactive Waste Management Complex.

\begin{tabular}{|l|l|l|c|}
\hline Shipment Number & \multicolumn{1}{|c|}{$\begin{array}{c}\text { Waste Stream } \\
\text { Identification \# }\end{array}$} & Package \# & Date of Disposal \\
\hline DPL10518 & LRY5LLFY08002 & 10 L823 & $\% / 9 / 10$ \\
\hline DPL10518 & LRY5LLFY08002 & 10 L824 & $6 / 10$ \\
\hline & & & \\
\hline & & & \\
\hline & & & \\
\hline & & & \\
\hline & & & \\
\hline & & & \\
\hline
\end{tabular}

This certification is provided as a courtesy to the waste generator for information purposes only.

/s/ :Theresa Hale

WGS Signature

Waste Inspector

Title

/s/: Jon Tanka

RWMC Signature

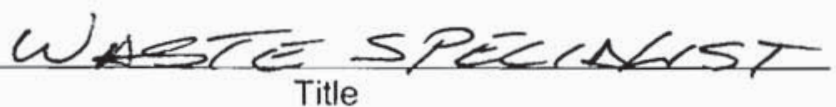

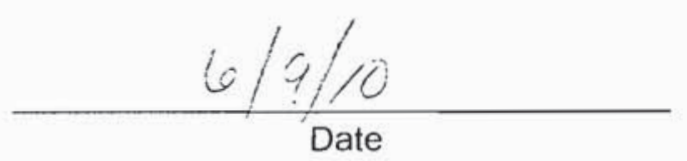

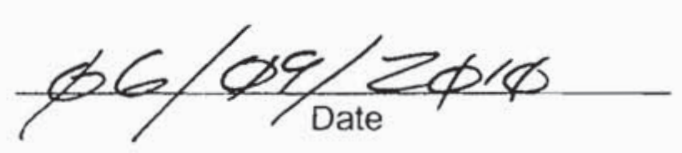

(Reference: OP-2151.304) 


\begin{tabular}{|lcr|}
\hline NSTec & CERTIFICATE OF DISPOSAL & 03/01/10 \\
Form & Rev. 01 \\
FRM-2217 & (LOW LEVEL WASTE) & Page 1 of 1 \\
\hline
\end{tabular}

Nevada Test Site

This Certificate acknowledges that the following shipments) of waste have been disposed at the Nevada Test Site Radioactive Waste Management Complex.

\begin{tabular}{|l|l|l|l|}
\hline \multicolumn{1}{|c|}{ Shipment Number } & \multicolumn{1}{|c|}{$\begin{array}{c}\text { Waste Stream } \\
\text { Identification \# }\end{array}$} & Package \# & Date of Disposal \\
\hline DPL10519 & LRY5LLFY08002 & 10 L825 & $6 / 9 / / 0$ \\
\hline DPL10519 & LRY5LLFY08002 & 10 L826 & $6 / 9 / 0$ \\
\hline & & & \\
\hline & & & \\
\hline & & & \\
\hline & & & \\
\hline & & & \\
\hline & & & \\
\hline
\end{tabular}

This certification is provided as a courtesy to the waste generator for information purposes only.

/s/ :Theresa Hale

WGS Signature

Waste Inspector

Title

/s/ :Jon Tanka

RWMC Signature

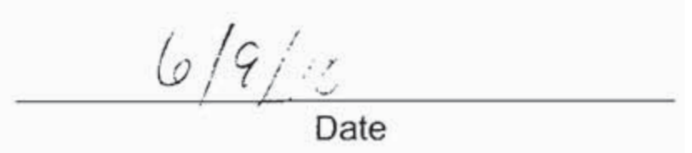

Date

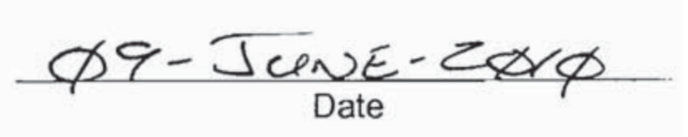

(Reference: OP-2151.304) 
NSTec

Form

FRM-2217
CERTIFICATE OF DISPOSAL

(LOW LEVEL WASTE)
$03 / 01 / 10$

Rev. 01

Page 1 of 1

\section{Nevada Test Site}

This Certificate acknowledges that the following shipment(s) of waste have been disposed at the Nevada Test Site Radioactive Waste Management Complex.

\begin{tabular}{|l|l|l|l|}
\hline \multicolumn{1}{|c|}{$\begin{array}{c}\text { Waste Stream } \\
\text { Identification \# }\end{array}$} & Package \# & Date of Disposal \\
\hline DPL10520 & LRY5LLFY08002 & 10 L827 & $6 / 9 / 10$ \\
\hline DPL10520 & LRY5LLFY08002 & 10 L828 & \\
\hline & & & \\
\hline & & & \\
\hline & & & \\
\hline & & & \\
\hline & & & \\
\hline
\end{tabular}

This certification is provided as a courtesy to the waste generator for information purposes only.

/s/: Theresa Hale

WGS Signature

Waste Inspector

Title

/s/:Jon Tanaka

RWMC Signature

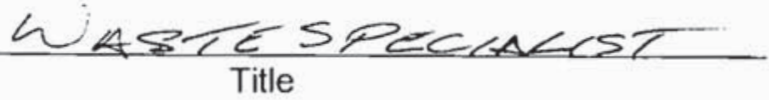

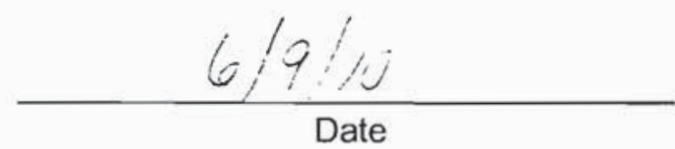

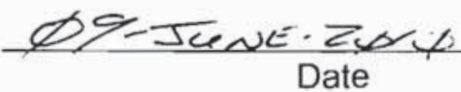


NSTec

Form

FRM-2217
CERTIFICATE OF DISPOSAL

(LOW LEVEL WASTE)
$03 / 01 / 10$

Rev. 01

Page 1 of 1

\section{Nevada Test Site}

This Certificate acknowledges that the following shipment(s) of waste have been disposed at the Nevada Test Site Radioactive Waste Management Complex.

\begin{tabular}{|l|l|l|l|}
\hline \multicolumn{1}{|c|}{ Shipment Number } & \multicolumn{1}{c|}{$\begin{array}{c}\text { Waste Stream } \\
\text { Identification \# }\end{array}$} & Package \# & Date of Disposal \\
\hline DPL10521 & LRY5LLFY08002 & 10 L829 & $6: 1 / 10$ \\
\hline DPL10521 & LRY5LLFY08002 & 10 L830 & \\
\hline & & & \\
\hline & & & \\
\hline & & & \\
\hline & & & \\
\hline & & & \\
\hline & & & \\
\hline
\end{tabular}

This certification is provided as a courtesy to the waste generator for information purposes only.

/s/:Theresa Hale

WGS Signature

Waste Inspector

Title

/s/: Jon Tanaka

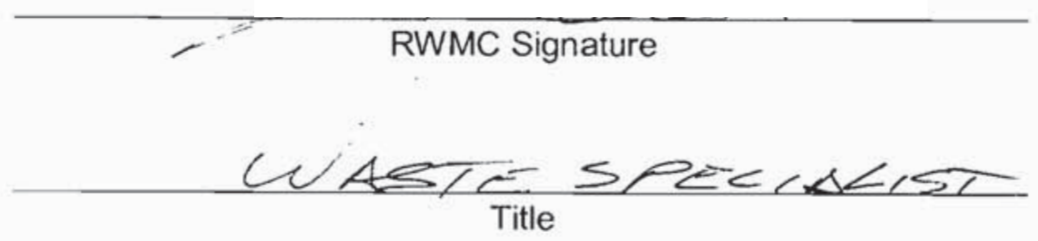

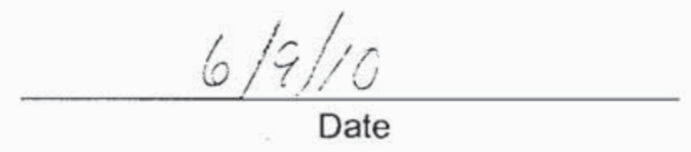

$\phi 9-3 e n s \quad 20 x$ 


\begin{tabular}{|lcr|}
\hline NSTec & CERTIFICATE OF DISPOSAL & $03 / 01 / 10$ \\
Form & Rev. 01 \\
FRM-2217 & (LOW LEVEL WASTE) & Page 1 of 1 \\
\hline
\end{tabular}

Nevada Test Site

This Certificate acknowledges that the following shipments) of waste have been disposed at the Nevada Test Site Radioactive Waste Management Complex.

\begin{tabular}{|l|l|l|c|}
\hline \multicolumn{1}{|c|}{ Shipment Number } & \multicolumn{1}{|c|}{$\begin{array}{c}\text { Waste Stream } \\
\text { Identification \# }\end{array}$} & Package \# & Date of Disposal \\
\hline DPL10522 & LRY5LLFY08002 & 10 L831 & $6 / 9 / / 0$ \\
\hline DPL10522 & LRY5LLFY08002 & 10 L832 & $6 / 4 / 10$ \\
\hline & & & \\
\hline & & & \\
\hline & & & \\
\hline & & & \\
\hline & & & \\
\hline & & & \\
\hline
\end{tabular}

This certification is provided as a courtesy to the waste generator for information purposes only.

$$
\text { /s/ :Theresa Hale }
$$

WGS Signature

Waste Inspector

Title
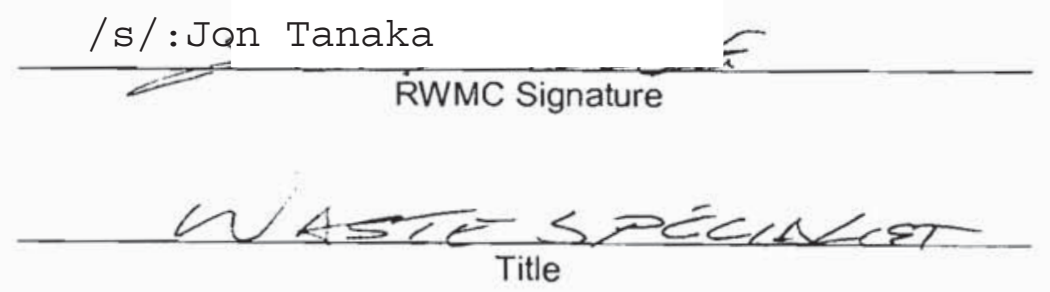
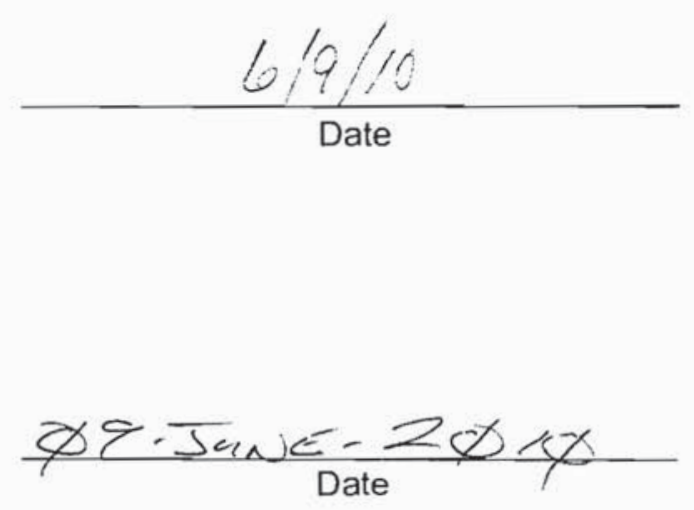

(Reference: OP-2151.304) 
NSTec

Form

CERTIFICATE OF DISPOSAL

03/01/10

FRM-2217

(LOW LEVEL WASTE)

Rev. 01

Page 1 of 1

\section{Nevada Test Site}

This Certificate acknowledges that the following shipment(s) of waste have been disposed at the Nevada Test Site Radioactive Waste Management Complex.

\begin{tabular}{|l|l|l|l|}
\hline Shipment Number & \multicolumn{1}{|c|}{$\begin{array}{c}\text { Waste Stream } \\
\text { Identification \# }\end{array}$} & Package \# & Date of Disposal \\
\hline DPL10523 & LRY5LLFY08002 & 10 L833 & J/Y//C \\
\hline DPL10523 & LRY5LLFY08002 & 10 L834 & \& / / $/ \mathrm{C}$ \\
\hline & & & \\
\hline & & & \\
\hline & & & \\
\hline & & & \\
\hline
\end{tabular}

This certification is provided as a courtesy to the waste generator for information purposes only.

/s/:Theresa Hale

WGS Signature

Waste Inspector

Title

/s/:Jon Tanaka

RWMC Signature

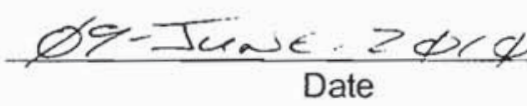


Form

(LOW LEVEL WASTE)

Rev. 01

FRM-2217

\section{Nevada Test Site}

This Certificate acknowledges that the following shipment(s) of waste have been disposed at the Nevada Test Site Radioactive Waste Management Complex.

\begin{tabular}{|l|l|l|l|}
\hline \multicolumn{1}{|c|}{$\begin{array}{c}\text { Waste Stream } \\
\text { Identification \# }\end{array}$} & Package \# & Date of Disposal \\
\hline DPL10524 & LRY5LLFY08002 & 10 L835 & \\
\hline DPL10524 & LRY5LLFY08002 & 10 L836 & \\
\hline & & & \\
\hline & & & \\
\hline & & & \\
\hline & & & \\
\hline
\end{tabular}

This certification is provided as a courtesy to the waste generator for information purposes only.

/s/: Theresa Hale

WGS Signature

Waste Inspector

Title

/s/:Jon Tanaka

RWMC Signature

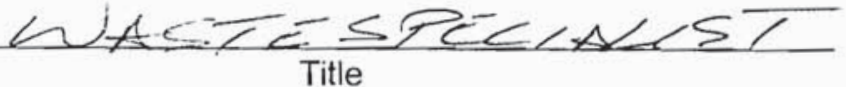

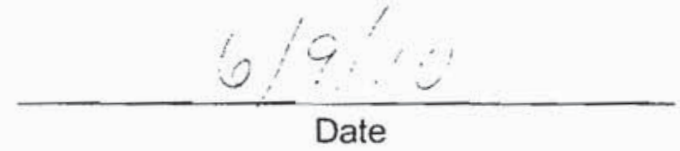

eq-June- 2040 


\begin{tabular}{|lcr|}
\hline NSTec & CERTIFICATE OF DISPOSAL & $03 / 01 / 10$ \\
Form & Rev. 01 \\
FRM-2217 & (LOW LEVEL WASTE) & Page 1 of 1 \\
\hline
\end{tabular}

Nevada Test Site

This Certificate acknowledges that the following shipments) of waste have been disposed at the Nevada Test Site Radioactive Waste Management Complex.

\begin{tabular}{|l|l|l|c|}
\hline \multicolumn{1}{|c|}{ Shipment Number } & \multicolumn{1}{c|}{$\begin{array}{c}\text { Waste Stream } \\
\text { Identification \# }\end{array}$} & Package \# & Date of Disposal \\
\hline DPL10525 & LRY5LLFY08002 & 10 L837 & 0 \\
\hline DPL10525 & LRY5LLFY08002 & 10 L838 & 1 \\
\hline & & & \\
\hline & & & \\
\hline & & & \\
\hline & & & \\
\hline & & & \\
\hline
\end{tabular}

This certification is provided as a courtesy to the waste generator for information purposes only.

/s/ :Theresa Hale

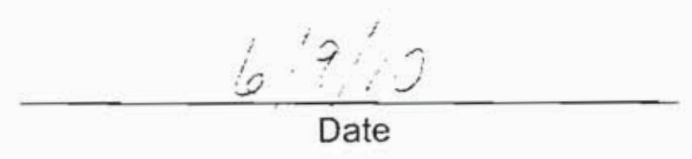

Waste Inspector

Title

/s/ :Jon Tanaka

RWMC Signature

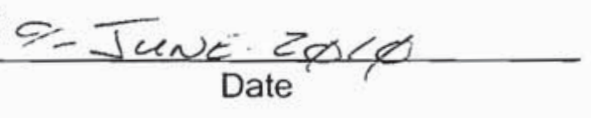




\begin{tabular}{|lcr|}
\hline NSTec & CERTIFICATE OF DISPOSAL & $03 / 01 / 10$ \\
Form & Rev. 01 \\
FRM-2217 & (LOW LEVEL WASTE) & Page 1 of 1 \\
\hline
\end{tabular}

Nevada Test Site

This Certificate acknowledges that the following shipments) of waste have been disposed at the Nevada Test Site Radioactive Waste Management Complex.

\begin{tabular}{|l|l|l|l|}
\hline Shipment Number & $\begin{array}{c}\text { Waste Stream } \\
\text { Identification \# }\end{array}$ & Package \# & Date of Disposal \\
\hline DPL10106 & LRY5LLFY08002 & $10 \mathrm{~L} 172$ & iloilo \\
\hline & & & \\
\hline & & & \\
\hline & & & \\
\hline & & & \\
\hline & & & \\
\hline & & & \\
\hline & & & \\
\hline
\end{tabular}

This certification is provided as a courtesy to the waste generator for information purposes only.

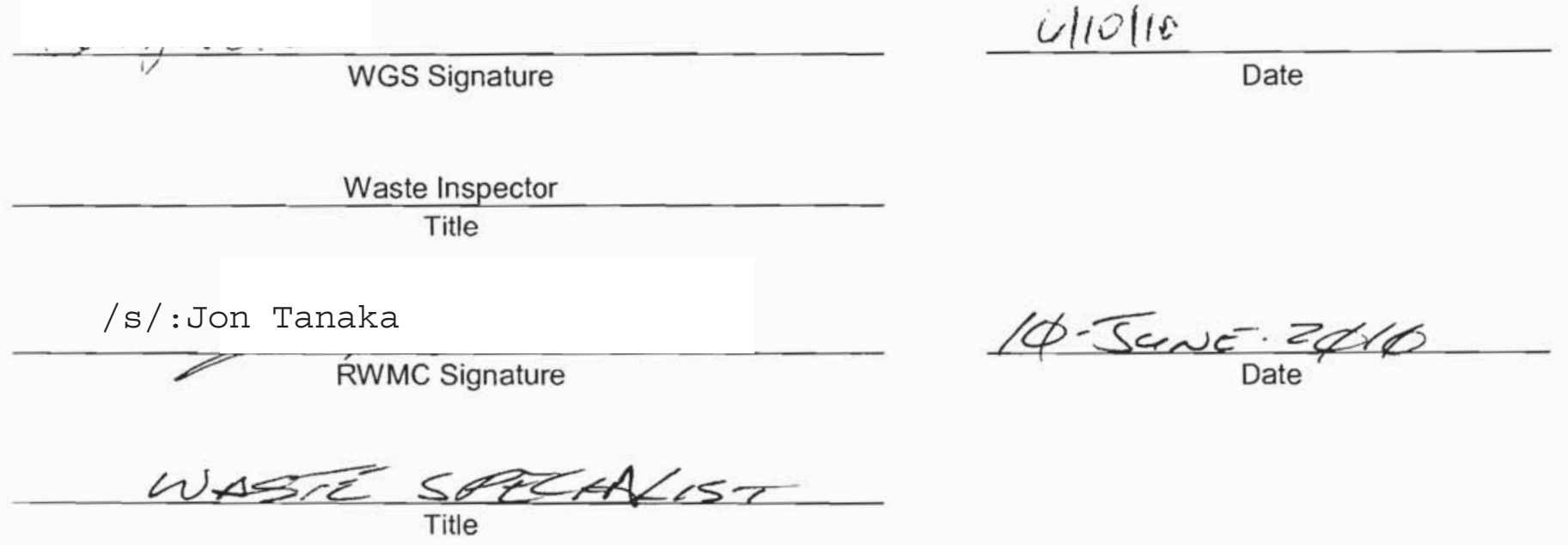

(Reference: OP-2151.304) 
NSTec

Form

FRM-2217
CERTIFICATE OF DISPOSAL

(LOW LEVEL WASTE)
03/01/10

Rev. 01

Page 1 of 1

\section{Nevada Test Site}

This Certificate acknowledges that the following shipment(s) of waste have been disposed at the Nevada Test Site Radioactive Waste Management Complex.

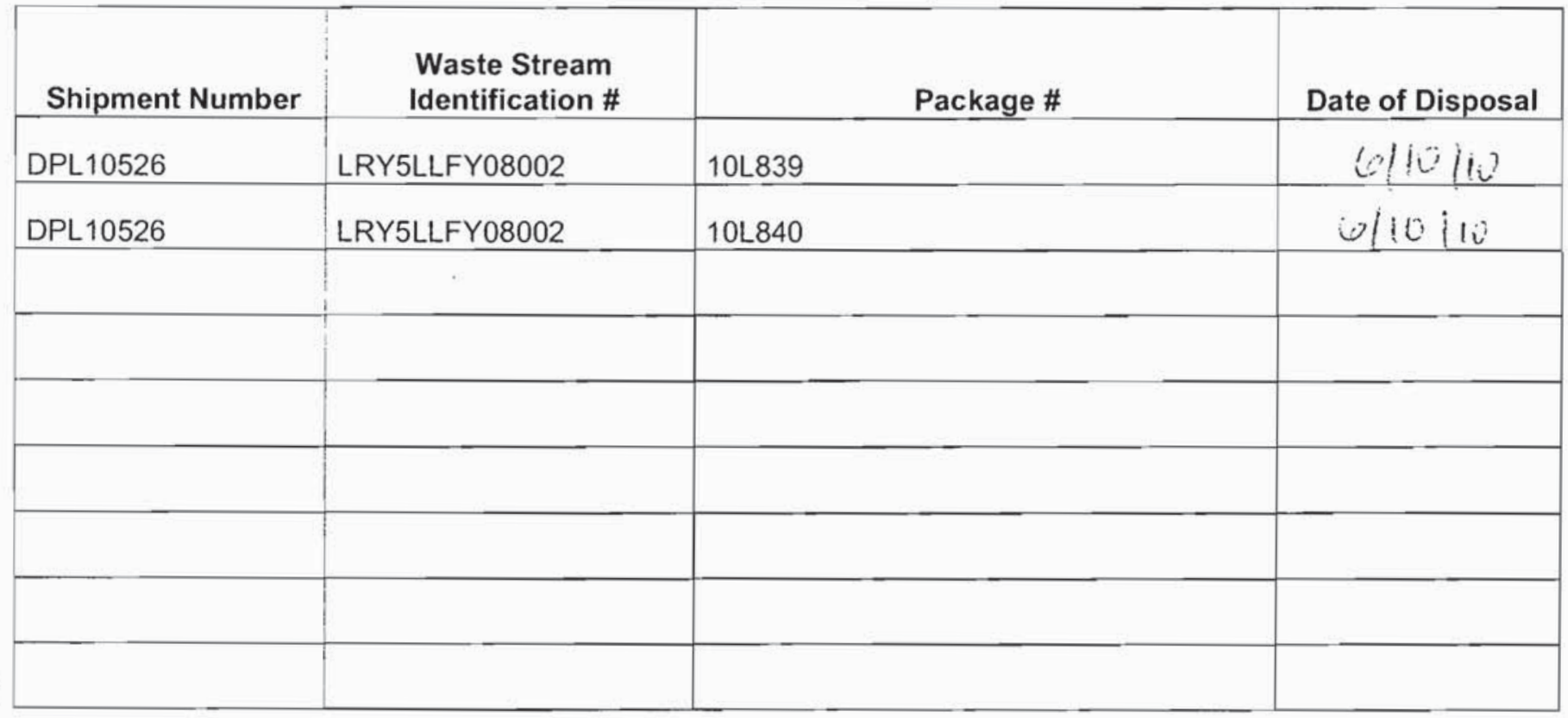

This certification is provided as a courtesy to the waste generator for information purposes only.

WGS Signature

Waste Inspector

Title

/s/:Jon Tanaka

RW'MC Signature

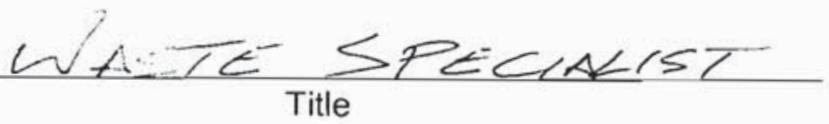

6110110

Date 
NSTec

Form

FRM-2217
CERTIFICATE OF DISPOSAL

(LOW LEVEL WASTE)
03/01/10

Rev. 01

Page 1 of 1

\section{Nevada Test Site}

This Certificate acknowledges that the following shipment(s) of waste have been disposed at the Nevada Test Site Radioactive Waste Management Complex.

\begin{tabular}{|l|l|l|l|}
\hline \multicolumn{1}{|c|}{$\begin{array}{c}\text { Waste Stream } \\
\text { Identification \# }\end{array}$} & \multicolumn{1}{|c|}{ Package \# } & Date of Disposal \\
\hline DPL10527 & LRY5LLFY08002 & 10 L841 & $6 ! 10 ! 10$ \\
\hline DPL10527 & LRY5LLFY08002 & 10 L842 & $6 ! 10 ! 10$ \\
\hline & & & \\
\hline & & & \\
\hline & & & \\
\hline & & & \\
\hline & & & \\
\hline
\end{tabular}

This certification is provided as a courtesy to the waste generator for information purposes only.

WGS Signature
$\frac{\text { Waste Inspector }}{\text { Title }}$
/s / : Jon Tanaka RWMC Signature
Rv




\begin{tabular}{|lcr|}
\hline NSTec & CERTIFICATE OF DISPOSAL & $03 / 01 / 10$ \\
Form & Rev. 01 \\
FRM-2217 & (LOW LEVEL WASTE) & Page 1 of 1 \\
\hline
\end{tabular}

Nevada Test Site

This Certificate acknowledges that the following shipments) of waste have been disposed at the Nevada Test Site Radioactive Waste Management Complex.

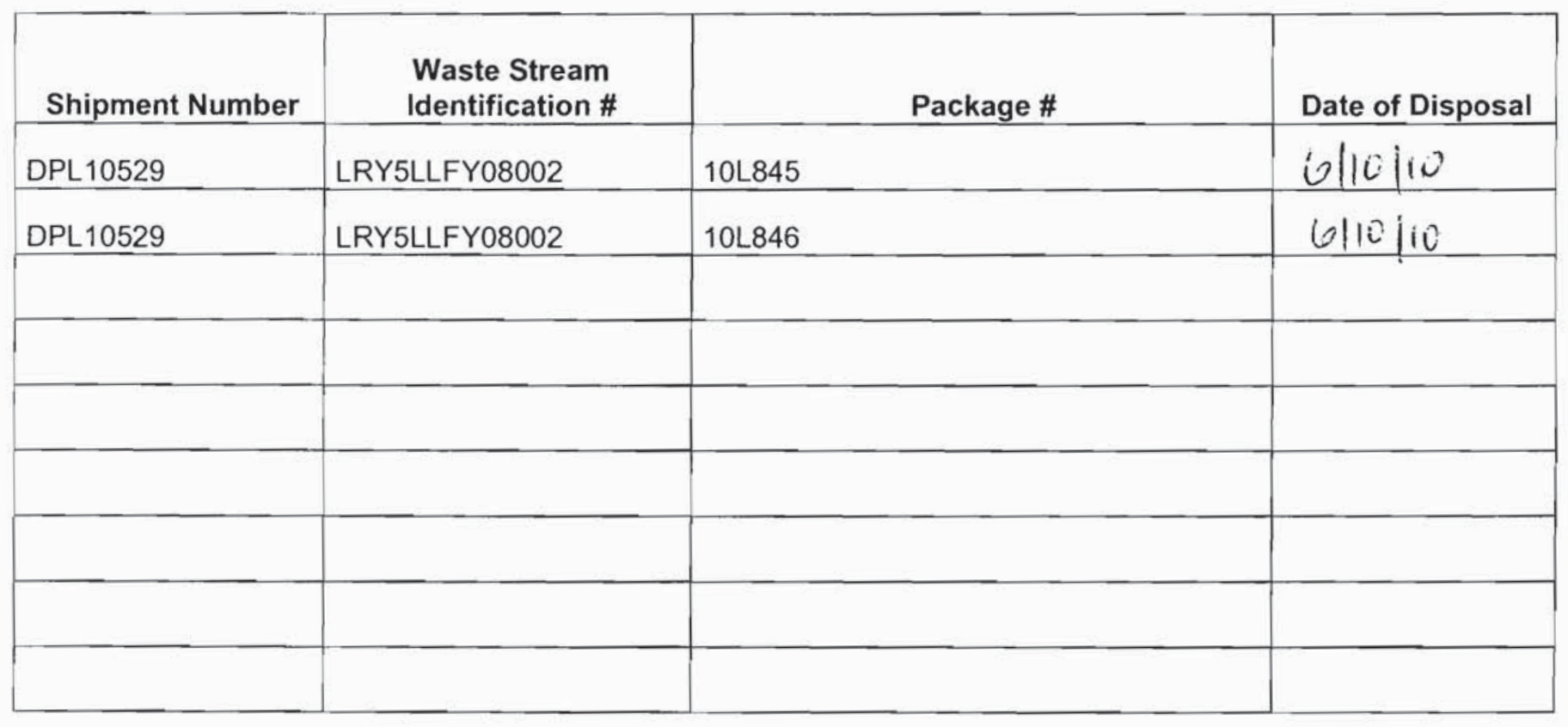

This certification is provided as a courtesy to the waste generator for information purposes only.

WGS Signature

Waste Inspector

Title

/s/: Jon Kanaka

RWMC Signature

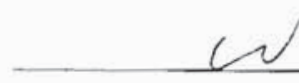

$6 / 1010$

Date

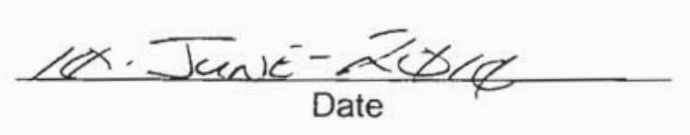

(Reference: OP-2151.304) 


\begin{tabular}{|lcr|}
\hline NSTec & CERTIFICATE OF DISPOSAL & $03 / 01 / 10$ \\
Form & Rev. 01 \\
FRM-2217 & (LOW LEVEL WASTE) & Page 1 of 1 \\
\hline
\end{tabular}

Nevada Test Site

This Certificate acknowledges that the following shipments) of waste have been disposed at the Nevada Test Site Radioactive Waste Management Complex.

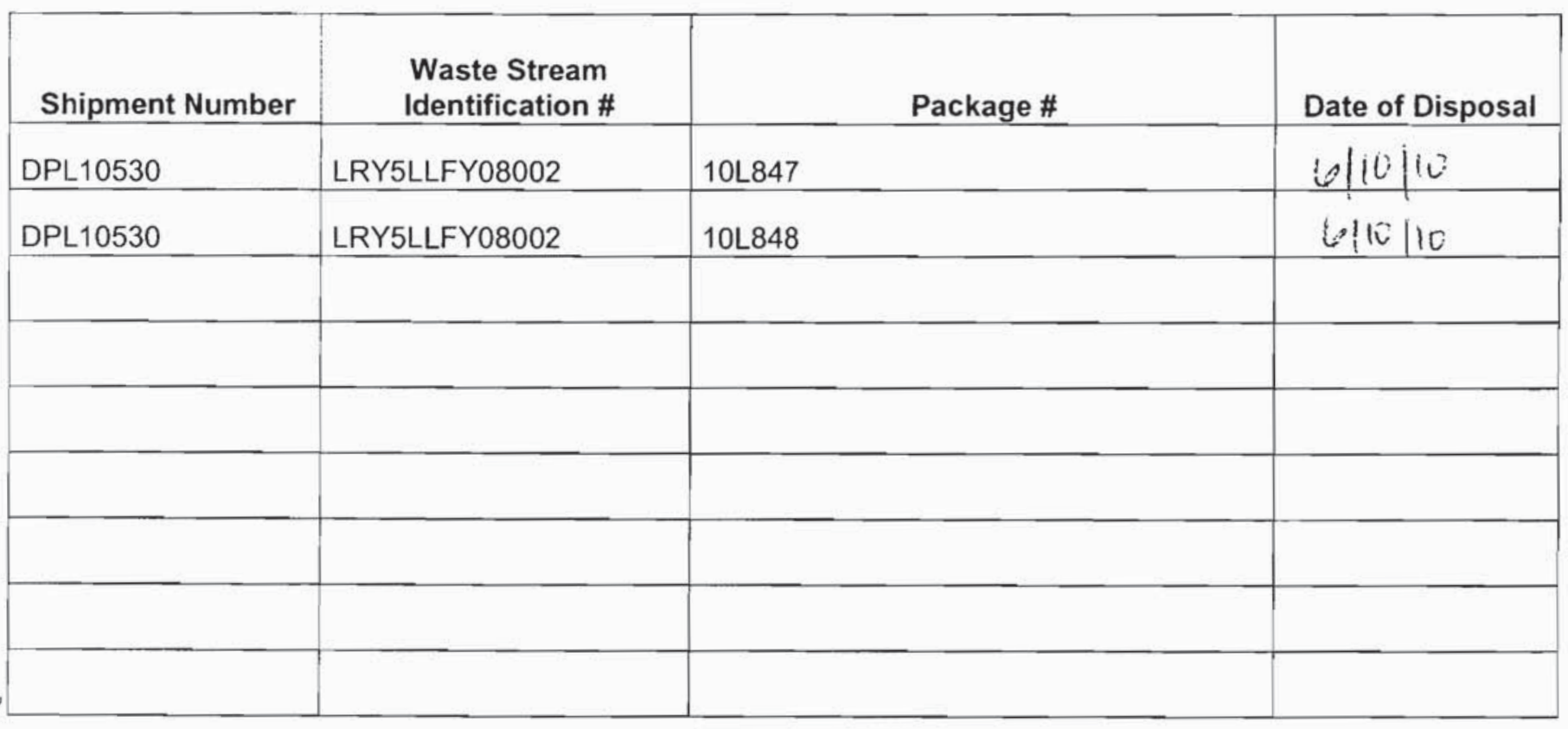

This certification is provided as a courtesy to the waste generator for information purposes only.

WGS Signature

Waste Inspector

Title

/s/: Jon Tanka

RWMC Signature

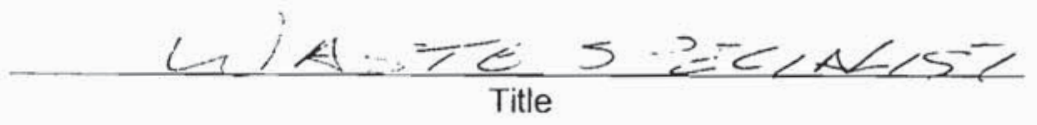

$6 \mid 10110$

Date

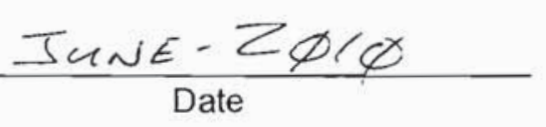

(Reference: OP-2151.304) 


\begin{tabular}{|lcr|}
\hline NSTec & CERTIFICATE OF DISPOSAL & $03 / 01 / 10$ \\
Form & Rev. 01 \\
FRM-2217 & (LOW LEVEL WASTE) & Page 1 of 1 \\
\hline
\end{tabular}

Nevada Test Site

This Certificate acknowledges that the following shipments) of waste have been disposed at the Nevada Test Site Radioactive Waste Management Complex.

\begin{tabular}{|l|l|l|l|}
\hline \multicolumn{1}{|c|}{$\begin{array}{c}\text { Shipment Number } \\
\text { Identification \# }\end{array}$} & \multicolumn{1}{|c|}{ Package \# } & Date of Disposal \\
\hline DPL10531 & LRY5LLFY08002 & 10 L849 & $6 / 10 / 10$ \\
\hline DPL10531 & LRY5LLFY08002 & 10 L850 & $6 / 10$ I IC \\
\hline & & & \\
\hline & & & \\
\hline & & & \\
\hline & & & \\
\hline & & & \\
\hline
\end{tabular}

This certification is provided as a courtesy to the waste generator for information purposes only.

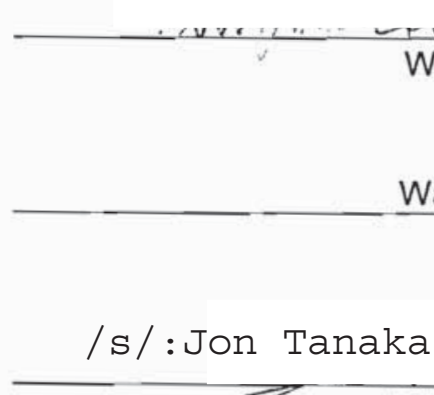

RWMC Signature uliclic

Date

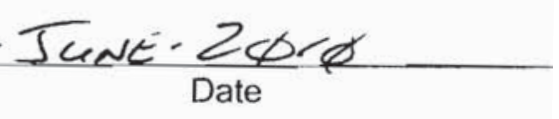

(Reference: OP-2151.304) 


\begin{tabular}{|lcr|}
\hline NSTec & CERTIFICATE OF DISPOSAL & $03 / 01 / 10$ \\
Form & Rev. 01 \\
FRM-2217 & (LOW LEVEL WASTE) & Page 1 of 1 \\
\hline
\end{tabular}

Nevada Test Site

This Certificate acknowledges that the following shipments) of waste have been disposed the Nevada Test Site Radioactive Waste Management Complex.

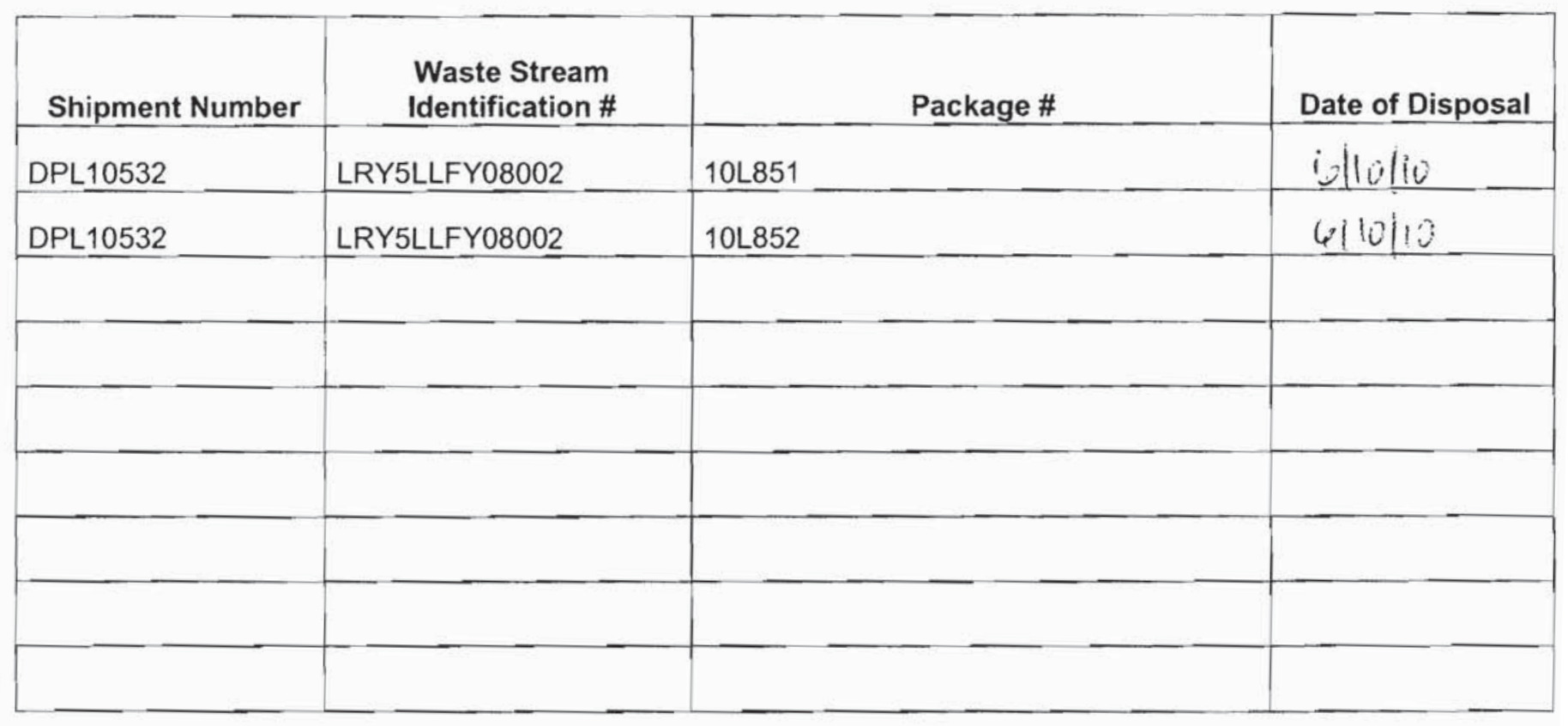

This certification is provided as a courtesy to the waste generator for information purposes only.

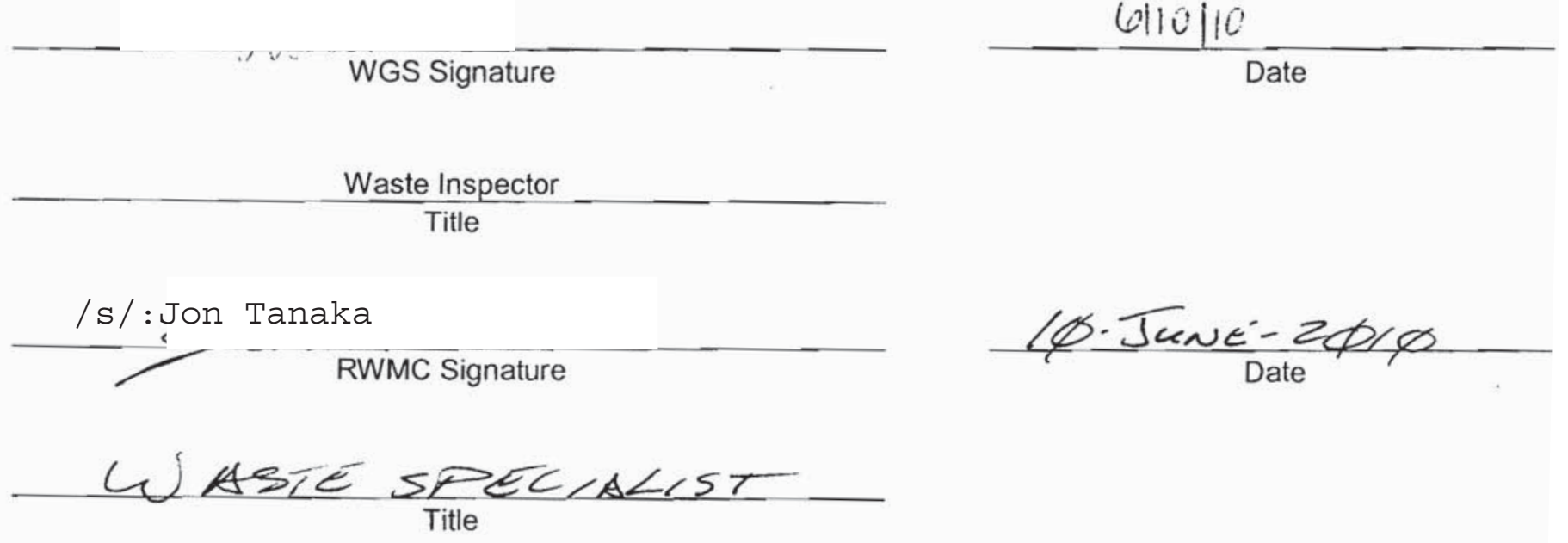

(Reference: OP-2151.304) 
NSTec

Form

FRM-2217
CERTIFICATE OF DISPOSAL

(LOW LEVEL WASTE)
$03 / 01 / 10$

Rev. 01

Page 1 of 1

\section{Nevada Test Site}

This Certificate acknowledges that the following shipment(s) of waste have been disposed at the Nevada Test Site Radioactive Waste Management Complex.

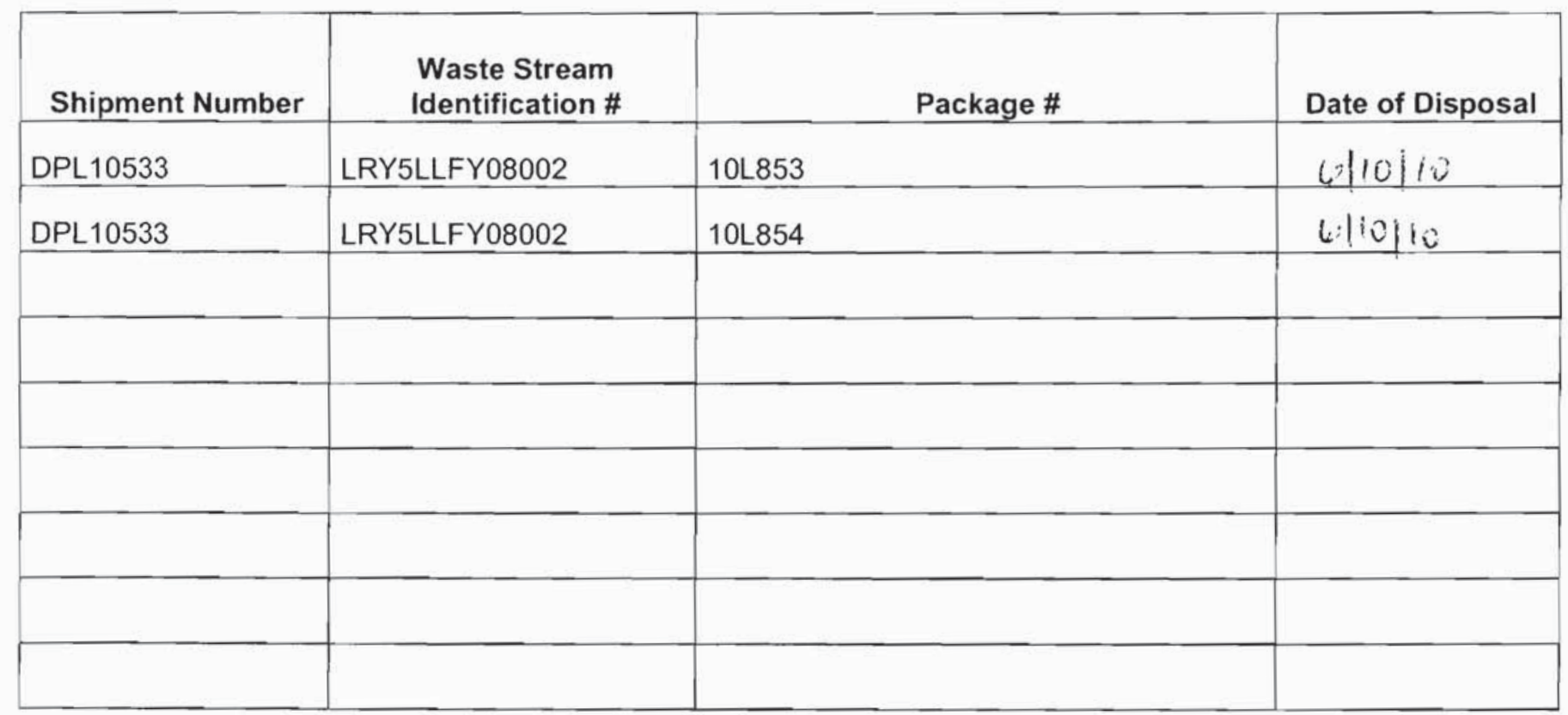

This certification is provided as a courtesy to the waste generator for information purposes only.

WGS Signature
Waste Inspector
Title
/s / : Jon Tanaka
RWMC Signature

$\frac{\text { Glic/lo }}{\text { Date }}$


NSTec

Form

FRM-2217
CERTIFICATE OF DISPOSAL

(LOW LEVEL WASTE)
03/01/10

Rev. 01

Page 1 of 1

\section{Nevada Test Site}

This Certificate acknowledges that the following shipment(s) of waste have been disposed at the Nevada Test Site Radioactive Waste Management Complex.

\begin{tabular}{|c|c|c|c|}
\hline Shipment Number & $\begin{array}{l}\text { Waste Stream } \\
\text { Identification \# }\end{array}$ & Package \# & Date of Disposal \\
\hline DPL10528 & LRY5LLFY08002 & $10 \mathrm{~L} 843$ & $6 / 14110$ \\
\hline DPL10528 & LRY5LLFY08002 & $10 L 844$ & $6|14| 10$ \\
\hline & & & \\
\hline & & & \\
\hline & & & \\
\hline & & & \\
\hline & & & \\
\hline & & & \\
\hline
\end{tabular}

This certification is provided as a courtesy to the waste generator for information purposes only.

$\frac{\text { WGS Signature }}{\frac{\text { Waste Inspector }}{\text { Title }}}$




\begin{tabular}{|lcr|}
\hline NSTec & CERTIFICATE OF DISPOSAL & R/o1/10 \\
Form & Rev. 01 \\
FRM-2217 & (LOW LEVEL WASTE) & Page 1 of 1 \\
\hline
\end{tabular}

Nevada Test Site

This Certificate acknowledges that the following shipments) of waste have been disposed at the Nevada Test Site Radioactive Waste Management Complex.

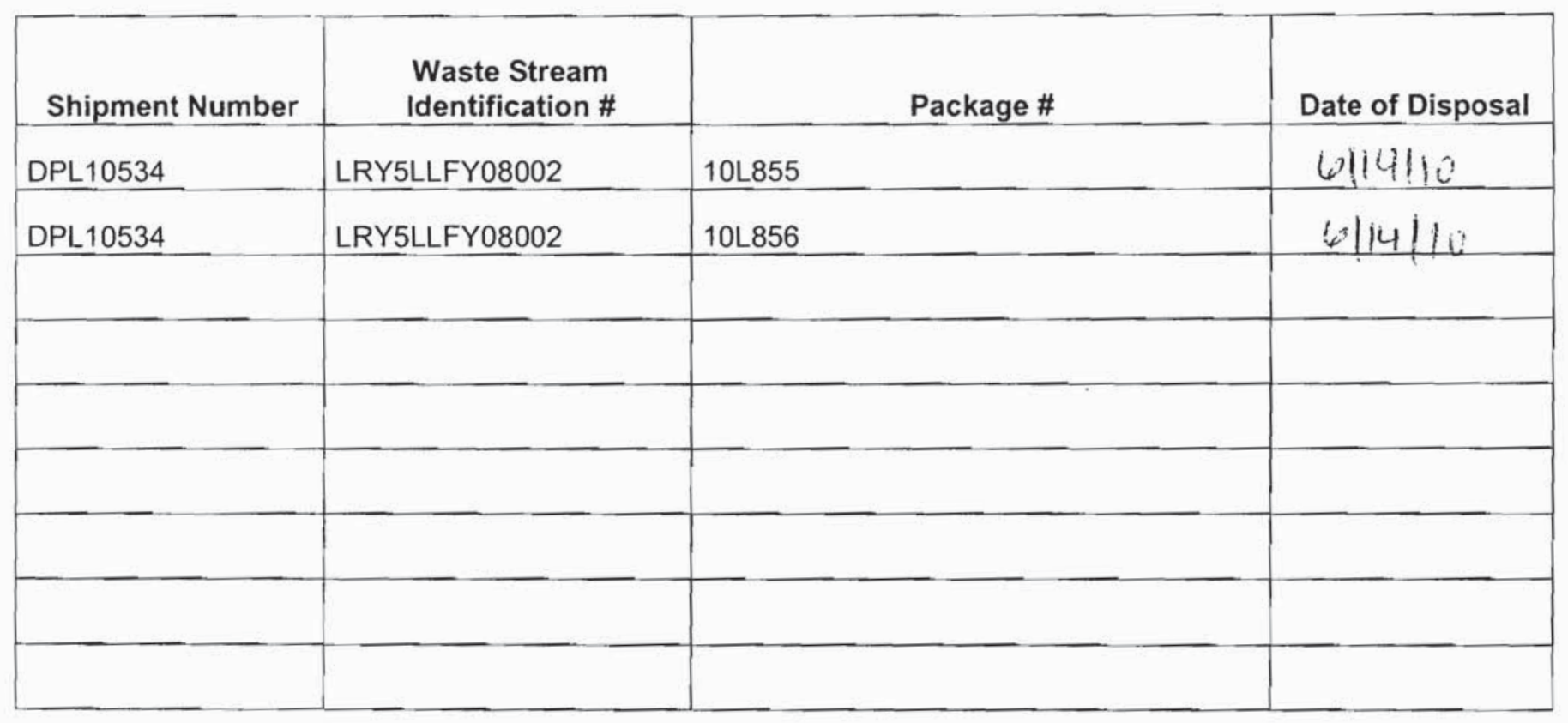

This certification is provided as a courtesy to the waste generator for information purposes only.

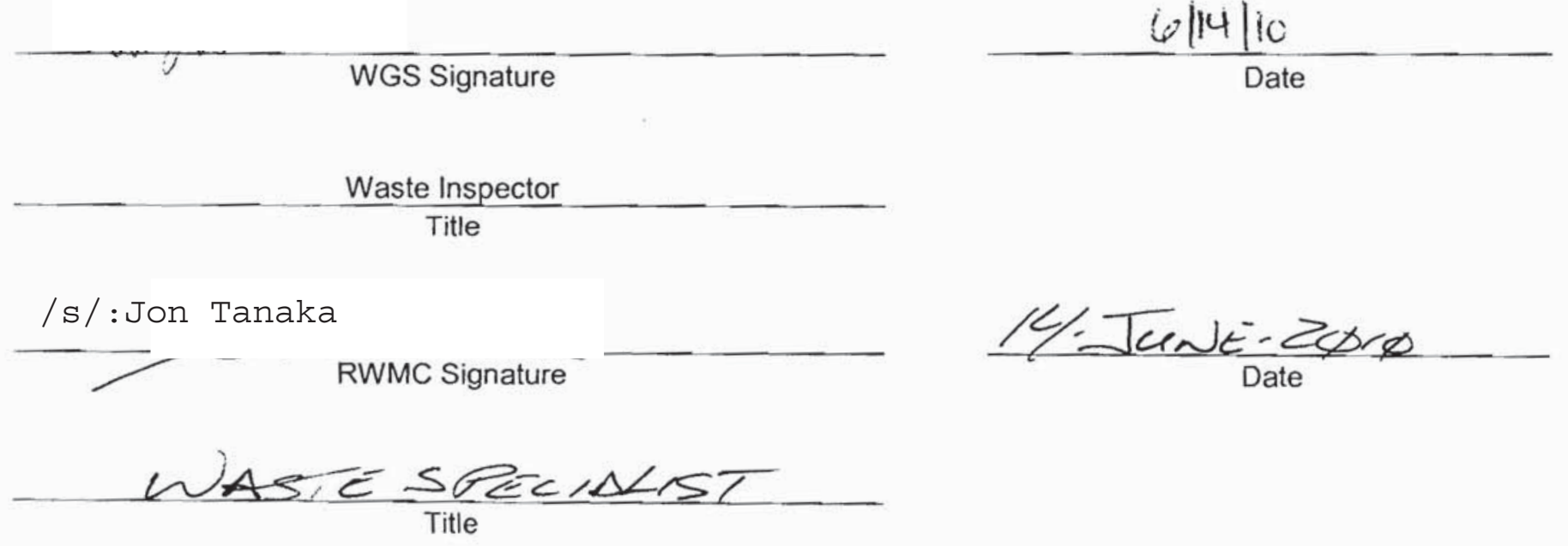

(Reference: OP-2151.304) 
NSTec

Form

FRM-2217
CERTIFICATE OF DISPOSAL

(LOW LEVEL WASTE)
03/01/10

Rev. 01

Page 1 of 1

\section{Nevada Test Site}

This Certificate acknowledges that the following shipment(s) of waste have been disposed at the Nevada Test Site Radioactive Waste Management Complex.

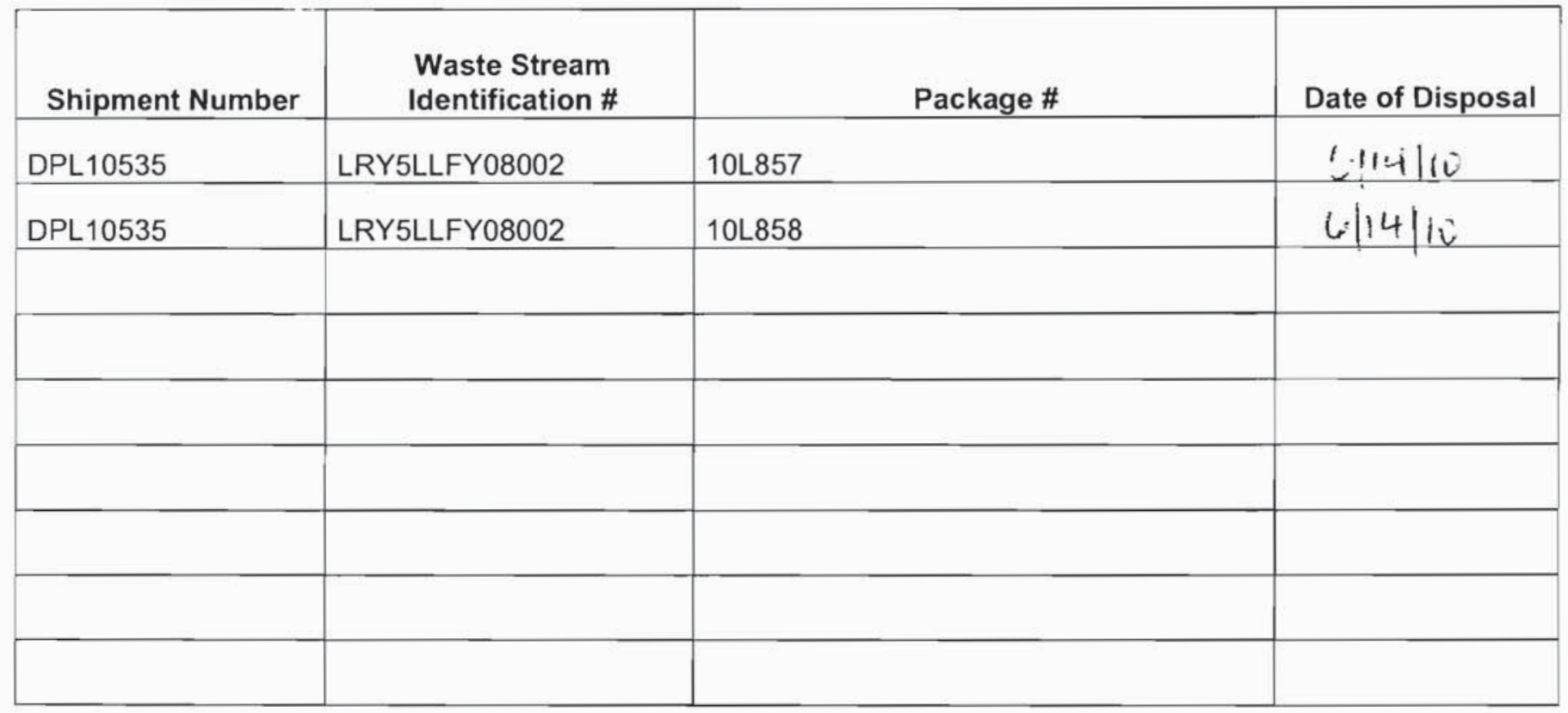

This certification is provided as a courtesy to the waste generator for information purposes only.

WGS Signature

Waste Inspector

Title

/s/:Jon Tanaka

RWMC Signature

7

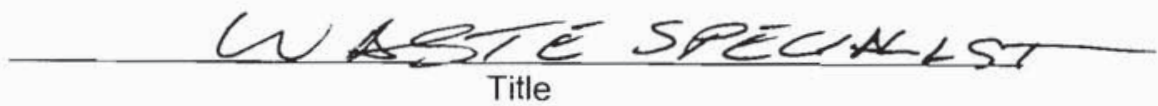

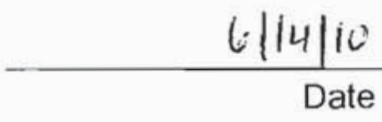

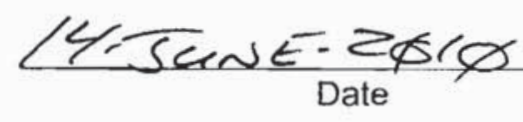




\begin{tabular}{|lcr|}
\hline NSTec & CERTIFICATE OF DISPOSAL & $03 / 01 / 10$ \\
Form & Rev. 01 \\
FRM-2217 & (LOW LEVEL WASTE) & Page 1 of 1 \\
\hline
\end{tabular}

Nevada Test Site

This Certificate acknowledges that the following shipments) of waste have been disposed at the Nevada Test Site Radioactive Waste Management Complex.

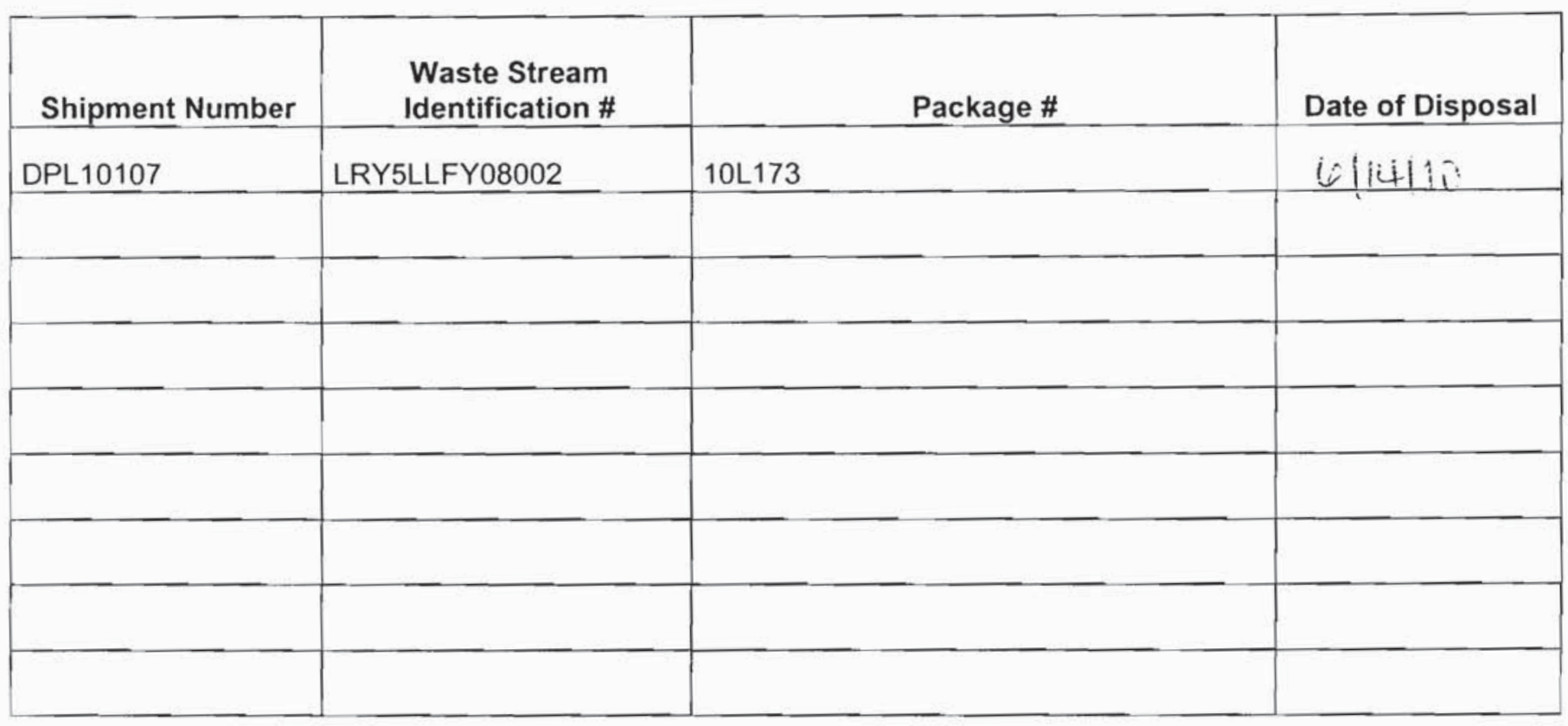

This certification is provided as a courtesy to the waste generator for information purposes only.

"WGS Signature

Waste Inspector

Title

/s/: Jon Kanaka

RWMC Signature

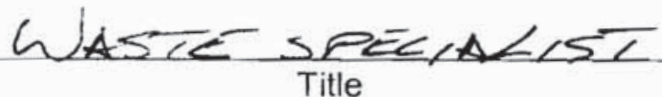

Q 144110

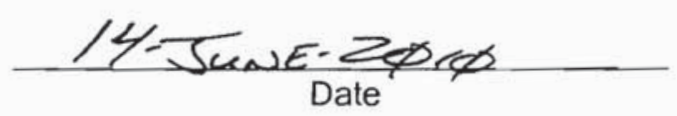


NSTec

Form

FRM-2217
CERTIFICATE OF DISPOSAL

(LOW LEVEL WASTE)
03/01/10

Rev. 01

Page 1 of 1

\section{Nevada Test Site}

This Certificate acknowledges that the following shipment(s) of waste have been disposed at the Nevada Test Site Radioactive Waste Management Complex.

\begin{tabular}{|c|c|c|c|}
\hline Shipment Number & $\begin{array}{l}\text { Waste Stream } \\
\text { Identification \# }\end{array}$ & Package \# & Date of Disposal \\
\hline DPL10536 & LRY5LLFY08002 & 10L859 & $6 ! 1416$ \\
\hline DPL10536 & LRY5LLFY08002 & 10L860 & willic \\
\hline & & & \\
\hline & & & \\
\hline & & & \\
\hline & & & \\
\hline & & & \\
\hline & & 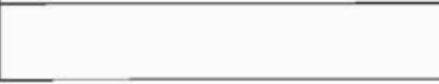 & \\
\hline
\end{tabular}

This certification is provided as a courtesy to the waste generator for information purposes only.

WGS Signature
Waste Inspector
Title

$$
\frac{6114110}{\text { Date }}
$$

/s/: Jon Tanaka

RWMC Signature

14. Tane $\operatorname{Tat}_{\text {Date }}^{2} \phi \varnothing$ 
NSTec

Form

FRM-2217
CERTIFICATE OF DISPOSAL

(LOW LEVEL WASTE)
03/01/10

Rev. 01

Page 1 of 1

\section{Nevada Test Site}

This Certificate acknowledges that the following shipment(s) of waste have been disposed at the Nevada Test Site Radioactive Waste Management Complex.

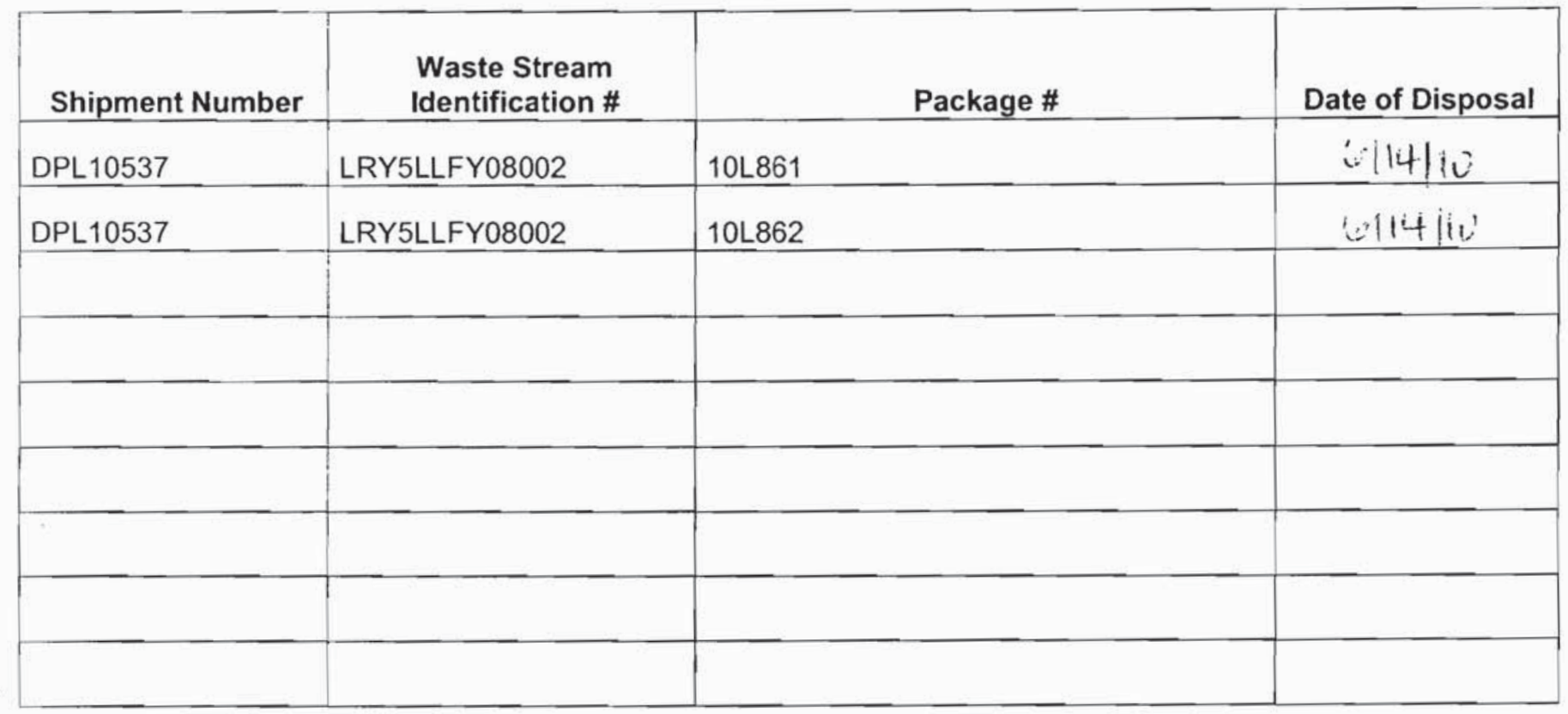

This certification is provided as a courtesy to the waste generator for information purposes only.

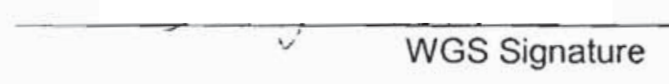

Waste Inspector

$$
\text { Title }
$$

\section{/s/: Jon Tanaka}

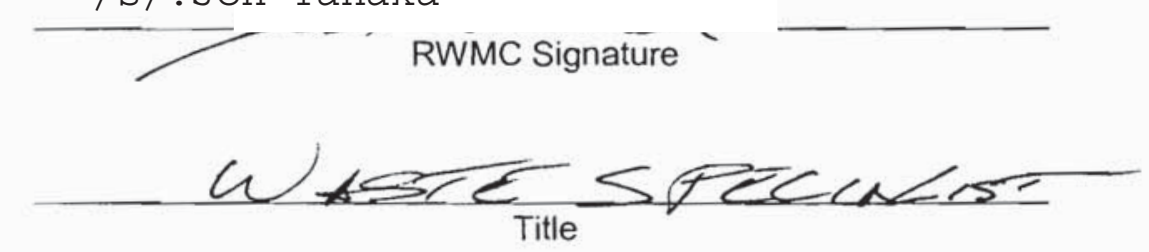

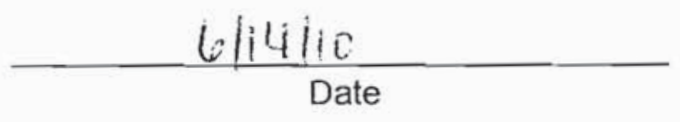

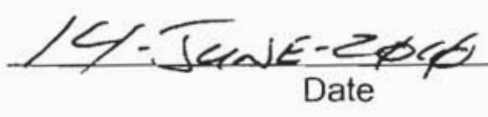


NSTec

Form

FRM-2217
CERTIFICATE OF DISPOSAL

(LOW LEVEL WASTE)
03/01/10

Rev. 01

Page 1 of 1

\section{Nevada Test Site}

This Certificate acknowledges that the following shipment(s) of waste have been disposed at the Nevada Test Site Radioactive Waste Management Complex.

\begin{tabular}{|c|c|c|c|}
\hline Shipment Number & $\begin{array}{l}\text { Waste Stream } \\
\text { Identification \# }\end{array}$ & Package \# & Date of Disposal \\
\hline DPL10538 & LRY5LLFY08002 & 10L863 & illicilic \\
\hline DPL10538 & LRY5LLFY08002 & $10\llcorner 864$ & Qllulli \\
\hline & & & \\
\hline & & & \\
\hline & & & \\
\hline & & & \\
\hline & & & \\
\hline & & & \\
\hline
\end{tabular}

This certification is provided as a courtesy to the waste generator for information purposes only.

$\frac{\text { WGS Signature }}{\text { Waste Inspector }}$

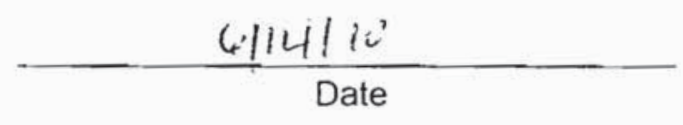

/s/: Jon Tanaka

RWMC Signature
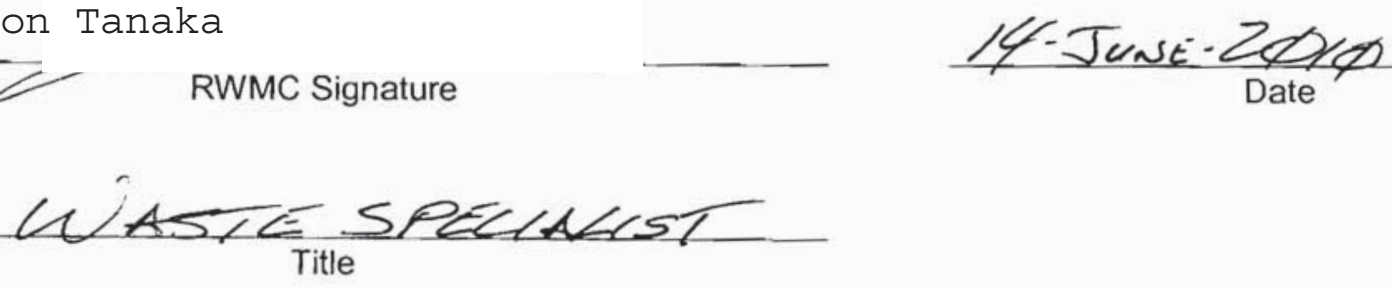


\section{Nevada Test Site}

This Certificate acknowledges that the following shipment(s) of waste have been disposed at the Nevada Test Site Radioactive Waste Management Complex.

\begin{tabular}{|c|c|c|c|}
\hline Shipment Number & $\begin{array}{l}\text { Waste Stream } \\
\text { Identification \# }\end{array}$ & Package \# & Date of Disposal \\
\hline DPL10539 & LRY5LLFY08002 & $10 L 865$ & $4 l i 4 i b$ \\
\hline DPL10539 & LRY5LLFY08002 & $10 L 866$ & $6 ! 14110$ \\
\hline & & & \\
\hline & & & \\
\hline & & & \\
\hline & & & \\
\hline & & & \\
\hline & & 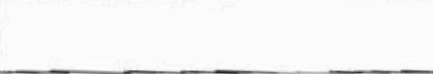 & \\
\hline
\end{tabular}

This certification is provided as a courtesy to the waste generator for information purposes only.

$\frac{\text { WGS Signature }}{\text { Witle }}$

$$
\text { Wh }|14|: i
$$

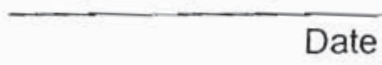

/s/:Jon Tanaka
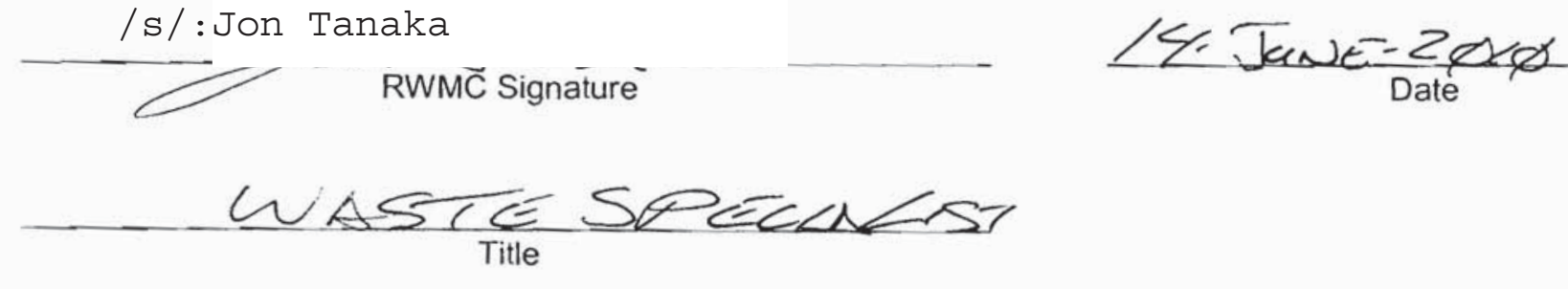
NSTec

Form

FRM-2217
CERTIFICATE OF DISPOSAL

(LOW LEVEL WASTE)
03/01/10

Rev. 01

Page 1 of 1

\section{Nevada Test Site}

This Certificate acknowledges that the following shipment(s) of waste have been disposed at the Nevada Test Site Radioactive Waste Management Complex.

\begin{tabular}{|c|c|c|c|}
\hline Shipment Number & $\begin{array}{l}\text { Waste Stream } \\
\text { Identification \# }\end{array}$ & Package \# & Date of Disposal \\
\hline DPL10540 & LRY5LLFY08002 & $10\llcorner 867$ & oliullc \\
\hline DPL10540 & LRY5LLFY08002 & 10L868 & 6110110 \\
\hline & & & \\
\hline & & & \\
\hline & & & \\
\hline & & & \\
\hline & & & \\
\hline & & & \\
\hline
\end{tabular}

This certification is provided as a courtesy to the waste generator for information purposes only.

WGS Signature

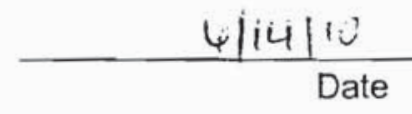

Waste Inspector

Title

/s/:Jon Tanaka

RWMC Signature

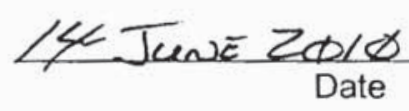

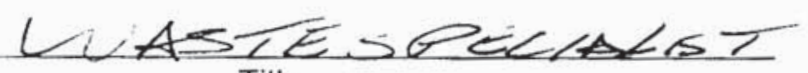

Title 
NSTec

Form

FRM-2217
CERTIFICATE OF DISPOSAL

(LOW LEVEL WASTE)
03/01/10

Rev. 01

Page 1 of 1

\section{Nevada Test Site}

This Certificate acknowledges that the following shipment(s) of waste have been disposed at the Nevada Test Site Radioactive Waste Management Complex.

\begin{tabular}{|c|c|c|c|}
\hline Shipment Number & $\begin{array}{l}\text { Waste Stream } \\
\text { identification \# }\end{array}$ & Package \# & Date of Disposal \\
\hline DPL10541 & LRY5LLFY08002 & 10L869 & 611410 \\
\hline DPL10541 & LRY5LLFY08002 & $10\llcorner 870$ & wlicillo \\
\hline & & & \\
\hline & & & \\
\hline & & & \\
\hline & & & \\
\hline & & & \\
\hline & & & \\
\hline
\end{tabular}

This certification is provided as a courtesy to the waste generator for information purposes only.

WGS Signature
Waste Inspector
Title

$\frac{6 / i 4 h i v}{\text { Date }}$

/s/:Jon Tanaka

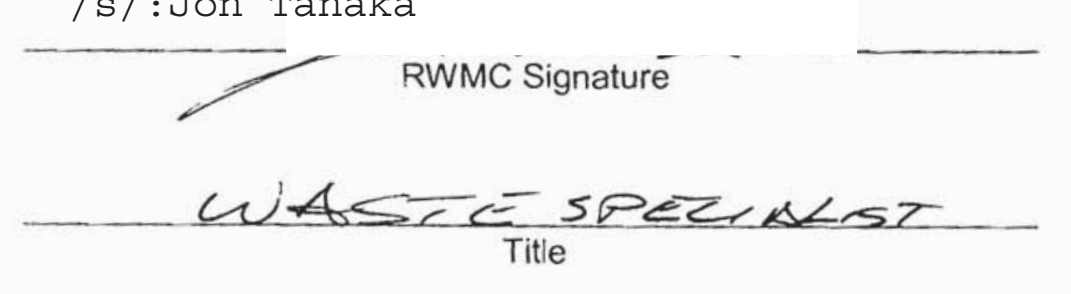




\begin{tabular}{|lcr|}
\hline NSTec & CERTIFICATE OF DISPOSAL & 03/01/10 \\
Form & Rev. 01 \\
FRM-2217 & (LOW LEVEL WASTE) & Page 1 of 1 \\
\hline
\end{tabular}

Nevada Test Site

This Certificate acknowledges that the following shipments) of waste have been disposed at the Nevada Test Site Radioactive Waste Management Complex.

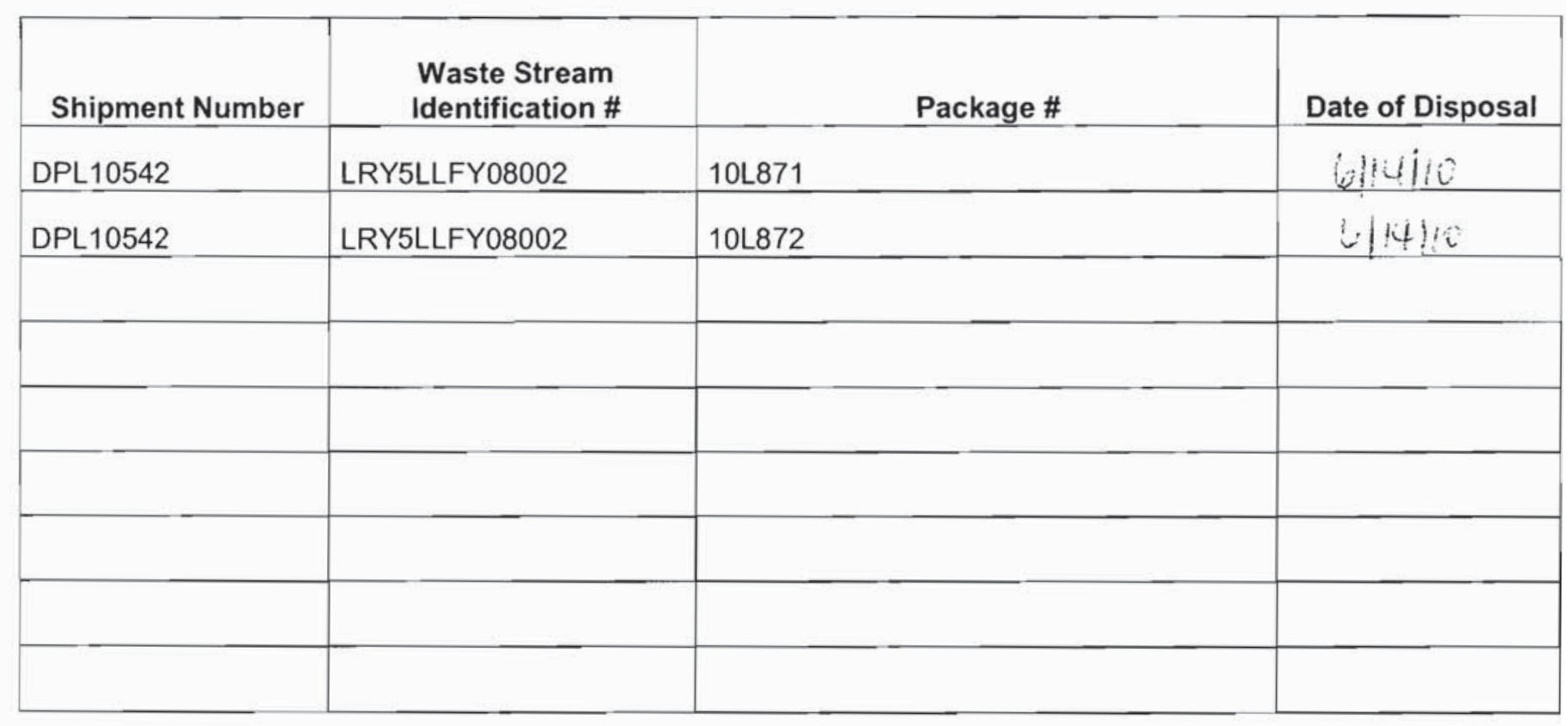

This certification is provided as a courtesy to the waste generator for information purposes only.
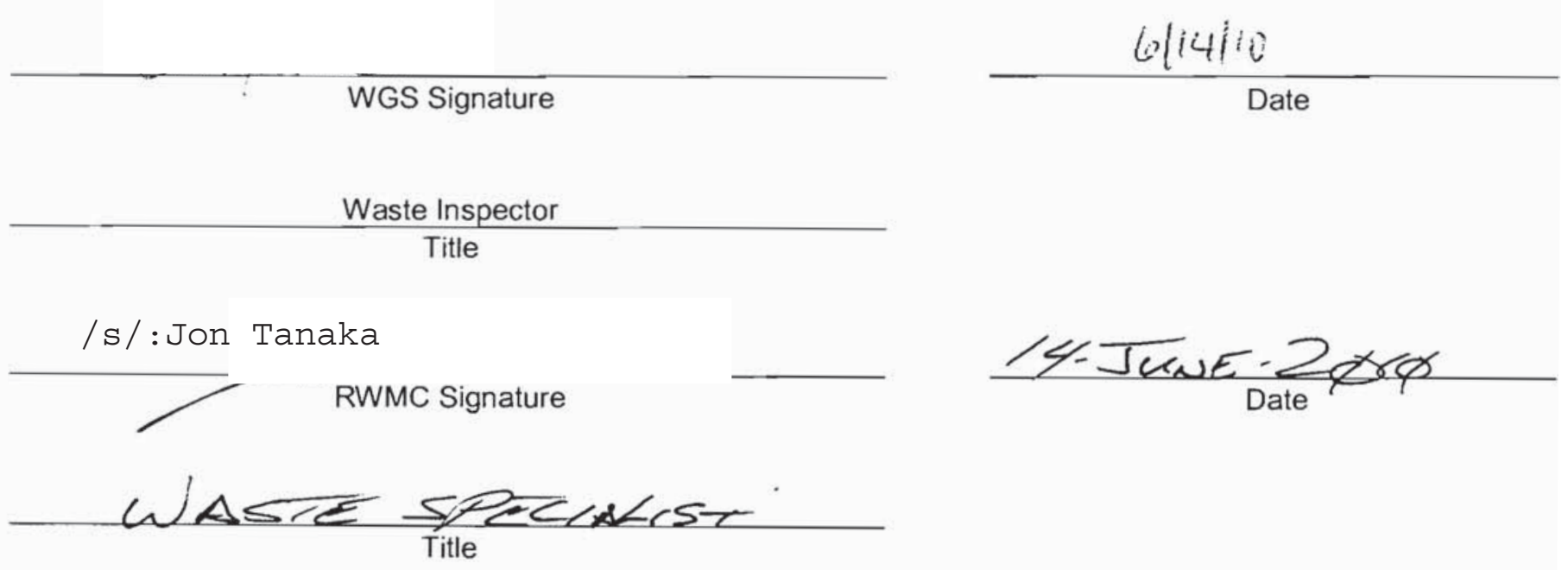
NSTec

Form

FRM-2217
CERTIFICATE OF DISPOSAL

(LOW LEVEL WASTE)
03/01/10

Rev. 01

Page 1 of 1

\section{Nevada Test Site}

This Certificate acknowledges that the following shipment(s) of waste have been disposed at the Nevada Test Site Radioactive Waste Management Complex.

\begin{tabular}{|c|c|c|c|}
\hline Shipment Number & $\begin{array}{l}\text { Waste Stream } \\
\text { Identification \# }\end{array}$ & Package \# & Date of Disposal \\
\hline DPL10543 & LRY5LLFY08002 & $10 \mathrm{~L} 873$ & 6114116 \\
\hline DPL10543 & LRY5LLFY08002 & $10 \underline{L} 874$ & $614+10$ \\
\hline & & & \\
\hline & & & \\
\hline & & & \\
\hline & & & \\
\hline & & & \\
\hline & & & \\
\hline
\end{tabular}

This certification is provided as a courtesy to the waste generator for information purposes only.

WGS Signature

Waste Inspector

Title /s / : Jon Tanaka

RWMC Signature

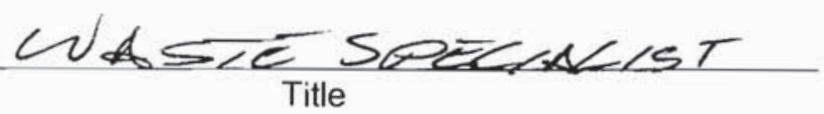

614110

Date

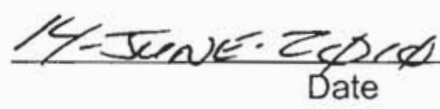




\begin{tabular}{|lcr|}
\hline NSTec & CERTIFICATE OF DISPOSAL & Rev /01/10 \\
Form & Rev. 01 \\
FRM-2217 & (LOW LEVEL WASTE) & Page 1 of 1 \\
\hline
\end{tabular}

Nevada Test Site

This Certificate acknowledges that the following shipments) of waste have been disposed at the Nevada Test Site Radioactive Waste Management Complex.

\begin{tabular}{|c|c|c|c|}
\hline Shipment Number & $\begin{array}{c}\text { Waste Stream } \\
\text { Identification \# }\end{array}$ & Package \# & Date of Disposal \\
\hline DPL10191 & \begin{tabular}{c} 
LRY5LLFY08002 \\
\hline
\end{tabular} & 102257 & $6 / 15 / 10$ \\
\hline & & & \\
\hline & & & \\
\hline & & & \\
\hline & & & \\
\hline
\end{tabular}

This certification is provided as a courtesy to the waste generator for information purposes only.

/s/: Theresa Hale

WGS Signature

Waste Inspector

Title

/s/: Jon Tanka

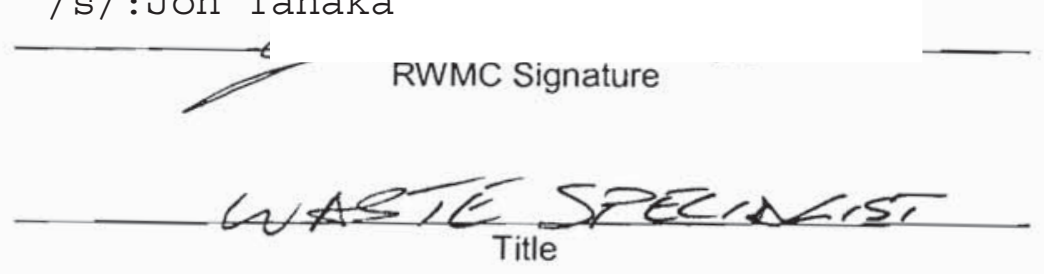

6

$6 / \frac{15 / 10}{\text { Date }}$

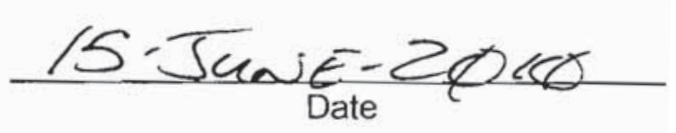

(Reference: OP-2151.304) 
NSTec

Form

FRM-2217
CERTIFICATE OF DISPOSAL

(LOW LEVEL WASTE)
03/01/10

Rev. 01

Page 1 of 1

\section{Nevada Test Site}

This Certificate acknowledges that the following shipment(s) of waste have been disposed at the Nevada Test Site Radioactive Waste Management Complex.

\begin{tabular}{|l|l|l|l|}
\hline Shipment Number & $\begin{array}{c}\text { Waste Stream } \\
\text { Identification \# }\end{array}$ & Package \# & Date of Disposal \\
\hline DPL10193 & LRY5LLF08002 & 10L259 & $6 / / 5 / /$ \\
\hline & & & \\
\hline & & & \\
\hline & & & \\
\hline & & & \\
\hline & & & \\
\hline
\end{tabular}

This certification is provided as a courtesy to the waste generator for information purposes only.

/s/:Theresa Hale

WGS Signature

Waste Inspector

Title

/s/:Jon Tanaka

RWMC Signature

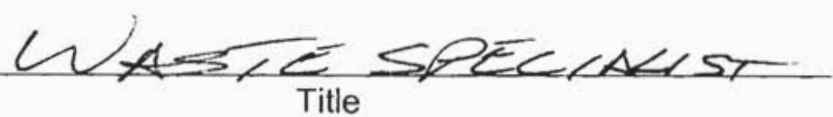

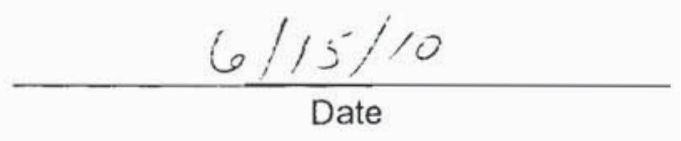

$\frac{15-\sqrt{u n}-20 x \phi}{\text { Date }}$ 
NSTec

Form

FRM-2217
CERTIFICATE OF DISPOSAL

(LOW LEVEL WASTE)
$03 / 01 / 10$

Rev. 01

Page 1 of 1

\section{Nevada Test Site}

This Certificate acknowledges that the following shipment(s) of waste have been disposed at the Nevada Test Site Radioactive Waste Management Complex.

\begin{tabular}{|c|c|c|c|}
\hline Shipment Number & $\begin{array}{l}\text { Waste Stream } \\
\text { Identification \# }\end{array}$ & Package \# & Date of Disposal \\
\hline DPL10544 & LRY5LLFY08002 & $10 L 875$ & $6 / 15$ \\
\hline DPL10544 & LRY5LLFY08002 & $10 L 876$ & $6 / 15 / 10$ \\
\hline & & & \\
\hline & & & \\
\hline & & & \\
\hline & & & \\
\hline & & 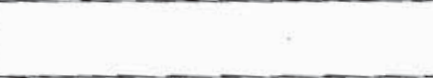 & \\
\hline & & & \\
\hline
\end{tabular}

This certification is provided as a courtesy to the waste generator for information purposes only.

$$
\text { /s/:Theresa Hale }
$$

WGS Signature

Waste Inspector

$$
\text { Title }
$$

/s/:Jon Tanaka

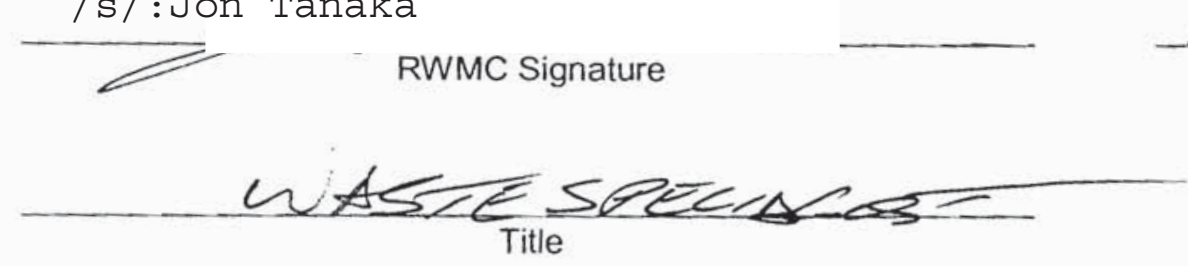

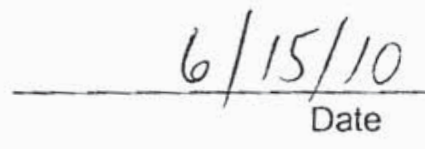

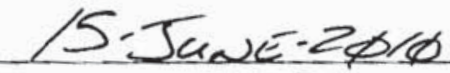

Date 
NSTec

Form

FRM-2217
CERTIFICATE OF DISPOSAL

(LOW LEVEL WASTE)
03/01/10

Rev. 01

Page 1 of 1

Nevada Test Site

This Certificate acknowledges that the following shipments) of waste have been disposed at the Nevada Test Site Radioactive Waste Management Complex.

\begin{tabular}{|l|l|l|l|}
\hline \multicolumn{1}{|c|}{$\begin{array}{c}\text { Shipment Number } \\
\text { Identification \# }\end{array}$} & Package \# & Date of Disposal \\
\hline DPL10545 & LRY5LLFY08002 & 10 L877 & $6 / 15 / 10$ \\
\hline DPL10545 & LRY5LLFY08002 & 10 L878 & $6 / 15 / 10$ \\
\hline & & & \\
\hline & & & \\
\hline & & & \\
\hline
\end{tabular}

This certification is provided as a courtesy to the waste generator for information purposes only.

/s/: Theresa Hale

WGS Signature

Waste Inspector

Title $\frac{6 / 15 / 10}{\text { Date }}$

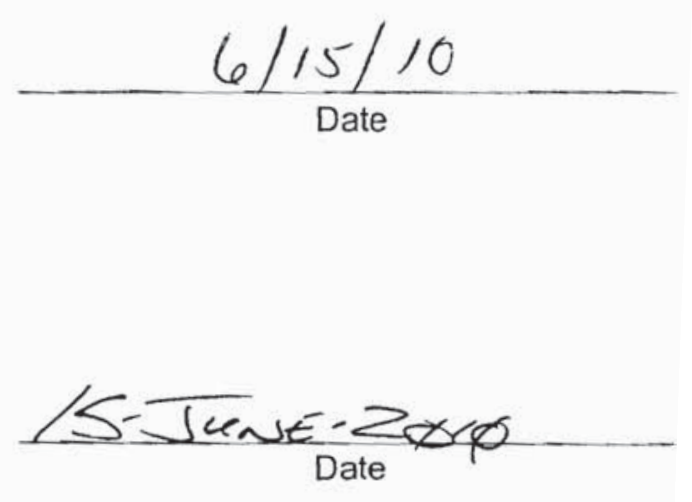

RWMC Signature

Title

(Reference: OP-2151.304) 
NSTec

Form

FRM-2217
CERTIFICATE OF DISPOSAL

(LOW LEVEL WASTE)
03/01/10

Rev. 01

Page 1 of 1

\section{Nevada Test Site}

This Certificate acknowledges that the following shipment(s) of waste have been disposed at the Nevada Test Site Radioactive Waste Management Complex.

\begin{tabular}{|c|c|c|c|}
\hline Shipment Number & $\begin{array}{c}\text { Waste Stream } \\
\text { Identification \# }\end{array}$ & Package \# & Date of Disposal \\
\hline DPL10546 & LRY5LLFY08002 & 10 L879 & $6 / 15 / 10$ \\
\hline DPL10546 & LRY5LLFY08002 & 10 L880 & $6 / 15 / 10$ \\
\hline & & & \\
\hline & & & \\
\hline & & & \\
\hline
\end{tabular}

This certification is provided as a courtesy to the waste generator for information purposes only.

/s/:Theresa Hale

WGS Signature

Waste Inspector

Title

/s/:Jon Tanaka

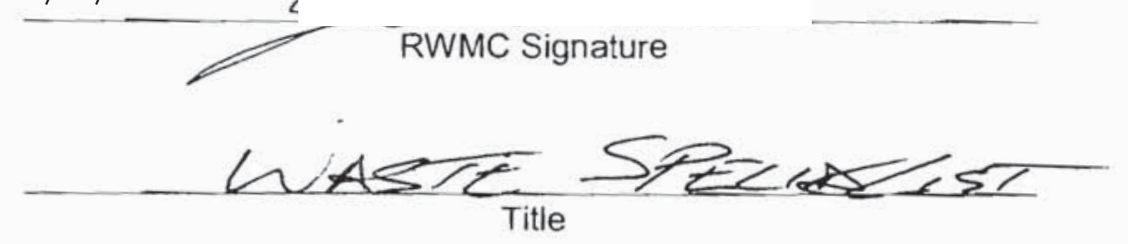

$-6 / 15 / 10$

$\frac{15 \cdot J_{u}}{\text { Date }}-2 \phi$ 
NSTec

Form

FRM-2217
CERTIFICATE OF DISPOSAL

(LOW LEVEL WASTE)
03/01/10

Rev. 01

Page 1 of 1

\section{Nevada Test Site}

This Certificate acknowledges that the following shipment(s) of waste have been disposed at the Nevada Test Site Radioactive Waste Management Complex.

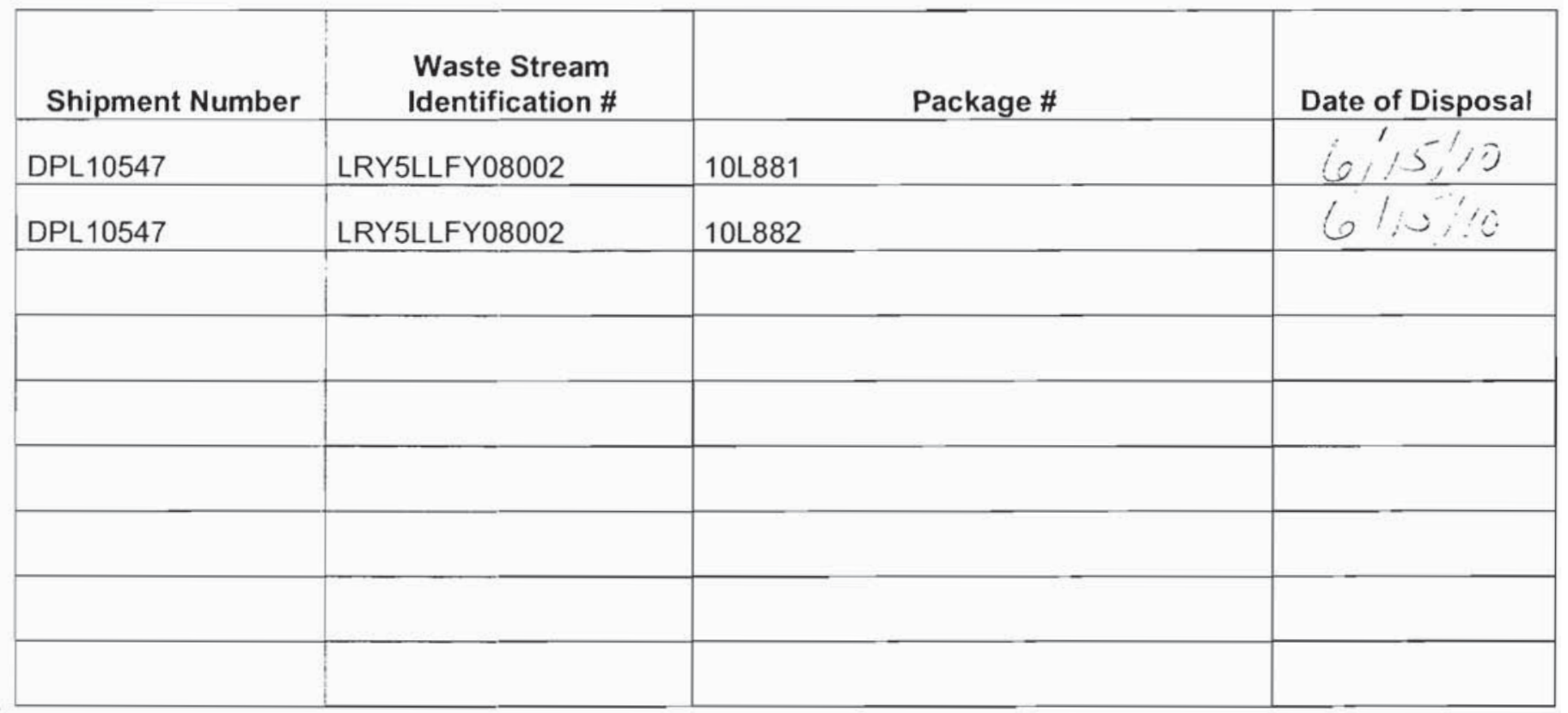

This certification is provided as a courtesy to the waste generator for information purposes only.

/s/:Theresa Hale

\section{WGS Signature}

Waste Inspector

$$
\text { Title }
$$

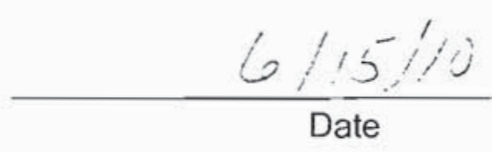

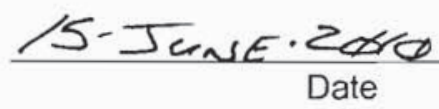


NSTec

Form

FRM-2217
CERTIFICATE OF DISPOSAL

(LOW LEVEL WASTE)
03/01/10

Rev. 01

Page 1 of 1

\section{Nevada Test Site}

This Certificate acknowledges that the following shipment(s) of waste have been disposed at the Nevada Test Site Radioactive Waste Management Complex.

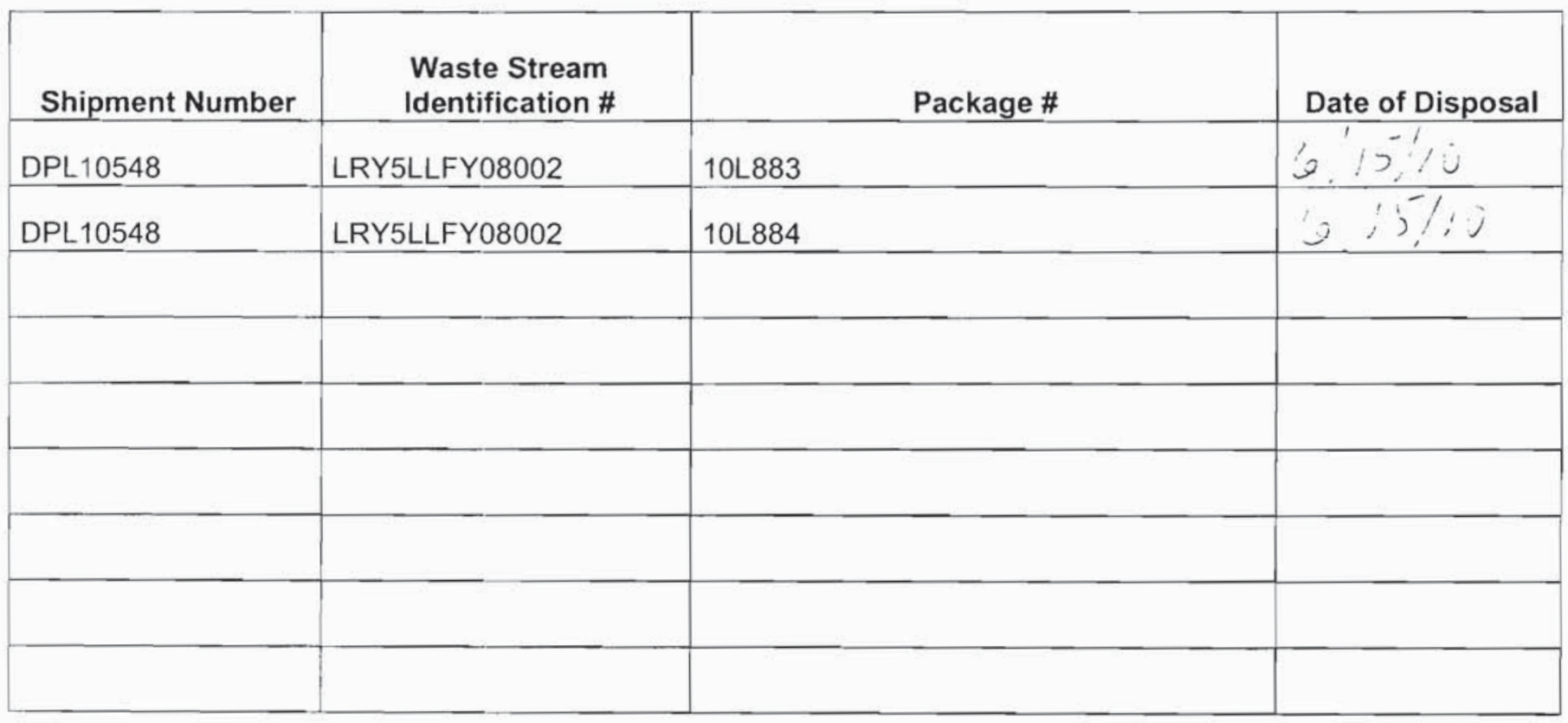

This certification is provided as a courtesy to the waste generator for information purposes only.

/s/:Theresa Hale

WGS Signature

Waste Inspector

Title

/s/:Jon Tanaka

RWMC Signature

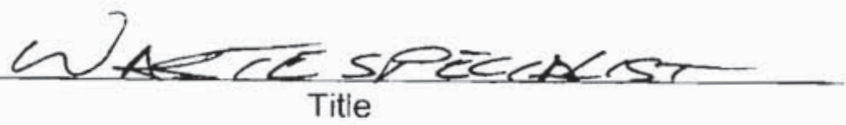

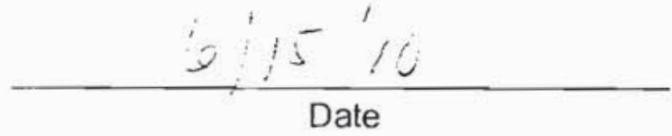

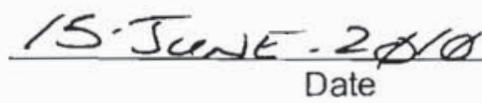


NSTec

Form

FRM-2217
CERTIFICATE OF DISPOSAL

(LOW LEVEL WASTE)
03/01/10

Rev. 01

Page 1 of 1

\section{Nevada Test Site}

This Certificate acknowledges that the following shipment(s) of waste have been disposed at the Nevada Test Site Radioactive Waste Management Complex.

\begin{tabular}{|c|c|c|c|}
\hline Shipment Number & $\begin{array}{l}\text { Waste Stream } \\
\text { Identification \# }\end{array}$ & Package \# & Date of Disposal \\
\hline DPL.10549 & LRY5LLFY08002 & 10L.885 & $6 \% 1510$ \\
\hline DPL10549 & LRY5LLFY08002 & $10 L 886$ & \\
\hline & & & \\
\hline & & & \\
\hline & & & \\
\hline & & & \\
\hline & & & \\
\hline & & & \\
\hline
\end{tabular}

This certification is provided as a courtesy to the waste generator for information purposes only.

$$
\text { /s/:Theresa Hale }
$$

WGS Signature

Waste Inspector

$$
\text { Title }
$$

\section{/s/:Jon Tanaka}

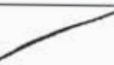

RWMC Signature

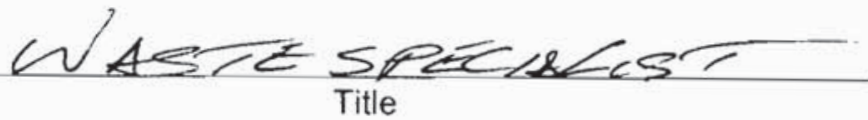

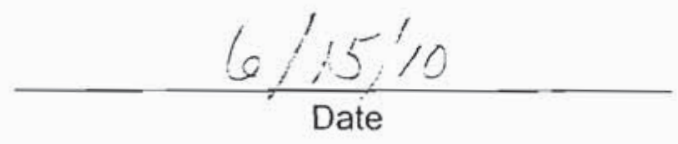

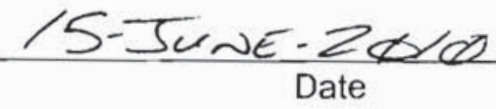


NSTec

Form

FRM-2217
CERTIFICATE OF DISPOSAL

(LOW LEVEL WASTE)
03/01/10

Rev. 01

Page 1 of 1

\section{Nevada Test Site}

This Certificate acknowledges that the following shipment(s) of waste have been disposed at the Nevada Test Site Radioactive Waste Management Complex.

\begin{tabular}{|l|l|l|l|}
\hline \multicolumn{1}{|c|}{ Shipment Number } & \multicolumn{1}{c|}{$\begin{array}{c}\text { Waste Stream } \\
\text { Identification \# }\end{array}$} & Package \# & Date of Disposal \\
\hline DPL10550 & LRY5LLFY08002 & 10 L887 & $6 / 15 / 10$ \\
\hline DPL10550 & LRY5LLFY08002 & 10 L888 & ( $/ 15 / 10$ \\
\hline & & & \\
\hline & & & \\
\hline & & & \\
\hline & & & \\
\hline & & & \\
\hline
\end{tabular}

This certification is provided as a courtesy to the waste generator for information purposes only.

/s/: Theresa Hale

WGS Signature

Waste Inspector

Title

/s/:Jon Tanaka

RWMC Signature

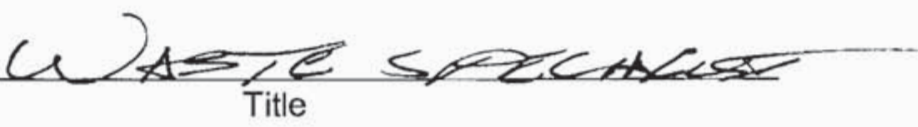

$\frac{6 / 15 / 10}{\text { Date }}$

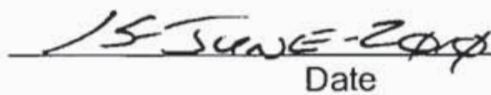


NSTec

Form

FRM-2217
CERTIFICATE OF DISPOSAL

(LOW LEVEL WASTE)
03/01/10

Rev. 01

Page 1 of 1

\section{Nevada Test Site}

This Certificate acknowledges that the following shipment(s) of waste have been disposed at the Nevada Test Site Radioactive Waste Management Complex.

\begin{tabular}{|l|l|l|c|}
\hline \multicolumn{1}{|c|}{$\begin{array}{c}\text { Whipment Number } \\
\text { Identification \# }\end{array}$} & \multicolumn{1}{|c|}{ Package \# } & Date of Disposal \\
\hline DPL10551 & LRY5LLFY08002 & 10 L889 & $1 / 5 / 10$ \\
\hline DPL10551 & LRY5LLFY08002 & 10 L890 & $6 / 5 / 5$ \\
\hline & & & \\
\hline & & & \\
\hline & & & \\
\hline & & & \\
\hline & & & \\
\hline
\end{tabular}

This certification is provided as a courtesy to the waste generator for information purposes only.

/s/:Theresa Hale

WGS Signature

Waste Inspector

Title

/s/:Jon Tanaka

RWMC Signature

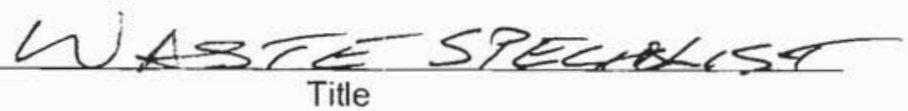

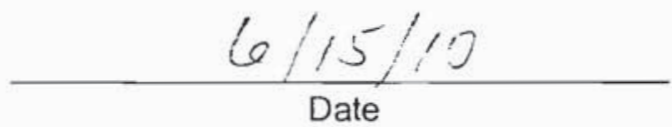

15- June 2010

Date 
NSTec

Form

FRM-2217
CERTIFICATE OF DISPOSAL

(LOW LEVEL WASTE)
03/01/10

Rev. 01

Page 1 of 1

Nevada Test Site

This Certificate acknowledges that the following shipments) of waste have been disposed at the Nevada Test Site Radioactive Waste Management Complex.

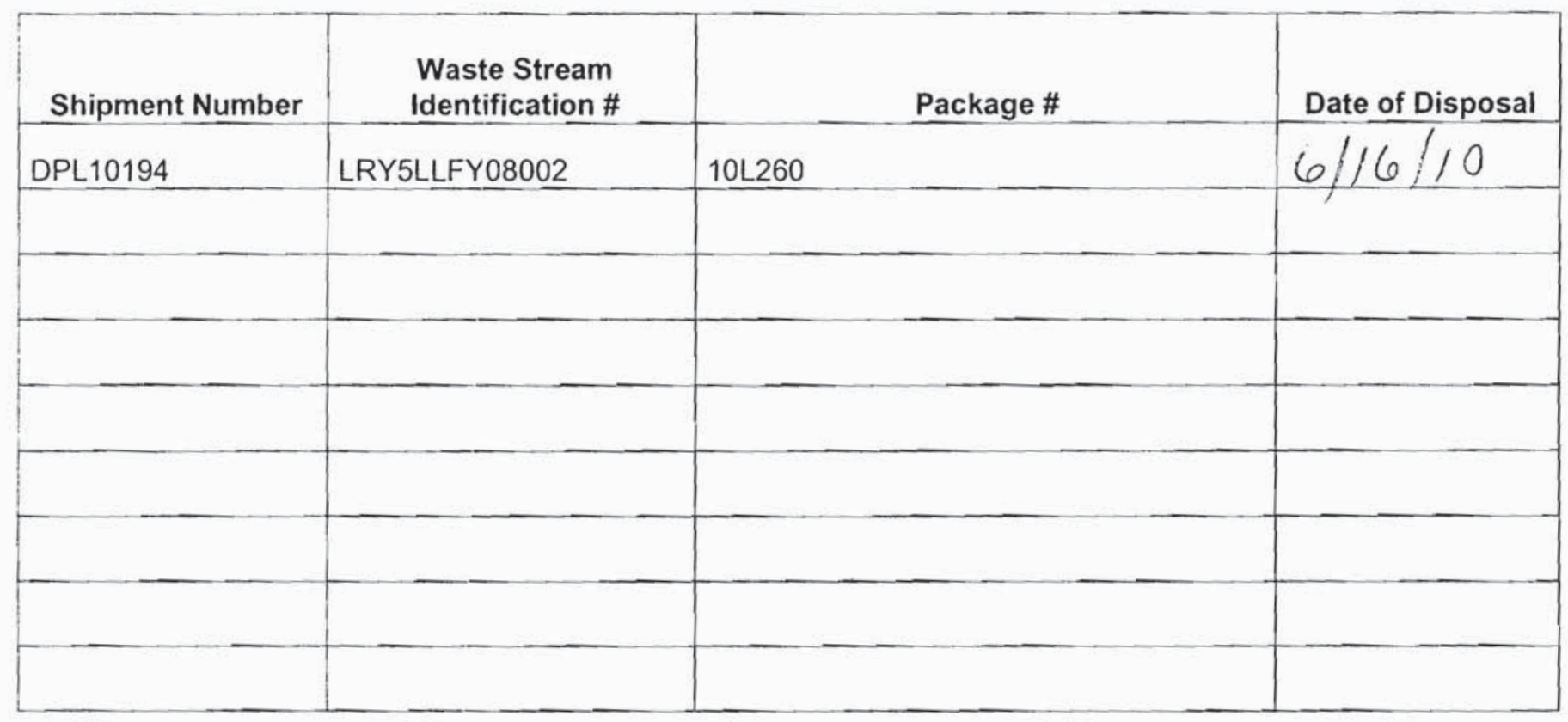

This certification is provided as a courtesy to the waste generator for information purposes only.

/s/ :Theresa Hale

WGS Signature

$6 / 16 / 10$

Waste Inspector

Title

/s/ :Jon Tanka

RWMC Signature

16-June-zQ⿻

Date

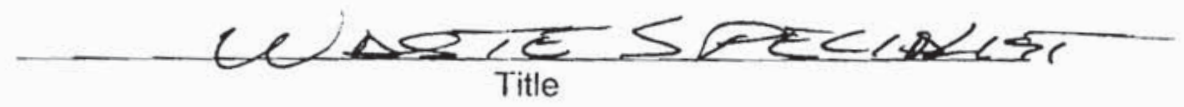


NSTec

Form

FRM-2217
CERTIFICATE OF DISPOSAL

(LOW LEVEL WASTE)
$03 / 01 / 10$

Rev. 01

Page 1 of 1

\section{Nevada Test Site}

This Certificate acknowledges that the following shipment(s) of waste have been disposed at the Nevada Test Site Radioactive Waste Management Complex.

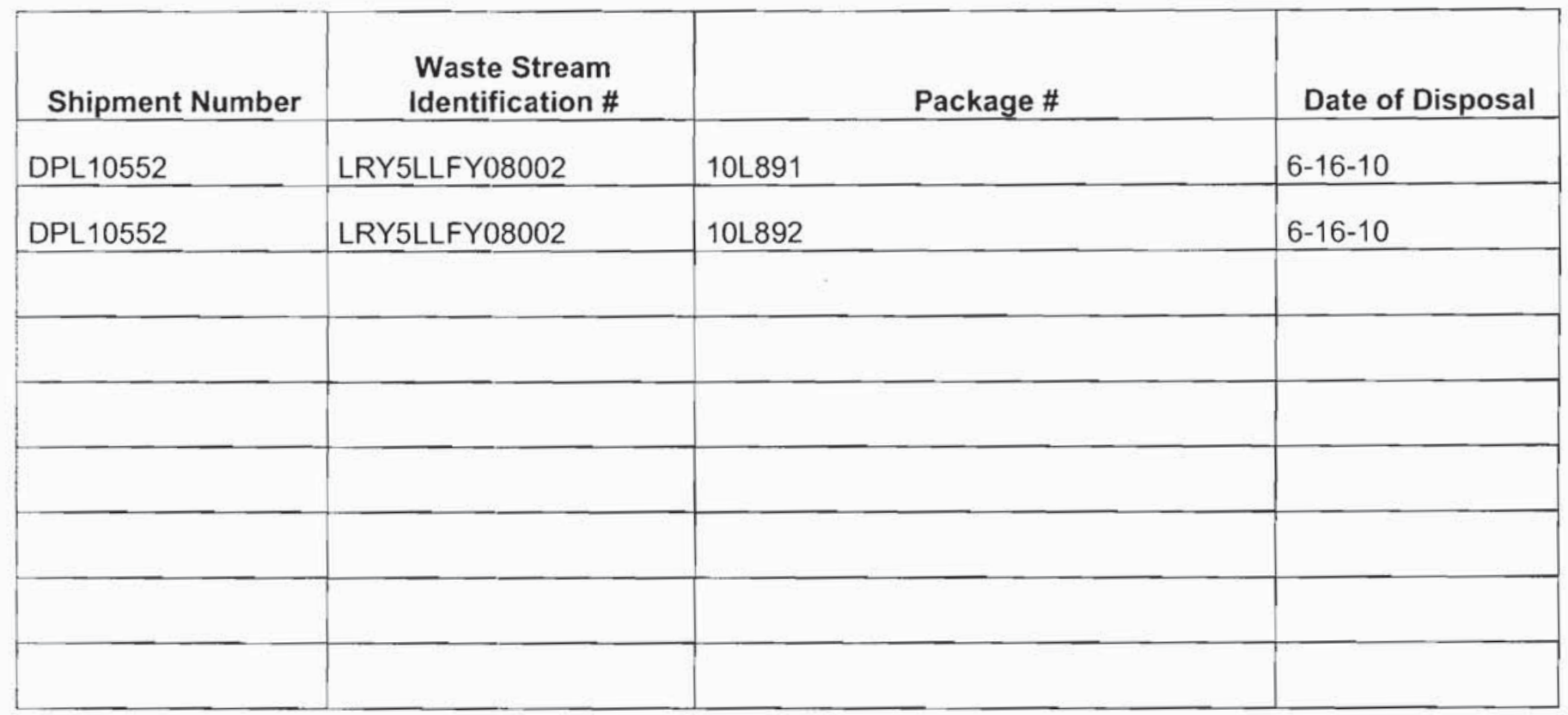

This certification is provided as a courtesy to the waste generator for information purposes only.

/s/:Theresa Hale

WGS Signature

Waste Inspector

Title

/s/:Jon Tanaka

RWḾC Signature

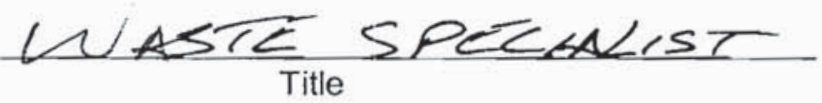

1-16-10

Date

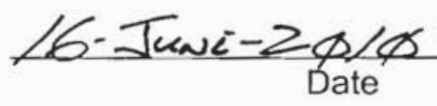


NSTec

Form

FRM-2217
CERTIFICATE OF DISPOSAL

(LOW LEVEL WASTE)
03/01/10

Rev. 01

Page 1 of 1

Nevada Test Site

This Certificate acknowledges that the following shipments) of waste have been disposed at the Nevada Test Site Radioactive Waste Management Complex.

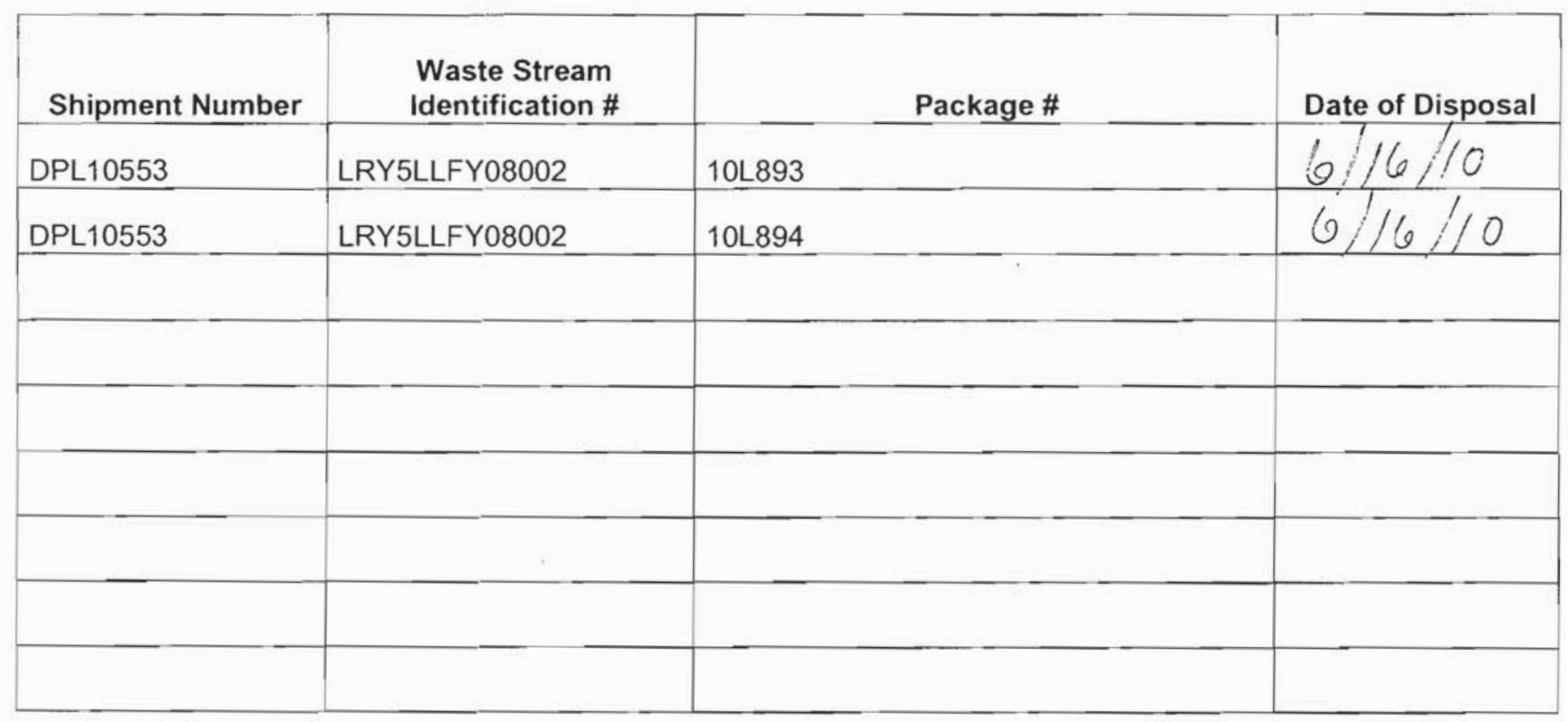

This certification is provided as a courtesy to the waste generator for information purposes only.

/s/: Theresa Hale

WGS Signature

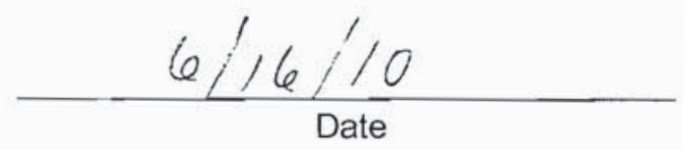

Waste Inspector

Title

/s/: Jon Tanka

RWMC Signature

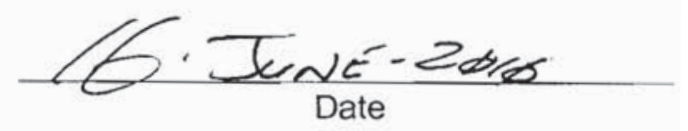

(Reference: OP -2151.304) 


\begin{tabular}{|lcr|}
\hline NSTec & CERTIFICATE OF DISPOSAL & 03/01/10 \\
Form & Rev. 01 \\
FRM-2217 & (LOW LEVEL WASTE) & Page 1 of 1 \\
\hline
\end{tabular}

Nevada Test Site

This Certificate acknowledges that the following shipments) of waste have been disposed at the Nevada Test Site Radioactive Waste Management Complex.

\begin{tabular}{|l|l|l|l|}
\hline \multicolumn{1}{|c|}{ Shipment Number } & \multicolumn{1}{|c|}{$\begin{array}{c}\text { Waste Stream } \\
\text { Identification \# }\end{array}$} & \multicolumn{1}{|c|}{ Package \# } & Date of Disposal \\
\hline DPL10554 & LRY5LLFY08002 & 10 L895 & $6 / 16 / 10$ \\
\hline DPL10554 & LRY5LLFY08002 & 10 L896 & $6 / 16 / 10$ \\
\hline & & & \\
\hline & & & \\
\hline & & & \\
\hline & & & \\
\hline & & & \\
\hline & & & \\
\hline
\end{tabular}

This certification is provided as a courtesy to the waste generator for information purposes only.

/s/ :Theresa Hale

WGS Signature

Waste Inspector

Title

/s/ :Jon Tanka

RWMC Signature

Title
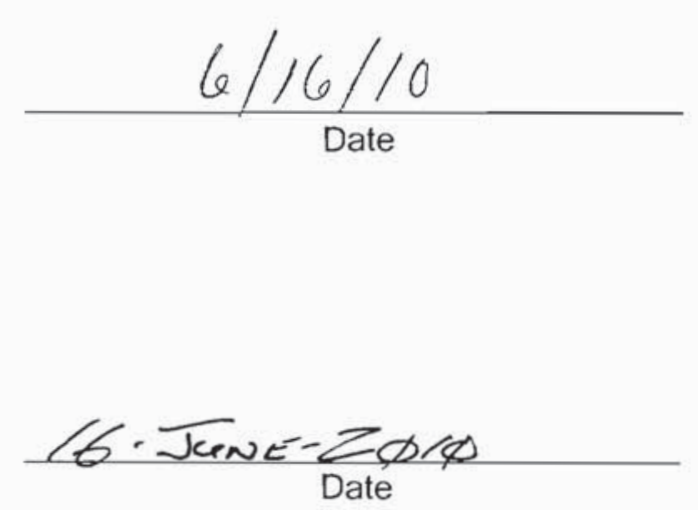

(Reference: OP-2151.304) 


\begin{tabular}{|lcr|}
\hline NSTec & CERTIFICATE OF DISPOSAL & $03 / 01 / 10$ \\
Form & Rev. 01 \\
FRM-2217 & (LOW LEVEL WASTE) & Page 1 of 1 \\
\hline
\end{tabular}

Nevada Test Site

This Certificate acknowledges that the following shipments) of waste have been disposed the Nevada Test Site Radioactive Waste Management Complex.

\begin{tabular}{|l|l|l|l|}
\hline \multicolumn{1}{c|}{ Shipment Number } & \multicolumn{1}{|c|}{$\begin{array}{c}\text { Waste Stream } \\
\text { Identification \# }\end{array}$} & \multicolumn{1}{c|}{ Package \# } & Date of Disposal \\
\hline DPL10555 & LRY5LLFY08002 & 10 L897 & $6 / 16 / 10$ \\
\hline DPL10555 & LRY5LLFY08002 & 10 L898 & $6 / 16 / 10$ \\
\hline & & & \\
\hline & & & \\
\hline & & & \\
\hline & & & \\
\hline & & & \\
\hline
\end{tabular}

This certification is provided as a courtesy to the waste generator for information purposes only.

/s/ :Theresa Hale

WGS Signature

Waste Inspector

Title

/s/: Jon Tanka

RWMC' Signature

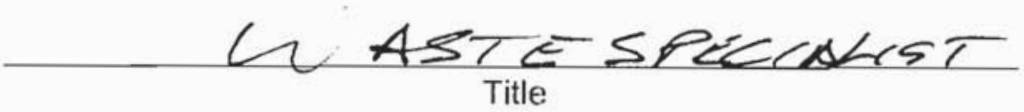

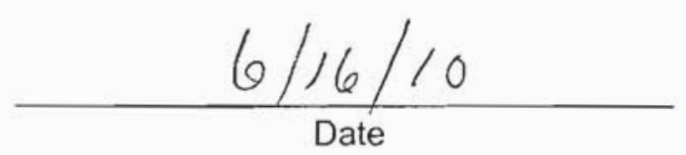

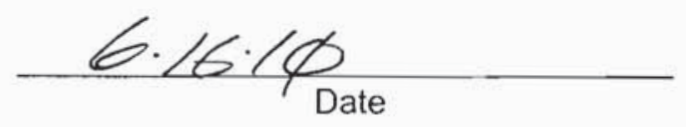

(Reference: OP-2151.304) 


\begin{tabular}{|lcr|}
\hline NSTec & CERTIFICATE OF DISPOSAL & $03 / 01 / 10$ \\
Form & Rev. 01 \\
FRM-2217 & (LOW LEVEL WASTE) & Page 1 of 1 \\
\hline
\end{tabular}

Nevada Test Site

This Certificate acknowledges that the following shipments) of waste have been disposed the Nevada Test Site Radioactive Waste Management Complex.

\begin{tabular}{|l|l|l|l|}
\hline \multicolumn{1}{|c|}{$\begin{array}{c}\text { Shipment Number } \\
\text { Waste Stream } \\
\text { Identification \# }\end{array}$} & \multicolumn{1}{|c|}{ Package \# } & Date of Disposal \\
\hline DPL10556 & LRY5LLFY08002 & 10 L899 & $6 / 16 / 10$ \\
\hline DPL10556 & LRY5LLFY08002 & 10 L.900 & $6 / 16 / 10$ \\
\hline & & & \\
\hline & & & \\
\hline & & & \\
\hline & & & \\
\hline & & & \\
\hline
\end{tabular}

This certification is provided as a courtesy to the waste generator for information purposes only.

/s/: Theresa Hale

WGS Signature

$6 / 16 / 10$

Date

Waste Inspector

Title

/s/: Jon Kanaka

RWMC Signature

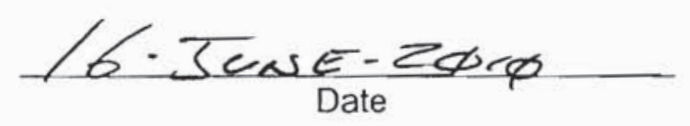

(Reference. OP_2151 $3 \cap 4$ ) 


\begin{tabular}{|lcr|}
\hline $\begin{array}{l}\text { NSTec } \\
\text { Form } \\
\text { FRM-2217 }\end{array}$ & CERTIFICATE OF DISPOSAL & $03 / 01 / 10$ \\
Rev. 01 \\
(LOW LEVEL WASTE)
\end{tabular}

Nevada Test Site

This Certificate acknowledges that the following shipments) of waste have been disposed at the Nevada Test Site Radioactive Waste Management Complex.

\begin{tabular}{|l|c|c|c|}
\hline Shipment Number & $\begin{array}{c}\text { Waste Stream } \\
\text { Identification \# }\end{array}$ & Package \# & Date of Disposal \\
\hline DPL10195 & LRY5LLFY08002 & 10 L6261 & $6 / 17 / 10$ \\
\hline & & & \\
\hline & & & \\
\hline & & & \\
\hline & & & \\
\hline & & & \\
\hline
\end{tabular}

This certification is provided as a courtesy to the waste generator for information purposes only.

/s/: Theresa Hale

WGS Signature

Waste Inspector

Title

/s/: Jon Tanka

- RWMC Signature
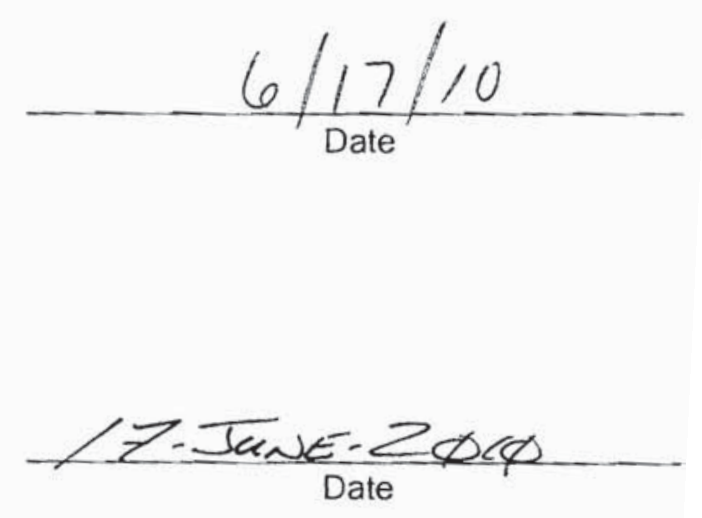
NSTec

Form

FRM-2217
CERTIFICATE OF DISPOSAL

(LOW LEVEL WASTE)
03/01/10

Rev. 01

Page 1 of 1

\section{Nevada Test Site}

This Certificate acknowledges that the following shipment(s) of waste have been disposed at the Nevada Test Site Radioactive Waste Management Complex.

\begin{tabular}{|l|l|l|l|}
\hline \multicolumn{1}{|c|}{ Shipment Number } & \multicolumn{1}{c|}{$\begin{array}{c}\text { Waste Stream } \\
\text { Identification \# }\end{array}$} & Package \# & Date of Disposal \\
\hline DPL10557 & LRY5LLFY08002 & 10 L901 & $6 / / 7 / 10$ \\
\hline DPL10557 & LRY5LLFY08002 & 10 L02 & $6 / 17 / 10$ \\
\hline & & & \\
\hline & & & \\
\hline & & & \\
\hline & & & \\
\hline
\end{tabular}

This certification is provided as a courtesy to the waste generator for information purposes only.

\section{/s/:Theresa Hale}

WGS Signature

Waste inspector

RWMC Signature

Lw Speriglist $\frac{6 / 17 / 10}{\text { Date }}$

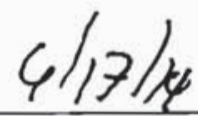

Date 
NSTec

Form

FRM-2217
CERTIFICATE OF DISPOSAL

(LOW LEVEL WASTE)
03/01/10

Rev. 01

Page 1 of 1

\section{Nevada Test Site}

This Certificate acknowledges that the following shipment(s) of waste have been disposed at the Nevada Test Site Radioactive Waste Management Complex.

\begin{tabular}{|l|l|l|l|}
\hline \multicolumn{1}{|c|}{$\begin{array}{c}\text { Whaste Stream } \\
\text { Identification \# }\end{array}$} & Package \# & Date of Disposal \\
\hline DPL10558 & LRY5LLFY08002 & 10L903 & 0 \\
\hline DPL10558 & LRY5LLFY08002 & 10 L904 & \\
\hline & & & \\
\hline & & & \\
\hline & & & \\
\hline & & & \\
\hline & & & \\
\hline
\end{tabular}

This certification is provided as a courtesy to the waste generator for information purposes only.

/s/:Theresa Hale

$$
\text { WGS Signature }
$$

Waste inspector

RWMC Signature

LLW Spewalest

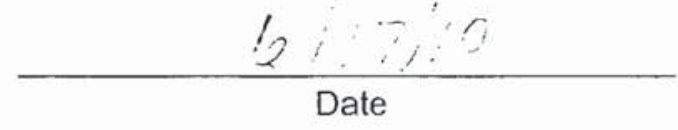

$6 / 71 / 4$

Date 
NSTeC

Form

FRM-2217
CERTIFICATE OF DISPOSAL

(LOW LEVEL WASTE)
03/01/10

Rev. 01

Page 1 of 1

\section{Nevada Test Site}

This Certificate acknowledges that the following shipment(s) of waste have been disposed at the Nevada Test Site Radioactive Waste Management Complex.

\begin{tabular}{|c|c|c|c|}
\hline Shipment Number & $\begin{array}{l}\text { Waste Stream } \\
\text { Identification \# }\end{array}$ & Package \# & Date of Disposal \\
\hline DPL10559 & LRY5LLFY08002 & $10\llcorner 905$ & $i \quad i$ \\
\hline DPL10559 & LRY5LLFY08002 & 10L906 & $\because \quad \because$ \\
\hline & & & \\
\hline & & & \\
\hline & & & \\
\hline & & & \\
\hline & & & \\
\hline & & & \\
\hline
\end{tabular}

This certification is provided as a courtesy to the waste generator for information purposes only.

/s/: Theresa Hale

WGS Signature

Waste inspector

Title

RWMC Signature

LLW Spacialist
$6 / 17 / 19$

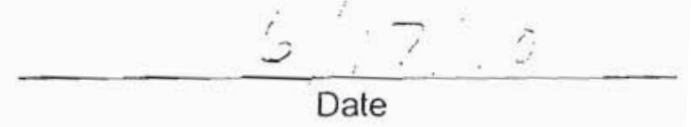

Date 


\begin{tabular}{|lcr|}
\hline NSTec & CERTIFICATE OF DISPOSAL & 03/01/10 \\
Form & Rev. 01 \\
FRM-2217 & (LOW LEVEL WASTE) & Page 1 of 1 \\
\hline
\end{tabular}

Nevada Test Site

This Certificate acknowledges that the following shipments) of waste have been disposed at the Nevada Test Site Radioactive Waste Management Complex.

\begin{tabular}{|l|l|l|l|}
\hline \multicolumn{1}{|c|}{ Shipment Number } & \multicolumn{1}{|c|}{$\begin{array}{c}\text { Waste Stream } \\
\text { Identification \# }\end{array}$} & Package \# & Date of Disposal \\
\hline DPL10560 & LRY5LLFY08002 & 10 L907 & 1 \\
\hline DPL10560 & LRY5LLFY08002 & 10 L908 & \\
\hline & & & \\
\hline & & & \\
\hline & & & \\
\hline & & & \\
\hline & & & \\
\hline
\end{tabular}

This certification is provided as a courtesy to the waste generator for information purposes only.

/s\%: Theresa Hale

WGS Signature

Date

Waste Inspector

Title

/s/: Jon Tanka

RWMC Signature

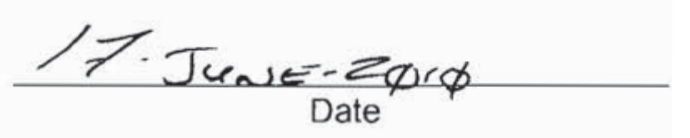

(Reference: OP-2151.304) 
NSTec

Form

FRM-2217

CERTIFICATE OF DISPOSAL

03/01/10

Rev. 01

(LOW LEVEL WASTE)

Page 1 of 1

\section{Nevada Test Site}

This Certificate acknowledges that the following shipment(s) of waste have been disposed at the Nevada Test Site Radioactive Waste Management Complex.

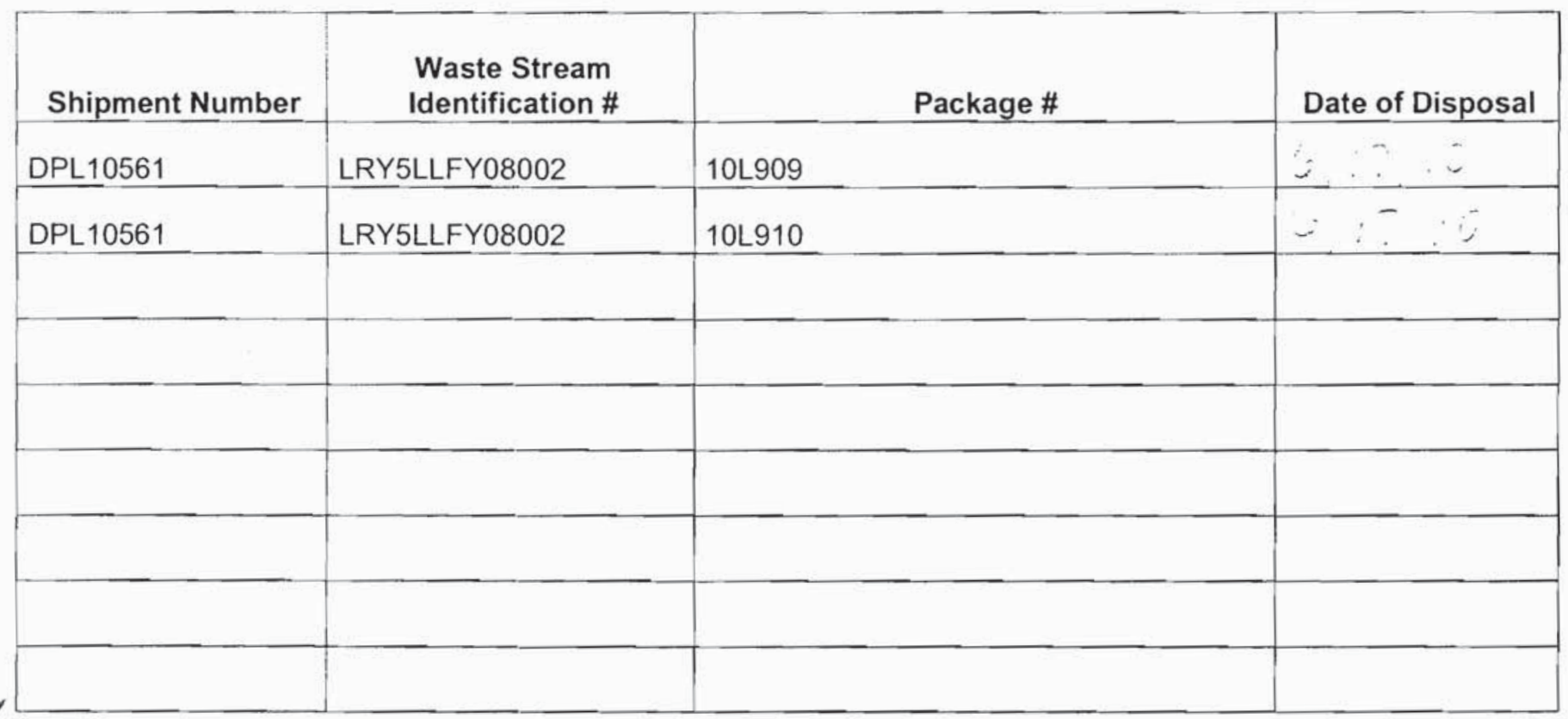

This certification is provided as a courtesy to the waste generator for information purposes only.

WGS Signature
$\frac{\text { Waste Inspector }}{\text { Title }}$

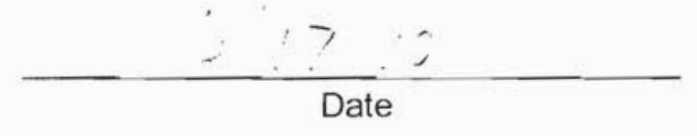

/s/: Jon Tanaka
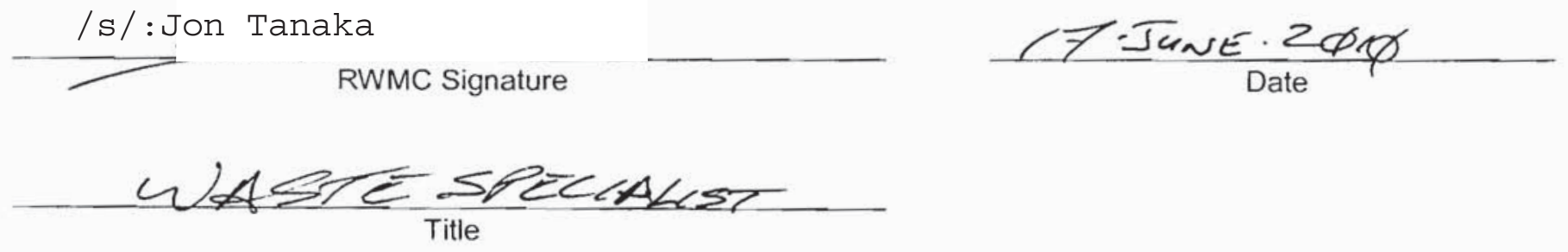
NSTec

Form

FRM-2217
CERTIFICATE OF DISPOSAL

(LOW LEVEL. WASTE)
03/01/10

Rev. 01

Page 1 of 1

\section{Nevada Test Site}

This Certificate acknowledges that the following shipment(s) of waste have been disposed at the Nevada Test Site Radioactive Waste Management Complex.

\begin{tabular}{|c|c|c|c|}
\hline Shipment Number & $\begin{array}{l}\text { Waste Stream } \\
\text { Identification \# }\end{array}$ & Package \# & Date of Disposal \\
\hline DPL10562 & LRY5LLFY08002 & $10 L 911$ & \\
\hline DPL10562 & LRY5LLFY08002 & $10 L 912$ & $\because$ \\
\hline & & & \\
\hline & & & \\
\hline & & & \\
\hline & & & \\
\hline & & & \\
\hline & & & \\
\hline
\end{tabular}

This certification is provided as a courtesy to the waste generator for information purposes only.

WGS Signature

Waste inspector

$$
\text { Title }
$$

/s/:Jon Tanaka

RWMC Signature

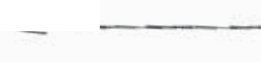

RWMC Signature

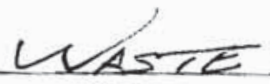

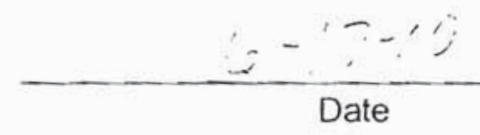

Y. June - 2 Date 
NSTec

Form

FRM-2217
CERTIFICATE OF DISPOSAL

(LOW LEVEL WASTE)
03/01/10

Rev. 01

Page 1 of 1

\section{Nevada Test Site}

This Certificate acknowledges that the following shipment(s) of waste have been disposed at the Nevada Test Site Radioactive Waste Management Complex.

\begin{tabular}{|l|l|l|l|}
\hline \multicolumn{1}{|c|}{$\begin{array}{c}\text { Waste Stream } \\
\text { Identification \# }\end{array}$} & Package \# & Date of Disposal \\
\hline DPL10563 & LRY5LLFY08002 & 10L913 & $6 / / 7 / / 6$ \\
\hline DPL10563 & LRY5LLFY08002 & 10L914 & $(1 / 7 / 1)$ \\
\hline & & & \\
\hline & & & \\
\hline & & & \\
\hline
\end{tabular}

This certification is provided as a courtesy to the waste generator for information purposes only.

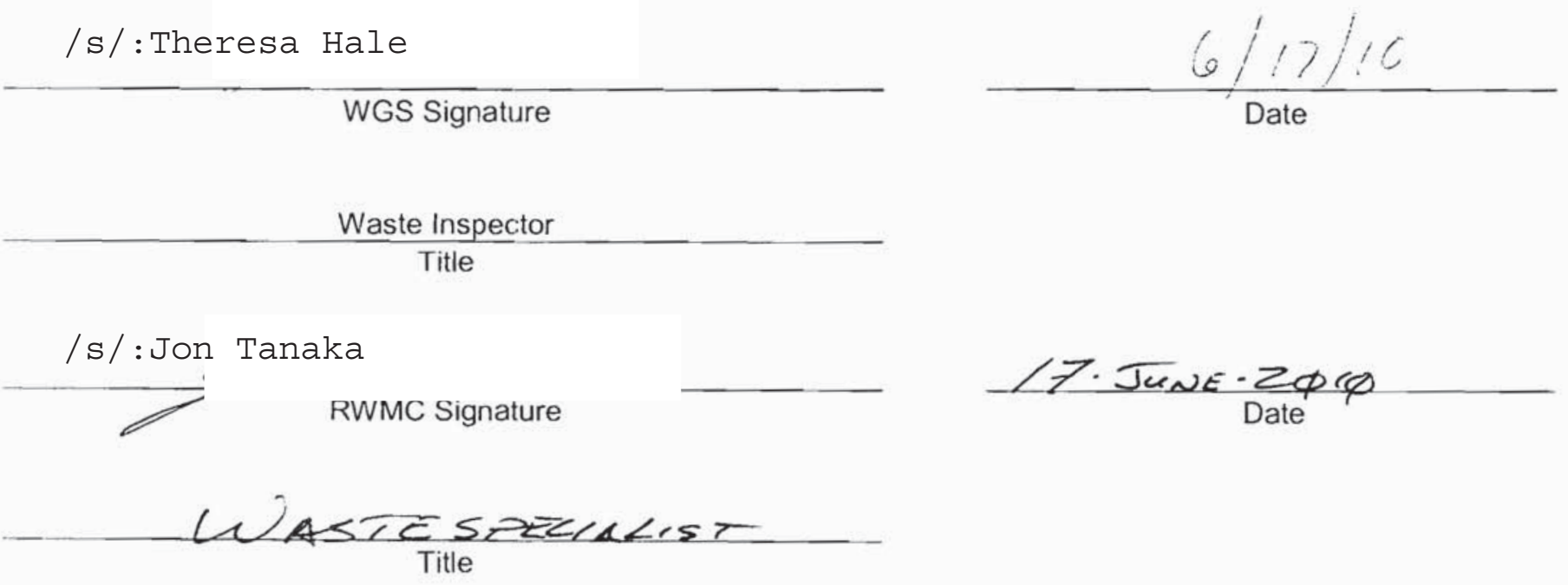


NSTec

Form

CERTIFICATE OF DISPOSAL

03/01/10

FRM-2217

(LOW LEVEL WASTE)

Rev. 01

Page 1 of 1

\section{Nevada Test Site}

This Certificate acknowledges that the following shipment(s) of waste have been disposed at the Nevada Test Site Radioactive Waste Management Complex.

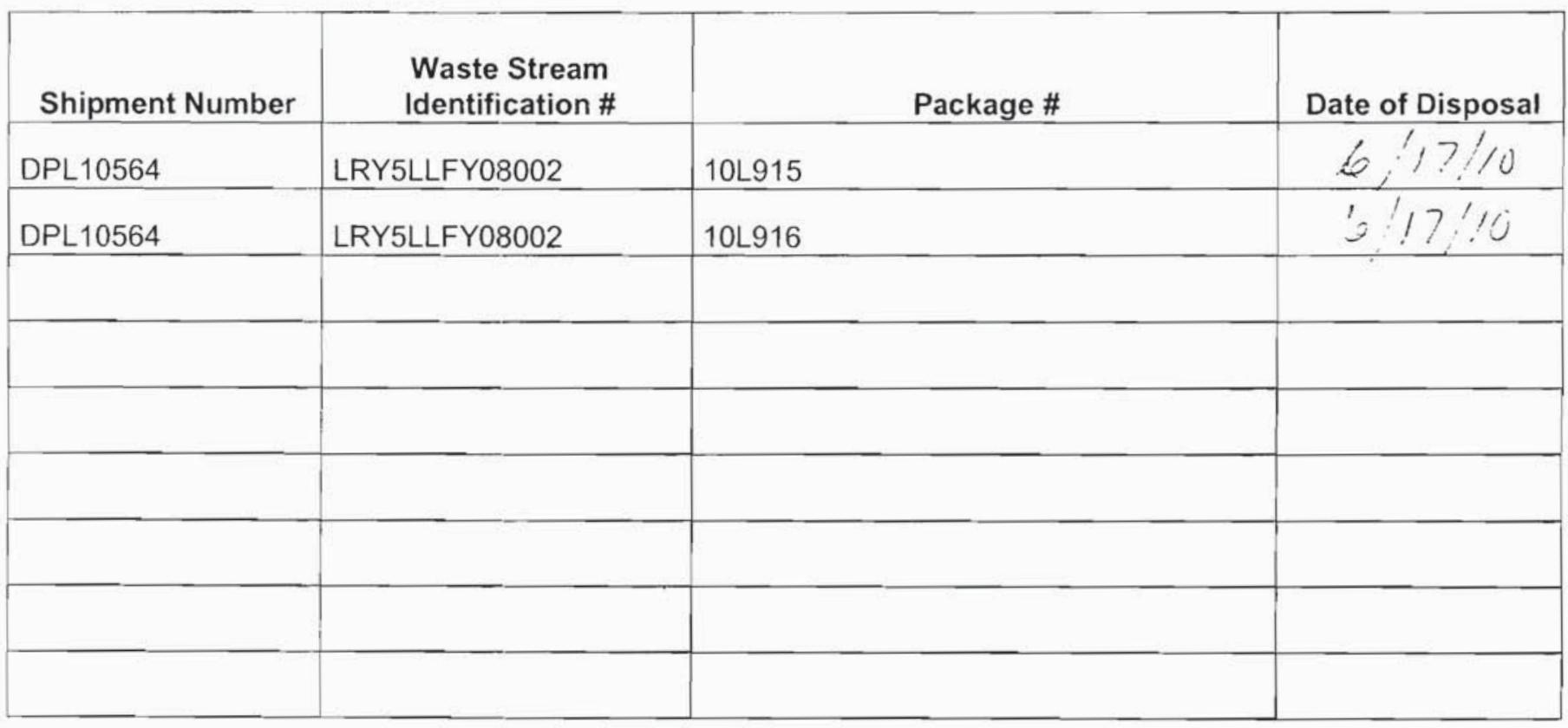

This certification is provided as a courtesy to the waste generator for information purposes only.

/s/:Theresa Hale

$$
\text { WGS Signature }
$$

Waste Inspector

$$
\text { Title }
$$

/s/:Jon Tanaka

RWM $\bar{C}$ Signature

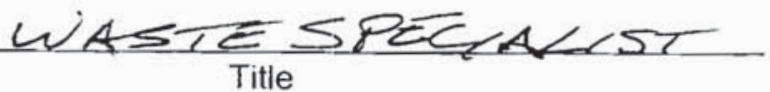

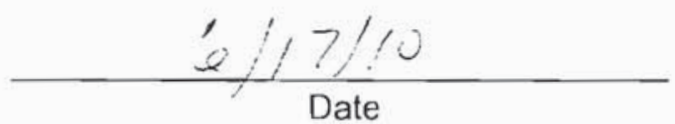

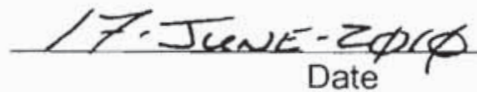




\section{Nevada Test Site}

This Certificate acknowledges that the following shipment(s) of waste have been disposed at the Nevada Test Site Radioactive Waste Management Complex.

\begin{tabular}{|c|c|c|c|}
\hline Shipment Number & $\begin{array}{l}\text { Waste Stream } \\
\text { Identification \# }\end{array}$ & Package \# & Date of Disposal \\
\hline DPL10114 & LRY5LLFY08002 & $10 \mathrm{~L} 180$ & lizilin \\
\hline DPL10114 & LRY5LLFY08002 & $10 \mathrm{~L} 344$ & $61 ?: 11$ \\
\hline & & & \\
\hline & & & \\
\hline & & & \\
\hline & & & \\
\hline & & & \\
\hline & & & \\
\hline
\end{tabular}

This certification is provided as a courtesy to the waste generator for information purposes only.

WGS Signature

Waste Inspector

Title

/s/:Jon Tanaka

RWMC Signature - -

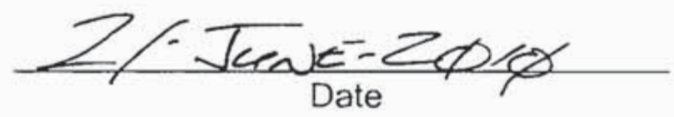


NSTec

Form

FRM-2217
CERTIFICATE OF DISPOSAL

(LOW LEVEL WASTE)
$03 / 01 / 10$

Rev. 01

Page 1 of 1

\section{Nevada Test Site}

This Certificate acknowledges that the following shipment(s) of waste have been disposed at the Nevada Test Site Radioactive Waste Management Complex.

\begin{tabular}{|l|l|l|l|}
\hline Shipment Number & $\begin{array}{c}\text { Waste Stream } \\
\text { Identification \# }\end{array}$ & Package \# & Date of Disposal \\
\hline DPL10197 & LRY5LLF08002 & 10L263 & UIIIII \\
\hline & & & \\
\hline & & & \\
\hline & & & \\
\hline & & & \\
\hline & & & \\
\hline
\end{tabular}

This certification is provided as a courtesy to the waste generator for information purposes only.

WGS Signature

d2110

Date

Waste Inspector

Title

/s/:Jon Tanaka

RWMC Signature

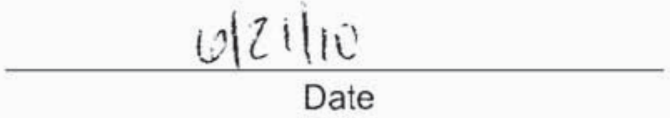

SASCE SWEC SACSS

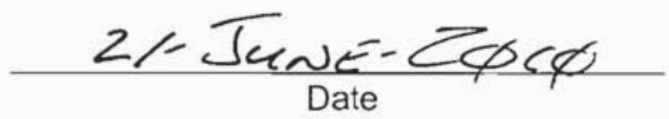




\begin{tabular}{|lcr|}
\hline NSTec & CERTIFICATE OF DISPOSAL & $03 / 01 / 10$ \\
Form & Rev. 01 \\
FRM-2217 & (LOW LEVEL WASTE) & Page 1 of 1 \\
\hline
\end{tabular}

Nevada Test Site

This Certificate acknowledges that the following shipments) of waste have been disposed at the Nevada Test Site Radioactive Waste Management Complex.

\begin{tabular}{|l|l|l|l|}
\hline \multicolumn{1}{|c|}{$\begin{array}{c}\text { Waste Stream } \\
\text { Identification \# }\end{array}$} & \multicolumn{1}{|c|}{ Package \# } & Date of Disposal \\
\hline DPL10565 & LRY5LLFY08002 & 10 L917 & $6 / 21 / 10$ \\
\hline DPL10565 & LRY5LLFY08002 & $10 L 918$ & $6 / 21 / 10$ \\
\hline & & & \\
\hline & & & \\
\hline & & & \\
\hline & & & \\
\hline & & & \\
\hline & & & \\
\hline
\end{tabular}

This certification is provided as a courtesy to the waste generator for information purposes only.

WGS Signature

Waste Inspector

Title

/s/: Jon Tanka

RWMC Signature

6121110

Date

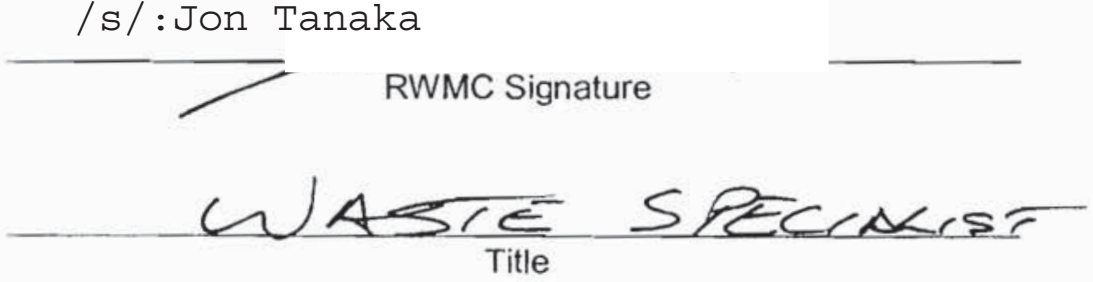

(Reference: OP-2151.304) 
NSTec

Form

FRM-2217
CERTIFICATE OF DISPOSAL

(LOW LEVEL WASTE)
03/01/10

Rev. 01

Page 1 of 1

\section{Nevada Test Site}

This Certificate acknowledges that the following shipment(s) of waste have been disposed at the Nevada Test Site Radioactive Waste Management Complex.

\begin{tabular}{|l|l|l|l|}
\hline \multicolumn{1}{|c|}{ Shipment Number } & $\begin{array}{c}\text { Waste Stream } \\
\text { Identification \# }\end{array}$ & Package \# & Date of Disposal \\
\hline DPL10566 & LRY5LLFY08002 & 10 L919 & Li?!!! \\
\hline DPL10566 & LRY5LLFY08002 & 10 L920 & \\
\hline & & & \\
\hline & & & \\
\hline & & & \\
\hline & & & \\
\hline
\end{tabular}

This certification is provided as a courtesy to the waste generator for information purposes only.

WGS Signature

Waste Inspector

Title

/s/: Jon Tanaka

RWMC Signature

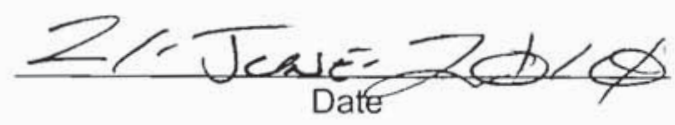


NSTec

Form

FRM-2217
CERTIFICATE OF DISPOSAL

(LOW LEVEL WASTE)
03/01/10

Rev. 01

Page 1 of 1

Nevada Test Site

This Certificate acknowledges that the following shipments) of waste have been disposed at the Nevada Test Site Radioactive Waste Management Complex.

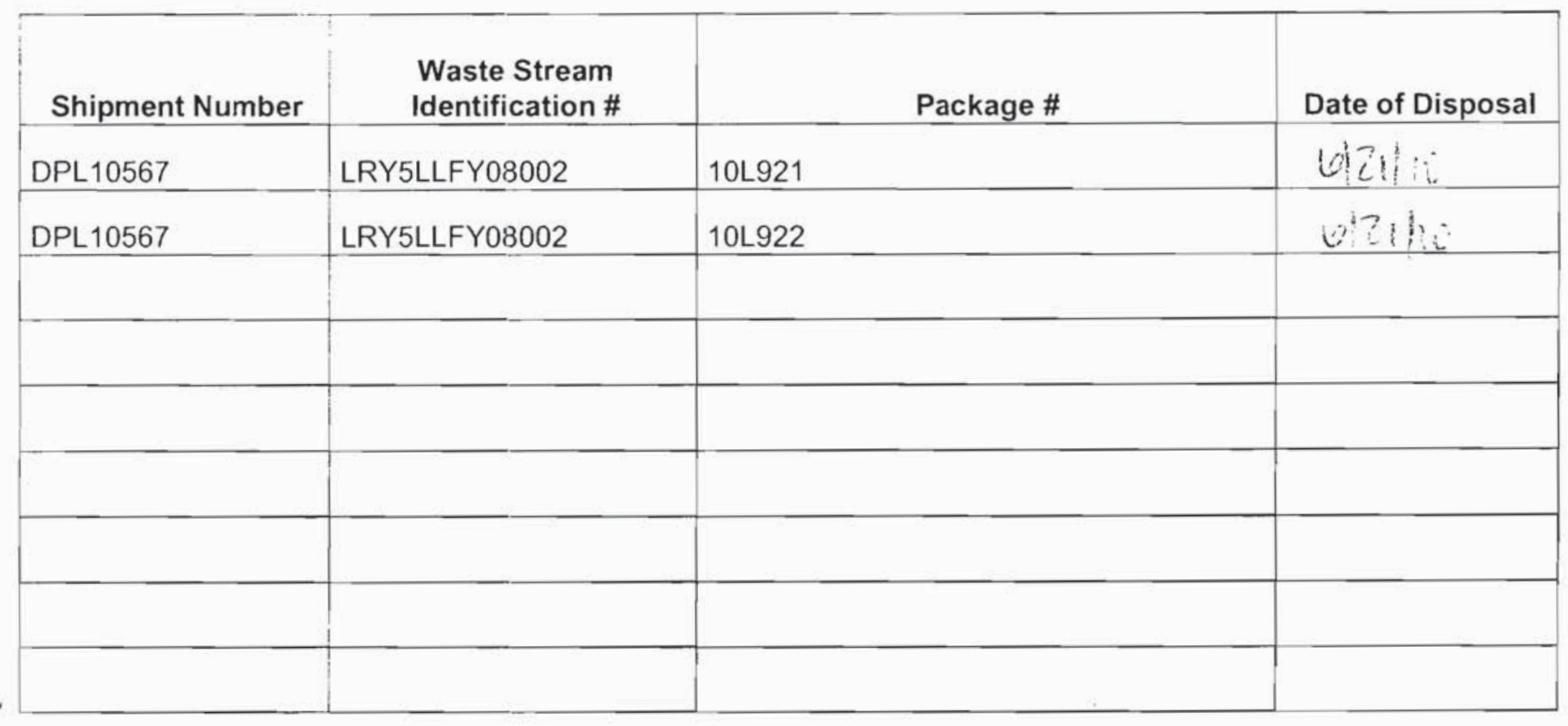

This certification is provided as a courtesy to the waste generator for information purposes only.

WGS Signature

Waste Inspector

Title
Li21110

Date

/s/: Jon Tanka

RWMC Signature

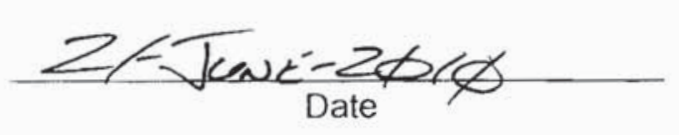

(Reference: OP-2151.304) 


\begin{tabular}{|lcr|}
\hline NSTec & CERTIFICATE OF DISPOSAL & 03/01/10 \\
Form & Rev. 01 \\
FRM-2217 & (LOW LEVEL WASTE) & Page 1 of 1 \\
\hline
\end{tabular}

Nevada Test Site

This Certificate acknowledges that the following shipments) of waste have been disposed the Nevada Test Site Radioactive Waste Management Complex.

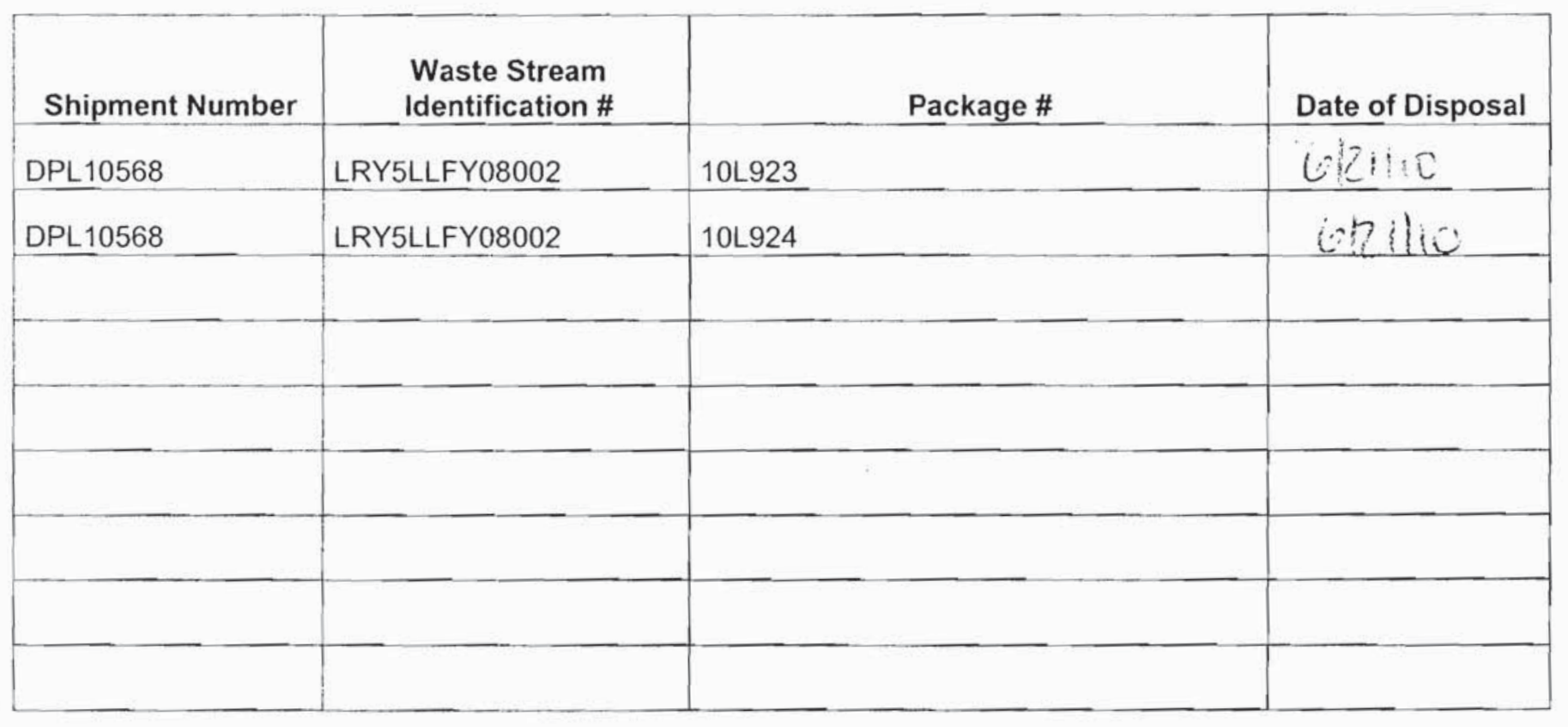

This certification is provided as a courtesy to the waste generator for information purposes only.

WGS Signature

Waste Inspector

Title /s/: Jon Kanaka

RWMC Signature •

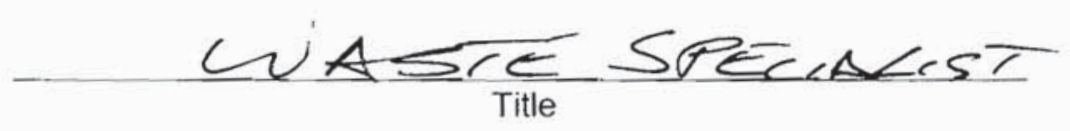

Q12110

Date

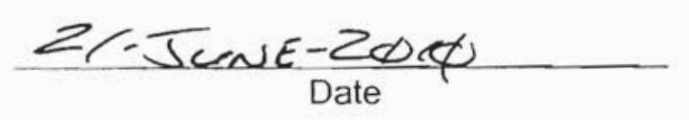

(Reference: OP -2151.304) 
NSTec

Form

FRM-2217
CERTIFICATE OF DISPOSAL

(LOW LEVEL WASTE)
03/01/10

Rev. 01

Page 1 of 1

\section{Nevada Test Site}

This Certificate acknowledges that the following shipment(s) of waste have been disposed at the Nevada Test Site Radioactive Waste Management Complex.

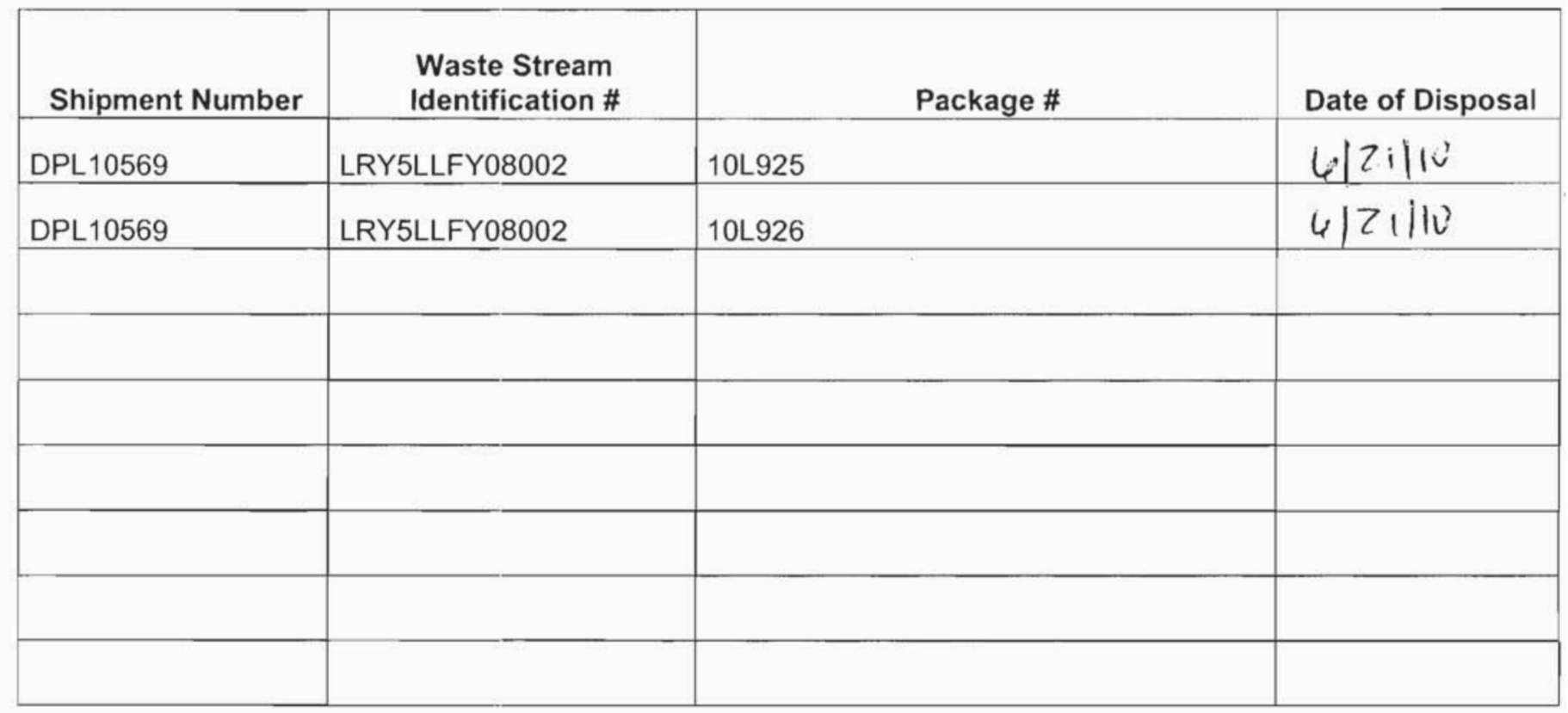

This certification is provided as a courtesy to the waste generator for information purposes only.

WGS Signature

6121110
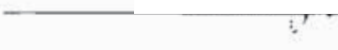

\section{(2) Signature}

Waste Inspector

$$
\text { Title }
$$

/s/: Jon Tanaka
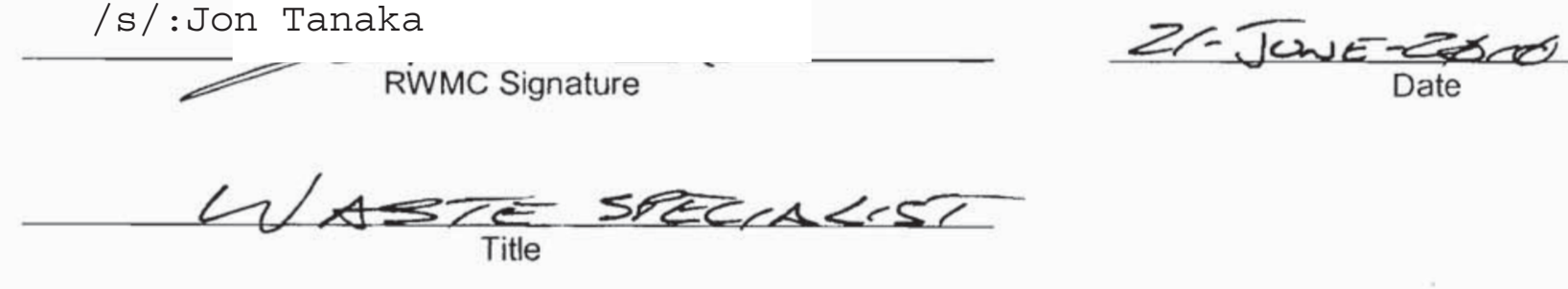


\begin{tabular}{|lcr|}
\hline NSTec & CERTIFICATE OF DISPOSAL & 03/01/10 \\
Form & Rev. 01 \\
FRM-2217 & (LOW LEVEL WASTE) & Page 1 of 1 \\
\hline
\end{tabular}

Nevada Test Site

This Certificate acknowledges that the following shipments) of waste have been disposed at the Nevada Test Site Radioactive Waste Management Complex.

\begin{tabular}{|l|l|l|c|}
\hline \multicolumn{1}{|c|}{ Shipment Number } & \multicolumn{1}{|c|}{$\begin{array}{c}\text { Waste Stream } \\
\text { Identification \# }\end{array}$} & Package \# & Date of Disposal \\
\hline DPL10570 & LRY5LLFY08002 & 10 L927 & (2) \\
\hline DPL10570 & LRY5LLFY08002 & 10 (028 & \\
\hline & & & \\
\hline & & & \\
\hline & & & \\
\hline & & & \\
\hline & & & \\
\hline & & & \\
\hline
\end{tabular}

This certification is provided as a courtesy to the waste generator for information purposes only.

WGS Signature

Waste Inspector

Title

/s/: Jon Tanaka

RWMC Signature

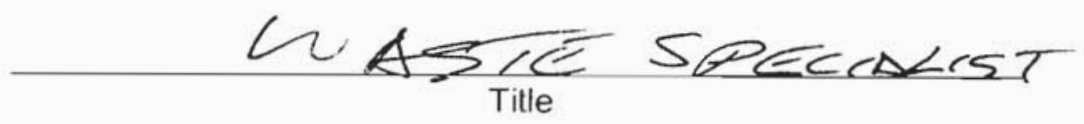

(Reference: OP-2151.304) 


\begin{tabular}{|lcr|}
\hline NSTec & & $03 / 01 / 10$ \\
Form & CERTIFICATE OF DISPOSAL & Rev. 01 \\
FRM-2217 & (LOW LEVEL WASTE) & Page 1 of $\mathbf{1}$ \\
\hline
\end{tabular}

Nevada Test Site

This Certificate acknowledges that the following shipments) of waste have been disposed at the Nevada Test Site Radioactive Waste Management Complex.

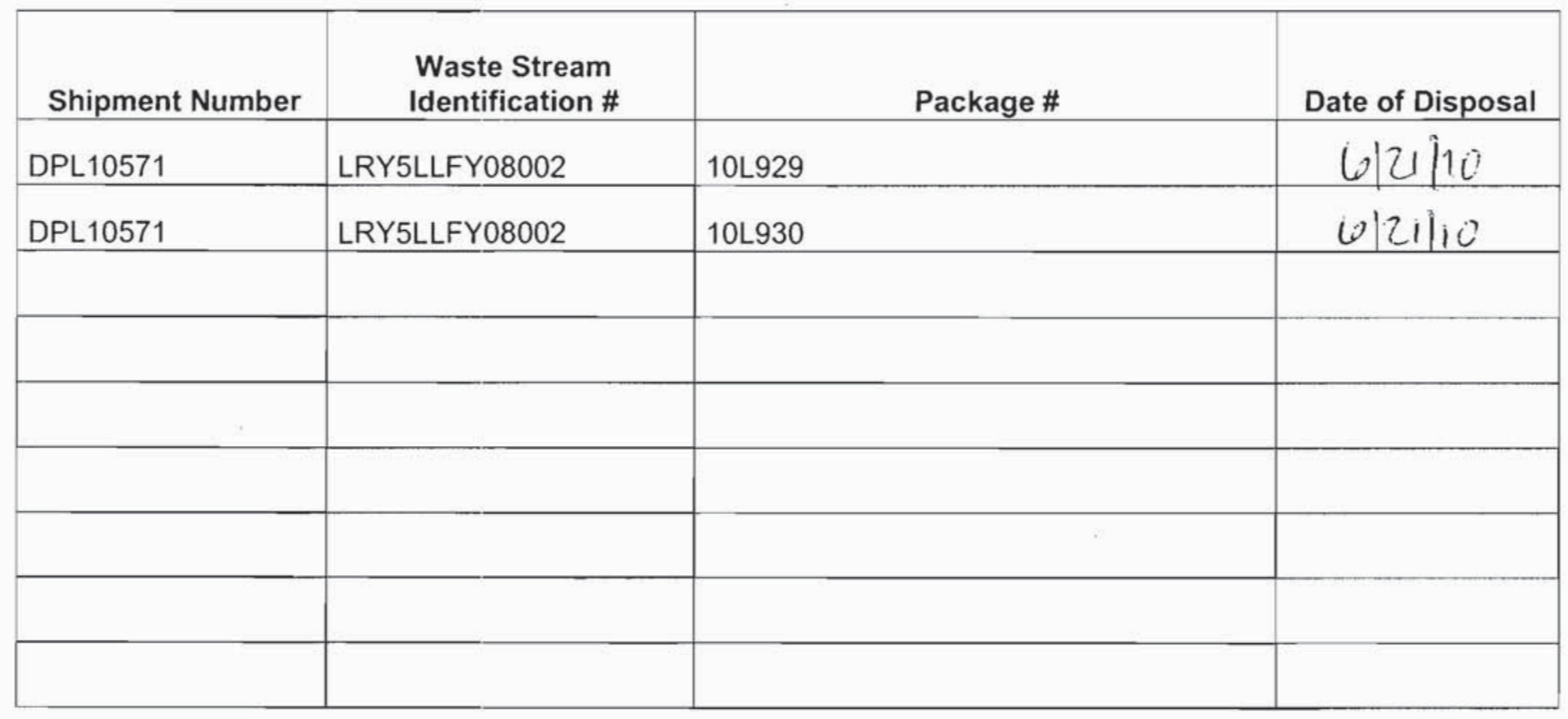

This certification is provided as a courtesy to the waste generator for information purposes only.

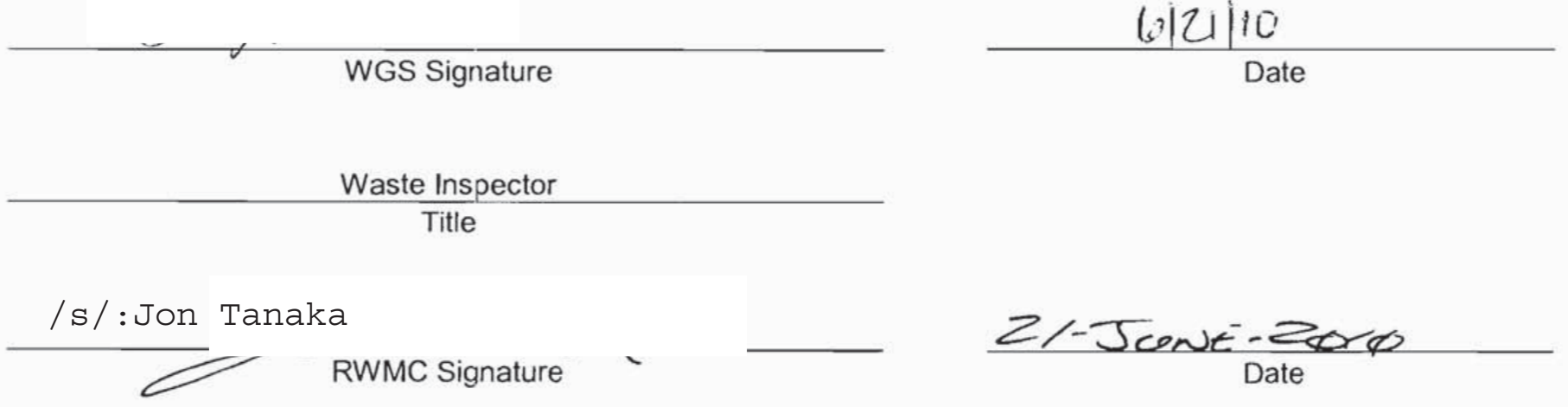

(Reference: OP-2151.304) 


\begin{tabular}{|lcr|}
\hline NSTec & CERTIFICATE OF DISPOSAL & $03 / 01 / 10$ \\
Form & Rev. 01 \\
FRM-2217 & (LOW LEVEL WASTE) & Page 1 of 1 \\
\hline
\end{tabular}

Nevada Test Site

This Certificate acknowledges that the following shipments) of waste have been disposed at the Nevada Test Site Radioactive Waste Management Complex.

\begin{tabular}{|l|l|l|l|}
\hline \multicolumn{1}{|c|}{$\begin{array}{c}\text { Waste Stream } \\
\text { Identification \# }\end{array}$} & \multicolumn{1}{|c|}{ Package \# } & Date of Disposal \\
\hline DPL10115 & LRY5LLFY08002 & 10 L181 & $6 / 22.10$ \\
\hline DPL10115 & LRY5LLFY08002 & 10 10343 & $6 / 22110$ \\
\hline & & & \\
\hline & & & \\
\hline & & & \\
\hline & & & \\
\hline & & & \\
\hline & & & \\
\hline
\end{tabular}

This certification is provided as a courtesy to the waste generator for information purposes only.

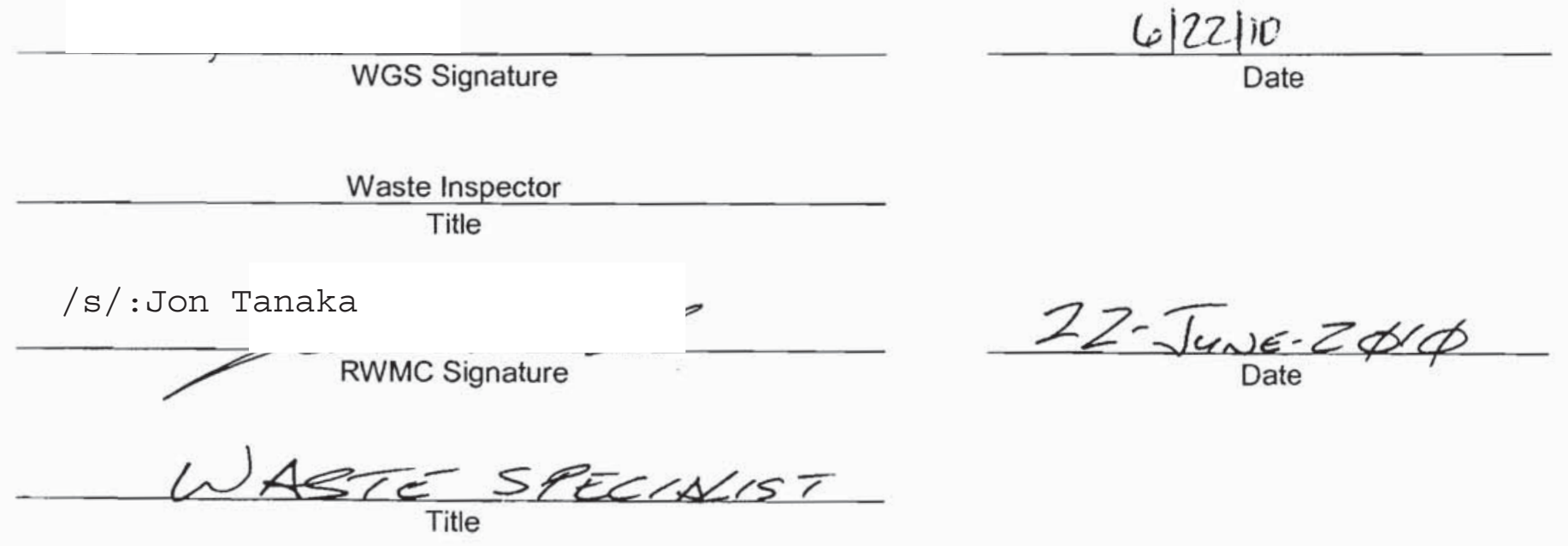




\begin{tabular}{|lcr|}
\hline NSTec & CERTIFICATE OF DISPOSAL & $03 / 01 / 10$ \\
Form & Rev. 01 \\
FRM-2217 & (LOW LEVEL WASTE) & Page 1 of 1 \\
\hline
\end{tabular}

Nevada Test Site

This Certificate acknowledges that the following shipments) of waste have been disposed at the Nevada Test Site Radioactive Waste Management Complex.

\begin{tabular}{|l|l|l|l|}
\hline \multicolumn{1}{|c|}{ Shipment Number } & \multicolumn{1}{|c|}{$\begin{array}{c}\text { Waste Stream } \\
\text { Identification \# }\end{array}$} & Package \# & Date of Disposal \\
\hline DPL10116 & LRY5LLFY08002 & 10 182 & $6 / 22 / 10$ \\
\hline DPL10116 & LRY5LLFY08002 & 10 L342 & $6 / 22110$ \\
\hline & & & \\
\hline & & & \\
\hline & & & \\
\hline & & & \\
\hline & & & \\
\hline & & & \\
\hline
\end{tabular}

This certification is provided as a courtesy to the waste generator for information purposes only.
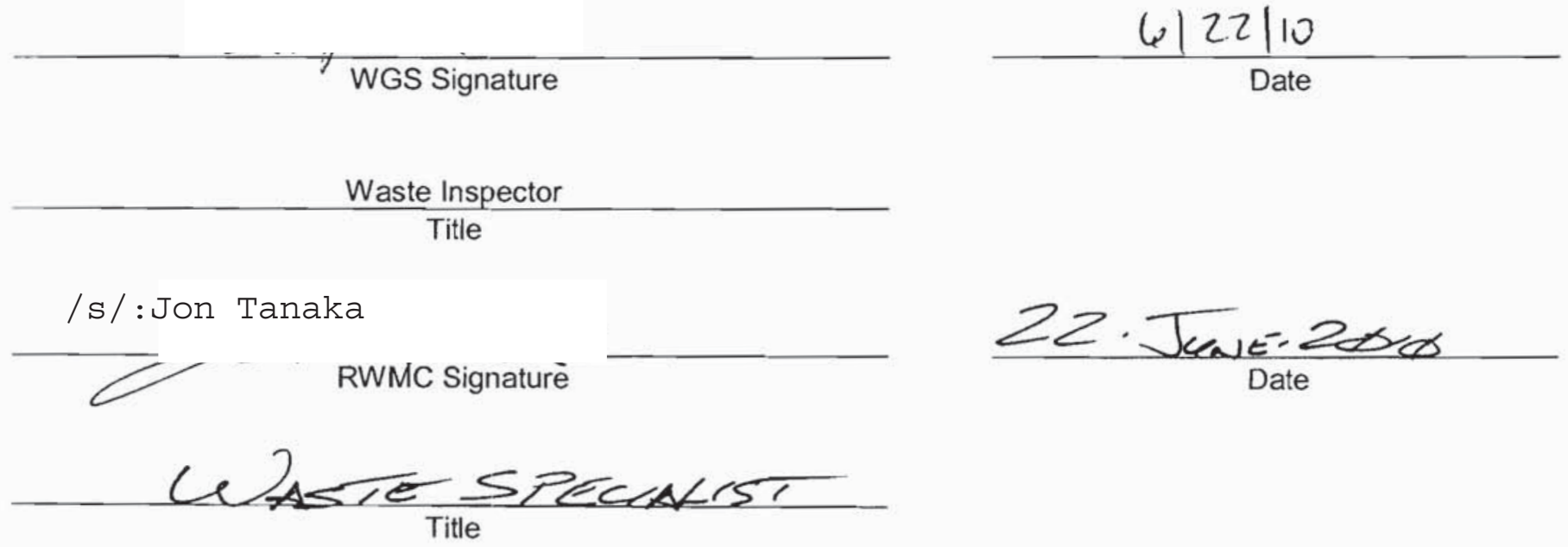

(Reference: OP-2151.304) 
NSTec

Form

FRM-2217
CERTIFICATE OF DISPOSAL

(LOW LEVEL WASTE)
03/01/10

Rev. 01

Page 1 of 1

\section{Nevada Test Site}

This Certificate acknowledges that the following shipment(s) of waste have been disposed at the Nevada Test Site Radioactive Waste Management Complex.

\begin{tabular}{|l|l|l|c|}
\hline \multicolumn{1}{|c|}{$\begin{array}{c}\text { Waste Stream } \\
\text { Identification \# }\end{array}$} & Package \# & Date of Disposal \\
\hline DPL10117 & LRY5LLFY08002 & 10 L183 & $6 / 22 / 10$ \\
\hline DPL10117 & LRY5LLFY08002 & 10 L341 & $6 / 22 \cdot 110$ \\
\hline & & & \\
\hline & & & \\
\hline & & & \\
\hline & & & \\
\hline & & & \\
\hline
\end{tabular}

This certification is provided as a courtesy to the waste generator for information purposes only.

WGS Signature

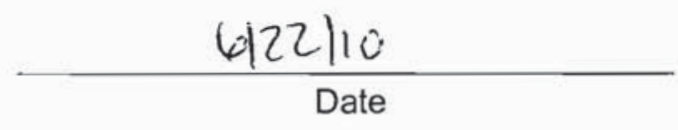

Waste Inspector

Title

/s/:Jon Tanaka

RWMC Signature

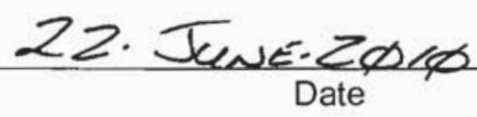

WASTE SPECHAST 
NSTec

Form

FRM-2217
CERTIFICATE OF DISPOSAL

(LOW LEVEL WASTE)
03/01/10

Rev. 01

Page 1 of 1

\section{Nevada Test Site}

This Certificate acknowledges that the following shipment(s) of waste have been disposed at the Nevada Test Site Radioactive Waste Management Complex.

\begin{tabular}{|l|l|l|l|}
\hline \multicolumn{1}{|c|}{ Shipment Number } & \multicolumn{1}{|c|}{$\begin{array}{c}\text { Waste Stream } \\
\text { Identification \# }\end{array}$} & Package \# & Date of Disposal \\
\hline DPL10118 & LRY5LLFY08002 & 10 L184 & W/22/10 \\
\hline DPL10118 & LRY5LLFY08002 & 10 L340 & C.2 2110 \\
\hline & & & \\
\hline & & & \\
\hline & & & \\
\hline & & & \\
\hline
\end{tabular}

This certification is provided as a courtesy to the waste generator for information purposes only.

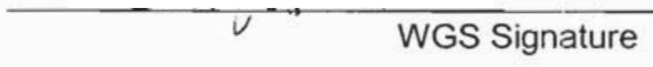

Waste Inspector
/s/:Jon Tanaka

RWMC Signature

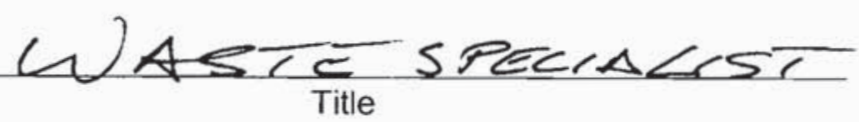

$6 \mid 22110$

Date

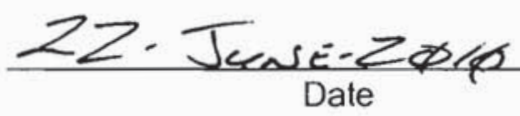




\section{Nevada Test Site}

This Certificate acknowledges that the following shipment(s) of waste have been disposed at the Nevada Test Site Radioactive Waste Management Complex.

\begin{tabular}{|l|l|l|l|}
\hline Shipment Number & \multicolumn{1}{|c|}{$\begin{array}{c}\text { Waste Stream } \\
\text { Identification \# }\end{array}$} & Package \# & Date of Disposal \\
\hline DPL10119 & LRY5LLFY08002 & 10 L185 & $6 / 22110$ \\
\hline DPL10119 & LRY5LLFY08002 & 10 L339 & $6 / 22110$ \\
\hline & & & \\
\hline & & & \\
\hline & & & \\
\hline & & & \\
\hline
\end{tabular}

This certification is provided as a courtesy to the waste generator for information purposes only.

WGS Signature

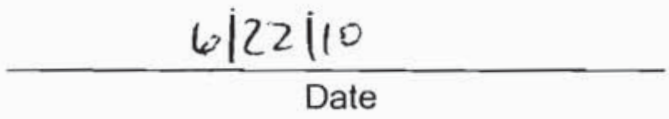

Waste Inspector

Title

/s/:Jon Tanaka

RWMC Signature
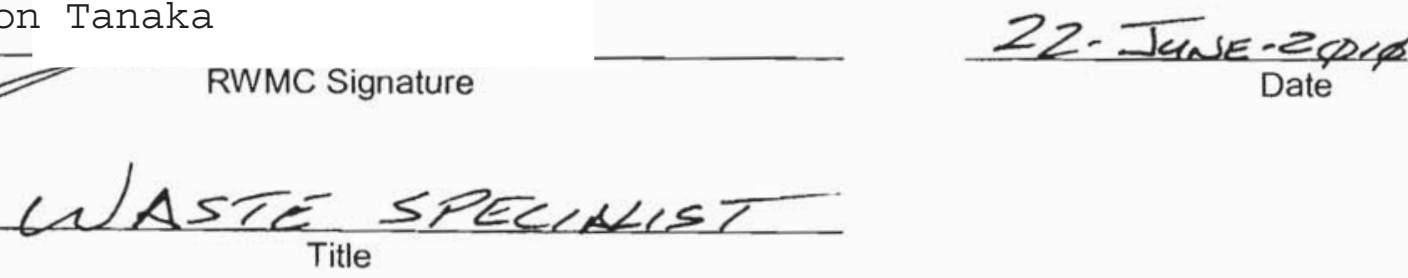
NSTec

CERTIFICATE OF DISPOSAL

03/01/10

Form

FRM-2217

(LOW LEVEL WASTE)

Rev. 01

Page 1 of 1

\section{Nevada Test Site}

This Certificate acknowledges that the following shipment(s) of waste have been disposed at the Nevada Test Site Radioactive Waste Management Complex.

\begin{tabular}{|c|c|c|c|}
\hline Shipment Number & $\begin{array}{l}\text { Waste Stream } \\
\text { Identification \# }\end{array}$ & Package \# & Date of Disposal \\
\hline DPL10120 & LRY5LLFY08002 & $10 \mathrm{~L} 186$ & 6122110 \\
\hline DPL10120 & LRY5LLFY08002 & 10L338 & 6122iio \\
\hline & & & \\
\hline & & & \\
\hline & & & \\
\hline & & & \\
\hline & & & \\
\hline & & & \\
\hline
\end{tabular}

This certification is provided as a courtesy to the waste generator for information purposes only.

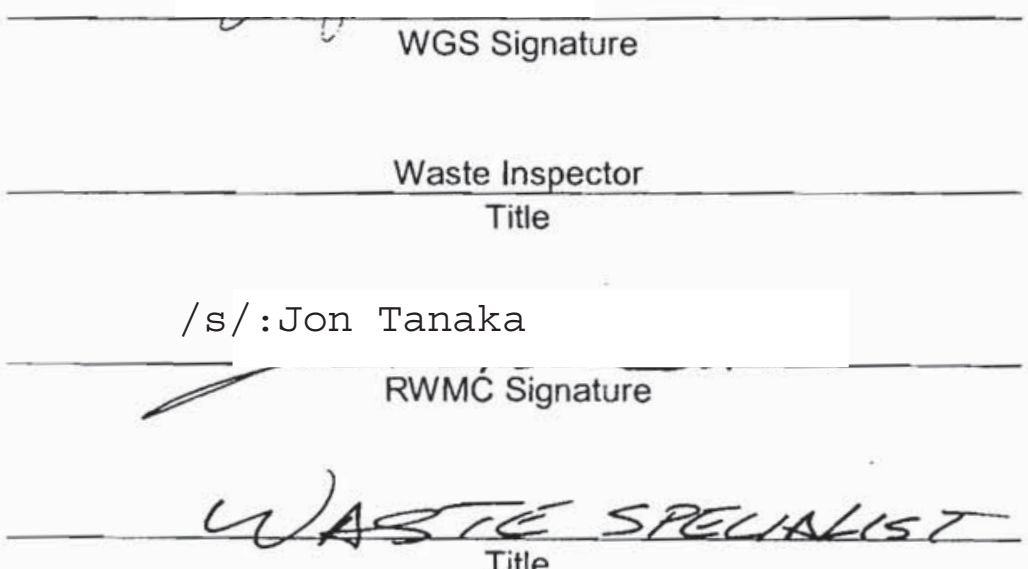
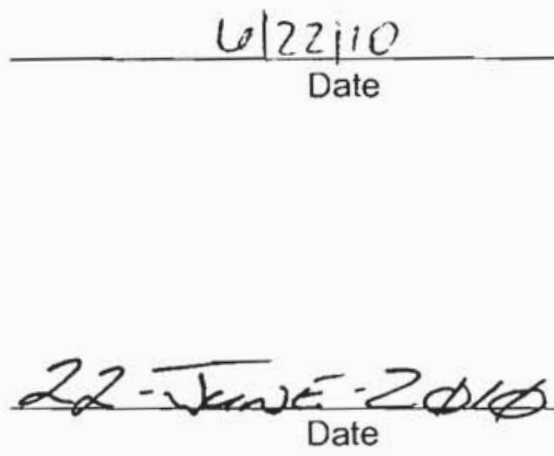
NSTec

Form

CERTIFICATE OF DISPOSAL

03/01/10

FRM-2217

(LOW LEVEL WASTE)

Rev. 01

Page 1 of 1

\section{Nevada Test Site}

This Certificate acknowledges that the following shipment(s) of waste have been disposed at the Nevada Test Site Radioactive Waste Management Complex.

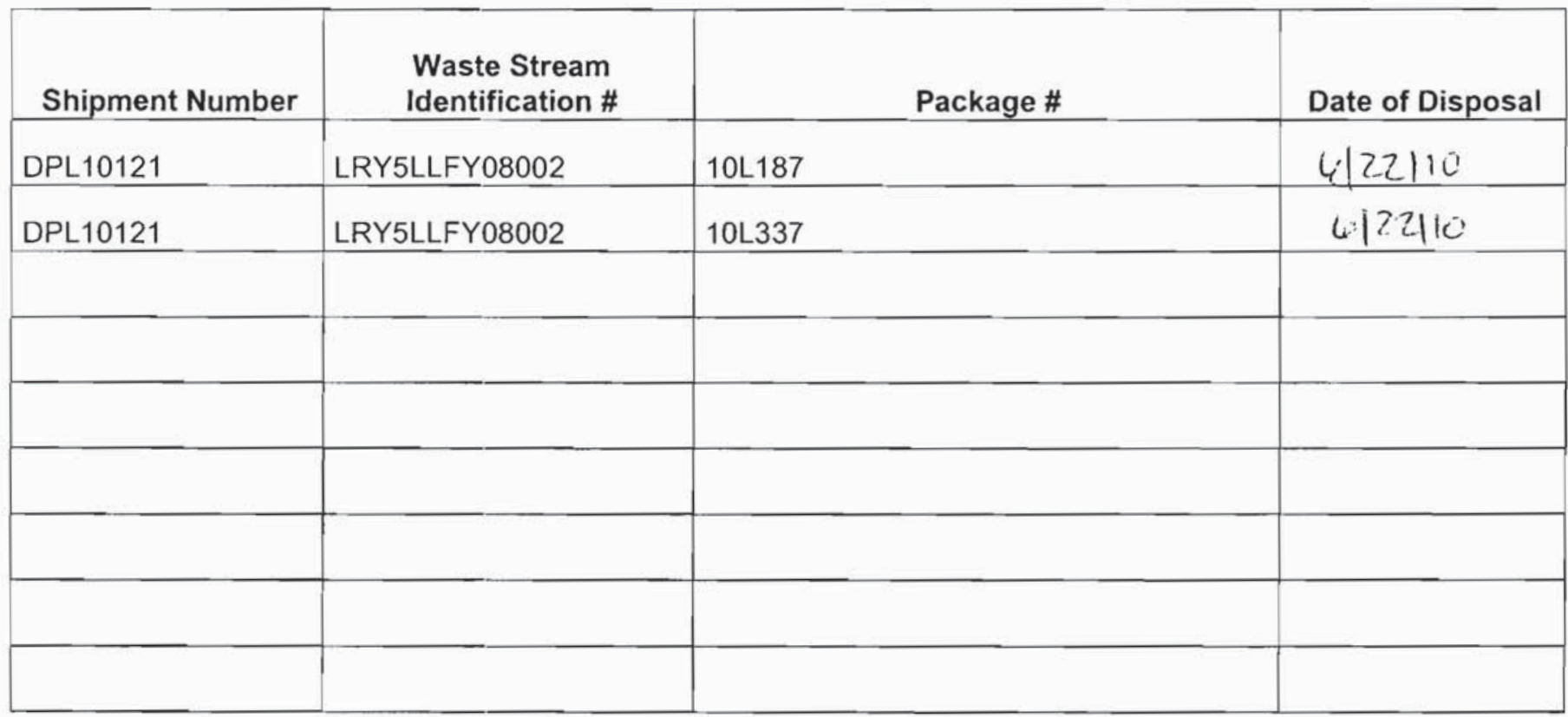

This certification is provided as a courtesy to the waste generator for information purposes only.

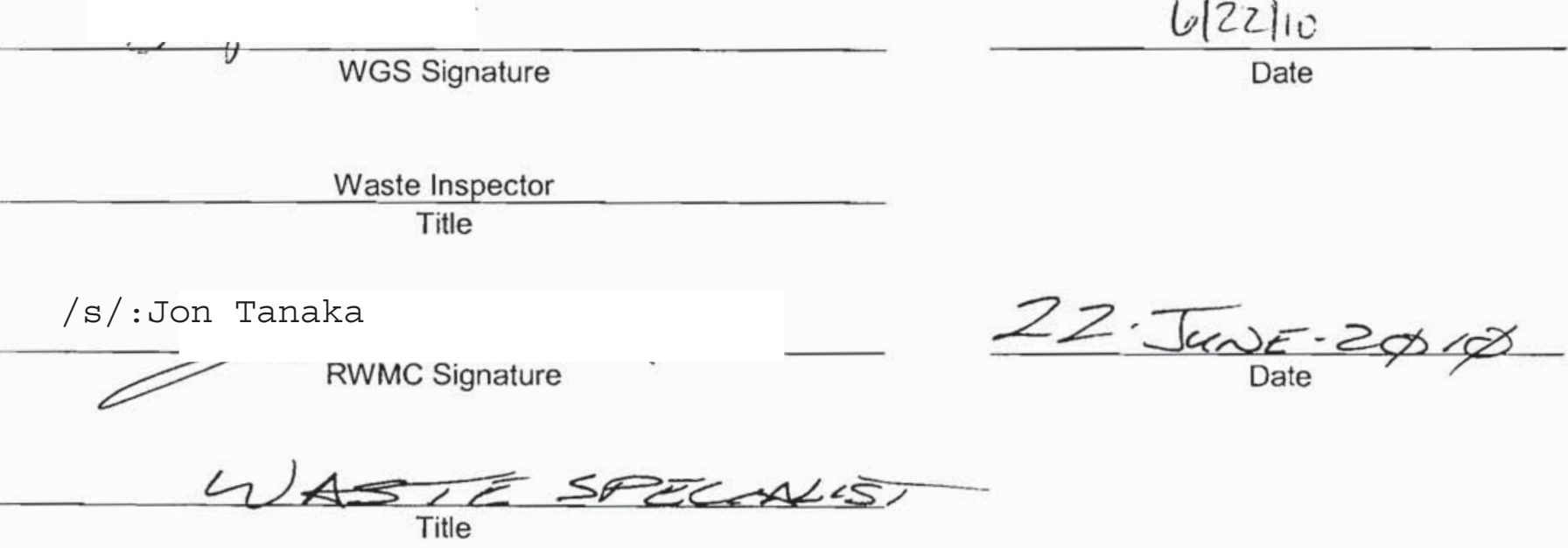


NSTec

Form

FRM-2217
CERTIFICATE OF DISPOSAL

(LOW LEVEL WASTE)
03/01/10

Rev. 01

Page 1 of 1

\section{Nevada Test Site}

This Certificate acknowledges that the following shipment(s) of waste have been disposed at the Nevada Test Site Radioactive Waste Management Complex.

\begin{tabular}{|l|l|l|l|}
\hline Shipment Number & $\begin{array}{c}\text { Waste Stream } \\
\text { Identification \# }\end{array}$ & Package \# & Date of Disposal \\
\hline DPL10198 & LRY5LLFY08002 & 10 L264 & 6/ (2-1iv) \\
\hline & & & \\
\hline & & & \\
\hline & & & \\
\hline & & & \\
\hline & & & \\
\hline & & & \\
\hline & & & \\
\hline
\end{tabular}

This certification is provided as a courtesy to the waste generator for information purposes only.

WGS Signature
$\frac{\text { Waste Inspector }}{\text { Title }}$
/ s/: Jon Tanaka
RWMC Signature


NSTec

Form

CERTIFICATE OF DISPOSAL

03/01/10

FRM-2217

(LOW LEVEL WASTE)

Rev. 01

Page 1 of 1

\section{Nevada Test Site}

This Certificate acknowledges that the following shipment(s) of waste have been disposed at the Nevada Test Site Radioactive Waste Management Complex.

\begin{tabular}{|c|c|c|c|}
\hline Shipment Number & $\begin{array}{l}\text { Waste Stream } \\
\text { Identification \# }\end{array}$ & Package \# & Date of Disposal \\
\hline DPL10122 & LRY5LLFY08002 & 10L 188 & i? 3110 \\
\hline DPL10122 & LRY5LLFY08002 & $10 \mathrm{~L} 336$ & 6123110 \\
\hline & & & \\
\hline & & & \\
\hline & & & \\
\hline & & & \\
\hline & & & \\
\hline & & & \\
\hline
\end{tabular}

This certification is provided as a courtesy to the waste generator for information purposes only.

WGS Signature

$$
\frac{612=\vdots 2}{\text { Date }}
$$

Waste Inspector

Title

/s/:Jon Tanaka

RWMC Signature
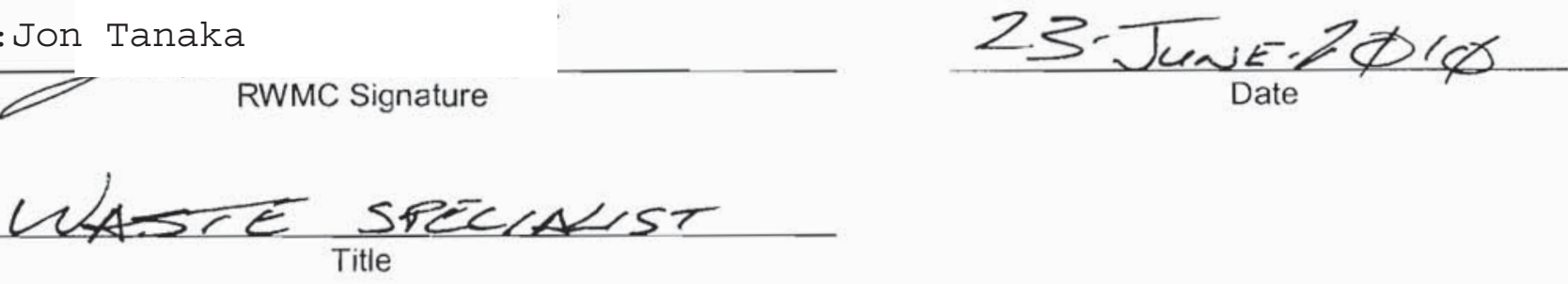
NSTec

Form

CERTIFICATE OF DISPOSAL

03/01/10

FRM-2217

(LOW LEVEL WASTE)

Rev. 01

Page 1 of 1

\section{Nevada Test Site}

This Certificate acknowledges that the following shipment(s) of waste have been disposed at the Nevada Test Site Radioactive Waste Management Complex.

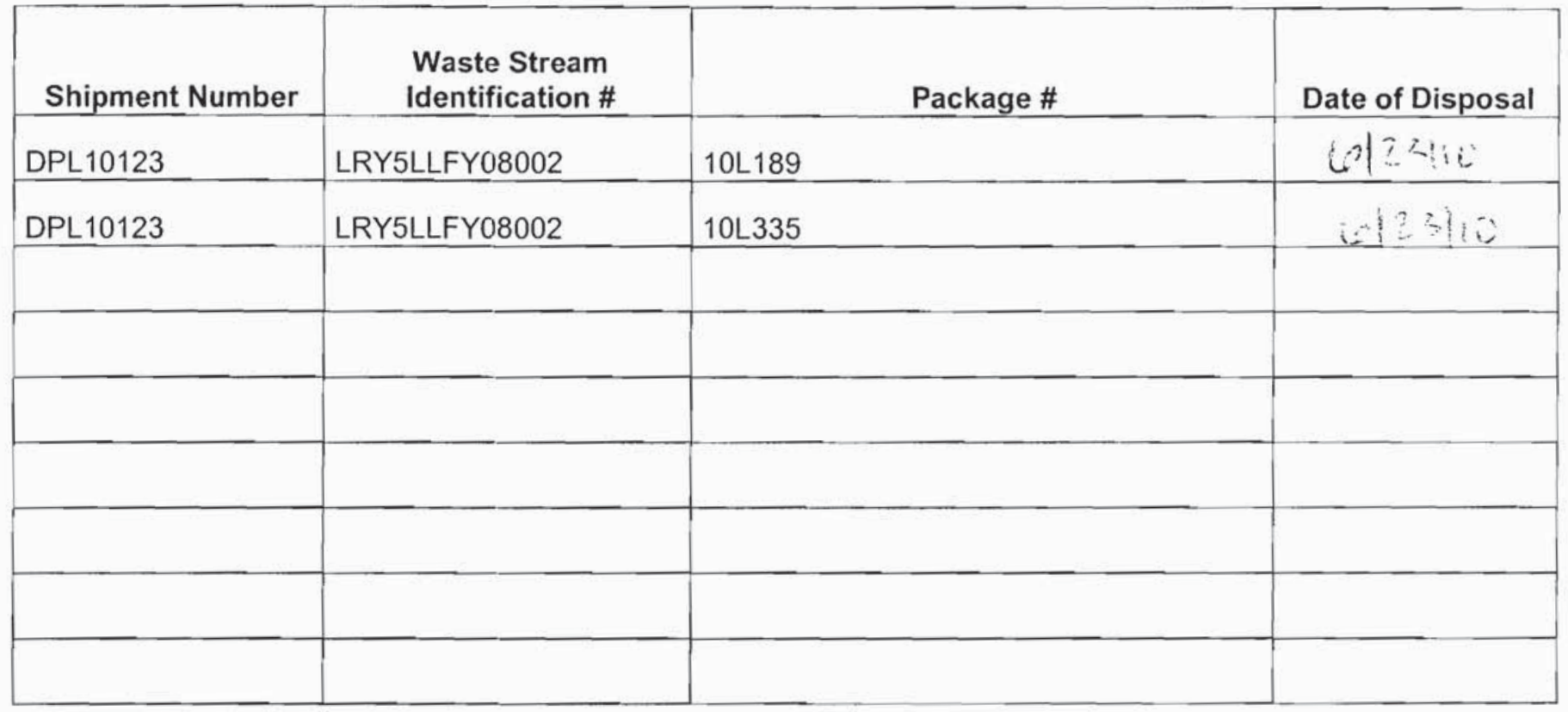

This certification is provided as a courtesy to the waste generator for information purposes only.
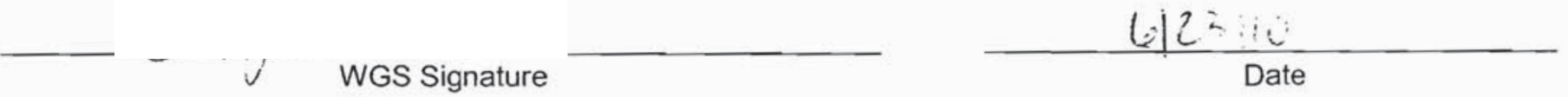

Waste Inspector

Title

/s/:Jon Tanaka

RWMC Signature

23. - Tedt $2 \phi 1 \phi$

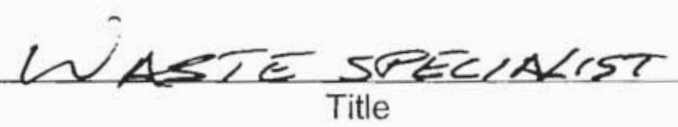




\begin{tabular}{|lcr|}
\hline NSTec & CERTIFICATE OF DISPOSAL & 03/01/10 \\
Form & Rev. 01 \\
FRM-2217 & (LOW LEVEL WASTE) & Page 1 of 1 \\
\hline
\end{tabular}

Nevada Test Site

This Certificate acknowledges that the following shipments) of waste have been disposed at the Nevada Test Site Radioactive Waste Management Complex.

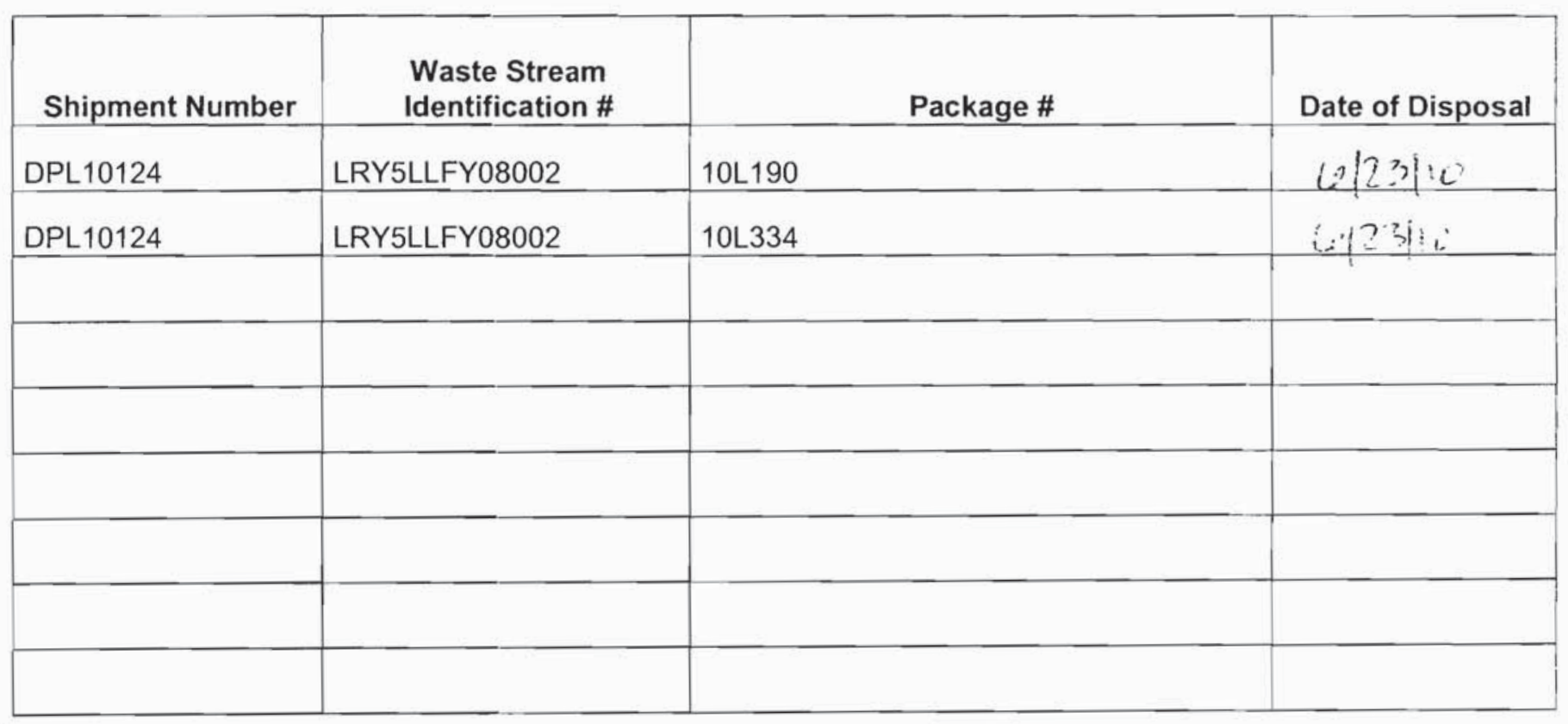

This certification is provided as a courtesy to the waste generator for information purposes only.

WGS Signature

Waste Inspector

Title

/s/: Jon Kanaka

RWMC Signature

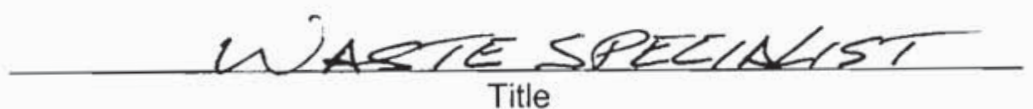

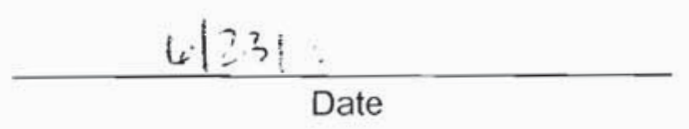

Date

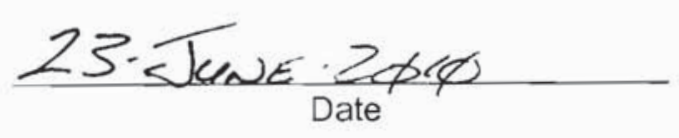

(Reference: OP-2151.304) 
NSTec

Form

CERTIFICATE OF DISPOSAL

03/01/10

FRM-2217

(LOW LEVEL WASTE)

Rev. 01

Page 1 of 1

\section{Nevada Test Site}

This Certificate acknowledges that the following shipment(s) of waste have been disposed at the Nevada Test Site Radioactive Waste Management Complex.

\begin{tabular}{|c|c|c|c|}
\hline Shipment Number & $\begin{array}{l}\text { Waste Stream } \\
\text { Identification \# }\end{array}$ & Package \# & Date of Disposal \\
\hline DPL10125 & LRY5LLFY08002 & 10L191 & $41231 i 2$ \\
\hline DPL10125 & LRY5LLFY08002 & $10\llcorner 333$ & 617310 \\
\hline & & & \\
\hline & & & \\
\hline & & & \\
\hline & & & \\
\hline & & & \\
\hline & & 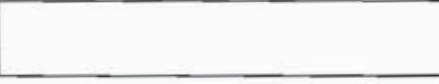 & \\
\hline
\end{tabular}

This certification is provided as a courtesy to the waste generator for information purposes only.

WGS Signature
Waste Inspector
Title

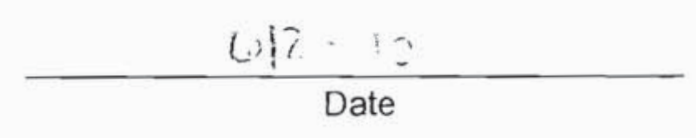

/s/: Jon Tanaka

RWMC Signature
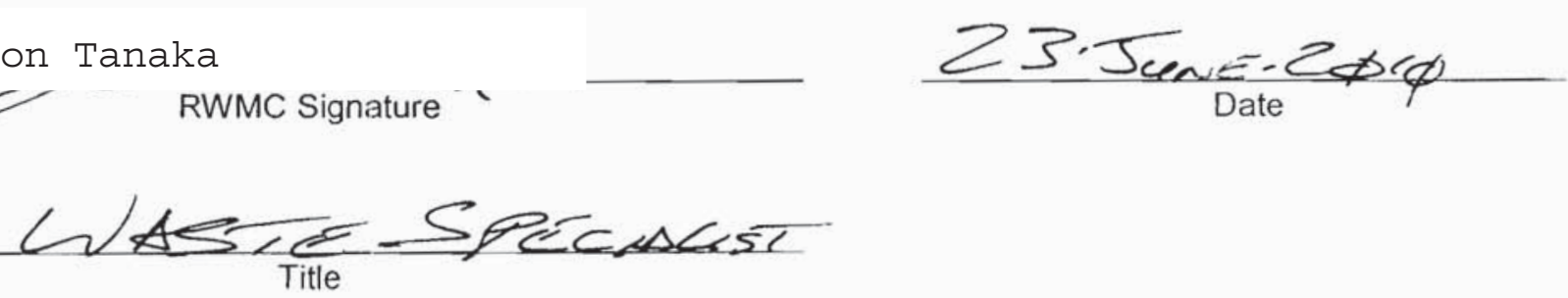
NSTec

Form

CERTIFICATE OF DISPOSAL

03/01/10

FRM-2217

(LOW LEVEL WASTE)

Rev. 01

Page 1 of 1

\section{Nevada Test Site}

This Certificate acknowledges that the following shipment(s) of waste have been disposed at the Nevada Test Site Radioactive Waste Management Complex.

\begin{tabular}{|l|l|l|l|}
\hline Shipment Number & \multicolumn{1}{|c|}{$\begin{array}{c}\text { Waste Stream } \\
\text { Identification \# }\end{array}$} & Package \# & Date of Disposal \\
\hline DPL10199 & LRY5LLY08002 & 10 L265 & $6 / 23 / 10$ \\
\hline & & & \\
\hline & & & \\
\hline & & & \\
\hline & & & \\
\hline & & & \\
\hline
\end{tabular}

This certification is provided as a courtesy to the waste generator for information purposes only.

\begin{tabular}{c}
\hline WGS Signature \\
Waste Inspector \\
Title
\end{tabular}

$$
\frac{6 \mid 23110}{\text { Date }}
$$

/s/:Jon Tanaka

RWMC Signature
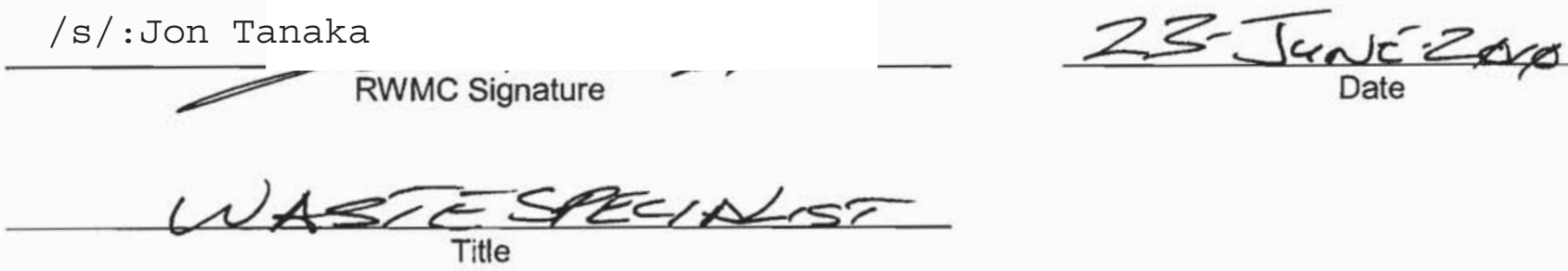


\begin{tabular}{|lcr|}
\hline NSTec & CERTIFICATE OF DISPOSAL & 03/01/10 \\
Form & Rev. 01 \\
FRM-2217 & (LOW LEVEL WASTE) & Page 1 of 1 \\
\hline
\end{tabular}

Nevada Test Site

This Certificate acknowledges that the following shipments) of waste have been disposed at the Nevada Test Site Radioactive Waste Management Complex.

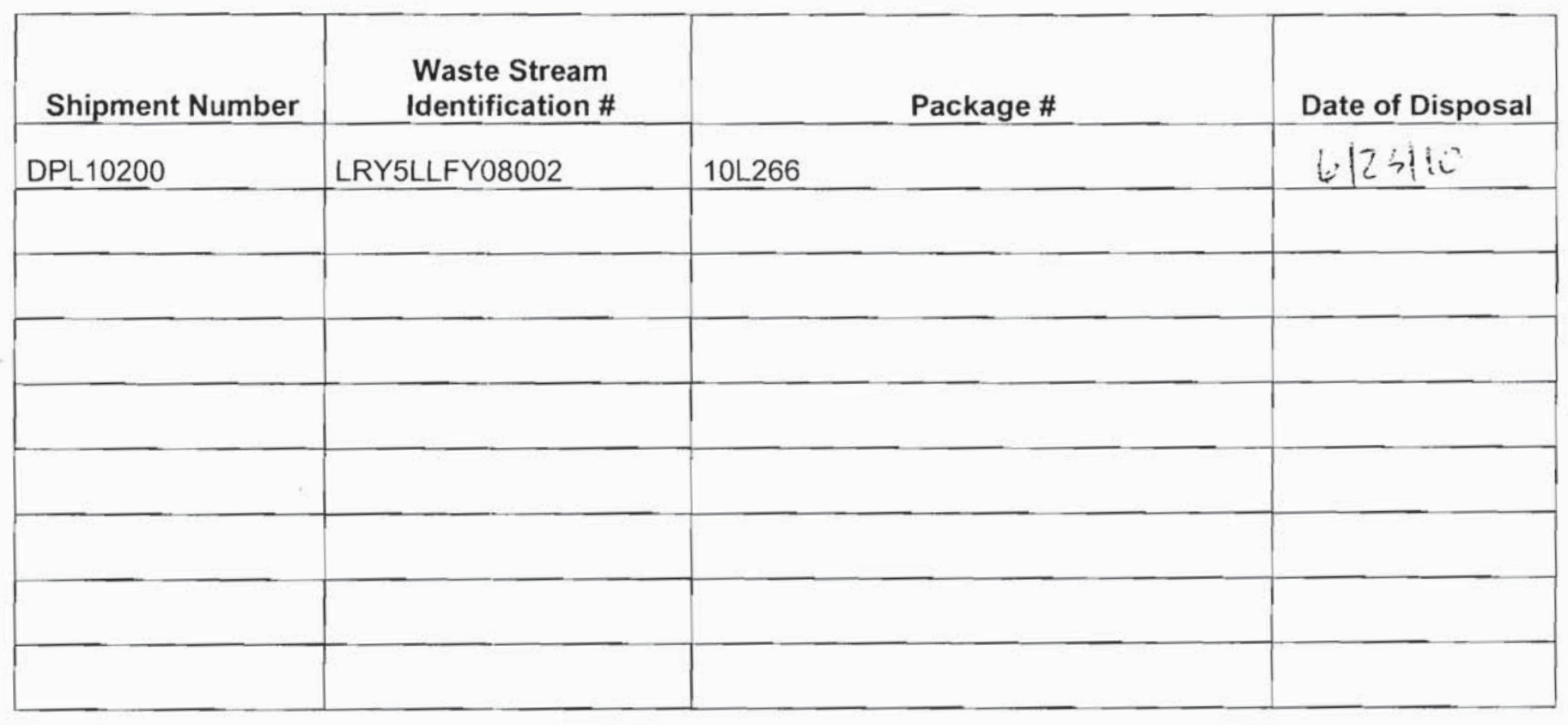

This certification is provided as a courtesy to the waste generator for information purposes only.

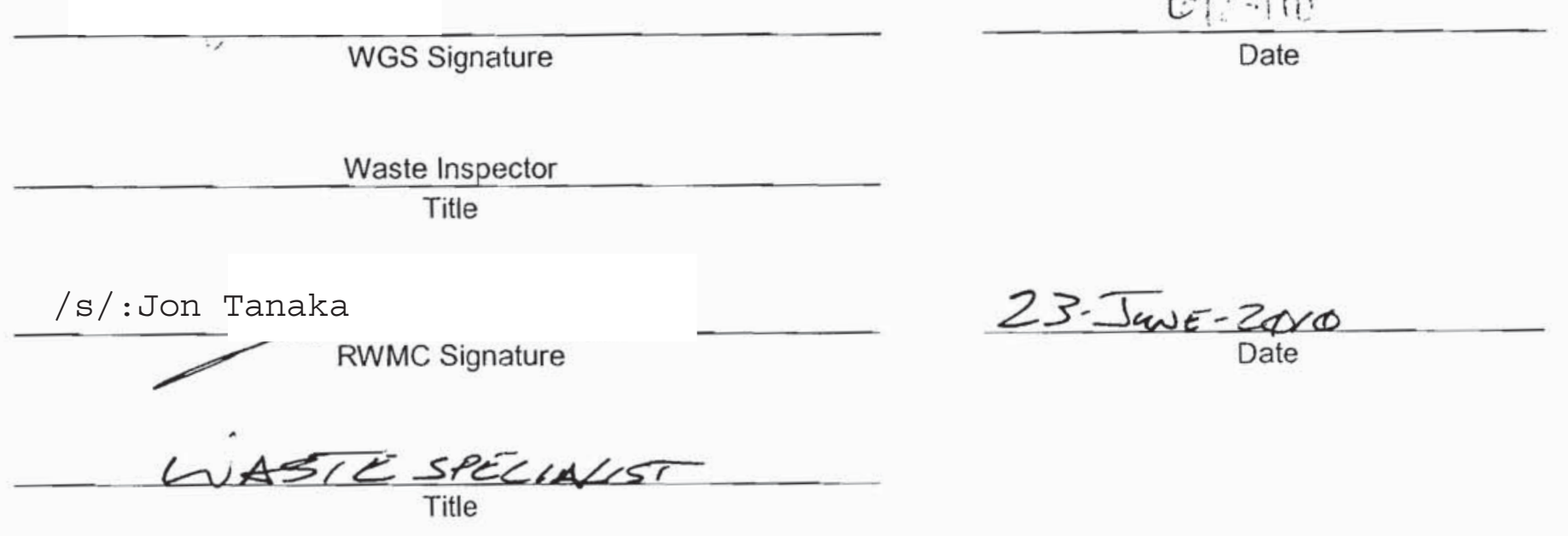

(Reference: OP-2151.304) 


\begin{tabular}{|lcr|}
\hline NSTec & CERTIFICATE OF DISPOSAL & 03/01/10 \\
Form & Rev. 01 \\
FRM-2217 & (LOW LEVEL WASTE) & Page 1 of 1 \\
\hline
\end{tabular}

Nevada Test Site

This Certificate acknowledges that the following shipments) of waste have been disposed at the Nevada Test Site Radioactive Waste Management Complex.

\begin{tabular}{|c|c|c|c|}
\hline Shipment Number & $\begin{array}{c}\text { Waste Stream } \\
\text { Identification \# }\end{array}$ & Package \# & Date of Disposal \\
\hline DPL10201 & LRY5LLFY8002 & 10 L267 & CI 23116 \\
\hline & & & \\
\hline & & & \\
\hline & & & \\
\hline & & & \\
\hline & & & \\
\hline & & & \\
\hline
\end{tabular}

This certification is provided as a courtesy to the waste generator for information purposes only.

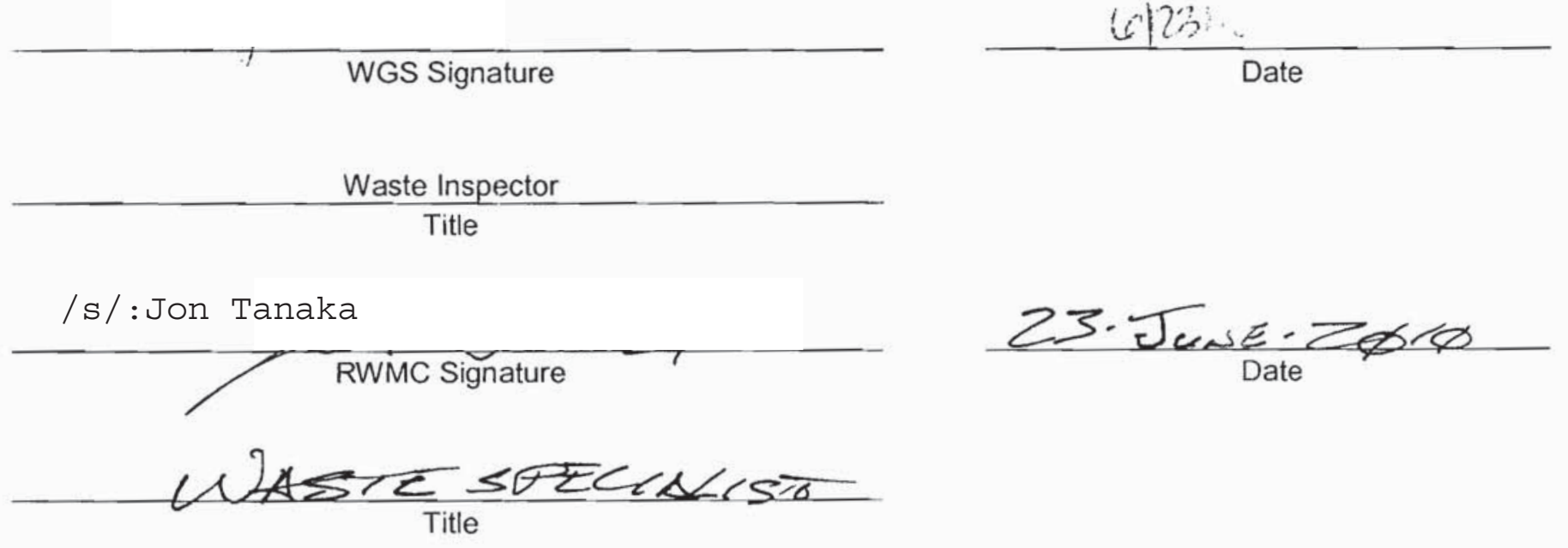

(Reference: OP-2151.304) 
NSTec

Form

CERTIFICATE OF DISPOSAL

$03 / 01 / 10$

FRM-2217

(LOW LEVEL WASTE)

Rev. 01

Page 1 of 1

\section{Nevada Test Site}

This Certificate acknowledges that the following shipment(s) of waste have been disposed at the Nevada Test Site Radioactive Waste Management Complex.

\begin{tabular}{|c|c|c|c|}
\hline Shipment Number & $\begin{array}{l}\text { Waste Stream } \\
\text { Identification \# }\end{array}$ & Package \# & Date of Disposal \\
\hline DPL10202 & LRY5LLFY08002 & 10L268 & $4123:-$ \\
\hline & & & \\
\hline & & & \\
\hline & & & \\
\hline & & & \\
\hline & & & \\
\hline & & & \\
\hline & & & \\
\hline
\end{tabular}

This certification is provided as a courtesy to the waste generator for information purposes only.

WGS Signature

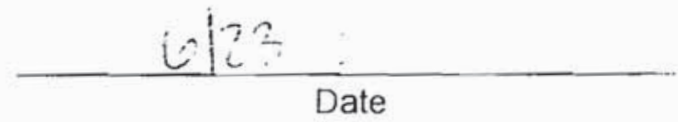

Waste Inspector

Title

/s/:Jon Tanaka

RWMC Signature
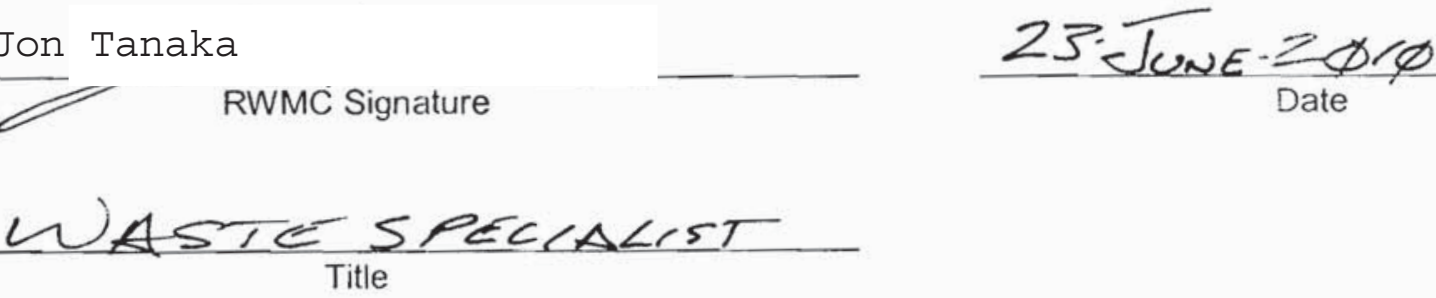
NSTec

Form

FRM-2217
CERTIFICATE OF DISPOSAL

(LOW LEVEL WASTE)
03/01/10

Rev. 01

Page 1 of 1

\section{Nevada Test Site}

This Certificate acknowledges that the following shipment(s) of waste have been disposed at the Nevada Test Site Radioactive Waste Management Complex.

\begin{tabular}{|l|l|l|l|}
\hline Shipment Number & $\begin{array}{c}\text { Waste Stream } \\
\text { Identification \# }\end{array}$ & Package \# & Date of Disposal \\
\hline DPL10203 & LRY5LLFY08002 & 10 L269 & U.? \\
\hline & & & \\
\hline & & & \\
\hline & & & \\
\hline & & & \\
\hline
\end{tabular}

This certification is provided as a courtesy to the waste generator for information purposes only.
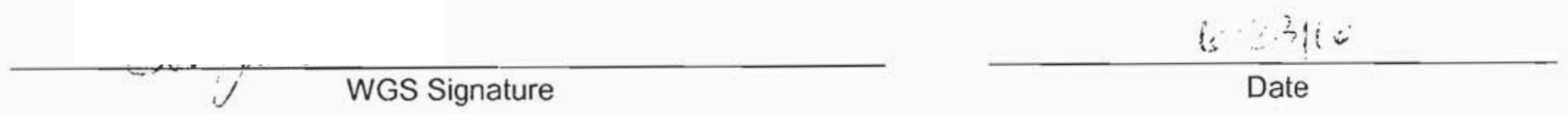

Waste Inspector

Title

\section{/s/:Jon Tanaka}

RWMC Signature

Q6.23.

WASTE $\frac{S T \text { ECrACrST }}{\text { Title }}$ 
NSTec

Form

FRM-2217
CERTIFICATE OF DISPOSAL

(LOW LEVEL WASTE)
03/01/10

Rev. 01

Page 1 of 1

\section{Nevada Test Site}

This Certificate acknowledges that the following shipment(s) of waste have been disposed at the Nevada Test Site Radioactive Waste Management Complex.

\begin{tabular}{|l|l|l|l|}
\hline \multicolumn{1}{|c|}{$\begin{array}{c}\text { Waste Stream } \\
\text { Identification \# }\end{array}$} & Package \# & Date of Disposal \\
\hline DPL10126 & LRY5LLFY08002 & 10 L192 & $6 ! 24 \mid 10$ \\
\hline DPL10126 & LRY5LLFY08002 & 10 L332 & $6 \mid 24 / 10$ \\
\hline & & & \\
\hline & & & \\
\hline & & & \\
\hline & & & \\
\hline & & & \\
\hline
\end{tabular}

This certification is provided as a courtesy to the waste generator for information purposes only.

WGS Signature
Waste Inspector
Title

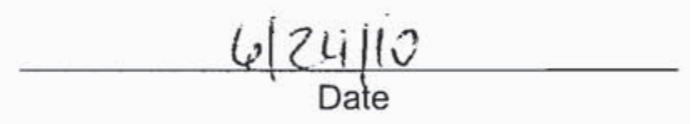

\section{/s/:Jon Tanaka}

RWMC Signature
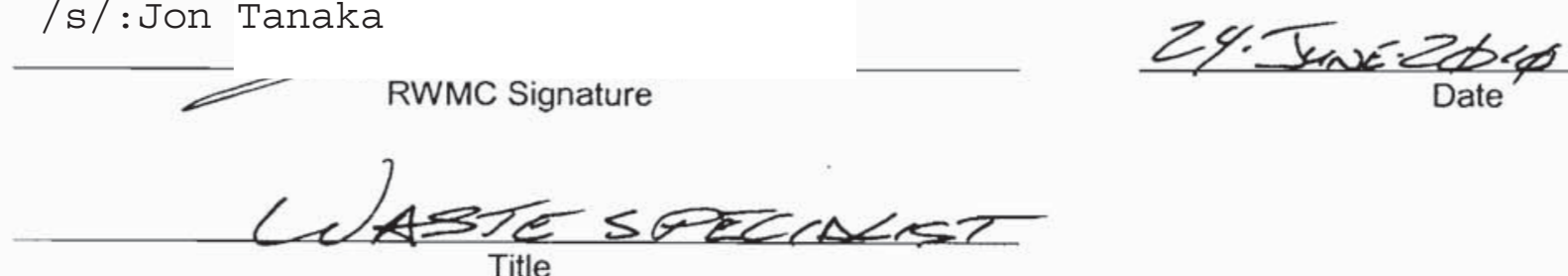

\section{Title}




\begin{tabular}{|lcr|}
\hline NSTec & CERTIFICATE OF DISPOSAL & $03 / 01 / 10$ \\
Form & Rev. 01 \\
FRM-2217 & (LOW LEVEL WASTE) & Page 1 of 1 \\
\hline
\end{tabular}

Nevada Test Site

This Certificate acknowledges that the following shipments) of waste have been disposed at the Nevada Test Site Radioactive Waste Management Complex.

\begin{tabular}{|l|l|l|l|}
\hline \multicolumn{1}{|c|}{ Shipment Number } & $\begin{array}{c}\text { Waste Stream } \\
\text { Identification \# }\end{array}$ & Package \# & Date of Disposal \\
\hline DPL10127 & LRY5LLFY08002 & 10 193 & $6-24-10$ \\
\hline DPL10127 & LRY5LLFY88002 & 10 10331 & $6-24-10$ \\
\hline & & & \\
\hline & & & \\
\hline & & & \\
\hline & & & \\
\hline & & & \\
\hline
\end{tabular}

This certification is provided as a courtesy to the waste generator for information purposes only.

/s/: Theresa Hale

WGS Signature

Waste Inspector

Title

/s/ :Jon Tanka

RWMĆ Signature
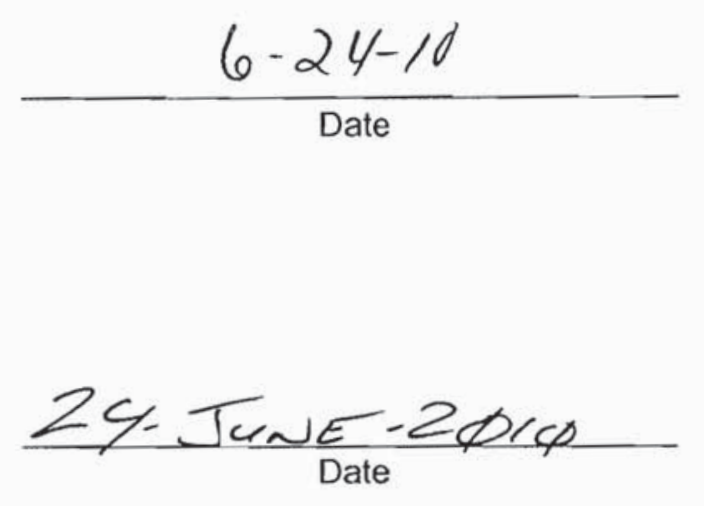


\begin{tabular}{|lcr|}
\hline NSTec & CERTIFICATE OF DISPOSAL & $03 / 01 / 10$ \\
Form & Rev. 01 \\
FRM-2217 & (LOW LEVEL WASTE) & Page 1 of 1 \\
\hline
\end{tabular}

Nevada Test Site

This Certificate acknowledges that the following shipments) of waste have been disposed at the Nevada Test Site Radioactive Waste Management Complex.

\begin{tabular}{|l|l|l|c|}
\hline \multicolumn{1}{|c|}{ Shipment Number } & \multicolumn{1}{c|}{$\begin{array}{c}\text { Waste Stream } \\
\text { Identification \# }\end{array}$} & Package \# & Date of Disposal \\
\hline DPL10128 & LRY5LLFY08002 & 10 L194 & $6-24-10$ \\
\hline DPL10128 & LRY5LLFY08002 & 10 L330 & $6-24-10$ \\
\hline & & & \\
\hline & & & \\
\hline & & & \\
\hline & & & \\
\hline & & & \\
\hline
\end{tabular}

This certification is provided as a courtesy to the waste generator for information purposes only.

/s/: Theresa Hale

WGS Signature

Waste Inspector

Title

/s/ :Jon Tanaka

RWMC Signature

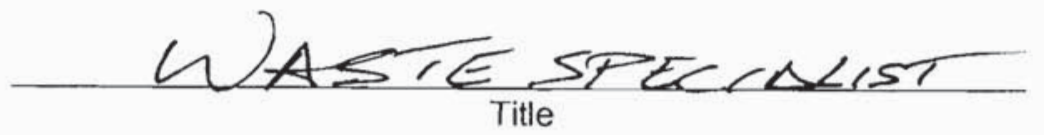

$$
\frac{6-24-10}{\text { Date }}
$$

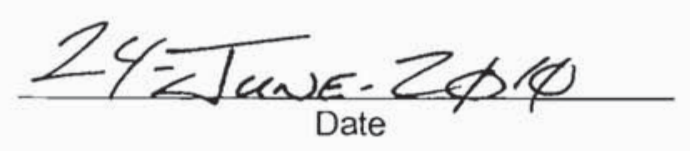

(Reference: OP-2151.304) 
NSTec

Form

FRM-2217
CERTIFICATE OF DISPOSAL

(LOW LEVEL WASTE)
03/01/10

Rev. 01

Page 1 of 1

\section{Nevada Test Site}

This Certificate acknowledges that the following shipment(s) of waste have been disposed at the Nevada Test Site Radioactive Waste Management Complex.

\begin{tabular}{|l|l|l|l|}
\hline Shipment Number & $\begin{array}{c}\text { Waste Stream } \\
\text { Identification \# }\end{array}$ & Package \# & Date of Disposal \\
\hline DPL10204 & LRY5LLFY8002 & 10 L270 & (0)2410 \\
\hline & & & \\
\hline & & & \\
\hline & & & \\
\hline & & & \\
\hline
\end{tabular}

This certification is provided as a courtesy to the waste generator for information purposes only.

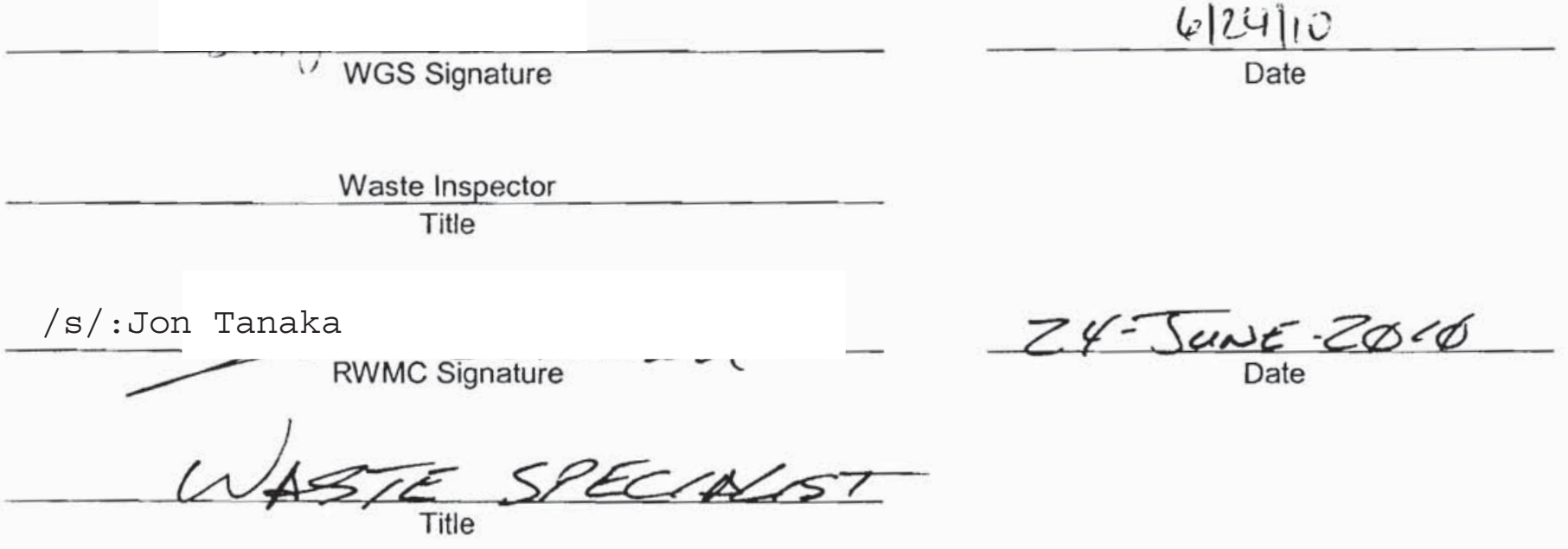


NSTeC

CERTIFICATE OF DISPOSAL

$03 / 01 / 10$

Form

(LOW LEVEL WASTE)

Rev. 01

FRM-2217

\section{Nevada Test Site}

This Certificate acknowledges that the following shipment(s) of waste have been disposed at the Nevada Test Site Radioactive Waste Management Complex.

\begin{tabular}{|l|l|l|l|}
\hline \multicolumn{1}{|c|}{ Shipment Number } & \multicolumn{1}{|c|}{$\begin{array}{c}\text { Waste Stream } \\
\text { Identification \# }\end{array}$} & Package \# & Date of Disposal \\
\hline DPL10132 & LRY5LLFY08002 & 10 L198 & 6/28/ic) \\
\hline DPL10132 & LRY5LLFY08002 & 10 L326 & $6 / 28 / \mathrm{i}^{2}$ \\
\hline & & & \\
\hline & & & \\
\hline & & & \\
\hline & & & \\
\hline
\end{tabular}

This certification is provided as a courtesy to the waste generator for information purposes only.

\section{$\checkmark \quad$ WGS Signature}

Waste Inspector /s/: Jon Tanaka

RWWMC Signature

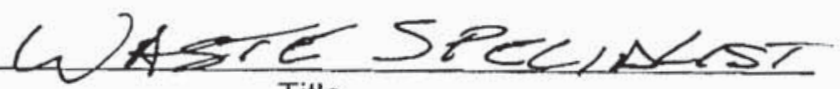

$\underset{\text { Late }}{\text { Gichlic }}$

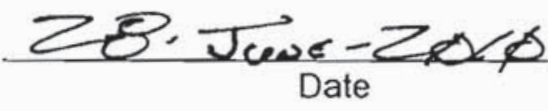


NSTec

Form

FRM-2217
CERTIFICATE OF DISPOSAL

(LOW LEVEL WASTE)
03/01/10

Rev. 01

Page 1 of 1

\section{Nevada Test Site}

This Certificate acknowledges that the following shipment(s) of waste have been disposed at the Nevada Test Site Radioactive Waste Management Complex.

\begin{tabular}{|l|l|l|l|}
\hline Shipment Number & \multicolumn{1}{|c|}{$\begin{array}{c}\text { Waste Stream } \\
\text { Identification \# }\end{array}$} & Package \# & Date of Disposal \\
\hline DPL10205 & LRY5LLFY08002 & 10L271 & 6 $/ 28 / 10$ \\
\hline & & & \\
\hline & & & \\
\hline & & & \\
\hline & & & \\
\hline & & & \\
\hline & & & \\
\hline
\end{tabular}

This certification is provided as a courtesy to the waste generator for information purposes only.

WGS Signature

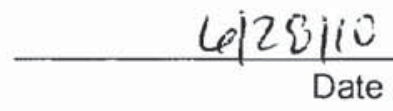

Waste Inspector

Title

/s/: Jon Tanaka

RWMC Signature

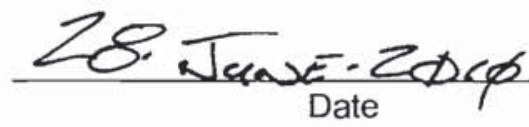

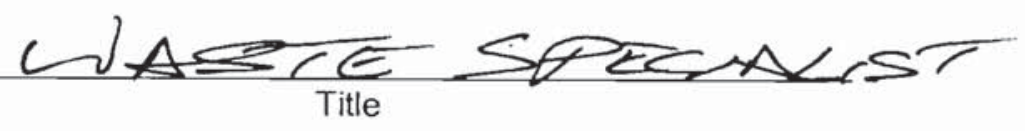


NSTec

Form

FRM-2217
CERTIFICATE OF DISPOSAL

(LOW LEVEL WASTE)
$03 / 01 / 10$

Rev. 01

Page 1 of 1

\section{Nevada Test Site}

This Certificate acknowledges that the following shipment(s) of waste have been disposed at the Nevada Test Site Radioactive Waste Management Complex.

\begin{tabular}{|l|l|l|l|}
\hline Shipment Number & $\begin{array}{c}\text { Waste Stream } \\
\text { Identification \# }\end{array}$ & Package \# & Date of Disposal \\
\hline DPL10206 & LRY5LLFY08002 & 10 L272 & $6 / 2$ \& 10 \\
\hline & & & \\
\hline & & & \\
\hline & & & \\
\hline & & & \\
\hline & & & \\
\hline & & & \\
\hline & & & \\
\hline
\end{tabular}

This certification is provided as a courtesy to the waste generator for information purposes only.

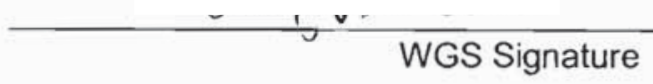

Waste Inspector

Titie

\section{/s/:Jon Tanaka}

RWMC Signature

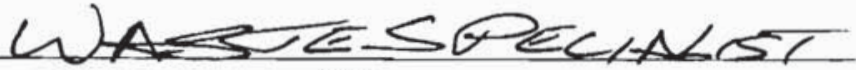

Title

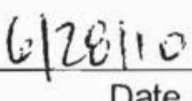

Date

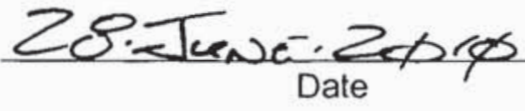


NSTec

Form

CERTIFICATE OF DISPOSAL

$03 / 01 / 10$

FRM-2217

(LOW LEVEL WASTE)

Rev. 01

Page 1 of 1

\section{Nevada Test Site}

This Certificate acknowledges that the following shipment(s) of waste have been disposed at the Nevada Test Site Radioactive Waste Management Complex.

\begin{tabular}{|l|l|l|l|}
\hline Shipment Number & \multicolumn{1}{|c|}{$\begin{array}{c}\text { Waste Stream } \\
\text { Identification \# }\end{array}$} & Package \# & Date of Disposal \\
\hline DPL10207 & LRY5LLFY08002 & 10 L273 & $6-28-10$ \\
\hline & & & \\
\hline & & & \\
\hline & & & \\
\hline & & & \\
\hline & & & \\
\hline
\end{tabular}

This certification is provided as a courtesy to the waste generator for information purposes only.

/s/: Theresa Hale

WGS Signature

Waste Inspector

Title

\section{/s/: Jon Tanaka}

¿ - RWMC Signaturé

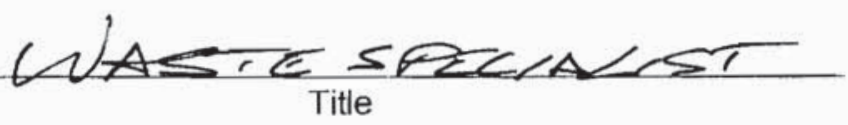

$6-28-10$

Date

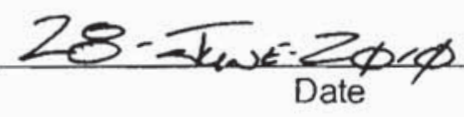


NSTec

Form

FRM-2217
CERTIFICATE OF DISPOSAL

(LOW LEVEL WASTE)
03/01/10

Rev. 01

Page 1 of 1

\section{Nevada Test Site}

This Certificate acknowledges that the following shipment(s) of waste have been disposed at the Nevada Test Site Radioactive Waste Management Complex.

\begin{tabular}{|l|l|l|l|}
\hline \multicolumn{1}{|c|}{ Shipment Number } & \multicolumn{1}{c|}{$\begin{array}{c}\text { Waste Stream } \\
\text { Identification \# }\end{array}$} & Package \# & Date of Disposal \\
\hline DPL10129 & LRY5LLFY08002 & 10 L195 & $6-29-10$ \\
\hline DPL10129 & LRY5LLFY08002 & 10 L329 & $6-29-10$ \\
\hline & & & \\
\hline & & & \\
\hline & & & \\
\hline & & & \\
\hline & & & \\
\hline
\end{tabular}

This certification is provided as a courtesy to the waste generator for information purposes only.
/s/:Theresa Hale
WGS Signature
$\frac{6-29-10}{\text { Date }}$
Waste Inspector

\section{Title}
/s/:Jon Tanaka

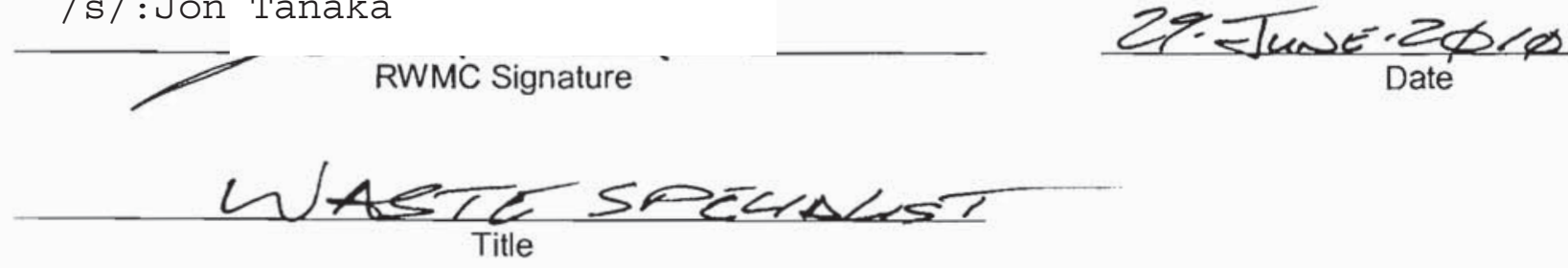




\begin{tabular}{|lcr|}
\hline NSTec & CERTIFICATE OF DISPOSAL & 03/01/10 \\
Form & Rev. 01 \\
FRM-2217 & (LOW LEVEL WASTE) & Page 1 of 1 \\
\hline
\end{tabular}

Nevada Test Site

This Certificate acknowledges that the following shipments) of waste have been disposed at the Nevada Test Site Radioactive Waste Management Complex.

\begin{tabular}{|l|l|l|l|}
\hline Shipment Number & \multicolumn{1}{|c|}{$\begin{array}{c}\text { Waste Stream } \\
\text { Identification \# }\end{array}$} & \multicolumn{1}{|c|}{ Package \# } & Date of Disposal \\
\hline DPL10130 & LRY5LLFY0802 & 10 196 & $6 / 29 / 10$ \\
\hline DPL10130 & LRY5LLFY88002 & 10 2328 & $6 / 29 / 10$ \\
\hline & & & \\
\hline & & & \\
\hline & & & \\
\hline & & & \\
\hline & & & \\
\hline & & & \\
\hline
\end{tabular}

This certification is provided as a courtesy to the waste generator for information purposes only.

/s/ :Theresa Hale

WGS Signature

Waste Inspector

Title

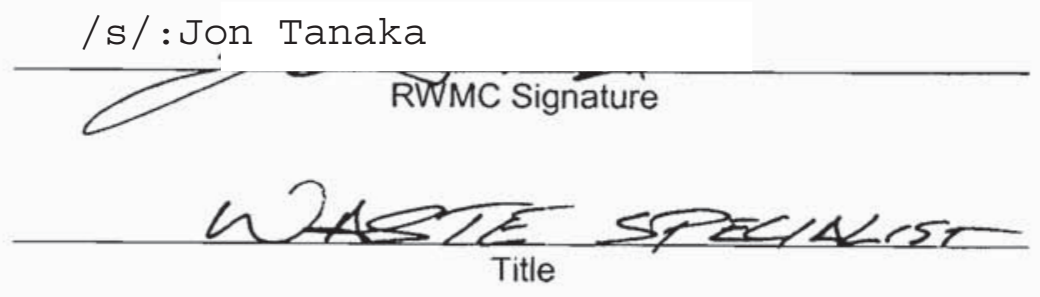

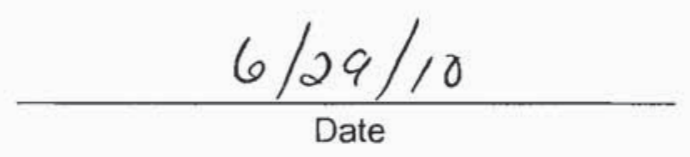

Date

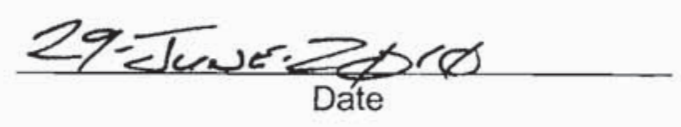

(Reference: OP-2151.304) 


\begin{tabular}{|lcr|}
\hline NSTec & CERTIFICATE OF DISPOSAL & 03/01/10 \\
Form & Rev. 01 \\
FRM-2217 & (LOW LEVEL WASTE) & Page 1 of 1 \\
\hline
\end{tabular}

Nevada Test Site

This Certificate acknowledges that the following shipments) of waste have been disposed at the Nevada Test Site Radioactive Waste Management Complex.

\begin{tabular}{|l|l|l|l|}
\hline Shipment Number & $\begin{array}{c}\text { Waste Stream } \\
\text { Identification \# }\end{array}$ & Package \# & Date of Disposal \\
\hline DPL10131 & LRY5LLFY08002 & $10 \mathrm{~L} 197$ & $6 / 29 / 10$ \\
\hline DPL10131 & LRY5LLFY08002 & $10 \mathrm{~L} 327$ & $6 / 29 / 10$ \\
\hline & & & \\
\hline & & & \\
\hline & & & \\
\hline & & & \\
\hline & & & \\
\hline
\end{tabular}

This certification is provided as a courtesy to the waste generator for information purposes only.

/s/ :Theresa Hale

WGS Signature

Waste Inspector

Title
$6 / 29 / 10$

Date

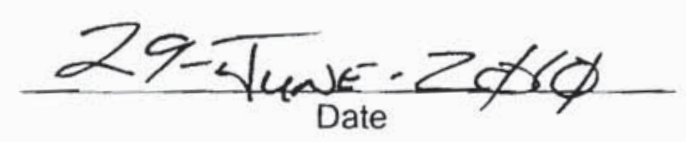

(Reference: OP -2151.304) 


\begin{tabular}{|lcr|}
\hline NSTec & CERTIFICATE OF DISPOSAL & 03/01/10 \\
Form & Rev. 01 \\
FRM-2217 & (LOW LEVEL WASTE) & Page 1 of 1 \\
\hline
\end{tabular}

Nevada Test Site

This Certificate acknowledges that the following shipments) of waste have been disposed at the Nevada Test Site Radioactive Waste Management Complex.

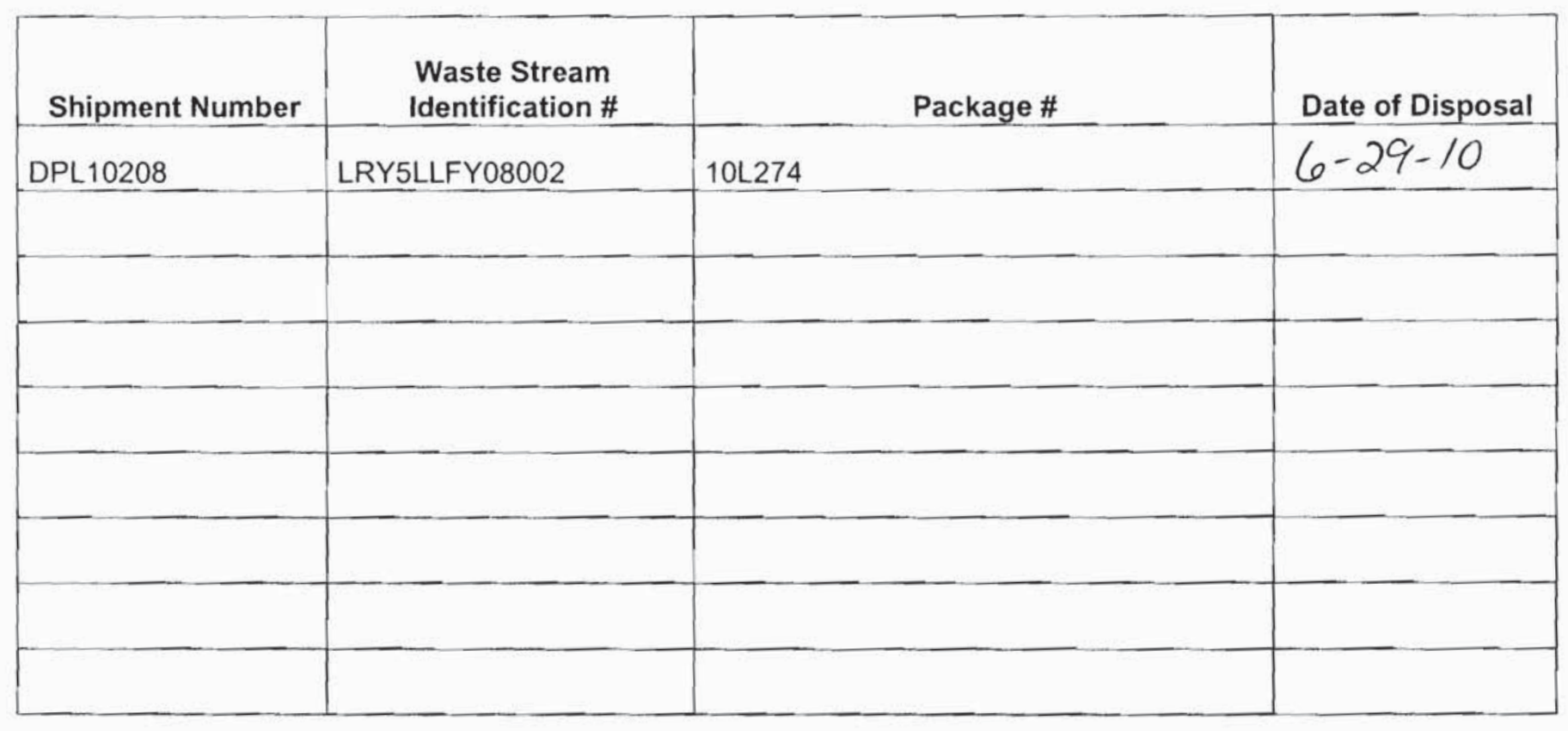

This certification is provided as a courtesy to the waste generator for information purposes only.

/s/: Theresa Hale

WGS Signature

Waste Inspector

Title

/s/ :Jon Tanka

RWMC Signature

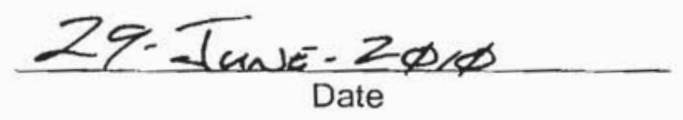

(Reference: OP-2151.304) 
NSTec

Form

CERTIFICATE OF DISPOSAL

03/01/10

FRM-2217

(LOW LEVEL WASTE)

Rev. 01

Page 1 of 1

\section{Nevada Test Site}

This Certificate acknowledges that the following shipment(s) of waste have been disposed at the Nevada Test Site Radioactive Waste Management Complex.

\begin{tabular}{|l|l|l|l|}
\hline Shipment Number & $\begin{array}{c}\text { Waste Stream } \\
\text { Identification \# }\end{array}$ & Package \# & Date of Disposal \\
\hline DPL10209 & LRY5LLFY08002 & 10 L275 & $6-29-10$ \\
\hline & & & \\
\hline & & & \\
\hline & & & \\
\hline & & & \\
\hline & & & \\
\hline & & & \\
\hline & & & \\
\hline
\end{tabular}

This certification is provided as a courtesy to the waste generator for information purposes only.

/s/:Theresa Hale

WGS Signature

Waste Inspector

Title

/s/:Jon Tanaka

RWMC Signature

WASTE SPECALIST
$6-29-10$

Date 


\begin{tabular}{|lcr|}
\hline NSTec & CERTIFICATE OF DISPOSAL & 03/01/10 \\
Form & Rev. 01 \\
FRM-2217 & (LOW LEVEL WASTE) & Page 1 of 1 \\
\hline
\end{tabular}

Nevada Test Site

This Certificate acknowledges that the following shipments) of waste have been disposed at the Nevada Test Site Radioactive Waste Management Complex.

\begin{tabular}{|c|c|c|c|}
\hline Shipment Number & $\begin{array}{c}\text { Waste Stream } \\
\text { Identification \# }\end{array}$ & \multicolumn{1}{|c|}{ Package \# } & Date of Disposal \\
\hline & LRY5LLFY08002 & 10 276 & $6 / 29 / 10$ \\
\hline & & & \\
\hline & & & \\
\hline & & & \\
\hline & & & \\
\hline & & & \\
\hline & & & \\
\hline
\end{tabular}

This certification is provided as a courtesy to the waste generator for information purposes only.

/s/ :Theresa Hale

WGS Signature

Waste Inspector

Title

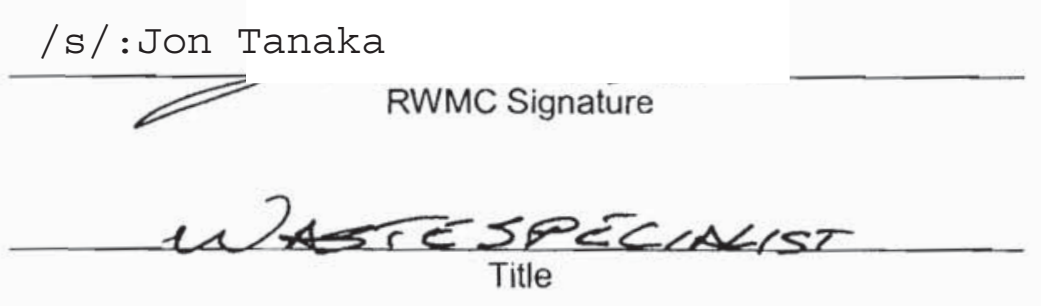

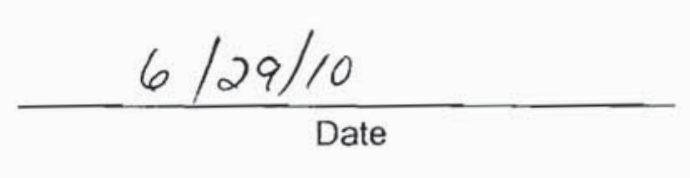

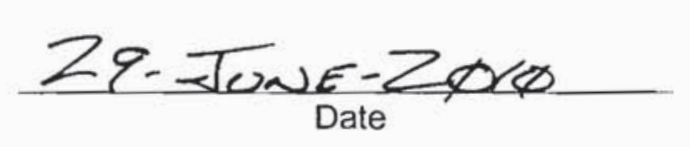

(Reference: OP-2151.304) 
NSTec

Form

CERTIFICATE OF DISPOSAL

FRM-2217

(LOW LEVEL WASTE)

Rev. 01

Page 1 of 1

\section{Nevada Test Site}

This Certificate acknowledges that the following shipment(s) of waste have been disposed at the Nevada Test Site Radioactive Waste Management Complex.

\begin{tabular}{|l|l|l|l|}
\hline Shipment Number & $\begin{array}{c}\text { Waste Stream } \\
\text { Identification \# }\end{array}$ & Package \# & Date of Disposal \\
\hline DPL10211 & LRY5LLFY08002 & 10 277 & $6 / 29 / 10$ \\
\hline & & & \\
\hline & & & \\
\hline & & & \\
\hline & & & \\
\hline & & & \\
\hline & & & \\
\hline & & & \\
\hline
\end{tabular}

This certification is provided as a courtesy to the waste generator for information purposes only.

\section{/s/:Theresa Hale}

\section{WGS Signature}

Waste Inspector

Title

\section{/s/:Jon Tanaka}

RWMC Signature

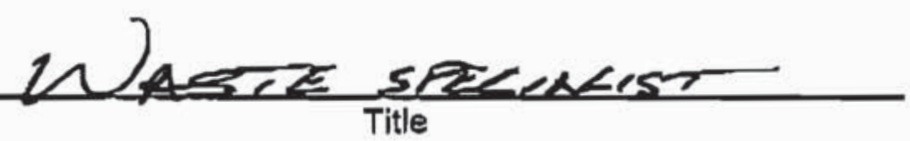

$$
\frac{6 / 29 / 10}{\text { Date }}
$$

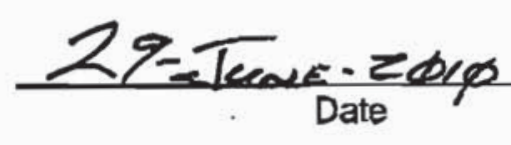


NSTeC

Form

FRM-2217
CERTIFICATE OF DISPOSAL

(LOW LEVEL WASTE)
03/01/10

Rev. 01

Page 1 of 1

\section{Nevada Test Site}

This Certificate acknowledges that the following shipment(s) of waste have been disposed at the Nevada Test Site Radioactive Waste Management Complex.

\begin{tabular}{|c|c|c|c|}
\hline Shipment Number & $\begin{array}{l}\text { Waste Stream } \\
\text { Identification \# }\end{array}$ & Package \# & Date of Disposal \\
\hline DPL10133 & LRY5LLFY08002 & 10L199 & $6 / 30 / 10$ \\
\hline DPL10133 & LRY5LLFY08002 & $10\llcorner 325$ & $6 / 30 / 10$ \\
\hline & & & \\
\hline & & & \\
\hline & & & \\
\hline & & & \\
\hline & & & \\
\hline & & & \\
\hline
\end{tabular}

This certification is provided as a courtesy to the waste generator for information purposes only.

/s/:Theresa Hale

WGS Signature

Waste Inspector

Title

/s/:Jon Tanaka

$\longrightarrow$

RWMC Signature

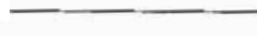

$\frac{3 \phi \cdot \sqrt{4 a x}-2 \phi \infty}{\text { Date }}$ 
NSTec

Form

FRM-2217
CERTIFICATE OF DISPOSAL

(LOW LEVEL WASTE)
03/01/10

Rev. 01

Page 1 of 1

\section{Nevada Test Site}

This Certificate acknowledges that the following shipment(s) of waste have been disposed at the Nevada Test Site Radioactive Waste Management Complex.

\begin{tabular}{|l|l|l|l|}
\hline \multicolumn{1}{|c|}{$\begin{array}{c}\text { Whipment Number } \\
\text { Identification \# }\end{array}$} & \multicolumn{1}{|c|}{ Package \# } & Date of Disposal \\
\hline DPL10134 & LRY5LLFY08002 & 10 200 & $6 / 30 / 10$ \\
\hline DPL10134 & LRY5LLFY08002 & 10 L324 & $6 / 30 / 10$ \\
\hline & & & \\
\hline & & & \\
\hline & & & \\
\hline & & & \\
\hline
\end{tabular}

This certification is provided as a courtesy to the waste generator for information purposes only.

/s/: Theresa Hale

WGS Signature

Waste Inspector

Title

/s/:Jon Tanaka

RWMC Signatūré

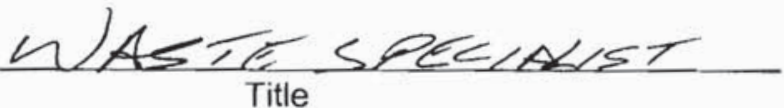

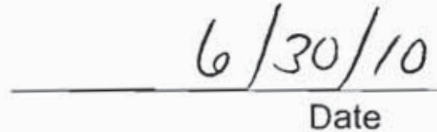

$\frac{\text { Sed Inve-zeres }}{\text { Date }}$ 


\begin{tabular}{|lcr|}
\hline NSTec & CERTIFICATE OF DISPOSAL & 03/01/10 \\
Form & Rev. 01 \\
FRM-2217 & (LOW LEVEL WASTE) & Page 1 of 1 \\
\hline
\end{tabular}

Nevada Test Site

This Certificate acknowledges that the following shipments) of waste have been disposed at the Nevada Test Site Radioactive Waste Management Complex.

\begin{tabular}{|l|l|l|l|}
\hline \multicolumn{1}{|c|}{$\begin{array}{c}\text { Shipment Number } \\
\text { Identification \# }\end{array}$} & \multicolumn{1}{|c|}{ Package \# } & Date of Disposal \\
\hline DPL10135 & LRY5LLFY08002 & 10 201 & $6 / 30 / 10$ \\
\hline DPL10135 & LRY5LLFY08002 & 10 L323 & $6 / 30 / 10$ \\
\hline & & & \\
\hline & & & \\
\hline & & & \\
\hline & & & \\
\hline & & & \\
\hline
\end{tabular}

This certification is provided as a courtesy to the waste generator for information purposes only.

/s/ :Theresa Hale

WGS Signature

Waste Inspector

Title

/s/: Jon Tanka

RWMC Signature

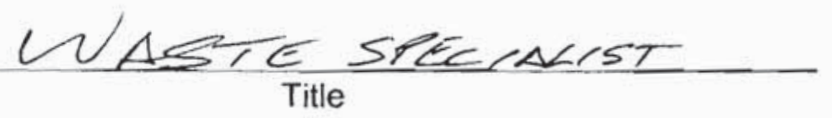

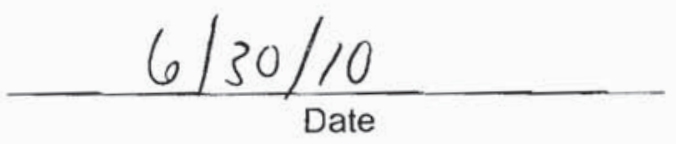

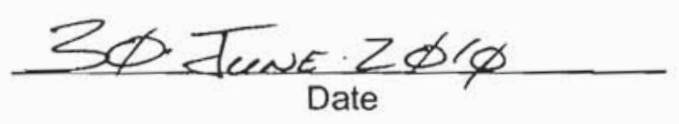

(Reference: OP-2151.304) 


\begin{tabular}{|lcr|}
\hline NSTec & CERTIFICATE OF DISPOSAL & $03 / 01 / 10$ \\
Form & Rev. 01 \\
FRM-2217 & (LOW LEVEL WASTE) & Page 1 of 1 \\
\hline
\end{tabular}

Nevada Test Site

This Certificate acknowledges that the following shipments) of waste have been disposed at the Nevada Test Site Radioactive Waste Management Complex.

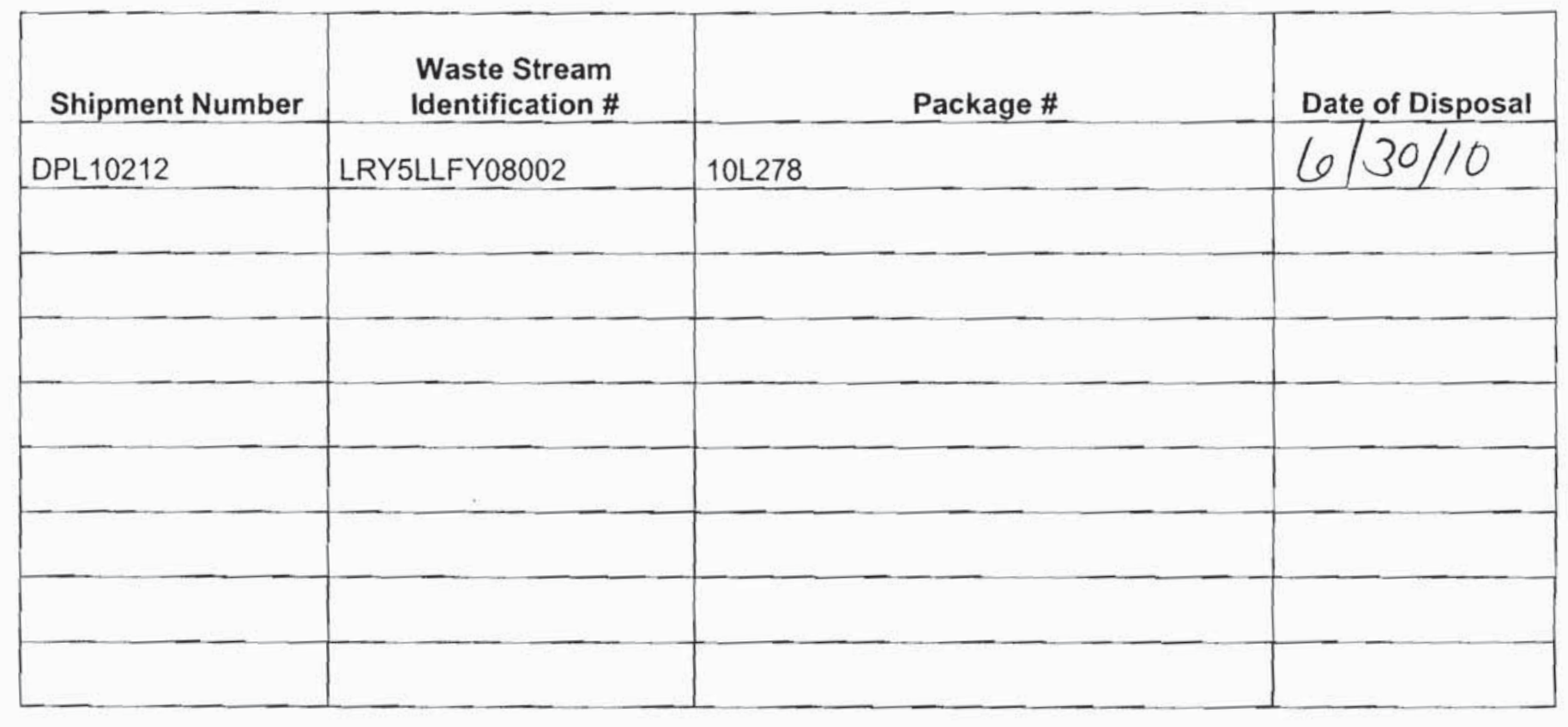

This certification is provided as a courtesy to the waste generator for information purposes only.

/s/ :Theresa Hale

WGS Signature

Waste Inspector

Title
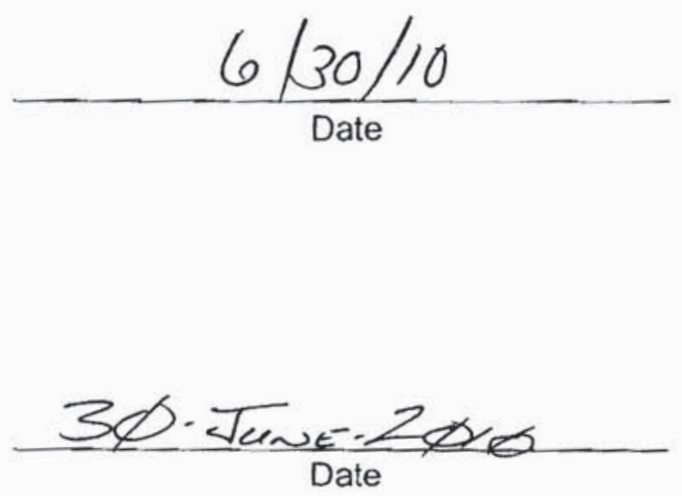

(Reference: OP-2151.304) 
NSTec

Form

FRM-2217
CERTIFICATE OF DISPOSAL

(LOW LEVEL WASTE)
03/01/10

Rev. 01

Page 1 of 1

\section{Nevada Test Site}

This Certificate acknowledges that the following shipment(s) of waste have been disposed at the Nevada Test Site Radioactive Waste Management Complex.

\begin{tabular}{|l|l|l|l|}
\hline Shipment Number & $\begin{array}{c}\text { Waste Stream } \\
\text { Identification \# }\end{array}$ & Package \# & Date of Disposal \\
\hline DPL10213 & LRY5LLFY08002 & 10 L279 & $6 / 30 / 10$ \\
\hline & & & \\
\hline & & & \\
\hline & & & \\
\hline & & & \\
\hline
\end{tabular}

This certification is provided as a courtesy to the waste generator for information purposes only.

/s/:Theresa Hale

WGS Signature

Waste Inspector

Title

/s/: Jon Tanaka

RWMC Signature

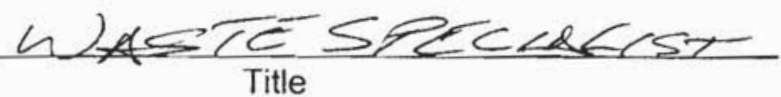

$\frac{6 / 30 / 10}{\text { Date }}$

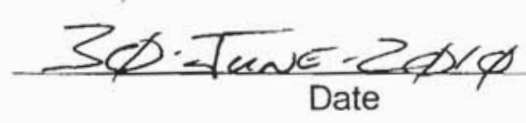




\begin{tabular}{|lrr|}
\hline NSTec & CERTIFICATE OF DISPOSAL & 03/01/10 \\
Form & Rev. 01 \\
FRM-2217 & (LOW LEVEL WASTE) & Page 1 of 1 \\
\hline
\end{tabular}

Nevada Test Site

This Certificate acknowledges that the following shipments) of waste have been disposed at the Nevada Test Site Radioactive Waste Management Complex.

\begin{tabular}{|c|c|c|c|}
\hline Shipment Number & $\begin{array}{c}\text { Waste Stream } \\
\text { Identification \# }\end{array}$ & \multicolumn{1}{|c|}{ Package \# } & Date of Disposal \\
\hline DPL10214 & LRY5LLFY08002 & $10 \mathrm{~L} 280$ & $6 / 30 / 10$ \\
\hline & & & \\
\hline & & & \\
\hline & & & \\
\hline & & & \\
\hline & & & \\
\hline
\end{tabular}

This certification is provided as a courtesy to the waste generator for information purposes only.

/s/ :Theresa Hale

WGS Signature

Waste Inspector

Title
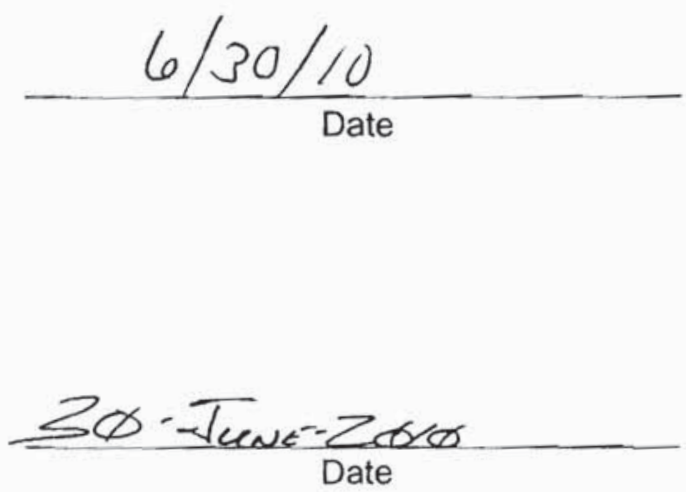

RWMC Signature

Title

(Reference: OP-2151.304) 


\begin{tabular}{|lcr|}
\hline NSTec & CERTIFICATE OF DISPOSAL & Rev. 01 \\
Form & (LOW LEVEL WASTE) & Page 1 of 1 \\
FRM-2217 & C \\
\hline
\end{tabular}

Nevada Test Site

This Certificate acknowledges that the following shipments) of waste have been disposed the Nevada Test Site Radioactive Waste Management Complex.

\begin{tabular}{|c|c|c|c|}
\hline Shipment Number & $\begin{array}{c}\text { Waste Stream } \\
\text { Identification \# } \\
\text { LRY5LLFY08002 }\end{array}$ & 10L281 & Package \# \\
\hline & & & $7-1-10$ \\
\hline & & & \\
\hline & & & \\
\hline & & & \\
\hline & & & \\
\hline & & & \\
\hline & & & \\
\hline
\end{tabular}

This certification is provided as a courtesy to the waste generator for information purposes only.

/s/ :Theresa Hale

WGS Signature

$-\frac{7-1-10}{\text { Date }}$

Waste Inspector

Title

/s/ :Jon Tanka

RWMC Signature

$\phi /-J_{u}<y-\sum_{D a t e} \phi$

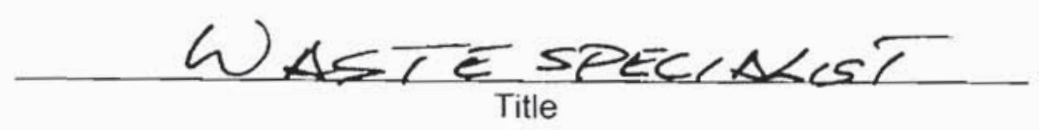

(Reference: OP-2151.304) 


\begin{tabular}{|lcr|}
\hline NSTec & CERTIFICATE OF DISPOSAL & $03 / 01 / 10$ \\
Form & Rev. 01 \\
FRM-2217 & (LOW LEVEL WASTE) & Page 1 of 1 \\
\hline
\end{tabular}

Nevada Test Site

This Certificate acknowledges that the following shipments) of waste have been disposed the Nevada Test Site Radioactive Waste Management Complex.

\begin{tabular}{|l|l|l|l|}
\hline \multicolumn{1}{|c|}{ Shipment Number } & $\begin{array}{c}\text { Waste Stream } \\
\text { Identification \# }\end{array}$ & \multicolumn{1}{c|}{ Package \# } & Date of Disposal \\
\hline DPL10216 & LRY5LLFY08002 & $10 \mathrm{~L} 282$ & $7-1-10$ \\
\hline & & & \\
\hline & & & \\
\hline & & & \\
\hline & & & \\
\hline & & & \\
\hline & & & \\
\hline
\end{tabular}

This certification is provided as a courtesy to the waste generator for information purposes only.

/s/: Theresa Hale

WGS Signature

Waste Inspector

Title

/s/: Jon Kanaka

RWMC Signature

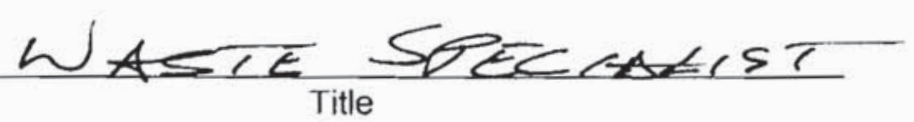

$7-1-10$

Date

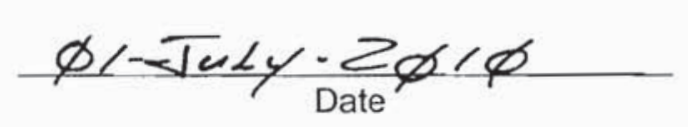

(Reference: OP-2151.304) 


\begin{tabular}{|lcr|}
\hline NSTec & CERTIFICATE OF DISPOSAL & 03/01/10 \\
Form & Rev. 01 \\
FRM-2217 & (LOW LEVEL WASTE) & Page 1 of 1 \\
\hline
\end{tabular}

Nevada Test Site

This Certificate acknowledges that the following shipments) of waste have been disposed at the Nevada Test Site Radioactive Waste Management Complex.

\begin{tabular}{|c|c|c|c|}
\hline Shipment Number & $\begin{array}{c}\text { Waste Stream } \\
\text { Identification \# }\end{array}$ & Package \# & Date of Disposal \\
\hline DPL10217 & LRY5LLFY08002 & 102283 & $7-1-10$ \\
\hline & & & \\
\hline & & & \\
\hline & & & \\
\hline & & & \\
\hline & & & \\
\hline
\end{tabular}

This certification is provided as a courtesy to the waste generator for information purposes only.

/s/ :Theresa Hale

WGS Signature

Waste Inspector

Title

/s/ :Jon Tanaka
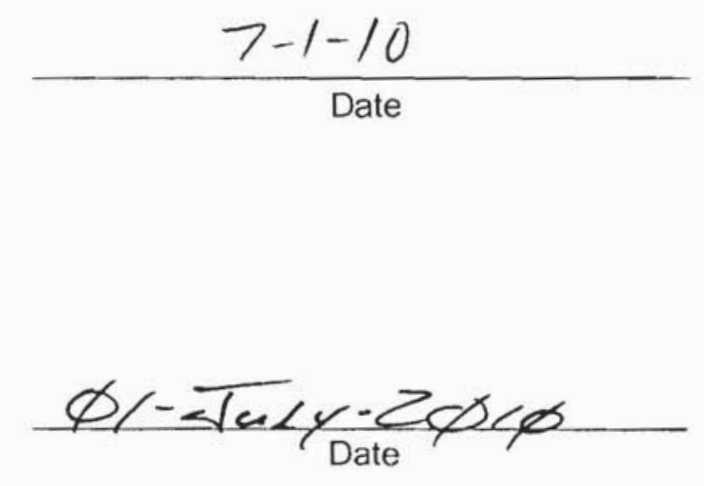

(Reference: OP-2151.304) 
NSTec

Form

CERTIFICATE OF DISPOSAL

03/01/10

FRM-2217

(LOW LEVEL WASTE)

Rev. 01

Page 1 of 1

\section{Nevada Test Site}

This Certificate acknowledges that the following shipment(s) of waste have been disposed at the Nevada Test Site Radioactive Waste Management Complex.

\begin{tabular}{|l|l|l|l|}
\hline Shipment Number & $\begin{array}{c}\text { Waste Stream } \\
\text { Identification \# }\end{array}$ & Package \# & Date of Disposal \\
\hline DPL10218 & LRY5LLFY08002 & 10L284 & $7-1-/ 0$ \\
\hline & & & \\
\hline & & & \\
\hline & & & \\
\hline & & & \\
\hline
\end{tabular}

This certification is provided as a courtesy to the waste generator for information purposes only.

/s/:Theresa Hale

WGS Signature

Waste Inspector

Title

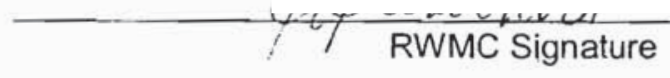

$\frac{7-1-10}{\text { Date }}$

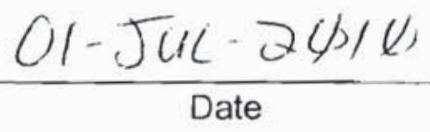




\begin{tabular}{|lcr|}
\hline NSTec & CERTIFICATE OF DISPOSAL & 03/01/10 \\
Form & Rev. 01 \\
FRM-2217 & (LOW LEVEL WASTE) & Page 1 of 1 \\
\hline
\end{tabular}

Nevada Test Site

This Certificate acknowledges that the following shipments) of waste have been disposed at the Nevada Test Site Radioactive Waste Management Complex.

\begin{tabular}{|l|l|l|l|}
\hline \multicolumn{1}{|c|}{$\begin{array}{c}\text { Shipment Number } \\
\text { Identification \# }\end{array}$} & \multicolumn{1}{|c|}{ Package \# } & Date of Disposal \\
\hline DPL10236 & LRY5LLFY08002 & $10 L 302$ & $7-1-10$ \\
\hline DPL10236 & LRY5LLFY08002 & $10 L 322$ & $7-1-10$ \\
\hline & & & \\
\hline & & & \\
\hline & & & \\
\hline & & & \\
\hline & & & \\
\hline
\end{tabular}

This certification is provided as a courtesy to the waste generator for information purposes only.

$$
\text { /s/ :Theresa Hale }
$$

WGS Signature

Waste Inspector

Title

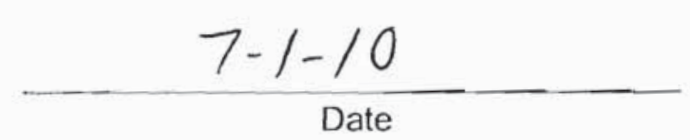

$\Phi \cdot$ Inky. Z ores 


\begin{tabular}{|lcr|}
\hline NSTec & CERTIFICATE OF DISPOSAL & $03 / 01 / 10$ \\
Form & Rev. 01 \\
FRM-2217 & (LOW LEVEL WASTE) & Page 1 of 1 \\
\hline
\end{tabular}

Nevada Test Site

This Certificate acknowledges that the following shipments) of waste have been disposed at the Nevada Test Site Radioactive Waste Management Complex.

\begin{tabular}{|l|l|l|l|}
\hline Shipment Number & \multicolumn{1}{c|}{$\begin{array}{c}\text { Waste Stream } \\
\text { Identification \# }\end{array}$} & Package \# & Date of Disposal \\
\hline DPL10237 & LRY5LLFY08002 & $10 L 303$ & $7-1-10$ \\
\hline DPL10237 & LRY5LLFY08002 & $10 L 321$ & $7-1-10$ \\
\hline & & & \\
\hline & & & \\
\hline & & & \\
\hline & & & \\
\hline & & & \\
\hline
\end{tabular}

This certification is provided as a courtesy to the waste generator for information purposes only.

/s/ :Theresa Hale

WGS Signature

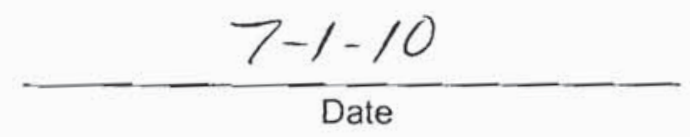

Waste Inspector

Title

/s/: Jon Tanka

RWMC Signature - - -
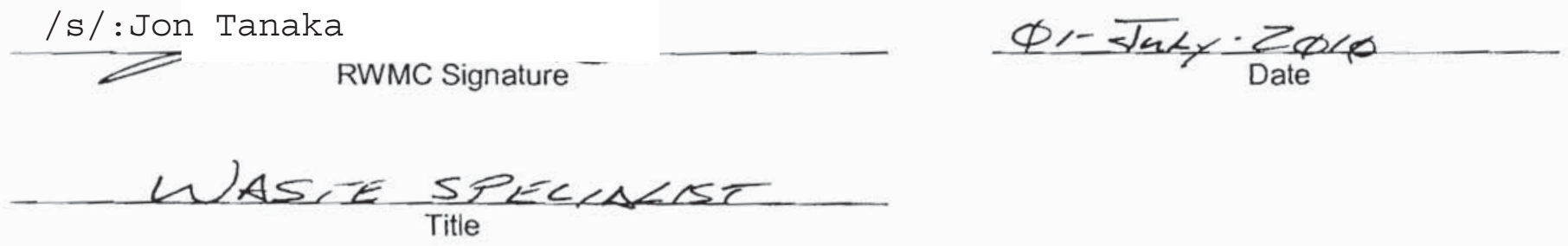

(Reference: OP-2151.304) 


\begin{tabular}{|lcr|}
\hline NSTec & CERTIFICATE OF DISPOSAL & $03 / 01 / 10$ \\
Form & Rev. 01 \\
FRM-2217 & (LOW LEVEL WASTE) & Page 1 of 1 \\
\hline
\end{tabular}

Nevada Test Site

This Certificate acknowledges that the following shipments) of waste have been disposed at the Nevada Test Site Radioactive Waste Management Complex.

\begin{tabular}{|l|l|l|l|}
\hline \multicolumn{1}{|c|}{$\begin{array}{c}\text { Waste Stream } \\
\text { Shipment Number }\end{array}$} & \multicolumn{1}{|c|}{ Package \# } & Date of Disposal \\
\hline DPL10238 & LRY5LLFY08002 & 10 304 & $7-1-10$ \\
\hline DPL10238 & LRY5LLFY08002 & 10 L320 & $7-1-10$ \\
\hline & & & \\
\hline & & & \\
\hline & & & \\
\hline & & & \\
\hline & & & \\
\hline & & & \\
\hline
\end{tabular}

This certification is provided as a courtesy to the waste generator for information purposes only.

/s/ :Theresa Hale

WGS Signature

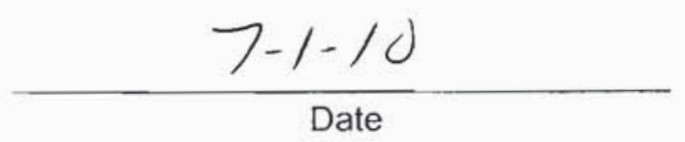

Waste Inspector

Title

/s/: Jon Kanaka

RWMC Signature

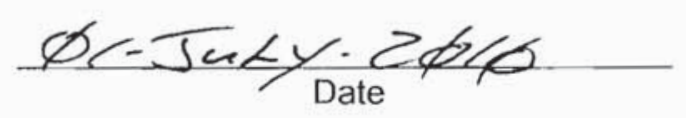

(Reference: OP-2151.304) 


\begin{tabular}{|lcr|}
\hline NSTec & CERTIFICATE OF DISPOSAL & Rev i/10 \\
Form & Rev \\
FRM-2217 & (LOW LEVEL WASTE) & Page 1 of 1 \\
\hline
\end{tabular}

Nevada Test Site

This Certificate acknowledges that the following shipments) of waste have been disposed at the Nevada Test Site Radioactive Waste Management Complex.

\begin{tabular}{|l|c|c|c|}
\hline Shipment Number & $\begin{array}{c}\text { Waste Stream } \\
\text { Identification \# }\end{array}$ & \multicolumn{1}{|c|}{ Package \# } & Date of Disposal \\
\hline & LRY5LLFY08002 & 10 2825 & $7 / 6 / 10$ \\
\hline & & & \\
\hline & & & \\
\hline & & & \\
\hline & & & \\
\hline & & & \\
\hline & & & \\
\hline & & & \\
\hline
\end{tabular}

This certification is provided as a courtesy to the waste generator for information purposes only.

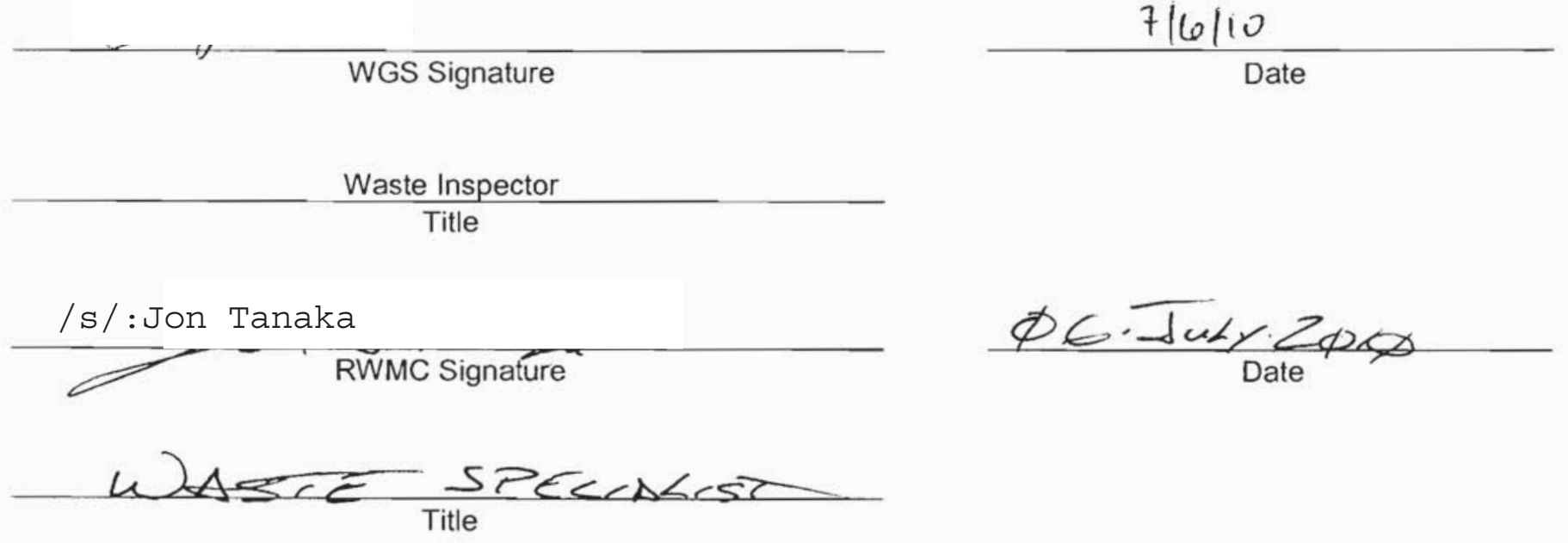


NSTec

Form

FRM-2217
CERTIFICATE OF DISPOSAL

(LOW LEVEL WASTE)
$03 / 01 / 10$

Rev. 01

Page 1 of 1

Nevada Test Site

This Certificate acknowledges that the following shipments) of waste have been disposed at the Nevada Test Site Radioactive Waste Management Complex.

\begin{tabular}{|l|l|l|c|}
\hline \multicolumn{1}{|c|}{ Shipment Number } & $\begin{array}{c}\text { Waste Stream } \\
\text { Identification \# }\end{array}$ & Package \# & Date of Disposal \\
\hline DPL10220 & LRY5LLFY08002 & 10 L286 & $7 / 6 / 10$ \\
\hline & & & \\
\hline & & & \\
\hline & & & \\
\hline & & & \\
\hline & & & \\
\hline
\end{tabular}

This certification is provided as a courtesy to the waste generator for information purposes only.

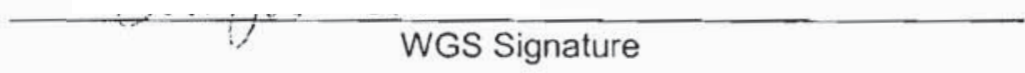

Waste Inspector

Title

/s/: Jon Tanaka

RWMMC Signature

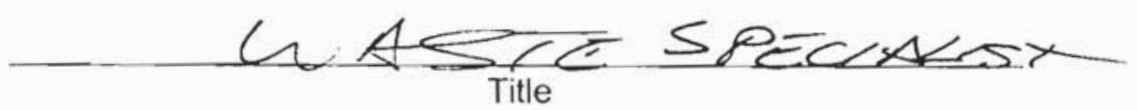

$716: 10$

Date

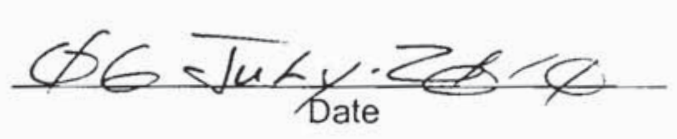

(Reference: OP-2151.304) 


\begin{tabular}{|lcr|}
\hline NSTec & CERTIFICATE OF DISPOSAL & $03 / 01 / 10$ \\
Form & Rev. 01 \\
FRM-2217 & (LOW LEVEL WASTE) & Page 1 of 1 \\
\hline
\end{tabular}

Nevada Test Site

This Certificate acknowledges that the following shipments) of waste have been disposed at the Nevada Test Site Radioactive Waste Management Complex.

\begin{tabular}{|l|l|l|l|}
\hline \multicolumn{1}{|c|}{ Shipment Number } & \multicolumn{1}{|c|}{$\begin{array}{c}\text { Waste Stream } \\
\text { Identification \# }\end{array}$} & \multicolumn{1}{|c|}{ Package \# } & Date of Disposal \\
\hline DPL10239 & LRY5LLFY08002 & 10 305 & $7 / 6 / 10$ \\
\hline DPL10239 & LRY5LLFY08002 & 10 L319 & $7 / 6 / 10$ \\
\hline & & & \\
\hline & & & \\
\hline & & & \\
\hline & & & \\
\hline & & & \\
\hline
\end{tabular}

This certification is provided as a courtesy to the waste generator for information purposes only.

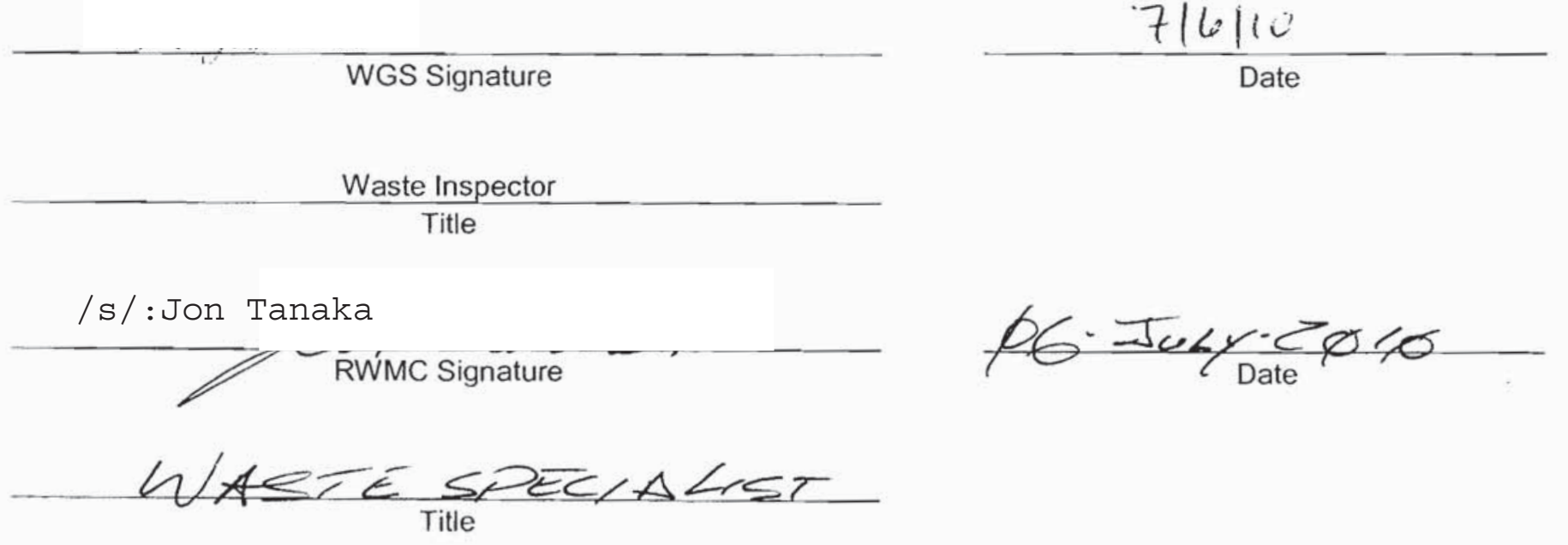

(Reference: OP-2151.304) 


\begin{tabular}{|lcr|}
\hline NSTec & CERTIFICATE OF DISPOSAL & 03/01/10 \\
Form & Rev. 01 \\
FRM-2217 & (LOW LEVEL WASTE) & Page 1 of 1 \\
\hline
\end{tabular}

Nevada Test Site

This Certificate acknowledges that the following shipments) of waste have been disposed the Nevada Test Site Radioactive Waste Management Complex.

\begin{tabular}{|l|l|l|l|}
\hline \multicolumn{1}{|c|}{$\begin{array}{c}\text { Shipment Number } \\
\text { Identification \# }\end{array}$} & Package \# & Date of Disposal \\
\hline DPL10240 & LRY5LLFY08002 & $10 L 306$ & $7 / 6 / 10$ \\
\hline DPL10240 & LRY5LLFY08002 & 10 L318 & $7 / 6 / 10$ \\
\hline & & & \\
\hline & & & \\
\hline & & & \\
\hline & & & \\
\hline & & & \\
\hline
\end{tabular}

This certification is provided as a courtesy to the waste generator for information purposes only.

WGS Signature

Waste Inspector

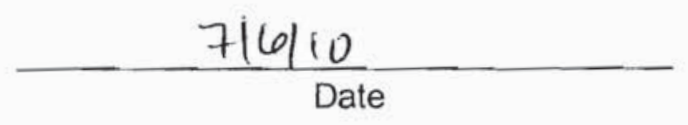

Date

$7 / 6 / 14$

Date

LLW Specialist

(Reference: OP-2151.304) 
NSTec

Form

FRM-2217
CERTIFICATE OF DISPOSAL

(LOW LEVEL WASTE)
03/01/10

Rev. 01

Page 1 of 1

\section{Nevada Test Site}

This Certificate acknowledges that the following shipment(s) of waste have been disposed at the Nevada Test Site Radioactive Waste Management Complex.

\begin{tabular}{|c|c|c|c|}
\hline Shipment Number & $\begin{array}{l}\text { Waste Stream } \\
\text { Identification \# }\end{array}$ & Package \# & Date of Disposal \\
\hline DPL10241 & LRY5LLFY08002 & $10\llcorner 307$ & 71016 \\
\hline DPL10241 & LRY5LLFY08002 & $10 \mathrm{~L} 317$ & 710110 \\
\hline & & & \\
\hline & & & \\
\hline & & & \\
\hline & & & \\
\hline & & & \\
\hline & & & \\
\hline
\end{tabular}

This certification is provided as a courtesy to the waste generator for information purposes only.

WGS Signature

Waste Inspector

Title

/s/:Jon Tanaka

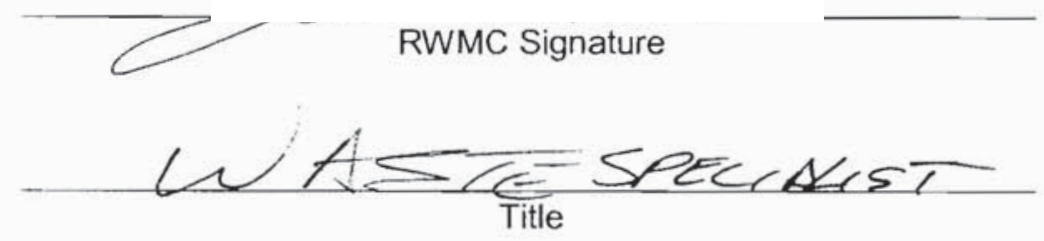

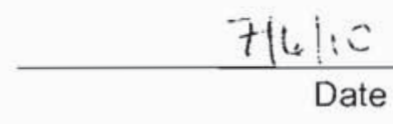

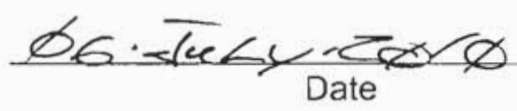




\begin{tabular}{|lcr|}
\hline NSTec & CERTIFICATE OF DISPOSAL & $03 / 01 / 10$ \\
Form & Rev. 01 \\
FRM-2217 & (LOW LEVEL WASTE) & Page 1 of 1 \\
\hline
\end{tabular}

Nevada Test Site

This Certificate acknowledges that the following shipments) of waste have been disposed at the Nevada Test Site Radioactive Waste Management Complex.

\begin{tabular}{|l|l|l|l|}
\hline Shipment Number & \multicolumn{1}{|c|}{$\begin{array}{c}\text { Waste Stream } \\
\text { Identification \# }\end{array}$} & Package \# & Date of Disposal \\
\hline DPL10221 & LRY5LLFY08002 & 10 L287 & $7-7-10$ \\
\hline DPL10221 & LRY5LLFY08002 & 10 L 301 & $7-7-10$ \\
\hline & & & \\
\hline & & & \\
\hline & & & \\
\hline & & & \\
\hline & & & \\
\hline
\end{tabular}

This certification is provided as a courtesy to the waste generator for information purposes only.

/s/: Theresa Hale

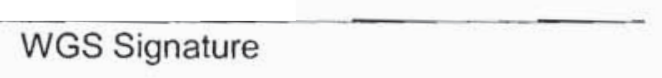

Waste Inspector Title

/s/: Jon Tanka

RWMC Signature

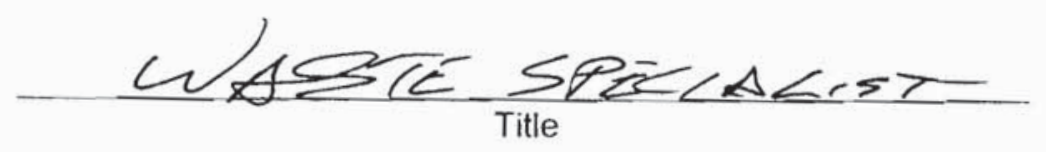

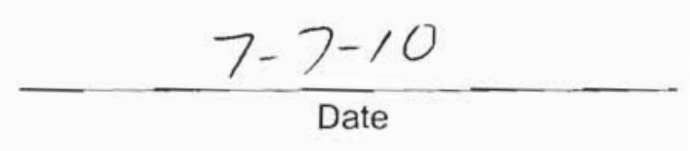

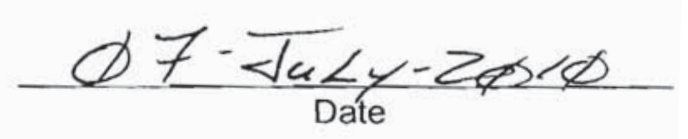

(Dnforanne. OP-21.51.304) 


\begin{tabular}{|lcr|}
\hline NSTec & CERTIFICATE OF DISPOSAL & $03 / 01 / 10$ \\
Form & Rev. 01 \\
FRM-2217 & (LOW LEVEL WASTE) & Page 1 of 1 \\
\hline
\end{tabular}

Nevada Test Site

This Certificate acknowledges that the following shipments) of waste have been disposed at the Nevada Test Site Radioactive Waste Management Complex.

\begin{tabular}{|l|l|l|l|}
\hline \multicolumn{1}{|c|}{ Shipment Number } & $\begin{array}{c}\text { Waste Stream } \\
\text { Identification \# }\end{array}$ & \multicolumn{1}{|c|}{ Package \# } & Date of Disposal \\
\hline DPL10222 & LRY5LLFY08002 & 10 2888 & $7-7-10$ \\
\hline DPL10222 & LRY5LLFY08002 & $10 L 300$ & $7-7-10$ \\
\hline & & & \\
\hline & & & \\
\hline & & & \\
\hline & & & \\
\hline & & & \\
\hline
\end{tabular}

This certification is provided as a courtesy to the waste generator for information purposes only.

/s/ :Theresa Hale

WGS Signature

Waste Inspector

Title

/s/: Jon Tanka

RWMC Signature -

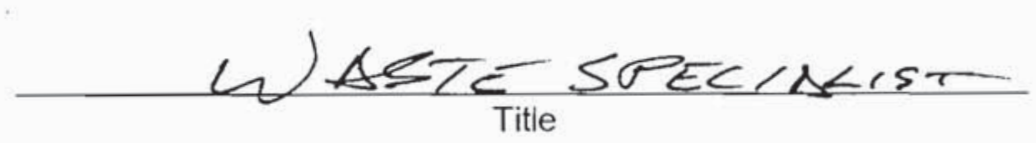

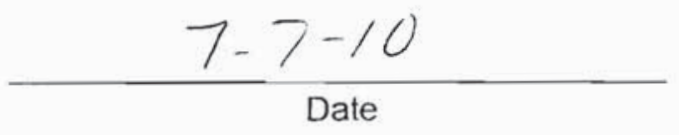

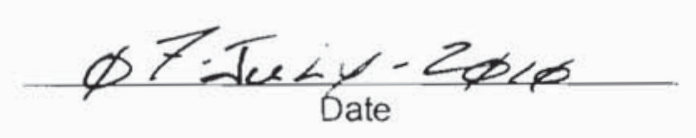

(Reference: OP-2151.304) 
NSTec

Form

FRM-2217
CERTIFICATE OF DISPOSAL

(LOW LEVEL WASTE)
03/01/10

Rev. 01

Page 1 of 1

Nevada Test Site

This Certificate acknowledges that the following shipments) of waste have been disposed at the Nevada Test Site Radioactive Waste Management Complex.

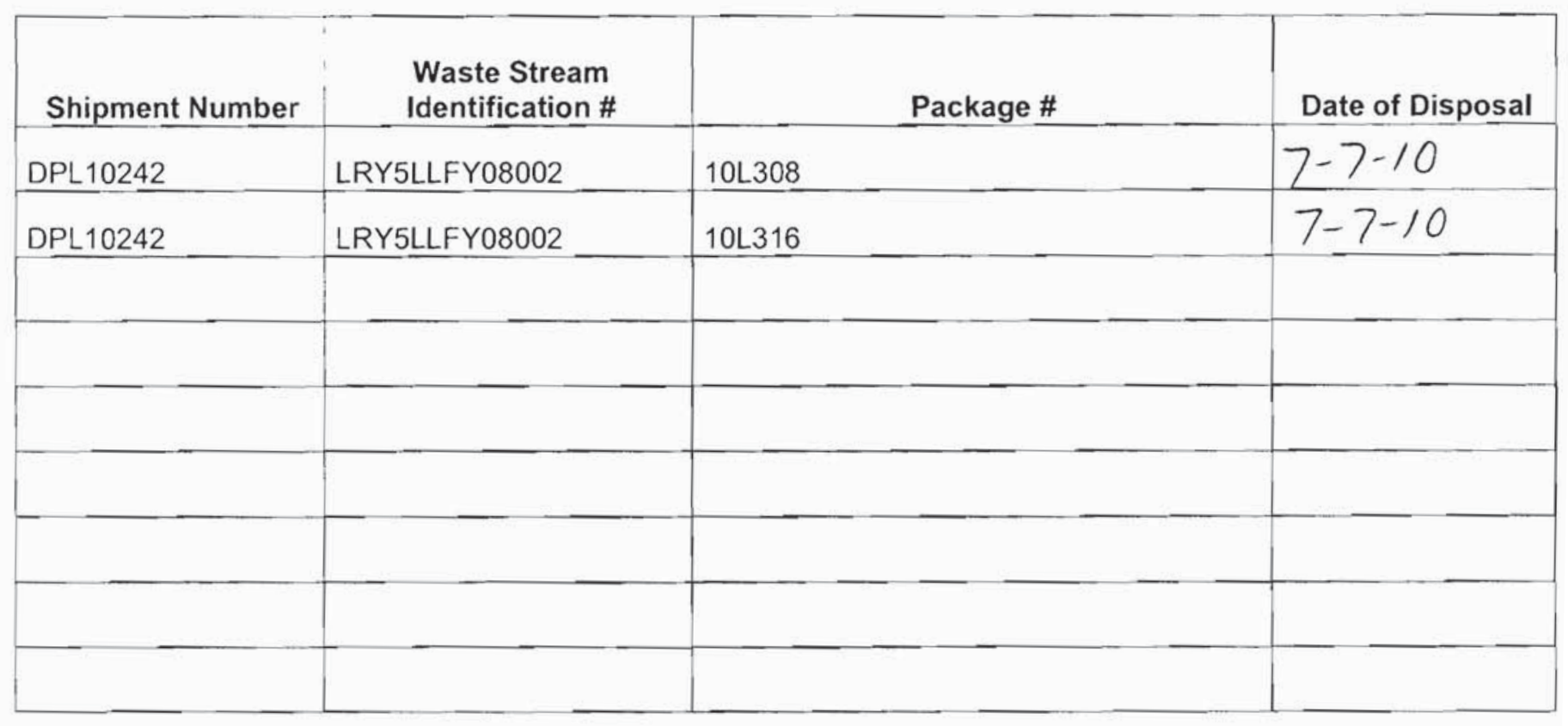

This certification is provided as a courtesy to the waste generator for information purposes only.

/s/ :Theresa Hale

WGS Signature

Waste Inspector

Title

/s/: Jon Kanaka

RWMC Signature

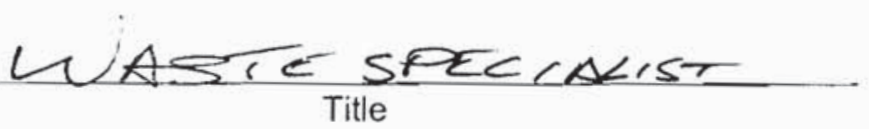

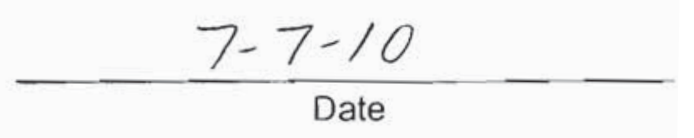

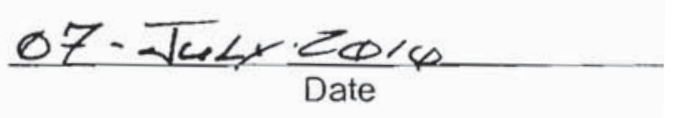

(Reference: OP-2151.304) 
NSTec

Form

FRM-2217
CERTIFICATE OF DISPOSAL

(LOW LEVEL WASTE)
03/01/10

Rev. 01

Page 1 of 1

\section{Nevada Test Site}

This Certificate acknowledges that the following shipment(s) of waste have been disposed at the Nevada Test Site Radioactive Waste Management Complex.

\begin{tabular}{|l|l|l|l|}
\hline \multicolumn{1}{|c|}{$\begin{array}{c}\text { Waste Stream } \\
\text { Identification \# }\end{array}$} & Package \# & Date of Disposal \\
\hline DPL10243 & LRY5LLFY08002 & 10 L309 & $7-7-10$ \\
\hline DPL10243 & LRY5LLFY08002 & 10 L315 & $7-7-10$ \\
\hline & & & \\
\hline & & & \\
\hline & & & \\
\hline & & & \\
\hline & & & \\
\hline
\end{tabular}

This certification is provided as a courtesy to the waste generator for information purposes only.

/s/:Theresa Hale

WGS Signature

Waste Inspector

Title

/s/:Jon Tanaka

CCATMC Signature
$7-7-10$

Date

$\phi 7 . \overline{T a k y}-2 \phi x \phi$ 
NSTec

Form

FRM-2217
CERTIFICATE OF DISPOSAL

(LOW LEVEL WASTE)
03/01/10

Rev. 01

Page 1 of 1

\section{Nevada Test Site}

This Certificate acknowledges that the following shipment(s) of waste have been disposed at the Nevada Test Site Radioactive Waste Management Complex.

\begin{tabular}{|l|l|l|l|}
\hline \multicolumn{1}{|c|}{$\begin{array}{c}\text { Whipment Number } \\
\text { Identification \# }\end{array}$} & \multicolumn{1}{c|}{ Package \# } & Date of Disposal \\
\hline DPL10244 & LRY5LLFY08002 & 10 L310 & $7-7-10$ \\
\hline DPL10244 & LRY5LLFY08002 & 10 L314 & $7-7-10$ \\
\hline & & & \\
\hline & & & \\
\hline & & & \\
\hline & & & \\
\hline
\end{tabular}

This certification is provided as a courtesy to the waste generator for information purposes only.

/s/: Theresa Hale

WGS Signature

Waste Inspector

Title

/s/: Jon Tanaka

RWMC Signature

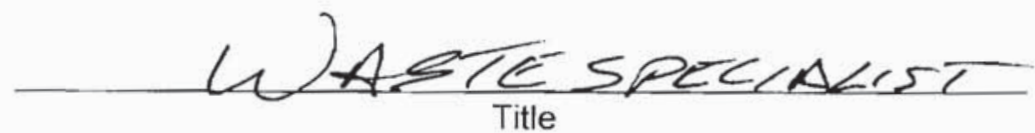

$$
\frac{7-7-10}{\text { Date }}
$$

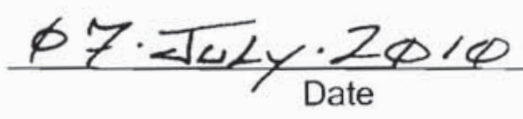


NSTec

Form

FRM-2217
CERTIFICATE OF DISPOSAL

(LOW LEVEL WASTE)
03/01/10

Rev. 01

Page 1 of 1

\section{Nevada Test Site}

This Certificate acknowledges that the following shipment(s) of waste have been disposed at the Nevada Test Site Radioactive Waste Management Complex.

\begin{tabular}{|l|l|l|l|}
\hline \multicolumn{1}{|c|}{ Shipment Number } & \multicolumn{1}{c|}{$\begin{array}{c}\text { Waste Stream } \\
\text { Identification \# }\end{array}$} & Package \# & Date of Disposal \\
\hline DPL10245 & LRY5LLFY08002 & 10 L311 & $7-7-10$ \\
\hline DPL10245 & LRY5LLFY08002 & 10 313 & $7-7-10$ \\
\hline & & & \\
\hline & & & \\
\hline
\end{tabular}

This certification is provided as a courtesy to the waste generator for information purposes only.
/s/: Theresa Hale
WGS Signature
Waste Inspector

\section{Title}
/s/:Jon Tanaka
RWMC Signature
$\phi 7-\sqrt{u} \angle y \cdot 2 \phi 1 \phi$

\section{(U) $A S T E$ SPEC $\triangle \angle S S E$}
$7-7-10$
Date


NSTec

Form

FRM-2217
CERTIFICATE OF DISPOSAL

(LOW LEVEL WASTE)
03/01/10

Rev. 01

Page 1 of 1

\section{Nevada Test Site}

This Certificate acknowledges that the following shipment(s) of waste have been disposed at the Nevada Test Site Radioactive Waste Management Complex.

\begin{tabular}{|l|l|l|l|}
\hline \multicolumn{1}{|c|}{ Shipment Number } & \multicolumn{1}{|c|}{$\begin{array}{c}\text { Waste Stream } \\
\text { Identification \# }\end{array}$} & Package \# & Date of Disposal \\
\hline DPL10109 & LRY5LLFY08002 & 10 L175 & $7-13-10$ \\
\hline DPL10109 & LRY5LLFY08002 & 10 L178 & $7-13-10$ \\
\hline & & & \\
\hline & & & \\
\hline & & & \\
\hline & & & \\
\hline
\end{tabular}

This certification is provided as a courtesy to the waste generator for information purposes only.

/s/:Theresa Hale

WGS Signature

7-13-10

Date

Waste Inspector

Title
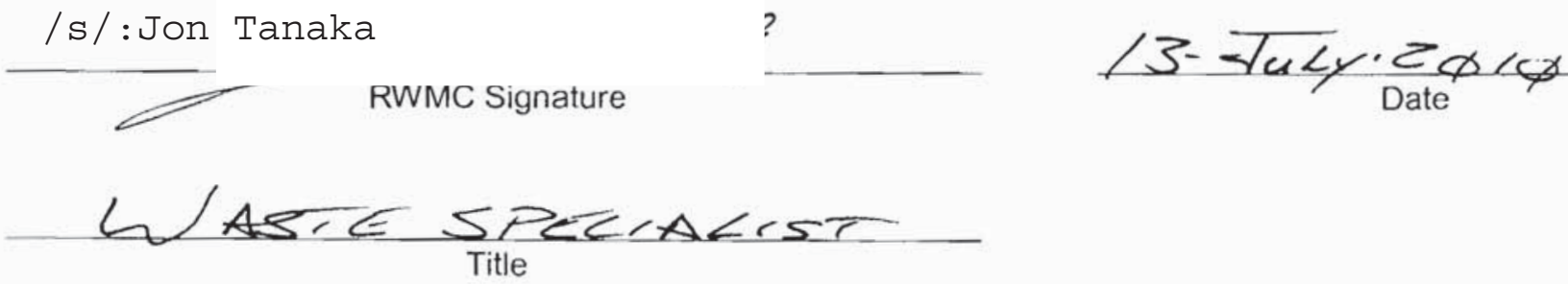


\begin{tabular}{|lcr|}
\hline NSTec & CERTIFICATE OF DISPOSAL & 03/01/10 \\
Form & Rev. 01 \\
FRM-2217 & (LOW LEVEL WASTE) & Page 1 of 1 \\
\hline
\end{tabular}

Nevada Test Site

This Certificate acknowledges that the following shipments) of waste have been disposed at the Nevada Test Site Radioactive Waste Management Complex.

\begin{tabular}{|l|l|l|l|}
\hline \multicolumn{1}{|c|}{ Shipment Number } & \multicolumn{1}{c|}{$\begin{array}{c}\text { Waste Stream } \\
\text { Identification \# }\end{array}$} & \multicolumn{1}{|c|}{ Package \# } & Date of Disposal \\
\hline DPL10108 & LRY5LLFY08002 & $10 L 174$ & $7-14-10$ \\
\hline DPL10108 & LRY5LLFY08002 & $10 L 177$ & $7-14-10$ \\
\hline & & & \\
\hline & & & \\
\hline & & & \\
\hline & & & \\
\hline & & & \\
\hline
\end{tabular}

This certification is provided as a courtesy to the waste generator for information purposes only.

/s/ :Theresa Hale

WGS Signature

Waste inspector

Title

RWMC Signature Date

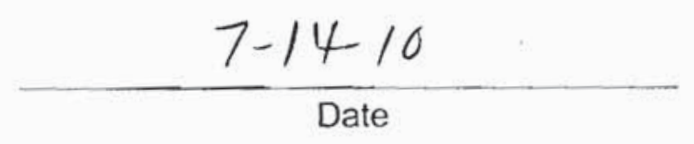

/s/: Jon Tanka

WASTE

Title

(Reference: OP-2151.304) 
NSTeC

Form

FRM-2217
CERTIFICATE OF DISPOSAL

(LOW LEVEL WASTE)
03/01/10

Rev. 01

Page 1 of 1

Nevada Test Site

This Certificate acknowledges that the following shipments) of waste have been disposed at the Nevada Test Site Radioactive Waste Management Complex.

\begin{tabular}{|l|l|l|l|}
\hline \multicolumn{1}{|c|}{$\begin{array}{c}\text { Waste Stream } \\
\text { Identification \# }\end{array}$} & Package \# & Date of Disposal \\
\hline DPL10110 & LRY5LLFY08002 & 10 L176 & $7-14-10$ \\
\hline DPL10110 & LRY5LLFY08002 & 10 1719 & $7-14-10$ \\
\hline & & & \\
\hline & & & \\
\hline & & & \\
\hline
\end{tabular}

This certification is provided as a courtesy to the waste generator for information purposes only.

/s/: Theresa Hale

$\frac{7-14-10}{\text { Date }}$

WGS Signature

Waste Inspector

Title

/s/ :Jon Kanaka

'RWMC Signature
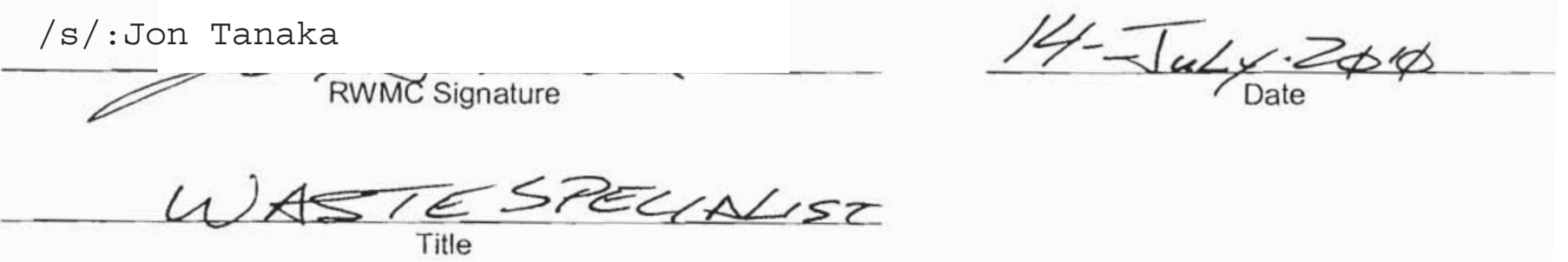

(Reference: OP-2151.304) 
NSTec

Form

FRM-2217
CERTIFICATE OF DISPOSAL

(LOW LEVEL WASTE)
03/01/10

Rev. 01

Page 1 of 1

\section{Nevada Test Site}

This Certificate acknowledges that the following shipment(s) of waste have been disposed at the Nevada Test Site Radioactive Waste Management Complex.

\begin{tabular}{|c|c|c|c|}
\hline Shipment Number & $\begin{array}{l}\text { Waste Stream } \\
\text { Identification \# }\end{array}$ & Package \# & Date of Disposal \\
\hline DPL10223 & LRY5LLFY08002 & 10L289 & $7-15-10$ \\
\hline DPL10223 & LRY5LLFY08002 & $10 L 299$ & $7-15-10$ \\
\hline & & . & \\
\hline & & & \\
\hline & & & \\
\hline & & & \\
\hline & & & \\
\hline & & & \\
\hline
\end{tabular}

This certification is provided as a courtesy to the waste generator for information purposes only.

/s/: Theresa Hale

WGS Signature

Waste Inspector

Title

/s/:Jon Tanaka

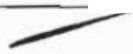

RWMC Signature

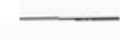

$-\frac{7-15-10}{\text { Date }}$

4 ADTE $5 B \leq E \angle A C R S T$ 
NSTec

Form

FRM-2217
CERTIFICATE OF DISPOSAL

(LOW LEVEL WASTE)
03/01/10

Rev. 01

Page 1 of 1

Nevada Test Site

This Certificate acknowledges that the following shipments) of waste have been disposed at the Nevada Test Site Radioactive Waste Management Complex.

\begin{tabular}{|l|c|c|c|}
\hline Shipment Number & $\begin{array}{c}\text { Waste Stream } \\
\text { Identification \# }\end{array}$ & Package \# & Date of Disposal \\
\hline DPL10246 & LRY5LLFY08002 & 10 L312 & $7.26-10$ \\
\hline & & & \\
\hline & & & \\
\hline & & & \\
\hline & & & \\
\hline
\end{tabular}

This certification is provided as a courtesy to the waste generator for information purposes only.

/s/ :Theresa Hale

$-\frac{7-26-10}{\text { Date }}$

Waste Inspector

Title

/s/ :Jon Tanka

RWMC Signature
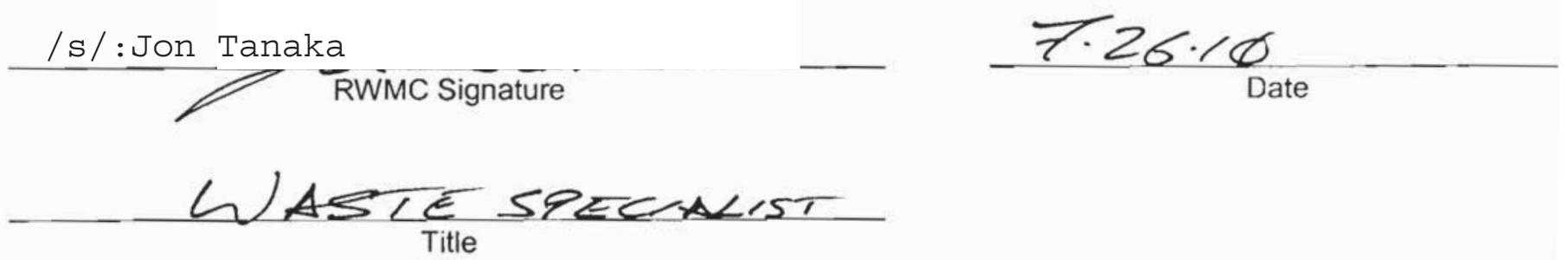

(Reference: OP-2151.304) 


\section{Nevada Test Site}

This Certificate acknowledges that the following shipment(s) of waste have been disposed at the Nevada Test Site Radioactive Waste Management Complex.

\begin{tabular}{|c|c|c|c|}
\hline Shipment Number & $\begin{array}{l}\text { Waste Stream } \\
\text { Identification \# }\end{array}$ & Package \# & Date of Disposal \\
\hline DPL10231 & LRY5LLFY08002 & $10 L 933$ & $1 / 10$ \\
\hline & & & \\
\hline & & & \\
\hline & & & \\
\hline & & & \\
\hline & & & \\
\hline . & & & \\
\hline & & & \\
\hline
\end{tabular}

This certification is provided as a courtesy to the waste generator for information purposes only.

/s/:Theresa Hale

WGS Signature

Waste Inspector

Title

TW RWMC Signature

setensh
$8 / 9 / 10$

Date

Date 


\begin{tabular}{|lcr|}
\hline NSTec & CERTIFICATE OF DISPOSAL & $03 / 01 / 10$ \\
Form & Rev. 01 \\
FRM-2217 & (LOW LEVEL WASTE) & Page 1 of 1 \\
\hline
\end{tabular}

Nevada Test Site

This Certificate acknowledges that the following shipments) of waste have been disposed at the Nevada Test Site Radioactive Waste Management Complex.

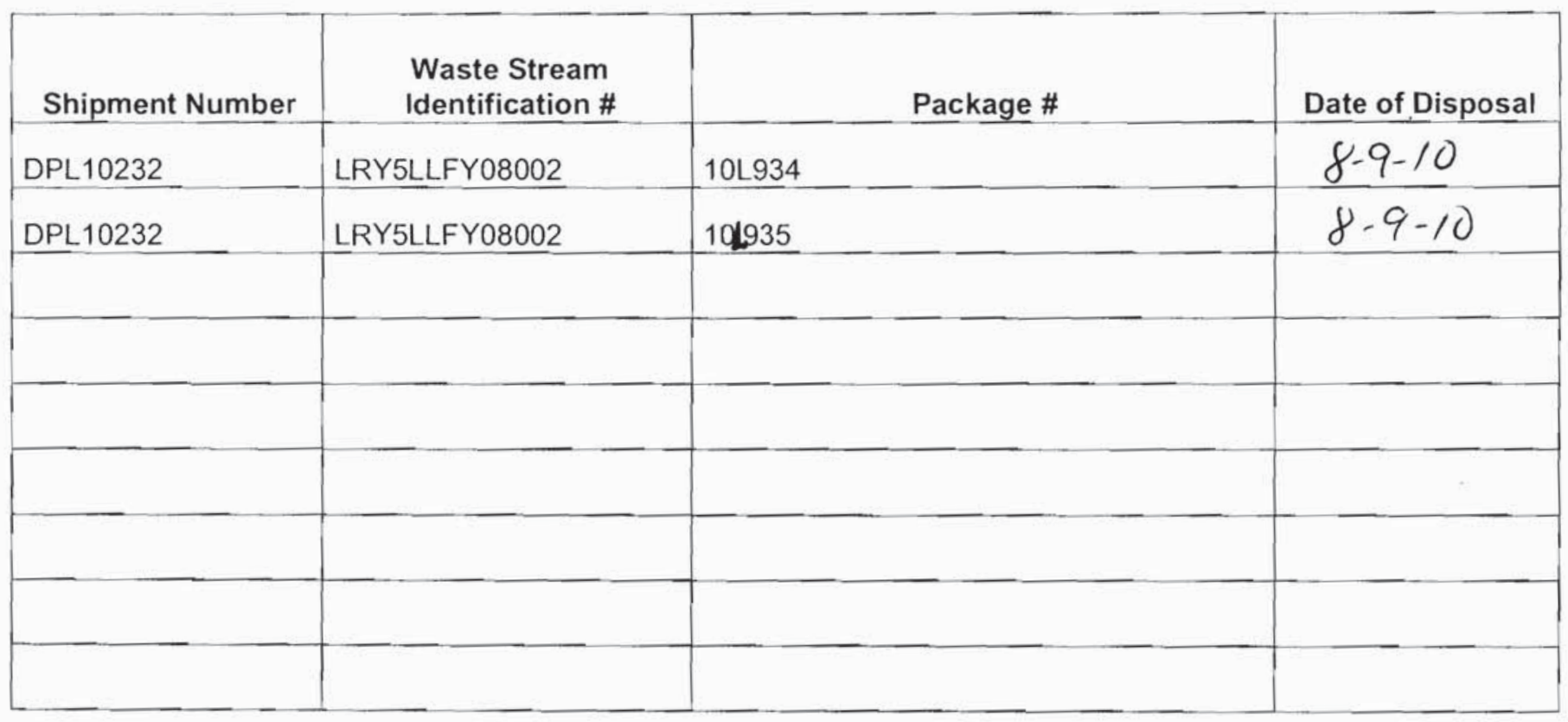

This certification is provided as a courtesy to the waste generator for information purposes only.

/s/ :Theresa Hale

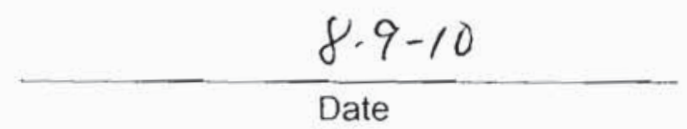

Waste Inspector

Title

RWVMC Signature

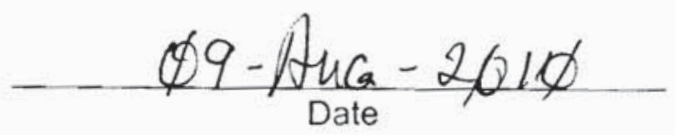

Waste Specialist

(Reference: OP-2151.304) 
NSTec

Form

FRM-2217
CERTIFICATE OF DISPOSAL

(LOW LEVEL WASTE)
03/01/10

Rev. 01

Page 1 of 1

\section{Nevada Test Site}

This Certificate acknowledges that the following shipment(s) of waste have been disposed at the Nevada Test Site Radioactive Waste Management Complex.

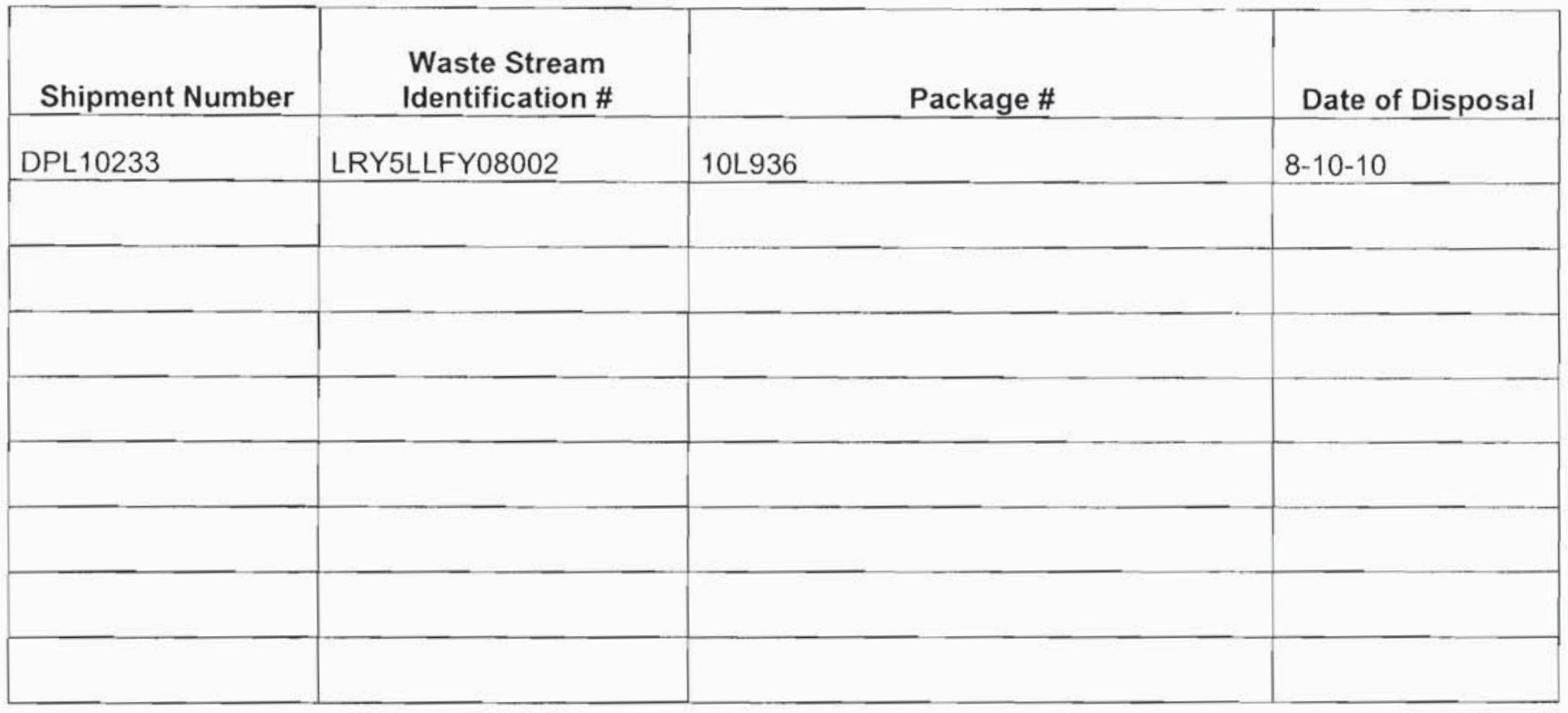

This certification is provided as a courtesy to the waste generator for information purposes only.

/s/:Theresa Hale

WGS Signature

8-10-10

Date

Waste Inspector

Title

$\because Y$ RWMC Signature

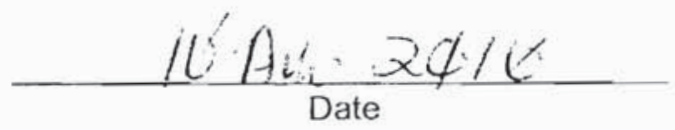

- Xevifist 
Addendum to CAU $113 \mathrm{CR}$

Revision: 0

Date: February 2011

THIS PAGE INTENTIONALLY LEFT BLANK 
Addendum to CAU $113 \mathrm{CR}$

Revision: 0

Date: February 2011

\section{CERTIFICATES OF DISPOSAL:}

\section{MiXed WASTE}


Addendum to CAU $113 \mathrm{CR}$

Revision: 0

Date: February 2011

\section{THIS PAGE INTENTIONALLY LEFT BLANK}


NSTec

Form

FRM-2217
CERTIFICATE OF DISPOSAL

(LOW LEVEL WASTE)
03/01/10

Rev. 01

Page 1 of 1

\section{Nevada Test Site}

This Certificate acknowledges that the following shipment(s) of waste have been disposed at the Nevada Test Site Radioactive Waste Management Complex.

\begin{tabular}{|c|c|c|c|c|}
\hline Shipment Number & $\begin{array}{l}\text { Waste Stream } \\
\text { Identification \# }\end{array}$ & Package \# & & Date of Disposal \\
\hline DPM11002 & LRY5MWFY09003 & 006171 & & I. $n 110$ \\
\hline DPM11002 & LRY5MWFY09003 & B00001 & & 10 \\
\hline DPM11002 & LRY5MWFY09003 & B00005 & & $11-01-10$ \\
\hline DPM11002 & LRY5MWFY09003 & B00046 & & 11-01-10 \\
\hline DPM11002 & LRY5MWFY09003 & B00128 & & 11-01-10 \\
\hline DPM11002 & LRY5MWFY09003 & B00130 & $\partial_{\tau} e_{H}$ & еsәләчц: /s/ \\
\hline DPM11002 & LRY5MWFY09003 & B00131 & & \\
\hline DPM11002 & LRY5MWFY09003 & B00133 & & $11-01-10$ \\
\hline
\end{tabular}

This certification is provided as a courtesy to the waste generator for information purposes only.

/s/:Theresa Hale

WGS Signature

Waste Inspector

Title
11-01-10

Date
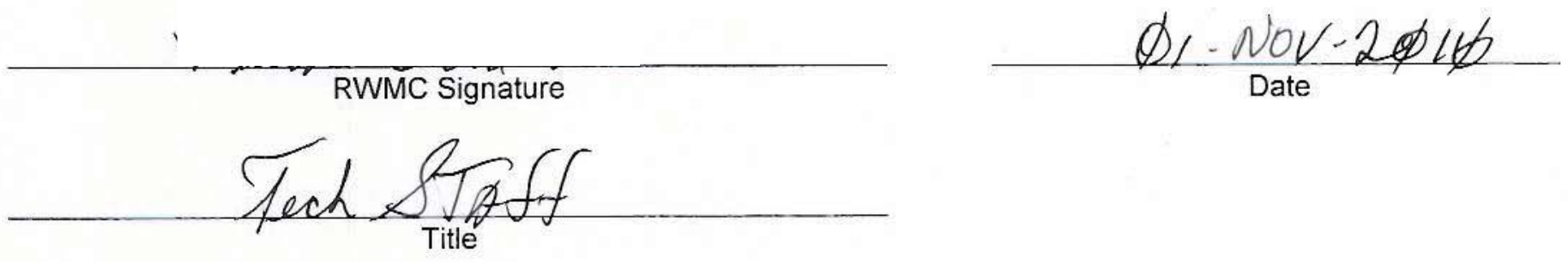


\section{Nevada Test Site}

This Certificate acknowledges that the following shipment(s) of waste have been disposed at the Nevada Test Site Radioactive Waste Management Complex.

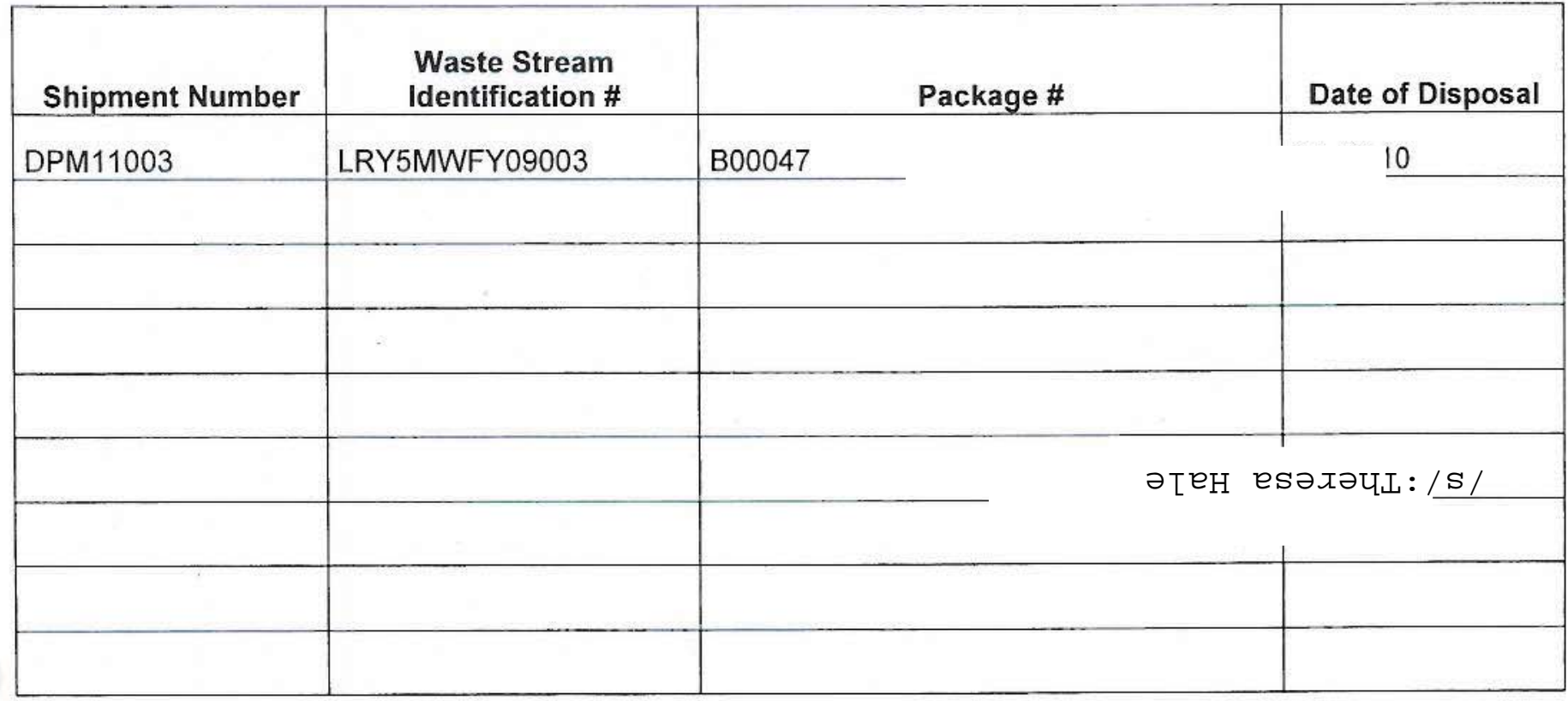

This certification is provided as a courtesy to the waste generator for information purposes only.

/s/:Theresa Hale

\section{WGS Signature}

Waste Inspector

Title

RWMC Signature

$$
\text { LLw spec }
$$

11-02-10

Date

\section{$11-2-10$}

Date 
Addendum to CAU $113 \mathrm{CR}$

Revision: 0

Date: February 2011

\section{CERTIFICATES OF DisPOSAL:}

\section{HYDROCARBON LOW-LEVEL WASTE}


Addendum to CAU $113 \mathrm{CR}$

Revision: 0

Date: February 2011

\section{THIS PAGE INTENTIONALLY LEFT BLANK}




\begin{tabular}{|lrr|}
\hline NSTec & CERTIFICATE OF DISPOSAL & $03 / 01 / 10$ \\
Form & Rev. 01 \\
FRM-2217 & (LOW LEVEL WASTE) & Page 1 of 1 \\
\hline
\end{tabular}

Nevada Test Site

This Certificate acknowledges that the following shipments) of waste have been disposed at the Nevada Test Site Radioactive Waste Management Complex.

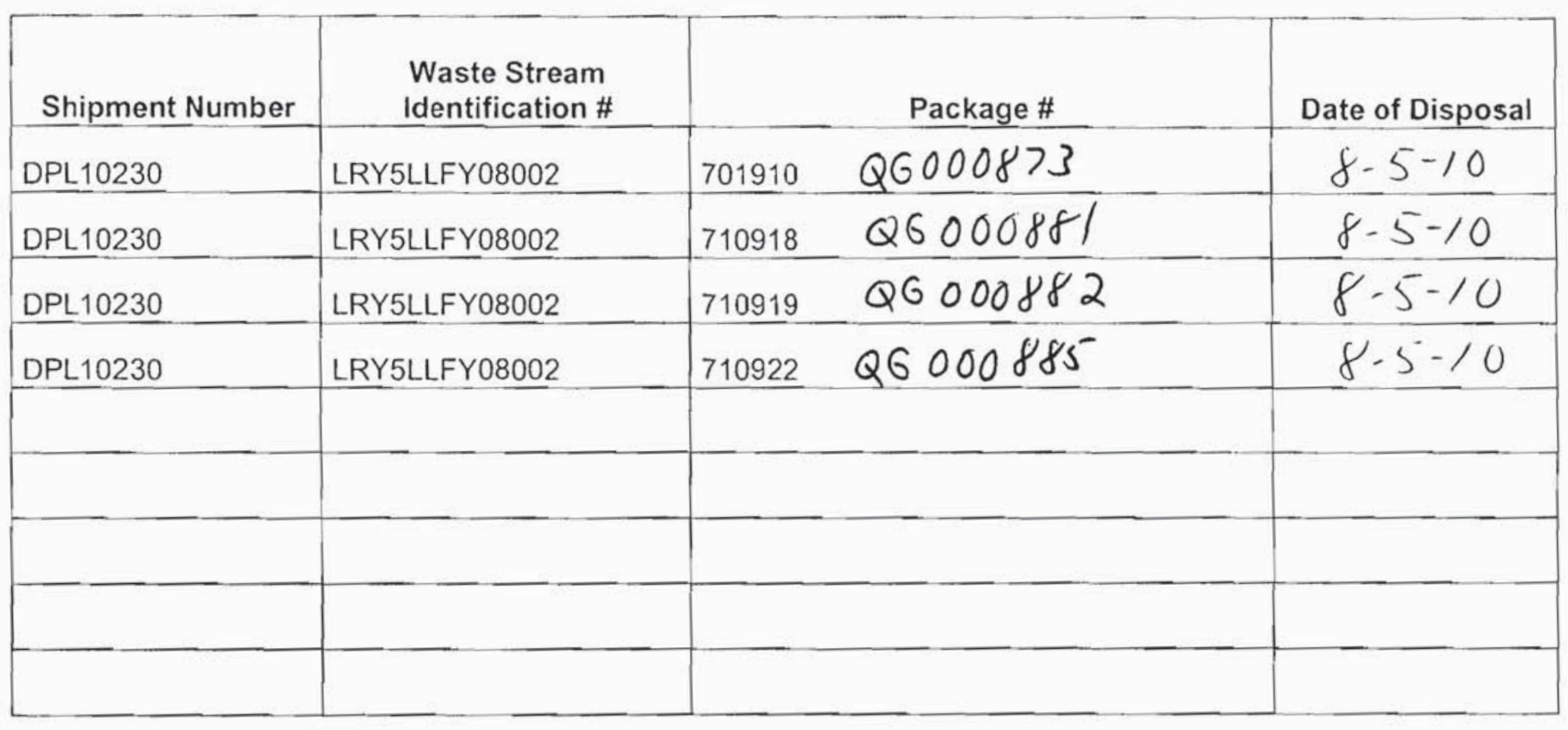

This certification is provided as a courtesy to the waste generator for information purposes only.

/s/ :Theresa Hale

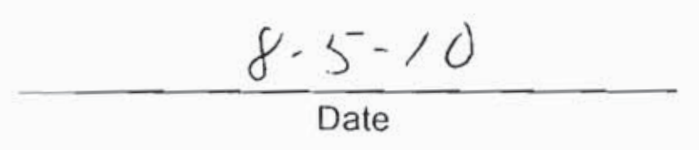

Waste Inspector

Title
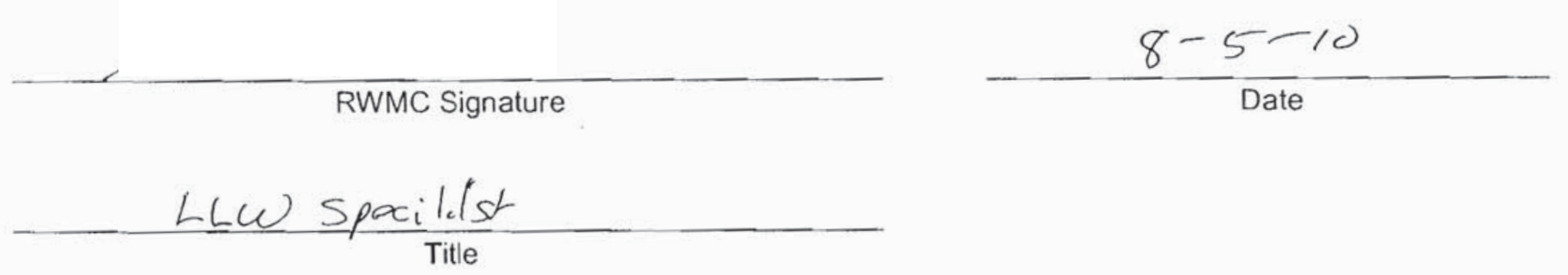

(Reference: OP-2151.304) 


\begin{tabular}{|lrr|}
\hline NSTec & CERTIFICATE OF DISPOSAL & R3/01/10 \\
Form & Rev. 01 \\
FRM-2217 & (LOW LEVEL WASTE) & Page 1 of 1 \\
\hline
\end{tabular}

Nevada Test Site

This Certificate acknowledges that the following shipments) of waste have been disposed at the Nevada Test Site Radioactive Waste Management Complex.

\begin{tabular}{|l|c|c|c|}
\hline Shipment Number & $\begin{array}{c}\text { Waste Stream } \\
\text { Identification \# }\end{array}$ & Package \# & Date of Disposal \\
\hline DPL10234 & LRY5LLFY08002 & 10 L937 $\quad(114154-71)$ & $8-18-10$ \\
\hline & & & \\
\hline & & & \\
\hline & & & \\
\hline & & & \\
\hline
\end{tabular}

This certification is provided as a courtesy to the waste generator for information purposes only.

/s/: Theresa Hale

WGS Signature

$\frac{8-18-10}{\text { Date }}$

Waste Inspector

Title
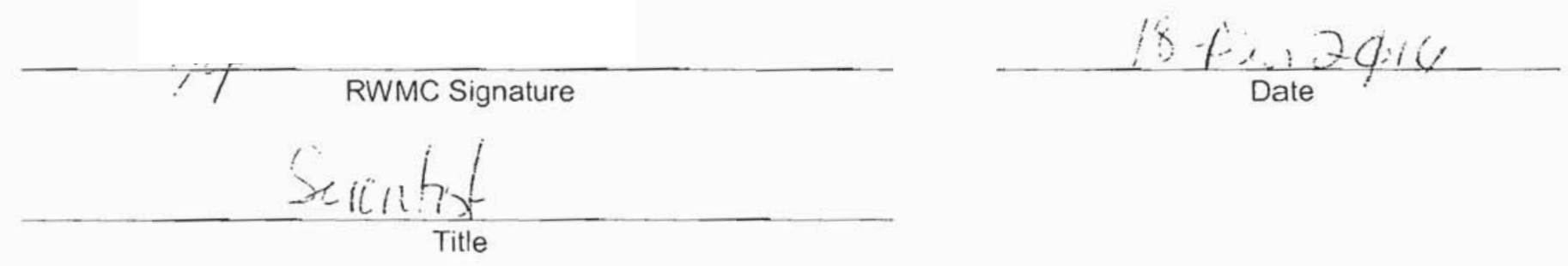

(Reference: OP-2151.304) 
Addendum to CAU $113 \mathrm{CR}$

Revision: 0

Date: February 2011

\section{CERTIFICATES OF DISPOSAL:}

\section{ASBEstos LOW-LEVEL WASTE}


Addendum to CAU $113 \mathrm{CR}$

Revision: 0

Date: February 2011

\section{THIS PAGE INTENTIONALLY LEFT BLANK}


NSTec

CERTIFICATE OF DISPOSAL

08/06/09

Form

(LOW LEVEL WASTE)

Rev. 0

FRM-2217

\section{Nevada Test Site}

This Certificate acknowledges that the following shipment(s) of waste have been disposed at the Nevada Test Site Radioactive Waste Management Site.

\begin{tabular}{|l|l|l|l|}
\hline Shipment Number & \multicolumn{1}{|c|}{$\begin{array}{c}\text { Waste Stream } \\
\text { Identification \# }\end{array}$} & Package \# & Date of Disposal \\
\hline DPL10046 & LRY5LLFY07003 & $710921($ QG000884) & $01-25-2010$ \\
\hline DPL10046 & LRY5LLFY07003 & $710926($ QG000889) & $01-25-2010$ \\
\hline & & & \\
\hline & & & \\
\hline & & & \\
\hline & & & \\
\hline
\end{tabular}

This certification is provided as a courtesy to the waste generator for information purposes only.

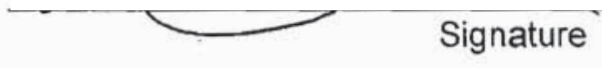

$01 / 25 / 14$

LLW Supervisor

Title

Instructions:

Shipment Number - enter shipment number from LWIS database.

Date of Disposal - enter date waste was placed in disposal cell. 
Addendum to CAU $113 \mathrm{CR}$

Revision: 0

Date: February 2011

THIS PAGE INTENTIONALLY LEFT BLANK 
Addendum to CAU 113 CR

Revision: 0

Date: February 2011

\section{WASTE MANIFESTS:}

\section{HAzARdous WAste}


Addendum to CAU $113 \mathrm{CR}$

Revision: 0

Date: February 2011

\section{THIS PAGE INTENTIONALLY LEFT BLANK}


Please print or type. (Form designed for use on elite (12-pitch) typewriter.)

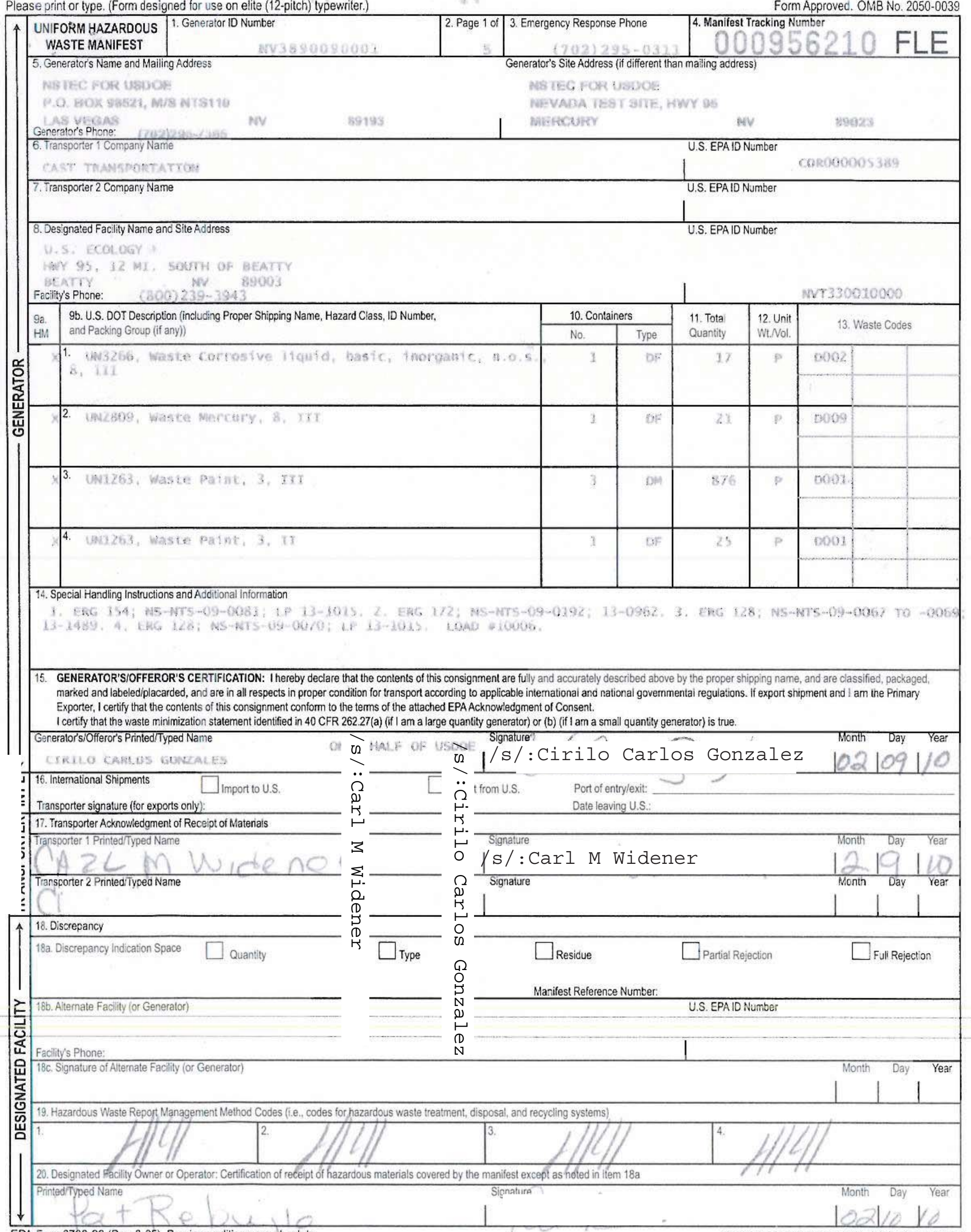


Please print or type. (Form designed for use on elite (12-pitch) typewriter.)

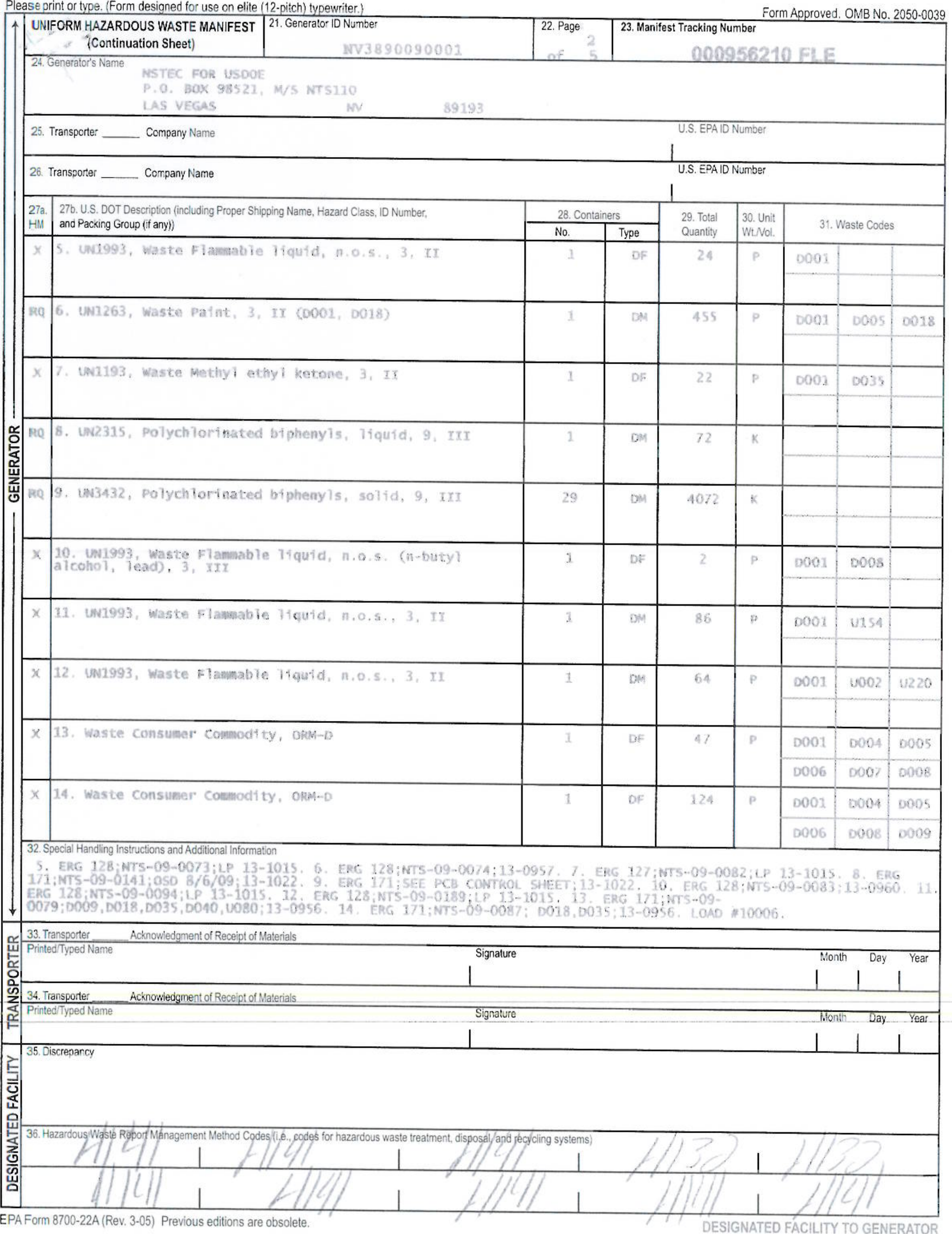




\section{3-08-10 i4:53 RCVD}

Please print or type. (Form designed for use on elite (12-pitch) typewriter.)

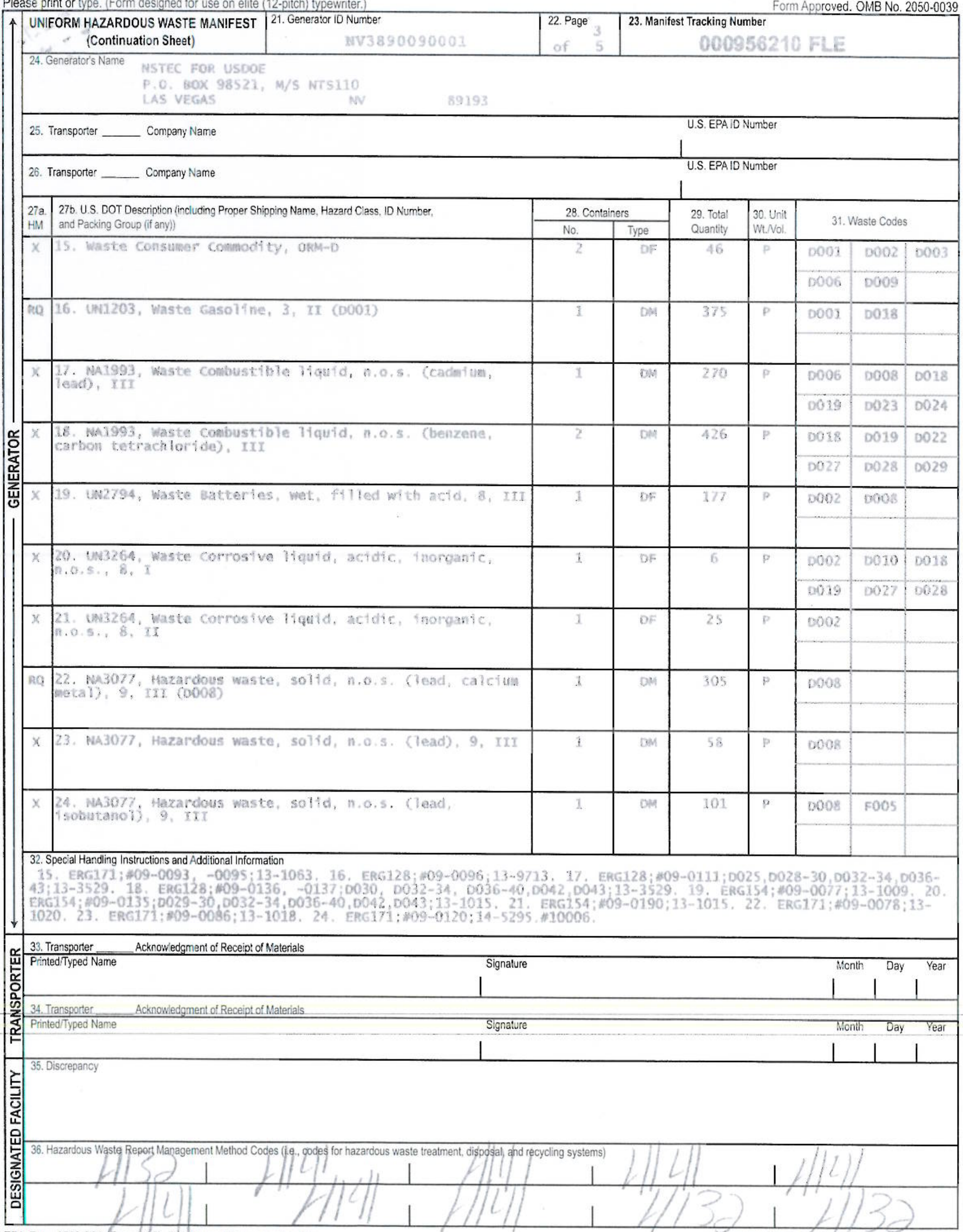


Please print or type. (Form designed for use on elite (12-pitch) typewriter.)

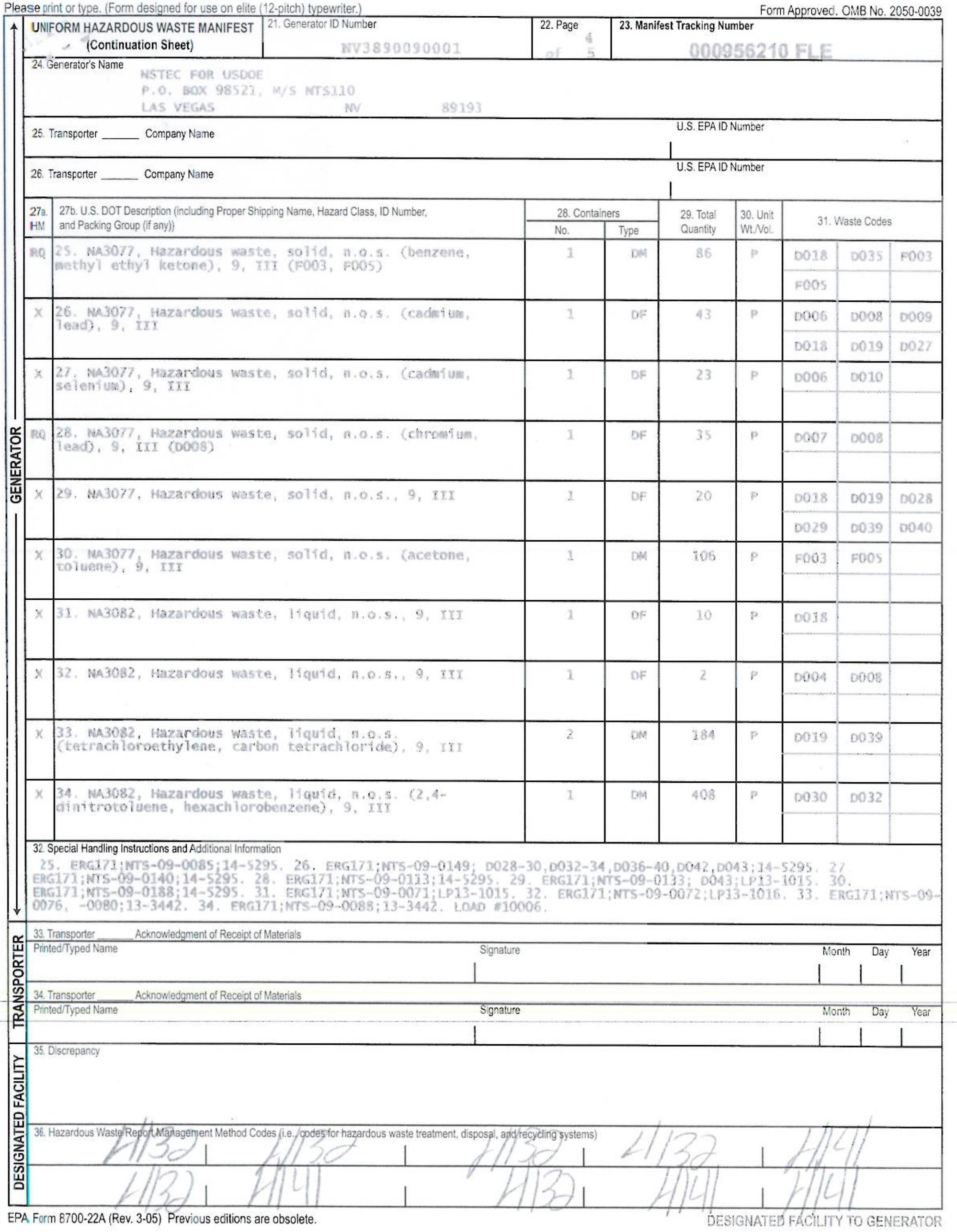


Please print or type. (Form designed for use on elite (12-pitch) typewriter.)

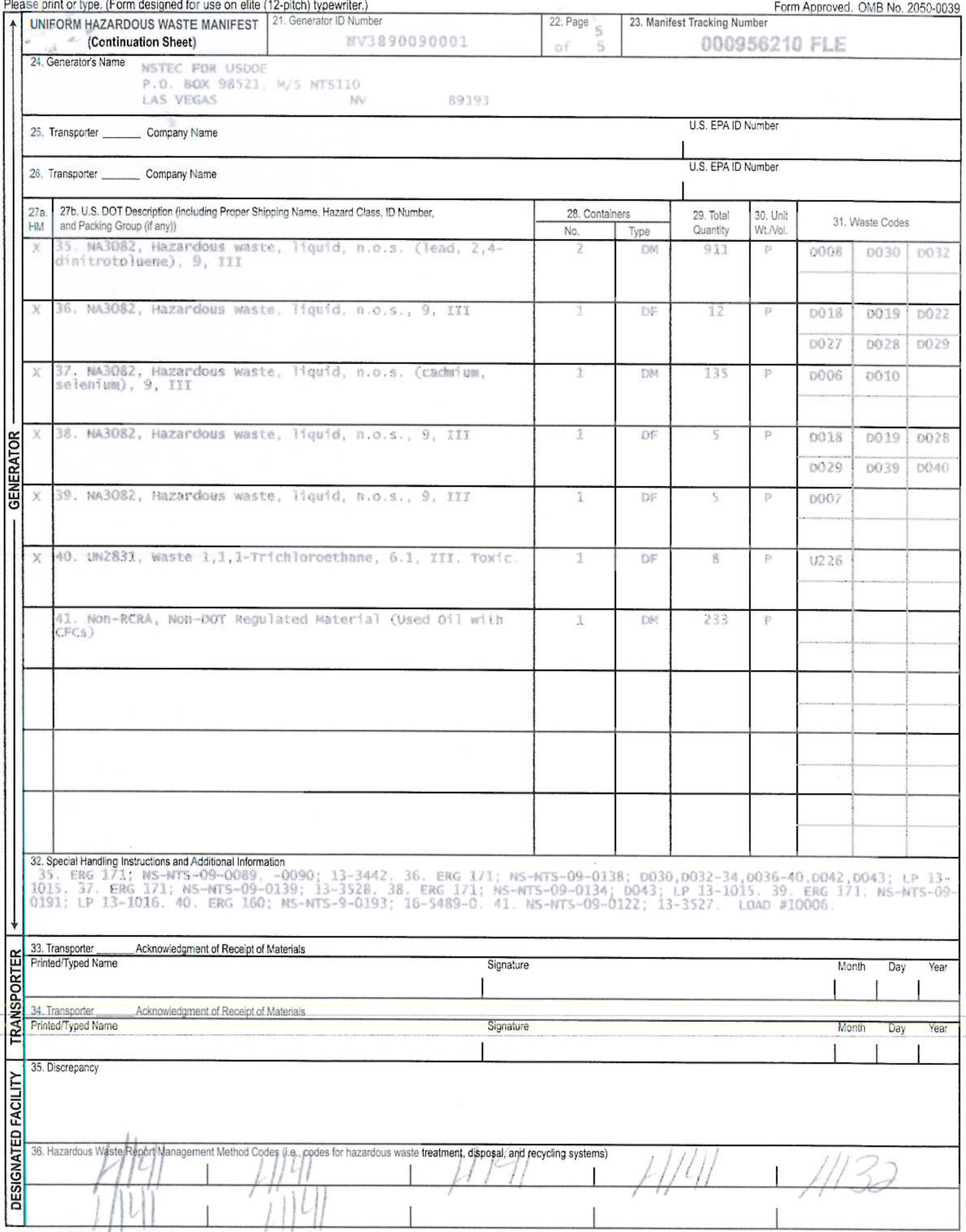


Please print or lype. (Form designed for use on elite (12-pilch) typewriter.)

Form Approved. OMB No. 2050-0039

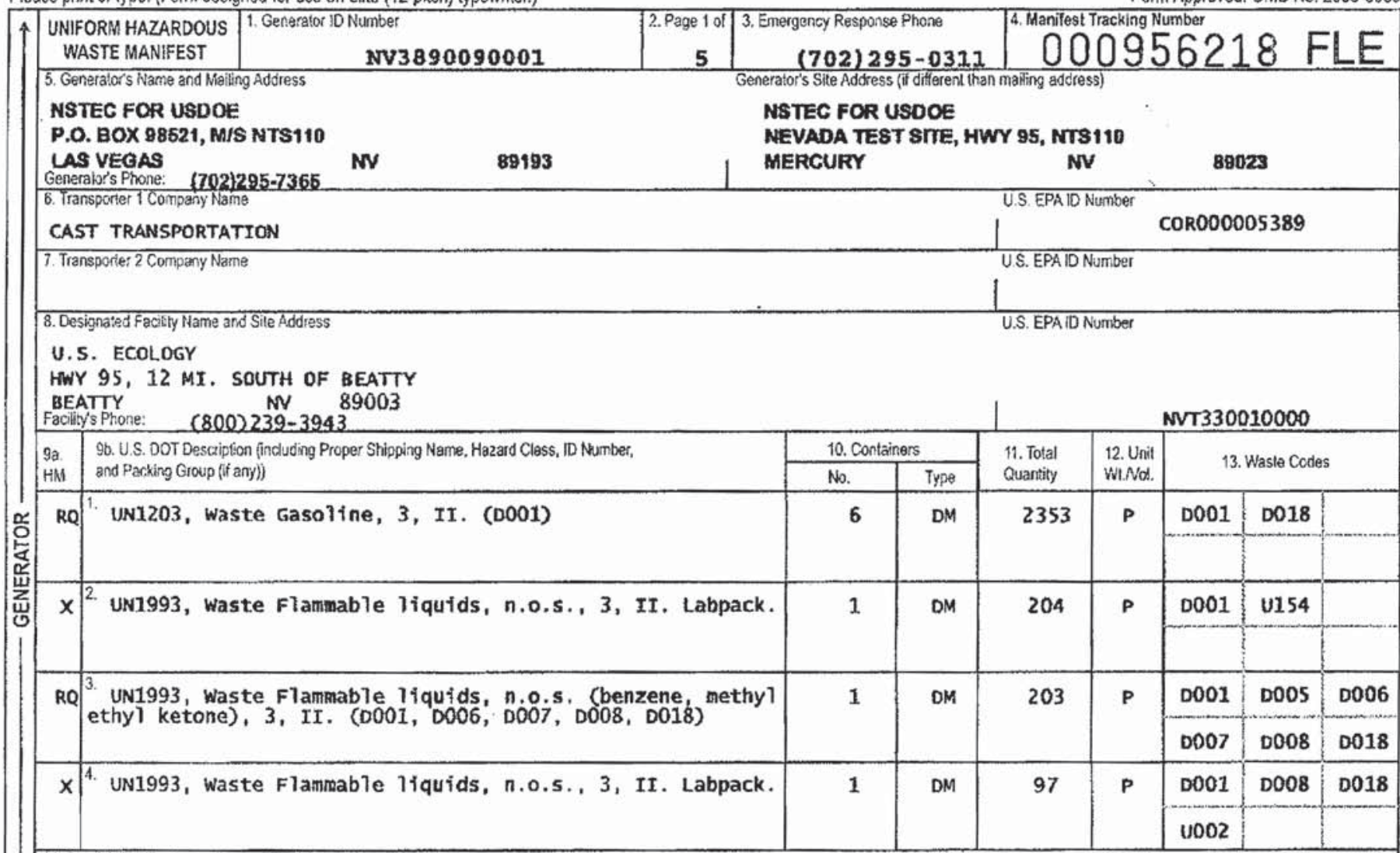

14. Special Handling Instructions and Additional information

1. ER 128;NS-NTS-10-0048 THRU -0053;13-9713, 2. ER 128;NS-NTS-10-0108;LP 13-1015. 3. ER 128;NS-NTS-10-0076;ALSO D035;13-0960. 4. ER 128;NS-NTS-10-0107;LP 13-101S. LOAD 10015 .

15. GENERATOR'SIOFFEROR'S CERTIFICATION: I hereby declare that the contents of Ints consignment are fully and accurately described above by the proper slipping name, and are classified, packaged, marked and labeiediplacarded, and are in all respecls in proper condition for transport according io applicable intemalional and nationai governmental regulations. If export shipment and I am the Primary Exporter, I cerlify that the contents of this consignment conform to the terms of the attached EPA Acknowiedgrnent of Consent.

1 certify that the waste minimization statement identified in 40 CFR 262.27(a) fill am a large cuantly generator) or (b) (ff I am a small quantity generator) is true.

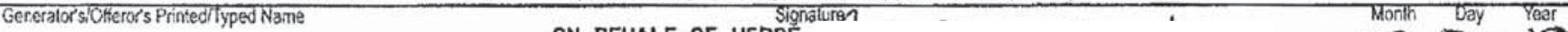

$\downarrow$ CIRILO CARLOS GONZALES on BeHALF of uspo\%

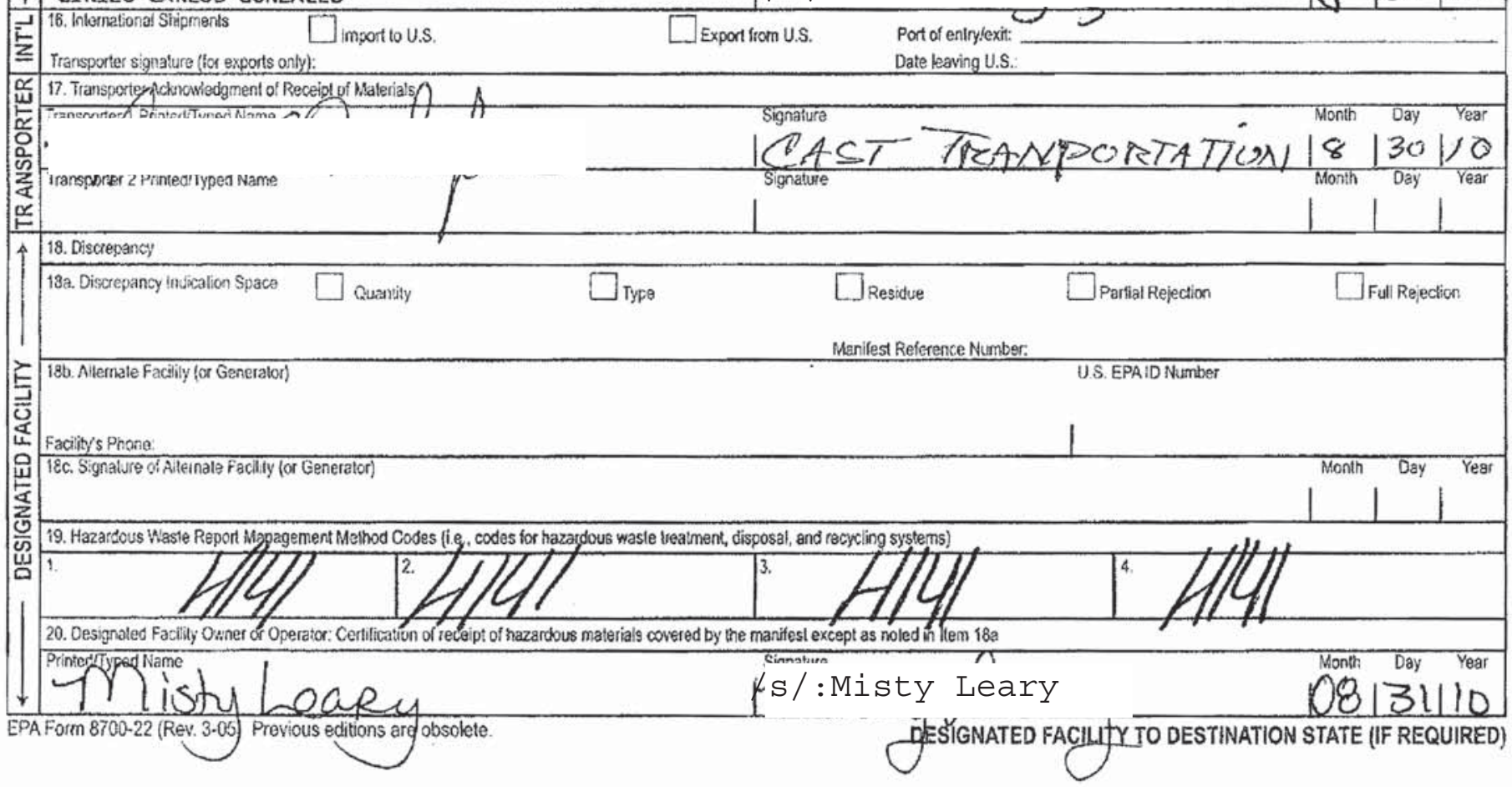


Please gint or lype. (Form designed for use on elite (12-pitci) ypewriter.)

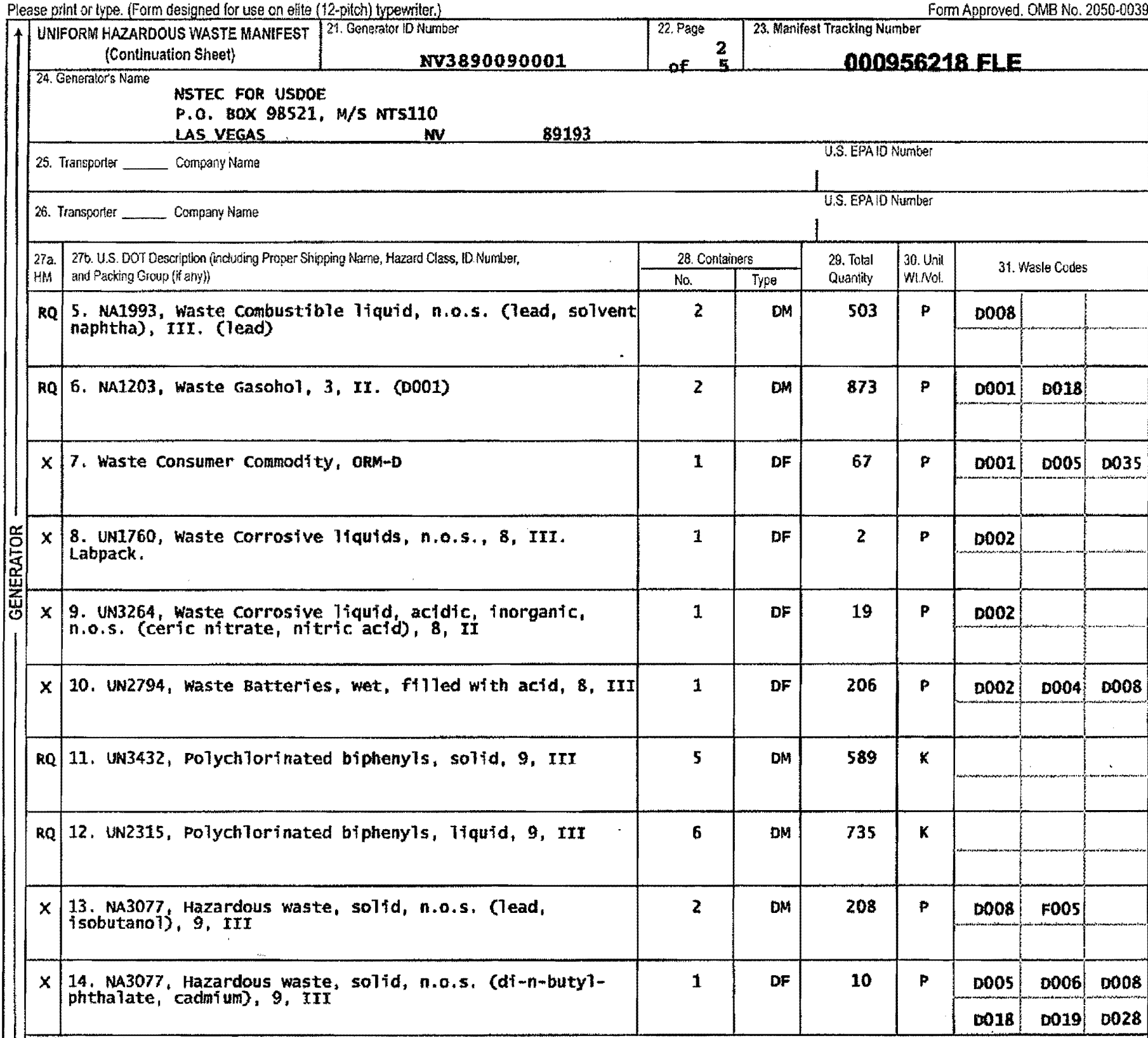

32. Special Handing Instruclions and Additional Infomation

5. ER128; 10-0085,-0086;13-3529, 6. ER128;-0087,-0088;13-9713. 7. ER171;-0106;13-0956. 8, ER154;-0061;LP 13-1015. 9. ER154;-0096;13-1007. 10. ER154;-0090;13-1009, 11. ER171;SEE PCE CONTROL SHEET DETATL; 13-1022. 12. ER171; SEE PCI CONTROL SHEET DETAIL; INCIN 13-1022. 13, ER171;-0054,0110;14-5295, 14, ER171;-0057;LDR HAS ADD'L CODES;14-5295. 1) LOAD 10015

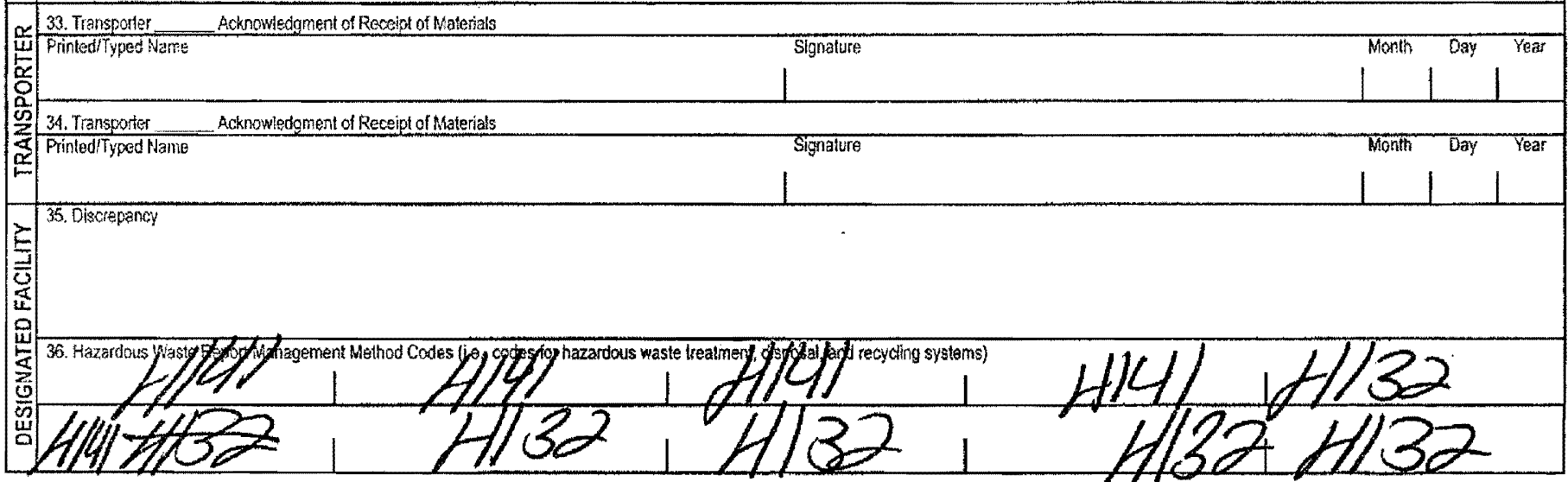


Please print or wpe. (Form designed for use on elite (12-pitch) typewriter)

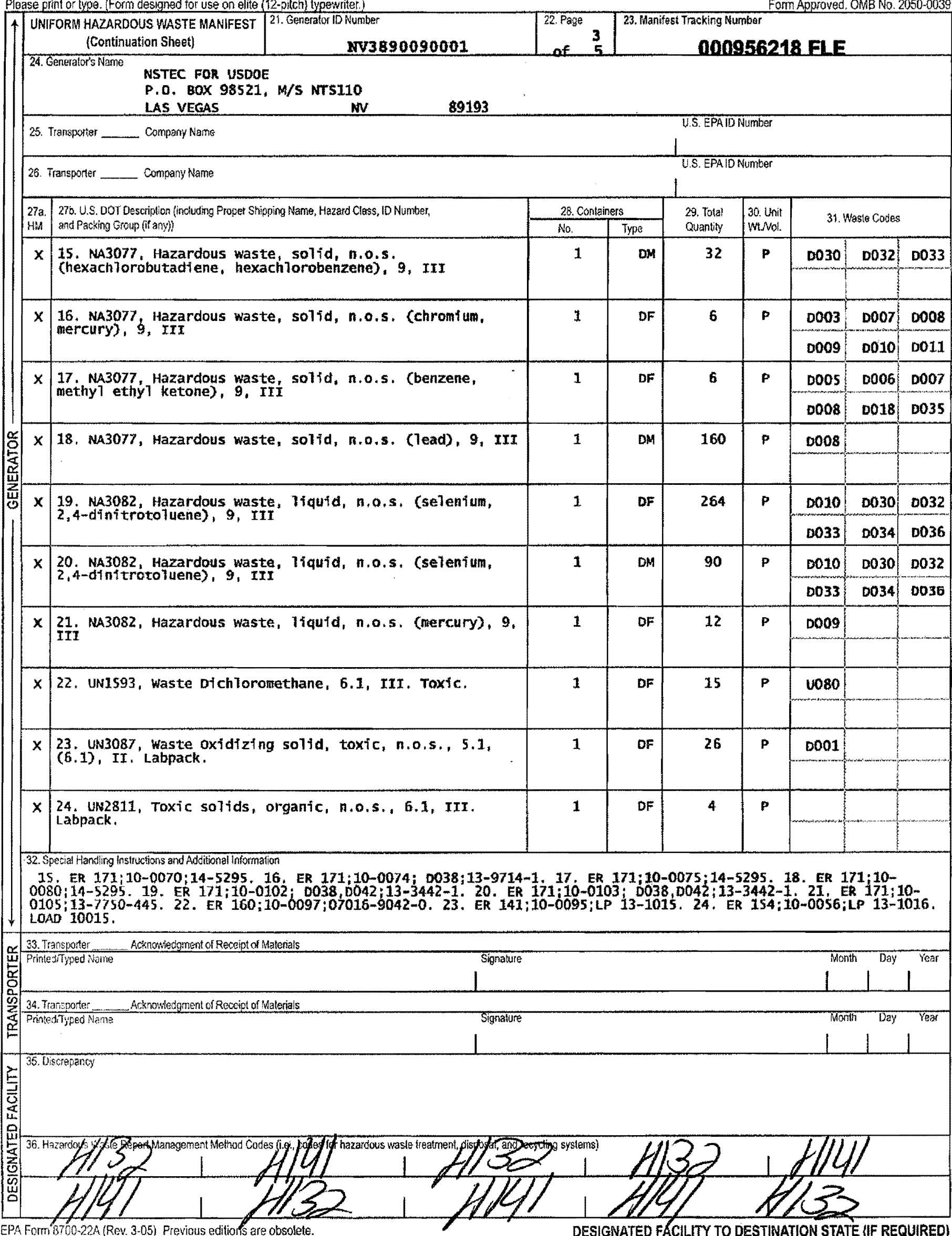


Please prin: or sype. (Fom designed for use on elite (12-pitch) lypewriter.)

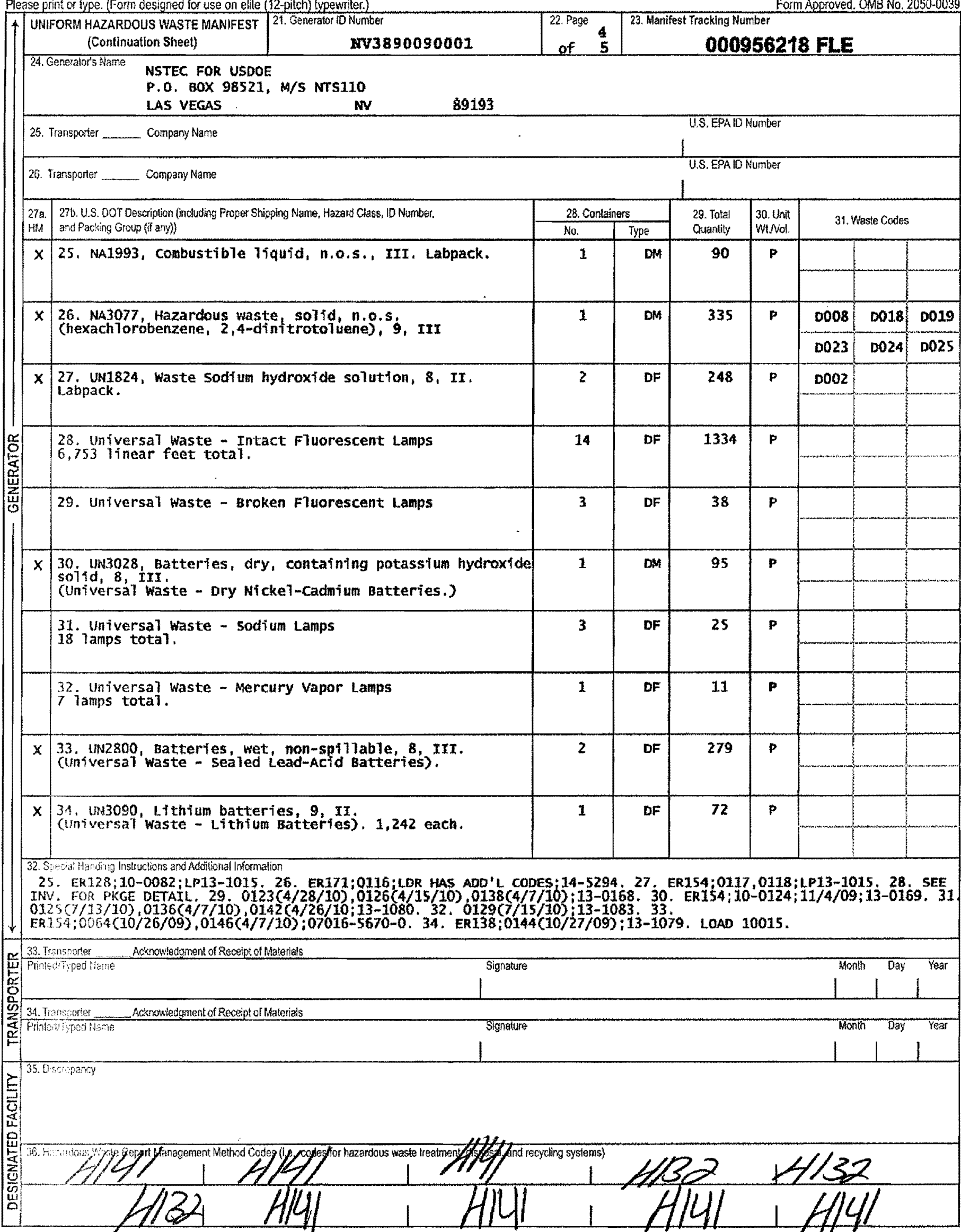




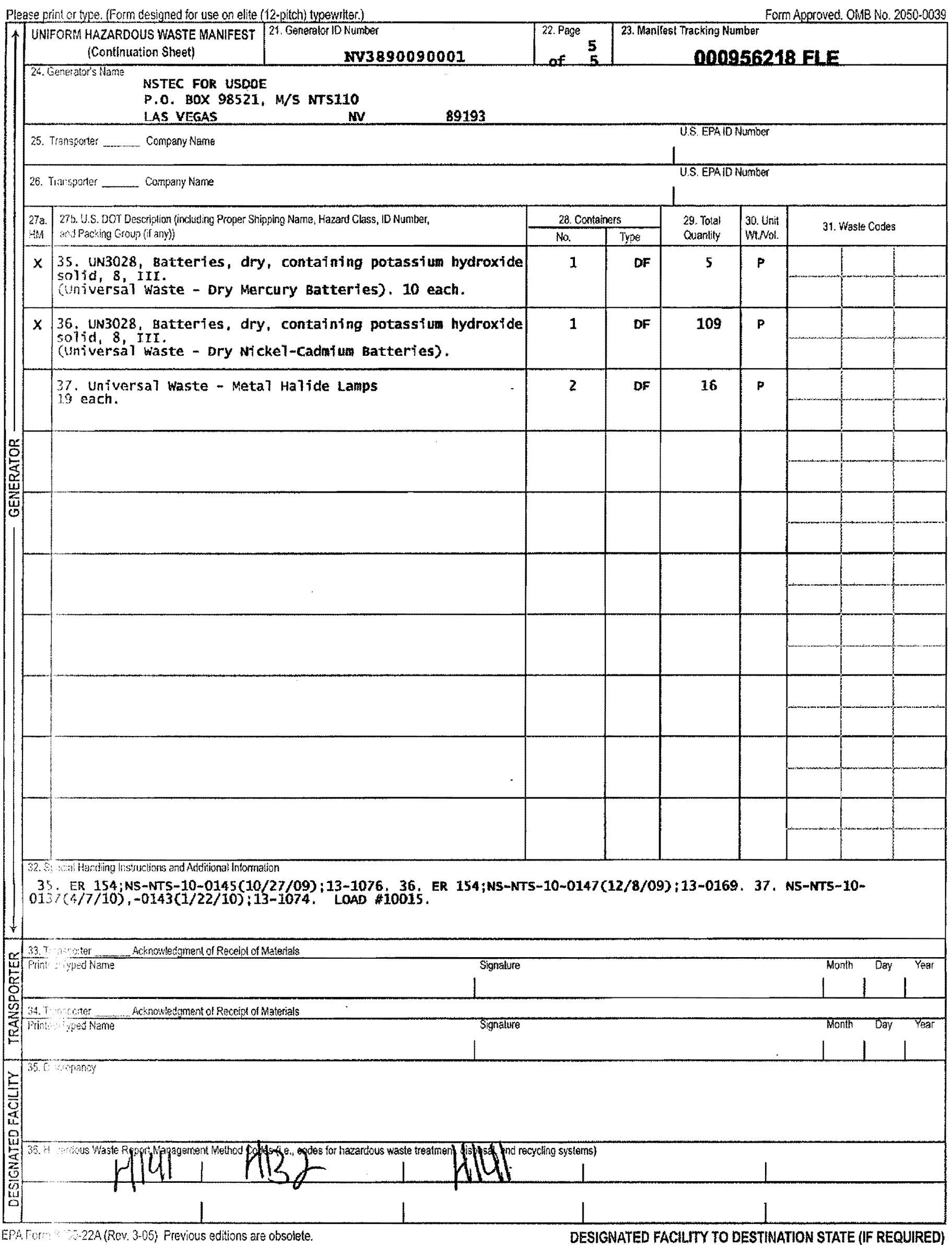




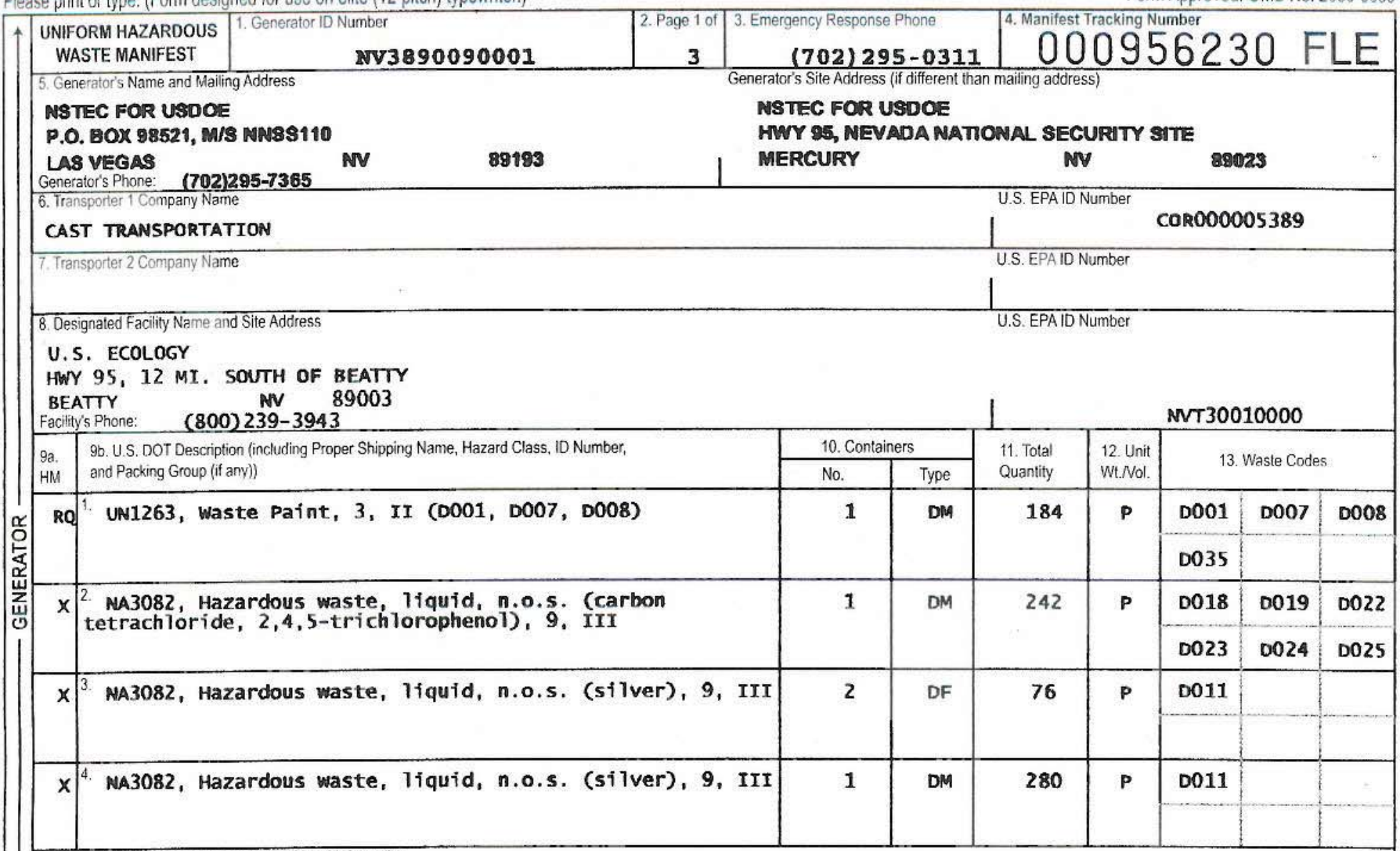

14. Special Handling Instructions and Additional Information

1. ER128;NS-NSS-11-000S;WP\#13-0957. 2. ER171;NS-NTS-10-0151;WP畨13-3528.ALSO D027-30, 32-34, 36-43. 3. ER171;NTS-100152, -0153;WP\#13-1013, 4. ER171;NTS-10-0158;WP\#13-1013. LOAD \#11003.

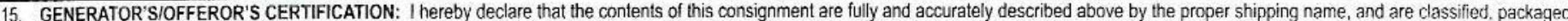
marked and labeled/placarded, and are in all respects in proper condition for transport according to applicable international and national governmental regulations. If export shipment and I am the Primary Exporter, I certify that the contents of this consignment conform to the terms of the attached EPAAcknowledgment of Consent.

I certify that the waste minimization statement identified in 40 CFR 262.27(a) (if I am a large quantity generator) or (b) (if I am a small quantity generator) is true. Generator's/Offeror's Printed/Typed Name

CIRILO CARLOS GONZALES
ON BEHALF OF USDOE Stannolima Cirilo $\square$ Export from U.S $\square$ import to U.S. Port of entrylexit

Transporter signature (for exports only): Date leaving U.S Hardy 1 Tomas Transporter 2 Printed/Typod Name

18. Discrepancy

18a. Discrepancy Indication Space $\square$ Quantity 


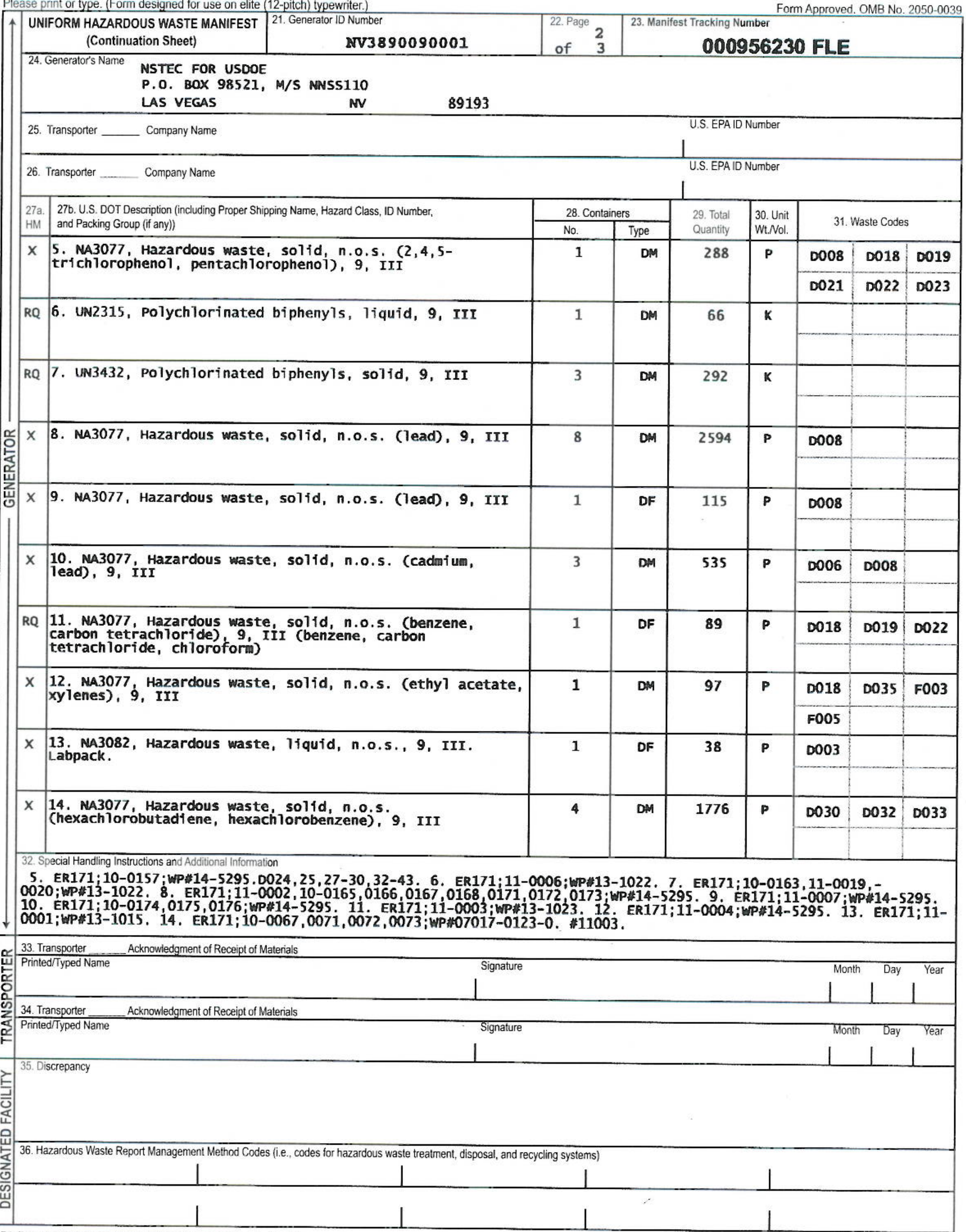


Addendum to CAU $113 \mathrm{CR}$

Revision: 0

Date: February 2011

THIS PAGE INTENTIONALLY LEFT BLANK 
Addendum to CAU $113 \mathrm{CR}$

Revision: 0

Date: February 2011

\section{APPENDIX G}

WASTE CHARACTERIZATION SAMPLE RESULTS 
Addendum to CAU $113 \mathrm{CR}$

Revision: 0

Date: February 2011 
Addendum to CAU $113 \mathrm{CR}$

Revision: 0

Date: February 2011

\section{WASTE CHARACTERIZATION SAMPLE RESULTS:}

\section{Four DRUMS OF WHITE POWDER}


Addendum to CAU $113 \mathrm{CR}$

Revision: 0

Date: February 2011

THIS PAGE INTENTIONALLY LEFT BLANK 
NSTec

PROJECT/CLIENTINFORMATION

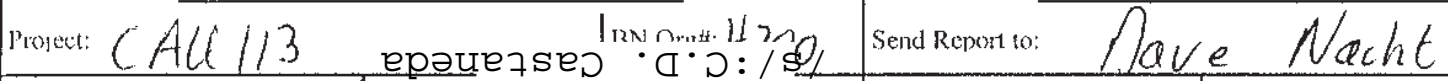

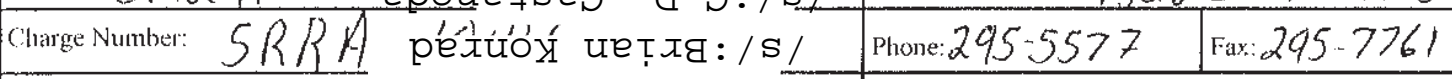

$\begin{aligned} \text { Tumaround: } & \text { () Standard }-14 \text { days IH, } 28 \\ & \text { () RUSH Prelimmary by: }\end{aligned}$

days Non-rad Env, 45 diays Rad Finv

pexuoy uetag: / sed contan (cleck)

Propec Manager: Tom Thiele

\begin{tabular}{|l|l|l}
\hline Phone: 2959290 & Fax: 295.7761 & M/s: NTS306 \\
\hline
\end{tabular}

$$
{ }^{1}-{ }^{2}-7 \times 14 \text { (1non-Rad Env) }
$$

$-1-{ }^{7}-14-28$ (Radiological linv)

pouezses $\cdot a \cdot 2: /$ s

\section{SAMPLE MANAGEMENT INFORMATION}

SDG: (III) V3369

(Non-Rad Env)

(Rad Env)

Samples submitted are associated with a signed Project SOW. (Y Y Y ( ) NO

Analyses entered here agree with the SOW

(x) YES ( ) NO ( ) N/A

If noi, identify the varation:

Subcontract Lab(s) used tor this work

LIONVKLE $104126-76$

\begin{tabular}{|c|c|c|c|c|c|c|c|c|c|}
\hline \multirow{2}{*}{ ID/DESCRIPTION } & \multicolumn{2}{|c|}{ SAMPLING } & \multirow{2}{*}{ MATRIX } & \multicolumn{2}{|c|}{ CONTAINER } & \multicolumn{3}{|c|}{ QC } & \multirow{2}{*}{$\begin{array}{l}\text { Pres-Analysts } \\
\text { eg. HCl-VOCs }\end{array}$} \\
\hline & DATE & TIME & & $\#$ & Est. Vol & MD & MS & MSD & \\
\hline $113 \cdot c 1-1$ & $11 / 14 / 09$ & 1251 & $S_{01} 1$ & 1 & 500 & & & & \\
\hline $113-C 1-1$ & & 6 & Soil & 1 & 125 & & & & \\
\hline $113 \cdot c 1-2$ & & 1255 & & 1 & 500 & & & & \\
\hline $113 \cdot c 1-2$ & & $\downarrow$ & & 1 & 125 & & & & \\
\hline $113-c 1-3$ & & 1305 & & 1 & 500 & & & & \\
\hline $113 \cdot 01-3$ & & $\downarrow$ & & 1 & 125 & & & & \\
\hline $113-(1-4$ & & 1308 & & 1 & 500 & & & & \\
\hline $113 \cdot c 1-4$ & & $\downarrow$ & & 1 & 125 & & & & \\
\hline $113-C 1-5$ & & $13 / 3$ & & 1 & 500 & & & & \\
\hline $113-(1-5$ & $y$ & 1 & $\sqrt{ }$ & 1 & 125 & & & & \\
\hline
\end{tabular}

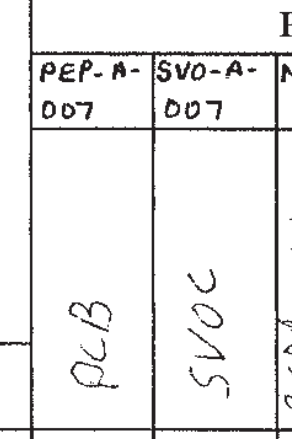

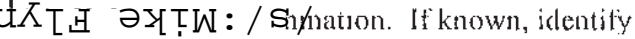

comlannaniss. Luls unformation will ensure compliance with applicable regulations and allow for the safe handling of the sample materials.

\section{Pay Item, Analysis, Method}

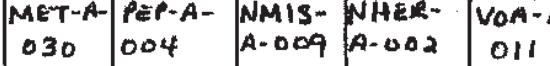

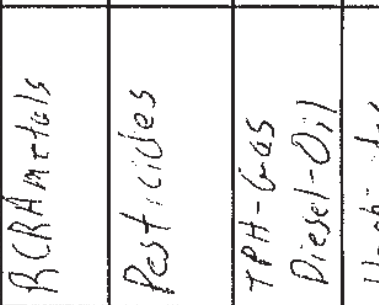

\section{CUSTODYTRANSFER}

Sampied/Relinquisished (prout)

MiLe F/C4D

vefor

Brian honrad

Signature

DATE/TIME

\#s/: Mike Flynn

/s/:Brian Konrad

12 Culog 1345

b. 157610823

$2 / 15 / 090832$

$1 / 2 / 16109$ e 1300

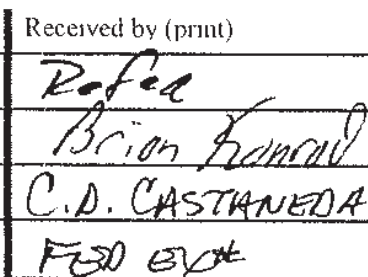

lat sepputive

$0^{n} y^{2}$

$x \quad 12189109$
Signature

DATE/TIMI

/s/:Brian Konrad / \$/:C.D. Castaneda 798227477918

$12 / 14652345$ 2/cslay 01823

$12 / 15 / 0900832$ $12 / 16 / 0901300$ FRM-0732 (1+/06) 


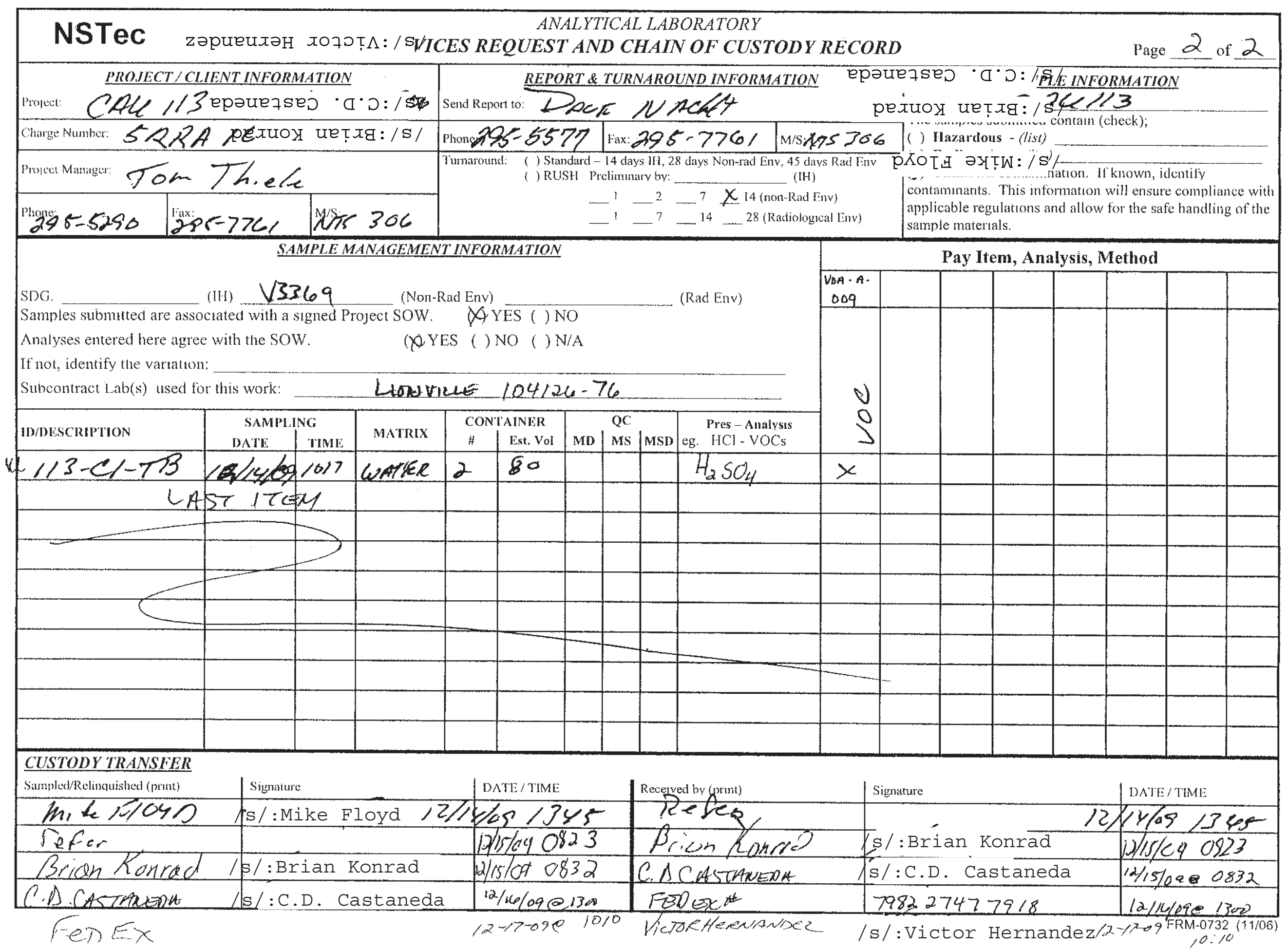


Laboratory: Lionville Laboratory

Client: National Security Technologies, LLC

Matrix: $\underline{\text { Solid }}$

Sampled: $\underline{12 / 14 / 0912: 51}$

Solids: $\underline{0.00}$

Batch: L912163
Laboratory ID: 0912042-01

Prepared: 12/21/09 10:41

Preparation: SW 3050B
SDG:

Project: $\underline{\mathrm{BOA}}$

\begin{tabular}{|c|l|c|c|c|c|}
\hline CAS NO. & Analyte & $\begin{array}{c}\text { Concentration } \\
(\mathbf{m g} / \mathbf{k g} \text { wet })\end{array}$ & $\begin{array}{c}\text { Dilution } \\
\text { Factor }\end{array}$ & $\mathrm{Q}$ & Method \\
\hline $7440-38-2$ & Arsenic & 3.05 & 1 & & $6010 \mathrm{~B}$ \\
\hline $7440-39-3$ & Barium & 17.4 & 1 & & $6010 \mathrm{~B}$ \\
\hline $7440-43-9$ & Cadmium & 0.0818 & 1 & $\mathrm{~J}$ & $6010 \mathrm{~B}$ \\
\hline $7440-47-3$ & Chromium & 1.74 & 1 & & $6010 \mathrm{~B}$ \\
\hline $7439-92-1$ & Lead & 0.943 & 1 & $\mathrm{U}$ & $6010 \mathrm{~B}$ \\
\hline $7782-49-2$ & Selenium & 1.42 & 1 & $\mathrm{U}$ & $6010 \mathrm{~B}$ \\
\hline $7440-22-4$ & Silver & 0.943 & 1 & $\mathrm{U}$ & $6010 \mathrm{~B}$ \\
\hline
\end{tabular}




\section{A}

Laboratory: Lionville Laboratory

Client: National Security Iechnologies, LLC

Matrix: Solid

Sampled: $12 / 14 / 0912: 51$

Solids: $\underline{0.00}$

Batch: L912148
L aboratory ID: 0912042-01

Prepared: 12/18/09 11:39

Preparation: SW 7471A Prep
SDG:

Project: $\underline{B O A}$

File ID: $\underline{H G 121802-41}$

Analyzed: $12 / 18 / 0917: 42$

Initial/Final: $\underline{0.34 \mathrm{~g} / 50 \mathrm{~mL}}$

Sequence: $\quad \underline{9120087}$ Calibration: $\underline{\text { UNASSIGNED }}$ Instrument: $\underline{\text { HG3 }}$

\begin{tabular}{|c|l|c|c|c|c|}
\hline CAS NO. & Analyte & $\begin{array}{c}\text { Concentration } \\
(\mathrm{mg} / \mathrm{kg} \text { wet })\end{array}$ & $\begin{array}{c}\text { Dilution } \\
\text { Factor }\end{array}$ & $\mathrm{Q}$ & Method \\
\hline $7439-97-6$ & Mercury & 0.0265 & 1 & $\mathrm{U}$ & $7471 \mathrm{~A}$ \\
\hline
\end{tabular}


Laboratory: Lionville Laboratory

Client: National Security Iechnologies, LLC

Matrix: $\underline{\text { Solid }}$

Sampled: $12 / 14 / 0912: 55$

Solids: $\quad \underline{0.00}$

Batch: $\underline{\text { L912163 }}$
Laboratory ID: $\underline{0912042-02}$

Prepared: 12/21/09 10:41

Preparation: SW 3050B
SDG:

Project: $\underline{\mathrm{BOA}}$

File ID: ICP1221B-017

Analyzed: 12/21/09 18:07

Initial/Final: $0.79 \mathrm{~g} / 50 \mathrm{~mL}$ Sequence: 9120114 Calibration: $\underline{\text { UNASSIGNED Instrument: Thermo iIEVA }}$

\begin{tabular}{|c|l|c|c|c|c|}
\hline CAS NO. & Analyte & $\begin{array}{c}\text { Concentration } \\
(\mathbf{m g} / \mathbf{k g} \text { wet })\end{array}$ & $\begin{array}{c}\text { Dilution } \\
\text { Factor }\end{array}$ & Q & Method \\
\hline $7440-38-2$ & Arsenic & 297 & 1 & $6010 \mathrm{~B}$ \\
\hline $7440-39-3$ & Barium & 11.3 & 1 & $6010 \mathrm{~B}$ \\
\hline $7440-43-9$ & Cadmium & 0.0566 & 1 & $\mathrm{~J}$ & $6010 \mathrm{~B}$ \\
\hline $7440-47-3$ & Chromium & 171 & 1 & $6010 \mathrm{~B}$ \\
\hline $7439-92-1$ & Lead & 0.633 & 1 & $\mathrm{U}$ & $6010 \mathrm{~B}$ \\
\hline $7782-49-2$ & Selenium & 0.949 & 1 & $\mathrm{U}$ & $6010 \mathrm{~B}$ \\
\hline $7440-22-4$ & Silver & 0.633 & 1 & $\mathrm{U}$ & $6010 \mathrm{~B}$ \\
\hline
\end{tabular}


Laboratory: Lionville Laboratory

Client: National Security Technologies, LLC

Matrix: $\underline{\text { Solid }}$

Sampled: $\underline{12 / 14 / 0912: 55}$

Solids: $\underline{0.00}$

Batch: L912148
Laboratory ID: $\quad 0912042-02$

Prepared: $12 / 18 / 0911: 39$

Preparation: SW 7471A Prep
SDG:

Project: $\underline{B O A}$

File ID: $\underline{\text { HG121802-44 }}$

Analyzed: $12 / 18 / 0917: 49$ Initial/F inal: $\underline{0.33 \mathrm{~g} / 50 \mathrm{~mL}}$

Calibration: UNASSIGNED Instrument: $\underline{\mathrm{HG} 3}$

\begin{tabular}{|c|l|c|c|c|c|}
\hline CAS NO. & Analyte & $\begin{array}{c}\text { Concentration } \\
\text { (mg/kg wet) }\end{array}$ & $\begin{array}{c}\text { Dilution } \\
\text { Factor }\end{array}$ & $\mathrm{Q}$ & Method \\
\hline $7439-97-6$ & Mercury & 0.0273 & 1 & $\mathrm{U}$ & $7471 \mathrm{~A}$ \\
\hline
\end{tabular}


Laboratory: Lionville Laboratory

Client: National Security Technologies, LLC

Matrix: $\underline{\text { Solid }}$

Sampled: $\underline{12 / 14 / 0913: 05}$

Solids: $\underline{0.00}$

Batch: $\underline{L 912163}$
Laboratory ID:

Prepared: $12 / 21 / 0910: 41$

Preparation: SW 3050B

$\underline{9120114}$
SDG:

Project: $\underline{\mathrm{BOA}}$

File ID: ICP1221B-018

Analyzed: 12/21/09 18:14

Initial/Final: $0.8 \mathrm{~g} / 50 \mathrm{~mL}$

\begin{tabular}{|c|l|c|c|c|c|}
\hline CAS NO. & Analyte & $\begin{array}{c}\text { Concentration } \\
(\mathbf{m g} / \mathbf{k g} \text { wet })\end{array}$ & $\begin{array}{c}\text { Dilution } \\
\text { Factor }\end{array}$ & Q & Method \\
\hline $7440-38-2$ & Arsenic & 3.33 & 1 & $6010 \mathrm{~B}$ \\
\hline $7440-39-3$ & Barium & 15.8 & 1 & & $6010 \mathrm{~B}$ \\
\hline $7440-43-9$ & Cadmium & 0.0598 & 1 & $\mathrm{~J}$ & $6010 \mathrm{~B}$ \\
\hline $7440-47-3$ & Chromium & 2.22 & 1 & $6010 \mathrm{~B}$ \\
\hline $7439-92-1$ & Lead & 0625 & 1 & $\mathrm{U}$ & $6010 \mathrm{~B}$ \\
\hline $7782-49-2$ & Selenium & 0.938 & 1 & $\mathrm{U}$ & $6010 \mathrm{~B}$ \\
\hline $7440-22-4$ & Silver & 0.625 & 1 & $\mathrm{U}$ & $6010 \mathrm{~B}$ \\
\hline
\end{tabular}




\section{INORGANIC ANALYSIS DATA SHEET}

$7471 \mathrm{~A}$

Laboratory: Lionville Laboratory

Client: National Security Technologies, LLC

Matrix: Solid

Laboratory ID: $\underline{0912042-03}$

Sampled: 12/14/0913:05

Solids: $\underline{0.00}$

Batch: $\underline{\mathrm{L} 912148}$
Prepared: 12/18/0911:39

Preparation: SW 7471A Prep
SDG:

Project: $\underline{\mathrm{BOA}}$

File ID: $\underline{\mathrm{HG} 121802-47}$

Analyzed: $12 / 18 / 09$ 17:56

Initial/Final: $\underline{0.3 \mathrm{~g} / 50 \mathrm{~mL}}$

\begin{tabular}{|c|l|c|c|c|c|}
\hline CAS NO. & Analyte & $\begin{array}{c}\text { Concentration } \\
(\mathbf{m g} / \mathrm{kg} \text { wet })\end{array}$ & $\begin{array}{c}\text { Dilution } \\
\text { Factor }\end{array}$ & $\mathbf{Q}$ & Method \\
\hline $7439-97-6$ & Mercury & 0.0300 & 1 & $\mathrm{U}$ & $7471 \mathrm{~A}$ \\
\hline
\end{tabular}


Laboratory: Lionville Laboratory

Client: National Security Technologies, LLC

Matrix: $\underline{\text { Solid }}$

Sampled: $12 / 14 / 0913: 08$

Solids: $\underline{0.00}$

Batch: $\lcm{\lfloor 912163}$
Laboratory ID: 0912042-04

Prepared: $12 / 21 / 0910: 41$

Preparation: $\underline{\text { SW 3050B }}$
SDG:

Project: $\underline{\mathrm{BOA}}$

File ID: $\underline{\text { ICP1221B-019 }}$

Analyzed: 12/21/09 18:22 Initial/Final: $0.74 \mathrm{~g} / 50 \mathrm{~mL}$ $\underline{9120114}$ Calibration: UNASSIGNED Instrument: Ihermo iIEVA

\begin{tabular}{|c|c|c|c|c|c|}
\hline CAS No. & Analyte & $\begin{array}{c}\text { Concentration } \\
\text { (mg/kg wet) }\end{array}$ & $\begin{array}{l}\text { Dilution } \\
\text { Factor }\end{array}$ & $Q$ & Method \\
\hline $7440-38-2$ & Arsenic & 4.15 & 1 & & $6010 \mathrm{~B}$ \\
\hline $7440-39-3$ & Barium & 15.5 & 1 & & $6010 \mathrm{~B}$ \\
\hline $7440-43-9$ & Cadmium & 0.0697 & 1 & $\mathbf{J}$ & $6010 \mathrm{~B}$ \\
\hline $7440-47-3$ & Chromium & 2.17 & 1 & & $6010 \mathrm{~B}$ \\
\hline $7439-92-1$ & Lead & 0.676 & 1 & $\mathrm{U}$ & $6010 \mathrm{~B}$ \\
\hline $7782-49-2$ & Selenium & 1.01 & 1 & $\mathrm{U}$ & $6010 \mathrm{~B}$ \\
\hline $7440-22-4$ & Silver & 0676 & 1 & $\mathrm{U}$ & $6010 \mathrm{~B}$ \\
\hline
\end{tabular}


L aboratory: Lionville Laboratory

Client: National Security Technologies, LLC

Matrix: $\underline{\text { Solid }}$

Sampled: $12 / 14 / 0913: 08$

Solids: $\quad \underline{0.00}$

Batch: $\underline{\mathrm{L} 912148}$

$$
\text { Laboratory ID: } 0912042-04
$$

Prepared: $12 / 18 / 0911: 39$

Preparation: SW 7471A Prep
SDG:

Project: $\underline{\mathrm{BOA}}$

File ID:

Analyzed: $12 / 18 / 09$ 17:59

Initial/Final: $0.35 \mathrm{~g} / 50 \mathrm{~mL}$

\begin{tabular}{|c|l|c|c|c|c|}
\hline CAS NO. & Analyte & $\begin{array}{c}\text { Concentration } \\
(\mathbf{m g} / \mathbf{k g} \text { wet })\end{array}$ & $\begin{array}{c}\text { Dilution } \\
\text { Factor }\end{array}$ & $\mathbf{Q}$ & Method \\
\hline $7439-97-6$ & Mercury & 00257 & 1 & $\mathrm{U}$ & $7471 \mathrm{~A}$ \\
\hline
\end{tabular}


Laboratory: Lionville Laboratory

Client: National Security Technologies, LLC

Matrix: $\underline{\text { Solid }}$

Sampled: $12 / 14 / 0913: 13$

Solids: $\underline{0.00}$

Batch: $\underline{\text { L912163 }}$
Laboratory ID: $\underline{\text { 0912042-05 }}$

Prepared: 12/21/09 10:41

Preparation: $\underline{\text { SW 3050B }}$
SDG:

Project: $\underline{\mathrm{BOA}}$

File ID: ICP1221B-020

Analyzed: 12/21/09 18:30

Initial/Final: $0.64 \mathrm{~g} / 50 \mathrm{~mL}$

\begin{tabular}{|c|c|c|c|c|c|}
\hline CAS NO. & Analyte & $\begin{array}{c}\text { Concentration } \\
\text { (mg/kg wet) }\end{array}$ & $\begin{array}{l}\text { Dilution } \\
\text { Factor }\end{array}$ & $\mathbf{Q}$ & Method \\
\hline $7440-38-2$ & Arsenic & 2.96 & 1 & & $6010 \mathrm{~B}$ \\
\hline $7440-39-3$ & Barium & 116 & 1 & & $6010 \mathrm{~B}$ \\
\hline $7440-43-9$ & Cadmium & 0.0626 & 1 & $\mathrm{~J}$ & $6010 \mathrm{~B}$ \\
\hline $7440-47-3$ & Chromium & 1.77 & 1 & & $6010 \mathrm{~B}$ \\
\hline $7439-92-1$ & Lead & 0.781 & 1 & $\mathrm{U}$ & $6010 B$ \\
\hline $7782-49-2$ & Selenium & 1.17 & 1 & $\mathrm{U}$ & $6010 \mathrm{~B}$ \\
\hline $7440-22-4$ & Silver & 0.781 & 1 & $\mathrm{U}$ & $6010 \mathrm{~B}$ \\
\hline
\end{tabular}


Laboratory: Lionville Laboratory

Client: National Security I echnologies, LLC

Matrix: $\underline{\text { Solid }}$

Sampled: $\quad 12 / 14 / 0913: 13$

Solids: $\underline{0.00}$

Batch: L912148
Laboratory ID: $\underline{0912042-05}$

Prepared: $\underline{12 / 18 / 0911: 39}$

Preparation: $\underline{\text { SW 7471A Prep }}$
SDG:

Project: $\underline{\mathrm{BOA}}$

File ID: $\underline{H G 121802-49}$

Analyzed: $\underline{12 / 18 / 0918: 01}$

Initial/Final: $\underline{0.32 \mathrm{~g} / 50 \mathrm{~mL}}$

\begin{tabular}{|c|l|c|c|c|c|}
\hline CAS NO. & Analyte & $\begin{array}{c}\text { Concentration } \\
(\mathrm{mg} / \mathrm{kg} \text { wet })\end{array}$ & $\begin{array}{c}\text { Dilution } \\
\text { Factor }\end{array}$ & $\mathrm{Q}$ & Method \\
\hline $7439-97-6$ & Mercury & 0.0281 & 1 & $\mathrm{U}$ & $7471 \mathrm{~A}$ \\
\hline
\end{tabular}


Laboratory: Lionville Laboratory

Client: National Security Technologies, LLC

Matrix:

Solid

Sampled:

12/14/09 12:51

Solids:

Batch:

CAS NO

L912199

Sequence:

Laboratory ID:

Prepared:

Preparation:

COMPOUND

630-20-6

$71-55-6$

1,1,1,2-Tetrachloroethane

$79-34-5$

79-00-5

75-34-3

75-35-4

96-18-4

120-82-1

96-12-8

106-93-4

95-50-1

107-06-2

78-87-5

541-73-1

106-46-7

78-93-3

591-78-6

108-10-1

67-64-1

71-43-2

75-27-4

$75-25-2$

74-83-9

$75-15-0$

56-23-5

108-90-7

75-00-3

67-66-3

74-87-3

10061-01-5

124-48-1

74-95-3

75-71-8

100-41-4

87-68-3

$75-09-2$

91-20-3

100-42-5

127-18-4

108-88-3
1,1,1-Trichloroethane

1,1,2,2-Tetrachloroethane

1,1,2-Trichloroethane

1,1-Dichloroethane

1,1-Dichloroethene

1,2,3-Trichloropropane

1,2,4-Trichlorobenzene

1,2-Dibromo-3-chloropropane

1,2-Dibromoethane

1,2-Dichlorobenzene

1,2-Dichloroethane

1,2-Dichloropropane

1,3-Dichlorobenzene

1,4-Dichlorobenzene

2-Butanone

2-Hexanone

4-Methyl-2-pentanone

Acetone

Benzene

Bromodichloromethane

Bromoform

Bromomethane

Carbon Disulfide

Carbon Tetrachloride

Chlorobenzene

Chloroethane

Chloroform

Chloromethane

cis-1,3-Dichloropropene

Dibromochloromethane

Dibromomethane

Dichlorodifluoromethane

Ethylbenzene

Hexachlorobutadiene

Methylene Chloride

Naphthalene

Styrene

Tetrachloroethene

Toluene
SDG:

Project: $\quad$ BOA

0912042-01

$12 / 22 / 0915: 26$

SW 5030B

Calibration:

File ID:

$\underline{\mathrm{K} 122212 . \mathrm{D}}$

Analyzed:

12/22/0915:26

Initial/Final: $\quad 1.1 \mathrm{~g} / 5 \mathrm{~mL}$

Instrument: $\quad 5970 \mathrm{~K}$

\begin{tabular}{|c|c|}
\hline CONC. (ug/kg wet) & $Q$ \\
\hline 22.7 & $\mathrm{U}$ \\
\hline 22.7 & $\mathrm{U}$ \\
\hline 22.7 & $\mathrm{U}$ \\
\hline 22.7 & $\mathrm{U}$ \\
\hline 22.7 & $\mathrm{U}$ \\
\hline 22.7 & $\mathrm{U}$ \\
\hline 22.7 & $\mathrm{U}$ \\
\hline 22.7 & $\mathrm{U}$ \\
\hline 27.3 & $\mathrm{U}$ \\
\hline 22.7 & $\mathrm{U}$ \\
\hline 22.7 & $\mathrm{U}$ \\
\hline 27.3 & $\mathrm{U}$ \\
\hline 22.7 & $\mathrm{U}$ \\
\hline 22.7 & $\mathrm{U}$ \\
\hline 22.7 & $\mathrm{U}$ \\
\hline 54.5 & $\mathrm{U}$ \\
\hline 54.5 & $\mathrm{U}$ \\
\hline 54.5 & $\mathrm{U}$ \\
\hline 54.5 & $\mathrm{U}$ \\
\hline 22.7 & $\mathrm{U}$ \\
\hline 27.3 & $\mathrm{U}$ \\
\hline 22.7 & $\mathrm{U}$ \\
\hline 45.5 & $\mathrm{U}$ \\
\hline 22.7 & $\mathrm{U}$ \\
\hline 22.7 & $\mathrm{U}$ \\
\hline 22.7 & $\mathrm{U}$ \\
\hline 45.5 & $\mathrm{U}$ \\
\hline 22.7 & $\mathrm{U}$ \\
\hline 45.5 & $\mathrm{U}$ \\
\hline 22.7 & $\mathrm{U}$ \\
\hline 22.7 & $\mathrm{U}$ \\
\hline 45.5 & $\mathrm{U}$ \\
\hline 45.5 & $\mathrm{U}$ \\
\hline 22.7 & $\mathrm{U}$ \\
\hline 27.3 & $\mathrm{U}$ \\
\hline 27.3 & $\mathrm{U}$ \\
\hline 27.3 & $\mathrm{U}$ \\
\hline 22.7 & $\mathrm{U}$ \\
\hline 22.7 & $\mathrm{U}$ \\
\hline 227 & $\mathrm{U}$ \\
\hline
\end{tabular}


Laboratory: Lionville Laboratory

Client: National Security Technologies, LLC

Matrix: $\quad$ Solid

Sampled:

12/14/09 12:51

Solids:

Batch:
SDG:

Project:

$\underline{0912042-01}$

$\underline{12 / 22 / 0915: 26}$

Prepared:

$\underline{\mathrm{SW} 5030 \mathrm{~B}}$

Preparation:

Calibration:

$\underline{\mathrm{BOA}}$

File ID:

K122212.D

Analyzed: $\quad \underline{12 / 22 / 0915: 26}$

Initial/Final: $\quad 1.1 \mathrm{~g} / 5 \mathrm{~mL}$

\begin{tabular}{|c|c|c|c|c|c|c|}
\hline Batch: & Sequence: & & alibration: & & instrument: & $\underline{5970 \mathrm{~K}}$ \\
\hline CAS NO. & \multicolumn{2}{|l|}{ COMPOUND } & DILUTION & \multicolumn{2}{|c|}{ CONC. (ug/kg wet) } & $Q$ \\
\hline $156-60-5$ & \multicolumn{2}{|l|}{ trans-1,2-Dichloroethene } & 1 & \multicolumn{2}{|c|}{22.7} & $\mathrm{U}$ \\
\hline $10061-02-6$ & \multicolumn{2}{|l|}{ trans-1,3-Dichloropropene } & 1 & \multicolumn{2}{|c|}{22.7} & $\mathrm{U}$ \\
\hline $79-01-6$ & \multicolumn{2}{|l|}{ Trichloroethene } & 1 & \multicolumn{2}{|c|}{22.7} & $\mathrm{U}$ \\
\hline $75-69-4$ & \multicolumn{2}{|l|}{ Trichlorofluoromethane } & 1 & \multicolumn{2}{|c|}{27.3} & $\mathrm{U}$ \\
\hline $75-01-4$ & \multicolumn{2}{|l|}{ Vinyl chloride } & 1 & \multicolumn{2}{|c|}{45.5} & $\mathrm{U}$ \\
\hline $1330-20-7$ & \multicolumn{2}{|l|}{ Xylenes, total } & 1 & \multicolumn{2}{|c|}{27.3} & $\mathrm{U}$ \\
\hline $563-58-6$ & \multicolumn{2}{|l|}{ 1,1-Dichloropropene } & 1 & \multicolumn{2}{|c|}{22.7} & $\mathrm{U}$ \\
\hline $87-61-6$ & \multicolumn{2}{|l|}{ 1,2,3-Trichlorobenzene } & 1 & \multicolumn{2}{|c|}{22.7} & $\mathrm{U}$ \\
\hline $95-63-6$ & \multicolumn{2}{|l|}{ 1,2,4-Trimethylbenzene } & 1 & \multicolumn{2}{|c|}{22.7} & $\mathrm{U}$ \\
\hline $108-67-8$ & \multicolumn{2}{|l|}{ 1,3,5-Trimethylbenzene } & 1 & \multicolumn{2}{|c|}{22.7} & $\mathrm{U}$ \\
\hline $142-28-9$ & \multicolumn{2}{|l|}{ 1,3-Dichloropropane } & 1 & \multicolumn{2}{|c|}{22.7} & $\mathrm{U}$ \\
\hline $590-20-7$ & \multicolumn{2}{|l|}{ 2,2-Dichloropropane } & 1 & \multicolumn{2}{|c|}{22.7} & $\mathrm{U}$ \\
\hline $95-49-8$ & \multicolumn{2}{|l|}{ 2-Chlorotoluene } & 1 & \multicolumn{2}{|c|}{45.5} & $\mathrm{U}$ \\
\hline $106-43-4$ & \multicolumn{2}{|l|}{ 4-Chlorotoluene } & 1 & \multicolumn{2}{|c|}{22.7} & $\mathrm{U}$ \\
\hline $99-87-6$ & \multicolumn{2}{|l|}{ 4-Isopropyltoluene } & 1 & & & $\mathrm{U}$ \\
\hline $108-86-1$ & Bromobenzene & & 1 & & & $\mathrm{U}$ \\
\hline $74-97-5$ & Bromochloromethane & & 1 & & & $\mathrm{U}$ \\
\hline $156-59-2$ & cis-1,2-Dichloroethene & & 1 & & & $\mathrm{U}$ \\
\hline $76-13-1$ & Freon-113 & & 1 & & & $\mathrm{U}$ \\
\hline $98-82-8$ & Isopropylbenzene & & 1 & & & $\mathrm{U}$ \\
\hline $104-51-8$ & n-Butylbenzene & & 1 & & & $\mathrm{U}$ \\
\hline $103-65-1$ & n-Propylbenzene & & 1 & & & $\mathrm{U}$ \\
\hline $135-98-8$ & sec-Butylbenzene & & 1 & & & $\mathrm{U}$ \\
\hline $98-06-6$ & tert-Butylbenzene & & 1 & & & $\mathrm{U}$ \\
\hline SYSTEM MC & NITORING COMPOUND & ADDED (ug/ $/ \mathrm{kg}$ wet) & CONC (ug/kg wet) & $\%$ REC & QC LIMITS & $\mathrm{Q}$ \\
\hline 1,2-Dichloros & ane-d4 & 227.27 & 188 & 82.5 & $63-151$ & \\
\hline Toluene-d8 & & 227.27 & 207 & 91.0 & $68-140$ & \\
\hline 4-Bromofluo & benzene & 227.27 & 211 & 92.7 & $66-122$ & \\
\hline
\end{tabular}

* Values outside of QC limits 
Laboratory: Lionville Laboratory

Client: National Security Technologies, LLC

Matrix:

Sampled:

Solids:

Batch:

\begin{tabular}{|c|c|}
\hline CASNO & COMPOIND \\
\hline $630-20-6$ & 1,1,1,2-Tetrachloroethane \\
\hline $71-55-6$ & 1,1,1-Trichloroethane \\
\hline $79-34-5$ & 1,1,2,2-Tetrachloroethane \\
\hline $79-00-5$ & 1,1,2-Trichloroethane \\
\hline $75-34-3$ & 1,1-Dichloroethane \\
\hline $75-35-4$ & 1,1-Dichloroethene \\
\hline $96-18-4$ & 1,2,3-Trichloropropane \\
\hline $120-82-1$ & 1,2,4-Trichlorobenzene \\
\hline $96-12-8$ & 1,2-Dibromo-3-chloropropane \\
\hline $106-93-4$ & 1,2-Dibromoethane \\
\hline $95-50-1$ & 1,2-Dichlorobenzene \\
\hline $107-06-2$ & 1,2-Dichloroethane \\
\hline $78-87-5$ & 1,2-Dichloropropane \\
\hline $541-73-1$ & 1,3-Dichlorobenzene \\
\hline $106-46-7$ & 1,4-Dichlorobenzene \\
\hline 78-93-3 & 2-Butanone \\
\hline $591-78-6$ & 2-Hexanone \\
\hline $108-10-1$ & 4-Methyl-2-pentanone \\
\hline $67-64-1$ & Acetone \\
\hline $71-43-2$ & Benzene \\
\hline $75-27-4$ & Bromodichloromethane \\
\hline $75-25-2$ & Bromoform \\
\hline $74-83-9$ & Bromomethane \\
\hline $75-15-0$ & Carbon Disulfide \\
\hline $56-23-5$ & Carbon Tetrachloride \\
\hline $108-90-7$ & Chlorobenzene \\
\hline $75-00-3$ & Chloroethane \\
\hline $67-66-3$ & Chloroform \\
\hline $74-87-3$ & Chloromethane \\
\hline $10061-01-5$ & cis-1,3-Dichloropropene \\
\hline $124-48-1$ & Dibromochloromethane \\
\hline $74-95-3$ & Dibromomethane \\
\hline $75-71-8$ & Dichlorodifluoromethane \\
\hline $100-41-4$ & Ethylbenzene \\
\hline $87-68-3$ & Hexachlorobutadiene \\
\hline $75-09-2$ & Methylene Chloride \\
\hline $91-20-3$ & Naphthalene \\
\hline $100-42-5$ & Styrene \\
\hline $127-18-4$ & Tetrachloroethene \\
\hline $108-88-3$ & Toluene \\
\hline
\end{tabular}

SDG:

Project: $\quad$ BOA

$\begin{array}{lll}\underline{0912042-02} & \text { File ID: } & \underline{\text { K122213.D }} \\ \underline{\text { 12/22/09 16:03 }} & \text { Analyzed: } & \underline{12 / 22 / 0916: 03} \\ \underline{\text { SW 5030B }} & \text { Initial/Final: } & \underline{1 \mathrm{~g} / 5 \mathrm{~mL}}\end{array}$

Calibration:

Instrum

$5970 \mathrm{~K}$

\begin{tabular}{|c|c|c|}
\hline DILUTION & CONC. (ug/kg wet) & $Q$ \\
\hline 1 & 25.0 & $\mathrm{U}$ \\
\hline 1 & 25.0 & $\mathrm{U}$ \\
\hline 1 & 25.0 & $\mathrm{U}$ \\
\hline 1 & 25.0 & $\mathrm{U}$ \\
\hline 1 & 25.0 & $\mathrm{U}$ \\
\hline 1 & 25.0 & $\mathrm{U}$ \\
\hline 1 & 25.0 & $\mathrm{U}$ \\
\hline 1 & 25.0 & $\mathrm{U}$ \\
\hline 1 & 30.0 & $\mathrm{U}$ \\
\hline 1 & 25.0 & $\mathrm{U}$ \\
\hline 1 & 25.0 & $\mathrm{U}$ \\
\hline 1 & 30.0 & $\mathrm{U}$ \\
\hline 1 & 25.0 & $\mathrm{U}$ \\
\hline 1 & 25.0 & $\mathrm{U}$ \\
\hline 1 & 25.0 & $\mathrm{U}$ \\
\hline 1 & 60.0 & $\mathrm{U}$ \\
\hline 1 & 60.0 & $\mathrm{U}$ \\
\hline 1 & 60.0 & $\mathrm{U}$ \\
\hline 1 & 60.0 & $\mathrm{U}$ \\
\hline 1 & 25.0 & $\mathrm{U}$ \\
\hline 1 & 30.0 & $\mathrm{U}$ \\
\hline 1 & 25.0 & $\mathrm{U}$ \\
\hline 1 & 50.0 & $\mathrm{U}$ \\
\hline 1 & 25.0 & $\mathrm{U}$ \\
\hline 1 & 25.0 & $\mathrm{U}$ \\
\hline 1 & 25.0 & $\mathrm{U}$ \\
\hline 1 & 50.0 & $\mathrm{U}$ \\
\hline 1 & 25.0 & $\mathrm{U}$ \\
\hline 1 & 50.0 & $\mathrm{U}$ \\
\hline 1 & 25.0 & $\mathrm{U}$ \\
\hline 1 & 25.0 & $\mathrm{U}$ \\
\hline 1 & 50.0 & $U$ \\
\hline 1 & 50.0 & $\mathrm{U}$ \\
\hline 1 & 25.0 & $\mathrm{U}$ \\
\hline 1 & 30.0 & $\mathrm{U}$ \\
\hline 1 & 30.0 & $\mathrm{U}$ \\
\hline 1 & 30.0 & $\mathrm{U}$ \\
\hline 1 & 25.0 & $\mathrm{U}$ \\
\hline 1 & 25.0 & $\mathrm{U}$ \\
\hline 1 & 25.0 & $\mathrm{U}$ \\
\hline
\end{tabular}


Laboratory: Lionville Laboratory

Client:

Matrix:

Sampled:

Solids:

Batch:
SDG:

Project:

0912042-02

12/22/0916:03

Prepared:

SW 5030B
BOA

File ID:

K122213.D

Analyzed: $\quad \underline{12 / 22 / 0916: 03}$

Initial/Final: $\quad \underline{\mathrm{g} / 5 \mathrm{~mL}}$

\begin{tabular}{|c|c|c|c|c|c|c|}
\hline CAS NO. & \multicolumn{2}{|l|}{ COMPOUND } & DILUTION & \multicolumn{2}{|c|}{ CONC. (ug/kg wet) } & $\mathrm{Q}$ \\
\hline $156-60-5$ & \multicolumn{2}{|l|}{ trans-1,2-Dichloroethene } & 1 & \multicolumn{2}{|c|}{25.0} & $\mathrm{U}$ \\
\hline $10061-02-6$ & \multicolumn{2}{|l|}{ trans-1,3-Dichloropropene } & 1 & \multicolumn{2}{|c|}{25.0} & $\mathrm{U}$ \\
\hline 79-01-6 & \multicolumn{2}{|l|}{\begin{tabular}{|l|} 
Trichloroethene \\
\end{tabular}} & 1 & \multicolumn{2}{|c|}{25.0} & $\mathrm{U}$ \\
\hline $75-69-4$ & \multicolumn{2}{|l|}{ Trichlorofluoromethane } & 1 & \multicolumn{2}{|c|}{30.0} & $\mathrm{U}$ \\
\hline $75-01-4$ & \multicolumn{2}{|l|}{ Vinyl chloride } & 1 & \multicolumn{2}{|c|}{50.0} & $\mathrm{U}$ \\
\hline $1330-20-7$ & \multicolumn{2}{|l|}{\begin{tabular}{|l|} 
Xylenes, total \\
\end{tabular}} & 1 & \multicolumn{2}{|c|}{30.0} & $\mathrm{U}$ \\
\hline $563-58-6$ & \multicolumn{2}{|l|}{ 1,1-Dichloropropene } & 1 & \multicolumn{2}{|c|}{25.0} & $\mathrm{U}$ \\
\hline $87-61-6$ & \multicolumn{2}{|l|}{ 1,2,3-Trichlorobenzene } & 1 & \multicolumn{2}{|c|}{25.0} & $\mathrm{U}$ \\
\hline $95-63-6$ & \multicolumn{2}{|l|}{ 1,2,4-Trimethylbenzene } & 1 & \multicolumn{2}{|c|}{25.0} & $\bar{U}$ \\
\hline $108-67-8$ & \multicolumn{2}{|l|}{ 1,3,5-Trimethylbenzene } & 1 & \multicolumn{2}{|c|}{25.0} & $\mathrm{U}$ \\
\hline $142-28-9$ & \multicolumn{2}{|l|}{ 1,3-Dichloropropane } & 1 & \multicolumn{2}{|c|}{25.0} & $\mathrm{U}$ \\
\hline $590-20-7$ & \multicolumn{2}{|l|}{ 2,2-Dichloropropane } & 1 & \multicolumn{2}{|c|}{25.0} & $\mathrm{U}$ \\
\hline $95-49-8$ & \multicolumn{2}{|l|}{ 2-Chlorotoluene } & 1 & \multicolumn{2}{|c|}{50.0} & $\mathrm{U}$ \\
\hline $106-43-4$ & \multicolumn{2}{|l|}{ 4-Chlorotoluene } & 1 & \multicolumn{2}{|c|}{25.0} & $\mathrm{U}$ \\
\hline $99-87-6$ & \multicolumn{2}{|l|}{ 4-Isopropyltoluene } & 1 & & & $\mathrm{U}$ \\
\hline 108-86-1 & Bromobenzene & & 1 & & & $\mathrm{U}$ \\
\hline $74-97-5$ & Bromochloromethane & & 1 & & & $\mathrm{U}$ \\
\hline $156-59-2$ & cis-1,2-Dichloroethene & & 1 & & & $\mathrm{U}$ \\
\hline $76-13-1$ & Freon-113 & & 1 & & & $\mathrm{U}$ \\
\hline 98-82-8 & Isopropylbenzene & & 1 & & & $\mathrm{U}$ \\
\hline $104-51-8$ & n-Butylbenzene & & 1 & & & $\mathrm{U}$ \\
\hline $103-65-1$ & n-Propylbenzene & & 1 & & & $\mathrm{U}$ \\
\hline $135-98-8$ & sec-Butylbenzene & & 1 & & & $\mathrm{U}$ \\
\hline $98-06-6$ & tert-Butylbenzene & & 1 & & & $\mathrm{U}$ \\
\hline SYSTEM MC & JITORING COMPOUND & ADDED (ug/kg wet) & CONC (ug/kg wet) & \% REC & QC LIMITS & $\mathrm{Q}$ \\
\hline 1,2-Dichloroe & ane-d4 & 250.00 & 212 & 84.9 & $63-151$ & \\
\hline Toluene-d8 & & 250.00 & 225 & 89.8 & $68-140$ & \\
\hline 4-Bromofluo & benzene & 250.00 & 234 & 93.5 & $66-122$ & \\
\hline
\end{tabular}

* Values outside of QC limits 
Laboratory: Lionville Laboratory

Client: $\quad$ National Security Technologies, LLC

Matrix:

Sampled:

Solids:

Batch:

\begin{tabular}{|c|c|}
\hline tch: & Sequence: \\
\hline CAS NO. & COMPOUND \\
\hline $630-20-6$ & 1,1,1,2-Tetrachloroethane \\
\hline $71-55-6$ & 1,1,1-Trichloroethane \\
\hline $79-34-5$ & 1,1,2,2-Tetrachloroethane \\
\hline $79-00-5$ & 1,1,2-Trichloroethane \\
\hline $75-34-3$ & 1,1-Dichloroethane \\
\hline $75-35-4$ & 1,1-Dichloroethene \\
\hline $96-18-4$ & 1,2,3-Trichloropropane \\
\hline $120-82-1$ & 1,2,4-Trichlorobenzene \\
\hline $96-12-8$ & 1,2-Dibromo-3-chloropropane \\
\hline $106-93-4$ & 1,2-Dibromoethane \\
\hline $95-50-1$ & 1,2-Dichlorobenzene \\
\hline $107-06-2$ & 1,2-Dichloroethane \\
\hline $78-87-5$ & 1,2-Dichloropropane \\
\hline $541-73-1$ & 1,3-Dichlorobenzene \\
\hline $106-46-7$ & 1,4-Dichlorobenzene \\
\hline $78-93-3$ & 2-Butanone \\
\hline $591-78-6$ & 2-Hexanone \\
\hline $108-10-1$ & 4-Methyl-2-pentanone \\
\hline 67-64-1 & Acetone \\
\hline $71-43-2$ & Benzene \\
\hline $75-27-4$ & Bromodichloromethane \\
\hline $75-25-2$ & Bromoform \\
\hline $74-83-9$ & Bromomethane \\
\hline $75-15-0$ & Carbon Disulfide \\
\hline $56-23-5$ & Carbon Tetrachloride \\
\hline $108-90-7$ & Chlorobenzene \\
\hline $75-00-3$ & Chloroethane \\
\hline $67-66-3$ & Chloroform \\
\hline $74-87-3$ & Chloromethane \\
\hline $10061-01-5$ & cis-1,3-Dichloropropene \\
\hline $124-48-1$ & Dibromochloromethane \\
\hline 74-95-3 & Dibromomethane \\
\hline $75-71-8$ & Dichlorodifluoromethane \\
\hline $100-41-4$ & Ethylbenzene \\
\hline $87-68-3$ & Hexachlorobutadiene \\
\hline $75-09-2$ & Methylene Chloride \\
\hline $91-20-3$ & Naphthalene \\
\hline $100-42-5$ & Styrene \\
\hline $127-18-4$ & Tetrachloroethene \\
\hline $108-88-3$ & Toluene \\
\hline
\end{tabular}

SDG:

Project: $\quad$ BOA

$\begin{array}{lll}\underline{0912042-03} & \text { File ID: } & \underline{\text { K122214.D }} \\ \underline{\text { 12/22/09 16:40 }} & \text { Analyzed: } & \underline{12 / 22 / 0916: 40} \\ \text { SW 5030B } & \text { Initial/Final: } & \underline{1.1 \mathrm{~g} / 5 \mathrm{~mL}}\end{array}$

Calibration:

Instrument:

$5970 \mathrm{~K}$

\begin{tabular}{|c|c|c|}
\hline DILUTION & CONC. (ug/kg wet) & $\mathrm{Q}$ \\
\hline 1 & 22.7 & $\mathrm{U}$ \\
\hline 1 & 22.7 & $\mathrm{U}$ \\
\hline 1 & 22.7 & $\mathrm{U}$ \\
\hline 1 & 22.7 & $\mathrm{U}$ \\
\hline 1 & 22.7 & $\mathrm{U}$ \\
\hline 1 & 22.7 & $\mathrm{U}$ \\
\hline 1 & 22.7 & $\bar{U}$ \\
\hline 1 & 22.7 & $\mathrm{U}$ \\
\hline 1 & 27.3 & $\mathrm{U}$ \\
\hline 1 & 22.7 & $\mathrm{U}$ \\
\hline 1 & 22.7 & $\mathrm{U}$ \\
\hline 1 & 27.3 & $\mathrm{U}$ \\
\hline 1 & 22.7 & $\mathrm{U}$ \\
\hline 1 & 22.7 & $\mathrm{U}$ \\
\hline 1 & 22.7 & $\mathrm{U}$ \\
\hline 1 & 54.5 & $\mathrm{U}$ \\
\hline 1 & 54.5 & $\mathrm{U}$ \\
\hline 1 & 54.5 & $\mathrm{U}$ \\
\hline 1 & 54.5 & $\bar{U}$ \\
\hline 1 & 22.7 & $\mathrm{U}$ \\
\hline 1 & 27.3 & $\mathrm{U}$ \\
\hline 1 & 22.7 & $\mathrm{U}$ \\
\hline 1 & 45.5 & $\mathrm{U}$ \\
\hline 1 & 22.7 & $\mathrm{U}$ \\
\hline 1 & 22.7 & $\mathrm{U}$ \\
\hline 1 & 22.7 & $\mathrm{U}$ \\
\hline 1 & 45.5 & $\mathrm{U}$ \\
\hline 1 & 22.7 & $\mathrm{U}$ \\
\hline 1 & 45.5 & $\mathrm{U}$ \\
\hline 1 & 22.7 & $\mathrm{U}$ \\
\hline 1 & 22.7 & $\mathrm{U}$ \\
\hline 1 & 45.5 & $\mathrm{U}$ \\
\hline 1 & 45.5 & $\mathrm{U}$ \\
\hline 1 & 22.7 & $\mathrm{U}$ \\
\hline 1 & 27.3 & $\mathrm{U}$ \\
\hline 1 & 27.3 & $\mathrm{U}$ \\
\hline 1 & 27.3 & $\mathrm{U}$ \\
\hline 1 & 22.7 & $\mathrm{U}$ \\
\hline 1 & 22.7 & $\mathrm{U}$ \\
\hline 1 & 22.7 & $\mathrm{U}$ \\
\hline
\end{tabular}




\section{ORGANIC ANALYSIS DATA SHEET 8260B}

Laboratory: Lionville Laboratory

Client: $\quad$ National Security Technologies, LLC

Matrix:

Sampled:

Solid

Solids:

Batch:

$\underline{12 / 14 / 0913: 05}$

Laboratory ID:

Prepared:

Preparation:

L912199 Sequence:

\section{}

CAS NO.

$10061-02-6$

$79-01-6$

$75-69-4$

$\underline{0912042-03}$

12/22/09 16:40

SW 5030B

SDG:

Project:

$\underline{B O A}$

75-01-4

Calibration:

File ID:

Analyzed:

Initial/Final: $\underline{\text { K122214.D }}$

$\underline{12 / 22 / 0916: 40}$

$1.1 \mathrm{~g} / 5 \mathrm{~mL}$ $5970 \mathrm{~K}$ Instrument: COMPOUND trans-1,2-Dichloroethene trans-1,3-Dichloropropene

Trichloroethene

Trichlorofluoromethane 1330-20-7 Vinyl chloride $563-58-6$ Xylenes, total

87-61-6

1,1-Dichloropropene

95-63-6

108-67-8 1,2,3-Trichlorobenzene

142-28-9 590-20-7 95-49-8

106-43-4 1,2,4-Trimethylbenzene 1,3,5-Trimethylbenzene 99-87-6 108-86-1 74-97-5 156-59-2 76-13-1 98-82-8 104-51-8 103-65-1 $135-98-8$ 98-06-6 1,3-Dichloropropane 2,2-Dichloropropane

2-Chlorotoluene 4-Chlorotoluene 4-Isopropyltoluene Bromobenzene Bromochloromethane cis-1,2-Dichloroethene

Freon-113 Isopropylbenzene n-Butylbenzene n-Propylbenzene sec-Butylbenzene tert-Butylbenzene

\begin{tabular}{|c|c|c|}
\hline DILUTION & CONC. (ug/kg wet) & $\mathrm{Q}$ \\
\hline 1 & 22.7 & $\mathrm{U}$ \\
\hline 1 & 22.7 & $\mathrm{U}$ \\
\hline 1 & 22.7 & $\mathrm{U}$ \\
\hline 1 & 27.3 & $\mathrm{U}$ \\
\hline 1 & 45.5 & $\mathrm{U}$ \\
\hline 1 & 27.3 & $\mathrm{U}$ \\
\hline 1 & 22.7 & $\mathrm{U}$ \\
\hline 1 & 22.7 & $\mathrm{U}$ \\
\hline 1 & 22.7 & $\mathrm{U}$ \\
\hline 1 & 22.7 & $\mathrm{U}$ \\
\hline 1 & 22.7 & $\mathrm{U}$ \\
\hline 1 & 22.7 & $\mathrm{U}$ \\
\hline 1 & 45.5 & $\mathrm{U}$ \\
\hline 1 & 22.7 & $\mathrm{U}$ \\
\hline 1 & 22.7 & $\mathrm{U}$ \\
\hline 1 & 27.3 & $\mathrm{U}$ \\
\hline 1 & 27.3 & $\mathrm{U}$ \\
\hline 1 & 22.7 & $\mathrm{U}$ \\
\hline 1 & 22.7 & $\mathrm{U}$ \\
\hline 1 & 22.7 & $\mathrm{U}$ \\
\hline 1 & 45.5 & $\mathrm{U}$ \\
\hline 1 & 22.7 & $\mathrm{U}$ \\
\hline 1 & 45.5 & $\mathrm{U}$ \\
\hline
\end{tabular}

\begin{tabular}{|l|c|c|c|c|c|}
\hline SYSTEM MONITORING COMPOUND & ADDED (ug/kg wet) & CONC (ug/kg wet) & $\%$ REC & QC LIMITS & Q \\
\hline 1,2-Dichloroethane-d4 & 227.27 & 182 & 80.0 & $63-151$ & \\
\hline Toluene-d8 & 227.27 & 216 & 94.9 & $68-140$ & \\
\hline 4-Bromofluorobenzene & 227.27 & 226 & 99.3 & $66-122$ & \\
\hline
\end{tabular}

* Values outside of QC limits 
Laboratory: Lionville Laboratory

Client:

Matrix:

Sampled:

Solids:

Batch:

\begin{tabular}{|c|l|}
\hline CAS NO. & COMPOUND \\
\hline $630-20-6$ & $1,1,1,2-$ Tetrachloroethane \\
\hline $71-55-6$ & $1,1,1-$ Trichloroethane \\
\hline $79-34-5$ & $1,1,2,2-$ Tetrachloroethane \\
\hline $79-00-5$ & $1,1,2-$ Trichloroethane \\
\hline $75-34-3$ & 1,1 -Dichloroethane \\
\hline $75-35-4$ & $1,1-$ Dichloroethene \\
\hline $96-18-4$ & $1,2,3$-Trichloropropane \\
\hline $120-82-1$ & $1,2,4-$-Trichlorobenzene \\
\hline $96-12-8$ & 1,2 -Dibromo-3-chloropropane \\
\hline $106-93-4$ & $1,2-$ Dibromoethane \\
\hline $95-50-1$ & $1,2-$ Dichlorobenzene \\
\hline $107-06-2$ & $1,2-$ Dichloroethane \\
\hline $78-87-5$ & $1,2-$ Dichloropropane \\
\hline $541-73-1$ & 1,3 -Dichlorobenzene \\
\hline $106-46-7$ & $1,4-$ Dichlorobenzene \\
\hline $78-93-3$ & 2-Butanone \\
\hline $591-78-6$ & 2 -Hexanone \\
\hline $108-10-1$ & 4-Methyl-2-pentanone \\
\hline $67-64-1$ & Acetone \\
\hline $71-43-2$ & Benzene \\
\hline $75-27-4$ & Bromodichloromethane \\
\hline $75-25-2$ & Bromoform \\
\hline $74-83-9$ & Bromomethane \\
\hline $75-15-0$ & Carbon Disulfide \\
\hline $56-23-5$ & Carbon Tetrachloride \\
\hline $108-90-7$ & Chlorobenzene \\
\hline $75-00-3$ & Chloroethane \\
\hline $67-66-3$ & Chloroform \\
\hline $74-87-3$ & Chloromethane \\
\hline $10061-01-5$ & cis-1,3-Dichloropropene \\
\hline $124-48-1$ & Dibromochloromethane \\
\hline $74-95-3$ & Dibromomethane \\
\hline $75-71-8$ & Dichlorodifluoromethane \\
\hline $100-41-4$ & Ethylbenzene \\
\hline $87-68-3$ & Hexachlorobutadiene \\
\hline $75-09-2$ & Methylene Chloride \\
\hline $91-20-3$ & Naphthalene \\
\hline $100-42-5$ & Styrene \\
\hline $127-18-4$ & Tetrachloroethene \\
\hline $108-88-3$ & Toluene \\
\hline & \\
\hline
\end{tabular}

SDG:

Project:

0912042-04

Prepared:

12/22/0917:17

SW 5030B

Calibration:

DILUTION
$\underline{B O A}$

File ID:

K122215.D

Analyzed: $\quad \underline{12 / 22 / 0917: 17}$

Initial/Final: $\quad \underline{1.2 \mathrm{~g} / 5 \mathrm{~mL}}$

Instrument: $5970 \mathrm{~K}$

\begin{tabular}{|c|c|c|}
\hline DILUTION & CONC. (ug/kg wet) & $\bar{Q}$ \\
\hline 1 & 20.8 & $\mathrm{U}$ \\
\hline 1 & 20.8 & $\mathrm{U}$ \\
\hline 1 & 20.8 & $\mathrm{U}$ \\
\hline 1 & 20.8 & $\mathrm{U}$ \\
\hline 1 & 20.8 & $\mathrm{U}$ \\
\hline 1 & 20.8 & $\mathrm{U}$ \\
\hline 1 & 20.8 & $\mathrm{U}$ \\
\hline 1 & 20.8 & $\mathrm{U}$ \\
\hline 1 & 25.0 & $\mathrm{U}$ \\
\hline 1 & 20.8 & $\mathrm{U}$ \\
\hline 1 & 20.8 & $\mathrm{U}$ \\
\hline 1 & 25.0 & $\mathrm{U}$ \\
\hline 1 & 20.8 & $\mathrm{U}$ \\
\hline 1 & 20.8 & $\mathrm{U}$ \\
\hline 1 & 20.8 & $\mathrm{U}$ \\
\hline 1 & 50.0 & $\mathrm{U}$ \\
\hline 1 & 50.0 & $\mathrm{U}$ \\
\hline 1 & 50.0 & $\mathrm{U}$ \\
\hline 1 & 50.0 & $\mathrm{U}$ \\
\hline 1 & 20.8 & $\mathrm{U}$ \\
\hline 1 & 25.0 & $\mathrm{U}$ \\
\hline 1 & 20.8 & $\mathrm{U}$ \\
\hline 1 & 41.7 & $\mathrm{U}$ \\
\hline 1 & 20.8 & $\mathrm{U}$ \\
\hline 1 & 20.8 & $\mathrm{U}$ \\
\hline 1 & 20.8 & $\mathrm{U}$ \\
\hline 1 & 41.7 & $\mathrm{U}$ \\
\hline 1 & 20.8 & $\mathrm{U}$ \\
\hline 1 & 41.7 & $\mathrm{U}$ \\
\hline 1 & 20.8 & $\mathrm{U}$ \\
\hline 1 & 20.8 & $\mathrm{U}$ \\
\hline 1 & 41.7 & U \\
\hline 1 & 41.7 & $\mathrm{U}$ \\
\hline 1 & 20.8 & $\mathrm{U}$ \\
\hline 1 & 25.0 & $\mathrm{U}$ \\
\hline 1 & 25.0 & $\mathrm{U}$ \\
\hline 1 & 25.0 & $\mathrm{U}$ \\
\hline 1 & 20.8 & $\mathrm{U}$ \\
\hline 1 & 20.8 & $\mathrm{U}$ \\
\hline 1 & 20.8 & $\mathrm{U}$ \\
\hline
\end{tabular}


Laboratory: Lionville Laboratory

Client: National Security Technologies, LLC

Matrix:

Sampled:

Solid

Solids:

12/14/0913:08

Batch:

Batch: $\quad \underline{\text { L912199 }}$ Sequence:

SDG:

Project:

Laboratory ID:

0912042-04

Prepared:

$\underline{12 / 22 / 0917: 17}$

Preparation:
$\underline{\mathrm{BOA}}$

File ID:

$\underline{\mathrm{K} 122215 . \mathrm{D}}$

Analyzed: $\quad 12 / 22 / 0917: 17$

Initial/Final: $\quad \underline{1.2 \mathrm{~g} / 5 \mathrm{~mL}}$

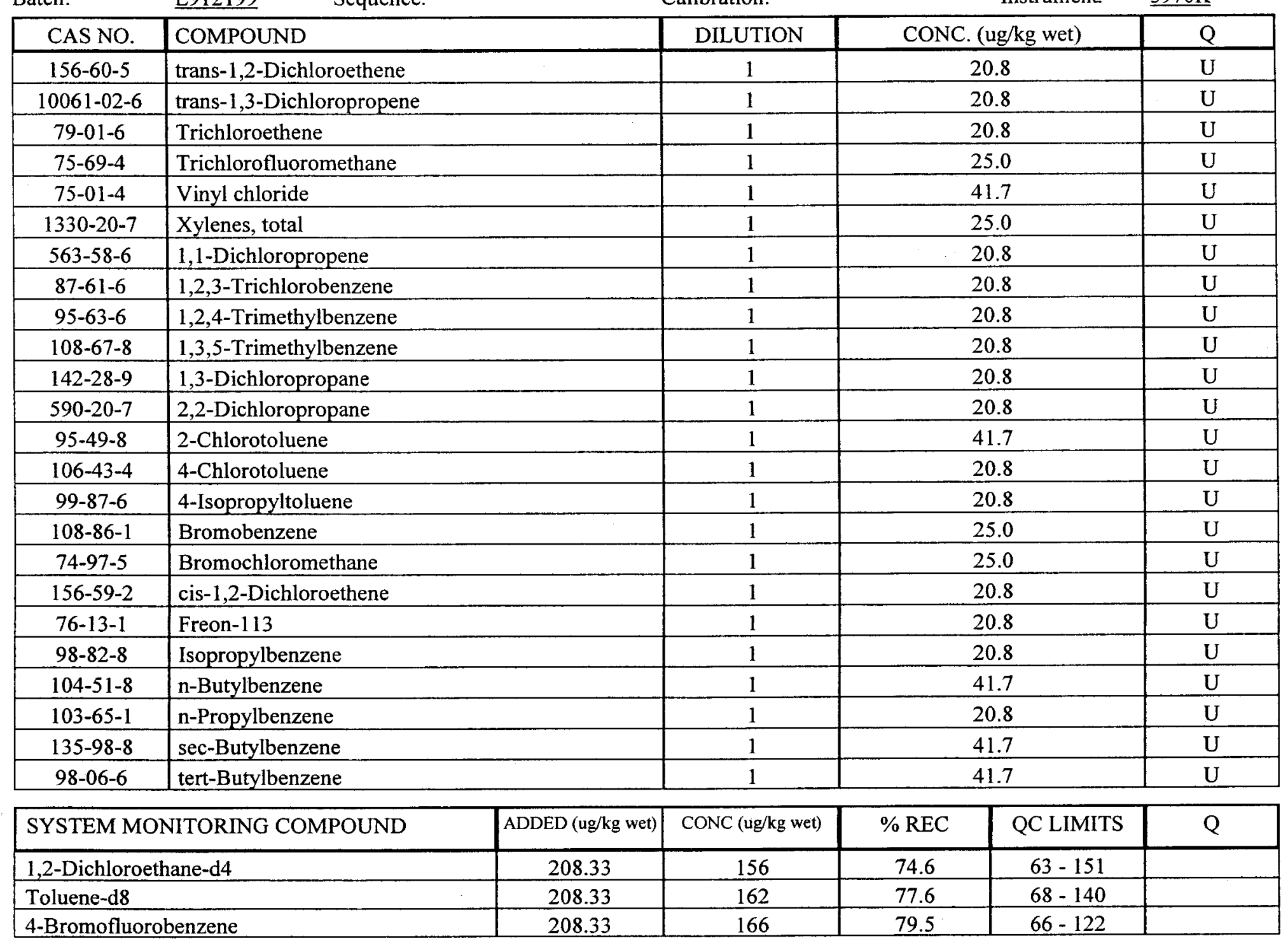

* Values outside of QC limits 


\section{ORGANIC ANALYSIS DATA SHEET 8260B}

Laboratory; Lionville Laboratory

Client:

Matrix:

Sampled:

Solids:

Batch:

\begin{tabular}{|c|c|}
\hline CAS NO. & COMPOUND \\
\hline $630-20-6$ & 1,1,1,2-Tetrachloroethane \\
\hline $71-55-6$ & 1,1,1-Trichloroethane \\
\hline $79-34-5$ & 1,1,2,2-Tetrachloroethane \\
\hline $79-00-5$ & 1,1,2-Trichloroethane \\
\hline $75-34-3$ & 1,1-Dichloroethane \\
\hline $75-35-4$ & 1,1-Dichloroethene \\
\hline $96-18-4$ & 1,2,3-Trichloropropane \\
\hline $120-82-1$ & 1,2,4-Trichlorobenzene \\
\hline $96-12-8$ & 1,2-Dibromo-3-chloropropane \\
\hline $106-93-4$ & 1,2-Dibromoethane \\
\hline $95-50-1$ & 1,2-Dichlorobenzene \\
\hline $107-06-2$ & 1,2-Dichloroethane \\
\hline $78-87-5$ & 1,2-Dichloropropane \\
\hline $541-73-1$ & 1,3-Dichlorobenzene \\
\hline $106-46-7$ & 1,4-Dichlorobenzene \\
\hline $78-93-3$ & 2-Butanone \\
\hline $591-78-6$ & 2-Hexanone \\
\hline 108-10-1 & 4-Methyl-2-pentanone \\
\hline $67-64-1$ & Acetone \\
\hline $71-43-2$ & Benzene \\
\hline $75-27-4$ & Bromodichloromethane \\
\hline $75-25-2$ & Bromoform \\
\hline $74-83-9$ & Bromomethane \\
\hline $75-15-0$ & Carbon Disulfide \\
\hline $56-23-5$ & Carbon Tetrachloride \\
\hline $108-90-7$ & Chlorobenzene \\
\hline $75-00-3$ & Chloroethane \\
\hline $67-66-3$ & Chloroform \\
\hline $74-87-3$ & Chloromethane \\
\hline $10061-01-5$ & cis-1,3-Dichloropropene \\
\hline $124-48-1$ & Dibromochloromethane \\
\hline $74-95-3$ & Dibromomethane \\
\hline $75-71-8$ & Dichlorodifluoromethane \\
\hline $100-41-4$ & Ethylbenzene \\
\hline $87-68-3$ & Hexachlorobutadiene \\
\hline $75-09-2$ & Methylene Chloride \\
\hline $91-20-3$ & Naphthalene \\
\hline $100-42-5$ & Styrene \\
\hline $127-18-4$ & Tetrachloroethene \\
\hline $108-88-3$ & Toluene \\
\hline
\end{tabular}

SDG:

Project:

$\underline{0912042-05}$

Prepared:

$\underline{12 / 22 / 0917: 53}$

Preparation:

SW 5030B
$\underline{B O A}$

File ID:

$\underline{\mathrm{K} 122216 . \mathrm{D}}$

Analyzed: $\quad \underline{12 / 22 / 0917: 53}$

Initial/Final: $\quad \underline{1.1 \mathrm{~g} / 5 \mathrm{~mL}}$

Calibration:
Instrument: $5970 \mathrm{~K}$

\begin{tabular}{|c|c|c|}
\hline DILUTION & CONC. (ug/kg wet) & $\mathrm{Q}$ \\
\hline 1 & 22.7 & $\mathrm{U}$ \\
\hline 1 & 22.7 & $\mathrm{U}$ \\
\hline 1 & 22.7 & $\mathrm{U}$ \\
\hline 1 & 22.7 & $\mathrm{U}$ \\
\hline 1 & 22.7 & $\mathrm{U}$ \\
\hline 1 & 22.7 & $\mathrm{U}$ \\
\hline 1 & 22.7 & $\mathrm{U}$ \\
\hline 1 & 22.7 & $\mathrm{U}$ \\
\hline 1 & 27.3 & $\mathrm{U}$ \\
\hline 1 & 22.7 & $\mathrm{U}$ \\
\hline 1 & 22.7 & $\mathrm{U}$ \\
\hline 1 & 27.3 & $\mathrm{U}$ \\
\hline 1 & 22.7 & $\mathrm{U}$ \\
\hline 1 & 22.7 & $\mathrm{U}$ \\
\hline 1 & 22.7 & $\mathrm{U}$ \\
\hline 1 & 54.5 & $\mathrm{U}$ \\
\hline 1 & 54.5 & $\mathrm{U}$ \\
\hline 1 & 54.5 & $\mathrm{U}$ \\
\hline 1 & 54.5 & $\mathrm{U}$ \\
\hline 1 & 22.7 & $\mathrm{U}$ \\
\hline 1 & 27.3 & $\mathrm{U}$ \\
\hline 1 & 22.7 & $\mathrm{U}$ \\
\hline 1 & 45.5 & $\mathrm{U}$ \\
\hline 1 & 22.7 & $\mathrm{U}$ \\
\hline 1 & 22.7 & $\mathrm{U}$ \\
\hline 1 & 22.7 & $\mathrm{U}$ \\
\hline 1 & 45.5 & $\mathrm{U}$ \\
\hline 1 & 22.7 & $\mathrm{U}$ \\
\hline 1 & 45.5 & $\mathrm{U}$ \\
\hline 1 & 22.7 & $\mathrm{U}$ \\
\hline 1 & 22.7 & $\mathrm{U}$ \\
\hline 1 & 45.5 & $\mathrm{U}$ \\
\hline 1 & 45.5 & $\mathrm{U}$ \\
\hline 1 & 22.7 & $\mathrm{U}$ \\
\hline 1 & 27.3 & $\mathrm{U}$ \\
\hline 1 & 27.3 & $\mathrm{U}$ \\
\hline 1 & 27.3 & $\mathrm{U}$ \\
\hline 1 & 22.7 & $\mathrm{U}$ \\
\hline 1 & 22.7 & $\mathrm{U}$ \\
\hline 1 & 22.7 & $\mathrm{U}$ \\
\hline
\end{tabular}




\section{ORGANIC ANALYSIS DATA SHEET 8260B}

Laboratory: Lionville Laboratory

Client:

Matrix:

Sampled:

National Security Technologies, LLC

Solids:

Batch:

\begin{tabular}{|c|}
\hline CAS NO. \\
\hline $156-60-5$ \\
\hline $10061-02-6$ \\
\hline $79-01-6$ \\
\hline $75-69-4$ \\
\hline $75-01-4$ \\
\hline $1330-20-7$ \\
\hline $563-58-6$ \\
\hline $87-61-6$ \\
\hline $95-63-6$ \\
\hline $108-67-8$ \\
\hline $142-28-9$ \\
\hline $590-20-7$ \\
\hline $95-49-8$ \\
\hline $106-43-4$ \\
\hline $99-87-6$ \\
\hline $108-86-1$ \\
\hline $74-97-5$ \\
\hline $156-59-2$ \\
\hline $76-13-1$ \\
\hline $98-82-8$ \\
\hline $104-51-8$ \\
\hline $103-65-1$ \\
\hline $135-98-8$ \\
\hline $98-06-6$ \\
\hline
\end{tabular}

Solid

12/14/09 13:13

Laboratory ID:

Prepared:

Preparation:
COMPOUND

trans-1,2-Dichloroethene

trans-1,3-Dichloropropene

Trichloroethene

Trichlorofluoromethane

Vinyl chloride

Xylenes, total

1,1-Dichloropropene

1,2,3-Trichlorobenzene

1,2,4-Trimethylbenzene

1,3,5-Trimethylbenzene

1,3-Dichloropropane

2,2-Dichloropropane

2-Chlorotoluene

4-Chlorotoluene

4-Isopropyltoluene

Bromobenzene

Bromochloromethane

cis-1,2-Dichloroethene

Freon-113

Isopropylbenzene

n-Butylbenzene

n-Propylbenzene

sec-Butylbenzene

tert-Butylbenzene
SDG:

Project:

$\underline{0912042-05}$

$\underline{12 / 22 / 0917: 53}$

SW 5030B
BOA

File ID:

$\underline{\mathrm{K} 122216 . \mathrm{D}}$

Analyzed: $\quad 12 / 22 / 0917: 53$

Initial/Final: $\quad 1.1 \mathrm{~g} / 5 \mathrm{~mL}$

Calibration:

Instrument: $\underline{5970 \mathrm{~K}}$

DILUTION

\begin{tabular}{|c|c|c|}
\hline UTION & CONC. (ug/kg wet) & Q \\
\hline 1 & 22.7 & $\mathrm{U}$ \\
\hline 1 & 22.7 & $\mathbf{U}$ \\
\hline 1 & 22.7 & $\mathrm{U}$ \\
\hline 1 & 27.3 & $\mathrm{U}$ \\
\hline 1 & 45.5 & $\mathrm{U}$ \\
\hline 1 & 27.3 & $\mathrm{U}$ \\
\hline 1 & 22.7 & $\mathrm{U}$ \\
\hline 1 & 22.7 & $\mathrm{U}$ \\
\hline 1 & 22.7 & $\mathrm{U}$ \\
\hline 1 & 22.7 & $\mathrm{U}$ \\
\hline 1 & 22.7 & $\mathrm{U}$ \\
\hline 1 & 22.7 & $\mathrm{U}$ \\
\hline 1 & 45.5 & $\mathrm{U}$ \\
\hline 1 & 22.7 & $\mathrm{U}$ \\
\hline 1 & 22.7 & $\mathrm{U}$ \\
\hline 1 & 27.3 & $\mathrm{U}$ \\
\hline 1 & 27.3 & $\mathrm{U}$ \\
\hline 1 & 22.7 & $\mathrm{U}$ \\
\hline 1 & 22.7 & $\mathrm{U}$ \\
\hline 1 & 22.7 & $\mathrm{U}$ \\
\hline 1 & 45.5 & $\mathrm{U}$ \\
\hline 1 & 22.7 & $\mathrm{U}$ \\
\hline 1 & 45.5 & $\mathrm{U}$ \\
\hline 1 & 45.5 & $\mathrm{U}$ \\
\hline
\end{tabular}

\begin{tabular}{|c|c|c|c|c|c|}
\hline SYSTEM MONITORING COMPOUND & ADDED (ug/kg wet) & CONC (ug/kg wet) & $\%$ REC & QC LIMITS & Q \\
\hline 1,2-Dichloroethane-d4 & 227.27 & 188 & 82.9 & $63-151$ & \\
\hline Toluene-d8 & 227.27 & 214 & 94.0 & $68-140$ & \\
\hline 4-Bromofluorobenzene & 227.27 & 233 & 102 & $66-122$ & \\
\hline
\end{tabular}

* Values outside of QC limits 
Laboratory:

Client:

Matrix:

Sampled:

Solids:

Batch:

\begin{tabular}{|c|c|}
\hline CAS NO. & COMPOUND \\
\hline $630-20-6$ & $1,1,1,2$-Tetrachloroethane \\
\hline $71-55-6$ & 1,1,1-Trichloroethane \\
\hline $79-34-5$ & 1,1,2,2-Tetrachloroethane \\
\hline $79-00-5$ & 1,1,2-Trichloroethane \\
\hline $75-34-3$ & 1,1-Dichloroethane \\
\hline $75-35-4$ & 1,1-Dichloroethene \\
\hline $96-18-4$ & 1,2,3-Trichloropropane \\
\hline $120-82-1$ & 1,2,4-Trichlorobenzene \\
\hline $96-12-8$ & 1,2-Dibromo-3-chloropropane \\
\hline $106-93-4$ & 1,2-Dibromoethane \\
\hline $95-50-1$ & 1,2-Dichlorobenzene \\
\hline $107-06-2$ & 1,2-Dichloroethane \\
\hline $78-87-5$ & 1,2-Dichloropropane \\
\hline $541-73-1$ & 1,3-Dichlorobenzene \\
\hline $106-46-7$ & 1,4-Dichlorobenzene \\
\hline $78-93-3$ & 2-Butanone \\
\hline $591-78-6$ & 2-Hexanone \\
\hline $108-10-1$ & 4-Methyl-2-pentanone \\
\hline $67-64-1$ & Acetone \\
\hline $71-43-2$ & Benzene \\
\hline $75-27-4$ & Bromodichloromethane \\
\hline $75-25-2$ & Bromoform \\
\hline $74-83-9$ & Bromomethane \\
\hline $75-15-0$ & Carbon Disulfide \\
\hline $56-23-5$ & Carbon Tetrachloride \\
\hline $108-90-7$ & Chlorobenzene \\
\hline $75-00-3$ & Chloroethane \\
\hline $67-66-3$ & Chloroform \\
\hline $74-87-3$ & Chloromethane \\
\hline $10061-01-5$ & cis-1,3-Dichloropropene \\
\hline $124-48-1$ & Dibromochloromethane \\
\hline $74-95-3$ & Dibromomethane \\
\hline $75-71-8$ & Dichlorodifluoromethane \\
\hline $100-41-4$ & Ethylbenzene \\
\hline $87-68-3$ & Hexachlorobutadiene \\
\hline $75-09-2$ & Methylene Chloride \\
\hline $91-20-3$ & Naphthalene \\
\hline $100-42-5$ & Styrene \\
\hline $127-18-4$ & Tetrachloroethene \\
\hline $108-88-3$ & Toluene \\
\hline
\end{tabular}

SDG:

Project:

0912042-06

Prepared:

12/21/0914:48

Preparation:

SW 5030B

Calibration:
BOA

File ID:

G122108.D

Analyzed: $\quad 12 / 21 / 0914: 48$

Initial/Final: $\quad 5 \mathrm{~mL} / 5 \mathrm{~mL}$

\begin{tabular}{|c|c|c|}
\hline DILUTION & CONC. (ug/L) & $\mathrm{Q}$ \\
\hline 1 & 5.00 & $\mathrm{U}$ \\
\hline 1 & 5.00 & $\mathrm{U}$ \\
\hline 1 & 5.00 & $\mathrm{U}$ \\
\hline 1 & 5.00 & $\mathrm{U}$ \\
\hline 1 & 5.00 & $\mathrm{U}$ \\
\hline 1 & 5.00 & U \\
\hline 1 & 5.00 & $\mathrm{U}$ \\
\hline 1 & 5.00 & $\mathrm{U}$ \\
\hline 1 & 5.00 & $\mathrm{U}$ \\
\hline 1 & 5.00 & $\mathrm{U}$ \\
\hline 1 & 5.00 & $\mathrm{U}$ \\
\hline 1 & 5.00 & $\mathrm{U}$ \\
\hline 1 & 5.00 & $\mathrm{U}$ \\
\hline 1 & 5.00 & $\mathrm{U}$ \\
\hline 1 & 5.00 & $\mathrm{U}$ \\
\hline 1 & 10.0 & $\mathrm{U}$ \\
\hline 1 & 10.0 & $\mathrm{U}$ \\
\hline 1 & 10.0 & $\bar{U}$ \\
\hline 1 & 10.0 & $\mathrm{U}$ \\
\hline 1 & 5.00 & $\mathrm{U}$ \\
\hline 1 & 3.60 & $\mathbf{J}$ \\
\hline 1 & 5.00 & $\mathrm{U}$ \\
\hline 1 & 5.00 & $\mathrm{U}$ \\
\hline 1 & 5.00 & $\mathrm{U}$ \\
\hline 1 & 5.00 & $\mathrm{U}$ \\
\hline 1 & 5.00 & $\mathrm{U}$ \\
\hline 1 & 5.00 & $\mathrm{U}$ \\
\hline 1 & 33.8 & \\
\hline 1 & 5.00 & $\mathrm{U}$ \\
\hline 1 & 5.00 & $\mathrm{U}$ \\
\hline 1 & 5.00 & $\mathrm{U}$ \\
\hline 1 & 5.00 & $\mathrm{U}$ \\
\hline 1 & 5.00 & $\mathrm{U}$ \\
\hline 1 & 5.00 & $\mathrm{U}$ \\
\hline 1 & 5.00 & $\mathrm{U}$ \\
\hline 1 & 5.00 & $\mathrm{U}$ \\
\hline 1 & 5.00 & $\mathrm{U}$ \\
\hline 1 & 5.00 & $\mathrm{U}$ \\
\hline 1 & 5.00 & $\mathrm{U}$ \\
\hline 1 & 5.00 & $\mathrm{U}$ \\
\hline
\end{tabular}


Laboratory: Lionville Laboratory

Client: $\quad$ National Security Technologies, LLC

Matrix:

Sampled:

Water

Solids:
Laboratory ID:

Prepared:

Preparation:

SDG:

Project:

$\underline{0912042-06}$

$\underline{12 / 21 / 0914: 48}$

SW 5030B

\section{BOA}

File ID:

G122108.D

Analyzed: $\quad \underline{12 / 21 / 0914: 48}$

Initial/Final: $\quad \underline{\mathrm{mL} / 5 \mathrm{~mL}}$

Batch:

Sequence:

Calibration: Instrument:

5973G

\begin{tabular}{|c|c|c|c|c|c|c|}
\hline CAS NO. & \multicolumn{2}{|l|}{ COMPOUND } & DILUTION & \multicolumn{2}{|c|}{ CONC. (ug/L) } & $Q$ \\
\hline $156-60-5$ & \multicolumn{2}{|l|}{ trans-1,2-Dichloroethene } & 1 & \multicolumn{2}{|c|}{5.00} & $\mathrm{U}$ \\
\hline $10061-02-6$ & \multicolumn{2}{|l|}{ trans-1,3-Dichloropropene } & 1 & \multicolumn{2}{|c|}{5.00} & $\mathrm{U}$ \\
\hline $79-01-6$ & \multicolumn{2}{|l|}{ Trichloroethene } & 1 & \multicolumn{2}{|c|}{5.00} & $\mathrm{U}$ \\
\hline $75-69-4$ & \multicolumn{2}{|l|}{ Trichlorofluoromethane } & 1 & \multicolumn{2}{|c|}{5.00} & $\mathrm{U}$ \\
\hline $75-01-4$ & \multicolumn{2}{|l|}{ Vinyl chloride } & 1 & \multicolumn{2}{|c|}{5.00} & $\mathrm{U}$ \\
\hline $1330-20-7$ & \multicolumn{2}{|l|}{ Xylenes, total } & 1 & \multicolumn{2}{|c|}{5.00} & $\mathrm{U}$ \\
\hline $563-58-6$ & \multicolumn{2}{|l|}{ 1,1-Dichloropropene } & 1 & \multicolumn{2}{|c|}{5.00} & $\mathrm{U}$ \\
\hline $87-61-6$ & \multicolumn{2}{|l|}{ 1,2,3-Trichlorobenzene } & 1 & \multicolumn{2}{|c|}{5.00} & $\mathrm{U}$ \\
\hline $95-63-6$ & \multicolumn{2}{|l|}{ 1,2,4-Trimethylbenzene } & 1 & \multicolumn{2}{|c|}{5.00} & $\mathrm{U}$ \\
\hline $108-67-8$ & \multicolumn{2}{|l|}{ 1,3,5-Trimethylbenzene } & 1 & \multicolumn{2}{|c|}{5.00} & $\mathrm{U}$ \\
\hline $142-28-9$ & \multicolumn{2}{|l|}{ 1,3-Dichloropropane } & 1 & \multicolumn{2}{|c|}{5.00} & $\mathrm{U}$ \\
\hline $590-20-7$ & \multicolumn{2}{|l|}{ 2,2-Dichloropropane } & 1 & \multicolumn{2}{|c|}{5.00} & $\mathrm{U}$ \\
\hline $95-49-8$ & \multicolumn{2}{|l|}{ 2-Chlorotoluene } & 1 & \multicolumn{2}{|c|}{5.00} & $\mathrm{U}$ \\
\hline $106-43-4$ & \multicolumn{2}{|l|}{ 4-Chlorotoluene } & 1 & \multicolumn{2}{|c|}{5.00} & $\mathrm{U}$ \\
\hline $99-87-6$ & \multicolumn{2}{|l|}{ 4-Isopropyltoluene } & 1 & & & $\mathrm{U}$ \\
\hline $108-86-1$ & Bromobenzene & & 1 & & & $\underline{U}$ \\
\hline $74-97-5$ & Bromochloromethane & & 1 & & & $\mathrm{U}$ \\
\hline $156-59-2$ & cis-1,2-Dichloroethene & & 1 & & & $\mathrm{U}$ \\
\hline $76-13-1$ & Freon-113 & & 1 & & & $\underline{U}$ \\
\hline $98-82-8$ & Isopropylbenzene & & 1 & & & $\mathrm{U}$ \\
\hline $104-51-8$ & n-Butylbenzene & & 1 & & & $\mathrm{U}$ \\
\hline $103-65-1$ & n-Propylbenzene & & 1 & & & $\mathrm{U}$ \\
\hline $135-98-8$ & sec-Butylbenzene & & 1 & & & $\mathrm{U}$ \\
\hline $98-06-6$ & tert-Butylbenzene & & 1 & & & $\mathrm{U}$ \\
\hline SYSTEM M & NITORING COMPOUND & ADDED (ug/L) & CONC (ug/L) & $\%$ REC & QC LIMITS & $\mathrm{Q}$ \\
\hline 1,2-Dichloro & hane-d4 & 50.000 & 52.4 & 105 & $64-140$ & \\
\hline Toluene-d8 & & 50.000 & 44.1 & 88 & $70-130$ & \\
\hline 4-Bromofluo & benzene & 50.000 & 55.3 & 111 & $81-115$ & \\
\hline
\end{tabular}

* Values outside of QC limits 
Project: BOA

Project Number: 60052-002-001

Reported:

Project Manager: Ted Redding
01/06/2010 15:14

\section{DRAFT: CAU 113-C1-1} 0912042-01 (Solid)

\begin{tabular}{|c|c|c|c|c|c|c|c|c|}
\hline Analyte & Result and Qualifier & $\begin{array}{l}\text { Reporting } \\
\text { Limit }\end{array}$ & Units & Dilution & Batch & Prepared & Analyzed & Method \\
\hline
\end{tabular}

Lionville Laboratory

DRAFT: Semivolatile Organic Compounds by SW846 8270C

1,2,4-Trichlorobenzene

1,2-Dichlorobenzene

1,3-Dichlorobenzene

1,4-Dichlorobenzene

2,4,5-I richlorophenol

2,4,6-Irichlorophenol

2,4-Dichlorophenol

2,4-Dimethylphenol

2,4-Dinitrophenol

2,4-Dinitrotoluene

2,6-Dinitrotoluene

2-Chloronaphthalene

2-Chlorophenol

2-Methylnaphthalene

2-Methylphenol

2-Nitroaniline

2-Nitrophenol

3,3-Dichlorobenzidine

3-Nitroaniline

4,6-Dinitro-2-methylphenol

4-Bromophenyl Phenyl Ether

4-Chloro-3-methylphenol

4-Chloroaniline

4-Chlorophenyl Phenyl Ether

4-Methylphenol

3- and/or 4-Methylphenol

4-Nitroaniline

4-Nitrophenol

Acenaphthene

Acenaphthylene

Anthracene

Benz[a]anthracene

Benzo[a] pyrene

Benzo[b] fluoranthene

Benzo[g,h,i] perylene

Benzo[k] fluoranthene

Bis(2-chloroethoxy) methane

Bis(2-chloroethyl) ether

Bis(2-chloroisopropyl) ether

\begin{tabular}{|c|c|c|}
\hline 19800 & $\mathrm{U}$ & 19800 \\
\hline 19800 & $\mathrm{U}$ & 19800 \\
\hline 19800 & $\mathrm{U}$ & 19800 \\
\hline 19800 & $\mathrm{U}$ & 19800 \\
\hline 19800 & $\mathrm{U}$ & 19800 \\
\hline 19800 & $\mathrm{U}$ & 19800 \\
\hline 19800 & $\mathrm{U}$ & 19800 \\
\hline 19800 & $\mathrm{U}$ & 19800 \\
\hline 99000 & $\mathrm{U}$ & 99000 \\
\hline 19800 & $\mathrm{U}$ & 19800 \\
\hline 19800 & $\mathrm{U}$ & 19800 \\
\hline 19800 & $\mathrm{U}$ & 19800 \\
\hline 19800 & $\mathrm{U}$ & 19800 \\
\hline 19800 & $\mathrm{U}$ & 19800 \\
\hline 19800 & $\mathrm{U}$ & 19800 \\
\hline 99000 & $\mathrm{U}$ & 99000 \\
\hline 19800 & $\mathrm{U}$ & 19800 \\
\hline 39600 & $\mathrm{U}$ & 39600 \\
\hline 99000 & $\mathrm{U}$ & 99000 \\
\hline 19800 & $\mathrm{U}$ & 19800 \\
\hline 19800 & $\mathrm{U}$ & 19800 \\
\hline 19800 & $\mathrm{U}$ & 19800 \\
\hline 19800 & $\mathrm{U}$ & 19800 \\
\hline 19800 & $\mathrm{U}$ & 19800 \\
\hline 19800 & $\mathrm{U}$ & 19800 \\
\hline 19800 & $\mathrm{U}$ & 19800 \\
\hline 99000 & U & 99000 \\
\hline 99000 & $\mathrm{U}$ & 99000 \\
\hline 19800 & $\mathrm{U}$ & 19800 \\
\hline 19800 & $\mathrm{U}$ & 19800 \\
\hline 19800 & $\mathrm{U}$ & 19800 \\
\hline 19800 & $\mathrm{U}$ & 19800 \\
\hline 19800 & $\mathrm{U}$ & 19800 \\
\hline 19800 & $\mathrm{U}$ & 19800 \\
\hline 19800 & $\mathrm{U}$ & 19800 \\
\hline 19800 & $\mathrm{U}$ & 19800 \\
\hline 19800 & $\mathrm{U}$ & 19800 \\
\hline 19800 & $\mathrm{U}$ & 19800 \\
\hline 19800 & $\mathrm{U}$ & 19800 \\
\hline
\end{tabular}

\begin{tabular}{|c|c|c|c|c|c|}
\hline ug/kg wet & 1 & 1.912182 & $12 / 22 / 2009$ & $12 / 31 / 2009$ & $8270 \mathrm{C}$ \\
\hline $\mathrm{Ig} / \mathrm{kg}$ wet & 1 & [.912182 & $12 / 22 / 2009$ & $12 / 31 / 2009$ & $8270 \mathrm{C}$ \\
\hline $\mathrm{Ig} / \mathrm{kg}$ wet & 1 & L912182 & $12 / 22 / 2009$ & $12 / 31 / 2009$ & $70 \mathrm{C}$ \\
\hline $\mathrm{g} / \mathrm{kg}$ wet & 1 & L.91 & $2 / 22 / 2009$ & $12 / 31 / 2009$ & $270 \mathrm{C}$ \\
\hline $\mathrm{g} / \mathrm{kg}$ wet & 1 & L912182 & $12 / 22 / 2009$ & $12 / 31 / 2009$ & $270 \mathrm{C}$ \\
\hline $\mathrm{g} / \mathrm{kg}$ wet & 1 & L91 & $12 / 22 / 2009$ & $12 / 31 / 2009$ & $3270 \mathrm{C}$ \\
\hline $\mathrm{g} / \mathrm{kg}$ wet & 1 & L.912182 & $12 / 22 / 2009$ & $12 / 31 / 2009$ & $270 \mathrm{C}$ \\
\hline $\mathrm{g} / \mathrm{kg}$ wet & 1 & L912182 & $12 / 22 / 2009$ & $12 / 31 / 2009$ & $270 \mathrm{C}$ \\
\hline $\mathrm{g} / \mathrm{kg}$ wet & 1 & L912182 & $12 / 22 / 2009$ & $12 / 31 / 2009$ & $3270 \mathrm{C}$ \\
\hline $\mathrm{g} / \mathrm{kg}$ wet & 1 & L.9. & $12 / 22 / 2009$ & $12 / 31 / 2009$ & $3270 \mathrm{C}$ \\
\hline $\mathrm{g} / \mathrm{kg}$ wet & 1 & L9 & $12 / 22 / 2009$ & $12 / 31 / 2009$ & $8270 \mathrm{C}$ \\
\hline $\mathrm{g} / \mathrm{kg}$ wet & 1 & L912182 & $12 / 22 / 2009$ & $12 / 31 / 2009$ & $8270 \mathrm{C}$ \\
\hline $\mathrm{g} / \mathrm{kg}$ wet & 1 & L. 912182 & $12 / 22 / 2009$ & $12 / 31 / 2009$ & $70 \mathrm{C}$ \\
\hline $\mathrm{Ig} / \mathrm{kg}$ wet & 1 & L912182 & $12 / 22 / 2009$ & $12 / 31 / 2009$ & $8270 \mathrm{C}$ \\
\hline $\mathrm{lg} / \mathrm{kg}$ wet & 1 & L.91 & $12 / 22 / 2009$ & $12 /$ & $70 \mathrm{C}$ \\
\hline $\mathrm{Ig} / \mathrm{kg}$ wet & 1 & L9 & $12 / 22 / 2009$ & $12 / 31 /$ & $8270 \mathrm{C}$ \\
\hline $\mathrm{lg} / \mathrm{kg}$ wet & 1 & L9 & $2 / 2009$ & $12 / 31 / 2$ & $8270 \mathrm{C}$ \\
\hline $\mathrm{lg} / \mathrm{kg}$ wet & 1 & & $2 / 2009$ & $12 / 31 / 2009$ & $8270 \mathrm{C}$ \\
\hline $\mathrm{gg} / \mathrm{kg}$ wet & 1 & L9 & $12 / 22 / 2009$ & $12 / 31 / 2009$ & $8270 \mathrm{C}$ \\
\hline $\mathrm{gg} / \mathrm{kg}$ wet & 1 & L912182 & $12 / 22 / 2009$ & 009 & $8270 \mathrm{C}$ \\
\hline $\mathrm{ug} / \mathrm{kg}$ wet & 1 & L91 & $12 / 22 / 2009$ & 009 & $70 \mathrm{C}$ \\
\hline $\mathrm{ug} / \mathrm{kg}$ wet & 1 & L9 & $12 / 22 / 2009$ & 09 & $0 \mathrm{C}$ \\
\hline $\mathrm{ug} / \mathrm{kg}$ wet & 1 & & 12 & 12 & $8270 \mathrm{C}$ \\
\hline $\mathrm{ug} / \mathrm{kg}$ wet & 1 & & $12 / 22 /$ & 12 & $8270 \mathrm{C}$ \\
\hline $\mathrm{ug} / \mathrm{kg}$ wet & 1 & & $12 / 22 / 2009$ & $12 / 3$ & $8270 \mathrm{C}$ \\
\hline $\mathrm{ug} / \mathrm{kg}$ wet & 1 & L9] & $12 / 22 / 2009$ & $12 / 31 / 2009$ & $8270 \mathrm{C}$ \\
\hline $\mathrm{Ig} / \mathrm{kg}$ wet & 1 & L912182 & $12 / 22 / 2009$ & $12 / 31 / 2009$ & $8270 \mathrm{C}$ \\
\hline $\mathrm{ug} / \mathrm{kg}$ wet & 1 & L912182 & $12 / 22 / 2009$ & 09 & $70 \mathrm{C}$ \\
\hline $\mathrm{ug} / \mathrm{kg}$ wet & 1 & L91 & $12 / 22 / 2009$ & $12 / 31 / 2009$ & $8270 \mathrm{C}$ \\
\hline $\mathrm{ug} / \mathrm{kg}$ wet & 1 & L91 & $12 / 22 / 2009$ & & $270 \mathrm{C}$ \\
\hline $\mathrm{ug} / \mathrm{kg}$ wet & 1 & I912182 & $12 / 22 / 2009$ & $/ 2009$ & $8270 \mathrm{C}$ \\
\hline $\mathrm{ug} / \mathrm{kg}$ wet & 1 & L.91 & $12 / 22 / 2009$ & $12 / 31 / 2009$ & $8270 \mathrm{C}$ \\
\hline $\mathrm{ug} / \mathrm{kg}$ wet & 1 & L91 & $12 / 22 / 2009$ & $12 / 31 / 2009$ & $8270 \mathrm{C}$ \\
\hline $\mathrm{ug} / \mathrm{kg}$ wet & 1 & L912182 & $12 / 22 / 2009$ & $12 / 31 / 2009$ & $8270 \mathrm{C}$ \\
\hline $\mathrm{ug} / \mathrm{kg}$ wet & 1 & L.912182 & $12 / 22 / 2009$ & $12 / 31 / 2009$ & $8270 \mathrm{C}$ \\
\hline $\mathrm{ug} / \mathrm{kg}$ wet & 1 & L.912182 & $12 / 22 / 2009$ & $12 / 31 / 2009$ & $8270 \mathrm{C}$ \\
\hline $\mathrm{ug} / \mathrm{kg}$ wet & 1 & L.912182 & $12 / 22 / 2009$ & $12 / 31 / 2009$ & $8270 \mathrm{C}$ \\
\hline $\mathrm{ug} / \mathrm{kg}$ wet & 1 & L.912182 & $12 / 22 / 2009$ & $12 / 31 / 2009$ & $8270 \mathrm{C}$ \\
\hline $\mathrm{ug} / \mathrm{kg}$ wet & 1 & L.912182 & $12 / 22 / 2009$ & $12 / 31 / 2009$ & $8270 \mathrm{C}$ \\
\hline
\end{tabular}


National Security Technologies, LLC

2621 Losee Road, Mail Stop NIS273

North Las Vegas NV, 89030
Project: $\mathrm{BOA}$

Project Number: 60052-002-001

Project Manager: Ied Redding
Reported:

01/06/2010 15:14

\section{DRAFT: CAU 113-C1-1} 0912042-01 (Solid)

\begin{tabular}{|lllllll}
\hline & & Reporting & & & \\
Analyte & Result and Qualifier & Limit & Units & Dilution & Batch & Prepared \\
\hline
\end{tabular}

\section{Lionville Laboratory}

DRAFT: Semivolatile Organic Compounds by SW846 8270C

\begin{tabular}{|c|c|c|c|c|c|c|c|c|c|}
\hline Bis(2-ethylhexyl) phthalate & 19800 & $\mathrm{U}$ & 19800 & ug/kg wet & 1 & L912182 & $12 / 22 / 2009$ & $12 / 31 / 2009$ & $8270 \mathrm{C}$ \\
\hline Butyl Benzyl Phthalate & 19800 & $\mathrm{U}$ & 19800 & $\mathrm{ug} / \mathrm{kg}$ wet & 1 & L.912182 & $12 / 22 / 2009$ & $12 / 31 / 2009$ & $8270 \mathrm{C}$ \\
\hline Chrysene & 19800 & $\mathrm{U}$ & 19800 & $\mathrm{ug} / \mathrm{kg}$ wet & 1 & L912182 & $12 / 22 / 2009$ & $12 / 31 / 2009$ & $8270 \mathrm{C}$ \\
\hline Dibenz $[a, h]$ anthracene & 19800 & $\mathrm{U}$ & 19800 & $\mathrm{ug} / \mathrm{kg}$ wet & 1 & L912182 & $12 / 22 / 2009$ & $12 / 31 / 2009$ & $8270 \mathrm{C}$ \\
\hline Dibenzofuran & 19800 & $\mathrm{U}$ & 19800 & $\mathrm{ug} / \mathrm{kg}$ wet & 1 & L912182 & $12 / 22 / 2009$ & $12 / 31 / 2009$ & $8270 \mathrm{C}$ \\
\hline Diethyl Phthalate & 19800 & $\mathrm{U}$ & 19800 & $\mathrm{ug} / \mathrm{kg}$ wet & 1 & L912182 & $12 / 22 / 2009$ & $12 / 31 / 2009$ & $8270 \mathrm{C}$ \\
\hline Dimethyl Phthalate & 19800 & $\mathrm{U}$ & 19800 & $\mathrm{ug} / \mathrm{kg}$ wet & 1 & L 912182 & $12 / 22 / 2009$ & $12 / 31 / 2009$ & $8270 \mathrm{C}$ \\
\hline Di-n-butyl Phthalate & 19800 & $\mathrm{U}$ & 19800 & $\mathrm{ug} / \mathrm{kg}$ wet & 1 & L912182 & $12 / 22 / 2009$ & $12 / 31 / 2009$ & $8270 \mathrm{C}$ \\
\hline Di-n-octyl Phthalate & 19800 & $\mathrm{U}$ & 19800 & $\mathrm{ug} / \mathrm{kg}$ wet & 1 & L912182 & $12 / 22 / 2009$ & $12 / 31 / 2009$ & $8270 \mathrm{C}$ \\
\hline Fluoranthene & 19800 & $\mathrm{U}$ & 19800 & $\mathrm{ug} / \mathrm{kg}$ wet & 1 & L.912182 & $12 / 22 / 2009$ & $12 / 31 / 2009$ & $8270 \mathrm{C}$ \\
\hline Fluorene & 19800 & $\mathrm{U}$ & 19800 & $\mathrm{ug} / \mathrm{kg}$ wet & 1 & L912182 & $12 / 22 / 2009$ & $12 / 31 / 2009$ & $8270 \mathrm{C}$ \\
\hline Hexachlorobenzene & 19800 & $\mathrm{U}$ & 19800 & $\mathrm{ug} / \mathrm{kg}$ wet & 1 & L912182 & $12 / 22 / 2009$ & $12 / 31 / 2009$ & $8270 \mathrm{C}$ \\
\hline Hexachlorobutadiene & 19800 & $\mathrm{U}$ & 19800 & $\mathrm{ug} / \mathrm{kg}$ wet & 1 & L912182 & $12 / 22 / 2009$ & $12 / 31 / 2009$ & $8270 \mathrm{C}$ \\
\hline Hexachlorocyclopentadiene & 19800 & $\mathrm{U}$ & 19800 & ug/kg wet & 1 & L912182 & $12 / 22 / 2009$ & $12 / 31 / 2009$ & $8270 \mathrm{C}$ \\
\hline Hexachloroethane & 19800 & $\mathrm{U}$ & 19800 & $\mathrm{ug} / \mathrm{kg}$ wet & 1 & L912182 & $12 / 22 / 2009$ & $12 / 31 / 2009$ & $8270 \mathrm{C}$ \\
\hline Indeno[1,2,3-cd]pyrene & 19800 & $\mathrm{U}$ & 19800 & $\mathrm{ug} / \mathrm{kg}$ wet & 1 & L.912182 & $12 / 22 / 2009$ & $12 / 31 / 2009$ & $8270 \mathrm{C}$ \\
\hline Isophorone & 19800 & $\mathrm{U}$ & 19800 & $\mathrm{ug} / \mathrm{kg}$ wet & 1 & L912182 & $12 / 22 / 2009$ & $12 / 31 / 2009$ & $8270 \mathrm{C}$ \\
\hline Naphthalene & 19800 & $\mathrm{U}$ & 19800 & ug/kg wet & 1 & L. 912182 & $12 / 22 / 2009$ & $12 / 31 / 2009$ & $8270 \mathrm{C}$ \\
\hline Nitrobenzene & 19800 & $\mathrm{U}$ & 19800 & $\mathrm{ug} / \mathrm{kg}$ wet & 1 & L912182 & $12 / 22 / 2009$ & $12 / 31 / 2009$ & $8270 \mathrm{C}$ \\
\hline N-Nitrosodi-n-propylamine & 19800 & $\mathrm{U}$ & 19800 & $\mathrm{ug} / \mathrm{kg}$ wet & 1 & L912182 & $12 / 22 / 2009$ & $12 / 31 / 2009$ & $8270 \mathrm{C}$ \\
\hline N-Nitrosodiphenylamine & 19800 & $\mathrm{U}$ & 19800 & $\mathrm{ug} / \mathrm{kg}$ wet & 1 & L912182 & $12 / 22 / 2009$ & $12 / 31 / 2009$ & $8270 \mathrm{C}$ \\
\hline Pentachlorophenol & 99000 & $\mathrm{U}$ & 99000 & $\mathrm{ug} / \mathrm{kg}$ wet & 1 & L.912182 & $12 / 22 / 2009$ & $12 / 31 / 2009$ & $8270 \mathrm{C}$ \\
\hline Phenanthrene & 19800 & $\mathrm{U}$ & 19800 & $\mathrm{ug} / \mathrm{kg}$ wet & 1 & L912182 & $12 / 22 / 2009$ & $12 / 31 / 2009$ & $8270 \mathrm{C}$ \\
\hline Phenol & 19800 & $\mathrm{U}$ & 19800 & $\mathrm{ug} / \mathrm{kg}$ wet & 1 & L912182 & $12 / 22 / 2009$ & $12 / 31 / 2009$ & $8270 \mathrm{C}$ \\
\hline Pyrene & 19800 & $\mathrm{U}$ & 19800 & $\mathrm{ug} / \mathrm{kg}$ wet & 1 & L.912182 & $12 / 22 / 2009$ & $12 / 31 / 2009$ & $8270 \mathrm{C}$ \\
\hline Benzoic Acid & 99000 & $\mathrm{U}$ & 99000 & $\mathrm{ug} / \mathrm{kg}$ wet & 1 & L912182 & $12 / 22 / 2009$ & $12 / 31 / 2009$ & $8270 \mathrm{C}$ \\
\hline Benzyl alcohol & 19800 & $\mathrm{U}$ & 19800 & $\mathrm{ug} / \mathrm{kg}$ wet & 1 & 1912182 & $12 / 22 / 2009$ & $12 / 31 / 2009$ & $8270 \mathrm{C}$ \\
\hline Tributylphosphate & 19800 & $\mathrm{U}$ & 19800 & $\mathrm{ug} / \mathrm{kg}$ wet & 1 & L912182 & $12 / 22 / 2009$ & $12 / 31 / 2009$ & $8270 \mathrm{C}$ \\
\hline Surrogate." 2-Fluorophenol & $\% *$ & $U$ & $25-121$ & & & 1912182 & $12 / 22 / 2009$ & $12 / 31 / 2009$ & $8270 \mathrm{C}$ \\
\hline Surrogate: Phenol-d5 & $\% *$ & $U$ & $24-113$ & & & $L 912182$ & $12 / 22 / 2009$ & $12 / 31 / 2009$ & $8270 \mathrm{C}$ \\
\hline Surrogate: Nitrobenzene-d.5 & $\% *$ & $U$ & $23-120$ & & & $L 912182$ & $12 / 22 / 2009$ & $12 / 31 / 2009$ & $8270 \mathrm{C}$ \\
\hline Surrogate: 2-Fluorobiphenyl & $\% *$ & $U$ & $30-115$ & & & $L 912182$ & $12 / 22 / 2009$ & $12 / 31 / 2009$ & $8270 \mathrm{C}$ \\
\hline Surrogate: 2,4 6-Tribromophenol & $\% *$ & $U$ & $19-122$ & & & $L 912182$ & $12 / 22 / 2009$ & $12 / 31 / 2009$ & $8270 \mathrm{C}$ \\
\hline Surrogate: $p$-Tierphenyl-d14 & $65 \%$ & & $18-137$ & & & $L 912182$ & $12 / 22 / 2009$ & $12 / 31 / 2009$ & $8270 \mathrm{C}$ \\
\hline
\end{tabular}


National Security Technologies, LLC

2621 Losee Road, Mail Stop NI'S273

North L as Vegas NV, 89030
Project: BOA

Project Number: 60052-002-001

Project Manager: Ied Redding
Reported:

01/06/2010 15:14

\section{DRAFT: CAU 113-C1-2} 0912042-02 (Solid)

\begin{tabular}{|llllllll}
\hline & & Reporting & & & & \\
Analyte & Result and Qualifier & Limit & Units & Dilution & Batch & Prepared \\
\hline
\end{tabular}

\section{Lionville Laboratory}

DRAFT: Semivolatile Organic Compounds by SW846 8270C

1,2,4-Trichlorobenzene

1,2-Dichlorobenzene

1,3-Dichlorobenzene

1,4-Dichlorobenzene

2,4,5-I richlorophenol

2,4,6-Irichlorophenol

2,4-Dichlorophenol

2,4-Dimethylphenol

2,4-Dinitrophenol

2,4-Dinitrotoluene

2,6-Dinitrotoluene

2-Chloronaphthalene

2-Chlorophenol

2-Methylnaphthalene

2-Methylphenol

2-Nitroaniline

2-Nitrophenol

3,3'-Dichlorobenzidine

3-Nitroaniline

4,6-Dinitro-2-methylphenol

4-Bromophenyl Phenyl Ether

4-Chloro-3-methylphenol

4-Chloroaniline

4-Chlorophenyl Phenyl Ether

4-Methylphenol

3- and/or 4-Methylphenol

4-Nitroaniline

4-Nitrophenol

Acenaphthene

Acenaphthylene

Anthracene

Benz[a]anthracene

Benzo[a] pyrene

Benzo[b] fluoranthene

Benzo[g,h,i] perylene

Benzo[k] fluoranthene

Bis(2-chloroethoxy) methane

Bis(2-chloroethyl) ether

Bis(2-chloroisopropyl) ether

\begin{tabular}{|c|c|c|}
\hline 18200 & $\mathrm{U}$ & 18200 \\
\hline 18200 & U & 18200 \\
\hline 18200 & $\mathrm{U}$ & 18200 \\
\hline 18200 & $\mathrm{U}$ & 18200 \\
\hline 18200 & $\mathrm{U}$ & 18200 \\
\hline 18200 & $\mathrm{U}$ & 18200 \\
\hline 18200 & $\mathrm{U}$ & 18200 \\
\hline 18200 & $\mathrm{U}$ & 18200 \\
\hline 90700 & $\mathrm{U}$ & 90700 \\
\hline 18200 & U & 18200 \\
\hline 18200 & $\mathrm{U}$ & 18200 \\
\hline 18200 & $\mathrm{U}$ & 18200 \\
\hline 18200 & $\mathrm{U}$ & 18200 \\
\hline 18200 & U & 18200 \\
\hline 18200 & U & 18200 \\
\hline 90700 & $\mathrm{U}$ & 90700 \\
\hline 18200 & $\mathrm{U}$ & 18200 \\
\hline 36300 & $\mathrm{U}$ & 36300 \\
\hline 90700 & $\mathrm{U}$ & 90700 \\
\hline 18200 & U & 18200 \\
\hline 18200 & $\mathrm{U}$ & 18200 \\
\hline 18200 & $\mathrm{U}$ & 18200 \\
\hline 18200 & $\mathrm{U}$ & 18200 \\
\hline 18200 & $\mathrm{U}$ & 18200 \\
\hline 18200 & $\mathrm{U}$ & 18200 \\
\hline 18200 & $\mathrm{U}$ & 18200 \\
\hline 90700 & $\mathrm{U}$ & 90700 \\
\hline 90700 & $\mathrm{U}$ & 90700 \\
\hline 18200 & $\mathrm{U}$ & 18200 \\
\hline 18200 & $\mathrm{U}$ & 18200 \\
\hline 18200 & $\mathrm{U}$ & 18200 \\
\hline 18200 & $\mathrm{U}$ & 18200 \\
\hline 18200 & $\mathrm{U}$ & 18200 \\
\hline 18200 & $\mathrm{U}$ & 18200 \\
\hline 18200 & $\mathrm{U}$ & 18200 \\
\hline 18200 & $\mathrm{U}$ & 18200 \\
\hline 18200 & $\mathrm{U}$ & 18200 \\
\hline 18200 & $\mathrm{U}$ & 18200 \\
\hline 18200 & $\mathrm{U}$ & 18200 \\
\hline
\end{tabular}

\begin{tabular}{|c|c|c|c|c|c|}
\hline $\mathrm{ug} / \mathrm{kg}$ wet & 1 & 912182 & $12 / 22 / 2009$ & $12 / 31 / 2009$ & 0270 \\
\hline $\mathrm{ug} / \mathrm{kg}$ wet & 1 & L912182 & $12 / 22 / 2009$ & $12 / 31 / 2009$ & $8270 \mathrm{C}$ \\
\hline $\mathrm{ug} / \mathrm{kg}$ wet & 1 & L.912182 & $12 / 22 / 2009$ & $2 / 31 / 2009$ & $70 \mathrm{C}$ \\
\hline $\mathrm{ug} / \mathrm{kg} \mathrm{v}$ & 1 & L9 & 009 & 09 & $0 \mathrm{C}$ \\
\hline $\mathrm{ug} / \mathrm{kg}$ wet & 1 & L912182 & $12 / 22 / 2009$ & $2 / 31 / 2009$ & $270 \mathrm{C}$ \\
\hline $\mathrm{ug} / \mathrm{kg}$ wet & 1 & L912182 & $12 / 22 / 2009$ & $12 / 31 / 2009$ & $270 \mathrm{C}$ \\
\hline $\mathrm{ug} / \mathrm{kg}$ wet & 1 & L912182 & $12 / 22 / 2009$ & $12 / 31 / 2009$ & $70 \mathrm{C}$ \\
\hline $\mathrm{ug} / \mathrm{kg}$ wet & 1 & L91 & $12 / 22 / 2009$ & $12 / 31 / 2009$ & $70 \mathrm{C}$ \\
\hline ug/kg wet & 1 & L91 & $12 / 22 / 2009$ & & $70 \mathrm{C}$ \\
\hline $\mathrm{ug} / \mathrm{kg}$ & 1 & L91 & $12 / 2$ & 09 & $70 \mathrm{C}$ \\
\hline ug/kg wet & 1 & L91 & $12 / 22 / 2009$ & $12 / 31 / 2009$ & $70 \mathrm{C}$ \\
\hline $\mathrm{ug} / \mathrm{kg}$ wet & 1 & L912182 & $12 / 22 / 2009$ & $12 / 31 / 2009$ & $8270 \mathrm{C}$ \\
\hline $\mathrm{ug} / \mathrm{kg} \mathrm{v}$ & 1 & 191 & $12 / 22 / 2009$ & $12 / 3$ & $70 \mathrm{C}$ \\
\hline ug/kg wet & 1 & L912182 & $12 / 22 / 2009$ & 009 & $70 \mathrm{C}$ \\
\hline ug/kg wet & 1 & L91 & $12 / 22 / 2009$ & $12 / 3$ & $8270 \mathrm{C}$ \\
\hline $\mathrm{ug} / \mathrm{kg}$ & 1 & L91 & $12 / 22 / 2$ & 09 & $0 \mathrm{C}$ \\
\hline $\mathrm{ug} / \mathrm{kg}$ & 1 & L9 & $12 / 2$ & 09 & $270 \mathrm{C}$ \\
\hline $\mathrm{ug} / \mathrm{kg}$ & 1 & L9 & $12 / 2$ & & $0 \mathrm{C}$ \\
\hline ug/kg wet & 1 & L9 & $12 / 2$ & $12 /$ & $70 \mathrm{C}$ \\
\hline ug/kg wet & 1 & L912 & $12 / 22 / 2009$ & $12 / 3$ & $8270 \mathrm{C}$ \\
\hline ug/kg wet & 1 & L91 & $12 / 22 / 2009$ & $12 / 3$ & $8270 \mathrm{C}$ \\
\hline $\mathrm{lg} / \mathrm{kg}$ wet & 1 & L91 & $12 / 22 / 2009$ & $12 / 3$ & $70 \mathrm{C}$ \\
\hline $\mathrm{ug} / \mathrm{kg} \mathrm{v}$ & 1 & L.9 & $12 /$ & $12 /$ & $0 \mathrm{C}$ \\
\hline $\mathrm{ug} / \mathrm{kg} \mathrm{v}$ & 1 & & & & \\
\hline $\mathrm{ug} / \mathrm{kg} \mathrm{v}$ & 1 & & 109 & 09 & \\
\hline $\mathrm{ug} / \mathrm{kg}$ wet & 1 & L91 & $12 / 22 /$ & $12 / 3$ & $8270 \mathrm{C}$ \\
\hline 1g/kg wet & 1 & L912182 & $12 / 22 / 2009$ & $12 / 31 /$ & $8270 \mathrm{C}$ \\
\hline $\mathrm{Ig} / \mathrm{kg}$ wet & 1 & 1.912182 & $12 / 22 / 2009$ & $12 / 31 / 2009$ & $8270 \mathrm{C}$ \\
\hline ug/kg wet & 1 & L91 & $12 / 22 / 2009$ & $12 / 3$ & $8270 \mathrm{C}$ \\
\hline ug/kg wet & 1 & L91 & $12 / 22 / 2009$ & 09 & $8270 \mathrm{C}$ \\
\hline $\mathrm{ug} / \mathrm{kg} \mathrm{v}$ & 1 & & $12 / 22 / 2009$ & $12 / 3$ & $0 \mathrm{C}$ \\
\hline ug/kg wet & 1 & L91 & $12 / 22 / 2009$ & $12 / 3$ & $8270 \mathrm{C}$ \\
\hline ug/kg wet & 1 & L.912 & $12 / 22 / 2009$ & $12 / 31$ & $8270 \mathrm{C}$ \\
\hline ug/kg wet & 1 & L91 & $12 / 22 / 2009$ & $12 / 31 / 2009$ & $8270 \mathrm{C}$ \\
\hline ug/kg wet & 1 & L912182 & $12 / 22 / 2009$ & $12 / 31 / 2009$ & $8270 \mathrm{C}$ \\
\hline $\mathrm{ug} / \mathrm{kg}$ wet & 1 & L912182 & $12 / 22 / 2009$ & $12 / 31 / 2009$ & $8270 \mathrm{C}$ \\
\hline ug/kg wet & 1 & 1912182 & $12 / 22 / 2009$ & $12 / 31 / 2009$ & $8270 \mathrm{C}$ \\
\hline $\mathrm{ug} / \mathrm{kg}$ wet & 1 & L912182 & $12 / 22 / 2009$ & $12 / 31 / 2009$ & $8270 \mathrm{C}$ \\
\hline $\mathrm{ug} / \mathrm{kg}$ wet & 1 & L912182 & $12 / 22 / 2009$ & $12 / 31 / 2009$ & $8270 \mathrm{C}$ \\
\hline
\end{tabular}


National Security Iechnologies, LLC

2621 Losee Road, Mail Stop NI'S273

North Las Vegas NV, 89030
Project: BOA

Project Number: 60052-002-001

Project Manager: Ied Redding
Reported:

01/06/2010 15:14

DRAFT: CAU 113-C1-2 0912042-02 (Solid)

\begin{tabular}{|lllllll}
\hline & & Reporting & & & \\
Analyte & Result and Qualifier & I imit & Units & Dilution & Batch & Prepared \\
\hline
\end{tabular}

Lionville Laboratory

DRAFT: Semivolatile Organic Compounds by SW846 8270C

\begin{tabular}{|c|c|c|c|c|c|c|c|c|c|}
\hline Bis(2-ethylhexyl) phthalate & 18200 & $\mathrm{U}$ & 18200 & $\mathrm{ug} / \mathrm{kg}$ wet & 1 & L.912182 & $12 / 22 / 2009$ & $12 / 31 / 2009$ & $8270 \mathrm{C}$ \\
\hline Butyl Benzyl Phthalate & 18200 & $\mathrm{U}$ & 18200 & $\mathrm{ug} / \mathrm{kg}$ wet & 1 & L912182 & $12 / 22 / 2009$ & $12 / 31 / 2009$ & $8270 \mathrm{C}$ \\
\hline Chrysene & 18200 & $\mathrm{U}$ & 18200 & $\mathrm{ug} / \mathrm{kg}$ wet & 1 & L912182 & $12 / 22 / 2009$ & $12 / 31 / 2009$ & $8270 \mathrm{C}$ \\
\hline Dibenz $[\mathrm{a}, \mathrm{h}]$ anthracene & 18200 & $\mathrm{U}$ & 18200 & $\mathrm{ug} / \mathrm{kg}$ wet & 1 & L912182 & $12 / 22 / 2009$ & $12 / 31 / 2009$ & $8270 \mathrm{C}$ \\
\hline Dibenzofuran & 18200 & $\mathrm{U}$ & 18200 & $\mathrm{ug} / \mathrm{kg}$ wet & 1 & L912182 & $12 / 22 / 2009$ & $12 / 31 / 2009$ & $8270 \mathrm{C}$ \\
\hline Diethyl Phthalate & 18200 & $\mathrm{U}$ & 18200 & $\mathrm{ug} / \mathrm{kg}$ wet & 1 & L912182 & $12 / 22 / 2009$ & $12 / 31 / 2009$ & $8270 \mathrm{C}$ \\
\hline Dimethyl Phthalate & 18200 & $\mathrm{U}$ & 18200 & $\mathrm{ug} / \mathrm{kg}$ wet & 1 & L912182 & $12 / 22 / 2009$ & $12 / 31 / 2009$ & $8270 \mathrm{C}$ \\
\hline Di-n-butyl Phthalate & 18200 & $\mathrm{U}$ & 18200 & $\mathrm{ug} / \mathrm{kg}$ wet & 1 & L912182 & $12 / 22 / 2009$ & $12 / 31 / 2009$ & $8270 \mathrm{C}$ \\
\hline Di-n-octyl Phthalate & 18200 & $\mathrm{U}$ & 18200 & $\mathrm{ug} / \mathrm{kg}$ wet & 1 & L912182 & $12 / 22 / 2009$ & $12 / 31 / 2009$ & $8270 \mathrm{C}$ \\
\hline Fluoranthene & 18200 & $\mathrm{U}$ & 18200 & $\mathrm{ug} / \mathrm{kg}$ wet & 1 & L912182 & $12 / 22 / 2009$ & $12 / 31 / 2009$ & $8270 \mathrm{C}$ \\
\hline Fluorene & 18200 & $\mathrm{U}$ & 18200 & ug/kg wet & 1 & L.912182 & $12 / 22 / 2009$ & $12 / 31 / 2009$ & $8270 \mathrm{C}$ \\
\hline Hexachlorobenzene & 18200 & $\mathrm{U}$ & 18200 & $\mathrm{ug} / \mathrm{kg}$ wet & 1 & L912182 & $12 / 22 / 2009$ & $12 / 31 / 2009$ & $8270 \mathrm{C}$ \\
\hline Hexachlorobutadiene & 18200 & $\mathrm{U}$ & 18200 & $\mathrm{ug} / \mathrm{kg}$ wet & 1 & L912182 & $12 / 22 / 2009$ & $12 / 31 / 2009$ & $8270 \mathrm{C}$ \\
\hline Hexachlorocyclopentadiene & 18200 & $\mathrm{U}$ & 18200 & ug/kg wet & 1 & L912182 & $12 / 22 / 2009$ & $12 / 31 / 2009$ & $8270 \mathrm{C}$ \\
\hline Hexachloroethane & 18200 & $\mathrm{U}$ & 18200 & ug/kg wet & 1 & L912182 & $12 / 22 / 2009$ & $12 / 31 / 2009$ & $8270 \mathrm{C}$ \\
\hline Indeno[1,2,3-cd]pyrene & 18200 & $\mathrm{U}$ & 18200 & $\mathrm{ug} / \mathrm{kg}$ wet & 1 & L912182 & $12 / 22 / 2009$ & $12 / 31 / 2009$ & $8270 \mathrm{C}$ \\
\hline Isophorone & 18200 & $\mathrm{U}$ & 18200 & ug/kg wet & 1 & L.912182 & $12 / 22 / 2009$ & $12 / 31 / 2009$ & $8270 \mathrm{C}$ \\
\hline Naphthalene & 18200 & $\mathrm{U}$ & 18200 & $\mathrm{ug} / \mathrm{kg}$ wet & 1 & L912182 & $12 / 22 / 2009$ & $12 / 31 / 2009$ & $8270 \mathrm{C}$ \\
\hline Nitrobenzene & 18200 & $\mathrm{U}$ & 18200 & $\mathrm{ug} / \mathrm{kg}$ wet & 1 & L912182 & $12 / 22 / 2009$ & $12 / 31 / 2009$ & $8270 \mathrm{C}$ \\
\hline N-Nitrosodi-n-propylamine & 18200 & $\mathrm{U}$ & 18200 & $\mathrm{ug} / \mathrm{kg}$ wet & 1 & 1912182 & $12 / 22 / 2009$ & $12 / 31 / 2009$ & $8270 \mathrm{C}$ \\
\hline N-Nitrosodiphenylamine & 18200 & $\mathrm{U}$ & 18200 & $\mathrm{ug} / \mathrm{kg}$ wet & 1 & L.912182 & $12 / 22 / 2009$ & $12 / 31 / 2009$ & $8270 \mathrm{C}$ \\
\hline Pentachlorophenol & 90700 & $\mathrm{U}$ & 90700 & $\mathrm{ug} / \mathrm{kg}$ wet & 1 & L912182 & $12 / 22 / 2009$ & $12 / 31 / 2009$ & $8270 \mathrm{C}$ \\
\hline Phenanthrene & 18200 & $\mathrm{U}$ & 18200 & ug/kg wet & 1 & L.912182 & $12 / 22 / 2009$ & $12 / 31 / 2009$ & $8270 \mathrm{C}$ \\
\hline Phenol & 18200 & $\mathrm{U}$ & 18200 & $\mathrm{ug} / \mathrm{kg}$ wet & 1 & L912182 & $12 / 22 / 2009$ & $12 / 31 / 2009$ & $8270 \mathrm{C}$ \\
\hline Pyrene & 18200 & $\mathrm{U}$ & 18200 & $\mathrm{ug} / \mathrm{kg}$ wet & 1 & L912182 & $12 / 22 / 2009$ & $12 / 31 / 2009$ & $8270 \mathrm{C}$ \\
\hline Benzoic Acid & 90700 & $\mathrm{U}$ & 90700 & $\mathrm{ug} / \mathrm{kg}$ wet & 1 & L912182 & $12 / 22 / 2009$ & $12 / 31 / 2009$ & $8270 \mathrm{C}$ \\
\hline Benzyl alcohol & 18200 & $\mathrm{U}$ & 18200 & $\mathrm{ug} / \mathrm{kg}$ wet & 1 & L912182 & $12 / 22 / 2009$ & $12 / 31 / 2009$ & $8270 \mathrm{C}$ \\
\hline Tributylphosphate & 18200 & $\mathrm{U}$ & 18200 & ug/kg wet & 1 & L912182 & $12 / 22 / 2009$ & $12 / 31 / 2009$ & $8270 \mathrm{C}$ \\
\hline Surrogate: 2-Fluorophenol & $\% *$ & $U$ & $25 \cdot 121$ & & & $L 912182$ & $12 / 22 / 2009$ & $12 / 31 / 2009$ & $8270 \mathrm{C}$ \\
\hline Surrogate: Phenol-d5 & $\% *$ & $U$ & $24-113$ & & & 1912182 & $12 / 22 / 2009$ & $12 / 31 / 2009$ & $8270 C$ \\
\hline Surrogate: Nitrobenzene-d5 & $\% *$ & $U$ & $2.3-120$ & & & $L 912182$ & $12 / 22 / 2009$ & $12 / 31 / 2009$ & $8270 \mathrm{C}$ \\
\hline Surrogate: 2-Fluorobiphenyl & $\% *$ & $U$ & $30-115$ & & & 1912182 & $12 / 22 / 2009$ & $12 / 31 / 2009$ & $8270 \mathrm{C}$ \\
\hline Surrogate: $2,4,6$-Tribromophenol & $\% *$ & $U$ & $19-122$ & & & $L 912182$ & $12 / 22 / 2009$ & $12 / 31 / 2009$ & $8270 \mathrm{C}$ \\
\hline Surrogate: $p$-Terphenyl-dl4 & $66 \%$ & & $18-137$ & & & $L 912182$ & $12 / 22 / 2009$ & $12 / 31 / 2009$ & $8270 \mathrm{C}$ \\
\hline
\end{tabular}


National Security Iechnologies, LIC

2621 Losee Road, Mail Stop NTS273

North L as Vegas NV, 89030
Project: BOA

Project Number: 60052-002-001

Project Manager: Ted Redding
Reported:

01/06/2010 15:14

DRAFT: CAU 113-C1-3 0912042-03 (Solid)

\begin{tabular}{|lllllll}
\hline & & Reporting & & & \\
Analyte & Result and Qualifier & Limit & Units & Dilution & Batch & Prepared \\
\hline
\end{tabular}

Lionville Laboratory

DRAFT: Semivolatile Organic Compounds by SW846 8270C

\begin{tabular}{|c|c|c|c|c|c|c|c|c|c|}
\hline 1,2,4-Trichlorobenzene & 16500 & $\mathrm{U}$ & 16500 & $\mathrm{ug} / \mathrm{kg}$ wet & 1 & L912182 & $12 / 22 / 2009$ & $12 / 31 / 2009$ & $8270 \mathrm{C}$ \\
\hline 1,2-Dichlorobenzene & 16500 & $\mathrm{U}$ & 16500 & $\mathrm{ug} / \mathrm{kg}$ wet & 1 & L912182 & $12 / 22 / 2009$ & $12 / 31 / 2009$ & $8270 \mathrm{C}$ \\
\hline 1,3-Dichlorobenzene & 16500 & $\mathrm{U}$ & 16500 & $\mathrm{ug} / \mathrm{kg}$ wet & 1 & L912182 & $12 / 22 / 2009$ & $12 / 31 / 2009$ & $8270 \mathrm{C}$ \\
\hline 1,4-Dichlorobenzene & 16500 & $\mathrm{U}$ & 16500 & ug/kg wet & 1 & L.912182 & $12 / 22 / 2009$ & $12 / 31 / 2009$ & $8270 \mathrm{C}$ \\
\hline $2,4,5$-I richlorophenol & 16500 & $U$ & 16500 & $\mathrm{ug} / \mathrm{kg}$ wet & 1 & L912182 & $12 / 22 / 2009$ & $12 / 31 / 2009$ & $8270 \mathrm{C}$ \\
\hline 2,4,6-Irichlorophenol & 16500 & $\mathrm{U}$ & 16500 & $\mathrm{ug} / \mathrm{kg}$ wet & 1 & L 912182 & $12 / 22 / 2009$ & $12 / 31 / 2009$ & $8270 \mathrm{C}$ \\
\hline 2,4-Dichlorophenol & 16500 & $\mathrm{U}$ & 16500 & $\mathrm{ug} / \mathrm{kg}$ wet & 1 & L.912182 & $12 / 22 / 2009$ & $12 / 31 / 2009$ & $8270 \mathrm{C}$ \\
\hline 2,4-Dimethylphenol & 16500 & $\mathrm{U}$ & 16500 & $\mathrm{ug} / \mathrm{kg}$ wet & 1 & L912182 & $12 / 22 / 2009$ & $12 / 31 / 2009$ & $8270 \mathrm{C}$ \\
\hline 2,4-Dinitrophenol & 82500 & $\mathrm{U}$ & 82500 & $\mathrm{ug} / \mathrm{kg}$ wet & 1 & L 912182 & $12 / 22 / 2009$ & $12 / 31 / 2009$ & $8270 \mathrm{C}$ \\
\hline 2,4-Dinitrotoluene & 16500 & $\mathrm{U}$ & 16500 & $\mathrm{ug} / \mathrm{kg}$ wet & 1 & L912182 & $12 / 22 / 2009$ & $12 / 31 / 2009$ & $8270 \mathrm{C}$ \\
\hline 2,6-Dinitrotoluene & 16500 & $\mathrm{U}$ & 16500 & $\mathrm{ug} / \mathrm{kg}$ wet & 1 & L912182 & $12 / 22 / 2009$ & $12 / 31 / 2009$ & $8270 \mathrm{C}$ \\
\hline 2-Chloronaphthalene & 16500 & $\mathrm{U}$ & 16500 & $\mathrm{ug} / \mathrm{kg}$ wet & 1 & L.912182 & $12 / 22 / 2009$ & $12 / 31 / 2009$ & $8270 \mathrm{C}$ \\
\hline 2-Chlorophenol & 16500 & $\mathrm{U}$ & 16500 & ug/kg wet & 1 & L912182 & $12 / 22 / 2009$ & $12 / 31 / 2009$ & $8270 \mathrm{C}$ \\
\hline 2-Methylnaphthalene & 16500 & $\mathrm{U}$ & 16500 & ug/kg wet & 1 & L912182 & $12 / 22 / 2009$ & $12 / 31 / 2009$ & $8270 \mathrm{C}$ \\
\hline 2-Methylphenol & 16500 & $\mathrm{U}$ & 16500 & ug/kg wet & 1 & L.912182 & $12 / 22 / 2009$ & $12 / 31 / 2009$ & $8270 \mathrm{C}$ \\
\hline 2-Nitroaniline & 82500 & $\mathrm{U}$ & 82500 & $\mathrm{ug} / \mathrm{kg}$ wet & 1 & L912182 & $12 / 22 / 2009$ & $12 / 31 / 2009$ & $8270 \mathrm{C}$ \\
\hline 2-Nitrophenol & 16500 & $\mathrm{U}$ & 16500 & $\mathrm{ug} / \mathrm{kg}$ wet & 1 & L912182 & $12 / 22 / 2009$ & $12 / 31 / 2009$ & $8270 \mathrm{C}$ \\
\hline 3,3'-Dichlorobenzidine & 33000 & $\mathrm{U}$ & 33000 & $\mathrm{ug} / \mathrm{kg}$ wet & 1 & L912182 & $12 / 22 / 2009$ & $12 / 31 / 2009$ & $8270 \mathrm{C}$ \\
\hline 3-Nitroaniline & 82500 & $\mathrm{U}$ & 82500 & $\mathrm{ug} / \mathrm{kg}$ wet & 1 & 1912182 & $12 / 22 / 2009$ & $12 / 31 / 2009$ & $8270 \mathrm{C}$ \\
\hline 4,6-Dinitro-2-methylphenol & 16500 & $\mathrm{U}$ & 16500 & $\mathrm{ug} / \mathrm{kg}$ wet & 1 & L912182 & $12 / 22 / 2009$ & $12 / 31 / 2009$ & $8270 \mathrm{C}$ \\
\hline 4-Bromophenyl Phenyl Ether & 16500 & $\mathrm{U}$ & 16500 & $\mathrm{ug} / \mathrm{kg}$ wet & 1 & L912182 & $12 / 22 / 2009$ & $12 / 31 / 2009$ & $8270 \mathrm{C}$ \\
\hline 4-Chloro-3-methylphenol & 16500 & $\mathrm{U}$ & 16500 & $\mathrm{ug} / \mathrm{kg}$ wet & 1 & L912182 & $12 / 22 / 2009$ & $12 / 31 / 2009$ & $8270 \mathrm{C}$ \\
\hline 4-Chloroaniline & 16500 & $\mathrm{U}$ & 16500 & ug/kg wet & 1 & L912182 & $12 / 22 / 2009$ & $12 / 31 / 2009$ & $8270 \mathrm{C}$ \\
\hline 4-Chlorophenyl Phenyl Ether & 16500 & $\mathrm{U}$ & 16500 & ug/kg wet & 1 & L.912182 & $12 / 22 / 2009$ & $12 / 31 / 2009$ & $8270 \mathrm{C}$ \\
\hline 3- and/or 4-Methylphenol & 16500 & $U$ & 16500 & $\mathrm{ug} / \mathrm{kg}$ wet & 1 & L912182 & $12 / 22 / 2009$ & $12 / 31 / 2009$ & $8270 \mathrm{C}$ \\
\hline 4-Methylphenol & 16500 & $\mathrm{U}$ & 16500 & $\mathrm{ug} / \mathrm{kg}$ wet & 1 & L.912182 & $12 / 22 / 2009$ & $12 / 31 / 2009$ & $8270 \mathrm{C}$ \\
\hline 4-Nitroaniline & 82500 & $\mathrm{U}$ & 82500 & $\mathrm{ug} / \mathrm{kg}$ wet & 1 & L912182 & $12 / 22 / 2009$ & $12 / 31 / 2009$ & $8270 \mathrm{C}$ \\
\hline 4-Nitrophenol & 82500 & $\mathrm{U}$ & 82500 & $\mathrm{ug} / \mathrm{kg}$ wet & 1 & L912182 & $12 / 22 / 2009$ & $12 / 31 / 2009$ & $8270 \mathrm{C}$ \\
\hline Acenaphthene & 16500 & $\mathrm{U}$ & 16500 & ug/kg wet & 1 & L912182 & $12 / 22 / 2009$ & $12 / 31 / 2009$ & $8270 \mathrm{C}$ \\
\hline Acenaphthylene & 16500 & $\mathrm{U}$ & 16500 & $\mathrm{ug} / \mathrm{kg}$ wet & 1 & L.912182 & $12 / 22 / 2009$ & $12 / 31 / 2009$ & $8270 \mathrm{C}$ \\
\hline Anthracene & 16500 & $\mathrm{U}$ & 16500 & $\mathrm{ug} / \mathrm{kg}$ wet & 1 & [.912182 & $12 / 22 / 2009$ & $12 / 31 / 2009$ & $8270 \mathrm{C}$ \\
\hline Benz[a]anthracene & 16500 & $\mathrm{U}$ & 16500 & ug/kg wet & 1 & L 912182 & $12 / 22 / 2009$ & $12 / 31 / 2009$ & $8270 \mathrm{C}$ \\
\hline Benzo[a] pyrene & 16500 & $\mathrm{U}$ & 16500 & ug/kg wet & 1 & L912182 & $12 / 22 / 2009$ & $12 / 31 / 2009$ & $8270 \mathrm{C}$ \\
\hline Benzo[b] fluoranthene & 16500 & $\mathrm{U}$ & 16500 & $\mathrm{ug} / \mathrm{kg}$ wet & 1 & L.912182 & $12 / 22 / 2009$ & $12 / 31 / 2009$ & $8270 \mathrm{C}$ \\
\hline Benzo[g,h,i] perylene & 16500 & $\mathrm{U}$ & 16500 & $\mathrm{ug} / \mathrm{kg}$ wet & 1 & L.912182 & $12 / 22 / 2009$ & $12 / 31 / 2009$ & $8270 \mathrm{C}$ \\
\hline Benzo[k] fluoranthene & 16500 & $\mathrm{U}$ & 16500 & ug/kg wet & 1 & L912182 & $12 / 22 / 2009$ & $12 / 31 / 2009$ & $8270 \mathrm{C}$ \\
\hline Bis(2-chloroethoxy) methane & 16500 & $\mathrm{U}$ & 16500 & $\mathrm{ug} / \mathrm{kg}$ wet & 1 & L.912182 & $12 / 22 / 2009$ & $12 / 31 / 2009$ & $8270 \mathrm{C}$ \\
\hline Bis(2-chloroethyl) ether & 16500 & $\mathrm{U}$ & 16500 & $\mathrm{ug} / \mathrm{kg}$ wet & 1 & 1.912182 & $12 / 22 / 2009$ & $12 / 31 / 2009$ & $8270 \mathrm{C}$ \\
\hline Bis(2-chloroisopropyl) ether & 16500 & $\mathrm{U}$ & 16500 & $\mathrm{ug} / \mathrm{kg}$ wet & 1 & L912182 & $12 / 22 / 2009$ & $12 / 31 / 2009$ & $8270 \mathrm{C}$ \\
\hline
\end{tabular}


National Security Iechnologies, LLC

2621 Losee Road, Mail Stop NT'S273

North Las Vegas NV, 89030
Project: $\mathrm{BOA}$

Project Number: 60052-002-001

Reported:

Project Manager: Ied Redding
01/06/2010 15:14

\section{DRAFT: CAU 113-C1-3} 0912042-03 (Solid)

\begin{tabular}{|llllllll}
\hline & & Reporting & & & & \\
Analyte & Result and Qualifier & Limit & Units & Dilution & Batch & Prepared & Analyzed \\
\hline
\end{tabular}

Lionville Laboratory

DRAFT: Semivolatile Organic Compounds by SW846 8270C

\begin{tabular}{|c|c|c|c|}
\hline Bis(2-ethylhexyl) phthalate & 16500 & $\mathrm{U}$ & 16500 \\
\hline Butyl Benzyl Phthalate & 16500 & $\mathrm{U}$ & 16500 \\
\hline Chrysene & 16500 & $\mathrm{U}$ & 16500 \\
\hline Dibenz $[\mathrm{a}, \mathrm{h}]$ anthracene & 16500 & $\mathrm{U}$ & 16500 \\
\hline Dibenzofuran & 16500 & $\mathrm{U}$ & 16500 \\
\hline Diethyl Phthalate & 16500 & $\mathrm{U}$ & 16500 \\
\hline Dimethyl Phthalate & 16500 & $\mathrm{U}$ & 16500 \\
\hline Di-n-butyl Phthalate & 16500 & $\mathrm{U}$ & 16500 \\
\hline Di-n-octyl Phthalate & 16500 & $\mathrm{U}$ & 16500 \\
\hline Fluoranthene & 16500 & $\mathrm{U}$ & 16500 \\
\hline Fluorene & 16500 & $\mathrm{U}$ & 16500 \\
\hline Hexachlorobenzene & 16500 & $\mathrm{U}$ & 16500 \\
\hline Hexachlorobutadiene & 16500 & $\mathrm{U}$ & 16500 \\
\hline Hexachlorocyclopentadiene & 16500 & $\mathrm{U}$ & 16500 \\
\hline Hexachloroethane & 16500 & $\mathrm{U}$ & 16500 \\
\hline Indeno[1,2,3-cd]pyrene & 16500 & $\mathrm{U}$ & 16500 \\
\hline Isophorone & 16500 & $\mathrm{U}$ & 16500 \\
\hline Naphthalene & 16500 & $\mathrm{U}$ & 16500 \\
\hline Nitrobenzene & 16500 & $\mathrm{U}$ & 16500 \\
\hline N-Nitrosodi-n-propylamine & 16500 & $\mathrm{U}$ & 16500 \\
\hline N-Nitrosodiphenylamine & 16500 & $\mathbf{U}$ & 16500 \\
\hline Pentachlorophenol & 82500 & $\mathrm{U}$ & 82500 \\
\hline Phenanthrene & 16500 & $\mathrm{U}$ & 16500 \\
\hline Phenol & 16500 & $\mathrm{U}$ & 16500 \\
\hline Pyrene & 16500 & $\mathrm{U}$ & 16500 \\
\hline Benzoic Acid & 82500 & $\mathrm{U}$ & 82500 \\
\hline Benzyl alcohol & 16500 & $\mathrm{U}$ & 16500 \\
\hline Tributylphosphate & 16500 & $\mathrm{U}$ & 16500 \\
\hline Surrogate: 2-Fluorophenol & $\% *$ & $U$ & $25-121$ \\
\hline Surrogate: Phenol-d5 & $\% *$ & $U$ & $24-113$ \\
\hline Surrogate: Nitrobenzene-d.5 & $\% *$ & $U$ & $23-120$ \\
\hline Surrogate: 2-Fluorobiphenyl & $\% *$ & $U$ & $30-115$ \\
\hline Surrogate: 2,4,6-Tribromophenol & $\% *$ & $U$ & $19-122$ \\
\hline Surrogate: $p$-Terphenyl-d14 & $55 \%$ & & $18-1.37$ \\
\hline
\end{tabular}

\begin{tabular}{|c|c|c|c|c|c|}
\hline $\mathrm{ug} / \mathrm{kg}$ wet & 1 & L.912182 & $12 / 22 / 2009$ & $12 / 31 / 2009$ & $8270 \mathrm{C}$ \\
\hline $\mathrm{ug} / \mathrm{kg}$ wet & 1 & L912182 & $12 / 22 / 2009$ & $12 / 31 / 2009$ & $8270 \mathrm{C}$ \\
\hline ug/kg wet & 1 & L912182 & $12 / 22 / 2009$ & $12 / 31 / 2009$ & $270 \mathrm{C}$ \\
\hline $\mathrm{ug} / \mathrm{kg}$ wet & 1 & L.912182 & $12 / 22 / 2009$ & $12 / 31 / 2009$ & $270 \mathrm{C}$ \\
\hline $\mathrm{ug} / \mathrm{kg}$ wet & 1 & L912182 & $12 / 22 / 2009$ & $12 / 31 / 2009$ & $8270 \mathrm{C}$ \\
\hline $\mathrm{ug} / \mathrm{kg}$ wet & 1 & L.912182 & $12 / 22 / 2009$ & $12 / 31 / 2009$ & $270 \mathrm{C}$ \\
\hline $\mathrm{ug} / \mathrm{kg}$ wet & 1 & L912182 & $12 / 22 / 2009$ & $12 / 31 / 2009$ & $270 \mathrm{C}$ \\
\hline $\mathrm{ug} / \mathrm{kg}$ wet & 1 & L912182 & $12 / 22 / 2009$ & $12 / 31 / 2009$ & $270 \mathrm{C}$ \\
\hline $\mathrm{ug} / \mathrm{kg}$ wet & 1 & L912182 & $12 / 22 / 2009$ & $12 / 31 / 2009$ & $8270 \mathrm{C}$ \\
\hline ug/kg wet & 1 & L912182 & $12 / 22 / 2009$ & $12 / 31 / 2009$ & $270 \mathrm{C}$ \\
\hline ug/kg wet & 1 & L912182 & $12 / 22 / 2009$ & $12 / 31 / 2009$ & $70 \mathrm{C}$ \\
\hline ug/kg wet & 1 & L912182 & $12 / 22 / 2009$ & $12 / 3$ & $270 \mathrm{C}$ \\
\hline ug/kg wet & 1 & L912182 & $12 / 22 / 2009$ & $12 / 31 / 2009$ & $8270 \mathrm{C}$ \\
\hline $\mathrm{ug} / \mathrm{kg}$ wet & 1 & L912182 & $12 / 22 / 2009$ & $12 / 31$ & $70 \mathrm{C}$ \\
\hline $\mathrm{gg} / \mathrm{kg}$ wet & 1 & L.91 & $12 / 22 / 2009$ & $12 / 31 / 2009$ & $8270 \mathrm{C}$ \\
\hline $\mathrm{lg} / \mathrm{kg}$ wet & 1 & 1.91 & $12 / 22 / 2$ & $12 / 3$ & $0 \mathrm{C}$ \\
\hline $\mathrm{ug} / \mathrm{kg}$ wet & 1 & L.91 & $12 / 22 / 2009$ & $12 / 3$ & $30 \mathrm{C}$ \\
\hline ug/kg wet & 1 & L912182 & $12 / 22 / 2009$ & $12 / 31 / 2009$ & $8270 \mathrm{C}$ \\
\hline $\mathrm{ug} / \mathrm{kg}$ wet & 1 & L.912182 & $12 / 22 / 2009$ & $12 / 31 / 2009$ & $8270 \mathrm{C}$ \\
\hline $\mathrm{ug} / \mathrm{kg}$ wet & 1 & L.912182 & $12 / 22 / 2009$ & $12 / 31 / 2009$ & $8270 \mathrm{C}$ \\
\hline $\mathrm{lg} / \mathrm{kg}$ wet & 1 & L912182 & $12 / 22 / 2009$ & $12 / 3$ & $0 \mathrm{C}$ \\
\hline $\mathrm{ug} / \mathrm{kg}$ wet & 1 & L91 & $12 / 22 / 2009$ & $12 / 31 / 2$ & $8270 \mathrm{C}$ \\
\hline $\mathrm{ug} / \mathrm{kg}$ wet & 1 & & $12 / 22 / 2009$ & $12 / 31 / 2009$ & $8270 \mathrm{C}$ \\
\hline $\mathrm{ug} / \mathrm{kg}$ wet & 1 & L912 & $12 / 22 / 2009$ & $12 / 31 / 2009$ & $8270 \mathrm{C}$ \\
\hline $\mathrm{ug} / \mathrm{kg}$ wet & 1 & L912182 & $12 / 22 / 2009$ & $12 / 31 / 2009$ & $8270 \mathrm{C}$ \\
\hline ug/kg wet & 1 & L912182 & $12 / 22 / 2009$ & $12 / 31 / 2009$ & $8270 \mathrm{C}$ \\
\hline $\mathrm{ug} / \mathrm{kg}$ wet & 1 & L912182 & $12 / 22 / 2009$ & $12 / 31 / 2009$ & $8270 \mathrm{C}$ \\
\hline \multirow[t]{7}{*}{$\mathrm{ug} / \mathrm{kg}$ wet } & 1 & L912182 & $12 / 22 / 2009$ & $12 / 31 / 2009$ & $8270 \mathrm{C}$ \\
\hline & & $L 912182$ & $12 / 22 / 2009$ & $12 / 31 / 2009$ & $8270 \mathrm{C}$ \\
\hline & & $L .912182$ & $12 / 22 / 2009$ & $12 / 31 / 2009$ & $8270 C$ \\
\hline & & $L 912182$ & $12 / 22 / 2009$ & $12 / 31 / 2009$ & $8270 \mathrm{C}$ \\
\hline & & L912182 & $12 / 22 / 2009$ & $12 / 31 / 2009$ & $8270 C$ \\
\hline & & $L 912182$ & $12 / 22 / 2009$ & $12 / 31 / 2009$ & $8270 C$ \\
\hline & & $L 912182$ & $12 / 22 / 2009$ & $12 / 31 / 2009$ & $8270 C$ \\
\hline
\end{tabular}


National Security Iechnologies, LL.C

2621 Losee Road, Mail Stop NIS273

North Las Vegas NV, 89030
Project: $\mathrm{BOA}$

Project Number: 60052-002-001

Project Manager: Ied Redding
Reported:

01/06/2010 15:14

DRAFT: CAU 113-C1-4 0912042-04 (Solid)

\begin{tabular}{|llllllll}
\hline & & Reporting & & & & & \\
Analyte & Result and Qualifier & Iimit & Units & Dilution & Batch & Prepared \\
\hline
\end{tabular}

Lionville Laboratory

DRAFT: Semivolatile Organic Compounds by SW846 8270C

1,2,4-Trichlorobenzene

1,2-Dichlorobenzene

1,3-Dichlorobenzene

1,4-Dichlorobenzene

2,4,5-I richlorophenol

2,4,6-Irichlorophenol

2,4-Dichlorophenol

2,4-Dimethylphenol

2,4-Dinitrophenol

2,4-Dinitrotoluene

2,6-Dinitrotoluene

2-Chloronaphthalene

2-Chlorophenol

2-Methylnaphthalene

2-Methylphenol

2-Nitroaniline

2-Nitrophenol

3,3'-Dichlorobenzidine

3-Nitroaniline

4,6-Dinitro-2-methylphenol

4-Bromophenyl Phenyl Ether

4-Chloro-3-methylphenol

4-Chloroaniline

4-Chlorophenyl Phenyl Ether

4-Methylphenol

3- and/or 4-Methylphenol

4-Nitroaniline

4-Nitrophenol

Acenaphthene

Acenaphthylene

Anthracene

Benz[a]anthracene

Benzo[a] pyrene

Benzo[b] fluoranthene

Benzo[g,h,i] perylene

Benzo[k] fluoranthene

Bis(2-chloroethoxy) methane

Bis(2-chloroethyl) ether

Bis(2-chloroisopropyl) ether

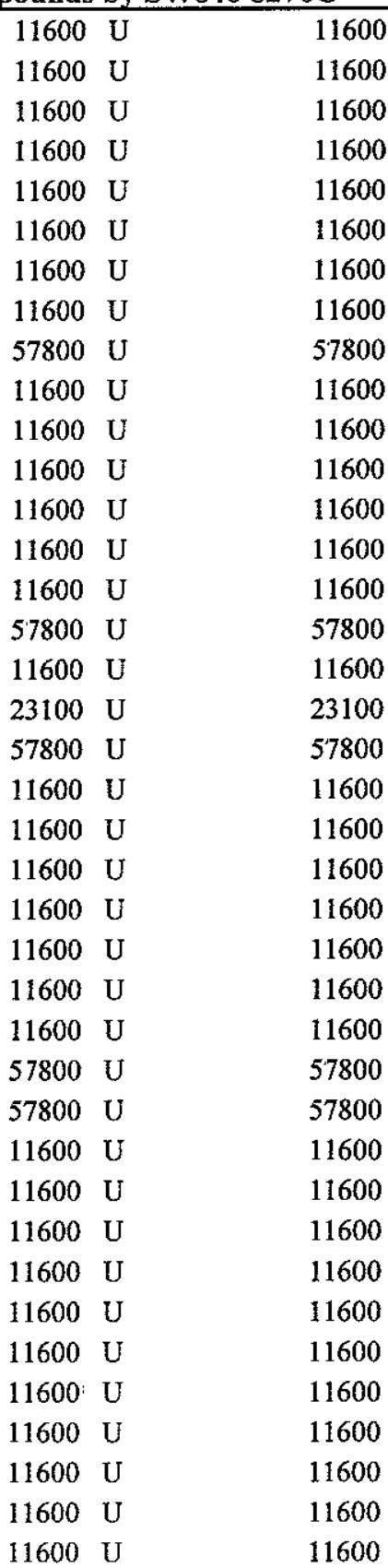

\begin{tabular}{|c|c|c|c|c|c|}
\hline $\mathrm{ug} / \mathrm{kg}$ wet & 1 & L.912182 & $12 / 22 / 2009$ & $12 / 31 / 2009$ & $8270 \mathrm{C}$ \\
\hline $\mathrm{Ig} / \mathrm{kg}$ wet & 1 & L912182 & $12 / 22 / 2009$ & $12 / 31 / 2009$ & $8270 \mathrm{C}$ \\
\hline $\mathrm{g} / \mathrm{kg}$ wet & 1 & L912182 & $12 / 22 / 2009$ & $12 / 31 / 2009$ & $270 \mathrm{C}$ \\
\hline $\mathrm{Ig} / \mathrm{kg}$ wet & 1 & L912182 & $12 / 22 / 2009$ & $12 / 31 / 2009$ & $8270 \mathrm{C}$ \\
\hline $\mathrm{lg} / \mathrm{kg}$ wet & 1 & L912182 & $12 / 22 / 2009$ & $12 / 31 / 2009$ & $8270 \mathrm{C}$ \\
\hline $\mathrm{Ig} / \mathrm{kg}$ wet & 1 & L912182 & $12 / 22 / 2009$ & $12 / 31 / 2009$ & $8270 \mathrm{C}$ \\
\hline $\mathrm{lg} / \mathrm{kg}$ wet & 1 & L.912182 & $12 / 22 / 2009$ & $12 / 31 / 2009$ & $8270 \mathrm{C}$ \\
\hline $\mathrm{Ig} / \mathrm{kg}$ wet & 1 & 1912182 & $12 / 22 / 2009$ & $12 / 31 / 2009$ & $70 \mathrm{C}$ \\
\hline $\mathrm{lg} / \mathrm{kg}$ wet & 1 & L912182 & $12 / 22 / 2009$ & $12 / 31 / 2009$ & $3270 \mathrm{C}$ \\
\hline $\mathrm{g} / \mathrm{kg}$ wet & 1 & L912182 & $12 / 22 / 2009$ & $12 / 31 / 2009$ & $8270 \mathrm{C}$ \\
\hline $\mathrm{g} / \mathrm{kg}$ wet & 1 & L912182 & $12 / 22 / 2009$ & $12 / 31 / 2009$ & $8270 \mathrm{C}$ \\
\hline $\mathrm{g} / \mathrm{kg}$ wet & 1 & L912182 & $12 / 22 / 2009$ & $12 / 31 / 2009$ & $8270 \mathrm{C}$ \\
\hline $\mathrm{dg} / \mathrm{kg}$ wet & 1 & L912182 & $12 / 22 / 2009$ & $12 / 31 / 2009$ & $70 \mathrm{C}$ \\
\hline $\mathrm{ug} / \mathrm{kg}$ wet & 1 & L912182 & $12 / 22 / 2009$ & $12 / 31 / 2009$ & $8270 \mathrm{C}$ \\
\hline $1 \mathrm{~g} / \mathrm{kg}$ wet & 1 & 191 & $12 / 22 / 2009$ & $12 / 31$ & $270 \mathrm{C}$ \\
\hline $\mathrm{lg} / \mathrm{kg}$ wet & 1 & L91 & $12 / 22 / 2009$ & $12 / 31 / 2009$ & $8270 \mathrm{C}$ \\
\hline $\mathrm{Ig} / \mathrm{kg}$ wet & 1 & 1.91 & $12 / 22 / 2009$ & $12 / 31 / 2$ & $8270 \mathrm{C}$ \\
\hline $1 \mathrm{~g} / \mathrm{kg}$ wet & 1 & L91 & $12 / 22 / 2009$ & $12 / 31 / 2009$ & $8270 \mathrm{C}$ \\
\hline $\mathrm{lg} / \mathrm{kg}$ wet & 1 & L912182 & $12 / 22 / 2009$ & $12 / 31 / 2009$ & $8270 \mathrm{C}$ \\
\hline $1 \mathrm{~g} / \mathrm{kg}$ wet & 1 & L912182 & $12 / 22 / 2009$ & $12 / 31 / 2009$ & $8270 \mathrm{C}$ \\
\hline $1 \mathrm{~g} / \mathrm{kg}$ wet & 1 & L.91 & $12 / 22 / 2009$ & $12 / 31$ & $8270 \mathrm{C}$ \\
\hline $\mathrm{Ig} / \mathrm{kg}$ wet & 1 & L9) & $12 / 2$ & 09 & \\
\hline $\mathrm{g} / \mathrm{kg}$ wet & 1 & & $12 / 22 /$ & $12 / 31$ & DC \\
\hline $\mathrm{g} / \mathrm{kg}$ wet & 1 & 182 & $12 / 22 / 2009$ & $12 / 31 / 2009$ & $8270 \mathrm{C}$ \\
\hline $\mathrm{Lg} / \mathrm{kg}$ wet & 1 & L912182 & $12 / 22 / 2009$ & $12 / 31 / 2009$ & $8270 \mathrm{C}$ \\
\hline ug/kg wet & 1 & L912182 & $12 / 22 / 2009$ & $12 / 31 / 2009$ & $8270 \mathrm{C}$ \\
\hline ug/kg wet & 1 & L912182 & $12 / 22 / 2009$ & $12 / 31 / 2009$ & $8270 \mathrm{C}$ \\
\hline $\mathrm{ug} / \mathrm{kg}$ wet & 1 & L91 & $12 / 22 / 2009$ & $12 / 31 / 2009$ & $8270 \mathrm{C}$ \\
\hline $\mathrm{ug} / \mathrm{kg}$ wet & 1 & L91 & $12 / 22 / 2$ & $12 / 31 / 2009$ & \\
\hline $\mathrm{ug} / \mathrm{kg}$ wet & 1 & 1912 & $12 / 22 / 2009$ & $12 / 31 / 2009$ & $8270 \mathrm{C}$ \\
\hline ug $/ \mathrm{kg}$ wet & 1 & L.912182 & $12 / 22 / 2009$ & $12 / 31 / 2009$ & $8270 \mathrm{C}$ \\
\hline $\mathrm{ug} / \mathrm{kg}$ wet & 1 & L912182 & $12 / 22 / 2009$ & $12 / 31 / 2009$ & $8270 \mathrm{C}$ \\
\hline $\mathrm{ug} / \mathrm{kg}$ wet & 1 & L912182 & $12 / 22 / 2009$ & $12 / 31 / 2009$ & $8270 \mathrm{C}$ \\
\hline $\mathrm{ug} / \mathrm{kg}$ wet & 1 & L912182 & $12 / 22 / 2009$ & $12 / 31 / 2009$ & $8270 \mathrm{C}$ \\
\hline $\mathrm{ug} / \mathrm{kg}$ wet & 1 & L912182 & $12 / 22 / 2009$ & $12 / 31 / 2009$ & $8270 \mathrm{C}$ \\
\hline $\mathrm{ug} / \mathrm{kg}$ wet & 1 & L.912182 & $12 / 22 / 2009$ & $12 / 31 / 2009$ & $8270 \mathrm{C}$ \\
\hline $\mathrm{ug} / \mathrm{kg}$ wet & 1 & L912182 & $12 / 22 / 2009$ & $12 / 31 / 2009$ & $8270 \mathrm{C}$ \\
\hline $\mathrm{ug} / \mathrm{kg}$ wet & 1 & L.912182 & $12 / 22 / 2009$ & $12 / 31 / 2009$ & $8270 \mathrm{C}$ \\
\hline $\mathrm{g} / \mathrm{kg}$ wet & 1 & L912182 & $12 / 22 / 2009$ & $12 / 31 / 2009$ & $8270 \mathrm{C}$ \\
\hline
\end{tabular}


National Security Iechnologies, ILC

2621 Losee Road, Mail Stop NTS273

North Las Vegas NV, 89030
Project: $\mathrm{BOA}$

Project Number: 60052-002-001

Project Manager: Ted Redding
Reported:

01/06/2010 15:14

DRAFT: CAU 113-C1-4 0912042-04 (Solid)

\begin{tabular}{|c|c|c|c|c|c|c|c|c|}
\hline Analyte & Result and Qualifier & $\begin{array}{l}\text { Reporting } \\
\text { Limit }\end{array}$ & Units & Dilution & Batch & Prepared & Analyzed & Method \\
\hline
\end{tabular}

Lionville Laboratory

DRAFT: Semivolatile Organic Compounds by SW846 8270C

\begin{tabular}{|c|c|c|c|c|c|c|c|c|c|}
\hline Bis(2-ethylhexyl) phthalate & 11600 & $\mathrm{U}$ & 11600 & ug/kg wet & 1 & L912182 & $12 / 22 / 2009$ & $12 / 31 / 2009$ & $8270 \mathrm{C}$ \\
\hline Butyl Benzyl Phthalate & 11600 & $\mathrm{U}$ & 11600 & ug/kg wet & 1 & L912182 & $12 / 22 / 2009$ & $12 / 31 / 2009$ & $8270 \mathrm{C}$ \\
\hline Chrysene & 11600 & $\mathrm{U}$ & 11600 & $\mathrm{ug} / \mathrm{kg}$ wet & 1 & L.912182 & $12 / 22 / 2009$ & $12 / 31 / 2009$ & $8270 \mathrm{C}$ \\
\hline Dibenz $[\mathrm{a}, \mathrm{h}]$ anthracene & 11600 & $\mathrm{U}$ & 11600 & $\mathrm{ug} / \mathrm{kg}$ wet & 1 & L912182 & $12 / 22 / 2009$ & $12 / 31 / 2009$ & $8270 \mathrm{C}$ \\
\hline Dibenzofuran & 11600 & $\mathrm{U}$ & 11600 & $\mathrm{ug} / \mathrm{kg}$ wet & 1 & L.912182 & $12 / 22 / 2009$ & $12 / 31 / 2009$ & $8270 \mathrm{C}$ \\
\hline Diethyl Phthalate & 11600 & $\mathrm{U}$ & 11600 & $\mathrm{ug} / \mathrm{kg}$ wet & 1 & L912182 & $12 / 22 / 2009$ & $12 / 31 / 2009$ & $8270 \mathrm{C}$ \\
\hline Dimethyl Phthalate & 11600 & $\mathrm{U}$ & 11600 & ug/kg wet & 1 & L912182 & $12 / 22 / 2009$ & $12 / 31 / 2009$ & $8270 \mathrm{C}$ \\
\hline Di-n-butyl Phthalate & 11600 & $\mathrm{U}$ & 11600 & $\mathrm{ug} / \mathrm{kg}$ wet & 1 & L.912182 & $12 / 22 / 2009$ & $12 / 31 / 2009$ & $8270 \mathrm{C}$ \\
\hline Di-n-octyl Phthalate & 11600 & $\mathrm{U}$ & 11600 & $\mathrm{ug} / \mathrm{kg}$ wet & 1 & L912182 & $12 / 22 / 2009$ & $12 / 31 / 2009$ & $8270 \mathrm{C}$ \\
\hline Fluoranthene & 11600 & $\mathrm{U}$ & 11600 & $\mathrm{ug} / \mathrm{kg}$ wet & 1 & L912182 & $12 / 22 / 2009$ & $12 / 31 / 2009$ & $8270 \mathrm{C}$ \\
\hline Fluorene & 11600 & $\mathrm{U}$ & 11600 & $\mathrm{ug} / \mathrm{kg}$ wet & 1 & L912182 & $12 / 22 / 2009$ & $12 / 31 / 2009$ & $8270 \mathrm{C}$ \\
\hline Hexachlorobenzene & 11600 & $\mathrm{U}$ & 11600 & ug/kg wet & 1 & L912182 & $12 / 22 / 2009$ & $12 / 31 / 2009$ & $8270 \mathrm{C}$ \\
\hline Hexachlorobutadiene & 11600 & $\mathrm{U}$ & 11600 & $\mathrm{ug} / \mathrm{kg}$ wet & 1 & L912182 & $12 / 22 / 2009$ & $12 / 31 / 2009$ & $8270 \mathrm{C}$ \\
\hline Hexachlorocyclopentadiene & 11600 & $\mathrm{U}$ & 11600 & $\mathrm{ug} / \mathrm{kg}$ wet & 1 & L912182 & $12 / 22 / 2009$ & $12 / 31 / 2009$ & $8270 \mathrm{C}$ \\
\hline Hexachloroethane & 11600 & $\mathrm{U}$ & 11600 & $\mathrm{ug} / \mathrm{kg}$ wet & 1 & L912182 & $12 / 22 / 2009$ & $12 / 31 / 2009$ & $8270 \mathrm{C}$ \\
\hline Indeno[ $[1,2,3-c d] p y r e n e$ & 11600 & $\mathrm{U}$ & 11600 & $\mathrm{ug} / \mathrm{kg}$ wet & 1 & 1912182 & $12 / 22 / 2009$ & $12 / 31 / 2009$ & $8270 \mathrm{C}$ \\
\hline Isophorone & 11600 & $\mathrm{U}$ & 11600 & $\mathrm{ug} / \mathrm{kg}$ wet & 1 & L912182 & $12 / 22 / 2009$ & $12 / 31 / 2009$ & $8270 \mathrm{C}$ \\
\hline Naphthalene & 11600 & $\mathrm{U}$ & 11600 & $\mathrm{ug} / \mathrm{kg}$ wet & 1 & L.912182 & $12 / 22 / 2009$ & $12 / 31 / 2009$ & $8270 \mathrm{C}$ \\
\hline Nitrobenzene & 11600 & $\mathrm{U}$ & 11600 & $\mathrm{ug} / \mathrm{kg}$ wet & 1 & L912182 & $12 / 22 / 2009$ & $12 / 31 / 2009$ & $8270 \mathrm{C}$ \\
\hline N-Nitrosodi-n-propylamine & 11600 & $\mathrm{U}$ & 11600 & ug/kg wet & 1 & L912182 & $12 / 22 / 2009$ & $12 / 31 / 2009$ & $8270 \mathrm{C}$ \\
\hline N-Nitrosodiphenylamine & 11600 & $\mathrm{U}$ & 11600 & $\mathrm{ug} / \mathrm{kg}$ wet & 1 & L912182 & $12 / 22 / 2009$ & $12 / 31 / 2009$ & $8270 \mathrm{C}$ \\
\hline Pentachlorophenol & 57800 & $\mathrm{U}$ & 57800 & $\mathrm{ug} / \mathrm{kg}$ wet & 1 & L912182 & $12 / 22 / 2009$ & $12 / 31 / 2009$ & $8270 \mathrm{C}$ \\
\hline Phenanthrene & 11600 & U & 11600 & $\mathrm{ug} / \mathrm{kg}$ wet & 1 & L912182 & $12 / 22 / 2009$ & $12 / 31 / 2009$ & $8270 \mathrm{C}$ \\
\hline Phenol & 11600 & $\mathrm{U}$ & 11600 & $\mathrm{ug} / \mathrm{kg}$ wet & 1 & L912182 & $12 / 22 / 2009$ & $12 / 31 / 2009$ & $8270 \mathrm{C}$ \\
\hline Pyrene & 11600 & $\mathrm{U}$ & 11600 & $\mathrm{ug} / \mathrm{kg}$ wet & 1 & L912182 & $12 / 22 / 2009$ & $12 / 31 / 2009$ & $8270 \mathrm{C}$ \\
\hline Benzoic Acid & 57800 & $\mathrm{U}$ & 57800 & $\mathrm{ug} / \mathrm{kg}$ wet & 1 & I.912182 & $12 / 22 / 2009$ & $12 / 31 / 2009$ & $8270 \mathrm{C}$ \\
\hline Benzyl alcohol & 11600 & $\mathrm{U}$ & 11600 & $\mathrm{ug} / \mathrm{kg}$ wet & 1 & L912182 & $12 / 22 / 2009$ & $12 / 31 / 2009$ & $8270 \mathrm{C}$ \\
\hline Iributylphosphate & 11600 & $\mathrm{U}$ & 11600 & $\mathrm{ug} / \mathrm{kg}$ wet & 1 & L.912182 & $12 / 22 / 2009$ & $12 / 31 / 2009$ & $8270 \mathrm{C}$ \\
\hline Surrogate: 2-Fluorophenol & $\% *$ & $U$ & $25-121$ & & & L.912182 & $12 / 22 / 2009$ & $12 / 31 / 2009$ & $8270 C$ \\
\hline Surrogate." Phenol-d5 & $\% *$ & $U$ & $24-113$ & & & $L 912182$ & $12 / 22 / 2009$ & $12 / 31 / 2009$ & $8270 C$ \\
\hline Surrogate. Nitrobenzene-d 5 & $\% *$ & $U$ & $23-120$ & & & L.912182 & $12 / 22 / 2009$ & $12 / 31 / 2009$ & $8270 C$ \\
\hline Surrogate: 2-Fluorobiphenyl & $\% *$ & $U$ & $30-115$ & & & $L 912182$ & $12 / 22 / 2009$ & $12 / 31 / 2009$ & $8270 \mathrm{C}$ \\
\hline Surrogate: 2,4,6-Tribromophenol & $\% *$ & $U$ & $19-122$ & & & 1912182 & $12 / 22 / 2009$ & $12 / 31 / 2009$ & $8270 C$ \\
\hline Surrogate: $p$-T'erphenyl-d14 & $76 \%$ & & $18-137$ & & & $L 912182$ & $12 / 22 / 2009$ & $12 / 31 / 2009$ & $8270 C$ \\
\hline
\end{tabular}


National Security Iechnologies, ILC

2621 Losee Road, Mail Stop NT'S273

North Las Vegas NV, 89030
Project: BOA

Project Number: 60052-002-001

Project Manager: Ted Redding
Reported:

01/06/2010 15:14

DRAFT: CAU 113-C1-5 0912042-05 (Solid)

\begin{tabular}{|lllllll}
\hline & & Reporting & & & \\
Analyte & Result and Qualifier & Limit & Units & Dilution & Batch & Prepared \\
\hline
\end{tabular}

Lionville Laboratory

DRAFT: Semivolatile Organic Compounds by SW846 8270C

\section{1,2,4-Trichlorobenzene}

1,2-Dichlorobenzene

1,3-Dichlorobenzene

1,4-Dichlorobenzene

2,4,5-Irichlorophenol

2,4,6-I richlorophenol

2,4-Dichlorophenol

2,4-Dimethylphenol

2,4-Dinitrophenol

2,4-Dinitrotoluene

2,6-Dinitrotoluene

2-Chloronaphthalene

2-Chlorophenol

2-Methylnaphthalene

2-Methylphenol

2-Nitroaniline

2-Nitrophenol

3,3'-Dichlorobenzidine

3-Nitroaniline

4,6-Dinitro-2-methylphenol

4-Bromophenyl Phenyl Ether

4-Chloro-3-methylphenol

4-Chloroaniline

4-Chlorophenyl Phenyl Ether

3- and/or 4-Methylphenol

4-Methylphenol

4-Nitroaniline

4-Nitrophenol

Acenaphthene

Acenaphthylene

Anthracene

Benz[a]anthracene

Benzo[a] pyrene

Benzo[b] fluoranthene

Benzo[g,h,i] perylene

Benzo[k] fluoranthene

Bis(2-chloroethoxy) methane

Bis(2-chloroethyl) ether

Bis(2-chloroisopropyl) ether

\begin{tabular}{|c|c|c|}
\hline 21400 & $\mathrm{U}$ & 21400 \\
\hline 21400 & $\mathrm{U}$ & 21400 \\
\hline 21400 & $\mathrm{U}$ & 21400 \\
\hline 21400 & $\mathrm{U}$ & 21400 \\
\hline 21400 & $\mathrm{U}$ & 21400 \\
\hline 21400 & $\mathrm{U}$ & 21400 \\
\hline 21400 & $\mathrm{U}$ & 21400 \\
\hline 21400 & $\mathrm{U}$ & 21400 \\
\hline 107000 & $\mathrm{U}$ & 107000 \\
\hline 21400 & $\mathrm{U}$ & 21400 \\
\hline 21400 & $\mathrm{U}$ & 21400 \\
\hline 21400 & $\mathrm{U}$ & 21400 \\
\hline 21400 & $\mathrm{U}$ & 21400 \\
\hline 21400 & U & 21400 \\
\hline 21400 & $\mathrm{U}$ & 21400 \\
\hline 107000 & $\mathrm{U}$ & 107000 \\
\hline 21400 & $\mathrm{U}$ & 21400 \\
\hline 42900 & $\mathrm{U}$ & 42900 \\
\hline 107000 & $\mathrm{U}$ & 107000 \\
\hline 21400 & $\mathrm{U}$ & 21400 \\
\hline 21400 & $\mathrm{U}$ & 21400 \\
\hline 21400 & $\mathrm{U}$ & 21400 \\
\hline 21400 & $\mathrm{U}$ & 21400 \\
\hline 21400 & $\mathrm{U}$ & 21400 \\
\hline 21400 & $\mathrm{U}$ & 21400 \\
\hline 21400 & $\mathrm{U}$ & 21400 \\
\hline 107000 & $\mathrm{U}$ & 107000 \\
\hline 107000 & $\mathrm{U}$ & 107000 \\
\hline 21400 & $\mathrm{U}$ & 21400 \\
\hline 21400 & $\mathrm{U}$ & 21400 \\
\hline 21400 & $\mathrm{U}$ & 21400 \\
\hline 21400 & $\mathrm{U}$ & 21400 \\
\hline 21400 & $\mathrm{U}$ & 21400 \\
\hline 21400 & $\mathrm{U}$ & 21400 \\
\hline 21400 & $\mathrm{U}$ & 21400 \\
\hline 21400 & $\mathrm{U}$ & 21400 \\
\hline 21400 & $\mathrm{U}$ & 21400 \\
\hline 21400 & $\mathrm{U}$ & 21400 \\
\hline 21400 & $\mathrm{U}$ & 21400 \\
\hline
\end{tabular}

ng wet

ug/kg wet

ug/kg wet

ug/ $\mathrm{kg}$ wet

ug/kg wet

$\mathrm{ug} / \mathrm{kg}$ wet

$\mathrm{ug} / \mathrm{kg}$ wet

$\mathrm{ug} / \mathrm{kg}$ wet

$\mathrm{ug} / \mathrm{kg}$ wet

$\mathrm{ug} / \mathrm{kg}$ wet

$\mathrm{ug} / \mathrm{kg}$ wet

$\mathrm{ug} / \mathrm{kg}$ wet

$\mathrm{ug} / \mathrm{kg}$ wet

$\mathrm{ug} / \mathrm{kg}$ wet

$\mathrm{ug} / \mathrm{kg}$ wet

$\mathrm{ug} / \mathrm{kg}$ wet

$\mathrm{ug} / \mathrm{kg}$ wet

ug/kg wet

$\mathrm{ug} / \mathrm{kg}$ wet

$\mathrm{ug} / \mathrm{kg}$ wet

ug/kg wet

ug/kg wet

$\mathrm{ug} / \mathrm{kg}$ wet

ug/kg wet

ug/kg wet

$\mathrm{ug} / \mathrm{kg}$ wet

$\mathrm{ug} / \mathrm{kg}$ wet

$\mathrm{ug} / \mathrm{kg}$ wet

$\mathrm{ug} / \mathrm{kg}$ wet

ug/kg wet

$\mathrm{ug} / \mathrm{kg}$ wet

$\mathrm{ug} / \mathrm{kg}$ wet

$\mathrm{ug} / \mathrm{kg}$ wet

ug/kg wet

ug/kg wet

$\mathrm{ug} / \mathrm{kg}$ wet

$\mathrm{ug} / \mathrm{kg}$ wet

ug/kg wet

ug/kg wet

$\mathrm{ug} / \mathrm{kg}$ wet

$\begin{array}{lll}1 & 1.912182 & 12 / 22 / 2009\end{array}$

$1912182-12 / 22 / 2009$

$1 \quad \begin{array}{lll}1 & 912182 & 12 / 22 / 2009\end{array}$

$1 \quad$ L912182 12/22/2009

$1 \quad$ L912182 12/22/2009

$1 \quad$ L912182 12/22/2009

$1 \quad$ L912182 $12 / 22 / 2009$

$1 \quad$ L.912182 12/22/2009

$1 \quad$ L912182 $12 / 22 / 2009$

$1 \quad$ L912182 12/22/2009

$1 \quad$ L $912182 \quad 12 / 22 / 2009$

L912182 12/22/2009

L.912182 12/22/2009

L912182 12/22/2009

L912182 12/22/2009

L $912182 \quad 12 / 22 / 2009$

L912182 12/22/2009

$\begin{array}{ll}1.912182 & 12 / 22 / 2009\end{array}$

L912182 12/22/2009

L $912182 \quad 12 / 22 / 2009$

L $912182 \quad 12 / 22 / 2009$

L912182 12/22/2009

L912182 12/22/2009

L.912182 12/22/2009

L.912182 $12 / 22 / 2009$

L912182 $12 / 22 / 2009$

L $912182 \quad 12 / 22 / 2009$

L912182 $12 / 22 / 2009$

L912182 12/22/2009

L.912182 12/22/2009

L $91218212 / 22 / 2009$

L $91218212 / 22 / 2009$

L912182 12/22/2009

$\begin{array}{ll}1.912182 & 12 / 22 / 2009\end{array}$

L.912182 $12 / 22 / 2009$

L.912182 12/22/2009

$\begin{array}{ll}1912182 & 12 / 22 / 2009 \\ \mathrm{~L} 912182 & 12 / 22 / 2009\end{array}$

$\begin{array}{ll}\mathrm{L} 912182 & 12 / 22 / 2009 \\ \mathrm{~L} .912182 & 12 / 22 / 2009\end{array}$

$\begin{array}{lll}1.912182 & 12 / 22 / 2009\end{array}$

L.912182 12/22/2009

$12 / 31 / 2009$

$12 / 31 / 2009$

$12 / 31 / 2009$

$12 / 31 / 2009$

$12 / 31 / 2009$

$12 / 31 / 2009$

$12 / 31 / 2009$

$12 / 31 / 2009$

$12 / 31 / 2009$

$12 / 31 / 2009$

$12 / 31 / 2009$

$12 / 31 / 2009$

$12 / 31 / 2009$

$12 / 31 / 2009$

$12 / 31 / 2009$

$12 / 31 / 2009$

$12 / 31 / 2009$

$12 / 31 / 2009$

$12 / 31 / 2009$

$12 / 31 / 2009$

$12 / 31 / 2009$

$12 / 31 / 2009$

$12 / 31 / 2009$

$12 / 31 / 2009$

$12 / 31 / 2009$

12/31/2009

$12 / 31 / 2009$

$12 / 31 / 2009$

$12 / 31 / 2009$

$12 / 31 / 2009$

$12 / 31 / 2009$

$12 / 31 / 2009$

$12 / 31 / 2009$

$12 / 31 / 2009$

$12 / 31 / 2009$

$12 / 31 / 2009$

$12 / 31 / 2009$

$12 / 31 / 2009$

$12 / 31 / 2009$
$8270 \mathrm{C}$

$8270 \mathrm{C}$

$8270 \mathrm{C}$

$8270 \mathrm{C}$

$8270 \mathrm{C}$

$8270 \mathrm{C}$

$8270 \mathrm{C}$

$8270 \mathrm{C}$

$8270 \mathrm{C}$

$8270 \mathrm{C}$

$8270 \mathrm{C}$

$8270 \mathrm{C}$

$8270 \mathrm{C}$

$8270 \mathrm{C}$

$8270 \mathrm{C}$

$8270 \mathrm{C}$

$8270 \mathrm{C}$

$8270 \mathrm{C}$

$8270 \mathrm{C}$

$8270 \mathrm{C}$

$8270 \mathrm{C}$

$8270 \mathrm{C}$

$8270 \mathrm{C}$

$8270 \mathrm{C}$

$8270 \mathrm{C}$

$8270 \mathrm{C}$

$8270 \mathrm{C}$

$8270 \mathrm{C}$

$8270 \mathrm{C}$

$8270 \mathrm{C}$

$8270 \mathrm{C}$

$8270 \mathrm{C}$

$8270 \mathrm{C}$

$8270 \mathrm{C}$

$8270 \mathrm{C}$

$8270 \mathrm{C}$

$8270 \mathrm{C}$

$8270 \mathrm{C}$

$8270 \mathrm{C}$ 
National Security Technologies, LLC

2621 Losee Road, Mail Stop NT'S273

North Las Vegas NV, 89030
Project: BOA

Project Number: 60052-002-001

Reported:

Project Manager: Ted Redding
01/06/2010 15:14

\section{DRAFT: CAU 113-C1-5} 0912042-05 (Solid)

\begin{tabular}{|llllllll}
\hline & & Reporting & & & & & \\
Analyte & Result and Qualifier & Limit & Units & Dilution & Batch & Prepared & Analyzed \\
\hline
\end{tabular}

\section{Lionville Laboratory}

DRAFT: Semivolatile Organic Compounds by SW846 8270C

\begin{tabular}{|c|c|c|c|}
\hline Bis(2-ethylhexyl) phthalate & 21400 & $\mathrm{U}$ & 21400 \\
\hline Butyl Benzyl Phthalate & 21400 & $\mathrm{U}$ & 21400 \\
\hline Chrysene & 21400 & $\mathrm{U}$ & 21400 \\
\hline Dibenz $[\mathrm{a}, \mathrm{h}]$ anthracene & 21400 & $\mathrm{U}$ & 21400 \\
\hline Dibenzofuran & 21400 & $\mathrm{U}$ & 21400 \\
\hline Diethyl Phthalate & 21400 & $\mathrm{U}$ & 21400 \\
\hline Dimethyl Phthalate & 21400 & $\mathrm{U}$ & 21400 \\
\hline Di-n-butyl Phthalate & 21400 & $U$ & 21400 \\
\hline Di-n-octyl Phthalate & 21400 & $\mathrm{U}$ & 21400 \\
\hline Fluoranthene & 21400 & $\mathrm{U}$ & 21400 \\
\hline Fluorene & 21400 & $\mathrm{U}$ & 21400 \\
\hline Hexachlorobenzene & 21400 & $\mathrm{U}$ & 21400 \\
\hline Hexachlorobutadiene & 21400 & $U$ & 21400 \\
\hline Hexachlorocyclopentadiene & 21400 & $\mathrm{U}$ & 21400 \\
\hline Hexachloroethane & 21400 & $\mathrm{U}$ & 21400 \\
\hline Indeno[1,2,3-cd]pyrene & 21400 & $\mathrm{U}$ & 21400 \\
\hline Isophorone & 21400 & $\mathrm{U}$ & 21400 \\
\hline Naphthalene & 21400 & $\mathrm{U}$ & 21400 \\
\hline Nitrobenzene & 21400 & $\mathrm{U}$ & 21400 \\
\hline N-Nitrosodi-n-propylamine & 21400 & $\mathrm{U}$ & 21400 \\
\hline $\mathrm{N}$-Nitrosodiphenylamine & 21400 & $\mathrm{U}$ & 21400 \\
\hline Pentachlorophenol & 107000 & $\mathrm{U}$ & 107000 \\
\hline Phenanthrene & 21400 & $\mathrm{U}$ & 21400 \\
\hline Phenol & 21400 & $\mathrm{U}$ & 21400 \\
\hline Pyrene & 21400 & $\mathrm{U}$ & 21400 \\
\hline Benzoic Acid & 107000 & $\mathrm{U}$ & 107000 \\
\hline Benzyl alcohol & 21400 & $\mathrm{U}$ & 21400 \\
\hline Iributylphosphate & 21400 & $\mathrm{U}$ & 21400 \\
\hline Surrogate: 2-Fluorophenol & $\% *$ & $U$ & $25-121$ \\
\hline Surrogate: Phenol-d5 & $\% *$ & $U$ & $24-113$ \\
\hline Surrogate: Nitrobenzene-d5 & $\% *$ & $U$ & $23-120$ \\
\hline Surrogate: 2-Fluorobiphenyl & $\% *$ & $U$ & $30-11.5$ \\
\hline Surrogate: 2,4,6-Tribromophenol & $\% *$ & $U$ & $19-122$ \\
\hline Surrogate: p-Terphenyl-d14 & $77 \%$ & & $18-1.37$ \\
\hline
\end{tabular}

\begin{tabular}{|c|c|c|c|c|c|}
\hline $\mathrm{ug} / \mathrm{kg}$ wet & 1 & L912182 & $12 / 22 / 2009$ & $12 / 31 / 2009$ & $8270 \mathrm{C}$ \\
\hline ug $/ \mathrm{kg}$ wet & 1 & L912182 & $12 / 22 / 2009$ & $12 / 31 / 2009$ & $8270 \mathrm{C}$ \\
\hline $\mathrm{ug} / \mathrm{kg}$ wet & 1 & 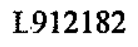 & $12 / 22 / 2009$ & $12 / 31 / 2009$ & $270 \mathrm{C}$ \\
\hline $\mathrm{ug} / \mathrm{kg}$ wet & 1 & L912182 & $12 / 22 / 2009$ & $12 / 31 / 2009$ & $8270 \mathrm{C}$ \\
\hline $\mathrm{ug} / \mathrm{kg}$ wet & 1 & L912182 & $12 / 22 / 2009$ & $12 / 31 / 2009$ & $8270 \mathrm{C}$ \\
\hline $\mathrm{ug} / \mathrm{kg}$ wet & 1 & L912182 & $12 / 22 / 2009$ & $12 / 31 / 2009$ & $8270 \mathrm{C}$ \\
\hline $\mathrm{ug} / \mathrm{kg}$ wet & 1 & L912182 & $12 / 22 / 2009$ & $12 / 31 / 2009$ & $8270 \mathrm{C}$ \\
\hline $\mathrm{ug} / \mathrm{kg}$ wet & 1 & L912182 & $12 / 22 / 2009$ & $12 / 31 / 2009$ & $8270 \mathrm{C}$ \\
\hline $\mathrm{ug} / \mathrm{kg}$ wet & 1 & L912182 & $12 / 22 / 2009$ & $12 / 31 / 2009$ & $8270 \mathrm{C}$ \\
\hline $\mathrm{ug} / \mathrm{kg}$ wet & 1 & L912182 & $12 / 22 / 2009$ & $12 / 31 / 2009$ & $8270 \mathrm{C}$ \\
\hline $\mathrm{ug} / \mathrm{kg}$ wet & 1 & L912182 & $12 / 22 / 2009$ & $12 / 31 / 2009$ & $8270 \mathrm{C}$ \\
\hline $\mathrm{ug} / \mathrm{kg}$ wet & 1 & L912182 & $12 / 22 / 2009$ & $12 / 31 / 2009$ & $270 \mathrm{C}$ \\
\hline $\mathrm{ug} / \mathrm{kg}$ wet & 1 & L912182 & $12 / 22 / 2009$ & $12 / 31 / 2009$ & $8270 \mathrm{C}$ \\
\hline $\mathrm{ug} / \mathrm{kg}$ wet & 1 & L.912182 & $12 / 22 / 2009$ & $12 / 31 / 2009$ & $8270 \mathrm{C}$ \\
\hline $\mathrm{ug} / \mathrm{kg}$ wet & 1 & L912182 & $12 / 22 / 2009$ & $12 / 31 / 2009$ & $8270 \mathrm{C}$ \\
\hline $\mathrm{ug} / \mathrm{kg}$ wet & 1 & L.912182 & $12 / 22 / 2009$ & $12 / 31 / 2009$ & $8270 \mathrm{C}$ \\
\hline $\mathrm{ug} / \mathrm{kg}$ wet & 1 & L912182 & $12 / 22 / 2009$ & $12 / 31 / 2009$ & $270 \mathrm{C}$ \\
\hline $\mathrm{ug} / \mathrm{kg}$ wet & 1 & L912182 & $12 / 22 / 2009$ & $12 / 31 / 2009$ & $8270 \mathrm{C}$ \\
\hline $\mathrm{ug} / \mathrm{kg}$ wet & 1 & L912182 & $12 / 22 / 2009$ & $12 / 31 / 2009$ & $8270 \mathrm{C}$ \\
\hline $\mathrm{ug} / \mathrm{kg}$ wet & 1 & L.912182 & $12 / 22 / 2009$ & $12 / 31 / 2009$ & $8270 \mathrm{C}$ \\
\hline ug/kg wet & 1 & L9 & $12 / 2$ & $12 / 31 / 2$ & $270 \mathrm{C}$ \\
\hline $\mathrm{ug} / \mathrm{kg}$ wet & 1 & L.9 & $12 / 22 / 2$ & $12 / 31 / 2009$ & $270 \mathrm{C}$ \\
\hline $\mathrm{lg} / \mathrm{kg}$ wet & 1 & L912182 & $12 / 22 / 2009$ & $12 / 31 / 2009$ & $8270 \mathrm{C}$ \\
\hline $\mathrm{ug} / \mathrm{kg}$ wet & 1 & L912182 & $12 / 22 / 2009$ & $12 / 31 / 2009$ & $8270 \mathrm{C}$ \\
\hline $\mathrm{ug} / \mathrm{kg}$ wet & 1 & L912182 & $12 / 22 / 2009$ & $12 / 31 / 2009$ & $8270 \mathrm{C}$ \\
\hline $\mathrm{ug} / \mathrm{kg}$ wet & 1 & L912182 & $12 / 22 / 2009$ & $12 / 31 / 2009$ & $8270 \mathrm{C}$ \\
\hline ug/ $/ \mathrm{kg}$ wet & 1 & L912182 & $12 / 22 / 2009$ & $12 / 31 / 2009$ & $8270 \mathrm{C}$ \\
\hline \multirow[t]{7}{*}{$\mathrm{ug} / \mathrm{kg}$ wet } & 1 & L912182 & $12 / 22 / 2009$ & $12 / 31 / 2009$ & $8270 \mathrm{C}$ \\
\hline & & $L 912182$ & $12 / 22 / 2009$ & $12 / 31 / 2009$ & $8270 \mathrm{C}$ \\
\hline & & $L 912182$ & $12 / 22 / 2009$ & $12 / 31 / 2009$ & $8270 \mathrm{C}$ \\
\hline & & L912I82 & $12 / 22 / 2009$ & $12 / 31 / 2009$ & $8270 \mathrm{C}$ \\
\hline & & $L 912182$ & $12 / 22 / 2009$ & $12 / 31 / 2009$ & $8270 \mathrm{C}$ \\
\hline & & 1912182 & $12 / 22 / 2009$ & $12 / 31 / 2009$ & $8270 \mathrm{C}$ \\
\hline & & $L 912182$ & $12 / 22 / 2009$ & $12 / 31 / 2009$ & $8270 \mathrm{C}$ \\
\hline
\end{tabular}


Laboratory: Lionville Laboratory

Client: National Security Technologies, LLC

Matrix: $\quad \underline{\text { Solid }}$

Sampled:

$\underline{12 / 14 / 0912: 51}$

Solids:

Batch:

CAS NO.
Laboratory ID:

Prepared:

Preparation:
SDG:

Project:

0912042-01

12/23/09 00:03

SW $3540 \mathrm{C}$

$\underline{\mathrm{BOA}}$

File ID: $\quad$ Lims export2770

Analyzed: $\quad 12 / 28 / 0921: 03$

Initial/Final: $\quad \underline{30 \mathrm{~g} / 1 \mathrm{~mL}}$

L912183 Sequence: 9120115 Calibration: $\underline{\text { UNASSIGNED Instrument: }}$

\begin{tabular}{|l|c|c|c|}
\hline COMPOUND & DILUTION & CONC. (ug/kg wet) & Q \\
\hline Diesel Range Organics & 1 & 3290 & $\mathrm{~J}$ \\
\hline Motor Oil & 1 & 10000 & $\mathrm{U}$ \\
\hline
\end{tabular}

\begin{tabular}{|l|c|c|c|c|c|}
\hline SYSTEM MONITORING COMPOUND & ADDED (ug/kg wet) & CONC (ug/kg wet) & $\%$ REC & QC LIMITS & Q \\
\hline p-Terphenyl & 6666.7 & 5950 & 89 & $39-129$ & \\
\hline
\end{tabular}

* Values outside of QC limits 


\section{ORGANIC ANALYSIS DATA SHEET}

8015M

113-C1-2

Laboratory: Lionville Laboratory

SDG:

Client: $\quad$ National Security Technologies, LLC

Project:

BOA

Matrix: $\quad$ Solid

Laboratory ID: $\quad \underline{0912042-02}$

Sampled:

$\underline{12 / 14 / 0912: 55}$

Prepared:

12/23/0900:03

Preparation:

SW $3540 \mathrm{C}$

File ID:

Lims export2772

Solids:
Analyzed: $\quad \underline{12 / 28 / 0922: 00}$

Initial/Final: $\quad 30 \mathrm{~g} / 1 \mathrm{~mL}$

\begin{tabular}{|c|c|c|c|c|}
\hline Batch: & Sequence: & Calibration: & UNASSIGNED Instrument: & $\underline{\mathrm{GC} 18}$ \\
\hline CAS NO. & COMPOUND & DILUTION & CONC. (ug/kg wet) & $\mathrm{Q}$ \\
\hline & Diesel Range Organics & 1 & 22100 & \\
\hline & Motor Oil & 1 & 10000 & $\mathrm{U}$ \\
\hline
\end{tabular}

\begin{tabular}{|l|c|c|c|c|c|}
\hline SYSTEM MONITORING COMPOUND & ADDED (ug/kg wet) & CONC (ug/kg wet) & $\%$ REC & QC LIMITS & Q \\
\hline p-Terphenyl & 6666.7 & 5840 & 88 & $39-129$ & \\
\hline
\end{tabular}

* Values outside of QC limits 


\section{ORGANIC ANALYSIS DATA SHEET}

8015M

Laboratory: Lionville Laboratory

Client:

Matrix:

Sampled:

National Security Iechnologies, LLC

Solid

Solids:

12/14/09 13:05

Batch:

CAS NO.

$$
\text { L912183 }
$$

Laboratory ID:

Prepared:

Preparation:

SDG:

Project:

$\underline{B O A}$

$$
\text { 0912042-03 }
$$

12/23/09 00:03

SW $3540 \mathrm{C}$

File ID:

Lims export 2774

Analyzed:

$\underline{12 / 28 / 0922: 58}$

Initial/Final: $\quad \underline{30 \mathrm{~g} / 1 \mathrm{~mL}}$

\begin{tabular}{|l|c|c|c|}
\hline COMPOUND & DILUTION & CONC. (ug/kg wet) & Q \\
\hline Diesel Range Organics & 1 & 5990 & \\
\hline Motor Oil & 1 & 10000 & $\mathrm{U}$ \\
\hline
\end{tabular}

\begin{tabular}{|l|c|c|c|c|c|}
\hline SYSTEM MONITORING COMPOUND & ADDED (ug/kg wet) & CONC (ug/kg wet) & $\%$ REC & QC LIMITS & Q \\
\hline p-Terphenyl & 6666.7 & 5760 & 86 & $39-129$ & \\
\hline
\end{tabular}

* Values outside of QC limits 


\section{ORGANIC ANALYSIS DATA SHEET}

8015M

113-C1-4

\begin{tabular}{|c|c|c|c|c|c|c|c|c|}
\hline Laboratory: & \multirow{2}{*}{\multicolumn{3}{|c|}{$\begin{array}{l}\text { Lionville Laboratory } \\
\text { National Security Technologies, LLC }\end{array}$}} & \multicolumn{2}{|r|}{ SDG: } & & & \\
\hline Client: & & & & \multicolumn{2}{|r|}{ Project: } & \multicolumn{3}{|l|}{$\underline{B O A}$} \\
\hline Matrix: & $\underline{\text { Solid }}$ & \multicolumn{2}{|c|}{ Laboratory ID: } & \multicolumn{2}{|c|}{$\underline{0912042-04}$} & File ID: & \multicolumn{2}{|c|}{ Lims_export2778 } \\
\hline Sampled: & $\underline{12 / 14 / 0913: 08}$ & \multicolumn{2}{|c|}{ Prepared: } & \multicolumn{2}{|c|}{ 12/23/0900:03 } & Analyzed: & \multicolumn{2}{|l|}{$12 / 29 / 0901: 50$} \\
\hline Solids: & & \multicolumn{2}{|c|}{ Preparation: } & \multicolumn{2}{|c|}{$\underline{\mathrm{SW} 3540 \mathrm{C}}$} & \multirow{2}{*}{$\begin{array}{l}\text { Initial/Final: } \\
\text { UNASSIGNED }\end{array}$} & \multicolumn{2}{|l|}{$\underline{30 \mathrm{~g} / 1 \mathrm{~mL}}$} \\
\hline Batch: & $\underline{\mathrm{L} 912183}$ & & $\underline{9120115}$ & & Calibration: & & Instrument: & $\mathrm{GC18}$ \\
\hline \multirow[t]{3}{*}{ CAS NO. } & \multicolumn{4}{|l|}{ COMPOUND } & DILUTION & \multicolumn{2}{|c|}{ CONC. (ug/kg wet) } & $Q$ \\
\hline & \multicolumn{4}{|c|}{ Diesel Range Organics } & 1 & \multicolumn{2}{|c|}{3300} & U. \\
\hline & \multicolumn{3}{|l|}{ Motor Oil } & & 1 & \multicolumn{2}{|c|}{10000} & $\mathrm{U}$ \\
\hline \multicolumn{3}{|c|}{ SYSTEM MONITORING COMPOUND } & \multicolumn{2}{|c|}{ ADDED (ug/kg wet) } & CONC (ug/kg wet) & $\%$ REC & QC LIMITS & $\bar{Q}$ \\
\hline \multicolumn{2}{|l|}{ p-Terphenyl } & & \multicolumn{2}{|c|}{6666.7} & 6090 & 91 & $39-129$ & \\
\hline
\end{tabular}

* Values outside of QC limits 


\section{ORGANIC ANALYSIS DATA SHEET}

$8015 \mathrm{M}$

Laboratory: Lionville Laboratory

Client:

Matrix:

Sampled:

National Security Technologies, LLC

$\underline{\text { Solid }}$

Solids:

12/14/09 13:13

Batch:

CAS NO.

Laboratory ID:

Prepared:

Preparation:
SDG:

Project:

0912042-05

12/23/09 00:03

SW $3540 \mathrm{C}$

BOA

File ID:

Lims export2780

Analyzed: $\quad \underline{12 / 29 / 0902: 47}$

Initial/Final: $\quad 30 \mathrm{~g} / 1 \mathrm{~mL}$ UNASSIGNED Instrument: $\underline{\mathrm{GC} 18}$

Sequence: $\quad 9120115$

Calibration:

Q

\begin{tabular}{|l|l|l} 
DILUTION & CONC. (ug/kg wet) & Q \\
\hline
\end{tabular}

\begin{tabular}{|l|c|c}
\hline Diesel Range Organics & 1 & 6550 \\
\hline
\end{tabular}

Motor Oil

\begin{tabular}{l|r}
1 & 10000 \\
\hline
\end{tabular}
$\mathrm{U}$

\begin{tabular}{|l|c|c|c|c|c|}
\hline SYSTEM MONITORING COMPOUND & ADDED (ug/kg wet) & CONC (ug/kg wet) & $\%$ REC & QC LIMITS & Q \\
\hline p-Terphenyl & 6666.7 & 3620 & 54 & $39-129$ & \\
\hline
\end{tabular}

* Values outside of QC limits 
Laboratory; Lionville Laboratory

Client: National Security Technologies, LLC

Matrix: $\quad \underline{\text { Solid }}$

Sampled:

$\underline{12 / 14 / 0912: 51}$

Solids:

Batch:

CAS NO.

12674-11-2

$11104-28-2$

11141-16-5

$53469-21-9$

12672-29-6

$11097-69-1$

11096-82-5 Aroclor 1260
SDG:

Project:

$\underline{0912042-01}$

12/28/0920:12

Preparation: $\quad \underline{\text { SW } 3540 \mathrm{C}} \quad$ Initial/Final: $\quad 10.01 \mathrm{~g} / 40 \mathrm{~mL}$

File ID:

PromiumPcb1690

Analyzed: $\quad 12 / 30 / 0917: 04$

Preparation: $\quad \underline{\text { SW } 3540 \mathrm{C}} \quad$ Initial/Final: $\quad 10.01 \mathrm{~g} / 40 \mathrm{~mL}$

\begin{tabular}{l|l|c|c|c|} 
L912210 Sequence: & 9120121 & Calibration: & UNASSIGNED Instrument: & GC13 SATIN \\
\hline COMPOUND & DILUTION & CONC. (ug/kg wet) & Q \\
\hline Aroclor 1016 & 1 & 159 & $\mathrm{U}$ \\
\hline Aroclor 1221 & 1 & 159 & $\mathrm{U}$ \\
\hline Aroclor 1232 & 1 & 159 & $\mathrm{U}$ \\
\hline Aroclor 1242 & 1 & 159 & $\mathrm{U}$ \\
\hline Aroclor 1248 & 1 & 159 & $\mathrm{U}$ \\
\hline Aroclor 1254 & 1 & 159 & $\mathrm{U}$ \\
\hline Aroclor 1260 & 1 & 159 & $\mathrm{U}$ \\
\hline
\end{tabular}

\begin{tabular}{|l|c|c|c|c|c|}
\hline SYSTEM MONITORING COMPOUND & ADDED (ug/kg wet) & CONC (ug/kg wet) & $\%$ REC & QC LIMITS & Q \\
\hline Decachlorobiphenyl & 99.900 & 265 & 266 & $43-144$ & $*$ \\
\hline Tetrachloro-meta-xylene & 99.910 & 213 & 213 & $52-141$ & $*$ \\
\hline
\end{tabular}

* Values outside of QC limits 
Laboratory: Lionville Laboratory

Client:

Matrix:

Sampled:

Solids:

Solids:

Batch:

CAS NO.

12674-11-2

$11104-28-2$

$11141-16-5$

53469-21-9

12672-29-6

$11097-69-1$

11096-82-5 Aroclor 1260
SDG;

Project:

Laboratory ID: $\quad \underline{0912042-02}$

Prepared:

12/28/0920:12

Preparation: SW $3540 \mathrm{C}$
$\underline{B O A}$

File ID:

Analyzed:

PromiumPcb1696

Initial/Final: $\quad 10.02 \mathrm{~g} / 20 \mathrm{~mL}$

\begin{tabular}{|l|c|c|c|c|c|}
\hline SYSTEM MONITORING COMPOUND & ADDED (ug/kg wet) & CONC (ug/kg wet) & $\%$ REC & QC LIMITS & Q \\
\hline Decachlorobiphenyl & 99.800 & 232 & 233 & $43-144$ & $*$ \\
\hline Tetrachloro-meta-xylene & 99.810 & 197 & 197 & $52-141$ & $*$ \\
\hline
\end{tabular}

* Values outside of QC limits 
Laboratory: Lionville Laboratory

Client:

Matrix:

Sampled;

Solids: National Security Technologies, LLC

$\underline{\text { Solid }}$

12/14/09 13:05

Batch:

CAS NO.

12674-11-2

$11104-28-2$

11141-16-5

$53469-21-9$

12672-29-6

$11097-69-1$

$11096-82-5$

Aroclor 1260

\begin{tabular}{|l|c|c|c|c|c|}
\hline SYSTEM MONITORING COMPOUND & ADDED (ug/kg wet) & CONC (ug $/ \mathrm{kg}$ wet) & $\%$ REC & QC LIMITS & Q \\
\hline Decachlorobiphenyl & 99.900 & 622 & 622 & $43-144$ & $*$ \\
\hline Tetrachloro-meta-xylene & 99.910 & 551 & 552 & $52-141$ & $*$ \\
\hline
\end{tabular}

SDG:

Project:

BOA

File ID: $\quad$ PromiumPcb1714

Analyzed: $\quad \underline{12 / 30 / 0919: 41}$

Initial/Final: $\quad 10.01 \mathrm{~g} / 40 \mathrm{~mL}$ UNASSIGNED Instrument:

GC13 SATIN

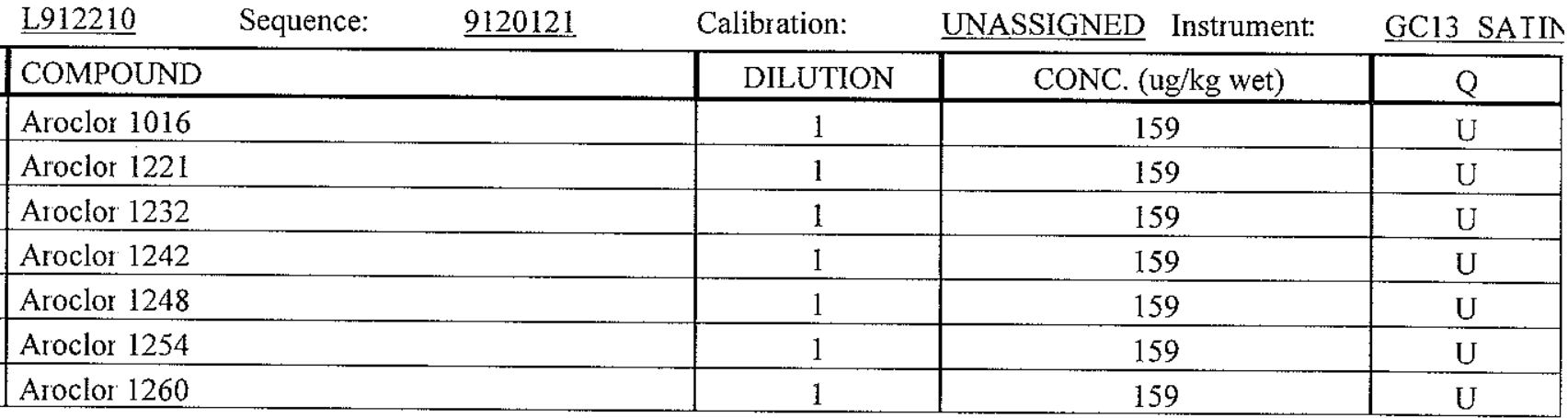

* Values outside of QC limits 


\section{ORGANIC ANALYSIS DATA SHEET}

\section{2}

Laboratory: Lionville Laboratory

Client: National Security Technologies, LLC

Matrix: $\quad \underline{\text { Solid }}$

Sampled:

$\underline{12 / 14 / 0913: 08}$

Solids:

Batch:

$\underline{L 912210}$

Laboratory ID:

Prepared:

Preparation:

SDG:

Project:

$\underline{B O A}$

$\underline{0912042-04}$

12/28/09 20:12

SW $3540 \mathrm{C}$

File ID:

PromiumPcb1720

Analyzed:

12/30/09 20:21

Initial/Final: $\quad \underline{10 \mathrm{~g} / 40 \mathrm{~mL}}$

\begin{tabular}{|c|l|c|c|c|}
\hline CAS NO. & COMPOUND & DILUTION & CONC. (ug/kg wet) & Q \\
\hline $12674-11-2$ & Aroclor 1016 & 1 & 160 & GC13 SATIN \\
\hline $11104-28-2$ & Aroclor 1221 & 1 & 160 & U \\
\hline $11141-16-5$ & Aroclor 1232 & 1 & 160 & $U$ \\
\hline $53469-21-9$ & Aroclor 1242 & 1 & 160 & U \\
\hline $12672-29-6$ & Aroclor 1248 & 1 & 160 & $U$ \\
\hline $11097-69-1$ & Aroclor 1254 & 1 & 160 & $U$ \\
\hline $11096-82-5$ & Aroclor 1260 & 1 & 160 & $U$ \\
\hline
\end{tabular}

\begin{tabular}{|l|c|c|c|c|c|}
\hline SYSTEM MONITORING COMPOUND & ADDED (ug/kg wet) & CONC (ug/kg wet) & $\%$ REC & QC LIMITS & Q \\
\hline Decachlorobiphenyl & 100.00 & 346 & 346 & $43-144$ & $*$ \\
\hline Tetrachloro-meta-xylene & 100.01 & 308 & 308 & $52-141$ & $*$ \\
\hline
\end{tabular}

* Values outside of QC limits 
Laboratory: Lionville Laboratory

Client:

Matrix:

Sampled:

Solids:

National Security Iechnologies, LLC

Solid

$\underline{12 / 14 / 0913: 13}$

Batch:

CAS NO.

12674-11-2

11104-28-2

$11141-16-5$

53469-21-9

12672-29-6

$11097-69-1$

\begin{tabular}{l|l}
$11096-82-5$ & Aroclor 1260 \\
\hline
\end{tabular}

Prepared:

Preparation:

COMPOUND

Aroclor 1016

Aroclor 1232

Aroclor 1242

Aroclor 1248

Aroclor 1254

Aroclor 1260
SDG:

Project:

BOA

Laboratory ID: $\quad \underline{0912042-05}$

12/28/0920:12

SW $3540 \mathrm{C}$

Calibration:

File ID:

PromiumPcb1726

Analyzed: $\quad \underline{12 / 30 / 0921: 01}$

Initial/Final: $\quad 10 \mathrm{~g} / 40 \mathrm{~mL}$

UNASSIGNED Instrument:

GC13 SAIIN

Sequence: $\quad 9120121$

\begin{tabular}{|c|}
\hline DILUTION \\
\hline 1 \\
\hline 1 \\
\hline 1 \\
\hline 1 \\
\hline 1 \\
\hline 1 \\
\hline 1 \\
\hline
\end{tabular}
CONC. (ug/kg wet)

SYSTEM MONITORING COMPOUND

Decachlorobiphenyl

Tetrachloro-meta-xylene

\begin{tabular}{|c|c}
\hline ADDED (ug/kg v \\
100.00 \\
100.01
\end{tabular}

$\mathrm{CONC}$

CONC (ug/ $\mathrm{kg}$ wet)

304

260

wet)

\begin{tabular}{|c|c|}
\hline$\%$ REC \\
\hline 304 \\
\hline 260 \\
\hline
\end{tabular}

160

160

160

\begin{tabular}{|l|l|}
\hline 160 & $\mathrm{U}$ \\
\hline 160 & $\mathrm{U}$ \\
\hline 160 & $\mathrm{U}$ \\
\hline 160 & $\mathrm{U}$ \\
\hline 160 & $\mathrm{U}$ \\
\hline
\end{tabular}

* Values outside of QC limits

\begin{tabular}{|c|c|}
\hline QC LIMITS & Q \\
\hline $43-144$ & $*$ \\
\hline $52-141$ & $*$ \\
\hline
\end{tabular}




\section{PESTICIDES ANALYSIS DATA SHEET}

L aboratory: Lionville Laboratory

Client: $\quad$ National Security Technologies, L

Matrix: $\quad$ Solid

Sampled:

Solids:

Batch:

\section{CAS NO.}

319-84-6

$58-89-9$

$319-85-7$

319-86-8

$76-44-8$

$309-00-2$

$1024-57-3$

959-98-8

$72-55-9$

$60-57-1$

$72-20-8$

$72-54-8$

33213-65-9

50-29-3

$7421-93-4$

$1031-07-8$

$72-43-5$

$800 I-35-2$
Laboratory ID:

Prepared:

Preparation:
SDG:

Project:

0912042-01

12/28/0920:12

SW $3540 \mathrm{C}$
BOA

File ID: $\quad$ Lims export1981

Analyzed: $\quad \underline{12 / 30 / 0916: 36}$

Initia//Final: $\quad 10.01 \mathrm{~g} / 40 \mathrm{~mL}$

UNASSIGNED Instrument:

$\mathrm{GC} 20$

\begin{tabular}{|l|c|c|c|c|c|}
\hline SYSTEM MONITORING COMPOUND & ADDED (ug/kg wet) & CONC (ug/kg wet) & $\%$ REC & QC LIMITS & Q \\
\hline \hline Tetrachloro-meta-xylene & 99.910 & 95.1 & 95.2 & $28-166$ & \\
\hline Decachlorobiphenyl & 99.900 & 99.1 & 99.2 & $37-153$ & \\
\hline
\end{tabular}

* Values outside of QC limits 
Laboratory: Lionville Laboratory

Client:

Matrix:

Sampled:

Solids:

Batch:

\begin{tabular}{l|l} 
Batch: & L912210 $\quad$ Sequence: \\
\hline \multicolumn{1}{|c|}{ CAS NO. } & COMPOUND \\
\hline $319-84-6$ & alpha-BHC \\
\hline $58-89-9$ & gamma-BHC \\
\hline $319-85-7$ & beta-BHC \\
\hline
\end{tabular}

National Security Technologies, L

Solid

$12 / 14 / 09 \quad 12: 55$

Laboratory ID:

Prepared:

$319-86-8$

76-44-8

309-00-2

1024-57-3

959-98-8

$72-55-9$

$60-57-1$

$72-20-8$

$72-54-8$

$33213-65-9$

50-29-3

$7421-93-4$

$1031-07-8$

$72-43-5$

$8001-35-2$

$12789-03-6$

delta-BHC

Heptachlor

Aldrin

Heptachlor epoxide

Endosulfan I

4,4'-DDE

Dieldrin

Endrin

4,4'-DDD

Endosulfan II

4,4'-DDT

Endrin aldehyde

Endosulfan sulfate

Methoxychlor

Toxaphene

Technical Chlordane

0912042-02

SDG:

Project:

$\underline{B O A}$

File ID:

Analyzed:

Lims export 1983

12/28/0920:12

SW 3540C
Initial/Final: $\quad 10.02 \mathrm{~g} / 20 \mathrm{~mL}$ UNASSIGNED Instrument: $\quad$ GC 20

\begin{tabular}{|c|c|c|c|c|c|}
\hline SYSTEM MONITORING COMPOUND & ADDED (ug/kg wet) & CONC (ug/kg wet) & $\% \mathrm{REC}$ & QC LIMITS & Q \\
\hline Tetrachloro-meta-xylene & 99.810 & 48.1 & 48.2 & $28-166$ & \\
\hline Decachlorobiphenyl & 99.800 & 53.7 & 53.8 & $37-153$ & \\
\hline
\end{tabular}

* Values outside of QC limits 
Laboratory: Lionville Laboratory

Client: National Security Technologies, L

Matrix: $\quad$ Solid

Sampled: $\quad \underline{12 / 14 / 0913: 05}$

Solids:

Batch:

CAS NO.

319-84-6

$58-89-9$

319-85-7

$319-86-8$

$76-44-8$

309-00-2

$1024-57-3$

959-98-8

$72-55-9$

$60-57-1$

$72-20-8$

$72-54-8$

$33213-65-9$

50-29-3

$7421-93-4$

1031-07-8

$72-43-5$

$8001-35-2$

12789-03-6
Laboratory ID:

Prepared:

Preparation:
SDG:

Project: $\quad$ BOA

$\underline{0912042-03}$

12/28/0920:12

SW $3540 \mathrm{C}$
File ID:

Analyzed:

Initial/Final: $\quad \underline{10.01 \mathrm{~g} / 40 \mathrm{~mL}}$

\begin{tabular}{|c|c|c|c|c|c|c|}
\hline CAS NO. & \multicolumn{2}{|l|}{ COMPOUND } & DILUTION & \multicolumn{2}{|c|}{ CONC. (ug/kg wet) } & Q \\
\hline $319-84-6$ & \multicolumn{2}{|l|}{ alpha-BHC } & 1 & \multicolumn{2}{|c|}{20.0} & $\mathrm{U}$ \\
\hline 58-89-9 & \multicolumn{2}{|l|}{ gamma-BHC } & 1 & \multicolumn{2}{|c|}{20.0} & $\mathrm{U}$ \\
\hline $319-85-7$ & \multicolumn{2}{|l|}{ beta-BHC } & 1 & \multicolumn{2}{|c|}{20.0} & $\mathrm{U}$ \\
\hline $319-86-8$ & \multicolumn{2}{|l|}{ delta-BHC } & 1 & \multicolumn{2}{|c|}{20.0} & U \\
\hline $76-44-8$ & \multicolumn{2}{|l|}{ Heptachlor } & 1 & \multicolumn{2}{|c|}{20.0} & $\mathrm{U}$ \\
\hline $309-00-2$ & \multicolumn{2}{|l|}{ Aldrin } & 1 & \multicolumn{2}{|c|}{20.0} & $\mathrm{U}$ \\
\hline $1024-57-3$ & \multicolumn{2}{|l|}{ Heptachlor epoxide } & 1 & \multicolumn{2}{|c|}{20.0} & $\mathrm{U}$ \\
\hline $959-98-8$ & \multicolumn{2}{|l|}{ Endosulfan I } & 1 & \multicolumn{2}{|c|}{20.0} & $\mathrm{U}$ \\
\hline $72-55-9$ & \multicolumn{2}{|l|}{ 4,4'-DDE } & 1 & \multicolumn{2}{|c|}{20.0} & $\mathrm{U}$ \\
\hline $60-57-1$ & \multicolumn{2}{|l|}{ Dieldrin } & 1 & \multicolumn{2}{|c|}{20.0} & U \\
\hline $72-20-8$ & \multicolumn{2}{|l|}{ Endrin } & 1 & \multicolumn{2}{|c|}{20.0} & $\mathrm{U}$ \\
\hline $72-54-8$ & \multicolumn{2}{|l|}{$4,4^{\prime}-\mathrm{DDD}$} & 1 & \multicolumn{2}{|c|}{20.0} & $\mathrm{U}$ \\
\hline $33213-65-9$ & \multicolumn{2}{|l|}{ Endosulfan II } & 1 & \multicolumn{2}{|c|}{20.0} & $\mathrm{U}$ \\
\hline $50-29-3$ & \multicolumn{2}{|l|}{ 4,4'-DDT } & 1 & \multicolumn{2}{|c|}{20.0} & $\mathrm{U}$ \\
\hline $7421-93-4$ & \multicolumn{2}{|l|}{ Endrin aldehyde } & 1 & \multicolumn{2}{|c|}{20.0} & $\mathrm{U}$ \\
\hline $1031-07-8$ & \multicolumn{2}{|l|}{ Endosulfan sulfate } & 1 & \multicolumn{2}{|c|}{20.0} & $\mathrm{U}$ \\
\hline $72-43-5$ & Methoxychlor & & 1 & & & $\mathrm{U}$ \\
\hline $8001-35-2$ & Toxaphene & & 1 & & & $\mathrm{U}$ \\
\hline $12789-03-6$ & Technical Chlordane & & 1 & & & $\mathrm{U}$ \\
\hline SYSTEM M & ITORING COMPOUND & ADDED (ug/ $/ \mathrm{kg}$ wet) & CONC (ug/kg wet) & $\%$ REC & QC LIMITS & $Q$ \\
\hline Tetrachloro- & a-xylene & 99.910 & 92.3 & 92.4 & $28-166$ & \\
\hline Decachlorob & enyl & 99.900 & 104 & 104 & $37-153$ & \\
\hline
\end{tabular}

* Values outside of QC limits

Calibration: UNASSIGNED Instrument: GC 20 


\section{PESTICIDES ANALYSIS DATA SHEET}

Laboratory:

Client:

Matrix:

Sampled:

Solids: Lionville Laboratory

National Security Technologies, L

$\underline{\text { Solid }}$

12/14/09 13:08

L aboratory ID:

Prepared:

Preparation:

Sequence: $\quad \underline{9120125}$

Batch: L912210
SDG:

Project: $\quad$ BOA

0912042-04 File ID: Lims export1995

12/28/0920:12 Analyzed: 12/30/0918:31

SW 3540C Initial/Final: $\quad \underline{10 \mathrm{~g} / 40 \mathrm{~mL}}$

Calibration: UNASSIGNED Instrument: $\mathrm{GC} 20$

\begin{tabular}{|c|c|c|c|c|}
\hline CAS NO. & COMPOUND & DILUTION & CONC. (ug/kg wet) & Q \\
\hline $319-84-6$ & alpha-BHC & 1 & 20.0 & $\underline{U}$ \\
\hline $58-89-9$ & gamma-BHC & 1 & 20.0 & $\mathrm{U}$ \\
\hline $319-85-7$ & beta-BHC & 1 & 11.2 & $\mathrm{~J}$ \\
\hline $319-86-8$ & delta-BHC & 1 & 20.0 & $\mathrm{U}$ \\
\hline $76-44-8$ & Heptachlor & 1 & 20.0 & $\mathrm{U}$ \\
\hline $309-00-2$ & Aldrin & 1 & 20.0 & U \\
\hline $1024-57-3$ & Heptachlor epoxide & 1 & 20.0 & U \\
\hline $959-98-8$ & Endosulfan I & 1 & 20.0 & $\mathrm{U}$ \\
\hline $72-55-9$ & 4,4'-DDE & 1 & 20.0 & $\underline{U}$ \\
\hline $60-57-1$ & Dieldrin & 1 & 20.0 & $\underline{U}$ \\
\hline $72-20-8$ & Endrin & 1 & 6.80 & $\mathrm{~J}$ \\
\hline $72-54-8$ & 4,4'-DDD & 1 & 9.60 & $\mathrm{~J}$ \\
\hline $33213-65-9$ & Endosulfan II & 1 & 20.0 & $\mathrm{U}$ \\
\hline $50-29-3$ & $4,4^{\prime}-$ DDT & 1 & 20.0 & U \\
\hline $7421-93-4$ & Endrin aldehyde & 1 & 20.0 & $\mathrm{U}$ \\
\hline $1031-07-8$ & Endosulfan sulfate & 1 & 20.0 & $\mathrm{U}$ \\
\hline $72-43-5$ & Methoxychlor & 1 & 20.0 & $\mathrm{U}$ \\
\hline $8001-35-2$ & Toxaphene & 1 & 200 & $\mathrm{U}$ \\
\hline $12789-03-6$ & Technical Chlordane & 1 & 200 & $\mathrm{U}$ \\
\hline
\end{tabular}

\begin{tabular}{|c|c|c|c|c|c|}
\hline SYSTEM MONITORING COMPOUND & ADDED (ug/kg wet) & CONC (ug/kg wet) & $\%$ REC & QC LIMITS & $\mathrm{Q}$ \\
\hline Tetrachloro-meta-xylene & 100.01 & 106 & 106 & $28-166$ & \\
\hline Decachlorobiphenyl & 100.00 & 115 & 115 & $37-153$ & \\
\hline
\end{tabular}

* Values outside of QC limits 
Laboratory: Lionville Laboratory

Client: $\quad$ National Security I echnologies. L

Matrix:

Sampled:

Solids:

Solids:

Batch:

CAS NO

\begin{tabular}{|l|}
\hline $319-84-6$ \\
\hline $58-89-9$ \\
\hline
\end{tabular}

$58-89-9$

319-85-7

319-86-8

$76-44-8$

$309-00-2$

1024-57-3

959-98-8

$72-55-9$

$60-57-1$

$72-20-8$

$72-54-8$

$33213-65-9$

$50-29-3$

$7421-93-4$

$1031-07-8$

$72-43-5$

$8001-35-2$

12789-03-6
Solid

$\underline{12 / 14 / 0913: 13}$

Labor atory ID:

Prepared:

Preparation:

$\underline{\mathrm{L} 912210}$

COMPOUND

alpha-BHC

gamma-BHC

beta-BHC

delta-BHC

Heptachlor

Aldrin

Heptachlor epoxide

Endosulfan I

4,4'-DDE

Dieldrin

Endrin

4,4'-DDD

Endosulfan II

4,4'-DDT

Endrin aldehyde

Endosulfan sulfate

Methoxychlor

Toxaphene

Technical Chlordane
SDG:

Project: $\quad$ BOA

0912042-05 File ID: Lims_export2001

12/28/0920:12

SW $3540 \mathrm{C}$

Analyzed:

12/30/09 19:10

Initial/Final: $\quad 10 \mathrm{~g} / 40 \mathrm{~mL}$

UNASSIGNED Instrument: $\mathrm{GC} 20$

Calibration:

\begin{tabular}{|c|c|c|}
\hline DLLUTION & CONC. (ug $/ \mathrm{kg}$ wet) & $\mathrm{Q}$ \\
\hline 1 & 20.0 & $\mathrm{U}$ \\
\hline 1 & 20.0 & $\mathrm{U}$ \\
\hline 1 & 8.40 & $\mathrm{~J}$ \\
\hline 1 & 20.0 & $\mathrm{U}$ \\
\hline 1 & 20.0 & $\mathrm{U}$ \\
\hline 1 & 20.0 & $\mathrm{U}$ \\
\hline 1 & 20.0 & $\mathrm{U}$ \\
\hline 1 & 20.0 & $\mathrm{U}$ \\
\hline 1 & 20.0 & $\mathrm{U}$ \\
\hline 1 & 20.0 & $\mathrm{U}$ \\
\hline 1 & 20.0 & $\mathrm{U}$ \\
\hline 1 & 20.0 & $\mathrm{U}$ \\
\hline 1 & 20.0 & $\mathrm{U}$ \\
\hline 1 & 20.0 & $\mathrm{U}$ \\
\hline 1 & 20.0 & $\mathrm{U}$ \\
\hline 1 & 20.0 & $\mathrm{U}$ \\
\hline 1 & 20.0 & $\mathrm{U}$ \\
\hline 1 & 200 & $U$ \\
\hline
\end{tabular}

\begin{tabular}{|c|c|c|}
\hline DLLUTION & CONC. (ug $/ \mathrm{kg}$ wet) & $\mathrm{Q}$ \\
\hline 1 & 20.0 & $\mathrm{U}$ \\
\hline 1 & 20.0 & $\mathrm{U}$ \\
\hline 1 & 8.40 & $\mathrm{~J}$ \\
\hline 1 & 20.0 & $\mathrm{U}$ \\
\hline 1 & 20.0 & $\mathrm{U}$ \\
\hline 1 & 20.0 & $\mathrm{U}$ \\
\hline 1 & 20.0 & $\mathrm{U}$ \\
\hline 1 & 20.0 & $\mathrm{U}$ \\
\hline 1 & 20.0 & $\mathrm{U}$ \\
\hline 1 & 20.0 & $\mathrm{U}$ \\
\hline 1 & 20.0 & $\mathrm{U}$ \\
\hline 1 & 20.0 & $\mathrm{U}$ \\
\hline 1 & 20.0 & $\mathrm{U}$ \\
\hline 1 & 20.0 & $\mathrm{U}$ \\
\hline 1 & 20.0 & $\mathrm{U}$ \\
\hline 1 & 20.0 & $\mathrm{U}$ \\
\hline 1 & 20.0 & $\mathrm{U}$ \\
\hline 1 & 200 & $U$ \\
\hline
\end{tabular}

\begin{tabular}{|l|c|c|c|c|c|}
\hline SYSTEM MONITORING COMPOUND & ADDED (ug/kg wet) & CONC (ug/kg wet) & \% REC & QC LIMITS & Q \\
\hline \hline Tetrachloro-meta-xylene & 100.01 & 80.8 & 80.8 & $28-166$ & \\
\hline \hline Decachlorobiphenyl & 100.00 & 92.0 & 92.0 & $37-153$ & \\
\hline
\end{tabular}

* Values outside of QC limits 
Laboratory: Lionville Laboratory

Client: National Security Iechnologies, LLC

Matrix: $\quad \underline{\text { Solid }}$

Sampled: $\quad$ 12/14/09 12:51

Solids:

Batch:

L912211

Prepared:

Preparation:

CAS NO. Laboratory ID:

SDG:

$\underline{\text { V3369 }}$

94-75-7

93-72-1

COMPOUND

Project:

0912042-01

12/28/0922:28

SW 8151A

Calibration:

BOA

File ID:

Lims export2278

Analyzed: $\quad \underline{01 / 07 / 1015: 18}$

Initial/Final: $\quad 2.023 \mathrm{~g} / 10 \mathrm{~mL}$ UNASSIGNED Instrument. GC 14

\begin{tabular}{|l|c|c|c|c|c|}
\hline SYSTEM MONITORING COMPOUND & ADDED (ug/kg) & CONC (ug/kg) & $\%$ REC & QC LIMITS & Q \\
\hline DCAA & 2471.6 & 1550 & 63 & $40-150$ & \\
\hline
\end{tabular}

* Values outside of QC limits 
Laboratory: Lionville Laboratory

Client: National Security Technologies, LLC

Matrix: $\quad$ Solid

Laboratory ID:

Prepared:

Preparation:

SDG:

Project:

$\underline{0912042-02}$

12/28/0922:28

Solids:

$\underline{12 / 14 / 0912: 55}$ $\underline{\text { V3369 }}$

BOA

File ID: $\quad$ Lims export2344

Analyzed: $\quad \underline{01 / 07 / 1017: 07}$

Initial/Final: $\quad 2.012 \mathrm{~g} / 10 \mathrm{~mL}$

UNASSIGNED Instrument: GC 14

Batch:

$\underline{\text { L912211 }}$ Sequence:

$\underline{0010011}$

Calibration:

CONC. (ug/kg)

94-75-7

$93-72-1$

COMPOUND

2,4-D

2,4,5-TP (Silvex) 497 249

\begin{tabular}{|l|c|c|c|c|c|}
\hline SYSTEM MONITORING COMPOUND & ADDED (ug/kg) & CONC (ug/kg) & $\%$ REC & QC LIMITS & Q \\
\hline DCAA & 2485.1 & 1810 & 73 & $40-150$ & \\
\hline
\end{tabular}

* Values outside of QC limits 
Laboratory: Lionville Laboratory

Client: National Security Technologies, LLC

Matrix: $\quad \underline{\text { Solid }}$

Sampled: $\quad \underline{12 / 14 / 0913: 05}$

Solids:

Batch:

CAS NO.

94-75-7

93-72-1

Laboratory ID:

Prepared:

Preparation:
SDG:

Project:

0912042-03

12/28/0922:28

SW 8151A
$\underline{\mathrm{V} 3369}$

BOA

File ID:

Lims export2345

Analyzed: $\quad \underline{01 / 07 / 1017: 44}$

Initial/Final: $\quad 2.034 \mathrm{~g} / 10 \mathrm{~mL}$

\begin{tabular}{|l|c|c|c|c|c|}
\hline SYSTEM MONITORING COMPOUND & ADDED (ug/kg) & CONC (ug/kg) & $\%$ REC & QC LIMITS & Q \\
\hline DCAA & 2458.2 & 1800 & 73 & $40-150$ & \\
\hline
\end{tabular}

* Values outside of QC limits 
Laboratory: Lionville Laboratory

Client: $\quad$ National Security Iechnologies, LLC

Matrix: $\quad \underline{\text { Solid }}$

Laboratory ID:

Prepared:

Solids:

12/14/0913:08
Preparation: $\quad$ SW 8151A

SDG:

Project:

$\underline{0912042-04}$

$\underline{12 / 28 / 0922: 28}$

Batch:

L912211 Sequence: $\quad \underline{0010011}$

Calibration:

V3369

CAS NO.

94-75-7

93-72-1

COMPOUND

2,4-D

2,4,5-TP (Silvex)

\begin{tabular}{|l|l}
\hline & DILUTION \\
\hline
\end{tabular}

SYSTEM MONITORING COMPOUND

DCAA

* Values outside of QC limits

BOA

File ID: $\quad$ Lims_export2346

Analyzed: $\quad \underline{01 / 07 / 1018: 20}$

Initial/Final: $\quad \underline{2.016 \mathrm{~g} / 10 \mathrm{~mL}}$

UNASSIGNED Instrument GC 14

\begin{tabular}{|c|c|c|}
\hline UTION & CONC. $(\mathrm{ug} / \mathrm{kg})$ & $\mathrm{Q}$ \\
\hline 1 & 496 & $\mathrm{U}$ \\
\hline 1 & 249 & $\mathrm{U}$ \\
\hline
\end{tabular}

1330

54

QC LIMITS

Q


Laboratory: Lionville Laboratory

Client:

Matrix:

Sampled:

Solids:

National Security Technologies, LLC

Solid

Laboratory ID:

Prepared:

Preparation:
SDG:

Project:

0912042-05

12/28/0922:28

SW 8151A
$\underline{\mathrm{V} 3369}$

BOA

File ID:

Analyzed: $\quad \underline{01 / 07 / 1018: 56}$

Initial/Final: $\quad 2.014 \mathrm{~g} / 10 \mathrm{~mL}$

Batch: L912211

Sequence: $\quad \underline{0010011}$

Calibration: UNASSIGNED Instrument: $\mathrm{GC} 14$

CAS NO. 94-75-7 93-72-1

COMPOUND
2,4-D

2,4,5-TP (Silvex) DILUTION

CONC. (ug/kg)

1
496 1 249 U SYSTEM MONITORING COMPOUND DCAA

\begin{tabular}{l|l} 
ADDED (ug/kg) & CONC (ug/kg)
\end{tabular} 2482.6 1780

* Values outside of QC limits 


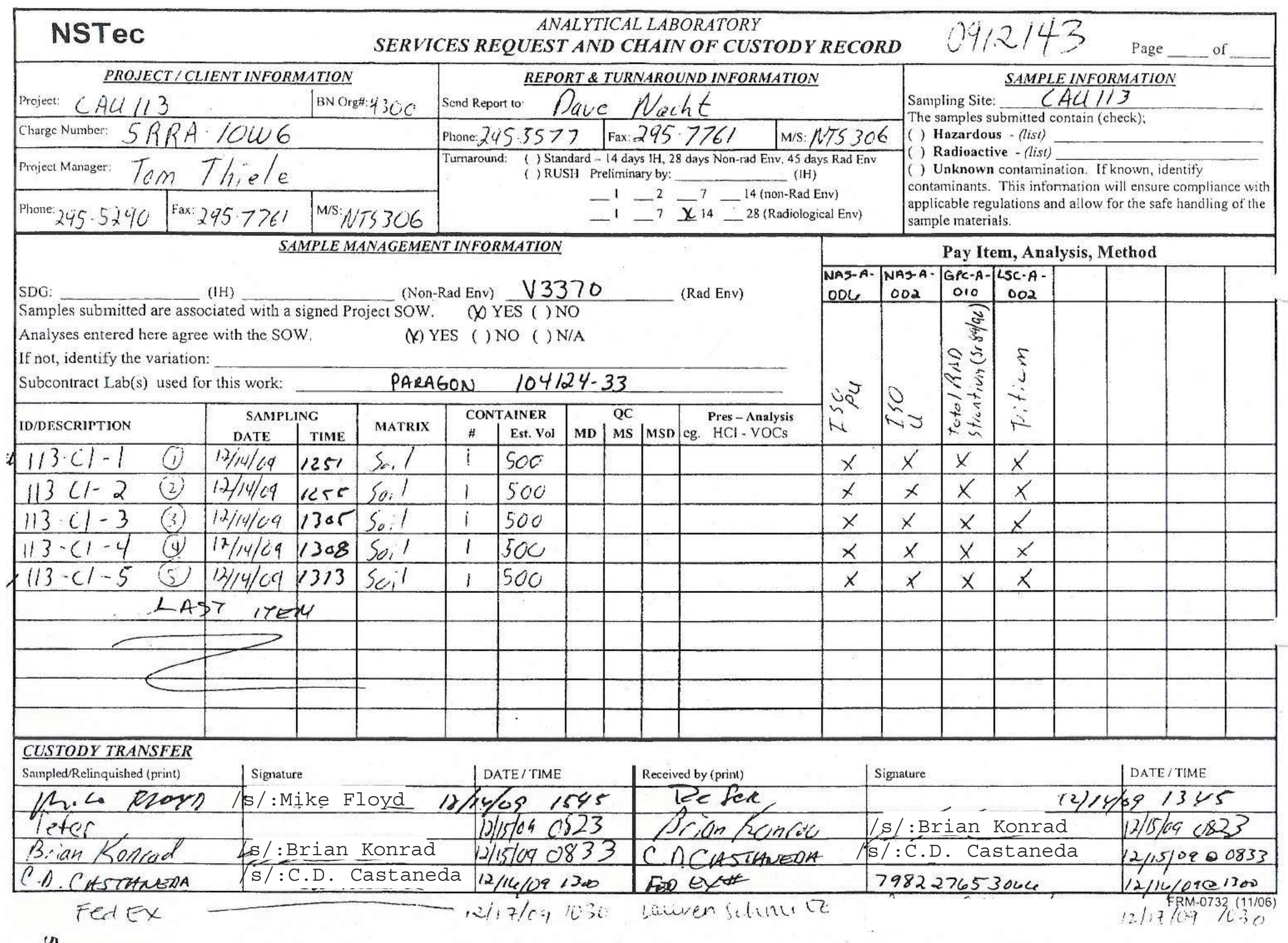




\section{Tritium Analysis By Liquid Scintillation Sample Results Summary}

Client Name: National Security Technologies, LLC Client Project Name: CAU 113 Client Project Number: V 3370
Laboratory Name: ALS Laboratory Group - FC

PAI Work Order: 0912143
Page: 1 of 1

Reported on: Tuesday, December 29, 2009 4:32:11 PM

\begin{tabular}{|c|c|c|c|c|c|c|c|c|c|c|}
\hline $\begin{array}{c}\text { Lab } \\
\text { Sample ID }\end{array}$ & Client Sample ID & $\begin{array}{l}\text { Sample } \\
\text { Type }\end{array}$ & Nuclide & Result $+/-2$ s TPU & MDC & Units & Matrix & Prep Batch & $\begin{array}{c}\text { Date } \\
\text { Analyzed }\end{array}$ & Flags \\
\hline 0912143-1 & CAU113-Cl-1 & Sample & $\mathrm{H}-3$ & $-8.71 \mathrm{E}-03+1-1.31 \mathrm{E}-02$ & $2.22 \mathrm{E}-02$ & $p C i / g$ & SOIL & $3 H 091218-5$ & $12 / 24 / 2009$ & $u$ \\
\hline $0912143-2$ & CAU113-Cl-2 & Sample & $\mathrm{H}-3$ & $-1.63 \mathrm{E}-03+1-1.84 \mathrm{E}-02$ & 3.10E-02 & $\mathrm{pCi} / \mathrm{g}$ & SOIL. & $3 \mathrm{H} 091218-5$ & $12 / 24 / 2009$ & u \\
\hline $0912143-3$ & CAU113-Cl-3 & Sample & $\mathrm{H}-3$ & $8.50 \mathrm{E}-04+/-1.67 \mathrm{E}-02$ & $2.80 E-02$ & $\mathrm{pCi} / \mathrm{g}$ & SOIL & 3H091218-5 & $12 / 24 / 2009$ & u \\
\hline $0912143-5$ & CAU113-Cl-5 & Sample & $\mathrm{H}-3$ & $-1.03 \mathrm{E}-02+1-1.80 \mathrm{E}-02$ & $3.06 \mathrm{E}-02$ & $\mathrm{pCi} / \mathrm{g}$ & SOIL & 3Н091218-5 & $12 / 24 / 2009$ & $u$ \\
\hline
\end{tabular}

\section{Comments:}

Qualifiers/Flags:
$U$ - Result is less than the sample specific MDC.
LT - Result is less than Requested MDC, greater than sample specific MDC.
Y1 - Chemical Yleld is in control at $100-110 \%$, Quantitative Yield is assumed.
Y2 - Chemical Yleld outside default limits.
$M$ - The requested MDC was not met
M3 - The requested MDC was not met, but the reported activity is greater than the reported MDC.

Date Printed: Tuesday, December 29, 2009
Abbreviations:

TPU - Total Propagated Uncertainty

MDC - Minimum Detectable Concentration

BDL - Below Detection Limit 


\section{Tritium Analysis By Liquid Scintillation}

\section{PAl 704 Rev 9 \\ Sample Results}

Lab Name: ALS Laboratory Group -- FC

Work Order Number: 0912143

Client Name: National Security Technologies, LLC

ClientProject ID: CAU 113 V3370

Field ID: CAU113-Cl-1
Lab ID: $0912143-1$

Analysis ReqCode: LSC-A-002
Sample Matrix: SOIL

Prep SOP: PAI 754 Rev 5

Date Collected: $14-\mathrm{Dec}-09$

Date Prepared: 21-Dec-09

Date Analyzed: 24-Dec-09
Prep Batch: 3H091218-5

QCBatchID: 3H091218-5-1

Run ID: 3H091218-5A

Count Time: 120 minutes

Report Basis: As Received
Final Aliquot: $104 \mathrm{~g}$

Prep Basis: As Received

Moisture(\%): -0.336

Result Units: $\mathrm{pCi} / \mathrm{g}$

File Name: B60_02_122302

\begin{tabular}{|c|c|c|c|c|c|}
\hline CASNO & Target Nuclide & Result +/- 2 S TPU & MDC & $\begin{array}{c}\text { Requested } \\
\text { MDC }\end{array}$ & Lab Qualifier \\
\hline $10028-17-8$ & $\mathrm{H}-3$ & $-8.71 \mathrm{E}-03+/-1.31 \mathrm{E}-02$ & $2.22 \mathrm{E}-02$ & $4.00 \mathrm{E}+02$ & $\mathrm{U}$ \\
\hline
\end{tabular}

\section{Comments:}

Qualifiers/Flags:

$U$-Result is less than the sample specific MDC

Y1 - Chemical Yield is in control at 100-110\%. Quantitative Yield is assumed.

Y2 - Chemical Yield outside default limits.

LT - Result is less than Requested MDC, greater than sample specific MDC.

M3 - The requested MDC was not met, but the reported activity is greater than the roported MDC.

$M$ - The requested MDC was not met.

Abbreviations:

TPU - Total Propagated Uncertainty

MDC - Minimum Detectable Concentration

$\mathrm{BDL}$ - Below Detection Limit

Data Package ID: H30912143-1 


\section{Tritium Analysis By Liquid Scintillation \\ PAI 704 Rev 9 \\ Sample Results}

Lab Name: ALS Laboratory Group -- FC

Work Order Number: 0912143

Client Name: National Security Technologies, LLC

ClientProject ID: CAU 113 V3370

Field ID: CAU113-Cl-2
Lab ID: $0912143-2$

Analysis ReqCode: LSC-A-002
Sample Matrix: SOIL Prep SOP: PAI 754 Rev 5

Date Collected: 14-Dec-09

Date Prepared: 21-Dec-09

Date Analyzed: 24-Dec-09
Prep Batch: 3H091218-5

QCBatchID: 3H091218-5-1

Run ID: 3H091218-5A

Count Time: 120 minutes

Report Basis: As Received
Final Aliquot: $73.5 \mathrm{~g}$

Prep Basis: As Received

Moisture(\%): -0.299

Result Units: $\mathrm{pCi} / \mathrm{g}$

File Name:B60_02_122302

\begin{tabular}{|c|c|c|c|c|c|}
\hline CASNO & Target Nuclide & Result +/- 2 s TPU & MDC & $\begin{array}{c}\text { Requested } \\
\text { MDC }\end{array}$ & \begin{tabular}{c} 
Lab Qualifier \\
\hline $10028-17-8$
\end{tabular} \\
\hline
\end{tabular}

\section{Comments:}

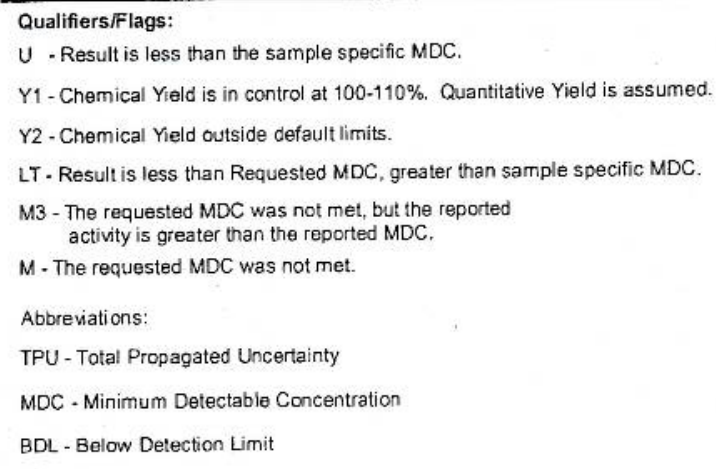

Data Package ID: H30912143-1 


\section{Tritium Analysis By Liquid Scintillation \\ PAl 704 Rev 9 \\ Sample Results}

Lab Name: ALS Laboratory Group -. FC

Work Order Number: 0912143

Client Name: National Security Technologies, LLC

ClientProject ID: CAU 113 V 3370

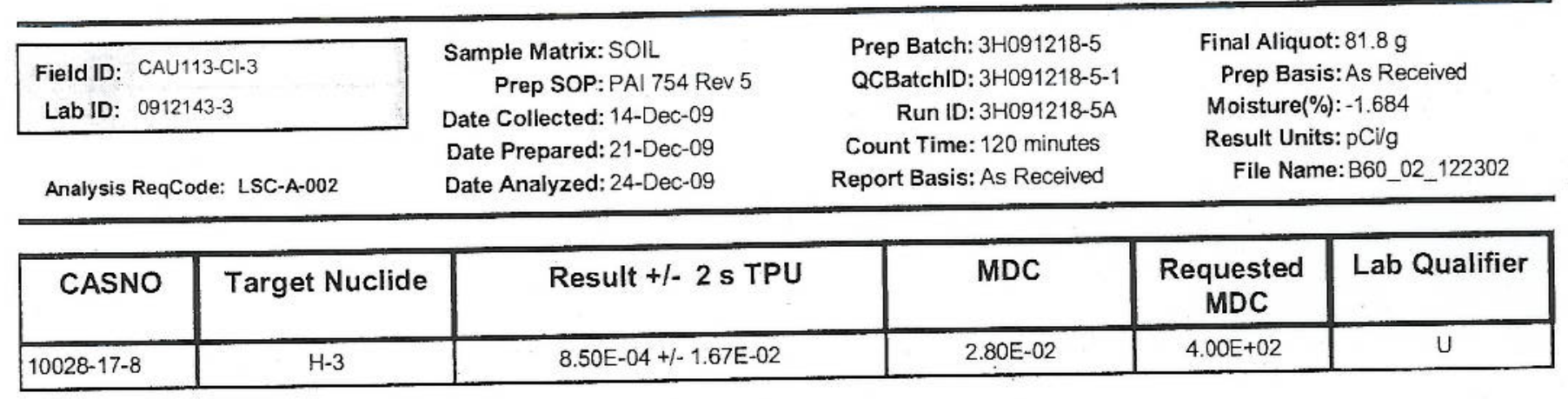

\section{Comments:}

Qualifiers/Flags:

$U$ - Result is less than the sample specific MDC.

Y1 - Chemical Yield is in control at $100-110 \%$. Quantitative Yield is assumed.

Y2 - Chemical Yield outside default limits.

LT - Result is less than Requested MDC, greater than sample specific MDC

M3 - The requested MDC was not mel, but the reported activity is greater than the reported MDC.

$M$ - The requested MDC was not met.

Abbreviations:

TPU - Total Propagated Uncertainty

MDC - Minimum Detectable Concentration

BDL - Below Detection Limit

Data Package ID: H30912143-1 


\section{Tritium Analysis By Liquid Scintillation \\ PAl 704 Rev 9 \\ Sample Results}

Lab Name: ALS Laboratory Group -- FC

Work Order Number: 0912143

Client Name: National Security Technologies, LLC

ClientProject ID: CAU 113 V3370

\begin{tabular}{l} 
Field ID: CAU113-CI-5 \\
Lab ID: $0912143-5$ \\
\hline
\end{tabular}

Analysis ReqCode: LSC-A-002
Sample Matrix: SOIL

Prep SOP: PAI 754 Rev 5

Date Collected: 14-Dec-09

Date Prepared: 21-Dec-09

Date Analyzed: 24-Dec-09
Prep Batch: 3H091218-5

QCBatchID: 3H091218-5-1

Run ID: 3 H091218-5A

Count Time: 120 minutes

Report Basis: As Received
Final Aliquot: $75.5 \mathrm{~g}$

Prep Basis: As Received

Moisture(\%): -1.390

Result Units: $\mathrm{pCi} / \mathrm{g}$

File Name:B60_02_122302

\begin{tabular}{|c|c|c|c|c|c|}
\hline CASNO & Target Nuclide & Result +/- 2 s TPU & MDC & $\begin{array}{c}\text { Requested } \\
\text { MDC }\end{array}$ & \begin{tabular}{c} 
Lab Qualifier \\
\hline $10028-17-8$
\end{tabular} \\
\hline
\end{tabular}

\section{Comments:}

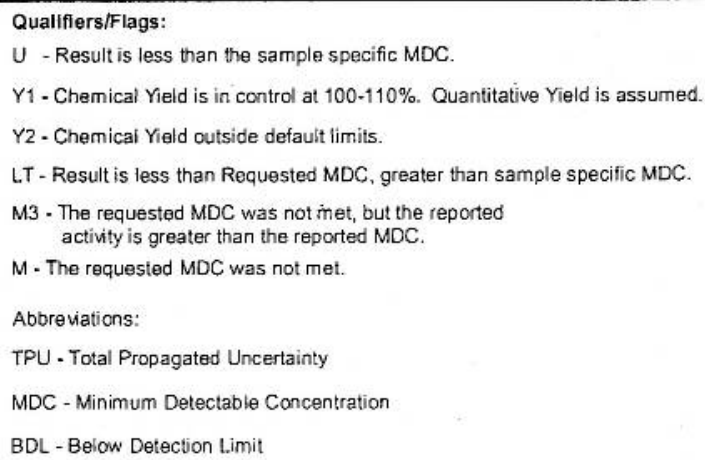




\section{Strontium-90 Analysis by GFPC Sample Results Summary}

Client Name: National Security Technologies, LLC Client Project Name: CAU 113 Client Project Number: V3370 Laboratory Name: ALS Laboratory Group -- FC
PAI Work Order: 0912143
Page: 1 of 1

Reported on: Tuesday, December 29, 2009 1:29:03 PM

\begin{tabular}{|c|c|c|c|c|c|c|c|c|c|c|}
\hline $\begin{array}{c}\text { Lab } \\
\text { Sample ID }\end{array}$ & Client Sample ID & $\begin{array}{l}\text { Sample } \\
\text { Type }\end{array}$ & Nuclide & Result +/- 2 s TPU & MDC & Units & Matrix & Prep Batch & $\begin{array}{c}\text { Date } \\
\text { Analyzed }\end{array}$ & Flags \\
\hline $0912143-1$ & CAU113-Cl-1 & Sample & Sr-90 & $1.37 E-01+/-3.26 E-01$ & $6.85 E-01$ & $\mathrm{pCi} / \mathrm{g}$ & SOIL & SR091218-1 & $12 / 22 / 2009$ & $\mathrm{u}$ \\
\hline $0912143-2$ & CAU113-Cl-2 & Sample & $\mathrm{Sr}-90$ & $-2.95 \mathrm{E}-02+/-3.39 \mathrm{E}-01$ & $7,31 E-01$ & $\mathrm{pCi} / \mathrm{g}$ & SOIL. & SR091218-1 & $12 / 22 / 2009$ & $\mathrm{u}$ \\
\hline $0912143-3$ & CAU113-Cl-3 & Sample & $\mathrm{Sr}-90$ & $1.42 \mathrm{E}-01+/-3.25 \mathrm{E}-01$ & $6.82 \mathrm{E}-01$ & $\mathrm{pCl} / \mathrm{g}$ & SOll & SR091218-1 & $12 / 22 / 2009$ & $u$ \\
\hline $0912143-4$ & CAU113-Cl-4 & Sample & Sr-90 & $1.01 \mathrm{E}-01+/-3.85 \mathrm{E}-01$ & $8.16 \mathrm{E}-01$ & $\mathrm{pCi} / \mathrm{g}$ & SOIL & SR091218-1 & $12 / 22 / 2009$ & U \\
\hline $0912143-5$ & CAU113-Cl-5 & Sample & Sr-90 & $3.59 E-01+/-3.49 E-01$ & $6.94 \mathrm{E}-01$ & $\mathrm{pCi} / \mathrm{g}$ & SOIL & SR091218-1 & $12 / 22 / 2009$ & $u$ \\
\hline
\end{tabular}

\section{Comments:}

QualitilersiFlags:
$U$ - Resuit is less than the sample specific MDC.
LT - Result is less than Requested MDC, greater than sample specific MDC.
Y1 - Chemical Yield is in control at 100-110\%, Quantitative Yield is assumed.
Y2 - Chemical Yield outside detault limits.
$M$ - The requested MDC was not met.
M3 - The reque sted MDC was not met, but the reported activity is greater than the reported MDC. Minimum Detectable Concentration




\section{Strontium-90 Analysis by GFPC \\ PAI 724 Rev 10 \\ Sample Results}

Lab Name: ALS Laboratory Group -- FC

Work Order Number: 0912143

Client Name: National Security Technologies, LLC

ClientProject ID: CAU 113 V 3370

\begin{tabular}{l|}
\hline Field ID: CAU113-Cl-1 \\
Lab ID: $0912143-1$
\end{tabular}

Analysis ReqCode: GPC-A-010
Sample Matrix: SOIL Prep SOP: PAI 707 Rev 10

Date Collected: 14-Dec-09

Date Prepared: 18-Dec-09

Date Analyzed: 22-Dec-09
Prep Batch: SR091218-1

QCBatchID: SR091218-1-1

Run ID: SR091218-1A

Count Time: 240 minutes

Report Basis: As Received
Final Aliquot: $0.752 \mathrm{~g}$

Prep Basis: As Received

Moisture(\%): NA

Result Units: $\mathrm{pCi} / \mathrm{g}$

File Name:SRC 1222

\begin{tabular}{|c|c|c|c|c|c|}
\hline CASNO & Target Nuclide & Result +/- 2 s TPU & MDC & $\begin{array}{c}\text { Requested } \\
\text { MDC }\end{array}$ & Lab Qualifier \\
\hline $10098-97-2$ & Sr-90 & $1.37 \mathrm{E}-01+/-3.26 \mathrm{E}-01$ & $6.85 \mathrm{E}-01$ & $1.00 \mathrm{E}+00$ & $\mathrm{U}$ \\
\hline
\end{tabular}

Chemical Yield Summary

\begin{tabular}{|c|c|c|c|c|c|c|}
\hline Carrier/Tracer & Amount Added & Result & Units & Yield & $\begin{array}{c}\text { Control } \\
\text { Limits }\end{array}$ & Flag \\
\hline STRONTIUM & $1.060 E+03$ & $7.13 E+02$ & ug & 67.0 & $40-110 \%$ & \\
\hline
\end{tabular}

\section{Comments:}

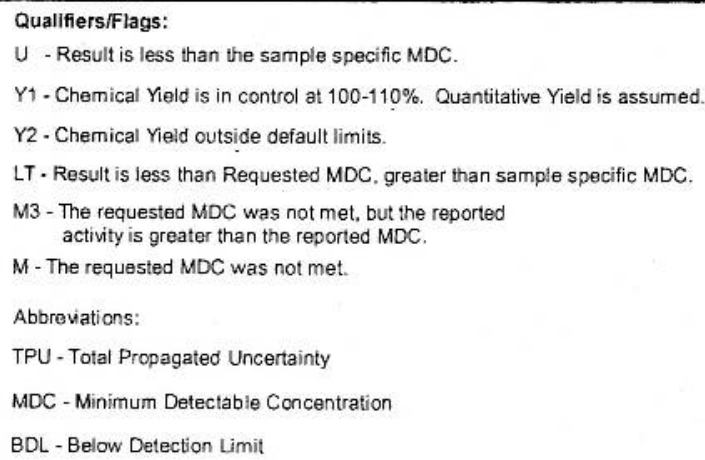

Data Package ID: SR0912143-1 


\section{Strontium-90 Analysis by GFPC}

PAI 724 Rev 10

Sample Results

Lab Name: ALS Laboratory Group - FC

Work Order Number: 0912143

Client Name: National Security Technologies, LLC

ClientProject ID: CAU 113 V3370

Field ID: CAU113-Cl-2
Lab ID: $0912143-2$

Analysis ReqCode: GPC-A-010
Sample Matrix: SOIL Prep SOP: PAI 707 Rev 10

Date Collected: 14-Dec-09

Date Prepared: 18-Dec-09

Date Analyzed: 22-Dec-09
Prep Batch: SR091218-1 QCBatchID: SR091218-1-1

Run ID: SR091218-1A

Count Time: 240 minutes

Report Basis: As Received
Final Aliqu ot: $0.752 \mathrm{~g}$

Prep Basis: As Received

Moisture(\%): NA

Result Units: $\mathrm{pCi} / \mathrm{g}$

File Name: SRC1222

\begin{tabular}{|c|c|c|c|c|c|}
\hline CASNO & Target Nuclide & Result +/- 2 s TPU & MDC & $\begin{array}{c}\text { Requested } \\
\text { MDC }\end{array}$ & \begin{tabular}{c} 
Lab Qualifier \\
\hline $10098-97-2$
\end{tabular} \\
\hline
\end{tabular}

\section{Chemical Yield Summary}

\begin{tabular}{|c|c|c|c|c|c|c|}
\hline Carrier/Tracer & Amount Added & Result & Units & Yield & $\begin{array}{c}\text { Control } \\
\text { Limits }\end{array}$ & Flag \\
\hline STRONTIUM & $1.100 E+03$ & $6.88 \mathrm{E}+02$ & ug & 62.6 & $40-110 \%$ & \\
\hline
\end{tabular}

\section{Comments:}

\section{Quallfiers/Flags:}

$U$ - Result is less than the sample specific MDC.

Y1 - Chemical Yield is in control at $100-110 \%$. Quantitative Yield is assumed.

Y2 - Chemical Yield outside default limits.

LT - Result is less than Requested MDC, greater than sample specific MDC.

M3 - The requested MDC was not met, but the reported activity is greater than the reported MDC.

$M$ - The requested MDC was not met.

Abbrevations:

TPU - Total Propagated Uncertainty

MDC - Minimum Detectable Concentration

BDL - Below Detection Limit

Data Package ID: SR0912143-1 


\section{Strontium-90 Analysis by GFPC \\ PAI 724 Rev 10 \\ Sample Duplicate Results}

Lab Name: ALS Laboratory Group -- FC

Work Order Number: 0912143

Client Name: National Security Technologies, LLC

ClientProject ID: CAU 113 V3370

Field ID: CAU113-Cl-2

Lab ID: 0912143-2DUP
Sample Matrix: SOIL

Prep SOP: PAI 707 Rev 10

Date Collected: 14-Dec-09

Date Prepared: 18-Dec-09

Date Analyzed: 22-Dec-09
Prep Batch: SR091218-1

QCBatchID: SR091218-1-1

Run ID: SR091218-1A

Count Time: 240 minutes

Report Basis: As Received
Final Aliquot: $0.743 \mathrm{~g}$

Prep Basis: As Received

Moisture(\%): NA

Result Units: $\mathrm{pCi} / \mathrm{g}$

File Name: SRC1222

\begin{tabular}{|c|c|c|c|c|c|}
\hline CASNO & Target Nuclide & Result +/- 2 S TPU & MDC & $\begin{array}{c}\text { Requested } \\
\text { MDC }\end{array}$ & Lab Qualifier \\
\hline $10098-97-2$ & Sr-90 & $1.58 E-01+/-3.70 E-01$ & $7.76 E-01$ & $1.00 E+00$ & $U$ \\
\hline
\end{tabular}

Chemical Yield Summary

\begin{tabular}{|c|c|c|c|c|c|c|}
\hline Carrier/Tracer & Amount Added & Result & Units & Yield & $\begin{array}{c}\text { Control } \\
\text { Limits }\end{array}$ & Flag \\
\hline STRONTIUM & $1.080 \mathrm{E}+03$ & $6.61 \mathrm{E}+02$ & ug & 61.1 & $40-110 \%$ & \\
\hline
\end{tabular}

\section{Comments:}

Qualifiers/Flags:

$U$ - Result is less than the sample specific MDC

Y1 - Chemical Yield is in control at $100-110 \%$. Quantitative yield is assumed.

Y2 - Chemical Yield outside default limits.

$L T$ - Result is less than Requested MDC, greater than sample specific MDC.

$M$ - The requested MDC was not met.

M3 - The requested MDC was not met, but thereported activity is greater than the reported MDC.

D - DER is greater than Control Limit of 3

Abbreviations:

TPU - Total Propagated Uncertainty

MDC - Minimum Detectable Concentration

BDL - Below Detection Limit

Data Package ID: SR0912143-1 


\section{Strontium-90 Analysis by GFPC \\ PAI 724 Rev 10 \\ Sample Results}

Lab Name: ALS Laboratory Group -- FC

Work Order Number: 0912143

Client Name: National Security Technologies, LLC

ClientProject ID: CAU 113 V3370

\begin{tabular}{ll|}
\hline Field ID: & CAU113-CI-3 \\
Lab ID: & $0912143-3$ \\
\hline
\end{tabular}

Analysis ReqCode: GPC-A-010
Sample Matrix: SOIL Prep SOP:PAI 707 Rev 10

Date Collected: 14-Dec-09

Date Prepared: 18-Dec-09

Date Analyzed: 22-Dec-09
Prep Batch: SR091218-1

QCBatchID: SR091218-1-1

Run ID: SR091218-1A

Count Time: 240 minutes

Report Basis: As Received
Final Aliquot: $0.746 \mathrm{~g}$

Prep Basis: As Received

Moisture(\%): NA

Result Units: pCi/g

File Name: SRC1222

\begin{tabular}{|c|c|c|c|c|c|}
\hline CASNO & Target Nuclide & Result +/- 2 s TPU & MDC & $\begin{array}{c}\text { Requested } \\
\text { MDC }\end{array}$ & \begin{tabular}{c} 
Lab Qualifier \\
\hline $10098-97-2$
\end{tabular} \\
\hline
\end{tabular}

Chemical Yield Summary

\begin{tabular}{|c|c|c|c|c|c|c|}
\hline Carrier/Tracer & Amount Added & Result & Units & Yieid & $\begin{array}{c}\text { Control } \\
\text { Limits }\end{array}$ & Flag \\
\hline STRONTIUM & $1.070 \mathrm{E}+03$ & $7.37 \mathrm{E}+02$ & ug & 68.8 & $40-110 \%$ & \\
\hline
\end{tabular}

\section{Comments:}

\footnotetext{
Qualifiers/Flags:

$U$ - Result is less than the sample specific MDC.

Y1 - Chemical Yield is in control at $100-110 \%$. Quantitative Yield is assumed.

Y2 - Chemical Yield outside default limits.

LT - Result is less than Requested MDC, greater than sample specific MDC.

M3 - The requested MDC was not met, but the reported activity is greater than the reported MDC.

$M$ - The requested MDC was not met.

Abbreviations:

TPU - Total Propagated Uncertainty

MDC - Minimum Detectable Concentration

BDL - Below Detection Limit
}

Data Package ID: SR0912143-1 


\section{Strontium-90 Analysis by GFPC \\ PAI 724 Rev 10 \\ Sample Results}

Lab Name: ALS Laboratory Group -- FC

Work Order Number: 0912143

Client Name: National Security Technologies, LLC

ClientProject ID: CAU 113 V 3370

\begin{tabular}{l}
\hline Field ID: CAU113-Cl-4 \\
Lab ID: $0912143-4$ \\
\hline
\end{tabular}

Analysis ReqCode: GPC-A-010
Sample Matrix: SOIL

Prep SOP: PAI 707 Rev 10

Date Collected: 14-Dec-09

Date Prepared: 18-Dec-09

Date Analyzed: 22-Dec-09
Prep Batch: SR091218-1

QCBatchID: SR091218-1-1

Run ID: SR091218-1A

Count Time: 240 minutes

Report Basis: As Received
Final Aliquot: $0.740 \mathrm{~g}$

Prep Basis: As Received

Moisture(\%): NA

Result Units: $\mathrm{pCi} / \mathrm{g}$

File Name:SRC1222

\begin{tabular}{|c|c|c|c|c|c|}
\hline CASNO & Target Nuclide & Result +/- 2 s TPU & MDC & $\begin{array}{c}\text { Requested } \\
\text { MDC }\end{array}$ & \begin{tabular}{c} 
Lab Qualifier \\
\hline $10098-97-2$
\end{tabular} \\
\hline
\end{tabular}

Chemical Yield Summary

\begin{tabular}{|c|c|c|c|c|c|c|}
\hline Carrier/Tracer & Amount Added & Result & Units & Yield & $\begin{array}{c}\text { Control } \\
\text { Limits }\end{array}$ & Flag \\
\hline STRONTIUM & $1.080 \mathrm{E}+03$ & $6.69 \mathrm{E}+02$ & ug & 62.0 & $40-110 \%$ & \\
\hline
\end{tabular}

\section{Comments:}

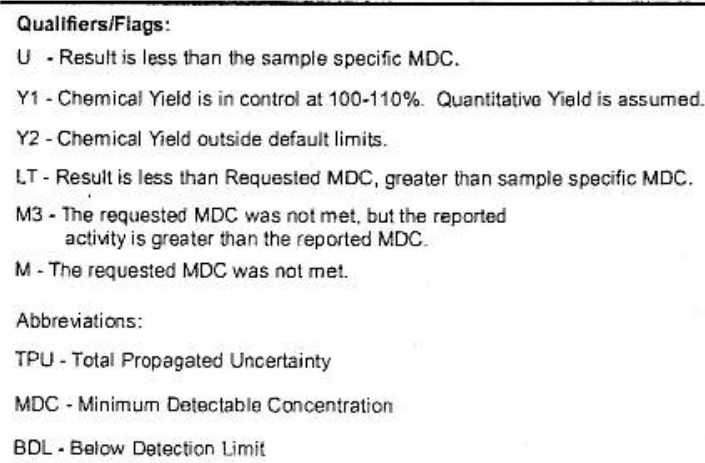

Data Package ID: SR0912143-1 


\section{Strontium-90 Analysis by GFPC \\ PAI 724 Rev 10 \\ Sample Results}

Lab Name: ALS Laboratory Group -. FC

Work Order Number: 0912143

Client Name: National Security Technoiogies, LLC

ClientProject ID: CAU 113 V 3370

\begin{tabular}{|c|c|c|c|c|c|}
\hline \multicolumn{2}{|c|}{$\begin{array}{l}\text { Field ID: CAU113-CI-5 } \\
\text { Lab ID: } 0912143-5 \\
\end{array}$} & $\begin{array}{l}\text { Sample Matrix: SOIL } \\
\quad \text { Prep SOP: PAI } 707 \text { Rev } 10 \\
\text { Date Collected: } 14-D e c-09 \\
\text { Date Prepared: } 18-D e c-09 \\
\text { Date Analyzed: } 22-\text {-Dec-09 }\end{array}$ & $\begin{array}{l}\text { Prep Batch: SR091218-1 } \\
\text { QCBatchID: SR091218-1-1 } \\
\text { Run ID: SR091218-1A } \\
\text { Count Time: } 240 \text { minutes } \\
\text { Report Basis: As Received }\end{array}$ & \multicolumn{2}{|c|}{$\begin{array}{l}\text { Final Aliquot: } 0.754 \mathrm{~g} \\
\text { Prep Basis: As Received } \\
\text { Moisture(\%): NA } \\
\text { Result Units: pCi/g } \\
\text { File Name: SRC1222 }\end{array}$} \\
\hline CASNO & Target Nuclide & Result +/- 2 s TPU & MDC & $\begin{array}{l}\text { Requested } \\
\text { MDC }\end{array}$ & Lab Qualifier \\
\hline $10098-97-2$ & Sr-90 & $3.59 \mathrm{E}-01+/-3.49 \mathrm{E}-01$ & $6.94 \mathrm{E}-01$ & $1.00 E+00$ & U \\
\hline
\end{tabular}

Chemical Yield Summary

\begin{tabular}{|c|c|c|c|c|c|c|}
\hline Carrier/Tracer & Amount Added & Result & Units & Yield & $\begin{array}{c}\text { Control } \\
\text { Limits }\end{array}$ & Flag \\
\hline STRONTIUM & $1.090 \mathrm{E}+03$ & $7.57 \mathrm{E}+02$ & ug & 69.6 & $40-110 \%$ & \\
\hline
\end{tabular}

\section{Comments:}

Data Package ID: SR0912143-1 


\section{Isotopic Uranium By Alpha Spectroscopy Sample Results Summary}

Client Name: National Security Technologies, LLC Client Project Name: CAU 113 Client Project Number: $\mathrm{V} 3370$
Laboratory Name: ALS Laboratory Group -- FC PAI Work Order: 0912143
Page: 1 of 2

Reported on: Tuesday, December 29, 2009 11:57:24 AM

\begin{tabular}{|c|c|c|c|c|c|c|c|c|c|c|}
\hline $\begin{array}{c}\text { Lab } \\
\text { Sample ID }\end{array}$ & Client Sample ID & $\begin{array}{l}\text { Sample } \\
\text { Type }\end{array}$ & Nuclide & Result $+1-2$ s TPU & MDC & Units & Matrix & Prep Batch & $\begin{array}{c}\text { Date } \\
\text { Analyzed }\end{array}$ & Flags \\
\hline 0912143-1 & CAU113-Cl-1 & Sample & U-233/234 & $4.18 \mathrm{E}-01+/-7.33 \mathrm{E}-02$ & 8.81E-03 & $\mathrm{pCl} / \mathrm{g}$ & SOIL & ASO91217-1 & $12 / 21 / 2009$ & \\
\hline $0912143-1$ & CAU113-Cl-1 & Sample & U-235 & $2.33 E-02+/-9.97 E-03$ & $6.35 E-03$ & pCirg & SOIL & ASO91217-1 & $12 / 21 / 2009$ & \\
\hline 0912143-1 & CAU113-Cl-1 & Sample & U-238 & $3.65 \mathrm{E}-01+/-6.52 \mathrm{E}-02$ & $8.81 E-03$ & $\mathrm{pCi} / \mathrm{g}$ & SOIL & ASO91217-1 & $12 / 21 / 2009$ & \\
\hline $0912143-2$ & CAU113-Cl-2 & Sample & $U-233 / 234$ & $4.62 E-01+/-7.97 E-02$ & $1.04 \mathrm{E}-02$ & $\mathrm{pCi} / \mathrm{g}$ & SOIL & AS091217-1 & $12 / 21 / 2009$ & \\
\hline $0912143-2$ & CAU113-Ci-2 & Sample & U-235 & $1.46 \mathrm{E}-02+/-8.59 \mathrm{E}-03$ & $9.77 \mathrm{E}-03$ & pCirg & SOIL & AS091217-1 & $12 / 21 / 2009$ & LT \\
\hline $0912143-2$ & CAU113-Cl-2 & Sample & U-238 & 4.05E-01+/-7.07E-02 & $5.09 \mathrm{E}-03$ & pCi/g & SOIL & ASO91217-1 & $12 / 21 / 2009$ & \\
\hline 0912143-3 & CAU113-Cl-3 & Sample & U-233/234 & $4.28 \mathrm{E}-01+/-7.48 \mathrm{E}-02$ & 1.19E-02 & $\mathrm{pCi} / \mathrm{g}$ & SOIL & AS091217-1 & $12 / 21 / 2009$ & \\
\hline $0912143-3$ & CAU113-Cl-3 & Sample & U-235 & $2.44 \mathrm{E}-02+1-1.06 \mathrm{E}-02$ & $9.05 E-03$ & $\mathrm{pCi} / \mathrm{g}$ & SOIL & AS091217-1 & $12 / 21 / 2009$ & \\
\hline $0912143-3$ & CAU113-Cl-3 & Sample & $U-238$ & $4.36 \mathrm{E}-01+/-7.58 \mathrm{E}-02$ & $5.26 \mathrm{E}-03$ & $\mathrm{pCi} / \mathrm{g}$ & SOR & ASO91217-1 & $12 / 21 / 2009$ & \\
\hline
\end{tabular}

Comments:

Data Package ID: UR0912143-1

\footnotetext{
Qualifiers/Flags:

$U$ - Result is less than the sample specific MOC.

LT - Result is less than Requested MDC, greater than sample specific MDC.

Y1 - Chemical Yield is in control at $100-110 \%$. Quantitative Yield is assumed

Y2- Chemical Yield outside default limits

$M$ - The requested $M D C$ was not met

$M 3$ - The requested MDC was not met, but the reported activity is greater than the reported MDC.
}

Aubreviations:

TPU - Total Propagated Uncertainty

MDC - Minimum Detectable Concentration 


\section{Isotopic Uranium By Alpha Spectroscopy Sample Results Summary}

Client Name: National Security Technologies, LLC Client Project Name: CAU 113

Client Project Number: V3370
Laboratory Name: ALS Laboratory Group -- FC

PAl Work Order: 0912143
Page: 2 of 2

Reported on: Tuesday, December 29, 2009 11:57:24 AM

\begin{tabular}{|c|c|c|c|c|c|c|c|c|c|c|}
\hline $\begin{array}{c}\text { Lab } \\
\text { Sample ID }\end{array}$ & Client Sample ID & $\begin{array}{c}\text { Sample } \\
\text { Type }\end{array}$ & Nuclide & Result $+1-2$ s TPU & MDC & Units & Matrix & Prep Batch & $\begin{array}{c}\text { Date } \\
\text { Analyzed }\end{array}$ & Flags \\
\hline $0912143-4$ & CAU113-Cl-4 & Sample & U-233/234 & $4.82 \mathrm{E}-01+/-8.37 \mathrm{E}-02$ & $5.63 \mathrm{E}-03$ & $\mathrm{pCi} / \mathrm{g}$ & SOIL & ASog1217-1 & $12 / 21 / 2009$ & \\
\hline $0912143-4$ & CAU113-Cl-4 & Sample & U-235 & $3.33 \mathrm{E}-02+/-1.24 \mathrm{E}-02$ & $6.62 E-03$ & $\mathrm{pCi} / \mathrm{g}$ & SOIL & AS091217.1 & $12 / 21 / 2009$ & \\
\hline $0912143-4$ & CAU113-Cl-4 & Sample & $U-238$ & 4.93E-01+/-8.55E-02 & 8. $23 \mathrm{E}-03$ & $\mathrm{pCi} / \mathrm{g}$ & SOIL & AS091217-1 & $12 / 21 / 2009$ & \\
\hline $0912143-5$ & CAU113-Cl-5 & Sample & U-233/234 & 4.31E-01+/-7.59E-02 & $1.01 E-02$ & pCi/g & SOIL & AS091217-1 & $12 / 21 / 2009$ & \\
\hline $0912143-5$ & CAU113-Cl-5 & Sampie & U-235 & $2.90 \mathrm{E}-02+/-1.15 \mathrm{E}-02$ & $6.66 \mathrm{E}-03$ & pCirg & SOIL & AS091217-1 & $12 / 21 / 2009$ & \\
\hline $0912143-5$ & CAU113-CI-5 & Sample & U-238 & $4.58 \mathrm{E}-01+/-7.99 \mathrm{E}-02$ & $5.66 \mathrm{E}-03$ & pCirg & SOIL & AS091217-1 & $12 / 21 / 2009$ & \\
\hline
\end{tabular}

Comments:

Data Package ID: UR0912143-1

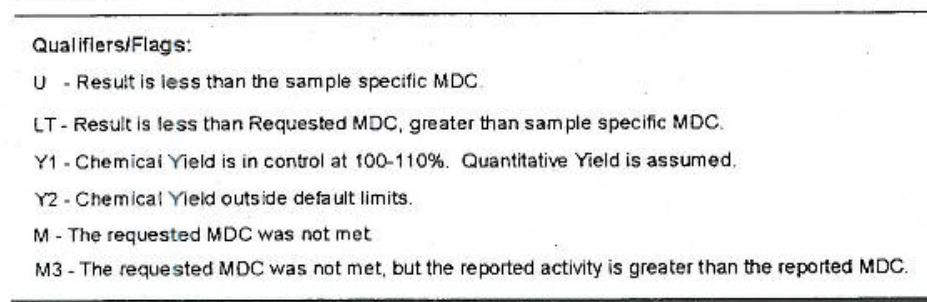

Date Printed: Tuesday, December 29, 2009

Abbreviations

TPU - Total Propagated Uncertainty

MDC - Minimum Detectable Concentration

$B O L$ - Below Detection Limit 


\section{Isotopic Uranium By Alpha Spectroscopy \\ PAI 714 Rev 11 \\ Sample Results}

Lab Name: ALS Laboratory Group -- FC

Work Order Number: 0912143

Client Name: National Security Technologies, LLC

ClientProject ID: CAU 113 V3370

Field ID: CAU113-CI-1
Lab ID: $0912143-1$

Sample Matrix: SOIL

Prep SOP: PAI 778 Rev 13

Date Collected: 14-Dec-09

Date Prepared: 17-Dec-09

Analysis ReqCode: NAS-A-002
Prep Batch: AS091217-1

QCBatchID: AS091217-1-1

Run ID: AS091217-1B

Count Time: 1000 minutes

Report Basis: As Received
Final Aliquot: $2.53 \mathrm{~g}$

Prep Basis: As Received

Moisture(\%): NA

Result Units: $\mathrm{pCi} / \mathrm{g}$

File Name: Spectrum \#1

\begin{tabular}{|l|c|c|c|c|c|}
\hline \multicolumn{1}{|c|}{ CASNO } & Target Nuclide & Result +/- 2 s TPU & MDC & $\begin{array}{c}\text { Requested } \\
\text { MDC }\end{array}$ & \begin{tabular}{c} 
Lab Qualifier \\
\hline $11-08-5$
\end{tabular} \\
\hline $15117-96-1$ & $\mathrm{U}-233 / 234$ & $4.18 \mathrm{E}-01+/-7.33 \mathrm{E}-02$ & $8.81 \mathrm{E}-03$ & $2.00 \mathrm{E}-02$ & \\
\hline $7440-61-1$ & $\mathrm{U}-235$ & $2.33 \mathrm{E}-02+/-9.97 \mathrm{E}-03$ & $6.35 \mathrm{E}-03$ & $2.00 \mathrm{E}-02$ & \\
\hline
\end{tabular}

\section{Chemical Yield Summary}

\begin{tabular}{|c|c|c|c|c|c|c|}
\hline Carrier/Tracer & Amount Added & Result & Units & Yield & $\begin{array}{c}\text { Control } \\
\text { Limits }\end{array}$ & Flag \\
\hline $\mathrm{U}-232$ & $1.740 \mathrm{E}+00$ & $1.36 \mathrm{E}+00$ & $\mathrm{pCi} / \mathrm{g}$ & 78.4 & $30-110 \%$ & \\
\hline
\end{tabular}

\section{Comments:}

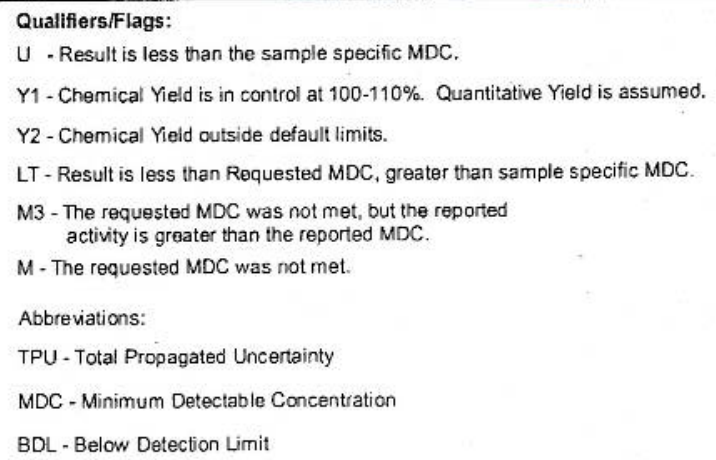

Data Package ID: UR0912143-1 


\section{Isotopic Uranium By Alpha Spectroscopy}

\section{PAI 714 Rev 11 \\ Sample Results}

Lab Name: ALS Laboratory Group -- FC

Work Order Number: 0912143

Client Name: National Security Technologies, LLC

ClientProject ID: CAU 113 V3370

Field ID: CAU113-Cl-2
Lab ID: $0912143-2$

Analysis ReqCode: NAS-A-002
Sample Matrix: SOIL

Prep SOP: PAI 778 Rev 13

Date Collected: 14-Dec-09

Date Prepared: 17-Dec-09

Date Analyzed: 21-Dec-09
Prep Batch: AS091217-1

QCBatchID: AS091217-1-1

Run ID: AS091217-1B

Count Time: 1000 minutes

Report Basis: As Received
Final Aliquot: $2.50 \mathrm{~g}$

Prep Basis: As Received

Moisture(\%): NA

Result Units: $\mathrm{pCi} / \mathrm{g}$

File Name:Spectrum \#1

\begin{tabular}{|l|c|c|c|c|c|}
\hline \multicolumn{1}{|c|}{ CASNO } & Target Nuclide & Result +/- 2 s TPU & MDC & $\begin{array}{c}\text { Requested } \\
\text { MDC }\end{array}$ & \begin{tabular}{c} 
Lab Qualifier \\
\hline $11-08-5$
\end{tabular} \\
\hline $15117-96-1$ & $\mathrm{U}-233 / 234$ & $4.62 \mathrm{E}-01+/-7.97 \mathrm{E}-02$ & $1.04 \mathrm{E}-02$ & $2.00 \mathrm{E}-02$ & \\
\hline $7440-61-1$ & $\mathrm{U}-235$ & $1.46 \mathrm{E}-02+/-8.59 \mathrm{E}-03$ & $9.77 \mathrm{E}-03$ & $2.00 \mathrm{E}-02$ & $\mathrm{LT}$ \\
\hline
\end{tabular}

Chemical Yield Summary

\begin{tabular}{|c|c|c|c|c|c|c|}
\hline Carrier/Tracer & Amount Added & Result & Units & Yield & $\begin{array}{c}\text { Control } \\
\text { Limits }\end{array}$ & Flag \\
\hline $\mathrm{U}-232$ & $1.760 \mathrm{E}+00$ & $1.49 \mathrm{E}+00$ & $\mathrm{pCi} / \mathrm{g}$ & 85.1 & $30-110 \%$ & \\
\hline
\end{tabular}

Comments:

\footnotetext{
Qualifiers/Flags:

$U$ - Result is less than the sample specific MDC

Y1 - Chemical Yield is in control at 100-110\%. Quantitative Yield is assumed.

Y2. Chemical Yield outside default limits.

LT - Result is less than Requested MDC, greater than sample specific MDC.

M3 - The requested MDC was not met, but the reported activity is greater than the reported MDC.

$M$ - The requested MDC was not met.

Abbreviations:

TPU - Total Propagated Uncertainty

MDC - Minimum Detectable Concentration

BDL - Below Detection Limit
}

Data Package ID: UR0912143-1 


\section{Isotopic Uranium By Alpha Spectroscopy \\ PAI 714 Rev 11 \\ Sample Results}

Lab Name: ALS Laboratory Group -- FC

Work Order Number: 0912143

Client Name: National Security Technologies, LLC

ClientProject ID: CAU 113 V3370

Field ID: CAU113-Cl-3
Lab ID: $0912143-3$

Analysis ReqCode: NAS-A-002
Sample Matrix: SOIL Prep SOP: PAl 778 Rev 13

Date Collected: 14-Dec-09

Date Prepared: 17-Dec-09

Date Analyzed: 21-Dec-09
Prep Batch: AS091217-1

QCBatchID: AS091217-1-1

Run ID: AS091217-1B

Count Time: 1000 minutes

Report Basis: As Received
Final Aliquot: $2.51 \mathrm{~g}$

Prep Basis: As Received

Moisture(\%): NA

Result Units: pCi/g

File Name: Spectrum \#1

\begin{tabular}{|l|c|c|c|c|c|}
\hline \multicolumn{1}{|c|}{ CASNO } & Target Nuclide & Result +/- 2 s TPU & MDC & $\begin{array}{c}\text { Requested } \\
\text { MDC }\end{array}$ & \begin{tabular}{c} 
Lab Qualifier \\
\hline $11-08-5$
\end{tabular} \\
\hline $15117-96-1$ & $\mathrm{U}-233 / 234$ & $4.28 \mathrm{E}-01+1-7.48 \mathrm{E}-02$ & $1.19 \mathrm{E}-02$ & $2.00 \mathrm{E}-02$ & \\
\hline $7440-61-1$ & $\mathrm{U}-235$ & $2.44 \mathrm{E}-02+/-1.06 \mathrm{E}-02$ & $9.05 \mathrm{E}-03$ & $2.00 \mathrm{E}-02$ & \\
\hline
\end{tabular}

\section{Chemical Yield Summary}

\begin{tabular}{|c|c|c|c|c|c|c|}
\hline Carrier/Tracer & Amount Added & Result & Units & Yield & $\begin{array}{c}\text { Control } \\
\text { Limits }\end{array}$ & Flag. \\
\hline $\mathrm{U}-232$ & $1.750 \mathrm{E}+00$ & $1.48 \mathrm{E}+00$ & $\mathrm{pCi} / \mathrm{g}$ & 84.2 & $30-110 \%$ & \\
\hline
\end{tabular}

\section{Comments:}

\section{Qualifiers/Flags:}

$U$ - Result is less than the sample specific MDC.

Y1 - Chemical Yield is in control at 100-110\%. Quantitative Yield is assumed.

Y2 - Chemical Yield outside default limits.

LT - Result is less than Requested MDC, greater than sample specific MDC.

M3 - The requested MDC was not met, but the reported

activity is greater than the reported MDC.

$M$ - The requested MDC was not met.

Abbreviations:

TPU - Total Propagated Uncertainty

MDC - Minimum Detectable Concentration

BDL - Below Detection Limit

Data Package ID: UR0912143-1 


\section{Isotopic Uranium By Alpha Spectroscopy}

\section{PAI 714 Rev 11 \\ Sample Results}

Lab Name: ALS Laboratory Group -- FC

Work Order Number: 0912143

Client Name: National Security Technologies, LLC

ClientProject ID: CAU 113 V3370

\begin{tabular}{l} 
Fieid ID: CAU113-Cl-4 \\
Lab ID: $0912143-4$ \\
\hline
\end{tabular}

Sample Matrix: SOIL

Prep SOP: PAI 778 Rev 13

Date Collected: 14-Dec-09

Date Prepared: 17-Dec-09

Date Analyzed: 21-Dec-09

Analysis ReqCode: NAS-A-002
Prep Batch: AS091217-1

QCBatchID: AS091217-1-1

Run ID: AS091217-1B

Count Time: 1000 minutes

Report Basis: As Received
Final Aliquot: $2.52 \mathrm{~g}$

Prep Basis: As Received

Moisture(\%): NA

Result Units: pCi/g

File Name: Spectrum \#1

Date Analyzed: 21-Dec-09

\begin{tabular}{|l|c|c|c|c|c|}
\hline \multicolumn{1}{|c|}{ CASNO } & Target Nuclide & Result +/- 2 s TPU & MDC & $\begin{array}{c}\text { Requested } \\
\text { MDC }\end{array}$ & \begin{tabular}{c} 
Lab Qualifier \\
\hline $11-08-5$
\end{tabular} \\
\hline $15117-96-1$ & $\mathrm{U}-233 / 234$ & $4.82 \mathrm{E}-01+/-8.37 \mathrm{E}-02$ & $5.63 \mathrm{E}-03$ & $2.00 \mathrm{E}-02$ & \\
\hline $7440-61-1$ & $\mathrm{U}-235$ & $3.33 \mathrm{E}-02+/-1.24 \mathrm{E}-02$ & $6.62 \mathrm{E}-03$ & $2.00 \mathrm{E}-02$ & \\
\hline
\end{tabular}

Chemical Yield Summary

\begin{tabular}{|c|c|c|c|c|c|c|}
\hline Carrier/Tracer & Amount Added & Result & Units & Yield & $\begin{array}{c}\text { Control } \\
\text { Limits }\end{array}$ & Flag \\
\hline $\mathrm{U}-232$ & $1.750 \mathrm{E}+00$ & $1.39 \mathrm{E}+00$ & $\mathrm{pCi} / \mathrm{g}$ & 79.6 & $30-110 \%$ & \\
\hline
\end{tabular}

\section{Comments:}

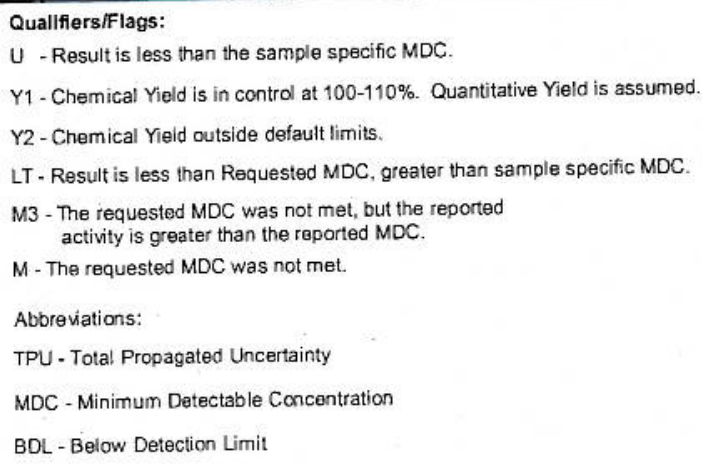




\section{Isotopic Uranium By Alpha Spectroscopy}

PAI 714 Rev 11

Sample Duplicate Results

Lab Name: ALS Laboratory Group -- FC

Work Order Number: 0912143

Client Name: National Security Technologies, LLC

ClientProject ID: CAU 113 V3370

\begin{tabular}{|c|}
\hline Field ID: CAU113-Cl-4 \\
\hline Lab ID: $0912143-4 D U P$ \\
\hline
\end{tabular}

Sample Matrix: SOIL

Prep SOP:PAI 778 Rev 13

Date Collected: 14-Dec-09

Date Prepared: 17-Dec-09

Date Analyzed: 21-Dec-09
Prep Batch: AS091217-1

QCBatchID: AS091217-1-1

Run ID: AS091217-1B

Count Time: 1000 minutes

Report Basis: As Received
Final Aliquot: $2.53 \mathrm{~g}$

Prep Basis: As Received

Moisture(\%): NA

Result Units: $\mathrm{pCi} / \mathrm{g}$

File Name: Spectrum \#1

\begin{tabular}{|c|c|c|c|c|c|}
\hline CASNO & Target Nuclide & Result +/- 2 s TPU & MDC & $\begin{array}{c}\text { Requested } \\
\text { MDC }\end{array}$ & \begin{tabular}{c} 
Lab Qualifier \\
\hline $11-08-5$
\end{tabular} \\
\hline U-233/234 & $5.01 \mathrm{E}-01+/-8.74 \mathrm{E}-02$ & $1.55 \mathrm{E}-02$ & $2.00 \mathrm{E}-02$ & \\
\hline $15117-96-1$ & $\mathrm{U}-235$ & $2.80 \mathrm{E}-02+/-1.17 \mathrm{E}-02$ & $8.67 \mathrm{E}-03$ & $2.00 \mathrm{E}-02$ & \\
\hline $7440-61-1$ & $\mathrm{U}-238$ & $4.99 \mathrm{E}-01+/-8.72 \mathrm{E}-02$ & $1.69 \mathrm{E}-02$ & $2.00 \mathrm{E}-02$ & \\
\hline
\end{tabular}

\section{Chemical Yield Summary}

\begin{tabular}{|c|c|c|c|c|c|c|}
\hline Carrier/Tracer & Amount Added & Result & Units & Yield & $\begin{array}{c}\text { Control } \\
\text { Limits }\end{array}$ & \begin{tabular}{c} 
Flag \\
\hline $\mathrm{U}-232$
\end{tabular} \\
\hline
\end{tabular}

\section{Comments:}

\footnotetext{
Quallfiers/Flags:

$U$ - Result is less than the sample specific MDC.

$\mathrm{Y} 1$ - Chemical Yield is in control at $100-110 \%$. Quantitative yield is assumed

Y2 - Chemical Yield outside default limits.

LT - Result is less than Requested MDC, greater than sample specific MDC.

$M$ - The requested MDC was not met.

M3 - The requested MDC was not met, but thereported activity is greater than the reported MDC

D - DER is greater than Control Limit of 3
}

\section{Abbreviations:}

TPU - Total Propagated Uncertainty

MDC - Minimum Detectable Concentration

BDL - Below Detection Limit

Data Package ID: UR0912143-1 


\title{
Isotopic Uranium By Alpha Spectroscopy
}

\author{
PAI 714 Rev 11 \\ Sample Results
}

Lab Name: ALS Laboratory Group -- FC

Work Order Number: 0912143

Client Name: National Security Technologies, LLC

ClientProject ID: CAU 113 V 3370

Field ID: CAU113-CI-5
Lab ID: $0912143-5$

Analysis ReqCode: NAS-A-002
Sample Matrix: SOIL

Prep SOP: PAI 778 Rev 13

Date Collected: 14-Dec-09

Date Prepared: 17-Dec-09

Date Analyzed: 21-Dec-09
Prep Batch: AS091217-1

QCBatchID: AS091217-1-1

Run ID: AS091217-1B

Count Time: 1000 minutes

Report Basis: As Received
Final Aliquot: $2.50 \mathrm{~g}$

Prep Basis: As Received

Moisture(\%): NA

Result Units: pCi/g

File Name: Spectrum \#1

\begin{tabular}{|l|c|c|c|c|}
\hline \multicolumn{1}{|c|}{ CASNO } & Target Nuclide & Result +/- 2 s TPU & MDC \\
\hline $11-08-5$ & $\mathrm{U}-233 / 234$ & $4.31 \mathrm{E}-01+/-7.59 \mathrm{E}-02$ & $1.01 \mathrm{E}-02$ & $2.00 \mathrm{E}-02$ \\
\hline $15117-96-1$ & $\mathrm{U}-235$ & $2.90 \mathrm{E}-02+/-1.15 \mathrm{E}-02$ & $6.66 \mathrm{E}-03$ & $2.00 \mathrm{E}-02$ \\
\hline $7440-61-1$ & $\mathrm{U}-238$ & $4.58 \mathrm{E}-01+/-7.99 \mathrm{E}-02$ & $5.66 \mathrm{E}-03$ & $2.00 \mathrm{E}-02$ \\
\hline
\end{tabular}

\section{Chemical Yield Summary}

\begin{tabular}{|c|c|c|c|c|c|c|}
\hline Carrier/Tracer & Amount Added & Result & Units & Yield & $\begin{array}{c}\text { Control } \\
\text { Limits }\end{array}$ & Flag \\
\hline $\mathrm{U}-232$ & $1.750 \mathrm{E}+00$ & $1.45 \mathrm{E}+00$ & $\mathrm{pCi} / \mathrm{g}$ & 82.7 & $30-110 \%$ & \\
\hline
\end{tabular}

\section{Comments:}

Quallfiers/Flags:

$U$ - Result is less than the sample specific MDC.

Y1 - Chemical Yield is in control at 100-110\%. Quantitative Yield is assumed.

Y2 - Chemical Yield outside default limits.

LT - Result is less than Requested MDC, greater than sample specific MDC.

$M 3$ - The requested MDC was not met, but the reported activity is greater than the reported MDC.

$M$ - The requested $M D C$ was not met.

Abbreviations:

TPU - Total Propagated Uncertainty

MDC - Minimum Dotectable Concentration

BDL - Below Detection Limit

Data Package ID: UR0912143-1 


\section{Isotopic Plutonium By Alpha Spectroscopy Sample Results Summary}

Client Name: National Security Technologies, LLC Client Project Name: CAU 113

Client Project Number: V3370
Laboratory Name: ALS Laboratory Group -- FC PAI Work Order: 0912143
Page: 1 of 2

Reported on: Tuesday, December 29, 2009 12:41:40 PM

\begin{tabular}{|c|c|c|c|c|c|c|c|c|c|c|}
\hline $\begin{array}{c}\text { Lab } \\
\text { Sample ID }\end{array}$ & Client Sample ID & $\begin{array}{c}\text { Sample } \\
\text { Type }\end{array}$ & Nuclide & Result + $/-2$ s TPU & MDC & Units & Matrix & Prep Batch & $\begin{array}{c}\text { Date } \\
\text { Analyzed }\end{array}$ & Flags \\
\hline $0912143-1$ & CAU113-Cl-1 & Sample & Pu-238 & $-7.61 \mathrm{E}-04+/-3.73 \mathrm{E}-03$ & $7,07 \mathrm{E}-03$ & $\mathrm{pCl} / \mathrm{g}$ & SOIL & AS091217-1 & $12 / 21 / 2009$ & $u$ \\
\hline 0912143-1 & CAU113-Cl-1 & Sample & Pu-239/240 & $3.04 \mathrm{E}-03+/-3.76 \mathrm{E}-03$ & $2.06 \mathrm{E}-03$ & $\mathrm{pCi} / \mathrm{g}$ & SOIL & AS091217-1 & $12 / 21 / 2009$ & LT \\
\hline $0912143-2$ & CAU113-Cl-2 & Sample & Pu-238 & $\mathrm{OE}+00+1-3.81 \mathrm{E}-03$ & 7.22E-03 & pcitg & SOIL & AS091217-1 & $12 / 21 / 2009$ & $U$ \\
\hline 0912143-2 & CAU113-Cl-2 & Sample & Pu-239/240 & $3.11 \mathrm{E}-03+1-3.84 \mathrm{E}-03$ & $2.11 \mathrm{E}-03$ & $\mathrm{pCi} / \mathrm{g}$ & SOIL & AS091217-1 & $12 / 21 / 2009$ & LT \\
\hline 0912143-3 & CAU113-Cl-3 & Sample & Pu-238 & 1.53E-03 +1- $3.76 \mathrm{E}-03$ & $5.63 E-03$ & $\mathrm{pCi} / \mathrm{g}$ & SOIL & AS091217-1 & $12 / 21 / 2009$ & $U$ \\
\hline $0912143-3$ & CAU113-CI-3 & Sample & Pu-239/240 & $-7.65 \mathrm{E}-04+1-3.75 \mathrm{E}-03$ & $8.24 E-03$ & $\mathrm{pCi} / \mathrm{g}$ & SOIL & AS091217-1 & $12 / 21 / 2009$ & $\mathrm{u}$ \\
\hline $0912143-4$ & CAU113-Cl-4 & Sample & Pu-238 & $1.30 E-03+1-6.39 E-03$ & $3.53 \mathrm{E}-03$ & pCifg & SOIL & AS091217-1 & $12 / 21 / 2009$ & $u$ \\
\hline $0912143-4$ & CAU113-Cl-4 & Sample & Pu-239/240 & 1.30E-03 +1-6.39E-03 & 3.53E-03 & pCirg & SOIL & AS091217-1 & $12 / 21 / 2009$ & $u$ \\
\hline $0912143-5$ & CAU113-Cl-5 & Sample & Pu-238 & $-7.66 \mathrm{E}-04+/-3.75 \mathrm{E}-03$ & 7.11E-03 & pCirg & SOIL & AS091217-1 & $12 / 22 / 2009$ & $u$ \\
\hline
\end{tabular}

Comments:

Data Package ID: PU0912143-1

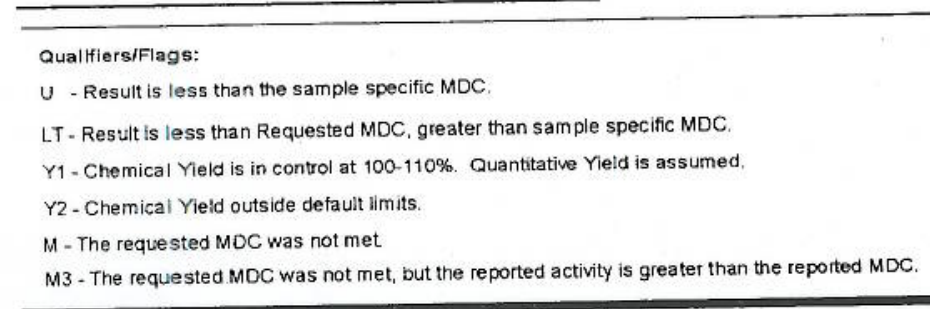

Date Printed: Tuesday, December 29, 2009

ALS Laboratory Group -- FC

Page 1 of 2

LIMS Version: $6.321 \mathrm{~A}$ 


\section{Isotopic Plutonium By Alpha Spectroscopy Sample Results Summary}

Client Name: National Security Technologies, LLC Client Project Name: CAU 113 Client Project Number: V3370
Laboratory Name: ALS Laboratory Group -- FC

PAI Work Order: 0912143
Page: 2 of 2

Reported on: Tuesday, December 29, 2009 12:41:40 PM

\begin{tabular}{|c|c|c|c|c|c|c|c|c|c|c|}
\hline $\begin{array}{c}\text { Lab } \\
\text { Sample ID }\end{array}$ & Client Sample ID & $\begin{array}{l}\text { Sample } \\
\text { Type }\end{array}$ & Nuclide & Result +l- 2 s TPU & MDC & Units & Matrix & Prep Batch & $\begin{array}{c}\text { Date } \\
\text { Analyzed }\end{array}$ & Flags \\
\hline $0912143-5$ & CAU113-Cl-5 & Sample & Pu-239/240 & $-1.53 \mathrm{E}-03+1-4.34 \mathrm{E}-03$ & $1.00 \mathrm{E}-02$ & $\mathrm{pCi} / \mathrm{g}$ & SOIL & ASO91217-1 & $12 / 22 / 2009$ & u \\
\hline
\end{tabular}

Comments:

Data Package ID: PU0912143-1

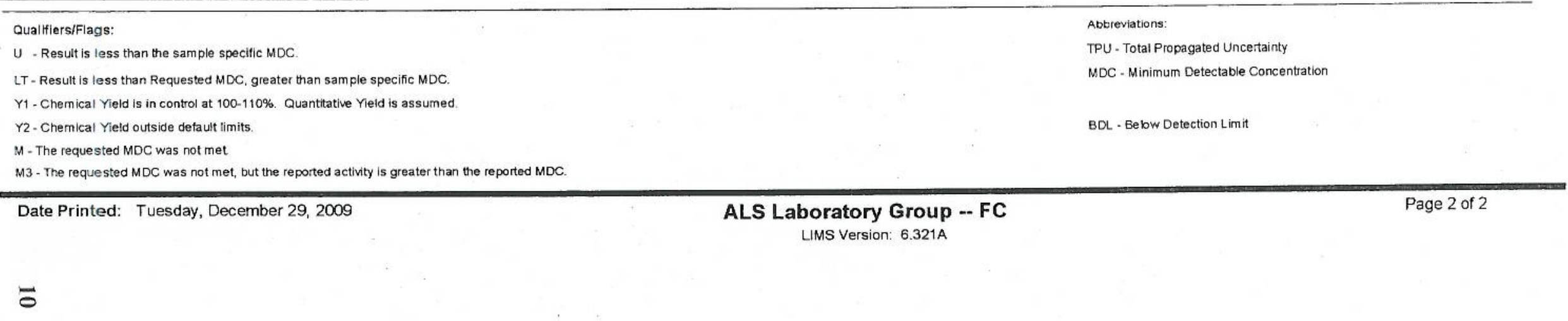




\section{Isotopic Plutonium By Alpha Spectroscopy \\ PAl 714 Rev 11 \\ Sample Results}

Lab Name: ALS Laboratory Group - FC

Work Order Number: 0912143

Client Name: National Security Technologies, LLC

ClientProject ID: CAU 113 V3370

Field ID: CAU113-Cl-1
Lab ID: $0912143-1$

Analysis ReqCode: NAS-A-006
Sample Matrix: SOIL

Prep SOP: PAl 778 Rev 13

Date Collected: 14-Dec-09

Date Prepared: 17-Dec-09

Date Analyzed: 21-Dec-09
Prep Batch: AS091217-1

QCBatchID: AS091217-1-1

Run ID: AS091217-1A

Count Time: 1000 minutes

Report Basis: As Received
Final Aliquot: $2.53 \mathrm{~g}$

Prep Basis: As Received

Moisture(\%): NA

Result Units: $\mathrm{pCi} / \mathrm{g}$

File Name: Spectrum \#1

\begin{tabular}{|l|c|c|c|c|c|}
\hline \multicolumn{1}{|c|}{ CASNO } & Target Nuclide & Result +/- 2 s TPU & MDC & $\begin{array}{c}\text { Requested } \\
\text { MDC }\end{array}$ & \begin{tabular}{l} 
Lab Qualifier \\
\hline $13981-16-3$
\end{tabular} \\
\hline $10-12-8$ & Pu-238 & $-7.61 \mathrm{E}-04+1-3.73 \mathrm{E}-03$ & $7.07 \mathrm{E}-03$ & $2.00 \mathrm{E}-02$ & $\mathrm{U}$ \\
\hline
\end{tabular}

\section{Chemical Yield Summary}

\begin{tabular}{|c|c|c|c|c|c|}
\hline Carrier/Tracer & Amount Added & Result & Units & Yield & $\begin{array}{c}\text { Control } \\
\text { Limits }\end{array}$ \\
\hline Pu-242 & $1.760 E+00$ & $1.42 E+00$ & $p C i / g$ & 80.8 & $30-110 \%$ \\
\hline
\end{tabular}

\section{Comments:}

Qualifiers/Flags:

$U$ - Result is less than the sample specific MDC.

Y1 - Chemical Yield is in control at 100-110\%. Quantitative Yield is assumed.

Y2 - Chemical Yield outside defauit limits.

LT - Result is less than Requested MDC, greater than sample specific MDC.

M3 - The requested MDC was not met, but the reported activity is greater than the reported MDC.

$M$ - The requested MDC was not met.

Abbreviations:

TPU - Total Propagated Uncertainty

MDC - Minimum Detectable Concentration

BDL - Below Detection Limit

Data Package ID: PU0912143-1 


\section{Isotopic Plutonium By Alpha Spectroscopy \\ PAI 714 Rev 11 \\ Sample Results}

Lab Name: ALS Laboratory Group -- FC

Work Order Number: 0912143

Client Name: National Security Technologies, LLC

ClientProject ID: CAU 113 V 3370

Field ID: CAU113-Cl-2
Lab ID: $0912143-2$

Analysis ReqCode: NAS-A-006
Sample Matrix: SOIL

Prep SOP:PAI 778 Rev 13

Date Collected: 14-Dec-09

Date Prepared: 17-Dec-09

Date Analyzed: 21-Dec-09
Prep Batch: AS091217-1

QCBatchID: AS091217-1-1

Run ID: AS091217-1A

Count Time: 1000 minutes

Report Basis: As Received
Final Aliquot: $2.50 \mathrm{~g}$

Prep Basis: As Received

Moisture(\%): NA

Result Units: $\mathrm{pCi} / \mathrm{g}$

File Name: Spectrum \#1

\begin{tabular}{|l|c|c|c|c|}
\hline \multicolumn{1}{|c|}{ CASNO } & Target Nuclide & Result +/- 2 s TPU & MDC \\
\hline $13981-16-3$ & Pu-238 & OE $+00+/-3.81 E-03$ & $7.22 E-03$ & $2.00 E-02$ \\
\hline $10-12-8$ & Pu-239/240 & $3.11 E-03+/-3.84 E-03$ & $2.11 E-03$ & $2.00 E-02$ \\
\hline
\end{tabular}

Chemical Yield Summary

\begin{tabular}{|c|c|c|c|c|c|c|}
\hline Carrier/Tracer & Amount Added & Result & Units & Yield & $\begin{array}{c}\text { Control } \\
\text { Limits }\end{array}$ & Flag \\
\hline Pu-242 & $1.780 \mathrm{E}+00$ & $1.32 \mathrm{E}+00$ & $\mathrm{pCi} / \mathrm{g}$ & 74.3 & $30-110 \%$ & \\
\hline
\end{tabular}

\section{Comments:}

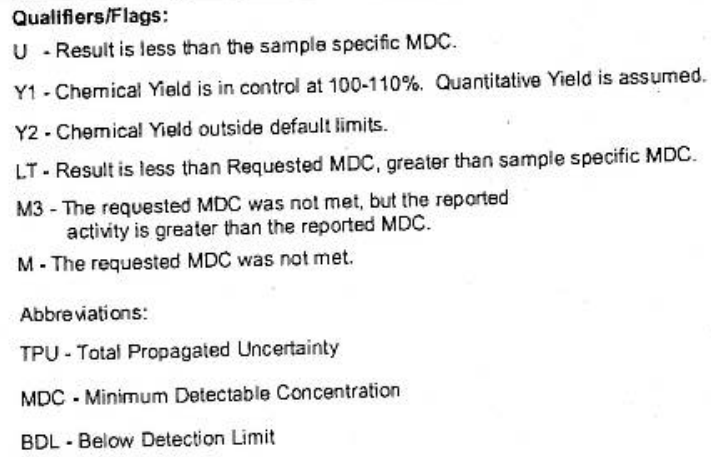

Data Package ID: PU0912143-1 


\section{Isotopic Plutonium By Alpha Spectroscopy \\ PAI 714 Rev 11 \\ Sample Results}

Lab Name: ALS Laboratory Group -- FC

Work Order Number: 0912143

Client Name: National Security Technologies, LLC

ClientProject ID: CAU 113 V 3370

\begin{tabular}{l}
\hline Field ID: CAU113-CI-3 \\
Lab ID: $0912143-3$ \\
\hline
\end{tabular}

Analysis ReqCode: NAS-A-006
Sample Matrix: SOIL Prep SOP: PAI 778 Rev 13

Date Collected: 14-Dec-09

Date Prepared: 17-Dec-09

Date Analyzed: 21-Dec-09
Prep Batch: AS091217-1

QCBatchID: AS091217-1-1

Run ID: AS091217-1A

Count Time: 1000 minutes

Report Basis: As Received
Final Aliquot: $2.51 \mathrm{~g}$

Prep Basis: As Received

Moisture(\%): NA

Result Units: $\mathrm{pCl} / \mathrm{g}$

File Name: Spectrum \#1

\begin{tabular}{|l|c|c|c|c|c|}
\hline \multicolumn{1}{|c|}{ CASNO } & Target Nuclide & Result +/- 2 s TPU & MDC & $\begin{array}{c}\text { Requested } \\
\text { MDC }\end{array}$ & \begin{tabular}{c} 
Lab Qualifier \\
\hline $13981-16-3$
\end{tabular} \\
\hline $10-12-8$ & Pu-238 & $1.53 \mathrm{E}-03+/-3.76 \mathrm{E}-03$ & $5.63 \mathrm{E}-03$ & $2.00 \mathrm{E}-02$ & $\mathrm{U}$ \\
\hline
\end{tabular}

\section{Chemical Yield Summary}

\begin{tabular}{|c|c|c|c|c|c|c|}
\hline Carrier/Tracer & Amount Added & Result & Units & Yield & $\begin{array}{c}\text { Control } \\
\text { Limits }\end{array}$ & Flag \\
\hline Pu-242 & $1.770 \mathrm{E}+00$ & $1.35 \mathrm{E}+00$ & $\mathrm{pCi} / \mathrm{g}$ & 76.3 & $30-110 \%$ & \\
\hline
\end{tabular}

\section{Comments:}

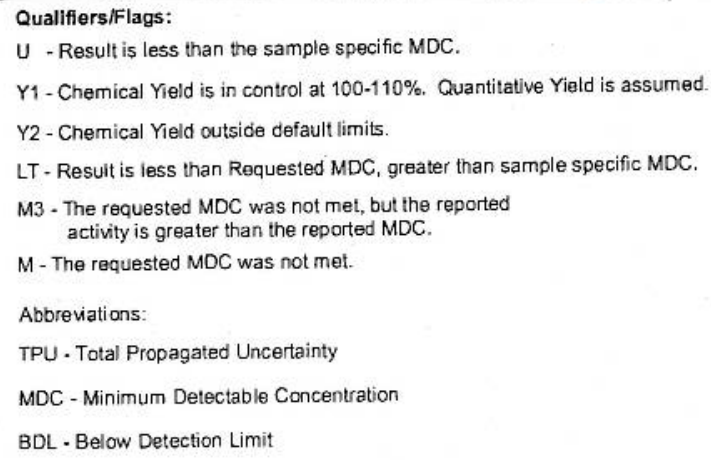

Data Package ID: PU0912143-1 


\section{Isotopic Plutonium By Alpha Spectroscopy \\ PAl 714 Rev 11 \\ Sample Results}

Lab Name: ALS Laboratory Group n- FC

Work Order Number: 0912143

Client Name: National Security Technologies, LLC

ClientProject ID: CAU 113 V3370

Field ID: CAU113-Cl-4
Lab ID: $0912143-4$

Analysis ReqCode: NAS-A-006
Sample Matrix: SOIL

Prep SOP: PAI 778 Rev 13

Date Collected: 14-Dec-09

Date Prepared: 17-Dec-09

Date Analyzed: 21-Dec-09
Prep Batch: AS091217-1

QCBatchID: AS091217-1-1

Run ID: AS091217-1A

Count Time: 1000 minutes

Report Basis: As Received
Final Aliquot: $2.52 \mathrm{~g}$

Prep Basis: As Received

Moisture(\%): NA

Result Units: $\mathrm{pCi} / \mathrm{g}$

File Name: Spectrum \#1

\begin{tabular}{|l|c|c|c|c|c|}
\hline \multicolumn{1}{|c|}{ CASNO } & Target Nuclide & Result +/- 2 s TPU & MDC & $\begin{array}{c}\text { Requested } \\
\text { MDC }\end{array}$ & \begin{tabular}{c} 
Lab Qualifier \\
\hline $13981-16-3$
\end{tabular} \\
\hline $10-12-8$ & Pu-238 & $1.30 \mathrm{E}-03+/-6.39 \mathrm{E}-03$ & $3.53 \mathrm{E}-03$ & $2.00 \mathrm{E}-02$ & $\mathrm{U}$ \\
\hline
\end{tabular}

\section{Chemical Yield Summary}

\begin{tabular}{|c|c|c|c|c|c|c|}
\hline Carrier/Tracer & Amount Added & Result & Units & Yield & $\begin{array}{c}\text { Control } \\
\text { Limits }\end{array}$ & Flag \\
\hline Pu-242 & $1.760 \mathrm{E}+00$ & $7.80 \mathrm{E}-01$ & $\mathrm{pCi} / \mathrm{g}$ & 44.2 & $30-110 \%$ & \\
\hline
\end{tabular}

\section{Comments:}

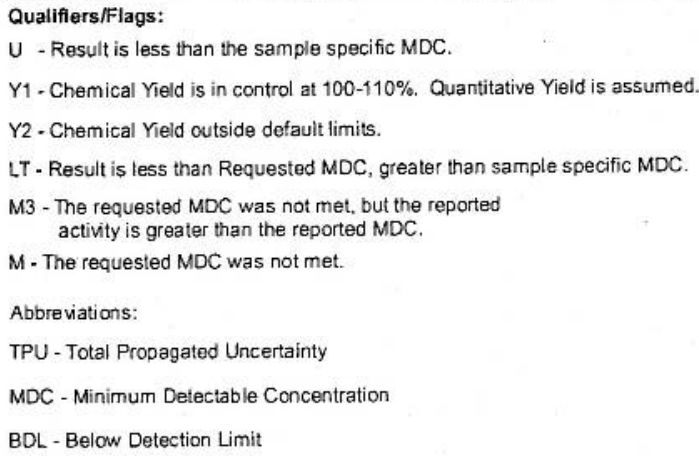

Data Package ID: PU0912143-1 


\section{Isotopic Plutonium By Alpha Spectroscopy \\ PAI 714 Rev 11 \\ Sample Duplicate Results}

Lab Name: ALS Laboratory Group - FC

Work Order Number: 0912143

Client Name: National Security Technologies, LLC

ClientProject ID: CAU 113 V3370

\begin{tabular}{l} 
Field ID: CAU113-CI-4 \\
Lab ID: $0912143-4 D U P$ \\
\hline
\end{tabular}

Sample Matrix: SOIL

Prep SOP: PAI 778 Rev 13

Date Collected: 14-Dec-09

Date Prepared: 17-Dec-09

Date Analyzed: 21-Dec-09
Prep Batch: AS091217-1

QCBatchID: AS091217-1-1

Run ID: AS091217-1A

Count Time: 1000 minutes

Report Basis: As Received
Final Aliquot: $2.53 \mathrm{~g}$

Prep Basis: As Received

Moisture(\%): NA

Result Units: $\mathrm{pCi} / \mathrm{g}$

File Name: Spectrum \#1

\begin{tabular}{|c|c|c|c|c|c|}
\hline CASNO & Target Nuclide & Result $+/-2$ s TPU & MDC & $\begin{array}{c}\text { Requested } \\
\text { MDC }\end{array}$ & \begin{tabular}{c} 
Lab Qualifier \\
\hline $13981-16-3$
\end{tabular} \\
\hline $10-12-8$ & Pu-238 & $-7.27 \mathrm{E}-04+1-4.82 \mathrm{E}-03$ & $1.02 \mathrm{E}-02$ & $2.00 \mathrm{E}-02$ & \\
\hline
\end{tabular}

\section{Chemical Yield Summary}

\begin{tabular}{|c|c|c|c|c|c|c|}
\hline Carrier/Tracer & Amount Added & Result & Units & Yield & $\begin{array}{c}\text { Control } \\
\text { Limits }\end{array}$ & Flag \\
\hline $\mathrm{Pu}-242$ & $1.760 \mathrm{E}+00$ & $1.40 \mathrm{E}+00$ & $\mathrm{pCi} / \mathrm{g}$ & 79.8 & $30-110 \%$ & \\
\hline
\end{tabular}

\section{Comments:}

\footnotetext{
Quallifiers/Flags:

$U$ - Result is less than the sample specific MDC.

Y1 - Chemical Yield is in control at 100-110\%. Quantitative yield is assumed.

Y2 - Chemical Yield outside default limits.

LT - Result is less than Requested MDC, greater than sample specific MDC.

$M$ - The requested MDC was not met.

M3 - The requested MDC was not met, but thereported activity is greater than the reported MDC.

D - DER is greater than Control Limit of 3
}

Abbreviations:

TPU - Total Propagated Uncertainty

MDC - Minimum Detectable Concentration

BDL - Below Detection Limit

Data Package ID: PU0912143-1 


\section{Isotopic Plutonium By Alpha Spectroscopy}

\section{PAI 714 Rev 11 \\ Sample Results}

Lab Name: ALS Laboratory Group -- FC

Work Order Number: 0912143

Client Name: National Security Technologies, LLC

ClientProject ID: CAU 113 V 3370

Field ID: CAU113-Cl-5
Lab ID: $0912143-5$

Sample Matrix: SOIL Prep SOP: PAI 778 Rev 13

Date Collected: 14-Dec-09

Date Prepared: 17-Dec-09

Date Analyzed: 22-Dec-09
Prep Batch: AS091217-1

QCBatchID: AS091217-1-1

Run ID: AS091217-1A

Count Time: 1000 minutes

Report Basis: As Received
Final Aliquot: $2.50 \mathrm{~g}$

Prep Basis: As Received

Moisture(\%): NA

Result Units: pCi/g

File Name: Spectrum \#1

\begin{tabular}{|l|c|c|c|c|}
\hline \multicolumn{1}{|c|}{ CASNO } & Target Nuclide & Result +/- 2 s TPU & MDC \\
\hline $13981-16-3$ & Pu-238 & $-7.66 \mathrm{E}-04+/-3.75 E-03$ & $7.11 E-03$ & $2.00 E-02$ \\
\hline $10-12-8$ & Pu-239/240 & $-1.53 E-03+/-4.34 \mathrm{E}-03$ & $1.00 \mathrm{E}-02$ & $2.00 \mathrm{E}-02$ \\
\hline
\end{tabular}

\section{Chemical Yield Summary}

\begin{tabular}{|c|c|c|c|c|c|c|}
\hline Carrier/Tracer & Amount Added & Result & Units & Yield & $\begin{array}{c}\text { Control } \\
\text { Limits }\end{array}$ & Flag \\
\hline Pu-242 & $1.770 \mathrm{E}+00$ & $1.30 \mathrm{E}+00$ & $\mathrm{pCi} / \mathrm{g}$ & 73.2 & $30-110 \%$ & \\
\hline
\end{tabular}

\section{Comments:}

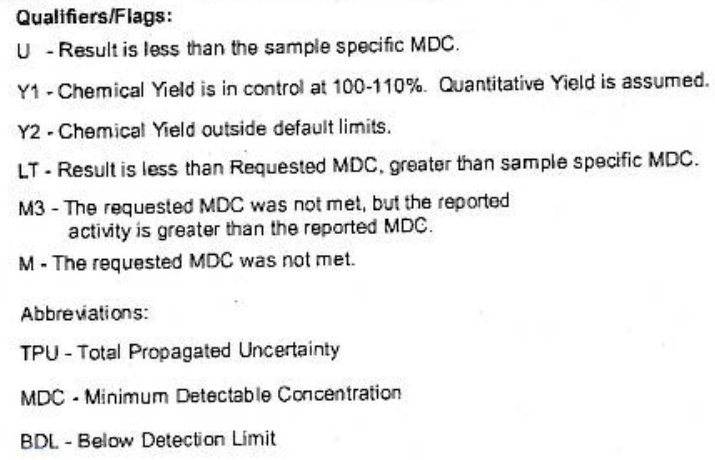

Data Package ID: PU0912143-1 
Addendum to CAU $113 \mathrm{CR}$

Revision: 0

Date: February 2011

THIS PAGE INTENTIONALLY LEFT BLANK 
Addendum to CAU $113 \mathrm{CR}$

Revision: 0

Date: February 2011

\section{WASTE CHARACTERIZATION SAMPLE RESULTS:}

\section{OIL DRAINED FROM EQUIPMENT}


Addendum to CAU $113 \mathrm{CR}$

Revision: 0

Date: February 2011

THIS PAGE INTENTIONALLY LEFT BLANK 
NSTec

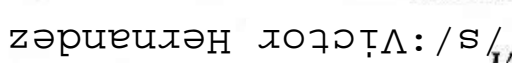

ANALYTICAL LABORATORY

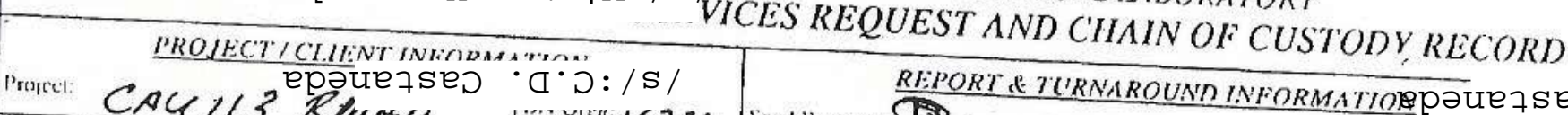

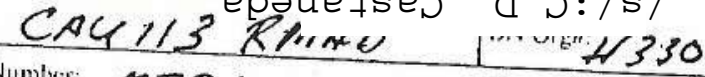

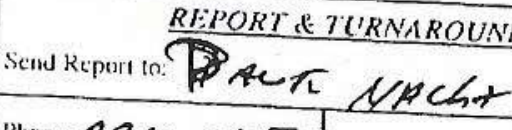

Paige _... - il

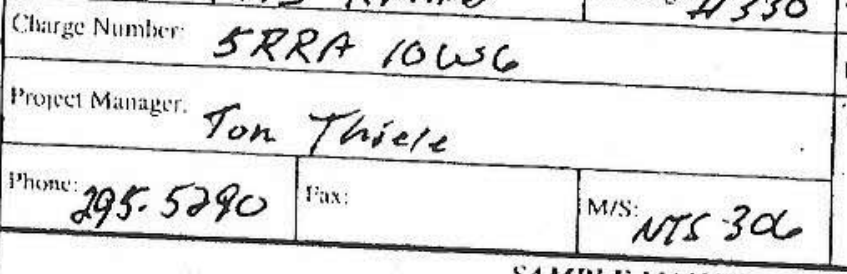
(one: $295-557 \rightarrow$ Fix

(1) Standard - 14 days ItH, 28 (inys Non-1ad tiny 15 ders $3 \propto$ () RliSH Prelimmary by:

\section{$-1-2-7 \quad X_{14}\left(\right.$ non-Rad $E_{n \mathrm{~N}}$ \\ $-1-^{7} \ldots{ }^{14}-28$ (Kikliswlugwall Env)}

\section{SAMPLE MANAGEMENT INFORMATION}

SDG:

(iii) $\mathrm{V3342}$ (Nen-Rad Env)

Samples submuled are associated with a signed Project SOW

Analyses entered here agree with the Sow

( ) YES ( ) NO

() YES ( ) NO () N/A

If not, adentify the vamatum

Subcomatal iab(s) used lor his work: Release \#104126-67

III)ESG TIIITON

EAT $113-01$ $113-02$ \begin{tabular}{c|c|c|}
\hline $113-7 B$ & $10-46-09$ & 0945 \\
\hline LAST & TH
\end{tabular}

SANIPIING:

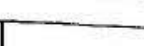

conitain

AINER \begin{tabular}{l|l|l|l}
$10-26-09$ & 0945 & 0.16
\end{tabular} $10-26-09 \mid 1000$

"

comen

\begin{tabular}{|c|c|c|c|c|c|}
\hline \multicolumn{2}{|c|}{ CONTAINER } & \multicolumn{3}{|c|}{$Q \mathrm{OC}$} & \\
\hline \# & Fss. Yoi & M1) & MS & MSD & cy. $\mathrm{HCl}$ - - VOAStysis \\
\hline 2 & $375 \mathrm{AL}_{\mathrm{AL}}$ & & & & \\
\hline
\end{tabular}

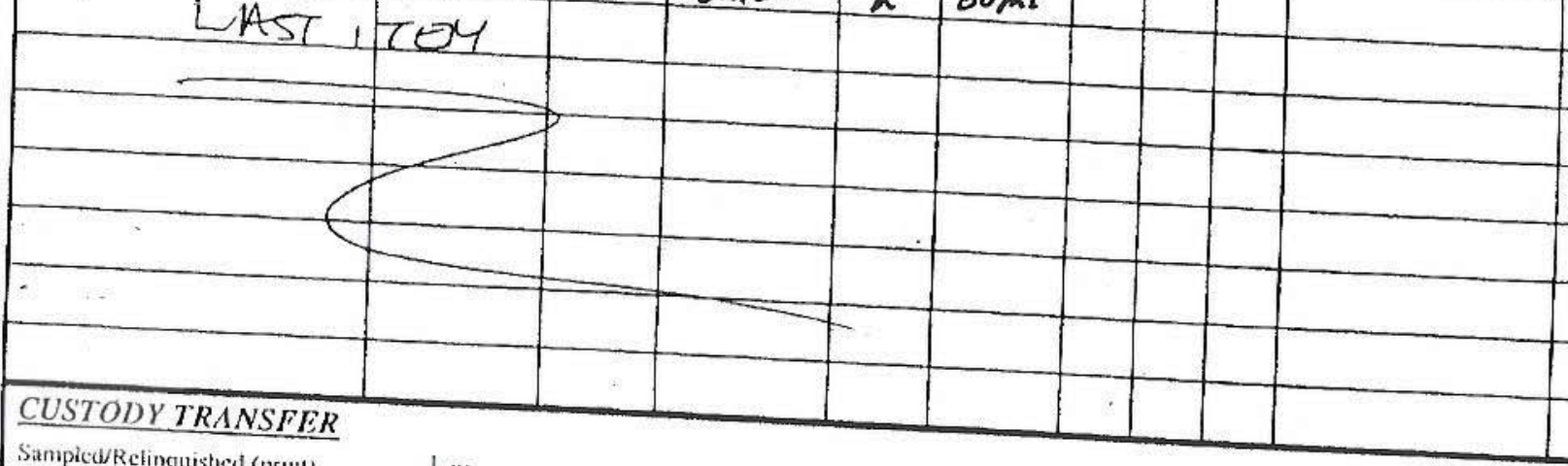

Simpicd/Relinquistied (prou!)

Malue fous

Chrspganer M'Gowl Cu CystranenA

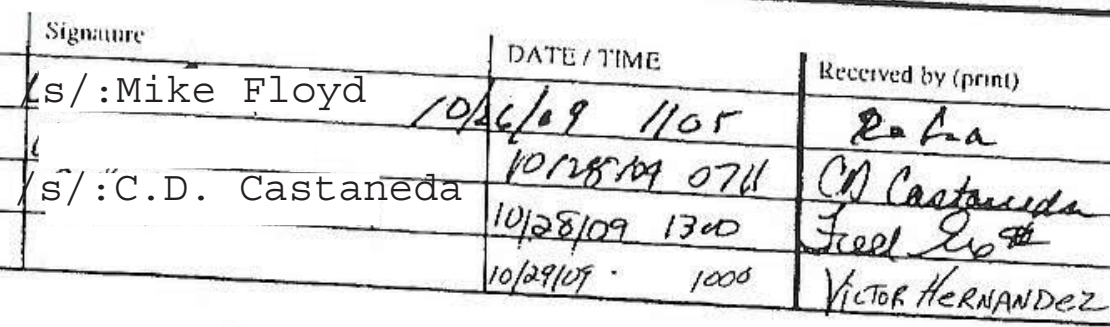

\section{Fes \&}

$10 / 29105$
MIPLIEINFORMATION

IACer3

fot

(1) Rialioskine - (list) -

(1) Unknown contambnathon. If knoww, identify

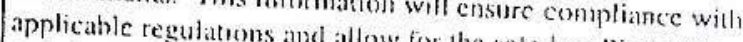
sampie materats.
sans allow for the satc hatadling of the

\section{Pay Item, Analysis, Method}

\section{VOA-A- PAPP-A-}

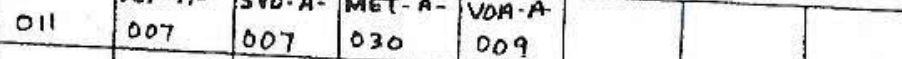

$-1$

Signature

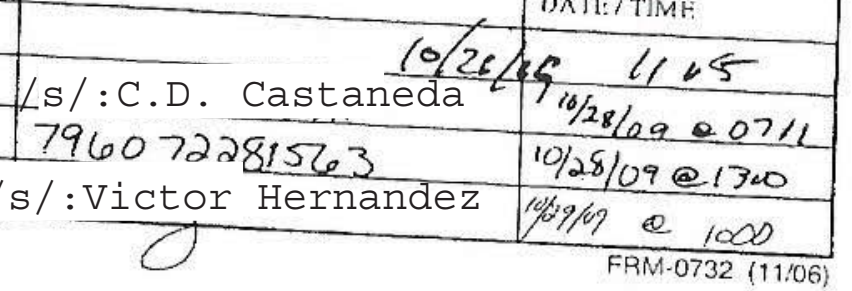




\section{PESTICIDES ANALYSIS DATA SHEET}

Laboratory: Lionville Laboratory

Client: National Security Iechnologies, L

Matrix: Oil

Sampled: $\quad$ 10/26/09 09:45

Solids:

Batch:
SDG:

Project:

$\underline{0910108-01}$

$\underline{11 / 04 / 0915: 46}$

SW 3580A
V3342

$\underline{B O A}$

File ID:

Analyzed:

Initial/Final:

$1.0123 \mathrm{~g} / 10 \mathrm{~mL}$ UNASSIGNED Instrument:

Calibration:

$\underline{11 / 05 / 09} 13: 55$
Laboratory ID:

Prepared:

Preparation:
PromiumPcb3286 Instrument GC 20

\begin{tabular}{|c|c|c|}
\hline LUTION & CONC. $(\mathrm{ug} / \mathrm{kg})$ & $\mathrm{Q}$ \\
\hline 1 & 395 & $\mathrm{U}$ \\
\hline 1 & 395 & $\mathrm{U}$ \\
\hline 1 & 395 & $\mathrm{U}$ \\
\hline 1 & 395 & $\mathrm{U}$ \\
\hline 1 & 395 & $\mathrm{U}$ \\
\hline 1 & 395 & $\mathrm{U}$ \\
\hline 1 & 395 & $\mathrm{U}$ \\
\hline
\end{tabular}

\begin{tabular}{|l|c|c|c|c|c|}
\hline SYSTEM MONITORING COMPOUND & ADDED (ug/kg) & CONC (ug/kg) & $\%$ REC & QC LIMITS & Q \\
\hline Decachlorobiphenyl & 987.85 & 446 & 45 & $10-150$ & \\
\hline \hline Tetrachloro-meta-xylene & 987.95 & 743 & 75 & $10-150$ & \\
\hline
\end{tabular}

* Values outside of QC limits 


\section{PESTICIDES ANALYSIS DATA SHEET}

Laboratory: Lionville Laboratory

Client:

Matrix:

Sampled:

Solids:

Batch:

CASNO.

12674-11-2

$11104-28-2$

$11141-16-5$

53469-21-9

12672-29-6

$11097-69-1$

$11096-82-5$
National Security Iechnologies, L

Oil

10/26/09 10:00

Laboratory ID:

Prepared:

Preparation:
SDG:
Project:

$\underline{\mathrm{V} 3342}$

0910108-02

11/04/09 15:46

SW $3580 \mathrm{~A}$

BOA

File ID:

PromiumPcb3324

Analyzed: $\quad 11 / 05 / 0916: 44$

Initial/Final: $\quad 1.0035 \mathrm{~g} / 10 \mathrm{~mL}$ L911034 Sequence: 9110014

Calibration: UNASSIGNED Instrument: $\mathrm{GC} 20$

\begin{tabular}{|l|c|c|c|}
\hline COMPOUND & DILUTION & CONC. (ug/kg) & $\mathrm{Q}$ \\
\hline Aroclor 1016 & 1 & 399 & $\mathrm{U}$ \\
\hline Aroclor 1221 & 1 & 399 & $\mathrm{U}$ \\
\hline Aroclor 1232 & 1 & 399 & $\mathrm{U}$ \\
\hline Aroclor 1242 & 1 & 399 & $\mathrm{U}$ \\
\hline Aroclor 1248 & 1 & 399 & $\mathrm{U}$ \\
\hline Aroclor 1254 & 1 & 399 & $\mathrm{U}$ \\
\hline Aroclor 1260 & 1 & 399 & $\mathrm{U}$ \\
\hline
\end{tabular}

\begin{tabular}{|l|c|c|c|c|c|}
\hline SYSTEM MONITORING COMPOUND & ADDED (ug/kg) & CONC (ug/kg) & $\%$ REC & QC LIMITS & Q \\
\hline \hline Decachlorobiphenyl & 996.51 & 349 & 35 & $10-150$ & \\
\hline \hline Tetrachloro-meta-xylene & 996.61 & 780 & 78 & $10-150$ & \\
\hline
\end{tabular}

* Values outside of QC limits 
Laboratory: Lionville Laboratory

Client: National Security Iechnologies, LLC

Matrix: Oil

Sampled: 10/26/09 09:45

Solids: $\quad \underline{0.00}$

Batch: L911041
Laboratory D: $\underline{\text { 0910108-01 }}$

Prepared: 11/05/09 12:02

Preparation: SW 3050B
SDG: $\underline{\text { V3342 }}$

Project: $\mathrm{BOA}$

File ID: ICP1106B-024

Analyzed: 11/06/09 17:28

Initial/Final: $\underline{0.64 \mathrm{~g} / 50 \mathrm{~mL}}$

\begin{tabular}{|c|l|c|c|c|c|}
\hline CAS NO. & Analyte & $\begin{array}{c}\text { Concentration } \\
(\mathbf{m g} / \mathbf{k g})\end{array}$ & $\begin{array}{c}\text { Dilution } \\
\text { Factor }\end{array}$ & Q & Method \\
\hline $7440-38-2$ & Arsenic & 0.781 & 1 & $\mathrm{U}$ & $6010 \mathrm{~B}$ \\
\hline $7440-39-3$ & Barium & 1070 & 1 & & $6010 \mathrm{~B}$ \\
\hline $7440-43-9$ & Cadmium & 5.38 & 1 & & $6010 \mathrm{~B}$ \\
\hline $7440-47-3$ & Chromium & 0.781 & 1 & $\mathrm{U}$ & $6010 \mathrm{~B}$ \\
\hline $7439-92-1$ & Lead & 7.88 & 1 & $6010 \mathrm{~B}$ \\
\hline $7782-49-2$ & Selenium & 0.387 & 1 & $\mathrm{~J}$ & $6010 \mathrm{~B}$ \\
\hline $7440-22-4$ & Silver & 0.781 & 1 & $\mathrm{U}$ & $6010 \mathrm{~B}$ \\
\hline
\end{tabular}


Laboratory: Lionville Laboratory

Client: National Security Technologies, LLC

Matrix: Oil

Sampled: 10/26/09 09:45

Solids: $\underline{0.00}$

Batch: L911090
Laboratory ID: 0910108-01

Prepared: $11 / 06 / 09$ 10:35

Preparation: SW 7471A Prep
SDG: $\underline{\text { V3342 }}$

Project: $\underline{\mathrm{BOA}}$

File ID: HG110901A-14

Analyzed: 11/09/09 14:22

Initial/Final: $\underline{0.3 \mathrm{~g} / 50 \mathrm{~mL}}$

\begin{tabular}{|c|l|c|c|c|c|}
\hline CAS NO. & Analyte & $\begin{array}{c}\text { Concentration } \\
(\mathbf{m g} / \mathbf{k g})\end{array}$ & $\begin{array}{c}\text { Dilution } \\
\text { Factor }\end{array}$ & Q & Method \\
\hline $7439-97-6$ & Mercury & 0150 & 5 & $\mathrm{U}$ & $7471 \mathrm{~A}$ \\
\hline
\end{tabular}


Laboratory: Lionville Laboratory

Client: National Security Technologies, LLC

Matrix: Oil

Sampled: $10 / 26 / 09$ 10:00

Solids: $\quad \underline{0.00}$

Batch: L911041
Laboratory ID: $\underline{0910108-02}$

Prepared: 11/05/09 12:02

Preparation: SW 3050B
SDG: V3342

Project: $\underline{\mathrm{BOA}}$

File 1D: ICP1106B-029

Analyzed: $\underline{11 / 06 / 0918: 06}$ Initial/Final: $\underline{0.61 \mathrm{~g} / 50 \mathrm{~mL}}$ Sequence: $\quad 9110025$ Calibration: UNASSIGNED Instrument: Thermo iTEVA

\begin{tabular}{|c|l|c|c|c|c|}
\hline CAS NO. & Analyte & $\begin{array}{c}\text { Concentration } \\
(\mathbf{m g} / \mathbf{k g})\end{array}$ & $\begin{array}{c}\text { Dilution } \\
\text { Factor }\end{array}$ & Q & Method \\
\hline $7440-38-2$ & Arsenic & 0820 & 1 & $\mathrm{U}$ & $6010 \mathrm{~B}$ \\
\hline $7440-39-3$ & Barium & 1100 & 1 & & $6010 \mathrm{~B}$ \\
\hline $7440-43-9$ & Cadmium & 5.11 & 1 & & $6010 \mathrm{~B}$ \\
\hline $7440-47-3$ & Chromium & 0.820 & 1 & $\mathrm{U}$ & $6010 \mathrm{~B}$ \\
\hline $7439-92-1$ & Lead & 7.96 & 1 & $6010 \mathrm{~B}$ \\
\hline $7782-49-2$ & Selenium & 0444 & 1 & $\mathrm{~J}$ & $6010 \mathrm{~B}$ \\
\hline $7440-22-4$ & Silver & 0820 & 1 & $\mathrm{U}$ & $6010 \mathrm{~B}$ \\
\hline
\end{tabular}


Laboratory: Lionville Laboratory

Client: National Security Technologies, LLC

Matrix: Oil

Sampled: $10 / 26 / 09$ 10:00

Solids: $\underline{0.00}$

Batch: $\underline{\mathrm{L} 911090}$

Sequence:
Laboratory ID: $\underline{0910108-02}$

Prepared: $11 / 06 / 09$ 10:35

Preparation: SW 7471A Prep
SDG: V3342

Project: BOA

File ID: HG110901A-18

Analyzed: 11/09/09 14:32

Initial/Final: $0.31 \mathrm{~g} / 50 \mathrm{~mL}$

9110036

Calibration: UNASSIGNED Instrument: $\underline{\mathrm{HG} 3}$

\begin{tabular}{|c|l|c|c|c|c|}
\hline CAS NO. & Analyte & $\begin{array}{c}\text { Concentration } \\
(\mathbf{m g} / \mathbf{k g})\end{array}$ & $\begin{array}{c}\text { Dilution } \\
\text { Factor }\end{array}$ & Q & Method \\
\hline $7439-97-6$ & Mercury & 0.145 & 5 & $\mathrm{U}$ & $7471 \mathrm{~A}$ \\
\hline
\end{tabular}




\section{ORGANIC ANALYSIS DATA SHEET 8260B}

Laboratory: Lionville Laboratory

Client: $\quad$ National Security Iechnologies, LLC

Matrix: $\quad \underline{\text { Oil }}$

Sampled: $\quad$ 10/26/09 09:45

Solids:

Batch:

\begin{tabular}{|c|l|}
\hline CAS NO. & COMPOUND \\
\hline $630-20-6$ & $1,1,1,2-$ Tetrachloroethane \\
\hline $71-55-6$ & $1,1,1-$ Trichloroethane \\
\hline $79-34-5$ & $1,1,2,2-$ Tetrachloroethane \\
\hline $79-00-5$ & $1,1,2-$ Trichloroethane \\
\hline $75-34-3$ & 1,1 -Dichloroethane \\
\hline $75-35-4$ & 1,1 -Dichloroethene \\
\hline $96-18-4$ & $1,2,3-$ Trichloropropane \\
\hline $120-82-1$ & $1,2,4-$ Trichlorobenzene \\
\hline $96-12-8$ & 1,2 -Dibromo-3-chloropropane \\
\hline $106-93-4$ & 1,2 -Dibromoethane \\
\hline $95-50-1$ & $1,2-$ Dichlorobenzene \\
\hline $107-06-2$ & 1,2 -Dichloroethane \\
\hline $78-87-5$ & 1,2 -Dichloropropane \\
\hline $541-73-1$ & 1,3 -Dichlorobenzene \\
\hline $106-46-7$ & $1,4-$ Dichlorobenzene \\
\hline $78-93-3$ & 2-Butanone \\
\hline $591-78-6$ & 2-Hexanone \\
\hline $108-10-1$ & 4-Methyl-2-pentanone \\
\hline $67-64-1$ & Acetone \\
\hline $71-43-2$ & Benzene \\
\hline $75-27-4$ & Bromodichloromethane \\
\hline $75-25-2$ & Bromoform \\
\hline $74-83-9$ & Bromomethane \\
\hline $75-15-0$ & Carbon Disulfide \\
\hline $56-23-5$ & Carbon Tetrachloride \\
\hline $108-90-7$ & Chlorobenzene \\
\hline $75-00-3$ & Chloroethane \\
\hline $67-66-3$ & Chloroform \\
\hline $74-87-3$ & Chloromethane \\
\hline $10061-01-5$ & cis-1,3-Dichloropropene \\
\hline $124-48-1$ & Dibromochloromethane \\
\hline $74-95-3$ & Dibromomethane \\
\hline $75-71-8$ & Dichlorodifluoromethane \\
\hline $100-41-4$ & Ethylbenzene \\
\hline $87-68-3$ & Hexachlorobutadiene \\
\hline $75-09-2$ & Methylene Chloride \\
\hline $91-20-3$ & Naphthalene \\
\hline $100-42-5$ & Styrene \\
\hline $127-18-4$ & Tetrachloroethene \\
\hline $108-88-3$ & Toluene \\
\hline & \\
\hline
\end{tabular}

SDG:

Project:

0910108-01

11/06/09 12:45

Prepared:

Preparation:
SW 5030B

\section{DRAF I V3342}

BOA

File ID: $\quad$ E110610.D

Analyzed: $\quad \underline{11 / 06 / 0912: 45}$

Initial/Final: $\quad 1.2 \mathrm{~g} / 500 \mathrm{~mL}$
Calibration:
Instrument $\quad \underline{5972 \mathrm{E}}$

\begin{tabular}{|c|c|c|}
\hline DILUTION & CONC. (ug/kg) & $\mathrm{Q}$ \\
\hline 1 & 2080 & $\mathrm{U}$ \\
\hline 1 & 2080 & $\mathrm{U}$ \\
\hline 1 & 2080 & $\bar{U}$ \\
\hline 1 & 2080 & $\mathrm{U}$ \\
\hline 1 & 2080 & $\mathrm{U}$ \\
\hline 1 & 2080 & $\mathrm{U}$ \\
\hline 1 & 2080 & U \\
\hline 1 & 2080 & $\mathrm{U}$ \\
\hline 1 & 2080 & $\bar{U}$ \\
\hline 1 & 2080 & $\bar{U}$ \\
\hline 1 & 2080 & $\mathrm{U}$ \\
\hline 1 & 2080 & $\mathrm{U}$ \\
\hline 1 & 2080 & $\mathrm{U}$ \\
\hline 1 & 2080 & $\mathrm{U}$ \\
\hline 1 & 2080 & $U$ \\
\hline 1 & 5000 & $\mathrm{U}$ \\
\hline 1 & 5000 & $\mathrm{U}$ \\
\hline 1 & 5000 & $\mathrm{U}$ \\
\hline 1 & 5000 & $\mathrm{U}$ \\
\hline 1 & 898 & $\mathrm{~J}$ \\
\hline 1 & 2080 & $\mathrm{U}$ \\
\hline 1 & 2080 & $\mathrm{U}$ \\
\hline 1 & 1180 & $\mathrm{~J}$ \\
\hline 1 & 2080 & $\mathrm{U}$ \\
\hline 1 & 2080 & $\mathrm{U}$ \\
\hline 1 & 2080 & U \\
\hline 1 & 2080 & $\mathrm{U}$ \\
\hline 1 & 2080 & $\mathrm{U}$ \\
\hline 1 & 2080 & $\mathrm{U}$ \\
\hline 1 & 2080 & U \\
\hline 1 & 2080 & $\mathrm{U}$ \\
\hline 1 & 2080 & $\mathrm{U}$ \\
\hline 1 & 2080 & $\mathrm{U}$ \\
\hline 1 & 2980 & \\
\hline 1 & 2080 & $\mathrm{U}$ \\
\hline 1 & 2080 & $\mathrm{U}$ \\
\hline 1 & 4680 & \\
\hline 1 & 2080 & $\mathrm{U}$ \\
\hline 1 & 2080 & $\mathrm{U}$ \\
\hline 1 & 6410 & \\
\hline
\end{tabular}




\section{B}

Laboratory: Lionville Laboratory

Client: National Security I echnologies. LLC

Matrix: Oil Laboratory ID:

Sampled: $\quad \underline{10 / 26 / 0909: 45}$

Solids:

Batch:

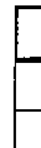

$\quad \underline{\text { L911102 }} \quad$ Sequence:

COMPOUND

$10061-02-6$

$79-01-6$

$75-69-4$

75-01-4

1330-20-7

$563-58-6$

$87-61-6$

95-63-6

$108-67-8$

$142-28-9$

$590-20-7$

95-49-8

106-43-4

99-87-6

108-86-1

$74-97-5$

156-59-2

76-13-1

98-82-8

104-51-8

103-65-1

135-98-8

98-06-6 trans-1,2-Dichloroethene trans-1,3-Dichloropropene Trichloroethene Trichlorofluoromethane

Vinyl chloride

Xylenes, total

1,1-Dichloropropene

1,2,3-Trichlorobenzene

1,2,4-Trimethylbenzene

Prepared:

Preparation:

1,3,5-Trimethylbenzene

1,3-Dichloropropane

2,2-Dichloropropane

2-Chlorotoluene

4-Chlorotoluene

4-Isopropyltoluene

Bromobenzene

Bromochloromethane

cis-1,2-Dichloroethene

Freon-113

Isopropylbenzene

n-Butylbenzene

n-Propylbenzene

sec-Butylbenzene

tert-Butylbenzene
SW 5030B

SDG:

Project:

0910108-01

Calibration:

\section{DRAFT V3342}

BOA

File ID: $\quad$ E110610.D

Analyzed: $\quad \underline{11 / 06 / 0912: 45}$

Initial/Final: $\quad \underline{1.2 \mathrm{~g} / 500 \mathrm{~mL}}$

\begin{tabular}{|c|c|c|}
\hline LUTION & CONC. $(\mathrm{ug} / \mathrm{kg})$ & $\mathrm{Q}$ \\
\hline 1 & 2080 & $\mathrm{U}$ \\
\hline 1 & 2080 & $\mathrm{U}$ \\
\hline 1 & 2080 & $\mathrm{U}$ \\
\hline 1 & 2080 & $\mathrm{U}$ \\
\hline 1 & 2080 & $\mathrm{U}$ \\
\hline 1 & 13300 & \\
\hline 1 & 2080 & $\mathrm{U}$ \\
\hline 1 & 2080 & $\mathrm{U}$ \\
\hline 1 & 6380 & \\
\hline 1 & 1800 & $\mathrm{~J}$ \\
\hline 1 & 2080 & $\mathrm{U}$ \\
\hline 1 & 2080 & $\mathrm{U}$ \\
\hline 1 & 2080 & $\mathrm{U}$ \\
\hline 1 & 2080 & $\mathrm{U}$ \\
\hline 1 & 639 & $\mathrm{~J}$ \\
\hline 1 & 2080 & $\mathrm{U}$ \\
\hline $\mathrm{l}$ & 2080 & $\mathrm{U}$ \\
\hline 1 & 2080 & $\mathrm{U}$ \\
\hline 1 & 2080 & $\mathrm{U}$ \\
\hline 1 & 438 & $\mathrm{~J}$ \\
\hline 1 & 2080 & $\mathrm{U}$ \\
\hline 1 & 2080 & $\mathrm{U}$ \\
\hline 1 & 665 & $\mathrm{~J}$ \\
\hline 1 & 2080 & $\mathrm{U}$ \\
\hline
\end{tabular}

\begin{tabular}{|l|c|c|c|c|c|}
\hline SYSTEM MONITORING COMPOUND & ADDED (ug/kg) & CONC (ug/kg) & $\%$ REC & QC IIMITS & Q \\
\hline 1,2-Dichloroethane-d4 & 20833 & 18700 & 89.6 & $63-151$ & \\
\hline Toluene-d8 & 20833 & 19300 & 92.5 & $68-140$ & \\
\hline 4-Bromofluorobenzene & 20833 & 19200 & 92.0 & $66-122$ & \\
\hline
\end{tabular}

* Values outside of QC limits 


\section{ORGANIC ANALYSIS DATA SHEET 8260B}

Laboratory: Lionville Laboratory

Client: $\quad$ National Security Technologies, LLC

Matrix: $\quad$ il

Sampled: $\quad \underline{10 / 26 / 0910: 00}$

Solids:

Batch:

\begin{tabular}{|c|c|}
\hline CAS NO. & COMPOUND \\
\hline $630-20-6$ & 1,1,1,2-Tetrachloroethane \\
\hline $71-55-6$ & 1,1,1-Trichloroethane \\
\hline $79-34-5$ & 1,1,2,2-Tetrachloroethane \\
\hline $79-00-5$ & 1,1,2-Trichloroethane \\
\hline $75-34-3$ & 1,1-Dichloroethane \\
\hline $75-35-4$ & 1,1-Dichloroethene \\
\hline $96-18-4$ & 1,2,3-Trichloropropane \\
\hline $120-82-1$ & 1,2,4-Trichlorobenzene \\
\hline $96-12-8$ & 1,2-Dibromo-3-chloropropane \\
\hline $106-93-4$ & 1,2-Dibromoethane \\
\hline $95-50-1$ & 1,2-Dichlorobenzene \\
\hline $107-06-2$ & 1,2-Dichloroethane \\
\hline $78-87-5$ & 1,2-Dichloropropane \\
\hline $541-73-1$ & 1,3-Dichlorobenzene \\
\hline $106-46-7$ & 1,4-Dichlorobenzene \\
\hline $78-93-3$ & 2-Butanone \\
\hline $591-78-6$ & 2-Hexanone \\
\hline $108-10-1$ & 4-Methyl-2-pentanone \\
\hline $67-64-1$ & Acetone \\
\hline $71-43-2$ & Benzene \\
\hline $75-27-4$ & Bromodichloromethane \\
\hline $75-25-2$ & Bromoform \\
\hline $74-83-9$ & Bromomethane \\
\hline $75-15-0$ & Carbon Disulfide \\
\hline $56-23-5$ & Carbon Tetrachloride \\
\hline $108-90-7$ & Chlorobenzene \\
\hline $75-00-3$ & Chloroethane \\
\hline $67-66-3$ & Chloroform \\
\hline $74-87-3$ & Chloromethane \\
\hline $10061-01-5$ & cis-1,3-Dichloropropene \\
\hline $124-48-1$ & Dibromochloromethane \\
\hline $74-95-3$ & Dibromomethane \\
\hline $75-71-8$ & Dichlorodifluoromethane \\
\hline $100-41-4$ & Ethylbenzene \\
\hline $87-68-3$ & Hexachlorobutadiene \\
\hline $75-09-2$ & Methylene Chloride \\
\hline $91-20-3$ & Naphthalene \\
\hline $100-42-5$ & Styrene \\
\hline $127-18-4$ & Tetrachloroethene \\
\hline $108-88-3$ & Toluene \\
\hline
\end{tabular}

SDG:

Project:

Laboratory ID:

Prepared:

Preparation: $\underline{0910108-02}$

11/06/0913:18

SW 5030B
DRAFI V3342

$\underline{B O A}$

File ID: $\quad$ E110611.D

Analyzed: $\quad 11 / 06 / 0913: 18$

Initial/Final: $\quad \underline{1 \mathrm{~g} / 500 \mathrm{~mL}}$

Instrument:

$5972 \mathrm{E}$

\begin{tabular}{|c|c|c|}
\hline DILUTION & CONC. (ug/kg) & $\mathrm{Q}$ \\
\hline 1 & 2500 & $\mathrm{U}$ \\
\hline 1 & 2500 & $\mathrm{U}$ \\
\hline 1 & 2500 & $\mathrm{U}$ \\
\hline 1 & 2500 & $\mathrm{U}$ \\
\hline 1 & 2500 & U \\
\hline 1 & 2500 & $\mathrm{U}$ \\
\hline 1 & 2500 & $\mathrm{U}$ \\
\hline 1 & 2500 & $\mathrm{U}$ \\
\hline 1 & 2500 & $\mathrm{U}$ \\
\hline 1 & 2500 & U \\
\hline 1 & 2500 & $\mathrm{U}$ \\
\hline 1 & 2500 & $\mathrm{U}$ \\
\hline 1 & 2500 & U \\
\hline 1 & 2500 & $\mathrm{U}$ \\
\hline 1 & 2500 & $\mathrm{U}$ \\
\hline 1 & 6000 & $\mathrm{U}$ \\
\hline 1 & 6000 & $\mathrm{U}$ \\
\hline 1 & 6000 & $\mathrm{U}$ \\
\hline 1 & 6000 & $\mathrm{U}$ \\
\hline 1 & 823 & $\mathrm{~J}$ \\
\hline 1 & 2500 & $\mathrm{U}$ \\
\hline 1 & 2500 & U \\
\hline 1 & 2500 & U \\
\hline 1 & 2500 & $\mathrm{U}$ \\
\hline 1 & 2500 & $\mathrm{U}$ \\
\hline 1 & 2500 & U \\
\hline 1 & 2500 & $\mathrm{U}$ \\
\hline 1 & 2500 & U \\
\hline 1 & 2500 & $\mathrm{U}$ \\
\hline 1 & 2500 & $\mathrm{U}$ \\
\hline 1 & 2500 & U \\
\hline 1 & 2500 & U \\
\hline 1 & 2500 & $\mathrm{U}$ \\
\hline 1 & 2820 & \\
\hline 1 & 2500 & $\mathrm{U}$ \\
\hline 1 & 2500 & U \\
\hline 1 & 6080 & \\
\hline 1 & 2500 & U \\
\hline 1 & 2500 & $\mathrm{U}$ \\
\hline 1 & 6310 & \\
\hline
\end{tabular}




\section{ORGANIC ANALYSIS DATA SHEET}

8260B

Laboratory: Lionville Laboratory

Client: National Security Iechnologies, LLC

Matrix: $\quad \underline{\text { Oil }}$

Sampled: $\quad \underline{10 / 26 / 0910: 00}$

Solids:

Batch:

CAS NO.

156-60-5

$10061-02-6$

79-01-6

$75-69-4$

$75-01-4$

1330-20-7

563-58-6

$87-61-6$

95-63-6

$108-67-8$

$142-28-9$

$590-20-7$

95-49-8

$106-43-4$

99-87-6

108-86-1

$74-97-5$

$156-59-2$

76-13-1

98-82-8

104-51-8

103-65-1

135-98-8

98-06-6
Laboratory ID:

Prepared:

Preparation:
SDG:

Project:

0910108-02

$\underline{11 / 06 / 0913: 18}$

SW 5030B
DRAFI V 3342

BOA

File ID:

Analyzed: $\quad \underline{11 / 06 / 0913: 18}$

Initial/Final: $\quad 1 \mathrm{~g} / 500 \mathrm{~mL}$

\begin{tabular}{|l|c|c|c|}
\hline COMPOUND & DILUTION & CONC. $(\mathrm{ug} / \mathrm{kg})$ & $\mathrm{Q}$ \\
\hline trans-1,2-Dichloroethene & 1 & 2500 & $\mathrm{U}$ \\
\hline trans-1,3-Dichloropropene & 1 & 2500 & $\mathrm{U}$ \\
\hline Trichloroethene & 1 & 2500 & $\mathrm{U}$ \\
\hline Trichlorofluoromethane & 1 & 2500 & $\mathrm{U}$ \\
\hline Vinyl chloride & 1 & 2500 & $\mathrm{U}$ \\
\hline Xylenes, total & 1 & 13700 & $\mathrm{U}$ \\
\hline 1,1-Dichloropropene & 1 & 2500 & $\mathrm{U}$ \\
\hline 1,2,3-Trichlorobenzene & 1 & 2500 & \\
\hline 1,2,4-Trimethylbenzene & 1 & 6930 & $\mathrm{~J}$ \\
\hline 1,3,5-Trimethylbenzene & 1 & 2190 & $\mathrm{U}$ \\
\hline 1,3-Dichloropropane & 1 & 2500 & $\mathrm{U}$ \\
\hline 2,2-Dichloropropane & 1 & 2500 & $\mathrm{U}$ \\
\hline 2-Chlorotoluene & 1 & 2500 & $\mathrm{U}$ \\
\hline 4-Chlorotoluene & 1 & 2500 & $\mathrm{~J}$ \\
\hline 4-Isopropyltoluene & 1 & 669 & $\mathrm{U}$ \\
\hline Bromobenzene & 1 & 2500 & $\mathrm{U}$ \\
\hline Bromochloromethane & 1 & 2500 & $\mathrm{U}$ \\
\hline cis-1,2-Dichloroethene & 1 & 2500 & $\mathrm{U}$ \\
\hline Freon-113 & 1 & 2500 & $\mathrm{U}$ \\
\hline Isopropylbenzene & 1 & 2500 & $\mathrm{U}$ \\
\hline n-Butylbenzene & 1 & 2500 & $\mathrm{U}$ \\
\hline n-Propylbenzene & 1 & 2500 & $\mathrm{~J}$ \\
\hline sec-Butylbenzene & 1 & 817 & $\mathrm{U}$ \\
\hline tert-Butylbenzene & 1 & 2500 & \\
\hline
\end{tabular}

\begin{tabular}{|l|c|c|c|c|c|}
\hline SYSTEM MONITORING COMPOUND & ADDED $(\mathrm{ug} / \mathrm{kg})$ & CONC $(\mathrm{ug} / \mathrm{kg})$ & $\%$ REC & QC LIMITS & Q \\
\hline 1,2-Dichloroethane-d4 & 25000 & 22400 & 89.6 & $63-151$ & \\
\hline Toluene-d8 & 25000 & 23100 & 92.4 & $68-140$ & \\
\hline 4-Bromofluorobenzene & 25000 & 25100 & 100 & $66-122$ & \\
\hline
\end{tabular}

* Values outside of QC limits 
Laboratory: Lionville Laboratory

Client: National Security Iechnologies, LLC

Matrix: Water

Sampled: $\quad$ 10/26/09 09:45

Solids:

Batch:

CASN

CAS NO.

630-20-6

$71-55-6$

$79-34-5$

$79-00-5$

75-34-3

$75-35-4$

96-18-4

$120-82-1$

96-12-8

106-93-4

95-50-1

$107-06-2$

78-87-5

541-73-1

$106-46-7$

78-93-3

591-78-6

108-10-1

67-64-1

71-43-2

75-27-4

75-25-2

74-83-9

75-15-0

56-23-5

108-90-7

$75-00-3$

67-66-3

74-87-3

10061-01-5

124-48-1

74-95-3

75-71-8

$100-41-4$

87-68-3

75-09-2

91-20-3

$100-42-5$

127-18-4

108-88-3
Laboratory ID:

Prepared:

Preparation:

COMPOUND

1,1,1,2-Tetrachloroethane

1,1,1-Trichloroethane

1,1,2,2-Tetrachloroethane

1,1,2-Trichloroethane

1,1-Dichloroethane

1,1-Dichloroethene

1,2,3-Trichloropropane

1,2,4-Trichlorobenzene

1,2-Dibromo-3-chloropropane

1,2-Dibromoethane

1,2-Dichlorobenzene

1,2-Dichloroethane

1,2-Dichloropropane

1,3-Dichlorobenzene

1,4-Dichlorobenzene

2-Butanone

2-Hexanone

4-Methyl-2-pentanone

Acetone

Benzene

Bromodichloromethane

Bromoform

Bromomethane

Carbon Disulfide

Carbon Tetrachloride

Chlorobenzene

Chloroethane

Chloroform

Chloromethane

cis-1,3-Dichloropropene

Dibromochloromethane

Dibromomethane

Dichlorodifluoromethane

Ethylbenzene

Hexachlorobutadiene

Methylene Chloride

Naphthalene

Styrene

Tetrachloroethene

Toluene
SDG:

Project:

0910108-03

11/06/09 12:12

SW 5030B
DRAFT V3342

BOA

File ID: $\quad \underline{\text { E110609.D }}$

Analyzed: $\quad 11 / 06 / 0912: 12$

Initial/Final: $\quad 5 \mathrm{~mL} / 5 \mathrm{~mL}$

L911103 Sequence: Calibration:

Instrument:

$\underline{5972 \mathrm{E}}$

DILUTION

\begin{tabular}{|c|c|c|}
\hline UTION & CONC. $(u g / L)$ & Q \\
\hline 1 & 5.00 & $\mathrm{U}$ \\
\hline 1 & 5.00 & U \\
\hline 1 & 5.00 & $\mathrm{U}$ \\
\hline 1 & 5.00 & U \\
\hline 1 & 5.00 & $\mathrm{U}$ \\
\hline 1 & 5.00 & $\mathrm{U}$ \\
\hline 1 & 5.00 & $\mathrm{U}$ \\
\hline 1 & 5.00 & U \\
\hline 1 & 5.00 & $\mathrm{U}$ \\
\hline 1 & 5.00 & $\mathrm{U}$ \\
\hline 1 & 5.00 & $\mathrm{U}$ \\
\hline 1 & 5.00 & U \\
\hline 1 & 5.00 & $\mathrm{U}$ \\
\hline 1 & 5.00 & $\mathrm{U}$ \\
\hline 1 & 5.00 & $\mathrm{U}$ \\
\hline 1 & 10.0 & $\mathrm{U}$ \\
\hline 1 & 10.0 & $\mathrm{U}$ \\
\hline 1 & 10.0 & $\mathrm{U}$ \\
\hline 1 & 10.0 & $U$ \\
\hline 1 & 5.00 & $\mathrm{U}$ \\
\hline 1 & 5.00 & $\mathrm{U}$ \\
\hline 1 & 5.00 & $\mathrm{U}$ \\
\hline 1 & 5.00 & $\mathrm{U}$ \\
\hline 1 & 5.00 & $\mathrm{U}$ \\
\hline 1 & 5.00 & $U$ \\
\hline 1 & 5.00 & $\mathrm{U}$ \\
\hline 1 & 5.00 & $\mathrm{U}$ \\
\hline 1 & 5.00 & $\mathrm{U}$ \\
\hline 1 & 5.00 & $\mathrm{U}$ \\
\hline 1 & 5.00 & $\mathrm{U}$ \\
\hline 1 & 5.00 & $\mathrm{U}$ \\
\hline 1 & 5.00 & $\mathrm{U}$ \\
\hline 1 & 5.00 & $\mathrm{U}$ \\
\hline 1 & 5.00 & $\mathrm{U}$ \\
\hline 1 & 5.00 & U \\
\hline 1 & 5.00 & $\mathrm{U}$ \\
\hline 1 & 5.00 & $\mathrm{U}$ \\
\hline 1 & 5.00 & U \\
\hline 1 & 5.00 & $\mathrm{U}$ \\
\hline 1 & 5.00 & $\underline{U}$ \\
\hline
\end{tabular}




\section{Laboratory: $\quad$ Lionville Laboratory}

Client: National Security Technologies, LLC

Matrix: Water

Sampled: $\quad \underline{10 / 26 / 0909: 45}$

Solids:

Batch:

\begin{tabular}{|l|l|}
\hline CAS NO. & COMPOUND \\
\hline $156-60-5$ & trans-1,2-Dichlotoethene \\
\hline
\end{tabular}

\begin{tabular}{|c|l}
\hline $156-60-5$ & trans-1,2-Dichlotoethene \\
\hline $10061-02-6$ & trans-1,3-Dichloropropene \\
\hline $79-01-6$ & Trichloroethene \\
\hline $75-69-4$ & Trichlorofluoromethane \\
\hline $75-01-4$ & Vinyl chloride \\
\hline
\end{tabular}

\begin{tabular}{l|l}
$1330-20-7$ & Xylenes, total \\
\hline
\end{tabular}

$563-58-6$

$87-61-6$
$95-63-6$

$108-67-8$

$142-28-9$

590-20-7

95-49-8

106-43-4

99-87-6

108-86-1

74-97-5

156-59-2

76-13-1

98-82-8

104-51-8

103-65-1

$135-98-8$

98-06-6
Laboratory ID:

Prepared:

Preparation:
SDG:

Project:

0910108-03

11/06/09 12:12

SW 5030B

\section{DRAF I V3342}

\section{BOA}

File ID: $\quad$ E110609.D

Analyzed: $\quad \underline{11 / 06 / 0912: 12}$

Initial/Final: $\quad \underline{5 \mathrm{~mL} / 5 \mathrm{~mL}}$

Calibration: Instrument: 5972E

\begin{tabular}{|c|c|c|}
\hline DILUTION & CONC. $(\mathrm{ug} / \mathrm{L})$ & $Q$ \\
\hline 1 & 5.00 & $\mathrm{U}$ \\
\hline 1 & 5.00 & $\mathrm{U}$ \\
\hline 1 & 5.00 & U \\
\hline 1 & 5.00 & $\mathrm{U}$ \\
\hline 1 & 5.00 & $\mathrm{U}$ \\
\hline 1 & 5.00 & $\mathrm{U}$ \\
\hline 1 & 5.00 & $\mathrm{U}$ \\
\hline 1 & 5.00 & $\mathrm{U}$ \\
\hline 1 & 5.00 & U \\
\hline 1 & 5.00 & $\mathrm{U}$ \\
\hline 1 & 5.00 & $\mathrm{U}$ \\
\hline 1 & 5.00 & $\mathrm{U}$ \\
\hline 1 & 5.00 & $\mathrm{U}$ \\
\hline 1 & 5.00 & $\mathrm{U}$ \\
\hline 1 & 5.00 & $\mathrm{U}$ \\
\hline 1 & 6.00 & U \\
\hline 1 & 5.00 & $\mathrm{U}$ \\
\hline 1 & 5.00 & $\mathrm{U}$ \\
\hline 1 & 5.00 & U \\
\hline 1 & 5.00 & $\mathrm{U}$ \\
\hline 1 & 5.00 & $\mathrm{U}$ \\
\hline 1 & 5.00 & $\mathrm{U}$ \\
\hline 1 & 6.00 & $\mathrm{U}$ \\
\hline 1 & 10.0 & $\mathrm{U}$ \\
\hline
\end{tabular}

\begin{tabular}{|l|c|c|c|c|c|}
\hline SYSTEM MONITORING COMPOUND & ADDED (ug/L) & CONC (ug/L) & $\%$ REC & QC LIMITS & Q \\
\hline 1,2-Dichloroethane-d4 & 50.000 & 46.9 & 94 & $64-140$ & \\
\hline Toluene-d8 & 50.000 & 44.4 & 89 & $70-130$ & \\
\hline 4-Bromofluorobenzene & 50.000 & 46.9 & 94 & $81-115$ & \\
\hline
\end{tabular}

* Values outside of QC limits 
National Security Technologies, IL.C

2621 Losee Road, Mail Stop NTS273

North Las Vegas NV, 89030
Project: $\mathrm{BOA}$

Project Number: 60052-002-001

Project Manager: Ied Redding
Reported:

$11 / 16 / 200914: 41$

\section{3-01}

0910108-01 (Oil)

\begin{tabular}{|lllllll}
\hline & & Reporting & & & & \\
Analyte & Result and Qualifier & Limit & Units & Dilution & Batch & Prepared \\
\hline
\end{tabular}

Lionville Laboratory

Semivolatile Organic Compounds by SW846 8270C

1,2,4-Trichlorobenzene

1,2-Dichlorobenzene

1,3-Dichlorobenzene

1,4-Dichlorobenzene

2,4,5-Irichlorophenol

2,4,6-Irichlorophenol

2,4-Dichlorophenol

2,4-Dimethylphenol

2,4-Dinitrophenol

2,4-Dinitrotoluene

2,6-Dinitrotoluene

2-Chloronaphthalene

2-Chlorophenol

2-Methylnaphthalene

2-Methylphenol

2-Nitroaniline

2-Nitrophenol

3,3'-Dichlorobenzidine

3-Nitroaniline

4,6-Dinitro-2-methylphenol

4-Bromophenyl Phenyl Ether

4-Chloro-3-methylphenol

4-Chloroaniline

4-Chlorophenyl Phenyl Ether

3- and/or 4-Methylphenol

4-Nitroaniline

4-Nitrophenol

Acenaphthene

Acenaphthylene

Anthracene

Benz[a]anthracene

Benzo[a] pyrene

Benzo[b] fluoranthene

Benzo[g,h,i] perylene

Benzo[k] fluoranthene

$\mathrm{Bis}$ (2-chloroethoxy) methane

Bis(2-chloroethyl) ether

Bis(2-chloroisopropyl) ether

Bis(2-ethylhexyl) phthalate

\section{U}

$3240 \mathrm{U}$

$3240 \mathrm{U}$

$3240 \mathrm{U}$

$3240 \mathrm{U}$

$3240 \mathrm{U}$

$3240 \mathrm{U}$

$3240 \mathrm{U}$

$16200 \mathrm{U}$

$3240 \mathrm{U}$

$3240 \mathrm{U}$

$3240 \mathrm{U}$

3240 U

$3240 \mathrm{U}$

$3240 \mathrm{U}$

$16200 \mathrm{U}$

$3240 \mathrm{U}$

$6470 \mathrm{U}$

$16200 \mathrm{U}$

3240 U

$3240 \mathrm{U}$

3240 U

$3240 \mathrm{U}$

$3240 \mathrm{U}$

$3240 \mathrm{U}$

$16200 \mathrm{U}$

$16200 \mathrm{U}$

$3240 \mathrm{U}$

$3240 \mathrm{U}$

3240 U

$3240 \mathrm{U}$

$3240 \mathrm{U}$

3240 U

3240 U

$3240 \mathrm{U}$

$3240 \mathrm{U}$

$3240 \mathrm{U}$

3240 U

26600

3240
3240
3240
3240
3240
3240
3240
3240
16200
3240
3240
3240
3240
3240
3240
16200
3240
6470
16200
3240
3240
3240
3240
3240
3240
16200
16200
3240
3240
3240
3240
3240
3240
3240
3240
3240
3240
3240
3240

$\mathrm{ug} / \mathrm{kg}$

$\mathrm{ug} / \mathrm{kg}$

$\mathrm{ug} / \mathrm{kg}$

$\mathrm{ug} / \mathrm{kg}$

$\mathrm{ug} / \mathrm{kg}$

$\mathrm{ug} / \mathrm{kg}$

$\mathrm{ug} / \mathrm{kg}$

$\mathrm{ug} / \mathrm{kg}$

ug/kg

$\mathrm{ug} / \mathrm{kg}$

$\mathrm{ug} / \mathrm{kg}$

$\mathrm{ug} / \mathrm{kg}$

$\mathrm{ug} / \mathrm{kg}$

$\mathrm{ug} / \mathrm{kg}$

$\mathrm{ug} / \mathrm{kg}$

$\mathrm{ug} / \mathrm{kg}$

$\mathrm{ug} / \mathrm{kg}$

$\mathrm{ug} / \mathrm{kg}$

$\mathrm{ug} / \mathrm{kg}$

$\mathrm{ug} / \mathrm{kg}$

$\mathrm{ug} / \mathrm{kg}$

ug/kg

ug/kg

ug/kg

$\mathrm{ug} / \mathrm{kg}$

$\mathrm{ug} / \mathrm{kg}$

ug/kg

ug/kg

$\mathrm{ug} / \mathrm{kg}$

$\mathrm{ug} / \mathrm{kg}$

$\mathrm{ug} / \mathrm{kg}$

$\mathrm{ug} / \mathrm{kg}$

$\mathrm{ug} / \mathrm{kg}$

$\mathrm{ug} / \mathrm{kg}$

$\mathrm{ug} / \mathrm{kg}$

$\mathrm{ug} / \mathrm{kg}$

$\mathrm{ug} / \mathrm{kg}$

$\mathrm{ug} / \mathrm{kg}$

$\mathrm{ug} / \mathrm{kg}$

$1 \quad$ L.911033 $11 / 04 / 2009$

$1 \quad \mathbf{2 9 1 1 0 3 3}$

$1 \quad$ L911033 11/04/2009

1 I $911033 \quad 11 / 04 / 2009$

1 L.911033 11/04/2009

$1 \quad$ I911033 11/04/2009

$1 \quad$ L911033 11/04/2009

1 L911033 11/04/2009

$1 \quad \mathrm{~L} 911033 \quad 11 / 04 / 2009$

$1 \quad 1911033 \quad 11 / 04 / 2009$

$1 \quad$ L911033 11/04/2009

1 L911033 11/04/2009

$1 \quad \mathrm{~L} 911033 \quad 11 / 04 / 2009$

1 L911033 11/04/2009

1 L911033 11/04/2009

$1 \quad \mathrm{~L} .911033 \quad 11 / 04 / 2009$

$1 \quad \mathbf{2} 911033 \quad 11 / 04 / 2009$

$1 \quad \mathrm{~L} .911033 \quad 11 / 04 / 2009$

1 L911033 11/04/2009

$1 \quad$ L911033 11/04/2009

$1 \quad L 91103311 / 04 / 2009$

$1 \quad 1911033 \quad 11 / 04 / 2009$

$1 \quad$ L911033 11/04/2009

$1 \quad$ L911033 11/04/2009

$\begin{array}{lll}1 & L 911033 & 11 / 04 / 2009 \\ 1 & 1911033 & 11 / 04 / 2009\end{array}$

1 L.911033 11/04/2009

1 L911033 11/04/2009

$1 \quad \mathrm{~L} 911033 \quad 11 / 04 / 2009$

1 L911033 11/04/2009

1 L911033 11/04/2009

1 L911033 11/04/2009

$1 \quad \mathrm{~L} 911033 \quad 11 / 04 / 2009$

$1 \quad 1911033 \quad 11 / 04 / 2009$

$\begin{array}{lll}1 & 1.911033 & 11 / 04 / 2009 \\ 1 & \mathrm{~L} 911033 & 11 / 04 / 2009\end{array}$

1 L.911033 11/04/2009

$\begin{array}{lll}1 & L .911033 & 11 / 04 / 2009 \\ 1 & \text { L.911033 } & 11 / 04 / 2009\end{array}$

$1 \quad 1911033 \quad 11 / 04 / 2009$

$\begin{array}{lll}1 & 1911033 & 11 / 04 / 2009 \\ 1 & \text { L911033 } & 11 / 04 / 2009\end{array}$

$\begin{array}{lll}1 & 1911033 & 11 / 04 / 2009 \\ 1 & 1911033 & 11 / 04 / 2009\end{array}$

$1 \quad 1911033 \quad 11 / 04 / 2009$
$11 / 09 / 2009$

$11 / 09 / 2009$

$11 / 09 / 2009$

$11 / 09 / 2009$

$11 / 09 / 2009$

$11 / 09 / 2009$

$11 / 09 / 2009$

$11 / 09 / 2009$

$11 / 09 / 2009$

$11 / 09 / 2009$

$11 / 09 / 2009$

$11 / 09 / 2009$

$11 / 09 / 2009$

$11 / 09 / 2009$

$11 / 09 / 2009$

$11 / 09 / 2009$

$11 / 09 / 2009$

$11 / 09 / 2009$

$11 / 09 / 2009$

$11 / 09 / 2009$

$11 / 09 / 2009$

$11 / 09 / 2009$

$11 / 09 / 2009$

11/09/2009

$11 / 09 / 2009$

$11 / 09 / 2009$

11/09/2009

$11 / 09 / 2009$

$11 / 09 / 2009$

11/09/2009

$11 / 09 / 2009$

$11 / 09 / 2009$

$11 / 09 / 2009$

$11 / 09 / 2009$

$11 / 09 / 2009$

$11 / 09 / 2009$

11/09/2009

$11 / 09 / 2009$

$11 / 09 / 2009$
$8270 \mathrm{C}$

$8270 \mathrm{C}$

$8270 \mathrm{C}$

$8270 \mathrm{C}$

$8270 \mathrm{C}$

$8270 \mathrm{C}$

$8270 \mathrm{C}$

$8270 \mathrm{C}$

$8270 \mathrm{C}$

$8270 \mathrm{C}$

$8270 \mathrm{C}$

$8270 \mathrm{C}$

$8270 \mathrm{C}$

$8270 \mathrm{C}$

$8270 \mathrm{C}$

$8270 \mathrm{C}$

$8270 \mathrm{C}$

$8270 \mathrm{C}$

$8270 \mathrm{C}$

$8270 \mathrm{C}$

$8270 \mathrm{C}$

$8270 \mathrm{C}$

$8270 \mathrm{C}$

$8270 \mathrm{C}$

$8270 \mathrm{C}$

$8270 \mathrm{C}$

$8270 \mathrm{C}$

$8270 \mathrm{C}$

$8270 \mathrm{C}$

$8270 \mathrm{C}$

$8270 \mathrm{C}$

$8270 \mathrm{C}$

$8270 \mathrm{C}$

$8270 \mathrm{C}$

$8270 \mathrm{C}$

$8270 \mathrm{C}$

$8270 \mathrm{C}$

$8270 \mathrm{C}$

$8270 \mathrm{C}$ 
National Security Technologies, LLC 2621 Losee Road, Mail Stop NIS273 North Las Vegas NV, 89030
Project: BOA

Project Number: 60052-002-001

Project Manager: Ied Redding
Reported:

11/16/2009 14:41

113-01

0910108-01 (Oil)

\begin{tabular}{|lllllllllllll}
\hline Analyte & Result and Qualifier & $\begin{array}{l}\text { Reporting } \\
\text { Limit }\end{array}$ & Units & Dilution & Batch & Prepared & Analyzed & Method \\
\hline
\end{tabular}

Lionville Laboratory

Semivolatile Organic Compounds by SW846 8270C

\begin{tabular}{|c|c|c|c|c|c|c|c|c|c|}
\hline Butyl Benzyl Phthalate & 3240 & $\mathrm{U}$ & 3240 & $\mathrm{ug} / \mathrm{kg}$ & 1 & L911033 & $11 / 04 / 2009$ & $11 / 09 / 2009$ & $8270 \mathrm{C}$ \\
\hline Chrysene & 3240 & $\mathrm{U}$ & 3240 & $\mathrm{ug} / \mathrm{kg}$ & 1 & L911033 & $11 / 04 / 2009$ & $11 / 09 / 2009$ & $8270 \mathrm{C}$ \\
\hline Dibenz[a,h]anthracene & 3240 & $\mathrm{U}$ & 3240 & $\mathrm{ug} / \mathrm{kg}$ & 1 & L.911033 & $11 / 04 / 2009$ & $11 / 09 / 2009$ & $8270 \mathrm{C}$ \\
\hline Dibenzofuran & 3240 & $\mathrm{U}$ & 3240 & $\mathrm{ug} / \mathrm{kg}$ & 1 & 1.911033 & $11 / 04 / 2009$ & $11 / 09 / 2009$ & $8270 \mathrm{C}$ \\
\hline Diethyl Phthalate & 3240 & $\mathrm{U}$ & 3240 & $\mathrm{ug} / \mathrm{kg}$ & 1 & L.911033 & $11 / 04 / 2009$ & $11 / 09 / 2009$ & $8270 \mathrm{C}$ \\
\hline Dimethyl Phthalate & 3240 & $\mathrm{U}$ & 3240 & $\mathrm{ug} / \mathrm{kg}$ & 1 & L911033 & $11 / 04 / 2009$ & $11 / 09 / 2009$ & $8270 \mathrm{C}$ \\
\hline Di-n-butyl Phthalate & 35600 & & 3240 & $\mathrm{ug} / \mathrm{kg}$ & 1 & L911033 & $11 / 04 / 2009$ & $11 / 09 / 2009$ & $8270 \mathrm{C}$ \\
\hline Di-n-octyl Phthalate & 3240 & $\mathrm{U}$ & 3240 & $\mathrm{ug} / \mathrm{kg}$ & 1 & L911033 & $11 / 04 / 2009$ & $11 / 09 / 2009$ & $8270 \mathrm{C}$ \\
\hline Fluoranthene & 3240 & $\mathrm{U}$ & 3240 & $\mathrm{ug} / \mathrm{kg}$ & 1 & L.911033 & $11 / 04 / 2009$ & $11 / 09 / 2009$ & $8270 \mathrm{C}$ \\
\hline Fluorene & 3240 & $\mathrm{U}$ & 3240 & $\mathrm{ug} / \mathrm{kg}$ & 1 & L.911033 & $11 / 04 / 2009$ & $11 / 09 / 2009$ & $8270 \mathrm{C}$ \\
\hline Hexachlorobenzene & 3240 & $\mathrm{U}$ & 3240 & $\mathrm{ug} / \mathrm{kg}$ & 1 & L911033 & $11 / 04 / 2009$ & $11 / 09 / 2009$ & $8270 \mathrm{C}$ \\
\hline Hexachlorobutadiene & 3240 & $\mathrm{U}$ & 3240 & $\mathrm{ug} / \mathrm{kg}$ & 1 & L911033 & $11 / 04 / 2009$ & $11 / 09 / 2009$ & $8270 \mathrm{C}$ \\
\hline Hexachlorocyclopentadiene & 3240 & $\mathrm{U}$ & 3240 & $\mathrm{ug} / \mathrm{kg}$ & 1 & I 911033 & $11 / 04 / 2009$ & $11 / 09 / 2009$ & $8270 \mathrm{C}$ \\
\hline Hexachloroethane & 3240 & $\mathrm{U}$ & 3240 & $\mathrm{ug} / \mathrm{kg}$ & 1 & L 911033 & $11 / 04 / 2009$ & $11 / 09 / 2009$ & $8270 \mathrm{C}$ \\
\hline Indeno[1,2,3-cd]pyrene & 3240 & $\mathrm{U}$ & 3240 & $\mathrm{ug} / \mathrm{kg}$ & 1 & L911033 & $11 / 04 / 2009$ & $11 / 09 / 2009$ & $8270 \mathrm{C}$ \\
\hline Isophorone & 3240 & $\mathrm{U}$ & 3240 & $\mathrm{ug} / \mathrm{kg}$ & 1 & 1911033 & $11 / 04 / 2009$ & $11 / 09 / 2009$ & $8270 \mathrm{C}$ \\
\hline Naphthalene & 3240 & $\mathrm{U}$ & 3240 & $\mathrm{ug} / \mathrm{kg}$ & 1 & 1911033 & $11 / 04 / 2009$ & $11 / 09 / 2009$ & $8270 \mathrm{C}$ \\
\hline Nitrobenzene & 3240 & $\mathrm{U}$ & 3240 & $\mathrm{ug} / \mathrm{kg}$ & 1 & L911033 & $11 / 04 / 2009$ & $11 / 09 / 2009$ & $8270 \mathrm{C}$ \\
\hline N-Nitrosodi-n-propylamine & 3240 & $U$ & 3240 & $\mathrm{ug} / \mathrm{kg}$ & 1 & L911033 & $11 / 04 / 2009$ & $11 / 09 / 2009$ & $8270 \mathrm{C}$ \\
\hline N-Nitrosodiphenylamine & 23200 & & 3240 & $\mathrm{ug} / \mathrm{kg}$ & 1 & L911033 & $11 / 04 / 2009$ & $11 / 09 / 2009$ & $8270 \mathrm{C}$ \\
\hline Pentachlorophenol & 16200 & $\mathrm{U}$ & 16200 & $\mathrm{ug} / \mathrm{kg}$ & 1 & L911033 & $11 / 04 / 2009$ & $11 / 09 / 2009$ & $8270 \mathrm{C}$ \\
\hline Phenanthrene & 3240 & $\mathrm{U}$ & 3240 & $\mathrm{ug} / \mathrm{kg}$ & 1 & L911033 & $11 / 04 / 2009$ & $11 / 09 / 2009$ & $8270 \mathrm{C}$ \\
\hline Phenol & 3240 & $\mathrm{U}$ & 3240 & $\mathrm{ug} / \mathrm{kg}$ & 1 & 1911033 & $11 / 04 / 2009$ & $11 / 09 / 2009$ & $8270 \mathrm{C}$ \\
\hline Pyrene & 3240 & $\mathrm{U}$ & 3240 & $\mathrm{ug} / \mathrm{kg}$ & 1 & L.911033 & $11 / 04 / 2009$ & $11 / 09 / 2009$ & $8270 \mathrm{C}$ \\
\hline Benzoic Acid & 16200 & $\mathrm{U}$ & 16200 & $\mathrm{ug} / \mathrm{kg}$ & 1 & L.911033 & $11 / 04 / 2009$ & $11 / 09 / 2009$ & $8270 \mathrm{C}$ \\
\hline Benzyl alcohol & 3240 & $\mathrm{U}$ & 3240 & $\mathrm{ug} / \mathrm{kg}$ & 1 & L911033 & $11 / 04 / 2009$ & $11 / 09 / 2009$ & $8270 \mathrm{C}$ \\
\hline TIC: Unknown 2 & 3420000 & $\mathbf{J}$ & & $\mathrm{ug} / \mathrm{kg}$ & 1 & L911033 & $11 / 04 / 2009$ & $11 / 09 / 2009$ & $8270 \mathrm{C}$ \\
\hline I IC: Unknown 1 & 7640000 & J & & $\mathrm{ug} / \mathrm{kg}$ & 1 & L911033 & $11 / 04 / 2009$ & $11 / 09 / 2009$ & $8270 \mathrm{C}$ \\
\hline IIC: I'ricosane, 2-methyl- & 3740000 & $\mathrm{~N}, \mathrm{~J}$ & & $\mathrm{ug} / \mathrm{kg}$ & 1 & 1.911033 & $11 / 04 / 2009$ & $11 / 09 / 2009$ & $8270 \mathrm{C}$ \\
\hline IIC: PAH2 & 2190000 & $J$ & & $\mathrm{ug} / \mathrm{kg}$ & 1 & 1911033 & $11 / 04 / 2009$ & $11 / 09 / 2009$ & $8270 \mathrm{C}$ \\
\hline IIC: PAH1 & 2090000 & $\mathrm{~J}$ & & $\mathrm{ug} / \mathrm{kg}$ & 1 & L911033 & $11 / 04 / 2009$ & $11 / 09 / 2009$ & $8270 \mathrm{C}$ \\
\hline IIC: Nonahexacontanoic Acid & 2510000 & $\mathrm{~N}, \mathrm{~J}$ & & $\mathrm{ug} / \mathrm{kg}$ & 1 & L.911033 & $11 / 04 / 2009$ & $11 / 09 / 2009$ & $8270 \mathrm{C}$ \\
\hline IIC: Nonadecane, 1-chloro- & 5480000 & $\mathrm{~N}, \mathrm{~J}$ & & $\mathrm{ug} / \mathrm{kg}$ & 1 & L911033 & $11 / 04 / 2009$ & $11 / 09 / 2009$ & $8270 \mathrm{C}$ \\
\hline TIC: n-Pentadecylcyclohexane & 2350000 & $\mathrm{~N}, \mathrm{~J}$ & & $\mathrm{ug} / \mathrm{kg}$ & 1 & L911033 & $11 / 04 / 2009$ & $11 / 09 / 2009$ & $8270 \mathrm{C}$ \\
\hline IIC: Alkane 1 & 7500000 & $\mathbf{J}$ & & $\mathrm{ug} / \mathrm{kg}$ & 1 & L911033 & $11 / 04 / 2009$ & $11 / 09 / 2009$ & $8270 \mathrm{C}$ \\
\hline IIC: n-Heptadecylcyclohexane & 3970000 & $\mathrm{~N}, \mathrm{~J}$ & & $\mathrm{ug} / \mathrm{kg}$ & 1 & 1911033 & $11 / 04 / 2009$ & $11 / 09 / 2009$ & $8270 \mathrm{C}$ \\
\hline Iributylphosphate & 3240 & $\mathrm{U}$ & 3240 & $\mathrm{ug} / \mathrm{kg}$ & 1 & L911033 & $11 / 04 / 2009$ & $11 / 09 / 2009$ & $8270 \mathrm{C}$ \\
\hline Surrogate: 2-Fluorophenol & $80 \%$ & & $25-12 I$ & & & 1911033 & $11 / 04 / 2009$ & $11 / 09 / 2009$ & $8270 \mathrm{C}$ \\
\hline
\end{tabular}


National Security Technologies, LIC 2621 Losee Road, Mail Stop NIS273

North Las Vegas NV, 89030
Project: BOA

Project Number: 60052-002-001

Project Manager: Ied Redding
Reported:

11/16/2009 14:41

\section{3-01}

0910108-01 (Oil)

\begin{tabular}{|c|c|c|c|c|c|c|c|c|}
\hline Analyte & Result and Qualifier & $\begin{array}{l}\text { Reporting } \\
\text { Limit }\end{array}$ & Units & Dilution & Batch & Prepared & Analyzed & Method \\
\hline
\end{tabular}

Lionville Laboratory

Semivolatile Organic Compounds by SW846 8270C

$\begin{array}{lll}\text { Surrogate: Phenol-d5 } & 74 \% & 24-113 \\ \text { Surrogate. Nitrobenzene-d5 } & 84 \% & 23-120 \\ \text { Surrogate: } 2-F l u o r o b i p h e n y l & 96 \% & 30-115 \\ \text { Surrogate: } 246-\text { Tribromophenol } & 27 \% & 19-122 \\ \text { Surrogate: } p \text {-Terphenyl-d14 } & 99 \% & 18-137\end{array}$

$\left[\begin{array}{llll}2.911033 & 11 / 04 / 2009 & 11 / 09 / 2009 & 8270 \mathrm{C}\end{array}\right.$

$\begin{array}{lllll}2911033 & 11 / 04 / 2009 & 11 / 09 / 2009 & 8270 \mathrm{C}\end{array}$

$\begin{array}{llll}2911033 & 11 / 04 / 2009 & 11 / 09 / 2009 & 8270 \mathrm{C}\end{array}$

$\begin{array}{lllll}1.911033 & 11 / 04 / 2009 & 11 / 09 / 2009 & 8270 \mathrm{C}\end{array}$

Surrogate: $p$-Terphenyl-d14

$18-137$

$\begin{array}{llll}L 911033 & 11 / 04 / 2009 \quad 11 / 09 / 2009 \quad 8270 C\end{array}$ 
National Security Technologies, LLC

2621 Losee Road, Mail Stop NIS273

North Las Vegas NV, 89030
Project: BOA

Project Number: 60052-002-001

Project Manager: Ied Redding
Reported:

11/16/2009 14:41

113-02

0910108-02 (Oil)

\begin{tabular}{|c|c|c|c|c|c|c|c|c|}
\hline Analyte & Result and Qualifier & $\begin{array}{l}\text { Reporting } \\
\text { Limit }\end{array}$ & Units & Dilution & Batch & Prepared & Analyzed & Method \\
\hline
\end{tabular}

Lionville Laboratory

Semivolatile Organic Compounds by SW846 8270C

\begin{tabular}{|c|c|c|c|c|c|c|c|c|c|}
\hline 1,2,4-Trichlorobenzene & 3140 & $\bar{U}$ & 3140 & $\mathrm{ug} / \mathrm{kg}$ & 1 & L911033 & $11 / 04 / 2009$ & $11 / 09 / 2009$ & $8270 \mathrm{C}$ \\
\hline 1,2-Dichlorobenzene & 3140 & $\mathrm{U}$ & 3140 & $\mathrm{ug} / \mathrm{kg}$ & 1 & L911033 & $11 / 04 / 2009$ & $11 / 09 / 2009$ & $8270 \mathrm{C}$ \\
\hline 1,3-Dichlorobenzene & 3140 & $\mathrm{U}$ & 3140 & $\mathrm{ug} / \mathrm{kg}$ & 1 & L911033 & $11 / 04 / 2009$ & $11 / 09 / 2009$ & $8270 \mathrm{C}$ \\
\hline 1,4-Dichlorobenzene & 3140 & $\mathrm{U}$ & 3140 & $\mathrm{ug} / \mathrm{kg}$ & 1 & L911033 & $11 / 04 / 2009$ & $11 / 09 / 2009$ & $8270 \mathrm{C}$ \\
\hline 2,4,5-Trichlorophenol & 3140 & $\mathrm{U}$ & 3140 & $\mathrm{ug} / \mathrm{kg}$ & 1 & L.911033 & $11 / 04 / 2009$ & $11 / 09 / 2009$ & $8270 \mathrm{C}$ \\
\hline 2,4,6-Trichlorophenol & 3140 & $\mathrm{U}$ & 3140 & $\mathrm{ug} / \mathrm{kg}$ & 1 & L911033 & $11 / 04 / 2009$ & $11 / 09 / 2009$ & $8270 \mathrm{C}$ \\
\hline 2,4-Dichlorophenol & 3140 & $\mathrm{U}$ & 3140 & $\mathrm{ug} / \mathrm{kg}$ & 1 & L911033 & $11 / 04 / 2009$ & $11 / 09 / 2009$ & $8270 \mathrm{C}$ \\
\hline 2,4-Dimethylphenol & 3140 & $\mathrm{U}$ & 3140 & $\mathrm{ug} / \mathrm{kg}$ & 1 & L911033 & $11 / 04 / 2009$ & $11 / 09 / 2009$ & $8270 \mathrm{C}$ \\
\hline 2,4-Dinitrophenol & 15700 & $\mathrm{U}$ & 15700 & $\mathrm{ug} / \mathrm{kg}$ & 1 & L911033 & $11 / 04 / 2009$ & $11 / 09 / 2009$ & $8270 \mathrm{C}$ \\
\hline 2,4-Dinitrotoluene & 3140 & $\mathrm{U}$ & 3140 & $\mathrm{ug} / \mathrm{kg}$ & 1 & L911033 & $11 / 04 / 2009$ & $11 / 09 / 2009$ & $8270 \mathrm{C}$ \\
\hline 2,6-Dinitrotoluene & 3140 & $\mathrm{U}$ & 3140 & $\mathrm{ug} / \mathrm{kg}$ & 1 & L.911033 & $11 / 04 / 2009$ & $11 / 09 / 2009$ & $8270 \mathrm{C}$ \\
\hline 2-Chloronaphthalene & 3140 & $\mathrm{U}$ & 3140 & $\mathrm{ug} / \mathrm{kg}$ & 1 & L911033 & $11 / 04 / 2009$ & $11 / 09 / 2009$ & $8270 \mathrm{C}$ \\
\hline 2-Chlorophenol & 3140 & $\mathrm{U}$ & 3140 & $\mathrm{ug} / \mathrm{kg}$ & 1 & L911033 & $11 / 04 / 2009$ & $11 / 09 / 2009$ & $8270 \mathrm{C}$ \\
\hline 2-Methylnaphthalene & 3140 & $\mathrm{U}$ & 3140 & $\mathrm{ug} / \mathrm{kg}$ & 1 & L911033 & $11 / 04 / 2009$ & $11 / 09 / 2009$ & $8270 \mathrm{C}$ \\
\hline 2-Methylphenol & 3140 & $\mathrm{U}$ & 3140 & $\mathrm{ug} / \mathrm{kg}$ & 1 & $\llcorner .911033$ & $11 / 04 / 2009$ & $11 / 09 / 2009$ & $8270 \mathrm{C}$ \\
\hline 2-Nitroaniline & 15700 & $\mathrm{U}$ & 15700 & $\mathrm{ug} / \mathrm{kg}$ & 1 & L911033 & $11 / 04 / 2009$ & $11 / 09 / 2009$ & $8270 \mathrm{C}$ \\
\hline 2-Nitrophenol & 3140 & $\mathrm{U}$ & 3140 & $\mathrm{ug} / \mathrm{kg}$ & 1 & L911033 & $11 / 04 / 2009$ & $11 / 09 / 2009$ & $8270 \mathrm{C}$ \\
\hline 3,3'-Dichlorobenzidine & 6270 & $\mathrm{U}$ & 6270 & $\mathrm{ug} / \mathrm{kg}$ & 1 & L.911033 & $11 / 04 / 2009$ & $11 / 09 / 2009$ & $8270 \mathrm{C}$ \\
\hline 3-Nitroaniline & 15700 & $\mathrm{U}$ & 15700 & $\mathrm{ug} / \mathrm{kg}$ & 1 & L.911033 & $11 / 04 / 2009$ & $11 / 09 / 2009$ & $8270 \mathrm{C}$ \\
\hline 4,6-Dinitro-2-methylphenol & 3140 & $\mathrm{U}$ & 3140 & $\mathrm{ug} / \mathrm{kg}$ & 1 & L911033 & $11 / 04 / 2009$ & $11 / 09 / 2009$ & $8270 \mathrm{C}$ \\
\hline 4-Bromophenyl Phenyl Ether & 3140 & $\mathrm{U}$ & 3140 & $\mathrm{ug} / \mathrm{kg}$ & 1 & L.911033 & $11 / 04 / 2009$ & $11 / 09 / 2009$ & $8270 \mathrm{C}$ \\
\hline 4-Chloro-3-methylphenol & 3140 & $\mathrm{U}$ & 3140 & $\mathrm{ug} / \mathrm{kg}$ & 1 & L911033 & $11 / 04 / 2009$ & $11 / 09 / 2009$ & $8270 \mathrm{C}$ \\
\hline 4-Chloroaniline & 3140 & $\mathrm{U}$ & 3140 & $\mathrm{ug} / \mathrm{kg}$ & 1 & L911033 & $11 / 04 / 2009$ & $11 / 09 / 2009$ & $8270 \mathrm{C}$ \\
\hline 4-Chlorophenyl Phenyl Ether & 3140 & $\mathrm{U}$ & 3140 & $\mathrm{ug} / \mathrm{kg}$ & 1 & L911033 & $11 / 04 / 2009$ & $11 / 09 / 2009$ & $8270 \mathrm{C}$ \\
\hline 3- and/or 4-Methylphenol & 3140 & $\mathrm{U}$ & 3140 & $\mathrm{ug} / \mathrm{kg}$ & 1 & L911033 & $11 / 04 / 2009$ & $11 / 09 / 2009$ & $8270 \mathrm{C}$ \\
\hline 4-Nitroaniline & 15700 & $\mathrm{U}$ & 15700 & $\mathrm{ug} / \mathrm{kg}$ & 1 & L911033 & $11 / 04 / 2009$ & $11 / 09 / 2009$ & $8270 \mathrm{C}$ \\
\hline 4-Nitrophenol & 15700 & $\mathrm{U}$ & 15700 & $\mathrm{ug} / \mathrm{kg}$ & 1 & L911033 & $11 / 04 / 2009$ & $11 / 09 / 2009$ & $8270 \mathrm{C}$ \\
\hline Acenaphthene & 3140 & $\mathrm{U}$ & 3140 & $\mathrm{ug} / \mathrm{kg}$ & 1 & L.911033 & $11 / 04 / 2009$ & $11 / 09 / 2009$ & $8270 \mathrm{C}$ \\
\hline Acenaphthylene & 3140 & $\mathrm{U}$ & 3140 & $\mathrm{ug} / \mathrm{kg}$ & 1 & L911033 & $11 / 04 / 2009$ & $11 / 09 / 2009$ & $8270 \mathrm{C}$ \\
\hline Anthracene & 3140 & $\mathrm{U}$ & 3140 & $\mathrm{ug} / \mathrm{kg}$ & 1 & L911033 & $11 / 04 / 2009$ & $11 / 09 / 2009$ & $8270 \mathrm{C}$ \\
\hline Benz[a]anthracene & 3140 & $\mathrm{U}$ & 3140 & $\mathrm{ug} / \mathrm{kg}$ & 1 & L.911033 & $11 / 04 / 2009$ & $11 / 09 / 2009$ & $8270 \mathrm{C}$ \\
\hline Benzo[a] pyrene & 3140 & $\mathrm{U}$ & 3140 & $\mathrm{ug} / \mathrm{kg}$ & 1 & 1911033 & $11 / 04 / 2009$ & $11 / 09 / 2009$ & $8270 \mathrm{C}$ \\
\hline Benzo[b] fluoranthene & 3140 & $\mathrm{U}$ & 3140 & $\mathrm{ug} / \mathrm{kg}$ & 1 & 1911033 & $11 / 04 / 2009$ & $11 / 09 / 2009$ & $8270 \mathrm{C}$ \\
\hline Benzo[g,h,i] perylene & 3140 & $\mathrm{U}$ & 3140 & $\mathrm{ug} / \mathrm{kg}$ & 1 & 1911033 & $11 / 04 / 2009$ & $11 / 09 / 2009$ & $8270 \mathrm{C}$ \\
\hline Benzo [k] fluoranthene & 3140 & $\mathrm{U}$ & 3140 & $\mathrm{ug} / \mathrm{kg}$ & 1 & L.911033 & $11 / 04 / 2009$ & $11 / 09 / 2009$ & $8270 \mathrm{C}$ \\
\hline Bis(2-chloroethoxy) methane & 3140 & $\mathrm{U}$ & 3140 & $\mathrm{ug} / \mathrm{kg}$ & 1 & L.911033 & $11 / 04 / 2009$ & $11 / 09 / 2009$ & $8270 \mathrm{C}$ \\
\hline Bis(2-chloroethyl) ether & 3140 & $\mathrm{U}$ & 3140 & $\mathrm{ug} / \mathrm{kg}$ & 1 & L.911033 & $11 / 04 / 2009$ & $11 / 09 / 2009$ & $8270 \mathrm{C}$ \\
\hline Bis(2-chloroisopropyl) ether & 3140 & $\mathrm{U}$ & 3140 & $\mathrm{ug} / \mathrm{kg}$ & 1 & L.911033 & $11 / 04 / 2009$ & $11 / 09 / 2009$ & $8270 \mathrm{C}$ \\
\hline Bis(2-ethylhexyl) phthalate & 34500 & & 3140 & $\mathrm{ug} / \mathrm{kg}$ & 1 & L911033 & $11 / 04 / 2009$ & $11 / 09 / 2009$ & $8270 \mathrm{C}$ \\
\hline
\end{tabular}


National Security Technologies, LIC

2621 Losee Road, Mail Stop NIS273

North Las Vegas NV, 89030
Project: $\mathrm{BOA}$

Project Number: 60052-002-001

Project Manager: Ied Redding
Reported:

11/16/2009 14:41

113-02

0910108-02 (Oil)

\begin{tabular}{|lllllll}
\hline Analyte & Result and Qualifier & $\begin{array}{l}\text { Reporting } \\
\text { Limit }\end{array}$ & Units & Dilution & Batch & Prepared \\
\hline
\end{tabular}

Lionville Laboratory

Semivolatile Organic Compounds by SW846 8270C

\begin{tabular}{|c|c|c|c|c|c|c|c|c|c|}
\hline Butyl Benzyl Phthalate & 3140 & $\mathrm{U}$ & 3140 & $\mathrm{ug} / \mathrm{kg}$ & 1 & L911033 & $11 / 04 / 2009$ & $11 / 09 / 2009$ & $8270 \mathrm{C}$ \\
\hline Chrysene & 3140 & $\mathrm{U}$ & 3140 & $\mathrm{ug} / \mathrm{kg}$ & 1 & I911033 & $11 / 04 / 2009$ & $11 / 09 / 2009$ & $8270 \mathrm{C}$ \\
\hline Diben $z[a$, h]anthracene & 3140 & $\mathrm{U}$ & 3140 & $\mathrm{ug} / \mathrm{kg}$ & 1 & L911033 & $11 / 04 / 2009$ & $11 / 09 / 2009$ & $8270 \mathrm{C}$ \\
\hline Dibenzofuran & 3140 & $\mathrm{U}$ & 3140 & $\mathrm{ug} / \mathrm{kg}$ & 1 & L.911033 & $11 / 04 / 2009$ & $11 / 09 / 2009$ & $8270 \mathrm{C}$ \\
\hline Diethyl Phthalate & 3140 & $\mathrm{U}$ & 3140 & $\mathrm{ug} / \mathrm{kg}$ & 1 & L.911033 & $11 / 04 / 2009$ & $11 / 09 / 2009$ & $8270 \mathrm{C}$ \\
\hline Dimethyl Phthalate & 3140 & $\mathrm{U}$ & 3140 & $\mathrm{ug} / \mathrm{kg}$ & 1 & L911033 & $11 / 04 / 2009$ & $11 / 09 / 2009$ & $8270 \mathrm{C}$ \\
\hline Di-n-butyl Phthalate & 52700 & & 3140 & $\mathrm{ug} / \mathrm{kg}$ & 1 & L.911033 & $11 / 04 / 2009$ & $11 / 09 / 2009$ & $8270 \mathrm{C}$ \\
\hline Di-n-octyl Phthalate & 3140 & $\mathrm{U}$ & 3140 & $\mathrm{ug} / \mathrm{kg}$ & 1 & L.911033 & $11 / 04 / 2009$ & $11 / 09 / 2009$ & $8270 \mathrm{C}$ \\
\hline Fluoranthene & 3140 & $\mathrm{U}$ & 3140 & $\mathrm{ug} / \mathrm{kg}$ & 1 & 1911033 & $11 / 04 / 2009$ & $11 / 09 / 2009$ & $8270 \mathrm{C}$ \\
\hline Fluorene & 3140 & $\mathrm{U}$ & 3140 & $\mathrm{ug} / \mathrm{kg}$ & 1 & L 911033 & $11 / 04 / 2009$ & $11 / 09 / 2009$ & $8270 \mathrm{C}$ \\
\hline Hexachlorobenzene & 3140 & $\mathrm{U}$ & 3140 & $\mathrm{ug} / \mathrm{kg}$ & 1 & L.911033 & $11 / 04 / 2009$ & $11 / 09 / 2009$ & $8270 \mathrm{C}$ \\
\hline Hexachlorobutadiene & 3140 & $\mathrm{U}$ & 3140 & $\mathrm{ug} / \mathrm{kg}$ & 1 & L.911033 & $11 / 04 / 2009$ & $11 / 09 / 2009$ & $8270 \mathrm{C}$ \\
\hline Hexachlorocyclopentadiene & 3140 & $\mathrm{U}$ & 3140 & $\mathrm{ug} / \mathrm{kg}$ & 1 & I911033 & $11 / 04 / 2009$ & $11 / 09 / 2009$ & $8270 \mathrm{C}$ \\
\hline Hexachloroethane & 3140 & $\mathrm{U}$ & 3140 & $\mathrm{ug} / \mathrm{kg}$ & 1 & L911033 & $11 / 04 / 2009$ & $11 / 09 / 2009$ & $8270 \mathrm{C}$ \\
\hline Indeno $[1,2,3-\mathrm{cd}]$ pyrene & 3140 & $\mathrm{U}$ & 3140 & $\mathrm{ug} / \mathrm{kg}$ & 1 & L.911033 & $11 / 04 / 2009$ & $11 / 09 / 2009$ & $8270 \mathrm{C}$ \\
\hline Isophorone & 3140 & $\mathrm{U}$ & 3140 & $\mathrm{ug} / \mathrm{kg}$ & 1 & 1911033 & $11 / 04 / 2009$ & $11 / 09 / 2009$ & $8270 \mathrm{C}$ \\
\hline Naphthalene & 3140 & $\mathrm{U}$ & 3140 & $\mathrm{ug} / \mathrm{kg}$ & 1 & L911033 & $11 / 04 / 2009$ & $11 / 09 / 2009$ & $8270 \mathrm{C}$ \\
\hline Nitrobenzene & 3140 & $\mathrm{U}$ & 3140 & $\mathrm{ug} / \mathrm{kg}$ & 1 & L911033 & $11 / 04 / 2009$ & $11 / 09 / 2009$ & $8270 \mathrm{C}$ \\
\hline N-Nitrosodi-n-propylamine & 3140 & $\mathrm{U}$ & 3140 & $\mathrm{ug} / \mathrm{kg}$ & 1 & L.911033 & $11 / 04 / 2009$ & $11 / 09 / 2009$ & $8270 \mathrm{C}$ \\
\hline N-Nitrosodiphenylamine & 36000 & & 3140 & $\mathrm{ug} / \mathrm{kg}$ & 1 & 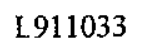 & $11 / 04 / 2009$ & $11 / 09 / 2009$ & $8270 \mathrm{C}$ \\
\hline Pentachlorophenol & 15700 & $\mathrm{U}$ & 15700 & $\mathrm{ug} / \mathrm{kg}$ & 1 & L911033 & $11 / 04 / 2009$ & $11 / 09 / 2009$ & $8270 \mathrm{C}$ \\
\hline Phenanthrene & 3140 & $\mathrm{U}$ & 3140 & $\mathrm{ug} / \mathrm{kg}$ & 1 & L.911033 & $11 / 04 / 2009$ & $11 / 09 / 2009$ & $8270 \mathrm{C}$ \\
\hline Phenol & 3140 & $\mathrm{U}$ & 3140 & $\mathrm{ug} / \mathrm{kg}$ & 1 & L.911033 & $11 / 04 / 2009$ & $11 / 09 / 2009$ & $8270 \mathrm{C}$ \\
\hline Pyrene & 3140 & $\mathrm{U}$ & 3140 & $\mathrm{ug} / \mathrm{kg}$ & 1 & I911033 & $11 / 04 / 2009$ & $11 / 09 / 2009$ & $8270 \mathrm{C}$ \\
\hline Benzoic Acid & 15700 & $\mathrm{U}$ & 15700 & $\mathrm{ug} / \mathrm{kg}$ & 1 & L911033 & $11 / 04 / 2009$ & $11 / 09 / 2009$ & $8270 \mathrm{C}$ \\
\hline Benzyl alcohol & 3140 & U & 3140 & $\mathrm{ug} / \mathrm{kg}$ & 1 & L.911033 & $11 / 04 / 2009$ & $11 / 09 / 2009$ & $8270 \mathrm{C}$ \\
\hline TIC: Unknown 2 & 4100000 & $\mathbf{J}$ & & $\mathrm{ug} / \mathrm{kg}$ & 1 & L911033 & $11 / 04 / 2009$ & $11 / 09 / 2009$ & $8270 \mathrm{C}$ \\
\hline IIC: Unknown 1 & 12300000 & $\mathrm{~J}$ & & $\mathrm{ug} / \mathrm{kg}$ & 1 & I911033 & $11 / 04 / 2009$ & $11 / 09 / 2009$ & $8270 \mathrm{C}$ \\
\hline TIC: PAF1 & 4050000 & $J$ & & $\mathrm{ug} / \mathrm{kg}$ & 1 & L911033 & $11 / 04 / 2009$ & $11 / 09 / 2009$ & $8270 \mathrm{C}$ \\
\hline IIC: Nonadecane, 1-chloro- & 7460000 & $\mathrm{~N}, \mathrm{~J}$ & & $\mathrm{ug} / \mathrm{kg}$ & 1 & L911033 & $11 / 04 / 2009$ & $11 / 09 / 2009$ & $8270 \mathrm{C}$ \\
\hline IIC: n-Heptadecylcyclohexane & 4230000 & $\mathrm{~N}, \mathrm{~J}$ & & $\mathrm{ug} / \mathrm{kg}$ & 1 & L.911033 & $11 / 04 / 2009$ & $11 / 09 / 2009$ & $8270 \mathrm{C}$ \\
\hline TIC: Ethanol, 2-(octadecyloxy)- & 6080000 & $\mathrm{~N}, \mathrm{~J}$ & & $\mathrm{ug} / \mathrm{kg}$ & 1 & $\mathrm{~L}, 911033$ & $11 / 04 / 2009$ & $11 / 09 / 2009$ & $8270 \mathrm{C}$ \\
\hline IIC: Eicosane, 2-cyclohexyl- & 4410000 & $\mathrm{~N}, \mathrm{~J}$ & & ug/kg & 1 & L911033 & $11 / 04 / 2009$ & $11 / 09 / 2009$ & $8270 \mathrm{C}$ \\
\hline IIC: Alkane 2 & 3590000 & $J$ & & $\mathrm{ug} / \mathrm{kg}$ & 1 & 1911033 & $11 / 04 / 2009$ & $11 / 09 / 2009$ & $8270 \mathrm{C}$ \\
\hline IIC: 1-Docosene & 3880000 & $\mathrm{~N}, \mathrm{~J}$ & & $\mathrm{ug} / \mathrm{kg}$ & 1 & L911033 & $11 / 04 / 2009$ & $11 / 09 / 2009$ & $8270 \mathrm{C}$ \\
\hline TIC: Alkane 1 & 3430000 & $\mathbf{J}$ & & $\mathrm{ug} / \mathrm{kg}$ & 1 & L.911033 & $11 / 04 / 2009$ & $11 / 09 / 2009$ & $8270 \mathrm{C}$ \\
\hline Tributylphosphate & 3140 & $\mathrm{U}$ & 3140 & $\mathrm{ug} / \mathrm{kg}$ & 1 & 1911033 & $11 / 04 / 2009$ & $11 / 09 / 2009$ & $8270 \mathrm{C}$ \\
\hline Surrogate: 2-Fluorophenol & $94 \%$ & & $25-121$ & & & 2911033 & $11 / 04 / 2009$ & $11 / 09 / 2009$ & $8270 C$ \\
\hline
\end{tabular}


264 Welsh Pool Road Exton, PA 19341

Phone: 610-280-3000

Fax: 610-280-3041

National Security Iechnologies, LLC

2621 L osee Road, Mail Stop NIS273

North Las Vegas NV, 89030
Project: $\mathrm{BOA}$

Project Number: 60052-002-001

Project Manager: Ted Redding
Reported:

$11 / 16 / 200914: 41$

113-02

0910108-02 (Oil)

\begin{tabular}{|lllllll}
\hline & & Reporting & & & & \\
Analyte & Result and Qualifier & Limit & Units & Dilution & Batch & Prepared \\
\hline
\end{tabular}

Lionville Laboratory

Semivolatile Organic Compounds by SW846 8270C

\begin{tabular}{lrr}
\hline Surrogate: Phenol-d5 & $89 \%$ & $24-113$ \\
Surrogate: Nitrobenzene-d5 & $102 \%$ & $23-120$ \\
Surrogate: 2 -Fluorobiphenyl & $119 \% *$ & $30-115$ \\
Surrogate: 2 4,6-Tribromophenol & $1 \% *$ & $19-122$ \\
Surrogate: $p$-Terphenyl-dl4 & $150 \% *$ & $18-137$
\end{tabular}

$\begin{array}{llll}1911033 & 11 / 04 / 2009 & 11 / 09 / 2009 & 8270 \mathrm{C} \\ L 911033 & 11 / 04 / 2009 & 11 / 09 / 2009 & 8270 \mathrm{C} \\ L 911033 & 11 / 04 / 2009 & 11 / 09 / 2009 & 8270 \mathrm{C} \\ L 911033 & 11 / 04 / 2009 & 11 / 09 / 2009 & 8270 \mathrm{C} \\ L 911033 & 11 / 04 / 2009 & 11 / 09 / 2009 & 8270 \mathrm{C}\end{array}$




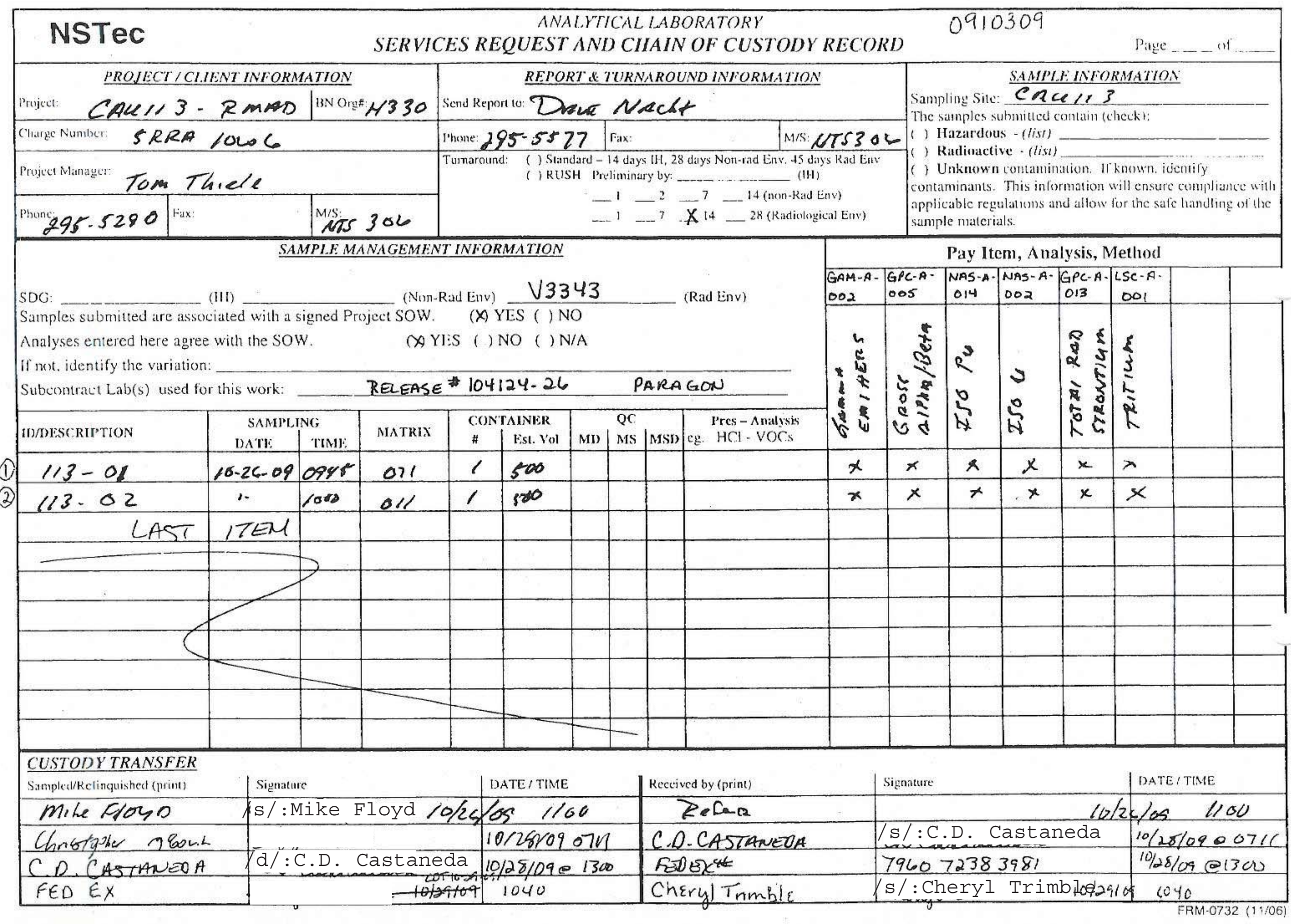




\section{Isotopic Plutonium By Alpha Spectroscopy Sample Results Summary}

Client Name: National Security Technologies, LLC Client Project Name: CAU 113 RMAD

Client Project Number: V3343
Laboratory Name: ALS Laboratory Group -- FC PAI Work Order: 0910309
Page: 1 of 1

Reported on: Wednesday, November 11, 2009 12:45:02 PM

\begin{tabular}{|c|c|c|c|c|c|c|c|c|c|c|}
\hline $\begin{array}{c}\text { Lab } \\
\text { Sample ID }\end{array}$ & Client Sample ID & $\begin{array}{c}\text { Sample } \\
\text { Type }\end{array}$ & Nuclide & Result +1- 2 s TPU & MDC & Units & Matrix & Prep Batch & $\begin{array}{c}\text { Date } \\
\text { Analyzed }\end{array}$ & Flags \\
\hline $0910309-1$ & $113-01$ & Sample & Pu-238 & $O E+00+/-4.03 E-03$ & $3.02 \mathrm{E}-03$ & pCitg & OlL. & ASO91102-3 & $11 / 5 / 2009$ & $u$ \\
\hline $0910309-1$ & $113-01$ & Sample & Pu-239/240 & $-5.56 \mathrm{E}-04+1-4.03 \mathrm{E}-03$ & 9. $35 \mathrm{E}-03$ & $\mathrm{pCi} / \mathrm{g}$ & OL & AS091102-3 & $11 / 5 / 2009$ & $u$ \\
\hline $0910309-2$ & $113-02$ & Sample & Pu-238 & $0 \mathrm{E}+00+/-3.49 \mathrm{E}-03$ & $2.61 E-03$ & pCi/g & OIL & AS091102-3 & $11 / 5 / 2009$ & $u$ \\
\hline $0910309-2$ & $113-02$ & Sample & Pu-239/240 & $9.65 \mathrm{E}-05+/-3.49 \mathrm{E}-03$ & 6.87E-03 & pCilg & OlL & AS091102-3 & $11 / 5 / 2009$ & $u$ \\
\hline
\end{tabular}

\section{Comments:}

Data Package ID: PU0910309-1

\footnotetext{
Qualifiers/Flags:

$U$ - Result is less than the sample specific MDC

LT - Result is less than Requested MDC, greater than sample specific MDC.

Y1 - Chemical Yield is in control at 100-110\%. Quantitative Yield is assumed.

Y2 - Chemical Yield outside default limits

$M$ - The requested MDC was not met.

M3 - The requested MDC was not met, but the re ported activity is greater than the reported MDC.
}

Abbreviation

TPU - Total Propagated Uncertainty (see PAI SOP 743)

MOC - Minimum Detectable Concentration (see PAI SOP 709)

BDL - Below Detection Limit 


\title{
Isotopic Plutonium By Alpha Spectroscopy
}

\author{
PAI 714 Rev 11 \\ Sample Results
}

Lab Name: ALS Laboratory Group -- FC

Work Order Number: 0910309

Client Name: National Security Technologies, LLC

ClientProject ID: CAU 113 RMAD V3343

\begin{tabular}{l} 
Field ID: $113-01$ \\
Lab ID: $0910309-1$ \\
\hline
\end{tabular}

Analysis ReqCode: NAS-A-014
Sample Matrix: OIL

Prep SOP: PAl 778 Rev 13

Date Collected: 26-Oct-09

Date Prepared: 02-Nov-09

Date Analyzed: 05-Nov-09
Prep Batch: AS091102-3

QCBatchID: AS091102-3-1

Run ID: AS091102-3B

Count Time: 300 minutes

Report Basis: As Received
Final Aliquot: $6.01 \mathrm{~g}$

Prep Basis: As Received

Moisture(\%): NA

Result Units: $p C i / g$

File Name: Spectrum \#1

\begin{tabular}{|l|c|c|c|c|c|}
\hline \multicolumn{1}{|c|}{ CASNO } & Target Nuclide & Result +/- 2 s TPU & MDC & $\begin{array}{c}\text { Requested } \\
\text { MDC }\end{array}$ & \begin{tabular}{c} 
Lab Qualifier \\
\hline $13981-16-3$
\end{tabular} \\
\hline $10-12-8$ & Pu-238 & $0 \mathrm{E}+00+/-4.03 \mathrm{E}-03$ & $3.02 \mathrm{E}-03$ & $5.00 \mathrm{E}-01$ & \\
\hline
\end{tabular}

\section{Chemical Yield Summary}

\begin{tabular}{|c|c|c|c|c|c|}
\hline Carrier/Tracer & Amount Added & Result & Units & Yield & $\begin{array}{c}\text { Control } \\
\text { Limits }\end{array}$ \\
\hline Pu-242 & $1.480 \mathrm{E}+00$ & $1.07 \mathrm{E}+00$ & $\mathrm{pCi} / \mathrm{g}$ & 72.4 & $30-110 \%$ \\
\hline
\end{tabular}

\section{Comments:}

\footnotetext{
Qualifiers/Flags:

$U$ - Result is less than the sample specific MDC.

Y1 - Chemical Yield is in control at $100-110 \%$. Quantitative Yield is assumed.

Y2 - Chemical Yieid outside default limits.

LT - Result is less than Requested MDC, greater than sample specific MDC.

M3 - The requested MDC was not met, but the reported

activity is greater than the reported MDC.

$M$ - The requested $M D C$ was not met.

Abbreviations:

TPU - Total Propagated Uncertainty (see PAI SOP 743)

MDC - Minimum Detectable Concentration (see PAI SOP 709)

$\mathrm{BDL}$ - Below Detection Limit
}

Data Package ID: PU0910309-1

Date Printed:Wednesday, November 11, 2009

ALS Laboratory Group - FC

LIMS Version: $6.308 \mathrm{~A}$
Page 1 of 2 


\section{Isotopic Plutonium By Alpha Spectroscopy \\ PAl 714 Rev 11 \\ Sample Results}

Lab Name: ALS Laboratory Group - FC

Work Order Number: 0910309

Client Name: National Security Technologies, LLC

ClientProject ID: CAU 113 RMAD V 3343

\begin{tabular}{|c|c|c|c|c|c|}
\hline \multicolumn{2}{|c|}{$\begin{aligned} & \text { Field ID: } 113-02 \\
& \text { Lab ID: } 0910309-2 \\
&\end{aligned}$} & \multirow{2}{*}{$\begin{array}{l}\text { Sample Matrix: OIL } \\
\quad \text { Prep SOP: PAI } 778 \text { Rev } 13 \\
\text { Date Collected: } 26-\text { Oct-09 } \\
\text { Date Prepared:02-Nov-09 } \\
\text { Date Analyzed:05-Nov-09 }\end{array}$} & \multirow{2}{*}{$\begin{array}{l}\text { Prep Batch: AS091102-3 } \\
\text { QCBatchID: AS091102-3-1 } \\
\text { Run ID: AS091102-3B } \\
\text { Count Time: } 300 \text { minutes } \\
\text { Report Basis: As Received }\end{array}$} & \multirow{2}{*}{\multicolumn{2}{|c|}{$\begin{array}{l}\text { Final Aliquot: } 6.02 \mathrm{~g} \\
\text { Prep Basis: As Received } \\
\text { Moisture(\%): NA } \\
\text { Result Units: pCi/g } \\
\text { File Name: Spectrum \#1 }\end{array}$}} \\
\hline Analysis ReqC & e: NAS-A-014 & & & & \\
\hline CASNO & Target Nuclide & Result $+1-2 \mathrm{~s}$ TPU & MDC & $\begin{array}{l}\text { Requested } \\
\text { MDC }\end{array}$ & Lab Qualifier \\
\hline $13981-16-3$ & Pu-238 & $\mathrm{OE}+00+/-3.49 \mathrm{E}-03$ & $2.61 \mathrm{E}-03$ & $5.00 E-01$ & U \\
\hline $10-12-8$ & Pu-239/240 & $9.65 E-05+/-3.49 E-03$ & $6.87 \mathrm{E}-03$ & $5.00 \mathrm{E}-01$ & U \\
\hline
\end{tabular}

Chemical Yield Summary

\begin{tabular}{|c|c|c|c|c|c|c|}
\hline Carrier/Tracer & Amount Added & Result & Units & Yield & $\begin{array}{c}\text { Control } \\
\text { Limits }\end{array}$ & Flag \\
\hline Pu-242 & $1.480 \mathrm{E}+00$ & $1.22 \mathrm{E}+00$ & $\mathrm{pCi} / \mathrm{g}$ & 82.5 & $30-110 \%$ & \\
\hline
\end{tabular}

Comments:

\footnotetext{
Qualifiers/Flags:

$U$-Result is less than the sample specific MDC.

Y1 - Chemical Yield is in control at 100-110\%. Quantitative Yield is assumed.

Y2 - Chemical Yield outside default limits.

LT - Result is less than Requested MDC, greater than sample specific MDC.

M3 - The requested MDC was not met, but the reported

activity is greater than the reported MDC.

$M$ - The requested $M D C$ was not met.

Abbreviations:

TPU - Total Propagated Uncertainty (see PAI SOP 743)

MDC - Minimum Detectable Concentration (see PAI SOP 709)

BDL. - Below Detection Limit
}

Data Package ID: PU0910309-1

Date Printed: Wednesday, November 11, 2009

ALS Laboratory Group - FC

Page 2 of 2

LIMS Version: $6.308 \mathrm{~A}$ 


\section{Isotopic Plutonium By Alpha Spectroscopy \\ PAI 714 Rev 11 \\ Sample Duplicate Results}

Lab Name: ALS Laboratory Group -- FC

Work Order Number: 0910309

Client Name: National Security Technologies, LLC

ClientProject ID: CAU 113 RMAD V3343

\begin{tabular}{|c|c|c|c|c|c|}
\hline \multicolumn{2}{|c|}{$\begin{array}{l}\text { Field ID: } 113-02 \\
\text { Lab ID: } 0910309-2 D U P\end{array}$} & $\begin{array}{l}\text { Sample Matrix: OIL } \\
\quad \text { Prep SOP: PAI } 778 \text { Rev } 13 \\
\text { Date Collected: } 26-\text { Oct-09 } \\
\text { Date Prepared: 02-Nov-09 } \\
\text { Date Analyzed: } 05-\text { Nov-09 }\end{array}$ & $\begin{array}{l}\text { Prep Batch: AS091102-3 } \\
\text { QCBatchID: AS091102-3-1 } \\
\text { Run ID: AS091102-3B } \\
\text { Count Time: } 300 \text { minutes } \\
\text { Report Basis: As Received }\end{array}$ & \multicolumn{2}{|c|}{$\begin{array}{l}\text { Final Aliquot: } 6.01 \mathrm{~g} \\
\text { Prep Basis: As Received } \\
\text { Moisture(\%): NA } \\
\text { Result Units: pCi/g } \\
\text { File Name: Spectrum \#1 }\end{array}$} \\
\hline CASNO & Target Nuclide & Result +/- 2 s TPU & MDC & $\begin{array}{c}\text { Requested } \\
\text { MDC }\end{array}$ & Lab Qualifier \\
\hline $13981-16-3$ & Pu-238 & $6.24 \mathrm{E}-04+1-3.23 \mathrm{E}-03$ & 4.69E-03 & 5.00E-01 & $U$ \\
\hline $10-12-8$ & $\mathrm{Pu}-239 / 240$ & $4.46 \mathrm{E}-04+/-3.23 \mathrm{E}-03$ & $7.50 \mathrm{E}-03$ & $5.00 \mathrm{E}-01$ & $U$ \\
\hline
\end{tabular}

\section{Chemical Yield Summary}

\begin{tabular}{|c|c|c|c|c|c|c|}
\hline Carrier/Tracer & Amount Added & Result & Units & Yield & $\begin{array}{c}\text { Control } \\
\text { Limits }\end{array}$ & Flag \\
\hline Pu-242 & $1.480 \mathrm{E}+00$ & $1.31 \mathrm{E}+00$ & $\mathrm{pCi} / \mathrm{g}$ & 88.7 & $30-110 \%$ & \\
\hline
\end{tabular}

Comments:

\footnotetext{
Qualifiers/Flags:

$U$-Result is less than the sample specific MDC.

$\mathrm{Y} 1$ - Chemical Yield is in control at $100-110 \%$. Quantitative yield is assumed.

Y2 - Chemical Yield outside default limits.

LT - Result is less than Requested MDC, greater than sample specific MDC.

$M$ - The requested $M D C$ was not met.

M3 - The requested MDC was not met, but thereported activity is greater than the reported MDC.

D. DER is greater than Control Limit of 3

Abbreviations:

TPU - Total Propagated Uncertainty (see PAI SOP 743)

MDC - Minimum Detectable Concentration (see PAI SOP 709)

BDL - Below Detection Limit
}

Data Package ID: PU0910309-1 


\title{
Gamma Spectroscopy Results
}

\author{
PAI 713 Rev 10 \\ Sample Results
}

Lab Name: ALS Laboratory Group -- FC

Work Order Number: 0910309

Client Name: National Security Technologies, LLC

ClientProject ID: CAU 113 RMAD V3343

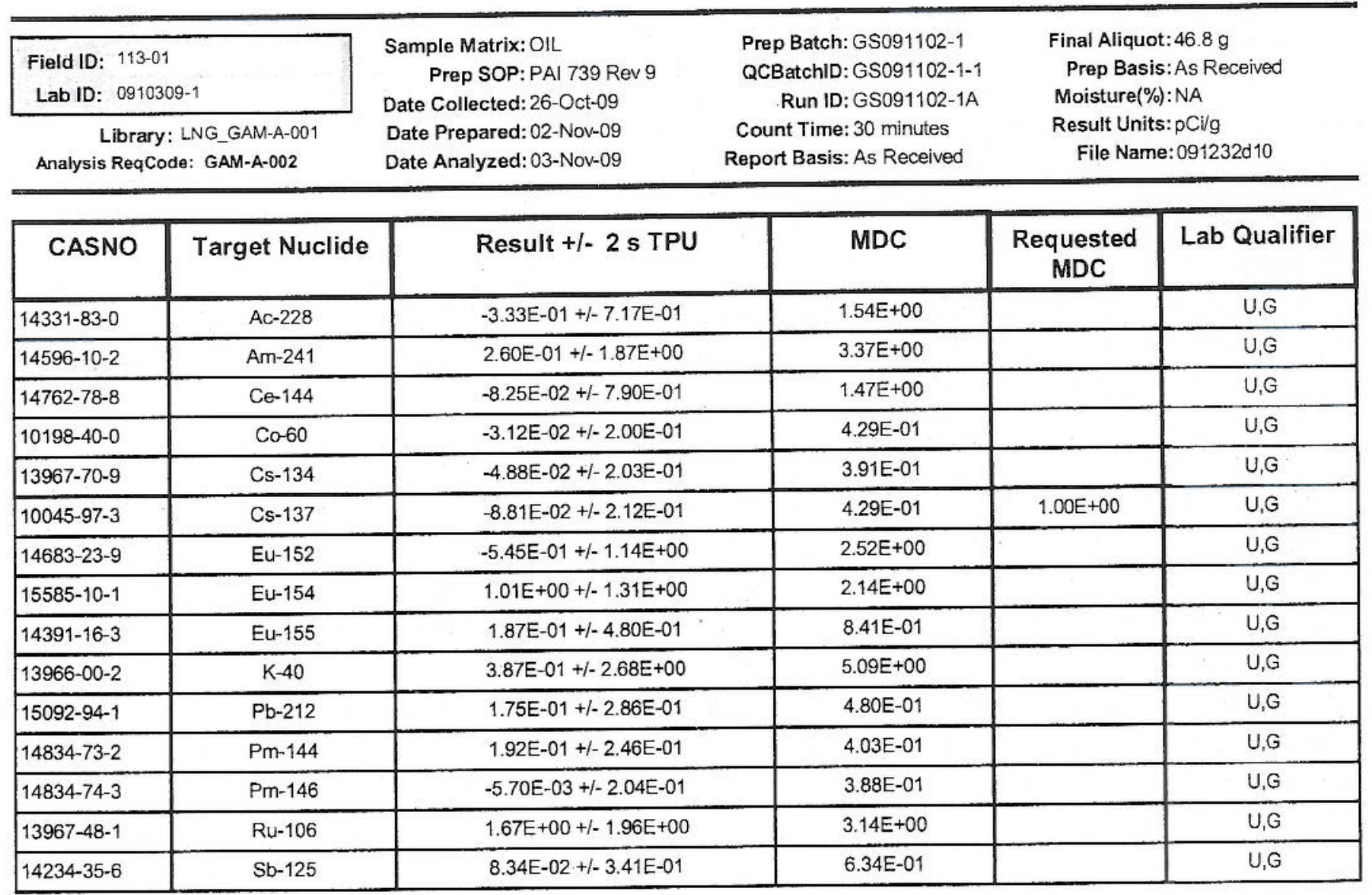

\section{Comments:}

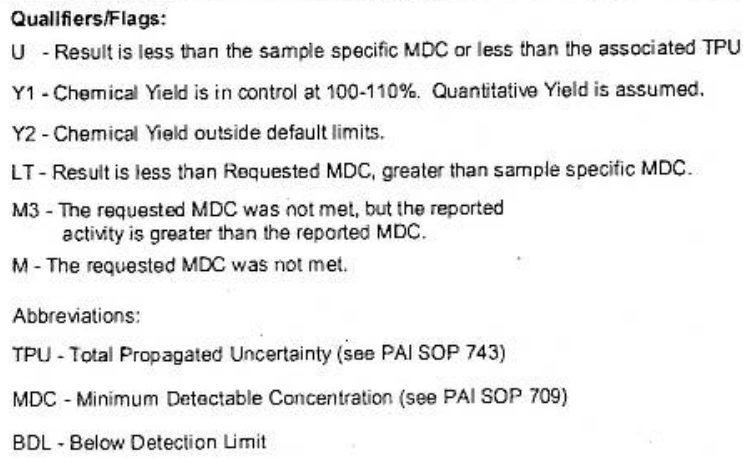




\section{Gamma Spectroscopy Results}

PAl 713 Rev 10

Sample Results

Lab Name: ALS Laboratory Group -- FC

Work Order Number: 0910309

Client Name: National Security Technologies, LLC

ClientProject ID: CAU 113 RMAD V3343

Field ID: $113-01$
Lab ID: $0910309-1$

Library: LNG_GAM-A-001

Analysis ReqCode: GAM-A-002
Sample Matrix: OIL

Prep SOP: PAl 739 Rev 9

Date Collected: 26-Oct-09

Date Prepared:02-Nov-09

Date Analyzed:03-Nov-09
Prep Batch: GS091102-1

QCBatchID: GS091102-1-1

Run ID: GS091102-1A

Count Time: 30 minutes

Report Basis: As Received
Final Aliquot: $46.8 \mathrm{~g}$

Prep Basis: As Received

Moisture(\%): NA

Result Units: $\mathrm{pCi} / \mathrm{g}$

File Name: $091232 d 10$

\begin{tabular}{|c|c|c|c|c|c|}
\hline CASNO & Target Nuclide & Result +/- $2 \mathrm{~s}$ TPU & MDC & $\begin{array}{c}\text { Requested } \\
\text { MDC }\end{array}$ & Lab Qualifier \\
\hline $15065-10-8$ & Th-234 & $-7.01 E-01+/-3.05 E+00$ & $5.67 \mathrm{E}+00$ & & $\mathrm{U}, \mathrm{G}$ \\
\hline $15117-96-1$ & $\mathrm{U}-235$ & $3.06 \mathrm{E}-01+/-8.02 \mathrm{E}-01$ & $1.39 E+00$ & & $U, G$ \\
\hline $13982-36-0$ & $Y-88$ & $-9.99 E-02+/-2.24 E-01$ & $4.70 \mathrm{E}-01$ & & $U, G$ \\
\hline
\end{tabular}

\section{Comments:}

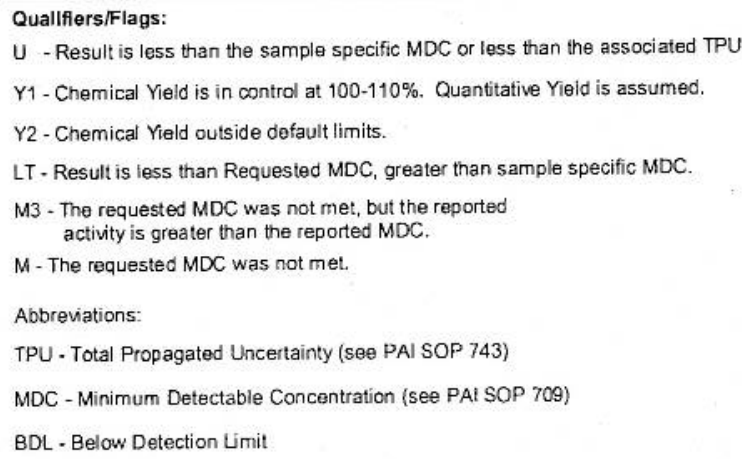




\title{
Gamma Spectroscopy Results
}

\author{
PAI 713 Rev 10 \\ Sample Duplicate Results
}

Lab Name: ALS Laboratory Group -- FC

Work Order Number: 0910309

Client Name: National Security Technologies, LLC

ClientProject ID: CAU 113 RMAD V3343

Field ID: $113-01$
Lab ID: $0910309-1 D U P$

Library: LNG_GAM-A-001
Sample Matrix: OIL

Prep SOP: PAl 739 Rev 9

Date Collected: 26-Oct-09

Date Prepared: 02-Nov-09

Date Analyzed: 03-Nov-09
Prep Batch: GS091102-1

QCBatchID: GS091102-1-1

Run ID: GS091102-1A

Count Time: 30 minutes

Report Basis: As Received
Final Aliquot: $45.6 \mathrm{~g}$

Prep Basis: As Received

Moisture(\%): NA

Result Units: pCi/g

File Name:091660d08

\begin{tabular}{|c|c|c|c|c|c|}
\hline CASNO & Target Nuclide & Result +/- 2 s TPU & MDC & $\begin{array}{c}\text { Requested } \\
\text { MDC }\end{array}$ & Lab Qualifier \\
\hline $14331-83-0$ & $A c-228$ & 4.45E-01 +/- 9.37E-01 & $1.65 E+00$ & & U,G \\
\hline $14596-10-2$ & Am-241 & $-1.79 \mathrm{E}-01+/-1.94 \mathrm{E}-01$ & 4.07E-01 & & $U, G$ \\
\hline $14762-78-8$ & $\mathrm{Ce}-144$ & $-9.24 \mathrm{E}-01+1-7.84 \mathrm{E}-01$ & $1.62 \mathrm{E}+00$ & & $U, G$ \\
\hline $10198-40-0$ & Co-60 & $2.55 E-02+/-2.38 E-01$ & 4.82E-01 & 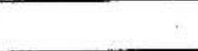 & U,G \\
\hline $13967-70-9$ & Cs-134 & $-1.95 \mathrm{E}-01+/-2.20 \mathrm{E}-01$ & $4.62 E-01$ & & U,G \\
\hline $10045-97-3$ & Cs-137 & $-1.39 E-01+1-2.37 E-01$ & 4.94E-01 & $1.00 E+00$ & U,G \\
\hline $14683-23-9$ & $\mathrm{Eu}-152$ & $-2.56 E-01+/-1.06 E+00$ & $2.41 \mathrm{E}+00$ & & U,G \\
\hline $15585-10-1$ & Eu-154 & $-6.90 E-01+/-1.11 E+00$ & $2.56 \mathrm{E}+00$ & & U,G \\
\hline $14391-16-3$ & Eu-155 & $0 \mathrm{E}+00+/-3.47 \mathrm{E}-01$ & $6.42 \mathrm{E}-01$ & & U,G \\
\hline $13966-00-2$ & $\mathrm{~K}-40$ & $1.85 E-01+/-3.06 E+00$ & $5.98 E+00$ & & $U, G$ \\
\hline $15092-94-1$ & $\mathrm{~Pb}-212$ & 2.17E-02 +/- 2.86E-01 & 5.17E-01 & & U,G \\
\hline $14834-73-2$ & $\mathrm{Pm}-144$ & $7.72 E-02+/-2.94 E-01$ & $5.22 \mathrm{E}-01$ & & U,G \\
\hline $14834-74-3$ & $P m-146$ & $0 E+00+/-1.83 E-01$ & $3.60 E-01$ & & U,G \\
\hline
\end{tabular}

\section{Comments:}

\section{Quallfiers/Flags:}

$U$-Result is less than the sample specific MDC or less than the associated TPU.

Y1 - Chemical Yield is in control at 100-110\%. Quantitative yield is assumed.

Y2 - Chemical Yield outside default limits.

LT - Result is less than Requested MDC, greater than sample specific MDC.

$M$ - The requested $M D C$ was not met.

M3 - The requested MDC was not met, but thereported activity is greater than the reported MDC.

D. DER is greater than Control Limit of 3
SQ - Spectral quality prevents accurate quantitation.

SI- Nuclide identification and/or quantitation is tentative.

$\mathrm{TI}$ - Nuclide identification is tentative.

$R$ - Nuclide has exceeded 8 halflives.

G-Sample density. differs by more than $15 \%$ of LCS density.

Abbreviations:

TPU - Total Propagated Uncertainty (see PAI SOP 743)

MDC - Minimum Detectable Concentration (see PAI SOP 709)

$\mathrm{BDL}$ - Below Detection Limit

Data Package ID: GSW0910309-1 


\section{Gamma Spectroscopy Results \\ PAI 713 Rev 10 \\ Sample Duplicate Results}

Lab Name: ALS Laboratory Group -- FC

Work Order Number: 0910309

Client Name: National Security Technologies, LLC

ClientProject ID: CAU 113 RMAD V3343

\begin{tabular}{|c|}
\hline Field ID: 113-01 \\
\hline Lab 1D: 0910309-1DUP \\
\hline
\end{tabular}

Library: LNG_GAM-A-001
Sample Matrix: OIL

Prep SOP: PAI 739 Rev 9

Date Collected: 26-Oct-09

Date Prepared: 02-Nov-09

Date Analyzed: 03-Nov-09
Prep Batch: GS091102-1

QCBatchID: GS091102-1-1

Run ID: GS091102-1A

Count Time: 30 minutes

Report Basis: As Received
Final Aliquot: $45.6 \mathrm{~g}$

Prep Basis: As Received

Moisture(\%): NA

Result Units: $\mathrm{pCi} / \mathrm{g}$

File Name:091660d08

\begin{tabular}{|c|c|c|c|c|c|}
\hline CASNO & Target Nuclide & Result $+1-2$ s TPU & MDC & $\begin{array}{c}\text { Requested } \\
\text { MDC }\end{array}$ & Lab Qualifier \\
\hline $13967-48-1$ & Ru-106 & $-8.29 E-01+/-1.92 E+00$ & $3.94 E+00$ & & U,G \\
\hline $14234-35-6$ & Sb-125 & $\mathrm{OE}+00+/-4.54 \mathrm{E}-01$ & $8.68 \mathrm{E}-01$ & 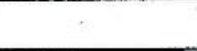 & U,G \\
\hline $15065-10-8$ & Th-234 & $1.78 \mathrm{E}+00+1-2.00 \mathrm{E}+00$ & $3.25 E+00$ & & U,G \\
\hline $15117-96-1$ & $\mathrm{U}-235$ & $1.29 \mathrm{E}-01+/-6.76 \mathrm{E}-01$ & $1.23 E+00$ & & U,G \\
\hline $13982-36-0$ & $Y-88$ & $-2.19 \mathrm{E}-01+/-2.97 \mathrm{E}-01$ & $6.34 \mathrm{E}-01$ & & U,G \\
\hline
\end{tabular}

\section{Comments:}

\begin{tabular}{ll}
\hline Quallfers/Flags: & SQ - Spectral quality prevents accurate quantitation. \\
U - Result is less than the sample specific MDC or less than the associated TPU. & SI- Nuclide identification and/or quantitation is tentative. \\
Y1 - Chemical Yield is in control at $100-110 \%$. Quantitative yield is assumed. & TI- Nuclide identification is tentative. \\
Y2 - Chemical Yield outside default limits. & R- Nuclide has exceeded 8 halflives. \\
LT - Result is less than Requested MDC, greater than sample specific MDC. & G-Sample density differs by more than $15 \%$ of LCS density. \\
M - The requested MDC was not met. & \\
M3 - The requested MDC was not met, but thereported activity is greater than the reported MDC.
\end{tabular}

D - DER is greater than Control Limit of 3

Abbreviations:

TPU - Total Propagated Uncertainty (see PAI SOP 743)

MDC - Minimum Detectable Concentration (see PAI SOP 709)

BDL - Below Detection Limit

Data Package ID: GSW0910309-1 


\title{
Gamma Spectroscopy Results
}

\author{
PAI 713 Rev 10 \\ Sample Results
}

Lab Name: ALS Laboratory Group -- FC

Work Order Number: 0910309

Client Name: National Security Technologies, LLC

ClientProject ID: CAU 113 RMAD V3343

Field ID: ${ }^{113-02}$
Lab ID: $0910309-2$

Library: LNG_GAM-A-001

Analysis ReqCode: GAM-A-002
Sample Matrix: OIL

Prep SOP: PAI 739 Rev 9

Date Collected: 26-Oct-09

Date Prepared: 02-Nov-09

Date Analyzed: 03-Nov-09
Prep Batch: GS091102-1

QCBatchID: GS091102-1-1

Run ID: GS091102-1A

Count Time: 30 minutes

Report Basis: As Received
Final Aliquot: $47.5 \mathrm{~g}$

Prep Basis: As Received

Moisture(\%): NA

Result Units: $\mathrm{pCi} / \mathrm{g}$

File Name:091326d09

\begin{tabular}{|c|c|c|c|c|c|}
\hline CASNO & Target Nuclide & Result +/- 2 s TPU & MDC & $\begin{array}{c}\text { Requested } \\
\text { MDC }\end{array}$ & Lab Qualifier \\
\hline $14331-83-0$ & $\mathrm{Ac}-228$ & 4.37E-01+/-8.74E-01 & $1.54 \mathrm{E}+00$ & & U,G \\
\hline $14596-10-2$ & Am-241 & 1.43E-01 +/-1.60E-01 & 2.54E-01 & & U,G \\
\hline $14762-78-8$ & $\mathrm{Ce}-144$ & $-1.99 E-01+/-6.10 E-01$ & $1.20 E+00$ & & U,G \\
\hline $10198-40-0$ & Co-60 & $-4.34 E-02+/-1.94 E-01$ & 4.67E-01 & & $U, G$ \\
\hline $13967-70-9$ & $\mathrm{Cs}-134$ & $\mathrm{OE}+00+1-1.29 \mathrm{E}-01$ & 2.67E-01 & & $\mathrm{U}, \mathrm{G}$ \\
\hline $10045-97-3$ & Cs-137 & $-1.02 E-01+/-2.04 E-01$ & 4.44E-01 & $1.00 E+00$ & U,G \\
\hline $14683-23-9$ & Eu-152 & $-2.16 \mathrm{E}-01+/-9.68 \mathrm{E}-01$ & $2.33 E+00$ & & U,G \\
\hline $15585-10-1$ & Eu-154 & $5.53 E-01+/-8.27 E-01$ & $1.36 \mathrm{E}+00$ & & U,G \\
\hline $14391-16-3$ & Eu-155 & $-1.45 E-01+/-2.83 E-01$ & $5.71 \mathrm{E}-01$ & $\therefore$ & U,G \\
\hline $13966-00-2$ & $K-40$ & $2.40 E+00+/-3.19 E+00$ & $5.18 \mathrm{E}+00$ & & U,G \\
\hline $15092-94-1$ & $\mathrm{~Pb}-212$ & $-1.40 E-01+/-2.30 E-01$ & 4.64E-01 & & U,G \\
\hline $14834-73-2$ & $\mathrm{Pm}-144$ & $-7.03 E-02+/-1.93 E-01$ & $4.08 \mathrm{E}-01$ & & U,G \\
\hline $14834-74-3$ & $\mathrm{Pm}-146$ & $-3.40 E-02+/-1.93 E-01$ & $3.92 \mathrm{E}-01$ & & U,G \\
\hline $13967-48-1$ & Ru-106 & $4.21 E-01+/-1.19 E+00$ & $2.26 \mathrm{E}+00$ & & U,G \\
\hline $14234-35-6$ & $\mathrm{Sb}-125$ & $-9.28 E-02+/-4.94 E-01$ & $9.66 \mathrm{E}-01$ & & U,G \\
\hline
\end{tabular}

\section{Comments:}

\section{Qualifiers/Flags:}

$U$ - Result is less than the sample specific MDC or less than the associated TPU

Y1 - Chemical Yield is in control at $100-110 \%$. Quantitative Yield is assumed.

Y2 - Chemical Yield outside default limits.

$L T$ - Result is less than Requested MDC, greater than sample specific MDC

M3 - The requested MDC was not met, but the reported

activity is greater than the reported MDC.

$M$ - The requested MDC was not met.

Abbreviations

TPU - Total Propagated Uncertainty (see PAI SOP 743)

MDC - Minimum Detectable Concentration (see PAI SOP 709)

BDL - Below Detection Limit

Data Package ID: GSW0910309-1
SQ - Spectral quality prevents accurate quantitation.

Si - Nuclide identification and/or quantitation is tentative.

TI - Nuclide identification is tentative.

$R$ - Nuclide has exceeded 8 halfives.

G - Sample density differs by more than $15 \%$ of LCS density. 


\section{Gamma Spectroscopy Results \\ PAI 713 Rev 10 \\ Sample Results}

Lab Name: ALS Laboratory Group -- FC

Work Order Number: 0910309

Client Name: National Security Technologies, LLC

ClientProject ID: CAU 113 RMAD V 3343

\begin{tabular}{|c|c|c|c|c|c|}
\hline \multicolumn{2}{|c|}{$\begin{array}{l}\text { Field ID: } 113-02 \\
\text { Lab ID: } 0910309-2 \\
\end{array}$} & \multirow{2}{*}{$\begin{array}{l}\text { Sample Matrix: OIL } \\
\quad \text { Prep SOP: PAI } 739 \text { Rev } 9 \\
\text { Date Collected: } 26-\text { Oct-09 } \\
\text { Date Prepared: 02-Nov-09 } \\
\text { Date Analyzed: 03-Nov-09 }\end{array}$} & \multirow{2}{*}{$\begin{array}{l}\text { Prep Batch: GS091102-1 } \\
\text { QCBatchID: GS091102-1-1 } \\
\text { Run ID: GS091102-1A } \\
\text { Count Time: } 30 \text { minutes } \\
\text { Report Basis: As Received }\end{array}$} & \multirow{2}{*}{\multicolumn{2}{|c|}{$\begin{array}{l}\text { Final Aliquot: } 47.5 \mathrm{~g} \\
\text { Prep Basis: As Received } \\
\text { Moisture(\%): NA } \\
\text { Result Units: } p \text { Ci } / \mathrm{g} \\
\text { File Name: } 091326 \mathrm{~d} 09\end{array}$}} \\
\hline $\begin{array}{l}\text { Librar } \\
\text { Analysis ReqC }\end{array}$ & $\begin{array}{l}\text { LNG_GAM-A-001 } \\
\text { e: GAM-A-002 }\end{array}$ & & & & \\
\hline CASNO & Target Nuclide & Result +/- 2 s TPU & MDC & $\begin{array}{c}\text { Requested } \\
\text { MDC }\end{array}$ & Lab Qualifier \\
\hline $15065-10-8$ & Th-234 & $9.55 \mathrm{E}-01+/-1.35 \mathrm{E}+00$ & $2.23 \mathrm{E}+00$ & & U,G \\
\hline $15117-96-1$ & $U-235$ & $9.93 \mathrm{E}-02+/-5.67 \mathrm{E}-01$ & $1.04 \mathrm{E}+00$ & & $U, G$ \\
\hline $13982-36-0$ & $Y-88$ & $-1.00 \mathrm{E}-01+/-2.51 \mathrm{E}-01$ & 5.45E-01 & & U,G \\
\hline
\end{tabular}

\section{Comments:}

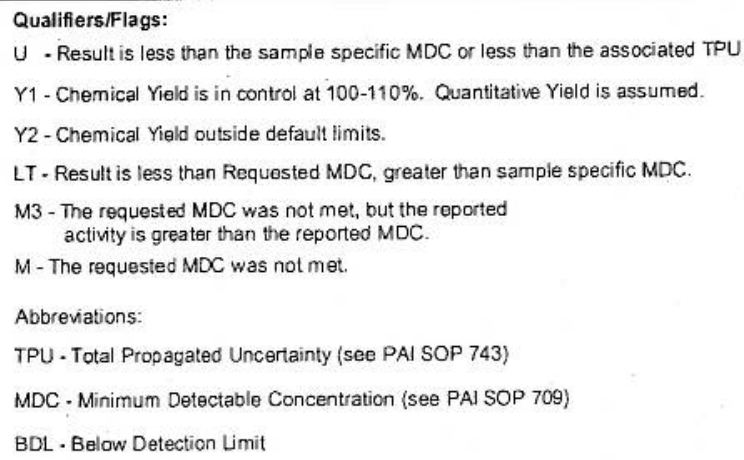

Data Package ID: GSW0910309-1 


\section{Gross Alpha/Beta Analysis by GFPC Sample Results Summary}

Client Name: National Security Technologies, LLC Client Project Name: CAU 113 RMAD

Client Project Number: V3343
Laboratory Name: ALS Laboratory Group -- FC

PAl Work Order: 0910309
Page: 1 of 1

Reported on: Wednesday, November 11, 2009 12:35:22 PM

\begin{tabular}{|c|c|c|c|c|c|c|c|c|c|c|}
\hline $\begin{array}{c}\text { Lab } \\
\text { Sample ID }\end{array}$ & Client Sample ID & $\begin{array}{c}\text { Sample } \\
\text { Type }\end{array}$ & Nuclide & Result $+/-2$ s TPU & MDC & Units & Matrix & Prep Batch & $\begin{array}{c}\text { Date } \\
\text { Analyzed }\end{array}$ & Flags \\
\hline $0910309-1$ & 113-01 & Sample & GROSS ALPHA & $-7.17 \mathrm{E}-03+/-5.25 \mathrm{E}-02$ & $1.34 \mathrm{E}-01$ & $\mathrm{pCi} / \mathrm{g}$ & OIL & AB091030-3 & $11 / 6 / 2009$ & $u$ \\
\hline $0910309-1$ & 113-01 & Sample & GROSS BETA & $6.74 \mathrm{E}-02+/-1.15 \mathrm{E}-01$ & $2.45 E-01$ & $\mathrm{pCi} / \mathrm{g}$ & OIL & AB091030-3 & $11 / 6 / 2009$ & $u$ \\
\hline $0910309-2$ & $113-02$ & Sample & GROSS ALPHA & $3.54 \mathrm{E}-01+/-1.25 \mathrm{E}-01$ & 1.39E-01 & $\mathrm{pCi} / \mathrm{g}$ & $\mathrm{OL}$ & AB091030-3 & $11 / 6 / 2009$ & \\
\hline $0910309-2$ & $113-02$ & Sample & GROSS BETA & 1.05E-01+/-1.23E-01 & 2.53E-01 & $\mathrm{pCi} / \mathrm{g}$ & OIL & AB091030-3 & $11 / 6 / 2009$ & $u$ \\
\hline
\end{tabular}

Comments:

Data Package ID: AB0910309-1

\section{Qualifiers/Flags:}

$U$ - Result is less than the sample specific MDC

LT - Result is less than Requested MDC, greater than sam ple specific MDC.

$Y 1$ - Chemical Yield is in control at $100-110 \%$. Quantitative Yield is assumed

Y2 - Chemicat Yield outside default limits.

$M$ - The requested $M D C$ was not met

M3 - The requested MDC was not met, but the reported activity is greater than the reported MDC
Abbreviations:

TPU - Total Propagated Uncertainty (see PAI SOP 743)

MDC - Minimum Detectable Concentration (see PAI SOP 709)

BDL - Below Detection Limt

Date Printed: Wednesday, November 11, 2009 


\section{Gross Alpha/Beta Analysis by GFPC \\ PAl 724 Rev 10 \\ Sample Results}

Lab Name: ALS Laboratory Group -- FC

Work Order Number: 0910309

Client Name: National Security Technologies, LLC

ClientProject ID: CAU 113 RMAD V3343

\begin{tabular}{l}
\hline Field ID: $113-01$ \\
Lab ID: $0910309-1$ \\
\hline
\end{tabular}

Analysis ReqCode: GPC-A-005
Sample Matrix: OIL

Prep SOP: PAl 702 Rev 19

Date Collected: 26-Oct-09

Date Prepared: 30-Oct-09

Date Analyzed: 06-Nov-09
Prep Batch: AB091030-3

QCBatchID: AB091030-3-1

Run ID: AB091030-3A

Count Time: 180 minutes

Report Basis: As Received
Final Aliquot: $2.02 \mathrm{~g}$

Prep Basis: As Received

Moisture(\%):NA

Result Units: $\mathrm{pCi} / \mathrm{g}$

File Name: ABC1106A

\begin{tabular}{|c|c|c|c|c|c|}
\hline CASNO & Target Nuclide & Result +/- 2 s TPU & MDC & $\begin{array}{c}\text { Requested } \\
\text { MDC }\end{array}$ & Lab Qualifier \\
\hline $12587-46-1$ & GROSS ALPHA & $-7.17 \mathrm{E}-03+/-5.25 \mathrm{E}-02$ & $1.34 \mathrm{E}-01$ & $3.00 \mathrm{E}-01$ & $\mathrm{U}$ \\
\hline $12587-47-2$ & GROSS BETA & $6.74 \mathrm{E}-02+/-1.15 \mathrm{E}-01$ & $2.45 \mathrm{E}-01$ & $5.00 \mathrm{E}-01$ & $\mathrm{U}$ \\
\hline
\end{tabular}

\section{Comments:}

\footnotetext{
Qualifiers/Flags:

$U$ - Result is less than the sample specific MDC.

Y1 - Chemical Yield is in control at 100-110\%. Quantitative Yield is assumed.

Y2 - Chemical Yield outside default limits.

LT - Result is less than Requested MDC, greater than sample specific MDC.

M3 - The requested MDC was not met, but the reported activity is greater than the reported MDC.

$M$ - The requested MDC was not met.

Abbreviations:

TPU - Total Propagated Uncertainty (see PAI SOP 743)

MDC - Minimum Detectable Concentration (see PAI SOP 709)

BDL - Below Detection Limit
}

Data Package ID: AB0910309-1 


\section{Gross Alpha/Beta Analysis by GFPC \\ PAl 724 Rev 10 \\ Sample Duplicate Results}

Lab Name: ALS Laboratory Group -.. FC

Work Order Number: 0910309

Client Name: National Security Technologies, LLC

ClientProject ID: CAU 113 RMAD V3343

Field ID: $113-01$
Lab ID: 0910309-1DUP

Sample Matrix: OIL
Prep SOP: PAI 702 Rev 19
Date Collected: $26-O c t-09$

Date Prepared: $30-0 c t-09$

Date Analyzed: 06-Nov-09
Prep Batch: AB091030-3

QCBatchID: AB091030-3-1

Run ID: AB091030-3A

Count Time: 180 minutes

Report Basis: As Received
Final Aliquot: $2.04 \mathrm{~g}$

Prep Basis: As Received

Moisture(\%): NA

Result Units: $\mathrm{pCi} / \mathrm{g}$

File Name: $A B C 1106 \mathrm{~A}$

\begin{tabular}{|c|c|c|c|c|c|}
\hline CASNO & Target Nuclide & Result +/- 2 s TPU & MDC & $\begin{array}{c}\text { Requested } \\
\text { MDC }\end{array}$ & \begin{tabular}{c} 
Lab Qualifier \\
\hline $12587-46-1$
\end{tabular} \\
\hline $12587-47-2$ & GROSS ALPHA & $2.96 \mathrm{E}-02+/-7.10 \mathrm{E}-02$ & $1.57 \mathrm{E}-01$ & $3.00 \mathrm{E}-01$ & \\
\hline
\end{tabular}

\section{Comments:}

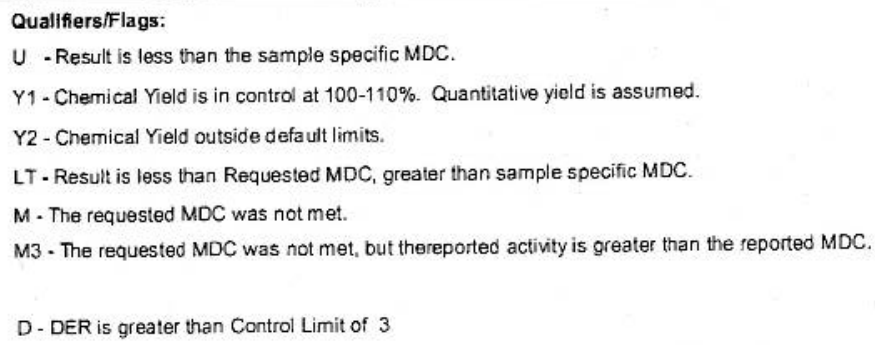

Data Package ID: AB0910309-1 


\section{Gross Alpha/Beta Analysis by GFPC \\ PAI 724 Rev 10 \\ Sample Results}

Lab Name: ALS Laboratory Group -. FC

Work Order Number: 0910309

Client Name: National Security Technologies, LLC

ClientProject ID: CAU 113 RMAD V3343

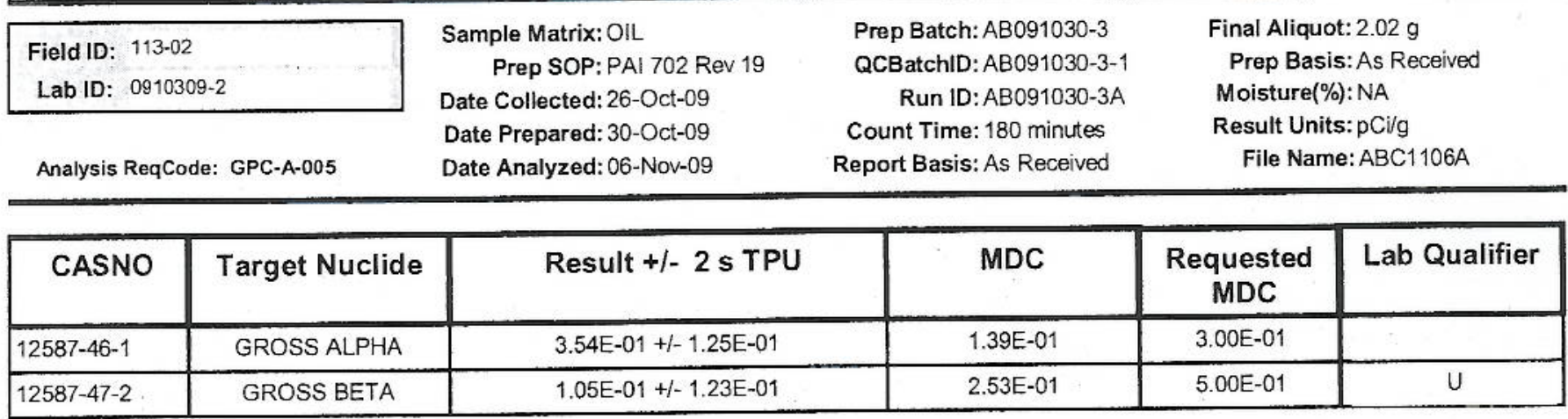

\section{Comments:}

\footnotetext{
Qualifiers/Flags:

$U$ - Result is less than the sample specific MDC.

Y1 - Chemical Yield is in control at 100-110\%. Quantitative Yield is assumed.

Y2 - Chemical Yield outside default limits.

LT - Result is less than Requested MDC, greater than sample specific MDC.

M3 - The requested MDC was not met, but the reported activity is greater than the reported MDC.

$M$ - The requested $M D C$ was not met.

Abbreviations:

TPU - Total Propagated Uncertainty (see PAI SOP 743)

MDC - Minimum Detectable Concentration (see PAI SOP 709)

BDL - Below Detection Limit
}

Data Package ID: AB0910309-1

Date Printed: Wednesday, November 11, 2009

ALS Laboratory Group - FC

LIMS Version: $6.308 \mathrm{~A}$

Page 2 of 2 


\section{Isotopic Uranium By Alpha Spectroscopy Sample Results Summary}

Client Name: National Security Technologies, LLC Client Project Name: CAU 113 RMAD Client Project Number: $V 3343$
Laboratory Name: ALS Laboratory Group -- FC PAI Work Order: 0910309
Page: 1 of 1

Reported on: Wednesday, November 11, 2009 12:50:13 PM

\begin{tabular}{|c|c|c|c|c|c|c|c|c|c|c|}
\hline $\begin{array}{c}\text { Lab } \\
\text { Sample ID }\end{array}$ & Client Sample ID & $\begin{array}{l}\text { Sample } \\
\text { Type }\end{array}$ & Nuclide & Result $+/-2$ s TPU & MDC & Units & Matrix & Prep Batch & $\begin{array}{c}\text { Date } \\
\text { Analyzed }\end{array}$ & Flags \\
\hline 0910309-1 & $113-01$ & Sample & $U-233 / 234$ & $9,17 \mathrm{E}-03+/-6.17 \mathrm{E}-03$ & 4.97E-03 & pCilg & OL & AS091102-3 & $11 / 5 / 2009$ & LT \\
\hline $0910309-1$ & $113-01$ & Sample & U-235 & $1.89 E-03+1-4.03 E-03$ & $5.85 \mathrm{E}-03$ & $\mathrm{pCi} / \mathrm{g}$ & OIL & AS091102-3 & $11 / 5 / 2009$ & $U$ \\
\hline $0910309-1$ & $113-01$ & Sample & $U-238$ & $2.55 \mathrm{E}-03+j-3.44 \mathrm{E}-03$ & 4.97E-03 & pCi/g & OLL & ASO91102-3 & $11 / 5 / 2009$ & $\mathrm{U}$ \\
\hline $0910309-2$ & $113-02$ & Sample & $U-233 / 234$ & $2.94 \mathrm{E}-03+/-5.33 \mathrm{E}-03$ & $3.98 \mathrm{E}-03$ & pCirg & OIL & AS091102-3 & $11 / 5 / 2009$ & $U$ \\
\hline $0910309-2$ & $113-02$ & Sample & U-235 & $-1.04 \mathrm{E}-03+/-6.25 \mathrm{E}-03$ & 1.09E-02 & pCilg & OIL & ASO91102-3 & $11 / 5 / 2009$ & $u$ \\
\hline $0910309-2$ & $113-02$ & Sample & $\cup-238$ & $-2.94 E-04+/-5.31 E-03$ & 1.15E-02 & pCilg & OL & ASC91102-3 & $11 / 5 / 2009$ & $U$ \\
\hline
\end{tabular}

Comments:

Data Package ID: UR0910309-1

\begin{tabular}{l}
\hline Qualifiers/Flags: \\
$U$ - Result is less than the sample specific MDC. \\
$L T$ - Result is less than Requested MDC, greater than sample specific MDC. \\
Y1 - Chemical Yield is in control at 100-110\%. Quantitative Yield is assumed. \\
$Y 2$ - Chemical Yield outside default limits. \\
$M$ - The requested MDC was not met. \\
$M 3$ - The requested MDC was not met, but the reported activity is greater than the reported MDC.
\end{tabular}

Date Printed: Wednesday, November 11, 2009 


\section{Isotopic Uranium By Alpha Spectroscopy \\ PAI 714 Rev 11 \\ Sample Results}

Lab Name: ALS Laboratory Group -- FC

Work Order Number: 0910309

Client Name: National Security Technologies, LLC

ClientProject ID: CAU 113RMAD V3343

\begin{tabular}{|c|c|c|c|c|c|}
\hline \multicolumn{2}{|c|}{$\begin{array}{l}\text { Field ID: } 113-01 \\
\text { Lab ID: } 0910309-1\end{array}$} & $\begin{array}{l}\text { Sample Matrix: OIL } \\
\quad \text { Prep SOP: PAI } 778 \text { Rev } 13 \\
\text { Date Collected: } 26-\text { Oct-09 } \\
\text { Date Prepared: 02-Nov-09 } \\
\text { Date Analyzed: } 05-\text { Nov-09 }\end{array}$ & $\begin{array}{l}\text { Prep Batch: AS091102-3 } \\
\text { QCBatchID: AS091102-3-1 } \\
\text { Run ID: AS091102-3C } \\
\text { Count Time: } 300 \text { minutes } \\
\text { Report Basis: As Received }\end{array}$ & \multicolumn{2}{|c|}{$\begin{array}{l}\text { Final Aliquot: } 6.01 \mathrm{~g} \\
\text { Prep Basis: As Received } \\
\text { Moisture(\%): NA } \\
\text { Result Units: } p \text { Ci/g } \\
\text { File Name: Spectrum \#1 }\end{array}$} \\
\hline CASNO & Target Nuclide & Result +/- 2 s TPU & MDC & $\begin{array}{c}\text { Requested } \\
\text { MDC }\end{array}$ & Lab Qualifier \\
\hline $11-08-5$ & $\mathrm{U}-233 / 234$ & $9.17 \mathrm{E}-03+/-6.17 \mathrm{E}-03$ & 4.97E-03 & $2.00 E-02$ & $\mathrm{LT}$ \\
\hline $15117-96-1$ & U-235 & 1.89E-03 +/- 4.03E-03 & $5.85 \mathrm{E}-03$ & $2.00 \mathrm{E}-02$ & $U$ \\
\hline $7440-61-1$ & $U-238$ & $2.55 \mathrm{E}-03+/-3.44 \mathrm{E}-03$ & 4.97E-03 & $2.00 \mathrm{E}-02$ & U \\
\hline
\end{tabular}

Chemical Yield Summary

\begin{tabular}{|c|c|c|c|c|c|c|}
\hline Carrier/Tracer & Amount Added & Result & Units & Yield & $\begin{array}{c}\text { Control } \\
\text { Limits }\end{array}$ & Flag \\
\hline $\mathrm{U}-232$ & $1.470 \mathrm{E}+00$ & $1.25 \mathrm{E}+00$ & $\mathrm{pCi} / \mathrm{g}$ & 85.1 & $30-110 \%$ & \\
\hline
\end{tabular}

\section{Comments:}

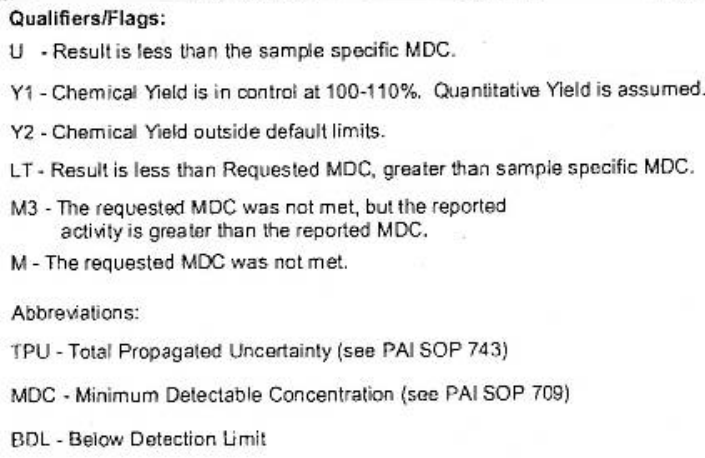

Data Package ID: UR0910309-1 


\section{Isotopic Uranium By Alpha Spectroscopy \\ PAI 714 Rev 11 \\ Sample Results}

Lab Name: ALS Laboratory Group -- FC

Work Order Number: 0910309

Client Name: National Security Technologies, LLC

ClientProject ID: CAU 113 RMAD V3343

Field ID: $113-02$
Lab ID: $0910309-2$

Analysis ReqCode: NAS-A-002
Sample Matrix: OIL

Prep SOP: PAI 778 Rev 13

Date Collected: 26-Oct-09

Date Prepared: 02-Nov-09

Date Analyzed: 05-Nov-09
Prep Batch: AS091102-3

QCBatchlD: AS091102-3-1

Run ID: AS091102-3C

Count Time: 300 minutes

Report Basis: As Received
Final Aliquot: $6.02 \mathrm{~g}$

Prep Basis: As Received

Moisture(\%): NA

Result Units: $\mathrm{pCi} / \mathrm{g}$

File Name: Spectrum \#1

\begin{tabular}{|c|c|c|c|c|c|}
\hline CASNO & Target Nuclide & Result +/- 2 s TPU & MDC & $\begin{array}{l}\text { Requested } \\
\text { MDC }\end{array}$ & Lab Qualifier \\
\hline $11-08-5$ & $U-233 / 234$ & 2.94E-03 +1- 5.33E-03 & 3.98E-03 & $2.00 \mathrm{E}-02$ & U \\
\hline $15117-96-1$ & U-235 & $-1.04 E-03+1-6.25 E-03$ & 1.09E-02 & 2.00E-02 & $U$ \\
\hline $7440-61-1$ & $U-238$ & $-2.94 \mathrm{E}-04+/-5.31 \mathrm{E}-03$ & 1.15E-02 & $2.00 \mathrm{E}-02$ & U \\
\hline
\end{tabular}

Chemical Yield Summary

\begin{tabular}{|c|c|c|c|c|c|c|}
\hline Carrier/Tracer & Amount Added & Result & Units & Yield & $\begin{array}{c}\text { Control } \\
\text { Limits }\end{array}$ & Flag \\
\hline $\mathrm{U}-232$ & $1.460 \mathrm{E}+00$ & $7.85 \mathrm{E}-01$ & $\mathrm{pCi} / \mathrm{g}$ & 53.8 & $30-110 \%$ & \\
\hline
\end{tabular}

\section{Comments:}

\footnotetext{
Qualifiers/Flags:

$U$ - Result is less than the sample specific MDC.

Y1 - Chemical Yield is in control at 100-110\%. Quantitative Yield is assumed

Y2 - Chemical Yield outside default limits.

LT - Result is less than Requested MDC, greater than sample specific MDC.

M3 - The requested MDC was not met, but the reported activity is greater than the reportod MDC

$M$ - The requested $M D C$ was not mot.

Abbreviations:

YPU - Total Propagated Uncertainty (see PAI SOP 743)

MDC - Minimum Detectable Concentration (see PAI SOP 709)

BDL - Below Detection Limit
}

Data Package ID: UR0910309-1 


\section{Isotopic Uranium By Alpha Spectroscopy \\ PAI 714 Rev 11 \\ Sample Duplicate Results}

Lab Name: ALS Laboratory Group -- FC

Work Order Number: 0910309

Client Name: National Security Technologies, LLC

ClientProject ID: CAU 113 RMAD V3343

\begin{tabular}{|l|l|}
\hline Field ID: & $113-02$ \\
Lab ID: & $0910309-2 D U P$ \\
\hline
\end{tabular}

Sample Matrix:OIL Prep SOP:PAI 778 Rev 13

Date Collected:26-Oct-09

Date Prepared: 02-Nov-09

Date Analyzed: 05-Nov-09
Prep Batch: AS091102-3

QCBatchID: AS091102-3-1

Run ID: AS091102-3C

Count Time: 300 minutes

Report Basis: As Received
Final Aliquot: $6.01 \mathrm{~g}$

Prep Basis: As Received

Moisture(\%): NA

Result Units: $\mathrm{pCi} / \mathrm{g}$

File Name: Spectrum \#1

\begin{tabular}{|c|c|c|c|c|c|}
\hline CASNO & Target Nuclide & Result +/- 2 s TPU & MDC & $\begin{array}{c}\text { Requested } \\
\text { MDC }\end{array}$ & \begin{tabular}{c} 
Lab Qualifier \\
\hline $11-08-5$
\end{tabular} \\
\hline $15117-96-1$ & $\mathrm{U}-233 / 234$ & $4.83 \mathrm{E}-03+1-4.80 \mathrm{E}-03$ & $6.74 \mathrm{E}-03$ & $2.00 \mathrm{E}-02$ & $\mathrm{U}$ \\
\hline $7440-61-1$ & $\mathrm{U}-235$ & $2.00 \mathrm{E}-03+1-4.10 \mathrm{E}-03$ & $8.69 \mathrm{E}-03$ & $2.00 \mathrm{E}-02$ & $\mathrm{U}$ \\
\hline
\end{tabular}

\section{Chemical Yield Summary}

\begin{tabular}{|c|c|c|c|c|c|c|}
\hline Carrier/Tracer & Amount Added & Result & Units & Yield & $\begin{array}{c}\text { Control } \\
\text { Limits }\end{array}$ & Flag \\
\hline $\mathrm{U}-232$ & $1.460 \mathrm{E}+00$ & $1.21 \mathrm{E}+00$ & $\mathrm{pCi} / \mathrm{g}$ & 82.9 & $30-110 \%$ & \\
\hline
\end{tabular}

\section{Comments:}

\footnotetext{
Qualifiers/Flags:

$U$ - Result is less than the sample specific MDC

Y1 - Chemical Yiald is in control at $100-110 \%$. Quantitative yield is assumed.

Y2 - Chemical Yield outside default limits.

LT - Result is less than Requestad MDC, greater than sample specific MDC

$M$ - The requested MDC was not met.

M3 - The requested MDC was not met, but thereported activity is greater than the reported MDC
}

D. DER is greater than Control Limit of 3

\section{Abbreviations}

TPU - Total Propagated Uncertainty (see PAI SOP 743)

MDC - Minimum Detectable Concentration (see PAI SOP 709)

BDL - Below Detection Limit

Data Package ID: UR0910309-1 


\section{Tritium Analysis By Liquid Scintillation Sample Results Summary}

Client Name: National Security Technologies, LLC Client Project Name: CAU 113 RMAD Client Project Number: V3343
Laboratory Name: ALS Laboratory Group -- FC PAI Work Order: 0910309
Page: 1 of 1

Reported on: Wednesday, November 11, 2009 12:40:33 PM

\begin{tabular}{|c|c|c|c|c|c|c|c|c|c|c|}
\hline $\begin{array}{c}\text { Lab } \\
\text { Sample ID }\end{array}$ & Client Sample ID & $\begin{array}{l}\text { Sample } \\
\text { Type }\end{array}$ & Nuclide & Result +/- 2 s TPU & MDC & Units & Matrix & Prep Batch & $\begin{array}{c}\text { Date } \\
\text { Analyzed }\end{array}$ & Flags \\
\hline $0910309-1$ & 113-01 & Sample & $\mathrm{H}-3$ & $1.03 E+01+/-1.43 E+01$ & $2.35 E+01$ & pCilg & Oll & $3 \mathrm{H} 091102-1$ & $11 / 5 / 2009$ & $\cup$ \\
\hline 0910309-2 & $113-02$ & Sample & $\mathrm{H}-3$ & $1.40 E+01+/-1.43 E+01$ & $2.30 E+01$ & $\mathrm{pCi} / \mathrm{g}$ & OIL & $3 \mathrm{H} 091102-1$ & $11 / 5 / 2009$ & $u$ \\
\hline
\end{tabular}

Comments:

Data Package ID: H30910309-1

\section{Qualiflers/Flags:}

$U$ - Result is less than the sample specific MDC.

LT - Result is less than Requested MDC, greater than sample specific MDC.

$Y 1$. Chemical Yield is in control at 100-110\%. Quantitative Yield is assumed.

Y2 - Chemical Yieid outside defautl limits.

$M$ - The requested $M D C$ was not met.

$M 3$ - The requested MDC was not met, but the reported activity is greater than the reported MDC.

\section{Abbreviations:}

TPU - Total Propagated Uncertainty (see PAI SOP 743)

MDC - Minimum Detectable Concentration (see PAI SOP 709)

BDL - Below Detection Limit

Date Printed: Wednesday, November 11, 2009 


\section{Tritium Analysis By Liquid Scintillation \\ PAl 704 Rev 9 \\ Sample Results}

Lab Name: ALS Laboratory Group -- FC

Work Order Number: 0910309

Client Name: National Security Technologies, LLC

ClientProject ID: CAU 113 RMAD V 3343

\begin{tabular}{ll|}
\hline Field ID: & $113-01$ \\
Lab ID: & $0910309-1$ \\
\hline
\end{tabular}

Analysis ReqCode: LSC-A-001
Sample Matrix: OIL

Prep SOP:PAl 700 Rev 10

Date Collected: 26-Oct-09

Date Prepared: 02-Nov-09

Date Analyzed: 05-Nov-09
Prep Batch: 3H091 102-1

QCBatchID: 3 H091102-1-1

Run ID: 3H091102-1A

Count Time: 30 minutes

Report Basis: As Received
Final Aliquot: $0.199 \mathrm{~g}$

Prep Basis: As Received

Moisture(\%): 100.000

Result Units: $\mathrm{pCi} / \mathrm{g}$

File Name:B60_08_110502

\begin{tabular}{|c|c|c|c|c|c|}
\hline CASNO & Target Nuclide & Result +/- 2 s TPU & MDC & $\begin{array}{c}\text { Requested } \\
\text { MDC }\end{array}$ & \begin{tabular}{c} 
Lab Qualifier \\
\hline $10028-17-8$
\end{tabular} \\
\hline
\end{tabular}

\section{Comments:}

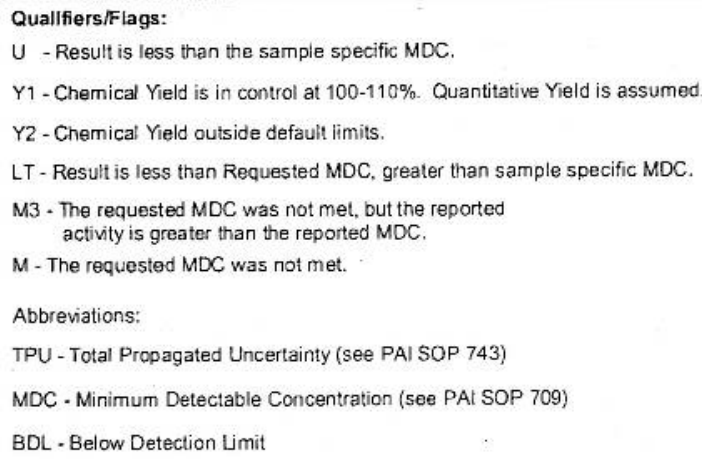

Data Package ID: H30910309-1 


\section{Tritium Analysis By Liquid Scintillation}

PAl 704 Rev 9

Sample Duplicate Results

Lab Name: ALS Laboratory Group - FC

Work Order Number: 0910309

Client Name: National Security Technologies, LLC

ClientProject ID: CAU 113 RMAD V3343

\begin{tabular}{l} 
Field ID: $113-01$ \\
Lab ID: $0910309-1$ DUP \\
\hline
\end{tabular}

Sample Matrix: OIL

Prep SOP: PAI 700 Rev 10

Date Collected: $26-$ Oct-09

Date Prepared: 02-Nov-09

Date Analyzed: 05-Nov-09
Prep Batch: 3H091 102-1

QCBatchID: 3 H091 102-1-1

Run ID: 3H091102-1A

Count Time: 30 minutes

Report Basis: As Received
Final Aliquot: $0.200 \mathrm{~g}$

Prep Basis: As Received

Moisture(\%): 100.000

Result Units: $\mathrm{pCi} / \mathrm{g}$

File Name:B60_08_110502

\begin{tabular}{|c|c|c|c|c|c|}
\hline CASNO & Target Nuclide & Result +/- 2 s TPU & MDC & $\begin{array}{c}\text { Requested } \\
\text { MDC }\end{array}$ & Lab Qualifier \\
\hline $10028-17-8$ & $\mathrm{H}-3$ & $1.37 \mathrm{E}+00+/-1.37 \mathrm{E}+01$ & $2.34 \mathrm{E}+01$ & $4.00 \mathrm{E}+02$ & $\mathrm{U}$ \\
\hline
\end{tabular}

\section{Comments:}

Quallifiers/Flags:

$U$-Result is less than the sample specific MDC.

Y1 - Chemical Yield is in control at $100-110 \%$. Quantitative yield is assumed.

Y2 - Chemical Yield outside default limits.

LT - Result is less than Requested MDC, greater than sample specific MDC.

$M$ - The requested MDC was not met.

M3 - The requested MDC was not met, but thereported activity is greater than the reported MDC.

D - DER is greater than Control Limit of 3

Abbreviations:

TPU - Total Propagated Uncertainty (see PAI SOP 743)

MDC - Minimum Detectable Concentration (see PAI SOP 709)

BDL - Below Detection Limit

Data Package ID: H30910309-1

Date Printed: Wednesday, November 11, 2009

ALS Laboratory Group -- FC

Page 1 of 1

LIMS Version: $6.308 \mathrm{~A}$ 


\section{Tritium Analysis By Liquid Scintillation \\ PAI 704 Rev 9 \\ Sample Results}

Lab Name: ALS Laboratory Group -- FC

Work Order Number: 0910309

Client Name: National Security Technologies, LLC

ClientProject ID: CAU 113 RMAD V3343

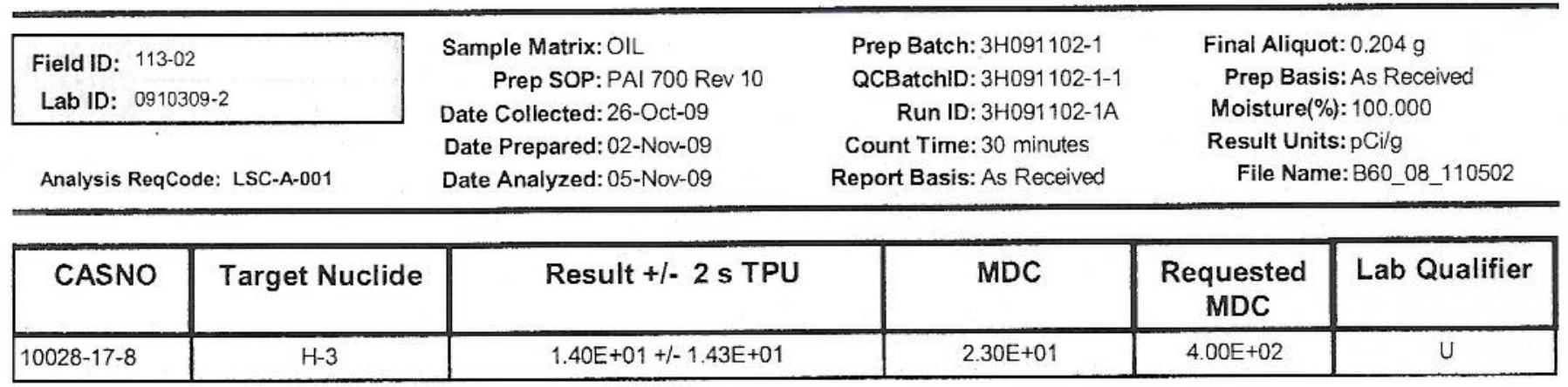

\section{Comments:}

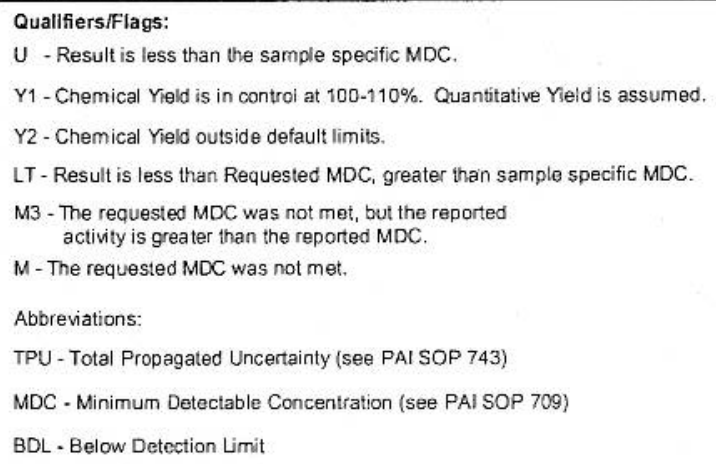




\section{Strontium-90 Analysis by GFPC Sample Results Summary}

Client Name: National Security Technologies, LLC Client Project Name: CAU 113 RMAD

Client Project Number: V3343
Laboratory Name: ALS Laboratory Group -- FC PAI Work Order: 0910309
Page: 1 of 1

Reported on: Wednesday, November 11, 2009 1:03:12 PM

\begin{tabular}{|c|c|c|c|c|c|c|c|c|c|c|}
\hline $\begin{array}{l}\text { Lab } \\
\text { Sample ID }\end{array}$ & Client Sample ID & $\begin{array}{l}\text { Sample } \\
\text { Type }\end{array}$ & Nuclide & Result $+/-2 \mathrm{~s}$ TPU & MDC & Units & Matrix & Prep Batch & $\begin{array}{c}\text { Date } \\
\text { Analyzed }\end{array}$ & Flags \\
\hline $0910309-1$ & $113-01$ & Sample & Sr-90 & $-6.75 \mathrm{E}-02+/-2.19 \mathrm{E}-01$ & $5.65 \mathrm{E}-01$ & pCilg & Oll & SR091030-1 & $11 / 5 / 2009$ & $u$ \\
\hline $0910309-2$ & $113-02$ & Sample & $\mathrm{Sr}-90$ & $-1.21 \mathrm{E}-01+/-2.00 \mathrm{E}-01$ & 5.35E-01 & $\mathrm{pCi} / \mathrm{g}$ & OH & SR091030-1 & $11 / 5 / 2009$ & $u$ \\
\hline
\end{tabular}

Comments:

Data Package ID: SR0910309-1

QualiflersiFlags:
$U$ - Result is less than the sample specific MDC.
LT. Result is less than Requested MDC, greater than sample specific MDC.
$Y 1$ - Chemical Yield is in control at 100-110\%. Quantitative Yield is assumed.
Y2 - Chemical Yield outside defautit limits.
$M$ - The requested MOC was not met.
M3 - The requested MDC was not met, but the reporied activity is greater than the reported MDC.

Date Printed: Wednesday, November 11, 2009
Abbreviations:

TPU - Total Propagated Uncertainty (see PAI SOP 743)

MDC - Minimum Detectable Concentration (see PAI SOP 709)

BDL - Below Detection Limit
ALS Laboratory Group - FC

LIMS Version: $6.308 \mathrm{~A}$ 


\section{Strontium-90 Analysis by GFPC \\ PAI 724 Rev 10 \\ Sample Results}

Lab Name: ALS Laboratory Group - FC

Work Order Number: 0910309

Client Name: National Security Technologies, LLC

ClientProject ID: CAU 113 RMAD V3343

\begin{tabular}{ll}
\hline Field ID: & $113-01$ \\
Lab ID: & $0910309-1$ \\
\hline
\end{tabular}

Analysis ReqCode: GPC-A-013
Sample Matrix: OIL

Prep SOP: PAI 707 Rev 10

Date Collected: $26-$ Oct-09

Date Prepared: 30-Oct-09

Date Analyzed: 05-Nov-09
Prep Batch: SR091030-1

QCBatchID: SR091030-1-1

Run ID: SR091030-1A

Count Time: 30 minutes

Report Basis: As Received
Final Aliquot: $1.99 \mathrm{~g}$

- Prep Basis: As Received

Moisture(\%):NA

Result Units: $\mathrm{pCi} / \mathrm{g}$

File Name: SRC1105

\begin{tabular}{|c|c|c|c|c|c|}
\hline CASNO & Target Nuclide & Result +/- 2 s TPU & MDC & $\begin{array}{c}\text { Requested } \\
\text { MDC }\end{array}$ & \begin{tabular}{c} 
Lab Qualifier \\
\hline $10098-97-2$
\end{tabular} \\
\hline
\end{tabular}

\section{Chemical Yield Summary}

\begin{tabular}{|c|c|c|c|c|c|c|}
\hline Carrier/Tracer & Amount Added & Result & Units & Yield & $\begin{array}{c}\text { Control } \\
\text { Limits }\end{array}$ & Flag \\
\hline STRONTIUM & $1.010 \mathrm{E}+03$ & $9.36 \mathrm{E}+02$ & ug & 92.4 & $40-110 \%$ & \\
\hline
\end{tabular}

\section{Comments:}

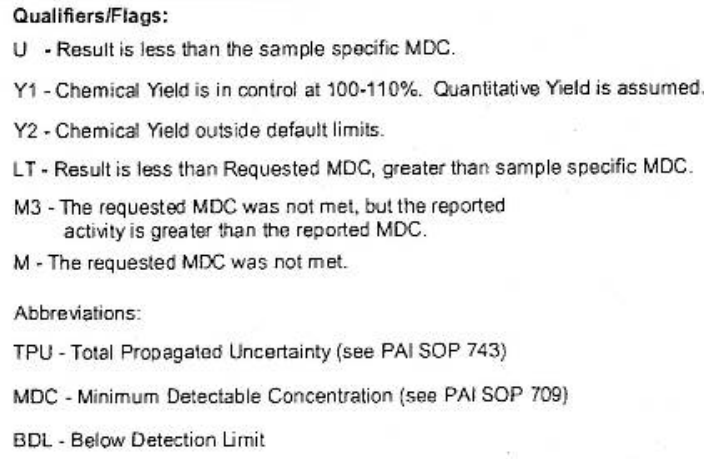

Data Package ID: SR0910309-1 


\section{Strontium-90 Analysis by GFPC \\ PAI 724 Rev 10 \\ Sample Results}

Lab Name: ALS Laboratory Group -. FC

Work Order Number: 0910309

Client Name: National Security Technologies, LLC

ClientProject ID: CAU 113 RMAD V3343

\begin{tabular}{|c|}
\hline $\begin{aligned} \text { Field ID: } & 113-02 \\
\text { Lab ID: } & 0910309-2\end{aligned}$ \\
\hline
\end{tabular}

Analysis ReqCode: GPC-A-013
Sample Matrix: OIL

Prep SOP: PAI 707 Rev 10

Date Collected: 26-Oct-09

Date Prepared: $30-0 c t-09$

Date Analyzed: 05-Nov-09
Prep Batch: SR091030-1 QCBatchID: SR091030-1-1

Run ID: SR091030-1A

Count Time: 30 minutes

Report Basis: As Received
Final Aliquot: $1.98 \mathrm{~g}$

Prep Basis: As Received

Moisture(\%): NA

Result Units: $\mathrm{pCi} / \mathrm{g}$

File Name: SRC1105

\begin{tabular}{|c|c|c|c|c|c|}
\hline CASNO & Target Nuclide & Result +/- 2 s TPU & MDC & $\begin{array}{c}\text { Requested } \\
\text { MDC }\end{array}$ & \begin{tabular}{c} 
Lab Qualifier \\
\hline $10098-97-2$
\end{tabular} \\
\hline
\end{tabular}

\section{Chemical Yield Summary}

\begin{tabular}{|c|c|c|c|c|c|c|}
\hline Carrier/Tracer & Amount Added & Result & Units & Yield & $\begin{array}{c}\text { Control } \\
\text { Limits }\end{array}$ & Flag \\
\hline STRONTIUM & $1.010 \mathrm{E}+03$ & $9.45 \mathrm{E}+02$ & ug & 93.8 & $40-110 \%$ & \\
\hline
\end{tabular}

\section{Comments:}

\footnotetext{
Qualifiers/Flags:

$U$ - Result is less than the sample specific MDC

Y1 - Chemical Yield is in control at $100-110 \%$. Quantitative Yield is assumed.

Y2 - Chemical Yield outside default limits.

LT - Result is less than Requested MDC, greater than sample specific MDC.

M3 - The requested MDC was not met, but the reported activity is greater than the reported MDC.

$M$ - The requested $M D C$ was not met.

Abbreviations:

TPU - Total Propagated Uncertainty (see PAI SOP 743)

MDC - Minimum Detectable Concentration (see PAI SOP 709)

BDL - Below Detection Limit
}

Data Package ID: SR0910309-1

Date Printed: Wednesday, November 11, 2009 


\section{Strontium-90 Analysis by GFPC \\ PAI 724 Rev 10 \\ Sample Duplicate Results}

Lab Name: ALS Laboratory Group -- FC

Work Order Number: 0910309

Client Name: National Security Technologies, LLC

ClientProject ID: CAU 113 RMAD V3343

\begin{tabular}{|c|c|c|c|c|c|}
\hline \multicolumn{2}{|c|}{$\begin{array}{l}\text { Field ID: } 113-02 \\
\text { Lab ID: } 0910309-2 D U P\end{array}$} & $\begin{array}{l}\text { Sample Matrix: OIL } \\
\quad \text { Prep SOP: PAI } 707 \text { Rev } 10 \\
\text { Date Collected: } 26-\text { Oct-09 } \\
\text { Date Prepared: } 30-\text { Oct-09 } \\
\text { Date Analyzed: } 05-\text { Nov-09 }\end{array}$ & $\begin{array}{l}\text { Prep Batch: SR091030-1 } \\
\text { QCBatchID: SR091030-1-1 } \\
\text { Run ID: SR091030-1A } \\
\text { Count Time: } 30 \text { minutes } \\
\text { Report Basis: As Received }\end{array}$ & \multicolumn{2}{|c|}{$\begin{array}{l}\text { Final Aliquot: } 1.99 \mathrm{~g} \\
\text { Prep Basis: As Received } \\
\text { Moisture(\%): NA } \\
\text { Result Units: pCi/g } \\
\text { File Name: SRC1105 }\end{array}$} \\
\hline CASNO & Target Nuclide & Result $+/-2$ s TPU & MDC & $\begin{array}{l}\text { Requested } \\
\text { MDC }\end{array}$ & Lab Qualifier \\
\hline $10098-97-2$ & Sr-90 & $6.18 \mathrm{E}-04+1-2.20 \mathrm{E}-01$ & 5.45E-01 & $1.00 E+00$ & $U$ \\
\hline
\end{tabular}

Chemical Yield Summary

\begin{tabular}{|c|c|c|c|c|c|c|}
\hline Carrier/Tracer & Amount Added & Result & Units & Yield & $\begin{array}{c}\text { Control } \\
\text { Limits }\end{array}$ & Flag \\
\hline STRONTIUM & $9.970 \mathrm{E}+02$ & $9.22 \mathrm{E}+02$ & ug & 92.5 & $40-110 \%$ & \\
\hline
\end{tabular}

\section{Comments:}

Quallifers/Flags:

$U$-Result is less than the sample specific MDC

Y1 - Chemical Yieid is in control at 100-110\%. Quantitative yield is assumed.

Y2 - Chemical Yield outside default limits.

$L T$ - Result is less than Requested MDC, greater than sample specific MDC.

$M$ - The requested MDC was not met.

M3 - The requested MDC was not met, but thereported activity is greater than the reported MDC

D. DER is greater than Control Limit of 3

Abbreviations:

TPU - Total Propagated Uncertainty (see PAI SOP 743)

MDC - Minimum Detectable Concentration (see PAI SOP 709)

BDL - Below Detection Limit

Data Package ID: SR0910309-1

Date Printed: Wednesday, November 11, 2009 


\section{APPENDIX H}

\section{CLARIFICATION OF FINAL END STATE FOR CORRECTIVE ACTION UNIT (CAU) 113: AREA 25, REACTOR MAINTENANCE, ASSEMBLY, AND DISASSEMBLY (R-MAD) FACILITY, CORRECTIVE ACTION SITE 25-41-01}

AND

NDEP APPROVAL LETTER 
Addendum to CAU $113 \mathrm{CR}$

Revision: 0

Date: February 2011 


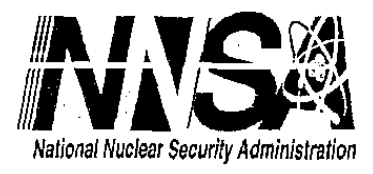

\author{
Department of Energy \\ National Nuclear Security Administration \\ Nevada Site Office \\ P.O. Box 98518 \\ Las Vegas, NV 89193-8518
}

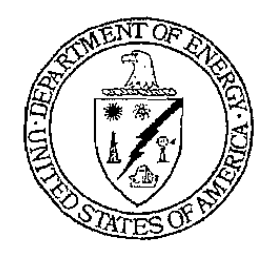

\title{
NOV 192009
}

Tim Murphy, Chief

Bureau of Federal Facilities

Division of Environmental Protection

2030 East Flamingo Road, Suite 230

Las Vegas, NV 89119-0818

\section{CLARIFICATION OF FINAL END STATE FOR CORRECTIVE ACTION UNIT (CAU) 113: AREA 25, REACTOR MAINTENANCE, ASSEMBLY, AND DISASSEMBLY (R-MAD) FACILITY, CORRECTIVE ACTION SITE 25-41-01}

Closure activities completed at CAU 113, including removal of hazardous materials and actions taken to render remaining radiological contamination inaccessible, are detailed in the approved Closure Report (CR) for CAU 113. A use restriction (UR) was implemented for radiological, polychlorinated biphenyl (PCB), and lead contamination. During the detailed planning for demolition activities, current conditions were noted that will require a slightly different approach to demolition and waste disposal than those outlined in the CR. These differences are described in the following paragraphs.

The planned work scope for fiscal years 2010 and 2011 includes demolition of Building 3110 and the associated water tower. Prior to demolition activities, asbestos-containing roofing material and remaining asbestos elbows that are present on the roof of the facility will be removed and disposed appropriately. The hydraulic rams located in basement rooms 6 and 7 will be left in place. During closure activities, the hydraulic rams were triple rinsed using diesel fuel per Title 40 Code of Federal Regulations (CFR) Part 761, encapsulated with sheet metal, and posted for radiological and PCB contamination. The hydraulic rams are currently classified as PCB Hydraulic Machines and, before being drained and triple rinsed, contained hydraulic fluid at concentrations greater than 1,000 parts per million. This letter requests approval to leave these hydraulic rams in place under a UR.

Building 3110 demolition debris will be classified as Radioactive PCB Bulk Product Waste. The CR stated that it would be reasonable to expect that the debris would not be classified as . low-level waste. The assumption was made in the CR that the debris would be managed as PCB Bulk Product Waste due to the PCB paint that covers most of the interior walls in Building 3110, and the debris would be disposed at a solid waste landfill. Although closure activities included decontamination of accessible surfaces, not all surfaces could be decontaminated to free release limits for removable contamination, and contamination remained in inaccessible surfaces. Steel plates, concrete, or expandable foam was applied to surfaces with removable contamination throughout the facility. The facility currently has no removable contamination, but fixed contamination is present ranging from 4,000 to 100,000 disintegrations per minute per 
100 square centimeters. During demolition of the facility, the fixed contamination may be released. As the debris is expected to contain removable contamination in excess of free release limits, the debris will be classified as Radioactive PCB Bulk Product Waste.

While most of the waste will be disposed at Area 5, some of the debris, which would otherwise be classified as Radioactive PCB Bulk Product Waste, will be placed in the basement and left in place under a UR. This letter requests concurrence for placing a portion of the building debris into the basement and placing a concrete cap over the material to make it inaccessible, similar to what was done for CAU 118: Area 27 Super Kukla Facility. Closure in place of these materials will not significantly change the current use restriction and will not pose an unreasonable risk of injury to health or the environment based on the following assessment.

\section{Nature and quantity of the debris:}

Approximately 29,000 cubic feet of demolition debris will be placed in the basement of the facility, the void spaces will be filled with soil, and the basement will be capped with at least 1 foot of concrete. The remaining demolition debris that does not fit in the basement will be packaged and disposed as Radioactive PCB Bulk Product Waste under a current approved waste profile at the Area 5 Radioactive Waste Management Site (RWMS). The debris contains "applied dried paint" that is not reactive or subject to decomposition from exposure to precipitation, as defined in 40 CFR 761.62(b)(1)(i). The UR will remain in place; the capped basement will be posted for radiological, PCB, and lead contamination; and annual inspections will be performed to verify the postings are in good condition and the UR is maintained.

\section{Proposed design of the containment:}

The walls and floors of the basement are constructed of reinforced concrete. The walls are generally 18 inches thick; however, in some areas, the wall thickness is as much as 3 feet. The basement floors are generally 6 inches thick; however, in some areas where the footer extends under the floor, the floor is over 4 feet thick. After the debris is placed in the basement, the void spaces will be filled with soil, and the basement will be capped with at least 1 foot of concrete. The area will then be use restricted for radiological, PCB, and lead contamination. Annual inspections will continue to be performed to verify the postings are in good condition and the UR is maintained.

\section{Hydrogeologic setting of the site:}

Area 25 is located in an intermontane valley bordered by highlands on all sides except for a large drainage outlet to the southwest. The Jackass Flats basin is underlain by alluvium, colluvium, and voicanic rocks of Cenozoic age. The alluvium and colluviums (with thickness of upwards to 1,000 feet) are above the saturated zone throughout most of Jackass Flats. Paleozoic age sedimentary rocks, limestones, and dolomites occur at greater depths. Precipitation measured at the Jackass Flats (4JA) Station from 2003 through 2008 ranged from 3.99 to 11.04 inches per year, with an average annual value of 7.74 inches. The mean annual potential evapotranspiration 
rate, as estimated for 2003 through 2008 at the Area 3 RWMS, was 61.71 inches. Depths to groundwater for the three water supply wells in Area 25 are approximately 1,039 feet, 927 feet, and 740 feet below ground surface.

\section{Any other factor influencing the quality and mobility of the leachate produced and the potential for it to migrate to ground or surface water:}

The reinforced concrete walls and floor of the basement along with the filling of all voids with soil and capping the basement with concrete prevents any migration of contaminants. In addition, infiltration of precipitation through subsurface media is not significant due to the low precipitation and high evapotranspiration rates common at the Nevada Test Site and the depth to groundwater. Therefore, no viable groundwater exposure pathway exists for the potential source material contained within the basement. In addition, the PCB Bulk Product Waste is "applied dried paint" that is not reactive or subject to decomposition from exposure to precipitation, as defined in 40 CFR 761.62(b)(1)(i).

In summary, this letter requests approval for the following:

- Closure in place of PCB Hydraulic Machines

- Closure in place of demolition debris in the basement of the facility

Please advise if this approach is acceptable. These revisions to the plans as outlined in the CR and any additional changes from the $\mathrm{CR}$, along with the revised post-closure inspections and reporting requirements for the UR, will be documented in a Record of Technical Change or an addendum to the $\mathrm{CR}$.

Please direct comments and questions to Kevin Cabble, of my staff, at 702-295-5000.

ERP:5874.TL

/s / : Robert F. Boehlecke

Robert F.'Boehlecke

Federal Project Director

Environmental Restoration Project 
cc:

J. J. MacDougall, NDEP, Las Vegas, NV

J. A. Wong, NDEP, Las Vegas, NV

J. T. Fraher, DTRA/CXTS, Kirtland AFB, NM

M. J. Krauss, NNES, Las Vegas, NV

T. D. Taylor, NNES, Las Vegas, NV

T. A. Thiele, NSTec, Las Vegas, NV

NSTec Technical Information Officer, Las Vegas, NV

NSTec Correspondence Control, MS NLV008

K. J. Cabble, ERP, NNSA/NSO, Las Vegas, NV

E. F. Di Sanza, WMP, NNSA/NSO, Las Vegas, NV

FFACO Group, PSG, NNSA/NSO, Las Vegas, NV

NNSA/NSO Read File 
December 3, 2009

Robert F. Boehlecke

Federal Project Director

Environmental Restoration Project

National Nuclear Security Administration

Nevada Site Office

P. O. Box 98518

Las Vegas, NV 89193-8518

RE: Clarification of Final End State for Corrective Action Unit (CAU) 113: Area 25 Reactor Maintenance, Assembly, and Disassembly (RMAD) Facility, Corrective Action Site 25-41-01

Dear Mr. Boehlecke,

The Nevada Division of Environmental Protection (NDEP) Bureau of Federal Facilities staff has received and reviewed the subject clarification and proposed revisions to closure activities at CAU 113, RMAD Facility. The proposed closure activities do not adversely impact, and are consistent with, the objectives identified in the previously-identified Closure Report (April 2003). In addition, because the closure activities, as described in the subject correspondence, do not alter the use restricitions already established in the previouslyapproved Closure Report, NDEP concurs with the proposed approach for reaching the final end state at CAU 113.

Please provide NDEP with an addendum to the Closure Report which documents the activities described in the subject correspondence. The addendum will be filed with the previouslyapproved Closure Report and will become part of the administrative record for CAU 113.

If you have any questions regarding this matter, please contact me at (702) 486-2850, extension 231, or Jeff MacDougall, at (702) 486-2850 extension 233.

Sincerely?

/s/:T.H. Murphy

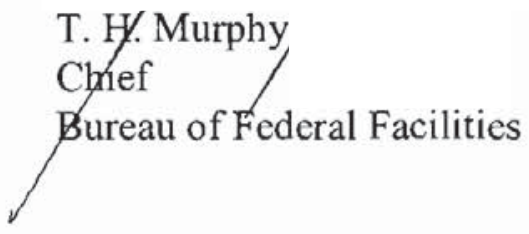

THM/JJM/jaw

ACTION AMEM
INFO
NSO/MGR
COR-

File Code 
Robert F. Boehlecke

Page 2

December 3, 2009

cc: J.T Fraher, DTRA/CXTS, Kirtland AFB, NM

E.F. Di Sanza, WMP, NNSA/NSO, Las Vegas, NV

K. J. Cabble, ERP, NNSA/NSO, Las Vegas, NV

FFACO Group, PSG, NNSA/NSO, Las Vegas, NV 
Addendum to CAU $113 \mathrm{CR}$

Revision: 0

Date: February 2011

\section{APPENDIX I}

\section{USE RESTRICTION DOCUMENTATION}


Addendum to CAU $113 \mathrm{CR}$

Revision: 0

Date: February 2011 


\section{CAU Use Restriction Information}

CAU Number/Description: CAU 113/Area 25 R-MAD Facility

Applicable CAS Number/Description: CAS 25-41-01/R-MAD Facility

Contact (Federal Sub-Project Director/Sub-Project): Kevin Cabble/Industrial Sites

Physical Description:

\begin{tabular}{|c|c|c|}
\hline urveye & (UTM, Zor & 27 , \\
\hline Point 1 & $567,969.82$ & $4,074,536.56$ \\
\hline Point 2 & $567,948.01$ & $4,074,523.58$ \\
\hline Point 3 & $567,942.90$ & $4,074,532.30$ \\
\hline Point 4 & $567,900.78$ & $4,074,508.16$ \\
\hline Point 5 & $567,888.76$ & $4,074,527.73$ \\
\hline Point 6 & $567,891.10$ & $4.074,529.96$ \\
\hline Point 7 & $567,874.83$ & $4,074,557.83$ \\
\hline Point 8 & $567,928.54$ & $4,074,586.23$ \\
\hline Point 9 & $567,960.24$ & $4,074,573.36$ \\
\hline Point 10 & $567,973.00$ & $4,074,552.00$ \\
\hline
\end{tabular}

Depth: $\underline{0-12 \mathrm{ft} \text { bgs }}$

Survey Method (GPS, etc): $\underline{\text { GPS }}$

Basis for UR:

Summary Statement: Radiological contamination is present in the concrete foundation and soil surrounding the foundation. Radiological and polychlorinated biphenyl contamination is present in the basements. Access to these areas has been restricted by a standard use restriction. Penetrations are not allowed in the use restricted area.

Contaminants Table:

\begin{tabular}{|c|c|c|c|}
\hline \multicolumn{4}{|c|}{$\begin{array}{l}\text { Maximum Concentration of Contaminants for CAU } 113 \\
\text { CAS 25-41-01, Area 25 R-MAD Facility }\end{array}$} \\
\hline Constituent & Maximum Concentration & Action Level & Units \\
\hline PCBs & 10,000 & 25 & ppm \\
\hline $\begin{array}{l}\text { Cs-137, Sr-90, U-234, } \\
\text { U-235, and U-238 }\end{array}$ & $\begin{array}{l}100,000 \text { beta/gamma; } \\
300 \text { alpha }\end{array}$ & $\begin{array}{c}\text { See the Nevada Test Site } \\
\text { Radiological Control } \\
\text { Manual }\end{array}$ & $\mathrm{dpm} / 100 \mathrm{~cm}^{2}$ \\
\hline
\end{tabular}

Site Controls: $\underline{\text { Signs }}$

UR Maintenance Requirements:

Description: Certify that postings are in place, intact, and readable. This UR must be entered into the DOE/NV Facility Information Management System (FIMS) and the FFACO databases.

Inspection/Maintenance Frequency: Annual

The future use of any land related to this Corrective Action Unit (CAU), as described by the above surveyed location, is restricted from any DOE or Air Force activity that may alter or modify the containment control as approved by the state and identified in the CAU CR or other CAU documentation unless appropriate concurrence is obtained in advance.

Comments: See the Addendum to the Closure Report for additional information on the condition of the site. Results of the annual inspection will be provided in the annual combined Nevada National Security Site Post-Closure Letter Report.

Submitted By:

Is/: Kevin Cabble

Date:

$2-14-11$ 


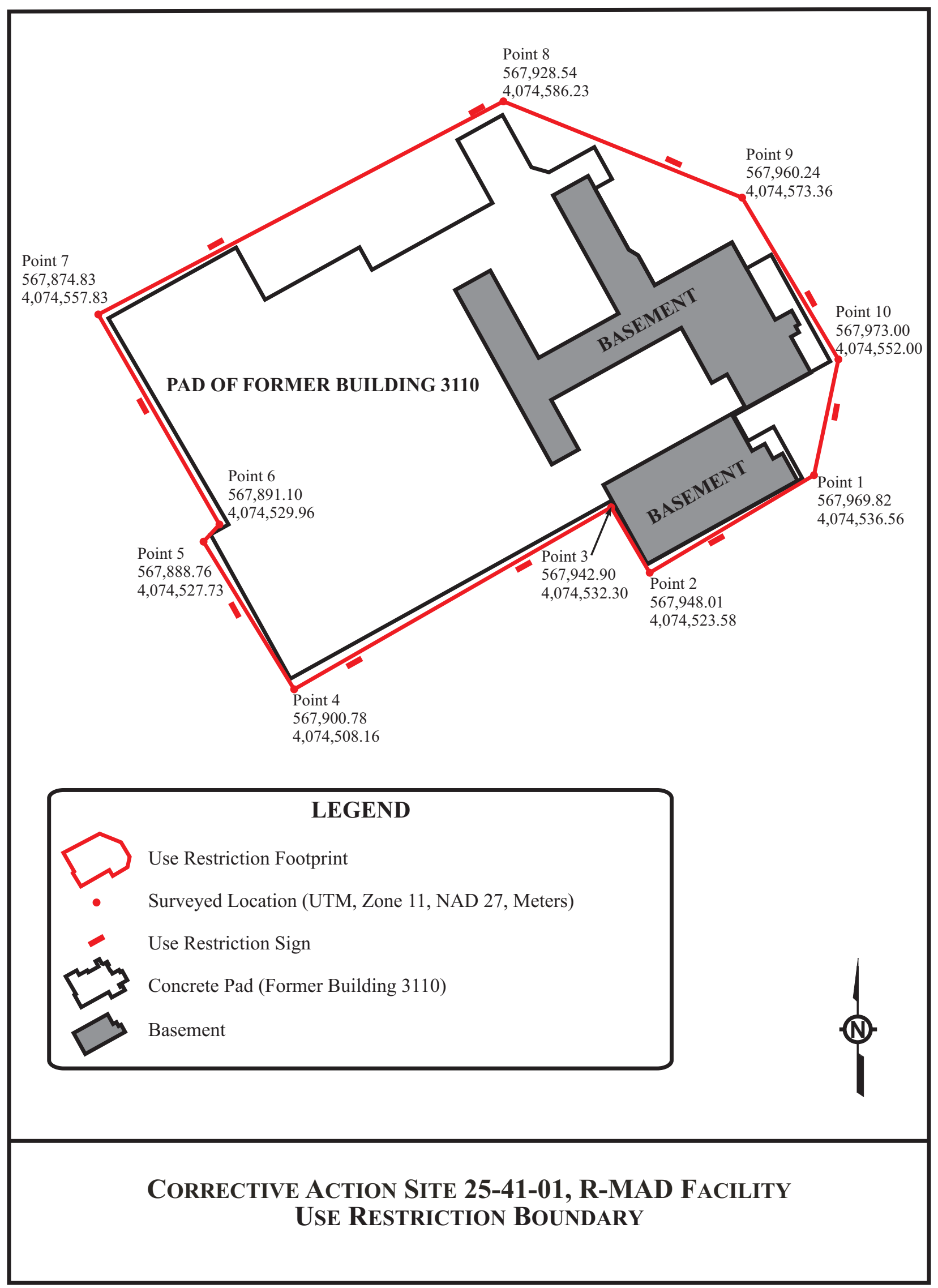


Addendum to CAU $113 \mathrm{CR}$

Revision: 0

Date: February 2011

\section{APPENDIX J}

\section{NEVADA DIVISION OF ENVIRONMENTAL PROTECTION COMMENT RESPONSE FORM}


Addendum to CAU $113 \mathrm{CR}$

Revision: 0

Date: February 2011 
Document Title: Draft Addendum to the Closure Report for Corrective Action Unit 113: Area 25 R-MAD Facility, Nevada National Security Site, Nevada

Revision Number: 0

NNSA/NSO Federal Sub-Project Director: Kevin Cabble Comment

$$
\text { No. }
$$

Document Date: December 2010

Author/Organization: NSTec

Reviewer/Organization/Phone: Jeff MacDougall/NDEP/486-2850 ext 231

Review Criteria: Full
1

Section 1.4.6, page 6: Please provide information and documentation pertinent to the characterization, transport, and disposal of the white powder waste. If any such information regarding its disposal is presented in Appendix F, please specify which information applies to this waste as it is not discernible as presented.

\section{Comment Response}

Text in Section 1.4.6 was revised as follows:

Four 55-gallon drums of white powder that were located in the Building 3110 yard were disposed as HW. Samples of the white powder were collected. There were no hazardous constituents detected above minimum detectable concentrations; however, minimum detectable concentrations below regulatory levels could not be achieved for hexachlorobutadiene, hexachlorobenzene, and 2,4-dinitrotoluene due to matrix interference. Therefore, the powder required disposal as HW. The sample results are located in Appendix G. The four 55-gallon drums were sent to U.S. Ecology in Beatty, Nevada, on February 16, 2011, and are listed on line 14 of the HW manifest for this shipment. The HW manifest is included in Appendix F. The draft report was written with the intent that the four drums of white powder would be disposed before submittal of the final report. Disposal is still planned to be completed before submittal of the final report. Waste disposal documentation for this waste will be included in Appendix F.

Hazardous waste related to housekeeping activities completed before demolition that was not identified in the draft document has also been identified in Section 1.4.6, and this information has been included as follows:

PPE and disposable sampling supplies used during sampling of the white powder were packaged in a 20-gallon drum for disposal as HW. The 20-gallon drum was sent to U.S. Ecology in Beatty, Nevada, on August 30, 2010, and is listed on line 15 of the HW manifest for this shipment. The HW manifest is included in Appendix F.

During housekeeping activities, several pieces of equipment located in the Building 3110 yard contained oil that was drained and consolidated. Due to an insufficient total volume of oil, the oil was only analyzed for radioactive constituents, metals, PCBs, volatile organic compounds, and semi-volatile organic compounds. After collecting the samples, no oil remained. However, PPE and disposable sampling supplies used during sampling of the oil were packaged in a 5-gallon drum, and sample results showed that this waste required disposal as HW. The sample results are located in Appendix G. The 5-gallon drum was sent to U.S. Ecology in Beatty, Nevada, on August 30, 2010, and is listed on line 14 of the HW manifest for this shipment. The HW manifest is included in Appendix F.

One mercury-containing item was removed from the facility, placed in a drum, and disposed as HW. The mercury-containing item was sent to U.S. Ecology in Beatty, Nevada, on February 9, 2010. The item was shipped with other mercury waste from other projects and is listed on line 2 of the HW manifest for this shipment included in Appendix F. 
Document Title: Draft Addendum to the Closure Report for

Corrective Action Unit 113: Area 25 R-MAD Facility, Nevada National Security Site, Nevada

Revision Number: 0

NNSA/NSO Federal Sub-Project Director: Kevin Cabble

\begin{tabular}{|l|l|}
$\begin{array}{l}\text { Comment } \\
\text { No. }\end{array}$ & \multicolumn{1}{c}{ Comment } \\
\hline 2 & $\begin{array}{l}\text { Section 1.5, page 6: Provide additional } \\
\text { explanation/justification for modifying the use restriction } \\
\text { and discuss the effect that this modification has on the } \\
\text { UR (i.e., did the use restricted area become smaller, } \\
\text { larger, etc.). }\end{array}$ \\
\hline
\end{tabular}

Document Date: December 2010

Author/Organization: NSTec

Reviewer/Organization/Phone: Jeff MacDougall/NDEP/486-2850 ext 231

Review Criteria: Full

\section{Comment Response}

The use restricted area is essentially equivalent to the original area. Additional points were added to

the boundary so that the shape of the use restriction better reflects the footprint of the building pad.

Text in Section 1.5 was revised as follows:

The constituents present and post-closure inspection requirements of the UR are unchanged.

However, the original description of the UR stated that contamination was present in

Building 3110. The revised UR summary states that all radiological and PCB-impacted

material is currently entombed in the basement of the facility. This includes the hydraulic rams and building debris.

The entire footprint of Building 3110 is use restricted as originally implemented in the Closure Report. Additional UR warning signs were installed around the building pad. The boundary of the new UR was surveyed. The size of the UR is essentially the same as the previous UR; however, the shape of the use restricted area more closely reflects the footprint of Building 3110. These points are listed on the revised UR form. 
Addendum to CAU 113 CR

Revision: 0

Date: February 2011

\section{LIBRARY DISTRIBUTION LIST}


Addendum to CAU $113 \mathrm{CR}$

Revision: 0

Date: February 2011 


\section{LIBRARY DISTRIBUTION LIST}

U.S. Department of Energy

National Nuclear Security Administration

Nevada Site Office

Technical Library

P.O. Box 98518, M/S 505

Las Vegas, NV 89193-8518

U.S. Department of Energy

Office of Scientific and Technical Information

P.O. Box 62

Oak Ridge, TN 37831-0062

Southern Nevada Public Reading Facility

c/o Nuclear Testing Archive

P.O. Box 98521, M/S 400

Las Vegas, NV 89193-8521

Manager, Northern Nevada FFACO

Public Reading Facility

c/o Nevada State Library \& Archives

Carson City, NV 89701-4285
1 (Uncontrolled, electronic copy)

1 (Uncontrolled, electronic copy)

2 (Uncontrolled, electronic copies)

1 (Uncontrolled, electronic copy) 
Addendum to CAU $113 \mathrm{CR}$

Revision: 0

Date: February 2011 